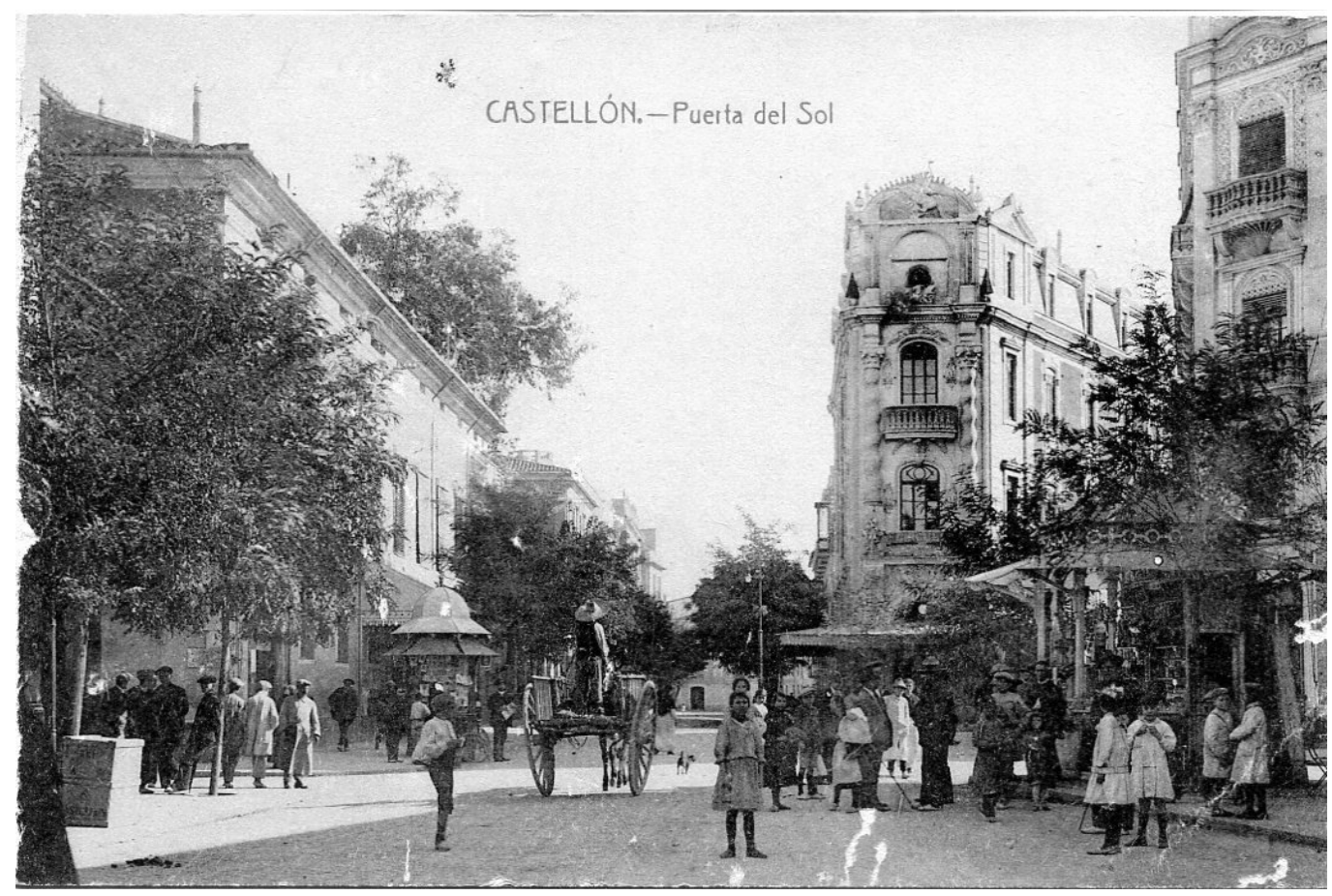

\title{
Castellón hacia la modernidad. Salud, educación y debate científico (1880-1918)
}

\section{Volumen I}

Tesis doctoral dirigida por: Dra. Rosa Monlleó Peris

Realizada por: Concepción Calvo Mas

Castellón, diciembre de 2015

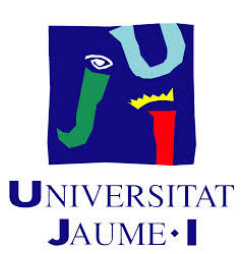

Facultad de Ciencias Humanas y Sociales

Departamento de Educación 
Castellón hacia la modernidad.

Salud, educación y debate científico

(1880-1918) 


\section{FRASES}

[...] pues como se dice, con noble acierto en la exposición al Ayuntamiento, la enseñanza reforma las costumbres, suaviza los modales, dilata los horizontes de la inteligencia, eleva los sentimientos del corazón, dispone y capacita para vivir la vida regular y ordenada de los pueblos modernos, a valorar los productos del trabajo, arranca la niñez de los brazos de la ociosidad y la vagancia, siendo por tanto el servicio público que mejor indemniza de los gastos que produce y uno de los sacrificios que mejor recompensados ha de ver nuestro Ayuntamiento.

La Provincia, 7/02/1889.

[...] España, la triste y mísera España, ésta olvidada nación rechazada por su bajo nivel hacía el África por toda Europa, escupe vilmente a sus hijos estudiosos, les rodea de obstáculos, los que debieran tender su mano al sabio, procuran hundirle en el precipicio del olvido, infundiendo en la clase ignorante esas supersticiones que suelen terminar siempre por el cruento sacrificio del Redentor.

Revista Médico-Farmaceútica, 17/07/1885. 


\section{ABREVIATURAS Y SIGLAS UTILIZADAS}

AACS: Actas del Ayuntamiento de Castellón.

BOPCS: Boletín Oficial de la Provincia de Castellón

C.D.M.H.UJI: Centro de Documentación de la Memoria Histórica de la Universidad Jaume I

G.A.T.E.P.A.C.: Grupo de Artistas y Técnicos Españoles para el Progreso de la Arquitectura contemporánea, más conocido por la sigla G.A.T.E.P.A.C., estuvo formado por un grupo de arquitectos activo desde antes de la Segunda República española cuyo fin fue promover la arquitectura racionalista.

TERMC: Tribunal Especial para la represión de la masonería y el comunismo. 


\section{INDICE}

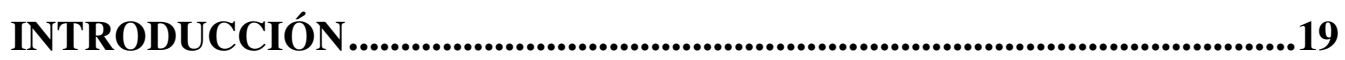

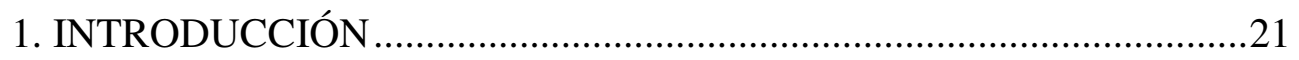

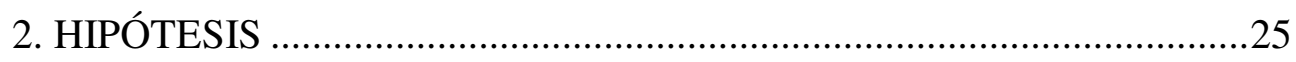

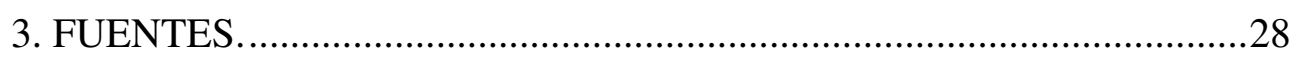

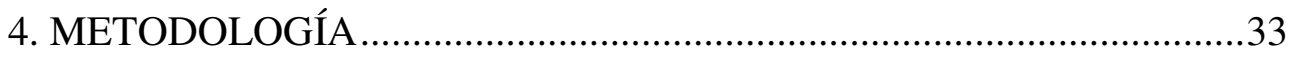

\section{PARTE I: SOCIEDAD URBANA, MODERNIDAD Y POLITICAS DE}

\section{HIGIENE EN CASTELLON}

\section{CAPÍTULO I: DESARROLLO URBANO EN CASTELLÓN}

DURANTE EL SIGLO XIX Y PRINCIPIOS DEL XX

1. LA DINAMICA POLITICA Y SOCIOECONÓMICA DE

CASTELLÓN

2. LA RED DE INFRAESTRUCTURAS Y TRANSPORTES. EL PUERTO DE CASTELLÓN Y LA PANDEROLA.........................................51

3. EL DESARROLLO URBANO DE CASTELLÓN ...

3.1. EL PROCESO DE LA EXPANSIÓN URBANA: LOS

PLANES DE ENSANCHE .63

4. LA VIVIENDA URBANA Y SUBURBANA ...........................................

4.1. LA CASA DEL LABRADOR, CON PAS DE CARRO .....................76

4.2. LA CASA DEL JORNALERO ……………………………….......... 81

4.3. LA CASA DEL OBRADOR ………………………………………..... 82

4.4. EL HÁBITAT RURAL TEMPORAL .................................................83

4.5. DE LA CASA SEÑORIAL A LA VIVIENDA

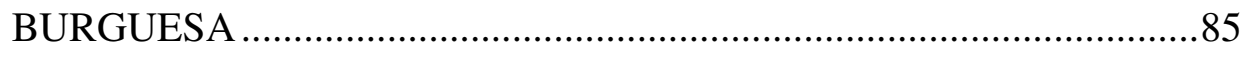

4.6. LA CASA SUBURBANA DE RECREO...........................................92

4.7. LOS INICIOS DE LA VIVIENDA OBRERA...................................93

5. EVOLUCIÓN DE LOS CENTROS DE ENSEÑANZA DE CASTELLÓN 
5.1. LAS ESCUELAS DE CASTELLÓN A FINALES DEL

SIGLO XIX Y PRINCIPIOS DEL XX . .104

5.2. EL INSTITUTO DE SEGUNDA ENSEÑANZA DE

CASTELLON

6. LA SANIDAD Y LOS CENTROS HOSPITALARIOS 123

6.1. LA HIGIENE Y LA ASISTENCIA BENEFICA. 123

6.2. EL HOSPITAL PROVINCIAL DE CASTELLON 130

7. LA FUNCION SOCIAL E HIGIENICA DEL PARQUE DECIMONÓNICO

7.1. EL PARQUE RIBALTA 146

CAPÍTULO II: LA HIGIENE URBANA EN CASTELLÓN 151

1. UNA APROXIMACIÓN A LAS POLÍTICAS DE HIGIENE EN

LA ÉPOCA CONTEMPORÁNEA 153

2. INFRAESTRUCTURAS URBANAS. SU EVOLUCIÓN .... 156

3. HIGIENE DE LAS CALLES 161

4. HIGIENE DE LOS EDIFICIOS PÚBLICOS Y VIVIENDAS 165

4.1. CONTROL Y CONDICIONES DE HABITABILIDAD DE

LA VIVIENDA URBANA Y SU EVOLUCIÓN. 166

5. HIGIENE DE LAS AGUAS 176

6. HIGIENE DE LOS ALIMENTOS 177

7. LOS CEMENTERIOS DE CASTELLÓN 181

8. LA PRENSA FIEL REFLEJO DE LA PREOCUPACIÓN POR LA HIGIENE EN CASTELLÓN 184

\section{PARTE II: MEDICINA, ENFERMEDAD Y MUERTE EN CASTELLÓN} CAPÍTULO III: LA MEDICINA Y LOS MÉDICOS A FINALES DEL SIGLO XIX Y PRINCIPIOS DEL SIGLO XX. 
1. LA MEDICINA EUROPEA DEL SIGLO XIX Y PRINCIPIOS

DEL SIGLO XX: DE LA TEORÍA MICROBIANA DE LAS

ENFERMEDADES A LA GENÉTICA

2. LA MEDICINA ESPAÑOLA: DE LOS FERNANDINOS E

ISABELINOS A LA JUNTA PARA LA AMPIACIÓN DE

ESTUDIOS

3. LA ENSEÑANZA MÉDICA: INFLUENCIA FRANCESA Y

ALEMANA

4. LOS MÉDICOS DE CASTELLÓN 209

4.1. BIOGRAFÍAS DESTACADAS DE PROFESIONALES

DE LA MEDICINA EN CASTELLÓN

4.1.1. JOSÉ CLARÁ PIÑOL (1858-1946).

4.1.2. JOSÉ GIL VALERO (1861-¿)

4.1.3. VICENTE GEA MARIÑÓ (1871-1956). 214

4.1.4. JUAN BAUTISTA BELLIDO TIRADO (1878-1953) 216

\section{CAPÍTULO IV: EVOLUCIÓN DEMOGRÁFICA E}

INCIDENCIA DE LAS ENFERMEDADES MÁS FRECUENTES

EN CASTELLÓN. UN ESTUDIO COMPARATIVO.

1. EVOLUCIÓN DEMOGRAFÍCA DE ESPAÑA: DEL MODELO

PREINDUSTRIAL AL CONTEMPORÁNEO.

2. CRECIMIENTO DEMOGRÁFICO Y ECONÓMICO DE CASTELLÓN: HACIA LA MODERNIDAD

3. ANÁLISIS DE ALGUNAS ENFERMEDADES QUE

AFECTARON CON MAYOR FRECUENCIA A LA

POBLACIÓN DE CASTELLÓN

3.1. EL PALUDISMO: ORÍGENES, TRANSMISIÓN Y

MEDIDAS EN CASTELLÓN.

3.1.1. El paludismo, enfermedad que afecta a los labradores 234

3.1.2. El paludismo en Castellón 237

3.2. LA DIFTERIA, ENFERMEDAD INFANTIL 246 
3.2.1. Medidas contra la Difteria y manifestaciones de la enfermedad 246

3.2.2. La Vacuna de la Difteria. 254

3.3. LA VIRUELA, UNA ENFERMEDAD DE TIEMPO

INMEMORIAL. EL ORIGEN DE LA VACUNOLOGÍA

MODERNA 256

3.3.1. La Viruela en Castellón .262

3.4. LA RABIA, ENFERMEDAD QUE TRANSMITÍAN LOS PERROS 267

3.5. LA LEPRA, UNA ENFERMEDAD MUY TEMIDA, PERO DE BAJA INCIDENCIA 268

3.6. EL DENGUE O LA GRIPE HACE SU APARICIÓN ENTRE 1889 Y 1890 273

4. UN ESTUDIO CUANTITATIVO Y COMPARATIVO DE LAS ENFERMEDADES QUE MÁS INCIDENCIA TUVIERON EN EL PAÍS VALENCIANO Y ESPAÑA 276

\section{CAPÍTULO V: EL CÓlERA MORBO EN CASTELLÓN, UNA} ENFERMEDAD TEMIDA 335

1. INTRODUCCIÓN 337

2. ALARMA EN CASTELLÓN ANTE EL CÓLERA A PARTIR DE 1882. PRECAUCIONES Y MEDIDAS PREVENTIVAS

3. CONSEJOS HIGIÉNICOS EN LA PRENSA DE CASTELLÓN CONTRA EL CÓLERA EN 1883.

4. LA LLEGADA DEL CÓLERA A EUROPA EN 1884.

PRECAUCIONES PARA EVITAR SU DIFUSIÓN EN ESPAÑA

5. ACUERDOS TOMADOS POR EL AYUNTAMIENTO DE

CASTELLÓN PARA COMBATIR EL CÓLERA EN 1884

5.1. MEDIDAS, CONSEJOS Y REMEDIOS A LA

POBLACIÓN PARA LA PREVENCIÓN DEL CÓLERA EN 1884. 
6. 1885, SE CUMPLEN LOS TEMORES DE LA DIFUSIÓN DEL CÓLERA

6.1. CONOCIMIENTO DEL ORIGEN DEL CÓLERA EN 1885 .

6.2. SÍNTOMAS Y TRATAMIENTO MÉDICO DEL

CÓLERA.

6.3. COMIENZO DEL CÓLERA EN CASTELLÓN. 394

6.3.1. El cólera en la ciudad de Castellón de la Plana: temor de la población al aislamiento 407

6.4. ACUERDOS Y MEDIDAS DE LAS AUTORIDADES

MUNICIPALES Y PROVINCIALES PARA PREVENIR DEL CÓLERA A LA POBLACIÓN DE CASTELLÓN. 408

6.4.1. Medidas económicas para socorrer a los epidemiados

6.4.2. Medidas sanitarias cuando se propagó el cólera en Castellón

6.5. ESTUDIO ESTADÍSTICO DE LA TRANSMISIÓN DEL CÓLERA EN LA CUIDAD DE CASTELLÓN DE LA PLANA.

6.6. ESTUDIO COMPARTIVO DE LA EPIDEMIA DE CÓLERA DE 1885 EN LA CIUDAD DE CASTELLÓN DE LA PLANA Y PROVINCIA.

6.7. ACTUACIONES DE LOS MÉDICOS ANTE EL CÓLERA: CALUMNIADOS Y TEMIDOS POR EL VECINDARIO

6.8. LA VACUNA DE FERRÁN EN CASTELLÓN, PROHIBICIONES Y APLICACIONES

CAPÍTULO VI: LA GRIPE DE 1918 EN CASTELLÓN 459

1. ORIGEN DE LA GRIPE Y DESARROLLO EN ESPAÑA. 461

2. LA APARICIÓN DE LA GRIPE EN CASTELLÓN. LA

GESTIÓN DECIDIDA DEL ALCALDE JOSÉ FORCADA Y EL 
DOCTOR CLARÁ FRENTE A LA PASIVIDAD DEL

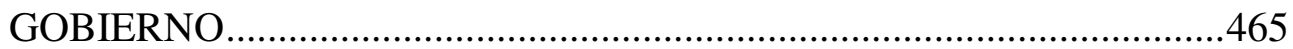

3. EVOLUCIÓN DE LA EPIDEMIA EN CASTELLÓN ............................475

4. ACTUACIÓNES MÉDICAS Y MEDIDAS PÚBLICAS PARA REFORZAR LA HIGIENE ANTE LA GRIPE 494

5. REMEDIOS CONTRA LA GRIPE APARECIDOS EN LA PRENSA 502

6. CONOCIMIENTO DEL ORIGEN DE LA GRIPE EN 1918. 510

\section{PARTE III: EDUCACIÓN SECUNDARIA Y ENSEÑANZA-}

APRENDIZAJE DE LAS CIENCIAS NATURALES. EL DEBATE

CIENTIFICO SOBRE DARWIN

CAPÍTULO VII: EL INSTITUTO RIBALTA, FUERZA

IMPULSORA DE LA CIENCIA Y LA EDUCACIÓN EN

CASTELLÓN (1880 - 1918).

1. EL INSTITUTO RIBALTA FUERZA IMPULSORA DE LA CIENCIA Y LA EDUCACIÓN EN CASTELLÓN (1880-1918)

1.1. LA APERTURA DEL CURSO EN EL INSTITUTO DE CASTELLÓN, UN ACONTECIMIENTO PÚBLICO.

2. LAS CONFERENCIAS DE LOS PROFESORES DEL INSTITUTO DE SEGUNDA ENSEÑANZA DE CASTELLÓN

3. LA DOCENCIA DE LAS CIENCIAS NATURALES EN EL INSTITUTO DE SEGUNDA ENSEÑANZA. PROFESORADO Y RECURSOS DE ENSEÑANZA-APRENDIZAJE

3.1. ALGUNAS BIOGRAFÍAS DESTACADAS DE LOS PROFESORES DE CIENCIAS NATURALES DEL INSTITUTO DE SEGUNDA ENSEÑANZA (1880-1918) ... 544

3.1.1. CATALINO ALEGRE 544

3.1.2. FRANCISCO DOMENECH BUESO 546

3.1.3. ANTIMO BOSCÁ SEYTRÉ. 549 
3.2. RECURSOS PARA LA ENSEÑANZA-APRENDIZAJE

UTILIZADOS POR LOS PROFESORES DE CIENCIAS

NATURALES: LIBROS, EXCURSIONES Y GABINETE DE

CIENCIAS NATURALES

3.2.1. Los libros de texto de Ciencias Naturales 550

3.2.2. Los libros de texto utilizados por los profesores de ciencias naturales del instituto de Castellón (1880 - 1918)

3.2.3. Las excursiones científicas 650

3.2.4. El Gabinete de Historia Natural del Instituto de Castellón 665

4. POLÉMICA EN LA IMPLANTACIÓN DE LA ESCUELA NORMAL DE MAESTRO.

CAPÍTULO VIII: UN EJEMPLO DE DEBATE CIENTÍFICO

EN TORNO AL DARWINISMO EN CASTELLÓN (1880-1909) 687

1. LA RECEPCIÓN DEL DARWINISMO EN ESPAÑA. 691

2. EL DARWINISMO EN VALENCIA 697

3. EL DARWINISMO EN CASTELLÓN .... .702

3.1. LA POSTURA ENFRENTADA DE CATÓLICOS Y REPUBLICANOS 708

4. CENTENARIO DEL NACIMIENTO DE DARWIN EN 1909 EN CASTELLÓN

\section{PARTE IV: HIGIENE, EDUCACIÓN SANITARIA Y COLONIAS} ESCOLARES.PROPUESTAS PARA CONSEGUIR UNA EDUCACIÓN INTEGRAL

CAPÍTULO IX: HIGIENE, SALUD Y EDUCACIÓN ESCOLAR 733

1. DE LA CARIDAD PÚBLICA AL RECONOCIMIENTO DEL DERECHO A LA EDUCACIÓN Y A LA SALUD POR PARTE DEL ESTADO. 
2. LAS PROPUESTAS DE LOS MÉDICOS HIGIENISTAS

PARA MEJORAR LA SALUD EN LA ESCUELA.

3. LA INTRODUCCIÓN DE LA INSPECCIÓN MÉDICO-

ESCOLAR EN EUROPA Y EN ESPAÑA

4. UN MODELO DE ESCUELA PARA CONSEGUIR UNA

EDUCACIÓN INTEGRAL

5. LA LEGISLACIÓN QUE REGULABA EN ESPAÑA LA

HIGIENE DE LOS EDIFICIOS ESCOLARES

6. LOS TRATADOS DE HIGIENE Y LA EDUCACIÓN

SANITARIA EN LA ESCUELA

7. SITUACIÓN DEPLORABLE DE LA ENSEÑANZA Y DE LA HIGIENE EN LAS ESCUELAS PÚBLICAS DE CASTELLÓN A FINALES DEL SIGLO XIX

8. MEJORA DE LA ENSEÑANZA EN CASTELLÓN EN LA

SEGUNDA DÉCADA DEL SIGLO XX

8.1. ANÁLISIS COMPARATIVO ENTRE LAS DISTINTAS

ESCUELAS Y ESTAS CON LA NORMATIVA VIGENTE.

9. ENTREVISTAS A MÉDICOS Y PERSONALIDADES EN LA

PRENSA DENUNCIAN LA TRISTE Y MÍSERA REALIDAD

DE LA INFANCIA

\section{CAPÍTULO X: LAS COLONIAS ESCOLARES EN}

CASTELLÓN

1. LA DIFUSIÓN DE LAS COLONIAS ESCOLARES EN

EUROPA

2. LAS COLONIAS ESCOLARES VALENCIANAS

3. GESTIÓN DE LA PRIMERA COLONIA ESCOLAR

CASTELLONENSE POR EL DOCTOR JOSÉ CLARÁ Y EL

INSPECTOR JOSÉ SENENT

3.1. PREPARACIÓN DE LA COLONIA.

3.2. LAS ACTIVIDADES EN LA COLONIA 855 
3.4. LA PRENSA SE INTERESA POR LA PRIMERA

COLONIA ESCOLAR EN CASTELLÓN. 863

3.5. DESARROLLO DE LA SEGUNDA Y TERCERA

COLONIA ESCOLAR 866

3.6. LOS BAÑOS ESCOLARES, OTRO MEDIO DE

DESARROLLAR LA SALUD. 869

3.7. LA ESCUELA-BOSQUE. 873

3.8. LAS COLONIAS ESCOLARES DESPUÉS DE 1918. 873 CONCLUSIONES 877

1. PRIMERA PARTE. SOCIEDAD URBANA. MODERNIDAD Y POLÍTICAS DE HIGIENE EN CASTELLÓN. 879

2. SEGUNDA PARTE: MEDICINA, ENFERMEDAD Y MUERTE EN CASTELLÓN .886

3. TERCER PARTE: EDUCACIÓN SECUNDARIA Y ENSEÑANZA-APRENDIZAJE DE LAS CIENCIAS NATURALES. EL DEBATE CIENTÍFICO SOBRE DARWIN .904

4. CUARTE: PARTE. HIGIENE, EDUCACIÓN SANITARIA Y COLONIAS ESCOLARES. PROPUESTAS PARA CONSEGUIR UNA EDUCACIÓN INTEGRAL 921

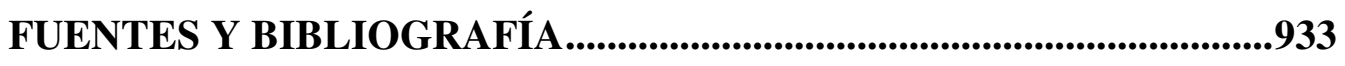

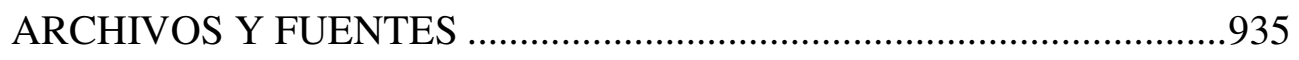

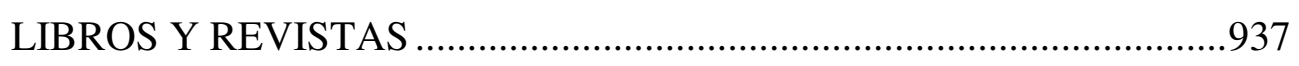

APÉNDICE DOCUMENTAL ........................................................................949 


\section{INTRODUCCIÓN}




\section{INTRODUCCIÓN}

En este trabajo de investigación estudiamos la evolución del urbanismo, la salud, la educación y el debate científico que se suscitó en el periodo estudiado en Castellón desde 1880 a 1918, periodo de amplias transformaciones hacia la modernidad, fruto del impulso de la Revolución Industrial en España y Castellón.

La temática elegida está condicionada por nuestra especialidad en Ciencias Naturales y por nuestra labor docente en el antiguo Magisterio y actualmente en el Departamento de Educación, donde impartimos Didáctica de las Ciencias Naturales y Educación para la Salud.

La elección de esta fase se basa en que entre 1880 y 1918, la ciudad de Castellón experimenta una serie de cambios económicos, demográficos, urbanísticas, sanitarias, etc., que le llevan a enfrentarse a nuevos retos en todos los campos de la sociedad. En estas transformaciones intervendrán grandes profesionales de la medicina, profesores, arquitectos, abogados, maestros/as que contribuirán a modernizar Castellón.

En el capítulo primero hacemos una introducción al área de estudio, puente de unión entre los siglos XIX y XX, que se desarrolla en el contexto de la ciudad burguesa y que experimenta importantes innovaciones que verán sus frutos en las primeras décadas del siglo $\mathrm{XX}$.

Estos cambios económicos, sociales, culturales y legislativos, que se venían gestando desde el nacimiento del Estado liberal, con el esfuerzo de políticos y la comprometida participación de intelectuales y profesionales, acabarán materializándose en importantes mejoras en todos los ámbitos de la vida social. Serán los avances en la higiene urbana, la salud y la educación, los aspectos que mas van a incidir en los cambios hacia la modernidad.

Un primer hecho fue el progresivo aumento de la población que se produjo gracias a la disminución de la mortalidad y la reducción de las enfermedades y epidemias al aumentar las medidas preventivas y las mejoras sanitarias. Otros dos factores característicos de este periodo que se producen en toda España, fue la regresión de la población rural y el crecimiento demográfico de la ciudad.

A partir del último tercio del siglo XIX, el País Valenciano experimenta una fuerte transformación tanto en el ámbito económico como en el aumento de 
productividad. Castellón, sin alterar su tradicional base agraria, realiza importantes cambios y modernizaciones, fruto del carácter emprendedor del agricultor castellonense y de la dinámica burguesa, sustituyendo cultivos tradicionales por otros más rentables y de marcado carácter exportación, como fue la plantación de viñedos y principalmente el naranjo, que pronto cubrió grandes superficies de las comarcas de la Plana. La fuerte demanda obligó a la progresiva mecanización e introducción de nuevos conocimientos técnicos para hacer una agricultura más dinámica, expansiva y productiva. De igual forma, la industria creció desde una doble vertiente, la auxiliar y derivada del sector agrícola, y la de larga tradición, como el sector cerámico, más concretamente el azulejero o el artesanal, todos ellos con constantes innovaciones técnicas y mano de obra especializada.

No cabe la menor duda que la capitalidad de Castellón fue decisiva para impulsar la vida económica y social de la ciudad. Pero la mejora en las infraestructuras era determinante para la consecución de estos objetivos. En este sentido, las fuerzas políticas, sociales y económicas aunaron esfuerzos para hacer llegar el ferrocarril a la Capital en fecha tan temprana como 1862, para la mejora y ampliación de la red de carreteras locales y nacionales abriendo nuevos mercados, o para conseguir las ayudas financieras necesarias para la construcción de un puerto comercial en el Grao de Castellón. Todo ello fomentó la inversión privada, instalandose un tranvía a vapor de vía estrecha, La Panderola, para enlazar los núcleos más productivos de la provincia con los puertos de Castellón y Burriana. Además de mercancías, este tranvia fue un importante medio de transporte para la movilidad interurbana de personas.

En la ciudad, las mejoras higiénicas, que supone la colocación de aceras y pavimentado de calles se inician a mediados del siglo XIX, sin embargo, las infraestructuras mas costosas y técnicamente mas complicadas, como la red de suministro de agua potable y el trazado del alcantarillado público se empiezan a instalar en las calles principales a partir de la última década del siglo XIX, completándose la ejecución del alcantarillado bien entrado el siglo XX. Para la evacuación de las aguas fecales y de lluvia de las viviendas se recurria a depósitos de letrinas y pozos ciegos.

También se realizaron mejoras en la higiene de los alimentos, con la construcción de un nuevo matadero o la cubrición de los mercados. Las ordenanzas de higiene intentaron frenar los focos infecciosos de ciertas prácticas. 
El fuerte crecimiento demográfico se materializa a finales del siglo XIX con la aparición de los primeros planes de ensanche y el desarrollo de los antiguos arrabales donde estaba asentada la población agrícola.

Los nuevos ensanches plantean un trazado en cuadricula de manzana cerrada, con calles anchas, rectas y bien orientadas, con unas ordenanzas que mejoran las condiciones higiénicas de las viviendas. Situados en la periferia, junto a la vía del tren, absorberán principalmente una población emigrante obrera no agrícola. El centro de la ciudad lo ocupará la burguesía, que realizara una importante transformación de la imagen urbana y proyectará también un ensanche en el extremo sureste de la ciudad, junto al nuevo Teatro Principal.

Del estudio de los distintos tipos de edificios que hay en la ciudad, la vivienda del agricultor es mayoritaria, tanto en el casco antiguo como en los arrabales. Suelen ser casas unifamiliares de una o dos plantas, con unas condiciones higiénicas muy deficientes, en donde las personas y el animal conviven en un espacio poco diferenciado, con un proceso de evolución y mejora lento, prolongándose las malas condiciones de habitabilidad en las primeras décadas del siglo XX. La vivienda de la clase burguesa se localiza en las calles y zonas más céntricas de la ciudad y exhibe desde el primer momento mejores condiciones de habitabilidad, que ira superando progresivamente. Junto a las nuevas casas unifamiliares de la clase social en ascenso, pronto surgen las viviendas por pisos de las clases acomodadas, edificaciones propias de una ciudad moderna.

Con la creación de las diputaciones los hospitales municipales pasan al gobierno y administración de la nueva institución. Es a partir de ese momento cuando el viejo Hospital de Trullos intensifica la actividad científica y asistencial.

Pero será la Instrucción General de Sanidad de 1904 la que plantea una importante modernización de la organización sanitaria y de la higiene pública, descentralizando la estructura sanitaria y reestructurando las juntas municipales y provinciales. También es el momento en el que se amplían las ordenanzas de policia urbana y aumenta el control de habitabilidad de las nuevas viviendas.

A finales del siglo XIX se está terminado de construir el nuevo Hospital Provincial, concebido como un edificio adaptado a las normas sanitarias imperantes, 
con una tipología en peine, a base de pabellones separados para alojar la hospitalización de los diferentes tipos de enfermos, procurando así el aislamiento y evitando la posibilidad de contagio.

También se ha hecho un estudio de la evolución de los centros educativos de primera y de segunda enseñanza en la ciudad de Castellón, en base a los cambios normativos, el modelo educativo, el tipo de edificio escolar y su emplazamiento en la cuidad. Para ello se han confeccionado una tabla y varios planos, donde se resumen estas transformaciones y mejoras en el espacio y en el tiempo.

La tabla refleja que hasta la última década del siglo XIX no se crea ninguna escuela nueva, manteniéndose las que habían antes del último tercio del mismo siglo, siendo la mayoría de ellas de finales del siglo XVIII. A partir de los últimos años del siglo XIX es cuando empiezan a surgir nuevas escuelas-habitación generalmente en locales alquilados. A finales de la primera década figuran ya grupos escolares de nueva construcción municipal. En la década siguiente surgen más grupos escolares, desapareciendo progresivamente las escuelas más antiguas. Los planos confeccionados reflejan la evolución y crecimiento de las escuelas, su localización en la ciudad, y como los nuevos grupos escolares se van desplazando del centro urbano a la periferia.

Tanto el esfuerzo del Ayuntamiento, como el trabajo de la Comisión de Instrucción Primaria, fueron decisivos para la consecución de estas mejoras. También los docentes y la opinión de la prensa ejercieron su influencia.

La demanda social de una mejor calidad en las condiciones de vida, unida a las reivindicaciones de médicos higienistas para sanear y purificar el ambiente ante la creciente situación de insalubridad de las ciudades, hace que los poderes públicos empiecen a crear pulmones verdes en las ciudades. Además de la función higiénicosanitaria y medio-ambiental, los jardines de la ciudad decimonónica cumplen otras funciones básicas que actúan en la higiene mental, como es la función recreativa o de esparcimiento y la didáctico-educativa, además de ser elemento emblemático y motor de prestigio y ostentación de la ciudad.

En este sentido, la creación del parque Ribalta supuso un impulso innovador para Castellón y una iniciativa de modernidad. Responde al cambio de mentalidad urbana par satisfacer una serie de exigencias de tipo recreativo e higiénico. 
Se trata de una zona verde de nueva creación y promoción municipal que se empezó a configurar a partir de 1868. El parque Ribalta, el más paradigmático del País Valenciano, está formado por un conjunto de jardines-paseo de estilo romántico y carácter paisajistico, que aún cumple muchas de las funciones por la que fue creado, propias de los parques decimonónicos.

\section{HIPÓTESIS}

Pretendemos demostrar qué parámetros de cambio social se dan en la ciudad de Castellón entre 1880 y 1918 que la conducen hacia la modernidad ${ }^{1}$. Para ello, estudiamos los cambios demográficos, los sectores productivos y las transformaciones urbanas.

Nuestro propósito es averiguar las condiciones higiénicas y sanitarias de la ciudad de Castellón y sus comarcas, así como la actuación de los ayuntamientos, prensa e instituciones provinciales frente a estos problemas, dentro del marco del País Valenciano y España.

También nos interesa indagar en las infraestructuras urbanas y en el estudio de la habitabilidad de los diferentes tipos de vivienda, para relacionarlas con la higiene y con las enfermedades en Castellón.

Los factores que de modo más evidente intervienen en el estado de salud de una población, unos son de tipo biológico (infecciosos, toxicológicos, genéticos, inmunitarios, raciales...) y otros son susceptibles de un análisis demográfico, como sucede con la correlación entre la estructura demográfica y el patrón epidemiológico de esa población. Pero también la organización social del trabajo desempeña un papel

\footnotetext{
${ }^{1}$ Según los historiadores la modernización es el proceso general de ruptura y transformación de las estructuras sociales, de las formas de vida y de los valores que se producen en Europa entre 1830 y 1870. Entendemos aquí por modernidad aquella forma de vida caracterizada por un proceso de desarrollo económico y social sustentado por la fuerza de un proceso industrializador que ha facilitado mejores estándares de vida, una creciente urbanización de la vida social, un proceso de democratización y secularización que desplaza los viejos modos de relación política clientelar y el peso de la Iglesia en los modos de pensar y vivir de la sociedad. Veánse MONLLEÓ PERIS, Rosa (2007): «Cultura urbana femenina y espacios de ocio en Castellón a finales del siglo XIX», en Dossiers Feministes 10. Espais de Bohèmia. Actrius, cupletistes i ballarine. Seminari d'Investigació Feminista. Universitat Jaume I.; SUÁREZ CORTINA, Manuel (2007): «Sociedad, cultura y política en la España de entre siglos», en SALAVERT FABIANI, Vicente y SUAREZ CORTINA, Manuel (eds.): El regeneracionismo en España. Política, educación, ciencia y sociedad. Universidat de València.
} 
fundamental: las condiciones laborales, el desarrollo o subdesarrollo tecnológico, las condiciones de vida de la población, la vivienda en la ciudad o el medio rural, las pautas de conducta frente a la conservación de la salud, las costumbres y las construcciones culturales de la enfermedad. Todo ello constituye un conglomerado de referentes y situaciones de riesgo o de protección de la salud, que a veces se asocian a un grupo o clase social o pueden relacionarse tal vez con situaciones de marginación.

En este contexto pretendemos analizar cualitativa y cuantitativamente la incidencia de las enfermedades que con mayor frecuencia afectaron a la ciudad de Castellón y cómo repercutió en la población una enfermedad endémica como el paludismo.

Investigamos la epidemia del cólera de 1885 en la ciudad y si la vacuna de Ferrán fue aceptada por la sociedad castellonense. Este capítulo es extenso porque no sólo analizamos cualitativa y cuantitativamente las muertes y afectados en la ciudad de Castellón, sino que lo ampliamos a toda la provincia. Hacemos análisis diario de las medidas sanitarias, nos interesa demostrar si está o no avanzada la medicina en España.

También nos ha interesado estudiar la repercusión de la epidemia gripal del año 1918 en Castellón y como fue vivida por sus habitantes.

Nos parece importante averiguar los remedios que se proponen en la medicina popular para el tratamiento de las enfermedades y estudiar el conocimiento científico de los profesionales de la medicina de Castellón. Nos interesa conocer la labor del Inspector Provincial de Sanidad, doctor José Clará, en relación con la salud.

En el orden educativo analizamos la aportación del Instituto de Segunda Enseñanza de Castellón al conocimiento de las Ciencias Naturales. Estudiamos la metodología científica que desarrollaron los profesores del Instituto: Catalino Alegre, Francisco Domenech y Antimo Boscá. Para ello hemos recogido las excursiones didácticas realizadas por estos profesores para que sus alumnos conocieran el Medio Natural; examinamos el material empleado en la enseñanza-aprendizaje de las Ciencias Naturales y, sobre todo, nos ha parecido interesante, averiguar si los libros de texto de dicha ciencia, que utilizaban los profesores, recogen las corrientes científicas europeas del momento.

Asimismo averiguamos la influencia que tuvieron los profesores del Instituto de Segunda Enseñanza en la sociedad castellonense con su participación en conferencias y 
debates sobre mejoras de la ciudad o políticas como la guerra de 1914: Catalino Alegre, Francisco Domench, Antimo Boscá, José Salinas, Miguel Martí Blat, José Albiñana...

También nos ha interesado analizar la polémica que se originó en Castellón por la negación de la Diputación de Castellón a crear la Escuela Normal de Maestros.

Otra hipótesis que pretendemos demostrar es que los intelectuales y científicos de Castellón mayoritariamente profesaban una ideología republicana que valoraba los nuevos avances científicos, entre ellos el darwinismo. Analizamos los debates científicos que estos intelectuales organizaron en Castellón, así como también los que profesaban otras ideas políticas como los liberales y los carlistas, en los espacios de sociabilidad para la ciudadanía.

Analizamos la polémica que se estableció en Castellón con el centenario del nacimiento de Darwin y estudiamos quienes aceptaron las teorías evolucionistas, y si, concretamente, el profesor del Instituto de Segunda Enseñanza, Catalino Alegre, aceptaba y enseñaba la teoría evolucionista a sus alumnos.

Una hipótesis que intentamos investigar es si Castellón, como ocurría en Europa y España, promueve actividades para elevar la salud de los niños y niñas menos favorecidos socialmente. Estudiamos el papel que tuvieron los médicos y pedagogos en la educación para la salud y la organización de actividades para promocionarla, como fueron las Colonia escolares, la Escuela bosque y los Baños de mar.

Otra de las hipótesis que hemos pretendido investigar es que Castellón y su provincia en estadísticas oficiales aparecen en los últimos lugares en alfabetización en Educación Primaria, cuando económicamente no era una provincia de las menos desarrolladas, por ello examinamos el estado de las escuelas a finales del siglo XIX hasta 1918 en la ciudad de Castellón, centrándonos preferentemente en las condiciones higiénicas y en la adecuación a la normativa vigente. El trabajo se ha centrado en la capital, dado que el estudio de las comarcas desbordaba y hacía excesivamente extensa este trabajo de investigación.

Nos ha parecido interesante analizar la labor de las personalidades de Castellón para que se establecieran en la ciudad las cantinas escolares, los roperos y la gota de leche.

Un estudio interesante ha sido averiguar la labor desarrollada del Inspector de Primera enseñanza, José Senent y el Inspector Provincial de Sanidad, José Clará, en la organización de las colonias escolares castellonenses. 


\section{FUENTES.}

En cuanto a las fuentes primarias, la prensa de Castellón de los años 1880-1918 nos ha ofrecido una información muy amplía que nos ha permitido empatizar con la sociedad de la ciudad. La lectura detenida de todos esos años, nos ha llevado a descubrir temas de gran interés para el estudio que nos proponíamos como, el estado de la higiene en las calles y en las casas, de los alimentos y del agua en la ciudad; la incidencia de las enfermedades que con mayor frecuencia afectaron a Castellón y sus comarcas, así como la actuación de los médicos ante éstas. Destaca sobre todo la información diaria de las epidemias del cólera de 1885, en La Provincia y en la Revista Médico-Farmacéutica, y la de la gripe de 1918, en El Clamor.

Otro tema importante de nuestra investigación ha sido la polémica que hubo en Castellón, desde 1882 hasta 1911, en torno al darwinismo y que hemos podido seguir gracias a diversos periódicos de la época: El Clamor, La Provincia, La Cruz de Castellón, El Cruzado, Revista de Castellón, Diario de la Plana, La Verdad y El Heraldo de Castellón, ha sido la prensa donde más información hemos obtenido de los debates darwinianos.

Es de destacar la gran suerte que hemos tenido al encontrar en el año 1914 en el periódico El Clamor la descripción realizada de las escuelas públicas de la ciudad, que nos ha servido para averiguar el estado de la enseñanza primaria en Castellón y del estado de la higiene de las mismas. También aparecen publicadas en el mismo periódico y en el mismo año intensas y completas entrevistas a médicos, abogados y sacerdotes, donde expresan lo que pensaban sobre la situación de la infancia en la ciudad.

En educación nos hemos encontrado también en La Provincia como en El Clamor, las descripciones de las excursiones a diferentes ecosistemas de Castellón que realizaban los profesores de ciencias naturales del Instituto de Enseñanza Secundaria, así como también, las conferencias sobre diversos temas que daban en los centros de sociabilidad de la ciudad, en donde se aprecia el ambiente de renovación en la enseñanza de nuestros intelectuales. En el periódico El Clamor y en la revista La Escuela, hemos encontrado información del desarrollo de las primeras colonias escolares castellonenses.

Para el análisis comparativo de las enfermedades que tuvieron lugar a finales del siglo XIX y principios del siglo XX una fuente primordial ha sido la consulta, en el 
Instituto Nacional de Estadística, de los Anuarios y los movimientos Naturales de Población, encontrándonos con algunos inconvenientes, como fue no disponer de la información relativa a todos los años del periodo estudiados.

También ha sido útil para nuestra investigación el Archivo de la Diputación Provincial, donde se conserva la colección completa de los boletines desde 1834 hasta nuestros días. Nos ha servido para consultar las circulares que enviaban los gobernadores a los alcaldes y subdelegados de Sanidad de la provincia de Castellón, comunicándoles lo que el Ministro de la Gobernación ordenaba. Pudimos también extraer los datos que figuran sobre la marcha de la epidemia de cólera en Castellón de la Plana y sus comarcas.

Asimismo se han consultado varias colecciones fotográficas de la época de estudio, entre ellas el Archivo Más, que conserva la Diputación Provincial de Castellón.

Otra fuente digna de destacar ha sido el libro de Actas del Ayuntamiento de Castellón. Hemos consultado las colecciones completas desde 1868 hasta 1918, que se conservan en el Archivo Histórico Municipal. Para nuestro estudio, han tenido particular interés las sesiones correspondientes a los acuerdos tomados sobre higiene y medidas contra las propagaciones de las epidemias de 1885 y 1918.

En el mismo Archivo Municipal hemos consultado los expedientes de Instrucción Pública corespondientes a los centros escolares de Castellón desde 1880 a 1930, que nos ha servido para estudiar la evolución y el estado de las escuelas en la ciudad.

También hemos examinado, en dicho Archivo, los expedientes de solicitud de permisos de obras, desde 1857 a 1940, para conocer la habitabilidad e higiene de las viviendas.; asimismo para ver algunas ordenanzas de urbanismo e higiene de la Capital, hemos accedido al Boletín Oficial de la Provincia que guarda el Archivo Municipal de Castellón.

En el Archivo Histórico del Colegio Territorial de Arquitectos de Castellón, hemos encontrado trabajos relacionados con tipologías de viviendas de antiguos barrios de la ciudad.

La Guias oficial de Castellón y Provincia, de 1890 a 1920, nos ha servido de orientación para conocer la localización de las escuelas municipales y privadas; los maestros y maestras que impartían la docencia; las instituciones y los profesionales. 
De gran interés para completar nuestros datos ha sido el hallazgo, en el Archivo de la Biblioteca Municipal, de tres tomos del Boletín de Estadística Municipal de Castellón, que nos ha servido para recoger los datos de mortalidad en la ciudad de 1914 a 1918, causada por diferentes enfermedades incluida la epidemia de gripe, que seguramente el Ayuntamiento publicó de manera extraordinaria por la situación que creó la gripe.

Para nuestra investigación educativa hemos consultado el Archivo Central del Ministerio de Educación y Cultura de Madrid. El Archivo ha sido de suma importancia para nuestra investigación porque hemos recopilado gran información de una serie de libros de higiene, escritos por médicos de la época de estudio, en los que aparece el estado de la higiene escolar y la salud de los niños y niñas.

En el Archivo Histórico del Instituto de Enseñanza Media de Castellón hemos consultado las Memorias de los años 1863-1918. En ellas se describe la naturaleza de los diferentes puestos de trabajo que ocupaba el profesorado, el material de los laboratorios, la compra de libros para la biblioteca, las notas y los premios otorgados al alumnado.

También hemos podido consultar los expedientes personales de los profesores del Instituto que ejercían en los años de estudio: Domingo Herrero, Catalino Alegre, Francisco Boscá, Antonio Maylin...

Para obtener información legislativa de la Enseñanza Primaria y Enseñanza Secundaria consultamos, en este archivo, los tomos I y II del libro titulado Compilación Legislativa de Instrucción Pública. (1878).

Referente al edificio que alberga el Instituto ha resultado de gran utilidad la consulta sobre la historia de su construcción en la documentación que consta en el archivo, como son los Planos originales y las Memorias técnicas.

Una parte de este archivo custodia los libros de texto utilizados en la enseñanza por el profesorado, lo que nos ha permitido la consulta y análisis del libro de Sandalio de Pereda y Martínez (1870): Programa razonado de un curso de Historia natural con nociones de Fisiología e Higiene.

El segundo libro que analizamos es de Emilio Ribera Gómez (1897), titulado: Elementos de Historia Natural. Éste libro lo hemos encontrado en el Archivo de la Biblioteca Municipal de Castellón. 
Además, en el Archivo Central del Ministerio de Educación de Alcalá de Henares hemos encontrado los expedientes personales de los profesores de ciencias naturales Catalino Alegre, Francisco Domenech y Antimo Boscá.

Por otra parte, la buena catalogación del Archivo Histórico del Colegio de Médicos de Castellón, nos ha sido muy útil como fuente de consulta, para ver el ritmo de colegiación, la relación de médicos con el número de habitantes, y las biografías destacadas de los profesionales de la medicina en Castellón durante el periodo de estudio.

En el Centro de la Memoria Histórica de la Universidad Jaume I de Castellón, hemos realizado consultas para completar las biografías de algunos profesionales de la medicina, y ver los expedientes del Tribunal Especial de Represión de la Masonería y el Comunismo contra algunos de estos profesionales.

También nos ha parecido interesante ver los planos y croquis del emplazamiento de la «Casa Hospedaje» de las colonias escolares castellonenses, por eso nos hemos desplazado al Archivo Histórico del Ayuntamiento de Lucena del Cid.

Nos han sido de gran utilidad para empatizar con la sociedad y estudiar los temas que investigamos: urbanismo, higiene, enfermedades y educación, los libros clásicos de consulta obligada por los historiadores cuando inicia un estudio, y contextualizarlo en la ciudad de Castellón en los siglos XIX y XX.

Bernardo Mundina escribe: Historia, Geografía y Estadística de la provincia de Castellón (1873). En este libro nos habla del Hospital Provincial, del Instituto Provincial, del colegio de niños huérfanos de San Vicente Ferrer...

Juan Antonio Balbás es el autor de El libro de la Provincia de Castellón, (1892), en su libro nos habla de la peste de 1647 y 1648, de la Instrucción Primaria, Instituto de Segunda Enseñanza de Castellón: creación, número de alumnos directores que tuvo el Instituto, material de enseñanza de Historia Natural, de Fisica y Química y de Agricultura.

Pascual Madoz publicó: Diccionario Geográfico-Estadístico-Histórico de Alicante, Castellón y Valencia, nos ha sido muy útil por la información que nos proporciona sobre historia, profesiones, edificios públicos, escuelas enfermedades como el paludismo, etc.

Carlos Sarthou Carreres escribió: Geografía General del Reino de Valencia (1913), el valor de la obra consiste en el contenido de una extensa información sobre 
distintos aspectos de Castellón y sus comarcas que nos ha servido para introducirnos en la geografía, población, planos de la ciudad, calles, edificios públicos, iglesias, etc.

Vicente Gimeno Michavila publica Del Castellón Viejo (1926), que nos pone en antecedentes sobre las fechas de las principales fundaciones y mejoras realizadas en Castellón, la Enseñanza Primaria en tiempos pasados; sobre los antecedentes del Teatro Principal, sobre el benefactor Bermúdez de Castro, los cementerios de Castellón, médicos beneméritos de siglos pasados y su actuación ante las enfermedades infecciosas, el alumbrado público, etc.

En las cuestiones educativos nos han sido de gran interés los libros de higiene escolar escritos por médicos de la época de estudio, entre otros destacamos: a Jules Delobel (1876): Higiene escolar; Joaquín Chillida Meliá (1882): Higiene de las escuelas; Vicente Miró Laporta, (1899): Higiene y Educación del niño; Eduardo Masip Budesca (1910): Higiene Escolar; Juan Rosado Fernández, (1913): Tratado Enciclopédico de Higiene y terapéutica Escolar, Doméstica y Social.

Y Para estudiar la primera colonia escolar castellonense ha sido muy importante la obra de Juan José Senent Ibáñez: Memoria de la Primera Colonia Escolar Castellonense en Lucena del Cid. 20 de julio a 20 de agosto de 1915.

Entre la bibliografía actual que más nos ha servido para trabajar los capítulos del trabajo de investigación podemos citar los que a continuación nombramos:

Para el urbanismo, el libro de Eugenio L. Burriel de Orueta (1971): «Desarrollo urbano de Castellón de la Plana», y el de Francisco Quirós (1991): Las ciudades españolas a mediados del siglo XIX.

Para infraestructuras y transportes, la publicación coordinada por Javier Torlá Valls (2003): Rumbo al progreso. El puerto de Catelló a través de la historia; y el libro que coordina Inmaculada Aguilar Civera (2013): Castellón, un territorio en comunicación. De la diligencia al TRAM.

Para la vivienda la serie dirigida por Joan F. Mira (1983): Temes d'etnografía valenciana.

Para la historia de Castellón, el libro dirigido por Manuel Chust (1992): Historia de Castellón.

Dentro del capítulo dedicado al estudio de la higiene y las enfermedades nos ha sido de gran apoyo las diversas publicaciones de José María López Piñero y Josep Lluís Barona Vilar. Asimismo nos hemos servido para estudiar la demografía en España de la 
obra de Vicente Pérez Moreda: «La crisis de mortalidad en la España interior. Siglos XVI. XIX y la obra publicada por Albert Carreas y Xavier Tafunell (Coord) titulada: Estadísticas históricas de España: siglos XIX-XX.

Para la histotia de la ciencia la obra coordinada por José Manuel Sánchez Ron (1998) titulada: Un siglo de ciencia en España.

En las cuestiones educativas ha sido de gran interés el libro de Capitán Díaz (1994): Historia de la Educación en España; el de Buenaventura Delgado Criado (Coord.) (1994): Historia de la educación en España y América Volumen 3, y la Revista: Historia de la Educación. Revista interuniversitaria, Núm.16, 1997. También, la tesis publicada de Nieves Hernández (2009): La evolución de las Ciencias Naturales en la Segunda Enseñanza Española (1836 - 1970), para estudiar los textos de Ciencias Naturales.

\section{METODOLOGÍA}

La metodología empleada para poner a prueba las anteriores hipótesis, parte de una rigurosa investigación de las fuentes utilizadas (documentación específica sobre el tema encontrada en archivos nacionales, provinciales y locales; colecciones legislativas; bibliografía; datos estadísticos; prensa; revistas...

A través de todos los documentos sacados de estas fuentes, hemos procurado realizar un análisis minucioso y crítico de cada uno de ellos con el fin de conocer con detalle la finalidad, las ideas y actuaciones y los intereses socio-culturales que confluyeron en el desarrollo de los acontecimientos investigados.

Teniendo en cuenta las aportaciones del materialismo histórico y de la Escuela de los Annales, hemos llevado a cabo unos supuestos metodológicos en nuestra investigación. Hay que destacar además que desde los años 80 del siglo XX han penetrado en España las nuevas corrientes historiográficas (Stone, microhistoria, tercera generación de los Annales, escuela marxista inglesa) que dan el mismo espacio de importancia a los aspectos económicos y a los ideológicos y culturales, por lo que los estudios sobre educación y su importancia social han cobrado nuevo auge para entender la sociedad y sus diferentes elementos de una forma más globalizada. Estas nuevas corrientes han emparentado y colaborado con otras ciencias sociales como la antropología, la sociología y la psicología. 
Partiendo de las tendencias historiográficas anteriormente citadas, hemos pretendido compaginar los siguientes métodos de investigación:

ANALÍTICO: Realizando una crítica externa de los documentos utilizados, así como de la procedencia y clasificación de los mismos para poder analizar el significado de cada texto según el contexto histórico en que está situado.

SINTÉTICO: A través del estudio global de los acontecimientos históricos, de sus causas y consecuencias hemos podido obtener una imagen global que nos ha hecho entender la realidad de lo acontecido.

DIALECTICO: Con este planteamiento, se ha pretendido realizar el estudio de las relaciones y la asociación de los acontecimientos y las ideas, teniendo en cuenta las coincidencias, contradicciones e intereses que subyacen debajo de las ideas y de los hechos.

ESTRUCTURAL: Este método nos ha permitido el estudio integrado de todas las actividades humanas, lo que facilita la comprensión interactiva de los aspectos político, social, económico, cultural y especialmente educativo.

CRONOLÓGICO: El encuadre cronológico ayuda a situar las ideas sociales y educativas en el tiempo histórico en que se desarrollan como consecuencia de un proceso iniciado en décadas anteriores.

CUANTITATIVO: Hemos aprovechado los datos obtenidos a lo largo de la investigación para establecer gráficos, porcentajes y cifras absolutas y relativas.

COMPARATIVO: La información y los datos obtenidos nos han permitido hacer una comparación con los obtenidos por otros autores que realizaron este mismo estudio aplicado a otras provincias de España y del País Valenciano. 


\section{PARTE I: SOCIEDAD URBANA, MODERNIDAD Y POLITICAS DE HIGIENE EN CASTELLON}


Castellón hacia la modernidad. Salud, educación y debate científico (1880-1918)

Parte I 


\section{CAPÍTULO I: DESARROLLO URBANO EN CASTELLÓN DURANTE EL SIGLO XIX Y PRINCIPIOS DEL XX}




\section{LA DINAMICA POLITICA Y SOCIOECONÓMICA DE CASTELLÓN}

El proceso revolucionario liberal de mediados del siglo XIX provocó en Castellón la sustitución casi completa de la oligarquía urbana borbónica que había regido la villa durante el siglo XVIII, por una burguesía mercantil y una clase media compuesta por pequeños propietarios, artesanos, profesionales liberales, funcionarios y maestros, con el naciente proletariado. Algunos de ellos, sobre todo después de la desamortización, fueron adquiriendo patrimonio rústico que aumentaron sus niveles de riqueza. ${ }^{2}$ La creación de la Liga de Contribuyentes en 1875, o del Círculo Mercantil en 1886 son ejemplos del dinamismo de esta pujante burguesía. ${ }^{3}$

En el último tercio del siglo XIX, pasado el largo proceso del asentamiento de la revolución liberal, sentadas las bases del cambio, se dio además una consolidación socioeconómica y afirmación social, un nuevo planteamiento político condicionado por la experiencia democrática del Sexenio y por el conservadurismo positivista que reinaba en Europa, que se tradujo en un juego de concesiones recíprocas entre el partido conservador de Cánovas del Castillo y el partido liberal constitucional de Sagasta, que garantizara la estabilidad y la dinámica del turnismo. Hasta el extremo que se aceptó por parte del partido progresista el «caciquismo» y el sufragio censitario masculino hasta 1890, con el objetivo de hacer posible aquella realidad. Quedaron fuera del sistema de turnos los carlistas, republicanos y partidos obreros.

En la ciudad de Castellón, el grupo conservador de la Restauración estuvo representado por el «cossi», nombre relacionado con los políticos de la Unión Liberal y que se mantuvo durante la Restauración ya que desde la época isabelina controlaba la mayoría de las instituciones públicas de la provincia, intentando beneficiarse del control administrativo.

En este periodo será Victorino Fabra quien organizará el sistema de control político de Castellón en relación con el duque de Tetuán en Madrid. De esta forma consiguió perpetuarse en el poder provincial, controlando la Diputación hasta 1893. A

\footnotetext{
2 MARTí Manuel (1992): «La Restauración», en ORTELls CHABRERA, Vicente (dir.), La Ciudad de Castellón, Ayuntamiento de Castellón, p. 535.

3 MONLLEÓ PERIS, Rosa (1998): «Del Sexenio democrático a la Guerra Civil», en ORTELLS CHABRERA, Vicente (dir.), La Ciudad de Castellón, Ayuntamiento de Castellón, p. 290.
} 
lo largo de la Restauración el grupo «cossi» atravesó diversos pactos y alianzas condicionadas por los cambios de la política general y por la evolución específica de la política provincial. Durante los primeros años de la Restauración se identifica con el partido de Cánovas y adopta el nombre de partido liberal conservador. A partir de 1881, siendo presidente de la Diputación y con el paso del duque de Tetuán a las filas liberales, favoreció su transformación en partido liberal fusionista, abandonando a sus socios los conservadores y siguió siendo el único interlocutor fiable del poder central. ${ }^{4}$

Desde 1891, en que con el sufragio universal copan los votos municipales los republicanos, vuelven a identificarse con el partido conservador. Otros personajes políticos destacados de este grupo fueron Domingo Herrero, Ruiz Vila, Carlos Ferrer.

Para la historiadora Rosa Monlléo ${ }^{5}$, los republicanos, al estar fuera del turno de partidos, tuvieron más éxito en cambiar las costumbres tradicionales y modos de pensamiento, que en modificar las instituciones y política gubernamental de la Monarquía. Su proyecto político era muy ambicioso: modernizar y democratizar España. Las iniciativas sociales y culturales de los republicanos contribuyeron decisivamente a despertar y educar la conciencia de las clases bajas. Sus manifestaciones extrapolíticas tenían gran poder de convocatoria popular interclasista: actividades educativas y culturales en ateneos, casinos o casas del pueblo lograron dar una alternativa al caciquismo. Por su poco peso en la política nacional tomaron como espacio de actuación la política municipal. Dentro de este contexto Francisco González Chermá y Fernando Gasset Lacasaña, fueron los dos líderes indiscutibles del partido republicano en la ciudad de Castellón. Aunque ambos tenían estrategias personales diferentes, llenaron casi setenta años de la vida política de Castellón, cuya característica predominante fue sin apenas solución de continuidad la prepotencia política del partido republicano. Francisco González Chermá incorporó a las clases populares de Castellón el discurso político del partido republicano y Fernando Gasset completó el carácter interclasista de este partido con la incorporación de las clases medias de profesionales y burguesía.

Con el establecimiento del sufragio universal masculino en 1890, la opción republicana se convierte en fuerza incuestionable en la ciudad de Castelló durante todo

\footnotetext{
${ }^{4}$ MARTÍ, Manuel (1992): op. cit., pp. 531-533.

5 MONLLEÓ PERIS, Rosa (1999): op. cit. p. 292.
} 
el periodo restauracionista. Teniendo también representación en la Diputación provincial.

Otros líderes republicanos que lucharon por mejorar las condiciones de la ciudad: José Antonio Balbás, Gaetà Huguet, Enrique Perales, Carlos Selma, Vicente Gea, Emilio Santa Cruz, José Forcada, Alvaro Pascual, Gimeno Michavila, Manuel Peláez. Algunos de los anteriores, y de los aquí citados, muchos de ellos abogados, médicos, docentes, cronistas o empresarios, son protagonistas en el presente trabajo de investigación.

La población castellonense crece en el periodo 1700-1900 al mismo ritmo que lo hace todo el País Valenciano, con un ciclo de cincuenta años de fuerte alza a partir de 1720, moderación a partir de 1770 y estancamiento o lento avance hasta 1840 , en que se reanuda gradualmente el crecimiento. Pero este desarrollo fue desigual en tierras castellonenses, mientras los municipios de la Plana se asemejan a los parámetros de toda la franja litoral, llegando a duplicar la población, las comarcas de interior se alejan progresivamente de estas pautas, situación que viene ya de atrás. ${ }^{6}$

En el transito del siglo XIX al XX, el progresivo aumento de la población total en España se produjo gracias a la disminución de la mortalidad y la reducción de las enfermedades y epidemias al aumentar las medidas preventivas y las mejoras sanitarias. ${ }^{7}$

En la última década del siglo XIX España se incorpora al régimen moderno de población. Otros dos fenómenos característicos de este periodo fueron la regresión de la población rural y el crecimiento demográfico urbano.

Castellón experimenta también este fenómeno fruto de las transformaciones económicas y sociales que se dan en todas las ciudades de España, sobre todo en aquellas que recae la responsabilidad de ser el eje administrativo de las comarcas de alrededor. Los habitantes de las poblaciones del interior, de las comarcas de Teruel y de distintos lugares de Castilla fueron los que más emigraron a la ciudad de Castellón.

\footnotetext{
6 PIQUERAS ARENAS, José Antonio (2013): «El lento paso hacia la modernidad: economía y transformaciones desiguales en el siglo XIX», en AGUILAR CIVERA, Inmaculada (coord.) Castellón, un territorio en comunicación: de la diligencia al TRAM, Valencia, Consellería d'Infraestructures, Territori i Medi Ambient, Generalitat Valenciana, p.113.

${ }^{7}$ MONLLEO PERIS, Rosa (1999): op. cit., p.287.
} 
Tabla 1 Evolución demográfica de la ciudad de Castellón

\begin{tabular}{|c|c|c|}
\hline Año & Habitantes & $\begin{array}{c}\text { Incremento } \\
\text { anual }\end{array}$ \\
\hline 1860 & 20.123 & 0,27 \\
\hline $\mathbf{1 8 7 7}$ & $\mathbf{2 3 . 3 9 7}$ & $\mathbf{0 , 9 5}$ \\
\hline $\mathbf{1 8 8 7}$ & $\mathbf{2 5 . 1 9 3}$ & $\mathbf{0 , 7 7}$ \\
\hline $\mathbf{1 9 0 0}$ & $\mathbf{2 9 . 9 0 4}$ & $\mathbf{1 , 4 4}$ \\
\hline $\mathbf{1 9 1 0}$ & $\mathbf{3 2 . 3 0 9}$ & $\mathbf{0 , 8 0}$ \\
\hline 1920 & 34.457 & 0,66 \\
\hline 1930 & 36.781 & 0,67 \\
\hline 1940 & 46.876 & 2,74 \\
\hline
\end{tabular}

Fuente: Agustí Segarra, «Evolución demográfica de Castelló de la Plana (1857-1936)». Boletín Sociedad Castellonense de Cultura, tomo LXII, 1986, p.146.

El último tercio del siglo XIX la sociedad castellonense experimenta una fuerte transformación tanto en el ámbito económico como en el aumento de productividad.

Sin alterar su base agraria, que es el sector predominante desde su fundación, algunos cultivos de larga tradición, como el cáñamo, entraron en crisis, siendo sustituidos por otros más rentables y de fuerte exportación, como la naranja -«la gallina de los huevos de oro», en expresión de Joan Fuster- fenómeno que no fue ajena la dinámica burguesía y el carácter emprendedor del agricultor castellonense, con su capacidad de adaptación a los cambios coyunturales.

También juega un papel predominante la mayor plantación de viñedos, en un momento en que la filoxera hace estragos en Francia, lo que produce una subida de precios del vino por el aumento de su exportación a Europa, obteniendo sustanciales ganancias, aunque años más tarde también experimentaremos la misma crisis con este cultivo. La progresiva mecanización y la aplicación de los nuevos conocimientos técnicos, como consecuencia de la fuerte demanda, propiciaron una agricultura más dinámica, expansiva y productiva, con unas relaciones capitalistas bien asentadas. ${ }^{8}$

De igual forma, la industria creció de forma paralela desde una doble vertiente: por un lado, con la expansión de determinados subsectores con larga tradición, como el cerámico o el artesanal y por otro, con la aparición de industrias destinadas a satisfacer

\footnotetext{
${ }^{8}$ MOLLEÓ PERIS, Rosa (1999): op. cit, p.287.
} 
las nuevas necesidades, entre las que destaca la industria auxiliar del sector citrícola y derivados de la vinícola.

En este proceso de producción todavía se mezcla el trabajo de artesanía con el de fábrica, pero esta le va ganando la partida al introducirse progresivamente las máquinas de vapor o la elaboración de abonos químicos, que no solo abastecen la provincia de Castellón, sino que también se envía a las riberas del Turia y del Júcar. ${ }^{9}$ El sector servicios también experimenta un acusado auge, por su condición administrativa de capital de provincia y el consiguiente aumento de población y la diversificación de funciones.

Todo este proceso dinamizador de la economía castellonense necesitaba de una adecuada infraestructura física y financiera para hacer realidad estos sectores económicos. Conscientes de ello, los castellonenses emprendieron una serie de iniciativas, fruto de las cuales serían la mejora y ampliación de las comunicaciones internas y externas mediante una red de carreteras y ferrocarriles, la construcción de puertos marítimos y la ampliación del sistema financiero, materializado en la expansión de la banca por tierras castellonenses.

La creación de la Liga de Contribuyentes en 1875, del Círculo Mercantil en 1886 y posterior nacimiento, en el año 1905, de la Cámara Oficial de Comercio, son ejemplos del dinamismo de la pujante burguesía mercantil y que fueron decisivas para impulsar los intereses económicos de los sectores agrícola, industrial y comercial. ${ }^{10}$

La agricultura castellonense de mediados del siglo XIX no difiere gran cosa de la de finales del siglo anterior. En el secano dominaba la vid, el algarrobo, el olivo y los cereales y en cuanto al regadío continuaban los productos hortícolas, cereales, frutas, y cáñamo. Pero desde mediados del XIX un nuevo cultivo, el naranjo, se extiende por el regadío de la Plana, principalmente en Villarreal Burriana y Almazora, no entrando en Castellón, en donde el cáñamo aún era el cultivo predominante.

Esta situación de relativa estabilidad no tardará en alterarse por una serie de factores tanto externos como internos. La crisis agrícola de 1862 estuvo motivada por el abaratamiento de los transportes consecuencia de la generalización de la navegación a vapor, lo que permitió colocar en nuestro país cereales de otros países de Europa y Estados Unidos a precios inferiores a los producidos en nuestro país, y el olivo entró en

\footnotetext{
${ }^{9}$ Ibídem, p. 288.

${ }^{10}$ MONLLEÓ PERIS, Rosa (1999): op. cit., p. 290.
} 
regresión en ciertas zonas debido al creciente empleo en el alumbrado de combustibles distintos del aceite de oliva, unido al auge del cultivo de la vid que obligó a talar muchos de ellos y sustituirlo por vides. ${ }^{11}$

Pero sin duda fue el viñedo el cultivo hegemónico en la segunda mitad del XIX; la crisis del «oidium» del periodo 1852-62 que afectó gravemente a los viñedos europeos y españoles, pero no a los valencianos que hizo aumentar la plantación.

El comercio del vino de carlón por los puertos o embarcaderos de Benicarló y Vinaròs constituyó la principal actividad. ${ }^{22}$ Años más tarde, a partir de 1878, la plaga de la filoxera redujo durante veinte años a la mitad la producción francesa de vinos. Este hecho conllevó a una mayor plantación de viñedos y a una espectacular subida de los precios del vino por el aumento de la exportación a Europa, obteniéndose sustanciosas ganancias. Con el cambio de siglo las exportaciones empezaron a descender, como consecuencia de la reconstrucción de los viñedos franceses con cepas americanas resistentes a la filoxera y la consiguiente recuperación. ${ }^{13}$

A la crisis de la agricultura española de 1862 hay que añadir en el País Valenciano la quiebra de dos industrias de fuerte arraigo, la sedera y la del cáñamo que incidirían sobre dos producciones básicas del regadío castellonense.

La crisis de la sedería comenzó con el ataque de «pebrina» sufrido por los gusanos de seda a partir de 1852. Pero como ha señalado Giralt, ${ }^{14}$ no fue la pebrina la única causa de la desaparición de la industria sedera, sino su deficiente estructura, que la incapacitó para resistir la competencia extranjera, sustituyendo la materia prima autóctona por importaciones de seda en bruto. La caída de la demanda industrial hizo que el agricultor perdiera todo interés por el cultivo de las moreras, que fueron taladas masivamente, lo que supuso además un impacto negativo en el paisaje rural ${ }^{15} \mathrm{y}$ un fuerte golpe para las economías de poblaciones como Castellón, Burriana y Villarreal.

\footnotetext{
${ }^{11}$ ABAD, Vicente (1992): «El crecimiento capitalista», en CHUST, Manuel (direc.): Historia de Castellón, Levante de Castellón, p.562

${ }^{12}$ PIQUERAS ARENAS, José Antonio (2013): op. cit., p.114 -115.

13 ABAD, Vicente (1992): op.cit., pp. 663-565.

14 GIRALT I RAVENTÓS, Emili (1968): «Problemas históricos de la industrialización en Valencia», en Estudios Geográficos. Instituto Juan Sebastián Elcano. Madrid, agosto-noviembre, p.377.

15 «[...] Las afueras de Castellón son deliciosas: por todas partes se observan campos cercados de moreras, y las áreas matizadas con cáñamo, maíces, trigos, alfalfas y hortalizas; se ven serpentear las aguas por varios canales que refrescan y fertilizan aquella tierra pingüe[...]», en MADOZ, Pascual (1982): Diccionario Geográfico estadístico-histórico de Alicante, Castellón y Valencia, Institución Alfonso el Magnánimo, Valencia, T.1, p.228. [Ediciónn facsímil del original, 1845].
} 
Las transformaciones de la nueva sociedad industrial llevan a que el tradicional cultivo del cáñamo, que había generado una prospera economía desde el siglo XVIII en Castellón, entre en crisis a mediados del siglo XIX prolongándose su agonía hasta final de siglo. Abastecía a una buena parte de la marina mercante y de guerra española, e incluso extranjera. Pero cuando los buques de vela empiezan progresivamente a sustituirse por los de vapor, la demanda de sogas y cabos desciende drásticamente. A lo que había que añadir la competencia del yute de las factorías italianas.16 A pesar de ello la industria artesanal familiar de confección de alpargatas y otros utensilios con esta fibra se mantiene dignamente hasta los primeros años del siglo XX. Símbolos de este brillante pasado industrial es L'hort dels soguers y la Llotja del cànem.

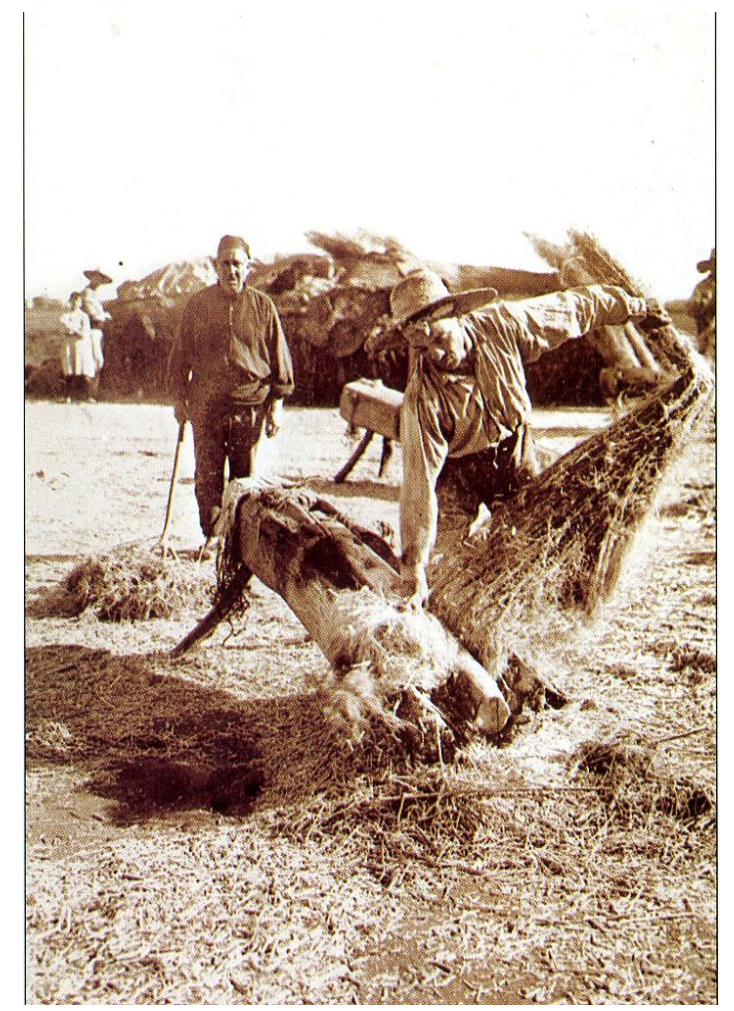

Manipulación del cáñamo. Conselleria de Cultura. D.G. del Patrimonio Cultural. (Foto: P. Alcántara)

En medio de todas estas dificultades, se abría camino un nuevo cultivo, la fruta dorada. La naranja fue, y es, uno de los principales motores de la economía castellonense. Una burguesía dinámica y de negocios interesada en introducir nuevas técnicas para comercializar las exportaciones de naranjas a los mercados nacionales y

\footnotetext{
${ }^{16}$ GARRIDO HERRERO, Samuel (2004): Canem gentil. L'evolució de les estructures agràries a la Plana de Castelló (1750-1930), Excm. Ajuntament de Castelló, pp. 68-75.
} 
europeos, y el establecimiento de industrias auxiliares relacionadas con el comercio de la naranja y otras actividades, junto con el esfuerzo conjunto de los agricultores, dispuestos a adaptarse a las nuevas exigencias de mercado, hizo que la naranja fuera ganando el terreno antes improductivo, imponiéndose en el horizonte comercial como una de las mercancías de más alto valor especulativo, capaz de amortizar con creces los cuantiosos gastos iniciales.

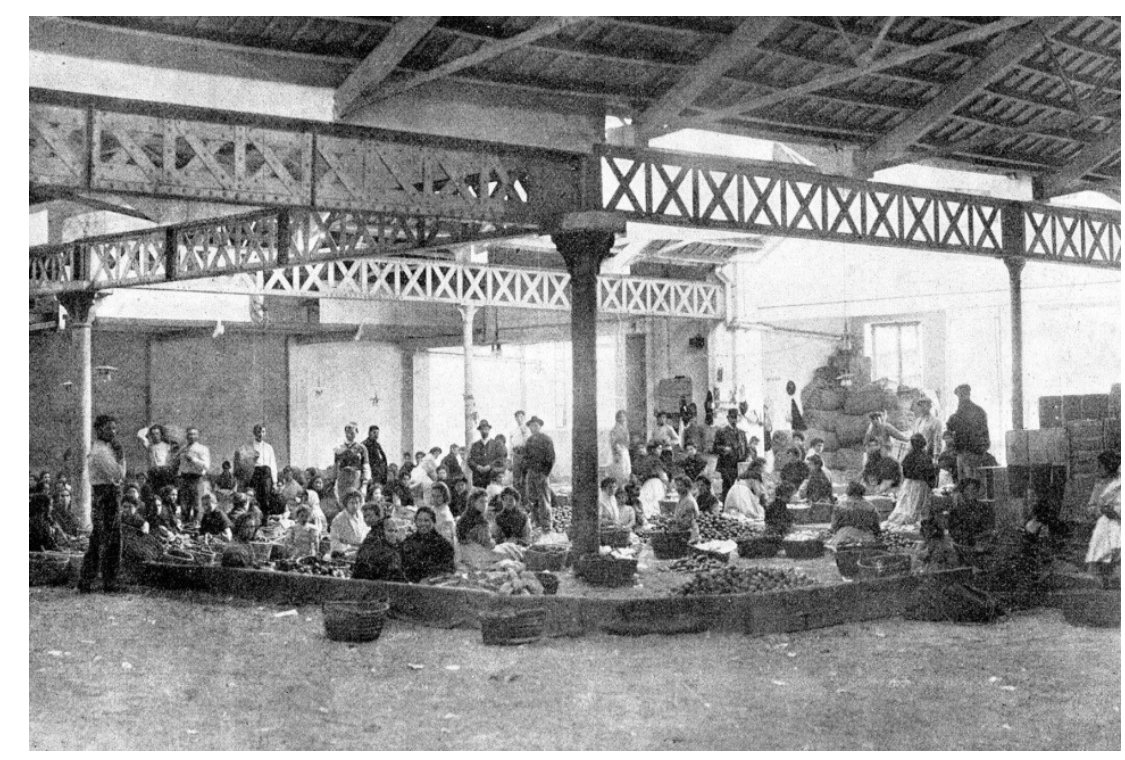

Interior de un almacén de confección de las naranjas. Clisé de J. García. Sarthou Carreres, Carlos (1913): Geografía General del Reino de Valencia

Para la historiadora Rosa Monlleó ${ }^{17}$, frente a lo que algunos estudiosos se han planteado si el «boom» naranjero fue uno de los factores que desviaron las inversiones industriales hacia la agricultura, en la actualidad queda clara otra hipótesis:

[...] el crecimiento agrícola ayudó en el despegue de la industria, puesto que la implantación del sector naranjero suponía una fuerte demanda de productos industriales, tanto por las actividades complementarias que derivaban de sector naranjero como por el consumo. Serrerías que elaboran las cajas de madera para embalar la naranja, producciones mecánicas como bombas para los motores de riego, básculas, maquinaria de los almacenes de naranja, industria química...un sinfín de actividades productivas que tienen en la naranja un impulsor directo de la industrialización $[\ldots]$

\footnotetext{
${ }^{17}$ MONLLEÓ, Rosa (1999): op. cit., p. 288.
} 
También proliferaron innumerables almacenes, edificios para la arquitectura del agua y construcciones anexas, que requirió de los diferentes oficios para su ejecución y para el mantenimiento de las instalaciones creadas.

El primer huerto de naranjos del que tenemos noticia es el del huerto del cura Monzó, en el término de Carcagente, del que nos habla Cabanilles. ${ }^{18}$ El cultivo del naranjo en plantaciones regulares en La Plana comenzó en Villarreal a finales del siglo XVIII desde donde se expandió a Almazora (1800) y a Burriana (1826). Entre 1839 y 1843, Manuel Cubedo y Manuel Usó acometieron las primeras plantaciones de naranjos para explotación comercial. ${ }^{19}$

Un comercio cada vez más activo, impulsado por una demanda creciente, actuó como motor de desarrollo de la economía citrícola valenciana en general y la castellonense en particular. A finales del primer tercio de siglo XIX la naranja de La Plana era transportada hacia el interior, mientras que a las playas de Burriana y Castellón llegaban los comerciantes mallorquines y catalanes, que compraban a los agricultores sus naranjas para venderlas en Barcelona y en los puertos del sur de Francia y luego en Gran Bretaña. El rápido crecimiento de este producto y la posterior apertura del mercado británico dieron lugar a un incremento de la demanda, que convertiría a la naranja en el cultivo más rentable del regadío de La Plana. ${ }^{20}$

Conocidas pronto las ventajas del injerto, proliferaron las variedades, que teniendo diferentes periodos de recolección, permitió alargar la duración de las campañas, que redundó en un aumento de mano de obra y de temporalidad de los contratos. Pero entre todas estas variedades de cítrico, Castellón fue pionera en la introducción del cultivo de la mandarina. El buen comportamiento de estos arbustos se extendió rápidamente a partir de 1865 . El primero que plantó naranjas en la Plana y que experimentó con la mandarina en sus huertos de Villarreal y Burriana fue José Polo de Bernabé, burgués afincado en Valencia, miembro activo de la Sociedad Económica de Amigos del País, fue uno de los primeros exportadores de naranja a Francia, Inglaterra, Alemania y Suiza. ${ }^{21}$

\footnotetext{
${ }^{18}$ CABANILLES, Antonio Josef (1975): Observaciones sobre la historia natural, geografía, agricultura, población y frutos del Reino de Valencia Tomo I, Biblioteca Valentina, p.207 [Edición facsímil del original. Madrid: Imprenta Real, 1795,1797].

19 ABAD, Vicente (1984): Historia de la naranja (1781-1939), Comité Gestión de la Exportación de Frutos Cítricos, p.5.

${ }^{20}$ Ibídem, p.50.

${ }^{21}$ GARRIDO HERRERO, Samuel (2004): op.cit, pp. 37 y 118.
} 
El impulso definitivo para el cultivo de la naranja en la huerta de Castellón se produjo en 1872 con la concesión de las aguas de la Rambla de la Viuda y con la construcción en 1884 del nuevo Azud o presa en el río Mijares por las Comunidades de regantes de Castellón y Almazora, transformándose una buena parte de las tierras de secano del término de Castelló en naranjales. Aunque la perforación de pozos por sociedades de regantes colaboró al suministro de agua de riego, la obra más importante fue el inicio de la construcción en 1909 del pantano de María Cristina en la misma Rambla de la Viuda, que permitiría regar los llanos de Castellón y Almazora. Con la inauguración de las obras del embalse en 1925,22 el cultivo de la naranja llegó a su máxima expansión en este periodo.

La primera etapa de comercialización de la naranja que se caracterizó por el monopolio que disfrutó en todos los mercados se prolongaría hasta finales de siglo, dando paso a un segundo periodo de consolidación y expansión europea de la naranja valenciana que se inicia a finales del XIX, con la apertura de nuevos mercados, en donde se incorpora Alemania, los Países Bajos, Países Escandinavos y Rusia, a pesar de la creciente competencia de Estados Unidos, Italia, Argel o Brasil. Este periodo expansivo se truncó bruscamente con el estallido de la Primera Guerra Mundial, pero con la llegada de la paz se olvidaron rápidamente los problemas y las exportaciones experimentaron un continuo crecimiento, aunque para muchos el periodo de la crisis supuso la primera fase de un proceso migratorio. ${ }^{23}$

Para Vicente Abad las causas del continuo crecimiento de la exportación en los años veinte hay que relacionarlo con las mejoras en el proceso de manipulación y selección de la naranja y en la reconversión de sus almacenes con la instalación de maquinaria moderna que permitía no solo abaratar costes, sino también presentar un producto mejor seleccionado y cuidado. También el incremento de la demanda hay que vincularlo con el incremento de la superficie cultivada, la introducción de variedades y con las mejoras de los transportes.

\footnotetext{
${ }^{22}$ GIMENO MICHAVILA, Vicente (1935): «La Rambla de la Viuda. Antecedentes históricos y estudio de las concesiones de aprovechamiento de aguas», Boletín Sociedad Castellonense Cultura, T. XVI, pp. 91-95. ${ }^{23} \mathrm{ABAD}$, Vicente (1984): op. cit., pp. 95-105.
} 
Con la experiencia pionera en cuestiones asociativas de los agricultores castellonense, ${ }^{24}$ se crea en 1896, fruto de las orientaciones del jesuita castellonense P. Vicent, el Gremio de Labradores de San Isidro, ${ }^{25}$ al que siguieron otros muchos, distribuidos por las comarcas del interior.

Gremios y Círculos evolucionaron, convirtiéndose en Sindicatos CatólicoAgrarios, al amparo de la Ley de Sindicatos Agrícolas de 1906, siendo destacable el establecimiento en 1919 de la Caja Rural Católica Agraria. También fueron adelantados los agricultores castellonenses en dar respuesta a los problemas de inseguridad en el campo, creándose en 1898, la primera Comunidad de Labradores de España, nacida al amparo de la Ley de Policía Rural de ese año, y cuyo inspirador fue el diputado republicano castellonense Fernando Gasset. ${ }^{26}$

Una buena referencia para conocer la situación de la industria castellonense de finales del siglo XIX la tenemos en la Exposición Provincial, organizada por el Casino de Artesanos de Castellón en 1887. Una vez más, la Liga de Contribuyentes junto con otras instituciones públicas y privadas se esforzó por convertir las anquilosadas ferias en verdaderos concursos en los que la agricultura, la industria y las artes aplicadas encuentren un merecido estímulo. La exposición instalada en el edificio del Instituto, se dividía en tres secciones: Agricultura, Industria y Comercio y Bellas Artes, esta última reflejo del interés que despertaban las artes plásticas entre la burguesía ilustrada. De la exposición se deduce la existencia de una industria artesanal que estaba en fase de incorporación a los métodos de fabricación industrial y lo más importante dar a conocer la realidad industrial de la provincia y de impulsar su desarrollo. ${ }^{27}$ La exposición provincial incluía tanto la producción autóctona, como la procedente de industrias foráneas que se estaban incorporando en los sectores de producción y transformación local, como: abonos químicos, herramientas y maquinaria para la agricultura e industria.

De entre los sectores industriales castellonenses, fue el cerámico, y mas concretamente el azulejero, el primero en recorrer el camino que lleva desde la artesanía a la industria propiamente dicha, y lo hizo precisamente en la segunda mitad del siglo

\footnotetext{
24 « [... La clase labradora, la más numerosa y de mayor arraigo de la población decidió constituirse en Gremio, formando las Ordenanzas para su régimen y gobierno en mayo de 1817 [...]», en GIMENO MICHAVILA, Vicente (1926), Imp. Hijo de J. Armengot, Castellón de la Plana, pp. 92-93.

${ }^{25}$ GARRIDO HERRERO, Samuel (1986): Los trabajadores de las derechas, Diputació Castelló, pp.133- 140.

${ }^{26}$ ABAD, Vicente (1992): «El crecimiento capitalista», Historia de Castellón, Levante de Castellón, p.566.

${ }^{27}$ MONLLEÓ, Rosa (1999): op. cit., p. 290.
} 
XIX, incorporando técnicas y procedimientos de fabricación acordes con las necesidades de una industria creciente. El proceso de cambio y modernización se hizo relativamente rápido, debido a la larga tradición de la Real Fábrica de Alcora, que desde su creación, en 1727 , aportaría constantes innovaciones técnicas y mano de obra especializada. ${ }^{28}$

El sector azulejero castellonense inicia su andadura, a principios del siglo XIX, con la instalación de un par de fábricas en Castelló (1820) y en Onda (1827), y a finales de siglo el binomio Castellón-Onda se había convertido ya en un potente núcleo industrial, capaz de competir con el formado por Valencia-Manises, al que superará definitivamente a principios del siglo XX. El crecimiento de la industria del azulejo estuvo ligado al aumento de la demanda por parte de la industria de la construcción, a su asociación o uso higiénico-sanitario y al gusto estético- decorativo en la arquitectura Modernista imperante en ese momento. ${ }^{29}$ También el fuerte crecimiento de esta industria se vio ralentizado por la Primera Guerra Mundial, pero finalizada ésta el crecimiento aumentó considerablemente. Por último, otra rama de la producción castellonense que alcanzaría una notable expansión en estos años fue la industria auxiliar del sector citrícola. El comercio naranjero precisaba de una serie de servicios y oficios complementarios relacionados con industrias de serrería, mecánicas y de producción de papel y timbrado.

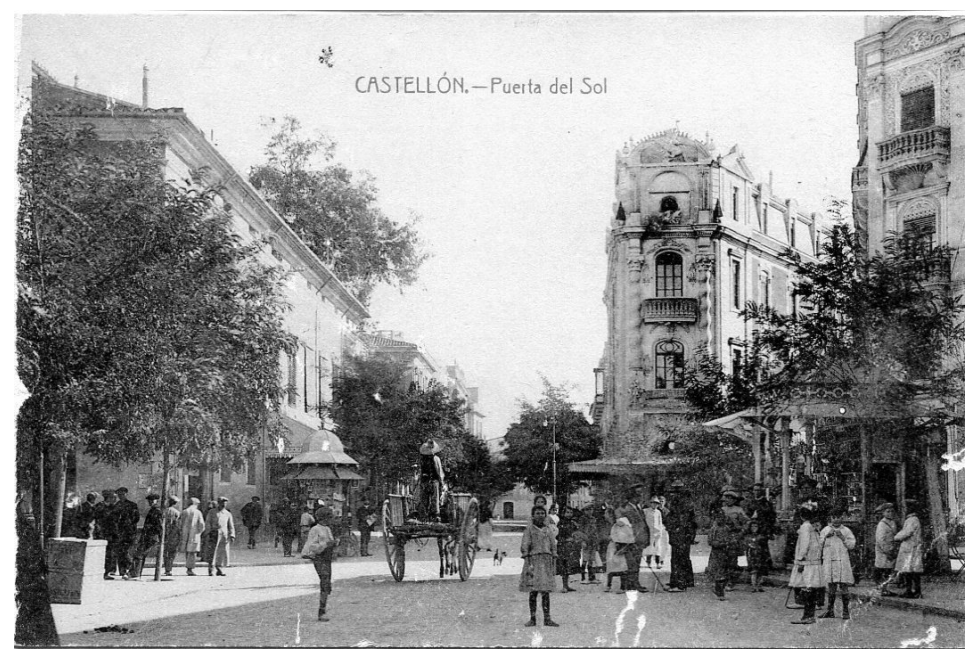

Edificio del Círculo Mercantil en la Puerta del Sol (1915). Fuente: Tarjeta postal. Edición B. Derenzi

\footnotetext{
28 ABAD, Vicente (1992): op. cit., p. 573.

29 PIQUERAS ARENAS, José Antonio (2013): «El lento paso hacia la modernidad: economía y transformaciones desiguales en el siglo XIX», en AGUILAR CIVERA, Inmaculada (coord.) Castellón, un territorio en comunicación: de la diligencia al TRAM, Valencia, Consellería d'Infraestructures, Territori i Medi Ambient, Generalitat Valenciana, pp120-121.
} 
Todos estos adelantos económicos y tecnológicos que hemos mencionado anteriormente se pudieron llevar a efecto porque desde diversos frentes se apoyó un proyecto de desarrollo que iba acorde con las transformaciones de la sociedad y la economía española y europea. En este sentido, intelectuales, burgueses y políticos aunarán sus esfuerzos para conseguir que Castellón quedara a un nivel digno de capital de las comarcas que la rodean. ${ }^{30}$

Dentro de este contexto, fue la evolución del sistema financiero y la labor de las instituciones y asociaciones, el motor que posibilitó todas estas aspiraciones económicas. El fuerte volumen de negocios de la burguesía castellonense favoreció en la temprana fecha de 1885 el establecimiento de una sucursal del Banco de España, que agilizaría las transacciones económicas. No solo la banca pública acudió a la pujante economía castellonense, también las instituciones privadas, tanto de crédito como de ahorro, empiezan desde principios del siglo XX a instalarse en la capital, y algo más tarde en las poblaciones de mayor crecimiento económico de la provincia. ${ }^{31}$

Además de la Liga de Contribuyentes, fundada en 1875, aparecen otras asociaciones que ocupan un lugar preferente en la ciudad. En 1886 se constituye el Círculo Industrial y Mercantil de Castelló; en 1901 nace la Cámara Oficial de Comercio. También otras instituciones aúnan esfuerzos por conseguir ayudas del Gobierno, como las Federaciones Agrarias de Levante, nacidas en 1898, y a nivel provincial la Junta de Agricultura, Industria y Comercio o a nivel municipal la Cámara Agrícola.

\section{LA RED DE INFRAESTRUCTURAS Y TRANSPORTES. EL PUERTO DE CASTELLÓN Y LA PANDEROLA}

No cabe la menor duda de que la capitalidad de Castellón -reconocida oficialmente en 1833- fue decisiva para impulsar la vida económica y social de la ciudad, adecuándola a la condición que ostentaba. Durante las décadas siguientes se impulsaron mejoras como la construcción del Teatro Principal, el Hospital Provincial, el

\footnotetext{
${ }^{30}$ MONLLEÓ, Rosa (1999): op. cit., p. 289.

${ }^{31}$ ABAD, Vicente (1992): op. cit., pp. 579-580.
} 
Parque Ribalta o las instalaciones de suministro de agua potable, la red de saneamiento y el alumbrado, servicios propios que también se estaban produciendo en otras capitales de provincia. Pero sin duda, dentro de este conjunto de mejoras sobresalía la imperiosa necesidad de invertir en la ampliación de las comunicaciones, haciendo llegar el ferrocarril, la construcción de una red de carreteras y la implantación de un puerto artificial en el Grao.

Uno de los problemas fundamentales que condicionaba el desarrollo económico de la provincia de Castellón, y del resto de España, eran las infraestructuras y los transportes.

Finalizada la primera guerra carlista, a partir de la década de los años cuarenta, el estado liberal decidió avanzar hacia la industrialización. La apertura a la economía internacional posibilitó los recursos financieros, los productos y las tecnologías necesarias para empezar a modernizar la arcaica industria española. Para ello se inició un programa de mejoras de las infraestructuras españolas cuya finalidad era unificar el mercado e intensificar la producción, entre ellos podemos citar el plan de ferrocarriles, puertos y carreteras.

Dentro de este contexto la llegada del ferrocarril en España fue necesaria para el éxito de la industrialización y vertebración territorial iniciada en el siglo XVIII. Su posterior desarrollo durante la segunda mitad del siglo XIX revolucionó el sistema de transporte e introdujo una serie de cambios en las comunicaciones que mejorarían la accesibilidad general. El intercambio comercial y humano contribuyó al desarrollo y especialización de las economías regionales.

En el País Valenciano la irrupción del ferrocarril favoreció la extensión de la agricultura comercial mediante la canalización de la producción hacía mercados nacionales e internacionales. Posteriormente, la red secundaria de ferrocarriles y de vía estrecha fueron, en concreto, los que favorecieron las conexiones con los puertos del litoral. En apenas treinta años se había preconfigurado la red principal de ferrocarriles y en las dos últimas décadas del siglo se impulsó la red secundaria y complementaria de vía estrecha. ${ }^{32}$

\footnotetext{
32 SORIANO MARTí, Javier y PONS CHUST, Raül (2014): «La Panderola, patrimonio de la Plana. 125 años configurando el paisaje (1888-2013)», 18 Cuadernos del Museo del Transporte de la Comunidad Valenciana, Valencia, Generalitat Valenciana, p.8.
} 
La promulgación en 1850 de una ley que aprobaba el apoyo del Estado a las inversiones ferroviarias hizo posible que el empresario valenciano José Campo Pérez (Marques de Campo), que ocupaba la gerencia de la Sociedad Valenciana de Fomento iniciara gestiones para diseñar una red general en el País Valenciano y sus conexiones de largo recorrido. Las primeras negociaciones para el trazado de una línea de ferrocarril Valencia -Madrid, que «convirtiese a Valencia en Corte de España» son de 1845. Pero durante la fase de ejecución del primer tramo Valencia-Almansa (18521859) la Ley General de Ferrocarriles de 1855 opta por Alicante como punto de conexión de Madrid-Aranjuez con el Mediterráneo, siendo adjudicatario de dicha concesión José de Salamanca y Mayol (Marqués de Salamanca). Este hecho cambio las iniciativas empresariales valencianas dirigiendo ahora su mirada hacia Cataluña y la frontera con Francia. ${ }^{33}$ Es el momento en el que se inicia la concesión del tramo Valencia-Tarragona, establecida así en la ley General de Ferrocarriles de 1856, lo cual permitió que la red ferroviaria de la Compañía (Alicante-Valencia-Almansa) A.V.T. recorriera la provincia de Castellón de norte a sur, poniéndose en servicio en diciembre de 1862 el primer tramo entre Valencia y Castellón. En la Plana, este medio de transporte dio al comercio una nueva dimensión y condujo a la rápida exportación vinícola y posterior desarrollo de la naranja. La llegada del tendido ferroviario a PortBou en $1890^{34}$ dio un impulso definitivo al transporte de mercancías castellonenses, especialmente a la exportación de la naranja.

La proliferación de compañías ferroviarias desembocó después de la crisis de finales de los setenta en la quiebra de la mayoría de ellas, que fueron absorbidas por las grandes compañías de los Ferrocarriles del Norte y MZA (Madrid-Zaragoza-Alicante). ${ }^{35}$

Pronto el ferrocarril no era suficiente para dar cumplimiento a las necesidades de la economía castellonense, cuyos productos seguían saliendo mayoritariamente por vía marítima, lo que hacía necesario aproximarlos hasta el litoral. De ahí surge la necesidad de incorporar un trazado ferroviario complementario de vía estrecha que conectara los

\footnotetext{
${ }^{33}$ MUÑOZ RUBIO, Miguel (2013): « La red ferroviaria de ancho ibérico de Castellón entre 1862 1929. La movilidad ferroviaria al servicio del desarrollo regional», AGUILAR CIVERA, Inmaculada (coord.) Castellón, un territorio en comunicación: de la diligencia al TRAM, Valencia, Conselleria d'Infraestructures, Territori i Medi Ambient, Generalitat Valenciana, p.44-45.

${ }^{34}$ ABAD, Vicente (1992): op. cit., 576.

35 ABAD, Vicente (2007): « La naranja y el ferrocarril», en AGUILAR CIVERA, Inmaculada (coord.), Historia del ferrocarril en las comarcas valencianas: La Plana, Valencia, Conselleria d'Infraestructures, Territori i Medi Ambient, Generalitat Valenciana, p. 216.
} 
núcleos urbanos periféricos a la capital y de mayor desarrollo económico con el Grao de Castellón y de Burriana, a través de un tranvía de vapor, conocido como la Panderola. ${ }^{36}$

A partir de la Restauración, la Ley de Obras Públicas de 1877, incluyó dentro del plan general ferroviario ayudas financieras para la construcción de una red secundaria de ferrocarriles, en su mayoría de vía estrecha, de ámbito local, comarcal o regional. Dentro de este marco legal, el periodo 1880-1900 viene marcado por un importante auge en la construcción de los ferrocarriles de vía estrecha, que pasaron de $360 \mathrm{~km}$ a poco más de $1.900 \mathrm{~km} \cdot{ }^{37}$ Esta red secundaria fue en concreto la que mejoró las conexiones con el interior y a su vez con los puertos del litoral, dando un acceso rápido y efectivo a los centros de consumo más alejados y supliendo las deficiencias tecnológicas del transporte por carretera. El transporte de productos manufacturados, cerámica, pero principalmente la naranja fue el más beneficiado con la integración de estos pequeños ferrocarriles en el transporte marítimo.

En el País Valenciano, esta red secundaria de ferrocarriles estratégicos de vía estrecha, ${ }^{38}$ llegaba donde la red principal no alcanzaba, consolidándose como un mecanismo de mayor cohesión territorial, vigorizando mercados dispersos y acercando los municipios. El importante tráfico de pasajeros y mercancías que generó este transporte, redundó en un mejor desarrollo industrial y social. El uso de este medio de prosperidad y modernidad se convirtió en un nuevo espacio de sociabilidad, aproximando a los diferentes grupos sociales y reforzando los vínculos de identidad cultural del País.

En el siglo XIX fueron tres las líneas principales que articulaban la zona sur de Valencia, la de la Rivera que partiendo del Grao de Valencia finalizaba en Játiva y posteriormente llegaba hasta Mogente, y otra de vía estrecha hasta Villanueva de Castellón que recorría los pueblos de la Rivera, desde Jativa partía otra línea de ferrocarril que pasando por Onteniente y Albaida finalizando en Alcoy; la de la Safor,

\footnotetext{
${ }^{36}$ Según la traducción del Diccionario Salt (Consellería de Educación, Generalitat Valenciana), una panderola sería un escarabajo de cocina.

37 PONS CHUST, Raúl (2013): «La Panderola (1888-1963). Una aproximación histórica», en AGUILAR CIVERA, Inmaculada (coord.), Castellón, un territorio en comunicación: de la diligencia al TRAM, Valencia, Conselleria d'Infraestructures, Territori i Medi Ambient, Generalitat Valenciana, p.57.

${ }^{38}$ Las características técnicas de la vía estrecha (ancho inferior al normal español que es de 1,67) resultaba fundamental porque se adaptaban mejor a las vicisitudes del terreno y permitía diseños mucho más versátiles que los de vía ancha. Llegando a tener algunos un ancho de $0,75 \mathrm{~cm}$, como el tranvía a vapor de Onda al Grau de Castelló, conocido como la Panderola.
} 
que partiendo de Carcagente terminaba en Gandia-Denia; y la de la Costera, que desde Gandia llegaba hasta Alcoy. Desde allí partía por carretera la diligencia a Alicante.

La compañía de ferrocarril explotadora de la línea Alcoy a Muro y puerto de Gandia, fundada en 1882 con el nombre Alcoy and Gandia Railway and Harbour Company Limited, se mantuvo en funcionamiento desde 1892 hasta 1969, pasando a depender de FEVE (Ferrocarriles de Vía Estrecha) en 1965. Desde 1908 tenía conexiones con la compañía de Ferrocarriles de Villena a Alcoy y Yecla. En la estación de Gandia enlazaba con el ferrocarril Carcagente-Denia.

A partir de los años noventa, como consecuencia de la incorporación en 1851 de Utiel-Requena, de gran riqueza vinícola, a la provincia de Valencia se amplía la red comarcal de Valencia-Utiel y también la de Valencia-Manises-Liria. El trazado regional de Sagunto-Teruel-Calatayud no entraría en servicio hasta principios del siglo XX.

También por las mismas fechas se inicia en la ciudad de Valencia la densa red de tranvías y sus ramificaciones con las poblaciones limítrofes del área de influencia; pasando de la tracción animal al tendido eléctrico.

En estos años se plantea la necesidad de construir un ferrocarril de vía estrecha que aproximara, principalmente, las naranjas y los productos cerámicos de la Plana de Castellón a los puertos de su entorno. En la ciudad de Castellón la Compañía OGC del Tranvía a vapor de Onda al Grao de Castelló fue una empresa ferroviaria que aglutinaba los intereses de un grupo de burgueses catalanes cuyo verdadero motivo de la inversión fue la naranja. Aunque las expectativas de los empresarios no se cumplieron y la compañía entro en suspensión de pagos durante los primeros años, poco a poco el coeficiente de exportación se fue equilibrando gracias al tráfico de pasajeros que repercutía más ganancias que las mercancías. A finales de los años veinte todo se precipitó y los beneficios cayeron en picado hasta que en 1932 la empresa se declaró en quiebra y el Estado se hizo cargo de la actividad. ${ }^{39}$

\footnotetext{
39 SORIANO MARTÍ, Javier y PONS CHUST, Raül (2014): La Panderola, patrimonio de la Plana.125 años configurando el paisaje (1888-2013), Valencia, Generalitat Valenciana, Valencia, Cuadernos del Museo de Transporte de la Comunidad Valenciana, $\mathrm{n}^{\circ}$ 18, Cátedra Demetrio Ribes, Consellería de Infraestructuras, Territorio y Medio Ambiente, p.5.
} 


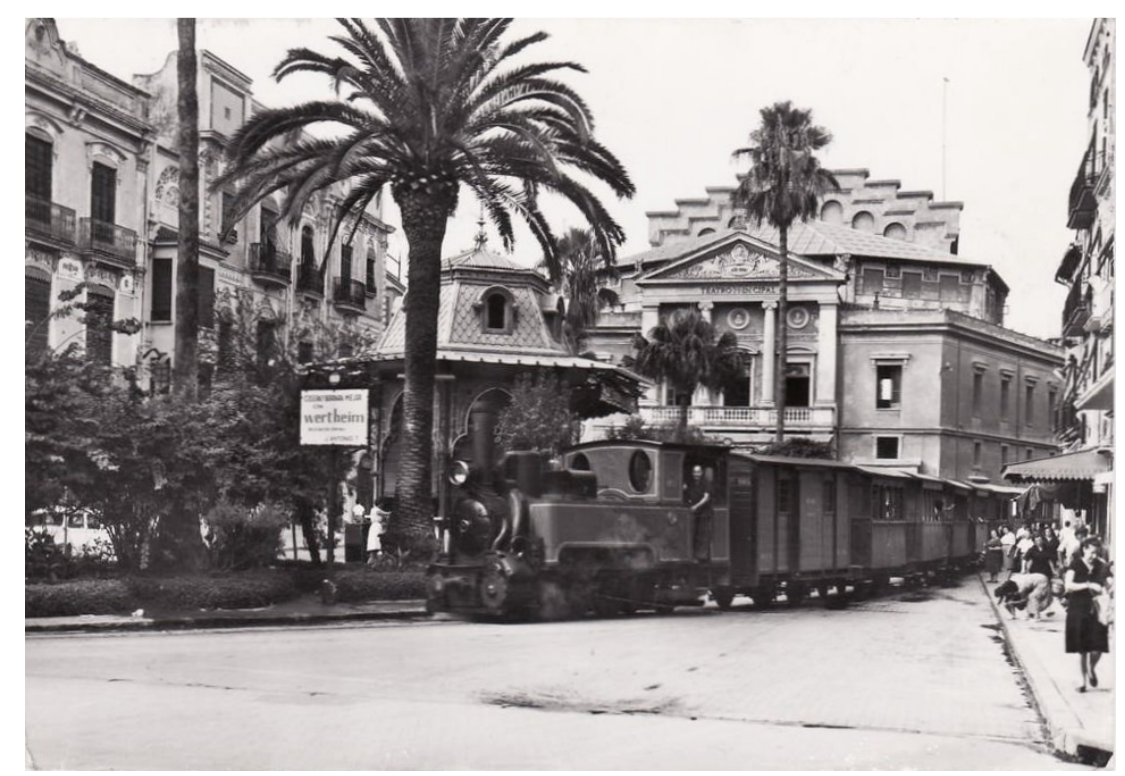

La Panderola atravesando la plaza de la Paz, al fondo el Teatro Principal.

Fuente: Castellón en blanc i negre

La línea conocida popularmente como la Panderola, estuvo en servicio desde 1888 hasta 1963 y unía la localidad de Onda con el Grao de Castelló, atravesando Villarreal, Almazora, y Castellón. Su excepcional trazado, discurriendo por calles y plazas de los núcleos urbanos que atravesaba, exhibe una vocación más propia de tranvía para transporte de pasajeros que de mercancías, lo que con el tiempo se confirmaría.

Desde 1907 hasta 1965 se amplió un ramal que unía Villarreal con Burriana y su puerto. La Panderola también marcó un hito en la integración y desarrollo territorial de las comarcas interiores ${ }^{40}$ y litorales y fue el único de todos los proyectos ferroviarios presentados durante el siglo XIX que triunfó. ${ }^{41}$

\footnotetext{
${ }^{40}$ Según la prensa de 1888: «permitirá á esta rica y extensa comarca, cambiar lo variado de sus frutos de la montaña y el llano, y dar a todo fácil salida por nuestra playa, que en no lejano plazo debe convertirse en seguro puerto», El Clamor de Castellón, 2/02/1888.

${ }^{41}$ Antes de la Panderola, ya desde 1866 se presentaron tres iniciativas ferroviarias de la Cía. del tranvía del OGC que no prosperaron. Todos estos proyectos estaban relacionados con la intención de completar la red ferroviaria básica de la provincia con la finalidad de unir las comarcas interiores con el litoral. En ese sentido, hubo planes tan variados como infructuosos: la unión del puerto de Vinaròs con la cuenca carbonera de Utrillas (Teruel) pasando por la comarca de Els Ports; la conexión de esta línea con Castelló con un ramal que pasara por Sant Mateu; una vía directa con Aragón por Vistabella o Lucena; el enlace entre Segorbe y Viver con Castelló a través de Vall d'Uixo, en PONS CHUST, Raül (2013): op. cit., p.60. La aparición de este proyecto que partiendo del ramal de Torres-Torres hasta Vila-real enlazaría con el tranvía de Onda al Grau de Castelló, vía Vall d'Uixo, Nules y Vilavella, desviando un ramal a Betxí aprovechando las negociaciones entre OGC y la Sociedad de Minas de Mercurio de Betxí, en PERIS TORNER, Juan (1994): Tren a vapor entre Onda y el Grao de Castellón de la Plana, Ayuntamiento de Castellón, p 56.
} 


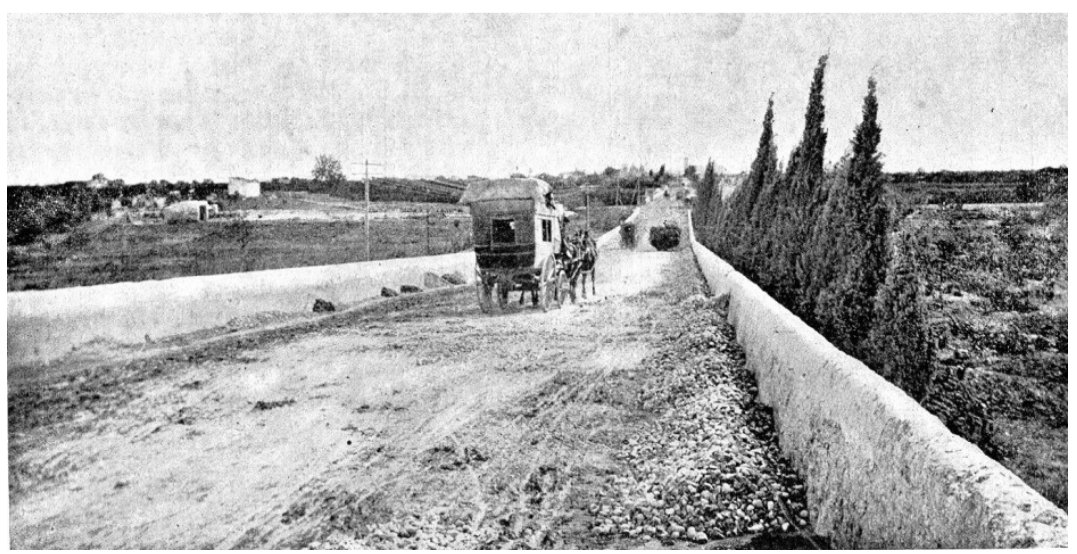

Carretera Nacional Valencia Barcelona.

Fuente: SARTHOU CARRERES, Carlos (1913): Geografía del Reino de Valencia

El impulso de las comunicaciones fue muy desigual, frente al papel dinamizador que experimentó el ferrocarril, las carreteras jugaron en un primer momento un papel secundario y complementario respecto al ferrocarril. No es hasta finales de los años treinta del siglo XIX cuando el territorio de la actual provincia de Castellón toma forma y empieza a vertebrarse a partir de las rutas históricas. ${ }^{42}$

Dada su condición de capital de la nueva provincia, y al amparo de la primera Ley de carreteras de 1851 se aprueban sucesivos planes con los que se inicia una estratégica red de carreteras para enlazar con otras capitales de provincia y con los pueblos del interior. El proceso fue lento y dificultoso, dado los pocos recursos disponibles y la accidentada topografía del interior de la provincia.

Para establecer el Gobierno el plan de inversiones y subvenciones, clasifica en 1877 las carreteras atendiendo a criterios de importancia, como carreteras de primer orden, segundo y tercer orden.

Serán los antiguos caminos reales de Valencia y de Aragón los que adquieren mayor auge e inversión, permaneciendo más contenidos los presupuestos en la red viaria del interior y con la provincia de Teruel. A mediados del siglo XIX la red de

\footnotetext{
${ }^{42}$ Madoz lamenta la escasez y estado de las carreteras a mediados del siglo XIX, « [...] Además de la carretera real de Barcelona á Valencia, que pasa por el centro de Castellón, hay algunos caminos vecinales que se dirigen á Almazora, Alcora y Borriol, que se hayan en mal estado, pues no habiendo fondos destinados para su reparación, se tiene que hacer esta por los terratenientes. Los correos son diarios de la Corte y vice-versa, y hay también una diligencia diaria para Valencia y otra para Vinaroz [...]», en MADOZ, Pascual (1982): Diccionario geográfico-estadístico-histórico de Alicante, Castellón y Valencia, edición de R. Aracil y M. García Bonafé, Valencia, Alfons el Magnànim, 2 volumenes, T.1, p.229.
} 
carreteras en la provincia de Castellón contaba con unos mil kilómetros, triplicándose antes de que terminara la centuria. ${ }^{43}$

Las comunicaciones por carretera fue imprescindible para transportar hacia el mar los productos del interior. A lo largo del siglo XIX se hacen mejoras en la carretera real de Valencia a Castellón de primer orden; las de segundo orden hasta Vinaroz y la de Sagunto a Teruel, y las de tercer orden de Vinaroz a la Iglesuela; Onda al Grao de Burriana, Lucena a Castellón; Almazora a Castellón; Burriana a Villareal.44

Con subvención del estado se inicia en 1860 la ampliación y mejora de la carretera de tercer orden de Morella a Zaragoza, que adquiere gran importancia para el futuro tráfico del puerto. Una carretera que ponía en comunicación a Castellón con zonas productoras agrícolas de gran importancia y destacada zona vinícola. ${ }^{45}$

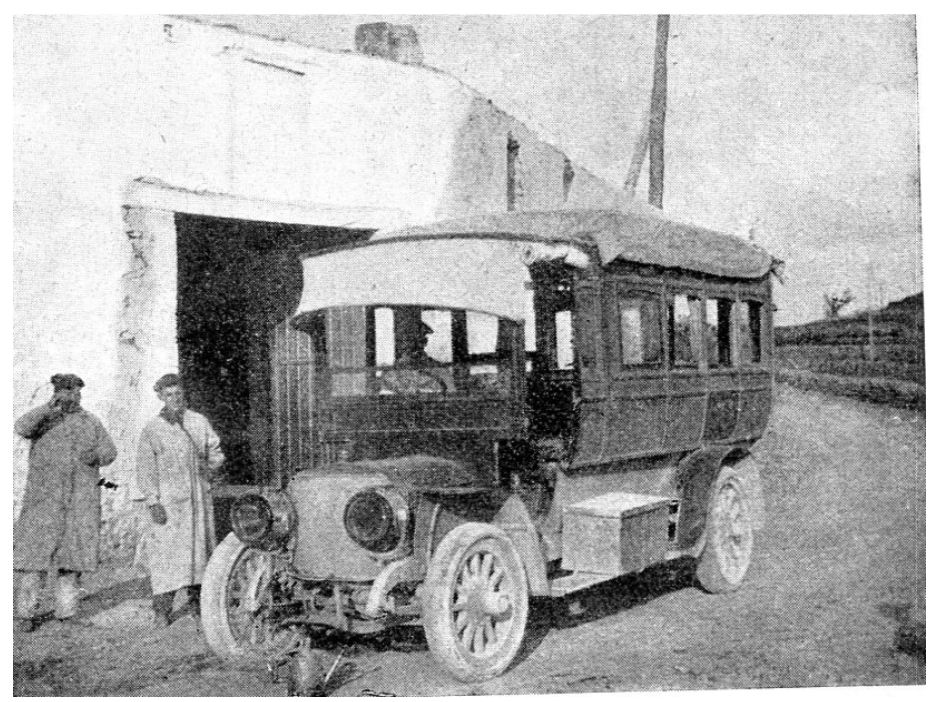

El coche automóvil-correo de Morella.

Fuente: SARTHOU CARRERES, Carlos (1913): Geografía del Reino de Valencia. Cliché del autor

Será a partir de 1909 cuando se inicia la explotación de líneas de autobuses, principalmente en itinerarios no reservados por compañías férreas. Tienen la finalidad de conectar el interior de la provincia con la capital. La primera de ellas se estableció

\footnotetext{
43 CÁMARA BOLUdA, Vanesa; BAU IZQUIERDO, Rafael (2013): «Evolución de las comunicaciones por carretera en la provincia de Castellón a lo largo del siglo XX», en AGUILAR CIVERA, Inmaculada (Coord.), Castellón, un territorio en comunicación: de la diligencia al TRAM, Valencia, Conselleria d'Infraestructures, Territori i Medi Ambient, Generalitat Valenciana, p.91.

${ }^{44}$ SARthou CARRERES, Carlos (1913): Geografía del Reino de Valencia. Provincia de Castellón, ed. Alberto Martín, Barcelona, p.330- 333.

${ }^{45}$ CLIMENT VIGUER, Susana (2013): «El puerto de Castellón y las comunicaciones en el transito al siglo XX», en AGUILAR CIVERA, Inmaculada (coord.), Castellón, un territorio en comunicación: de la diligencia al TRAM,Valencia,Conselleria d'Infraestructures, Territori i Medi Ambient, Generalitat Valenciana, p.23.
} 
entre Cabanes y Castelló, siendo posteriormente prolongada hasta San Mateo y Morella «coche del Pelechá», otras compañías como la Hispano Suiza cubría otros núcleos urbanos como Segorbe o Vall de uxó. ${ }^{46}$

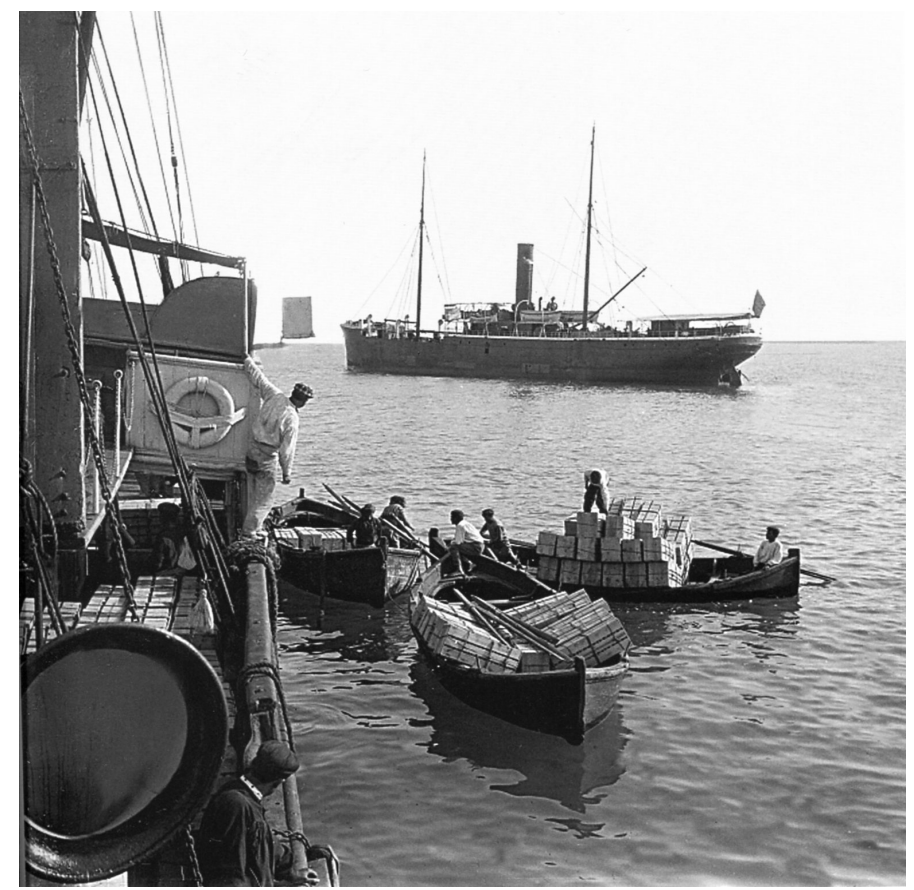

Carga de naranjas mediante barcazas. Fuente: VALLS TORLÁ, Javier; LLANSOLA GIL, Gerard; MOLLEÓ PERIS, Rosa (2003): Rumbo al progreso el puerto de Castelló a través de la historia

La organización del sistema portuario se fue estructurando en la segunda mitad del siglo XIX. Un proceso que se desarrollaría entre 1851 y 1880 , concretándose en una legislación homogeneizada para todo el sistema.

Dentro del programa de mejoras de las infraestructuras que el régimen liberal inició se encontraba el establecimiento de puertos habilitados para la importación de géneros coloniales y extranjeros en todas las provincias. A pesar de que en $1841 \mathrm{el}$ Ayuntamiento de Castellón recibe oficio proponiéndole esta posibilidad, que fue aceptada, para lo cual acondicionó el camino-paseo viejo del mar entre Castellón y el Grao, por orden del gobernador Ramón de Campoamor en 1847, la institución concejil nunca recibió respuesta. Sin embargo el fondeadero fue mejorado con muelles de madera provisionales. ${ }^{47}$

\footnotetext{
${ }^{46}$ PERIS TORNER, Juan (2004): El tranvía a vapor de Onda al Grao de Castellón de la Plana. 18888-1963, ed. Peris Torener, Juan, p 60.

47 CLIMENT VIGUER, Susana (2013): «El puerto de Castellón y las comunicaciones en el transito al sigloXX », en AGUILAR CIVERA, Inmaculada (coord.), Castellón, un territorio en comunicación: de la
} 
La ausencia de puertos $^{48}$ y de instalaciones a propósito obligaba a hacer los embarques desde la misma playa, mediante barcas de remo para ser trasladadas a los veleros y vapores fondeados en las inmediaciones de Vinaroz, Burriana, y Castellón. Solo Benicarló contaba con puerto. En 1803 se inician las gestiones para dotar de un puerto artificial en Vinaroz, ${ }^{49}$ finalizándose en 1875, según proyecto del ingeniero Leandro Alloza. Burriana disponía en 1889 de un embarcadero de hierro y madera que fue construido por una firma corredora de frutas inglesa. ${ }^{50}$

Los puertos fueron imprescindibles para dinamizar la agricultura de exportación en las comarcas litorales y prelitorales de la Plana. Mientras que las comarcas del interior continuaron con una estructura agraria muy tradicional y escasa estructura comercial, con progresivo abandono poblacional.

El esfuerzo para que la capital de la Plana tuviera un puerto comercial, acabó por unir, no sin fricciones, a todo el espectro político castellonense: republicanos, conservadores, liberales e incluso carlistas; y a todas las corporaciones y sociedades de la ciudad. ${ }^{51}$ La burguesía buscaba comercializar sus productos tanto en el mercado interior de España, como en el internacional, por eso la construcción del puerto la consideraban un asunto prioritario, que además reafirmaba la condición de Castelló como capital de provincia.

Las autoridades municipales dieron el primer paso, solicitando la concesión de un puerto, que fue aceptado en 1865 mediante Real Orden, ordenando la construcción

diligencia al TRAM, Valencia, Conselleria d'Infraestructures, Territori i Medi Ambient, Generalitat Valenciana, p.73.

48 En 1716 varias villas castellonenses, Villarreal, Burriana y Almazora, solicitaron al monarca un embarcadero para favorecer el tráfico de productos de la zona. Esto indica un periodo de recuperación económica, y por tanto de excedente de productos por parte de los agricultores, especialmente la producción y comercialización del cáñamo. En el siglo XVIII, la liberalización del comercio con América, Castellón se apunta al intenso tráfico con productos como la seda, la cerámica de Alcora y el vino de Benicarlo a través del puerto de Cádiz, en FELIU FRANCH, Joan (2002) « La cerámica en la carretera de Indias. 1800-1820», Millars, $\mathrm{n}^{\circ} \mathrm{XXV}$, pp. 83-117.

${ }^{49}$ El puerto de Vinaroz estaba especializado en la exportación de vino y de productos de Zaragoza. En 1709 se autorizó al puerto de Vinaroz el comercio exterior. Durante el reinado de Carlos IV se solicita la construcción de un puerto, proyectándose una primera fase en 1803 que no se llevó a efecto. En 1851 se consigue el permiso para su construcción, inaugurándose en 1875 el primer puerto del norte valenciano. Fue sede de la Administración de Aduanas hasta su traslado al Grao de Castellón en 1870, en RODRÍGUEZ MOYA, Inmaculada (2013): «Un puerto para Castellón: Historia de sus arquitecturas e infraestructuras», en AGUILAR CIVERA, Inmaculada (coord.) Castellón, un territorio en comunicación: de la diligencia al TRAM,Valencia,Conselleria d'Infraestructures,Territori i Medi Ambient,Generalitat Valenciana,p150-151 ${ }^{50}$ PIQUERAS ARENAS, José Antonio (2013): op. cit. p.123.

${ }^{51}$ CLIMENT Viguer, Susana (2013): Leandro Alloza, un ingeniero de Castellón, Valencia, Cuadernos del Museo de Transporte de la Comunidad Valenciana, nº 15, Cátedra Demetrio Ribes, Consellería de Infraestructuras, Territorio y Medio Ambiente, p.18. 
de un muelle de abrigo en el fondeadero del Grao. ${ }^{52}$ El Ayuntamiento se vio en la necesidad de convocar, como dictaba la ley, a los mayores contribuyentes, para que fuera aprobado el gasto. ${ }^{53}$ Pero hasta su realización transcurrieron 40 años. En ese periodo se había casi duplicado la población y la provincia había pasado a ser una potencia económica de primer orden al potenciar a la agricultura de exportación y sus industrias relacionadas, a la vez que aumentaba en peso la azulejería.

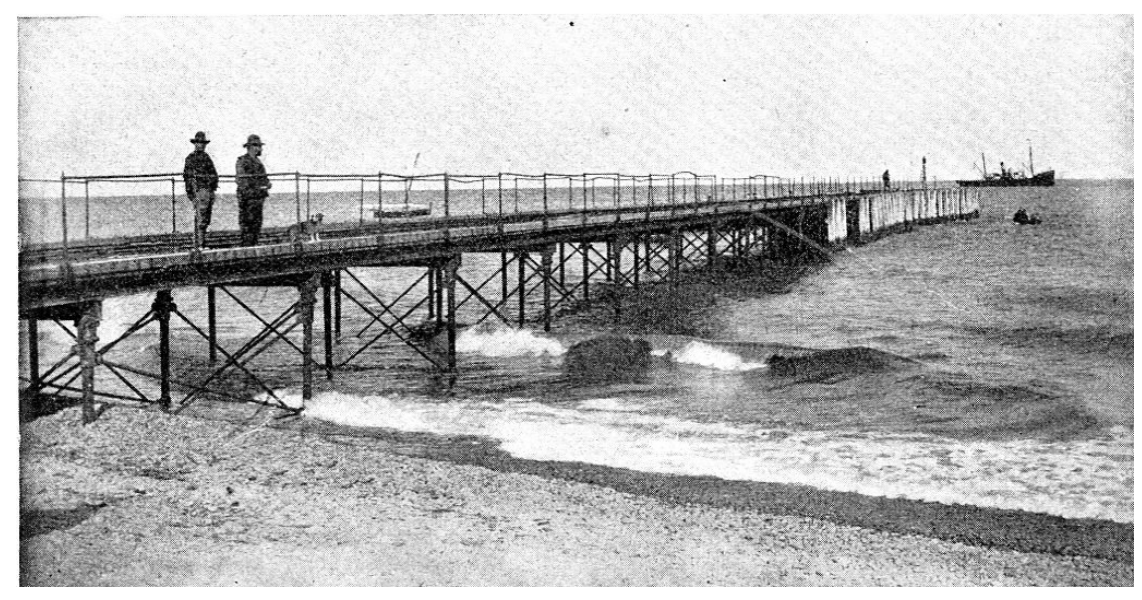

Muelle de hierro en el Grao de Burriana.

Fuente: SARTHOU CARRERES, Carlos (1913): Geografía del Reino de Valencia

Entre 1865 y1876, la crisis económica, fundamentalmente financiera y vinculada a las concesiones ferroviarias de 1866, junto con las convulsiones políticas y cambios de régimen, había dejado en punto muerto el proyecto.

Constituida en 1876 la Liga de Contribuyentes, será esta sociedad cívica la que más se implique en la consecución del proyecto, aprobando en ese mismo año el Anteproyecto por el Ministerio de Fomento, cada vez más necesario para acoger a los más de 250 buques al año que fondeaban en las costas de La Plana. ${ }^{54}$

Problemas legales paralizaron la financiación estatal, en un momento en el que el puerto de Vinaroz monopolizaba todo el comercio del Maestrazgo. ${ }^{55}$

La inhibición del Estado al declarar que el puerto de Castellón solo podía ser competencia del Ayuntamiento y de la Diputación, propició la creación de la Junta del Puerto en 1880, formada por distintas comisiones del Ayuntamiento, la Diputación y la

\footnotetext{
${ }^{52} \mathrm{ABAD}$, Vicente (1992): op. cit., p. 576.

${ }^{53}$ CLIMENT VIGUER, Susana (2013):op. cit., p. 20.

54 VALLS TORLÁ, Javier; LlANSOLA GIL, Gerard; MOLLEÓ PERIS, Rosa (2003): Rumbo al progreso el puerto de Castelló a través de la historia, VALLS TORLÁ Javier (coord.), editores Lunwerg, p.44.

${ }^{55}$ CLIMENT VIGUER, Susana (2013): op. cit., p.74.
} 
Liga, que resolvió encargar al ingeniero Leandro alloza, en 1881, un proyecto de construcción de un puerto comercial. ${ }^{56}$

Un año después, el 10 de diciembre de 1882, un Real Decreto declaraba al puerto de Castellón y el de Vinaroz de interés general de $2^{\circ}$ orden, recibiendo en 1883 la subvención estatal. Los puertos así calificados debían constituir un centro desde donde se «irradiase el comercio y el tráfico para el interior y se recibiera de este riqueza y vida para la navegación de todas las clases». Como consecuencia de una fase de abandono las obras del Dique de Levante no comenzaron hasta 1891 y con un ritmo muy lento, hasta que en 1902 se creó la Junta de Obras del Puerto de Castellón que tomó a su cargo todo lo relativo a la construcción del puerto. La dedicación de la citada Junta hizo que se acelerase la construcción. Las obras continuaron a buen ritmo, y en 1931, el Puerto de Castellón trabajaba con normalidad al contar entre sus instalaciones con los muelles de Costa y la escollera de Levante, el dique transversal y un tinglado frutero. ${ }^{57}$

El puerto de Burrianas8 continuó sobreviviendo unos años más con el embarcadero de madera de 1889. Aunque el proyecto de puerto presentado por el promotor burrianense Peris Fuentes fue declarado de utilidad pública en 1908, las obras no habían comenzado en el segundo decenio del siglo XX. Con el cambio de titularidad a favor del pueblo de Burriana y aprobado el proyecto reformado por el Gobierno de Primo de Ribera, a raíz de su visita a Burriana en 1924, se inician las obras de prolongación del dique de Levante en 1927. La Segunda República será la encargada de terminar las obras del puerto. ${ }^{59}$

\footnotetext{
${ }_{57}^{56}$ ABAD, Vicente (1992): op. cit., p. 577.

${ }^{57}$ VALLS TORLÁ, Javier; LLANSOLA GIL, Gerard; MOLLEÓ PERIS, Rosa (2003): op. cit., pp. 44-47.

${ }^{58}$ A mediados del XIX se especializó en el comercio de la naranja, canalizando los centros de producción de Almazora, Villarreal y el propio de Burriana, para lo cual disponía de tranvía de tracción animal desde Burriana al Grao. Este intenso tráfico y la cercanía de Castelló, causó el enfrentamiento entre ambas poblaciones. En 1882 solicita Burriana la construcción de un puerto que le fue denegada. En 1888 construyo un muelle- embarcadero de hierro la empresa londinense «Isaac \& Sons», en RODRíGUEZ MOYA, Inmaculada (2013): «Un puerto para Castellón: Historia de sus arquitecturas e infraestructuras», en AGUILAR CIVERA, Inmaculada (coord.) Castellón, un territorio en comunicación: de la diligencia al TRAM, Valencia, Conselleria d'Infraestructures, Territori i Medi Ambient, Generalitat Valenciana, pp.150-152.

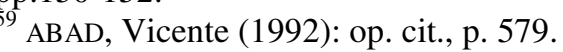




\section{EL DESARROLLO URBANO DE CASTELLÓN}

\subsection{EL PROCESO DE LA EXPANSIÓN URBANA: LOS PLANES DE ENSANCHE}

Castellón, nacida como una comunidad de agricultores, se desarrolló así durante siglos. La función industrial estaba centrada principalmente en la artesanía y en la transformación de productos del campo y ganaderos, derivados de su economía tradicional. Modelos similares los encontramos en poblaciones de la comarca de la Plana, como Almazora, Villarreal, Burriana, Nules o Almenara. Su trazado regular ${ }^{60}$ y disposición axial, responde a la clásica tipología propia de un asentamiento a lo largo de un camino o eje principal, en este caso el camino real de Valencia a Barcelona que a finales del siglo XVIII discurrirá por la céntrica calle de Enmedio.

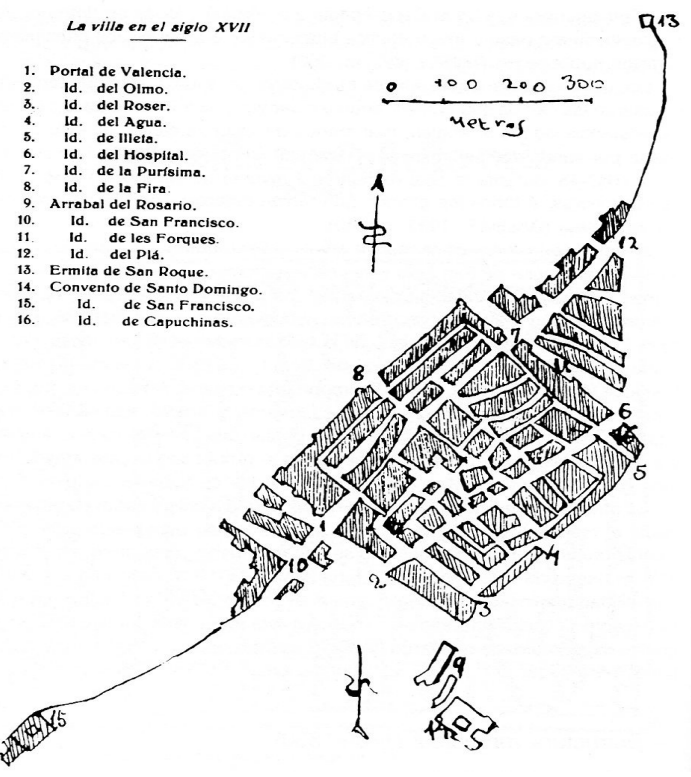

\section{Plano de Castellón, siglo XVII. Fuente: Gimeno Michavila, Vicente (1926), Del Castellón Viejo}

Desde finales del siglo XVII y durante el siglo XVIII, consecuencia del rápido crecimiento de la población, favorecido por su mayor avance económico, la ciudad desborda las murallas medievales, que derribará a final de dicho siglo. Es cuando se consolidan los arrabales que se habían empezado a configurar en el siglo XVI.

\footnotetext{
${ }^{60}$ En el siglo XIII, con la repoblación cristiana iniciada por Jaume I surgen los principales núcleos urbanos de la Plana. Los recintos rectangulares y el trazado regular en damero de los asentamientos responde a una concepción racional de la estructura urbana, frente a la irregularidad y el caos de la ciudad hispanomusulmana. TORRES BALBAS Leopoldo (1968): «La Edad Media», Resumen Histórico del urbanismo en España, Instituto de Estudios de la Administración Local, Madrid, pp.121-126.
} 
En 1786 se llega a una población de 11.739 habitantes $^{61}$ y en 1795 , contaba según Cavanilles con más de 13.000 almas. La riqueza agrícola del cáñamo, seda y trigo, su industria derivada y artesanía textil produce un desarrollo espectacular. El huerto gremial de los sogueros se convierte desde mediados del siglo XVIII en el centro del trabajo del cáñamo. Sogueros, alpargateros, curtidores pelaires y tejedores de lana y lino son los artesanos más característicos de la época. Estos oficios aparecen en numerosas calles, reflejándose en la tipología de las viviendas. ${ }^{62}$

La estructura poblacional tiene un marcado carácter agrícola y menos artesanal. Para Eugenio Burriel, en los barrios del casco antiguo el 60\% de la población trabaja en el sector agrícola, la actividad artesanal y manufacturera supone el $23 \%$, siendo la mitad sogueros, seguido de tejedores; la presencia de pescadores y pastores es muy baja. Únicamente en las parroquias del centro están los agricultores más pudientes y donde más disminuye el sector primario, que es suplantado por el artesanal y comercial; es también donde se localiza la nobleza. Los arrabales tienen más de un $80 \%$ de agricultores, en ellos se concentra la mitad del campesinado, en donde algo menos de la mitad son agricultores propietarios y el resto asalariados o jornaleros del campo.

La expansión de la ciudad en el XVIII es de carácter rural, conformando los menos pudientes los nuevos barrios extramuros al norte, sur y oeste. El límite oriental de la ciudad constituye una barrera tradicional al avance urbano hacia la fértil huerta, así como a la zona pantanosa de la marjal.

Durante este periodo de crecimiento demográfico y económico la ciudad experimenta su primer ensanche e importantes reformas higiénicas propias de un mundo moderno. El gobernador Antonio Bermúdez de Castro (1791-1807) hizo sentir su influencia ilustrada en muchos aspectos de la vida social y política de la villa, pero sobre todo ha pasado a la historia como el que abrió las puertas hacia el urbanismo moderno. ${ }^{63}$ Derribadas las murallas medievales (1794), crecen los arrabales y se expande la ciudad con anchas y rectas calles arboladas a lo largo del antiguo cinturón murado. También se crea en dicho perímetro tres nuevas plazas: la del Calvario (hoy

\footnotetext{
${ }^{61}$ MARÍA, P. Ramón DE (1933): «Del Castellón viejo o del Sas», Boletín de la Sociedad Castellonense de Cultura, t. XIV, pp. 203-206.

62 BURRIEL de URIETA, Eugenio L. (1971): Desarrollo urbano de Castellón de la Plana, Estudios Geográficos, no 23, Madrid, p. 216.

63 SANCHEZ ADELL. José (1949): «El Gobernador Bermúdez de Castro. Notas para el estudio de una época en Castellón: 1.791-1807». B.S.C.C., t. XXV, pp.207-242; 257-258.
} 
plaza Tetuán); la Plaza Nueva ${ }^{64}$ (1798), en el antiguo pla de la Fira (hoy plaza del Rey) donde se continuó realizando las tradicionales ferias y desde 1800 el mercado de los lunes, y la plaza de Mallorca en el extremo sudoeste de la población, en pleno barrio de la Trinidad. Igualmente se saca de la Plaza Vieja (hoy plaza Mayor) el cementerio, ${ }^{65}$ reubicándose fuera de la ciudad (1804), donde hoy está el paseo Ribalta.

El fuerte crecimiento económico del periodo conoció también importantes obras publicas relacionadas con la ampliación y mejoras de infraestructuras, como la rectificación del camino Real, que se hará pasar por dentro de la población y la construcción del nuevo y monumental puente sobre el río Mijares ${ }^{66}$ (1798), lo que supuso una importante mejora en la accesibilidad y comunicaciones.

Los dos barrios extramuros más numerosos, ahora atravesados por la carretera de Valencia a Cataluña, son el de San Félix al norte y el de San Francisco al sur, que en 1769 contenían ya el $40 \%$ de los habitantes de la ciudad.

Para el geógrafo Vicent Ortells Chabrera, durante el primer tercio del siglo XVIII se estima por igual el número de labradores que residen en la villa y en el arrabal de San Félix, medio siglo después es aproximadamente el $30 \%$ y el $70 \%$ respectivamente. En 1960 aún el 33\% de los agricultores de Castellón viven en este arrabal, con mucha distancia con el resto de barrios. Los nuevos barrios que se empiezan a desarrollar son de calles rectas, anchas, abiertas, con manzanas amplias y bien orientadas, donde se traslada un gran número de labradores propietarios de tierras, que necesitan casas más grandes donde guardar los aperos, animales y buscando la proximidad de sus campos. También se empieza a asentar allí la población emigrante, generalmente asalariados de los oficios y jornaleros del campo. Urbanísticamente los agricultores aportan con estos trazados un elemento de modernización, frente a la población apiñada en calles estrechas, tortuosas y poco ventiladas por las cercas de la muralla.

Las viviendas son similares a las del casco antiguo, a base de planta baja o planta baja y piso con estrecha fachada a la calle y gran profundidad de parcela; pero los

\footnotetext{
64 Gimeno michavila, Vicente (1984): Del Castellón Viejo, Castellón, Caja de Ahorros y Monte de Piedad de Castellón, p.29. [Edición facsímil del original, Est. Tip. Hijo de J. Armengot, Castellón de la Plana, 1926].

${ }^{65}$ GIMENO MICHAVILA, Vicente. op. cit., p.92-93.

66 SARThOU CARRERES, Carlos (1915): Geografía General del Reino de Valencia, Editorial Alberto Martín, Barcelona, p.64.
} 
servicios básicos de saneamiento, potabilidad e higiene de las calles y viviendas seguirán siendo deplorables hasta bien entrado el siglo XX.

Es importante destacar que la clase labradora, la de mayor arraigo de la población, proyectó constituirse en agrupación para su régimen y gobierno. Las Ordenanzas del Gremio de labradores de Castellón, la primera que se crea en España, fue fundada en 1819, y como reza en sus estatutos, tenía por objeto la unión de la clase, el fomento de la agricultura y la realización de prácticas para el perfeccionamiento de los cultivos. Así como un régimen económico y control para la facilidad de riegos, pozos, caminos a la huerta y al secano y otras infraestructuras, además de los medios para preservar los frutos expuestos al hurto. ${ }^{67}$

Durante el primer tercio del siglo XIX se mantienen los mismos parámetros económicos, y aunque el crecimiento poblacional es más lento, la ciudad continua expandiéndose con amplias calles al arrimo de las nuevas rondas. También los barrios de San Felix y de San Francisco se desarrollan de forma más racional y ordenada.

Como consecuencia del inicio de las guerras carlistas, en 1837, la población tiene que volver a levantar un cerco para defenderse. El nuevo trazado murado se apoya ahora en los antiguos conventos externos a la población, cuyos edificios sirvieron de fortines y baterías, quedando huertos y extensos terrenos vacíos dentro de los muros, rellenándose poco a poco a lo largo del siglo. ${ }^{68}$

Hasta 1882 no se inicia el derribo de las ya deterioradas murallas. La primera abertura es para comunicar la ciudad con la estación de ferrocarril, construyéndose para tal fin el paseo de San Vicente. Prosiguiendo en 1885 con otros portales y lienzos de muralla, facilitando de esta forma el crecimiento de la población. ${ }^{69}$

Se adjunta plano de la ciudad de Castellón del año1880, poco antes del derribo de las murallas.

\footnotetext{
${ }^{67}$ GIMENO MICHAVILA, Vicente. op. cit., p.92-93.

${ }^{68}$ BURRIEL de URIETA, Eugenio L. (1971): op. cit., p.210-219.

${ }^{69}$ Ibídem, p. 222.
} 


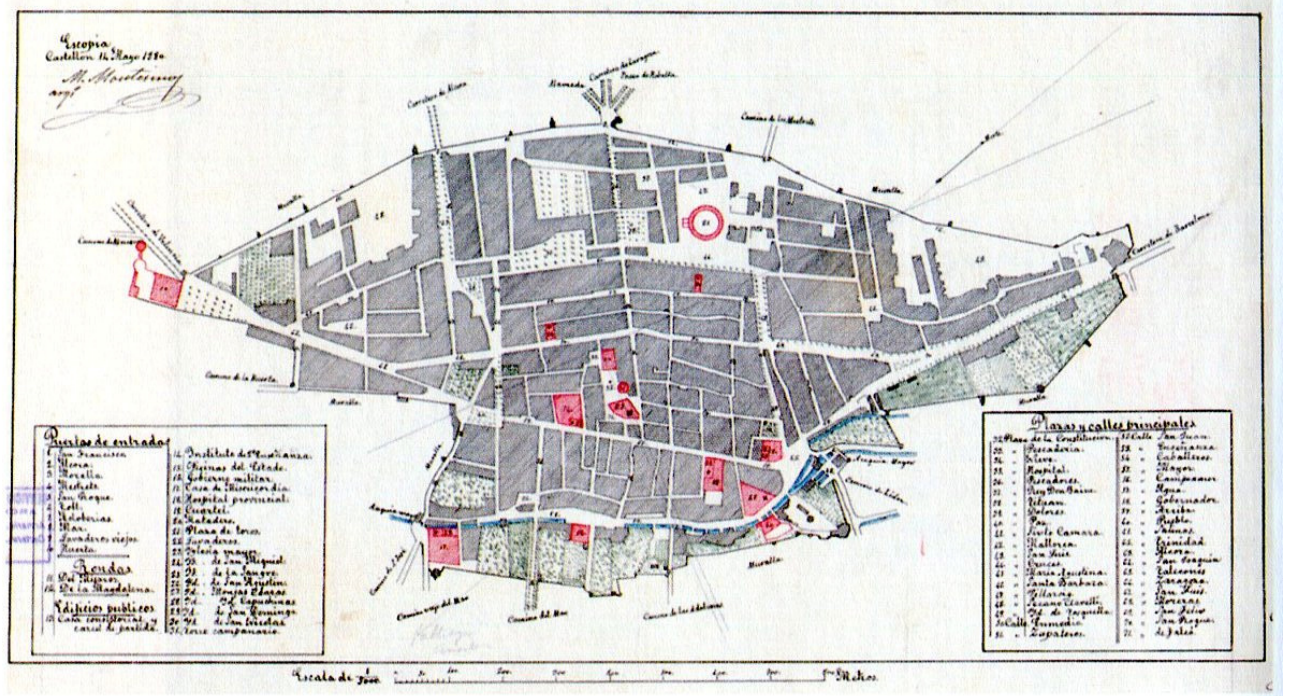

Plano de la ciudad de Castellón, año1880. Según el arquitecto Manuel Montesinos Arlandiz Fuente: Archivo Histórico Municipal de Castellón

Castellón en 1833 había sido convertido en capital de la nueva provincia. El impacto de este hecho no se hizo esperar. Terminada la primera guerra civil, el gobernador Ramón de Campoamor (1847-1848) fomenta las comunicaciones con el interior de la provincia, el decoro urbano, y el trazado de un nuevo camino al Grao, lo que supuso el desarrollo del caserío marítimo. La nueva carretera al mar fue concebida con gran modernidad, bordeada de dos amplios paseos arbolados para esparcimiento de los ciudadanos. Igualmente en 1860 se abre la carretera a Morella y Zaragoza, proyectandose en su primer tramo dos amplios paseos ajardinados: el paseo Ribalta (1868) y el paseo de la Alameda (1876). En 1862 se inaugura el ferrocarril a Valencia, localizándose la estación entre la carretera de Zaragoza y los espacios jardineros. En estas fechas también el cementerio se aleja más allá del ferrocarril, el vacío que deja lo ocupa el citado paseo Ribalta. $^{70}$

A lo largo de la última década del siglo XIX se está construyendo el nuevo Hospital Provincial y la cárcel modelo Provincial; se inaugura la nueva plaza de toros, el Teatro Principal, la audiencia, y se instalan entidades como el Banco de España, el Monte de Piedad, la Cámara de Comercio, la Cámara Oficial Agraria y otra serie de edificios y entidades emblemáticas propias de su condición capitalina. También una serie de servicios públicos se ubican en edificios y conventos desamortizados: el

\footnotetext{
${ }^{70}$ Ibídem.
} 
Instituto de Segunda Enseñanza, el Museo y el Archivo se instalan en el exconvento de las monjas Clarisas; en el convento de San Francisco se instala el cuartel militar; el exconvento de San Agustín se acondiciona para el Gobierno Civil y oficinas del Estado; y el convento de Dominicos se rehabilita para la Casa de Beneficencia.

A finales del siglo la ciudad empieza a cambiar su fisonomía de vieja población agraria, acomodándose a su nueva situación de capital administrativa, de servicios y de centro de comunicaciones.

Aunque la industria del cáñamo languidece, será principalmente el fuerte auge del monocultivo de la naranja, de marcado carácter exportador y la naciente industria cerámica, los factores económicos que generarán el impulso hacia el desarrollo comercial de Castellón.

Para ello, además de su privilegiada condición de capital de provincia, de fuerte raíz agraria, ${ }^{71}$ con importante concentración de servicios administrativos y profesionales, fue decisivo para el futuro de la ciudad la presencia del ferrocarril de la red nacional, favoreciendo el comercio nacional e internacional, y como centro privilegiado de recepción y distribución de la provincia; las mejoras de las comunicaciones terrestres y la nueva red de carreteras, mejorando y abriendo nuevos mercados con el interior de la provincia; la construcción del puerto, iniciado entre 18821891, canalizando una importante salida de productos agrícolas, y por último, el transporte interurbano de personas y mercancías a través del tranvía de vapor (18881963), la Panderola. Todos estos factores, avalados con el reciente sistema bancario y financiero, generaron entre 1887-1910 un importante desarrollo económico, que se materializó en una significativa afluencia de población emigrante, procedente mayoritariamente de las comarcas más deprimidas del interior de la provincia.

En un marco socioeconómico similar al descrito para el último tercio del siglo XIX, la actividad productiva y pública continúa en las décadas siguientes. El inicio a principios de siglo de las obras del pantano de María Cristina, va a permitir transformar en regadío, para el cultivo de la naranja, extensas zonas de secano. También la

\footnotetext{
${ }^{71}$ «[...] no podemos olvidar el auge agrícola. Castellón sigue siendo un núcleo básicamente agrario pero capitalista, impulsado no solo por las facilidades del transporte, sino también por el desarrollo de nuevos productos con marcado carácter exportador -naranjas, patatas, cebollas, hortalizas- que permitieron superar la crisis decimonónica de los cultivos tradicionales (seda y cáñamo). En el plano industrial es importante registrar la aparición de una nueva producción: los azulejos [...]»Ibídem, p. 223.
} 
construcción del nuevo edificio del Instituto General y Técnico va a suponer un importante foro cultural.

Consecuencia de este importante crecimiento económico y demográfico, la ciudad de Castellón experimenta una importante renovación urbana, surgiendo a finales del siglo XIX los primeros planes de ensanche.

La sociedad burguesa adoptó el higienismo como un bien social necesario para el progreso, el bienestar y el trabajo. El desarrollo industrial acompañado de los movimientos migratorios sembró el caos social y urbano, creciendo las ciudades por encima de sus posibilidades. Esto obligó a los organismos públicos en el siglo XIX a reorganizar la ciudad desde unos planteamientos acordes a las necesidades de la nueva sociedad, en la que la higiene fue un imperativo moral.

La higiene tuvo una relación directa y continua en la conformación urbanística y arquitectónica de las ciudades modernas. Era prioritario, sobre todo en las grandes aglomeraciones acometer el grave problema que para la salud pública suponía la falta de ventilación y habitación en las viviendas, el suministro y distribución de agua potable, la existencia de una red de alcantarillado y de un sistema de vertidos. También los higienistas del siglo XIX contribuyeron al cambio de la mentalidad urbana, especialmente en cuanto se refiere a apreciar la limpieza, la salubridad, el sol, los jardines y los espacios amplios.

En este sentido, los nuevos planes de urbanización exhiben una planificación más racional y coherente y su diseño y desarrollo supuso una significativa mejora en la higiene urbana. ${ }^{72}$

A partir de 1870-80 se generalizan los ensanches en España, siendo relevantes en el País Valenciano ${ }^{73}$ los de Valencia, Alicante, Alcoy, Orihuela y Elche. Tambien en Castellón, entre 1880-90, se inician los nuevos trazados urbanos.

Para financiar su ejecución los ayuntamientos se acogieron a la Ley de Ensanches y Reformas de Poblaciones de 1876 y sucesivas. ${ }^{74}$

\footnotetext{
72 La participación de los médicos higienistas, a mediados del siglo XIX, es ya significativa en el urbanismo de la ciudad. En 1859, el Ayuntamiento de Valencia publica una memoria para el ensanche de la Ciudad, presentada por una comisión integrada por Vicente Boix (Cronista de la Ciudad), Manuel Encinas (higienista) y Santiago Monleó (arquitecto), en PEÑIN IBAÑEZ, Alberto (1978): Valencia 18741959 Ciudad, arquitectura y arquitectos, ETSAV, p.28.

${ }^{73}$ Según censos de la población española del INE, en 1900 Valencia tenía una población de 213.550; Alicante 50.142; Orihuela 28.530; Alcoy 32.053; Castellón 29.904; Elche 27.380, siguiéndole Alzira, Requena Sueca; Villareal, Villena, Játiva, Burriana,...
} 


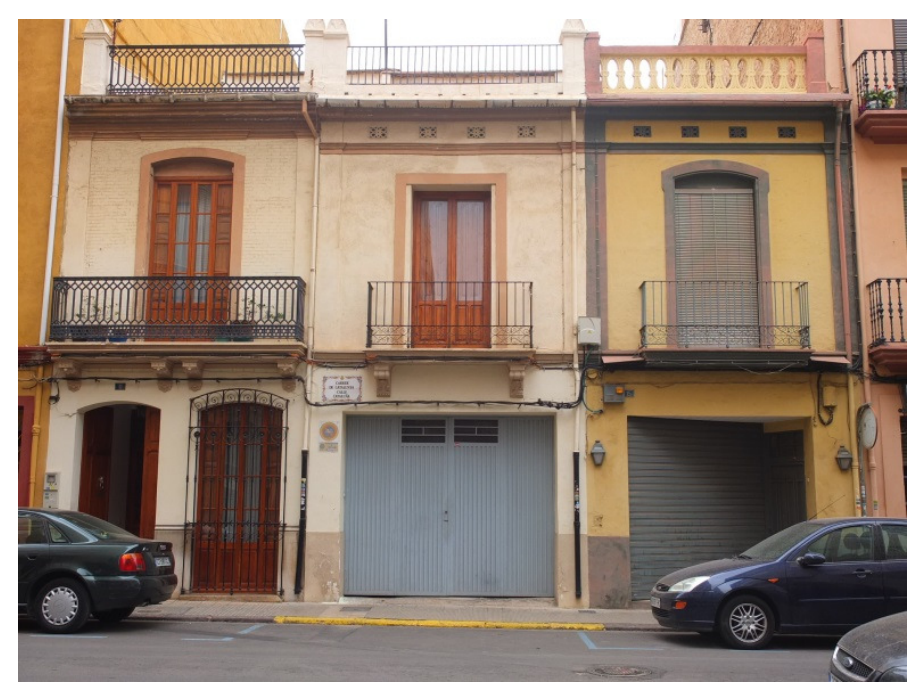

Viviendas en el ensanche de 1880 de Els Mestrests. Fondo fotográfico: Colección Concepción Calvo

En la mayoría de los casos se trata del típico ensanche ${ }^{75}$ en cuadricula de «trazado a cordel», según las normas de aquellos años. Las viviendas, dispuestas entre medianeras, conforman una manzana cerrada sobre una malla ortogonal de calles rectas y anchas, generalmente arboladas. Las esquinas de las manzanas están resueltas en amplio chaflán para favorecer el tráfico rodado.

La normativa permitía crear patios interiores de manzana, con el fin de mejorar la iluminación y ventilación de las estancias posteriores, y la altura máxima de las viviendas no debía sobrepasar el ancho de la calle para poder disponer de suficiente iluminación y ventilación. Cuando las manzanas tenían dimensiones generosas, podían construirse viviendas interiores recayendo al patio de manzana. Estos patios eran

${ }^{74}$ La primera Ley de Ensanche data de 1864 (29 de junio), señala que los ayuntamientos pueden urbanizar los terrenos, expropiando el terreno para viales y usos públicos a su costa. Para resarcirlos por estas responsabilidades el Estado les cede la contribución territorial sobre la zona durante 25 años. En 1867 se consagra la técnica de planeamiento con el Reglamento de la citada Ley de Ensanche. En 1876 se promulga una Ley de Ensanches y Reformas de Poblaciones que retoca algunos aspectos básicos. En 1892 el sistema se hace definitivo con una nueva Ley que regula los ensanches. De 1879 es la Ley de expropiación forzosa, que instrumentaliza la ejecución de los ensanches y reformas interiores.

75 Estos planteamientos higienistas fueron difundidos en España durante el reinado de Isabel II, por Idelfonso Cerdá (1859) en el ensanche de Barcelona o Carlos M. Castro (1860) en el ensanche de Madrid en donde incorporan zonas verdes como espacios de salubridad, en donde las zonas verdes se intercalaban de forma arbitraria dentro de la trama. El proyecto de I. Cerdá, aceptado en 1860, preveía siete parques para nueve manzanas de la trama urbana y jardincillos entre ellas. La especulación desvirtuó su plan y ningún jardín se puso en práctica. A partir de 1870-80 se generalizaron los ensanches en casi todas las ciudades españolas: los proyectos preveían la incorporación de de jardines en el interior de las manzanas y parques más amplios, en los límites de la trama. SOTO CABA, Victoria (1993): «Jardines de la Ilustración y el Romanticismo en España», en BUTTLAR von Adrian, Jardines del Clasicismo y el Romanticismo. El jardín paisajista, editorial Nerea, p.323-324. 
ajardinados para uso comunitario, como sucedía en algunas manzanas del ensanche de Valencia $^{76}$ o en paradigmático ensanche de Ildefonso Cerdá en Barcelona. Pero la especulación pronto desvirtúo estos espacios comunitarios diseñados para la salud física y mental, cubriéndose en planta baja para locales comerciales.

Entre 1885-1890 se aprueba en Castellón las nuevas alineaciones de los ensanches de Almelar y Mestrets, situadas en la zona oeste de la ciudad. ${ }^{77}$ Estas están dispuestas en manzana cerrada sobre un trazado en cuadricula de anchas calles, siguiendo un diseño similar a los ensanches anteriormente descritos, pero de dimensiones mas reducidas.

Esta amplia expansión supuso importantes mejoras urbanísticas e higiénicas en el nuevo orden urbano. Se localizó en el extrarradio de la ciudad, entre la ronda oeste y la línea de ferrocarril, en la zona más alta y seca de la población, junto a una zona de dominio público formada por el recién creado parque de Ribalta, el nuevo Hospital Provincial y la plaza de toros. Está formado en su mayoría por viviendas unifamiliares de planta baja y piso, aún de estrecha fachada y acusada profundidad, de modesta condición, para una población generalmente emigrante obrera, no agrícola, en donde se mezclan junto a las viviendas naves y talleres. Su tipología, aunque mejora sensiblemente las condiciones higiénico-sanitarias, presenta cierta similitud con los contiguos barrios de labradores de San Felix y de Trinidad.

También en 1885 se crea el ensanche de Herrero, situado en la zona sureste de la población, junto al nuevo Teatro Principal, entre la plaza de la Paz y la acequia mayor; pretendía ser el ensanche burgués de la ciudad pero no terminó de prosperar. ${ }^{78}$

Se trata en este caso de manzanas de mayores dimensiones, en su mayoría para viviendas colectivas con uno o dos pisos por planta, de cuatro alturas y mediana apariencia, con algunos edificios importantes. El tamaño de la manzana permitía la formación en su interior de patios mancomunados, para dar luz y ventilación a las estancias posteriores de las viviendas, siguiendo los planteamientos higienistas de los

\footnotetext{
76 SIMO, Trinidad ((1973): La arquitectura de la renovación urbana en Valencia, Albatros Ediciones, Valencia, p.41.

77 SIMÓ Trinidad. (1987): «Arquitectura y Urbanismo. 1874-1920», AGUILERA CERNI, Vicente (coor.) Historia del Arte valenciano, T.5 (Entre dos siglos), Consorcí D'Editors Valencians,S.A., p.58.

78 BURRIEL de URIETA, Eugenio L.(1971): Desarrollo urbano de Castellón de la Plana, Estudios Geográficos, no 23, Madrid, pp.224-226.
} 
ensanches de las grandes capitales, pero el incumplimiento reiterado de la profundidad edificable, hizo en muchos casos inviable esta mejora higiénica del patio de manzana.

Paralelamente a este crecimiento periférico, donde mayoritariamente se alojará el proletariado urbano, se acometen en el centro de la población varias reformas interiores, actuaciones todas ellas hechas contra la ciudad histórica, para acomodar a la nueva burguesía, acogiéndose para su ejecución y financiación a las citadas leyes urbanísticas estatales. ${ }^{79}$ Se abren, prolongan o ensanchan calles que estaban cerradas por las murallas o por su propia estructura medieval, con el objetivo de mejorar la circulación de personas y vehículos e higienizar zonas del casco antiguo. También se configuran varias plazas en las explanadas de los antiguos portales: como la nueva plaza de la Paz, la plaza de La Unión (puerta del Sol) y la plaza de la Independencia, donde se localizará junto a las nuevas residencias de la emergente burguesía terrateniente y exportadora, la vida social, cultura y financiera de la ciudad.

Por otro lado, el creciente desarrollo del puerto va hacer avanzar las edificaciones junto a la carretera del Mar, en un típico despliegue tentacular de la urbe. Se trata especialmente de almacenes y talleres y casas de modesta condición, el barrio de Tenerías surge, poco a poco, a su lado; algo parecido se empieza a producir en el acceso por la carretera de Valencia. ${ }^{80}$ Los viejos barrios de labradores también se desarrollan hasta acotarse con caminos y los nuevos barrios.

Años después, el arquitecto José Gimeno Almela redacta el primer Plan de ensanche de la ciudad, aprobado en 1914, en el que recoge las alineaciones de los ensanches de 1885 y 1890 del arquitecto Godofredo Ros de Ursinos, el ensanche del camino del mar y las reformas interiores del casco antiguo. Y lo más importante de aquellos años, la asignación a cada sector urbano de sus propias ordenanzas de habitabilidad y diseño. ${ }^{81}$

Estas fueron las directrices del desarrollo de la ciudad para las próximas décadas. El crecimiento de los ensanches fue lento e irregular. En 1920 sus tres barrios en cuadricula tienen ya personalidad, pero hasta 1940 no se completaran.

\footnotetext{
79 De 1879 es la Ley de Expropiación forzosa, que instrumentaliza la ejecución de los ensanches y reformas interiores. Ley de Ensanches y reformas de poblaciones, de 1876.

${ }^{80}$ BURRIEL de URIETA, Eugenio L. (1971): op. cit, p.226

${ }^{81}$ PEÑIN, A.; GRANDE, F., VARELA, S. (1988): «Arquitectura y Urbanismo», en AGUILERA CERNI, Vicente (coor.) Historia del Arte valenciano. El siglo XX hasta la guerra del 36, T.6, Consorcí D’Editors Valencians, S.A., p.34.
} 


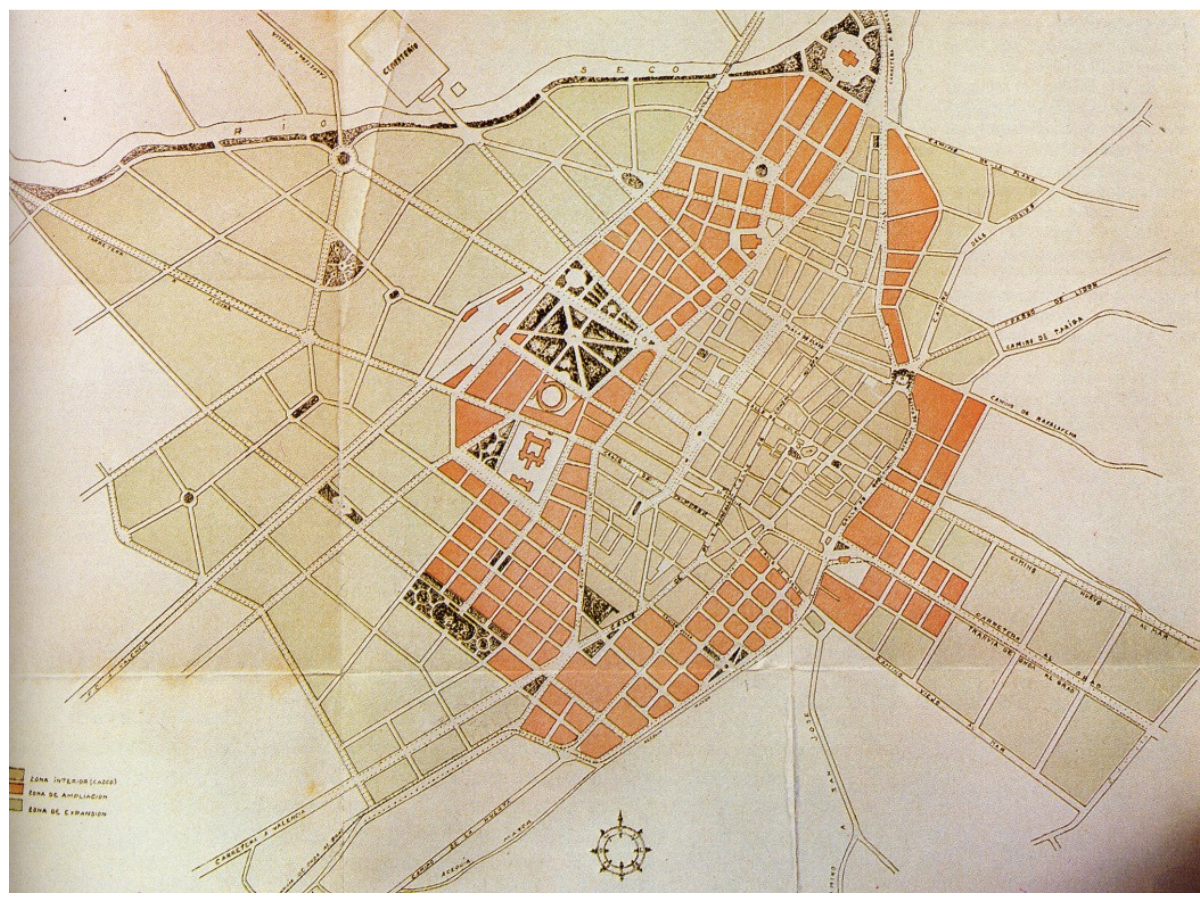

Plan General de Ordenación y Urbanización de Castellón, año 1924

Traver Tomas, Vicente (1925): Un plan general de ordenación y urbanización de Castellón, Boletín de la Sociedad Castellonense de Cultura, T.VI

Tras la aparición del Reglamento de Obras y Servicios en el año 1925, Castellón dispondrá de un Plan General de Ordenación y Urbanización. ${ }^{82}$ Su autor, seleccionado tras un corcuso público de anteproyectos, será el arquitecto castellonense Vicente Traver. El Plan, aprobado en 1928, introduce por vez primera la idea de «zoning» en el planeamiento, subdividiendo el área urbana en tres sectores, casco viejo, zona de ampliación y zona de extensión o expansión, recurriendo a las tipologías higienistas imperantes en el momento, y adecuando cada uno de ellos a las doctrinas de Ildefonso Cerdá para el en ensanche y de Ebenezer Howard (ciudad jardín) para la extensiva. ${ }^{83}$

Su claridad formal, la adecuada información técnica, con la incorporación de las variables de soleamiento, arbolado y saneamiento, hacen del mismo uno de los planes de mayor interés técnico- higienista del País Valenciano. ${ }^{84}$

\footnotetext{
${ }^{82}$ GIMENO MICHAVILA, Vicente. op. cit., p.36.

83 TRAVER TOMÁS, Vicente (1925): «Un plan general de ordenación y urbanización de Castellón», BSCC, T.VI p.189-198.

${ }^{84}$ PEÑIN, A.; GRANDE, F.;VARELA, S. (1988): op.cit.p.37.
} 


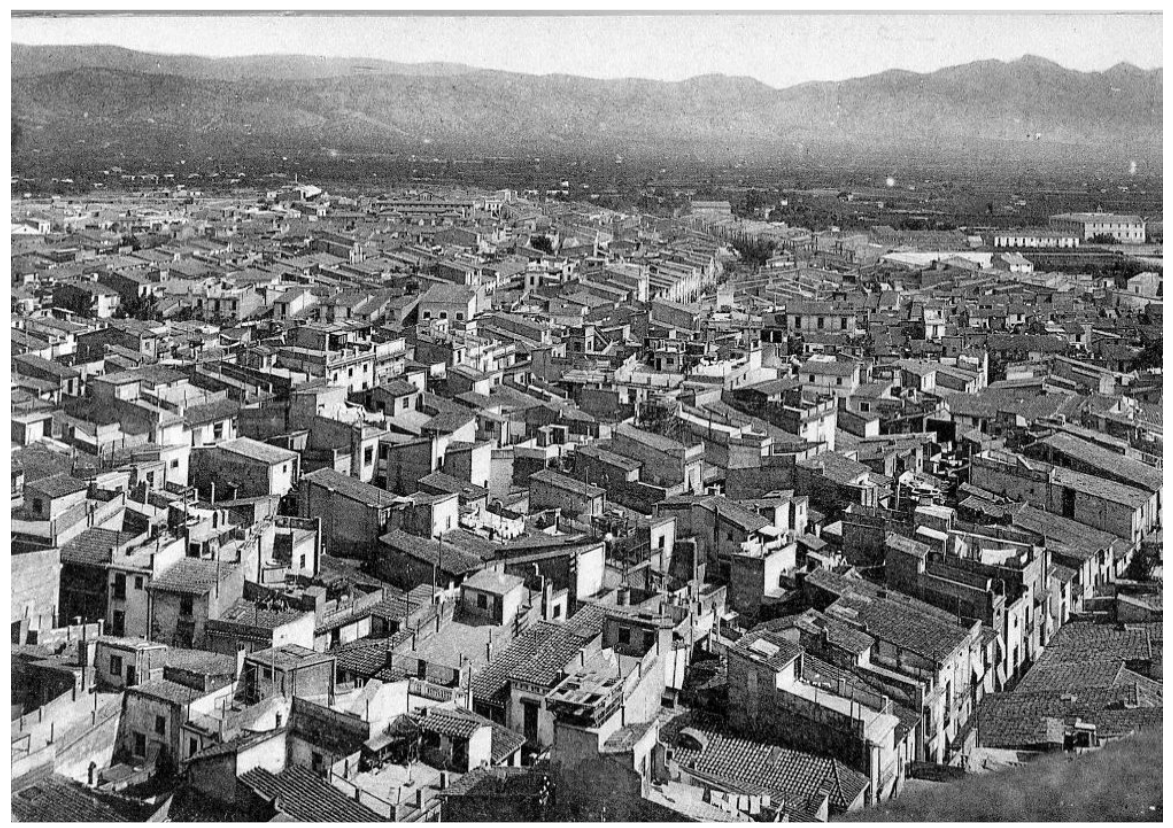

Castellón a finales del primer tercio del siglo XX, en donde se puede apreciar aún la uniformidad en las alturas de las viviendas y el tipo de parcelación, de estrecha fachada y gran profundidad. Fuente: Vista general, tarjeta postal, L. Roisin, fot-Barcelona

\section{LA VIVIENDA URBANA Y SUBURBANA}

La vivienda del agricultor es mayoritaria en la población de Castellón, tanto en el casco antiguo como en los arrabales. En el siglo XVIII casi las tres quintas partes de la población activa se dedican a la agricultura. Esta proporción decae hasta el 38 por ciento en 1900, manteniéndose algo por debajo hasta bien entrado el siglo XX. ${ }^{85}$

Hasta finales de los años sesenta del siglo XX el tipo labrador sigue presente en las calles con sus trajes, bicicletas, incluso con el carro, manteniendo sus coloquios sentados en las puertas de las casas después de la jornada de trabajo.

Esta tipológica viviendista, propia del siglo XVII, que podemos ver en muchas poblaciones de nuestras comarcas de análoga economía, supone una evolución y renovación constante del patrimonio edificado desde el centro urbano a la periferia.

Constan generalmente desde su inicio de una sola planta, que evolucionó con el tiempo a dos alturas, en donde las personas y el animal conviven en un mismo espacio poco diferenciado. Con unas infraestructuras urbanas y condiciones higiénicas muy

\footnotetext{
85 BURRIEL de URIETA, Eugenio L. (1971): Desarrollo urbano de Castellón de la Plana, Estudios Geográficos, no 123 , Madrid, p.265.
} 
deficientes, en donde los servicios de agua potable y alcantarillado no tienen su presencia hasta bien entrada la primera década del siglo $\mathrm{XX}$, teniendo que utilizar depósitos de letrinas y pozos ciegos para la evacuación de aguas residuales y pluviales. Las que tienen dos alturas desarrollan parte de la vida familiar en la planta superior, eliminado así el contacto continuo con el suelo y las cuadras.

Las que cumplen funciones artesanales tienen dos o más pisos: la planta baja aloja el taller y el corral, situándose la vivienda en planta piso, con escalera interior o exterior por fachada, utilizando la última planta para almacén de material de los oficios y también para las cosechas. Siendo las condiciones de salubridad de la casa muy similares.

En el reducido espacio del hábitat rural y su entorno, hay un continuo contacto entre las personas que trabajan el campo y los animales que le son de apoyo.

La vivienda de la clase social en ascenso aumenta en el último tercio del siglo XIX, yendo acompañada de nuevos gustos decorativos y criterios arquitectónicos. Aunque surgen nuevas viviendas unifamiliares, la casa burguesa por pisos comienza a tener una presencia destacada en las dos últimas décadas, localizándose principalmente en las calles más céntricas del casco antiguo, siendo sus condiciones de habitabilidad y diseño sensiblemente mejores. La altura no sobrepasa los tres cuatro pisos, resolviéndose generalmente a base de dos viviendas por planta, en donde los nuevos modelos alternan la propiedad con el régimen de alquiler. En un primer momento los servicios higiénicos son compartidos por la comunidad en la planta baja, pero con el tiempo son alojados en las diferentes viviendas, mejorando las condiciones de habitabilidad para esta clase social. El agua potable se empieza a distribuir a partir de la última década del XIX, y el alcantarillado fue la infraestructura más tardía, no iniciándose su trazado por las calles más céntricas y principales hasta bien entrada la primera década del siglo XX.

La vivienda suburbana de recreo también experimenta en la primera década del siglo XX sensibles mejoras en los espacios de habitabilidad e higienicos, y situándose sobre un basamento o podio que la aísla del suelo.

Por último, las viviendas obreras empiezan a surgir con el inicio del nuevo siglo, recogiendo la herencia de las nuevas infraestructuras y los primeros reglamentos de salubridad y normativas urbanísticas. Su localización se generaliza en los nuevos ensanches y en los antiguos arrabales. En su mayoría son unifamiliares en hilera de uno 
o dos pisos, de reducidas dimensiones y con aspecto todavía de tradición agrícola. Las condiciones de habitabilidad garantizan iluminación y ventilación en todas sus estancias, con servicio higiénico individual en cada vivienda.

\subsection{LA CASA DEL LABRADOR, CON PAS DE CARRO}

El tipo más elemental y probablemente más antiguo que nos encontramos es la casa de una sola planta. Ésta se articula sobre el «pas del carro» que atraviesa la vivienda perpendicularmente a la calle, paso que suele encontrase junto a uno de los muros laterales, con fachada generalmente de cuatro metros, «casa a una mà»; o las menos corrientes, en posición central, «casa a dues mans», con mayor anchura de fachada. ${ }^{86}$ La primera estancia la ocupa, además del paso del animal y del carro, un pequeño espacio para alojar los cantaros de agua y una o dos alcobas, de las que solo ventila una de ellas. En el segundo tramo de la casa está la cocina, que suele formar junto con el comedor y el salón de estar un espacio único, siendo el lugar más importante de la vida familiar. Esta amplia estancia principal está separada por un patio descubierto del corral, la cuadra y los aperos, y donde también hay un altillo o entreplanta para la paja y el forraje.

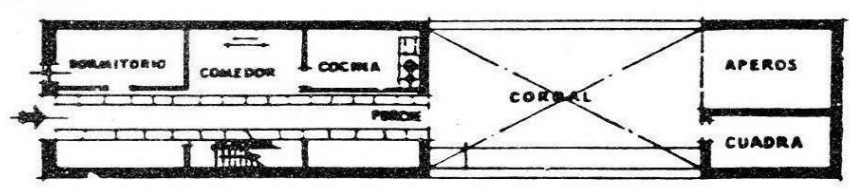

- Casa a una mà

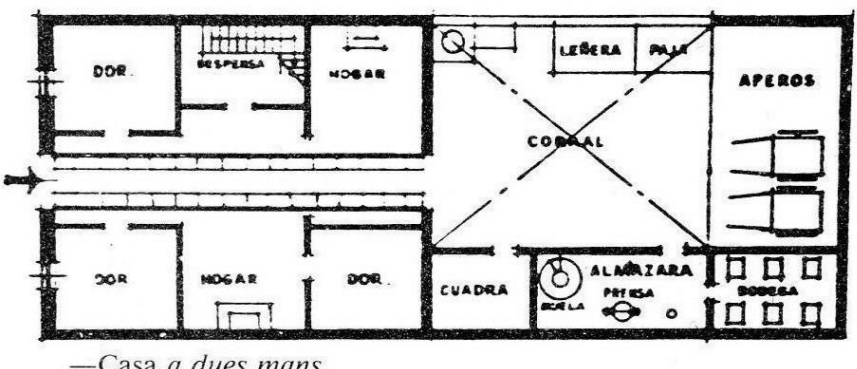

Tipos de casas de labradores « con pas de carro», según Casas Torres. Fuente: BOIGUES, Carles. (1983): Les cases agrupades i urbanes: tipus i evolución

\footnotetext{
${ }^{86}$ BOIGUES, Carles. (1983): «Les cases agrupades i urbanes: tipus i evolución», en MIRA, Joan. (Coord.), Temes d'etnografia valenciana, Alfons el Magnànim. p. 267.
} 
En el corral, además de los animales está el retrete y el pozo ciego, también está el lugar donde se fermenta el vino o los lechos donde se produce el estiércol, ${ }^{87}$ práctica que se remonta a finales de la Edad Media.

La cubierta con acabado de teja, generalmente es a dos vertientes, hacia la calle y hacia el patio interior. Los muros, dada la escasez de piedra en la zona, son generalmente de tapial (tierra, cal y paja con algo de piedra para dar consistencia). El suelo y los tabiques de la planta baja están en contacto directo con el terreno, y es por donde suben las humedades. El piso de la planta baja, en la zona de paso del animal es de tierra compactada con acabado de cantos de río, y las franjas, donde apoyan las ruedas del carro a su paso hasta el patio, son generalmente de losas de piedra. En la cocina, junto a la chimenea hay una pequeña zona chapada de azulejo hasta media altura, con el suelo acabado con mortero de cal, el resto de estancias suelen ser iguales o simplemente de tierra compactada. Los forjados son de madera con revoltones o bovedillas de ladrillo o yeso. La parcelación más frecuente presenta un ancho a la calle de aproximadamente cuatro metros y gran profundidad, entre 16 y 20 metros. La fachada es lisa con acabado de mortero de cal, tiene amplia puerta adintelada para el paso del carro, y reducido ventanal en la zona de bajocubierta, lugar donde se almacenan los productos del campo. Ver fotos y planos adjuntos de esta tipología edilicia.

87 SANCHEZ GOZALBO, A .(1972): « La sanidad en el Castellón trecentista (veterinarios, médicos y boticarios)» B.S.C.C., t. XLVIII, pp.246-247. «Recluida dentro del recinto fortificado la pequeña villa se abastecía con aguas procedentes de pozos, sin tener donde verter sus aguas residuales las casas, las más de una sola planta, no era de extrañar que la peste, tan frecuente en todos las latitudes y otras pandemias azotaran su vecindario. Eran estrechas sus calles, algunas principales en el siglo XVI empedradas; algunas con rudimentarias cloacas en la periferia destinadas a absorber el agua torrencial de las calles transversales (orientación E-W) con ligera pendiente. Este rudimentario alcantarillado no recogía ninguna de las aguas residuales de las casas, que las vertían, con los excrementos humanos y de las bestias que tenían en las cuadras, en lechos de establos y corrales, como hasta hace poco tiempo se veía en muchos pueblos. Cuando la yacija se podría en cuadras y corrales se limpiaban estos y se amontonaba el estiércol en el pla den Guardiola, llanura frente al portal del mismo nombre en el pla den Trullois o pla del Spital, donde se le removía y acababa su fermentación para después aprovecharlo en el abono y fertilización en las tierras de pan llevar. Sobre estos femers dictó más de una medida, no todas de carácter sanitario, el Consejo e intervino regulando su emplazamiento y recogida, el Mustaçaf. Para su higiene y limpieza tenían los vecinos baños públicos, de indudable ascendencia árabe. Intramuros, pegado a la muralla SE., poco más o menos donde está hoy la plaza de Hernán Cortés, antigua de Pescadores. En 1599 pierde su uso transformándose en fábrica de jabón [...]» 


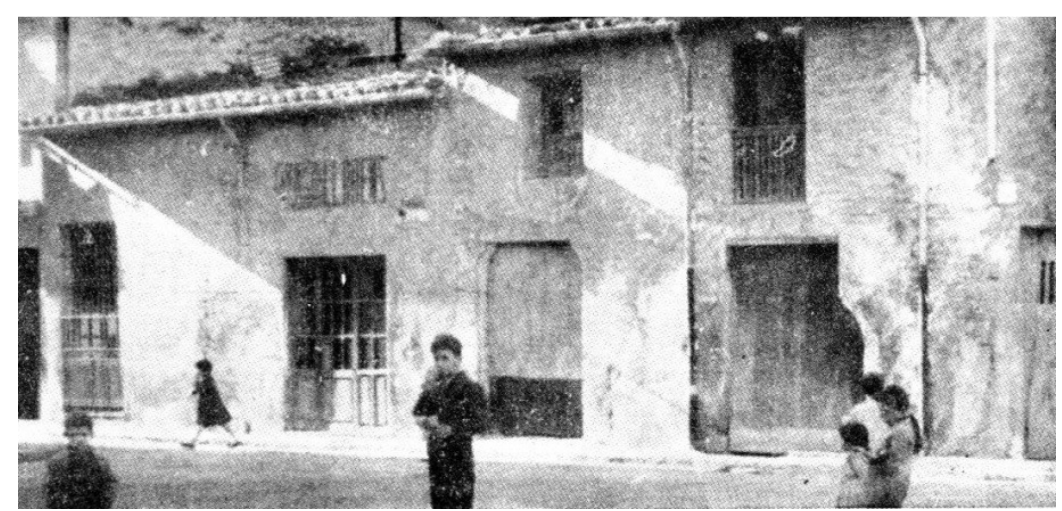

Casas en la calle de la Barraca. Fuente: Traver Tomas, Vicente (1958): Antigüedades de Castellón

La planta baja con desván o cambra, es un tipo estructural que evoluciona del anterior. Suele presentar dos variantes: la primera, y más frecuente, es un hueco en fachada similar a una puerta, para poder acceder las cosechas directamente a la andana sin pasar por el interior de la casa. La otra variante es un espacio superior, en bajocubierta de menor altura que la planta baja, y no tiene más luz y ventilación que unas pequeñas aberturas sin carpintería. La escalera de comunicación entre las dos alturas se encuentra generalmente junto al espacio de la cocina.

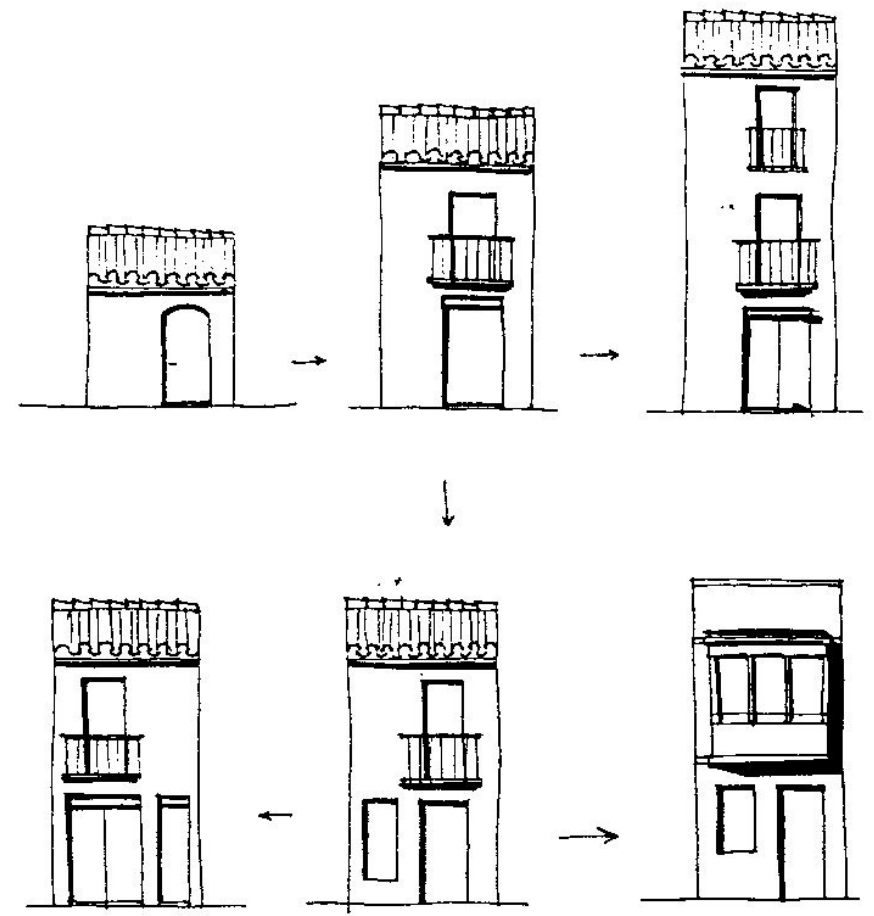

Esquema del origen y evolución de la tipológia en el Barrio de San Felix de Castellón Fuente: Archivo Histórico del Colegio de Arquitectos de Castellón 
El incremento demográfico del siglo XVIII, que se prolonga durante el siglo XIX, va acompañado en el campo constructivo de dos movimientos paralelos: por un lado, una expansión importante de la construcción y por otro lado de una sobrevaloración de las casas ya existentes. Es así como surge un tipo nuevo, readaptando o sobreelevando, la cambra como espacio habitable, generalmente para alojar la familia de algún hijo o hija. Estas modificaciones obligan a ocupar, y en consecuencia a reducir sensiblemente el antiguo patio descubierto y a edificar nuevos espacios de almacén para las cosechas. La última morfología resultado de la variación del tipo y que aparece aproximadamente a partir de la década de 1880, como resultado de nuevas condiciones económicas y demográficas, se refiere a la casa de tres plantas: dos pisos y desván, en donde la planta baja se usa para las funciones de día, y la superior aloja los dormitorios y una sala a la calle. Esta nueva variante mejora noblemente las condiciones de habitabilidad de la casa del labrador. ${ }^{88}$

En el primer tercio del siglo $\mathrm{XX}$, la cambra también se ha utilizado como vivienda de alquiler o se ha vendido, originando un cambio de la propiedad, con una modificación sustancial en la fachada, apareciendo una entrada independiente de la principal. Es la popular escaleta, nombre al que se designa esta variante tipológica.

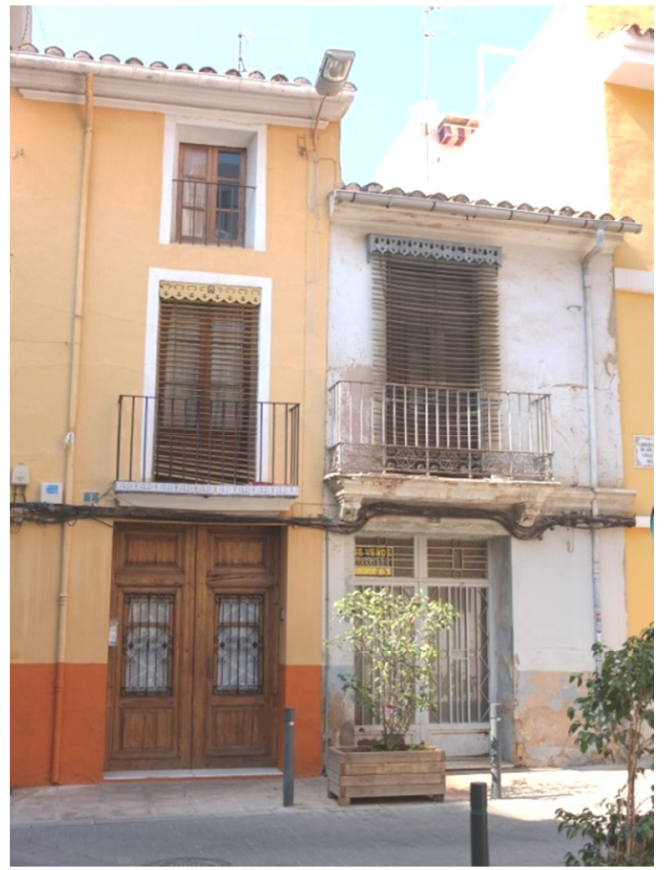

Casa de labradores en el barrio de San Félix de Castellón. Fondo fotográfico: Concepción Calvo

\footnotetext{
${ }^{88}$ Para mayor abundamiento, ver la descripción de « La casa del labrador en el viejo Raval», en Apéndice Documental, $\mathrm{N}^{\circ} 1$.
} 
A partir de los años veinte aparecen cambios en la composición exterior de la casa y en la distribución y servicios interiores, como resultado de una desvinculación de una parte de la población de las actividades agrícolas. Estos cambios pueden resumirse en una diferenciación de la cocina del espacio de estar; la asignación en el uso de las alcobas; la progresiva aparición del cuarto de baño, aunque todavía el retrete aparece como un elemento aparte, sin casi importancia espacial dentro de la casa y estando mas próximo al mundo del corral. ${ }^{89}$

Los tipos anteriormente reseñados los podemos encontrar en muchos pueblos de nuestras comarcas que desarrollan actividades agrícolas similares, en donde han permanecido los usos hasta finales de 1960.
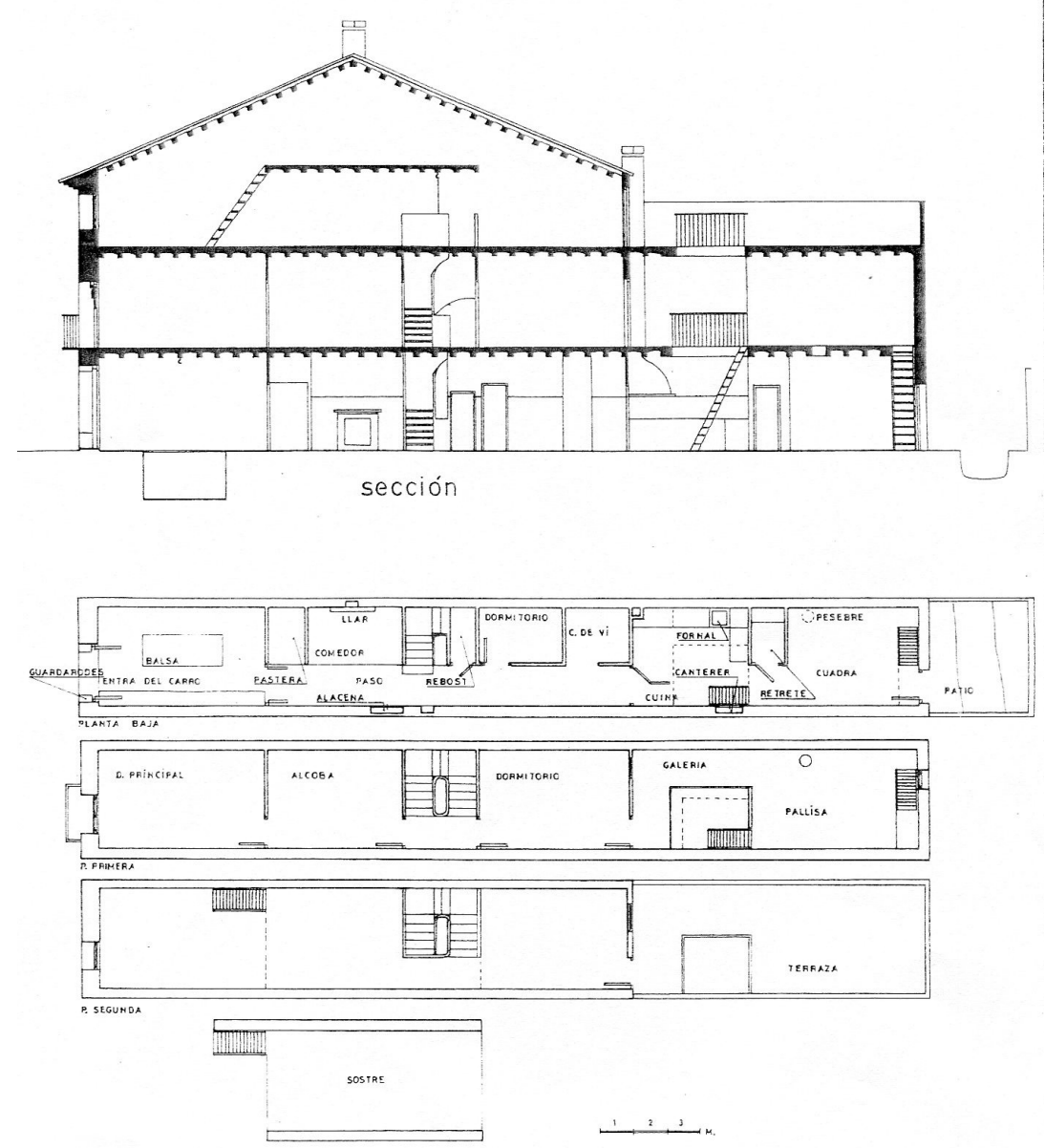

Plano de plantas y sección de una vivienda de llaurador artesá en el viejo Raval. Fuente: Ledesma Fernando « La casa del labrador en el viejo Raval», Magdalena 89

\footnotetext{
${ }^{89}$ BOIGUES, Carles. (1983): op.cit., pp. 270-277.
} 


\subsection{LA CASA DEL JORNALERO}

Responde a una solución tipológica similar. Está resuelta en una sola planta o planta baja y piso, y presenta un frente de fachada no mayor de 4 metros, con una profundidad sensiblemente menor, aproximada de15 metros, en donde se incluye un pequeño patio-corral al fondo de la vivienda, donde se crían animales domésticos para el consumo.

La primera parte de la casa está reservada para un pequeño vestíbulo-pasillo y una o dos alcobas, generalmente sin ventilación y sin un uso específico; en la segunda parte está la cocina-comedor, recayente al patio, y donde se realiza la vida familiar. Un elemento que lo caracteriza es que la puerta de la calle es sensiblemente más estrecha que en la casa del labrador, ya que no hay necesidad de entrar el carro.

Esta tipología surge a mediados del siglo XVIII, principalmente en los arrabales, donde empezó a asentarse una importante población emigrante. A finales del XIX, con el mayor crecimiento demográfico y económico, atraído principalmente por el monocultivo de la naranja, vuelven a surgir, esta vez en forma de pequeñas promociones o cooperativas de viviendas, pero con el mismo carácter agrícola tradicional.

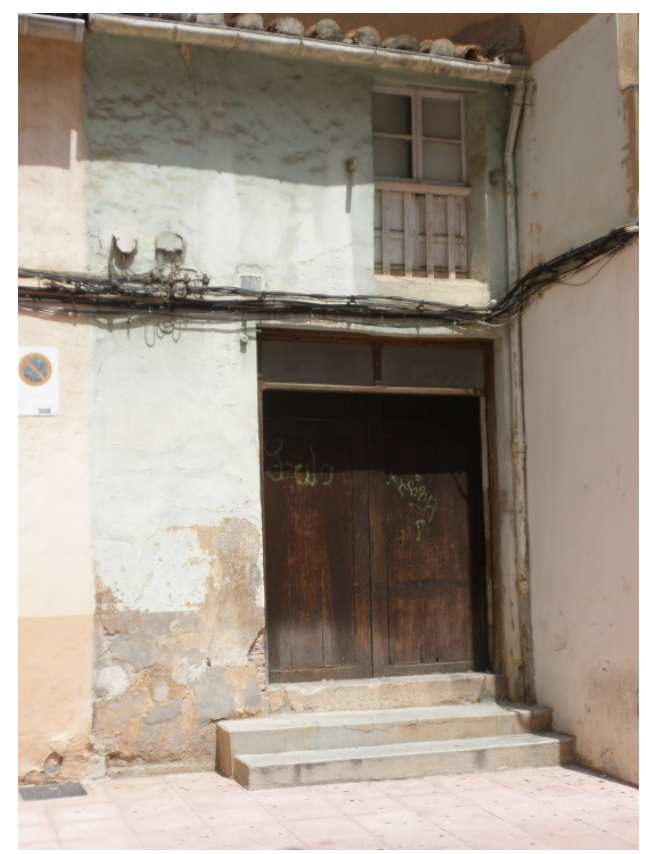

Casa del jornalero del campo, en el arrabal de la Trinidad. Fondo fotográfico: Concepción Calvo 


\subsection{LA CASA DEL OBRADOR}

Es un edificio de carácter mixto, que compatibiliza las funciones artesanales con las de vivienda: en donde la planta baja aloja el taller y las cuadras, situándose la vivienda en planta piso. El acceso a la misma se realiza por escalera interior o por escalera exterior situada en fachada. Tiene en la mayoría de los casos un tercer piso, a modo de desván, que aprovecha el espacio de bajocubierta para almacén. Dependiendo del oficio las dimensiones pueden variar, pero el esquema general es similar en todos los casos. Se trata de un espacio flexible y generalmente diáfano en planta baja, en donde también suele haber una pequeña zona de cocina-estar, que desemboca en un patio-corral situado al fondo de la edificación, donde se aloja el animal, se ubica el carro y también hay un lugar para el retrete.

Muchas veces, el trabajo artesanal que se realizaba en el vestíbulo, en la puerta de entrada o en la calle, se tenía que desmontar para pasar el carro.

Esta tipología es también resultado de la transformación o adaptación de la casa del labrador anteriormente descrita, como consecuencia de periodos de fuerte demanda de actividades derivadas de la agricultura o de ciertas artesanías. En este sentido, el mayor desarrollo de estos edificios se empieza a generar a partir del siglo XVIII, mediante un sistema de producción preindustrial, en donde la casa es un espacio de producción donde se manufacturan los productos propios del gremio. ${ }^{90}$

Como consecuencia del largo periodo que duró la industria derivada del cáñamo, seda y artesanía textil, se produjo un desarrollo espectacular de este tipo de construcciones. Sogueros, alpargateros, curtidores pelaires y tejedores de lana y lino son los artesanos más característicos. Estos oficios aparecen en numerosas calles, reflejándose en la tipología de las viviendas. Eugenio Burriel nos describe el diseño y los problemas higiénicos de una casa de $\operatorname{sogueros}^{91}$ :

La manipulación de grandes bolsas de fibra, que por la estrechez de la escalera no entraban, se introducían por un amplio hueco en la fachada; además se tenía que preservar la casa del abundante polvo que se levantaba con el peinado de la fibra. Para ello la casa disponía de una amplia estancia en la falsa (bajo cubierta)

\footnotetext{
${ }^{90}$ BOIGUES, Carles. (1983): op.cit., pp. 283-284

${ }^{91}$ BURRIEL de URIETA, Eugenio L. (1971): op.cit., p.212.
} 
con un gran hueco con antepecho de balaustres de madera, que estaba protegido por un amplio alero del que colgaba la polea para subir la bala. Al obrador se entraba por una trampilla horizontal en lo alto de la escalera que se cerraba herméticamente.

En la imagen anterior podemos observar, tal y como nos describe el profesor Eugenio Burriel, el típico obrador del cáñamo con su polea, que lucía en muchas fachadas de la villa por las calles de Gumbau, Arriba, plaza Nueva y sus inmediaciones.
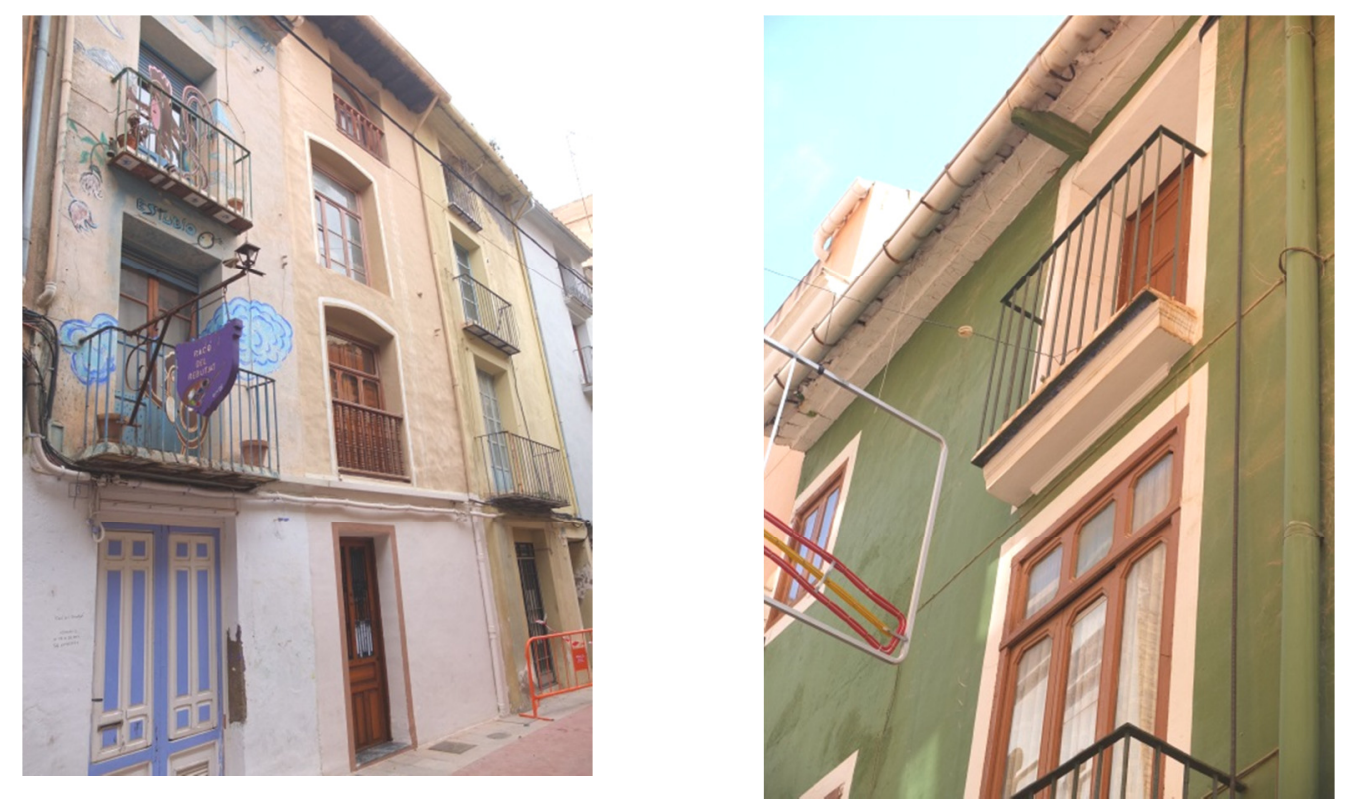

Antigua casa de obrador, aún con la viga de madera que sujetaba la polea por debajo de la cubierta Fondo documental: Concepción Calvo

Hoy día, aunque muy transformadas, se conserva un número significativo de estas edificaciones en ciertos barrios del centro de la ciudad, que fue en donde más se localizaron estas actividades del sector secundario.

\subsection{EL HÁBITAT RURAL TEMPORAL}

El labrador propietario y el jornalero del campo, que pasan el día en el campo, requieren de un espacio cubierto para guardar los aperos, comer, descansar y también para cobijar el animal. La mayoría de los predios disponen de sencillas construcciones con pequeño corral para animales domésticos, un porche bien orientado y un pozo de agua en sus alrededores. 
El espacio interior tiene dos zonas claramente diferenciadas: el ámbito del animal con el pesebre y el pajar, y el entorno habitado que cobija un espacio único formado por el estar-comedor-cocina. También suele haber un altillo de madera, al que se accede por una empinada escalera, y que ocupa la mitad del espacio inferior, en donde suele haber una cama junto al pajar. El suelo de la planta baja es de tierra compactada y solamente la zona de la chimenea tiene suelo de cemento y la pared está alicatada hasta mitad altura. ${ }^{92}$

Se puede constatar el diario y estrecho contacto entre las personas, el animal y el medio natural, en un espacio tan acotado.

El tipo elemental que aún persiste, tiene una variante que evolucionó hasta transformase en la alquería en la huerta o en el maset en el secano, donde las familias solían pasar la estación canicular.

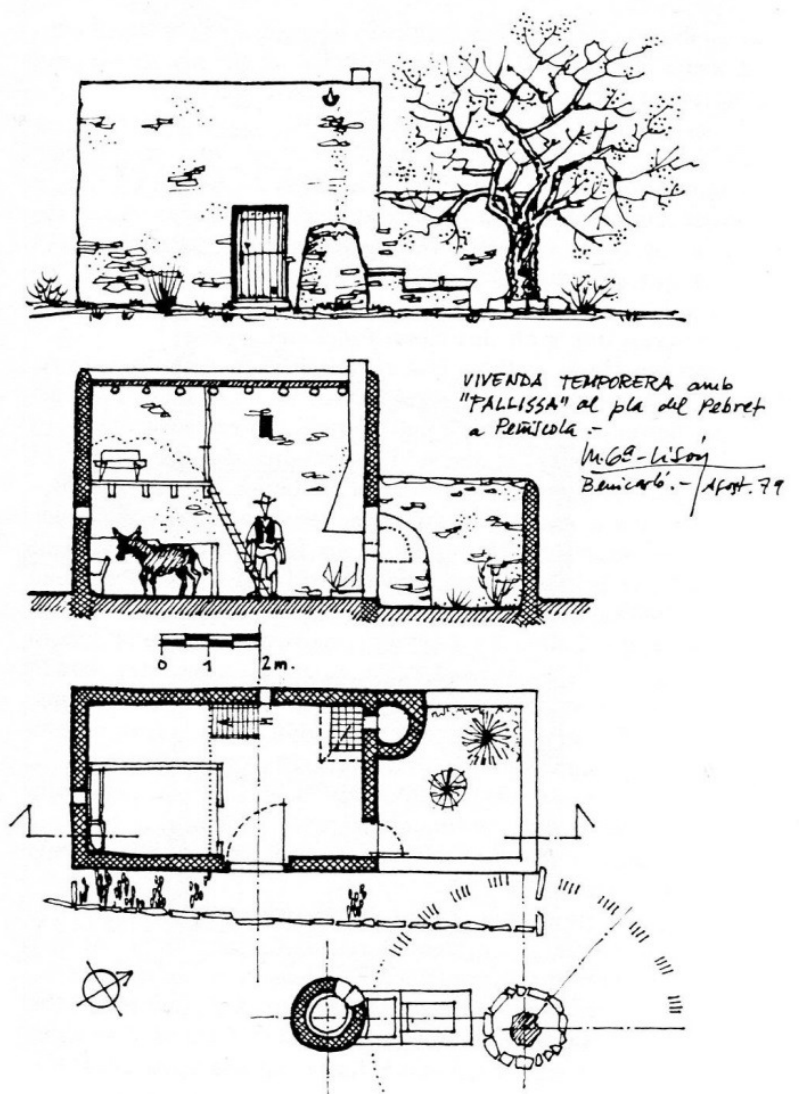

Vivienda temporera con «pallissa». Fuente: García Lisón, Miguel; Zaragoza Catalán, Arturo (1983): «Arquitectura rural primitiva en seco»

\footnotetext{
92 GARCIA LISÓN, Miguel; ZARAGOZÀ CATALAN, Arturo (1983): «Arquitectura Rural primitiva en seco», en MIRA, Joan. (coor.), Temes d'etnografia valenciana, Alfons el Magnànim. p. 171-177.
} 


\subsection{DE LA CASA SEÑORIAL A LA VIVIENDA BURGUESA}

Los antecedentes de las casas burguesas hay que buscarlo en las casas aristocráticas del XVII, que se prolonga en el palacio barroco del XVIII y que sufrirá cambios importantes para adaptarse a la propiedad horizontal. La combinación dará como resultado la casa de la naciente burguesía liberal que asimilará con agrado aquellos símbolos de poder. ${ }^{93}$ Aunque de menores dimensiones, se mantendrá el amplio portal de acceso con zaguán, situándose en segundo plano una ampulosa escalera. Los pisos superiores tienen varias viviendas por planta, en donde la distribución de cada vivienda procura tener un máximo de habitaciones iluminadas y bien ventiladas a la calle o a los patios interiores. Las plantas bajas ofrecen diversos usos para los servicios propios o como alquiler de locales de negocios. En la composición y decoración de sus fachadas predominan los estilos académicos o eclécticos, solamente a finales de siglo irrumpe tímidamente el nuevo lenguaje modernista.

La familia, el negocio y las manifestaciones públicas de su poder económico y de su consolidación social como clase, son algunos de los principios básicos de la nueva sociedad, en la que el ámbito de la vivienda no era ajeno a estas consideraciones del modo de vida burgués. En este sentido, la localización de la vivienda familiar, su tamaño, el lujo, el decoro, la limpieza y las instalaciones higiénicas que disponía, determinaban el nivel socioeconómico de la familia burguesa que lo habitaba. La casa se convirtió en el lugar para el tiempo libre, además de espacio de trabajo; la casa era un lugar social, pero curiosamente privado, además de objeto e imagen de prestigio. ${ }^{94}$

Estas residencias unifamiliares y plurifamiliares tenían una rígida distribución de sus espacios, pasando de los salones de uso familiar y de vida social, situados en la zona más representativa y noble de la casa, a las habitaciones para el estricto uso privado. Incluso estos últimos se encontraban diferenciados en zonas para cada uno de los miembros de la familia. ${ }^{95}$ Situación completamente opuesta a la que tenían las clases

\footnotetext{
${ }^{93}$ BOHIGES, Carles (1983): op. cit, p.286. También en BOHIGUES Carles., p.285 [...] el palacio del XVII conserva todavía el esquema de composición espacial que recuerda los palacios góticos: organizados alrededor de un patio central, al que se accede por amplio zaguán que conecta a la calle a través de un gran portal, patio del que arranca una desarrollada escalera que sube a las dependencias del señor, mientras que los criados se encuentran en la planta baja. Al fondo del patio están los establos para las caballerías, y espacio para los carruajes [...].

${ }^{94}$ RIBADULLA CUMPLIDO, Concha (2006): Vida cotidiana y confort en la Valencia burguesa (1850-1990), Biblioteca Valenciana Generalitat Valenciana, p.52.

${ }^{95}$ Ibídem, p.57.
} 
menos acomodadas, y que hemos visto en las viviendas anteriormente descritas, en donde el confort y la privacidad no existía, siendo las alcobas espacios no diferenciados, ${ }^{96}$ además de no disponer de los mínimos higiénicos.

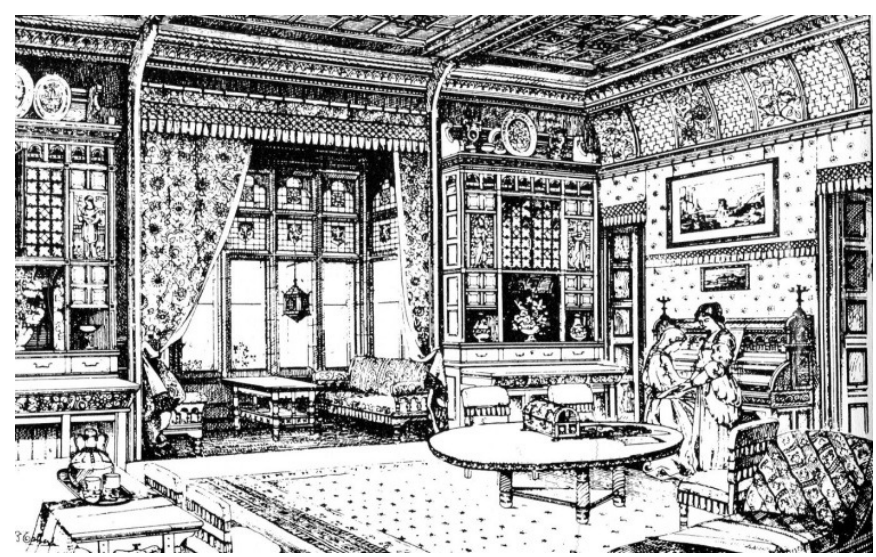

Un interior burgués: sala de estar diseñada por B.Talbert en 1869.

Fuente: Sica Paulo (1981): Historia del urbanismo. El siglo XIX

Es el momento en el que entran en el escenario de la nueva sociedad valenciana los profesionales de la arquitectura, rivalizando con abogados y espacialmente con los médicos, que hasta entonces había tenido gran predicamento, por su destacada labor durante todo el siglo XIX en intentar erradicar epidemias, y concienciar sobre los graves problemas de salubridad que azotaban las poblaciones.

Fueron los arquitectos, al servicio de la ideología dominante, los artífices que fielmente interpretaron las ideas burguesas, materializando sus aspiraciones. Hasta el extremo que se convirtieron en una profesión de élite, como una de las más influyentes y apetecidas. $^{97}$

\footnotetext{
${ }^{96}$ Un factor determinante en la organización de la vivienda burguesa es la noción de intimidad. «En el siglo XIX se va generalizando al menos entre las clases acomodadas, un afán de intimidad que ya había hecho su aparición, aunque solo en el seno de la aristocracia, a finales del siglo XVII, y sobre todo durante el siglo XVIII: Hasta esas fechas se vivía en común y el aislamiento y la privacidad eran prácticamente imposibles; la vida diaria tenía lugar en una habitación que compartían los diversos miembros de la familia, los huéspedes y hasta el servicio; no existían habitaciones según funciones, y un mismo cuarto podía servir de comedor, de dormitorio y de recibimiento. Esta promiscuidad entre personas y esta multifuncionalidad de las habitaciones se mantuvo durante el siglo XIX en las viviendas de las clases menos acomodadas, en las que una única pieza podía llegar a ser cocina, lugar apto para comer e incluso servir de habitación para dormir la familia [...] », en GOMEZ-FERRER MORANT, Guadalupe (1997): «La vida privada», en JOVER ZAMORA, José María, (coor.), Historia de España por Ramón Menéndez Pidal. T.XXXIII, Los fundamentos de la vida laboral (1834-1900). La sociedad, la economía y las formas de vida. Espasa Calpe, Barcelona, p.642-643.

${ }_{97}$ PEÑIN IBAÑEZ, Alberto (1978): Valencia.1874-1959 Ciudad, Arquitectura y Arquitectos, Universidad Politécnica de Valencia, ETSAV, Valencia, p.17.
} 


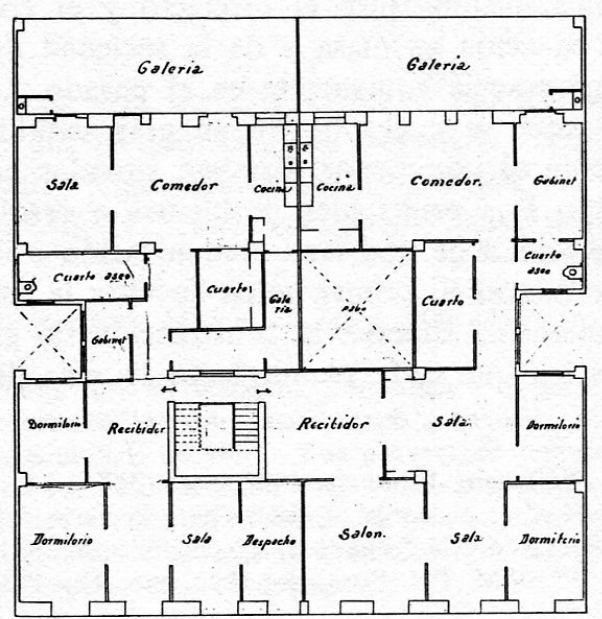

Demetrio Ribes: Planta de una de las viviendas de A. Marco, Valencia 1910. Fuente: Benito Goerlich, Daniel (1983): La arquitectura del eclecticismo en Valencia. Vertientes de la arquitectura valenciana entre 1875 y 1925

La ciudad de Castellón experimenta a partir del último tercio del siglo XIX un significativo crecimiento demográfico y un importante fenómeno migratorio, principalmente de población procedentes de la propia provincia, así como un importante despliega económico agrícola y exportador sin precedentes, que se prolongará hasta finales de la primera década del siglo XX, que junto con su condición de capital de provincia, va a consolidar en pocos años una nutrida burguesía agraria y terrateniente, de pequeños comerciantes e industriales, a la que no faltará el cuadro de profesionales y funcionarios. Todos ellos serán los artífices de las importantes transformaciones de la vivienda y de la renovación urbana de la capital.

A diferencia de lo que sucedió en importantes núcleos urbanos del País Valenciano, como Valencia o Alicante, donde la burguesía se asentó en los barrios más céntricos y saneados de la ciudad, ocupando pronto los nuevos ensanches, con diseños más higiénicos y mejor equipados; en Castellón, la nueva sociedad emergente, probablemente dado el menor tamaño de la ciudad, no tuvo necesidad de ello, decantándose por las zonas más céntricas del casco antiguo; de manera que los primeros planes de ensanches del XIX fueron dirigidos a la población emigrante y a las clases menos pudientes, asentándose desde 1880-1890 en la franja oeste de la ciudad, en los ensanches de Almelar y Mestrets. Aunque hubo un cierto deseo de realizar un ensanche burgués, el de Herrero, en 1890, situado en el triángulo sureste de la ciudad, pronto 
fracasó. Aunque hicieron presencia casas de mediana apariencia y algunas importantes. $^{98}$

Así pues, a partir de puntuales reformas interiores, las nuevas viviendas -que mejoran en condiciones de habitabilidad-, la vida comercial y los espacios para el ocio, se empezaron a localizarse en las principales calles y plazas del casco antiguo, de manera que las calles más estrechas y menos apetecibles de los barrios del centro, permanecerán poco alterados en su estructura social.
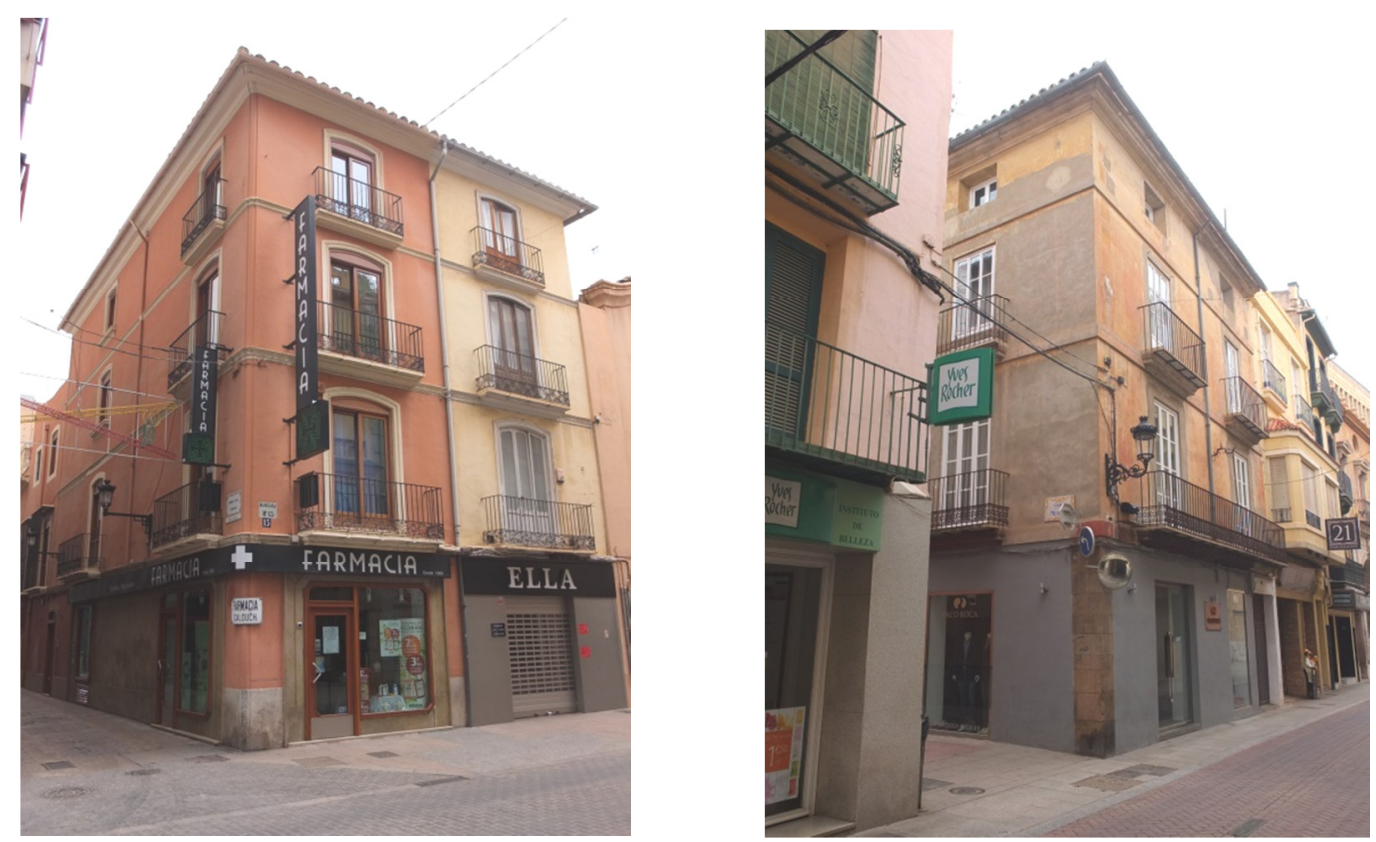

Primeras casas burguesas por pisos del último tercio del siglo XIX, en la calle Emnedio y en la calle Colón de Castellón. Fuente documental: Concepción Calvo

La implantación de las nuevas viviendas burguesas irán sustituyendo las antiguas casas de estrecha fachada y gran profundidad, teniendo que ser necesario en muchos casos el derribo de dos o tres para poder levantar la nueva edificación. Esto debió suponer la erradicación de las clases sociales con menor poder adquisitivo e históricamente asentadas, teniendo que trasladarse a vivir muchas familias a los barrios periféricos. Este hecho no debió ser aislado, en muchas poblaciones del territorio español pudieron darse situaciones similares.

\footnotetext{
${ }^{98}$ BURRIEL DE URUETA, Eugenio 1. (1971): op. cit., p. 223-226.
} 
El nuevo edificio de viviendas, generalmente plurifamiliar, no sobrepasaba las cuatro alturas. Del amplio portal de entrada se pasaba a un espacioso y decorado zaguán, que conectaba con una generosa escalera iluminada cenitalmente, con barandilla artística, que distribuía al menos dos viviendas por planta. La cubierta era generalmente inclina con acabado de teja, donde también solía haber un «terrat» para tender la ropa.

La fachada presenta una marcada jerarquización, como resultado de la estratificación social de su interior. Los pisos más cotizados eran los más bajos. El primero o «principal» además de ser el de mayor comodidad de acceso, interiormente era el que ostentaba mayor lujo y servicios higiénicos, exteriormente también estaba más profusamente ornamentado. El «mirador», ${ }^{99}$ como elemento exclusivamente burgués, no solía faltar en la fachada de las primeras plantas. A medida que los pisos ganan en altura serán menos apreciados, más económicos y en consecuencia más sencillo y menos dotados de servicios, yendo a vivir familias más modestas. La parte de fachada recayente a estas plantas estaba modestamente adornada, y disponía de balcones que reducían su amplitud con la altura, siendo los huecos de la última planta unas sencillas ventanas, como se puede observar en las fotos que acompañan al texto.

La distribución en planta de la casa colocaba a la calle las piezas que se consideraban más «nobles»: salón, comedor y despacho, mientras que los dormitorios y servicios se localizaran en la parte posterior, realizándose la iluminación y ventilación a través de estrechos e irregulares patios de luces.

Las primeras viviendas que se construyen no disponían de los servicios higiénicos mínimos. Solía existir una palangana con o sin pedestal, y un retrete, el comú, para varias viviendas, ubicado generalmente en una habitación de la planta baja. También en los espacios comunes había tinajas o depósitos para acopiar el agua de consumo que traía el aguadero.

\footnotetext{
${ }^{99}$ Solo en el tipo de vivienda burguesa es donde aparece el mirador. Se trata en realidad de un pequeño espacio recuperado que aproxima a las personas, a las mujeres básicamente, a la calle. Ni la mujer que pertenece a la aristocracia, que continúa viviendo en su palacio, ni la mujer perteneciente al proletariado tiene necesidad de esto: la primera por que le interesa guardar su diferenciación social; la segunda porque su contacto con la calle es real, vive prácticamente en ella cuando lo desea $\mathrm{y}$, por lo tanto, no siente añoranza de comunicación, producto de una mayor interrelación social (...) El piso «principal» ofrece también, sobre todo a la mujer, relegada en la casa la mayor parte del día, la posibilidad de un mayor contacto, aunque sea tan solo visual, con la calle, la cual ejercerá sobre ella un poderoso y comprensible atractivo [...], SIMÓ Trinidad (1973): La arquitectura de la renovación urbana en Valencia, Albatros Ediciones, p.37.
} 
Las casas más importantes o las familias más influyentes disponían en los bajos del inmueble de una cisterna, que se llenaba a través de una conducción subterránea que unía otras de la ciudad con el punto de suministro. En estos casos se bombeaba el agua a un deposito situado en la cubierta, y por gravedad se daba servicio a cada vivienda, pudiendo de esta manera disponer cada casa de retrete y otros servicios higiénicos. Con la distribución del suministro del agua potable por la ciudad, a partir de la segunda década del siglo XX se empieza a generalizar la instalación de bombas para subir el agua a las viviendas.
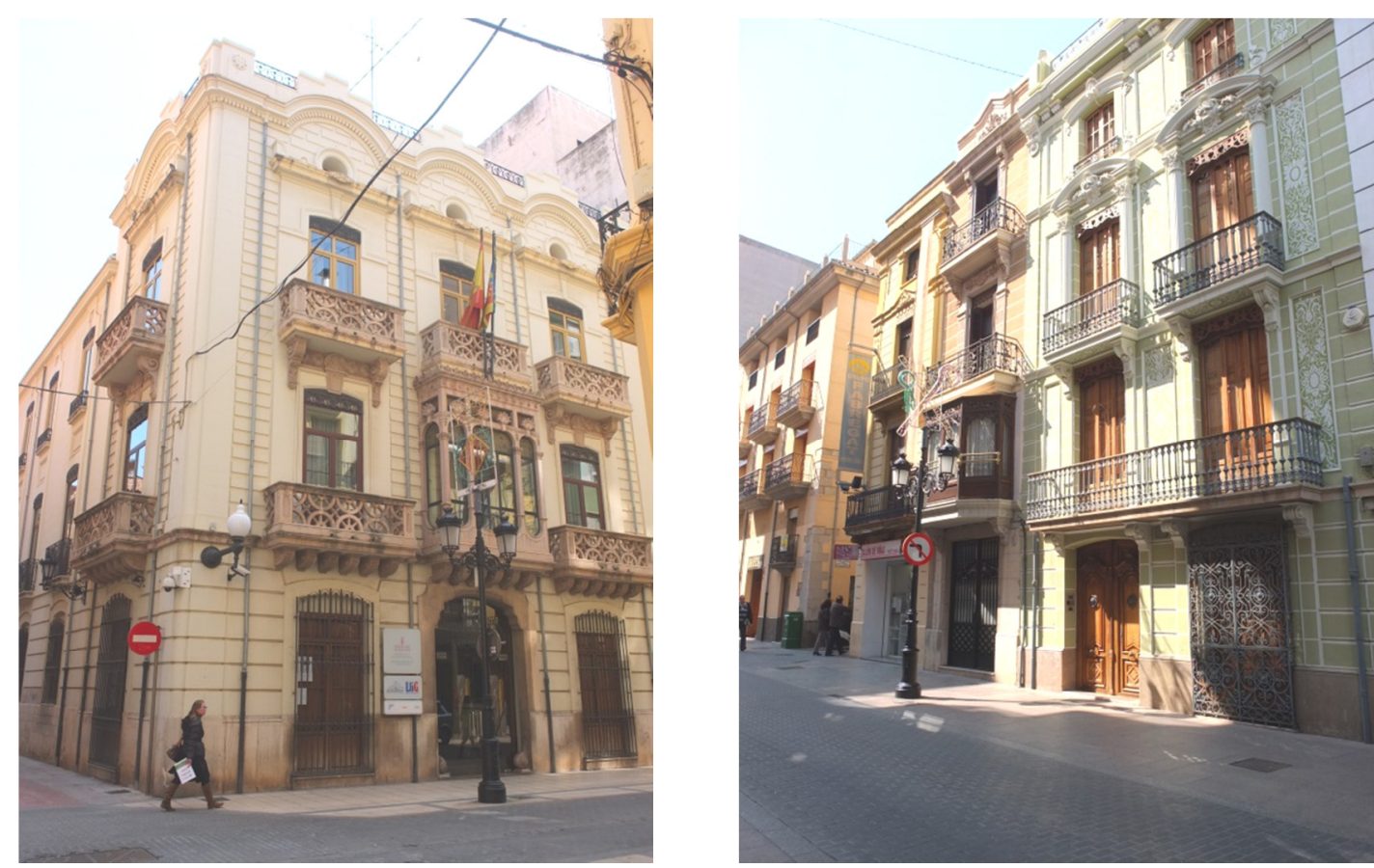

Casas de la burguesía agrícola y terrateniente de la primera década del siglo XX. Fondo fotográfico: Concepción Calvo

Las casas unifamiliares o las casas por pisos disponían de una red vertical de desagües, que vertía las aguas fecales en los depósitos de letrinas o fosa séptica de decantación, que estaban enterrados en el subsuelo del edificio. Las aguas de lluvia de los patios y de los tejados vestían al pozo ciego.

También se practicaban pozos en propiedades particulares para obtener el caudal necesario de agua, con los riesgos que para la salud pública conllevaba.

Con la red municipal de agua potable y la posterior instalación del alcantarillado se empezaron a instalar en las viviendas de más rango los primeros cuartos de baño. 
Siendo completos en la primera y segunda planta, reduciéndose el número de aparatos en las superiores, llegando a haber solo un retrete en la última.

El tipo de alumbrado era otro factor de distinción social: en las casas pobres, predominaba el candil, la palmatoria o el quinqué. En las casas ricas, con la llegada a la ciudad de Castellón del gas (1867) o la electricidad (1879), que fueron unos servicios mucho más tempranos en el tiempo que los anteriores, empezaron a lucir las modernas bombillas y las lujosas arañas de cristal.

Después de algunas décadas, con la introducción del ascensor, junto con las ideas de los higienistas de mediados del siglo XIX y las nuevas aportaciones de los Congresos Internacionales de Arquitectura Moderna (CIAM), como el conocido como la «Carta de Atenas» de 1933, contribuyeron al cambio de mentalidad de la población urbana, revalorizando el sol y el aire, desapareciendo definitivamente cualquier referencia a la antigua estructura del palacio barroco, cambiando la heterogeneidad social de estas edificaciones, para albergar un solo tipo social de usuario, teniendo mayor demanda los pisos altos, en donde las terrazas y solanas sustituirán a los balcones y miradores.

Esta aptitud respecto al lugar de residencia, también se traslada desde finales del siglo XIX al mar y la montaña, que empieza a ser apreciado por las clases más acomodadas, que buscan en la vida al aire libre el mejoramiento de sus condiciones higiénicas. $^{100}$

Siguiendo el ejemplo de la aristocracia y la nobleza, las vacaciones era un signo de distinción y prestigio social, y un baremo de lo saneada que se encontraba la economía familiar. Era también un modo de escapar de los rigores insalubres del estío en las ciudades, buscando buenas temperaturas agradables y lugares tranquilos. El no poder disfrutar de este retito estival era una «declaración de pobreza y de cursilería». ${ }^{101}$

En Castellón, también es el momento en el que la burguesía compagina las vacaciones, en pequeñas finca del campo en la zona de expansión que rodea la capital, los masets, o las masías del interior del término, con la temporada de baños en la playa.

\footnotetext{
100 TABERNER PASTOR, Francisco (1987): Valencia entre el Ensanche y la reforma interior, Edicions Alfons El Magnànim y COACV, Valencia, p.65.

${ }^{101}$ RIBADULLA CUMPLIDO, Concha (2006): op.cit, p.178.
} 


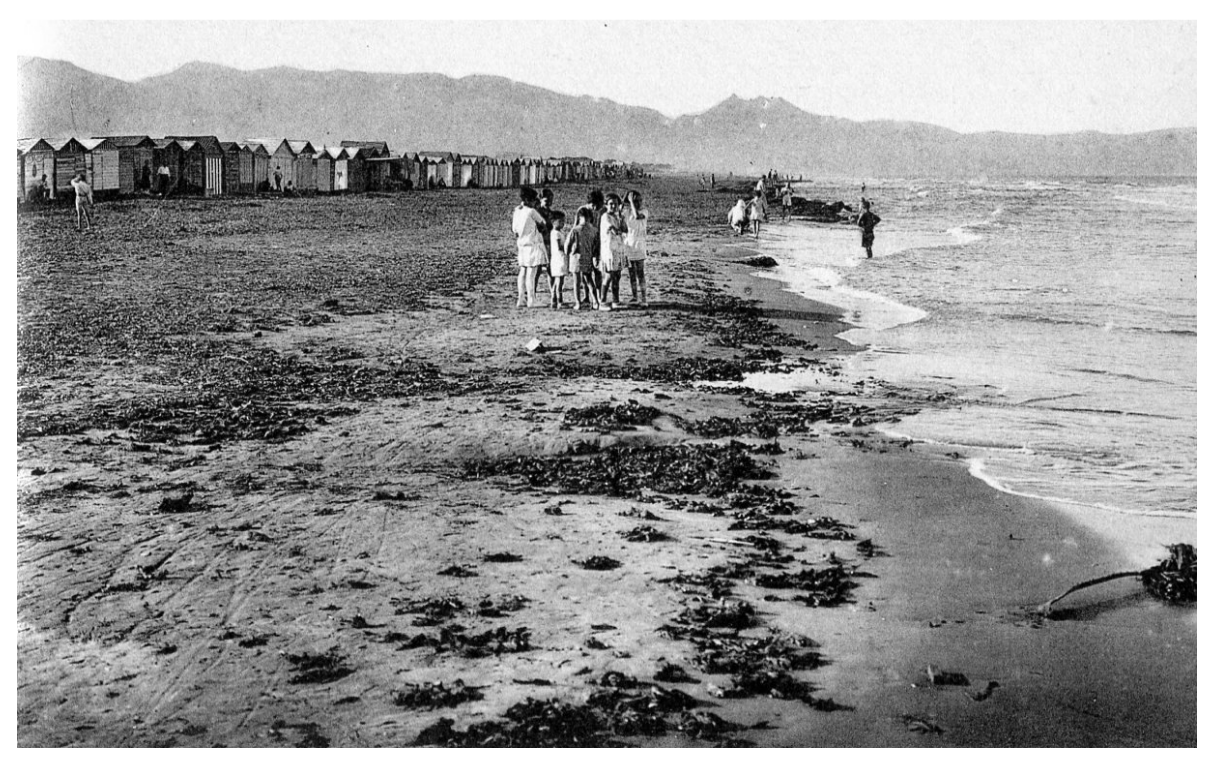

Playa del Pinar de Castellón. Fuente: Tarjeta postal, L. Roisin, fot-Barcelona

\subsection{LA CASA SUBURBANA DE RECREO}

Hay un tipo de casa en el País Valenciano, que desde las últimas décadas del siglo XIX acoge las aspiraciones del esparcimiento burgués. Se trata de una vivienda aislada de verano o de descanso de fin de semana, situada en los alrededores de muchas de nuestras ciudades, que sería imposible de comprender si no observamos la interrelación entre el mundo rural y el urbano. Los masets de Castellón (conjunto de «chalets» de veraneo de la burguesía local que a lo largo del primer tercio del siglo XX empezaron a ocupar una amplia franja en la zona poniente de la ciudad), se trata de un proceso de formación de una nueva tipología a partir de la evolución de tipos de arquitectura rural, ${ }^{102}$ en donde se compagina el periodo estival o de temporada con la pequeña explotación agrícola.

En estos masets se mantiene una manera de construir influida esencialmente por la tradición de la zona y el estilo y las iconografías procedentes de las arquitecturas «cultas». El resultado no es un simple resultado formal, sino la aparición de una nueva tipología con unas nuevas leyes de evolución. ${ }^{103}$

La casa tiene una o dos plantas y está situada sobre un basamento o podio que la aísla del suelo. El espacio de la casa define un amplio lugar central, la sala, que sitúa a

\footnotetext{
102 DEL REY AYNAT, Miguel (1983): «Introducció a l'arquitectura tradicional», en MIRA, Joan. (Coord.), Temes d'etnografia valenciana, Alfons el Magnànim. p.188.

${ }^{103}$ DEL REY AYNAT, Miguel (2010) : Arquitectura rural valenciana, Fundació Mas i Terra, .p.326-327.
} 
ambos lados habitaciones bien ventiladas, generalmente una de ellas es la cocina. El espacio central de la casa, que es el más representativo, comparte la zona del comedor con el de otras funciones sociales.

La terraza, que está elevada y cubierta, ocupa todo el frente de la fachada principal. En general la casa exhibe buenas condiciones higiénicas y sus estancias una clara diferenciación de funciones.

Estas construcciones, con similares características, también las podemos encontrar en Villarreal, Almazora, Benicarló, y en la zona de playa, en las villas de Benicasim, Nules o Moncofar.

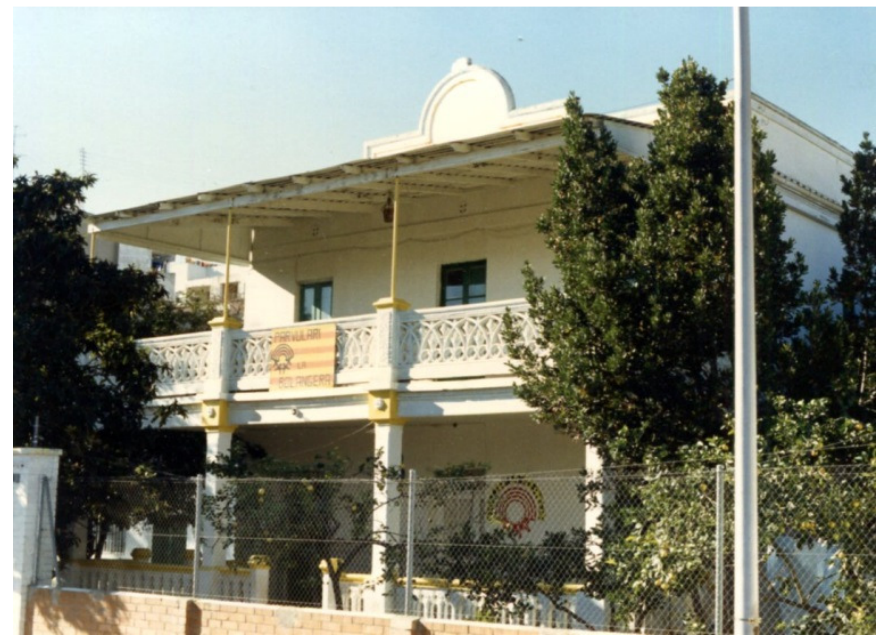

Maset de Castellón junto a la antigua vía del tren. Fondo fotográfico: Colección Concepción Calvo

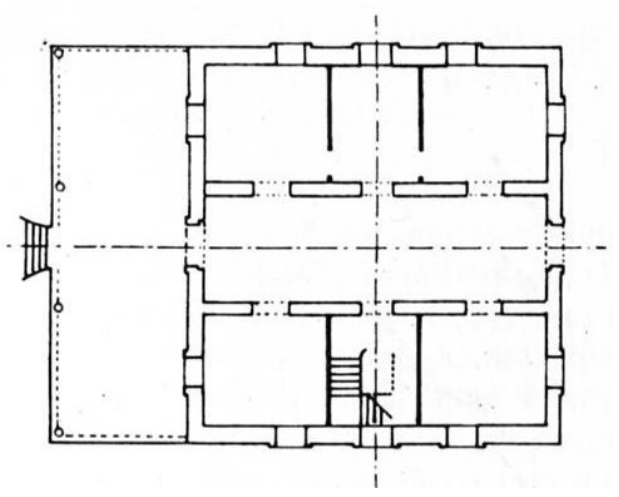

Plano de la planta baja de un maset.

Fuente: Del Rey Aynat, Miguel (1983): Introducció a l’arquitectura tradicional

\subsection{LOS INICIOS DE LA VIVIENDA OBRERA}

El desarrollo urbano del industrialismo lleva consigo el crecimiento demográfico de las ciudades, tanto por las aportaciones de la emigración como por la propia 
renovación interna que trae pareja toda época de economía abundante. Lo que obliga por razones de orden ideológico, económico y también de higiene y salubridad a remodelar el entorno urbano para construir viviendas. El hacinamiento de las clases trabajadoras en las zonas más degradadas y antiguas de los núcleos urbanos y la aparición de miserables barriadas periferias, carentes de servicios higiénicos, supuso un fuerte contraste y tensión social, frente a la visión ordenada e higiénica de los nuevos barrios burgueses en fase de desarrollo, trazados éstos según las pautas de los modernos ensanches, más racionales y mejor equipados.

En un primer momento el problema se planteó entre construir casas mixtas, tomando como referencia los modelos de la casa acomodada, ${ }^{104}$ en las que convivir los distintos estratos sociales, o nuevos barrios siguiendo los planteamientos de los moralistas y urbanistas utópicos, entre los que se citan a Camilo Sitte y Ebenezer Howard, que en Europa están ensayando nuevos prototipos. ${ }^{105}$

La solución mixta no prosperó, por especulativa y abusiva por parte de los promotores. Además, en muchas ocasiones, se trataba de adecuar a los nuevos usos un patrimonio inmobiliario existente en barrios degradados. Esta oferta marginal supuso a la clase obrera un claro retroceso, no solo para la higiene física sino también para la higiene mental.

Paralelamente, en el segundo tercio del siglo XIX, y a raíz de las teorías de los socialistas utópicos, se empezó a experimentar para el alojamiento obrero con la «caserna» o casa de vecindad de diversas plantas, organizado en «calle-galería» a donde daban las distintas viviendas, para uso exclusivo de una única clase social, la del proletariado: poco costosa desde el punto de vista constructivo y del aprovechamiento del suelo, en la que los trabajadores entran en el proceso inmobiliario como cooperativistas. Con las agitaciones y revueltas de 1848, la casa colectiva pierde el favor que disfrutaba y es rechazada en el plano teórico. ${ }^{106}$ En este sentido, tras varias

\footnotetext{
104 GOMEZ-FERRER MORANT, Guadalupe (1997): op. cit., p.655.

105 CHOAY Françoise (1976): El urbanismo utopías y realidades, editorial Blume, Barcelona, p.21.

106 «...] El control político de la fuerza del trabajo, impone ante todo, la necesidad de evitar la concentración y la asociación de los obreros, y por otra parte incluso se piensa que la gran casa de vecindad quizá induzca a una especie de asociación mental con los modelos más radicales del falansterio«socialista» propuesto por Fourier. Por ello en esta fase se concreta el tipo de la casa individual con huerto, que parece reforzar el sentido de propiedad -de una propiedad naturalmente, que en ningún caso hace dueño de los instrumentos de producción-, la estabilidad familiar y las virtudes burguesas, mientras tiende a diluir y a extinguir las relaciones sociales. Los teóricos franceses y alemanes insisten, en particular, en la capacidad de este tipo edificativo para vincular al obrero a la tierra y alejarlo de las
} 
experiencias, serán las teorías de Ebenezer Howard, con el modelo de Ciudad Jardín, ensayado en Inglaterra, el que tendrá mayor aceptación. En España, el modelo de Arturo Soria, con la Ciudad Lineal de Madrid, aunque atractivo no llevó a prosperar.

Hasta mediados del siglo XIX apenas había legislación social en Europa que protegiera mínimamente a la clase obrera de los abusos del sector empresarial. El problema del alojamiento de la población obrera en España se intentó solucionar a partir de 1853 con diversas medidas legislativas con escaso resultado. Pero las huelgas, el crecimiento de las asociaciones laborales, la ascensión de la UGT, del PSOE y de las fuerzas políticas republicanas, serán amenazas contra la estabilidad e inmovilidad de los estamentos dominantes.

Además, la creencia de que los problemas sanitarios de la ciudad podrían afectar a toda la población sin distinción, aunque los focos de insalubridad estuvieran separados espacialmente, aceleró la puesta en marcha de medidas, arbitradas por el reformismo de los gobiernos de la monarquía. Estos estudios los abordó principalmente el Instituto de Reformas Sociales, creando en 1904, sobre el que recayó la tarea de proponer formas de afrontar la cuestión de la vivienda obrera en el país. De ahí nace la legislación de ámbito nacional sobre la construcción de Casas Baratas que, a partir de 1911, establece el marco para que, efectivamente, pueda subvencionarse la actuación de patronatos y sociedades constructoras de viviendas para obreros. Modificada varias veces y tras la crisis de 1917, en 1925, se complementa con una Ley de Casas Económicas para la clase media y para aliviar el paro. ${ }^{107}$ Adquiriendo esta incipiente legislación con los años un mayor desarrollo.

La proletarización de una parte importante de la sociedad valenciana comienza a fínales del siglo XIX. La vivienda obrera en Alicante se inicia muy pronto. En fecha tan temprana como 1889 ya se había promovido el barrio de Benalúa, de corte racionalista inspirado en el pensamiento higienista y en la idea de Ciudad-Jardín, dotado de un cierto nivel de autonomía y de una serie de equipamientos, según proyecto del arquitecto José Guardiola, que pasa a ser el primer ejemplo valenciano de urbanización

tentaciones de la metrópoli [...], SICA, Paolo (1981): Historia del urbanismo. El siglo XIX (volumen $2^{\circ}$ ), Instituto de Estudios de Administración Local, p.1153-1161.

107 TERÁN, Fernando (1993): «Arquitectura y Urbanismo», Historia de España, Tomo XXXIX. La edad de plata de la cultura española (1898-1936) Identidad. Pensamiento y vida. Hispanidad, Espasa Calpe, Madrid, p.601-605. 
en el extrarradio. ${ }^{108}$ Constaba de 450 viviendas con manzanas enteras, del tipo adosado, con dos plantas y patio interior, con calles rectas y arboladas, hoy en gran parte desaparecido por restituciones permanentemente de edificación moderna, ${ }^{109}$ y poco respetuosas con los valores culturales del conjunto. De similares características, pero más tardía, son las actuaciones en Raval Roig, San Blas, y en la primera década del XX, las que realiza el Circulo Obrero Católico. Estas primeras urbanizaciones fueron muy pronto englobadas por los Ensanches; lo mismo sucedió en Valencia, Elche y Castellón con otros barrios emergentes. Aunque barrios obreros como tales no se producen hasta entrado el siglo $\mathrm{XX} .^{110}$

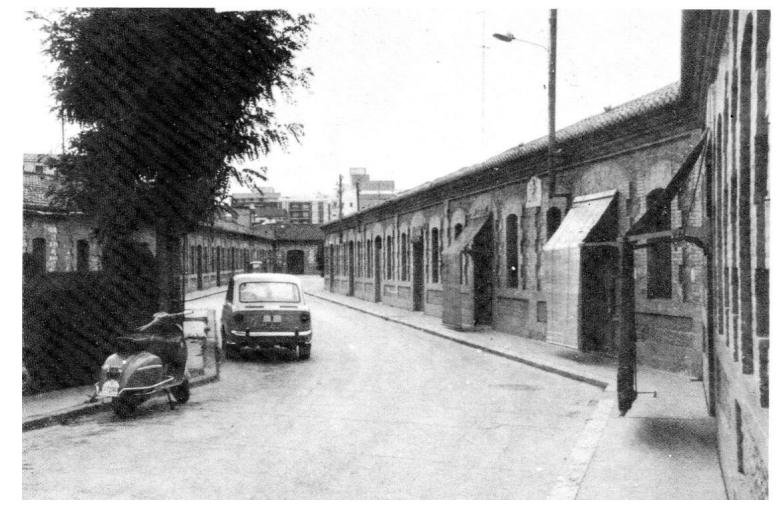

Grupo Ramón Castro, c/ Jesús (1911) J.M.Cortina

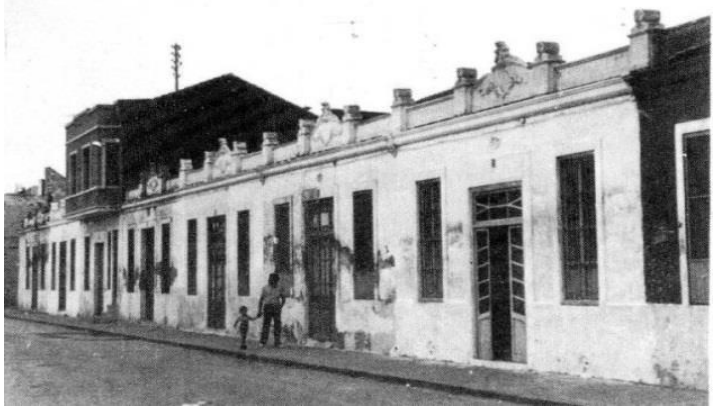

Grupo Tranviarios en Nazaret (1919), Desconocido

Fuente: Peñín Ibañez, Alberto (1978): Valencia 1874-1959. Ciudad. Arquitectura y arquitectos

En 1901 se crea en Valencia la Sociedad Constructora de Casas para Obreros de suscripción pública y dedicada a la construcción de viviendas para trabajadores de la industria o el comercio, que pasamos a describir, y que realiza varias promociones, con tipología de viviendas entremedianeras con patio trasero y una sola planta con 9 metros de fachada, entrada central y estar al fondo, dos habitaciones a fachada, una interior, un cuarto para el retrete y cocina, con patio interior, no superando la superficie de 70 metros. Su aspecto exterior es muy similar a las construcciones tradicionales, a base de ladrillo, mampostería y cubierta de teja. Entre ellas, en 1907, el grupo Ramón Castro,

\footnotetext{
108 NAVARRA VEA, José Ramón (1999): «La modernización de la ciudad», en MATEO MARTíneZ, Carlos (coor.). Los inicios de la modernización en Alicante. 1882-1914, Caja Ahorros Mediterráneo, pp.163-164. 109 SIMÓ Trinidad. (1987): «Arquitectura y Urbanismo. 1874-1920», en AGUILERA CERNí, Vicente, (Coord.), Historia del Arte valenciano. Entre dos siglos.T.5, Consorcí D’Editors Valencians,S.A., p.61.

110 PEÑIN,A.;GRANDE,F.;VARELA,S.(1988): «Arquitectura y Urbanismo.1910-1936»,en AGUILERA CERNÍ, Vicente, (coor.), Historia Arte valenciano. El siglo XX hasta la guerra del 36. Tomo 6, Consorci d'Editors valencians,S.A, Valencia, p.60.
} 
presenta el primer intento de formar una unidad más o menos autónoma y diferenciada con pequeña zona verde, al estilo de las promociones de barrio obrero después usuales. Se trata de dos hileras de casas de planta baja enfrentadas, configurado una pequeña plaza arbolada en cuña, abriendo hacia la calle Jesús. A partir de estos grupos y ya promulgada la primera Ley Española de Casas Baratas (12 de junio de 1912) y formadas las primeras agrupaciones sindicales, el paso siguiente son las Cooperativas obreras, entre las que se cuenta con la Mutualidad Obrera de Tranviarios que construye en varios barrios y municipios. En general continúa la tipologia de una planta con distribución similar, en donde el tratamiento de fachada es sencillo con los huecos pequeños, a base de ladrillo y revestimiento de cemento. ${ }^{111}$

En el v Congreso Nacional de Arquitectos celebrado en Valencia durante la Exposición Regional de 1909, una de las ponencias fue «La casa obrera», entre sus conclusiones se abogaba por la dispersión de estos grupos por la ciudad, a ser posible en las afueras y en manzanas abiertas, resuelta en plana baja y piso y con altura no superior al ancho de la calle. Por dichas fechas, las teorías sobre la nueva ciudad, el urbanista británico Ebenezer Howard, proponen conjugar las ideas reformistas con el higienismo de finales del XIX; ello dio lugar a la utilización del término «cuidad-jardín» para designar el nuevo tipo de hábitat urbano. De fecha mucho más tardía tenemos dentro de este tipo la ciudad jardín en Alicante, la denominada General Marvá (1925) a base de vivienda aislada con jardín; en Elche el Hogar-Jardín (1932). En Valencia hay que recordar la ciudad-jardín del Paseo al Mar, para las Cooperativas de Artes Gráficas y la Asociación de la Prensa (1926). ${ }^{112}$

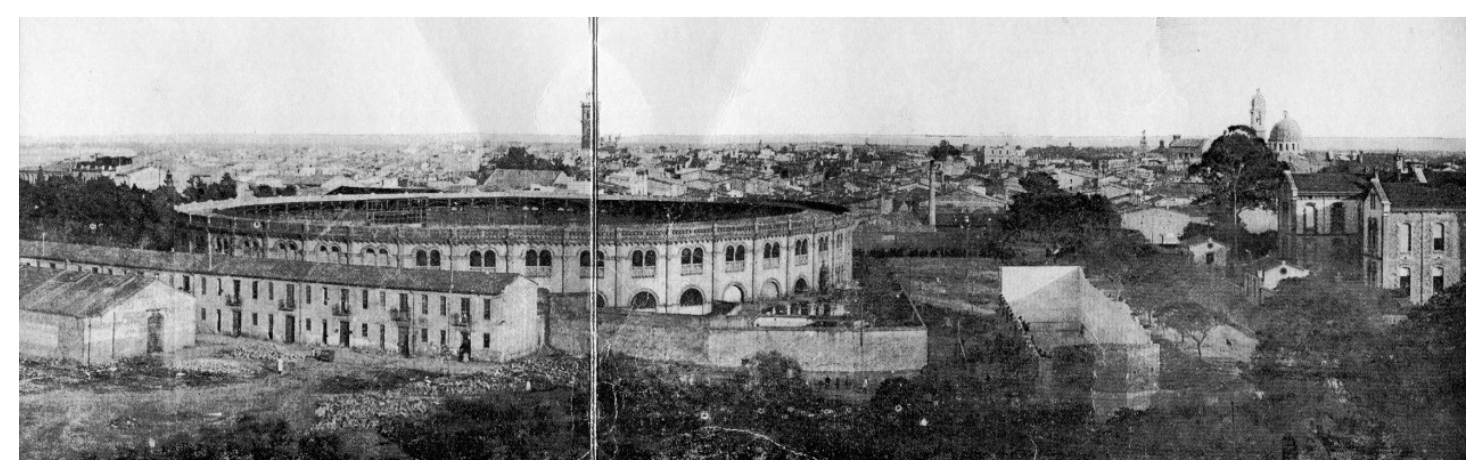

Panorámica de Castellón, en la primera década del siglo XX. En primer plano grupo de casas el pañet. Fuente: Castelló en blanc i negre

\footnotetext{
111 PEÑIN IBAÑEZ, Alberto (1978): op. cit., p.70.

112 PEÑIN, A.; GRANDE, F.;VARELA, S. (1988): op.cit., p.65.
} 
En Castellón, como primeras viviendas obreras tenemos, de los primeros años del XX, el grupo el pañet, junto a la plaza de toros. Se trata de una promoción de viviendas de reducidas dimensiones y modesta construcción de las que tan solo quedan diez, dentro de una edificación en hilera de dos plantas, con una vivienda en cada una de ellas y con acceso individual por escalera a fachada de la superior. ${ }^{113}$

Similares soluciones, pero con una vivienda de dos plantas las encontramos en los barrios de San Félix y San Roque, para residencia de agricultores, asalariados del campo y otros oficios, conservando el modelo agrícola tradicional.

Algo más tarde, en la calle Félix Breva, en pleno ensanche de El Almelar, se edifica un grupo de viviendas de dos plantas de las que tan solo quedan ocho. La fachada a base de formas clásicas y elementos cerámicos, exhibe una mayor intencionalidad expresiva. Ajustándose las condiciones de habitabilidad a los reglamento de policía municipal y a la autorización de Junta de Sanidad.

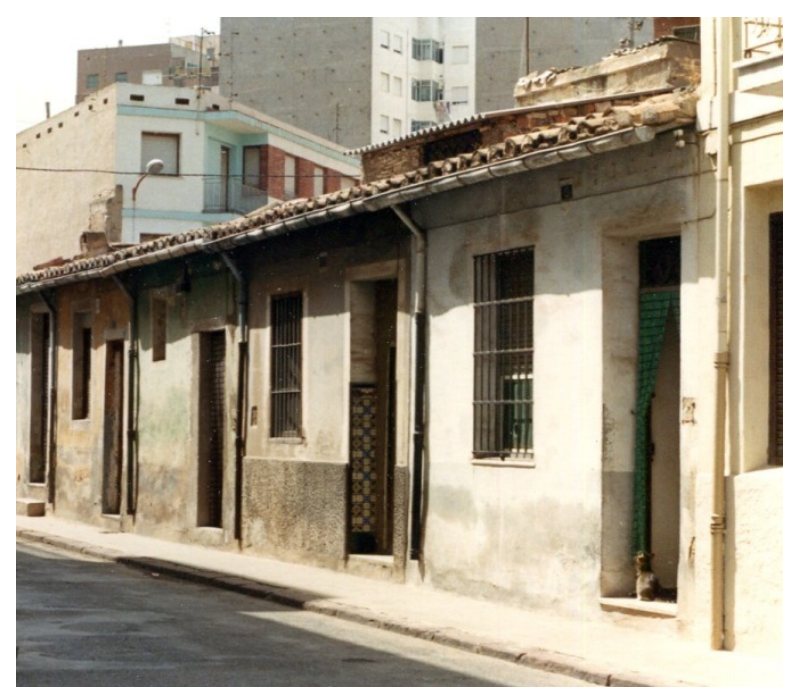

Viviendas en hilera en el ensanche del Mestrets. Fondo fotográfico, Concepción Calvo.

Hasta 1920 y ante la escasez de viviendas, se forma en Castellón la Junta de Fomento y Mejora de Habitaciones Económicas y Baratas, cuya misión fue procurar un hábitat sencillo y asequible a las clases menos favorecidas económicamente. La construcción de estas casas se asemeja al esquema agrícola propio de la zona. Se trata de viviendas en hilera en planta baja o planta baja y piso, de escasa fachada y acusada profundidad, con patios de ventilación para las diferentes estancias. A estos tipos pertenece la Cooperativa Obrera de Casas Baratas Bovalar (1922), del arquitecto Luis

\footnotetext{
113 Ibídem, p.62.
} 
Ros, en el barrio El Almelar, para trabajadores de la UGT, con un total de 86 solares ocupando toda una manzana, junto a la actual avenida del Oeste. Únicamente se construyó una primera fase de viviendas en hilera, resueltas en planta baja con desván, conservándose actualmente cuatro.

Del tipo de ciudad-jardín es el proyecto de cooperativa de 31 casa baratas El Estepar (1927), que no se llevó a efecto. Y la cooperativa obrera de 30 casas baratas del arquitecto Maristany (1930) en el barrio dels Mestrets, en la calle Padre Tosca, para trabajadores de los oficios. Su tipología, aunque similar a la de la cooperativa Bovalar, tiene ya una cierta intencionalidad de diseño en los estudios de planta y alzado. ${ }^{114}$
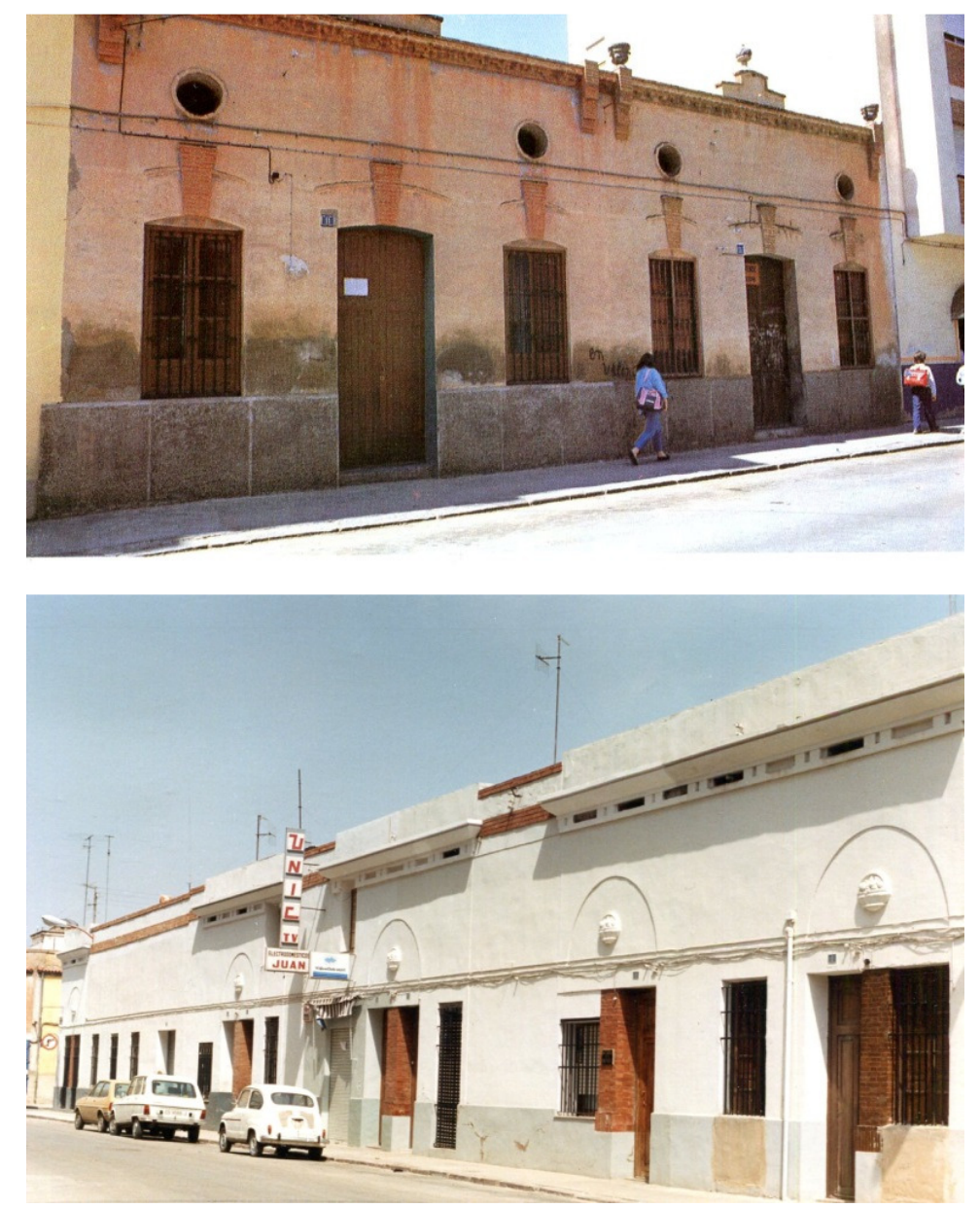

Cooperativa Obrera de Casas Baratas, en Bovalar (foto sup.) y Mestrets (foto. inferior) Fuente: Peñin, A.; Grande, F.; Varela, S. (1988): «Arquitectura y Urbanismo.1910-1936»

\footnotetext{
${ }^{114}$ Ibídem, p.68.
} 


\section{EVOLUCIÓN DE LOS CENTROS DE ENSEÑANZA DE CASTELLÓN}

Aunque fue notable el desarrollo que adquirió la enseñanza en tiempos de Carlos III, creándose nuevas escuelas para ofrecer una educación elemental a todos los españoles, en Castellón, trascurrido más de la mitad del siglo XVIII no existía más que la antigua escuela de la villa, agregada a las Aulas de Latinidad. ${ }^{115}$ También es el momento en el que se reconstruye el viejo edificio de las aulas, ${ }^{116}$ con capacidad para dos amplias salas de Gramática y un pequeño oratorio a la Virgen de la Sabiduría. Las obras, que dieron comienzo en 1776, fueron sufragadas por José Climent i Avinent, obispo que fue de Barcelona, nacido en Castellón y antiguo alumno de estas aulas. El edificio, propiedad del Ayuntamiento desde su fundación en época medieval, continuó con su mantenimiento hasta 1846, que es cuando se crea el Instituto de Segunda Enseñanza, suprimiéndose desde entonces las aulas de Gramática de esta ciudad. ${ }^{117}$

En la temprana fecha de 1851, el Ayuntamiento crea la primera escuela de párvulos $^{118}$ de la ciudad, instalándose en las antiguas Aulas. ${ }^{119}$ Aprobada la desamortización de 1855, el Ayuntamiento protestó del despojo que se hacía, reclamando las aulas, por lo que se excluyen de la venta, volviendo al patrimonio municipal por tener destino de uso público. También se instala en dichas aulas, a partir de 1868 , la primera escuela nocturna de adultos ${ }^{120}$ para instruir a la clase trabajadora. En 1887 el Ayuntamiento traslada la escuela de párvulos a una casa de alquiler, propiedad de Vicente Carpi Rubert, situada en la calle de Arriba, 139 (ahora calle de Alloza), para

\footnotetext{
${ }^{115}$ BALBAS, Juan A. (1987): El libro de la provincia de Castellón, Caja de Ahorros y Monte de Piedad de Castellón, Barcelona, p.321. [Edición facsímil del original. Castellón, Imprenta y Librería de J. Armengot, Emmedio,17., 1892]

${ }^{116}$ Llegaron a haber en España más de cuatro mil Escuelas de Gramática Latina, en ellas se preparaba para los estudios eclesiásticos y universitarios, impartiéndose las clases en latín. Su calidad pedagógica y científica era escasa, porque basaban su docencia en el memorismo.

${ }_{117}^{117}$ BALBAS, Juan. A. (1987): op. cit, p. 312-313.

118 El Plan de Instrucción primaria de 21 de julio de 1838, en el Titulo IX, art.38., recomienda la utilidad de las escuelas de párvulos. El Reglamento de las Escuelas públicas de Instrucción elemental, de 26 de noviembre de 1838, confirma esta misma idea. La Ley de Instrucción pública de 1857, la Ley Moyano, consideraba la enseñanza primaria dividida en tres niveles: párvulos, elemental y superior, pero como las anteriores, simplemente recomendaba el establecimiento de escuelas de párvulos, no su obligatoriedad. La primera fue creada en 1838 por Pablo Montesinos. En España habían 41 escuelas de párvulos en 1850.

${ }^{119}$ BALBAS, Juan. A., op. cit, p. 312-313.

${ }^{120}$ Ibídem, op. cit, p.314.
} 
lo cual se verifica la habitabilidad e idoneidad del inmueble. ${ }^{121}$ Podemos ver por las ilustraciones que se adjuntan, que se trata de una típica casa de labradores con su corral al fondo. La casa-escuela tiene tres pisos: en la planta baja hay una amplia sala de clase con graderío, que recibe luz cenitalmente, un patio, retretes que vierten a un deposito de letrinas con conducto vertical de ventilación, lavabos y despacho para el profesor; en el piso primero está la cocina, el comedor con un local higíenico, y en la planta superior hay tres habitaciones.
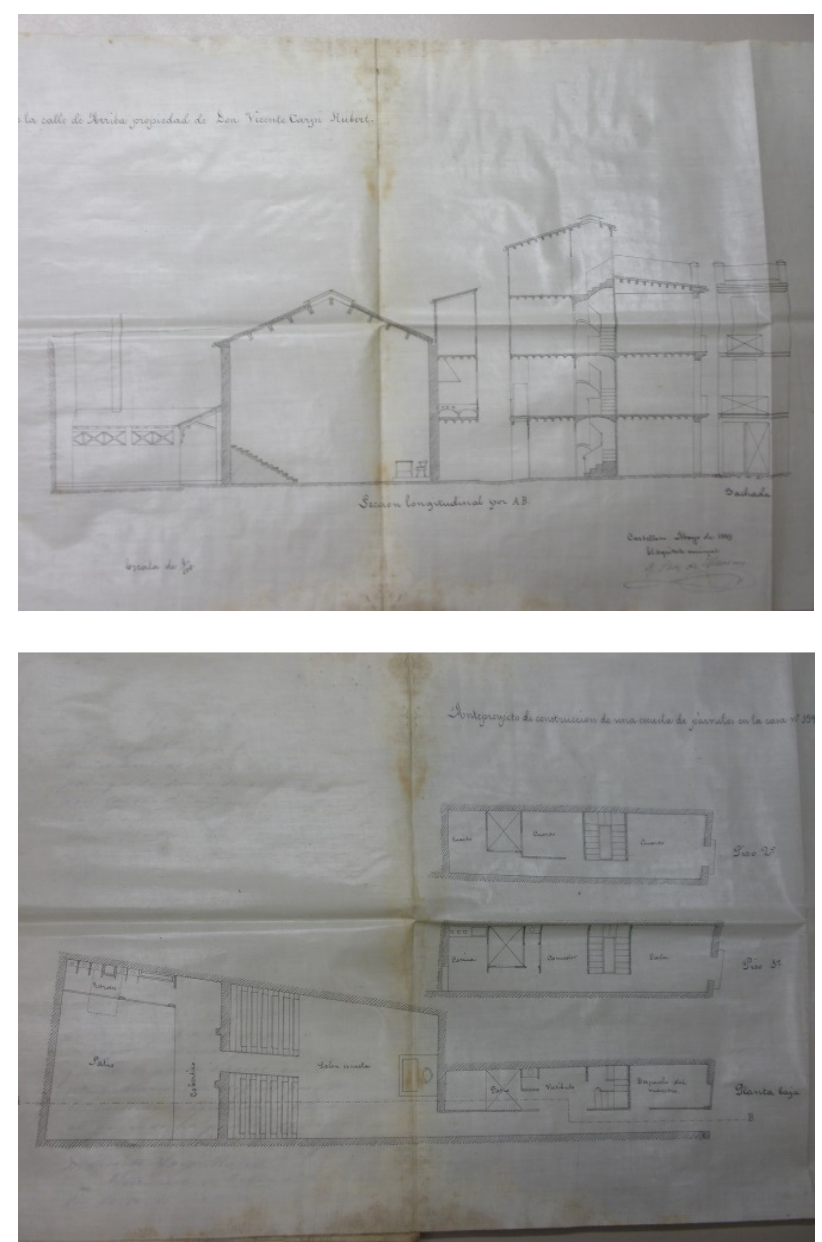

Planos de anteproyecto de la Escuela de párvulos de niños y niñas, año 1888, en calle de Arriba, 139 Fuente documental: Archivo Histórico Municipal de Castellón

El diseño de la gran sala de planta baja, donde se impartía la actividad escolar, presenta gran similitud con las ilustraciones que figuran en el Manual de Manuel Montesinos,

\footnotetext{
${ }^{121}$ En 1888, a petición del Ayuntamiento, el arquitecto municipal, Godofredo Ros de Ursinos, emite informe del estado del edificio y planos de anteproyecto para su adaptación como colegio público de párvulos, en «Expediente para la adquisición en arriendo de la casa $\mathrm{n}^{\circ} 139$ de la calle de Arriba, propiedad de D. Vicente Carpi Rubert, destinada a escuela de párvulos». Instrucción pública. Centros escolares (1853-1889), Archivo HistMunicipal de Castellón.
} 
publicados en $1840 .{ }^{122}$ En la primera década del siglo XX el parvulario de niñas se traslada a la Escuela del Real, adaptándose ahora el edificio para escuela unitaria de niñas. Según las Guías Oficiales de Castellón permaneció allí hasta entrada la década de 1920. Ver Tabla 2. Evolución de las escuelas en Castellón.

En la última década del siglo XIX, las antiguas Aulas de Latinidad se incorporan como ampliación al contiguo hospital de Trullols, utilizándose para estancias de enfermos, asistidos por las Hermanas de la Caridad. Trasladado el hospital a un nuevo emplazamiento en 1907, se remodelan las Aulas en 1911, para albergar una escuela pública de primaria y párvulos de niñas, con capacidad para cuatro aulas, con dos amplios patios.

El obispo Climent edifica a sus expensas, en el año 1754, una Escuela de primeras letras para niños, en los bajos de una casa de su propiedad, en la plaza de Pescadores, pasando al presupuesto de propios del Ayuntamiento a partir de 1797, por otorgamiento del Rey Carlos IV, ${ }^{123}$ más tarde se amplía también la escuela para niñas.

En el mismo lugar, se funda en 1798 la benéfica institución de la Casa de Huérfanos de niños y niñas de San Vicente Ferrer, como legado de José Climent.

La población de Castellón tenía en 1778 más de 3.000 vecinos y no existía en la misma una sola escuela de niñas. En octubre de 1780, Isabel Ferrer, habilita en su propia casa una escuela para niñas, dotándola con tres maestras y facilitándoles habitación. Poco tiempo después concurrían a la misma 220 niñas. En 1786, el Rey Carlos III, concede a la benefactora autorización para que establezca una escuela gratuita de niñas bajo la protección real. La fundadora, en su testamento, legó a la fundación la Casa de Enseñanza y la mayor parte de sus bienes. ${ }^{124}$

En 1775, el Canónigo Magistral de Valencia, José Climent, solicita autorización para la construcción de dos hornos de «pan cocer», el forn del Pla o de los Huérfanos en el arrabal de San Félix y otro en el rabal de San Francisco. Con el beneficio de los

\footnotetext{
${ }^{122}$ El plano deja intuir el Modelo de aula de párvulos, niños y niñas en las gradas del fondo, que muestra la lámina número 2 del Manual para maestros de la escuela de párvulos, escrito en virtud del acuerdo de la Sociedad encargada de propagar y mejorar la educación del pueblo, de Pablo Montesino de 1840. El diseño y disposición del aula están tomados de las reproducciones de Infant Schools inglesas de Wilderspin de quien asimismo las tomó, en Francia, J.D.-M Cochin en su Manuel des salles d'asile de 1833. Dicha disposición responde a la separación entre un espacio para la enseñanza simultanes (gradas situadas al fondo) y otro para la enseñanza mútua (bancos con asientos en filas en primer plano).

${ }^{123}$ GIMENO MiChavila, Vicente. (1984): Del Castellón Viejo, Caja de Ahorros y Monte de Piedad de Castellón, p.62. [Edición facsímil del original, Est. Tip. Hijos de J.Armengot Castellón de la Plana., 1926] ${ }^{124}$ GIMENO MICHAVILA, V. (1984):Op. cit, p.269-271.
} 
mismos se atenderían las necesidades de la escuela ya fundada y dos más que deberían construirse junto a aquellos. ${ }^{125}$ Pensamos que se trata de la Escuela de niños del Real (plaza Sixto Cámara, 18, ahora plaza del Real), ubicada en el arrabal de San Francisco y de la Escuela de niños del Hospital (Hospital nº de San Félix.

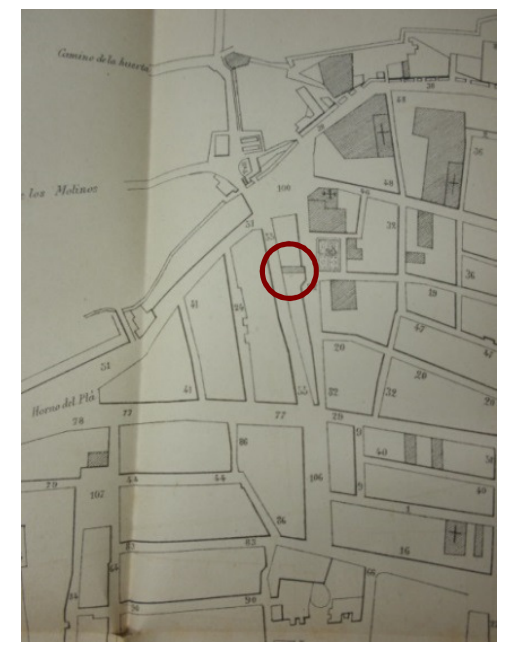

Emplazamiento de la antigua Escuela del Hospital, en la plaza del Hospital, 7 (actual plaza de las Aulas) Fuente: Plano Guía Oficial de Castellón y Provincia de 1890

Ante la imposibilidad de cumplir el Ayuntamiento las obligaciones impuestas por las normas de asistencia a las escuelas por falta de medios para instruir los 1270 niños de la villa, ${ }^{126}$ en el año 1790 José Breva, presbítero y Maestro principal de Latinidad, costea a sus costa otra escuela en el mismo barrio, haciendo construir además una «pieza de enseñanza» para niñas. ${ }^{127}$ Se trata de la escuela denominada de las Balsas, ubicada en la plaza del mismo nombre, (actualmente Plaza Isabel la Católica, 27).

A finales del siglo XVIII, de las cuatro escuelas que se acababan de establecer, nos habla el gobernador Bermúdez de Castro; y en efecto, en el presupuesto de Propios del Ayuntamiento, del año 1798, son ya cuatro las escuelas que pasan a depender del Ayuntamiento $^{128}$. Existiendo además el Colegio de Huérfanos de niños y niñas, con carácter de público, instituido por el obispo Climent y la Escuela gratuita de niñas, fundada a sus expensas por Isabel Ferrer ${ }^{129}$. Sin embargo, antes del último tercio del

\footnotetext{
${ }^{125}$ GIMENO MICHAVILA, V. (1984): Op. cit., p.270.

${ }^{126}$ GIMENO MICHAVILA, V.(1984): Op. cit., p.60.

127 BELTRAN ESCRIG, Julia (1993): «La educación de la mujer en el siglo XVIII. Aportaciones de Isabel Ferrer», en Isabel Ferrer i el seu temps: Castelló al segle XVIII, Diputació de Castelló, p. 232.

${ }^{128}$ BALBAS, Juan. A. (1987): Op. cit, p.326.

${ }^{129}$ GIMENO MICHAVILA, V.(1984): Op. cit., p.62.
} 
siglo XIX tan solo se crean dos nuevas escuelas públicas ${ }^{130}$ en la capital, una de niños asociada a la Casa de Beneficencia y la ya citada de párvulos, de la calle de Arriba, además de tres privadas. Consecuencia de las desamortizaciones, el convento de dominicos se acondiciona en 1822 como Casa Asilo de Beneficencia; la creación de su escuela de instrucción primaria, provista por oposición, es de $1867 .{ }^{131}$ También tenemos noticias, por expedientes de Instrucción Pública del AHMC, de un proyecto de escuela municipal para niñas, del año 1863, en calle San Joaquin y adyacentes (actual calle Ruiz Zorrilla,esquina con la Puerta del Sol y plaza Real, que al parecer no se llevó a efecto. ${ }^{132}$

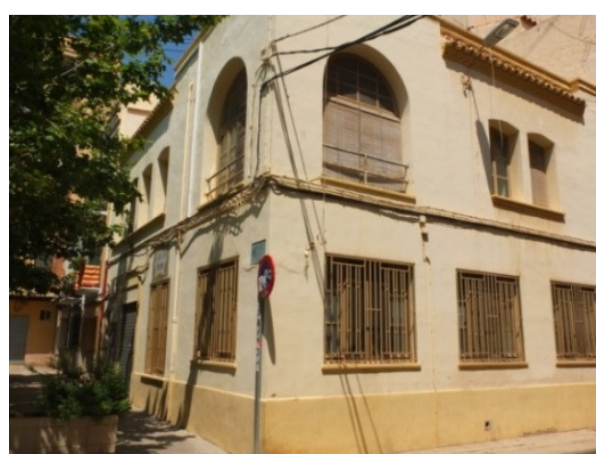

Esquina de la plaza Isabel la Católica (antigua plaza de Las Balsas) donde estaba la Escuela municipal de las Balsas. Fuente: Foto, Concepción Calvo

\subsection{LAS ESCUELAS DE CASTELlóN A FINALES DEL SIGLO XIX Y PRINCIPIOS DEL XX}

Juan A. Balbas nos dice que en 1845 había en la provincia 137 escuelas de niños y 56 de niñas, a las que concurrían un total de 8.772 estudiantes, siendo 4,32, el número

\footnotetext{
${ }^{130}$ Sobre el estado de las escuelas en el siglo XIX nos comenta el archivero Juan Balbas: «Debemos confesar que no estaba mal atendida la enseñanza en esta ciudad a últimos del siglo pasado y a principios de este. Desde entonces solo dos escuelas se han creado: una de niñas y la de párvulos. Téngase en cuenta la enorme diferencia que hay entre aquellos tiempos y los presentes, el aumento de repoblación y las exigencias de la época actual, y comprenderán nuestros lectores lo poquísimo que ha progresado la Instrucción primaria en esta ciudad. Así es, que la desproporción entré el número de habitantes y el de escuelas es desconsolador, y a las siete que aquí existen, hállanse instaladas en edificios que están muy lejos de reunir las condiciones higiénicas que la ciencia y las leyes prescriben. Por fortuna, de poco tiempo a esta parte obsérvanse notables mejoras en este sentido, gracias al celo de nuestro ayuntamiento (...) »BALBAS, Juan. A. (op. cit, p.326

${ }^{131}$ MUNDINA, B. (1988): Historia geografía y estadística de la provincia de Castellón, Caja de Ahorros y Monte de Piedad de Castellón, p.194. [Edición facsímil del original, Imprenta y Librería de Rovira Hermanos, Castellón, 1873]

${ }^{132}$ El citado proyecto de nueva escuela municipal de niñas, del año 1862, consta de una gran sala para la enseñanza unitaria en planta baja, y comedor, cocina y otras salas menores en la planta principal. Dispone de cisterna de agua potable y los servicios higienicos son cuatro retretes situado en patio planta baja y uno en planta piso, que vierten a un pozo de aguas sucias. Esta escuela de niñas puede estar relacionado con la que J.A. Balbas, en 1887, cita en pag.326, del Libro de la Provincia de Castellón, cuando se refiere a que solo dos escuelas se han creado en lo que va de siglo: una de niñas y la de párvulo.
} 
de alumnos por cada cien habitantes. Cuarenta años después, en 1886, aumentaron las escuelas a 461, (de niños 161; de niñas 150; de párvulos 13; de adultos 95, y privadas 42) con 32.235 alumnos matriculados. A pesar de este aumento de escolarización, favorecido por la enseñanza obligatoria y gratuita de la Ley de 1857, el nivel de analfabetismo era aún muy elevado.

Según el estudio estadístico de la Instrucción pública de 1885, realizado por José Jimeno Agius, ${ }^{133}$ por cada cien varones solo saben leer y escribir 19,72 y 6,80 mujeres en la provincia de Castellón, figurando estos porcentajes entre los más bajos de España. En peor situación se encontraba la capital, figurando entre las últimas en la escala, con el 25,87 de los hombres y el 12,52 de las mujeres. Sin embargo, en cuanto al número de habitantes por alumno y a lo que gastaba en instrucción pública la provincia, su situación es más favorable con relación a la media española. A partir de los datos anteriormente expuestos y para una población en la provincia de Castellón de 292.437 habitantes, en el año 1887, el porcentaje de asistencia a la escuela podemos establecerlo en un 20-25 por ciento en edad escolar. En 1887 Castellón tenía un 82\% de analfabetos en su población. El Estado contaba en 1900 con el 63\% de analfabetos.

La razón de ser de esta situación, al margen del alto absentismo escolar que era importante, consecuencia de la temprana edad en la que los niños y niñas entraban a trabajar, ${ }^{134}$ hay que buscarlo en la falta de escuelas.

La profesora Consol Aguilar, nos dice, que a partir del último tercio del siglo XIX la prensa local se hace eco del malestar ciudadano por la falta de escuelas públicas, en donde el número de los que solicitan ingreso en las mismas es superior al de plazas ofertadas, también hay demanda de escuelas gratuitas de ambos sexos, en los abultados y desatendidos barrios; indicando al mismo tiempo el interés del concejal republicano Fernando Gasset por la mejora de la instrucción pública. ${ }^{135}$ También por los mismos medios se denunciaba el deplorable estado físico de las escuelas, muchas de ellas medio

\footnotetext{
${ }^{133}$ José Jimeno Agius (Segorbe, 1835-1901). Abogado, economista y político valenciano. Fundador del Imparcial. Diputado del Partido Progresista por el distrito de Castellón de La Plana, en las elecciones generales de 1869. En las de 1898 se presenta por el Partido Liberal Fusionista.

${ }^{134}$ No debemos perder de vista que en esta sociedad agraria, la mayor parte de los niños trabajaban con sus padres en las tareas agrícolas y/o manufactureras desde temprana edad y especialmente las niñas tenían que ayudar a las madres en la casa, el cuidado de los hijos y de los mayores. Tan solo las familias acomodadas, liberadas de la necesidad de contar con los sueldos de resto de la familia, podrían permitirse que sus hijos estudiaran.

135 AGUILAR RÓDENAS, Consol. (1985): La Educación en Castellón a través de la prensa (1868-1900), Col-lecció Universitaria. Diputación de Castelló, p.55.
} 
arruinadas, con escasa iluminación, malas condiciones de salubridad y aulas pequeñas de elevado hacinamiento. ${ }^{136}$

Asimismo se daban charlas por parte de maestros y profesores del Instituto sobre el deficiente estado de las escuelas, y los técnicos municipales denunciaban en sus inspecciones, informes y reformas, el lamentable estado higiénico de algunos centros. ${ }^{137}$

También la Comisión permanente de Instrucción Pública tuvo un papel importante en la consecución de mejoras y aumento de centros escolares. Los informes de la Comisión fueron siempre escuchados y atendidos por el Ayuntamiento para solucionar las deficiencias. ${ }^{138}$

Como vemos, a pesar de que la Ley de Instrucción Pública del 9 de septiembre de 1857 establecía las primeras condiciones para la creación de escuelas, programas, número de alumnos por aula, que se fijó en 60 y condiciones higiénicas de los mismos, los resultados no se empezaron a vislumbrar hasta la última década del siglo XIX.

En este sentido, conocemos por la Guía Oficial de Castellón y Provincia, que en la capital existían en 1894 los siguientes centros escolares públicos:

Escuela de niños de Pestagua, calle Conde Pestagua, 3 y 5; Escuela de niños y niñas del Real, ${ }^{139}$ plaza de Sixto Cámara,18 (ahora del Real); Escuela de Centro de niños, calle Mayor 126; Escuela de niños de la Beneficencia, calle del Rosario,11; Escuela de niñas de las Balsas, plaza de las Balsas, 26 (ahora Isabel la Católica); Escuela Centro de niñas, aneja a la Normal de Maestras, plaza de la Unión ( luego Castelar, actualmente Puerta del Sol); Escuela de párvulos, calle de Arriba,139 (actualmente calle Alloza); Escuela de niños y niñas del caserío del Grao, ${ }^{140}$ y el Instituto Provincial de Segunda Enseñanza, situado desde su fundación, en 1846, en el desamortizado convento de las monjas Clarisas, de la calle Mayor,29.

\footnotetext{
${ }^{136}$ AGUILAR RÓDENAS, Consol. (1985): op. cit, pp.80-81.

${ }^{137}$ La Provincia, 28/081898

138 En los expedientes de Instrucción Pública. Centros escolares (1853-1932) del Archivo Histórico Municipal de Castellón, se conservan informes de la Comisión de Instrucción pública, donde se ha podido constatar la fundamental labor que ejerció y la diligencia del Ayuntamiento para solucionar y mejorar la situación escolar.

${ }^{139}$ El 23 de septiembre de 1891 se aprueba la liquidación de las obras de reforma, derribo de una casa contigua en c/Menor,52 y ensanche de la escuela pública de niñas de la ciudad llamada del Real, en expedientes de Instrucción Pública de Centros Escolares (1891-1909) Archivo Municipal de Castellón.

${ }^{140}$ Construida por el Ayuntamiento con la tutela de Cayetano Huguet, en AGUILAR RÓDENAS, Consol. (1985): op.cit. p.56.
} 
Como podemos observar por la Guía del año 1894, ya no figura la Escuela de Huérfanos de San Vicente, ${ }^{141}$ que cambia de emplazamiento en 1884 a la calle Mayor 126, tomando el nombre de Escuela Centro de niños y tampoco figura la Escuela del Hospital que cambia de localización en 1883, trasladándose a la calle Pestagua 3 y 5. Se continuó llamando oficialmente del Hospital y en el año 1898 figura ya como Escuela de Pestagua. ${ }^{142}$

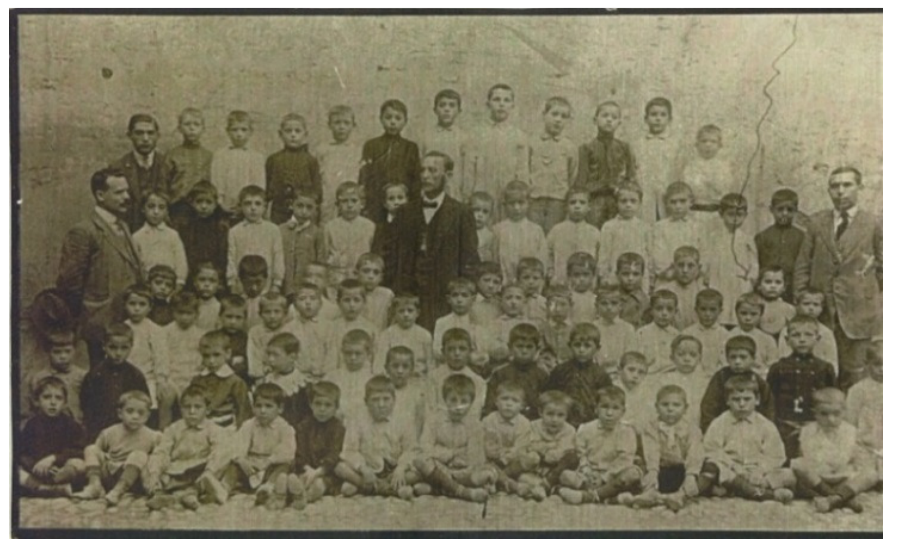

El maestro Francisco Canós Sanmartín, con profesores y alumnos, en la escuela de Pestagua. Fuente: Colección fotográfica, José Prades

De la labor que ejerció en sus visitas rutinarias e inspecciones a las escuelas de la ciudad la Comisión de Instrucción Primaria, merece destacar una de ellas, en donde se hace mención de la situación de la vieja Escuela de las Balsas y del estado de otras

141 La Comisión de Instrucción Pública Provincial, con fecha 7 de diciembre de 1893, ante las «[...]deficientes condiciones que por lo antiguo y ruinoso del local que ocupa la escuela de San Vicente y la incompleta instrucción que en ella se imparte, a pesar de la idoneidad y esfuerzo del profesor y director del mismo, D. José Cheza, y conveniente separación de piezas y distribución y la deplorable situación higiénica, han inducido a la Comisión Provincial de Instrucción Pública a procurar el traslado de la citada escuela a otro local mejor acondicionado y que responda a las modernas prescripciones pedagógicas. Por fortuna la Comisión ha encontrado a satisfacción la casa $\mathrm{n}^{\circ} 126$ de la calle Mayor, por un arriendo de cuatro años y un precio de 337 pesetas al año, para entrar a partir del 1 de enero de 1884. Destinado a escuela y habitación del profesor [...]», en Expedientes de Instrucción Pública. Centros escolares (1891-1909), A.H.M.C. También, en los mismos expedientes (1891-1909) consta que en 1897 esta misma Escuela-Centro pasa a la calle Caballeros. La escuela comprendia tres grados: preparatorio, elemental y superior, figurando tres maestros y como profesor-director José Cheza. Por la Guía de Castellón y la Provincia de 1914, tenemos noticias que se traslada a otra casa de alquiler, esta vez a la calle González Chermá,52,2 ( ahora Enmnedio), volviendo años mas tarde al anterior emplazamiento.

${ }^{142}$ La antigua escuela del Hospital, desde 1881 ha sufrido importantes reformas, dado su lamentable estado de conservación. La Comisión de Instrucción Pública propone el arriendo durante el plazo mínimo de cuatro años, a razón de tres pesetas diarias, de la escuela de niños que ha de construir el Excmo. Sr. Conde de Pestagua en los solares que posee en la calle de Naranjeros, como consta en Acta Municipal de 31 de Marzo de 1892. En Sesión del 5 de enero de 1882, a propuesta del Sr. Gasset, para corresponder a las deferencias de que es objeto esta Corporación por parte del Sr. Conde Pestagua, se acuerda sustituir el nombre de la calle Naranjeros por Pestagua. Por último, se acuerda en Sesión de 14 de enero de 1893, trasladar la escuela hasta ahora llamada del Hospital, al edifico situado en el número tres de la calle Naranjeros que ha construido el Señor Conde Pestagua. Se continuó llamando oficialmente del Hospital. En las elecciones del 16 de marzo de 1898 , el distrito $5^{\circ}$ ya figura como Escuela de Pestagua. 
escuelas a finales de la primera década del siglo XX. Transcribimos por su interés el citado informe.

Excelentísimo Señor.

La Comisión permanente de Instrucción pública, con el deseo de que sus trabajos resulten provechosos para las importantes actuaciones que le están confiadas, ha girado visita a las escuelas de la Capital, a fin de capacitarse del estado de la enseñanza primaria y conocer al propio tiempo las condiciones de los edificios. De unos locales salió gratamente impresionada, de otros hubo de llevarse el doloroso convencimiento de que no responden a las exigencias de una acertada prescripción pedagógica, sin reunir siquiera condiciones para dejar garantizada la seguridad personal de los niños que a ellas concurren.

Sin duda alguna que la escuela de las Balsas impresionaría de igual modo el ánimo de cualquiera que la visitase, pues la pésima distribución del local y la inminente ruina que el edificio amenaza la hace inviable para el objeto a que está destinada.

Fundándose en esto, la Comisión se considera en el deber de proponer a V.E se acuerde el traslado de la citada escuela de las Balsas, a una nueva casa que al efecto se alquile, y que tan pronto esté vacía, se proceda al inmediato derribo del edificio desalojado.

V.E. sin embargo resuelva lo que mejor estime. Castellón 9 Enero 1894. ${ }^{143}$

El Ayuntamiento, dando respuesta al citado informe de la Comisión, traslada la Escuela de las Balsas a un local alquilado en la calle de las Cruces, número $10 .{ }^{144}$ Reconstruido el citado edificio, según proyecto del arquitecto municipal, vuelve en 1813 la Escuela a su anterior emplazamiento. Más tarde, en la Guía Oficial de Castellón y Provincia de 1923 deja de figurar la citada escuela.

Entre los centros educativos privados que se citan en las guías de Castellón de la última década del siglo XIX, tenemos el Colegio de Segunda Enseñanza de la Purísima Concepción, agregado al Instituto y que gozaba de gran fama por los brillantes resultados académicos; el colegio de niños, en calle Cardona Vives,12; el Colegio de San Lorenzo, en calle de la Enseñanza, 39; el colegio de niñas de las hermanas de la Consolación, en calle Enseñanza, 4; además de cuatro colegios de señoritas en la calle Enmedio 56; calle Obispo Climent 22; calle Zapateros, plaza de la Constitución 28 (actualmente plaza Mayor) y calle Falcó; el colegio de niñas de la Purísima Concepción, en calle de Enchin 18 (actualmente calle Vera); el colegio de Sagrado Corazón de Jesús de las hermanas Carmelitas de la Caridad, en calle Zapateros 56. Por último, merecen

\footnotetext{
${ }^{143}$ Expedientes de Instrucción Pública. Centros escolares (1891-1909). Archivo Municipal de Castellón.

${ }^{144}$ La Escuela de las Balsas se traslada el 31 de mayo de 1894 a una casa propiedad de Jaime Miralles Monfort, en la calle de las Cruces, 10 (Plaza Amalio Gimeno, ahora Rey Don Jaime), en Expedientes de Instrucción Pública, Centros escolares, A.H.M.C.
} 
citarse otros centros educativos: como la academia de preparatoria de segunda enseñanza, la de comercio y la de mercantil. La academia de francés, la de preparatoria para carreras especiales de ayudantes de Obras públicas, la escuela de pintura, la escuela de taquigrafía y la escuela de música.

Como podemos observar, a partir de las dos últimas décadas del siglo diecinueve es cuando comienzan a emerger en Castellón un significativo número de centros privados, muchos de ellos pertenecientes a órdenes o instituciones religiosas. La religión y la Iglesia Católica tenían un peso decisivo en la vida española en estos años, es prácticamente un lugar común. La vida privada, las costumbres, las festividades, la moral y la vida familiar, discurrían controladas, reguladas y ritualizadas por la Iglesia Católica. Algo parecido ocurría con la vida pública. Reconocida constitucionalmente como religión de Estado en la España de la Restauración, se puede observar en la expansión de las órdenes religiosas y en el prestigio que adquirieron entre las clases altas los colegios religiosos, como signo de estatus.

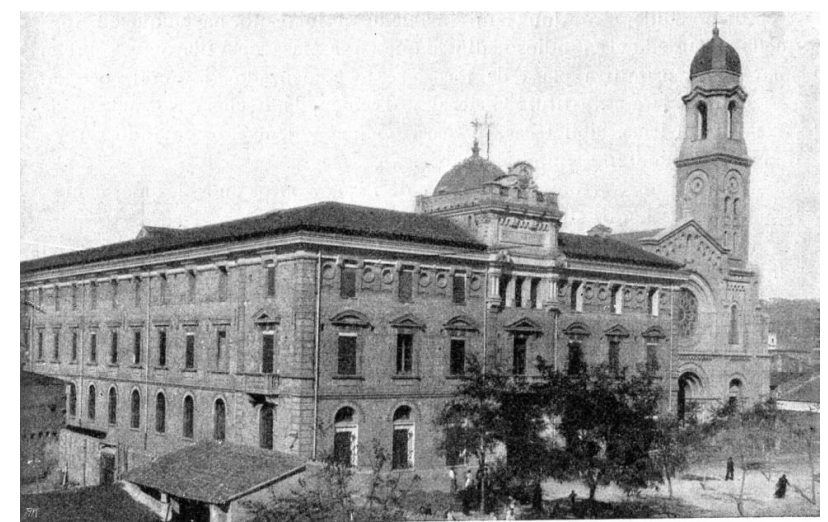

Edificio de las Escuelas Pías en la ciudad de Castellón.

Fuente: Sarthou Carreres, Carlos (1913): Geografía del Reino de Valencia

Entre los colegios privados religiosos queremos resaltar el Colegio de los Padres Escolapios, donde acudían alumnos de las familias burguesía más acomodadas de la sociedad castellonense, y que por su capacidad, por las condiciones higiénicas de sus instalaciones y el equipamiento escolar, marcó un hito de modernidad en su época.

A final de siglo, en 1897, comienzan las obras del centro escolar de primera enseñanza y posteriormente de secundaria de las Escuelas Pías, finalizando la construcción el año 1900. Se construyó con rentas y bienes de la herencia del presbítero 
castellonense J. B. Cardona Vives ${ }^{145}$. Ocupa parte de una manzana cuadrangular situada en el ya consolidado barrio de la Trinidad, contiguo al primer ensanche de 1885 del barrio de El almelar, situado al suroeste de la población.

El edificio, obra del arquitecto provincial, Manuel Montesinos Arlandiz, reúne una mezcla de estilos de la época. Su planta se estructura con dos amplios patios de tipo claustral, al que vierten las aulas y otras dependencias, estando dichos espacios bien iluminadas y ventiladas. Dispone de buenos laboratorios, biblioteca y salón de actos. Esta tipología la veremos más tarde, en 1917, en el nuevo Instituto de Segunda Enseñanza, la Normal de Maestros y la Escuela de Artes é Industrias, proyectado por el arquitecto municipal Francisco Tomas Traver.

Con el inicio del siglo XX se producen importantes mejoras en las escuelas públicas, tanto a nivel pedagógico como higiénico. En pocos años más de la mitad de las escuelas públicas son graduadas, creciendo en número y tamaños los centros.

El Real Decreto de 26 de octubre de 1901, por el que el Estado asume los gastos de personal y mantenimiento supone un alivio a los municipios, pudiendo de esta forma invertir más en la mejora y creación de nuevos edificios escolares. También el Real Decreto de abril de 1905, de Carlos María Cortezo, amplia y agiliza las subvenciones. El mismo decreto publica las nuevas Instrucciones Técnico-higiénicas para la construcción de los nuevos colegios. Muy pronto, el celo del Ayuntamiento empieza a dar los primeros frutos, ampliando y mejorando las escuelas existentes y construyendo otras nuevas ajustadas a las recientes normas técnicas.

Hasta el momento todos los establecimientos oficiales de instrucción pública que hemos citado estaban situados en edificios existentes adaptados para la función docente, muchos de ellos alquilados y reformados por el Ayuntamiento.

No hay que olvidar que en muchas poblaciones de nuestras comarcas, las escuelas estaban ubicadas en los propios edificios concejiles, en dependencias habilitadas al efecto, y que por falta de recursos económicos han perdurado hasta bien entrada la década de los años sesenta del pasado siglo XX.

La construcción de los primeros grupos escolares adaptados a las nuevas instrucciones no se deja esperar, en 1908 se están construyendo dos en los barrios

\footnotetext{
145 MIR PASCUAL, Sonia; FUSTER GARCIA, Pascual (2010): Manuel Montesinos Arlandiz, Ayuntamiento de Castellón, p.208.
} 
extremos de la ciudad. ${ }^{146}$ Se trata de la Escuela Pública de niños de la Ronda Magdalena, con una dotación de tres aulas; ampliándose pocos años después con una solución similar para niñas. En 1921 toma el nombre de Grupo Escolar Concepción Arenal $^{147}$. El edificio constaba de planta baja, con amplio patio, ocupando una extensa parcela regular del nuevo ensanche en cuadricula de 1890, en el barrio de els Mestrets (entre Paseo de Ribalta y calle Joaquín Costa) al noroeste de la ciudad, donde ya habían algunas manzanas edificadas. En la década de los años sesenta del siglo XX se derriba la primitiva construcción, edificándose en el mismo solar otra escuela que aun se conserva, con algunas reformas recientes, se trata del actualmente Colegio Público Cervantes.

La otra Escuela Pública para niños y niñas de nueva construcción es la de la calle Herrero, que pasa a llamarse por las mismas fechas que la anterior, Grupo Escolar Maestro Castelló, y a principios de la década de los años cuarenta toma el nombre de Mártires del Magisterio. Distribuido en dos plantas, dispone de tres aulas para niños y tres para niñas, con espacioso patio arbolado. Situado a las espaldas del Teatro Principal, ocupa parte de una manzana del nuevo ensanche de 1890, al sureste de la ciudad. Derribada la primera construcción en la década de los años sesenta, se construye sobre un solar algo mayor una nueva escuela, actualmente es el Colegio Público Herrero.

La Guía de Castellón y Provincia, del año 1913, amplia la relación de escuelas municipales, citando para niñas: las Aulas de Latinidad, en la calle Caballeros, recientemente remodelada en 1912, con capacidad para un aula de párvulos en planta baja y tres de primaria en planta primera, con una dotación de cuatro maestras. Para niños se enumeran los colegios situados en la calle Pí y Margall, 139-1º (actualmente calle Trinidad), y habían con un maestro, el situado en la calle Ros de Ursinos, $2-1^{\circ} .^{148}$

Por los datos que proporciona sobre la escolarización Carlos Sarthou ${ }^{149}$ en 1915, en Castellón capital habían 25 escuelas públicas completas, con asistencia de 2000 alumnos, y cinco colegios privados elementales, más varias academias y colegios

\footnotetext{
${ }^{146}$ GIMENO MICHAVILA, V. op. cit., p.34.

147 Ibídem.

${ }^{148}$ La Junta local de Primera enseñanza ha acordado el 17 de noviembre de 1909, trasladar la escuela que dirigen los maestros Fancisco Benedito y Luis Pérez, pasen a la casa $\mathrm{n}^{\circ} 2$ escalerilla de la calle de Ros de Ursinos y a la casa $n^{\circ} 139$ triplicado principal de la calle Pi i Margall, en Expedientes de Instrucción Pública. Centros escolares (1891-1909) A.H.P.C.

${ }^{149}$ SARTHOU CARRERAS, Carlos (1915): op.cit.p. 355.
} 
particulares.La misma Guía de Castellón y Provincia, del año 1922, para niños figuran los siguientes centros públicos: la Escuela Centro, en la calle Mayor,126; la Escuela del Real, en la plaza Sixto Cámara,18, con dotación para dos maestros; el Grupo Escolar Concepción Arenal en la Ronda Magdalena; el Centro Escolar de Maestro Castelló, en la calle Herrero (con dotación para tres maestros), las escuelas públicas situadas en la calle Conde Pestagua, 5; en la calle Pi y Margall, 139-1 ${ }^{\circ}$ y en la calle Ros de Ursinos, 2-1 $1^{\circ}$ «escalerilla» y el colegio del caserío de Grao.

Para niñas figuran los siguientes centros públicos: la Escuela Centro de Normal de maestras, en la plaza Emilio Castellar (actualmente Puerta del Sol); el Centro Escolar Concepción Arenal, en la Ronda Magdalena, con la dotación de tres maestras; el Centro Escolar de Maestro Castelló, en la calle Herrero, con dotación para una maestra; la Escuela de las Aulas, en calle Caballeros, con dotación para tres maestras; la Escuela del Real, en la plaza Sixto Cámara; la Escuela de la Enseñanza, en la calle Enseñanza y la Escuela del caserío del Grao, con dotación para una maestra.

Los centros de párvulos, para niños y niñas, se instalan en la Escuela de las Aulas para niñas; en la Escuela Centro para niños y en la Escuela del Real para ambos sexos.

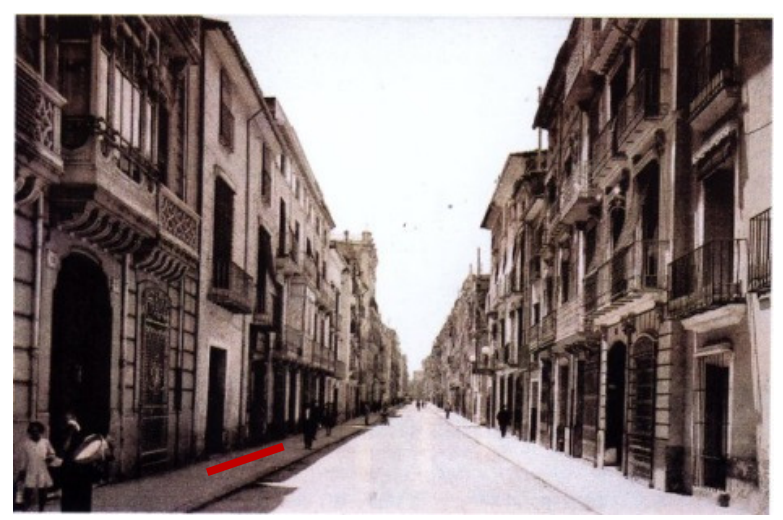

Escuela Centro de niños, calle Mayor, 126. Segunda casa del lado izquierdo de la calle. Fuente: Colección fotográfica: Morales, M; García L., Castellón sigloXX

A finales de los años veinte el mapa escolar cambia sensiblemente, desapareciendo paulatinamente las escuelas situadas en el centro de la ciudad y en locales alquilados, por los nuevos grupos escolares ${ }^{150}$ que se localizados en el

\footnotetext{
150 Vicente Gimeno Michavila nos cuenta que [...] En mayo de 1913 emitió el Ayuntamiento un empréstito de un millón de pesetas, con cuyo importe se municipalizaron los servicios de luz y de agua; adquiriéndose solares en las calles de San Roque, Pelayo y Ronda Mijares, para construir sobre los mismos nuevos centros escolares, [...], en GIMENO MICHAVILA, V. (1984) op. cit., p.34.
} 
extrarradio. Además de los grupos anteriormente citados, podemos mencionar el Grupo Escolar Adsuara, en la calle San Roque; el Grupo Escolar Ejército en la calle Lepanto y el Grupo Escolar Gaetá Huguet, próximo a la vía del tren (actualmente Avd. Barcelona, 6), todos ellos junto a los nuevos ensanches. Ya no podemos hablar de escuelas, se trata de agrupaciones escolares que responden a los prototipos propuestos por el Ministerio de Instrucción Pública. Con el Real Decreto de 1920 el Estado se hace cargo de la financiación y construcción de las escuelas, introduciendo nuevos modelos, ahora más cercanos a la ideología institucionista. El Grupo Escolar Ejército puede ser un ejemplo de estos nuevos planteamientos.

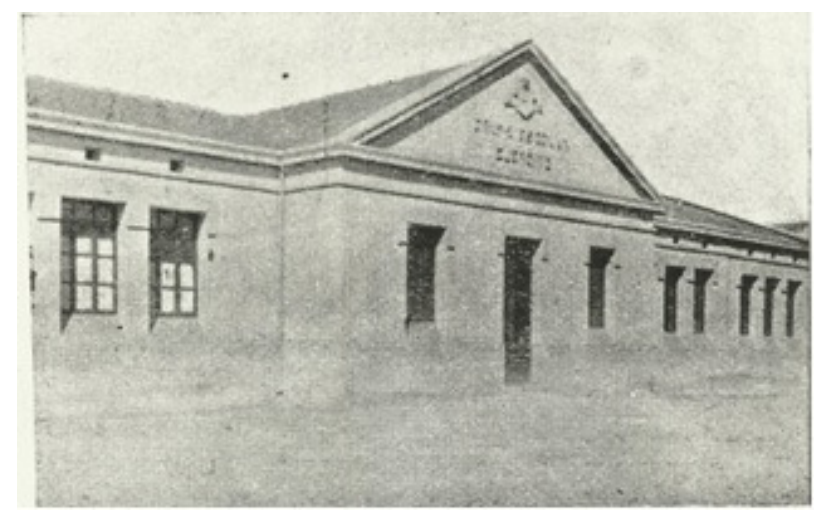

Grupo escolar Ejército, construido en la década 1920 Fuente: Colección fotográfica José Prades

Un tema que no debemos pasar por alto, es el gran interés que el Ayuntamiento manifestaba por impulsar las escuelas nocturnas de adultos, impartiéndose las clases en los centros escolares municipales. Como ya hemos indicado anteriormente, el Ayuntamiento, coincidiendo con el Sexenio Revolucionario, el mismo año 1868, instala en las antiguas aulas de Latinidad la primera escuela nocturna de adultos, para instruir a la clase trabajadora en los oficios y en las primeras letras. A través de la información de las Guías Oficiales de Castellón y Provincia y por los expedientes de Instrucción Pública del Archivo Histórico Municipal de Castellón, hemos podido constatar que a finales del siglo XIX, un nutrido grupo de profesores de las escuelas públicas impartían en los mismos locales clases nocturnas a los adultos. Como sucedía con la Escuela de la Beneficencia, la Escuela del Real, la Escuela de Pestagua, la Escuela del Centro de niños y la Escuela de la calle Pi i Margall.

Hemos confeccionado una tabla resumen (tabla 2) donde se puede observar el proceso de evolución de las escuelas municipales de Castellón en el transito del siglo XIX al siglo XX. A partir de la última década del siglo XIX se empieza a producir un significativo aumento de escuelas, desapareciendo progresivamente las más antiguas o 
cambiando algunas a mejores emplazamientos. A finales de la primera década del siglo XX empiezan a surgir los primeros grupos escolares. También hemos elaborado dos mapas escolares: uno del último tercio del siglo XIX y el otro del primer tercio del siglo XX, para materializar en el plano de la ciudad los datos consultados que hacen referencia a este campo de la información y poder ver cómo ha evolucionado del centro a la periferia el crecimiento y localización de las escuelas públicas en la ciudad de Castellón. Pasando de pequeñas escuelas-habitación, generalmente en locales alquilados, a grupos escolares de nueva construcción.

Tabla 2. Evolución de las escuelas en Castellón en el tránsito del siglo XIX al siglo XX

\begin{tabular}{|c|c|c|c|c|c|c|c|c|c|c|c|}
\hline $\begin{array}{l}\text { ESCUELAS MUNICIPALES } \\
\text { EN CASTELLÓN }\end{array}$ & Situación & 1798 & 1851 & 1872 & 1890 & 1895 & 1900 & 1910 & 1915 & 1920 & 1930 \\
\hline $\begin{array}{l}\text { Escuela antigua de la Villa } \\
\text { Niños }\end{array}$ & $\begin{array}{l}\text { Edificio Aulas de Latinidad } \\
\text { Plaza. Hospital,3 }\end{array}$ & $\mathbf{X}$ & & & & & & & & & \\
\hline $\begin{array}{l}\text { Esc. Huérfanos de San Vicente } \\
\text { niños/ niñas }\end{array}$ & $\begin{array}{l}\text { Plaza. Pescadores } \\
\text { Actual c/Obispo Climent, } 22\end{array}$ & $\mathbf{X}$ & $\mathbf{X}$ & $\mathbf{X}$ & $\mathbf{X}$ & & & & & & \\
\hline $\begin{array}{l}\text { Escuela de la Enseñanza } \\
\text { Niñas }\end{array}$ & C/ Enseñanza, 30. & $\mathbf{X}$ & $\mathbf{X}$ & $\mathbf{X}$ & $\mathbf{X}$ & $\mathbf{X}$ & $\mathbf{X}$ & $\mathbf{X}$ & $\mathbf{X}$ & $\mathbf{X}$ & \\
\hline $\begin{array}{l}\text { Escuela del Real } \\
\text { Niños, niñas, párvulos, nocturna adultos. }\end{array}$ & $\begin{array}{l}\text { Plaza. Sixto Cámara, } 18 \\
\text { (Plaza. del Real) }\end{array}$ & $\mathbf{X}$ & $\mathbf{X}$ & $\mathbf{X}$ & $\mathbf{X}$ & $\mathbf{X}$ & $\mathbf{X}$ & $\mathbf{X}$ & $\mathbf{X}$ & $\mathbf{X}$ & $\mathbf{X}$ \\
\hline $\begin{array}{l}\text { Escuela del Hospital } \\
\text { Niños y nocturo de adultos }\end{array}$ & $\begin{array}{l}\text { Plaza. Hospital,7 } \\
\text { (actual,c/ San Luis) }\end{array}$ & $\mathbf{X}$ & $\mathbf{X}$ & $\mathbf{X}$ & $\mathbf{X}$ & & & & & & \\
\hline $\begin{array}{l}\text { Escuela de las Balsas } \\
\text { Niñas }\end{array}$ & $\begin{array}{l}\text { Plaza. Balsas,26 ( plaza. Isabel } \\
\text { Católica). Desde } 1894 \text { en c/ de } \\
\text { las Cruces (Rey Jaime) y } \\
\text { vuevel a plaza.Balsas en } 1913\end{array}$ & $\mathbf{X}$ & $\mathbf{X}$ & $\mathbf{X}$ & $\mathbf{X}$ & $\mathbf{X}$ & $\mathbf{X}$ & $\mathbf{X}$ & $\mathbf{X}$ & & \\
\hline $\begin{array}{l}\text { Escuela de la Beneficencia } \\
\text { Niños, niñas y nocturno de adultos }\end{array}$ & c/ Rosario, 11 & & & $\mathbf{X}$ & $\mathbf{X}$ & $\mathbf{X}$ & $\mathbf{X}$ & $\mathbf{X}$ & $\mathbf{X}$ & $\mathbf{X}$ & \\
\hline $\begin{array}{l}\text { Escuela de Párvulos, c/ Alloza } \\
\text { Niños y niñas }\end{array}$ & $\begin{array}{l}\text { Edif. Aulas de Latinidad, } 1851 \\
\text { y desde } 1888 \text { en c/ Arriba } 139\end{array}$ & & $\mathbf{X}$ & $\mathbf{X}$ & $\mathbf{X}$ & $\mathbf{X}$ & $\mathbf{X}$ & & & & \\
\hline $\begin{array}{l}\text { Escuela unitaria, c/ Alloza } \\
\text { Niñas }\end{array}$ & c/ Arriba 139 (Alloza) & & & & & & & $\mathbf{X}$ & $\mathbf{X}$ & $\mathbf{X}$ & \\
\hline $\begin{array}{l}\text { Escuela Aulas de Latinidad } \\
\text { Niñas / párvulos }\end{array}$ & $\begin{array}{l}\text { Plaza. de las Aulas } \\
\text { C/Caballeros ( act. Pza. Aulas) }\end{array}$ & & & & & & & & $\mathbf{X}$ & $\mathbf{X}$ & $\mathbf{X}$ \\
\hline $\begin{array}{l}\text { Escuela del Centro, aneja } \\
\text { Normal de Maestras, niñas } \\
\end{array}$ & $\begin{array}{l}\text { C/ Mayor,10 y plaza. Castelar } \\
\text { (act.Puerta.del Sol) desde } 1894\end{array}$ & & & & $\mathbf{X}$ & $\mathbf{X}$ & $\mathbf{X}$ & $\mathbf{X}$ & $\mathbf{X}$ & $\mathbf{X}$ & $\mathbf{X}$ \\
\hline $\begin{array}{l}\text { Escuela del caserío del Grao } \\
\text { Niños / niñas }\end{array}$ & $\begin{array}{l}\text { Diferentes. emplazamientos. } \\
\text { desde } 1892\end{array}$ & & & & & $\mathbf{X}$ & $\mathbf{X}$ & $\mathbf{X}$ & $\mathbf{X}$ & $\mathbf{X}$ & $\mathbf{X}$ \\
\hline $\begin{array}{l}\text { Escuela Conde Pestagua } \\
\text { Niños, (traslado Esc. Hospital en 1893) }\end{array}$ & $\begin{array}{l}\text { C/ Naranjeros ( actualmente, } \\
\text { c/ Conde Pestagua) }\end{array}$ & & & & & $\mathbf{X}$ & $\mathbf{X}$ & $\mathbf{X}$ & $\mathbf{X}$ & $\mathbf{X}$ & \\
\hline $\begin{array}{l}\text { Escuela del Centro de niños } \\
\text { niños /párvulos y nocturno de adultos } \\
\text { (traslado Esc. Huérfanos S.Vicente 1893) }\end{array}$ & $\begin{array}{l}\text { c/ Mayor } 126 \text { y en } \\
\text { c/Enmedio,52,2 de } 1910-1915\end{array}$ & & & & & $\mathbf{X}$ & $\mathbf{X}$ & $\mathbf{X}$ & $\mathbf{X}$ & $\mathbf{X}$ & \\
\hline $\begin{array}{l}\text { Escuela calle Pi y Margall } \\
\text { Niños, niñas y nocturna de adultos } \\
\end{array}$ & C/Pi y Margall, $130-1^{\circ}$ & & & & & & & $\mathbf{X}$ & $\mathbf{X}$ & $\mathbf{X}$ & $\mathbf{X}$ \\
\hline $\begin{array}{l}\text { Escuela calle Ros de Ursinos } \\
\text { Niños }\end{array}$ & C/Ros de Ursinos, $2^{\circ}-1^{\circ}$ & & & & & & & $\mathbf{X}$ & $\mathbf{X}$ & $\mathbf{X}$ & \\
\hline $\begin{array}{l}\text { Grupo escolar calle Herrero } \\
\text { Niños / niñas,( desde 1920, Grupo } \\
\text { Maestro Castelló, actual Herrero) }\end{array}$ & C/Moyano,6 & & & & & & & $\mathbf{X}$ & $\mathbf{X}$ & $\mathbf{X}$ & $\mathbf{X}$ \\
\hline $\begin{array}{l}\text { Grupo escolar Ronda Magdalena } \\
\text { Niños/niñas, ( desde 1920, Grupo } \\
\text { Concepción Arenal, actual Cervantes) }\end{array}$ & $\begin{array}{l}\text { Ronda Magdalena } \\
\text { (c/actual,Concepción Arenal,2) }\end{array}$ & & & & & & & $\mathbf{X}$ & $\mathbf{X}$ & $\mathbf{X}$ & $\mathbf{X}$ \\
\hline $\begin{array}{l}\text { Grupo escolar Adsuara } \\
\text { Niños/niñas, (actual Obispo Climent) } \\
\end{array}$ & C/ San Roque & & & & & & & & & & $\mathbf{X}$ \\
\hline $\begin{array}{l}\text { Grupo escolar Ejercito } \\
\text { Niños / párvulos }\end{array}$ & C/ Lepanto, 7 & & & & & & & & & & $\mathbf{X}$ \\
\hline $\begin{array}{l}\text { Grupo escolar Gaetá Huguet } \\
\text { Niños/niñas }\end{array}$ & $\begin{array}{l}\text { Actualmente, Avenida } \\
\text { Barcelona,6 }\end{array}$ & & & & & & & & & & $\mathbf{X}$ \\
\hline
\end{tabular}

Fuente: Elaboración propia 


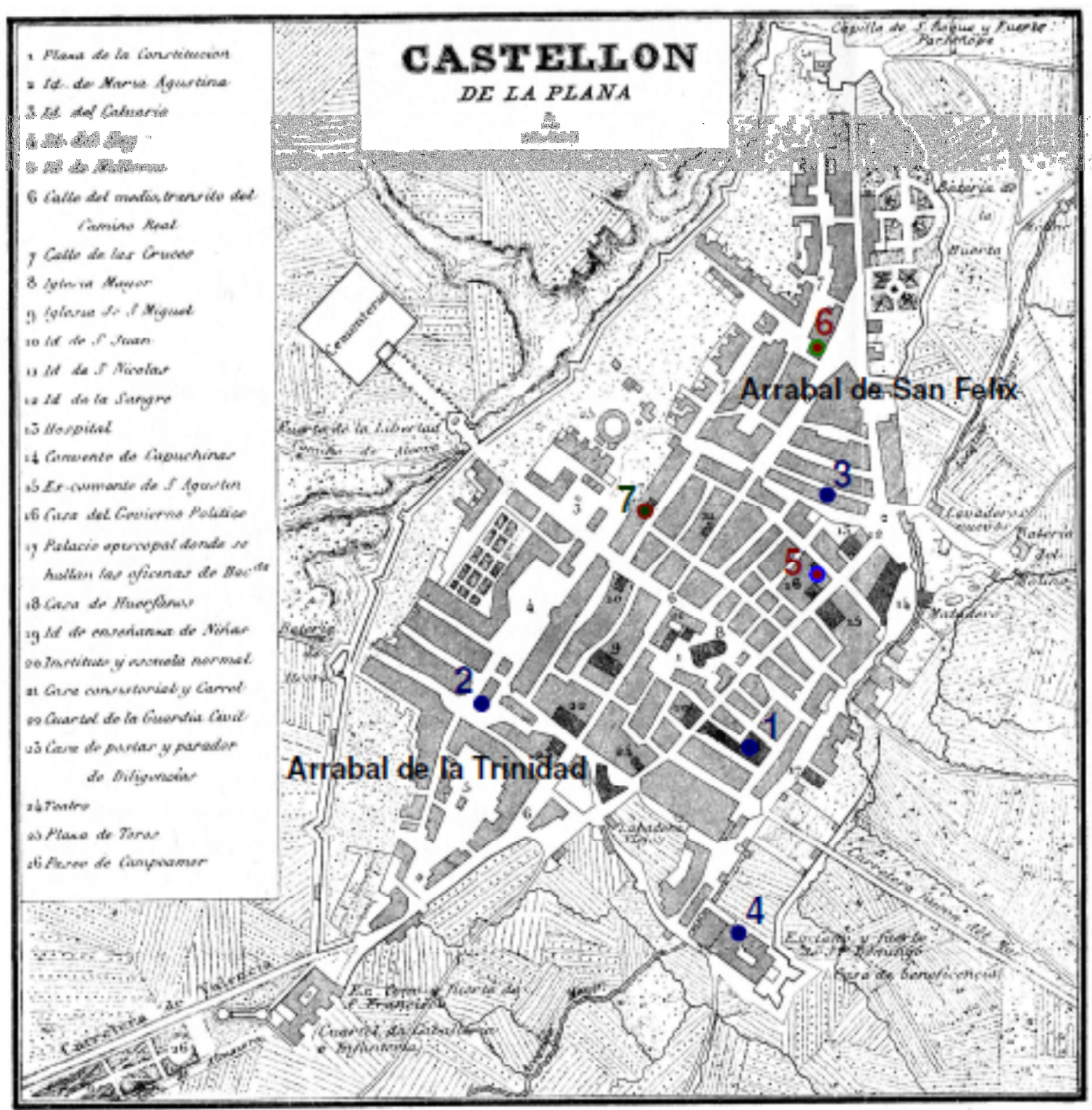

\section{ESCUELAS MUNICIPALES}

Anterior a 1880

\section{Escuela de niños}

1.- Escuela Huérfanos

2.- Escuela del Real

3.- Escuela del Hospital

4.- Escuela de Beneficencia

Escuela de niñas

5.- Escuela de la Enseñanza

6.- Escuela de las Balsas

Escuela de párvulos

7.- Escuela párvulos

Plano de Castellón de la Plana, año1853.

Fuente: Francisco Coello. Diccionario Geográfico y Estadistico. Atlas de España y sus posesiones de ultramar 


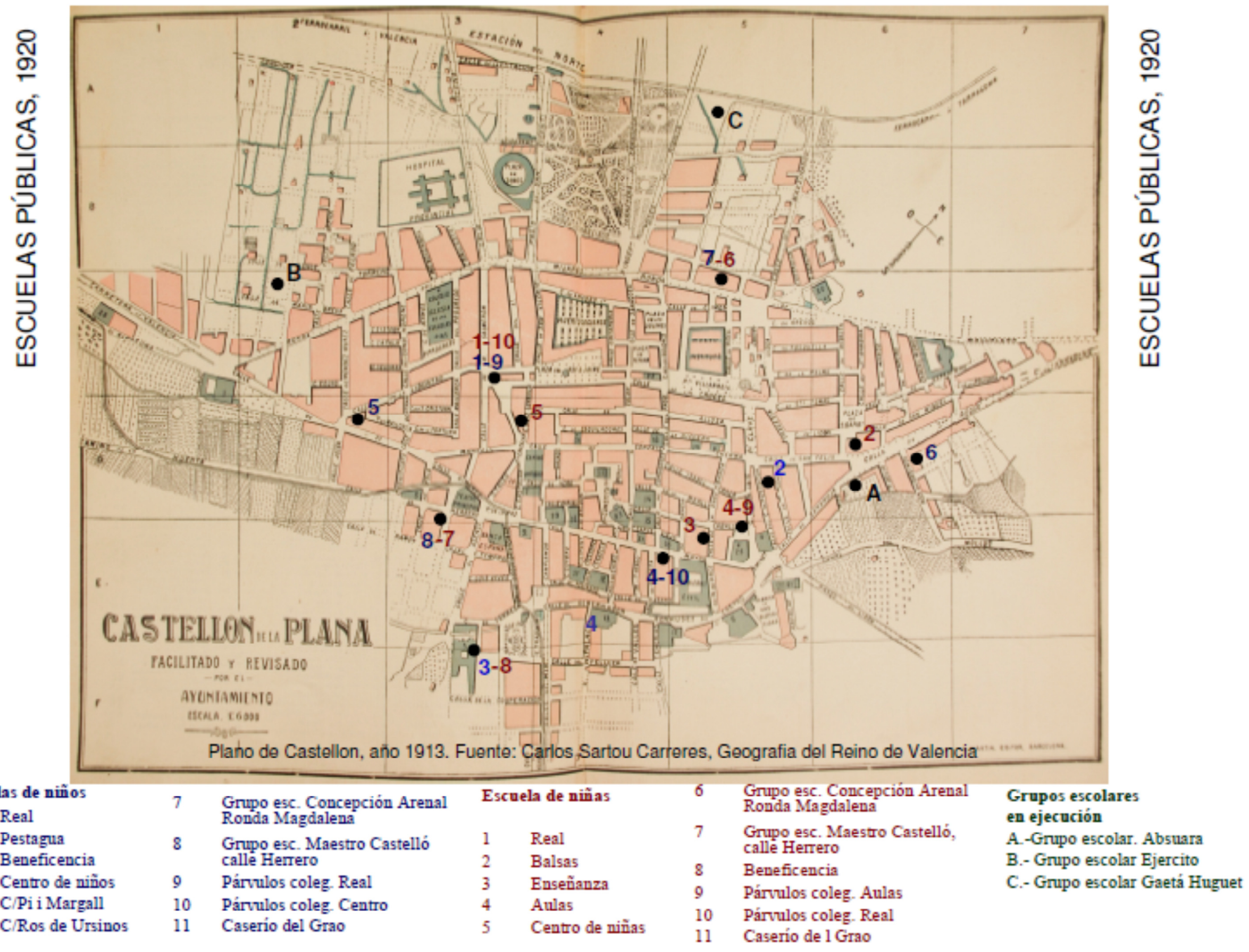




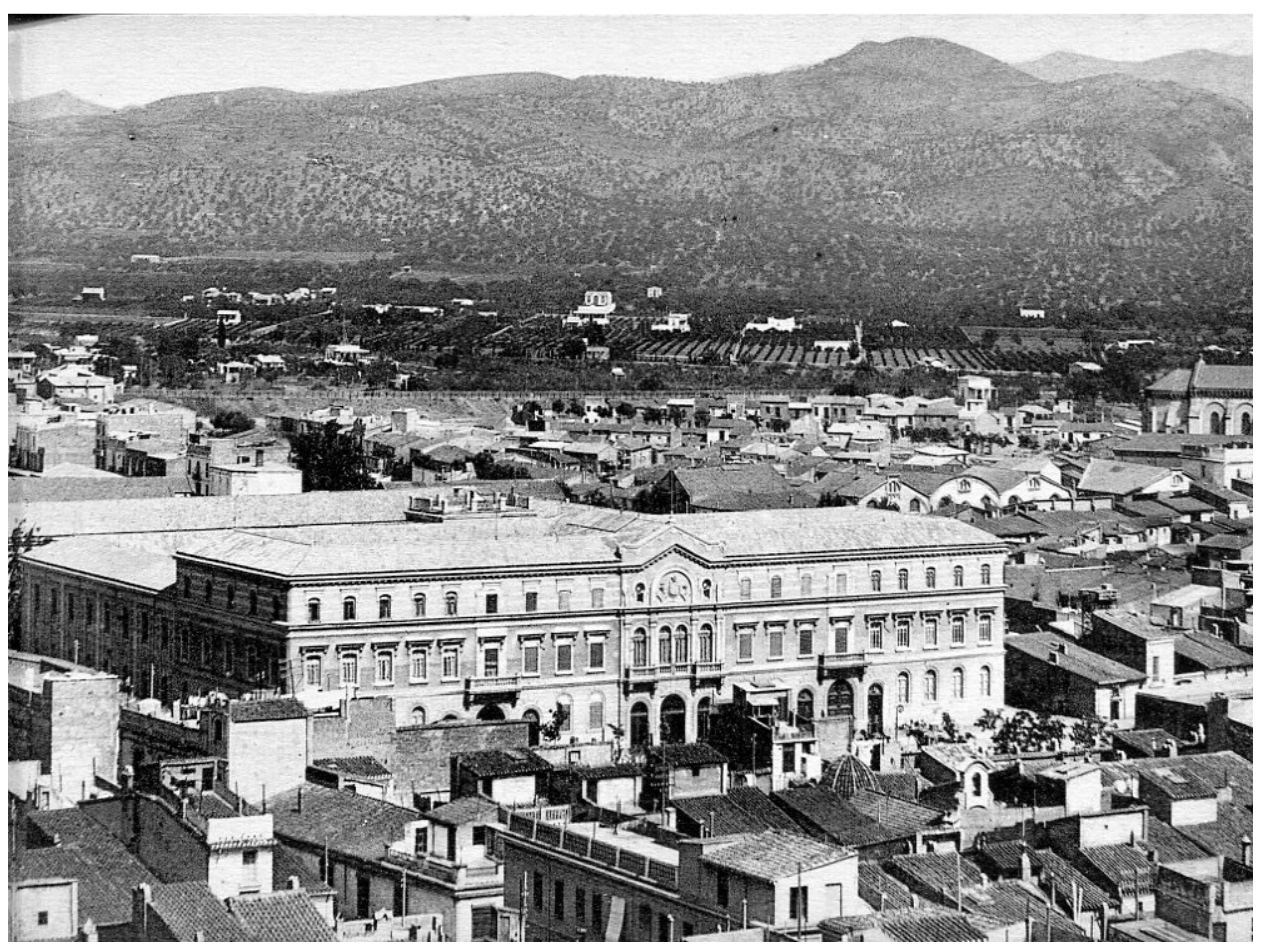

Instituto General y Técnico de Castellón. Fuente: Tarjeta Postal. L. Roisin, fot. Barcelona

\subsection{EL INSTITUTO DE SEGUNDA ENSEÑANZA DE CASTELLON}

La Enseñanza Secundaria comenzó a ordenarse legislativamente en todas las naciones de Europa a principios del siglo XIX, bajo los parámetros ideológicos del liberalismo. También en España, el liberalismo convierte este tema educativo en el nivel de enseñanza típico y distintivo de la burguesía, cuando hasta ese momento era de la aristocracia.

Así lo manifiesta Quintana en el proyecto de ordenación de la enseñanza pública de 1814 « la ausencia de enseñanza en el pasado es la causa del atraso en que se halla la educación en nuestra Monarquía». Esta idea será asumida en el futuro incluso por los reformadores socialistas: Fernando Giner de los Rios (1879-1949), ministro de Instrucción Pública y de Bellas artes de la Segunda República declaró ante el Parlamento: «la segunda enseñanza decidirá la cultura del país.»

En paralelo al desarrollo científico-técnico decimonónico que determina la industrialización y el crecimiento urbano, la conquista del control político por parte de la burguesía hizo de la Enseñanza Secundaria una cuestión de élites, un nivel de instrucción propio de las clases acomodadas. Defendían una enseñanza para todos, pero 
tan solo en el primer nivel. La Secundaría, se dirige a las clases altas y medias, formándolos para el acceso a la Universidad. ${ }^{151}$

Desde su inicio se le asigna una finalidad doble: fomentar las ciencias para una profesión liberal, y conectar con todos los conocimientos «útiles y agradables», asegurando que tuviera un carácter propedéutico para la Universidad, o de preparación intelectual del ser humano para aquellos que no fueran a continuar estudios.

La Enseñanza Secundaria, paso a ocupar un puesto muy importante en el sistema escolar, convirtiéndose a la vez en un poderoso instrumento de clasismo, al servicio de la burguesía. El currículo se agrupaba en torno a tres núcleos de conocimiento: Física y Matemáticas (teóricos y prácticos), Literatura y Arte y Ciencias Morales y Políticas. Habría un centro de Segunda Enseñanza en cada capital de provincia, que recibiría el nombre de «Universidad de provincia.»

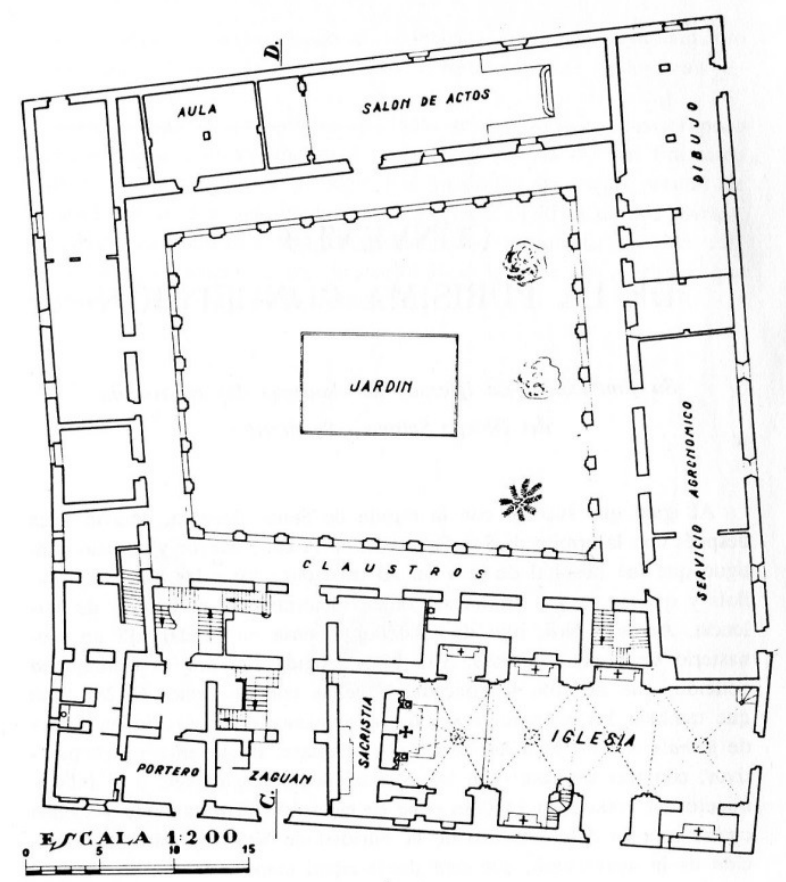

Convento de Santa Clara. Adaptado a Instituto de Segunda Enseñanza.

Fuente: Traver Tomas, Vicente (1958): Antigüedades de Castellón

La Secundaria será el nivel de enseñanza más cuidado en su organización, en sus textos, en sus profesores, en su currículo y también en su financiación.

\footnotetext{
151 VILLACORTA BAÑOS, Francisco (1993): Culturas y mentalidades en el siglo XX, Editorial Síntaxis, Madrid, p.21.
} 
Pero en España, durante el último siglo y medio, la Secundaria ha conocido casi medio centenar del reformas y ninguna ha sido del todo satisfactoria. Ello se debe, a la dificultad de definir los tres grandes problemas de este nivel educativo: su naturaleza, su destinatario y su contenido curricular.

En Castellón, en 1846 fue creado el Instituto de Segunda Enseñanza a raíz del desarrollo de Plan Pidal, ${ }^{152}$ que luego se consolidaría con la Ley Moyano, alejándolo de la dimensión democrática que algunos liberales intentaron darle en su inicio, pasando a constituirse en la ciudad y en la provincia como una educación de las denominadas clases medias, operando el Bachillerato y el propio edificio como elementos de prestigio y de imagen de poder. ${ }^{153}$

Las aulas de Gramática, tal y como se ha reseñado anteriormente, se suprimieron, pasando sus últimos maestros Fermín Gil y Joaquín Ramón, profesores de latín, a formar parte del claustro de catedráticos del Instituto.

Se implanto el Instituto de tercera categoría, pasando en pocos años a segunda. En un primer momento la enseñanza era de tres años de duración y tenía seis catedráticos que impartían lógica, moral-religión, historia, geografía, elementos de matemáticas, latín y castellano, con una matrícula para toda la provincia entre $80-100$ alumnos. También compartía el mismo lugar la Escuela Normal de instrucción primaria a la que concurrían unos 200 alumnos y realizaba prácticas en dos escuelas públicas, una de párvulos y otra de adultos. ${ }^{154}$ Para su instalación se acondicionó el exconvento de las monjas clarisas, situado en la calle Mayor. Además de las instalaciones docentes anteriormente citadas, el inmueble alojó también la Biblioteca y el Museo provincial, la Academia de Dibujo, la Estación Meteorológica, las oficinas de la Junta de Agricultura , Industria y Comercio, y desde 1851, el acreditado Colegio de internos pensionados ya citado, que tenía 30-40 alumnos de la provincia, tutelado por Anselmo Jordán.

En el curso 1859-60 contaba el Instituto con 233 alumnos matriculados, no muchos más que a final de siglo. En el último decenio, siendo Directores del centro

\footnotetext{
${ }^{152}$ R.O. de 26 de junio de 1846

153 PARRA MONSERRAT, David (2014): La educación silenciosa. Espacios escolares, discurso de poder e imaginarios colectivos, en XIII Coloquio Internacional de Geocritica. El control del espacio y los espacios de control, Barcelona, 5-10 de mayo 2014, p. 3.

${ }^{154}$ MADOZ Pascual (1982): op.cit, p.226.
} 
Pedro Aliaga y Catalino Alegre, se matricularon 2.472 alumnos, obteniendo el grado de Bachiller 323. ${ }^{155}$

El carácter elitista de la segunda enseñanza explica, según la profesora Vicenta Altava, la respuesta tan minoritaria que este tuvo en la provincia de Castellón durante los años de la Restauración, ya que fundamentalmente benefició a un reducido número de alumnos cuyas familias formaban parte de la élite local provincial. ${ }^{156}$

Con el tiempo, el nuevo Instituto, símbolo de modernidad y progreso, se dotó de un completo gabinete de Física-Química y Agricultura y de interesantes colecciones en el gabinete de Historia Natural, y que hoy forman parte del «museo» del centro. Las prácticas de agricultura y jardinería se realizaban en la mejor huerta de la ciudad, en un extenso cuadrilátero, situado a la derecha del camino del Mar, aproximadamente a un kilómetro de distancia. ${ }^{157}$
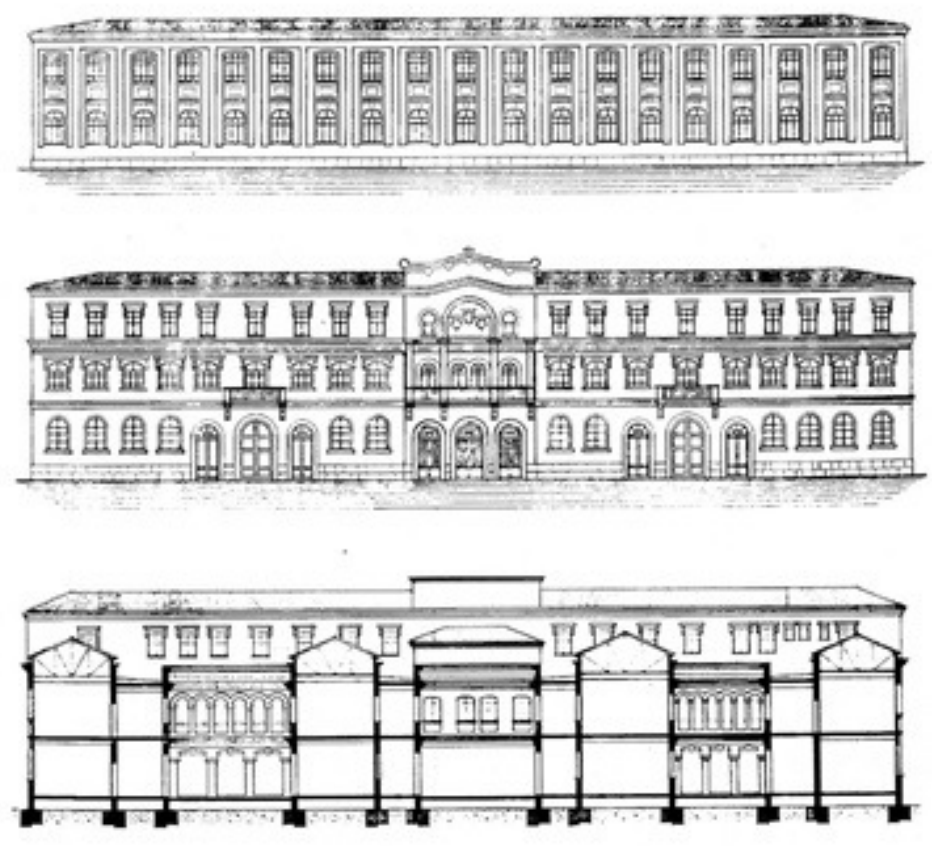

Alzados y sección del Instituto General y Técnico Fuente: Llop Vidal, Enric (1996): Guía d’arquitectura Castelló

\footnotetext{
155 BALBAS, Juan .A. Op. cit, p. 329-331.

156 ALTAVA RUBIO, Vicenta (1994): «La función social del Instituto de Castellón en el siglo XX». En L’Institut F. Ribalta, Castellón, Diputación de Castellón, p. 110-115.

${ }^{157}$ MUNDINA, Bernardo. op. cit, p. 190.
} 


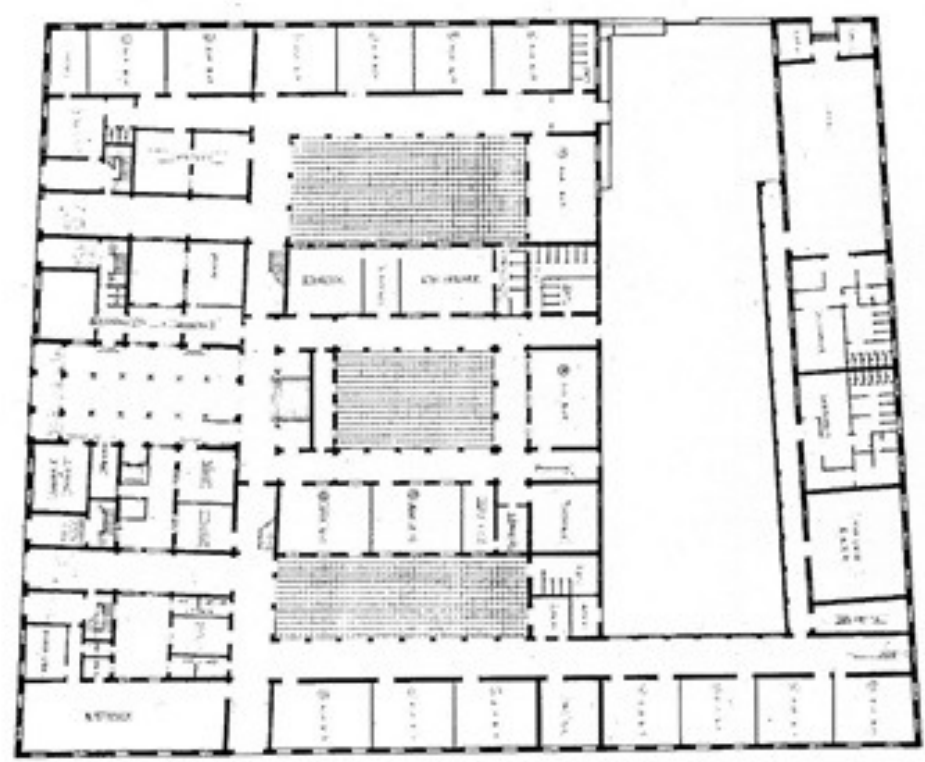

Planta general del Instituto General y Técnico

Fuente: Llop Vidal, Enric (1996): Guía d’arquitectura Castelló

En 1901 el Ministerio de instrucción pública, dirigido por el conde de Romanones publicó un Real Decreto reformando y modernizando la educación en la línea de algunos regeneracionistas, pasando a denominarse Institutos Generales y Técnicos, con diferentes reglamentos y fundamentos (sustituyendo al de 1859) para los nuevos planes de estudio de bachillerato. Y en los nuevos edificios destinados a la segunda enseñanza debían ubicarse también las enseñanzas técnicas de Magisterio, Agricultura, ${ }^{158}$ Comercio, Bellas Artes y Artes Industriales, lo que implicó que el Instituto de Castellón comenzará a compartir su local con la Escuela Normal de Maestras (a partir de 1902) y con la Escuela de Artes y Oficios ( a partir de 1906) ${ }^{159}$

Estas nuevas condiciones, junto con el rápido crecimiento que la ciudad experimenta a finales de siglo, que se traduce en un fuerte aumento de alumnado, pronto el viejo edificio se quedó pequeño.

\footnotetext{
${ }^{158}$ Digna de destacar fue la cátedra de Agricultura que tenía como objetivo principal sacar de la rutina y el retraso a los labradores, instruyéndolos en las nuevas técnicas de la agricultura, en MONLLEÓ PERIS, Rosa (1998): «Del Sexenio democrático a la Guerra Civil»,op. cit, p. 302.

${ }^{159}$ PARRA MONSERRAT, David (2014): La educación silenciosa. Espacios escolares, discurso de poder e imaginarios colectivos, en XIII Coloquio Internacional de Geocritica. El control del espacio y los espacios de control, Barcelona, 5-10 de mayo 2014, p. 8.
} 
El nuevo Instituto General y Técnico, Escuela Normal y de Artes y Oficios, se terminó de construir en 1917 y ocupó el vacío que dejó la primitiva plaza de toros, recayendo su fachada principal a la antigua calle de las Cruces.

Para el historiador Jaime Perís, las nuevas instalaciones sirvieron para consolidar el prestigio de la segunda enseñanza pública en la provincia, desplazando a un segundo plano la enseñanza privada de las congregaciones religiosa, ${ }^{160}$ que como hemos reseñados anteriormente, estaban aumentando y adquiriendo un cierto prestigio en las últimas décadas entre las capas sociales más acomodadas.

Proyectado por el entonces arquitecto municipal, Francisco Tomás Traver, el monumental edificio tiene dos y tres alturas, según zonas, y se distribuye en planta alrededor de tres patios de tipo claustral, que se corresponden en origen con los tres centros de enseñanza. Esta distribución interior marca una clara jerarquización en el rango de las distintas enseñanzas. El Instituto, concebido como el responsable de la enseñanza preparatoria para los estudios universitarios, ocupa la franja central del edificio, la única que disponía de calefacción, salón de actos, otras instalaciones y la que estaba mejor decorada.

Hay otro patio en la fachada posterior, alargado y en posición trasversal, que era el jardín de ensayos agrícolas, que en 1948 se pavimentó, transformándose en patio de recreo y de deportes. A partir de la década de los cincuenta se empiezan a hacer más adaptaciones en el edificio, sin perder la configuración original.

La fachada principal, que presenta claros rasgos historicistas inspirados en el Renacimiento español, también manifiesta sus diferencias formales en los tres accesos independientes. El central, se realiza por tres grandes puertas que dan paso a un amplio vestíbulo con columnas de piedra, del que parte una ampulosa escalera, tipo imperial, realizada en mármol. El salón de actos, situado encima del vestíbulo, es una emblemática y deliciosa pieza cúbica, de estructura de tipo pompeyano, a base de acusadas pilastras corintias con mascarones a modo de mensuras de apoyo y techo arquitrabado, simulando profundos casetones. Está totalmente decorado con alegorías realizadas por el pintor castellonense y profesor de la escuela de Artes y Oficios, Vicente Castell, en 1915, alusivas a la Gramática, Geometría, Geografía, Dibujo, Física y Química, Agricultura, Religión e Historia. En la parte frontal la Ley y la Justicia. El

\footnotetext{
${ }^{160}$ PERIS DOMINGUEZ, Jaime (1994): El edificio del Instituto Francisco Ribalta, In L'Institut F. Ribalta, Diputació de Castelló, p.235.
} 
edificio educativo presenta cierta similitud con la antigua Universidad de Barcelona, incluso el paraninfo de aquel tiene un tratamiento alegórico parecido al nuestro. ${ }^{161}$ Esta relación semántica no es casual, ya que desde su nacimiento, los institutos de segunda enseñanza exhiben una cierta «filiación universitaria» presentándose ante la sociedad como « templos de la ciencia y del saber.»En este sentido y como sucedía en otras capitales de provincia, el Instituto de Castellón, desde los primeros años, era una de las instituciones que despliega mayor actividad y nivel cultural.

Se celebraban las «conferencias agrícolas», que según la ley debían de participar en ella los profesores, darse de forma gratuita y los domingos. En el salón de actos se daban conferencias, recitales, y en 1880 se celebraron los festejos de la inauguraron del Ateneo Obrero Castellonense. En las aulas se impartían clases nocturnas para adultos que compartía el instituto con la escuela pública de niños del Hospital, y en sus instalaciones se realizaron importantes eventos de interés ciudadano, como la exposición sobre agricultora, industria y artes, en 1887, organizada por el casino de Artesanos. $^{162}$

También es digno de destacar la colaboración que profesores del Instituto mantuvieron en el espacio político y cultural de la ciudad, colaborando en coloquios, en la prensa y en revistas especializadas. Su participación en debates sobre la higiene, la salud o la educación, así como la asistencia y organización de congresos científicos. Todos estos aspectos los estudiamos en el capitulo VII «El Instituto fuerza impulsora de la educación y la ciencia en Castellón.

\section{LA SANIDAD Y LOS CENTROS HOSPITALARIOS}

\subsection{LA HIGIENE Y LA ASISTENCIA BENEFICA}

El ideario ilustrado «progreso-felicidad», produjo en el campo de la medicina importantes transformaciones en la sociedad europea, como la necesidad de mejorar la atención médica a las clases más desprotegidas.

\footnotetext{
${ }^{161}$ LLOP VIDAL, Enric (Coord.)(1996): Guia d'arquitectura Castelló. Diputación de Castelló, p.181-182.

${ }^{162}$ MONLLEÓ PERIS, Rosa (1998): op. cit, p. 306.
} 
Las altas tasas de mortalidad por enfermedades y epidemias, afectaban a las clases más bajas, por causas añadidas a la propia enfermedad: como las insalubres condiciones de vida y de trabajo, el hacinamiento y la nutrición, lo que propició la necesidad de realizar estudios sobre la mortalidad producida por estas causas.

Los primeros escritos en nuestro país, acerca del tratamiento de las enfermedades de los trabajadores mediante preceptos de carácter higienista, datan de mediados del siglo XVIII. En concreto, los médicos españoles: Francisco López de Arévalo, José Masdevall y Ambrosio María Ximénez de Lorite se ocupan, en sendos informes redactados a lo largo de la última mitad del siglo XVIII, de la problemática del proletariado industrial. ${ }^{163}$ Pero la publicación en 1790 de la obra del médico vienés J.P.Frank, titulada La miseria del pueblo, madre de enfermedades, y otros estudios, reabrieron la conciencia en la medicina pública.

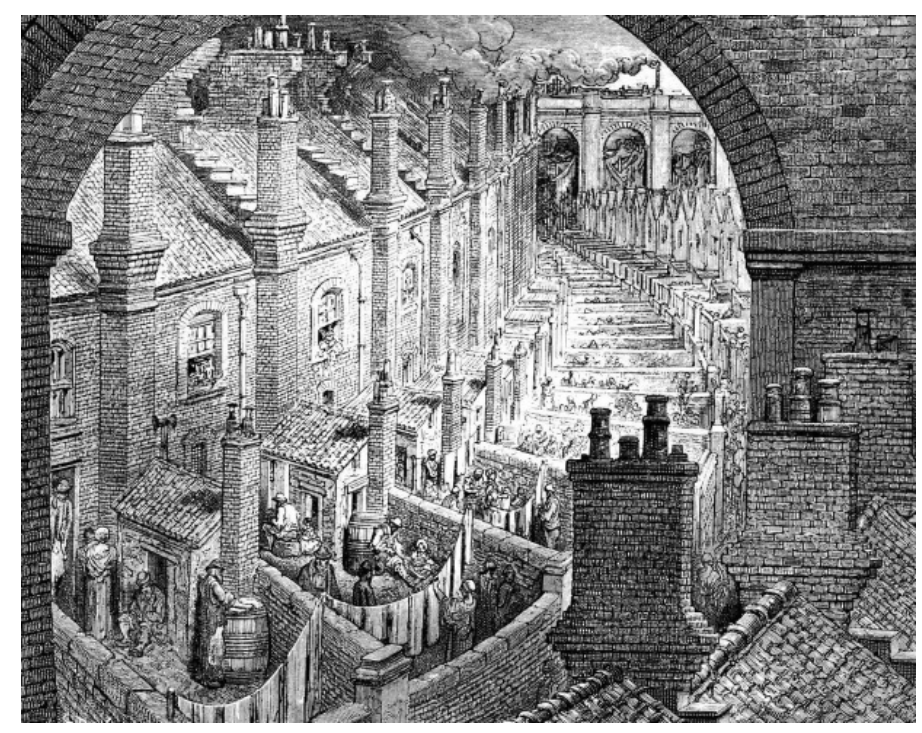

Grabado de Doré «Over London by rail». Fuente: Sica, Paolo (1981): Historia del urbanismo. El siglo XIX, Instituto de Estudios de la Administración Local

No obstante será, durante la compleja transición histórica, entre los años finales de la Ilustración y los primeros albores del movimiento romántico, cuando tendrá lugar, en nuestro país, el desarrollo conceptual definitivo del higienismo como doctrina de base científica. El movimiento higienista español participó directamente, desde el

\footnotetext{
${ }^{163}$ ALCAIDE GONZÁLEZ, Rafael (1999): «La introducción y el desarrollo del higienismo en España durante el siglo XIX. Precursores, continuadores y marco legal de un proyecto científico y social», Scripta Nova. Revista Electrónica de Geografía y Ciencias Sociales. Universidad de Barcelona (ISSN 1138-9788) nº 50, de 15 de octubre. Universidad de Barcelona, pp.3-5.
} 
primer momento, de los avances en dicha materia que se produjeron en Europa. De hecho, tres de las personalidades médicas más importantes en sus inicios, mantuvieron un continuo contacto con los científicos más importantes en la materia, tanto en Inglaterra -cuna del higienismo de carácter social- como en otros países herederos de una tradición más asentada en los preceptos ilustrados. El exilio protagonizado por los liberales, como el medico Mateo Seoane, a partir de la vuelta al trono de Fernando VII en 1824, explica una de las causas que favorecieron estos contactos, sin desmerecer las personalidades médicas que, desde el absolutismo, también contribuyeron a la consolidación de la doctrina higiénica en la primera mitad del siglo XIX, como Francisco Méndez Álvaro o Benito Avilés. Pedro Felipe Monlau i Roca, defensor del liberalismo, al regreso de su exilio en Francia (1839) comenzó una larga tarea de divulgación sanitaria, entre 1846 y 1855, dirigida a todos los ámbitos sociales a través de sus Elementos de higiene. ${ }^{164}$

La herencia ilustrada del XVIII y el afianzamiento de la doctrina liberal, genera en España, tras la muerte de Fernando VII, un conjunto de cambios políticos y sociales que van a permitir, a mediados del siglo XIX, después de varios intentos fallidos, ${ }^{165}$ las reformas necesarias para dotar a toda España de una organización sanitaria. Tanto los citados higienistas, que desplegaron una innegable influencia moralista en el ámbito del gobierno y otras instituciones, como la constante amenaza del cólera morbo asiático en la década de los 40, la extensa epidemia de 1854-1855 y de otras infecciones, fueron los motivos por los que el gobierno decidiera al final combatir de forma colectiva esas enfermedades, que no distinguían de clases sociales cuando se desataban. En este sentido, conscientes de que la asistencia sanitaria es un bien general, cuyo mantenimiento beneficia a todos, se desarrollan desde las instituciones públicas una serie de actuaciones con la finalidad de instaurar una organización en el ramo administrativo de la sanidad, en la que se establece una única autoridad sanitaria centralizada en el Ministerio de Gobernación y dependiendo de ella todo el ramo sanitario a nivel provincial y municipal, creándose servicios y centros de asistencia sanitaria.

\footnotetext{
164 ALCAIDE GONZÁLEZ, Rafael (1999): op.cit., pp.7-13.

${ }^{165}$ En el «trienio», Mateo Seoane intentó una fórmula de ordenación sanitaria proponiendo la creación de una Dirección General de Sanidad a imitación de otros países de Europa. Si bien este intento no prosperó, su propuesta marcó las pautas para dictámenes posteriores.
} 
El Real Decreto Orgánico de Sanidad de 1847 y la Real Orden sobre el Reglamento orgánico y atribuciones del Consejo y las Juntas de Sanidad, fue la antesala de la Ley Orgánica de Sanidad de 1855, que supuso la ruptura con las estructuras características del Antiguo Régimen y la constitución de un sistema sanitario acorde con el prototipo de mentalidad liberal. Planteó la asunción por el Estado de actuaciones encaminadas a combatir el fenómeno epidémico, la asistencia sanitaria y el establecimiento de un régimen de beneficencia para atender a los huérfanos pobres y menesterosos. Paralelamente empiezan a surgir sociedades de socorro. ${ }^{166}$

Este cuerpo normativo de servicios sanitarios, ha de servir para el desenvolvimiento de la sanidad en el resto del siglo, hasta la Instrucción General de Sanidad de 1904, al que debe añadirse el desarrollo normativo de inspección y salubridad urbana.

Bajo el reinado de Isabel II se inicia una organización racional de la sanidad española. Se reordenan las Juntas Provinciales y Municipales; se aprueba la Reglamentación Médica, la Ley General Sanitaria y el Reglamento de inspección de carnes. Se creó el Cuerpo de sanidad militar y la fundación de la Cruz Roja española. Además se dio impulso a las diferentes ramas de la beneficencia.

Ese proceder, junto con los descubrimientos en microbiología, el empleo de las vacunas, los continuados avances técnicos y una amplia divulgación de los contenidos médicos, determinaron una paulatina mejora en las condiciones de vida de la población (nutrición, vivienda, trabajo, etc.) y la adquisición de un conocimiento científico más amplio acerca de los remedios curativos a emplear contra enfermedades tan temidas como el cólera-morbo, la tuberculosis o la sífilis. A lo largo del siglo se suceden otra serie de disposiciones legales en materia de higiene municipal, reglamentos de la enseñanza de la medicina y la cirugía, casas de maternidad, beneficencia, farmacia,

\footnotetext{
166 «La precariedad de la cobertura social ante los riesgos de enfermedad y accidente se revestía, con frecuencia, de evidentes rasgos de caridad y de beneficencia, de la mano de congregaciones religiosas, normalmente de monjas, que mantenían servicios creados por filántropos o, incluso, por las propias instituciones públicas (...) por otro lado, la prosperidad económica de algunas familias impulsó la creación de centros asistenciales de caridad, impulsados por el más puro filantropismo propio de la época; en tercer lugar, el obrerismo y la naciente conciencia de clase propició, entre otros logros, la creación de diversas sociedades de socorros mutuos, con la finalidad de asistir a los obreros enfermos, incapacitados o necesitados sin necesidad de acudir a la caridad de los pudientes. La primera de estas sociedades en el País Valenciano surgió en 1890 Alcoy, denominada La Unión, se nutría de aportaciones semanales de los socios, que pagaban el 1\% y el 2\% de su salario». En la misma ciudad, en 1892 aparece la sociedad El Trabajo; en Villena se funda El Porvenir en 1898 (...)» PONCE HERRERO, Gabino (1999): «La modernización de los servicios», coor. MATEO MARTINEZ, Carlos, Los inicios de la modernización en Alicante, 1882-1914, ed. Caja de Ahorros del Mediterráneo, p.190.
} 
epidemias y vacunas, hospital públicos general, hospitales espaciales (manicomios) y sanidad administrativa. ${ }^{167}$

Los textos legislativos que surgen con el nuevo siglo, plantean una importante modernización de la organización sanitaria y de la higiene pública. La Instrucción General de Sanidad de 1904, fue más que la culminación de experiencias anteriores, planteó una descentralización de la organización sanitaria, que siguió contando con la existencia de juntas provinciales y municipales, que se materializo en la segunda década del siglo XX con la publicación en 1925 de los Reglamentos de Sanidad Municipal y Provincial. El primero de ellos establecía las competencias que debían asumir los ayuntamientos en materia de higiene publica, como aprovisionamiento de agua potable, eliminación y tratamiento de excretas y aguas residuales, higiene de las viviendas, higiene de los alimentos. Además asignaba la responsabilidad del Cuerpo de Inspectores Municipales de Sanidad y de proporcionar asistencia médica gratuita a familias pobres del municipio. Lo que obligó a contratar a médicos y farmacéuticos titulados. En el ámbito provincial establecía la organización sanitaria de la demarcación territorial, con el apoyo técnico de los inspectores provinciales y la Junta Provincial de Sanidad. ${ }^{168}$

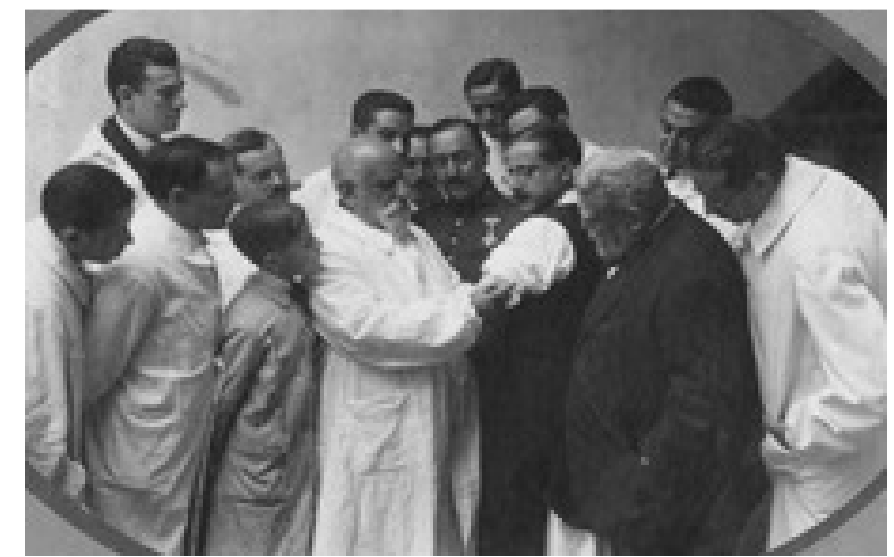

El Doctor Ferran contra el cólera. Fuente:

http://www.biografiasyvidas.com/biografia/f/ferran.htm. [consultado: 5/03/2015]

Los médicos valencianos, que habían jugado un papel clave en el estudio para la mejora de la salud pública, y en el cambio de mentalidad de las formas de vida,

\footnotetext{
167 JAVIER VIÑES, José: La sanidad española en la segunda mitad del siglo XIX, (http://www. navarra.es nr/rdonlyres/b3ad83b1-1186-4c20-a1bff3d58be8986e/146741/03lasanidad, pp.71-76 [visitado 3/06/2015].

168 BARONA VILAR, Carmen (2006): Las políticas de la salud. La sanidad valenciana 1855 y 1936 , Universidad de Valencia, p.20.
} 
incrementan su actividad y protagonismo a partir de la segunda mitad del XIX. La creación en 1840 del Instituto Médico Valenciano, sus campañas higienistas recogida en los Boletines (1852-77) y Crónicas Médicas (1877-96), junto con aportaciones como La Topografía Médica de Juan Bautista Peset (1878) o la de Alicante, del médico Evaristo Manero Mollá (1883), culminación de las topografías medicas valencianas, iniciadas por una Comisión Especial del Instituto y los Congresos, ${ }^{169}$ hacen de la profesión médica la más dinámica y avanzada.

Al igual que en otras poblaciones del territorio valenciano, la provincia de Castellón, durante el último cuarto de siglo, el fuerte crecimiento demográfico y las mejoras sociales, no solo en la capital, sino en otras poblaciones de la provincia, especialmente en las comarcas de la Plana, fue el momento de la gran eclosión de la profesión médica. Las demandas sociales aceleraron la creación y mejoras de los servicios sanitarios y la asistencia médica rural reglada. La asistencia a los municipios tiene una larga tradición de médicos titulares o de beneficencia, iniciada ya en el siglo XVIII, al servicio de las ciudades y pueblos para atender a menesterosos, que fue sufriendo sucesivas reglamentaciones a lo largo del siglo ( $1868,1873,1891)$. La asistencia benéfica municipal comenzó a organizarse de forma más racional a base de cuerpos de beneficencia municipales, abriéndose establecimientos para asistencia urgente, como las Casas de Socorro (1880), se estableció unas normas para la asistencia benéfica médica y farmacéutica (1884) y el reglamento de hospitalización domiciliaria (1885).

Creadas las diputaciones provinciales, los hospitales municipales pasan al gobierno y administración de la nueva institución. La normativa, dentro del contexto de la asistencia benéfica, data de mediados del siglo XIX (1848-1852) y preveía hospitales provinciales en cada una de las capitales de provincia, asignando la responsabilidad de la asistencia domiciliaria a los municipios.

\footnotetext{
169 BARONA VILAR, Carmen (2006): Las políticas de la salud. La sanidad valenciana 1855 y 1936 , Universidad de Valencia, pp.95-96.
} 


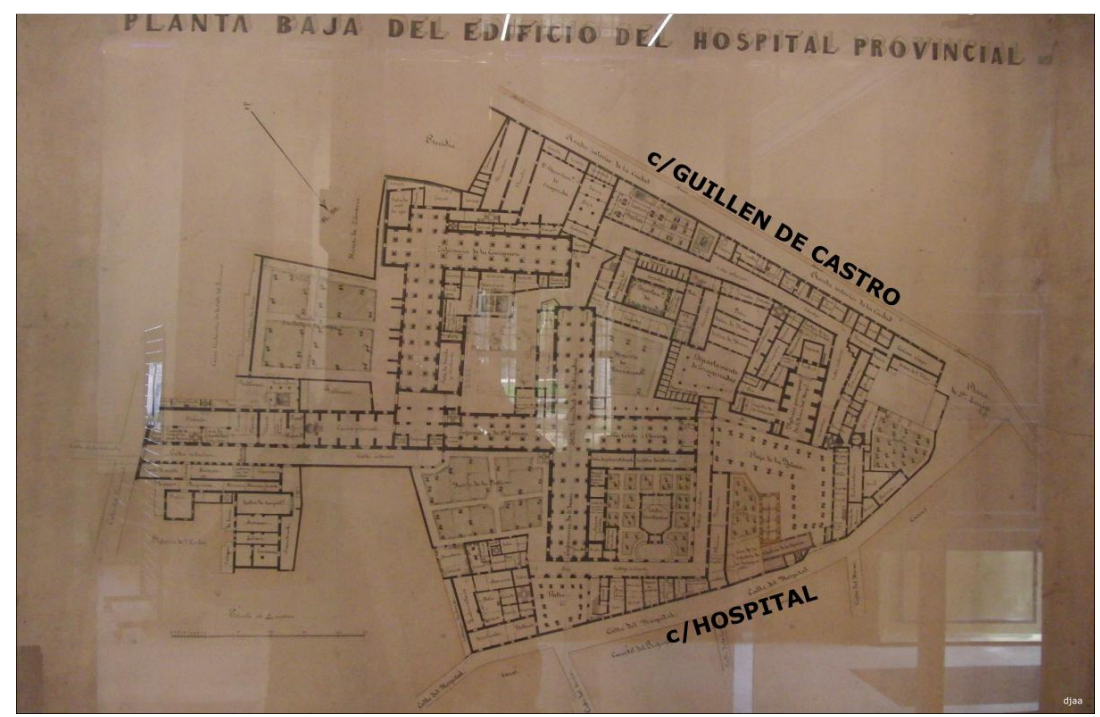

Hospital General de Valencia. Fuente:

http://www.jdiezarnal.com/valenciahospitalgeneralplano01.jpg

El antiguo Hospital General de Valencia, de singular tipología hospitalaria cruciforme, ${ }^{170}$ pasa a depender de la Diputación Provincial en la primera mitad del siglo XIX. Será entonces, a partir de 1849, cuando se inician importantes obras, adaptando sus instalaciones a los cambios que iban sucediéndose en la propia actividad médica. También se producen amplias construcciones anexas en el interior de la propia manzana. Entre 1875-86, los arquitectos Sebastián Monleón y Antonio Martorell colmatan el solar del hospital con la construcción de la Facultad de Medicina, haciéndola recaer a la calle Guillen de Castro. ${ }^{171}$

En Alicante, el Hospital Provincial se alojó en un primer momento en el antiguo Hospital de San Juan de Dios. Derribado éste, en fecha tan temprana como 1852, se construye uno nuevo en el barrio de San Antón, con dos salas de cirugía de hombres, dos para cirugía de mujeres y una para «enfermos distinguidos», con 130 camas en total

\footnotetext{
${ }^{170}$ Fundado en 1484 el Hospital General de Valencia, comenzó su construcción en 1494 y duró hasta bien entrado el siglo XVI. El edificio estuvo compuesto por dos enfermerías con planta de cruz, dos pisos y cimborrio octogonal en el centro, siguiendo un modelo que había surgido en el norte de Italia y que permitía separar a los enfermos según su sexo y sus dolencias, al tiempo que se permitía controlar todas las salas desde el espacio central. Es el primero en España que siguió este moderno y práctico esquema cruciforme. De similares características es el Hospital de la Santa Cruz, 1504-1514, de Toledo, en BERCHEZ, Joaquín (1994): Arquitectura renacentista valenciana (1500-1570), Bancaixa, Obra Social, p.92. Su influjo llegó claramente a las instituciones hospitalarias creadas por la colonización española en el Nuevo Mundo, por ejemplo a los hospitales de Guadalajara en Méjico y en Santiago de Chile.

${ }^{171}$ TABERNER PASTOR, Francisco (coor.): Guía de arquitectura de Valencia (2 $2^{\mathrm{a}}$ edición), Icaro CTAV., Antiguo Hospital (ficha 256).
} 
y 13 facultativos, pero pronto quedo obsoleto. ${ }^{172}$ Hasta 1924 no se empieza a construir otro nuevo, proyectado por el arquitecto Juan Vidal. Se trata del ejemplo más paradigmático de la ya consolidada tipología hospitalaria en peine, formado por doble fila de ocho pabellones unidos por un cuerpo central. Hoy día, rehabilitado, es el Museo Arqueológico Provincial de Alicante (MARQ). ${ }^{173}$

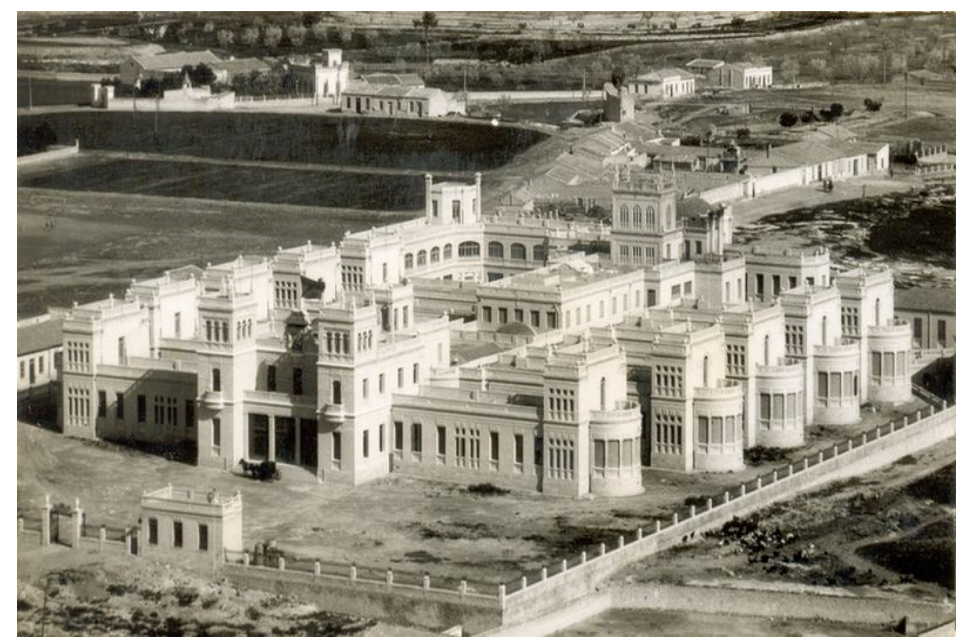

El Hospital Provincial de Alicante a principios de los años treinta. Fuente: http://drsoler.com/blog/el-marq-y-el-hospital-provincial-de-alicante-una-nostalgia/

\subsection{EL HOSPITAL PROVINCIAL DE CASTELLON}

En Castellón, el Hospital Provincial funcionó en el antiguo hospital de Trullols, que reunía malas condiciones higiénicas. La construcción de uno nuevo fue más tardía, comenzando las obras en 1885.

Podemos afirmar que se trata del edificio público más importante que se llevó a cabo en la ciudad de Castellón en el siglo XIX. Su valor social, arquitectónico e histórico marcó un hito en el desarrollo y evolución de la ciudad.

\footnotetext{
172 PONCE HERRERO, Gabino (1999): op. cit, p.191.

173 JAEN i URBAN, Gaspar, (dir.): Guía de Arquitectura de la Provincia de Alicante, CTAA.
} 


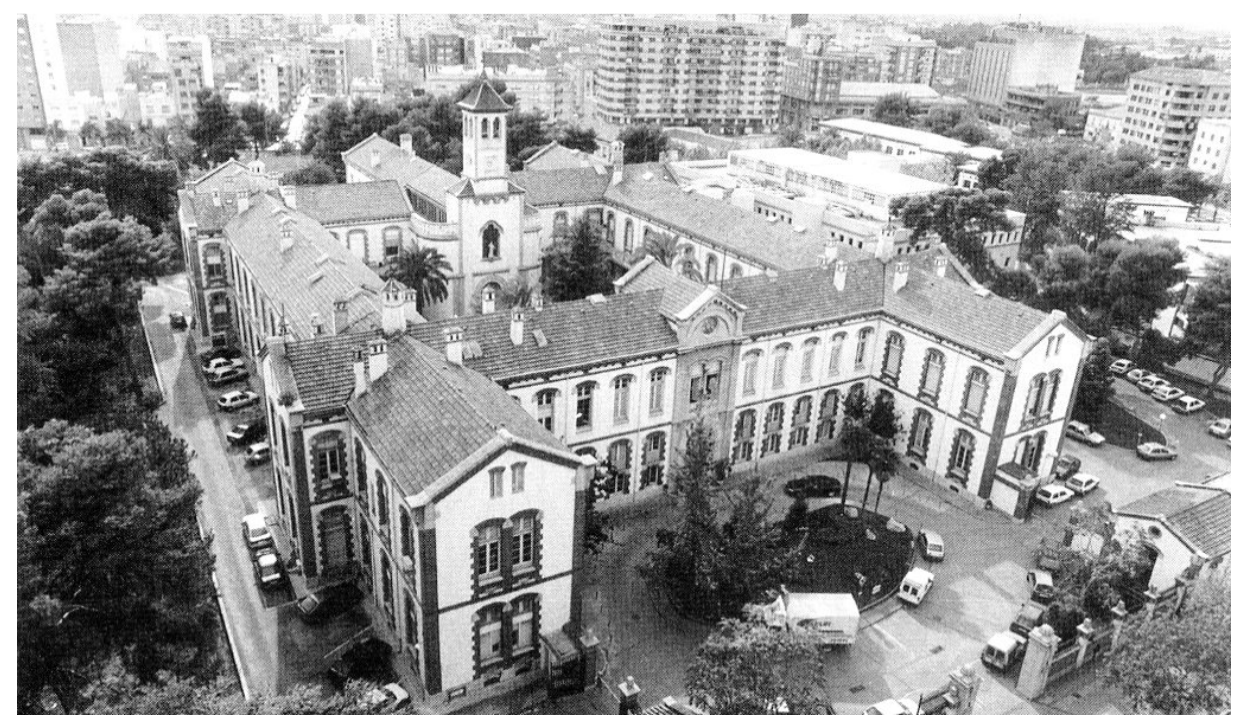

Vista desde el acceso principal del Hospital Provincial de Castellón: Fuente: Mir Soria, Patricia y Fuster Garcia, Pascual (2010): Manuel Montesinos Arlandiz. Arquitecto provincial y exponente del eclecticismo en Castellón

La década de los años ochenta del siglo XIX fue un periodo de intensa vida social y crecimiento económico para la ciudad de Castellón, tanto agrícola como industrial, que permitió realizar proyectos ambiciosos y necesarios para la capital, será el momento en el que surge el nuevo Hospital Provincial.

La normativa vigente, dentro del contexto de la asistencia benéfica, data de mediados del siglo XIX (1848-1852) y preveía algunos centros asistenciales nacionales, que acabaron siendo muy pocos, hospitales provinciales en cada una de las capitales de provincia, y asignaba la responsabilidad de la asistencia domiciliaria a los municipios.

Las primeras noticias de un hospital civil ${ }^{174}$ en Castellón, dotado con 10 camas, es de 1391. Fue fundado por Guillén de Trullols, quien dio para ello una casa de la calle Mayor y varia tierras y censos. La iniciativa de Trullols pone de manifiesto el interés que Castellón demostraba por la salud de aquellos menos favorecidos. De hecho ya existía otro, el de la Villa, fundado en época de Jaume I, que ocupaba el lugar donde luego estuvo el convento de las monjas Clarisas. Un siglo después, en 1498, se acordó «pedir el favor real» para que los dos hospitales existentes se fundieran en uno y que este se estableciera en la casa hospital de Trullols, por ser más espaciosa y sólida ${ }^{175}$.

\footnotetext{
${ }^{174}$ Se trata de fundaciones caritativas promovidas por asociaciones de laicos (ni eclesiásticos ni monjes) para el cuidado de los enfermos, apoyadas por la burguesía cuyo poder se fue incrementando conforme avanzaba la Edad Media. Algunas de ellas han llegado hasta nuestros días.

175 MIR SORIA, Patricia y FUSTER GARCIA, Pascual (2010): Manuel Montesinos Arlandiz. Arquitecto provincial y exponente del eclecticismo en Castellón, Ayuntamiento de Castellón, p.221.
} 
Su construcción corresponde a varias épocas, siendo el conjunto resultado de la anexión de varias casas contiguas. Al amplio jardín de entrada (hoy Plaza de las Aulas) daban habitaciones de los convalecientes. Durante la gobernación de Bermúdez de Castro se realizaron importantes reformas y ampliaciones, finalizando las mismas en 1804. ${ }^{176}$

Será en 1860 cuando el hospital deja de ser municipal para pasar a depender de la institución provincial, creada en 1822. A partir de entonces se realizan importantes adaptaciones, llegando a anexionarse a sus servicios el edificio de las antiguas Aulas de latinidad. Es a partir de este momento cuando se intensifica la actividad científica y asistencial, ejerciendo entre 1875 a 1899, como Médico Mayor, el Doctor Felix Roig. ${ }^{177}$

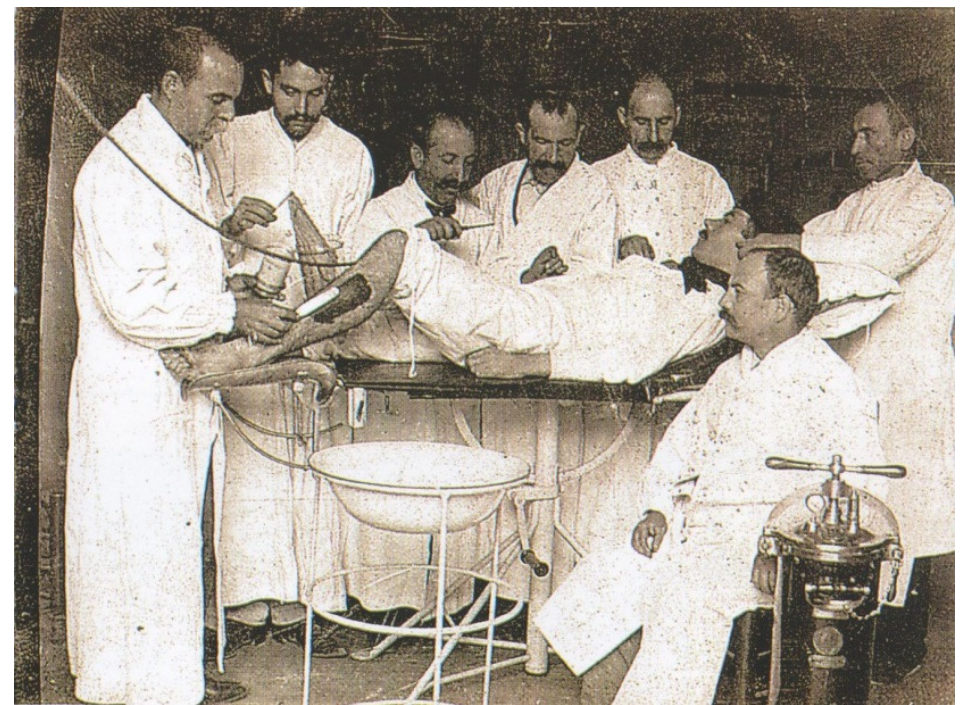

Sesión quirúrgica en el Hospital de Trullols. Fuente: Colección, Miquel Gómez

Ante la falta de capacidad y condiciones para dar respuesta a las nuevas exigencias asistenciales, se plantea en 1864 la construcción de un nuevo hospital, pero hasta 1878 no se redacta el proyecto técnico por el arquitecto provincial Manuel Montesinos Arlandis. Iniciadas las obras en 1882, la falta de consignación presupuestaria en determinados periodos hizo retrasar las obras doce años, finalizándose en 1894. También la falta de presupuesto para equiparlo con las infraestructuras indispensables, demoran la inauguración oficial hasta 1907. De todo este proceso

\footnotetext{
${ }^{176}$ GIMENO MICHAVILA, Vicente (1984): op.cit.,p .25.

177 MÁS TORRECILLAS, Vicente Javier (1997): El Hospital provincial proyecto inconcluso Aproximación histórica, Diputación de Castelló, p.52.
} 
destaca la infatigable labor del doctor José Clará para que el hospital fuera una realidad, y la del director del nuevo centro Antonio Carmona. ${ }^{178}$

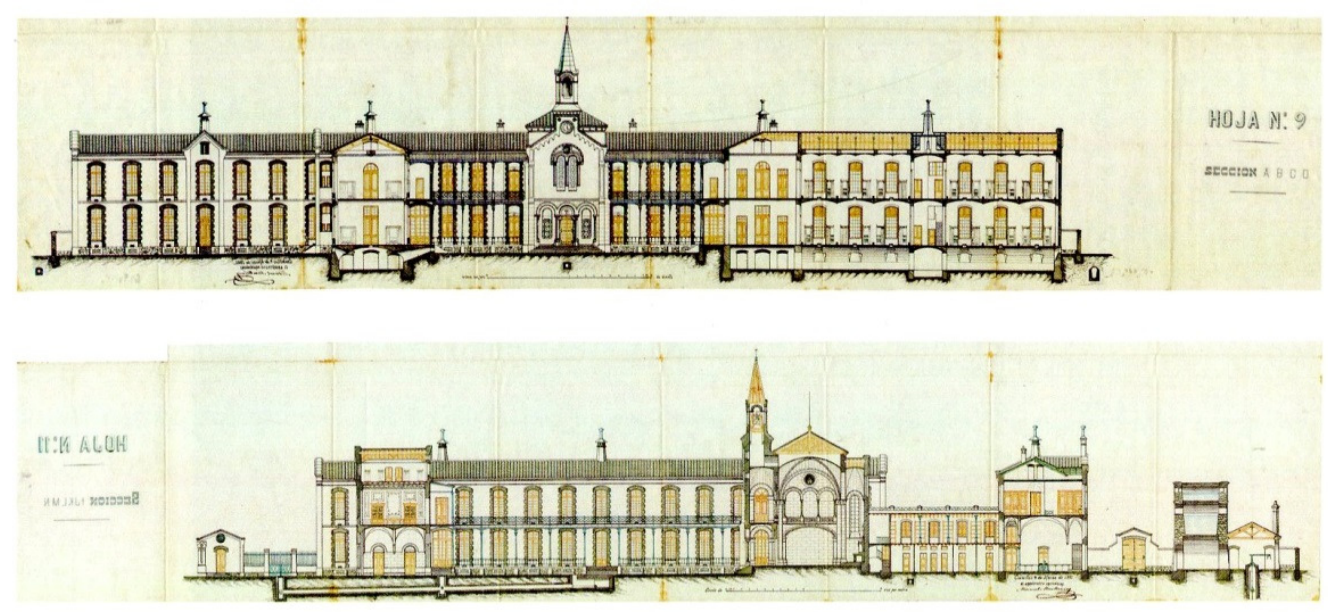

Sección longitudinal y sección trasversal del proyecto original del Hospital Provincial de Castellón, firmado por Manuel Montesinos Arlandiz. Fuente: Archivo Provincial de la Diputación de Castellón

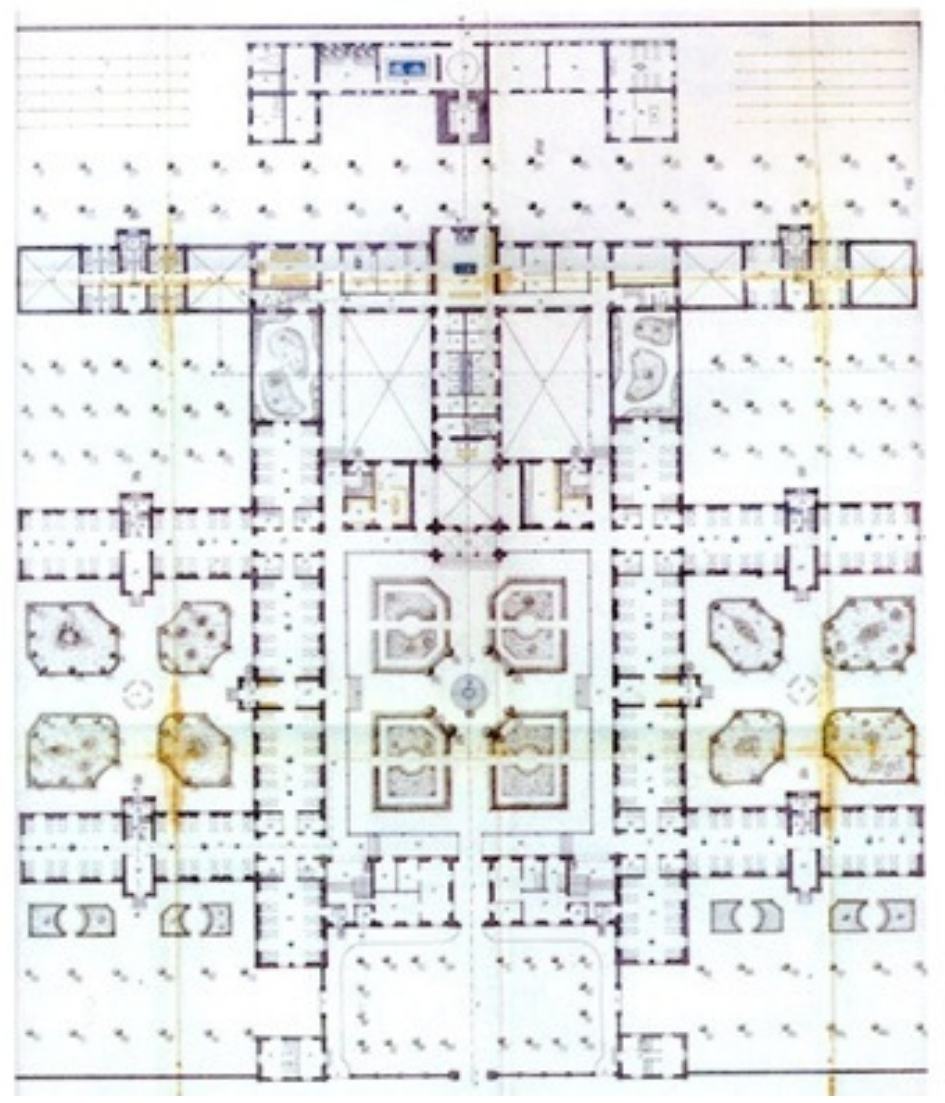

Plano de planta del proyecto original del Hospital Provincial de Castellón, firmado por Manuel Montesinos Arlandiz. Fuente: Archivo Provincial de la Diputación de Castellón

${ }^{178}$ MÁS TORRECILLAS, Vicente Javier (1997): op. cit, p.52-53. 
El hospital, ejemplo del más puro racionalismo decimonónico, fue concebido como un edificio adaptado a las normas higiénicas y constructivas imperantes tanto en España como en Europa. Consta de dos plantas y sótano, capilla y anexos para servicios complementarios. Los planos originales del proyecto plantean una tipologia en peine, a base de pabellones ${ }^{179}$ separados con accesos independientes, conformando una disposición en U de patios abiertos para alojar la hospitalización de los enfermos, evitando con este aislamiento la posibilidad de contagio. Las alas estaban intercomunicadas entre ellas por uno de sus extremos, a través de un cuerpo central dispuesto alrededor de un gran patio ajardinado, de tipo claustral, que alojaba la administración y los servicios.
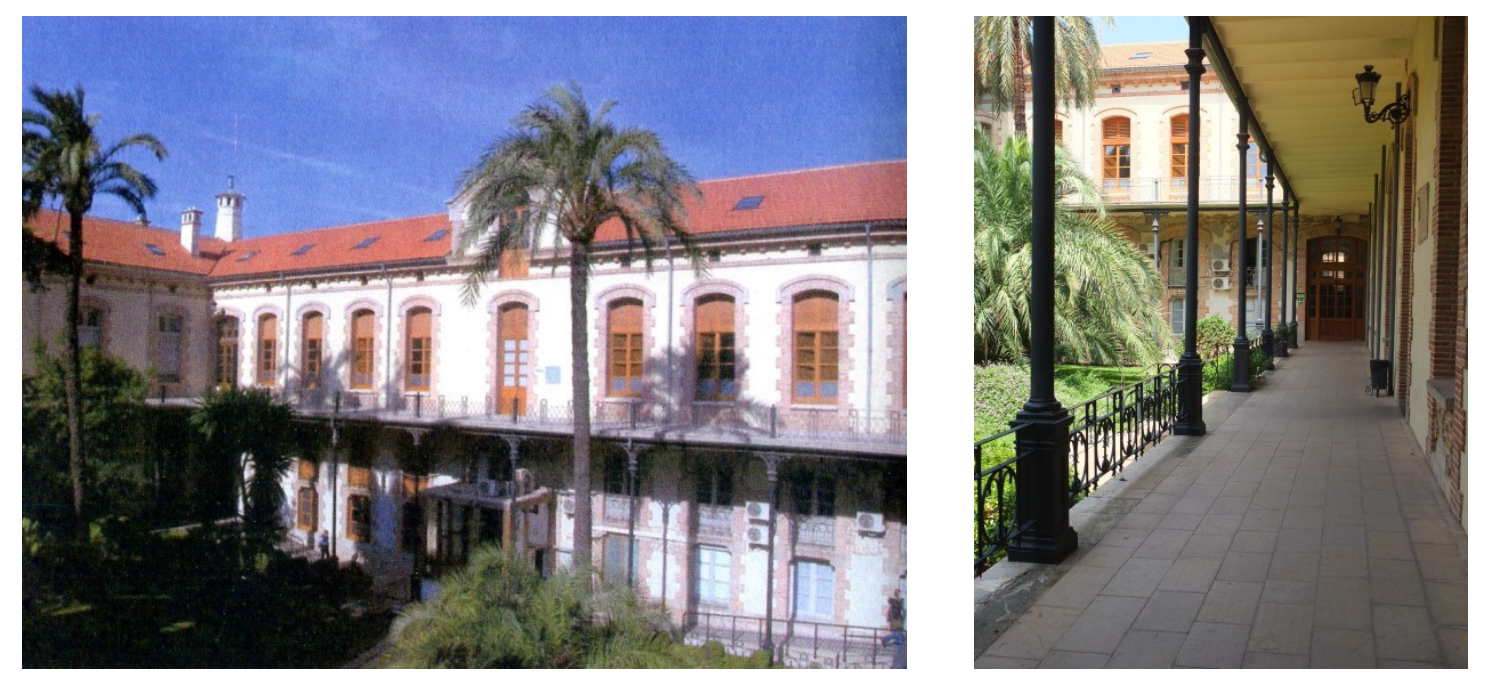

Patio central y pasillo perimetral del Hospital Provincial de Castellón. Fondo fotográf.: Concepción Calvo

También estaba previsto que existiera un pabellón de baños, un pabellón de locos, uno de leprosos, uno de maternidad, una sala de enfermos generales, otra de cirugía, una botiga y laboratorio, incluso un departamento de pensionistas. Pero las

\footnotetext{
179 (...)Kuhn, en la parte referente a hospitales del Handbuch der Architektur, de aproximadamente 1897, todavía llama al proyecto de pabellones «la forma mas perfecta de arquitectura para hospitales» y Guadet, en su famoso Eléments et théories de l'architecture (1902), defiende también los pabellones (...). En Italia el nuevo Pammatone de 1907-1922, tiene pabellones. La plena aceptación del plano con pabellones vino con el Hópital Lariboisiére de París, proyectado en 1839 y construido en 1846-1854, con 905 camas En Alemania, el Friedrichshain, en Berlín (1868) fue el primer hospital con pabellones (...), en PEVSNER, Nikolaus (1980): Historia de las tipologias arquitectónicas, G.G, pp.182-186. Pero los antecedentes de esta tipologia hospitalaria en peine hay que buscarlo en los arquitectos revolucionaros franceses del dieciocho, más concretamente en J.-N.-L. Durand, en su Précis des leçons, vol.II, 1809, en KAUfMANN, Emil (1978): Tres arquitectos Revolucionarios: Boullée, Ledoux y Lequeu, ed. Gustavo Gili,S.A, Barcelona.
} 
restricciones económicas obligaron a poner en funcionamiento un proyecto inconcluso, con una importante reducción de la superficie proyectada, eliminando parte de los pabellones independientes, ${ }^{180}$ lo que redundó en una merma en el control y aislamiento de los enfermos, perdiendo el edificio la calidad sanitaria. De esta forma, la hospitalización se redujo a los cuatro cuerpos que conforman el patio central.

En veinticinco años, desde que se inician las obras hasta que se finalizan, el edificio ya se había quedado pequeño. La población de Castellón había aumentado más de un 30 por ciento, lo que obligó a realizar ampliaciones a finales de la segunda décadas del siglo XX, principalmente para alojar enfermos de lepra y tuberculosis. ${ }^{181}$ Aunque se edificaron los nuevos edificios a base de pabellones independientes, no se ajustaron al proyecto original, lo que supuso una ruptura con la concepción higiénica global del proyecto y un impacto negativo en la estética del conjunto.

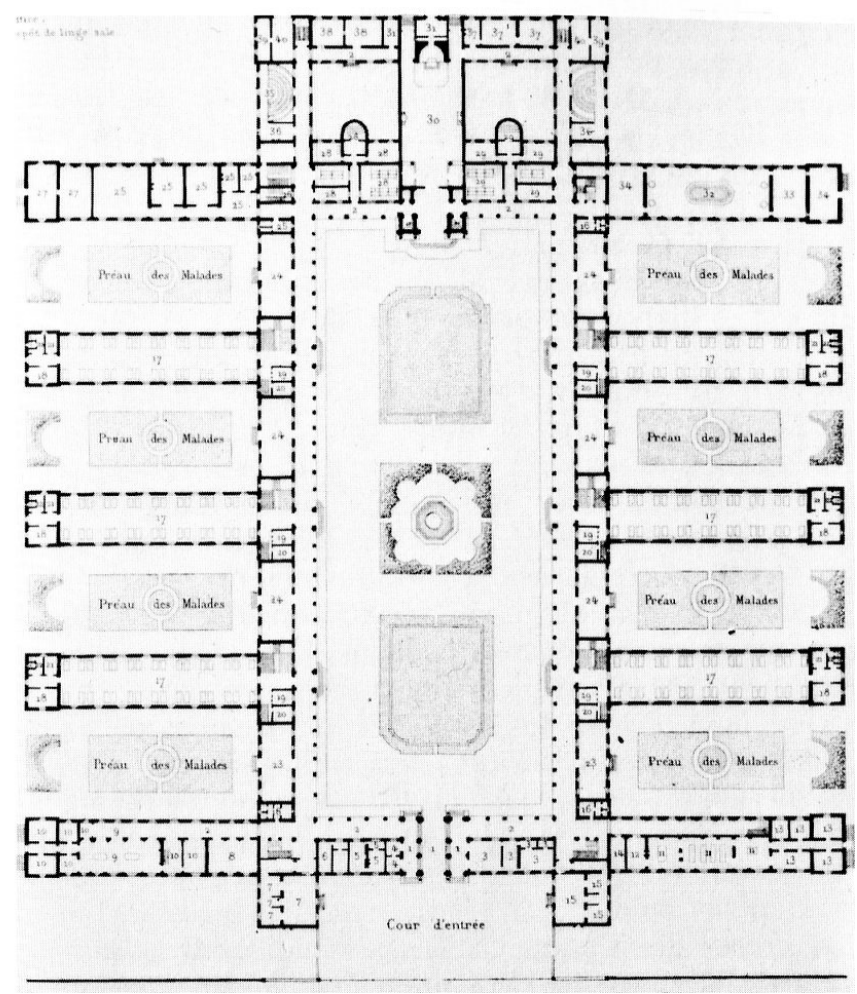

Planta hospital del Lariboisière, Paris. Fuente: Pevsner, Nikolaus, Historia de las tipologias arquitectónicas

\footnotetext{
${ }^{180}$ MÁS TORRECILLAS, Vicente Javier (1997): op. cit, p.67-71.

${ }^{181}$ Las Provincia, 13/07/1918.
} 
Según reza en la memoria técnica de proyecto, Montesinos se inspira en modelos españoles y europeos, como el Hospital francés de Brest, del arquitecto galo Ms. Petres, el Hospital Lariboisière, 1839-1854, de Gauthier o el Kin’s College Hospital de Inglaterra. Pero el referente más directo lo encontramos en el Hospital civil «Oliver» ${ }^{182}$ de Alcoy. Primer ejemplo en tierras valencianas, del tipo de pabellones aislados. Fue edificado entre 1868-1877 según proyecto del arquitecto catalán Geroni Granell Mundet, es de estilo académico, de marcada simetría y acusada sobriedad. ${ }^{183} \mathrm{Su}$ inauguración tuvo transcendencia estatal, ya que en el se recoge la tipología de la época.

El hospital (hoy centro geriátrico) está compuesto por tres volúmenes de varios pisos, a base de dos pabellones laterales en forma de $\mathrm{T}$, donde se alojaban los enfermos separados por sexos y los servicios hospitalarios en planta baja, y un tercer cuerpo central, cuadrado, que contiene el acceso al centro y una espaciosa capilla con elevada cúpula. Dos galerías laterales unen los tres cuerpos. En la parte posterior hay varias construcciones para servicios complementarios, conformando el conjunto un amplio patio. $^{184}$ Igual como sucede en el Hospital Provincial de Castellón, el espacio presenta una disposición de planta abierta que permite se formen pequeños patios abiertos que relacionan el interior con la naturaleza, manteniendo el aislamiento clínico adecuado.

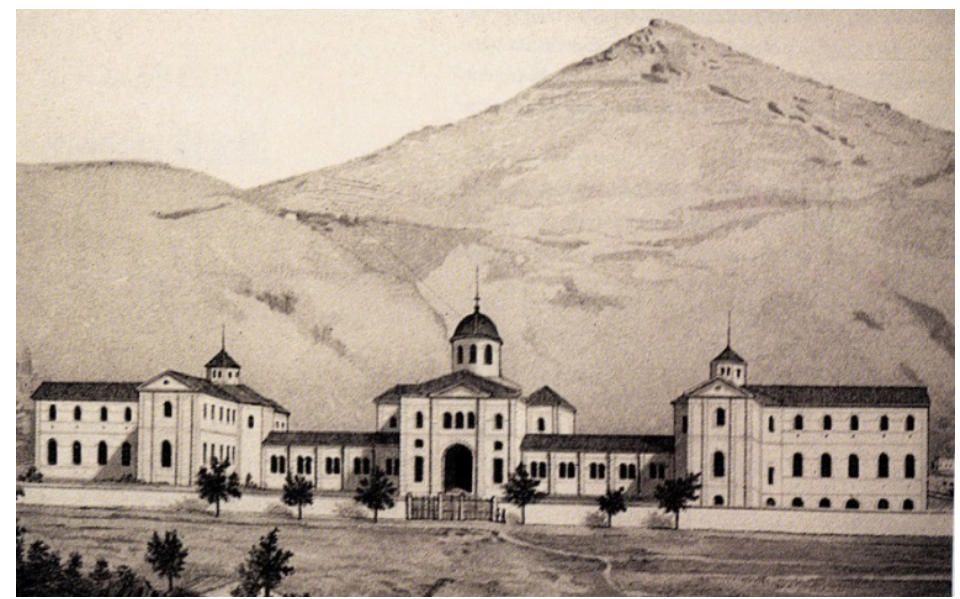

Hospital civil de Oliver. Fuente:

http://vilaplanasousaonil.blogspot.com/

\footnotetext{
${ }^{182}$ Este interesante hospital de grandes dimensiones que ocupaba toda una manzana del barrio de Santa Rosa, fue creado en el último tercio del siglo XIX por el filántropo alcoyano del siglo XIX A. Oliver. Su inauguración tuvo transcendencia estatal. En el que ese recoge la tipología hospitalaria de la época, en JAEN I URBAN, Gaspar, (dir.): Guía de Arquitectura de la Provincia de Alicante, Icaro, CTAA, ficha 26.

${ }^{183}$ SIMÓ, Trinidad. (1987): «Arquitectura y Urbanismo. 1874-1920», en AGUILERA CERNÍ, Vicente (coor.), Historia del Arte valenciano,T.5, Valencia, Consorcí D’Editors Valencians,S.A., p.64.

184 JAEN i URBAN, Gaspar, (dir.): op.cit.,f. 26.
} 


\section{LA FUNCION SOCIAL E HIGIENICA DEL PARQUE DECIMONÓNICO}

Con el reformismo ilustrado del siglo XVIII y a partir del reinado de Carlos III, las ciudades empiezan a sanearse y embellecerse, tanto en lo tocante a la legislación como a la realización práctica. Es el momento en el que empiezan a surgir los paseos y salones arbolados, como lugar de encuentro, «donde dejarse ver» y realizar actos sociales. El ejemplo del Salón del Prado (1767) y otros como el Paseo de las Delicias o el Paseo de la Virgen del Puerto en Madrid, se repite en otras poblaciones, como la Alameda de Málaga (1785), con tres filas de olmos, y en Granada los paseos a orillas del Genil, también se crean paseos en Cádiz, Sevilla, Valladolid, Bilbao. En Valencia se mejora el paseo de la Alameda, cuyo trazado databa de mediados del XVII, ${ }^{185}$ y en Barcelona el Paseo de Gracia o el primitivo Paseo de la Rambla.

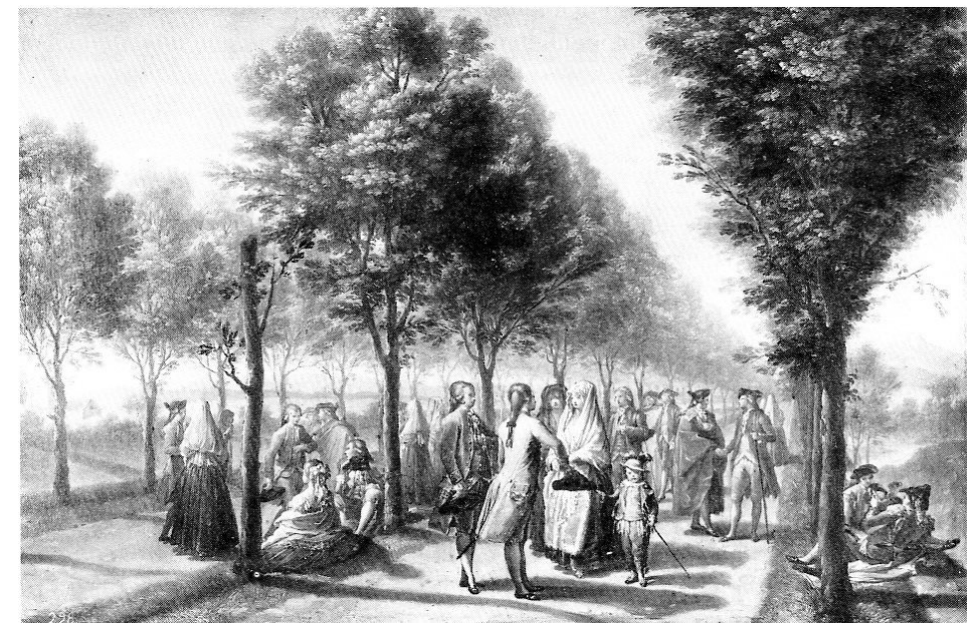

Francisco Bayeu: El Paseo de las Delicias, 1785 (Museo del Prado) Fuente: Hansmann, Wilfried (1989) Jardines del Renacimiento y el Barroco

Todos estos jardines responden a un modelo formado por filas de calles plantadas de árboles, la central, más ancha y ajardinada es para peatones, las laterales para carruajes, ${ }^{186}$ los extremos del salón o paseo se solían jalonar con rotondas que alojaban arquitecturas conmemorativas o fuentes monumentales, como en el Paseo del Prado o la Alameda de Valencia. También es cuando se inicia la ordenación del

\footnotetext{
185 RABANAL YUS, Aurora (1989): «Los jardines del Renacimiento y el Barroco en España», en HANSMANN Wilfried (coor.), Jardines del Renacimiento y del Barroco, editorial Nerea.p.388.

${ }^{186}$ QUIROS LINARES, Francisco (1991): Las ciudades españolas a mediados del siglo XIX, ed. Ámbito Editores, p.86.
} 
territorio, la transformación y el cambio de la jardinería y el proteccionismo agrícola desde miras fisiocráticas ${ }^{187}$ y que tuvo poca fortuna.

A principios del siglo XIX, en Europa, el jardín experimenta sensibles signos de cambio, pasando de los «jardines áulicos» que empezaron a abrirse al público a mediados del XVIII, al arte de los «jardines nuevos», ${ }^{188}$ vinculados al fenómeno de la expansión urbana, impulsada por la Revolución Industrial. Parques y jardines mas que para el disfrute de unos cuantos como parte integrante de las grandes residencias señoriales, se crean sobre todo para satisfacer las exigencias higiénicas, recreativas y educativas de los habitantes de las ciudades. Y de esta manera, los términos de este arte ya no son solamente de índole estética y técnica, sino que han de afrontar también todo un conjunto de necesidades sociales. ${ }^{189}$

El diseño responde desde mediados de siglo a una revalorización progresiva de las formas geométricas, hasta que llega a afianzarse un tipo de jardín compuesto, que alberga tanto formas libres paisajistas del jardín inglés del XVIII, como elementos del jardín clásico francés del XVII. El esteticismo romántico y la predilección por las colecciones botánicas y especies exóticas, como consecuencia de los avances científicos y las grandes expediciones botánicas al Nuevo Mundo, que se realizaron durante el siglo XVIII, son factores que también influyen de manera decisiva en la configuración del jardín decimonónico.

Con el reinado de Isabel II es cuando se consolida el nuevo diseño de jardinería, en donde también se empieza a incorporar el modelo paisajista, en convivencia con el jardín clasicista, creándose la primera Escuela Normal de Jardineros y Horticultores, que influyó de manera decisiva en los nuevos proyectos. Con el tiempo estas escuelas pasarían a forman parte de las disciplinas de los Institutos de Enseñanza Media.

La creación de jardines y paseos arbolados, más tarde parques urbanos, muestra la necesidad que la sociedad decimonónica tiene de nuevos espacios públicos en los que el entorno debe ser natural. ${ }^{190}$ Esta concepción de la naturaleza urbanizada o de la

\footnotetext{
187 SOTO CABA, Victoria (1993): «Jardines de la Ilustración y el Romanticismo en España», en BUTTLAR von Adrian (coor.), Jardines del Clasicismo y el Romanticismo. El jardín paisajista, ed. Nerea. p.285.

${ }^{188}$ Frente a los jardines palaciegos de uso privado, para el deleite de unos pocos, surgen los nuevos jardines multitudinarios, de uso polivalente, para el recreo de la burguesía y el proletariado.

${ }^{189}$ FARIELLO, Francesco (2004): La arquitectura de los jardines. De la antigüedad al siglo XX, Editorial Reverté, p.261.

190 «El aumento demográfico, los crecientes conocimientos sobre higiene, las ideas de revalorización de la naturaleza de la época romántica y la necesidad social de puntos y lugares de contacto para los
} 
ciudad naturalizada adquiere una gran fuerza, y será reivindicada desde muchas posiciones. Hoy día, aún, los partidarios de jardines y plazas blandas superan con creces la construcción de plazas duras. ${ }^{191}$

En Castellón, a finales del XVIII, durante la gobernación del ilustrado Bermúdez de Castro (1791-1807), es cuando surgen los primeros espacios ajardinados en calles y plazas, coincidiendo con las obras de saneamiento y de reformas urbanas motivadas por el derribo de las murallas medievales. Posteriormente, durante el periodo de regencia de María Cristina y el reinado de Isabel II, se enriquece con nuevos paseos y jardines, situados principalmente en los accesos a la población, imprimiendo a la nueva capital de provincia (1833) prestigio e imagen de modernidad, al igual que sucedía en otras poblaciones del territorio español.

En 1840 se proyecta junto al acceso sur de la población, en el camino Real de Valencia, el paseo público llamado la alameda de San Francisco, ${ }^{192}$ frente al Cuartel de Infantería de dicho nombre, y en 1847, por iniciativa del Jeje político, Ramón de Campoamor, el hermoso y nuevo camino o paseo del Mar con el jardín del Ovalo o de la «media naranja». También se tiene noticia de otro paseo público llamado de Campoamor, en las afueras de la población, entre la carretera de Madrid y el camino de Almanzora, que no llegó a construirse. ${ }^{193}$ Son jardines con un paseo central longitudinal jalonado de plazoletas o rotondas de diferentes tamaños, con un trazado regular y geométrico de caminos secundarios y parterres, que nos recuerda por su diseño el paseo de la Glorieta (1815) o el del Parterre (1850) de Valencia, y que luego, dos décadas mas tarde, veremos de similar diseño los nuevos paseos de Ribalta y del Obelisco junto a la nueva carretera de Zaragoza y estación de ferrocarril. La vegetación estaba formada por árboles de gran porte, a base de álamos o plátanos, y arbustos de hoja perenne que

ciudadanos son factores que impulsan la creación de estos paseos ajardinados». Los jardines como función de intercomunicación ciudadana, creados por la clase ascendente, protagonizan su presencia a mediados del siglo XIX, en SIMÓ Trinidad (1973): op. cit., p.51 y 53.

${ }^{191}$ Hoy día, los gasto de mantenimiento que conlleva para los ayuntamientos las zonas verdes, está erradicado la naturaleza de la ciudad, creando los nuevos espacios para el esparcimiento sin árboles y sin tierra, que son sustituidos por materiales pétreos o cerámicos.

192 «Solo en la parte Sur, y junto a la puerta que sale para Valencia, hay un paseo pequeño que quedó abandonado por causa de la guerra y que ahora trata de reponerse y mejorarse por el Ayuntamiento, para cuyo efecto hay ya nombrado una comisión en su seno que debe entender en el asunto [...]», en MADOZ, Pascual (1982): op.cit.p.228.

193 GIMENO MICHAVILA, Vicente: op.cit. p.29. 
conformaban recortados y geométricos parterres. En las plazoletas o rotondas, donde solían haber bancos corridos, se desarrollaba la «vida social». 194

El uso público de los parques comienza a mediados del siglo XVIII, abriéndose progresivamente a los ciudadanos los fastuosos jardines áulicos del XVII. Las ideas liberales propugnadas por la ilustración y la ruptura con el Antiguo Régimen que supuso la Revolución Francesa, implica la reivindicación para el pueblo de los parques y jardines de los privilegiados, así como la sensibilización hacia la naturaleza, propugnada por filósofos y pensadores, tal es el caso de J.J. Rousseau en su libro El Emilio. Lo que redundará en una mejora de la calidad del ser humano.

La Revolución industrial es seguida casi inmediatamente por un impresionante crecimiento demográfico en las ciudades y por un drenaje, sin precedentes, del campo, en beneficio del desarrollo urbano. Estas grandes masas de población obrera, que no dio tiempo a realojar en condiciones, generaron viviendas insalubres, con una total ausencia de naturaleza en los barrios más pobres. Las inhumanas condiciones contribuyeron a una rápida degradación física y moral de sus moradores. Por contra, el contacto con la naturaleza tiene virtudes moralizadoras e higiénicas. Así, el medio natural puede influir positivamente sobre la conducta moral de los ciudadanos, mejorando además su calidad de vida. El argumento higienista era utilizado ampliamente por los defensores del parque como solución a problemas sociales. ${ }^{195}$

La demanda social de una mejor calidad en las condiciones de vida, unida a las reivindicaciones de médicos higienistas, hace que los poderes públicos tengan que dar solución a estas demandas sociales. Es el momento en el que nace el concepto, uso y gestión del parque que hoy conocemos. Unas veces, acondicionando al uso público antiguos jardines aislados y privados de la nobleza, y en otros, proyectado de nueva planta parques públicos para el uso y disfrute de todos, como el caso que nos ocupa del parque Ribalta de Castellón.

Como respuesta a esta situación de insalubridad ciudadana, surge entre los médicos higienistas ingleses la idea de crear pulmones verdes en las ciudades para sanear, para purificar el ambiente y mejorar la calidad de vida. Paralelamente, las ideas de los socialistas utópicos van más allá, para ellos las zonas verdes no solo cumplen un

\footnotetext{
${ }^{194}$ SANTAMARIA, María Teresa (1995): El parque de Ribalta, Generalitat Valenciana, p.21 y 23.

195 GARCIA LORCA, Andrés Miguel (1989): «El parque urbano como espacio multifuncional: origen, evolución y principales funciones», revista Paralelo 37, nº 13, pp. 106-107.
} 
papel de higiene física, sino también y fundamentalmente, para volver a estimular el contacto del ser humano con la naturaleza, que es moralmente positivo, ${ }^{196}$ lo que supone no solo una mejora de la salud física sino también de la salud moral. Muchas de las ideas de los socialistas fracasaron por pura utopía, sin embargo, sus planteamientos sobrevivieron y constituyeron uno de los elementos fundamentales que asumieron en el último tercio del siglo XIX otras asociaciones cívicas defensoras del medio ambiente (los ecologistas de hoy día), que reivindicaban que el centro de la ciudad fuera una zona verde, para purificar el ambiente y para fomentar que los ciudadanos acudan allí en su tiempo libre. ${ }^{197}$

La introducción de la naturaleza en las ciudades se debe a dos factores: los procesos de industrialización que imponen unas transformaciones a las ciudades; por otra parte el prestigio adquirido por la naturaleza, que asume una valoración positiva y a la que se atribuyen desde el siglo XIX valores pedagógicos, terapéuticos, estéticos, etc.

El siglo XIX supone el final de un proceso en aras a conseguir la recreación de la naturaleza en el espacio urbano para la educación y recreo del pueblo. A la vez que constituye el punto de partida en orden a la consideración del parque como regulador de la salud física y mental, moderador del medio ambiente y como espacio público de prestigio a cargo de los municipios.

El parque urbano desde su creación es un espacio multifuncional muy integrado dentro del contexto urbano y accesible por primera vez a todas las clases sociales, desempeñando unos usos entrelazados que se van consolidando a lo largo del siglo XIX.

En este sentido las aportaciones de los CIAM (Congresos Internacionales de Arquitectura Moderna), siendo el IV de ellos celebrado en Atenas en 1933, recogen en sus Actas las funciones sociales que deben cumplir los parques urbanos, que están basadas en muchos principios decimonónico, y que hoy día pensamos no han variado sensiblemente. De una manera resumida se puede establecer: ${ }^{198}$

- Las zonas verdes urbanas han de jugar el papel que les corresponde como elementos reguladores del medio ambiente.

\footnotetext{
${ }^{196}$ Según J.J.Rousseau, el ser humano en contacto con la naturaleza es más puro, más noble, mas humano y cuando se aleja tiene tendencias de animalidad.

${ }^{197}$ GARCIA LORCA, Andrés Miguel (1989), op., cit., pp. 106-107.

198 RODRIGUEZ AVIAL, Luis (1982): Zonas verdes y espacios libres, Instituto Estudios Administración Local, Madrid, p.88.
} 
- La presencia de espacios verdes es también estimulable, por la acción directa sobre la psiquis del hombre.

- El espacio verde tiene una función de marco físico de una gran parte de relaciones sociales

- El espacio físico ha de ser soporte físico de actividades propias del recreo y del descanso.

- Conseguir una mejora de la imagen estética de la ciudad es una función del espacio verde.

- En resumen, el ejercicio de estas funciones es contribuir al óptimo desarrollo de la personalidad física, psíquica y espiritual del individuo urbano a lo largo de las etapas que componen la vida.

En base a ello establece Andrés Miguel García cinco funciones básicas que ayudan a reconstruir el papel social del parque decimonónico: la función recreativa y de esparcimiento, la función ambiental, la función higiénico-sanitario, la función didácticaeducativa y la función estética y de prestigio.

La estructura social decimonónica ha favorecido los lugares de tertulia, esparcimiento y ocio activo y pasivo, creando entre otros espacios urbanos los jardines y parques públicos para dichos eventos. Estas zonas verdes, para fomentar el encuentro y los actos sociales multitudinarios, requerían de ámbitos complementarios dentro del propio parque: como kioscos para la música, casetas para refrescos, estanques con aves o para ir en barca, pequeños zoológicos, agrupaciones botánicas exóticas y árboles singulares, zonas de juegos y deportivas compatibles con el uso y espacios para la fiesta.

La función ambiental es la más compleja. El parque se puede considerar un bioma regulador de las condiciones de carácter climático-térmico y amortiguador de efectos ambientales nocivos, como puede ser la contaminación atmosférica o sónica. Todo ello de vital importancia para la calidad de vida de los habitantes de las ciudades.

El parque tiene una función conservacionista de la naturaleza, por su extensión y porte vegetal permite la formación, organización y división de espacios en orden al desarrollo de biotopos, es decir de espacios físicos naturales donde se desarrolla la biocenosis o comunidad de animales y vegetales vivos de distintas especies que conviven en un mismo lugar. Su propagación se produce en «escalón», es decir que el 
parque enlaza con la ciudad mediante franjas, calles o avenidas arboladas, de manera que el efecto del ecosistema del parque se transmite al resto de la ciudad. ${ }^{199}$

No hay más que recordar las fotos y planos de época en donde el parque Ribalta enlazaba hasta el centro de la ciudad a través de calles rectas, anchas, todas ellas arboladas.

También ejerce un importante papel como regulador climático. La presencia de masas vegetales ejerce un control de la humedad, de la temperatura y de los vientos que influyen en las zonas urbanas próximas, favoreciendo el confort en el clima urbano, como es reducir la sequedad o refrigerar el ambiente del parque y de su entorno próximo.

Muchos árboles urbanitas son amortiguadores de efectos ambiéntales nocivos, como la polución atmosférica fijando el polvo y materias residuales, depuran bacterias, generan oxígeno, fijan gases tóxicos, emiten vapores balsámicos, etc. Según estudios realizados pueden llegar a reducir la contaminación ambiental entre un 10 y 20 por ciento en comparación con otras zonas sin vegetación.

Otra de las funciones es la higiénico-sanitaria. Se trata de paliar la degradación física y moral. Consecuencia de los factores anteriormente enunciados, los parques ejercen una función oxigenante y bactericida que evitan las enfermedades de carácter epidémico, como paliar la difusión de determinadas enfermedades. También hay que añadir su función anti-estrés, relajante y estabilizadora del plano psíquico, consecuencia de la vibración y alternancias de colores, de fondos y formas, aspectos muy reconocidos desde la antigüedad. También hay estudios sobre ciertas plantas como la Jacaranda mimosifolia, las acacias, espinos, etc., que influyen positivamente más que otras en la salud psíquica de las personas. ${ }^{200}$

Para la función didáctica-educativa, el parque es un espacio para que el ciudadano y especialmente el niño aprendan aspectos de la naturaleza. Volviendo otra vez a J.J. Rousseau, el parque produce educación cívica, educación en valores, se aprende a convivir con la naturaleza y despierta la sensibilidad para conocer, respetar y cohabitar con otras formas de vida. En definitiva a valorar el entorno natural.

\footnotetext{
199 CAlvo AldEA, Diodora; MOLINA Álvarez, Ma Teresa; SAlvachúA RodríGuEZ, Joaquín (2009): Ciencias de la Tierra y Medioambientales. MacGraw-Hill. p. 378.

${ }^{200}$ GARCIA LORCA, Andrés Miguel (1989), op., cit., p. 109.
} 
Educar con la naturaleza y en el ambiente natural ha sido un objetivo de pedagogos y educadores. El parque ofrece grandes posibilidades de educación ambiental, lo que proporcionará al educando una valoración de la naturaleza y de sus efectos sobre la especie humana altamente positiva, a la vez de completar su formación.

Giner de los Ríos defendía la utilidad de las excursiones escolares como un modo de practicar el método intuitivo en la enseñanza. Por este método el alumno toma una parte activa en la formación de sus conocimientos en contraposición del verbalismo y el formalismo utilizados en los métodos escolares de la época. ${ }^{201}$

La Institución Libre de Enseñanza potenció las excursiones escolares para sensibilizar y cuidar el medio ambiente. El respeto, preservación, estudio, contemplación y reposo moral que proporciona el medio natural que nos rodea se constituyó en uno de los objetivos perseguidos por Giner, Cossío, y otros destacados institucioncitas. $^{202}$

Los conocimientos científicos y la sistemática investigación en el campo de las ciencias naturales, la taxonomía linneana, la predilección por colecciones botánicas y especies exóticas, resultado de la divulgación de expediciones botánicas, dan como resultado a lo largo del siglo XIX, la creación de los primeros jardines de tipo botánico en las grandes capitales de provincia. Otras ciudades, como Castellón, que no ostentaron ese privilegio, cuando diseñaron a lo largo del siglo diecinueve los nuevos jardines y parques urbanos, le dieron vocación de jardín botánico, como el de Ribalta, de lo se tiene constancia. Hecho que otorga a estas zonas verdes su condición ilustrativa.

La función estética y de prestigio es la más difícil de definir y cuantificar porque la estética está supeditada a unos gustos -por otra parte fácilmente predecibles- según la ideología, estrato social y nivel cultural, más que a unos valores objetivamente estéticos y que además varían con el tiempo. De cualquier forma, un amplio sector social y cultural coinciden en que estos espacios verdes embellecen las la ciudad.

La burguesía decimonónica se preocupó de hacer ciudad, creando y cuidando el diseño de los espacios de sociabilidad. Entre ellos el parque urbano fue el más paradigmático. Además de ejercer las funciones anteriormente reseñadas, el parque se

\footnotetext{
201 CAPITÁn DíAz (1994): Historia de la educación en España. Tomo II Pedagogía Contemporánea Dykinson, Madrid. p.276.

202 VEGA GIL, Leoncio (1997): Pedagogía institucionista y educación social en Castilla y León., en Historia de la Educación Revista interuniversitaria Número 16. Universidad de Salamanca. p. 269.
} 
convirtió en motor de prestigio ${ }^{203}$, en hito y emblema de identidad de la ciudad. Una gran ciudad tenía que contar para considerarla como tal con un gran parque urbano.

También tuvieron una gran influencia estos medios naturales desde el punto de vista económico. Con el crecimiento de las ciudades, los nuevos ensanches se situaron preferentemente alrededor de estas zonas verdes. Difícilmente encontraremos en el entorno de estos parques y jardines edificios de mala calidad. La construcción de parques es susceptible de crear riqueza. En el caso que nos ocupa, la implantación del parque Ribalta supuso el desarrollo de la ciudad en esa dirección.

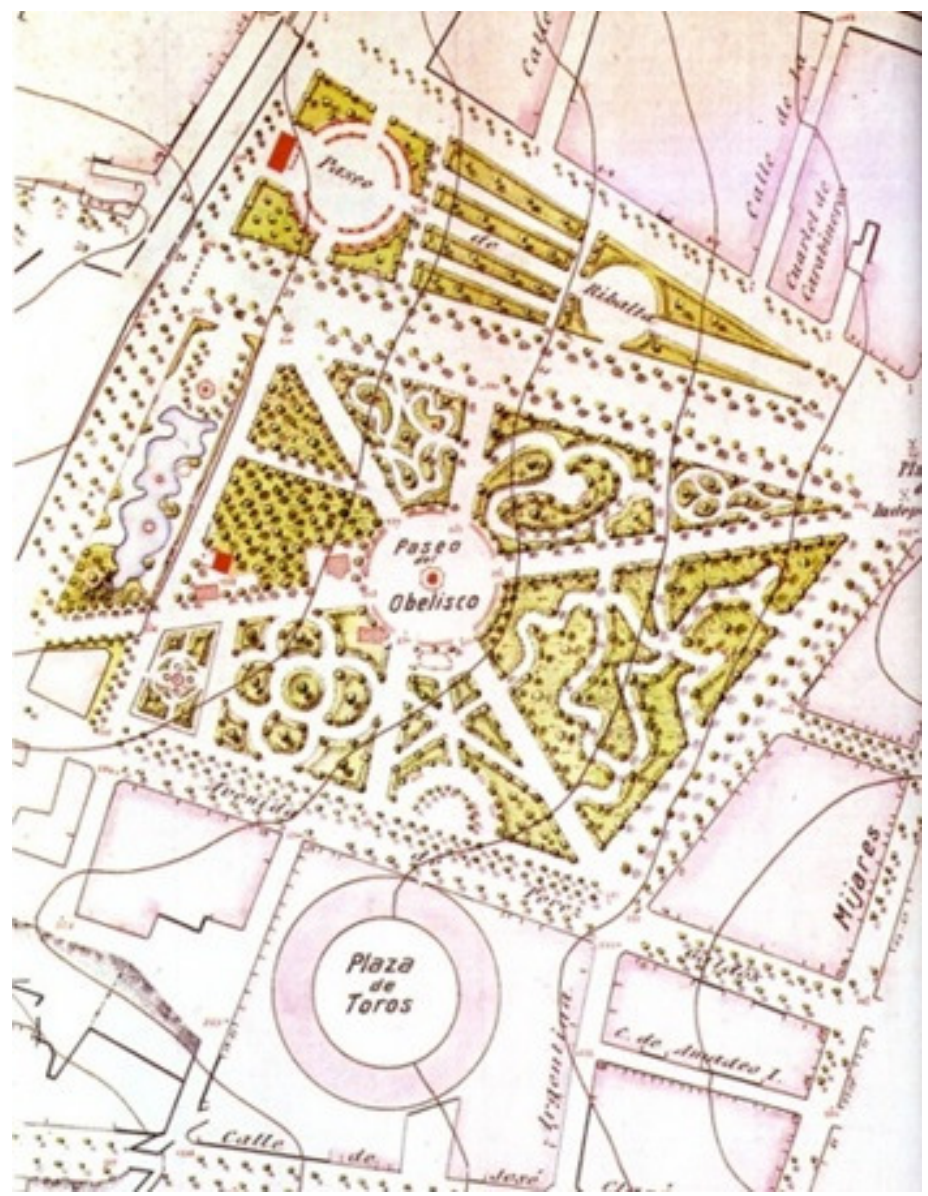

Plano atribuido a Juan Mañá, 1926, Ayuntamiento de Castellón. Fuente: Santamaría, María Teresa (1995): El Parque de Ribalta

\footnotetext{
${ }^{203}$ Napoleón fue el primer gobernante que empezó a crear parques y jardines de nueva planta. Cuando en sus campañas por Europa conquistaba una ciudad, lo primero que hacía era implantar un parque, por razones de prestigio. Porque decía que una gran ciudad debía tener un gran parque, para embellecerla y como emblema de la misma. Estos eran en ocasiones temáticos, como el jardín arqueológico que abrió en las ruinas de la ciudad de Roma.
} 


\subsection{EL PARQUE RIBALTA}

La creación del Parque Ribalta (1868-1876-1910) supuso un impulso innovador para Castellón y una iniciativa de modernidad sin precedentes. Se trata de una zona verde de nueva implantación y de promoción municipal.

Su configuración parte del último tercio del siglo XIX cuando la capital inicia lentamente, desde una infraestructura económica y social de tipo agrario, un avance hacia la industrialización que también se produce en todo el País Valenciano, y que empezará a materializarse en la imagen de la ciudad a partir de las dos últimas décadas del siglo XIX.

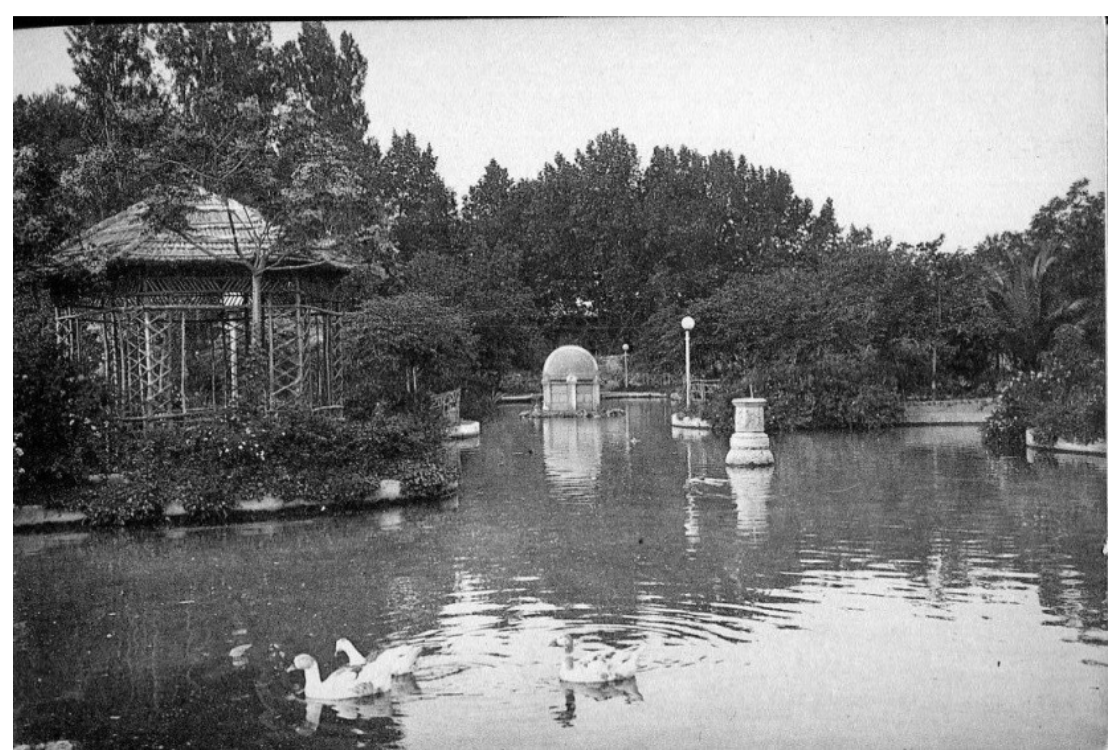

Tarjeta Postal-12.Castellón de la Plana, Estanque del Paseo de Ribalta, L.Roisin, fot.-Barcelona

Recién inaugurada la línea de ferrocarril Valencia-Castellón (1862), que tanto ansiaba la burguesía agrícola y mercantil de la región, y el trazado en sus inmediaciones de la nueva carretera a Zaragoza por Morella, la clase dirigente, que controlaba el desarrollo de la ciudad, se apresuró a fomentar la iniciativa municipal para la ejecución de nuevos jardines y paseos públicos en el entorno de estas infraestructuras de acceso a la ciudad, como lugar de reunión ciudadana y como elemento emblemático, motor de prestigio y de ostentación; exhibiendo al viajero y al visitante el poder económico de sus habitantes, como antesala de la ciudad que se quería implantar.

$\mathrm{Su}$ diseño responde a una composición que permaneciendo disciplinada en formas geométricas dentro de los cánones académicos, se macla en una sutil trama 
irregular de caminos serpenteantes, de influencia del jardín anglo-chino ${ }^{204}$-los «paseos de filosofos»- ${ }^{205} \mathrm{y}$ espacios sorpresa, que se diluyen en libres formas paisajistas. Lo jalonan de manera algo descuidada una variada vegetación de arbustos y tupidos árboles de gran envergadura - palmáceas, ficus, magnolios- y otros de crecimiento libre plátanos, álamos- predominando en general las especies botánicas de hoja perenne.

Creado con vocación de jardín botánico ${ }^{206}$, como sucedía con otros similares de la época, el resultado es una fastuosa y variada escenografía forestal, en donde colecciones botánicas centenarias y especies exóticas, no fáciles de conseguir hoy día, se han aclimatado perfectamente al medio. El pintoresco jardín de Ribalta conserva aún la estructura primera de su configuración: la nueva visión del mundo natural, del más ortodoxo jardín romántico.

El parque está formado por dos jardines cuadriláteros y otro triangular de desigual tamaño, apoyados en amplios paseos con rotondas de diferentes dimensiones. El ámbito central es el «salón social de la ciudad» y charnela de los otros dos jardines, confluyendo las alineaciones de los tres paseos en la plaza de la Independencia, de la que emerge en su centro la monumental «Farola».

Además está salpicado de amables arquitecturas de diferentes épocas, que cumplen funciones complementarias al uso (bancos, balaustradas, caseta del pozo, kiosco para las aves acuáticas, templete de música, palomar, etc.), y como obligado en todo jardín romántico no faltaba el estanque con la «cabaña del pescador» en uno de sus márgenes (hoy día desaparecido) y la «montañita artificial» de peñascos y plantas silvestres, con gruta y presencia de agua, como reproducción en miniatura de la

\footnotetext{
204 BUTTLAR, von Adrian (1993): Jardines del Clasicismo y el Romanticismo. El jardín paisajista, ed. Nerea, p.94.

${ }^{205}$ Uniendo los grandes paseos hay senderos interiores con vericuetos, los románticos paseos a los que se les pone el nombre como es el caso de los «paseos de filósofos » o «maranyetres», en http://www.cult.gva.es/dgpa/ documentación/interno/1164.pdf

${ }^{206}$ [...] La primera vegetación del Paseo Viejo estuvo compuesta fundamentalmente por algunos cipreses que quedaron del antiguo calvario, pinos trasplantados del Pinar, eucaliptos y álamos cultivados en viveros cercanos. Pero en 1877, cuando se plantó el Paseo Nuevo, se completó con otras plantas de las que aún perduran algunas que han adquirido gran valor. En 1876, había sido nombrado director de Jardines y Paseos Municipales de la Ciudad Tomás Clará y Ferrer y jardinero de los Paseos, a las órdenes del anterior, Francisco Tirado [...] En la elección de especies que constituyeron la vegetación de los paseos se hace patente una intención ilustrada, la variedad de especies que contiene, a modo de colección botánica, muy en boga en la segunda mitad del sigloxIX. Este hecho era frecuente entonces en los jardines públicos y alguno de los grandes privados que hacían gala de poseer una diversidad hasta entonces solo conocida en los jardines botánicos [...] Tomás Clará no se conformó con las especies que se cultivaban en Castellón y se fue a comprar plantas a Barcelona y Valencia, e incluso al Jardín Botánico valenciano [...] en SANTAMARIA, María Teresa (1995): El parque de Ribalta, Generalitat Valenciana, pp.95 y 92.
} 
naturaleza, de influencia del jardín chino. Este pequeño montículo tiene sus antecedentes en el valenciano jardín de Romero, hoy llamado de Monforte ${ }^{207}$, proyectado en 1859 .

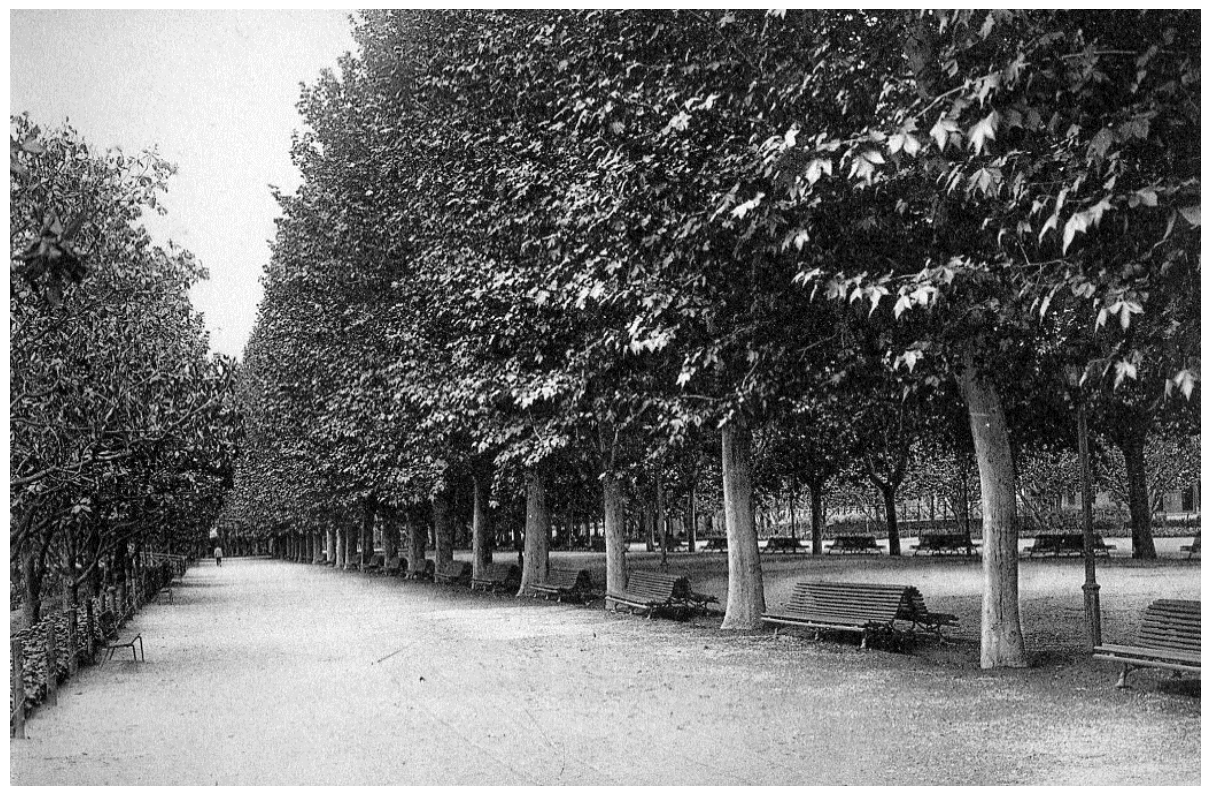

Tarjeta Postal-9.Castellón de la Plana, Paseo Central del Parque de Ribalta, L.Roisin, fot.-Barcelona

Construido el nuevo cementerio de San José en $1860,{ }^{208}$ según diseño del arquitecto Manuel Montesinos Arlandiz, y quedando libre el espacio que ocupaba el antiguo cementerio, sobre aquel lugar decidió el primer ayuntamiento constituyente de 1868, siendo alcalde Carlos Ferrer, la construcción de un primer jardín, llamado Paseo de Ribalta, siendo el autor de los planos el director de Caminos Luis Alfonso. ${ }^{209} \mathrm{De}$ forma triangular y adosado a la nueva carretera de Zaragoza, su diseño responde a los jardines realizados décadas anteriores en la ciudad, siendo sus antecedentes el jardín isabelino del Paseo de la Glorieta de Valencia. Fue concebido con un paseo central y plazoletas circulares que articulan los caminos secundarios y transversales, desembocando el conjunto en una plaza de mayores dimensiones, con banco corrido de piedra y respaldo de hierro, en donde desarrollar la vida social.

El segundo jardín, de mayores dimensiones, también proyectado por Luis Alfonso, siendo alcalde Domingo Herrero, es denominado Paseo de la Alameda y más tarde Paseo del Obelisco. Está resuelto mediante dos vías principales que son las dos

\footnotetext{
207 SANTAMARIA, María Teresa (1995): op. cit, p. 21.

${ }^{208}$ GIMENO MICHAVILA, Vicente (1984):op. cit, p.180.

${ }^{209}$ SANTAMARIA, María Teresa (1995): op. cit, p. 18.
} 
diagonales del cuadrilátero, cuyo punto de encuentro es la rotonda central ovalada delimitada por un banco corrido de piedra con respaldo abalaustrado, donde se desarrolla la vida social del jardín. Situado entre el trazado de la línea del ferrocarril y la carretera de Zaragoza, el esquema general de este nuevo paseo tiene como fin principal el incluir en un paseo peatonal el camino recto de la Estación con la ciudad. ${ }^{210}$ Contiguo al jardín existía otro paseo, para el tránsito de carruajes, que unía la estación con la céntrica Plaza del Rey, se trata del ya citado Paseo arbolado de San Vicente.

Será en 1910, por una permuta de terrenos del Ayuntamiento con la Compañía de Ferrocarriles, cuando la carretera de Zaragoza, que separaba los dos jardines pasa a formar parte del conjunto jardinero ${ }^{211}$. Acondicionada dicha carretera como Paseo Central, su amplitud y diafanidad se consideró ideal para emplazar en ella el «salón de la ciudad», como espacio polivalente de actos multitudinarios, con andén central para los carruajes y como «paseo de coches». Podemos decir que es el momento del nacimiento del parque ${ }^{212}$ de Ribalta, como resultado de la adición de jardines y aglutinador de las funciones sociales de la clase ascendente que lo idearon.

El cumplimiento de estas exigencias recreativas, ambientales, higiénicosanitarias, educativas, estilísticas y de prestigio social, lo conecta claramente con los parques urbanos decimonónicos y con la herencia ilustrada de la jardinería.

\footnotetext{
${ }^{210}$ La tendencia de disponer jardines al arrimo de las estaciones de ferrocarril y paseos arbolados para conectar estas con los núcleos urbanos fue muy habitual. Casos similares, pero a menor escala, los encontramos en Benicarló, Vilarreal, Borriana o Nules. También era corriente disponer alineaciones de viviendas unifamiliares suburbanas adosadas al trazado de la vía del tren, la contemplación del paso del tren era un privilegio y un espectáculo.

${ }^{211}$ SANTAMARIA, María Teresa (1995): op. cit, p.47.

${ }^{212}$ El diccionario de uso del español de María Moliner, define parque como «terreno público o privado destinado a recreo, con arbolado y plantas de adorno, más grande que un jardín».
} 


\section{CAPÍTULO II: LA HIGIENE URBANA EN CASTELLÓN}




\section{UNA APROXIMACIÓN A LAS POLÍTICAS DE HIGIENE EN LA ÉPOCA CONTEMPORÁNEA}

A lo largo del siglo XIX, la sociedad española vivió grandes transformaciones que afectaron tanto a su sistema político como a su estructura social. Estas transformaciones tuvieron lugar en el marco de la construcción del estado liberal, una de cuyas características más relevantes fue la sustitución de una sociedad estamental definida por el estatus, propia del Antiguo Régimen, por otra basada en las clases y dinamizada por la burguesía como grupo social emergente.

En el terreno sanitario, el siglo XIX también se constituyó en un periodo de importantes cambios que tuvieron como objetivo contribuir a una mayor protección social frente al proceso de enfermar. Una de las aportaciones más importantes de este siglo fue la progresiva delimitación de lo que debía entrar a formar parte del terreno de lo público y que, por lo tanto, quedaba englobado en la esfera del Estado, frente a lo que escaparía a sus competencias y en consecuencia debía asumirse desde el sector privado.

A mediados del siglo XIX salió a la luz el primer texto legislativo sanitario: la Ley de Sanidad de 28 de noviembre de 1855. El modelo organizativo que se desarrolló a partir de esta Ley se basó en una centralización de la política sanitaria desde su órgano rector: la Dirección General de Sanidad, en el seno del Ministerio de la Gobernación. Esta centralización se vio perpetuada a escala provincial en la delegación y la figura de los gobernadores civiles que eran los responsables en la toma de decisiones sobre política sanitaria. Sin embargo, la independencia de los gobiernos provinciales en lo que se refiere a la adopción de estrategias en el terreno de la higiene pública fue muy limitada, y siempre estuvo tutelada por el Gobierno Central. Lo mismo ocurría con los ayuntamientos cuya capacidad para desarrollar iniciativas en el terreno sanitario constituyó motivo de discrepancias y enfrentamientos entre los distintos niveles de la administración.

La ley de 1855 dedicaba escasa atención a las competencias de los ayuntamientos, sus atribuciones se centraban básicamente en garantizar el cumplimiento de las medidas higiénicas en sus diferentes vertientes. Éstas abarcaban la higiene 
urbana, la de los alimentos, la de los cementerios, y el control de las aguas, tanto de bebida como las estancadas o nocivas para la salud. ${ }^{213}$

A la necesidad de cambio y modernización, que comenzaba a hacerse patente en la sociedad española de finales del siglo XIX, bajó la influencia de los países más desarrollados europeos, se unió el cambio en los riesgos para la salud, y el concepto de especificidad etiológica ganó terreno, como producto del desarrollo de la microbiología, e incorporó la nueva concepción del contagio animado a las ideas etiológicas de corte ambientalista y químico características de la etapa anterior. Estos cambios en la interpretación del proceso de enfermar condujeron a una serie de variaciones en las estrategias para prevenir y combatir la enfermedad. La organización sanitaria y el papel de los profesionales de la salud tampoco pudieron mantenerse al margen de estas innovaciones, y ello justificó la necesidad de crear un nuevo marco legal capaz de dar respuesta al desarrollo de una nueva administración sanitaria, ordenada en la Instrucción General de Sanidad, decretada en enero de 1904.

La Instrucción de Sanidad de 1904 no fue más que la culminación de una serie de tentativas de sustitución de la Ley de Sanidad de 1855, iniciadas a partir de la Restauración de 1875, que habían resultado estériles. La primera fue el Proyecto de Ley de Sanidad de 1882, que no llegó a consolidarse por los sucesivos cambios ministeriales coincidentes con su tramitación. Transcurrieron doce años hasta dar paso a un segundo intento, con el Proyecto de Ley de Bases de 1894, que tampoco se llevó a cabo por falta de presupuesto. El tercer intento frustado se produjo en 1899 con la presentación ante el senado de un nuevo Proyecto de Ley de Bases de Sanidad que corrió la misma suerte que el anterior. Por fin, para evitar un nuevo fracaso, la Instrucción General de Sanidad no fue tramitada como una ley sometida a aprobación parlamentaria, sino que entró en vigor como un decreto-ley, que, aunque tenía carácter providsional, mantuvo su vigencia hasta 1944.

El modelo por ella propuesto definió tres componentes en la nueva estructura administrativa: el nivel ejecutivo lo integraba el Ministerio de la Gobernación y los gobiernos civiles, como delegados provinciales de éste. En segundo lugar, mantuvo el nivel consultivo heredado del siglo anterior que estaba representado por el Real Consejo de Sanidad y las juntas de sanidad provincial y municipal. El tercer nivel fue la creación

\footnotetext{
213 BARON VILAR, Carmen (2006): Las políticas de la salud. La sanidad valenciana entre 1855 y 1936. Universitat de València, pp.17-19.
} 
de un organismo técnico representado por las inspecciones de sanidad en cada uno de los niveles administrativos general, provincial y municipal.

Por tanto la organización sanitaria en el periodo de estudio pivotó sobre dos grandes textos legislativos: la Ley de Sanidad de 1855, y características del Antiguo Régimen y la constitución de un sistema sanitario acorde con el prototipo de mentalidad liberal.la Instrucción General de Sanidad de 1904. La primera supuso la ruptura con las estructuras características del antiguo Régimen y la constitución de un sistema sanitario acorde con el prototipo de mentalidad liberal. Planteó la asunción por el Estado de actuaciones sanitarias inespecíficas, encaminadas a combatir el fenómeno epidémico y, en el terreno de la asistencia sanitaria, el establecimiento de un régimen de beneficencia para atender a los huérfanos y pobres. Aunque este modelo asistencial no se modificó sustancialmente, la Instrucción de 1904 potenció las acciones higiénico-sanitarias al incorporar los postulados de la bacteriología y la higiene de laboratorio, sin dejar de conceder importancia a las epidemias. ${ }^{214}$

La higiene urbana, entendida como mejora de las condiciones de salubridad de calles, viviendas, suministros y locales públicos y privados, constituía uno de los lugares comunes de la intervención municipal. En síntesis, las medidas adoptadas durante el periodo que va entre 1880 y los comienzos del siglo XX consistían en:

-Limpieza de calles y plazas. Riego con agua limpia a determinadas horas del día.

-Retirada de basuras, inmundicias y limpieza de pozos ciegos. Desplazar los depósitos de inmundicias (basureros y estercoleros) a las afueras de los núcleos de población y alejados de los caminos.

-Higiene de las viviendas, favoreciendo los mecanismos de ventilación, barrer y asear habitaciones, blanquear el interior y exterior de las casas, alquerías y barracas, limpiar letrinas y evitar el depósito de estiércol y basuras.

${ }^{214}$ Ibídem, p 20. 
-Inspección de edificios públicos (casa capitular, colegios de niños y niñas, albergues de pobres, lavadero, locales de sociedades profesionales, cementerios, etc.), especialmente en casos de epidemia. ${ }^{215}$

\section{INFRAESTRUCTURAS URBANAS. SU EVOLUCIÓN}

El rápido crecimiento y transformación de las ciudades, inducida por los cambios económicos y demográficos, requería una renovación de las infraestructuras y servicios urbanos. Mientras que las mejoras en el alumbrado e incluso en la pavimentación de calles y ejecución de aceras resultaban asequibles para la mayoría de municipios, el alcantarillado de pluviales y el de fecales con su depuración, o la traída de aguas y su distribución canalizada a cada vivienda, suponía mucha mayor inversión y dificultad técnica. ${ }^{216}$ Por esta razón, mientras la pavimentación y el alumbrado se empiezan a introducir a mediados del siglo XIX, las conducciones de agua $\mathrm{y}$ especialmente el alcantarillado es mucho más tardío.

Las calles en la gran mayoría de las poblaciones eran de tierra compactada con guijarros. La introducción de un firme empedrado en las calzadas, a base de cantos de río y posteriormente el adoquinado de piedra, hizo más cómoda la circulación de personas, vehículos y animales, además de ser una mejora higiénica, al reducir el polvo, la formación de barro y facilitar la limpieza. Estas calzadas estaban diseñadas con una ligera pendiente hacia el centro de la calle, por donde discurría una rigola o canaleta para favorecer la evacuación de las aguas de lluvia, de la limpieza y de los charcos, solución constructiva que aún podemos ver en algunos pueblos de las comarcas del interior.

\footnotetext{
215 Ibídem, pp. 285-287.

216 A partir de la Constitución de las Cortes de Cádiz de 1812 y la progresiva consolidación de la ideología liberal burguesa se empezó a considerar que cuidar la población era una obligación. Las políticas higienistas establecían en muchos casos el éxito o fracaso de los gobiernos municipales, ya que tenían capacidad de promover la ejecución de infraestructuras urbanas y otros servicios dirigidos a mejorar la salubridad de las ciudades. Pero estas atribuciones precisaban de grandes inversiones que tenían que realizarse en poco tiempo, como eran la conducción de aguas o el saneamiento, para ello requerían de ayudas o préstamos difíciles de conseguir, a cambio se optaba por la realización de calles, encintado de aceras o la renovación de los sistemas de alumbrado público, en AGUILAR CIVERA, Inmaculada (2005): «El ciclo del agua en la ciudad de Valencia (1850-1900)», en Historia de la Ciudad de Valencia IV. Valencia, ICARO-Col.legi Territorial d'Arquitectes de la Comunitat Valenciana (CTAV), p.197-198.
} 
Posteriormente se introducen las aceras con sus bordillos de piedra. La elevación de las aceras tenía la finalidad de separar por seguridad, el tránsito peatonal del tráfico rodado y evitar que el agua de la calzada invadiese el espacio de los peatones. La incorporación de la acera permitió eliminar la rigola central, que inclinaba los vehículos dificultando su cruce, colocando dos rigolas en los extremos de la calzada, junto a los bordillos de las aceras, evacuando de esta manera las aguas de la calzada y de las aceras. La ejecución de las aceras solía correr a cargo de los vecinos. La existencia de calzadas pavimentadas y aceras, como el aumento de vehículos, eran signos de modernidad en toda Europa. ${ }^{217}$

A mediados de siglo XIX el abastecimiento de agua era por pozos, o conduciéndola mediante canalización desde fuentes o ríos próximos, almacenándola en aljibes repartidos por la ciudad. Su distribución a domicilio se realizaba mediante aguadores o con el esfuerzo familiar.

Por las mismas fechas el alcantarillado era inexistente en la mayoría de las ciudades. Un progreso higiénico notable era el evitar los pozos negros ${ }^{218}$ y las pestilentes limpiezas periódicas o el todavía frecuente vertido de aguas negras en la vía pública. En muchas ciudades la carencia de aguas corrientes unida a la precariedad de las lluvias y a su irregularidad estacional, reducía la capacidad de arrastre de los desagües en los que fácilmente se estancaban los detritus.

También fueron muy frecuentes los lavaderos de uso público o de propiedad privada, que estuvieron presentes en casi todas las poblaciones. A los cuales se acudía para lavar la ropa, en un agua semiestancada, en donde se compartían toda clase de gérmenes patógenos.

\footnotetext{
${ }^{217}$ QUIROS LINARES, Francisco (1991): Las ciudades españolas a mediados del siglo XIX, ed. Ambito Editores, pp.43-44.

218 « En Madrid, por ejemplo, Philip Hauser calcula en la década de los años 1880 la existencia de más de 3.000 pozos negros contaminantes, señalaba también que la mayoría de los sumideros carecía de sifones y censaba en 4.000 las viviendas que carecían de suministro de agua potable. Una década después, el mismo autor, en su Geografía médica de la Península Ibérica denunciaba, a partir de los datos recogidos directamente de los Inspectores Provinciales de Sanidad, que la práctica totalidad de las capitales de provincia carecían de las infraestructuras sanitarias adecuadas en lo que se refiere al tratamiento de aguas sucias y de bebida, control e higiene de los alimentos, limpieza y salubridad de las calles [...] Si hemos de dar crédito a sus palabras, de las siete capitales españolas con más de 100.000 habitantes, solo Zaragoza y Sevilla disponían en 1913 de una red extensa de alcantarillado, aunque en estos casos el suministro de agua era deficiente. En otras ciudades grandes como Valencia, Málaga o Madrid, el suministro de agua era bueno pero el alcantarillado era pésimo», en BARONA VILLAR, José Lluís (2002): Salud, enfermedad y muerte. La sociedad valenciana entre 1833 y 1939, Institució Alfons el Magnànim, Valencia, pp.22-23.
} 
En la ciudad de Castellón las aceras se empiezan a colocar a partir de 1847 en las calles principales, siendo el pavimentado de las calzadas algo posterior. En 1913 el Ayuntamiento pide un préstamo para seguir haciendo aceras y adoquinar muchas calles del casco antiguo, no llegando estas mejoras a los barrios periféricos hasta entrada la segunda década del siglo XX. ${ }^{219}$

Desde antiguo la población se abastecía de pozos existentes dentro del casco antiguo y barrios periféricos y de las aguas procedentes del río Mijares, tomándolas de la llamada acequia mayor que pasaba junto a las murallas, por donde ahora discurre la calle Gobernador, éstas, mediante conductos subterráneos abastecían también a 160 cisternas o aljibes ${ }^{220}$ en casas particulares de las que se beneficiaban las familias más pudientes. El resto de la población tenía que acudir diariamente a los omplidors que estaban en la calle Gobernador, por donde pasaba la acequia mayor, para llenar los cantaros, transportándolos en los carrets d'aiguader a cada casa para llenar las tinajas que estaban por lo general detrás de la puerta principal de la casas de labradores, o en depósitos en los bajos de las casas por pisos, costumbre que existió hasta finales del siglo XIX y que fue desapareciendo paulatinamente, una vez canalizadas por la ciudad las aguas de la Rambla de la Viuda. ${ }^{221}$ La misma conducción también ofrecía un sistema de regadío a los numerosos huertos que la ciudad albergaba. El suministro de aguas procedentes de la Rambla de la Viuda es aprobado por el Ayuntamiento en 1872. ${ }^{22}$

En 1868 se empieza a instalar fuentes públicas, pero no se generaliza hasta 1905. En dicho año se distribuyen por toda la ciudad, siendo abastecidas por el agua de pozo construido en el Paseo del Obelisco ${ }^{223}$ La distribución de agua potable mediante canalización a cada vivienda no se inicia hasta la última década del siglo XIX, siendo su ejecución muy lenta. En 1912 aún se está instalando la red de distribución de agua potable por muchas calles secundarias del casco antiguo. ${ }^{224}$

El problema higiénico y sanitario que más preocupaba a políticos y ciudadanos era la eliminación de aguas residuales y las basuras. Castellón padeció en la primera

\footnotetext{
${ }^{219}$ GIMENO MICHAVILA, Vicente (1984): op. cit.,p.35.

${ }^{220}$ MADOZ, Pascual (1982): op.cit, p.228.

${ }^{221}$ También existían pozos públicos dentro de la población, otros en los huertos próximos. En el arrabal de San Francisco existía un pozo y otro en el de San Félix, junto a la ermita de San Roque, en GIMENO MICHAVILA, Vicente (1984): op.cit., p.34-164.

${ }^{222}$ Ibídem p. 30.

${ }^{223}$ Ibídem, p.34.

${ }^{224}$ Ibídem.
} 
mitad de siglo dos epidemias de cólera importantes, la primera en 1834 y la segunda en 1855, cuyo origen en buena medida era la contaminación que estas aguas recibían de los pozos ciegos $^{225}$. Para paliar este problema el Ayuntamiento dicta algunas disposiciones higiénicas, estas no hacían sino recordar el «Reglamento de Policía» que desde mediados del siglo XVIII estaba vigente. Entre ellas merece especial mención, la estricta prohibición de echar agua a la calle, la mayor parte mezclada con orín, se prohibía también tirar aguas fecales a los desagües públicos que discurrían desde la plaza de los Lavaderos Viejos hasta la salida del molino que estaban detrás del convento de Capuchinos y, además, las autoridades municipales exigían a la población construir depósitos de letrinas. ${ }^{226}$ También era común disponer de un pequeño huerto dentro del recinto amurallado o en su entorno exterior inmediato, además de tener animales de crianza para el autoconsumo, por lo que la acumulación de desperdicios con el objeto de fabricar estiércol era una costumbre extendida entre las capas populares. Las autoridades castellonenses procedieron no solo a prohibirlo sino que además inspeccionaban su verificación. El recurso habitual para frenar los focos infecciosos era encalar las casas y otros espacios de uso. ${ }^{227}$

La instalación de una red de alcantarillado para conectar los desagües de cada vivienda se inicia en la primera década del siglo XX. El proceso fue muy lento, y a mediados de la segunda década las infraestructuras urbanas de saneamiento, agua potable y pavimentación no han llegado aún a ciertas parroquias del casco antiguo, ni a los barrios periféricos, únicamente podemos hablar de alumbrado y de fuentes públicas. $^{228}$

Para mejorar la higiene de los alimentos se construye el nuevo matadero público en 1842, junto a la actual calle Gobernador, desapareciendo el que existía en la plaza de

\footnotetext{
225 «Las consecuencias que la ausencia de alcantarillado provocaba en la salud de la población eran señaladas por los higienistas: en 1887, recordaban que no había una sola ciudad en España que dispusiera de un alcantarillado que, en Inglaterra se había revelado como medio suficiente para «desafiar confiadamente el cólera y demás azotes epidémicos», en FERRATER Carlos (1999): «La vida cotidiana. El ocio», MATEO MARTINEZ, Carlos (coord.), Los inicios de la modernización en Alicante, 1882-1914, Caja de Ahorros del Mediterráneo p.331.

${ }^{226}$ CHUST CALERO, Manuel (1998): «La ciudad de Castellón durante el siglo XIX», en ORTELLS, Vicente (Dir.), La Ciudad de Castellón de la Plana, Castellón, Ayuntamiento de Castellón, p.276.

${ }^{227}$ CHUST CALERO, Manuel (1998): op. cit, p. 274.

${ }^{228}$ SARTHOU CARRERES, Carlos (1913): Geografía General del reino de Valencia. Provincia de Castellón, Editorial Alberto Martí, Barcelona, p. 36
} 
la Pescadería, ampliándose en $1913 .{ }^{229}$ Por los mismos motivos, y en esta última fecha, se cubre con estructura metálica el mercado creado en 1903 en la plaza del Ayuntamiento y se proyecta otro cubierto en la plaza de la Pescadería, ${ }^{230}$ mejorándolo con la construcción de plintos o cajones uniformes ${ }^{231}$ para aislar los alimentos del contacto con el suelo.

Existían varios lavaderos. Los lavaderos viejos estaban situado en la explanada del portal d'Om, (actualmente plaza de la Paz); los lavaderos nuevos cerca del matadero, junto a la acequia mayor; el lavadero de Santo Domingo estaba también junto a la acequia mayor, próximo a la casa de Beneficencia, que sobrevivió hasta 1935; el del Toll, era un charco o balsa que se formaba en el foso norte de la muralla medieval, cubriéndose estos dos últimos en $1912{ }^{232}$ Son espacios públicos naturales o artificiales, en los que la gente, generalmente mujeres, lavaban la ropa o las pieles de animales.

El empuje urbanizador que se respira a partir de 1865 viene acompañado de la técnica y el progreso. El alumbrado público es uno de los servicios públicos que antes se instala, siguiendo los estadios de su evolución: alumbrado público con aceite (1833), alumbrado con petróleo (1863), alumbrado con gas (1871); alumbrado eléctrico $1879 .{ }^{233}$

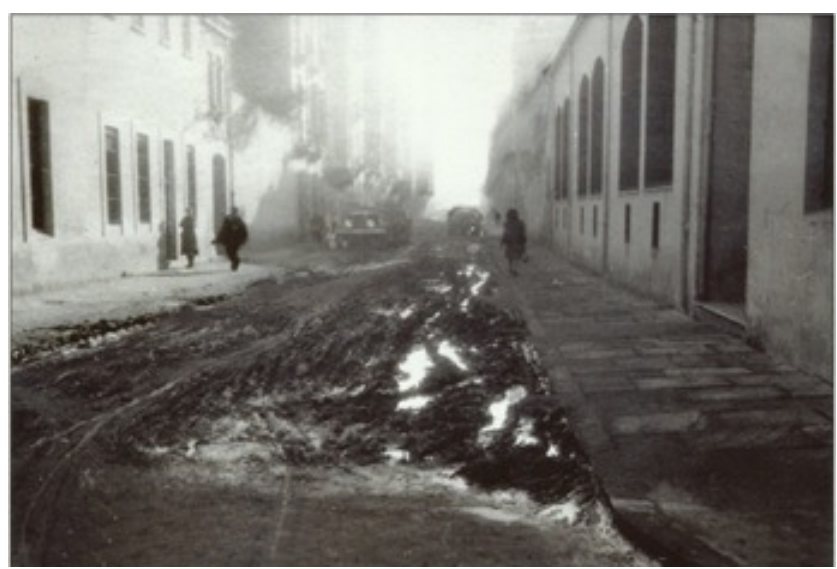

Calle Moyano esquina calle Herrero, con aceras de piedra y calzada de tierra compactada. A la derecha de la imagen el Grupo Escolar de la calle Herrero, que entró en funcionamiento en 1910 (denominándose Maestro Castelló en la segunda década del siglo XX). Foto aproximadamente de finales del primer tercio siglo XX.

Fuente documental: Colección José Prades

\footnotetext{
229 «Este punto tan importante para la salud pública se construyó en el año 1842, tiene una luneta ó claraboya en el centro, de 5 metros cuadrados, sus paredes están chapadas de finos y vidriados azulejos blancos, hasta la altura de dos metros; tiene las oficinas propias, aunque pequeñas, montadas con curiosidad y aseo [...]», en MUNDINA, Bernardo (1988): Historia geografía y estadística de la provincia de Castellón, Caja de Ahorros y Monte de Piedad de Castellón, Barcelona, p.197 [Edición facsímil del original, Imprenta y librería de Rovira hermanos, Castellón, 1873].

230 GIMENO MICHAVILA, Vicente: op.cit.p.35.

231 QUIROS LINARES, Francisco (1991): op. cit, p 48.

232 GIMENO MICHAVILA, Vicente, op.cit.p. 34.

233 GIMENO MICHAVILA, Vicente: op.cit., pp.259-252.
} 


\section{HIGIENE DE LAS CALLES}

En los años que hemos estudiado, la falta de higiene en las calles era un tema muy recurrente en la prensa de Castellón, pues el cólera amenazaba desde las vecinas playas africanas, y la población no cumplía con las disposiciones vigentes.

Ya desde principios del siglo XIX los periódicos critican las costumbres antiguas de lanzar aguas sucias de fregar a la calle y basura por las puertas y ventanas, o también la costumbre de usar la calle para hacer la matanza del cerdo o para realizar los trabajos de los artesanos. ${ }^{234}$

En 1857, el alcalde Antonio Vera publica un edicto de buen gobierno donde da una serie de instrucciones para que las calles de Castellón adquieran la categoría de ciudad. Entre éstas figuran que las caballerías o los carruajes cargados de paja, de leña o con cargas voluminosas han de transitar por calles amplias. Los vecinos han de barrer la parte de calle de delante de su casa y regarla en verano dos veces al día. Queda prohibido cortar leña en la calle y lanzar por los balcones basura y agua. Se prohíbe a los artesanos: tintoreros, silleros y peleteros que pusieran a secar en la calle sus artefactos de manera que interceptasen el paso a los peatones. Además se prohíben los juegos de pelota, de cartas y de chapas en las calles. Y no se ha de dejar en la calle materiales de las obras. ${ }^{235}$

Las zonas más conflictivas en cuanto a la higiene, eran la calle de las monjas Claras, donde la prensa afirmaba se había convertido en una «letrina» y la calle Esquiladores, que parecía un «sumidero». Muchos vecinos de la calle de Enmedio tenían la costumbre de arrojar inmundicias y aguas sucias por las puertas «escuseras» de sus respectivas casas. ${ }^{236}$

\footnotetext{
${ }^{234}$ Ya, en 1785, según el Título XVI de las Ordenanzas para el Régimen y Gobierno de la villa de Castellón de la Plana aprobado por S. M., se prohibía echar, animales muertos, aguas sucias, inmundicias que causaran putrefacción y mal olor, ni hacer montones de estiércol. La Ordenanza LXIV del Régimen de Gobierno de la villa de Castellón de 1785, manda que cada vecino riegue su casa, «sin charcos, ni lodos, procurando la frescura tan conveniente a la salud pública». En la Ordenanza LXV, del mismo Régimen de Gobierno, se prohibe que los obradores amontonen sus herramientas en la calle, impidiendo el tránsito de los vecinos. Asimismo en el Reglamento de Higiene Municipal de Castellón de 1908 y en las Prescripciones Sanitarias acordadas por la Junta Provincial de Sanidad y aprobadas por el Ayuntamiento de Castellón en 1911, se prohibía verter aguas sucias de fábricas y talleres, las aguas procedentes de los servicios domésticos de las casas y los residuos de cualquier clase.

${ }^{235}$ MONLLEÓ PERIS, Rosa (1992): «1822. Castelló, capital de provincia» en ORTELLS CABRERA, Vicente (Coord.): La ciudad de Castellón de la Plana. Excmo. Ayuntamiento de Castellón de la Plana. pp. 302.

${ }^{236}$ El Clamor, 16/05/1880; La Provincia, 29/07/1880.
} 
La prensa hace referencia también al pestilente olor que despedía el sumidero que existía en las calles contiguas a la plaza de la pescadería, y añade que no se explica con facilidad el abandono de ciertos servicios de los cuales depende la salud pública. El Clamor se lamenta de este hecho y dice: «Tenga en consideración el señor Alcalde que el cargo que ejerce lleva en sí deberes muy sagrados que cumplir, no se reduce todo a lucir la vara en las solemnidades religiosas» ${ }^{237}$

En el cuartel de San Francisco había un foso sobre el que se arrojaban aguas sucias, sobras de rancho e inmundicias que contribuían a la insalubridad del cuartel. La prensa llamaba la atención de la autoridad local para que tomara cartas en el asunto. ${ }^{238}$

Los vecinos tomaban el fresco invadiendo las aceras, y los artesanos las ocupaban ejerciendo sus trabajos cotidianos, pero lo que más preocupaba eran las basuras y estercoleros que se hacinaban en las viviendas y después eran arrastradas en pleno día por las calles «infestando la atmosfera hasta producir nauseas a los más fuertes, ni mucho menos que al ser avisados los infractores por sus vecinos se mofen los primeros haciendo alarde de su impunidad». 239

El Clamor publica una crónica del periódico La Defensa sobre la falta de higiene pública, dirigida al Alcalde de Castellón. En ella denuncia los focos de inmundicias de los alrededores de la ciudad, la suciedad de las calles, los estercoleros, las aguas para el consumo y la falta de condiciones higiénicas de los mercados:

Señor Alcalde: La cuestión de la limpieza pública que tanto interés reclama, la tiene usía abandonada. No importa para usía que todos los días le denunciemos abusos y concretemos. No le importa a usía que varios vecinos le supliquen que aparte de sus alrededores los focos de inmundicia que les infeccionan. No le importa a usía nada que persistan y aumenten todas aquellas causas que alteran la salud pública, porque las calles siguen tan sucias como siempre; los estercoleros en sus sitios, las aguas para el consumo en iguales o peores condiciones, los lavaderos despidiendo pestes, los corrales fabricando estiércol, algunas casas

\footnotetext{
${ }^{237}$ El Clamor, 23/05/1880.

${ }^{238}$ La Provincia, $7 / 05 / 1882$.

${ }^{239}$ El Clamor, 8/07/1883. Las Prescripciones sanitarias acordadas por la Junta Provincial de Sanidad y aprobadas por el Ayuntamiento de la capital de 1911, ordenaba la extracción de estiercol de las cuadras, antes de las siete de la mañana en invierno y antes de las cinco de la mañana en verano, prohibiendo depositarlo en la vía pública y, además, debía conducirse en carros con lonas impermeables. Se prohibía tener el estiércol en las casas más de tiempo de cuatro días, ni depositarlo en el interior de la población más tiempo que el designado por las autoridades. Estas prescripciones ya se recogen en el Reglamento de Higiene Municipal de 1908.
} 
convertidas en depósitos de eventraciones de reses, los mercados sin condiciones de ninguna clase y en una palabra, los abusos a la orden del día, y, en otra palabra, las medidas sanitarias durmiendo el sueño del olvido [...]. ${ }^{240}$

Cuando llovía se formaba barro y grandes charcos en las calles que impedían el tránsito por la vía pública y además se consideraba que era un peligro para la salud, por los «miasmas» que desprendían y que eran origen de las fiebres tercianas. ${ }^{241}$ Ver foto anterior de la calle Moyano, esquina con la calle Herrero.

En las calles se almacenaba la basura hasta bien entrada la mañana. Se unía a todo esto los malos olores que desprendían algunas calles enclavadas en distintos barrios de la ciudad. ${ }^{242}$

El Heraldo de Castellón recoge las quejas del público por las múltiples infracciones al bando de buen gobierno que se registraban en la capital. Se llama la atención a la alcaldía sobre los montones de basura que se extraían en pleno día de las casas de las calles más céntricas de la capital y sobre el escandaloso abuso de la mendicidad. ${ }^{243}$

También denuncia que por un boquete de la acequia Mayor contiguo a la casa de la Misericordia, las vecinas se lavaban «con más desahogo que si lo hicieran en sus casas» $^{244}$

Las aceras de las calles estaban por lo general en mal estado provocando accidentes a los transeúntes que, «fiados en lo que debían ser aquellas, no miran donde colocan los pies». Cuando llovía, el agua quedaba estancada o se formaba un barro pegajoso en las aceras, que «hace besar el santo suelo a más de un pobre transeúnte».

Asimismo estaban continuamente interceptadas por carros en construcción y montones de alfalfa, haciendo caso omiso al bando de buen gobierno. ${ }^{245}$

En 1884 se están construyendo aún las aceras de la calle Trinidad. Asimismo el Ayuntamiento estaba en trámites de derribar el portal de San Francisco, que por ser el punto por donde pasaban numerosos coches y carruajes y por donde se comunicaba la

\footnotetext{
${ }^{240}$ El Clamor, 2/09/1883.

${ }^{241}$ La Provincia, 30/03/1884.

${ }^{242}$ El Heraldo de Castellón, 12/03/1896.

${ }^{243}$ El Heraldo de Castellón, 30/07/1896.

${ }^{244}$ Ibídem.

${ }^{245}$ El Clamor, 15/07/1883; La Provincia, 21/02/1884 y 9/03/1884.
} 
ciudad con «los importante pueblos de La Plana, era necesario para el mejor servicio público.» 246

Después de la epidemia de cólera, la Junta Local de Sanidad, acordó redactar una memoria relativa a las mejoras que debían adoptarse en la salubridad pública, para que el ayuntamiento las tuviera presentes al confeccionar los nuevos presupuestos. Fue designado como ponente el doctor José Clará. ${ }^{247}$

Existían en Castellón algunos ganados vacunos que durante el día pacían por el término municipal y por la noche los encerraban en el centro y arrabales de la población. Algunas de esas agrupaciones padecían la viruela, con lo que la Junta de Sanidad provincial acordó obligar a cerrar los ganados fuera de la ciudad, para evitar el roce continuado que los habitantes de la población pudieran tener con estos focos de infección. $^{248}$

Normalmente los pastores no cumplían con los acuerdos de la Junta de Sanidad encerrando sus ganados donde mejor les parecía. ${ }^{249}$

La prensa denuncia que el alcalde de Castellón con el fin de «recoger votos», permitió pese a la prohibición de la Junta de Sanidad, que los ganados pernoctaran dentro de los muros de la capital:

El Sr alcalde de esta capital, con el noble propósito, al parecer, de recoger media docena de votos, permitió a los pastores de ganados de reses destinados al consumo de leche y carnes de la ciudad la intromisión de los animalitos que pacen en nuestros campos. Y como las casas donde albergan los pastores y ganados medio confundidos y expuestos a asfixiarse no reúnen condiciones higiénicas, amén de la prohibición absoluta que las leyes y Junta de Sanidad reclamaron de la alcaldía privando la existencia de reses dentro de los muros de la capital, y como ya tenemos en casa la tempestad epidémica siendo muchísimas las personas atacadas por la viruela, nos ocurre preguntar: ¿Hasta cuándo, Sr alcalde ha de durar su capricho rebelde a las leyes y hasta el instinto de conservación? Si V. no nos da el ejemplo de

\footnotetext{
${ }^{246}$ La Provincia, 10/02/1884, 21/02/1884 y 6/03/1884.

${ }^{247}$ La Provincia, 10/01/1886.

${ }^{248}$ El Clamor, 11/11/1883.

${ }^{249}$ En la Ordenanza LXXV del Régimen de Gobierno de la villa de Castellón de 1875, ya se prohíbia los cerdos sueltos por la ciudad «para que crezcan y se engorden y se rifen o se vendan [...]».
} 
ejecutar lo que sus superiores le piden con sujeción a las leyes, ¿con que principio de autoridad cuenta su señoría para que todos los castellonenses le respetemos? $?^{250}$

\section{HIGIENE DE LOS EDIFICIOS PÚBLICOS Y VIVIENDAS}

Otro tema que preocupaba a la prensa de Castellón era la higiene de los edificios. Sobre todo sale con bastante frecuencia el conducto de las aguas sucias que existía en la pared del Instituto Provincial.

¿Para los edificios que pertenecen a la corporación provincial rezan las ordenanzas municipales en lo que hace referencia a higiene y ornato?

Los hechos parecen desmentirlo; porque tenemos por ejemplo el conducto de aguas sucias que existe en la pared del Instituto que forma parte de la calle de las monjas Claras, el cual despiden tan pestilente olor que no hay nariz que lo resista. ${ }^{251}$

Asimismo las críticas iban dirigidas a la falta de higiene del Hospital Provincial, ${ }^{252}$ puesto que al encontrarse las secciones de higiene y obstetricia en una misma sala, no existía en ésta la limpieza exigida en los establecimientos destinados a la curación de enfermos:

[...] Desde hace algún tiempo se nota por parte del gobierno civil gran interés en organizar convenientemente la sección de higiene; pero estos propósitos no producen todo el resultado que es de desear, merced a la incuria de la diputación provincial.

El abuso antes denunciado es el testimonio elocuente de esta afirmación.

¡Cuestiones de higiene la diputación provincial!

Si fueran de sufragios. ${ }^{253}$

\footnotetext{
${ }^{250}$ El Clamor, 27/01/1884.

${ }^{251}$ El Clamor, 25/07/1880.

${ }^{252}$ Según el Reglamento de Higiene Municipal de 1908 los inspectores municipales de Sanidad debían vigilar la higiene de los hospitales y asilos corrigiendo las deficiencias que se observaran tanto en lo que respecta a las condiciones de los locales, como del régimen bajo el cual funcionaban.

${ }^{253}$ Ibídem.
} 
Por las descripciones de casas realizadas en el Capitulo I, en Castellón era habitual la convivencia y crianza de animales domésticos en las casas lo que generaba unas cifras más elevadas de epizootias, enfermedades transmitidas por ellos. En las casas de campo, y en general, en todas las viviendas periféricas, y muchas del centro de la ciudad, el ámbito doméstico albergaba no sólo la vivienda familiar, sino también el corral, el almacén para los productos agrícolas y el ganado, habitualmente situado en la planta baja, donde se almacenaba también el estiércol, los carros y los utensilios de trabajo en el campo.

Pero muchas de esas viviendas carecían de sistemas de desagüe de aguas residuales, de letrina o retrete, y los pozos ciegos a menudo provocaban filtraciones o habían de ser evacuados en condiciones poco higiénicas. Como consecuencia de todo ello había mayor incidencia de las enfermedades infecciosas trasmisibles por contaminación hídrica y por la falta de higiene individual y de la vivienda, como la fiebre tifoidea o el paludismo. ${ }^{254}$ En verano, algunas casas de Castellón eran un peligro sanitario para la población, pues sus habitantes almacenaban durante meses en los patios o corrales, los abonos y el estiércol sobre los cuales hacían sus funciones fisiológicas toda la familia, al mismo tiempo, vertían sobre las materias fecales las aguas sucias que allí se evaporaban y fermentaban.

La prensa se lamenta que con el excesivo calor que hacía en verano, la salud del vecindario se viera afectada por la falta de aseo, vigilancia y de visitas domiciliarias para enterarse las autoridades y la Junta de Sanidad de las condiciones higiénicas que reunían algunas viviendas que «por indolencia y abandono o ignorancia de sus dueños se hallan convertidas en focos de pestilencia, que fácilmente pueden desarrollar una epidemia que diezme la población». ${ }^{255}$

\subsection{CONTROL Y CONDICIONES DE HABITABILIDAD DE LA VIVIENDA URBANA Y SU EVOLUCIÓN.}

Una manera de conocer el estado de habitabilidad de las nuevas viviendas de la ciudad de Castellón en el periodo que nos ocupa, así como el nivel de exigencia que imponían las normas de policía urbana y el control que el Ayuntamiento ejercía, es a

\footnotetext{
${ }^{254}$ BARONA VILAR, Josep Lluis. op. cit., pp. 62-63.

${ }^{255}$ El Heraldo de Castellón, 11/07/1896.
} 
través de las licencias de obras. Para ello se ha consultado en el Archivo Histórico Municipal de Castellón los expedientes de obras.

Anterior a 1858 no figura ningún expediente de obras en el citado Archivo Municipal. $^{256}$

A partir de dicha fecha y hasta principios de la primera década del siglo XX, aparece en los expedientes de obras únicamente información del exterior de la casa, por lo que desconocemos como era la distribución interior y sus condiciones higiénicas. ${ }^{257}$ Los únicos documentos que nos pueden permitir aproximarnos al conocimiento de su habitabilidad en esa época es a través de las ordenanzas de policía, ${ }^{258}$ por escritos publicados, declaraciones de políticos, conferencias de médicos y otros profesionales, recogidos en la prensa de la época.

Para la concesión de licencias de obras de reforma o de nueva construcción de viviendas en esos años, únicamente figura una instancia solicitando el tipo de obra que se pretende realizar, un plano de situación del solar, con las alineaciones a la vía pública y otro de la fachada, indicando la altura, el número de pisos y la distribución de los huecos con sus dimensiones. ${ }^{259}$ Cuando se trata de un simple proyecto de cambio de fachada o de elevación de un piso, en el plano de fachada aparece dibujada la actual y la reformada, figurando con diferente tipo de línea o de color cada una de ellas. Ver las ilustraciones de los diseño de fachadas para concesión de licencias de obra, año 1880.

\footnotetext{
256 La única información sobre condiciones de habitabilidad de las viviendas son las que recoge las Ordenanzas para el Régimen y Gobierno de la Ilustres Villa de Castellón de la Plana, de 1785. La ordenanza QLXIX: «Siempre que se haya de hacer nueva o rectificar la parte principal de las casas que miren a la calle o callejón de la villa y sus arrabales, deberán los albañiles, los dueños de las casas, antes de empezar ni abrir cimentos dar parte al Regidor del mes o el Almutacen, al tiempo de empezar la obra, para que se haga con correspondencia, perfección, vista y hermosura.». También la ordenanza LXX:« En las calles, por muy anchas que sean, no se harán, ni permitirán saledizos ni habitaciones voladas [...] que dicha villa tiene en sus casas y plazas el derecho de conservar, desembarazadas, hermosas, y sin peligros [...]» Ordenanzas para el Régimen y Gobierno de la ilustre villa de Castellón de la Plana, aprobado por S.M y Señores del Real y Supremo Consejo de Castilla, Valencia, en la imprenta de Benito Monfort, Año 1785 Facsímil, 2013, Ayuntamiento de Castellón de la Plana.

257 Una inspección in situ hoy día sería muy complicado, ya que muchos de estos edificios han desaparecido. De los existentes, su reconocimiento conlleva una gran dificultad, ya que muchas de sus fachadas han sido alteradas y renovadas. Además, muchos de ellos han sufrido interiormente importantes transformaciones, con la introducción de mejoras higiénicas y nuevos materiales, por lo que su valor de autenticidad se ha perdido, además, al ser privados el acceso resulta más complicado.

${ }^{258}$ Las Disposiciones de Policía de 1871, en sus artículos 3 al 13 hacen referencia a las condiciones higiénicas de los edificios.

${ }^{259}$ Los dibujos de las fachadas aparecen muy simplificados, no figurando en ellos ornamentación alguna. Los acabados estéticos se realizaba durante la ejecución de la obra al gusto del maestro de obras o del propietario. Son pocas en las que aparece la fachada dibujada con detalles decorativos. Se corresponden generalmente con las viviendas de las familias más pudientes económicamente, en las que el arquitecto o el maestro de obras realizan una propuesta con el estilo de mayor actualidad.
} 
Se desprende que la concesión de licencias de obras se centra en las normas urbanísticas relativas a la anchura de la calle y altura de la edificación, para preservar la adecuada ventilación y asoleo de las vías públicas, ${ }^{260}$ y las habitaciones cuyas ventanas recaen a ella. Además de respetar la anchura suficiente para la circulación de vehículos de tracción animal y facilitar la maniobra de entrada y salida de carros y otros aperos en las casas.

Terminada la obra, será la Comisión de policía urbana, tal y como consta en los informes de concesión de licencia, la que verifique si la obra realizada en el interior de la vivienda cumple con las condiciones higiénicas municipales.

En todos los informes técnicos de autorización de obras de viviendas figura por escrito la necesidad de «cumplir con las disposiciones de los artículos 3 al 13 del bando de policía urbana de $1871 »$, recordando además que la «obra se realice con solidez, gastando buenos materiales y empleándolos según las reglas del arte», así como la medida higiénica referentes a que «se coloquen canales en los aleros de todos los tejados, provistos de los necesarios tubos de bajada de agua», evitando así la caída libre del agua de lluvia a la vía pública y a los patios interiores de la casa.

\footnotetext{
${ }^{260}$ En el Reglamento de Higiene Municipal de Castellón de la Plana de 1908, en su Capítulo II: De la Higiene Municipal, establece el $\mathrm{Art}^{\circ} 5$, en referencia a las vías públicas que «el trazado, orientación, dirección anchura y de más condiciones de las vías públicas de nueva creación será objeto de un detenido estudio por la Junta de Sanidad [...] Los tres objetivos principales en toda vía pública: condiciones de asoleamiento de todas ellas en las distintas estaciones del año, ventilación completa y sequedad del suelo lograda con un pavimento perfectamente impermeable».
} 


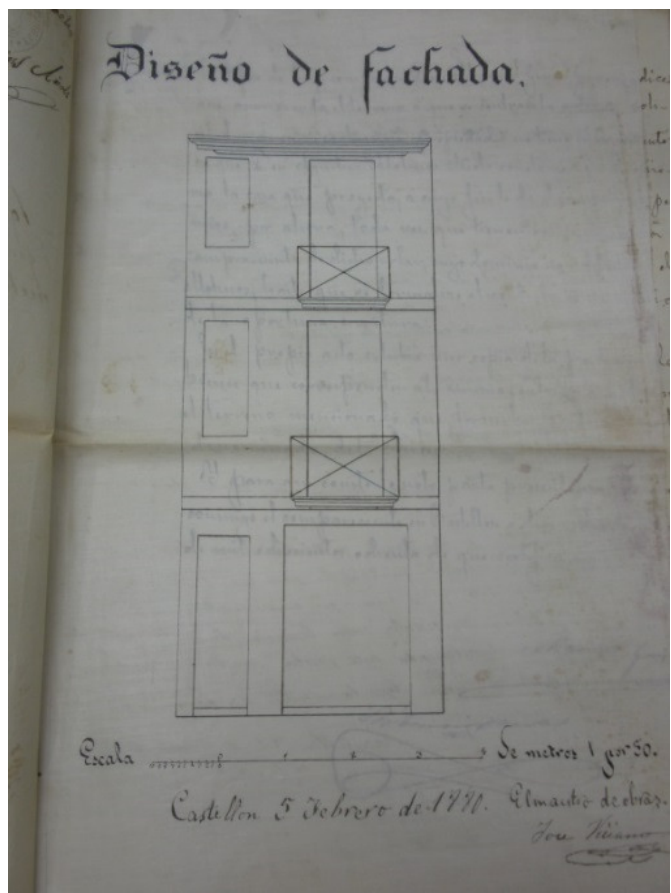

Disposición vertical de los ejes de puertas y ventanas de la fachada

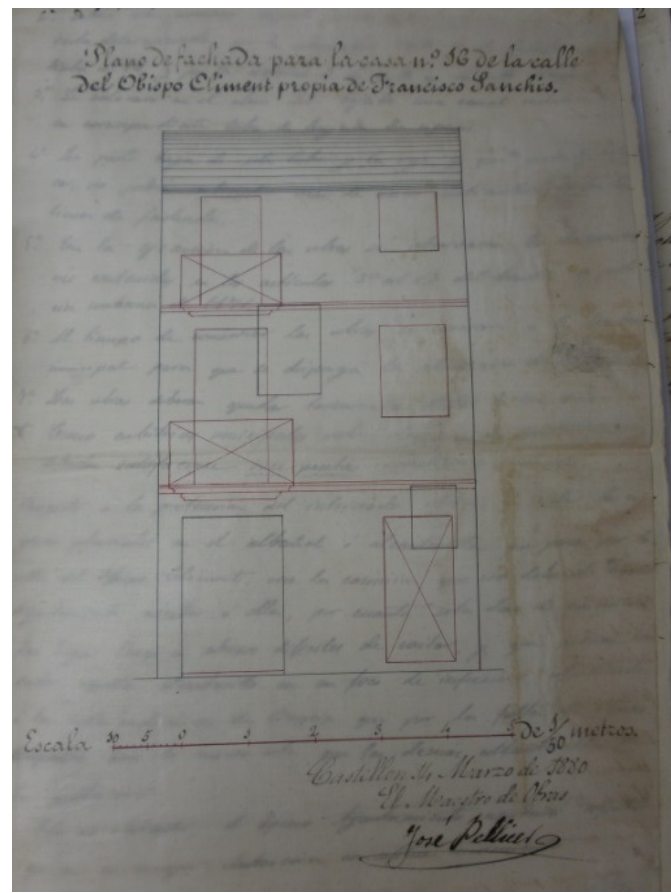

Modificación y elevación de planta, donde aparece

dibujada la fachada actual y la proyectada

Planos de licencias de obras de 1880. Fuente: Archivo Municipal de Castellón

Entre las observaciones e incidencias, que generalmente aparecen en los informes técnicos de la Comisión de policía urbana para la concesión de licencias, figura como fijar las alineaciones de las fachadas y la insistencia de que la distribución de los huecos de las fachadas estén ordenados y simétricos. ${ }^{261}$ Ver los planos adjuntos.

${ }^{261}$ Se transcribe concesión de licencias de obras de 26 de junio de 1885, en donde se expresan estos extremos y otras condiciones: «La importancia de la obra y la posición especial que ocupa, hizo fijar la atención de los infrascritos, en primer lugar en las líneas de sus fachadas, y del examen de la misma resultó, que la de la calle de Moreras es tal que el día que se haga el proyecto de esta calle debe respetarse forzosamente, ya que es una recta que afecta a gran número de casas y no puede ser sustituida con ventaja por ninguna otra, opinando en consecuencia los infrascritos por su conservación. Por idénticas razones debe conservase la de la calle principal del edificio recayente a la calle de San Roque, pero no sucede lo propio en la de la calle San Félix [...] Respecto a las fachadas en sí mismas oponían los infrascritos: $1^{\circ}$ que la de la calle de Moreras produce un mal efecto la desigual separación de las líneas de huecos, por lo que debe obligarse al dueño de la casa, que lo disponga de una manera más simétrica presentando un nuevo plano a la aprobación del Excmo. Ayuntamiento; $2^{\circ}$ que la altura del $2^{\circ}$ piso es escasa en prejuicio del buen aspecto de la fachada y de las buenas condiciones de la habitación, por lo que deberá elevarse dicho segundo piso hasta que tenga dos metros y medio por lo menos entre el pavimento y la parte inferior de los maderos de cubierta. La fachada de la calles san Roque se considera aceptable, pero habrá que recorrer el hueco de la puerta hasta que venga al centro de la fachada [...] Además de las condiciones de lo hasta ahora expuesto, se desprenden las siguientes $1^{\text {a }}$ La obra se hará con solidez gastando buenos materiales y empleándolos según las reglas del arte. $2^{\mathrm{a}}$ se colocaran canales en los aleros de todos los tejados, provistos de los necesarios tubos de bajada de aguas $3^{\circ}$ Se pintaran las fachadas empleando. colores claros agradables y poco brillantes, y destacando los elementos de construcción del edificio [...] En la ejecución de la obra se tendrá presentes las disposiciones de los artículos 3 al 13 del bando de 
Con la aprobación del Reglamento de Policía de 26 de junio de 1901, la documentación que se presenta para la concesión de licencias de obras de nueva construcción de edificios, es mucho más exhaustiva en relación a las condiciones de habitabilidad e higiene del interior de las viviendas.

Junto a una memoria técnica de materiales y obras a realizar, se acompaña una colección de planos explicativos de las condiciones métricas e higiénicas a cumplir en la nueva vivienda.

Además de los planos ya comentados de situación del solar y de fachadas, figuran planos de cada uno de los pisos de la casa, en donde aparece dibujada la distribución de las diferentes estancias con su nombre y dimensiones. Todas las habitaciones tienen huecos de iluminación y ventilación a la calle o a los patios interiores. Se constata una diferenciación de funciones, en donde la cocina está separada del comedor con ventilación propia. El retrete está situado junto a la cocina y ocupa un pequeño cuarto ventilado. Todas las estancias se pueden aislarse con puertas para preservar la intimidad. Tal y como lo exigen los reglamentos de higiene y policía.

También existe un plano denominado de «obras subterráneas», en donde aparece dibujado con medidas la red de colectores; los depósitos de letrinas, al que vierten las aguas fecales, que pasa por un proceso de decantación, para su posterior evacuación, y un pozo sumidero (pozo ciego) al que vierten canalizadas las aguas de lluvia procedentes de los patios interiores y de los tejados que recaen a ellos.

Por último, en el plano denominado de sección vertical, aparecen marcados los distintos pisos con la dimensión de altura y el tipo de escalera. Por encima de la cubierta sobresale la chimenea de extracción de humos de las cocinas y el tubo de ventilación de los depósitos de letrinas. Se pueden ver estas descripciones en las láminas adjuntas.

policía de 1871[...]», en Archivo Municipal de Castellón: Informes licencias de obras: Año1885, Registro general 207; Expediente-7. Informe de Comisión de Policía Urbana, asociada del arquitecto municipal de 26 de junio de 1885 de proyecto de una de nueva en calle de San Félix, esquina con calle Moreras y calle de San Roque, propiedad de Juan Torres Sangüesa. 


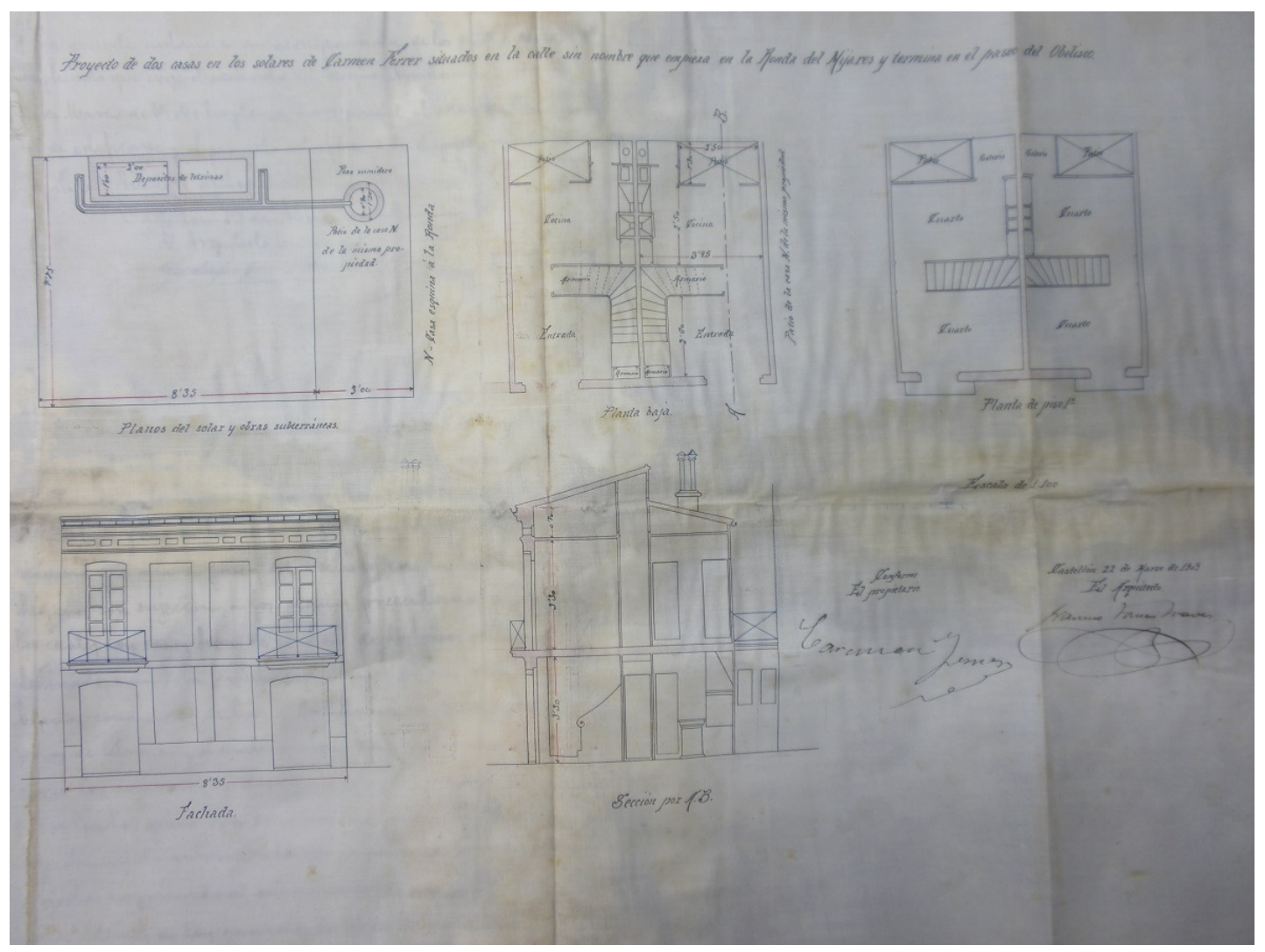

Planos: planta baja, planta primera, alzado, sección AB y plano del solar y «obras subterráneas». Expediente de licencia de obras 25/1909. Fuente: Archivo Municipal de Castellón

Se transcribe el informe técnico de concesión de licencia (25/1909) del proyecto de dos casas en los solares de Carmen Ferrer, situados en la calle sin nombre que empieza en la Ronda Mijares y termina en el paseo del Obelisco, que aparece dibujado en la ilustración superior:

\section{Excmo. Ayuntamiento.}

La comisión de policía urbana asociada del arquitecto municipal, se ha enterado de la instancia de Carmen Ferrer, solicitando autorización para construir dos casas en solares cerrados que posee en los números pares de la calle sin nombre que une el Paseo del Obelisco con la Ronda Magdalena con sujeción a los planos presentados; según los cuales las casas han de constar de dos pisos cada uno destinados solo para habitación, cuyas piezas reúnen buenas condiciones de luz y ventilación directa. Los pozos de letrinas están bien situados así como las cañerías de desagüe afluentes a ellos.

Por tanto, opina esta comisión que puede el Excmo. Ayuntamiento autorizar la ejecución de obra proyectada, imponiendo al peticionario las siguientes condiciones además de las generales de 26 de Julio de 1901.

$1^{a}$ La fachada se construirá según el plano presentado a la misma línea que la acera de enfrente dejando para la calle un espacio libre de doce metros.

$2^{\mathrm{a}}$ La obra deberá quedar terminada a los seis meses de expedida la licencia. 


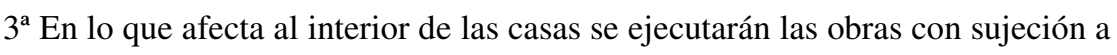
los planos presentados y prescripciones siguientes.

a) Se colocará un tubo de ventilación para los pozos de letrinas que sobresalga del tejado y tenga de doce a quince centímetros de diámetro.

b) Las fábricas de las conducciones y pozo de letrinas serán de mortero hidráulico y se enlucirán con buen mortero de cemento que asegure la impermeabilidad de estas construcciones.

c) Se colocaran canales en los aleros de todos los tejados, provistos de los necesarios tubos de bajada de aguas.

d) Se solarán los patios de ladrillo o losas para evitar el encharcamiento e infiltración en el terreno de las aguas que en ellos se viertan.

La ejecución de las obras estará sujeta a la inspección del Ayuntamiento ejercida por las comisiones de policía urbana.

Castellón 13 de junio de 1909

El Arquitecto municipal, Godofredo Ros de Ursinos.
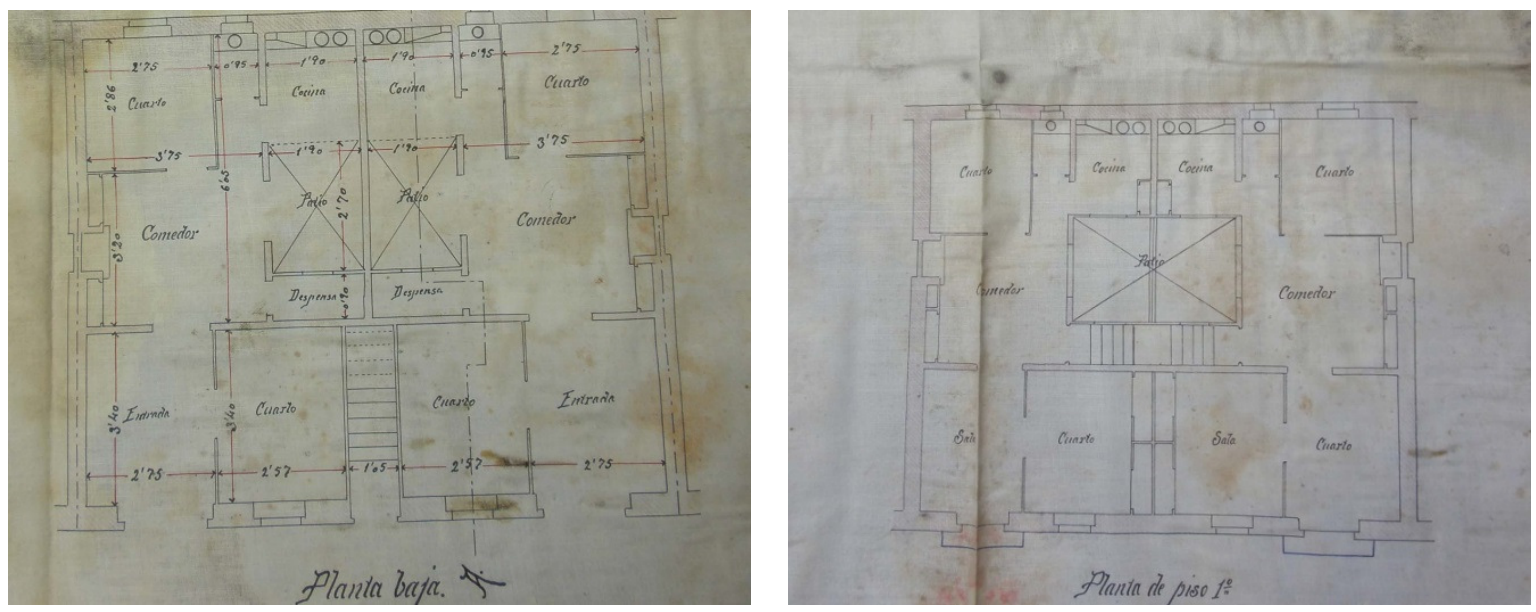

Nivel de habitabilidad de viviendas de nueva construcción a principios del siglo XX.

Planos de distribución y huecos de iluminación y ventilación a fachada y patios interiores de todas las habitaciones. Separación de cocina y retrete. Expediente de licencia de obras 13/1909.

Fuente: Archivo Municipal de Castellón 
A finales de la primera década, el nuevo Reglamento de Higiene Municipal de Castellón de la Plana, de 1908, introduce pocas novedades higiénicas en las viviendas, sobre las que ya se veían aplicando. Una de ellas, es el Art. 7.2, por el cual, la concesión de la habitabilidad de las nuevas viviendas y de los locales públicos, requieren del informe favorable del Inspector de Sanidad y de la autorización de la Junta de Sanidad. ${ }^{262}$ Situación, que por otro lado, se venía produciendo con anterioridad, y que este Reglamento recoge ahora expresamente, ampliando sus competencias.

Transcribimos el Articulo.7, que hace referencia a las condiciones de habitabilidad y control higienicos.

«Art.7 De las condiciones sanitarias de las viviendas y establecimientos públicos y privados.

1.- Como regla general, todos los departamentos de una casa destinados a habitación deberá recibir luz y aire del exterior. Los dormitorios deberán tener una cubicación minima de 20 metros por persona. La cocina una iluminación natural suficiente y una ventilación independiente del resto de la casa.

Los patios interiores deben tener una superficie suficiente para que la luz del sol bañe su suelo en todas las estaciones Debe impedirse por cuantos medios sean posibles la humedad en los suelos y paredes, a cuyo fin se ha de procurar el aislamiento de los muros y de los pisos, del suelo subsuelo húmedo, por medio de materiales impermeables, una absoluta impermeabilización en las cañerías de aguas potables y residuales y una construcción irreprochable de los pozos negros y letrinas que necesariamente debe tener toda casa, con ventilación directa al patio interior.

2.- Para la habitación de nuevas viviendas particulares y de establecimientos públicos o privados, será indispensable la autorización de la Junta de Sanidad, como dispone el art. 115 de la Instrucción. A este fin informará a la Junta el Inspector de Sanidad previa visita que realice ordenada por el Ayuntamiento [...]»

Tampoco las Prescripciones Sanitarias acordadas por la Junta Provincial de Sanidad de 1911 y aprobadas por el Ayuntamiento de Castellón introducen novedades en las condiciones higiénicas de las viviendas.

\footnotetext{
${ }^{262}$ Con la aprobación de la Instrucción General de Sanidad de 1904, se inicia la descentralización de la organización sanitaria, reestructurándose las antiguas Juntas Provinciales de Sanidad y la del Cuerpo de Inspectores Municipales de Sanidad. Aunque hasta 1925 no se aprueban los Reglamentos de Sanidad Municipal y Provincial.
} 
Consultados los expedientes de obras de los periodos 1920 y 1930, no se observan cambios apreciables en la documentación técnica a presentar para la concesión de licencias de obras, de las que ya se exigían en los primeros años del siglo XX.

Los planos y las descripciones escritas reflejan similares condiciones de habitabilidad. Figurando aún, y en todos los casos, el plano de «obras de subsuelo», con las balsas de letrinas y el pozo ciego. Lo que hace suponer que aún no estaba completa la red municipal de alcantarillado con su sistema de depuración, o que el Ayuntamiento seguía permitiendo el anterior sistema de vertido.

Conviene destacar de los expedientes de licencias de obras de viviendas consultados, que el nivel de exigencia de habitabilidad e higiene era el mismo para cualquier sector de la ciudad.

A mediados de la segunda década del siglo XX, empiezan a aparecer permisos de obras en diferentes zonas de la ciudad para la instalación de electro-bombas en las viviendas y en las industrias. Lo que hace suponer que ya existe una red general de agua potable que abastece a toda la capital.

Para una aproximación a la actividad constructiva podemos decir, que hasta 1900 más del 70 por cien de las licencias de obras eran reformas de fachada o elevación de uno o varios pisos. Se localizaban generalmente en las calles principales, en las secundarias del centro y en los antiguos arrabales de San Félix y de la Trinidad. Los expedientes de licencias de nuevas edificaciones figuran por lo general en los nuevos ensanches y en el extremo norte del barrio de San Félix, junto a la cárcel nueva.

En las dos primeras décadas del siglo XX el porcentaje se invierte, figurando casi un 70 por cien de licencias de nueva construcción, localizándose preferentemente en la zona centro de la ciudad, hasta el límite con los ensanches.

También empiezan a aparecer, a partir de la primera década del siglo XX, expedientes de licencias de obra de importantes casas burguesas unifamiliares, aunque predominan las casas por pisos, en las calles más céntricas de la ciudad.

En las dos últimas décadas del siglo XIX, la media anual de licencias de obras pasa de 100 a 120 expedientes, incluyendo tanto las obras de reformas como las construcciones de nueva planta.

En las dos primeras décadas del XX, los expedientes por año evolucionan de 160 a 200, y en la década de los años treinta sobrepasan los 250 expedientes por año. 
Se trata en muchos casos de viviendas unifamiliares. Cuando se presentan agrupadas no sobrepasan las dos o tres viviendas adosadas, siendo menos frecuentes las viviendas por pisos. En general no sobrepasan las tres cuatro alturas. Las superficies son en general reducidas y la construcción sencilla.
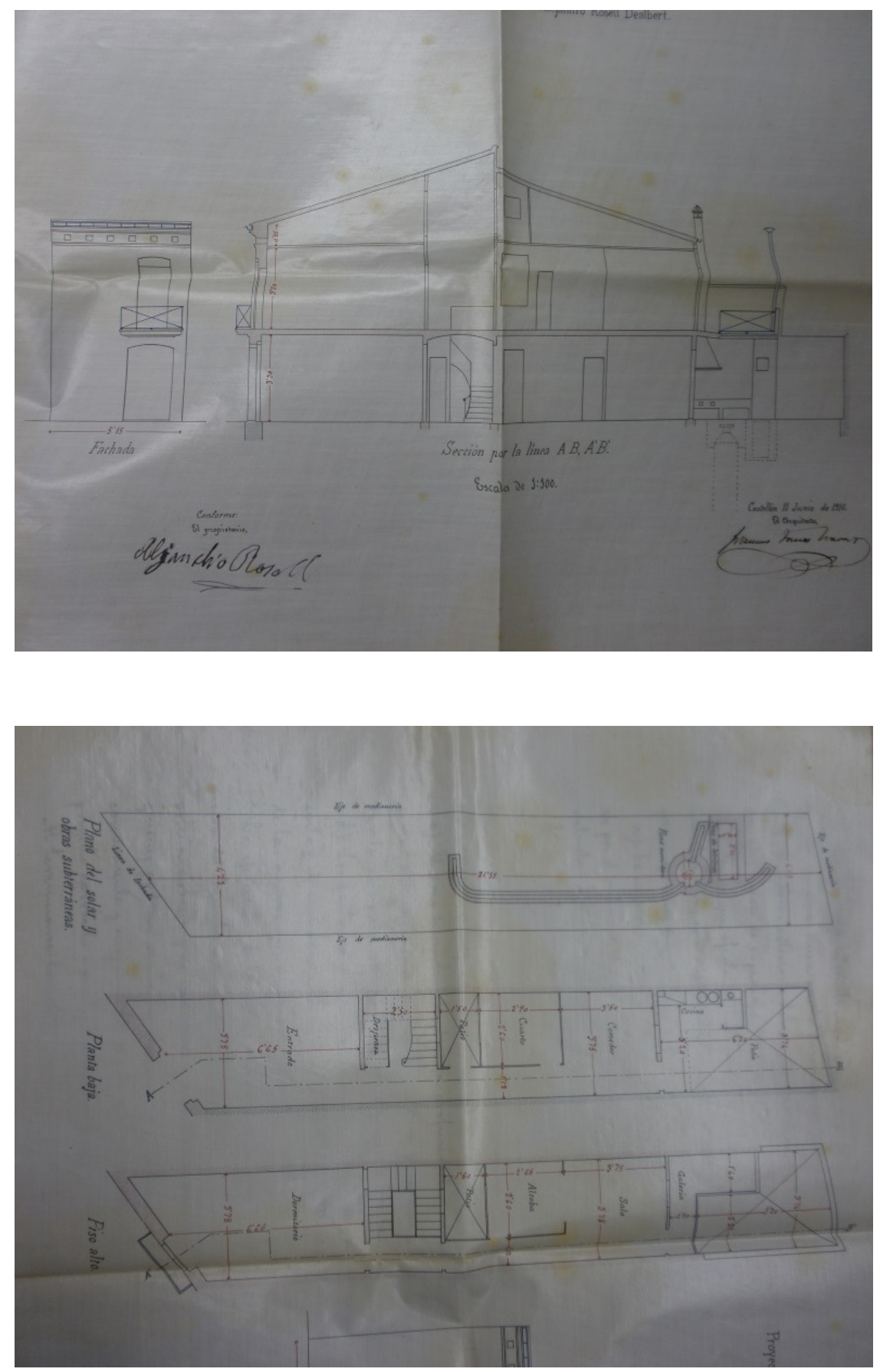

Plantas de distribución, alzado, plano de «obras subterráneas» (depósito de letrinas y pozo ciego) y sección por línea $\mathrm{AB}$, con los conductos de chimenea de la cocina y ventilación del depósito de letrinas. Expediente de licencia de obras 37/1909. Fuente: Archivo Municipal de Castellón 


\section{HIGIENE DE LAS AGUAS}

En Castellón, los dueños de las cisternas se quejaban del mal estado en que se encontraba el Sequiol, ${ }^{263}$ canal por donde llegaban a la población las aguas potables con que se llenaban dichos depósitos. ${ }^{264}$

En las primeras décadas del siglo XX, el Inspector provincial de Sanidad, José Clará, se preocupó por estudiar las condiciones de las aguas que servían para abastecer los diferentes pueblos de la provincia, con objeto de que la autoridad gubernativa obligara a los municipios a realizar las mejoras indispensables para aumentar los caudales y que aquellas reunieran las condiciones de potabilidad. ${ }^{265}$

El gobernador civil, a la vista de los resultados de dichos estudios, ordenó a las Juntas locales de Sanidad que realizaran aquellas obras que proponía la inspección de sanidad. ${ }^{266}$

En 1914 el prestigioso médico, Vicente Gea Mariño, escribe un artículo en El Clamor haciendo una crítica a los señores que componían la comisión permanente de la Junta de Sanidad por la falta de agua en Castellón.

\footnotetext{
${ }^{263}$ El Sequiol. Se trata de una acequia secundaria que regaba el alters-zonas más elevadas situadas por encima de la cota de la acequia Mayor- junto a la antigua Vila medieval. La acequia fue también conocida, dentro de las murallas, como séquia de les monges por abastecer el huerto del convento que éstas tenían en Santa Clara, en la actual plaza del mismo nombre. A finales del siglo XVI se abastecía un lavadero y un abrevadero para animales junto al camino del mar, antes de entrar en la ciudad, mientras que en su interior se documentan huertos en las parroquias de Santa María y Santo Tomás, en el extremo meridional y oriental de la Vila. Además de una sabonería en el carrer d'aigua que antes fue utilizada como baño público. De hecho, las mismas ordenanzas indicaban que los domingos, desde la salida del sol hasta su puesta, el caudal de agua de esta acequia entraba dentro de la ciudad para regar los huertos y llenar las cisternas de las casas. GUINOT RODRIGUEZ, Enrique; SELMA CASTELL, Sergi. (2002): Las Acequias de la Plana de Castelló. Camins D’Aigua. El Patrimonio Hidraúlico Valenciano, Valencia, Generalitat Valenciana. p. 96.

${ }^{264}$ La Provincia, 23/02/1888.

${ }^{265}$ El capítulo II y artículo $6^{\circ}$ del Reglamento de Higiene municipal del año 1908, dice que:« Las aguas destinadas al consumo público procedente de la Rambla de la Viuda deberán ser captadas, filtradas, recogidas en depósitos y canalizadas por la población en las condiciones precisas para asegurar su limpieza, para impedir que contengan materia orgánica o los productos de su descomposición y para evitar que puedan en su largo trayecto contaminarse, transformándose en vehículo apropiado de enfermedades para sus consumidores; Iguales condiciones han de tener las de los pozos y las que procedentes del río Mijares se depositen en las cisternas particulares de las casas; la Junta procederá al estudio del importantísimo problema del servicio de aguas potables de la población, sin duda el que más interesa a su salubridad, sin desmayar por sus muchas dificultaders y proponiéndose mejorarle hasta llegar al desiderátum, que es tener agua con exceso, desprovista de bacterias y de materia orgánica y en absoluto protegida contra las contaminaciones exteriores. Por el Laboratorio municipal se practicaran análisis químicos y bacteriológicos de las aguas de que se abastece la población, mensualmente por lo menos en épocas normales y diariamente durante las epidemias o cuando existan fundados temores de que puedan desarrollarse».

${ }^{266}$ El Clamor 19/04/1912.
} 
Castellón estaba falto de agua; en muchas casas no tenían ni la precisa para beber y en estas condiciones la higiene era un mito y «los organismos encargados de vigilar por ella solo sirven para extender títulos honoríficos a los individuos que la componen».

Con esas condiciones las fiebres tifoideas eran muy corrientes en la población. Sólo una medida inmediata había que tomar: «mandar que por encima de todo y contra viento y marea llenara la Sociedad Fomento Agrícola los depósitos y así solucionar el conflicto por quince o veinte días».

La salud pública estaba amenazada de serios peligros por la falta de agua en la Ciudad. ${ }^{267}$

El 30 de marzo de 1914 se reunieron con el Gobernador Civil, el Inspector de Sanidad y comisiones del Ayuntamiento y Fomento Agrícola llegando a un acuerdo para que la sociedad de las aguas potables contratara con algunos pozos el suministro de agua, combinándolos de forma que la facilitaran durante las veinticuatro horas del día, llevándolas por cañería cerrada.

\section{HIGIENE DE LOS ALIMENTOS}

A lo largo de todo el siglo XIX, y particularmente a partir de 1834, se desarrolló un amplio marco legislativo que aspiraba a regular las condiciones de salubridad de los mercados y también de otros lugares de venta de alimentos, así como de los mataderos públicos y privados. Este despliegue normativo se desarrolló paralelamente a la consolidación de un marco sanitario municipal. Durante los años centrales del siglo XIX se intensificó la presión política para mejorar el control de la salubridad de los alimentos y concretamente de la carne y su comercialización. ${ }^{268}$

Las medidas de vigilancia y control de alimentos se acentuaban considerablemente de forma automática ante la amenaza de epidemias o durante su desarrollo. Una medida habitual era la de prohibir la entrada en el municipio de verduras, frutas y hortalizas procedentes de zonas infectadas por epidemias. Pero también se adoptaban otras como ordenar el traslado de pescaderías, carnicerías u

\footnotetext{
${ }^{267}$ El Clamor 26/03/1914.

${ }^{268}$ BARONA op. cit., p. 121.
} 
hornos, al informar la inspección que estaban situados en lugares poco ventilados y ser considerados focos activos de infección. ${ }^{269}$

El Ayuntamiento de Castellón tomó medidas higiénicas destinadas a observar la higiene del matadero y el transporte de reses desde el mismo a los puntos de venta.

En Sesión Ordinaria de 18 de marzo de 1880, acordó blanquear el matadero público y que el traslado de reses muertas, desde dicho establecimiento hasta las casas particulares o puntos de venta, se hiciera en carruajes construidos exprofeso, completamente cerrados por telas metálicas, según aconsejaban las reglas de ornato y limpieza que debían observarse en toda población y muy particularmente en una capital de provincia. ${ }^{270}$

Más adelante se prohibió la conducción de carnes al hombro y de la manera «repugnante con que hoy se hace». ${ }^{271}$

Se acordó la limpieza de la acequia de riego de la partida de Rafalafena en el trayecto que pasa por debajo del matadero público. ${ }^{272}$

Se habían observado varios casos de cerdos con elefantiasis, el Ayuntamiento acordó que se arrojasen al sumidero para evitar las malas consecuencias para la salud pública. Este acuerdo se fundaba, aparte de las nociones de higiene y salud pública que se iban cumpliendo, en la ordenanza 78 de las de esta ciudad que prevenía que el concejal de mes velara para que la carne que se vendía en las carnicerías estuviera sin el menor motivo de sospecha en cuanto a su calidad. ${ }^{273}$

El concejal Francisco Esteve, miembro de la Comisión de Beneficencia y Sanidad, denunciaba que los cerdos atacados de elefantiasis se mataban en las casas particulares, y después se compraban por los tocineros para venderlos luego en los puntos públicos de venta, «cosa que debe impedirse, recomendando al perito proveedor el reconocimiento más escrupuloso». ${ }^{274}$

En Castellón, el público se quejaba del peso y calidad de muchos géneros alimenticios que se vendían en tiendas y puestos de venta, así como de los vinos y aguardientes, por las adulteraciones de que eran objeto. La prensa reiteradamente

\footnotetext{
${ }^{269}$ Ibídem, p. 124.

${ }^{270}$ AACS, 18/03/1880.

${ }^{271}$ AACS, 17/06/1880.

${ }^{272}$ AACS, 7/10/1880.

${ }^{273}$ Ibídem.

${ }^{274}$ AACS, 14/02/1884.
} 
llamaba la atención de las autoridades competentes para que tomaran las medidas oportunas. $^{275}$

Las familias se quejaban de la mala costumbre que tenían las cabreras de ordeñar un poco de leche y mezclarla con un líquido que no se sabía si era agua con almidón, agua con leche o alguna otra adulteración. ${ }^{276}$

El periódico El Clamor recordaba a los vendedores de sustancias alimenticias los artículos 356 y 547 del Código penal.

Artículo 356: El que cualquiera mezcla nociva a la salud alterase las bebidas o comestibles destinadas al consumo público, o vendiese géneros corrompidos, o fabricase o vendiese objetos, cuyo uso sea necesariamente nocivo a la salud, será castigado con las penas de arresto mayor en su grado máximo a prisión correccional en su grado mínimo y multa de 125 a 1250 pesetas.

Artículo 547: El que defraudase a otro en la sustancia, cantidad o calidad de las cosas que lo entregase en virtud de un título obligatorio, será castigado con la pena de arresto mayor $\left[\ldots . .{ }^{277}\right.$

La pescadería estaba situada junto a la cárcel, en la plaza central de la ciudad. Al considerarse que constituían dos focos de infección, la Junta de Sanidad ordenó su traslado a la plaza de María Agustina, resultando «el remedio peor que la enfermedad», pues allí existían en un reducido espacio, el hospital, los lavaderos, el matadero y la cloaca de desagüe del hospital que «apesta y envenena aquella atmosfera.»

Pues justamente en medio de estos focos, algo peores que los hacinados en la plaza de la pescadería, nos han puesto la venta del pescado bajo el resguardo de débiles cañas que no evitaran por cierto rebajar la altísima temperatura durante todo el día que el sol sostiene en la citada plaza de María Agustina.

\footnotetext{
${ }^{275}$ La Provincia, 19/03/1882.

${ }^{276}$ La Provincia, 29/03/85. En las Prescripciones sanitarias acordadas por la Junta Provincial de Sanidad y aprobadas por el Ayuntamietno en 1911, se dice que: «Se extremarán las medidas para impedir la alteración de bebidas y alimentos y en la inspección diaria del mercado, se observará, con el mayor rigor, las carnes, pescados, hortalizas y frutas, decomisando y destruyendo las que no se encuentren en perfectas condiciones de conservación y que pudieran ser perjudiciales para la salud.Se practicarán los análisis de las leches de las vaquerías, para garantizar su calidad e impedir las alteraciones de que pudieran ser objeto». Todas estas prescripciones ya eran recogidas por los reglamentos de higiene municipal de años anteriores.

${ }^{277}$ Ibídem.
} 
¿No sería más higiénico que la venta del pescado se verificara en la plaza de la Paz, punto, que además de ser más céntrico, reúne muchísimas mejores condiciones que el elegido? ${ }^{278}$

La situación de la pescadería en la Plaza de María Agustina ocasionaba muchas quejas de los vecinos, pues debido a lo apartado que se encontraba del centro de la población y a las malas condiciones del tinglado allí construido, no acudía el público «ni siquiera las pescaderas», resintiéndose la venta del pescado.

La prensa pide al Ayuntamiento que el referido puesto se estableciera en otro punto del capital, más céntrico y de mejores condiciones que el que se encontraba. ${ }^{279}$

De todas maneras, se decía que el pescado que se vendía, no reunía las condiciones sanitarias adecuadas. ${ }^{280}$

La higiene en los puestos del mercado dejaba mucho que desear. Se recomendaba cubrir con gasas las carnes, pero la mayor parte de las veces no se cumplía. La fruta se vendía demasiado verde o demasiado madura.

La prensa se queja del poco caso de la recomendación que se hacía de cubrir con gasas las carnes de los puestos del mercado y pide que se retirara de las paradas de la plaza, la fruta verde y excesivamente madura.

También llama la atención del mal estado del carro del matadero y de que se dejase en la plaza, a la disposición de todos los perros, los pilones de cortar la carne durante las horas de venta. ${ }^{281}$

La prensa comenta que Castellón es la ciudad en donde se come más caro que en ninguna, siendo hasta escandaloso el precio de muchos artículos. «Las sardinas que tanto consumen las clases trabajadoras aun siendo muy malas, se pagan a 15 cuartos docena». ${ }^{282}$

Después de la epidemia del cólera, Castellón tenía muchas deficiencias en todos los aspectos higiénicos. La Provincia escribe que Castellón se encuentra en un lamentable atraso en muchísimas mejoras. Lamenta que las calles se rieguen con agua sucia, de la falta de inspección de los artículos de consumo, por lo que era muy

\footnotetext{
${ }^{278}$ El Clamor, 27/07/1884.

${ }^{279}$ La Provincia, 31/08/1884.

${ }^{280}$ La Provincia, 29/03/1885.

${ }^{281}$ El Heraldo de Castellón, 30/07/1896.

${ }^{282}$ La Provincia, 22/02/1885.
} 
frecuente que el comprador se viera defraudado por vendedores sin escrúpulos; la higiene de las calles; los cadáveres de animales como perros y gatos en algunas de las calles, «despidiendo pestíferos miasmas», y los charcos de «agua corrompida que infeccionan la atmosfera.»

Bajo el punto de vista material, necesita muchas mejoras esta ciudad, de las cuales hemos indicado las que no exigen grandes gastos para su realización. Basta que el Ayuntamiento quiera, para que sean una realidad la policía e higiene de las calles. No sucede lo mismo con las otras mejoras correspondientes al orden moral, las cuales exigen para realizarse cuantiosísimos gastos, que acaso el estado precario de la Hacienda municipal no permita. ${ }^{283}$ :

\section{LOS CEMENTERIOS DE CASTELLÓN}

Las políticas municipales de los cementerios y muladares estuvieron directamente condicionadas por una serie de normativas que tendían a regular su ubicación y trazado, así como las condiciones de los enterramientos, especialmente en tiempo de epidemia. La ley de 1877 y la Real Orden de 1910 contenían regulaciones específicas acerca de las condiciones de salubridad de los cementerios y el Estatuto Municipal de 1924 planteaba su municipalización, así como la de los muladares. A partir de ésta última normativa se fue estableciendo la pauta general de no enterrar antes de las 24 horas de certificada la defunción, ni mantener el cadáver más de 24 horas en casa y su traslado al cementerio en carruaje cubierto, para allí ser sepultado en una lápida cerrada herméticamente. ${ }^{284}$

Una Real Orden de 1882 declaraba la obligación de los municipios de velar por las condiciones higiénicas de los cementerios y establecía las siguientes normas: debían emplazarse al menos a medio kilómetro de cualquier núcleo de población; a mayor altura que el pueblo; en sentido contrario a la dirección de los vientos; en terreno calcáreo o arcilloso; lejos de ríos, pozos, fuentes o conducciones de agua de uso doméstico. Por lo que se refiere a sus dimensiones, se establecía que debían estar

\footnotetext{
${ }^{283}$ La Provincia, 3/01/1886.

${ }^{284}$ BARONA VILAR, Josep Lluís. (2002). Salud, enfermedad y muerte. La sociedad valenciana entre 1833 y 1939. Institució Alfons el Magnànim, Valencia. pp. 285-286.
} 
perfectamente rodeados de un muro de al menos dos metros de alto y tener una extensión al menos cinco veces mayor que las defunciones estimadas al año, para no tener que remover la tierra de las sepulturas al practicar una inhumación, al menos en cinco años. Cada fosa debía tener dos metros de largo por ochenta centímetros de ancho, y entre metro y medio y dos metros de profundidad, teniéndose que reservar en torno a medio metro entre las sepulturas. Había que disponer también de una sala de autopsias, un mortuorio, una capilla y un cuarto para el vigilante. Estas novedades legislativas provocaron de inmediato, en muchos municipios, las inspecciones y los informes en los que se analizaban las deficiencias y los incumplimientos. ${ }^{285}$

Ante la deficiente situación que presentaban la mayoría de los cementerios de la provincia de Castellón, las respectivas juntas de sanidad proponían la construcción de otro nuevo en un lugar más apartado del núcleo urbano y en mejores condiciones topográficas, en función del régimen de los vientos había que destinar un lugar apartado para depositar los animales muertos.

En Castellón, el primer cementerio comunal se construyó en 1320, en la llamada Plaza Vieja, después llamada de la Constitución, en el sitio donde estaba ubicado un mercadillo, y una posada convertida al final del siglo XVII en Palacio Municipal, al lado de éste se encontraban la carnicería y pescadería.

Posteriormente se acordó por el Ayuntamiento la desaparición del antiguo Cementerio de la Plaza Vieja, y se pensó en la construcción de otro nuevo, emplazado detrás del calvario, en el lugar que hoy ocupa el Paseo Ribalta.

El nuevo cementerio se llamó del Calvario, por estar a espaldas del mismo, «950 pasos de la Iglesia Mayor y a 400 de las últimas casas del poblado».

Empezaron las obras el 17 de octubre de 1803, y se concluyeron las mismas el 31 de enero de 1804.

El incesante desarrollo de la población de Castellón hizo pensar en la necesidad de su traslado, construyéndose otro nuevo en 1860.

El Ayuntamiento acordó el 19 de noviembre de 1868 construir en el solar que ocupaba el Cementerio del Calvario, un Paseo, dándole el nombre del célebre pintor Ribalta y colocar la estatua de éste en su centro.

${ }^{285}$. Ibídem, pp. 286-287. 
El gran desarrollo de la edificación urbana hizo que, al cabo de medio siglo de existencia, hubiera necesidad de trasladar el Cementerio del Calvario a otro sitio más distante de la población, emplazándose el mismo al otro lado del río seco, realizándose las obras bajo la dirección del arquitecto Manuel Montesinos Arlándiz, terminándose las mismas el 6 de octubre de $1860 .^{286}$

Un problema de higiene era el traslado de los féretros desde la Iglesia parroquial al cementerio público, pues constituía un espectáculo poco edificante para la población castellonense. En sesión ordinaria de 15 de enero de 1880, el Ayuntamiento de Castellón acuerda variar el itinerario de los coches fúnebres que desde la Iglesia parroquial se dirigían al cementerio público. Al construirse el paseo de Ribalta la población en masa pedía que se evitara en un lugar de distracción y esparcimiento el frecuente espectáculo de los entierros que por sus inmediaciones pasaban. El Ayuntamiento presidido por Domingo Herrero, haciéndose fiel intérprete de los deseos de la población en sesión de 9 de mayo de 1876, acordó comprar los terrenos que debía ocupar el nuevo camino del cementerio, venciendo las dificultades económicas que a ello se oponían. La opinión general deseaba que el tránsito de los cortejos fúnebres, dentro de la población, se verificase por el camino más corto y excusado apartándolo de las calles más conocidas de la ciudad. ${ }^{287}$

En muchos pueblos de la provincia, a pesar de lo dispuesto en circulares y reales órdenes, tenían el cementerio dentro de los pueblos: Artana, Almazora, Arañuel, Catí. Cirat, Canet lo Roig, Castell de Cabres, Corachar, Fanzara, Ballestar, Gaibiel, Vallibona y Zucaina. ${ }^{288}$

Dentro de las casas, existía la costumbre, aun estando condenado por las leyes, de rodear a los difuntos por sus parientes y convecinos por espacio de 24 horas «aspirando los pestilentes miasmas que despiden». ${ }^{289}$

En pueblos importantes de la provincia como Almazora, además de tener el cementerio dentro de la ciudad, se toleraba la celebración de oficios, con los cadáveres

\footnotetext{
${ }^{286}$ GIMENO MiChavila, Vicente. (1984). Del Castellón Viejo. Publicaciones de Seminario de Estudios Económicos y Sociales de la Caja de Ahorros y Monte de Piedad de Castellón. pp. 180-186.

${ }^{287}$ Actas del Ayuntamiento de Castellón (a partir de ahora AACS), 15/01/1880.

${ }^{288}$ La Provincia, 18/07/1880.

${ }^{289}$ El Clamor, 19/08/1883. Según el artículo $8^{\circ}$ del Reglamento de Higiene Municipal de Castellón de la Plana de 1911, la permanencia de un cadáver en la casa mortuoria no podía exceder de veinticuatro horas y, la conducción de los cadáveres se debía efectuar siempre en cajas o ataúdes cerrados y por el camino más corto de la casa mortuoria al cementerio.
} 
al descubierto durante la celebración y, además, los cadáveres se trasladaban descubiertos desde la casa mortuoria a la iglesia y desde esta al cementerio. En Almazora cadáveres tifoideos eran expuestos en los zaguanes de las casas con grave peligro de la salud pública. ${ }^{290}$

Ante la proximidad del cólera de 1885 , la prensa insta a los ayuntamientos a que adoptara con tiempo, enérgicas y radicales medidas encaminadas a sostener la salud pública. Para ello denuncian todos los abusos y faltas contrarias a la higiene.

Denuncian el estado de los cementerios de la provincia. En Herbés, el cementerio estaba enclavado dentro del casco de la población y en sitio poco ventilado; en Peñarroya, tenía también el campo santo junto a la plaza principal del pueblo, con los agravantes de que por la misma puerta se entraba a la escuela y al cementerio, y los niños veían de cerca las inhumaciones cuando estaban en clase, «aspirando las emanaciones que se desprenden de la morada de la muerte». El Clamor propone a los Gobernadores de Castellón y Teruel, a que pertenecían respectivamente los pueblos citados corregir cuanto antes ésta faltas. ${ }^{291}$

\section{LA PRENSA FIEL REFLEJO DE LA PREOCUPACIÓN POR LA HIGIENE EN CASTELLÓN}

La prensa continuamente se preocupaba por denunciar la falta de higiene en la capital para que el Ayuntamiento no olvidara las prescripciones del Gobernador Civil. Esta preocupación aumentaba cuando llegaban los calores.

En mayo de 1890 se publica una circular del Gobierno Civil ${ }^{292}$ en la que pide que, ante la proximidad de los calores en que la salud pública suele alterarse, principalmente en las localidades donde se descuida la policía sanitaria, que todos los alcaldes cuiden de la salud pública y que mejoren las condiciones higiénicas de sus respectivos distritos, haciendo que desaparezcan todos los focos de infección que en ellos hubiere, y que se cumplieran rigurosamente las leyes sanitarias.

\footnotetext{
${ }^{290}$ El Clamor, $13 / 01 / 1884$ y 20/01/1884.

${ }^{291}$ El Clamor, 19/04/1885.

${ }^{292}$ El Boletín Oficial de la Provincia de Castellón de Castellón 20/05/ 1890. (A partir de ahora BOPCS).
} 
Para conseguirlo recomendaba vigilar constantemente la calidad de los alimentos que se vendían al público, «para que sean puros y sanos», prohibiendo la venta y el tráfico de los que estuvieran alterados, por causa físicas o por la mala fe de los vendedores.

También pedía la vigilancia de los establecimientos de comestibles, de vacas, cabras y burras de leche; los mataderos y lavaderos públicos. Lo mismo se debían vigilar las aguas potables «cuya pureza ha de procurarse» sin olvidar cuanto se refiere a la fabricación y venta del pan, a la salubridad de las carnes y pescados, y a la adulteración de la leche y demás sustancias alimenticias.

Asimismo encomendaba el cuidado y reparación y limpieza de los conductos de aguas sucias, letrinas, sumideros, alcantarillas y arroyos; del aseo de las fuentes, calles, plazas y mercados; de la desaparición de los depósitos de materias animales y vegetales en putrefacción existentes dentro o en las cercanías de la población, prohibiendo de la manera más absoluta el establecimiento de estercoleros que estuvieran situados a menos de 40 metros de las viviendas. Igualmente debía procurarse la extinción de los efluvios pantanosos y vigilar escrupulosamente los cementerios, cuidando que las fosas tuvieran la profundidad conveniente que aconsejaban la ciencia y las leyes.

Para cumplir con todos estas obligaciones, los alcaldes contaban con el auxilio de las Juntas Municipales de Sanidad, de los Médicos titulares, Inspectores de carne y los Veterinarios: $:^{293}$

Cuando aparece el periódico El Heraldo de Castellón en 1895, en su exposición de principios se hace eco de la preocupación por las medidas de higiene que compartía la ciudadanía, los políticos y la prensa en ese momento. Según dice su misión sería apoyar todas las mejoras por la que suspiraba el ciudadano de Castellón:

[...] la terminación de las obras del puerto; las del Hospital, las de la cárcel; el adoquinado de las calles que lo consientan; la construcción de fuentes públicas; la del mercado de hierro en la plaza Vilaroig; la del cuartel de caballería contiguo al fuerte de San Roque; la del alcantarillado; el derribo de los edificios que impidan el ensanche de la vía pública; el saneamiento del inmediato caserío marítimo; el aumento del alumbrado; la escrupulosa observancia de las ordenanzas municipales en los que a los abusos de la higiene y de policía urbana se refiera; la custodia del

\footnotetext{
293 BOPCS, 20/05/1890; La Provincia 25/05/1890.
} 
campo; la conservación de la vía pública y la de los caminos vecinales; los abusos en el peso y en el género de la venta pública. ${ }^{294}$

Siguiendo con su preocupación constante en denunciar los abusos en la falta de higiene, El Heraldo de Castellón escribe un artículo titulado « ¿En dónde estamos en Castellón o en Chodos?», en el que denuncia las acciones insalubres de los ciudadanos de Castellón, y sobre todo la costumbre de matar los cerdos en la vía pública:

¿Estamos en el mísero lugar de Chodos o en la hermosa y culta capital de la Plana?

No es bastante que aquí disponga cada cual a su antojo de la vía pública, aprovechándola a todas horas para taller de sus oficios.

No es bastante tampoco que criadas y mayordomos echen a la calle las aguas sucias de sus fregaderos o sacudan en los balcones las polvorientas pieles y alfombras de las habitaciones de sus señores, que ahora se hace también de la calle matadero público y como si nada ocurriera; como si la ley de policía urbana igual que las ordenanzas municipales se hubieran escrito para los ciegos y no rezaran nada con las autoridades de una capital de provincia de la importancia y del buen nombre de la nuestra.

¿A quién diremos, señor alcalde; a quien haremos creer señores concejales, que en Castellón de la Plana, en una de las más hermosas y más importantes capitales de España se sacrifican cerdos en la vía pública?

A nadie que lo digamos nos dará crédito y sin embargo es un verdad como un templo.

Se sacrifican cerdos en las calles de Castellón de la Plana y se sacrifican y ciencia y paciencia de las autoridades y a la paciencia y ciencia también de un matadero que le cuesta su dinero al vecindario.

Lo que ocurre aquí no ocurre ciertamente, no ya en el lugar de Chodos que es el que demasiado ligeramente hemos elegido para compararlo con Castellón, no, si no en la más miserable aldea del rincón más olvidado de España.

Sacrificar cerdos en las calles de Castellón y a la luz de la aliaga y del romero; aquí, donde hay un matadero, aparte de otros mil sitios apartados para llevar

${ }^{294}$ El Heraldo de Castellón, 2/01/1895. 
a cabo cómodamente la clase de sacrificios a que nos referimos, era lo único que nos faltaba ver en esta ciudad.

¿Es, en Castellón donde vivimos o vivimos en el caserío del Tormo de Cirat?

¡Señor alcalde!

¡Señores concejales del xcelentísimo ayuntamiento de Castellón1

Más favor para la capital de la Plana y menos tolerancia para los que equivocados seguramente viven hoy en Castellón la vida del Castellón del año 2.

Pase-que no debía pasar-lo de cada vecino disponga a su capricho de la vía pública.

Pase también- que tampoco debía pasar-lo de que las criadas conviertan en letrinas de los corrales de sus casas, el arroyo de la calle.

Pero lo de la matanza de los cerdos en aquel mismo sitio, eso, señor alcalde; eso, señores concejales, no puede pasar. ${ }^{295}$

En otro artículo, denunciaba que las aguas residuales se vertían directamente a la calle; que las casas del vecindario eran frontones para el juego de pelota de los niños; las alfombras y las pieles se sacudían en los balcones y ventanas; se regaba a todas horas las macetas que se cultivaban en los balcones, mojando a los transeúntes, y por último denuncia que los vecinos ocupen las calles ya sea para la industria, recreo, etc., haciendo el uso contrario de lo que mandaban las Ordenanzas municipales. El Heraldo de Castellón hace referencia a la necesidad de aumentar el servicio de policía del Ayuntamiento para vigilar estas actuaciones:

El buen nombre de Castellón y la importancia de una capital como la nuestra, bien merece un servicio de policía más escrupuloso que el que tiene, y a eso vamos por el presente ruego, con la promesa formal de no volver a ocuparnos más del asunto, cansados de clamar en el desierto y convencidos del aburrimiento de nuestros lectores por nuestra insistencia en la atendible materia del objeto mismo de las presentes líneas. ${ }^{296}$

${ }^{295}$ El Heraldo de Castellón, 23/01/1895.

${ }^{296}$ El Heraldo de Castellón, 13/02/1895. 
Más adelante, ante la indiferencia del Ayuntamiento, El Heraldo de Castellón dirige una carta al Gobernador denunciando la matanza de cerdos en la vía pública «porque muy lejos de corregirse; aumenta cada día con más extraordinario escándalo». «Dispuestos a proscribir de la hermosa y culta capital de la Plana las costumbres y silencio de la alcaldía de Castellón y acudimos a V.S. para que prohíba terminantemente la matanza de cerdos en la vía pública, librando a este vecindario de un espectáculo tan repugnante e inculto como el que nos ocupa [...].» ${ }^{297}$

La higiene de Castellón en las dos primeras décadas del siglo XX, no cambió significativamente, un artículo publicado en El Clamor por el médico republicano, Vicente Gea, deja bien a las claras cual era la situación de la ciudad.

Gea escribe dicho artículo ante la amenaza de invasión de la epidemia gripal. En el artículo hace una crítica de la higiene en la ciudad de Castellón.

El artículo titulado «Para hacer higiene se necesitan tres cosas: DINERO, DINERO Y MUCHO DINERO» expone que en un país palúdico por excelencia, aún no se había hecho ningún estudio sobre el Paludismo.

Castellón tenía en 1918 una población de 35.000 habitantes y solo disponía de agua de «mala calidad» para una población de 10.000; el agua de la Rambla de la Viuda estaba infectada y la de los pozos no era potable.

Como consecuencia de la escasez de agua no se podía realizar la evacuación de los residuos orgánicos. El alcantarillado servía para verter las aguas sucias, los retretes y todos los líquidos residuales con grave peligro para la salud de la población. En las alcantarillas fermentaban los productos residuales y se convertían en un foco de infección.

La mayor parte de las viviendas tenían falta de luz y ventilación, habitaciones pequeñas, subsuelo húmedo e infectado en la mayor parte de las casas. En ellas se almacenaban las basuras y se dejaba que fermentara varios meses para convertirse luego en estiércol. Además convivían con las personas crías de cerdos, conejos y otros animales.

En cuanto a la higiene individual de las personas, Gea afirma que éstas sólo se bañan en verano o «cuando llueve si lo coge fuera de casa», «vive para la calle más que para sí y procura vestir mejor que comer. Gasta en lo superfluo más que en lo necesario.

${ }^{297}$ El Heraldo de Castellón, 16/02/1895. 
Desconoce las más elementales prácticas higiénicas respecto al uso de alimentos, bebidas, norma de vida, etc.»

$\mathrm{Y}$ ahora se nos ocurre preguntar icree alguien, pensando de buena fe, que con una reunión más o menos de la junta $\mathrm{A}$, que con una visita o una memoria más del inspector B se va a conseguir modificar este estado de cosas?

Entendemos que no y afirmamos al acabar como exponíamos al comenzar

Lo más caro es la salud, es natural, es lo mejor y para defenderla se necesita sólo dinero para instruir, dinero para destruir y dinero para construir. ${ }^{298}$

${ }^{298}$ El Clamor, 2/09/1918. 


\section{PARTE II: MEDICINA, ENFERMEDAD Y MUERTE EN CASTELLÓN}


Castellón hacia la modernidad. Salud, educación y debate científico (1880-1918)

Parte II 
CAPÍTULO III: LA MEDICINA Y LOS MÉDICOS A FINALES DEL SIGLO XIX Y PRINCIPIOS DEL SIGLO XX 


\section{LA MEDICINA EUROPEA DEL SIGLO XIX Y PRINCIPIOS DEL SIGLO XX: DE LA TEORÍA MICROBIANA DE LAS ENFERMEDADES A LA GENÉTICA}

Al comienzo del siglo XIX la medicina hereda las orientaciones del XVIII y domina un vitalismo que no acaba de renunciar a los últimos reductos del hipocratismo, y ve surgir una serie de nuevas mentalidades que, dando un giro espectacular a la visión del cuerpo humano y de la enfermedad hasta entonces imperante, se encaran con la realidad del proceso morboso mediante la utilización de los recursos de la ciencia positiva que, al revés de las ciencias naturales, intentan y consiguen la objetivación y visualización de la enfermedad por vía no especulativa.

De una parte, en la Francia Napoleónica, una serie de médicos eminentes (Bichat, Corvisart, Bayle, Laennec), seguidos por otros clínicos europeos, fundamentan la medicina científica en el conocimiento de la lesión anatómica que la produce: la enfermedad, para ellos, será simplemente la consecuencia de una alteración estructural más o menos limitada, susceptible de ser estudiada de visu, merced a los recursos diagnósticos que permiten la contemplación directa, desde los métodos endoscópicos hasta el empleo de los rayos x y, si fuera preciso, la cirugía exploratoria. Para los médicos que siguen esta mentalidad anatomoclínica lo fundamental en medicina es el cuerpo humano en su estructura anatómica, en tanto que sede de una lesión morfológica que es preciso modificar, curar o suprimir. ${ }^{299}$

En contraposición a la «medicina hospitalaria» de comienzos del siglo XIX, surge a mediados del siglo, la medicina de laboratorio, cuyo objetivo central fue conseguir, además, una explicación científica de las enfermedades sólidamente fundamentada en los saberes físicos, químicos y biológicos. Por ello, la investigación experimental de laboratorio pasó a ser una fuente primordial de la ciencia médica, tal como afirmó Claude Bernard: «Yo considero el hospital sólo como vestíbulo de la medicina científica, como el primer campo de observación en que debe entrar el médico, pero el verdadero santuario de la medicina científica es el laboratorio».

\footnotetext{
${ }^{299}$ AlBARRaCín TeUlón, Agustín (1993):«Las Ciencias Médicas», en MENÉNDEZ PIDAL, Ramón: Historia de España tomo XXXIX. La Edad de Plata de la cultura española (1898-1936) Identidad. Pensamiento y Vida. Hispanidad. Espasa Calpe, Madrid, pp. 498.
} 
Desde mediados del siglo XIX, el primer cambio fue la indagación microscópica de las lesiones anatómicas y su interpretación mediante la biología celular. Por otra parte, se superó la visión estática de la enfermedad propia de los anatomoclínicos, introduciendo un punto de vista dinámico mediante el estudio de las disfunciones orgánicas con los medios de las ciencias experimentales. Descartando las interpretaciones de tipo especulativo, la orientación fisiopatológica de la «medicina de laboratorio» entendió los trastornos funcionales como procesos energéticos o materiales, investigándolos respectivamente con los recursos de la física y de la química.

La microbiología, contribución etiológica fundamental de la «medicina de laboratorio», se viene desarrollando desde mediados del siglo XIX hasta la actualidad. No puede hablarse de genética médica en sentido estricto hasta la segunda mitad del siglo XX, cuando ha comenzado a fundamentarse en la biología molecular. ${ }^{300}$

A partir de los trabajos fundamentales de Pasteur, Koch y Ehrlich, los médicos europeos comienzan a ver claro: la patología microbiana enseña a considerar aquellas enfermedades como la consecuencia de una agresión bacteriana. El cuerpo humano es ahora importante no por conseguir la sede de una lesión anatómica o ser expresión de una disfunción orgánica, sino en tanto que escenario de la lucha entre una concreta parte de ese, a través de sus células o tejidos, y un microrganismo atacante. La investigación se hacen ahora más complicada porque a la directa acción de las toxinas bacterianas viene a unirse una serie de complejas reacciones biológicas fruto de procesos inmunitarios. El médico puede conocer la enfermedad infecciosa utilizando pruebas que se basan en estas reacciones -aglutinación, precipitación, etc. -, o bien visualizando directamente los gérmenes mediante su cultivo, tinción y utilización del microscopio. La actuación médica consistirá en diagnosticar y combatir la infección con los escasos medios que en el siglo XIX se conocen. ${ }^{301}$

Dos nombres destacan por encima de todos, dos nombres que sin duda merecen el título que con frecuencia se les ha otorgado, el de «benefactores de la humanidad»: el francés Louis Pasteur (1822-1895) y el alemán Robert Koch (1843-1910), los fundadores de la bacteriología, los científicos que descubrieron el origen microbiano de

\footnotetext{
300 PIÑERo LóPEZ, José María (2002): La Medicina en la Historia. La esfera de los Libros, Madrid, p.489.

301 ALBARRACÍn TEULÓN, Agustín (1993), op. cit. pp. 499.
} 
los procesos infectocontagiosos. Pasteur fue un químico y físico que no desdeñó los problemas «aplicados» y que terminó ocupándose de problemas médicos.

Louis Pasteur, no siendo ajeno al mundo que le rodeaba, se interesó por problemas relacionados con la agricultura y con la industria de la seda o de la cerveza, al igual que por el origen de algunas enfermedades; de hecho, existe una continuidad entre sus trabajos en todos ellos. Así, sus estudios sobre disimetría molecular le condujeron a ocuparse del alcohol amílico, activo también ópticamente. Ahora bien, resulta que el alcohol amílico desempeña un papel importante en la fermentación láctica. Al introducirse en el campo de la fermentación, Pasteur demostró que ésta era el resultado de la acción de organismos vivos microscópicos, y que no se producía cuando se excluían o aniquilaban (sometiéndoles, por ejemplo, a la acción del calor, la forma más primitiva de un proceso que, tras ser perfeccionado, recibió, en honor suyo el nombre de pasteurización).

En 1862 escribió «Memoria sobre los corpúsculos organizados que existen en la atmosfera. Examen de la doctrina de las generaciones espontáneas», en el que presentó los resultados con los que demostraba que hay microrganismos que viven en el aire que nos rodea y que pueden contaminar incluso el cultivo más estéril. Mostraba allí, asimismo, que si un caldo de cultivo estéril era introducido en un recipiente sellado al vacío, en el que no podía penetrar el aire, no surgía ningún microorganismo, establecido este punto, era razonable pensar en aplicar el nuevo planteamiento al origen de enfermedades, algo que condujo a Pasteur, hacía 1877, al estudio del ántrax o carbunco, cuya causa asoció también con un microrganismo.

El médico alemán Robert Koch tras desarrollar métodos sencillos para hacer crecer y examinar cultivos bacterianos descubrió el bacilo de la tuberculosis, responsable en aquella época de la muerte en el mundo de millones de personas cada año.

Gracias a las investigaciones de Pasteur y de Koch, y de los que vinieron tras ellos, se llegó a conocer con gran precisión científica la relación causal entre microorganismos y enfermedades infecciosas. Surgió así un modo nuevo de concebir la enfermedad: la teoría microbiana de la enfermedad. 
Producto, asimismo, de la teoría microbiana de la enfermedad fue una extensión radical de las técnicas asociadas a una técnica semiempírica existente desde hacía mucho: la vacunación. ${ }^{302}$

Al final del siglo XIX fue surgiendo la idea de que los procesos responsables de la herencia tienen lugar en el núcleo de las células, más concretamente en los cromosomas. Si a esto le sumamos el redescubrimiento, en 1900, del trabajo de Mendel, nos encontramos con el nacimiento de una nueva ciencia: la genética.

Un médico inglés, Archibald Edward Garrod (1857.1936), fue el primero que relacionó un desorden humano con las leyes mendelianas de la herencia. En 1896, Garrod se interesó por pacientes con un raro, pero poco dañino trastorno, conocido como alcaptonuria, cuya manifestación más llamativa es el oscurecimiento de la orina tras su exposición al aire. Después de una serie de estudios, concluyó que el trastorno era de naturaleza congénita, esto es, que se heredaba de los progenitores; que no era el resultado, como hasta entonces se pensaba, de una infección bacteriana.

Garrod encontró un punto de apoyo en otro genetista británico: William Bateson (1861-1926). Tras licenciarse en la universidad de Cambridge en 1882, Bateson amplió estudios en Estados Unidos, donde se interesó por los problemas relacionados con la evolución de las especies, decidiendo, antes de que se redescubriese el trabajo de Mendel, que las especies no evolucionan de manera continua, sino a «saltos». Instalado de nuevo en su patria, como profesor en Cambridge, Bateson supo de los trabajos que Garrod estaba acometiendo y los interpretó con la ayuda de las ideas de la genética mendeliana, es decir, tomando como base caracteres dominantes y recesivos. ${ }^{303}$

Los trabajos de Garrod no suscitaron mucho interés entre sus contemporáneos, y sus recomendaciones de que se estudiasen las enfermedades en términos bioquímicos no resultaron demasiado eficaces. Los genetistas estaban ocupados con organismos más simples que los seres humanos que él estudiaba, la bioquímica se encontraba todavía en su infancia y muchas de las enfermedades que analizaba Garrod eran poco frecuentes y los médicos rara vez se encontraban con ellas en sus prácticas clínicas. Sin embargo, en la década de 1950, cuando se empezó a comprender el papel directo que los genes

\footnotetext{
302 ORDÓÑEZ, Javier, NAVARRO, Víctor; SÁNCHEZ RON, José Manuel. (2007): Historia de la ciencia. Espasa Calpe, Madrid. pp. 499-502.

${ }^{303}$ Ibídem, 618-621.
} 
desempeñan en la producción de proteínas concretas, Garrod comenzó a adquirir la reputación de que ahora goza como el «padre de la genética química».

Pronto la bioquímica mostró su poder, gracias a las investigaciones de, entre otros, Hans Krebs 1900-1981, o de su maestro, Otto Warburg 1883-1970, responsable del descubrimiento del mecanismo de la oxidación celular. La bioquímica desempeñó un papel central en el estudio de los procesos metabólicos, en la purificación, aislamiento y caracterización de enzimas, cinética de las reacciones que éstas catalizan, y en su integración en efectos fisiológicos, como la contracción muscular o el crecimiento de tejidos. ${ }^{304}$

Más influyente que Garrod, tanto para el desarrollo como para la institucionalización de la genética, fueron las investigaciones de Thomas Hunt Morgan (1866-1945), un estadounidense que se doctoró en 1890 en la Universidad Jons Hopkins y que se distinguió en el estudio de las mutaciones, proceso que constituye el mecanismo responsable de los cambios evolutivos, contrarrestando la estabilidad de la herencia. Morgan era muy escéptico con respecto al mendelismo, esto es, a una teoría de la herencia que utilizase unidades discretas. Su cambio de actitud se debió a las investigaciones que emprendió con Drosophila melanogaster, la mosca del vinagre.

En su libro The Theory of the Gene (La teoría de los genes) escrito en 1928, sintetizó las principales ideas a las que había llegado tras décadas de investigaciones, desarrollando «la teoría de los genes».

El desarrollo de la genética fue abriendo el camino a grandes avances en la comprensión de la vida, hasta el punto que si del siglo XIX se puede decir, en lo que se refiere a las ciencias biomédicas, que fue el siglo de la fisiología, el XX fue el de la genética y de la biología molecular. En el plano teórico, fue entonces cuando se obtuvo una base firme para entender la evolución: al ser ésta la fuente principal de novedad biológica, la mutación de genes se erigía en el motor que la dirigía. Ahora bien, durante la primera mitad del siglo XX, mientras la genética se convertía en la reina de las ciencias biológicas, la naturaleza física del concepto central, el gen, continuó envuelta en el misterio. Todavía en 1950, en un artículo titulado «El desarrollo de la teoría de los genes» Hermann J. Muller (1890-1967), que había sido colaborador de Morgan y se había convertido en uno de los más grandes genéticos y defensores de la teoría de los

${ }^{304}$ Ibídem, pp. 622-623. 
genes, declaraba que nadie sabía de qué estaban hechos los genes, cómo podían ser capaces de imponer su carácter sobre los organismos que los transportan o cómo se reproducen fielmente en la división celular. ${ }^{305}$

\section{LA MEDICINA ESPAÑOLA: DE LOS FERNANDINOS E ISABELINOS A LA JUNTA PARA LA AMPIACIÓN DE ESTUDIOS}

Para entender lo que la medicina española fue a lo largo del siglo XIX, es preciso detenerse previamente en lo que la misma había llegado a ser en los últimos decenios del siglo XVIII.

Por una parte, una Universidad tradicional, anquilosada, en la que la huella de la medicina medieval no permitía abrirse a las nuevas corrientes renovadoras que las universidades europeas inauguraban- tan solo el esfuerzo aislado de los novatores-; de otro lado, algún cambio innovador como el de la Universidad de Valencia de manos de su rector Vicente Blasco, y en tercer término, la institucionalización de una ciencia al margen de la universidad tradicional, la constituida por las Sociedades Médicas. Ya en 1699 se había fundado en Sevilla la Regia sociedad Médica donde se discutía cualquier novedad científica. El choque entre estas Academias y la ciencia oficial universitaria atestigua el muro de incomprensión que ayudaron a alzar y mantener las polémicas que se suscitaron entre partidarios de una tradición médica con vigencia aún en las universidades y quienes, desde nuevas instituciones, propugnaron un cambio innovador.

Las Academias poseían un carácter minoritario frente a la ciencia oficial que se imponía en el mundo europeo de la época; pero no agotan las posibilidades de acceder al saber por caminos al margen de la institución universitaria.

Pero al mismo tiempo, a finales del siglo XVIII, la enseñanza de la cirugía, hasta ahora dispensada en la propia Universidad que forma cirujanos latinos, o en manos de empíricos sin ilustración denominados cirujanos romancistas, ha dado lugar a una profesión menospreciada frente al status social del médico. El utilitarismo de la época va a afectar a tal formación deficitaria, instituyendo los Colegios de Cirugía que van a

\footnotetext{
${ }^{305}$ Ibídem, pp. 624-627.
} 
dar lugar al incremento de la consideración social de los cirujanos, condicionada por la eficacia cada vez mayor de sus actuaciones. Imitando lo que en otros países se ha constituido se crean en España los Reales Colegios de Cirugía, sin duda la institución más importante del siglo XVIII. ${ }^{306}$

La formación que en estos centros reciben los cirujanos primero, y más tarde, a partir de 1827, también los médicos, se caracteriza por un aire innovador, cuyas principales características son: la enseñanza obliga a la utilización de libros extranjeros como textos, con numerosas traducciones; se celebran en ellas juntas en las que se discuten cuestiones médicas; se conceden ayudas económicas a cirujanos para que viajen al extranjero y se contratan cirujanos de otros países, con el deseo de que introduzcan en España la medicina europea.

Los avatares históricos de los primeros años del siglo XIX van a dar lugar a que tales esperanzas se agosten. Ante la situación que vive el país, primero por la propia guerra y más tarde por la represión absolutista, aquella prometedora medicina ilustrada se desgaja ideológicamente. Los médicos, más conservadores consideran que todo esfuerzo de renovación y europeización ilustrado ha sido un error, y van a propugnar la incomunicación con el extranjero. Por otro lado, hay algunos profesionales que quieren proseguir esa europeización de la medicina, pero piensan que esta tarea modernizadora de la ciencia puede llevarse a cabo desde actitudes diferentes: para unos, dentro del marco de la política francesa posrevolucionaria que encabeza Napoleón. Son los afrancesados; para otros, afirmando la necesidad de la independencia política nacional y buscando raíces españolas a su postura. Son los liberales, que al regreso de Fernando VII sufren persecución y exilio; para un tercer grupo, que militan en las filas del absolutismo, deberá llevarse a cabo la reforma de la medicina dentro de tal ideología absoluta. $^{307}$

«Fernandinos» fueron los profesionales que, nacidos en su mayoría en los últimos años del siglo XVIII, iniciaron su actividad con posterioridad a la Guerra de la Independencia y se adentraron en los años del gobierno de Isabel II.

En este periodo hubo figuras interesantes, entre ellas, el anatomista Lorenzo Boscasa Igual (1786-1857), que publicó en 1844 un Compendio de anatomía general y

\footnotetext{
306 ALBARRACÍn TEULÓN, Agustín (1988): «Las ciencias biomédicas en España de 1800 a 1936». En SÁNCHEZ RON, José Manuel, (ed.). Ciencia y sociedad en España CSIC, Madrid, pp. 143-144.

${ }^{307}$ Ibídem, p. 146.
} 
descriptiva; los fisiólogos Juan Mosácula Cabrera (1794-1831)- autor de unos Elementos de fisiología- y sobre todo, Joaquín Hysern Molleras (1804-1883), que realizó una labor experimental original que fue criticada-le acusaron de dar mucha importancia a los experimentos-y careció de continuación. La transición al pensamiento anatomoclínico la cumplió Antonio Hernández Morejón (1773-1856) en Valencia y en Madrid, y Francisco Juanich (1798-1868) en Barcelona. el foco principal de la nueva mentalidad estuvo en Cádiz, siendo sus representantes pedro María González (17631837) y Francisco Laso de la Vega y Orcajada (1785-1836), líder de un grupo de clínicos integrados por José de Gadorqui, autor de un tratado de enfermedades respiratorias (1840).

A pesar del bajo nivel del saber médico, hubo entre 1800 y 1848 , técnicos de cirugía de notable valor. La cirugía «fernandina» estuvo representada por Diego de Argumosa Obregón (1792-1865), considerado el «restaurador de la cirugía española». Argumosa introdujo la anestesia en España, técnica que había sido presentada en Estados Unidos, en público y por primera vez con éxito, en 1846. Cirujanos fernandinos fueron también, Antonio San Germán (1755-1833) autor de un libro de texto utilizado durante muchos años; Melchor Sánchez de Toca (1806-1880), médico de Isabel II, y Tomás Corral Oña (/1807-1882), que asistiría al nacimiento de Alfonso XII. Todos ellos seguidores del movimiento anatomopatológico, fueron profesores de la Facultad de Medicina de Madrid. Por su parte, la higiene y la política sanitaria contaron con Pedro Monlau Roca (1808-1871) y con Francisco Méndez Álvaro (1805-1883).

Médicos isabelinos fueron aquellos que encauzaron la medicina hacia el nuevo siglo; en su haber contaron la introducción de la medicina de laboratorio, de la que la anatomía patológica sería su más temprana manifestación y la que antes consolidaría. Entre ellos Juan Fourquet Muñoz 1807-1865, y el anatómico y cirujano Pedro González de Velasco (1815-1882), que fundó la revista El anfiteatro anatómico español. Aureliano Maestre de San Juan Muñoz (1828-1890) ocupó la primera cátedra de histología dotada en España, fundó la Sociedad Española de Histología el año 1874.

A la generación isabelina pertenecieron los médicos que protagonizaron una importante polémica doctrinal: positivismo frente a un añejo ideario hipocrático. Médico hipocrático fue, entre otros, José de Letamendi Manjarrés (1828-1897). Letamendi, catedrático de anatomía en Barcelona, su ciudad natal, y luego de patología general en Madrid desde 1878, fue el más significado crítico del positivismo, en 
cambio, los positivistas estuvieron representados por Pedro Mata y por Ezequiel Martín Pedro. $^{308}$

La renovación médica iniciada incluyó una tímida emergencia de las especialidades médicas: la dermatología, de la mano de José Olavide Landazábal (18361901)- impulsor del Hospital de San Juan de Dios de Madrid y la pediatría, con Mariano Benavente (1818-1885). Con el antecedente de la Patología psicológica de Juan Bautista Peset y Vidal, la psiquiatría se desarrolló en dos grupos. En Cataluña destacaron Emilio Pi i Molist (1824-1892), Juan Giné i Partagás (1836-1903) - cuya obra Tratado teórico-práctico de frenopatología sirvió para institucionalizar la psiquiatría en España - y Arturo Galcerán - que fundó la Sociedad de Psiquiatría y Neurología de Barcelona. El grupo madrileño se constituyó alrededor de Pedro Mata Fontanet (1811-1877), autor de un Tratado de la razón humana (1878) y creador en España de la medicina legal y del cuerpo de médicos forenses. A Mata le seguirá José María Esquerdo Zaragoza (1842-1912), que se distinguió por la creación de centros asistenciales.

Federico Rubio y Galí (1827-1902), representante del quehacer quirúrgico, fue máximo exponente de los médicos isabelinos. Rubio y Gali fue diputado a Cortes y senador del Reino. Este pionero de la cirugía en España se caracterizó por practicar en cadáver todas las operaciones quirúrgicas, que, en su tiempo, eran corrientes; ello le permitió introducir en España las técnicas quirúrgicas más actuales y también practicar algunas innovadoras. ${ }^{309}$

Fernandinos e isabelinos prepararon la transición hacia el nuevo siglo, paso que realizaron dos generaciones de profesionales. En la primera de ellas destacaron el anatómico Julian Calleja Sánchez 1836-1913, autor de un Tratado de anatomía, el patólogo José de Letamendi, ya citado y el clínico Bartolomé Robert Yarzabal (18421902). A mediados del siglo XIX nacieron los más destacados miembros de la segunda generación -los de la Restauración-, generación que fue designada por Laín Entralgo «generación de sabios» que reincorporaron a España al terreno de las contribuciones originales: junto a la obra de Ramón y Cajal, iniciada en Valencia y Barcelona, Ramón Turró (1854-1926), junto a Jaime Pi y Sunyer (1851-1897), trabajan en el laboratorio

\footnotetext{
308 GARCÍA BARRENO, Pedro (1998): «La medicina española hacia su modernización» en SANCHEZ RON, José Manuel ed.: Un siglo de ciencia en España. Consellería de Cultura y Ciencia. Valencia, pp. 141-143. ${ }^{309}$ Ibídem.
} 
municipal de Barcelona, creado en 1877, entonces dirigido por Jaime Ferrán (18521929). Por su parte, José Ribera (1852-1912), funda en Madrid la cirugía infantil. Alejandro San Martin (1847-1908) crea y cultiva con mentalidad fisiopatológica la cirugía vascular. Luis Simarro Lacambra (1851-1921) investiga la histología del sistema nervioso, la neurología clínica y la psiquiatría. José Gómez Ocaña (1860-1919) eleva el nivel docente de la fisiología experimental en su catedra de Madrid. Federico Olóriz Aguilera (1855-1912) es anatomista y antropólogo, y buen conocedor del evolucionismo biológico. Salvador Cardenal (1852-1927) introduce en su servicio quirúrgico de Barcelona el método listeriano de la antisepsia, que aprendió en París. Eugenio Gutiérrez (1851-1914) es artífice de la moderna ginecología operatoria en España, tras formarse en la capital francesa. 310

$\mathrm{Al}$ iniciarse el siglo $\mathrm{XX}$ la concatenación de una serie de figuras $\mathrm{y}$ de instituciones que han comenzado a abrir las puertas de sus cátedras, laboratorios e institutos a la medicina europea, preparan el terreno para que los jóvenes médicos, a partir de 1905, vayan a completar su formación médica en las instituciones europeas.

La Junta para Ampliación de Estudios y los laboratorios que crea posibilitarán la dedicación a la investigación para asimilar las mejores virtudes del extranjero y convertirse de hecho en semillero para la instrucción del futuro cuerpo docente de la Universidad. Tras el objetivo inicial de designar candidatos para su estancia en el extranjero, se inicia la preparación de los mismos, antes de su salida, con vistas a un conocimiento anticipado de las técnicas y materias que habrán de desarrollar fuera de España. A tal fin. A partir de 1910 en la pequeña residencia de la calle Fortuny, en Madrid, y luego, desde 1915, en los altos del Hipódromo, una y otra dirigidas por Alberto Jiménez Fraud (1883-1964), una serie de laboratorios -de anatomía microscópica con Luis Calandre Ibáñez, de Química general con José Sureda y Julio Blanco, de Química fisiológica con Antonio Madinaveitia y José Sacristán, de Fisiología general con Juan Negrín, de Histología normal y patológica con Nicolás Achucarro-, van anticipando a los estudiantes lo que luego será su tarea fuera de España.

Todas las ramas de la medicina fueron objeto de atención. Este conocimiento de la medicina extranjera supuso para España que un centenar de cátedras universitarias, en

\footnotetext{
${ }^{310}$ ALBARRACÍn TEULÓN, Agustín (1993), op. cit. p.502.
} 
las distintas facultades de Medicina nacionales, fueron ocupadas a partir de entonces por catedráticos que habían sido médicos becados por la Junta. ${ }^{311}$

\section{LA ENSENANZA MÉDICA: INFLUENCIA FRANCESA Y ALEMANA}

La profunda transformación que significó en todos los órdenes la Revolución Francesa se manifestó de forma muy clara en el terreno de la enseñanza médica. La completa ruptura con las instituciones del Ancien Régimen permitió crear un nuevo modelo cuyas características básicas, acorde con los supuestos de la mentalidad anatomoclínica, continúan hoy vigente en la docencia médica de todos los países. Como hito inicial del mismo puede señalarse el informe que Antoine de Fourcroy presentó a la Convención en 1794. En él se consideraba la observación junto a la cama del enfermo y en la sala de autopsias como centro de la enseñanza y, al carácter libresco de la docencia tradicional, se afirmaba que la nueva debía consistir en «leer poco, ver mucho, hacer mucho». De acuerdo con estos criterios se fundaron en 1795 unos centros, llamados Écoles de Santé y poco después Écoles de Médecine, sin ninguna relación con las universidades, que habían sido suprimidas por un decreto de la Convención dos años antes.

El cambio revolucionario de la organización docente se completó en 1808 con la creación de un nuevo tipo de universidad, en la que las escuelas citadas se integraron como Facultades de Medicina. El correspondiente decreto fue promulgado por Napoleón, debido a lo cual suele llamarse Universidad «Napoleónica» a la todavía hoy existente. La nueva enseñanza médica acabó con la separación entre médicos y cirujanos, y quedó inseparablemente unida a los hospitales debido a que consistía fundamentalmente en un aprendizaje clínico. Entre otras muchas novedades didácticas se desarrollaron en ella dos de gran trascendencia posterior: la lección clínica, como forma de exposición magistral a base de casos concretos, y el internado en servicios hospitalarios anterior a la graduación.

\footnotetext{
${ }^{311}$ Ibídem, pp. 504-506.
} 
En Alemania, como en la mayoría de los países europeos, se asimiló la reforma francesa, pero desde unos planteamientos que convirtieron a sus universidades en escenarios centrales de la «medicina de laboratorio» durante la segunda mitad del siglo XIX. Dichos planteamientos fueron formulados originalmente por Wilhelm von Humboldt en dos memoriales de 1809 destinados a la reorganización de la enseñanza médica en la Universidad de Berlín. Consistían esencialmente en dos principios: adscribir la formación de los médicos a facultades de medicina en universidades públicas, que debían ser para el Estado una responsabilidad económica y administrativa de primer orden, y mantener estrechamente asociadas la investigación y la enseñanza tanto en la selección del profesorado como en la práctica docente. Estos principios guiaron realmente el desarrollo posterior de la institución universitaria en los distintos estados alemanes, por lo que este modelo acostumbra a denominarse Humboldts Universität. Condujo en la práctica a un fenómeno de extraordinaria trascendencia: la aparición del profesional de la enseñanza y la investigación médicas, dedicado a ellas en exclusividad tras varios años de preparación científica consagrados principalmente a la «tesis de habilitación» que faculta para la docencia. Por otra parte, el importante gasto público destinado a las universidades hizo posible una organización basada en un instituto para cada disciplina básica y una Klinik (hospital universitario de carácter monográfico) para cada asignatura clínica. Institutos y clínicas ofrecieron los medios adecuados para el desarrollo de la investigación y de la nueva concepción de la docencia, convirtiéndose por ello en los núcleos de importantes escuelas en casi todos los campos de la medicina. El modelo alemán se difundió después a la mayor parte de Europa y a Estados Unidos.

En cambio, Inglaterra carecía de tradición médica universitaria. Las universidades de Oxford y Cambridge, las únicas existentes hasta fechas muy tardías, tuvieron muy escaso interés por la enseñanza médica, que, acabó en ellas reducida a poco más de una serie de formalidades escolásticas para la concesión de títulos. ${ }^{312}$

En España, la asimilación tanto del modelo francés como del alemán se desarrolló con graves deficiencias. La primera de las grandes aportaciones de la reforma francesa, la unificación de médicos y cirujanos, se intentó en 1827, pero las distintas posibilidades de acceder a él por parte de los médicos y los cirujanos «puros»

\footnotetext{
312 PIÑERO LÓPEZ, José María (2002), op. cit. pp. 623-624.
} 
prolongaron todavía la confusión más de una década. Hasta el plan de estudios de 1843 y su reforma en 1845 no se consiguió la efectiva unificación de la enseñanza y la titulación médicas, dentro de un modelo estatal y centralista de universidad que cristalizó en la Ley Moyano (1857) y que se ha mantenido hasta las reformas del último cuarto del siglo XX.

El título de «licenciado en medicina y cirugía» concedido por las universidades bajo el control ministerial, ha facultado para el ejercicio profesional desde entonces, aunque a finales del siglo XX tropieza con obstáculos planteados por la implantación del sistema de médicos internos y residentes (MIR) para la formación posgraduada, y por la integración de España en la Unión Europea. El único paréntesis digno de mención se produjo como consecuencia del liberalismo académico radical consecutivo a la revolución democrática de 1868, cuya expresión normativa fue un decreto que permitió la creación de numerosas «escuelas libres y escuras provinciales» de medicina, que desaparecieron tras la Restauración, con la excepción de unas pocas que se convirtieron en facultades de medicina estatales. Por otra parte, los sucesores de los antiguos cirujanos, después de una serie de reformas, se convirtieron en practicantes. Lo mismo que las matronas, su formación quedó adscrita a las facultades de medicina y su titulación, bajo control ministerial. ${ }^{313}$

Las primeras carreras universitarias de mujeres fueron Medicina y Farmacia. Hay que destacar que la incorporación de la mujer a los estudios de medicina planteó numerosos debates en la prensa del siglo XIX. En España llegaban noticias de interés que la prensa médica transmitía a sus lectores. Continuamente se ponía en entredicho las aptitudes y cualidades de la mujer, así como de los grandes inconvenientes que suponía para su honor, su moral, etc. el ejercicio de la medicina.

Durante el siglo XIX la profesión de comadronas, matronas o parteras, sufre diversas vicisitudes, planteándose cuestiones referentes a lo conveniente o no de su existencia, a los requisitos exigidos, al campo de sus atribuciones especialmente en relación con los médicos.

La mejora del nivel científico de las matronas se produjo con la ordenanza de Carlos IV en 1804. Existían matronas con prestigio social cuyos conocimientos eran reconocidos.

\footnotetext{
${ }^{313}$ Ibídem, p.625.
} 
En referencia a su actividad profesional y al ámbito de sus atribuciones, aparece en el capítulo 24 del Reglamento para el Régimen y Gobierno de los Colegios de Medicina y Cirugía y de los profesores que ejerzan estas facultades.

La Real Cédula correspondiente, se expidió el 10 de diciembre de 1828. Los artículos 11 y 12 hacen referencia a la instrucción que debían recibir las matronas o parteras. Las que querían obtener este título habían de acreditar haber practicado la Obstetricia por espacio de cuatro años con un Facultativo o Comadre aprobada, o bien dos años de prácticas y dos de estudios en alguno de los Colegios de Medicina y Cirugía. El catedrático supernumerario les enseñaba todo lo referente al modo de asistir a las parturientas y de socorrer a las criaturas cuando nacían «apopléticas o asfícticas». Además debían saber leer y escribir y si querían ser aprobadas de parteras o matronas, tenían que ser examinadas por tres catedráticos de los Colegios. ${ }^{314}$

En la Ley de Instrucción Pública de 1857, el artículo 41 dice «Igualmente determinará el Reglamento las condiciones necesarias para obtener el título de matrona o partera».

El 21 de noviembre de 1861, el Ministerio de Fomento publica un Reglamento para la enseñanza de practicantes y matronas. Las condiciones para ser admitida a la matrícula de Partera o Matrona entre otras, eran: haber cumplido 20 años de edad; ser casada o viuda, las casadas debían presentar la autorización de sus maridos y ambas debían justificar buena vida y costumbres mediante una certificación de sus respectivos párrocos; debían también haber recibido la Primera enseñanza Elemental completa, que se comprobaría mediante un examen en la Escuela Normal de Maestras. ${ }^{315}$

La moderna enfermería se inició en 1836 por el alemán Theodor Fliedner y cuya gran protagonista fue desde 1860 la inglesa Florence Nightingale y su escuela en el $S t$ Thomas Hospital de Londres. Su principal introductor en España fue el gran cirujano Federico Rubio Galí, quien fundó en 1895 una escuela de enfermeras en el Instituto de terapéutica Operatoria de Madrid, practicantes, comadronas y enfermeras fueron integrados el año 1953 en el nuevo título de «ayudante técnico sanitario», que se ha mantenido hasta la creación de la Diplomatura en Enfermería (1977). ${ }^{316}$

\footnotetext{
314 ALVAREZ RICART, María del Carmen (1988): La mujer como profesional de la medicina en la España del siglo XIX. Anthropos, Barcelona, pp. .172-173.

${ }^{315}$ Ibídem, pp. 175-176.

${ }^{316}$ PIÑERO LÓPEZ, José María (2002), op. cit. pp. 626.
} 


\section{LOS MÉDICOS DE CASTELLÓN}

Según el historiador Francisco Mezquita Broch, ${ }^{317}$ y que nosotros hemos podido comprobar a lo largo de nuestra investigación, los profesionales de la medicina tuvieron mucha influencia en la vertebración de la sociedad, en la conformación de una élite social a la cabeza de la ciencia necesaria para Castellón, y un peso social y político indudable.

Un número importante de los profesionales de la medicina desarrollaron sus conocimientos científicos impartiendo conferencias en los centros de sociabilidad de Castellón y en sus escritos en la prensa, contribuyendo con ello a elevar la cultura científica de los castellonenses. Ejemplos los tenemos con Vicente Gea Mariño (18711956), José Gil Valero (1861-¿?) Juan Marco Salvador, Francisco Badenes Champel, Ramón Penichet Delgado, etc. Asimismo muchos licenciados en medicina fueron profesores del Instituto de Enseñanza Media de Castellón, citamos como ejemplo: a Domingo Herrero, Pedro Aliaga, profesor de matemáticas y director del Instituto en 1896; Antonio Forns y Sanz de Andino (profesores de Gimnasia).

Los médicos también influyen en los planteamientos higienistas de la ciudad mediante el desarrollo de los nuevos ensanches y de zonas verdes que cumplía una doble finalidad: de higiene y educativa. Podemos citar a Domingo Herrero, que fue alcalde de la ciudad en 1876. Propicio la creación de lo que ahora es el Parque Ribalta y que en su día se planteó como jardín botánico según las corrientes higienistas que se estaban dando en toda Europa

Asimismo intervinieron profesionalmente en los momentos más graves para nuestra ciudad como fue en la epidemia de cólera en 1885 y en la epidemia de gripe de 1918. Podemos citar entre ellos a Torres Roig, en la primera, y sobre todo al profesional por antonomasia del saber hacer en la profesión, doctor José Clará Piñol, que desplegó gran actividad en las dos epidemias citadas, y sobre todo, el interés que desplegó junto al Inspector de Primera Enseñanza, José Senent, en la creación de la Primera Colonia Escolar de Castellón.

\footnotetext{
317 MEZQUiTA BROCH, Francisco (2000):«Fuentes históricas para la Historia del Colegio de Médicos de Castellón, en I Centenario Colegio de Médicos de Castellón. Ilustre Colegio Oficial de Médicos de Castellón, pp.32-33.
} 
Al principio del siglo XIX los médicos ejercían su actividad sin estar colegiados, pues el Colegio de Médicos, otro ejemplo de aplicar las leyes y controlar la profesión médica, fue creado en 1898. En el ritmo de colegiación de los médicos de Castellón lo podemos distinguir en varias etapas, la primera, que abarca desde la creación del Colegio en 1898 hasta 1902, coincidiendo con el final de la obligatoriedad de la colegiación, en todo este periodo se inscriben 31 médicos; la segunda, hasta el año 1920, cuando se impone definitivamente la obligatoriedad, aparecen 37 médicos que ejercen en Castellón; la tercera que llega hasta junio de 1938, cuando Castellón es ocupada por el general Franco, en la que se inscriben 50 médicos más, pero de la cual no sabemos exactamente las bajas, los traslados o las defunciones; y por último hasta 1944, aparecen 22 médicos más, con la misma salvedad de la etapa anterior. En total 140 médicos inscritos en el Colegio, pero no podemos asegurar que cubran a todos, por varias razones, una es la que ya hemos comentado sobre la colegiación. ${ }^{318}$ De los 140 médicos inscritos en el Colegio, 51 se licenciaron en la Facultad de Medicina de Valencia, le siguen Madrid con 10; Zaragoza y Barcelona con 6 cada una; Granada con 3, Salamanca y Santiago con 2 y Cádiz, Valladolid y la Habana con 1. Es decir, el factor geográfico era importante a la hora de escoger el lugar de estudio.

La especialidad más numerosa en la ciudad, era la Pediatría con 10 especialistas; le seguían la Ginecología (Partos) con 9; Oftalmología con 7; Cirugía general, con 6, Otorrinolaringología, Radiología, Venérea-sífilis, con 5; Digestivo, Odontología, Vías respiratorias con 3; Análisis clínicos, Cardiología y nutrición, con 2; Aparato circulatorio, Medicina interna, Nutrición y secreciones internas, Urología, con 1. ${ }^{319}$

Una cuestión importante es saber la relación de médicos con el número de habitantes para ver hasta qué punto la sociedad estaba asistida. Tenemos dos datos importantes con los cuales podemos hacer alguna comparación: la primera es de 18981902, y la segunda, de 1920. En 1900, Castellón tenía 29.904 habitantes para los cuales ejercían 31 médicos; en 1900, Alicante tenía 62.546 habitantes para los cuales tenía 38 médicos. Las cifras de Castellón representan 964 habitantes por médico. En 1920, Castellón tenía 34.457 habitantes para los cuales había 37 médicos, resultando 931 habitantes por médico, en Alicante no hay cifras para 1920, pero en 1925 tenía 85 médicos. Todas estas cifras vienen a demostrar que el nivel asistencial por el número de

\footnotetext{
${ }^{318}$ Ibídem.

${ }^{319}$ Ibídem, pp. 30-31.
} 
profesionales era bueno y además la tendencia iba mejorando, había que ver si la educación sanitaria o las posibilidades económicas de los enfermos les permitían acceder a ello.

\subsection{BIOGRAFíAS DESTACADAS DE PROFESIONALES DE LA MEDICINA EN CASTELLÓN}

Los médicos de finales del siglo XIX y principios del XX es un colectivo que irrumpe con la fuerza de sus estudios universitarios, unido con otros colectivos parecidos para tratar de modernizar nuestra sociedad. En general, la numerosa irrupción de los profesionales de la medicina a finales del siglo XIX en Castellón representa una mejora social considerable, si tenemos en cuenta que la estructura profesional de Castellón nos mostraba una sociedad donde el peso rural todavía era muy definitorio, con el $37,10 \%$ que se dedicaba fundamentalmente a la agricultura, pero que realmente afectaba mucho más que las mismas cifras indican. Los médicos, por la consideración social de la profesión se situarán como una élite en el seno de una clase media acomodada, al lado de la administración local influyendo con sus opiniones no solamente en cuestiones relativas a la profesión sino en todas las que afectaban a la sociedad.

Entre los profesionales de la medicina de la época que estamos estudiando destacan por su bien hacer en la profesión, José Clará Piñol y, por su influencia en la política del momento en la ciudad, Vicente Gea Mariño. También hacemos referencia a otros profesionales que estuvieron implicados en la política de Castellón.

\subsubsection{JOSÉ CLARÁ PIÑOL (1858-1946)}

El doctor José Clará nació en Torreblanca en 1858. Se licenció en la Universidad de Valencia, en 1881 y se colegió en Castellón en 1898, según el Real Recreto de 12 de abril de 1898, y se volvió a colegiar en 1917. Comenzó a ejercer el 1 de agosto de 1881 en Castellón. Se dio de baja en el Colegio de Médicos el 30 de junio de 1938 por retirarse del ejercicio profesional por motivo de su edad avanzada. ${ }^{320}$

\footnotetext{
${ }^{320}$ Archivo del Colegio de Médicos de Castellón. (A partir de ahora ACMCS). Registro General de Colegiados. Tomo I números 1-500.
} 
El 4 de enero de 1883 fue nombrado cirujano primero del Hospital y enseguida médico forense. Su prestigio se acrecentó cuando, además de la práctica de sus especialidades, con medios materiales rudimentarios, se volcó hacia los servicios hospitalarios de tipo general y atendió con entusiasmo la investigación y los trabajos de laboratorio que le convirtieron en pionero de la medicina preventiva a través de vacunas contra la rabia, que Louis Pasteur había practicado en Francia. El hospital de Trullols de Castellón fue referencia básica igualmente con motivo de la epidemia del cólera que se extendió por media Europa, también en España y con focos virulentos en la provincia castellonense. El doctor Clará tuvo ocasión de trabajar en perfecta sintonía con el joven bacteriólogo Jaime Ferrán, responsable de dirigir en España todas las operaciones sanitarias.

El doctor Clará hizo las siguientes observaciones: «Fueron experiencias memorables. Los procedimientos vacunales se hallaban en sus albores y no teníamos antecedentes. Ferrán empleó ya una vacuna con gérmenes vivos y abrimos nuevos horizontes en las técnicas de vacunación preventiva».

Como cirujano, efectuó operaciones a enfermos de toda la provincia. También creó los servicios oficiales de Higiene para atender a la infancia.

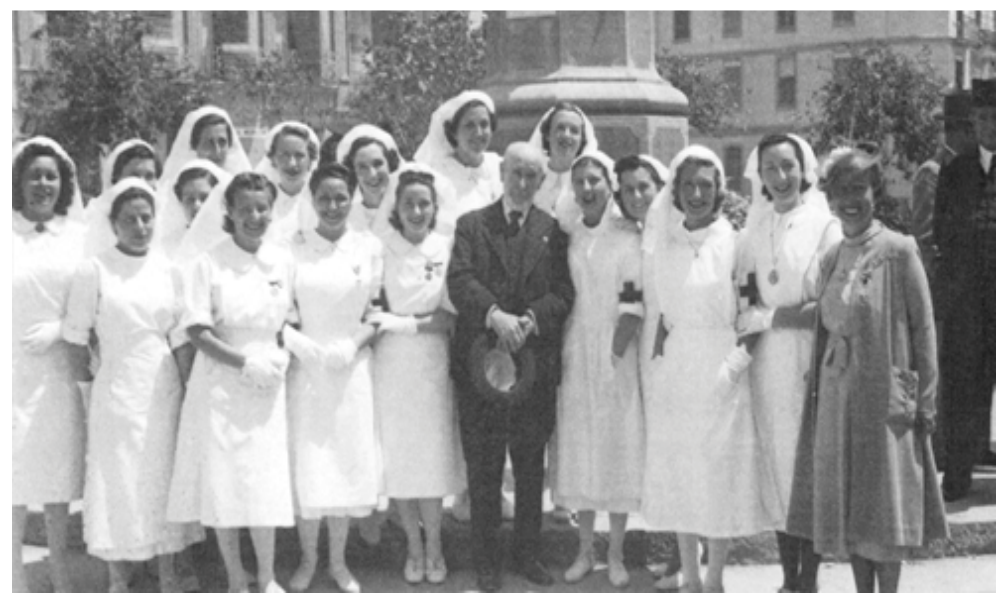

El doctor José Clara con las enfermeras del Hospital Provincial.Fondo Fotográfico: Colección José Prades.

En 1898 ganó las oposiciones para inspector de Sanidad, asumió la dirección del Hospital y sufrió la lentitud en la construcción del nuevo Hospital en la carretera de 
Alcora. Presidente honorario del Colegio de Médicos, recibió la Gran Cruz de la Orden de Beneficencia, fue nombrado Académico de la Historia.

En la Guerra Civil, ya jubilado, fue respetado por ambos bandos contendientes y pudo seguir con su labor sanitaria. Al final de sus días fue concejal del Ayuntamiento de Castellón.

El año 1918 fue una fecha imborrable para la sanidad castellonense, ya que a finales del verano se declaró una epidemia de gripe. Los focos se dispersaron por la provincia. El primero provocó gran número de muertes por el Maestrazgo, en San Mateo, Catí, Xert, Morella y después Salsadella, Alcalá y Torreblanca. Poco a poco se fue propagando también a Eslida, Torás, Segorbe.., cada día llegaban a Castellón 30 o 40 casos de enfermos graves que tenían que ser encamados en el Hospital Provincial, afectando igualmente a los vecinos de la capital. Como Inspector Provincial de Sanidad el doctor Clará dirigió las operaciones de atención a los enfermos, visitó cada uno de los pueblos afectados y marcó la pauta a seguir a todo el personal sanitario. El centro de mando lo tenía en el propio hospital, pero viajaba diariamente a las zonas con mayor incidencia. La violencia de la gripe asoló a media España, per enriqueció el concepto de sanidad civil con muchos avances, especialmente en la necesidad de vacunaciones masivas, de las que fue pionero el doctor José Clará. ${ }^{321}$

\subsubsection{JOSÉ GIL VALERO (1861-;)}

Nació en Valencia el 5 de octubre de 1861, se licenció en Medicina y Cirugía en 1894. Ejerció en Eslida desde 1897 y se colegió por primera vez en 1899. Residente en Villareal, llego a ser jefe de los republicanos de la ciudad y diputado a Cortes, junto al también médico republicano Vicente Gea, por el distrito de Castellón en 1915. ${ }^{322}$

Gil Valero fue iniciado en la logia Sol Naciente $n^{\circ} 8$ de Villarreal el 12 de marzo de 1926, adoptando el nombre simbólico de Leonardo da Vinci.

Los datos que aparecen sobre él en su expediente masónico ${ }^{323}$ son muy escasos, incidiendo únicamente en su iniciación, tanto en el informe de la Comisaría General de Información de la Dirección General de Seguridad, que solo da cuenta de la ficha que

\footnotetext{
${ }^{321}$ BELLÉS, Salvador (2012): «Seres humanos de Castellón. Operador de leyenda en años de epidemias en elperiodicomediterraneo.com/.../seres-humanos-de-castellon-por-salvador-belles-operador-de-ley... Última entrada 30/10/2012.

${ }^{322}$ ACMCS. Registro General de Colegiados. Tomo I números 1-500.

${ }^{323}$ Centro de la Meoria Histórica, (desde ahora C.D.M.H. UJI), Legajo 318 B, expediente 33.
} 
sobre él existe en su Archivo Masónico, como de la Sección Especial de la Delegación del Estado para la Recuperación de Documentos, que el 3 de marzo de 1942 informaba al Ministerio del Ejército que sobre Gil Valero sólo poseía los datos de su iniciación y de que había sido denunciado como masón en la Declaración Retractación presentada por Manuel Usó Jarque el 22 de mayo de 1940.

Le fue incoado un sumario por el Tribunal Espacial de Represión de la Masonería y el Comunismo en 1942, con el número de registro del TERMC ${ }^{324} 167$, que no ha podido ser hallado en el Centro Documental de la Memoria Histórica de Salamanca.

\subsubsection{VICENTE GEA MARIÑÓ (1871-1956)}

Vicente Gea Mariño nació en Castellón en 1871 en el seno de una familia acomodada. Se licenció en la Universidad de Valencia el 25 de octubre de 1895. Empezó a ejercer en Castellón en 1896 y con fecha 8 de agosto de 1899 se dio de alta en el Colegio de Médicos con el número 4, en la especialidad de medicina general. Al interrumpirse la colegiación entre 1906 y 1917, por no ser obligatoria, Gea volvió a colegiarse el 17 de junio de 1917. El Ayuntamiento de Castellón le dedica una calle en 1989.

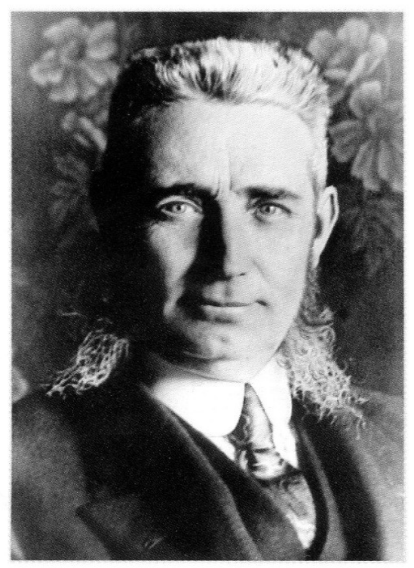

Vicente Gea Mariño. Fuente: I Centenario del Ilustre Colegio Oficial de Médicos de Castellón

Fue presidente del Colegio de Médicos desde 1919 a 1927 y desde 1930 a 1932. El 29 de diciembre de 1947, por acuerdo de la Junta Directiva y por haber cumplido sus bodas de oro con la profesión se le concede el título de Colegiado de Honor ${ }^{325}$

\footnotetext{
${ }^{324}$ TERMC: Tribunal Especial para la represión de la masonería y el comunismo.

${ }^{325}$ ACMCS. Registro General de Colegiados, 1898.
} 
Vicente Gea era republicano perteneciente a los federalistas integrados junto con los unionistas en la Federación Provincial de Castellón. En 1899 fue nombrado concejal junto con Enrique Gimeno Michavila, que era presidente de los federales. ${ }^{326}$

Fue elegido diputado provincial por el distrito de Castellón en las elecciones de 1915, junto con José Gil Valero, jefe de los republicanos de Villarreal ${ }^{327}$

Vicente Gea dio varias conferencias sobre el darwinismo en el Círculo Mercantil que le valieron fuertes ataques de la prensa neocatólica por defender abiertamente la evolución de las especies; asimismo dio varias conferencias sobre Ciencias Naturales en los centros de sociabilidad republicana. Era un notable conferenciante que sabía hermanar admirablemente los conocimientos científicos con la sencillez del lenguaje para que fueran comprendidos por los asistentes que no poseían una formación científica. Demostraba un notable conocimiento de la ciencia de su tiempo en cada una de las conferencias que daba. Los títulos de las conferencias más notables fueron: «Darwin y su escuela», «Función de Nutrición», «El origen del hombre», «Lo infinitamente grande y lo infinitamente pequeño», «Sol y agua en relación con la vida orgánica», «El tabaco», etc.

También dio una conferencia sobre «La higiene en las escuelas», con otros científicos, en representación de la Liga Contra la Ignorancia. En el Instituto General y Técnico se celebró una asamblea para pedir al Gobierno mejoras en la enseñanza y sanidad. Gea participó entre otros oradores con una conferencia sobre este tema. ${ }^{328}$

Asimismo, en Semana Santa los republicanos organizaban conferencias sobre temas filosóficos religiosas en el Centro Republicano, Vicente Gea fue invitado varias veces disertando sobre estos temas donde defendía siempre la verdad de la ciencia en oposición a «históricos dogmatismos sin correspondencia con la civilización moderna».

Siendo diputado defendió abiertamente la implantación de la Escuela Normal de Maestros que la Diputación de Castellón se negaba a crear, asimismo se interesó vivamente por el desarrollo de las cantinas escolares, los roperos y la gota de leche en Castellón.

Gea Mariño había sido iniciado en la logia Juan Prim nº 193 de Valencia, según informó esta logia al Gran Oriente Español en octubre de 1893, para que la Obediencia

\footnotetext{
${ }^{326}$ ARCHILES CARDONA, Francisco (2001): Parlar en nom del poble. Cultura política, discurs $i$ mobilització social al republicanisme castellonense (1891 - 1909). Excm. Ajuntament de Castelló. p.37.

${ }^{327}$ El Clamor, 15/03/1915.

${ }^{328}$ El Clamor, 10/05/1909.
} 
le proveyera de una carta de recomendación para los masones de Paris, a donde Gea iba a realizar una estancia de estudios y de un certificado del grado de aprendiz, que fue fechado el 11 de noviembre de 1893 y firmado por el Gran Maestre Miguel Morayta.

En 1894 pertenecía al Capítulo Integridad nº 28 de Castellón de la Plana, conservándose un certificado de su investidura al grado $4^{\circ}$ en diciembre de 1895 .

A pesar de contar con 73 años, el Tribunal Especial de Represión de la Masonería y el Comunismo le incoó el sumario 1373/1944, (CDMH. TERMC 11518), acusándole del delito de masonería, habiendo alcanzado el grado $4^{\circ}$ y de no haber presentado la Declaración Retracción a la que obligaba la Ley de 1 de marzo de 1940. Fue condenado el 6 de octubre de 1945 a la pena de 12 años y 1 día de Reclusión Menor y las accesorias correspondientes, que cumplió en prisión atenuada en su domicilio hasta que el 18 de febrero de 1948 el Consejo de Ministros le conmutó esta pena por la sanción de separación e inhabilitación para cargos políticos y sindicales. ${ }^{329}$

\subsubsection{JUAN BAUTISTA BELLIDO TIRADO (1878-1953)}

Nació el 20 de agosto de 1878 en Castellón. Se licenció en la Universidad de Valencia en 1901 e ingresó en el Colegio de Médicos en 1911. Se dio de baja del Colegio de Médicos por acuerdo del Consejo Directivo de 16 de marzo de 1940 por hallarse cumpliendo condena impuesta por los tribunales de justicia por su actuación en «La Revolución Marxista». En sesión de 12 de Julio de 1941 se le concede el reingreso por haber reanudado su ejercicio profesional, fijando su residencia en Almazora. ${ }^{330}$

\footnotetext{
329 CDMHUJ. Expedientes de Causas. Sumario 1374-44 contra Vicente Gea Mariño por delitos de Masonería. Ver también CALVO MÁS, Concepción (2012):«Médicos represaliados en la Posguerra de Castellón. Vicente Gea Mariño y Juan Bautista Bellido Tirado, republicanos y masones», en prensa.

${ }^{330}$ ACMCS. Registro General de Colegiados. Tomo n ${ }^{\circ} 1$ al 500.
} 


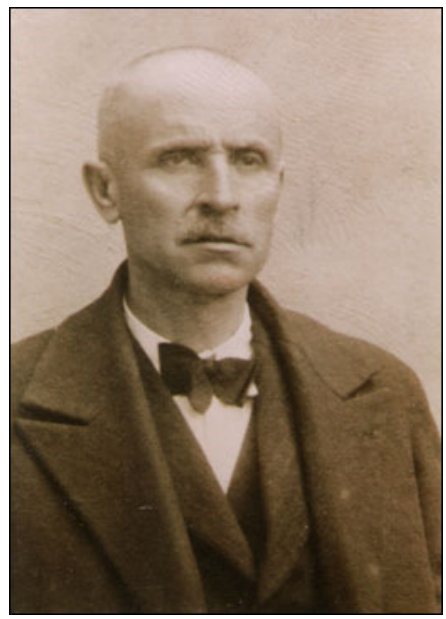

BELLIDO BLASCO, Juan Bautista (2012)

«Remembranza: Juan Bautista Bellido Tirado Castellón 20/8/1878 - 18/11/1952: médico y decano del Hospital Provincial de Castellón». Fiuente: www.memoriacastello.cat/11050603.html. [30/10/2012]

En 1904 empezó a trabajar como médico interino en el Hospital Provincial de Castellón. Su vida profesional estuvo en aquel tiempo vinculada al doctor José Clará Piñol .En 1925 ganó las oposiciones a Médico de Sala que se celebraron en Valencia.

El 12 de abril de 1930 fue nombrado Decano del Hospital Provincial. El cargo lo ostentaría ocho años, durante todo el periodo de la Segunda República, hasta la ocupación de Castellón en 1938 por las tropas sublevadas. ${ }^{331}$

Cuando sobrevino la sublevación militar de julio de 1936, Juan Bautista Bellido permaneció en su cargo. El gobernador civil le encomendó la organización de la sanidad provincial, de este modo fue presidente del denominado Comité de Sanidad Provincial del Frente Popular.

Castellón permaneció fiel al Gobierno Republicano legal. En este contexto, el Hospital fue refugio de algunas personas de significación derechista.

Perteneció al Partido Republicano de Alejandro Lerroux, formación política que abandonó para adscribirse a la Unión Republicana de Diego Martínez Barrios. En una votación fue nombrado candidato a la alcaldía de Castellón. Fue compromisario para las elecciones presidenciales de febrero de 1936.

Se dice que pertenecía a la francmasonería y era muy «asiduo concurrente a la logia que establecieron en la iglesia de San Agustín de Castellón y que dirigía Gómez Hidalgo, destacado masón». ${ }^{332}$

\footnotetext{
${ }^{331}$ BELLIDO BLASCO, Juan Bautista (2012) «Remembranza: Juan Bautista Bellido Tirado Castellón 20/8/1878 - 18/11/1952: médico y decano del Hospital Provincial de Castellón», en www.memoriacastello.cat/11050603.html. [30/10/2012].

${ }^{332}$ Archivo Histórico Nacional, FC-CAUSA_GENERAL, 1399, Exp.2
} 
El 16 de junio de 1936 es conducido a la prisión donde se le abre el expediente procesal 2987. Entre la fecha de detención y el 25 de agosto en que es conducido a la cárcel de Torrero (Zaragoza) es sometido al procedimiento sumarísimo de urgencia, identificada con el número 219 C.

La sentencia del Tribunal del Consejo de Guerra, procedimiento sumarísimo, echada en Castellón el 9 de julio de 1938, le atribuyen haber pertenecido al Partido Radical, a Unión Republicana, haber sido designado en febrero de 1936 candidato a la alcaldía por el Frente Popular, compromisario para la elección de presidente de la República y director del Hospital, cargo desde el cual desarrolló intensa labor de propaganda contra el Movimiento Nacional, llegando a decir que a Franco había que matarlo y arrastrarlo; le reconoce que no tomó parte en la detención de enfermos del Hospital, pero dicen que no hizo lo suficiente para evitarlo. Lo condenan a reclusión perpetua por delito de adhesión a la rebelión militar, además de la interdicción civil, inhabilitación absoluta y pago de responsabilidades civiles, siendo trasladado a la prisión de Torrero (Zaragoza). Fue puesto en libertad condicional en 1940 tras sucesivas conmutaciones de pena. En 1946 recibió el indulto por la pena de cárcel por el delito de rebelión.

Tiempo después, recién indultado, solicitó el reingreso al Hospital que le fue varias veces denegado. Expulsado del Hospital y cesado como funcionario de la Diputación, y teniendo prohibido ejercer temporalmente en Castellón, abrió consulta en Almazora durante el tiempo que duró el destierro. Regresó a Castellón y reanudó el ejercicio médico en su consulta de la Plaza de la Independencia $n^{\circ} 8$, murió en 1953, a los $74 \operatorname{años}^{333}$

\footnotetext{
${ }^{333}$ BELLIDO BLASCO, Juan Bautista, op. cit.; CALVO MÁS Concepción, op. cit.

Otros médicos que influyeron en la sociedad de Castellón fueron Juan Salvador Marco y Luis San de Andino. De éstos dos profesionales de la medicina no figuran la fecha de nacimiento y de muerte en el Registro General de Colegiados. Juan Marco se licenció en Medicina en 1910, aunque no figura en el Registro la Universidad, ingresó en el Colegio de Médicos en 1917. Era médico especialista en Partos y ejerció en Castellón. Fue republicano y vicepresidente de la Unión Republicana Propagandista. En los centros de sociabilidad republicanos pronunció varias conferencias sobre Ciencias Naturales, entre ellas figura: «Los microbios», «Funciones de reproducción»...

Luis Sanz de Andino Bellver nació en Almusafes, se licenció en Medicina y Cirugía en la Universidad de Valencia en 1882. Dejó la profesión en 1897 y en 1899 se colegió en Castellón. Fue profesor de Educación Física en la Escuela Normal de Maestras y en el Instituto de Segunda Enseñanza de Castellón. ACMCS. Registro General de Colegiados, 1898.
} 


\section{CAPÍTULO IV: EVOLUCIÓN DEMOGRÁFICA E INCIDENCIA DE LAS ENFERMEDADES MÁS FRECUENTES EN CASTELLÓN. UN ESTUDIO COMPARATIVO}


Según Josep Lluis Barona Vilar, la salud humana se encuentra condicionada no solo por factores biológicos, sino también por otros de carácter cultural y social. Por todo ello, el proceso de conservación y de reproducción social de la salud incorpora al menos las dimensiones biológica, ecológica, psicológica, cultural y económica.

Los factores que de modo más evidente intervienen en el estado de salud de una población son, entre otros, los de tipo biológico (infecciones, toxicológicos, genéticos, inmunitarios, raciales, etc.) y los susceptibles de un análisis demográfico, como sucede con la correlación entre la estructura demográfica y el patrón epidemiológico de esa población. Pero también la organización social del trabajo desempeña un papel fundamental: las condiciones de vida de la población, la vivienda en la ciudad o el medio rural, las pautas de conducta frente a la conservación de la salud, las costumbres y las construcciones culturales de la enfermedad. ${ }^{334}$

El incipiente desarrollo de una demografía sanitaria durante la segunda mitad del siglo XIX aporta al menos la evidencia de que durante esa época y los comienzos del siglo XX, las condiciones sanitarias en que se encontraban las poblaciones españolas eran por lo general, muy deficientes. Que tanto la población como los políticos eran conscientes de ello se deja ver en las Cuestiones fundamentales de higiene pública en España elaboradas por el Real Consejo de Sanidad, publicado en 1901. También el testimonio de los salubristas lo reitera a través de un sinfín de informes, bandos, propuestas institucionales y folletos. Ya hemos comentado en otro capítulo que, en Madrid, Philip Hauser ${ }^{335}$ calculaba en la década de los años 1880 la existencia de más de 3.000 pozos negros contaminantes, señalaba también que la mayoría de los sumideros carecía de sifones y censaba en más de 4.000 las viviendas que carecían de suministro de agua potable. Una década después, el mismo autor, en su Geografía médica de la Península Ibérica denunciaba, que a partir de los datos recogidos directamente de los Inspectores provinciales de Sanidad, la práctica totalidad de las capitales de provincia carecían de las infraestructuras sanitarias adecuadas en lo que se refiere al tratamiento de aguas sucias y de bebida, control e higiene de alimentos, limpieza y salubridad de las calles. ${ }^{336}$

\footnotetext{
${ }^{334}$ BARONA VILAR, Josep Lluís. (2002). Salud, enfermedad y muerte. La sociedad valenciana entre 1833 y 1939. Institució Alfons el Magnànim, Valencia, pp. 15-16.

${ }^{335}$ HAUSER, Philippe (1902), en BARONA VILAR, Josep Lluis (2002), op. cit. p. 22.

${ }^{336}$ Ibídem, pp. 21-22.
} 
En el siglo XIX las enfermedades del aparato digestivo, excluidos el cólera y la disentería, eran las que más fallecimientos ocasionaban, seguidas de las enfermedades respiratorias. La década de los setenta fue la de mayor mortalidad debido a la tuberculosis pulmonar y a infecciones en la población menor de cuatro años; en 1885 debido a la epidemia de cólera, hubo un fuerte aumento en el número de fallecimientos. En la segunda década del siglo XX se observa un aumento de la mortalidad causada por la epidemia de gripe de 1918; y aunque en conjunto la mortalidad fue descendiendo y este descenso se mantuvo en los años veinte y treinta, la guerra civil elevó estas cifras durante los años en que se desarrolló la contienda. ${ }^{337}$

En cuanto a la mortalidad infantil hay un moderado descenso a partir de 1905; E. Ramos y M. A. Villatoro han estudiado las causas de muerte en menores de cuatro años hasta mediados del siglo XX y estas fueron la diarrea, la bronquitis aguda, la neumonía, la meningitis simple, las alteraciones congénitas y la prematuridad. Ese descenso observado en dicha mortalidad se debió a la disminución de la muerte por diarrea, y eso fue consecuencia de unas mejores condiciones higiénicas. Esta disminución se vio interrumpida en los tres años que duró la guerra civil. ${ }^{338}$

Las primeras décadas del siglo XX fueron escenario de toda una serie de medidas profilácticas, preventivas e institucionales dirigidas a afrontar la vergüenza pública que representaba la elevada mortalidad de los niños: una legislación protectora de la infancia, la fundación de nuevos centros de acogida de niños, la gota de leche, los dispensarios de puericultura y las campañas de vacunación, fueron aspectos concretos de las estrategias médicas y políticas encaminadas a mejorar las condiciones de vida de la infancia y atajar la muerte de los niños. ${ }^{339}$

\footnotetext{
${ }^{337}$ BÁGUENA CERVELLERA, María José, «La enfermedad y su prevención». en la Historia de la Medicina Valenciana, Tomo III, p. 129. Citada por SUllER TRILLES, Vicenta (1998): Medicina y Enfermedad a principios del siglo XX en España. Un estudio comparativo. Trabajo inédito de investigación, dirigido por la doctora MONLLEÓ PERIS, Rosa. Departamento de Historia, Geografía y Arte.

${ }^{338}$ Ibídem, p. 129.

339 BARONA VILAR, Josep Lluis. op. cit. pp. 61-62.
} 


\section{EVOLUCIÓN DEMOGRAFÍCA DE ESPAÑA: DEL MODELO PREINDUSTRIAL AL CONTEMPORÁNEO}

En el siglo XIX puede afirmarse que en términos generales, cada país europeo adquirió sus propios perfiles en el proceso de transición demográfico, desde la economía del Antiguo Régimen a la era del capitalismo industrial. A largo plazo, las naciones avanzadas se aproximaron rápidamente en cuanto a sus rasgos estructurales en el comportamiento de su régimen demográfico: disminución de la mortalidad y mantenimiento e incluso avances en la natalidad, en una primera fase, para caer luego a largo plazo. El resultado del nuevo orden en la población fue un mayor crecimiento vegetativo y una creciente esperanza de vida.

En España el proceso de modernización del ciclo demográfico no tuvo lugar hasta el siglo XX. En contraste con la evolución de los efectivos poblacionales de los países europeos que habían experimentado desde la segunda mitad del siglo XVIII el proceso industrializador, España sólo creció modestamente y con ritmos más lentos que los que alcanzaron Gran Bretaña, Alemania, Francia o Suecia a lo largo del siglo XIX.

A comienzos del siglo XIX la población española rondaba los 11 millones de personas; mientras que en 1877 las cifras del censo arrojaban un total de 16.622.175 (tabla 1$)^{340}$

Tabla 1. Población de España (por sexos y total) y tasas de crecimiento acumulativo anual, 1787-2001. Población de hecho. Península, Illes Balears y Canarias

\begin{tabular}{|c|c|c|c|c|c|}
\hline Año & Hombres & Mujeres & Total & $\begin{array}{c}\text { Índice de } \\
\text { población } \\
\text { (base 1900 } \\
\mathbf{1 0 0}\end{array}$ & $\begin{array}{c}\text { Tasa de } \\
\text { crecimiento } \\
\text { acumulativo } \\
\text { anual } \\
\text { Porcentaje }\end{array}$ \\
\hline 1787 & 5.190 .448 & 5.202 .468 & 10.392 .916 & 56 & $\ldots$ \\
\hline 1797 & 5.220 .299 & 5.320 .922 & 10.535 .975 & 57 & 0,14 \\
\hline 1857 & 7.663 .541 & 7.790 .973 & 15.454 .514 & 83 & $\ldots$ \\
\hline 1860 & 7.740 .842 & 7.904 .230 & 15.645 .072 & 84 & 0,34 \\
\hline
\end{tabular}

\footnotetext{
340 NICOLAU ROSER, (2005): «Población, salud y actividad», en CARRERAS, Albert y TAFUnELL, Xavier: Estadística histórica de España. Volumen I, Fundación BBVA, Bilbao. p. 124.
} 


\begin{tabular}{|l|l|l|l|l|l|}
\hline 1877 & 8.125 .862 & 8.496 .313 & 16.622 .175 & 89 & 0,36 \\
\hline 1887 & 8.601 .333 & 8.948 .275 & 17.549 .608 & 94 & 0,54 \\
\hline 1897 & 8.779 .240 & 9.329 .370 & 18.108 .610 & 97 & 0,31 \\
\hline 1900 & 9.071 .965 & 9.522 .440 & 18.594 .405 & 100 & 0,89 \\
\hline 1910 & 9.674 .168 & 10.252 .982 & 19.927 .150 & 107 & 0,70 \\
\hline 1920 & 10.315 .655 & 10.987 .507 & 21.303 .162 & 115 & 0,67 \\
\hline
\end{tabular}

Fuente: NICOLAU ROSER, (2005): «Población, salud y actividad», en CARRERAS, Albert y TAFUNELL, Xavier: Estadística histórica de España. Volumen I, Fundación BBVA, Bilbao. p. 124.

Para todo el siglo, la tasa de crecimiento anual se movió entorno del 0,5 por 100, no más allá de las que se habían alcanzado en el siglo XVIII. A grandes rasgos el siglo XIX presentó unas tasas de natalidad todavía muy altas con unas tasas de mortalidad también elevadas, lo cual se combinó con fuertes corrientes migratorias que se concentraron en periodos muy concretos y en regiones particulares. Ello caracterizaba todavía un ciclo demográfico de tipo antiguo o de transición. ${ }^{341}$

El mayor aumento de la población durante el siglo XIX se produjo en el periodo comprendido entre los años 1814 a 1855 . Entre 1821 y 1860 la tasa de crecimiento anual fue del 0,76 por 100 , el doble de la calificada como modesta tasa del 0,42 por 100 , alcanzada en la segunda mitad del siglo XVIII. ${ }^{342}$

Las transformaciones sociales acaecidas durante este siglo como el cambio de la propiedad feudal en propiedad liberal burguesa, la venta de tierras de titularidad eclesiástica y municipal y la desvinculación y la supresión de los diezmos, hicieron aumentar la producción de la agricultura elevando las rentas disponibles en el sector agrario, haciendo disminuir relativamente las tasas de mortalidad y elevando las de natalidad. $^{343}$

Los demógrafos han señalado que España, a pesar de las insuficiencias estadísticas existentes hasta 1858 desde el censo de Floridablanca realizado en 1787, poseía una tasa bruta de natalidad alta, pero todavía presentaba una tasa bruta de mortalidad muy elevada durante gran parte del siglo XIX. La primera se movió casi siempre por encima del 35 por 1.000 mientras que la segunda se orientó al alza entre

\footnotetext{
341 SAIZ PASTOR, Candelaria y VIDAL OLIVARES, Javier (2001): El fin del Antiguo Régimen, Síntesis, Madrid. pp. 15-17.

342 Ibídem, p. 18.

${ }^{343}$ Ibídem. Ver PÉREZ MOREDA, Vicente (1980): Las crisis de mortalidad en la España interior. Siglos XVI - XIX. Siglo veintiuno editores. México, España, Argentina. pp. 407-418.
} 
1858 y 1868 entre el 29 y el 34 por 1.000. Esto ha conducido a los especialistas en demografía histórica a centrarse en el estudio de las razones que se escondían detrás de una mortalidad tan acusada, cuyo signo tan negativo realmente lastraba el proceso de modernización del ciclo demográfico español.

La difusión epidémica de enfermedades infecto-contagiosas fueron dos de las razones principales que contribuyen a explicar las pérdidas de población de la España del siglo XIX. En particular, los historiadores económicos han puesto el acento en las repercusiones negativas que las crisis de subsistencias, asociadas a las malas cosechas recurrentes a lo largo del Antiguo Régimen y primera mitad del siglo XIX, tuvieron en la elevada mortalidad que presentan las estadísticas vitales españolas.

Las enfermedades epidémicas fueron importantes en la medida en que el hambre ocasionada por la escasez y el encarecimiento de las subsistencias debilitaba los organismos humanos y los hacía más vulnerables frente a enfermedades endémicas, como la fiebre amarilla y sobre todo el cólera morbo. Las epidemias se manifestaron en la España de la primera mitad del siglo más o menos asociadas cronológicamente con las disminuciones de cosechas. En particular fueron importantes los brotes de cólera de 1833-1835, que produjeron, entre 90.000 y 300.000 muertes, el de 1854-1856 que ocasionó casi 240.000 víctimas y el del año 1885 causante de una mortalidad de alrededor de 120.000 personas. Las evaluaciones que se han llevado a cabo sobre el impacto de las enfermedades de carácter epidémico señalan que para todo el siglo XIX hubo unas 700.000 personas que fallecieron víctimas del contagio de algún tipo de dolencia infecto-contagiosa.

Las crisis de subsistencias no tuvieron efectos significativos de carácter general aunque sí a escala de ciudades concretas, comarcas o regiones especialmente afectadas por las peores coyunturas sobre el comportamiento de la mortalidad a largo plazo. Los efectos fueron más ligeros y afectaron mucho más a la caída temporal de la nupcialidad y la tasa de fecundidad, pero mucho menos sobre el crecimiento de la mortalidad. Han sido los estudios posteriores los que han ido acotando con mayor precisión las razones de la elevada mortalidad española del XIX, y uno de los factores que han apuntado como responsable de la alta mortandad ha sido la mortalidad infantil y juvenil.

La mortalidad infantil española fue de las más altas de Europa hasta comienzos del siglo XX, sobre todo la que afectaba a los niños durante el primer año de vida. 
Fueron tiempos en que las epidemias se produjeron sin cesar, en particular el cólera, pero también la viruela, la difteria y sarampión, cebándose en la población infantil y juvenil. Hay que señalar también en la incidencia de la mortalidad infantil, el deterioro de las condiciones de vida de los niños como consecuencia de la incorporación de la mujer al mercado de trabajo. Si bien ésta no parece ser una explicación aplicable al caso español, sí lo es el hecho de que se difundiesen hábitos poco higiénicos a consecuencia de la introducción de nodrizas en los usos sociales de la crianza y con la extensión de la lactancia artificial en vez del uso del biberón. A esta elevada mortalidad también contribuyó el bajo uso de la vacunación y en algunos casos el descrédito en que cayeron algunas vacunas como la de la viruela. ${ }^{344}$

En los tres primeros años de vida, la mortalidad infantil en España era mayor que la de los países europeos de su entorno, con 13,7 puntos por encima de Italia. Con respecto a Francia, la mortalidad española era en 1900 casi 24 puntos superior durante el primer año de vida, aumentaba considerablemente durante el segundo año y se mantenía sustancialmente más elevada hasta el grupo de edad comprendido entre los 15 y 20 años. En esa franja las tasas de mortalidad general de ambos países se igualan y en los grupos de mayor edad iba adquiriendo gradientes progresivamente más favorables a la sociedad española con respecto a la francesa. ${ }^{345}$

Independientemente de las argumentaciones de tipo médico o de los cambios en los usos sociales del papel de la mujer en las economías europeas, en el caso español fue más evidente la relación existente entre malas cosechas, insuficiencia alimenticia por escasez y por mala distribución comercial de los productos agrarios y la todavía muy elevada mortalidad infantil y juvenil. Las hambrunas y los problemas asociados a las crisis de subsistencias se encontraban en la base de la elevada mortalidad infantil y juvenil hasta incluso en el último cuarto del siglo XIX, en que las epidemias fueron todavía muy importantes como impulsoras de esta mortalidad. ${ }^{346}$

La cifra anual de defunciones y la tasa bruta de mortalidad de la población española siguieron, desde finales el siglo XIX hasta la década de 1950, una clara tendencia decreciente, alterada profundamente en tres ocasiones: la epidemia de cólera de 1885, la de la gripe de 1918 y la Guerra Civil española.

\footnotetext{
${ }^{344}$ SAIZ PASTOR, Candelaria y VIDAL OLIVARES, Javier op.cit. pp- 20-22.

345 BARONA VILAR, Josep lluis (2002). op. cit. p.60.

${ }^{346}$ SAIZ PASTOR, Candelaria y VIDAL OLIVARES, Javier (2001):op. cit. p. 21.
} 
Entre 1900 y 1930 la población de España aumenta en cinco millones de personas, con un incremento anual doble al del periodo anterior 1877-1900, y con una densidad de 37 habitantes por kilómetro cuadrado, una de las más bajas de Europa occidental.

Los tres últimos lustros del siglo XIX se caracterizaron por: recesión en los índices absolutos y relativos de mortalidad, que se estanca en el 30 por 1.000; retroceso en los índices de crecimiento vegetativo, fijándose en torno al 5 por 1.000; débil decrecimiento del índice absoluto de nacimientos, que se sitúa en 1900 en 34,8 por 1.000 frente al 37,9 por 1.000 de 1977.

Hasta comienzos del siglo XX se vive una situación demográfica preindustrial, un periodo de pretransición con alta mortalidad, alta natalidad, con una esperanza de vida media de 35 años y con un incremento de población realmente bajo.

El periodo comprendido entre 1900 y 1931 puede dividirse en dos subgrupos, separados en 1918, año que provocó gran número de defunciones.

Desde 1900 a 1918, podemos observar la paulatina disminución de la mortalidad que se explica por los progresos médicos, la mejor distribución de recursos económicos y los adelantos en la higiene, sanidad pública y los logros de derechos sociales por el trabajador. La mortalidad desciende desde 28,8 por 1.000 , en 1900 , a 22,3 por 1.000 en 1917.

De 1919 a 1931, superados los efectos de la gripe de 1918, la mortalidad continúa descendiendo más aceleradamente que la natalidad, de modo que el crecimiento vegetativo pasó de 4,9, en 1919, a 11,4 en 1930. El mayor índice de crecimiento corresponde a 1926, con el 19,8, quizá como consecuencia del corto bienestar que la Dictadura de Primo de Rivera supuso y de la reducción de las emigraciones tras la guerra de 1914-1918. En definitiva, se trata en los dos subperiodos de un crecimiento sostenido de la población con una sola crisis grave, la producida por la gripe de 1918, verdadero cenit de las grandes epidemias de nuestra historia y consecuencia en parte de múltiples factores: la guerra, carencia o escasez de productos alimenticios, la avitaminosis consiguiente y la desnutrición en amplias regiones del país y en la clases sociales peor dotadas. ${ }^{347}$

\footnotetext{
${ }^{347}$ SÁNCHEZ JIMÉNEZ, José (1984): «La Población española en el primer tercio del siglo XX. La estructura del sistema democrático». en MENENDEZ PIDAL, Ramón: Historia de España. Los comienzos del siglo XX. La Población, La Economía, La sociedad (1898-1931). Espasa Calpe, vol. XXXVII, pp. 183-186.
} 


\section{CRECIMIENTO DEMOGRÁFICO Y ECONÓMICO DE CASTELLÓN: HACIA LA MODERNIDAD}

La ciudad de Castellón contaba a finales de 1857 con 19.945 personas. Setenta años después según el censo de 1930 la población de la ciudad era de 36.781 habitantes.

Castellón, tal como se puede apreciar en la tabla 2, registra en su población un aumento considerable y en cierta medida constante, aunque no uniforme. La ciudad tiene periodos donde el movimiento natural, especialmente en el siglo XIX, y sobre todo el migratorio mantienen unas fluctuaciones considerables. El crecimiento de la población castellonense en este periodo es superior al de todo el País Valenciano. Esta evolución diferente queda reflejada al comparar la población de la ciudad con la «provincial». En el siglo XIX las comarcas castellonenses registran una población creciente, pero en la entrada al nuevo siglo las comarcas interiores ven como su población comienza a descender. ${ }^{348}$

Tabla 2. La población en el País Valenciano y en la ciudad de Castellón

\begin{tabular}{|c|c|c|c|c|}
\hline \multirow{2}{*}{ Año } & \multicolumn{2}{|c|}{ País Valencià } & \multicolumn{2}{c|}{ Castelló } \\
\cline { 2 - 5 } & Población & $\begin{array}{c}\text { Incremento } \\
\text { anual }\end{array}$ & Población & $\begin{array}{c}\text { Incremento } \\
\text { anual }\end{array}$ \\
\hline 1857 & 1.246 .270 & - & 19.945 & \\
\hline 1860 & & & 20.123 & 0,27 \\
\hline 1877 & 1.371 .161 & 0,59 & 23.393 & 0,95 \\
\hline 1887 & 1.459 .461 & 0.64 & 25.193 & 0,77 \\
\hline 1900 & 1.587 .533 & 0.68 & 29.904 & 1,44 \\
\hline 1910 & 1.704 .127 & 0,73 & 32.309 & 0,80 \\
\hline 1920 & 1.745 .514 & 0,24 & 34.457 & 0,66 \\
\hline 1930 & 1.896 .758 & 0,87 & 36.781 & 0,67 \\
\hline 1940 & 2.176 .670 & 1,48 & 46.876 & 2,74 \\
\hline
\end{tabular}

Fuente: Censos de la Población. I.N.E. en SEGARRA BLASCO, Agustí (1986): «Evolució demográfica de Castelló de la Plana (1857 - 1936). Boletín de la Sociedad Castellonense de Cultura. Tomo LXII. Castellón, Abril - Junio. p. 146

\footnotetext{
${ }^{348}$ SEgARRA BLASCO, Agustí (1986): «Evolució demográfica de Castelló de la Plana (1857 - 1936). Boletín de la Sociedad Castellonense de Cultura. Tomo LXII. Castellón, Abril - Junio. pp. 145-146.
} 
En la evolución de la población castellonense hay que distinguir una serie de subperiodos que cuentan con datos comunes. En la etapa comprendida en el siglo XIX, 1857-1900, las altas tasas de natalidad han perdurado junto con la aparición de mortalidades casi catastróficas, debido sobre todo a epidemias, enfermedades infecciosas y la persistencia de crisis alimentarias. Además la entrada de inmigrantes ha posibilitado un crecimiento considerable. En esta segunda mitad del XIX, el movimiento vegetativo se caracteriza por unas alternancias entre saldos positivos y negativos, propios de una sociedad del Antiguo Régimen.

Las epidemias del siglo XIX son causadas por el cólera, enfermedad importada de países asiáticos, aparecidas en el continente europeo a partir de 1830. En los años 18591860 se sufre una epidemia en la cual la Plana no resulta de las zonas más afectadas, a pesar de grandes estragos en comarcas valencianas, como ocurrió en la Huerta de Valencia. Si las consecuencias de esta catástrofe no fueron importantes, no se puede decir lo mismo de la pandemia de 1885. En este caso todo el País Valenciano resultó muy afectado, tanto en las ciudades como en las zonas rurales, siendo su incidencia desigual para las distintas clases sociales y la estructura de edades. En este último aspecto fueron los jóvenes los más afectados, incidiendo sobre la oferta de mano de obra y la tasa de natalidad 15 o 20 años después. ${ }^{349}$

Las tierras valencianas fueron las más afectadas, la crisis económica que estaba sufriendo el País Valenciano contribuyó a que sus comarcas estuvieran predispuestas para la catástrofe. Las heladas de enero, las lluvias excepcionales en el invierno y la primavera, las riadas e inundaciones, las malas cosechas y la situación decadente de la industria sedera, explican la repercusión de la epidemia en el País Valenciano.

En las últimas cuatro décadas del siglo XIX, encontramos dieciocho años que presentan un saldo negativo del movimiento natural, es decir, la población castellonense, al margen de los efectivos provenientes de la inmigración, registra más muertes que nacimientos. Dada la fuerte relación de la natalidad y mortalidad con la situación económica, la estrecha dependencia de la comarca hacia el sector primario fue la principal causa de este comportamiento, superado con creces en el resto de países europeos. El conjunto de la sociedad española nada más presenta saldos negativos en los años dominados por fuertes catástrofes demográficas.

\footnotetext{
349 NADAL, Jordi (1973): La población española (siglos XVI a XX). Ariel, Barcelona. p. 159.
} 
En la Plana, la agricultura de autoconsumo, carente de excedentes para el mercado, obliga a depender de la marcha de los cultivos por lo que se refiere a la naranja, que vive una aceleración considerable en los años centrales del siglo, y al vino, producto comercializable por las comarcas interiores. La dependencia exterior acaba siendo determinante.

En el periodo 1895-1900 se registran en Castellón 4.568 nacidos vivos frente a 5.253 defunciones. Otra vez, la crisis comercial incide fuertemente sobre el producto de estas comarcas, sobre todo lo que se relaciona con el vino, la prensa de la ciudad se hacía eco de los escasos rendimientos del producto en las comarcas de Lucena, Viver y el Maesrazgo. ${ }^{350}$ Ante estas perspectivas el creciente volumen de habitantes decide emigrar a Cataluña. En Castellón la situación no es menos crítica que en el resto. El Heraldo de Castellón denuncia el caos urbanístico de la ciudad, así como el precario estado de la clase obrera. ${ }^{351}$

El conjunto de obreros y jornaleros de la ciudad, incrementada por el aumento de inmigrantes, resulta especialmente afectado por la marcha del comercio y los cultivos. La intensificación de los cítricos y el acceso de labradores a ser pequeños propietarios, establecen unas relaciones capitalistas en el campo junto con una demanda creciente de jornaleros, dando lugar este monocultivo a la reducción de los sectores no relacionados con la naranja (cáñamo, algarrobas, hortalizas), y a una fuerte dependencia hacia este producto. La clase obrera será especialmente afectada durante esta segunda mitad del siglo por el alto precio de los alimentos, la aparición de epidemias y enfermedades infecciosas (especialmente la tuberculosis), la insalubridad de las ciudades, la falta de una infraestructura sanitaria y la guerra.

En el periodo de 1901-1920, la crisis de final de siglo se refleja con un decrecimiento vegetativo durante los últimos cinco años, lo cual no impide que la venida de inmigrantes suponga el 97 por cien del aumento intercensal. Una crítica coyuntura económica incide sobre la fecundidad y el número de muertes, pero por otra parte el papel de la ciudad como destino de las comarcas excedentarias, supone la venida de inmigrantes en los momentos críticos. En los años de la Primera Guerra Mundial, a pesar que muchos castellonenses decidieron emigrar dada la caótica situación de la ciudad, la venida de trabajadores provenientes de las comarcas interiores

\footnotetext{
${ }^{350}$ Heraldo de Castellón, 14/02/1895.

${ }^{351}$ Heraldo de Castellón, 23/02/1895.
} 
y de otras zonas del Estado, crea un circuito que da como resultado una mayor población en los años de crisis.

El primer decenio del siglo, al contrario que el precedente, representa una fuerte aportación del movimiento natural y una disminución de las inmigraciones. Respecto a las tasas brutas, la natalidad y la mortalidad, con la entrada al siglo XX, la tendencia decreciente marca una uniformidad constante, únicamente alterada por la mortalidad de los años de la Guerra Mundial y especialmente por la gripe de 1918.

Si en el año 1903 la tasa de natalidad local era de 32, 27 por mil, la española era de 36,2, tasas elevadas las dos que evidencian el retardo demográfico español, a pesar de estar la población de habla catalana más adelantada. Hay que decir, sin embargo, que en el año 1920 el comportamiento de la natalidad había mejorado, se encontraba en un 25,18 y un 29,3. Con respecto a las defunciones, en estos años, Castellón contaba con un 27,29 y 22, 59 por mil, frente al Estado que contaba con un 24,8 y un 23,2 por mil. En este periodo, se nota claramente un avance en el comportamiento demográfico de la sociedad castellonense. La mejora de las condiciones sanitarias locales y por otra parte, la venida de nuevos activos comprendidos, entre los veinte y los cuarenta años, inciden sobre la caída de las defunciones. Además la fecundidad comienza a ser regulada, huyendo del comportamiento fisiológico del siglo pasado. No hay que olvidar que la mejora de la dieta alimentaria favorece la disminución de la mortalidad infantil.

Con la entrada del nuevo siglo la Plana empieza a resurgir en el aspecto económico, las inversiones en el campo transformando el secano (algarrobas, vino, cáñamo) en regadío (naranja) es un negocio rentable, consolidando una burguesía local que nace con el comercio del vino y la Liga de Contribuyentes.

Pero la situación creada por la Primera Guerra Mundial representó una grave crisis para la economía castellonense. La reducción de las importaciones españolas y el incremento de las manufacturas exportadas, dio lugar a una subida de los precios de los productos de consumo con un nivel de los salarios estacionario. En el País Valenciano, a la crisis general se sumó la caída de las exportaciones citrícolas. La reducción de las importaciones de la naranja por parte del gobierno inglés, el bloqueo alemán y la falta de material ferroviario para el mercado español, produjo una paralización del campo y de los sectores industriales. La producción manufacturera que no se canalizó hacía una economía de guerra no encontró salida, las naranjas se quedaron en el árbol, y los miles 
de jornaleros solo les quedaba la caridad y la emigración. La crisis se agudizó en 1917, en la Plana se produjeron revueltas pidiendo pan, trabajo, barcos y vagones. ${ }^{352}$

El periodo de 1921-1936 se caracteriza por la continuidad respecto al periodo anterior. El movimiento natural de la población mantiene las tendencias dadas desde principios de siglo. La natalidad continúa disminuyendo por debajo de la general del Estado, en cambio la mortalidad refleja unas variaciones remarcables. A principios de los años veinte, la grave situación del país va a suponer para Castellón una situación crítica de gran parte de su población.

Después de una década, donde la creciente demanda de los países europeos posibilitó una forma de expansión de la exportación citrícola y de los negocios en general, la Gran Crisis creó una recesión en el campo valenciano junto con la aparición del problema del paro. Por otra parte el retorno de los emigrantes agravó la situación.

Castellón en el siglo XIX tenía unas altas tasas de mortalidad que hasta el siglo XX no bajan del 30 por cien, con unas variaciones considerables a lo largo del periodo que indican la indefensión de la ciudad frente a las epidemias y las crisis económicas. Los efectos de la crisis agrícola de finales de siglo XIX representan una mortandad superior a los nacimientos, situación que se volverá a repetir con la crisis producida en la Primera Guerra Mundial. ${ }^{353}$

\section{ANÁLISIS DE ALGUNAS ENFERMEDADES QUE AFECTARON CON MAYOR FRECUENCIA A LA POBLACIÓN DE CASTELLÓN}

Desde 1880 a 1918 en Castellón se dieron, con relativa frecuencia, enfermedades que afectaron a su población en diferente grado. Algunas de ellas como el paludismo, la difteria, la viruela, la rabia, la lepra y el dengue son objeto de análisis en este punto. Las enfermedades del cólera y la gripe, por su mayor importancia como epidemias, serán analizadas en capítulos posteriores.

\footnotetext{
352 ROMEU ALFARO Fernanda (1964): La crisis de 1917 y sus consecuencias económicas y sociales en la Región Valenciana. Saitabí, XIV. PP. 118-125.

${ }^{353}$ SEgARRA BLASCO, Agustí (1986), op. cit. pp. 152-155.
} 


\subsection{EL PALUDISMO: ORÍGENES, TRANSMISIÓN Y MEDIDAS EN CASTELLÓN}

Una de las enfermedades endémicas que afectó a la población de Castellón en todas las épocas pasadas fue el paludismo o malaria.

El paludismo era descrito como el conjunto de fiebres infecciosas conocidas en los textos médicos del siglo XVIII bajo los nombres de «tercianas», «cuartanas», «fiebres estacionales»o «calenturas intermitentes». La verdadera causa del paludismo era desconocida. Incluso no se le diferenciaba bien dentro del conjunto de infecciones, confundiéndolo a veces con el tifus, gripe, hepatitis y tuberculosis, lo que dificulta la posterior identificación de la epidemia.

Para los médicos de la época las tercianas eran consecuencia del ambiente corrupto generado por las aguas encharcadas. La teoría médica del momento hacía hincapié en el contagio que nacía en el agua pútrida y que se transmitía a través del aire. El autor de esta teoría, Giovanni María Lancisi, no solo la había formulado, sino que había contrastado su validez al desecar las lagunas pantanosas de Roma. Adelantándose a otros médicos interesados en el tema, Lancisi consideraba que los miasmas no provenían solamente de la putrefacción del agua, sino de la materia orgánica en descomposición de los animales e insectos qué vivían en los pantanos.

El aire, según la medicina de la época, era el elemento por el cual circulaban los vapores miasmáticos, por ello tenía gran importancia la situación de los arrozales en relación a los pueblos, su distancia y la dirección que tomaban los vientos. Incluso había que tener en cuenta la naturaleza de estos últimos; unos arrozales a poniente de un núcleo de población, unían al viento procedente de allí, temperaturas calurosas que aumentaban la malignidad de las miasmas desplazadas. El propagador de la epidemia, el mosquito, no despertaba el recelo de los cultivadores y médicos, y si era citado en los informes tomaba más el aspecto de una molestia adjunta a los terrenos pantanosos que el de la causa de una epidemia.

En la actualidad sabemos que el paludismo se produce por la irrupción en la sangre humana del plasmodio. Este protozoo, parásito de las personas, provoca en su sangre la destrucción periódica de millones de glóbulos rojos, que es causa de fiebres en el organismo humano y debilidad corporal. La infección palúdica se transmite con el protozoo a través de un animal intermedio o vector que es el mosquito anofeles, el cual adquiere el plasmodio al alimentarse con sangre de un organismo atacado de paludismo. 
Este plasmodio se reproduce en el estómago de los mosquitos, y es inyectado en la sangre humana otra vez, cuando el mosquito vuelve a alimentarse picando a un ser humano, que de esta forma contrae el paludismo.

Hay cuatro especies de plasmodio, de ellas tres reconocidas por su intervención en la propagación del paludismo en España: el Plamodium vivax, el malariae y el falciparum. Es este último el más importante por su fuerte implantación en la cuenca mediterránea, y por su probada intervención en las epidemias palúdicas en España durante el siglo XVIII. El Plamodium falciparum es de los tres el más virulento, por haber sido el que más recientemente tomó contacto con el organismo humano, y por lo tanto el que se adaptó más tarde a él. ${ }^{354}$

\subsubsection{El paludismo, enfermedad que afecta a los labradores}

Según Mateu Tortosa ${ }^{355}$, aunque el paludismo había estado presente antes en Valencia, es durante el siglo XVIII cuando aumenta su morbilidad. La razón de este hecho es la acomodación del Plasmodium falciparum con el Anofeles atroparvus, que facilita su extensión dada la mayor movilidad del nuevo vector. Con ello se unían el protozoo palúdico más virulento con la variedad del mosquito con mayores posibilidades para moverse por todo el país. En segundo lugar, las transformaciones de numerosas tierras en arrozales provocaron cambios ecológicos de efectos imprevisibles sobre el medio animal; con estas mutaciones se favoreció la expansión del mosquito, que alcanzaba a un mayor número de comarcas. Por último, el incremento de la población valenciana posibilita una mejor y mayor difusión de la epidemia al poder actuar en tierras de mayor densidad demográfica.

Asimismo, las condiciones en que se desarrollaba el trabajo destruían la salud de los jornaleros. A los mosquitos y al ambiente pestilente había que añadir lo fatigoso de la preparación, siembra y cosecha de este cultivo. Recorriendo los campos agachados, atrapados por el barro, envueltos por nubes de mosquitos y soportando altas temperaturas. Todo ello, unido a un fuerte ritmo de trabajo con el fin de acabar antes de que la lluvia o el granizo de octubre destruyeran la cosecha. Esto debilitaba el cuerpo del jornalero y lo empujaba hacia la enfermedad o la muerte.

\footnotetext{
${ }^{354}$ MATEU TORTOSA, Enric. (1987). Arroz y paludismo. Riqueza y conflictos en la sociedad valenciana del siglo XVIII. Edicions Alfons el Magnànim. Valencia. pp. 79-80.

${ }^{355}$ Ibídem, pp. 80-82.
} 
El cultivo del arroz propiciaba las enfermedades infecciosas del aparato digestivo. El agua de los arrozales contaminaba las acequias, y al filtrarse en los campos iba a parar a los pozos de donde bebían las poblaciones. Las cuales ingerían un agua que al haber estado en contacto con los arrozales, llevaba la podredumbre de los abonos y demás materias en putrefacción. Eso explica las diferencias en mortalidad entre los pueblos grandes y las aldeas pequeñas. Las ciudades y pueblos grandes, disponían de fuentes públicas con unas condiciones higiénicas muy aceptables para su época. En cambio, en los pueblos pequeños la gente bebía el agua de pozos y cisternas contaminadas, cuando no en las mismas acequias que regaban los campos del arrozal. Por ello no es extraño que las autoridades, ante una epidemia, trataran siempre de higienizar las conducciones del agua, evitando pozos y cisternas, y proyectando fuentes que garantizaran la pureza de agua. Acciones que quedaban en su mayoría como proyectos utópicos que los vecinos demandaban, y que las autoridades, por falta de recursos, no realizaban. ${ }^{356}$

Una de las zonas que con mayor intensidad sufrió el paludismo fue El Delta del Ebro. Empezó a ser una zona endémica desde los comienzos del cultivo de arroz en 1859. Según García Roselló, en su tesis doctoral, ${ }^{357}$ la actividad agraria había sido tradicionalmente escasa en la desembocadura del río. La alta salinidad sólo permitía cultivos de cereales y hortalizas y la población presentaba unos altos índices de dispersión. La nueva red fluvial para el riego, el canal proveniente del término municipal de Xerta, fue inaugurada en 1857 y comportó la llegada de un caudal de agua dulce que junto con un clima templado propició la reproducción del mosquito transmisor de la enfermedad y el recrudecimiento de la misma. El cultivo del arroz en el Delta fue autorizado en 1868 y tuvo como consecuencia un gran crecimiento de la población inmigración desde zonas limítrofes y de Valencia. La gran superficie anegada del Delta tras el inicio del cultivo del arroz tuvo como consecuencia la expansión del mosquito anofeles en los arrozales y zonas circundantes que convirtió este territorio en uno de los más endémicos de España.

\footnotetext{
${ }^{356}$ Ibídem. Ver también: BELTRÁN I FOS, Enric (1984): L'arròs, Institució Alfons el Magnànim, Valencia. pp. 7-11.

357 GARCÍA ROSELlÓ, Joaquín María. (2011): Historia de las medicinas alternativas y complementarias en les Terres de L'Ebre durante la edad contemporánea. Tesis inédita, dirigida por SÁNCHEZ CERVELLÓ, Josep. Departament d' Història de l'Art. Facultat de Lletres. Universitat Rovira i Virgili.
} 
La malaria era una enfermedad de gran peso en la psicología colectiva. La importancia epidemiológica en lugares de Extremadura como Talayuela, hizo que en los años 20, el Gobierno español se implicase en un proyecto piloto en colaboración con la Fundación Rockefeller para erradicar un mal de tan enormes dimensiones, que resultaba intolerable para una sociedad en proceso de modernización. Odón de Buen fue el encargado de encabezar ese proyecto, que incorporaba medidas de higiene y salubridad, pero también terapéuticas basadas en el desarrollo de investigaciones de laboratorio. Por Real Orden de 23 de Agosto de 1920, se había nombrado una comisión nacional para organizar la lucha antipalúdica que estaba presidida por Gustavo Pittaluga. Su función consistía en verificar ensayos científicos en una zona gravemente atacada por el paludismo en la provincia de Cáceres: Talayuela.

La comisión antipalúdica propició la publicación en 1924 de un Real Decreto que contenía los aspectos principales de la lucha contra la enfermedad: la constitución de una Comisión Central y a partir de ella, una comisiones provinciales y locales necesarias, las premisas para la declaración oficial de las zonas palúdicas, los derechos y deberes de las zonas declaradas palúdicas, el suministro de la quinina con fines terapéuticos y las políticas sobre profilaxis en arrozales y cultivos análogos. El Decreto establecía un plazo de tres meses para que se constituyera la Comisión Central y redactase la Reglamentación del Decreto Ley. Las medidas que instauró la comisión nacional consistía en el análisis hematológico de las personas sospechosas de padecer la enfermedad, intento de suprimir las vías de infección, estudio de los mosquitos infectantes y aplicación de tratamiento de los enfermos con quinina y píldoras que la contenían mezclada con arsénico y hierro.

Según el profesor Josep Lluís Barona, la sociedad valenciana no fue escenario de estrategias preventivas o terapéuticas de tanta envergadura. No obstante, el problema sanitario que representaba el paludismo era objeto de acercamiento en las páginas de la prensa médica valenciana y testimonio en las tipografías médicas. Pesaba seguramente sobre la opinión pública el peso de una larga polémica de casi seis siglos a lo largo de los cuales prohombres e instituciones de la sociedad valenciana habían debatido estrategias de prohibición del cultivo del arroz en los marjales o incluso la desecación 
de las grandes superficies pantanosas. El informe del naturalista Antonio José Cavanilles a finales del siglo XVIII fue uno más entre otros. ${ }^{358}$

Desde la década de 1850 se produjo un ciclo de sequias y fríos con las consiguientes malas cosechas, crisis de subsistencias y epidemias en toda España. A la epidemia del cólera en la provincia de Valencia se añadió el aumento de las fiebres intermitentes o tercianas producidas por los arrozales. La reglamentación de las plantaciones de arroces parece ser que en 1865 se habían liberalizado para remediar las pérdidas que las inundaciones del Júcar habían causado en 1864. Como consecuencia se multiplicaron las plantaciones ilegales y el aumento de las tercianas en los pueblos de la ribera del Júcar. ${ }^{359}$

\subsubsection{El paludismo en Castellón}

El foco más grande de emanaciones palúdicas que tenía Castellón era el terreno conocido con el nombre de El Cuadro: «que son unas marjales muy extensas situadas detrás del pinar del Grao, cuyas pantanosas aguas se corrompen durante los calores del verano e infeccionan la atmósfera con sus exhalaciones pestilentes».

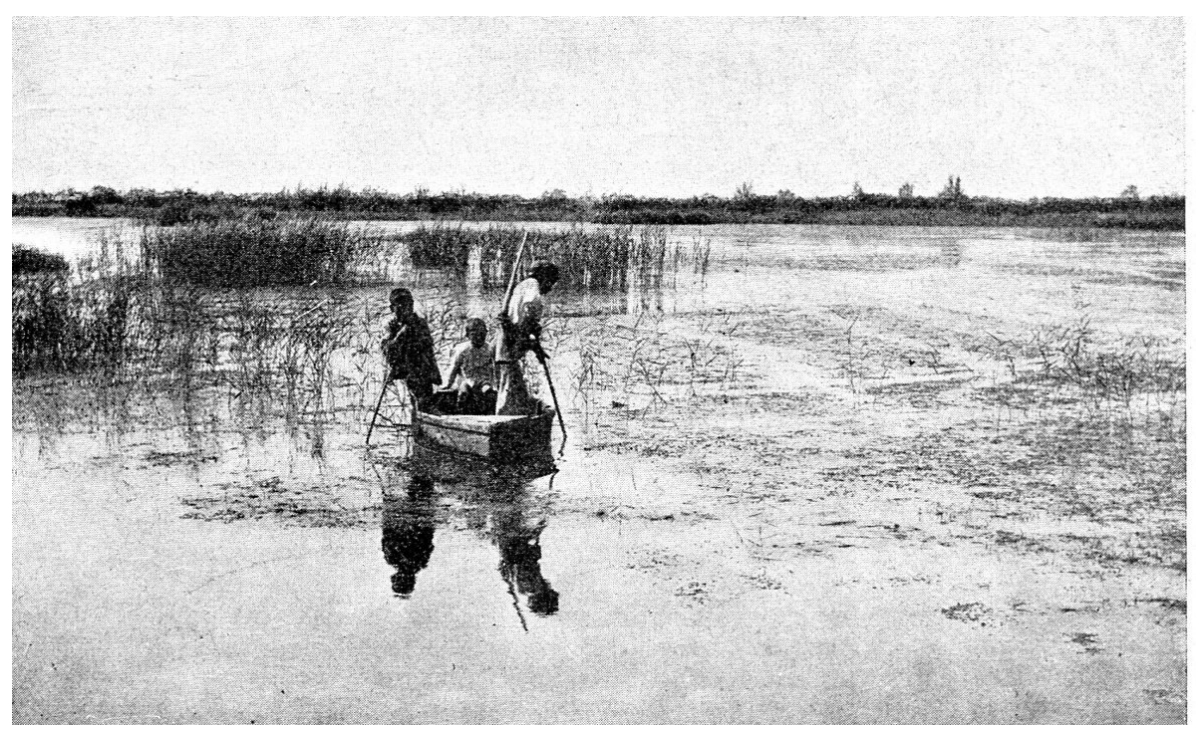

Castellón, Laguna del cuadro, denominada «El Lluent». Fuente: Carlos Sarthou Carreres (1914): Geografía General del reino de Valencia. Provincia de Castellón

\footnotetext{
358 BARONA VILAR, Josep Lluis. (2002) Salud, enfermedad y muerte. La sociedad valenciana entre 1833 y 1839. Institució Alfons el Magnànim, València. pp. 274-276.

${ }^{359}$ MONLLEÓ PERIS, Rosa (1996): La Gloriosa en Valencia (1864-1868). Edicions Alfons el Magnànim. Generalitat Valènciana, Valencia p. 154.
} 
En todos los tiempos encontramos disposiciones encaminadas a remediar las fiebres palúdicas.

En el siglo XVI continuaba la preocupación por el saneamiento de los marjales, y en 1533 piden a Carlos I autorización para formar con las del término y las contiguas de Benicassim, una albufera, dando entrada en toda extensión pantanosa a las aguas del mar. No llega a realizarse la proyectada albufera y las aguas de la marjal juntamente con las de las balsas del cáñamo, siguieron haciendo estragos.

Según el archivero Juan Antonio Balbás, se ignoran los motivos porqué no se llevó a cabo la proyectada albufera:

Tal vez surgieron inconvenientes en su ejecución o quizás lo impidieran vicisitudes políticas sobrado frecuentes en todos tiempos. Creemos no obstante, que el citado proyecto no hubiera remediado el mal; pues en los veranos secos y cálidos muy frecuentes en este país meridional, se evaporarían lentamente las aguas, se descompondrían las sustancias animales y los despojos vegetales acumulados anteriormente, y viciando la atmosfera, producirían los mismos funestos resultados. $^{360}$

Balbás expone que el medio de saneamiento más eficaz sería desecar los terrenos pantanosos, levantando su fondo. «Pues no sólo se trataría de conquistar a la agricultura extensiones considerables de terreno completamente pérdidas por la incuria, sino también de proporcionar mejores condiciones de existencia a los habitantes de esta comarca, haciendo desaparecer la causa que altera su salud durante el otoño». Sigue exponiendo Balbás:

Conviene insistir en esta materia y que las autoridades presten toda su atención a este importante asunto, y mucho más que ahora que tan próxima está la construcción del puerto en nuestra playa. Las ventajas que se reportarían con el saneamiento de todas estas marjales, serían incalculables, el Grao se convertiría en una estación deliciosa de baños, que dejaría muy atrás las más nombradas de Europa y nuestro suelo a cubierto ya de las deletéreas emanaciones de El Cuadro, sería

\footnotetext{
${ }^{360}$ BALBÁS, José Antonio. «La higiene pública en Castellón durante los tiempos pasados y saneamiento del cuadro». Revista de Castellón, 1/06/1882 y 15/06/1882.
} 
indudablemente el país sano por excelencia y el abrigo de todos los que afectados del pecho buscan hoy lejos de su patria el alivio de sus dolencias. ${ }^{361}$

En Castellón había preocupación por saber el origen de las fiebres palúdicas. Así, la prensa de Castellón publica un artículo sobre el descubrimiento de los microbios que producen las tercianas.

Describen que nacen en el seno de pequeños charcos, que pasan por diferentes fases de existencia y realizan el ciclo entero de su vida sin salir del lago en que nacieron; penetran en el organismo humano por el aire que respiramos; allí se adaptan al nuevo medio y constituye el comienzo del contagio de la enfermedad, del estado anómalo para la persona que tuvo la desgracia de convertirse en su morada.

Afirman que la existencia de tan peligrosos seres, «[...] que antes solo se sospechaba, está ya demostrada por la observación y la experiencia».

Se describe cómo se obtiene la sangre a través de un pinchazo en la pulpa de un dedo, con una aguja muy limpia. Recogida la sangre se deposita en un portaobjetos, se la cubre y se extiende observándola al microscopio. A continuación sigue diciendo que un estudio detenido descubre varias formas extrañas que tienen en común, entre otras, la propiedad de ser destruidas por la quinina.

Hay allí cuerpos esféricos de cinco a seis milésimas de milímetro. Los cuerpos extraños están adheridos a los glóbulos sanguíneos a expensas de los cuales se nutren; cuando se realiza la destrucción del glóbulo rojo, queda solo una masa parduzca que representa su materia colorante, y es absorbida por los organismos descritos. 362

La Revista Médico-Farmacéutica de Castellón publica en diferentes números, la tesis doctoral de Manuel Lassala Emo titulada: Etiología del paludismo, en donde muestra lo que se sabía de dicha enfermedad en los años ochenta del siglo XIX.

En esos años no se sabía la etiología del paludismo; existían multitud de investigaciones sobre las condiciones genésicas y cualidades peculiares de la malaria,

\footnotetext{
${ }^{361}$ Ibídem.

${ }^{362}$ La Provincia, 25/02/1883.
} 
pero cuando se trataba de determinar la causa intima o el verdadero agente físico, se entraba en la esfera de la conjetura y muchos autores preferían confesar que lo ignoraban, esperando que trabajos ulteriores dieran más luz sobre este asunto.

Muchos médicos prestigiosos adoptaron el Fitoparasitismo para explicar la etiología del paludismo.

La definición que más se aceptaba por todos los autores era la siguiente: el «mefitismo palúdico es una viciación particular que adquiere el aire en los lugares donde hay aguas estancadas». Según Lassala Emo, esta definición no puede ser más inexacta, porque primero, puede haber mefitismo palúdico donde no hay aguas estancadas; segundo, porque pueden haber aguas estancadas donde no hay mefitismo palúdico, y tercera, porque las aguas estancadas pueden desarrollar otros mefitismos. Según el citado autor, se entiende por mefitismo palúdico «la viciación del aire por el agente del paludismo». 363

Los vecinos del Grao eran los más castigados por la enfermedad por lo que había preocupación de que «aquel populoso barrio quedara desierto».

La prensa se queja del abandono que tenían las distintas corporaciones municipales del caserío del Grao, que hacía que aquella población perdiera cada día las condiciones de salubridad y las calenturas intermitentes, se desarrollasen cada año con más intensidad. Por ello «la colonia que durante la época del calor se traslada al pueblo terminará por disminuir y hasta abandonarla si el Ayuntamiento no toma medidas». ${ }^{364}$

La solución que proponen es no tolerar que se hicieran plantaciones de cáñamo en los predios situados junto a las acequias de los marjales, ni que se llevaran dichas plantaciones en puntos que lo tenían prohibido.

La idea que se tenía de Castellón era muy positiva, pero para dar a la capital la importancia que debía tener, había que destruir:

El foco mefítico y temible que hacía el Este se extiende amenazador en el círculo que forman los llamados cuadros, verdadera laguna estigia que lleva en el aire el imperio de su fatal influencia. Castellón tiene un suelo fértil donde se planta el trigo, el cáñamo, la caña, la naranja, la cepa más preciada, y la oliva, donde todo arraiga y da fruto, con un clima el más benigno y un aire puro, y un cielo azul y

\footnotetext{
${ }^{363}$ Revista Médico Farmacéutica, 17/11/81 p. 306.

${ }^{364}$ La Provincia, 19/08/1880.
} 
siempre limpio, con vecindario laborioso, sufrido y por ende honrado y pacífico, con la categoría que en la provincia ocupa. Con su proximidad al mar que es el gran camino del comercio y con la topográfica situación que la determina, está llamada a otra vida mayor de actividad y engrandecimiento que la vida pobre y casi rutinaria que hoy lánguidamente arrastra. ${ }^{365}$

Las tercianas eran consideradas el castigo mayor que pesaba sobre la gente de mar y sobre los labradores, ya que había familias enteras enfermas:

Y es lo más sensible que no puedan sustraerse a la fatalidad que les agobia. Sabido es que las tercianas reconocen como una de sus principales causas productoras la emanación palúdica de las lagunas y aguas estancadas de poco fondo, emanaciones que constantemente infeccionan el ambiente con nocivos miasmas que el hombre recibe con el aire que respira, introduciendo así en su organismo, como traidor enemigo, la semilla contagiosa de tan penosa enfermedad. ${ }^{366}$

Las playas no eran muy frecuentadas debido al temor de contagiarse de las «fiebres», y las familias buscaban otras zonas alejadas del litoral donde pasar el verano.

La prensa se pregunta si no sería conveniente la desaparición de esas aguas y la plantación de arbolado en el terreno que ocupan.

[...] ¿No convendría acaso la emancipación de esos terrenos para cualquier explotación, el cultivo de eucaliptos por ejemplo, que es hoy objeto de lucrativas empresas y árbol es por sí un antídoto a la enfermedad que deseamos evitar?

Ahora bien, ¿Es tan difícil y costosa la desecación de esos pantanos? ¿Existen obstáculos tan poderosos que impidan su propia desaparición?

Creemos que no. Su gran proximidad al mar facilita muy ventajosamente el desagüe. El producto que a aquellos terrenos puede arrancar el cultivo es patente en la contigua marjalería, fértil y frondosa; cuando otra no, la indicada plantación de eucaliptus había de superar con magnificencia, estamos seguros a los gastos relativamente menores que se ocasionaran.

\footnotetext{
${ }^{365}$ El Clamor, 22/08/1880.

${ }^{366}$ Ibídem.
} 
Pero hay otro medio: sáquese aquella porción de tierras a subasta, cédase en condiciones y requisitos útiles a manos que particularmente se encarguen de realizar la mejora; no dudamos que habría quien tome sobre sí la empresa. ${ }^{367}$

La opinión pública de Castellón reclamaba la solución a los problemas de salud que ocasionaban los cuadros y las aguas «sin corriente» de la marjalería. Si Castellón había de entrar en el camino del progreso, una de las mejoras era la desecación de los cuadros como preludio y base de otras de mayor coste.

En la capital, las fiebres palúdicas se dejaban sentir en el arrabal de San Roque, que era la parte más enfermiza de la población y en la que mayor número de atacados por las tercianas se registraban, «consecuencia precisa de su mayor proximidad al temible foco y más frecuente o desnudo contacto con los aires infeccionados que de su lado soplan».

Los barrios más afectados fueron los del Norte de la población, San Félix y San Roque, porque allí vivía una población eminentemente agrícola. La trilogía secano, huerta, marjal preside la historia económica de Castellón, aunque la huerta ha sido siempre el eje vital. A finales del siglo XVIII casi las tres quintas partes de los activos se dedican a la agricultura. Los jornaleros residen preferentemente en los arrabales, edificados como núcleos rurales pobres. ${ }^{368}$

En 1884 se declararon insalubres más de mil hectáreas de terrenos pantanosos y marjales comprendidos entre la ciudad de Castellón y Benicasim. ${ }^{369}$

El Clamor publica un artículo de La Revista de Castellón de 15 de junio de 1884 sobre el proyecto de la sociedad La Fertilizadora para desecar y sanear los terrenos conocidos por «el Cuadro y marjales adyacentes».

Desde hacía muchos años, preocupaba a los estudiosos de la salubridad pública, el gran número de afecciones intermitentes que en Castellón se padecían.

[...] y reconociendo como la ciencia reconoce hoy que esta clase de afecciones son producto de los miasmas y emanaciones desprendidos de las aguas

\footnotetext{
${ }^{367}$ El Clamor, 27/11/1881.

368 BURRIEL DE ORUETA, Eugenio (1971): «Desarrollo urbano de Castellón de la Plana», Estudios geográficos, $\mathrm{n}^{\circ}$ XXXII, Madrid. Revista Saitabi. op. cit. p.266.

${ }^{369}$ La Provincia, 10/04/1884.
} 
estancadas cenagosas y en putrefacción, se ha visto que los focos de donde proceden estas emanaciones son los puntos conocidos con el nombre de Cuadros.

El proyecto de La Fertilizadora encontró defensores decididos y serias oposiciones. El proyecto comprendía:

- La desecación y saneamiento de los terrenos pantanosos o encharcados enclavados en el término de Castellón y el de Benicasim.

- Aprovechamiento de las aguas que corrían por las acequias, barrancos de $L a$ Ralla, Obra, Obertella, Molinera, Senillar, Travesera, Mota, Fileta, Plana y Entrilles, para regar los terrenos desecados y otros de secano.

- Instalación de un establecimiento de pesca y piscicultura, aprovechando al efecto las aguas sobrantes del riego antes indicado.

- Formación de un banco ostrícola en el Mediterráneo frente a la masía de Los Frailes.

Hubo mucha polémica y lucha de intereses entre los propietarios de los marjales y la empresa La Fertilizadora en el deslinde de los terrenos.

Uno de los informes favorables al proyecto fue el de la Junta Provincial de Sanidad, que interrogada sobre si era conveniente para la salud pública la desecación de los terrenos pantanosos, contestó afirmativamente «ya que como saben hasta los profanos en las ciencias médicas, los pantanos son el origen de la malaria que ocasiona las intermitentes». Sin embargo había serias dudas de que el proyecto de $L a$ Fertilizadora acabara con las fiebres palúdicas que, según la prensa, ocasionaba el cincuenta por ciento de los enfermos de Castellón.

No obstante, se creía que la desecación de Los Cuadros, en la extensión que se proponían en el proyecto, podía contribuir a que disminuyera el número de enfermos de tercianas, pero también se pensaba que nunca sería bastante para que dichas enfermedades dejaran de presentarse con frecuencia en Castellón. 
Las razones que argumenta la prensa eran: En primer lugar, el proyecto de la Fertilizadora no comprendía todos los terrenos pantanosos o encharcados del término municipal, y añadía:

[...] pues nadie ignora que desde la acequia de Entrilles hacía la parte sur del término municipal de esta ciudad queda una gran extensión de terrenos en condiciones completamente idénticas a los declarados insalubres y por consiguiente han de continuar siendo origen y causas de gran número de intermitentes. ${ }^{370}$

En segundo lugar, no se debía dar demasiada importancia a la desecación de los cuadros ya que otra de las causas de las intermitentes era las aguas encharcadas en las balsas de curar cáñamo:

Cuya causa, claro está, que ha de persistir por más que se realice el proyecto en cuestión. Dedujese de lo expuesto que si bien bajo el concepto que hoy examinamos el proyecto no puede negarse que ofrece alguna ventaja, no debemos hacernos ilusiones sobre la desaparición de las intermitentes en esta ciudad, aun suponiendo, y es mucho suponer, que la desecación fuera tan completa que jamás se encharcarán las aguas en los terrenos que se trata de fertilizar. ${ }^{371}$

Antes que la empresa La Fertilizadora, unos cuantos hombres de negocios concibieron el plan de sanear Los Cuadros de Castellón. Presentaron los planos de saneamiento a las autoridades y por no reunir las condiciones científicas que la ley exigía fueron rechazados. Años después, la empresa arriba citada, concibe otro plan más basto dentro de las exigencias legales, y después de vencer miles de contrariedades, por Real Orden de 22 de febrero de 1884 son declarados «insalubres» los terrenos señalados por La Fertilizadora.

Ni antes ni después de la declaración de insalubridad levantó la voz ningún propietario. Pero en vista que circulaban rumores de descontento entre varios propietarios de terrenos comprendidos en los planos de saneamiento, la citada sociedad La Fertilizadora publicó -unos días antes de salir las comisiones oficiales de ingenieros

\footnotetext{
${ }^{370}$ El Clamor, 22/06/1884.

${ }^{371}$ Ibídem.
} 
y ayuntamiento a comprobar los deslindes- una hoja impresa prometiendo a los descontentos reformar de común acuerdo los planos salvando los intereses particulares que se creyeran perjudicados, levantando al efecto actas notariales que sirviera de garantía para los propietarios y como punto de partida para la empresa.

Nadie se opuso a «la buena fe» demostrada por La Fertilizadora. Sin embargo, horas antes de salir las comisiones, debido a ciertos trabajos de zapa, se había logrado soliviantar a los marjaleros, diciéndoles que iban a robarles los marjales, que el Gobierno, previos los informes facultativos, había declarado insalubres sus campos «cediéndolos a una sociedad». El Gobierno era el que había dado la orden para que robaran sus bienes. «Id y sublevaros contra el poder que así lo ha dispuesto». ${ }^{372}$

El 1 de diciembre de 1917, El Clamor, publica un artículo que titula «Los estragos del paludismo en España», donde hace hincapié en los problemas económicos que ocasionaba aparte de los sanitarios. ${ }^{373}$

En el año 1916, España tenía 9.216 términos municipales, de los que se consideraban palúdicos 1.492, más de la octava parte. La dimensión de los focos morbosos en hectáreas representaba la suma de 305.331, «que en cifras redondas y descontando el desmérito natural que les hace perder el terrible mosquito, 25 millones y medio de pesetas».

Esos mismos terrenos saneados, valían, 126 millones y medio de pesetas; de manera que sólo por esta razón perdía la riqueza nacional un valor de 101 millones de pesetas.

El número de enfermos en 1916 era de 509.420, de los cuales fallecieron 2.139:

Entre vivos y muertos consumieron 2.094.200 pesetas, dinero que empleado en sanear los terrenos palúdicos daría al cabo de seis y ocho años el resultado de hacer desaparecer de España las fiebres larvadas.

Calculando que cada enfermo, obreros del campo casi todos, han perdido quince días de trabajo por la enfermedad, resulta un total de 3.141.300 días perdidos; o sea 8.606 años y 110 días.

\footnotetext{
${ }^{372}$ El Clamor, 29/06/1884.

${ }^{373}$ El Clamor, 1/12/1917.
} 
Estos días se traducen en jornales (a dos pesetas), y entonces representan una pérdida anual de 6.282 .600 pesetas, que sumadas a los 10.695 .000 valores de las vidas desaparecidas, ofrecen un total de 16.677 .600 pesetas. ${ }^{374}$

\subsection{LA DIFTERIA, ENFERMEDAD INFANTIL}

La difteria compartía con la viruela el papel responsable destacado de la mortalidad infantil. Su distribución socioeconómica era tan desigual como la de la tuberculosis. Por ejemplo Luis Marco en su libro sobre La difteria en Madrid (1888), destacó que solamente en un barrio pobre (Chamberí) hubo 189 muertes por esta causa, mientras que los 25 más ricos sumaron 129.

El descenso de la mortalidad se produjo gracias al suero antidiftérico obtenido por Emil von Behring y Émil Roux, que se difundió en Europa a partir de 1894. En poco más de una década, en España, por ejemplo, los fallecimientos se dividieron por diez, pasando la tasa de mortalidad específica por cien mil habitantes de 66 en los años ochenta a 28 en las fechas iniciales del siglo XX. No obstante, la difteria no llegó entonces a desaparecer. En nuestro país produjo el año 1920 casi tres mil muertes y en 1939, al final de la guerra civil, más de cuatro mil. Únicamente durante la segunda mitad del siglo XX había pasado a ser en Europa un problema residual, gracias principalmente a la vacunación. ${ }^{375}$

En los años ochenta del siglo XIX La difteria causaba muchas víctimas en Castellón, « [...] sin que su progresivo desarrollo se oponga a ninguna medida higiénica». La prensa llama la atención de las autoridades para que adoptara las disposiciones que la ciencia aconsejaba. ${ }^{376}$

\subsubsection{Medidas contra la Difteria y manifestaciones de la enfermedad}

En 1884, ante las circunstancias que atravesaba Castellón con respecto a la enfermedad diftérica, La Provincia, publica un artículo del especialista y director del Hospital de niños, Dr. Brochlcaus, traducido directamente del periódico alemán Die Gesellschaft.

\footnotetext{
374 Ibídem.

${ }^{375}$ Lopez piñero, José María (2002): La Medicina en la Historia, La Esfera de los libros, Madrid, p. 655.

${ }^{376}$ La Provincia, 2/10/1884.
} 
La difteria que había tomado gran incremento en Europa desde hacía pocos años había llamado poderosamente la atención de los hombres de ciencias, « [...] habiéndose conseguido resultados tan satisfactorios, que bien podemos congratularnos de ellos».

En el artículo, se culpa al descuido o torpeza de las madres, «[...] pues si estas llamasen al médico desde que advierten en sus criaturas síntomas anormales, ciertamente que no habría que lamentar defunciones».

Para prevenir la difteria, se aconseja llevarles abrigados; evitar las corrientes de aire en las habitaciones; alimentarle bien y sin exageraciones; librarles de humedades; lavar las habitaciones de muy tarde en tarde; «Darles a todo pasto el agua de alquitrán y la leche»; no sacarles de casa sino a horas de sol a sitios donde hubiera poca vegetación; apartarles del roce con los demás niños y lavar la ropa en casa evitando las lavanderas (eran consideradas un peligro constante para la salud pública); de vez en cuando fumigar las habitaciones con una mezcla de incienso, benjuí y estoraque a partes iguales echándolo sobre ascuas.

Se prohibía jugar con frutas porque «[...] las algas diftéricas, que son las que constituyen las falsas membranas, se crían sobre las naranjas; esta es la fruta más peligrosa y dañina». «[...] observando fielmente estos preceptos, es seguro que los niños no serán atacados del crup ni de anginas diftéricas».

Para la curación de la difteria, el citado doctor, indicaba la esencia de trementina, en jarabe o en leche; los vapores de brea o la misma esencia; las pulverizaciones de una disolución al $8 \%$ de sulfato de hierro, vinagre puro o de agua de cal.

Si el desarrollo de las algas globulares, entofitos, fuese muy violenta-crup- $-{ }^{377}$ y la acción de los anteriores medicamentos no surtieran efecto pronto, que peligrase la

\footnotetext{
377 La difteria es una enfermedad infecto-contagiosa de origen bacteriano que ocasiona una intensa inflamación en la faringe y los tejidos cercanos. En ausencia de tratamiento, puede provocar la asfixia del enfermo. Actualmente, gracias a la aplicación sistemática de la vacuna antidiftérica a los niños, la incidencia de esta enfermedad en nuestro medio es casi nula. El agente etiológico de la difteria es el Corynebacterium diphteriae, que se caracteriza porque elabora y secreta en la sangre una toxina muy potente con efectos tóxicos en diversos tejidos del organismo. El hábitat natural de esta bacteria es las mucosas respiratorias o algunas veces la piel de los enfermos o los portadores sanos. La fuente de la infección son las secreciones mucosas de estas personas, que se propagan en el aire en forma de pequeñas gotas. La vía de contagio es respiratoria y el periodo de contagio se inicia al cabo de unas horas o unos días del contagio, y se extiende hasta que los síntomas remiten del todo. Después de penetrar en el organismo por vía respiratoria, los gérmenes se reproducen en la mucosa nasal, la faríngea y la laríngea, y hasta en la tráquea, y provocan la inflamación y la muerte celular de estos tejidos, y una secreción entre blanquecina y gris a partir de la cual se forman las llamadas pseudomembranas diftéricas, que en los casos graves pueden obstruir completamente las vías respiratorias. La enfermedad se inicia con la
} 
vida del niño, recomendaba la traqueotomía, « [...] pues solo en este caso debe practicarse». 378

En Artana y otros pueblos de la provincia existían muchos casos de crup, siendo bastantes las víctimas que ocasionaba. ${ }^{379}$

Como consecuencia de los muchos casos de difteria que se presentaban en Castellón, la Junta de Sanidad local acordó que además de las medidas de desinfección y aislamiento que se tomaran en cada caso particular, se pasaran con frecuencia visitas médicas a las escuelas de párvulos, para que no se admitieran en ellas a los niños que presentaran síntomas prodrómicos o sospechosos de tan terrible enfermedad. ${ }^{380}$

Igualmente la Junta Local de Sanidad acordó prevenir a los profesores de instrucción primaria que no toleraran la asistencia a sus escuelas a los niños con síntomas sospechosos de difteria.

Asimismo se nombraron varios médicos para inspeccionar las escuelas privadas y adoptar en ellas igual medida. ${ }^{381}$

Era de obligado cumplimiento que los médicos informaran a la alcaldía de los individuos atacados y fallecidos de difteria, para que la autoridad hiciera cumplir las medidas de la Junta, como trasladar el cadáver al cementerio, enseguida que falleciera la víctima, sin dar lugar a las prácticas ordinarias, y además fumigar, blanquear y limpiar la habitación y las ropas. ${ }^{382}$

Otro preservativo que se aconsejaba contra el crup y la difteria era el azufre mezclado con agua.

La revista que se publicaba en La Provincia, titulada: La Madre y el Niño aconsejaba a las madres lo que debían hacer frente la enfermedad de la difteria:

\footnotetext{
inflamación de las mucosas faríngea o laríngea o bien las dos a la vez, dolor de cuello, ronquera, tos, dificultad respiratoria, fiebre elevada y malestar general. Al cabo de unas horas, se observa la formación de las pseudomembranas diftéricas, gruesas y adherentes, de un color gris, que solo se pueden desprender de las mucosas con dificultad y que al hacerlo provocan pequeñas hemorragias. El desarrollo de las pseudomembranas puede provocar una oclusión más o menos pronunciada de las vías aéreas que precise lar necesidad de practicar al enfermo una traqueotomía para favorecer el acceso del aire a los pulmones. Se llamaba Crup diftérico a la propagación de las falsas membranas de la difteria a la laringe, las cuales impidiendo la entrada y salida del aire en los pulmones daban lugar a fenómenos de sofocación, de intoxicación de la sangre por el ácido carbónico y como consecuencia la asfixia del enfermo.

${ }^{378}$ La Provincia, 6/11/1884.

${ }^{379}$ La Provincia, 18/12/1884.

${ }^{380}$ El Clamor, 4/01/1885.

${ }^{381}$ La Provincia, 11/01/12885.

${ }^{382}$ El Clamor, 8/02/1885.
} 
La difteria es cuatro veces más mortífera que el tifus y ocho más que la tosferina; urge, pues acudir pronto y con energía cuando se presenta, sobre todo en los niños pequeños».

Los accesos bruscos de sofocación durante la noche, acompañados de tos bronca (perruna que dicen algunas madres), deben inquietar menos que la tos pertinaz, sobre todo de igual índole, que produce síntomas de asfixia y aumenta en intensidad y frecuencia acompañada de fiebre alta. ${ }^{383}$

Los consejos eran examinar la garganta del niño en cuanto éste sintiera la menor molestia al tragar o alteración en la voz, se hallara triste y calenturiento.

Vigilar los niños débiles y predispuestos a catarros, dándoles una alimentación vigorosa y tónica sin exagerar los abrigos al cuello y cabeza, pero preservándolos de la humedad y de todo cambio brusco de temperatura.

La orientación de las habitaciones donde permanecieran los niños debía ser al mediodía, huyendo de las alcobas oscuras y estrechas, y evitando que la cuna se hallara entre camas de personas adultas.

Las nodrizas debían vigilar al niño cuando mamaba para observar si tragaba bien, «[...] siendo un síntoma de interés el que no mame y que se presente un flujo de moco blanquecino por la fosas nasales».

Aislar a los niños que viven en compañía del afectado, y no utilizar los niños sanos los objetos que utilizaban los enfermos.

No emplear remedios que no constituyeran un tratamiento racional recomendado por el médico, aunque autorizaba a las madres a facilitar la expulsión de las falsas membranas con un vomitivo como la ipecacuana. «La peor complicación que puede sobrevenir en un caso de difteria es el desorden y el pánico en los que rodean al enfermo, conviene en lo posible que no lo cuiden personas muy afectadas, a fin de que las curas se hagan como es debido y las prescripciones sigan con puntualidad exquisita».

Por último, se recomendaba la traqueotomía, «[...] siempre que se haga a tiempo y por consejo de la ciencia. No hay que olvidar que es una operación de urgencia vital». 384

\footnotetext{
${ }^{383}$ La Provincia, 12/03/1885.

${ }^{384}$ La Madre y el Niño. La Provincia, 12/03/1885.
} 
En 1885 El Boletín Oficial, para evitar la generalización de la difteria en algunos pueblos de la provincia, publicó unos consejos con el fin de que no se extendiera la enfermedad.

Se recomendaba sumergir las ropas del enfermo en un barreño con agua y cloruro de cal (vulgarmente llamado «polvo de gas»). Después de permanecer tres o cuatro horas en remojo, se podían entregar al lavado, teniendo cuidado de someterlas antes a la acción del agua hirviendo y no mezclándolas con otras prendas; hervir los utensilios utilizados: vasos, tazas, cubiertos, etc. a la acción del agua hirviendo; quemar las ropas y los diversos objetos usados por el enfermo, antes que cualquier otro medio de desinfección; deshacer los colchones, jergones y almohadas de la cama, donde hubiera fallecido el enfermo. Después de esto quemar azufre sobre ascuas dentro de la habitación herméticamente cerrada y no abrirla hasta después de veinticuatro horas; rascar las paredes y el techo de las habitaciones, y después pintarlas con cal. Los suelos de azulejo, mosaicos, etc. lavarlos con agua caliente cargada de cloruro de cal, y las puertas, ventanas y vigas lavarlas con jabón de potasa.

Estos consejos iban dirigidos a los jefes de familia. Cuando se trataba de enfermos pobres, eran las autoridades locales las que debían cuidar de su cumplimiento. $^{385}$

Durante el año 1885 ocurrieron en Castellón 809 nacimientos y 957defunciones, resultando 148 muertos más que nacidos. Esta diferencia era debida a las epidemias de cólera y difteria que se propagaron en dicho año. ${ }^{386}$

En Valencia, según La Provincia, la difteria se extendía de una manera alarmante. No sólo atacaba a los niños sino también a las personas adultas. «En Castellón sin que haya desaparecido dicha enfermedad, no presenta los caracteres graves que tiene en Valencia». 387

En 1888, La Provincia, publica una carta dirigida al director general de comunicación, señor Mansi, fechada en Chichester (condado de Sussex) y firmada por Anna Kuntfielt, en la que ésta manifiesta que, teniendo noticia de que la difteria estaba causando estragos en España, y no conociendo a ningún español, le remite una receta

\footnotetext{
${ }^{385}$ El Clamor, 21/12/1885.

${ }^{386}$ La Provincia, 14/01/1886.

${ }^{387}$ La Provincia, 4/02/1886.
} 
copiada de un periódico profesional científico, para que un médico español la ensayara y pudiera recomendar su uso si el ensayo resultara satisfactorio.

El medio curativo consistía en poner una cucharadita de flor de azufre en una copita de agua y revolviéndolo bien con el dedo, pues con «la cuchara el azufre no se mezcla bien con el agua». Cuando el azufre estaba bien mezclado, el enfermo debía hacer gárgaras con ello, y en diez minutos se hallaba el atacado fuera de peligro. Según decía la receta, el azufre destruye todo género de hongos en las personas, en los animales y en las plantas en pocos minutos. En vez de escupir el gargarismo, se recomendaba tragarlo.

En los casos extremos, cuando el hongo se había desarrollado hasta obstruir casi la garganta, con objeto de facilitar el gargarismo, se introducía el azufre en la garganta poniéndolo en un cañón de pluma y soplando, y cuando las fungosidades se habían contraído, entonces, se daba el gargarismo mencionado.

Si algún enfermo no podía hacer gárgaras, sobre un ascua se espolvoreaba la cantidad de una cucharilla pequeña de azufre, o a veces dos y se hacía aspirar al enfermo el humo. De este modo las fungosidades eran destruidas. ${ }^{388}$

En septiembre de 1888, la Junta Provincial de Sanidad se reunió con el Gobernador a fin de que los asistentes resolvieran los medios preventivos para hacer frente a la difteria y nombraran una comisión dentro de su seno para el mismo fin. ${ }^{389}$

En el mes de octubre de 1888, aumentaba la alarma por los casos de difteria en Castellón, las familias temían que la enfermedad afectara a sus hijos. Se insta a la Junta Provincial de Sanidad a que aumentara el rigor y la severidad de sus medidas, a fin de contener el contagio y la extensión de tan terrible azote infantil. ${ }^{390}$

El Gobernador convocó a la Junta Provincial de Sanidad por el aumento de casos de difteria que se había observado en los quince primeros días del mes de octubre de 1888 , que ascendían a trece casos.

También se leyó una cartilla sanitaria conteniendo las instrucciones a que debían atenerse en los casos de invasión diftérica, escrita por el médico Antidio Desbertrant, ponente de la comisión que en la sesión anterior se nombró al efecto.

\footnotetext{
${ }^{388}$ La Provincia, 23/09/1888.

${ }^{389}$ La Provincia, 23/09/1888.

${ }^{390}$ La Provincia, 14/10/1888.
} 
Dicha cartilla, que se insertó en el Boletín Oficial, contenía en su parte dispositiva la desinfección periódica por el ácido sulfuroso, los locales y el material de los establecimientos donde los niños acudían en gran número y permanecían muchas horas en ellos. Quemar en el local de las escuelas -herméticamente cerrado los sábados por la tarde- 100 gramos de azufre por metro cúbico de capacidad, no abriendo estos locales hasta los lunes siguientes, dos horas antes de la entrada de los niños en las clases.

Atendiendo al riesgo de contagio y con el fin de evitar molestias al vecindario, con la adopción de medidas represivas para conseguir el aislamiento de los invadidos, la Juntas Locales de Sanidad, médicos de la población y autoridades locales debían divulgar los peligros a que se exponían las personas sanas con la proximidad de los atacados.

El ayuntamiento de cada población donde se registraran casos de difteria, debía nombrar, del cuerpo de practicantes, uno o más individuos según fuera el número de habitantes de aquella y el número que en la misma hubiera alcanzado la difteria, destinados a la vigilancia de los invadidos, y los cuales debían visitar dos veces al día por lo menos, cada uno de los atacados y obligar a las familias a que bajo su dirección y en su presencia se ejecutaran escrupulosamente las desinfecciones siguientes: lavar con una solución de bicloruro de mercurio al uno por mil y después con agua que haya sido hervida las vasijas y objetos de loza, barro, cristal y madera, inmediatamente usadas por el enfermo. Los objetos metálicos que fueran atacados por esta sustancia, se debían sumergir durante treinta minutos por lo menos en agua hirviendo; las ropas usadas por el enfermo, que por cualquier circunstancia no se podían quemar, se debían dejar apartadas en la misma habitación del invadido, para ser desinfectadas después de muerto o curado éste; a continuación se debía proceder a la desinfección de sus ropas y muebles de la habitación por medio del ácido sulfuroso. Para ello se quemaba en la habitación completamente cerrada 250 gramos de azufre por metro cúbico de capacidad debiendo permanecer cerrada 2 días por lo menos; nada más el ayuntamiento tuviera aviso de una defunción, el alcalde debía ordenar el traslado del cadáver al depósito del cementerio, recorriendo las calles y sitios menos transitados y haciéndose la inhumación en fosas de mayor profundidad que la ordinaria; los médicos de la población también debían dar inmediatamente aviso al ayuntamiento de los casos de difteria que se presentaran en la ciudad. 
También se indicaba que la Corporación tendría existencias, mientras en esa población hubieran casos de difteria, de leña, azufre y solución de bi-cloruro de mercurio al 1 por 1000, teñida con un color de anilina, a fin de facilitarlas gratuitamente a las familias necesitadas. El alcalde debía procurar que no se cometieran transgresiones a los reglamentos de sanidad y policía urbana en lo que a la salud pública se refiere, aplicando el castigo a los que faltasen a ellos. Diariamente el alcalde debía dar cuentas de las nuevas invasiones y defunciones de difteria que en la población ocurriesen. ${ }^{391}$

En la última semana del mes de octubre de 1888, solo había en Castellón un solo caso de difteria y las expectativas eran positivas si se cumplían las disposiciones que la Junta de Sanidad tenia ordenada. ${ }^{392}$

En 1889 se repetían los casos de difteria; la prensa recomendaba cumplir con las disposiciones vigentes a fin de evitar la propagación de la enfermedad. Se creía que la negligencia y la ignorancia por parte de las familias era la causa de que la enfermedad se extendiera. ${ }^{393}$

Algunos hijos de personalidades de Castellón también murieron por causa de la difteria, como fue la única hija del jefe de los republicanos Francisco González Chermá y la del abogado de Castellón Mateo Asensi. ${ }^{394}$

También en la provincia proliferaban los casos de difteria. En Villarreal había casos de difteria hacía días hasta el punto que el Gobernador dispuso que se tomaran todas las medidas necesarias para evitar el contagio. ${ }^{395}$

En el mes de julio de 1889, no habían casos de difteria en la capital, no obstante, seguían apareciendo noticias en la prensa para impedir su difusión.

Dicha enfermedad tiene al parecer un poder de difusión poco extenso alrededor del enfermo, y es transportable a grandes distancias, principalmente por los objetos que están en contacto con el enfermo. Además el germen de la enfermedad, es muy tenaz, lo cual explica la reproducción de la difteria en las mismas familias con intervalos de varios años. Por lo tanto es preciso destruir los objetos que han estado en contacto con los diftéricos cuando no se les puede someter

\footnotetext{
${ }^{391}$ La Provincia, 18/10/1888. El alcalde de Castellón en 1888 era Antonio Forns, médico.

${ }^{392}$ La Provincia, 28/10/1888.

${ }^{393}$ La Provincia, 24/01/1889.

${ }^{394}$ La Provincia, 20/01/1889, 24/01/1889; 31/01/1889.

${ }^{395}$ La Provincia, 13/06/1889.
} 
a una desinfección completa, por lo cual hay que recurrir a aparatos que den $120^{\circ}$ con un presión de dos atmosferas. ${ }^{396}$

Otro remedio contra la difteria era el alcohol. Se debía administrar diluido en agua en partes iguales, por peso, y se daba cucharadas repetidas veces. Con sólo este procedimiento desaparecían los síntomas malignos. El alcohol disolvía las exudaciones diftéricas de la garganta, y hacía bajar la temperatura, calmando a la vez el pulso y destruyendo los gérmenes del mal absorbidos por las glándulas así como purificando la sangre. $^{397}$

En Eslida, la difteria y el sarampión, en los primeros cuarenta días de 1890, ocasionaron más de 40 víctimas. ${ }^{398}$

\subsubsection{La Vacuna de la Difteria}

En 1895, El Heraldo de Castellón señala que «Ya no ofrece duda alguna los trabajos del doctor Roux, para la curación de la difteria, constituyen no solo una esperanza sino una hermosa realidad para los padres que ven a los hijos expuestos a los ataques de esa enfermedad traidora y cruel que deja tantas cunas vacías y que tantas angustias produce y tantas lágrimas arranca a las pobres madres».

Continúa diciendo que el doctor Ferrán tenía en el Laboratorio Microbiológico Municipal de Barcelona algunos caballos inmunizados de los que se obtiene el suero antidiftérico con todas las garantías de pureza y perfecta elaboración que exige la ciencia.

[...] y creemos que fuera muy conveniente que la corporación municipal de Castellón solicitase del doctor Ferrán el envío de una cantidad de suero antidiftérico para que en caso necesario pudiesen emplearlo los médicos de esta ciudad.

Esto mismo han hecho los ayuntamientos de los más importantes poblaciones de España y confiamos que el nuestro procurará estar a la altura de los

\footnotetext{
${ }^{396}$ La Provincia, 11/07/1889.

${ }^{397}$ La Provincia, 13/10/1889.

${ }^{398}$ La Provincia, 13/02/1890.
} 
que hayan demostrado más interés en estos asuntos, verdaderamente humanitario y que habrán de agradecerlo todas las madres. ${ }^{399}$

Más adelante, el mismo periódico resalta los casos de curación gracias a la vacuna de la difteria, para convencer a los que ponían en duda el tratamiento del doctor Roux. Anticipa la noticia que de cinco niños sometidos en Cartagena al referido tratamiento, « [...] dos habían expulsado a la segunda y tercera inyección respectivamente, las falsas membranas; otro que había sufrido la traqueotomía, continuaba en estado satisfactorio; otro estaba en convalecencia, y el último, con difteria faríngea quedó a las dos inyecciones sin fiebre y sin las falsas membranas». ${ }^{400}$

En sesión de 25 de enero de 1895, el ayuntamiento acordó adquirir todo lo necesario para combatir la difteria por el método del doctor Roux. ${ }^{401}$

Dos médicos de Vinaroz fueron comisionados por el Ayuntamiento para trasladarse a Barcelona con el objeto de adquirir del laboratorio del doctor Ferrán el suero antidiftérico del doctor Roux. Fueron atendidos con gran deferencia por parte de Ferrán y sus ayudantes, quienes les facilitaron «una gran dosis de aquel maravilloso suero». 402

En Castellón, fue comisionado para adquirir del doctor Ferrán el suero de Roux antidiftérico, el concejal del ayuntamiento Andrés Puig. La cantidad de suero que se adquirió fue pequeño y se agotó rápidamente por la gran demanda que había. ${ }^{403}$

En la ciudad, el propietario de la Farmacia Catalana, fue el primero en adquirir el suero antidiftérico; en la primera plana de El Heraldo de Castellón, aparece un anuncio dirigido a los «señores médicos» sobre la adquisición de dicho suero. ${ }^{404}$

\footnotetext{
${ }^{399}$ Heraldo de Castellón, 16/01/1895.

${ }^{400}$ Heraldo de Castellón, 18/01/1895.

${ }^{401}$ Heraldo de Castellón, 26/01/1895.

${ }^{402}$ Heraldo de Castelló, 4/02/1895.

${ }^{403}$ Heraldo de Castellón, 28/02/1895.

${ }^{404}$ Ibídem.
} 


\subsection{LA VIRUELA, UNA ENFERMEDAD DE TIEMPO INMEMORIAL. EL ORIGEN DE LA VACUNOLOGÍA MODERNA}

La historia de la viruela alcanzó uno de sus hitos muy poco tiempo después del descubrimiento de la vacuna. Un ilustre alicantino, Francisco Javier Balmis y Berenguer $^{405}$, cirujano, médico, botánico y sobre todo un gran emprendedor, lideró la Real Expedición filantrópica de la vacuna, que fue patrocinada por el Rey Carlos IV. Balmis llevó durante los años de 1803 a 1806, la vacuna de la viruela a América, Filipinas y China en un periodo agotador alrededor del mundo que supone una de las gestas más gloriosas de nuestra salud pública.

La viruela es una de las enfermedades transmisibles más antiguas que ha conocido la humanidad, sus datos de mortalidad durante los siglos XVII a XIX son impactantes y los brotes epidémicos que ocasionó la hicieron temible.

La enfermedad alteró la situación demográfica de algunas regiones e influyó políticamente cobrándose la vida de reyes y emperadores. Desde tiempo inmemorial fue combatida con las herramientas terapéuticas de que se disponía en cada momento. No es hasta el siglo XVIII cuando se empieza a vislumbrar un remedio eficaz para doblegarla. Serán los hombres de la Ilustración los que proporcionen un método novedoso para conseguirlo: la inoculación preventiva de viruela vacuna, más tarde llamada vacunación. La figura de Edward Jenner marca un antes y un después en esa lucha del hombre contra los estragos de la enfermedad.

No habían trascurrido más que cinco años desde la genial intuición de Jenner, cuando Francisco Javier Balmis, curtido en viajes y batallas, traduce la obra de Moreau de la Sarhe, difusor en Europa de las ideas de Jenner sobre la vacuna, y obtiene el mando para llevar a cabo el proyecto innovador que supuso la Real Expedición de la Vacuna.

Las personas observaron y aprendieron que si se sobrevivía a la viruela una vez, ya no la volvías a padecer y de su manifestación más visible, la pústula, podían extraer el antídoto para defenderse de ella.

Nació así, en distintos lugares y épocas, la práctica de inocular la sustancia morbosa desde los individuos variolosos a los que permanecían sanos. Aquel esfuerzo

\footnotetext{
405 BALAGUER I PERIGÜELL, Emili (1996): Balmis o L'esperit de la Il-lustració en la medicina española, Generalitat Valeenciana, Valencia.
} 
por combatirla duró siglos y la técnica de variolización fue practicada de diversas maneras, según las regiones y los utensilios disponibles. También se supo que no era bueno el contacto directo, en estrecho hacinamiento, con los enfermos y que en los malos tiempos de epidemia podía aislarse a pueblos enteros o ciudades durante, al menos, cuarenta días, para limitar su propagación.

A finales del siglo XVIII, se observó que ciertas personas, en contacto con una enfermedad variolosa que padecían las vacas, adquirían la propiedad de no padecer viruelas. Se procedió a inocular el fluido extraído de pústulas de las vacas en individuos sanos, lo que resultaba menos dañino para las personas que la variolización. Allí estuvo el origen de la vacunación, un legado de la Ilustración. La difusión de la práctica no estuvo exenta de gran controversia, en la que participaron todas las clases sociales, pero se fue aceptando hasta generalizarse ampliamente. La enfermedad que provocaba la vacuna era más benigna que la variolización y el procedimiento no exigía medidas como el aislamiento del vacunado, ni obligaba a la interrupción del trabajo. En años sucesivos, conforme fue propagándose el método vacunal, las autoridades sanitarias y legisladoras, desarrollaron campañas de vacunación en masa que hicieron declinar la mortalidad por viruela. No obstante, a lo largo del siglo XIX aparecieron nuevas oleadas epidémicas que hicieron dudar del valor de la vacuna.

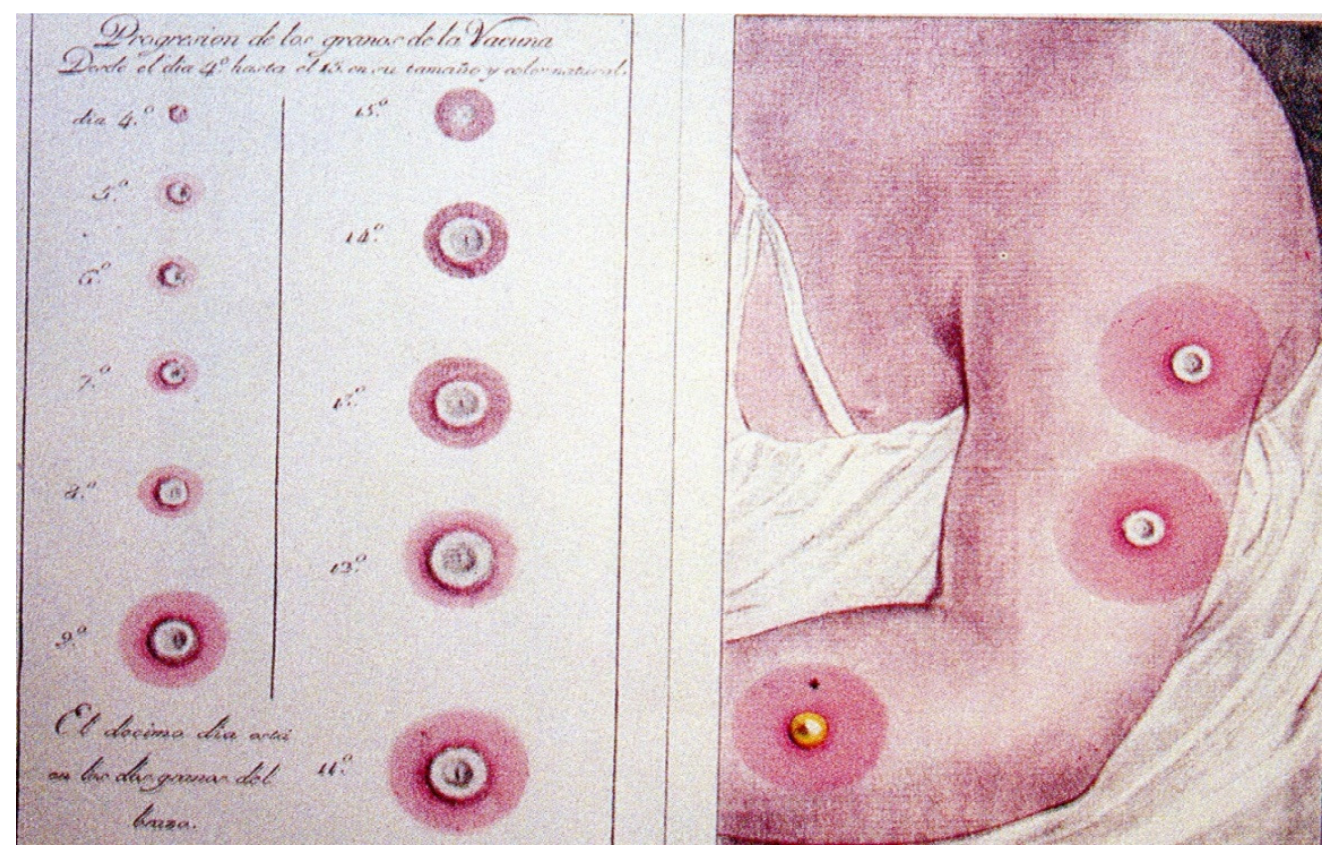

Progresión de los granos de la vacuna desde el día $4^{\circ}$ hasta el 15. Fuente: López Piñero, José María y Jerez Moliner, Felipe. (1999): La imagen científica de la vida. La contribución valenciana a la ilustración médica y biológica (siglos XVI-XIX) 
Habían transcurrido casi cien años desde el inicio de la vacunación. Entonces, por medio de la experimentación en laboratorio, comenzó a hacerse realidad la inmunización artificial, generalizando aquel método para otras enfermedades transmisibles y abriendo, con ello, una amplia perspectiva que dará origen a la vacunología moderna.

La viruela fue desapareciendo de la faz de la tierra gracias al progreso de la higiene, el saneamiento y la vacunación. El esfuerzo coordinado de las naciones durante los sextos y séptimos decenios del siglo XX, dio el impulso definitivo para conseguir su extinción.

En el siglo XVIII, la viruela causaba en Europa más de 400.000 muertes anuales y deja a un tercio de los supervivientes ciegos. Pero ese será también el siglo de propagación del método inoculador, que restará virulencia a la enfermedad, el siglo XIX será el de la propagación de la vacuna, y el XX, el de la erradicación de la enfermedad.

Antes y después de ser denominada como viruela, la enfermedad recibió muchos nombres. Estaban relacionados con los signos clínicos por los que se manifestaba, con el nivel de conocimiento que de ella se tenía en el momento, con el horror que producía o con asociación a las regiones de dónde provenía. ${ }^{406}$

En Europa, se menciona por primera vez la palabra viruela, variola, por Marius de Avenches (hacia 530-593), que fue obispo de Lausana y declarado santo a su muerte.

En el mundo anglosajón los nombres de la viruela tienen raíces distintas al de la viruela.

La pústula es llamada en inglés pock o pokes (bolsa o saco). El vocablo se alteró tomando el nombre fonético de pox, usado desde el siglo $\mathrm{x}$ para dar nombre a un conjunto de enfermedades diferentes, caracterizadas por presentar pústulas eruptivas en la piel (sarampión rubeola, etc.,). Pox fue posteriormente utilizado, en la literatura médica del siglo XV, para designar cualquier enfermedad venérea.

Cowpox, viruela de las vacas, es una enfermedad- vacuna que aparece en las ubres de las vacas de un color azul más o menos lívido.

Aunque las causas de la viruela permanecían oscuras, no lo eran así sus efectos o manifestaciones, y en base a ellos se establecieron diferentes clasificaciones. Las teorías

\footnotetext{
406 TUELLS, José y RAMIREZ, Susana (2003). Balmis et Variola. Valencia, Generalitat Valenciana. pp. 1719.
} 
médicas de la segunda mitad del siglo XVIII y principios del XIX que indagaron sobre las causas de la enfermedad, fueron las más prolijas en ese intento explicativo.

El virus y su familia, los poxvirus, será «visto» y descrito por Buist (1886), Prowazek (1905), Paschen (1906) y Ledingham (1931).

Antes de Pasteur, las vacunas, desde finales del XIX, solo eran una forma intuitiva de luchar contra una única enfermedad, después de él se convierten en un instrumento preventivo sistematizado y aplicable a otras infecciosas.

En España, la administración tomó parte activa en pro de la vacuna y en $L a$ Gaceta de Madrid se anunciaron cuantas novedades se iban produciendo. La Real cédula de 21 de abril de 1805 ordenaba que en todos los hospitales de las capitales de España se dedicara una sala para conservar el fluido vacuno, y que se administrara gratis a los pobres. $^{407}$

En 1815 (Real Orden de 14 de agosto) y 1817 (circular de 8 de julio) se articulan o ratifican las anteriores disposiciones. Coincidiendo con la pandemia de los años treinta, se prohíbe la asistencia de los niños a la escuela sin estar vacunados (R.O. del 30 de noviembre de 1833).

En 1855 se promulga la primera Ley de Sanidad (Ley Orgánica de Sanidad del 28 de noviembre) que dedica un capítulo a la vacunación y hace recaer la responsabilidad de practicarla en las instituciones o autoridades.

Desde 1851 el Instituto Médico Valenciano, entidad privada, había creado la Comisión Central de Vacunación con objeto de organizar y aplicar la vacuna gratuitamente a los indigentes de Valencia. Hasta 1880, esta institución fue el principal suministrador de vacuna en España.

Por Real Decreto y siendo Ministro de Fomento Manuel Ruiz Zorrilla, el 24 de julio de 1871, se crea el Instituto Nacional de Vacuna. Se le hacía dependiente directamente de la Academia de Medicina, lo que interfirió los planes que ésta tenía de crear uno propio. Tampoco faltaron reticencias del Instituto valenciano, el mayor distribuidor de vacuna hasta ese momento, ni de algunos médicos deseosos de fundar sus propios centros de vacunación. La respuesta oficial fue una Real Orden de diciembre de 1872 que determinaba que no era necesaria la autorización del Gobierno para establecer Institutos de vacunación a los médicos.

\footnotetext{
${ }^{407}$ Balaguer i perigüell, Emili (1996): L'esperit de la Il.lustració en la medicina española. Generalitat Valenciana. pp. 34-39.
} 
Durante el año 1873, el gobierno de la República intentó activar el Instituto de Vacunación trayendo vacuna de Nápoles y París con el fin de conservarla y reproducirla. Así mismo se dispuso la obligatoriedad de la vacunación y revacunación de cuantas personas estuvieran bajo la dependencia de las autoridades civiles.

A la vez se multiplican los institutos privados de vacunación, había tres en Barcelona, dos en Madrid, otros en La Coruña, Granada, Santander o Valencia, se suceden órdenes y reglamentos (en 1875 y 1876) intentando reorganizar la producción, investigación y actividad práctica en materia vacunal.

La situación de la viruela en España, durante los años finales del siglo XIX se caracterizaba por:

- Persistencia de oleadas epidémicas concurrentes con las europeas, que producían de 5.000 a 6.000 muertes por año, en los momentos de recrudecimiento de los brotes $(1879,1888-1892)$.

- Incumplimiento generalizado de las medidas preservativas de aislamiento, desinfección o cuarentena.

- Escasez de datos centralizados y falta de perspectiva general para abordar los brotes. No había informes sobre cobertura vacunal, ni se comunicaba la incidencia de casos con la rapidez necesaria para adoptar medidas preventivas. No es hasta 1885 (R.O. de 5 de enero), cuando se organizan las estadísticas sanitarias y se incluye a la viruela entre las enfermedades sometidas a vigilancia epidemiológica.

- Resistencia de la población al acto vacunal. Motivadas por la insuficiente explicación proporcionada por la clase médica a dos preguntas clave: ¿la vacuna transmite la sífilis? Y ¿por qué es necesaria la revacunación?

- Dispersión en las directrices científicas, originadas por la división de la clase médica entre vacunistas y antivacunistas, a lo que hay que añadir la práctica de la vacunación por colectivos paramédicos. 
- Las condiciones del acto vacunal. Había una vacuna de pago y una para pobres. Aun tratándose del mismo producto, en muchos lugares se practicaba en precaria situación higiénica y por personal no suficientemente preparado, para los que solo constituía una oportunidad más de negocio. El uso de la glicerina como conservante y reductor de la contaminación bacteriana, mejoró la efectividad y evitó muchos efectos indeseables.

Deficiencias en el control institucional. Las autoridades siempre iban a remolque de los acontecimientos, promulgando decretos al ritmo de los brotes epidémicos. $^{408}$

La situación en los primeros años del siglo XX no difiere mucho. Durante el primer decenio, España ocupa el segundo lugar entre los países europeos por número de casos, con un total de 37.000 defunciones, detrás de Rusia (400.000) y por delante de Italia (18.000), Portugal (14.000) y Francia (11.000). Por el contrario, países como Alemania (386), Austria (312), Suecia (35), Noruega (35) y Dinamarca (13) tenían en ese período un aceptable control sobre la enfermedad.

El gobierno de Antonio Maura, vista la situación epidémica, promulga en 1903 un Real Decreto, recogido en la publicación del Ministro de la Gobernación Datos históricos acerca de la vacuna en España, leyes y decretos contra la viruela, vacunación obligatoria, prologa el entonces Director General de Sanidad, Carlos María Cortezo. El artículo sexto declara que «Será obligatorio la vacunación y revacunación, con arreglo al art. 99 de la ley de Sanidad, en tiempos de epidemia o recrudecimiento de la endemia, a saber, desde que en el distrito municipal exista pluralidad de enfermos variolosos o las defunciones por viruela pasen de 1 por 1000 los fallecidos».

A pesar de las dificultades, la vacunación empieza a extenderse de forma masiva, ayudada por el establecimiento de delegaciones provinciales de Sanidad. En 1909, se ordena vacunar a todos los empleados del Estado, Provincia o Municipio y que se interese de las grandes empresas la vacunación de su personal. Sin embargo, los brotes persisten, en Badajoz 1917, Ciudad Real y Madrid 1918, Valencia, Bilbao, Santander, Pamplona y Ciudad Real (1919) y Valladolid, Almería y Guipúzcoa (1920). La mortalidad por viruela en España alcanza entre 1900-09 un total de 41.827

408 TUELLS, José y RAMIREZ, Susana (2003). op. cit., pp. 249-252. 
defunciones, que se reducen a casi la mitad durante la siguiente década, 24.512 (191019) y 9.727 en la tercera.

A partir de 1926 el declive de la viruela es evidente, consiguiéndose una situación de pre-erradicación en 1929. Solo habrá un repunte de la viruela en 1939-41, durante los años inmediatos al final de la Guerra Civil (1936-39).

La ley de bases de Sanidad de 1944 declaró la obligatoriedad de las vacunaciones contra la viruela y la difteria, incluyéndolas entre las enfermedades de declaración obligatoria. Acorde con los progresos en la vacunación, a finales de los años cuarenta deja de ser endémica y a partir de 1955 no se dan más casos de viruela en España, por lo que se consideró erradicada. ${ }^{409}$

\subsubsection{La Viruela en Castellón}

En los años ochenta del siglo XIX se presentaban muchos casos de viruela en la ciudad.

En la provincia de Castellón, pueblos como Villarreal sufrieron en 1882 una epidemia de viruela que produjo 84 defunciones. ${ }^{410}$

La prensa llamaba continuamente la atención de la Junta de Sanidad para que tomara las medidas oportunas a fin de evitar que la viruela tuviera mayores proporciones.

El 11 de abril de 1883 se reunió la Junta de Sanidad para acordar las disposiciones convenientes con el fin de aminorar en lo posible la extensión que podía tomar la viruela en la capital por falta de precauciones. ${ }^{411}$

La Junta Local de Sanidad exigía a todos los alumnos de la ciudad el certificado facultativo de haber sido vacunados si tenían menos de siete años o revacunados en el caso de haber cumplido dicha edad.

La Corporación Municipal ordenaba a los médicos titulares que procedieran, en el plazo más breve posible, a la vacunación gratuita de los niños pobres de la ciudad, autorizándoles para adquirir los tubos o cristales de linfa necesarios. ${ }^{412}$

\footnotetext{
${ }^{409}$ TUELLS, J Y RAMIREZ, S. Opus cit. pp. 53-54. También, sobre la enfermedad de la viruela y la vacuna, en LÓPEZ PIÑERO, José María y BUENO CAÑIGRAL, Francisco Jesús (2009): Segundo Centenario de la Real Expedición Filantrópica de la Vacuna de la Viruela 1803 - 2003, Consell Valencià de Cultura, Valencia. ${ }^{410}$ El Clamor, 3/09/1882.

411. La Provincia, 8/04/1883; La Provincia, 12/04/1883.

${ }^{412}$ El Clamor, 2/03/1884; AACS 29/05/1880.
} 
Acto seguido, el alcalde de la ciudad convocaba a la Junta Local de Primera Enseñanza, a fin de someter a su aprobación el acuerdo tomado por la Junta Local de Sanidad en el que se exigía a todos los alumnos de las escuelas certificado facultativo de haber sido vacunados.

El Ayuntamiento señalaba un día para la propagación gratis de la verdadera linfa vacuna del Cowpox del Glovester. ${ }^{413}$

La Junta Local de Instrucción Pública, oída la proposición de sanidad de no admitir en las escuelas a los niños no vacunados, acordó que los profesores abrieran un registro en el que se consignara dicha circunstancia. ${ }^{414}$

En Castellón, no se cumplían las disposiciones dictadas por el Ayuntamiento de vacunar a todos los niños contra la viruela por miedo a la reacción, tampoco los maestros cumplían con el dictamen del Ayuntamiento.

La corporación municipal dictó una disposición para impedir que acudieran a los centros de instrucción niños que llevaran el «germen del mal» o se encontraran desprevenidos contra él.

Los esfuerzos del Ayuntamiento no fueron secundados por los primeramente interesados, antes bien, algunos burlaron la vigilancia de los maestros y médicos, funcionarios a quienes quedaron encomendados de ejecutar lo dispuesto por la corporación municipal.

Las personas, en su mayoría, ignoraban los beneficios de la vacunación, y procuraban la manera de engañar a los facultativos. Los padres de familia transigiendo con el miedo de los niños a vacunarse, o porque éste no muriera a consecuencia de la revacunación, como había ocurrido en algunos casos, determinaron que el niño no fuera a la escuela con la esperanza de que más adelante, todo quedara tranquilo y olvidados las disposiciones municipales.

Los maestros, para evitar que los niños no dejasen de acudir a la escuela, eludieron el cumplimiento de las disposiciones municipales, pidiendo a los médicos que en las papeletas que expedían conforme a lo dispuesto por la sección de Sanidad, faltasen a la verdad de los hechos, haciendo constar vacunaciones y revacunaciones que no existían, o bien alterando la edad de los revacunados. ${ }^{415}$

\footnotetext{
${ }^{413}$ La Provincia, 2/03/1884.

${ }^{414}$ La Provincia, 6/03/1884.

${ }^{415}$ La Provincia, 30/03/1884.
} 
Como medio profiláctico para curar la viruela se recomendaba tomar miel mezclada con agua, pues según la prensa, este remedio curó a tres niños.

Como los tres casos citados parecen ser bastantes para pronunciar en favor de la miel como un remedio eficaz y sencillo contra la viruela, queremos darlo a conocer al público y especialmente a los señores médicos, quienes pueden hallar la causa entre los buenos efectos de aquel específico y usarla de una manera ilustrada y conveniente. $^{416}$

En el mes de mayo de 1884 proliferaban en la ciudad de Castellón las fiebres exantemáticas (viruela, roséola, sarampión, escarlatina,...) y la prensa de Castellón recomendaba a la Junta municipal de Sanidad la «más severa y escrupulosa inspección de las escuelas y demás puntos donde se reúnen los niños, a fin de evitar las funestísimas consecuencias del contagio en semejantes enfermedades». ${ }^{417}$

Por las calles de Castellón había casos de mendigos que iban acompañados de niños con viruela «No solo por un sentimiento de humanidad, por prescripción higiénica debe prohibirse espectáculo tan lamentable» ${ }^{418}$

En 1889, se registraban en la provincia algunos casos de viruela como en marzo en Vinaroz y Torreblanca; en 1895 en Almazora, dictando el gobernador civil las medidas oportunas para atajarla. ${ }^{419}$

En Castellón, en 1895, aparte del dengue, se registraban algunos casos de viruela. Se temía que con la debilidad del convaleciente del dengue fuera atacado de viruela, y las consecuencias entonces de la «epidemia reinante serian verdaderamente terribles». 420

La Junta Local de Sanidad teniendo noticias de que en algunos pueblos inmediatos se padecía la viruela acordó, en la reunión del día 25 de enero de 1895 , adelantar las vacunaciones y revacunaciones que anualmente practicaban los médicos

\footnotetext{
${ }^{416}$ La Provincia, 27/04/84.

${ }^{417}$ La Provincia, 29/05/1884.

${ }^{418}$ La Provincia, 4/11/1888.

${ }^{419}$ La Provincia, 11/04/1889; La Provincia, 25/04/1889; Heraldo de Castellón, 23/01/1895.

${ }^{420}$ Heraldo de Castellón, 23/01/1895.
} 
titulares del Ayuntamiento y prevenir a todos los facultativos de la capital que dieran cuenta de los casos que tuvieran en tratamiento. ${ }^{421}$

En el siglo XX, la viruela siguió haciendo estragos en la capital. El inspector de Sanidad, en una sesión celebrada por la Junta Provincial de Sanidad, en abril de 1915, dio lectura a una Memoria sobre la epidemia de viruela que tuvo lugar en Castellón.

Durante dicha epidemia hubo 257 casos, 182 en adultos y 75 en niños. Todas las invasiones tuvieron lugar en individuos no vacunados, siendo el número de defunciones de 8 adultos y 7 niños.

En el Hospital Provincial, ingresaron 99 enfermos, todos los demás fueron aislados en sus domicilios, los que fueron desinfectados convenientemente por el servicio municipal de desinfección.

Se practicaron durante el transcurso de la epidemia 1.167 vacunaciones y 19.288 revacunaciones, total 30.455 operaciones, cuya mayoría fueron practicadas por el cuerpo facultativo de Beneficencia municipal, habiendo sido la vacuna facilitada gratuitamente por el Ayuntamiento.

Según el doctor Clará, la viruela que en años anteriores había casi desaparecido en la provincia, había aumentado notablemente en 1915, y este aumento era debido al poco interés que se observaba en los pueblos en los servicios de vacunación y sobre todo de revacunación. Había pueblos en la provincia donde no se practicaba ninguna vacunación, a pesar de remitirles la vacuna necesaria para ello. ${ }^{422}$

En la segunda decena del siglo XX aumentó la propagación de la vacuna antivariólica según los datos proporcionados por la Junta Provincial de Sanidad, celebrada el 1 de abril de 1917. Durante ese año se repartieron entre los pueblos de la provincia 898 viales de vacuna antivariólica de 10 dosis cada uno procedentes del Instituto Nacional de Higiene de Alfonso XIII.

Según los datos suministrados por las alcaldías se practicaron 7.185 vacunaciones y 9.243 revacunaciones.

Durante el mismo periodo ocurrieron 201 casos de viruela en 26 pueblos, solo en tres de ellos el número de invasiones fue superior a 10 y en 8 se limitó a una sola. La mortalidad fue de 19 personas. ${ }^{423}$

\footnotetext{
${ }^{421}$ Heraldo de Castellón, 26/01/1895.

${ }^{422}$ El Clamor, 26/04/1915.

${ }^{423}$ El Clamor, 3/04/1917.
} 
Según la prensa, en 1916, el estado sanitario de la provincia era bastante satisfactorio. La mortalidad que en 1915 fue de 5.978, en 1916, fue de 5.476. Ocurrieron 502 defunciones menos.

La natalidad seguía decreciendo desde 1905 en que fue de 10.420, y en 1916 fue de $7.094 .^{424}$

En 1917, el inspector provincial de Sanidad José Clará, informó que se había declarado un epidemia de viruela en Tirig y Canet lo Roig, debido a la dejadez del médico Cayetano Matamoros a quien se le instruyó expediente. El gobernador ordenó que se vacunaran y revacunaran todos los vecinos, dándole cuenta diariamente de todas las operaciones que se llevaran a cabo, advirtiéndole que por cada día que dejara de verificarlo le impondría la máxima multa.

El gobernador estaba dispuesto a castigar con dureza al médico de Tirig, tan pronto se concretaran los cargos que contra él mismo hacia la sociedad de Socorros Mutuos de aquel pueblo y de la cual formaban parte la mayoría de los vecinos.

Asimismo se daba cuenta a la dirección general de Sanidad de la aparición de las enfermedades contagiosas en los pueblos.

En Canet lo Roig se declaró también la meningitis cerebro-espinal, donde habían ocurrido 26 casos en niños menores de 14 años, de los cuales fallecieron 10; se desconfiaba que pudieran sobrevivir los que aún no habían muerto, dada la gravedad en que se encontraban los niños. ${ }^{425}$

El gobernador civil, de acuerdo con el inspector provincial de Sanidad, pidió al Instituto del Alfonso XII material sanitario y aparatos para atacar tan terrible enfermedad y rogándoles que se le asignase un médico.

La comisión médica del Instituto de Alfonso XII vino con material sanitario a Canet lo Roig para atacar la enfermedad que tanto se cebaba en los niños de aquel pueblo.

El instituto envió para estudiar la epidemia aparecida en Canet lo Roig, a dos médicos bacteriólogos, acompañados por el inspector de Sanidad José Clará, con el fin de dictar las medidas más convenientes para extinguirla. ${ }^{426}$

\footnotetext{
${ }^{424}$. El Clamor, 3/04/1917.

${ }^{425}$ El Clamor, 14/04/1917.

${ }^{426}$ El Clamor, 18/04/1917 y 19/04/1917.
} 
Los institutos de vacunación, creados para producir y distribuir vacuna, comienzan a proliferar por toda Europa a mediados de siglo XIX, en ocasiones serán financiados por la iniciativa privada y, en otras, por la administración pública o sanitaria y por instituciones médicas.

En la ciudad existía un instituto privado de vacunación que estaba situado en la calle Campoamor y después en la calle San Juan, número 19 (hoy calle Colón), donde se propagaba la verdadera linfa vacuna, en dicha corporación se celebraban dos sesiones semanales. Hasta 1880, el Instituto Médico Valenciano fue el principal suministrador de vacuna al Instituto castellonense.

En el mismo establecimiento se vendían los tubos de vacuna extraídos directamente de la ternera.

El gobernador de la provincia aprobaba el reglamento de la sociedad del instituto de vacunación que quisiera establecerse en Castellón. ${ }^{427}$

\subsection{LA RABIA, ENFERMEDAD QUE TRANSMITÍAN LOS PERROS}

Fue el químico y bacteriólogo francés Luis Pasteur, quien consiguió, al final de su vida, obtener la vacuna antirrábica. El éxito de la aplicación de su vacuna antirrábica entre 1885 y 1886 a casi 2.500 personas motivó una suscripción popular, cuyos fondos permitieron la fundación del Instituto Pasteur (1888). ${ }^{428}$

En Castellón no eran pocos los casos que se producían de personas mordidas por perros rabiosos.

Para defenderse de los perros rabiosos se mataban con estricnina. Los agentes municipales arrojaban morcillas envenenadas y los niños corrían tras ellos para verlos agonizar. La prensa aconsejaba que se cogieran los perros vagabundos con lazo y que por lo menos que se exterminaran por la noche. ${ }^{429}$

En 1889, La Provincia publica el descubrimiento de la vacuna antirrábica y dice que el doctor Jaime Ferrán, director del laboratorio microbiológico municipal de Barcelona, había remitido a la Academia de Ciencias de París una nota detallada sobre

\footnotetext{
${ }^{427}$ El Clamor, 15/04/1883; La Provincia, 20/03/1884; La Provincia, 12/03/1885.

${ }^{428}$ LÓPEZ PIÑERO, José María (2002): La Medicina en la Historia, La Esfera de los Libros, Madrid. p. 536.

${ }^{429}$ La Provincia, 8/06/1884.
} 
el particular, en la cual describía la morfología de dicho microrganismo exponiendo los procedimientos de que se había valido para aislarle, cultivarle e inocularle. ${ }^{430}$

El Instituto de Vacunación Antirrábico fue instalado por la Diputación en el Hospital Provincial. En dicho instituto fueron tratados gran número de personas mordidas por perros rabiosos. Por ejemplo, en 1915 fueron sometidas al tratamiento preventivo antirrábico 68 personas mordidas por animales sospechosos de rabia, en una proporción de 37 perros y 5 gatos ${ }^{431}$ y, en 1917, fueron sometidas al tratamiento preventivo antirrábico 69 personas mordidas por animales domésticos, en una proporción de 40 perros y 1 gato. ${ }^{432}$

Se recomendaba la extinción de todos los perros vagabundos y la sujeción de los mismos mientras durara el periodo de infección.

\subsection{LA LEPRA, UNA ENFERMEDAD MUY TEMIDA, PERO DE BAJA INCIDENCIA}

En 1860, Méndez Álvaro, en su Memoria sobre la lepra en España, caracterizó su epidemiología a partir del análisis de las 284 encuestas de los casos censados en la estadística realizada en los años 1851 y 1852.

A pesar de que la descripción epidemiológica evidenció una realidad alejada claramente de la visión popular, la comunidad científica necesitó más información, de base científica, para cambiar el paradigma. El descubrimiento del Mycobacterium leprae, en 1878, la superación de la hipótesis hereditaria por la infecciosa, el mejor conocimiento de su clínica y la aparición de la moderna terapéutica y de su epidemiología, modificaron el paradigma de la enfermedad, de manera que a finales del primer tercio del siglo Xx, la estrategia de abordaje de la lepra -sustentado sobre bases científicas- era radicalmente distinta a lo que había sido en años anteriores. ${ }^{433}$

La prevalencia, a tenor de lo obtenido por las diferencias estadísticas sobre enfermos de lepra realizadas a lo largo del siglo XIX, era baja: 284 en 1851-52; 521 en 1878; y 522 en 1904, con gran estabilidad espacial (tabla 3) tanto provincial como local,

\footnotetext{
${ }^{430}$ La Provincia, 3/01/1889.

${ }^{431}$ El Clamor, 26/04/1915.

${ }^{432}$ El Clamor, 3/04/1917.

${ }^{433}$ MARTÍNEZ NAVARRO, Joan Ferrán (2009): «Lepra y salud pública en España» en COMES IGLESIA (Dir.): Cuidados y Consuelos. Cien años de Fontilles, Generalitat Valenciana, Valencia. p. 51.
} 
de manera que a finales del siglo XIX estaban bien identificadas las zonas endémicas: tres peninsulares -Valencia, Andalucía y Galicia- y una insular, Canarias. Diferentes autores como Hauser, ${ }^{434}$ Sánchez Puente, etc., consideraron esta prevalencia baja e hicieron estimaciones al alza, que no llegaron a cambiar el sentido de ser una enfermedad de baja prevalencia.

Tabla 3.- Prevalencia de la lepra en España

\begin{tabular}{|c|c|c|c|c|c|}
\hline PROVINCIAS & $\begin{array}{l}\text { Año1851 } \\
\text { Número } \\
\text { enfermos }\end{array}$ & $\begin{array}{l}\text { Año1878 } \\
\text { Número } \\
\text { enfermos }\end{array}$ & $\begin{array}{l}\text { Año1904 } \\
\text { Número } \\
\text { enfermos }\end{array}$ & $\begin{array}{l}\text { Año1914 } \\
\text { Número } \\
\text { enfermos }\end{array}$ & $\begin{array}{c}\text { Número de } \\
\text { Ayuntamientos }\end{array}$ \\
\hline Albacete & & 9 & & 1 & 1 \\
\hline Alicante & & 68 & 31 & 137 & 43 \\
\hline Almería & 51 & & & 22 & 8 \\
\hline Ávila & & 1 & & & $\gg$ \\
\hline Badajoz & & & & 14 & 8 \\
\hline Burgos & & 2 & & & $\gg$ \\
\hline Barcelona & & 2 & & 5 & 3 \\
\hline Cádiz & 28 & & 1 & 13 & 8 \\
\hline Canarias & & & & 76 & 25 \\
\hline Castellón & 30 & 51 & 70 & 84 & 23 \\
\hline Ciudad real & & & & 1 & 1 \\
\hline Córdoba & 4 & 8 & 21 & 32 & 16 \\
\hline Coruña & & & 21 & 53 & 16 \\
\hline Cuenca & & & & 1 & 1 \\
\hline Gerona & & & & 1 & 1 \\
\hline Granada & 51 & 74 & 27 & 27 & 16 \\
\hline Guadalajara & & & & 1 & 1 \\
\hline Huelva & & 19 & 6 & 19 & 10 \\
\hline Jaén & 18 & & & 53 & 17 \\
\hline Lérida & & & & 2 & 2 \\
\hline Logroño & & & & 1 & 1 \\
\hline Lugo & & 18 & & 6 & 1 \\
\hline Madrid & & 2 & & 2 & 2 \\
\hline
\end{tabular}

${ }^{434}$ HAUSER, Phillipe (1913): Geografía médica de la península Ibérica. Tomo III, Madrid, Imprenta E. Arias. pp. 17-18, en MARTínEZ NAVARRO, Joan Ferrán (2009), opus. cit, p. 52. 


\begin{tabular}{|l|c|c|c|c|c|}
\hline Málaga & 61 & 15 & 67 & 54 & 1 \\
\hline Murcia & 2 & & & 3 & 1 \\
\hline Orense & & 12 & & 68 & 26 \\
\hline Pontevedra & & 135 & 27 & 2 & 2 \\
\hline Salamanca & & & & 1 & 1 \\
\hline Santander & 24 & 45 & 34 & 17 & 13 \\
\hline Sevilla & & 7 & 9 & 20 & 59 \\
\hline Tarragona & 15 & 53 & 122 & 155 & 1 \\
\hline Valencia & & & & 1 & 342 \\
\hline Vizcaya & 284 & 253 & 436 & 873 & \\
\hline Total & & & & & 10 \\
\hline
\end{tabular}

Fuente: Sánchez Puente, Juan (1915): Contribución al estudio de la monografía del bacilo de la lepra humana, con algunos experimentos y consideraciones acerca del mismo. E. Maestre, Madrid, en Martínez Navarro, Joan Ferrán (2009)

La cuestión del contagio era el problema más complicado. Se aceptó la etiología bacteriana -Mycobacterium leprae- y, por tanto, el carácter infeccioso de la enfermedad, así como la presencia del germen en las lesiones y secreciones (espacialmente las nasales), pero no se conocía la forma de trasmisión, si bien para determinar la construcción de las hipótesis se centraría en la información epidemiológica: forma de presentación de los casos, con un dominio de clusters familiares y sociales, y la presencia en las lesiones del germen. La situación la podemos resumir al ser una enfermedad de prevalencia baja, con focos endémicos y limitados al medio rural, preferentemente, y a la presencia de grupos familiares o sociales con exposiciones continuas y prolongadas.

Sólo dos de las hipótesis formuladas - hereditarias y contagiosas- fueron destacadas, dejando al margen determinadas discusiones acerca del valor de otras posibles causas como la pobreza, la alimentación o los mosquitos.

La hipótesis hereditaria se basó en la observación acerca de la presentación de los casos en pequeñas agrupaciones espaciales, en municipios, preferentemente rurales, y la acumulación de casos familiares.

Para los partidarios de la hipótesis contagiosa, ésta tenía dos formas de transmisión: indirecta y directa, si bien ésta última poco frecuente, de acuerdo con las observaciones epidemiológicas que encontraron pocos casos relacionados de forma 
directa con el caso fuente, lo que hizo pensar en una baja capacidad contagiosa de la enfermedad.

A pesar de que la evidencia epidemiológica nos mostraba una situación de baja endemia y escasa capacidad de difusión, el peso del paradigma tradicional sustentaba un miedo a la enfermedad que las mismas autoridades sanitarias apenas conseguían superar. Por ello se mantuvieron severas medidas de control de la enfermedad centradas básicamente en las condiciones del aislamiento. Así Hauser, ${ }^{435}$ recoge las medidas propuestas por la comisión nombrada por la Academia de Medicina Práctica de Barcelona en1860 para evitar su propagación:

- Prohibir el matrimonio si alguno de los contrayentes fuese sospechoso de la lepra, previo examen de facultativos.

- Separar los leprosos que se hallaren casados.

- Impedir que las leprosas críen hijos, propios ni ajenos.

- Vigilar para que los solteros que ofrezcan indicios del mal no tengan comunicación con mujer alguna.

- Colocar en aposentos separados del resto de la familia a aquellos cuyos tubérculos estuviesen ulcerados.

- Trasladar a los hospitales los leprosos pobres, faltos de buenos alimentos y del conveniente aseo.

- Cuidar de que no se propague el mal por medio de la vacunación, atendiendo con esmero a la procedencia del virus.

- Evitar el fraude de expender al público carnes de cerdos lazarinos, que en aquel país llaman masells.

- Hacer responsables del cumplimiento de estas disposiciones a los magistrados, a las familias y a los médicos.

Estas medidas, de la segunda mitad del siglo XIX, responden a la hipótesis hereditaria que restringía la incorporación de los leprosos en la familia (por su posible

${ }^{435}$ HAUSER, Phillipe, (1915), en MARTÍNEZ NAVARRO, Joan Ferrán, opus cit, pp. 54-55. 
transmisión hereditaria) y no en las relaciones sociales cotidianas. Esta situación cambió a lo largo del primer tercio del siglo XX.

En los años ochenta de siglo XIX había casos de lepra en la ciudad de Castellón. En la Casa Provincial de Misericordia ingresaron dos niños que procedían de padres leprosos fallecidos a consecuencias del mal de San Lázaro. Y, como según la ciencia, esta enfermedad era hereditaria y contagiosa, se decidió que dichos niños debían aislarse, caso de tener derecho a ser asilados, para evitar el peligro de ser contagiados los demás albergados.

La prensa de Valencia dio la noticia que en Villarreal había muchos casos de lepra seguidos algunos de ellos de defunción. El gobernador pidió al pueblo citado antecedentes acerca del particular, de lo que resultó que no existían más que tres leprosos, que la padecían hacía más de cuatro años. ${ }^{436}$

En Castellón de la Plana se montó una clínica en la calle Ximénez, cuyo director se declaraba especialista en la curación de muchas enfermedades, pero con preferencia de la lepra.

La prensa se queja de que en el centro de Castellón de la Plana, uno de los puntos más concurridos, se convirtiera en lugar de reunión de los enfermos que sufrían tan contagioso mal. Este hecho fue denunciado al doctor Clará, inspector provincial de Sanidad, para que lo evitara por los medios que la ley le concedía. El doctor Clará se preocupaba porque estos enfermos estuvieran aislados. ${ }^{437}$

En 1915 había en Castellón, según el doctor Clará, 76 leprosos, 18 de ellos albergados en el Hospital Provincial y el resto en 17 pueblos.

El Gobierno tenía el proyecto de construir leproserías en número suficiente para recluir a todo los enfermos. En la segunda decena del siglo XX, el Hospital Provincial podía albergar mayor número de enfermos gracias a los dos pabellones que se construyeron para este fin, pudiendo recluirse todos los que en los pueblos no tenían las condiciones de aislamiento.

Las órdenes del gobernador eran terminantes a algunas alcaldías, especialmente a la de Villarreal, donde el número de leprosos sin hospitalizar era muy numeroso. ${ }^{438}$

\footnotetext{
${ }^{436}$ La Provincia, 10/03/1889.

${ }^{437}$ El Clamor, 5/11/1914.

${ }^{438}$ El Clamor, 26/04/1915.
} 
La Junta Provincial de Sanidad, en sesión del 1 de abril de 1917 daba los siguientes datos: En la provincia residían 68 leprosos repartidos en 19 pueblos, en el Hospital Provincial se albergaban 11. Los 68 leprosos eran 35 varones y 33 mujeres.

\subsection{EL DENGUE O LA GRIPE HACE SU APARICIÓN ENTRE 1889 Y 1890}

A mediados de diciembre de 1889 la gripe invadió España. La enfermedad era conocida con los nombres de dengue, trancazo, gripe, influenza, etc. se estaba extendiendo por las principales provincias de España, pero principalmente era en Madrid donde en muy pocos días fueron atacados más de 6.000 personas, penetrando en algunos hospicios y asilos.

Según dice la prensa la enfermedad era benigna y el vecindario la había acogido con indiferencia. ${ }^{439}$

En Madrid, Cánovas y Silvela estaban atacados por la enfermedad. En Barcelona, el dengue se propagó con gran rapidez en 1890, hasta el punto que se cerraban peluquerías, por estar atacados todos los dependientes; en las cárceles, se encontraban la mayoría de los reclusos y empleados enfermos. La enfermedad se complicaba con una pulmonía. ${ }^{440}$

En Paris los atacados pasaban del 60 por cien, en Lisboa, estaban atacados más de la mitad de la población. También estaba extendida en Estados Unidos, México, Italia, etc.

En Valencia presentaba caracteres alarmantes y había la creencia de que se ocultaba el número de los atacados, que se calculaban en unos 8.000. La alcaldía hizo circular una hoja, en la que se indicaban las precauciones que debían adoptarse para que la influencia del mal fuera menos perniciosa.

El rector de la universidad, dispuso que todos los establecimientos superiores continuaran cerrados hasta mediados de enero. ${ }^{441}$

En Castellón la humedad reinante favorecía aún más la enfermedad, que día a día, iba tomando mayor incremento en la ciudad, donde difícilmente se podía señalar una familia que no tuviera ningún enfermo en casa.

\footnotetext{
${ }^{439}$ La Provincia, 19/12/1889.

${ }^{440}$ La Provincia, 1/01/1890.

${ }^{441}$ La Provincia, 9/01/1889.
} 
La prensa señalaba que la epidemia tenía un carácter benigno, y se reducía a tener que pasar algunos días molestos en la cama, y hacerle frente guardando las prescripciones higiénicas y guardándose de las recaídas.

Los médicos pensaban que la enfermedad imperante no era otra cosa que una calentura perniciosa, de forma neumónica en la mayor parte de los casos. Para combatir la enfermedad se usaba la quinina y sus sales, especialmente el sulfato. Algunos médicos aseguraban haber administrado en varios casos tres gramos de sulfato de quinina en un solo día, obteniendo excelentes resultados.

La mayor parte de las personalidades de Castellón estaban atacadas de la enfermedad. También penetró en los cuarteles de San Francisco y guardia civil, causando numerosa bajas. En los centros oficiales y puntos públicos de recreo se notaba la incidencia de la gripe, pues algunos estaban desiertos. Las hermanas de la caridad que prestaban sus servicios en el Hospital fueron todas víctimas del llamado popularmente «trancazo». 442

A pesar del número de atacados, había pocas defunciones, por ello se decía que la enfermedad era benigna.

La Junta Local de Sanidad dispuso la clausura indefinida de todos los establecimientos públicos y privados mientras continuara la enfermedad.

Todos los pueblos de la provincia estaban invadidos por la enfermedad. En la ciudad, el mal continuaba siendo benigno. Si no se tomaban precauciones, la enfermedad se convertía en pulmonía.

En el cuartel de San Francisco había días que el número de atacados por la enfermedad era de 50 y las autoridades militares, entre otra medidas, dispusieron que la música amenizara con sus acordes las horas del rancho. ${ }^{443}$

En la provincia, la mayoría de los pueblos del Maestrazgo se había presentado la epidemia.

A medida que la epidemia iba decreciendo aumentaban las afecciones de los órganos respiratorios que degeneraban en pulmonías. ${ }^{444}$

\footnotetext{
${ }^{442}$ La Provincia, 5/01/1890.

${ }^{443}$ La Provincia, 9/01/1890.

${ }^{444}$ La Provincia, 12/01/1890.
} 
A mediados de enero la enfermedad decrecía y la nuevas invasiones eran muy pocas. «Si la enfermedad no recrudece, muy pronto se reanudarán las tareas escolares, suspendidas hoy por esta causa». ${ }^{445}$

Según la Sociedad de Medicina de Barcelona, la epidemia de gripe se presentaba en tres formas distintas:

- Forma nerviosa, cuando se presentaba de una manera brusca, con fuerte dolor de cabeza, quebrantamiento en todos los miembros y tendencias al síncope, y la fiebre alcanzaba los 40 y $41^{\circ}$, con gran agitación general. A las doce horas se presentaban otros síntomas acompañados de dolor fuerte, que remitían a las veinticuatro horas. Muchas veces la convalecencia era corta, pero el enfermo sentía dolores en todo el cuerpo.

- Forma catarral. Ésta solía estar en incubación durante dos días, subiendo lentamente la temperatura. Los síntomas esenciales eran los ataques de toses violentas y convulsivas. A los dos días la calentura desaparecía gradualmente y no súbitamente, y la curación para ser definitiva necesitaba diez días.

- Forma gástrica. En ella predominaban los desarreglos digestivos, presentándose algunas veces vómitos que aliviaban al enfermo. La duración media de esta forma se hallaba entre las dos primeras. ${ }^{446}$

A últimos de mayo de 1890, reaparecía otra vez el dengue o «trancazo» en la provincia.

El dengue o trancazo visitaba muy a menudo Castellón. En 1895, la prensa señalaba la aparición del mal en la capital, los enfermos se contaban a millares y eran varias las familias en las que ni uno siquiera de sus individuos se libró del contagio. «No ataca con fuerza, pero requiere escrupulosos y continuados cuidados por el peligro a que degenere en pulmonía». ${ }^{44}$

${ }^{445}$ La Provincia, 16/01/1890.

${ }^{446}$ La Provincia, 9/02/1890.

${ }^{447}$ Heraldo de Castellón, 11/01/1895. 


\section{UN ESTUDIO CUANTITATIVO Y COMPARATIVO DE LAS ENFERMEDADES QUE MÁS INCIDENCIA TUVIERON EN EL PAÍS VALENCIANO Y ESPAÑA}

Nos ha parecido conveniente, después de realizar un análisis cualitativo de los orígenes, manifestaciones y tratamiento médico de las enfermedades epidemiológicas más comunes, realizar un estudio comparativo de las causas de mortalidad y la incidencia que tuvieron en el País Valenciano y España durante el periodo comprendido desde finales del siglo XIX a principios del siglo XX.

En el estudio comparativo que vamos a realizar nos centraremos sobre todo en comentar las enfermedades que tuvieron más incidencia en los primeros años del siglo XX, puesto que hasta entonces los censos que proporciona el Instituto Nacional de Estadística no detallan las diversas enfermedades comunes. No obstante, hemos creído conveniente hacer un análisis introductorio de los años 1869 y 1870, más el sexenio de $1886-92 .^{448}$

Los años 1869 y 1870 (tablas 4, 5, 6, y 7) los debemos enmarcar en un periodo de crisis económica con malas cosechas, insuficiencia alimenticia iniciada en 1866 y que repercute en los años sucesivos que estamos estudiando. Una prueba de ello es que en 1869 tanto las enfermedades comunes como las epidémicas son más numerosas que en 1870, porque en este año y a partir de 1871 la crisis económica va disminuyendo.

Hay que notar una mayor mortalidad en el sexo masculino, frente al femenino tanto a nivel del País Valenciano como de España, mientras que por muerte senil debido a que hay más mujeres que hombres vivos mueren más personas del sexo femenino.

También hacemos notar que por muerte violenta es la sección de hombres los que presentan las cifras más elevadas, suponemos que al estar el hombre más integrado y ser cabeza de familia tiene las responsabilidades más directas, lo cual puede llevarle al suicidio, a las reyertas y sobre todo resulta curioso observar como en la provincia de Valencia e incluso en la capital, la proporción por muerte violenta es elevadísima respecto a la cifra total de España (tanto en provincias como en capitales). Creemos que

\footnotetext{
${ }^{448}$ Algunos de los datos que figuran en las tablas han sido extraidos del trabajo de investigación inédito, de SULLER TRILLES, Vicenta, op. cit., y qué, posteriormente, hemos corroborado en el Instituto Nacional de Estadística.
} 
las discusiones familiares por herencias de tierras es un factor que siempre ha influido en ese aumento citado.

Tabla 4. Mortalidad en 1869 en capitales del País Valenciano y capitales de España

\begin{tabular}{|l|l|l|l|l|l|l|l|l|l|}
\hline CAUSAS & A H & A M & CS H & CS M & V H & V M & C. E.H & C.E.M & $\begin{array}{l}\text { Total } \\
\text { P.V. }\end{array}$ \\
\hline $\begin{array}{l}\text { Enfermedad } \\
\text { común }\end{array}$ & 632 & 563 & 447 & 399 & 2070 & 1738 & 35065 & 31205 & 5849 \\
\hline $\begin{array}{l}\text { Enf. epidémicas y } \\
\text { contagiosas }\end{array}$ & 0 & 0 & 0 & 0 & 3 & 1 & 4179 & 3811 & 4 \\
\hline $\begin{array}{l}\text { Muerte natural } \\
\text { repentina }\end{array}$ & 4 & 2 & 1 & 1 & 5 & 1 & 833 & 198 & 14 \\
\hline $\begin{array}{l}\text { Muerte violenta } \\
\text { Muerte senil }\end{array}$ & 3 & 5 & 5 & 3 & 94 & 20 & 833 & 198 & 140 \\
\hline \begin{tabular}{l} 
Totales \\
\hline
\end{tabular} & 652 & 576 & 454 & 403 & 2214 & 1835 & 41861 & 36772 & 6134 \\
\hline
\end{tabular}

Fuente: Instituto Nacional de Estadística. Elaboración propia.

Tabla 5. Mortalidad año 1869 en las provincias del País Valenciano y España

\begin{tabular}{|l|l|l|l|l|l|l|l|l|l|}
\hline CAUSAS & A H & A M & CS H & CS M & V H & V M & E H & E M & Total \\
\hline Enf. común & 6244 & 5686 & 4136 & 3897 & 9890 & 9120 & 235277 & 222523 & 38973 \\
\hline $\begin{array}{l}\text { Enfermedades } \\
\text { epidémicasy } \\
\text { contagiosas }\end{array}$ & 758 & 379 & 378 & 368 & 670 & 652 & 28856 & 28766 & 3205 \\
\hline $\begin{array}{l}\text { Muerte natural } \\
\text { repentina }\end{array}$ & 76 & 50 & 52 & 33 & 109 & 84 & 3982 & 3267 & 404 \\
\hline $\begin{array}{l}\text { Muerte } \\
\text { violenta }\end{array}$ & 166 & 48 & 109 & 18 & 342 & 47 & 4285 & 1077 & 730 \\
\hline $\begin{array}{l}\text { Muerte senil } \\
\text { Motales }\end{array}$ & 222 & 268 & 186 & 210 & 338 & 445 & 10198 & 12329 & 1669 \\
\hline Th6 & 6431 & 4861 & 4526 & 11349 & 10348 & 282598 & 267962 & 44981 \\
\hline
\end{tabular}

Fuente: Instituto Nacional de Estadística. Elaboración propia. 


\section{Gráfica 1. Mortalidad en el año 1869 en las provincias del País Valenciano}

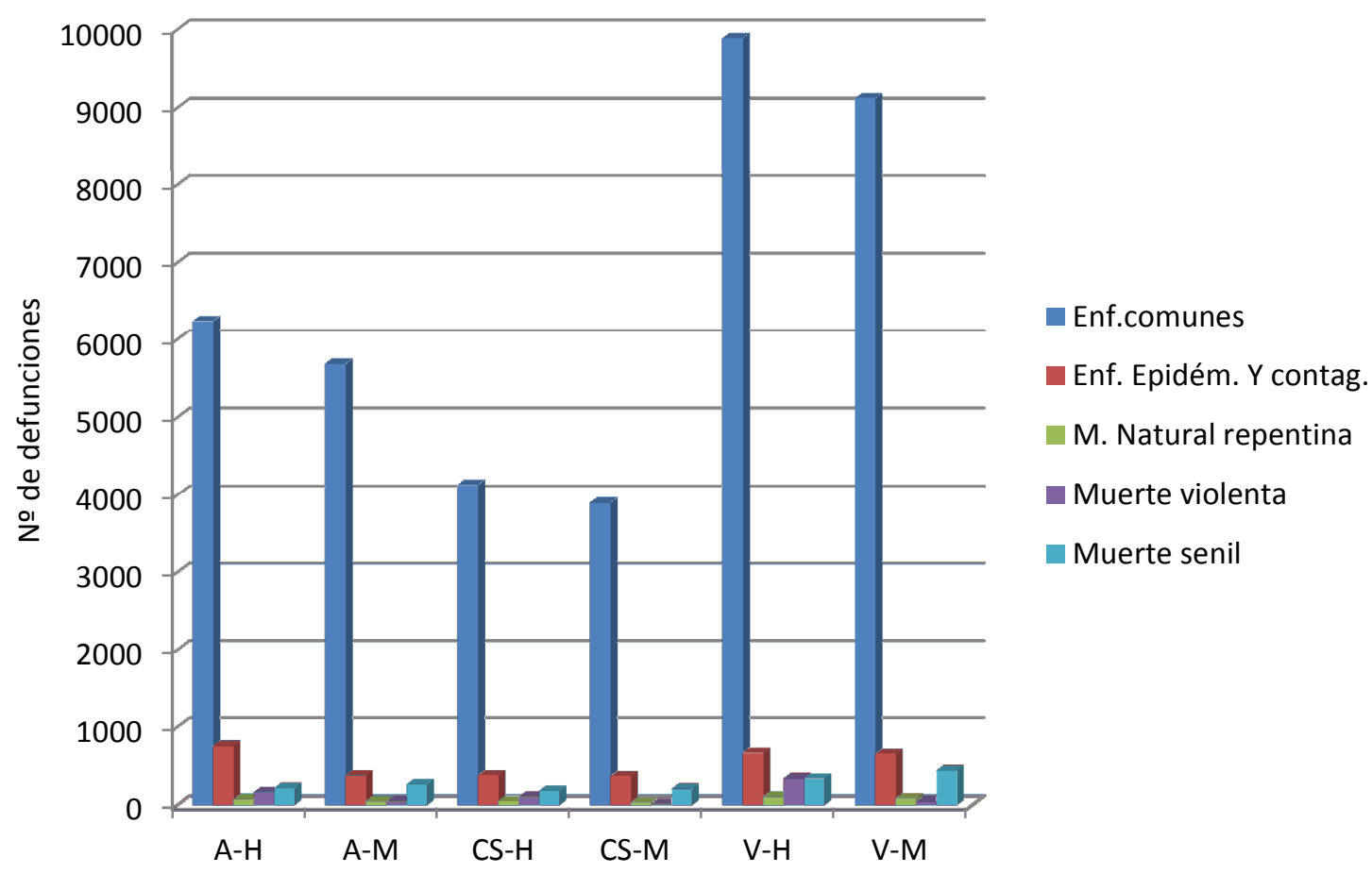

Fuente: Instituto Nacional de Estadística. Elaboración propia

Tabla 6. Mortalidad en el año 1870 en las capitales del País Valenciano y las capitales de España

\begin{tabular}{|l|l|l|l|l|l|l|l|l|l|}
\hline CAUSAS & A H & A M & CS H & CS M & V H & V M & C.E. H & C. E.M & $\begin{array}{c}\text { Total } \\
\text { P. V. }\end{array}$ \\
\hline $\begin{array}{l}\text { Enfermedad } \\
\text { común }\end{array}$ & 473 & 393 & 371 & 284 & 1859 & 1606 & 34197 & 30255 & 4986 \\
\hline $\begin{array}{l}\text { Enfermedades } \\
\text { epidémicas } \\
\text { contagiosas }\end{array}$ & 344 & 233 & 1 & 0 & 24 & 9 & 4150 & 3532 & 611 \\
\hline $\begin{array}{l}\text { Muerte natural } \\
\text { repentina }\end{array}$ & 6 & 2 & 1 & 1 & 5 & 4 & 920 & 772 & 19 \\
\hline $\begin{array}{l}\text { Muerte violenta } \\
\text { Muerte senil }\end{array}$ & 14 & 20 & 2 & 0 & 78 & 101 & 966 & 1167 & 215 \\
\hline Totales & 854 & 654 & 383 & 286 & 2011 & 1726 & 40862 & 35969 & 5914 \\
\hline
\end{tabular}

Fuente: Instituto Nacional de Estadística. Elaboración propia. 
Tabla 7. Mortalidad en el año 1870 en provincias del País Valenciano y España

\begin{tabular}{|l|l|l|l|l|l|l|l|l|l|}
\hline CAUSAS & A H & A M & CS H & CS M & V H & V M & E H & E M & $\begin{array}{c}\text { Total } \\
\text { P. V. }\end{array}$ \\
\hline Enfer. común & 5525 & 5137 & 4574 & 3996 & 9474 & 8439 & 230901 & 213665 & 37145 \\
\hline $\begin{array}{l}\text { Enfermedades } \\
\text { epidémicas y } \\
\text { contagiosas }\end{array}$ & 467 & 343 & 213 & 233 & 258 & 236 & 16565 & 15347 & 1750 \\
\hline $\begin{array}{l}\text { Muerte natural } \\
\text { repentina }\end{array}$ & 62 & 41 & 52 & 40 & 109 & 83 & 4025 & 3190 & 397 \\
\hline $\begin{array}{l}\text { Muerte } \\
\text { violenta }\end{array}$ & 140 & 25 & 81 & 26 & 231 & 60 & 3821 & 1143 & 563 \\
\hline $\begin{array}{l}\text { Muerte senil } \\
\text { Totales }\end{array}$ & 6400 & 5797 & 5087 & 4507 & 10526 & 9282 & 266038 & 246211 & 41599 \\
\hline
\end{tabular}

Fuente: Instituto Nacional de Estadística. Elaboración propia.

Gráfica 2. Mortalidad en el año 1870 en las capitales del País Valenciano

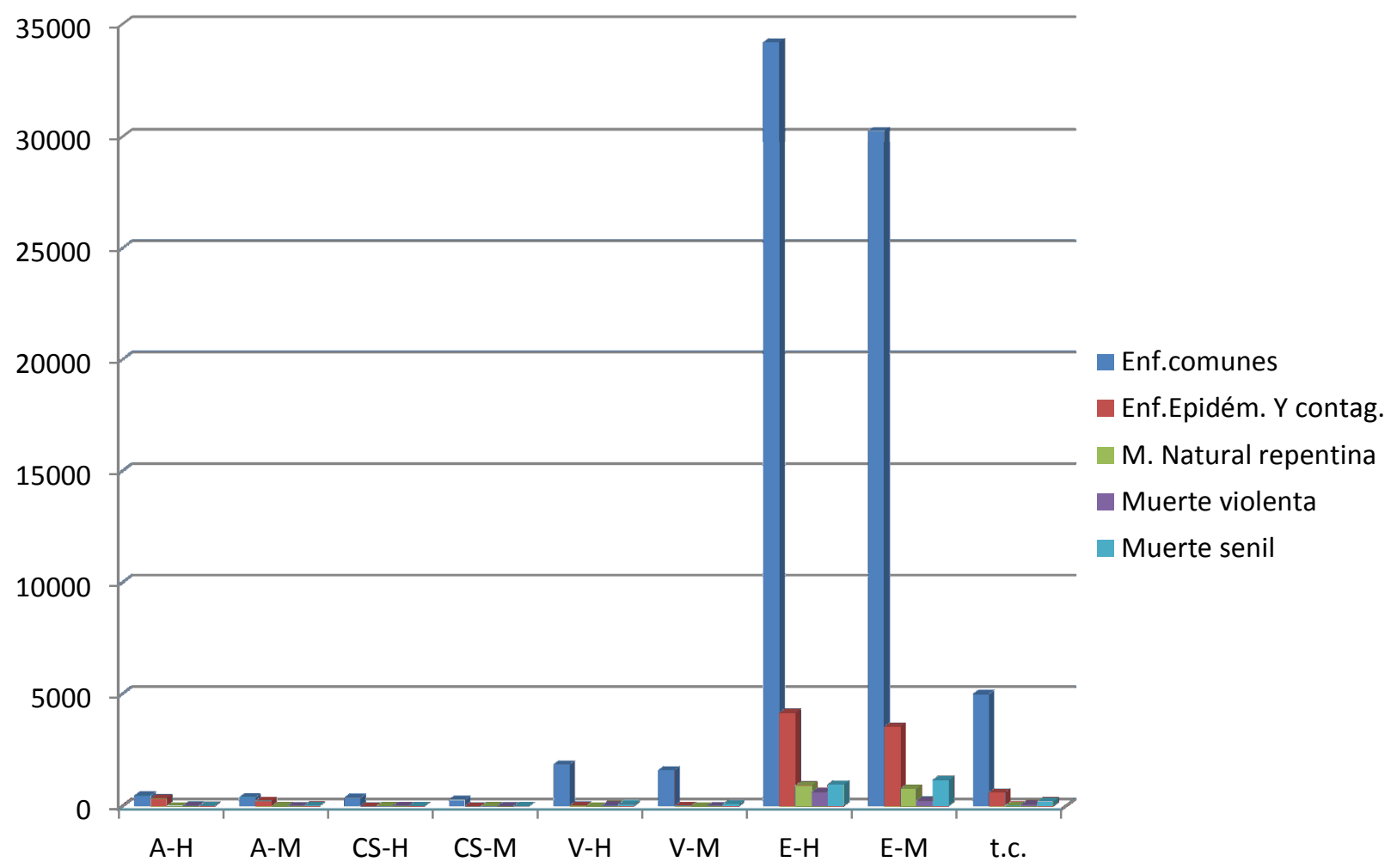

Fuente: Instituto Nacional de Estadística. Elaboración propia. 
En las tablas números 8 y 9, correspondiente a la mortalidad ente los años 188692, hemos podido comprobar cómo ésta va disminuyendo siguiendo el modelo europeo típico de sociedades que han iniciado la Revolución Industrial. No obstante, hay que destacar el periodo 1890-91 que junto con el año 1918, que estudiamos más adelante, constituye el momento de mayor mortalidad por gripe.

A nivel del País Valenciano la tendencia a la disminución progresiva de la mortalidad es mayor que a nivel nacional, lo cual nos permite suponer que el País Valenciano está situado en una de las zonas más desarrolladas de España. Además, queremos resaltar el caso de Valencia, en que debido a que se estaba industrializando de manera más rápida que Castellón y Alicante, se produjo una mayor mortalidad que podía ser debida al hacinamiento urbano con el consiguiente deterioro de las medidas higiénicas y normas de salubridad.

En cuanto al brote gripal de 1890-91 hemos advertido que el mayor aumento de la mortalidad en las provincias del País Valenciano (tabla 9) se debe a un mayor contacto comercial con otros países europeos (no hay que olvidar que los puertos de Valencia y Alicante representaban un peso económico mayor que otros puertos españoles) ya que nos relacionaban con puertos africanos y europeos.

Tabla 8. Mortalidad entre los años 1886-92 en las capitales del País Valenciano y las capitales de España

\begin{tabular}{|c|c|c|c|c|c|}
\hline AÑOS & ALI. & CAS. & VAL. & ESP. & Total P. V. \\
\hline 1886 & 1813 & 726 & 5674 & 85709 & 8213 \\
\hline 1887 & 1750 & 843 & 5057 & 93107 & 7650 \\
\hline 1888 & 1226 & 700 & 4289 & 86155 & 6215 \\
\hline 1889 & 1354 & 742 & 5479 & 90061 & 7575 \\
\hline 1890 & 1391 & 909 & 5430 & 92857 & 7730 \\
\hline 1891 & 1408 & 632 & 4589 & 89688 & 6629 \\
\hline 1892 & 1194 & 688 & 5587 & 86647 & 7469 \\
\hline Totales & 10136 & 5240 & 36105 & 624224 & 51481 \\
\hline
\end{tabular}

Fuente: Instituto Nacional de Estadística. Elaboración propia. 
Tabla 9. Mortalidad entre los años 1886-92 en las provincias del País Valenciano y España

\begin{tabular}{|c|c|c|c|c|c|}
\hline AÑOS & ALI. & CAS. & VAL. & ESP. & Total P. V. \\
\hline 1886 & 13956 & 8916 & 22073 & 509629 & 44945 \\
\hline 1887 & 14461 & 10153 & 23990 & 573448 & 48604 \\
\hline 1888 & 11853 & 8031 & 18609 & 529543 & 38493 \\
\hline 1889 & 11694 & 8766 & 21452 & 545097 & 41912 \\
\hline 1890 & 13629 & 10667 & 25803 & 577525 & 50098 \\
\hline 1891 & 12151 & 8458 & 19281 & 565964 & 39890 \\
\hline 1892 & 12378 & 9008 & 23099 & 554274 & 44485 \\
\hline Totales & 90121 & 63999 & 154307 & 3855480 & 308427 \\
\hline
\end{tabular}

Fuente: Instituto Nacional de Estadística. Elaboración propia.

Centrándonos en el año 1900 y la mortalidad por causa de enfermedad durante las estaciones del año en las capitales del País Valenciano, (Tabla 10), podemos comprobar que las enfermedades que más incidieron fueron las del aparato respiratorio y del aparato digestivo; les sigue las del sistema nervioso y sentidos; y destacar también la cuarta causa de mortalidad, la del aparato circulatorio (gráfica 3).

Tabla 10. Mortalidad por enfermedad en 1900 según las estaciones del año en el conjunto de las capitales del País Valenciano

\begin{tabular}{|l|c|c|c|c|c|}
\hline \multicolumn{1}{|c|}{ ENFERMEDADES } & INV. & PRI. & VER. & OTO. & ANUAL \\
\hline E. Generales & 7593 & 5748 & 6180 & 6304 & 25825 \\
\hline Sist. nervioso ysentidos & 4294 & 3712 & 3605 & 3521 & 15132 \\
\hline Sist. Circulatorio & 3203 & 2123 & 1754 & 2273 & 9353 \\
\hline Aparato Respiratorio & 7522 & 4265 & 2135 & 4146 & 18068 \\
\hline Aparato Digestivo & 2500 & 2775 & 5008 & 3480 & 13763 \\
\hline A. Genito-Urinario & 508 & 380 & 359 & 463 & 1710 \\
\hline Estado Puerperal & 128 & 120 & 117 & 127 & 492 \\
\hline Piel y Tejidos celulares & 213 & 233 & 208 & 239 & 893 \\
\hline Órganos locomoción & 368 & 397 & 522 & 430 & 1717 \\
\hline Vicios conformación & 78 & 92 & 146 & 90 & 406 \\
\hline
\end{tabular}




\begin{tabular}{|l|c|c|c|c|c|}
\hline Enfermedades infancia & 349 & 271 & 237 & 288 & 1145 \\
\hline Enfermedades vejez & 526 & 305 & 266 & 343 & 1440 \\
\hline Afecc. por causa ext & 338 & 281 & 327 & 285 & 1231 \\
\hline Enf. mal definidas & 721 & 563 & 723 & 767 & 2774 \\
\hline Totales & 28341 & 21265 & 21587 & 22756 & 93949 \\
\hline
\end{tabular}

Fuente: Instituto Nacional de Estadística. Elaboración propia.

\section{Gráfica 3. Defunciones por causa de enfermedad en 1900 durante las} estaciones del año en el conjunto de las capitales del País Valenciano

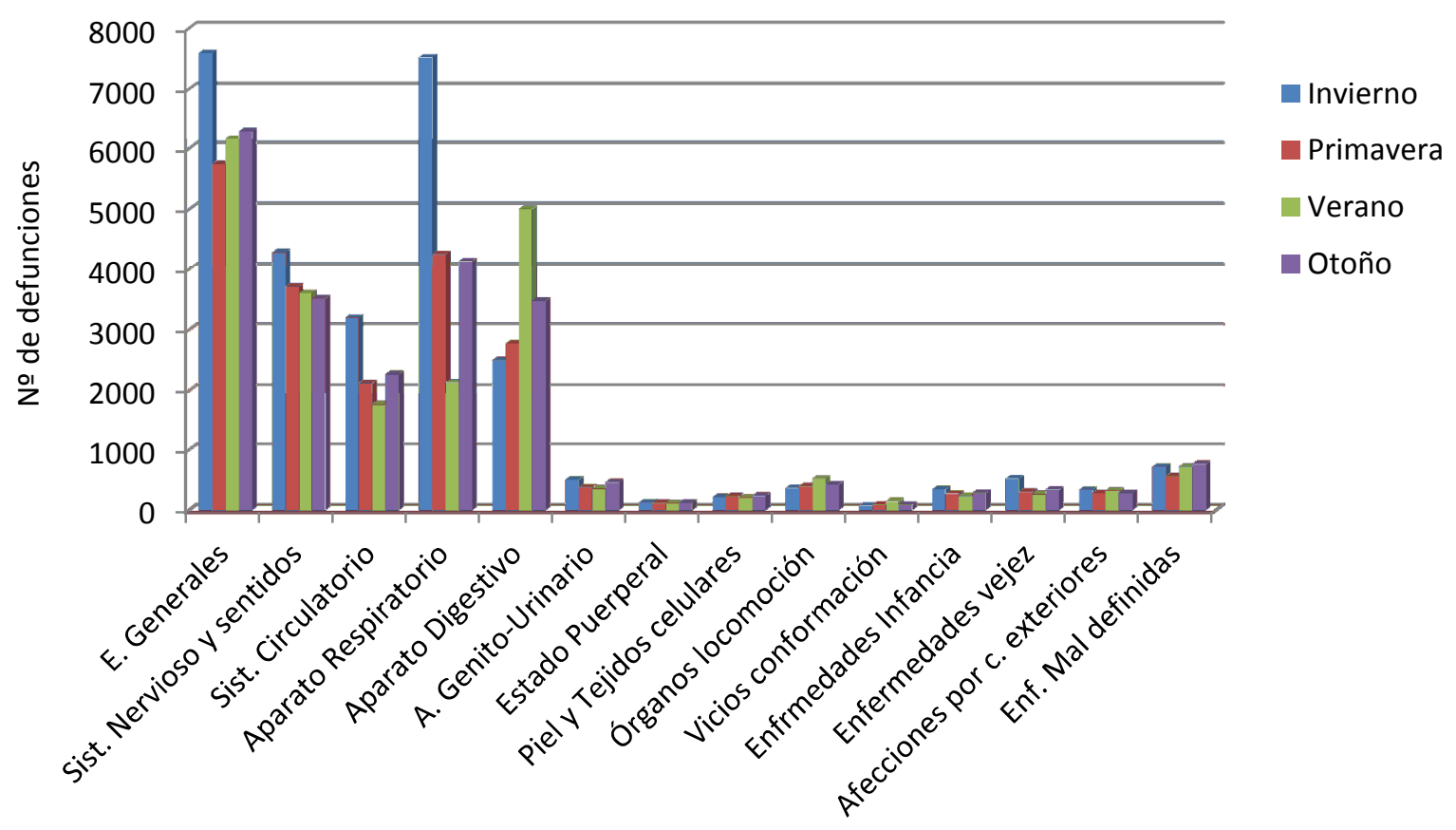

Fuente: Instituto Nacional de Estadística. Elaboración propia

Analizando los datos de mortalidad por enfermedad en el año 1900 en España (tabla 11), podemos observar también la cifra correspondiente a enfermedades infantiles, dado que sólo afecta a un sector de la población, llegando en 1900 a 10.245 defunciones cuando la enfermedad del aparato respiratorio (con mayor número de muertes) llega a 100.847. 
Tabla11. Mortalidad por enfermedad en 1900 en España

\begin{tabular}{|c|c|c|c|c|c|}
\hline ENFERMEDADES & INV. & PRI. & VER. & ото. & ANUAL \\
\hline E. Generales & 37970 & 29909 & 29085 & 28945 & 125909 \\
\hline Sist. Nervioso y sentidos & 22097 & 19307 & 18127 & 17662 & 77193 \\
\hline Sist. Circulatorio & 12857 & 9748 & 8005 & 10203 & 40813 \\
\hline Aparato Respiratorio & 40526 & 25550 & 13757 & 21014 & 100847 \\
\hline Aparato Digestivo & 16430 & 18074 & 40567 & 25117 & 100188 \\
\hline A. Genito-Urinario y a. & 2598 & 1803 & 1923 & 2600 & 8924 \\
\hline Estado Puerperal & 1014 & 870 & 797 & 876 & 3557 \\
\hline Piel y Tejidos celulares & 1286 & 1016 & 1266 & 1363 & 4931 \\
\hline Órganos locomoción & 2352 & 2303 & 3987 & 3242 & 11884 \\
\hline Vicios conformación & 749 & 827 & 872 & 800 & 3248 \\
\hline Enfrmedades Infancia & 3257 & 2320 & 2392 & 2276 & 10245 \\
\hline Enfermedades vejez & 3487 & 2245 & 1835 & 2834 & 10401 \\
\hline $\begin{array}{l}\text { Afecciones por causas } \\
\text { exteriores }\end{array}$ & 2044 & 1827 & 2207 & 1917 & 7995 \\
\hline Enf. Mal definidas & 7561 & 6353 & 8954 & 7713 & 30581 \\
\hline Totales & 154228 & 122152 & 133774 & 126562 & 536716 \\
\hline
\end{tabular}

Fuente: Instituto Nacional de Estadística. Elaboración propia.

Creemos que a pesar de los adelantos de la ciencia, un buen número de enfermedades están condicionadas por los cambios estacionales. Destacamos el mayor número de muertes en invierno, causadas por enfermedades del aparato respiratorio; sin embargo, es en la estación veraniega cuando las enfermedades del aparato digestivo aumentan de forma considerable debido a la falta de tratamientos de aguas y la no conservación de alimentos (gráfica 4). 


\section{Gráfica 4. Defunciones por causa de enfermedad en 1900 durante las} estaciones del año en España

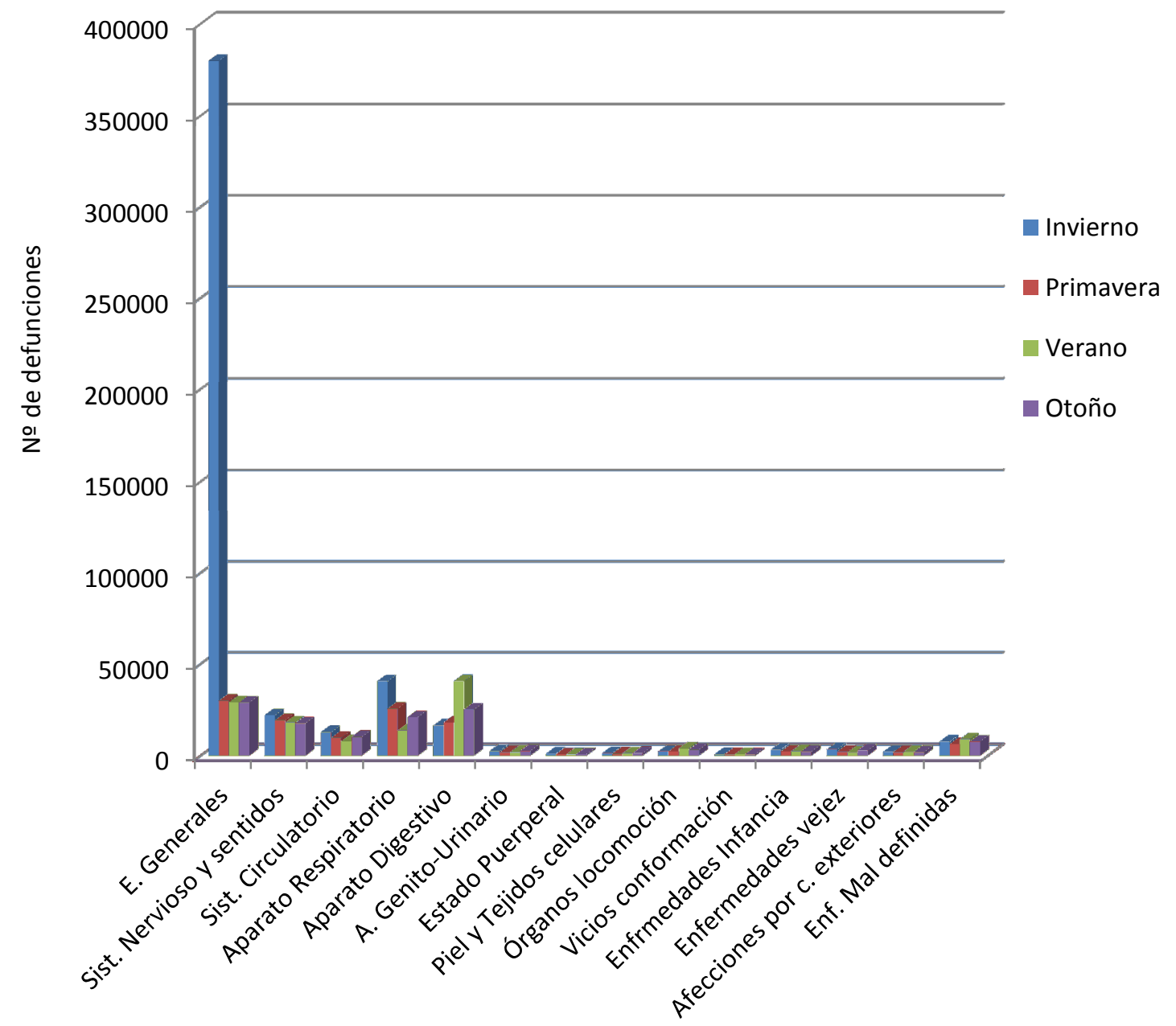

Fuente: Instituto Nacional de Estadística. Elaboración propia.

Continuamos en el País Valenciano en el año 1900 y observamos que las causas de mortalidad por enfermedad que más inciden en la población de sus provincias (gráfica 5) y en la de sus capitales (tabla 12) son la gripe y el tifus, y el sarampión en la población infantil. 
Gráfica 5. Mortalidad por enfermedad en 1900 en las provincias del País

\section{Valenciano $^{449}$}

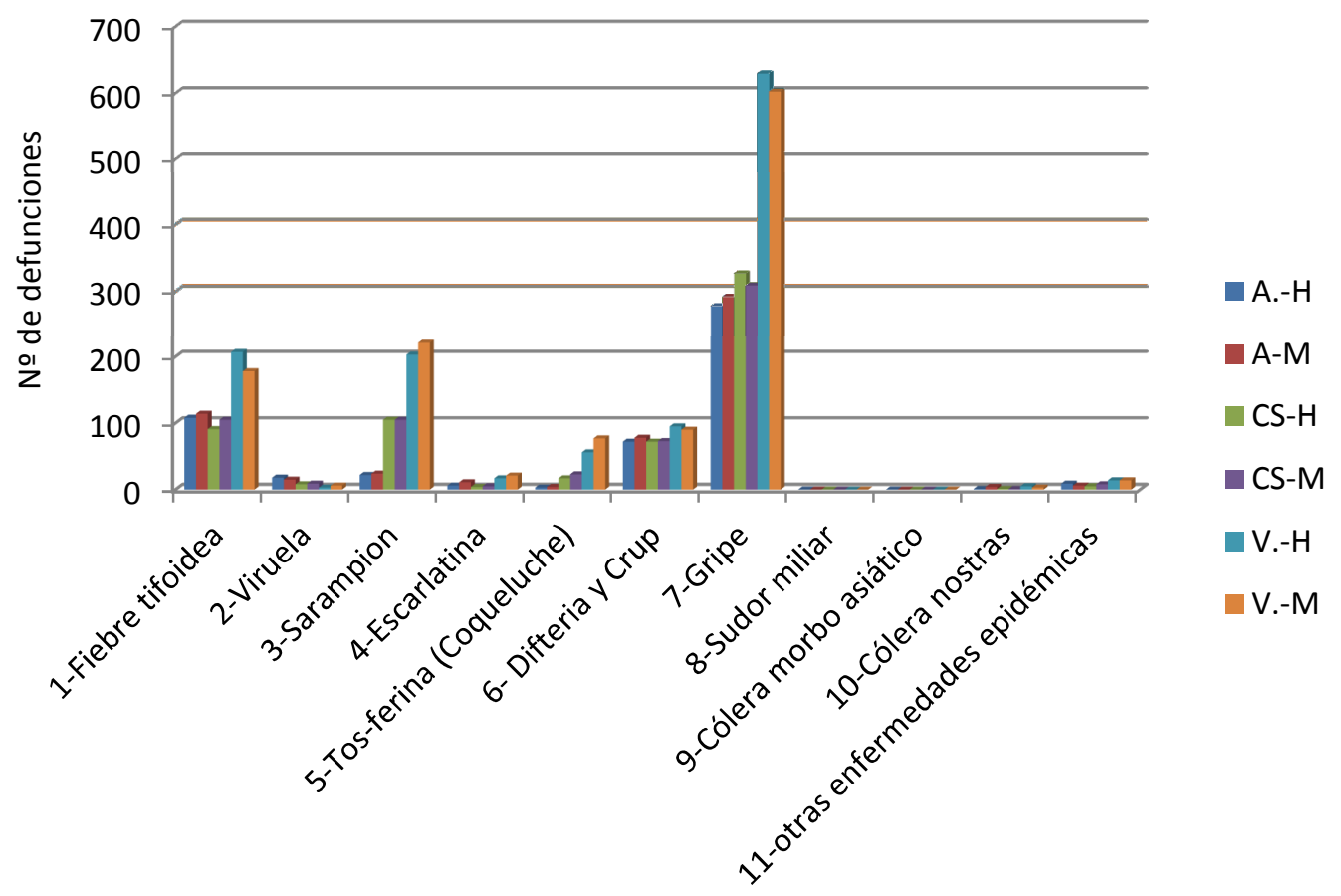

Fuente: Instituto Nacional de Estadística. Elaboración propia.

Tabla 12. Mortalidad por enfermedad en 1900 en las capitales del País Valenciano

\begin{tabular}{|l|c|c|c|c|c|c|c|}
\hline \multicolumn{1}{|c|}{ ENFERMEDADES } & A-H & A-M & CS-H & CS-M & V-H & V-M & Total \\
\hline Fiebre tifoidea & 4 & 3 & 3 & 2 & 47 & 41 & 100 \\
\hline Viruela & 0 & 0 & 1 & 4 & 3 & 2 & 10 \\
\hline Sarampion & 1 & 2 & 9 & 13 & 47 & 38 & 110 \\
\hline Escarlatina & 0 & 2 & 0 & 0 & 3 & 5 & 10 \\
\hline Tos-ferina (Coqueluche) & 3 & 1 & 0 & 0 & 8 & 7 & 19 \\
\hline Difteria y Crup & 5 & 4 & 5 & 8 & 6 & 9 & 37 \\
\hline Gripe & 17 & 24 & 46 & 40 & 152 & 194 & 473 \\
\hline Sudor miliar & 0 & 0 & 0 & 0 & 0 & 0 & 0 \\
\hline Cólera morbo asiático & 0 & 0 & 0 & 0 & 0 & 0 & 0 \\
\hline Cólera nostras & 0 & 0 & 0 & 0 & 0 & 0 & 0 \\
\hline $\begin{array}{l}\text { Otras enfermedades } \\
\text { epidémicas }\end{array}$ & 0 & 0 & 0 & 1 & 5 & 5 & 11 \\
\hline
\end{tabular}

Fuente: Instituto Nacional de Estadística. Elaboración propia.

${ }^{449}$ Ver tabla 1 del Apéndice documental $N^{\circ} 1$. 
Las estadísticas de los años 1901 y 1902 siguen la tónica de la de 1900 destacando el aumento de muertes por viruela, enfermedad que presentaba brotes discontinuos (gráficas 6 y 7). ${ }^{450}$

Gráfica 6. Defunciones por causa de enfermedad en 1901 en las capitales del

\section{País Valenciano}

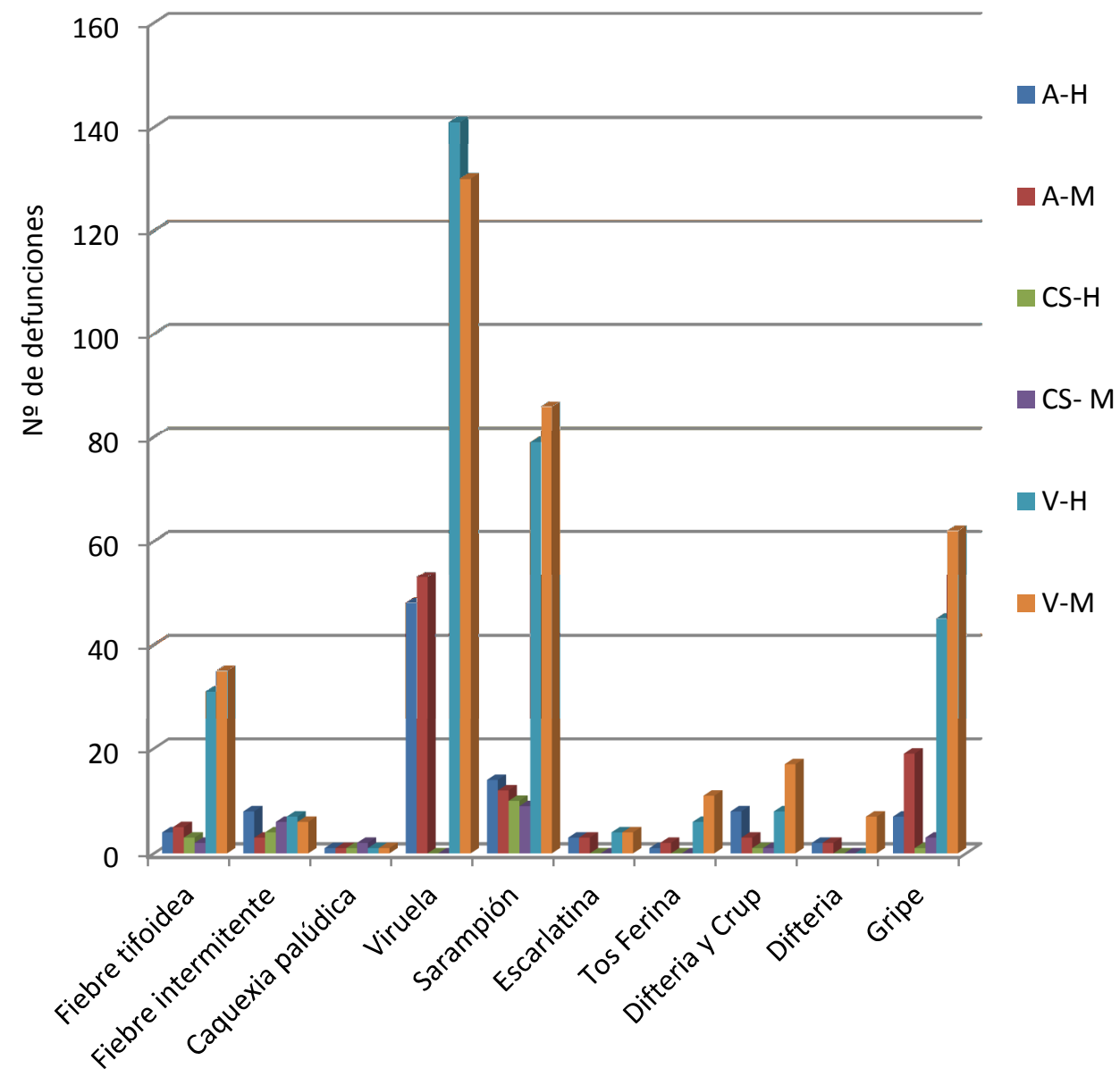

Fuente: Instituto Nacional de Estadística. Elaboración propia.

${ }^{450}$ Ver tabla 2 y 3 del Apéndice documental $n^{\circ} 1$. 
Gráfica 7. Mortalidad por enfermedad en 1902 en las provincias del País

\section{Valenciano}

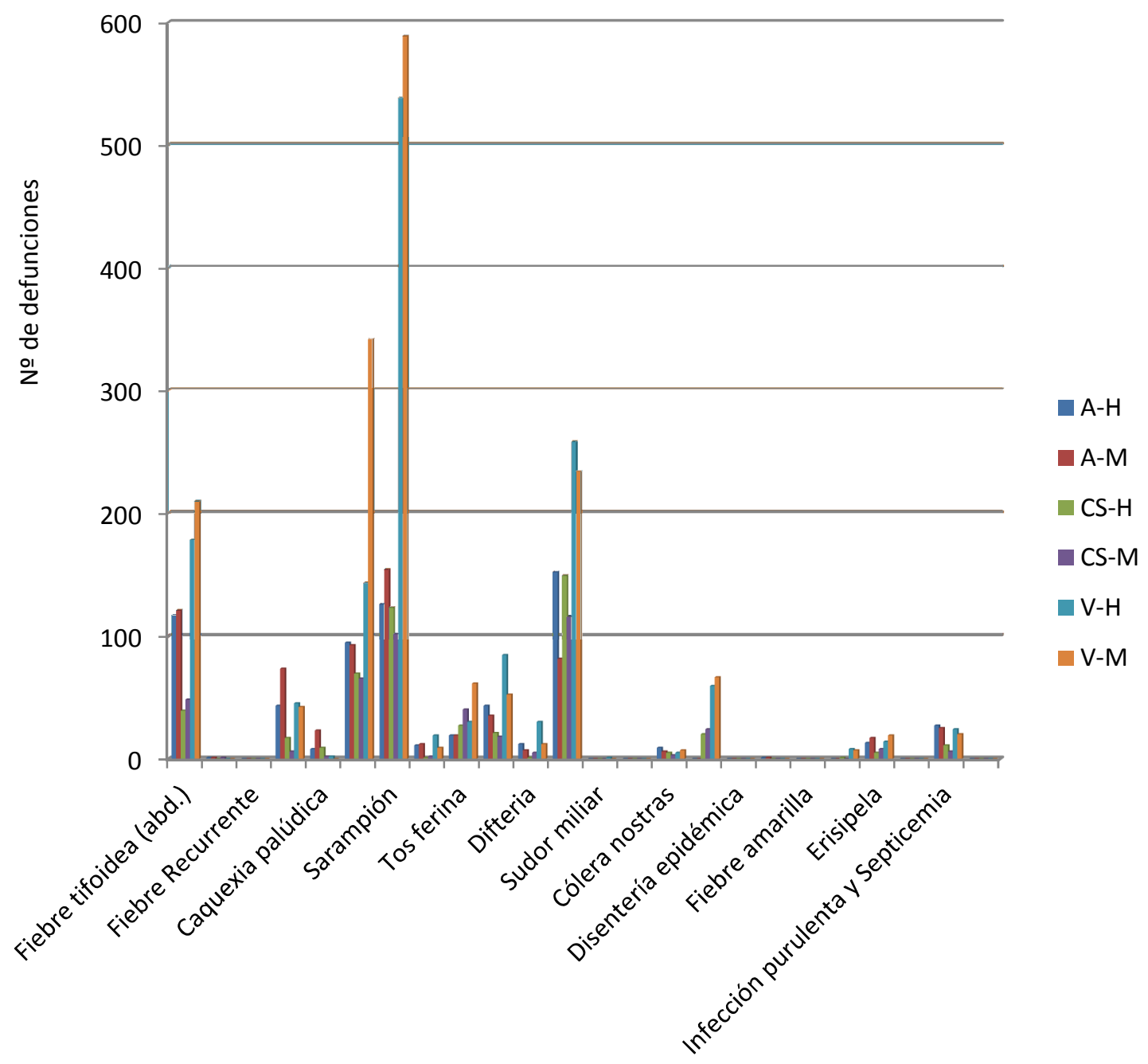

Fuente: Instituto Nacional de Estadística. Elaboración propia.

El estudio de los datos que nos ofrece el Instituto Nacional de Estadística sobre enfermedades causantes de mortalidad, nos ha sido muy útil para concretizar en otras enfermedades que en las estadísticas generales no aparecían, por ejemplo la tuberculosis pulmonar que nos da para Castellón capital (tabla 13 y gráfica 8) sólo en el año 1903, para varones 28 muertes y para mujeres 14 . 
Tabla 13. Causas de mortalidad en 1903 en la ciudad de Castellón de la Plana

\begin{tabular}{|c|c|c|}
\hline CAUSAS & CS-H & CS-M \\
\hline Fiebre tifoidea & 2 & 4 \\
\hline Tifus exantemático & 0 & 0 \\
\hline Fiebre Intermitente y caquexia palúdica & 1 & 3 \\
\hline Viruela & 0 & 2 \\
\hline Sarampión & 46 & 42 \\
\hline Escarlatina & 0 & 0 \\
\hline Coqueluche & 0 & 0 \\
\hline Difteria y Crup & 2 & 3 \\
\hline Gripe & 7 & 7 \\
\hline Cólera asiático & 0 & 0 \\
\hline Cólera nostras & 0 & 0 \\
\hline Otras enfermedades epidémicas & 1 & 0 \\
\hline Tuberculosis pulmonar & 28 & 14 \\
\hline Tuberculosis de las meninges & 5 & 5 \\
\hline Otras tuberculosis & 4 & 5 \\
\hline Sífilis & 0 & 0 \\
\hline Cánceres y otros tumores malignos & 7 & 10 \\
\hline Meningitis simple & 20 & 30 \\
\hline Congestión, hemorragia y reblandecimiento cerebral & 34 & 35 \\
\hline Enf. Orgánicas del corazón & 30 & 47 \\
\hline Bronquitis aguda & 20 & 20 \\
\hline Bronquitis crónica & 18 & 14 \\
\hline Neumonía & 6 & 9 \\
\hline Otras enfer. aparato Respiratorio & 22 & 25 \\
\hline Afecciones estómago (menos cáncer) & 3 & 2 \\
\hline Diarrea y enteritis (más 2 años) & 23 & 25 \\
\hline Diarrea y enteritis (menos 2 años) & 37 & 29 \\
\hline Hernias, obstrucciones intestinales & 4 & 2 \\
\hline Cirrosis del hígado & 6 & 6 \\
\hline Nefritis y mal de brigth & 9 & 8 \\
\hline Otras enfer. riñones, vejiga y anexos & 1 & 0 \\
\hline Tumores no cancerosos y enf. O genitales mujer & 0 & 0 \\
\hline Septicemia puerperal (fiebre, peritonitis, flebitis) & 0 & 1 \\
\hline Otros accidentes puerperales & 0 & 2 \\
\hline Debilidad congénita y vicios conformación & 6 & 11 \\
\hline Debilidad senil & 3 & 6 \\
\hline Suicidios & 1 & 0 \\
\hline Muertes violentas & 4 & 1 \\
\hline Otras enfermedades & 52 & 45 \\
\hline Enf. Desconocidas o mal definidas & 9 & 8 \\
\hline Total & 411 & 421 \\
\hline
\end{tabular}

Fuente: Instituto Nacional de Estadística. Elaboración propia. 


\section{Gráfica 8. Defunciones en 1903 en la ciudad de Castellón de la Plana}

Enf. Desconocidas o mal definidas Otras enfermedades Muertes violentas suicidios

Debilidad senil Debilidad congénita y vicios... Otros accidentes puerperales Septicemia puerperal (fiebre,.. Tumores no cancerosos y enf. O... Otras enfer. riñones, vejiga y anexos Nefritis y mal de brigth Cirrosis del hígado Hernias, obstrucciones intestinales Diarrea y enteritis (menos 2 años)

Diarrea y enteritis (mas 2 años) Afecciones estómago (menos cáncer) Otras enfer. apar. respiratorio neumonía

Bronquitis crónica

Bronquitis aguda Enf. Orgánicas del corazón Congestión, hemorragia y... Meningitis simple Cánceres y otros tumores malignos sífilis

Otras tuberculosis Tuberculosis de las meninges Tuberculosis pulmonar Otras enfermedades epidémicas Cólera nostras Cólera asiático gripe

Difteria y Crup coqueluche escarlatina sarampión Viruela Fiebre Intermitente y caquexia... Tifus exantemático Fiebre tifoidea (Abd.)
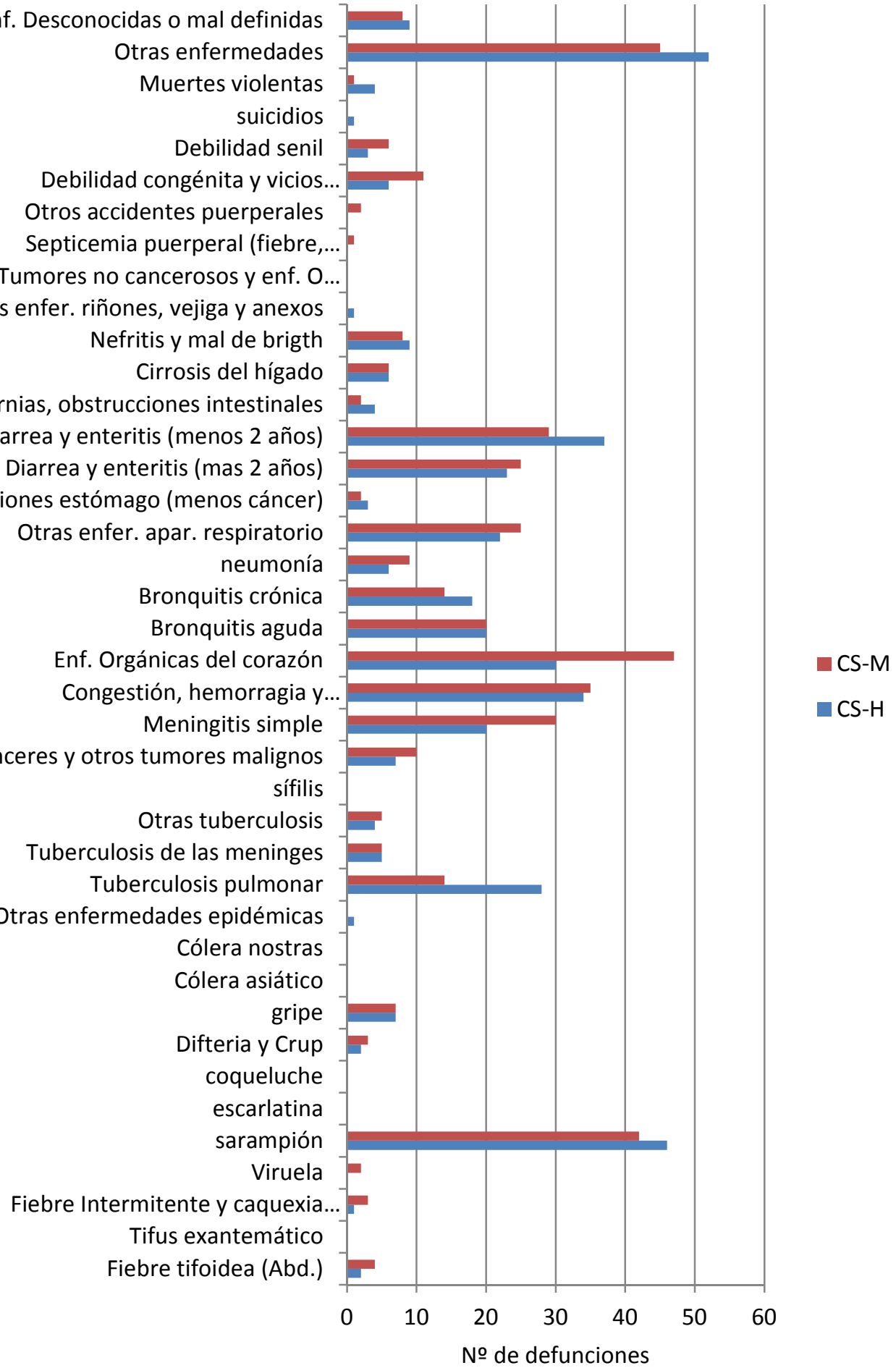

Fuente: Instituto Nacional de Estadística. Elaboración propia.

La tuberculosis pulmonar para toda la provincia presenta 157 defunciones en varones y 151 en mujeres (Tabla 14 y gráfica 9). 
Tabla 14. Causas de mortalidad en 1903 en la provincia de Castellón

\begin{tabular}{|c|c|c|}
\hline CAUSAS & CS-H & CS-M \\
\hline Fiebre tifoidea & 35 & 48 \\
\hline Tifus exantemático & 0 & 1 \\
\hline Fiebre Intermitente y caquexia palúdica & 17 & 17 \\
\hline Viruela & 17 & 15 \\
\hline Sarampión & 315 & 361 \\
\hline Escarlatina & 2 & 0 \\
\hline Coqueluche & 23 & 34 \\
\hline Difteria y Crup & 28 & 30 \\
\hline Gripe & 64 & 73 \\
\hline Cólera asiático & 0 & 0 \\
\hline Cólera nostras & 0 & 0 \\
\hline Otras enfermedades epidémicas & 32 & 40 \\
\hline Tuberculosis pulmonar & 157 & 151 \\
\hline Tuberculosis de las meninges & 28 & 25 \\
\hline Otras tuberculosis & 50 & 43 \\
\hline Sífilis & 1 & 0 \\
\hline Cánceres y otros tumores malignos & 49 & 64 \\
\hline Meningitis simple & 180 & 145 \\
\hline Congestión, hemorragia y reblandecimiento cerebral & 295 & 268 \\
\hline Enf. Orgánicas del corazón & 180 & 241 \\
\hline Bronquitis aguda & 271 & 216 \\
\hline Bronquitis crónica & 127 & 111 \\
\hline Neumonía & 115 & 99 \\
\hline Otras enfer. apar. Respiratorio & 178 & 190 \\
\hline Afecciones estómago (menos cáncer) & 55 & 27 \\
\hline Diarrea y enteritis (más 2 años) & 294 & 306 \\
\hline Diarrea y enteritis (menos 2 años) & 355 & 294 \\
\hline Hernias, obstrucciones intestinales & 30 & 13 \\
\hline Cirrosis del hígado & 42 & 42 \\
\hline Nefritis y mal de Brigth & 70 & 48 \\
\hline Otras enfer. riñones, vejiga y anexos & 14 & 1 \\
\hline Tumores no cancerosos y enf. O genitales mujer & 0 & 6 \\
\hline Septicemia puerperal (fiebre, peritonitis, flebitis) & 0 & 24 \\
\hline Otros accidentes puerperales & 0 & 20 \\
\hline Debilidad congénita y vicios conformación & 126 & 125 \\
\hline Debilidad senil & 42 & 74 \\
\hline Suicidios & 12 & 3 \\
\hline Muertes violentas & 71 & 23 \\
\hline Otras enfermedades & 466 & 390 \\
\hline Enfermedades desconocidas o mal definidas & 214 & 204 \\
\hline Total & 3955 & 3772 \\
\hline
\end{tabular}

Fuente: Instituto Nacional de Estadística. Elaboración propia. 


\section{Gráfica 9. Defunciones en 1903 en la provincia de Castellón}

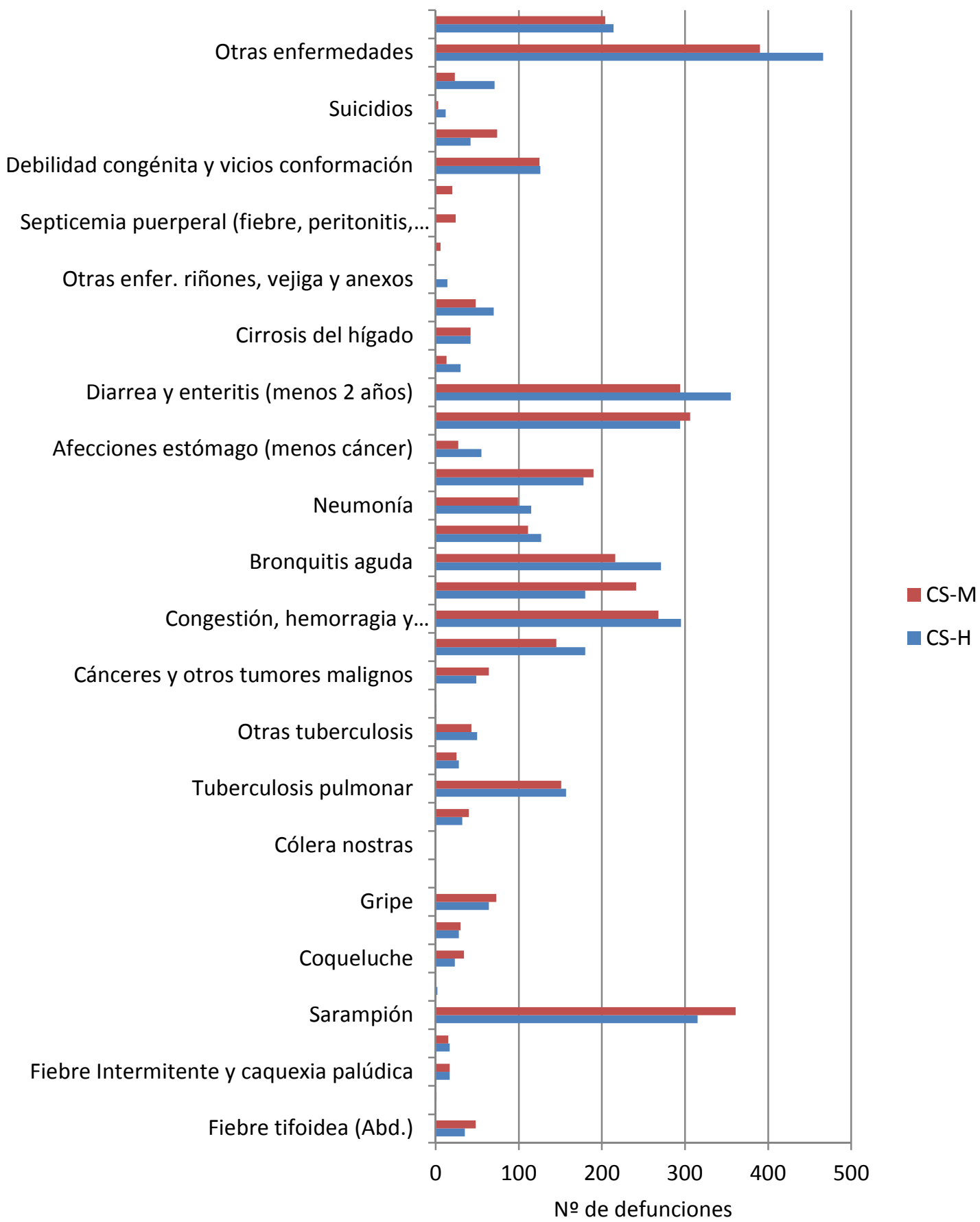

Fuente: Instituto Nacional de Estadística. Elaboración propia.

En las ciudades de Valencia y Alicante las defunciones por tuberculosis pulmonar fueron, en la primera 258 varones y 197 mujeres y en la segunda 54 varones y 31 mujeres. Las provincias de Valencia y Alicante sumaron 548 varones y 508 mujeres; y 335 varones y 273 mujeres, respectivamente. (Tablas 15-16-17-18 y gráficas 10-1112-13). 
Tabla 15. Causas de mortalidad en 1903 en la ciudad de Valencia

\begin{tabular}{|c|c|c|}
\hline CAUSAS & V-H & V-M \\
\hline Fiebre tifoidea (Abd.) & 54 & 46 \\
\hline Tifus exantemático & 0 & 0 \\
\hline Fiebre Intermitente y caquexia palúdica & 4 & 7 \\
\hline Viruela & 7 & 6 \\
\hline Sarampión & 44 & 38 \\
\hline Escarlatina & 7 & 4 \\
\hline Coqueluche & 2 & 6 \\
\hline Difteria y Crup & 8 & 9 \\
\hline Gripe & 56 & 66 \\
\hline Cólera asiático & 0 & 0 \\
\hline Cólera nostras & 0 & 0 \\
\hline Otras enfermedades epidémicas & 15 & 12 \\
\hline Tuberculosis pulmonar & 258 & 197 \\
\hline Tuberculosis de las meninges & 14 & 7 \\
\hline Otras tuberculosis & 27 & 25 \\
\hline Sífilis & 5 & 5 \\
\hline Cánceres y otros tumores malignos & 44 & 60 \\
\hline Meningitis simple & 204 & 228 \\
\hline Congestión, hemorragia y reblandecimiento cerebral & 157 & 170 \\
\hline Enf. Orgánicas del corazón & 194 & 211 \\
\hline Bronquitis aguda & 113 & 95 \\
\hline Bronquitis crónica & 74 & 66 \\
\hline Neumonía & 77 & 85 \\
\hline Otras enfer. aparato Respiratorio & 327 & 329 \\
\hline Afecciones estómago (menos cáncer) & 23 & 15 \\
\hline Diarrea y enteritis (más 2 años) & 221 & 287 \\
\hline Diarrea y enteritis (menos 2 años) & 225 & 179 \\
\hline Hernias, obstrucciones intestinales & 26 & 18 \\
\hline Cirrosis del hígado & 38 & 23 \\
\hline Nefritis y mal de Brigth & 55 & 53 \\
\hline Otras enfer. riñones, vejiga y anexos & 7 & 0 \\
\hline Tumores no cancerosos y enf. O genitales mujer & 0 & 3 \\
\hline Septicemia puerperal (fiebre, peritonitis, flebitis) & 0 & 26 \\
\hline Otros accidentes puerperales & 0 & 11 \\
\hline Debilidad congénita y vicios conformación & 81 & 49 \\
\hline Debilidad senil & 21 & 29 \\
\hline Suicidios & 5 & 2 \\
\hline Muertes violentas & 31 & 14 \\
\hline Otras enfermedades & 334 & 350 \\
\hline Enf. Desconocidas o mal definidas & 4 & 4 \\
\hline Total & 2762 & 2735 \\
\hline
\end{tabular}

Fuente: Instituto Nacional de Estadística. Elaboración propia. 


\section{Gráfica 10. Defunciones en 1903 en la ciudad de Valencia}

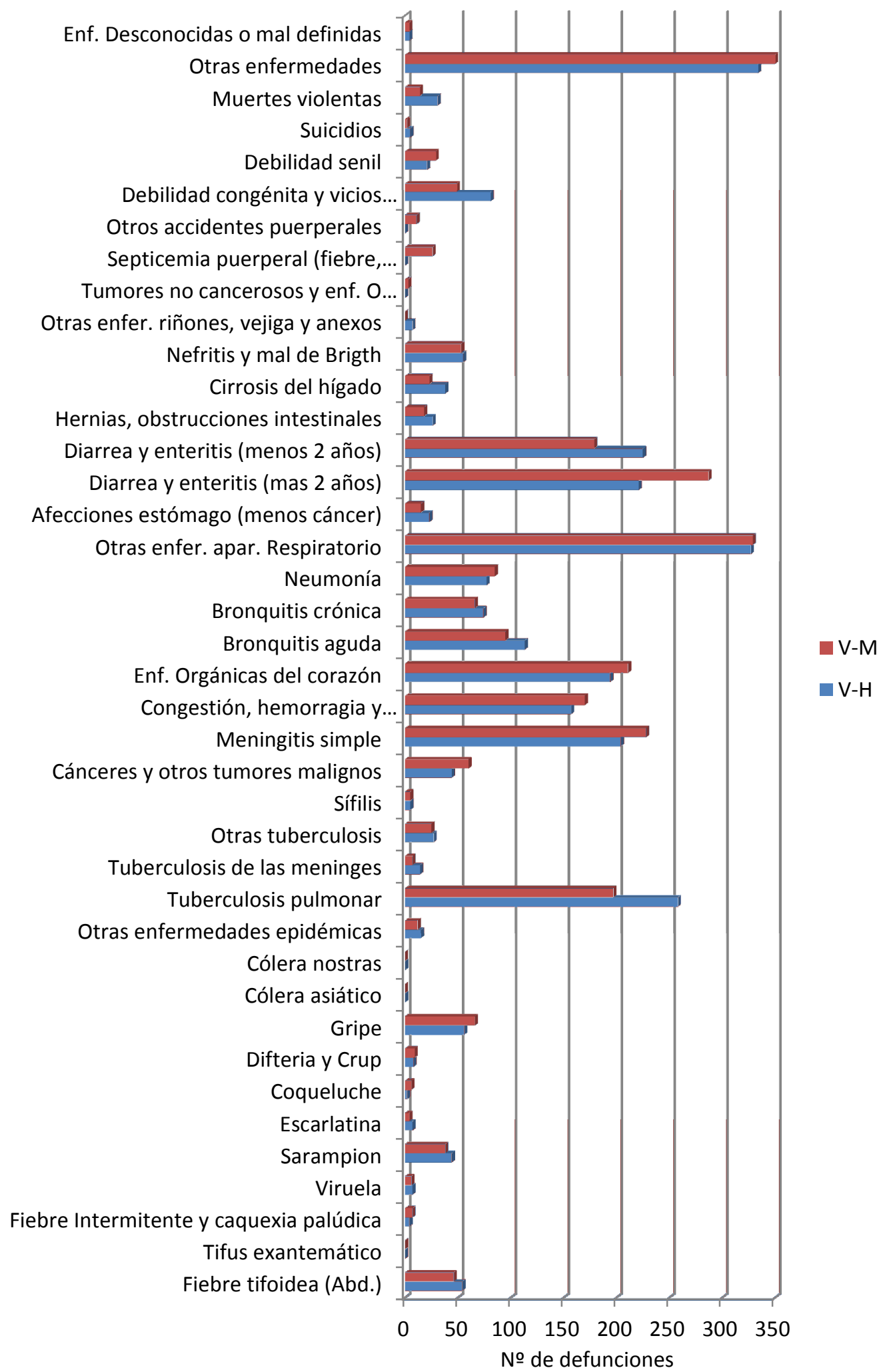

Fuente: Instituto Nacional de Estadística. Elaboración propia. 
Tabla 16. Causas de mortalidad en 1903 en la provincia de Valencia

\begin{tabular}{|c|c|c|}
\hline CAUSAS & V-H & V-M \\
\hline Fiebre tifoidea (Abd.) & 200 & 199 \\
\hline Tifus exantemático & 0 & 0 \\
\hline Fiebre Intermitente y caquexia palúdica & 25 & 41 \\
\hline Viruela & 64 & 58 \\
\hline Sarampión & 276 & 283 \\
\hline Escarlatina & 21 & 23 \\
\hline Coqueluche & 55 & 64 \\
\hline Difteria y Crup & 53 & 56 \\
\hline Gripe & 243 & 218 \\
\hline Cólera asiático & 0 & 0 \\
\hline Cólera nostras & 0 & 2 \\
\hline Otras enfermedades epidémicas & 81 & 81 \\
\hline Tuberculosis pulmonar & 548 & 508 \\
\hline Tuberculosis de las meninges & 41 & 37 \\
\hline Otras tuberculosis & 130 & 92 \\
\hline Sífilis & 8 & 6 \\
\hline Cánceres y otros tumores malignos & 144 & 155 \\
\hline Meningitis simple & 662 & 663 \\
\hline Congestión, hemorragia y reblandecimiento cerebral & 581 & 615 \\
\hline Enf. Orgánicas del corazón & 571 & 668 \\
\hline Bronquitis aguda & 473 & 342 \\
\hline Bronquitis crónica & 244 & 196 \\
\hline Neumonía & 234 & 232 \\
\hline Otras enfer. aparato Respiratorio & 936 & 841 \\
\hline Afecciones estómago (menos cáncer) & 101 & 58 \\
\hline Diarrea y enteritis (más 2 años) & 890 & 1012 \\
\hline Diarrea y enteritis (menos 2 años) & 972 & 883 \\
\hline Hernias, obstrucciones intestinales & 77 & 54 \\
\hline Cirrosis del hígado & 115 & 75 \\
\hline Nefritis y mal de Brigth & 211 & 162 \\
\hline Otras enfer. riñones, vejiga y anexos & 22 & 2 \\
\hline Tumores no cancerosos y enf. O genitales mujer & 0 & 8 \\
\hline Septicemia puerperal (fiebre, peritonitis, flebitis) & 0 & 83 \\
\hline Otros accidentes puerperales & 0 & 58 \\
\hline Debilidad congénita y vicios conformación & 377 & 293 \\
\hline Debilidad senil & 149 & 199 \\
\hline Suicidios & 33 & 8 \\
\hline Muertes violentas & 156 & 72 \\
\hline Otras enfermedades & 1303 & 1237 \\
\hline Enf. Desconocidas o mal definidas & 31 & 22 \\
\hline Total & 10027 & 9606 \\
\hline
\end{tabular}

Fuente: Instituto Nacional de Estadística. Elaboración propia. 


\section{Gráfica 11. Defunciones en 1903 en la provincia de Valencia}

Enf. Desconocidas o mal definidas Otras enfermedades Muertes violentas Suicidios

Debilidad senil

Debilidad congénita y vicios conformación

Otros accidentes puerperales Septicemia puerperal (fiebre, peritonitis,... Tumores no cancerosos y enf. O genitales... Otras enfer. riñones, vejiga y anexos Nefritis y mal de Brigth Cirrosis del hígado Hernias, obstrucciones intestinales Diarrea y enteritis (menos 2 años)

Diarrea y enteritis (mas 2 años) Afecciones estómago (menos cáncer)

Otras enfer. apar. Respiratorio

Neumonía

Bronquitis crónica

Bronquitis aguda

Enf. Orgánicas del corazón Congestión, hemorragia y...

Meningitis simple Cánceres y otros tumores malignos Sífilis

Otras tuberculosis Tuberculosis de las meninges

Tuberculosis pulmonar Otras enfermedades epidémicas Cólera nostras Cólera asiático Gripe

Difteria y Crup Coqueluche Escarlatina Sarampion Viruela

Fiebre Intermitente y caquexia palúdica

Tifus exantemático Fiebre tifoidea (Abd.)

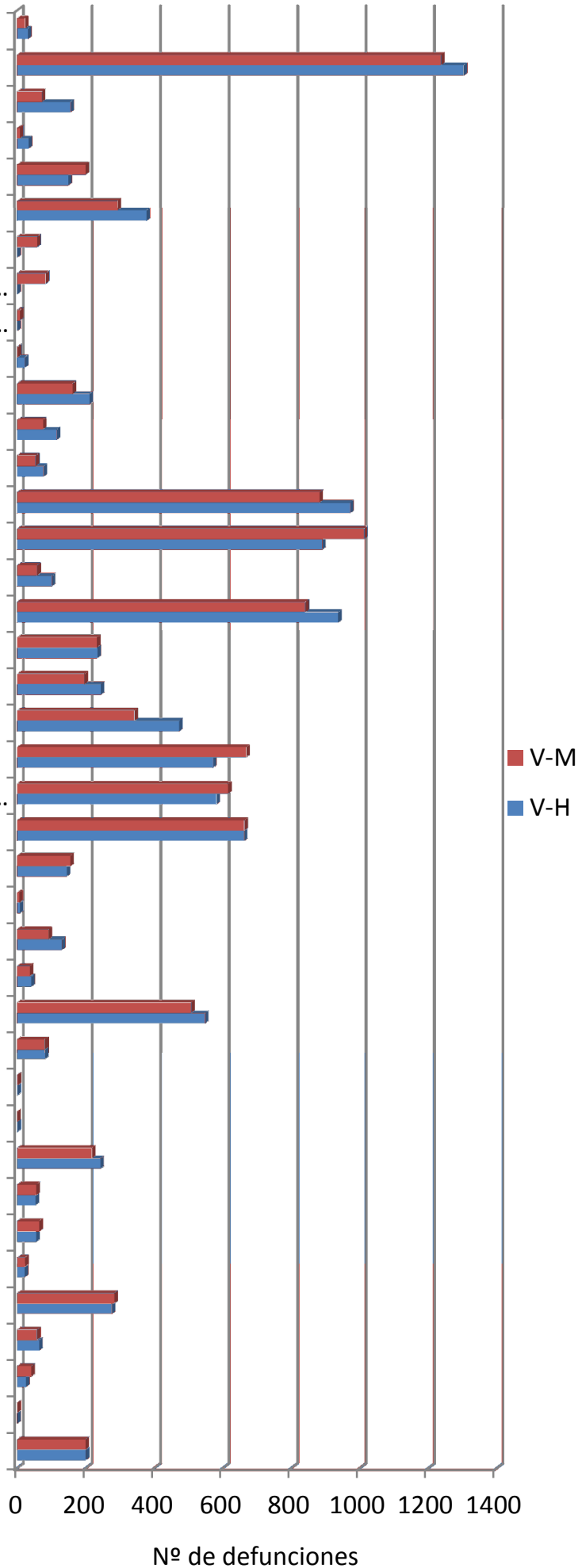

Fuente: Instituto Nacional de Estadística. Elaboración propia. 
Tabla 17. Causas de mortalidad en 1903 en la ciudad de Alicante

\begin{tabular}{|c|c|c|}
\hline CAUSAS & A-H & A-M \\
\hline Fiebre tifoidea (Abd.) & 3 & 3 \\
\hline Tifus exantemático & 0 & 0 \\
\hline Fiebre Intermitente y caquexia palúdica & 2 & 3 \\
\hline Viruela & 0 & 0 \\
\hline Sarampión & 1 & 0 \\
\hline Escarlatina & 0 & 0 \\
\hline Coqueluche & 2 & 0 \\
\hline Difteria y Crup & 1 & 4 \\
\hline Gripe & 4 & 14 \\
\hline Cólera asiático & 0 & 0 \\
\hline Cólera nostras & 0 & 0 \\
\hline Otras enfermedades epidémicas & 0 & 0 \\
\hline Tuberculosis pulmonar & 54 & 31 \\
\hline Tuberculosis de las meninges & 0 & 0 \\
\hline Otras tuberculosis & 6 & 2 \\
\hline Sífilis & 1 & 0 \\
\hline Cánceres y otros tumores malignos & 8 & 14 \\
\hline Meningitis simple & 22 & 32 \\
\hline Congestión, hemorragia y reblandecimiento cerebral & 23 & 37 \\
\hline Enf. Orgánicas del corazón & 42 & 56 \\
\hline Bronquitis aguda & 29 & 17 \\
\hline Bronquitis crónica & 25 & 24 \\
\hline Neumonía & 22 & 31 \\
\hline Otras enfer. aparato Respiratorio & 36 & 22 \\
\hline Afecciones estómago (menos cáncer) & 7 & 3 \\
\hline Diarrea y enteritis (mas 2 años) & 29 & 34 \\
\hline Diarrea y enteritis (menos 2 años) & 47 & 41 \\
\hline Hernias, obstrucciones intestinales & 3 & 2 \\
\hline Cirrosis del hígado & 11 & 0 \\
\hline Nefritis y mal de Brigth & 13 & 10 \\
\hline Otras enfer. riñones, vejiga y anexos & 2 & 0 \\
\hline Tumores no cancerosos y enf. O genitales mujer & 0 & 1 \\
\hline Septicemia puerperal (fiebre, peritonitis, flebitis) & 0 & 3 \\
\hline Otros accidentes puerperales & 0 & 1 \\
\hline Debilidad congénita y vicios conformación & 10 & 11 \\
\hline Debilidad senil & 15 & 27 \\
\hline Suicidios & 0 & 0 \\
\hline Muertes violentas & 18 & 5 \\
\hline Otras enfermedades & 127 & 107 \\
\hline Enf. Desconocidas o mal definidas & 10 & 10 \\
\hline Total & 573 & 545 \\
\hline
\end{tabular}

Fuente: Instituto Nacional de Estadística. Elaboración propia. 


\section{Gráfica 12. Defunciones en $\mathbf{1 9 0 3}$ en la ciudad de Alicante}

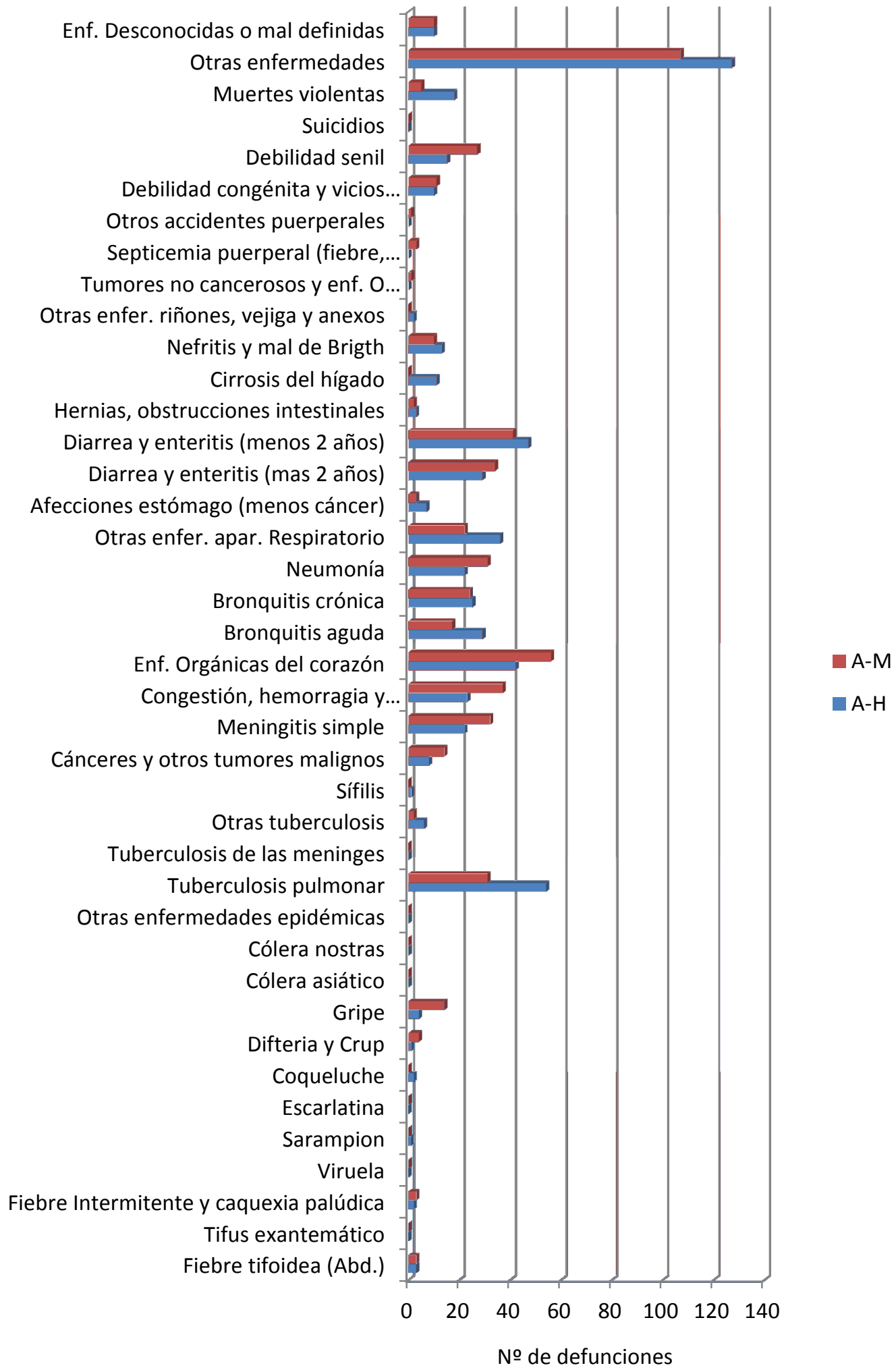

Fuente: Instituto Nacional de Estadística. Elaboración propia. 
Tabla 18. Causas de mortalidad en 1903 en la provincia de Alicante

\begin{tabular}{|c|c|c|}
\hline CAUSAS & A-H & A-M \\
\hline Fiebre tifoidea (Abd.) & 79 & 87 \\
\hline Tifus exantemático & 0 & 0 \\
\hline Fiebre Intermitente y caquexia palúdica & 54 & 48 \\
\hline Viruela & 11 & 11 \\
\hline Sarampión & 7 & 12 \\
\hline Escarlatina & 4 & 3 \\
\hline Coqueluche & 37 & 47 \\
\hline Difteria y Crup & 26 & 21 \\
\hline Gripe & 145 & 129 \\
\hline Cólera asiático & 0 & 0 \\
\hline Cólera nostras & 4 & 1 \\
\hline Otras enfermedades epidémicas & 23 & 25 \\
\hline Tuberculosis pulmonar & 335 & 273 \\
\hline Tuberculosis de las meninges & 15 & 8 \\
\hline Otras tuberculosis & 60 & 31 \\
\hline Sífilis & 6 & 0 \\
\hline Cánceres y otros tumores malignos & 70 & 91 \\
\hline Meningitis simple & 204 & 202 \\
\hline Congestión, hemorragia y reblandecimiento cerebral & 318 & 353 \\
\hline Enf. Orgánicas del corazón & 236 & 271 \\
\hline Bronquitis aguda & 248 & 159 \\
\hline Bronquitis crónica & 178 & 168 \\
\hline Neumonía & 226 & 201 \\
\hline Otras enfer. aparato Respiratorio & 287 & 241 \\
\hline Afecciones estómago (menos cáncer) & 55 & 31 \\
\hline Diarrea y enteritis (más 2 años) & 258 & 293 \\
\hline Diarrea y enteritis (menos 2 años) & 363 & 320 \\
\hline Hernias, obstrucciones intestinales & 38 & 19 \\
\hline Cirrosis del hígado & 48 & 32 \\
\hline Nefritis y mal de Brigth & 83 & 45 \\
\hline Otras enfer. riñones, vejiga y anexos & 21 & 6 \\
\hline Tumores no cancerosos y enf. O genitales mujer & 0 & 32 \\
\hline Septicemia puerperal (fiebre, peritonitis, flebitis) & 0 & 49 \\
\hline Otros accidentes puerperales & 0 & 13 \\
\hline Debilidad congénita y vicios conformación & 175 & 135 \\
\hline Debilidad senil & 103 & 168 \\
\hline Suicidios & 14 & 5 \\
\hline Muertes violentas & 86 & 40 \\
\hline Otras enfermedades & 874 & 766 \\
\hline Enf. Desconocidas o mal definidas & 263 & 255 \\
\hline Total & 4954 & 4591 \\
\hline
\end{tabular}

Fuente: Instituto Nacional de Estadística. Elaboración propia. 


\section{Gráfica 13. Defunciones en 1093 en la provincia de Alicante}

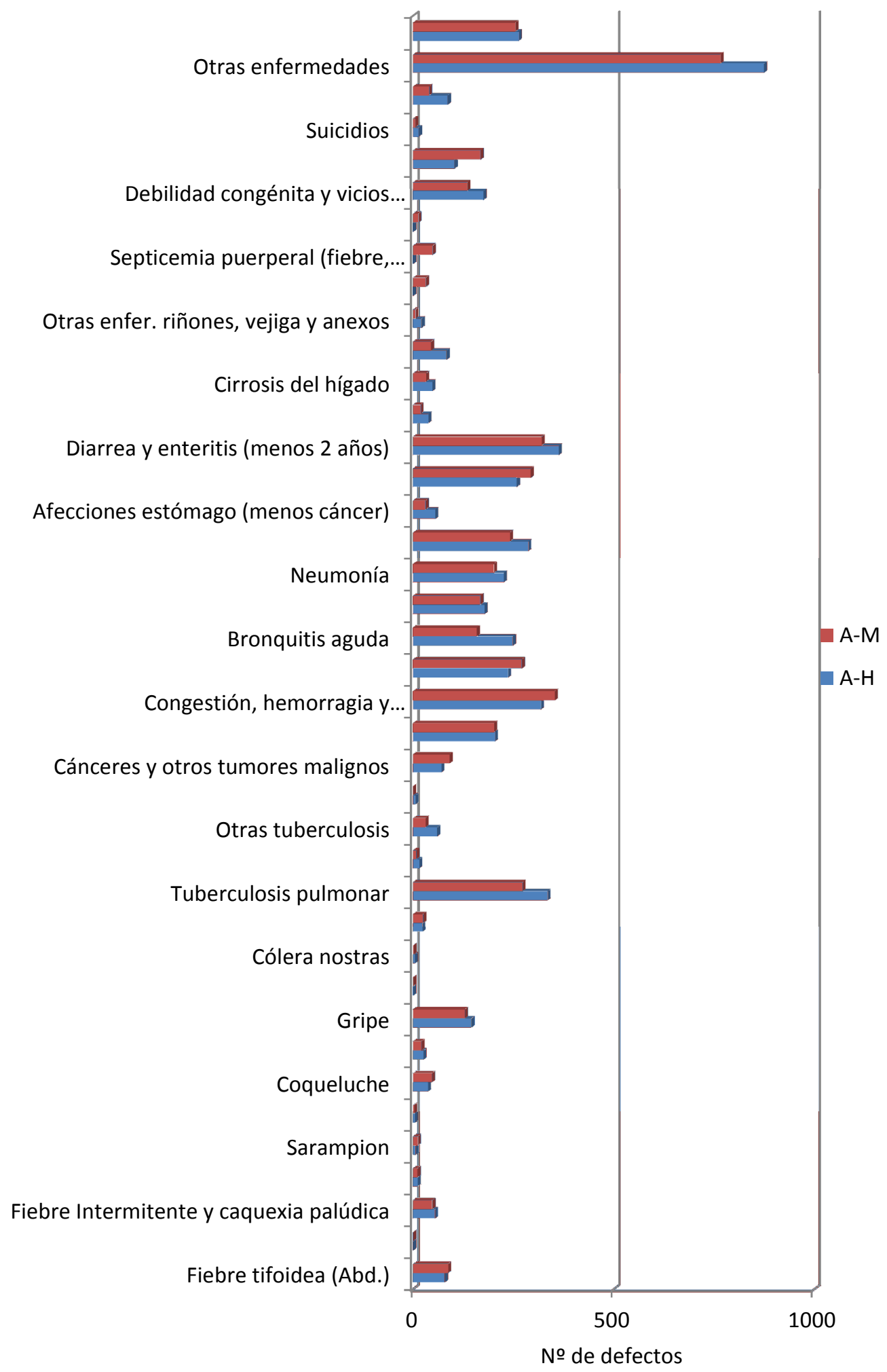

Fuente: Instituto Nacional de Estadística. Elaboración propia. 
En 1904 se aprecia el notable descenso de defunciones por sarampión en la ciudad de Castellón de la Plana (gráfica 14 y tabla 19), que había presentado unos elevados índices de mortalidad por esta enfermedad el año anterior. Éste descenso también es manifiesto en el resto de la provincia (gráfica 15 y tabla 20).

\section{Gráfica 14. Defunciones en 1904 en la ciudad de Castellón de la Plana}

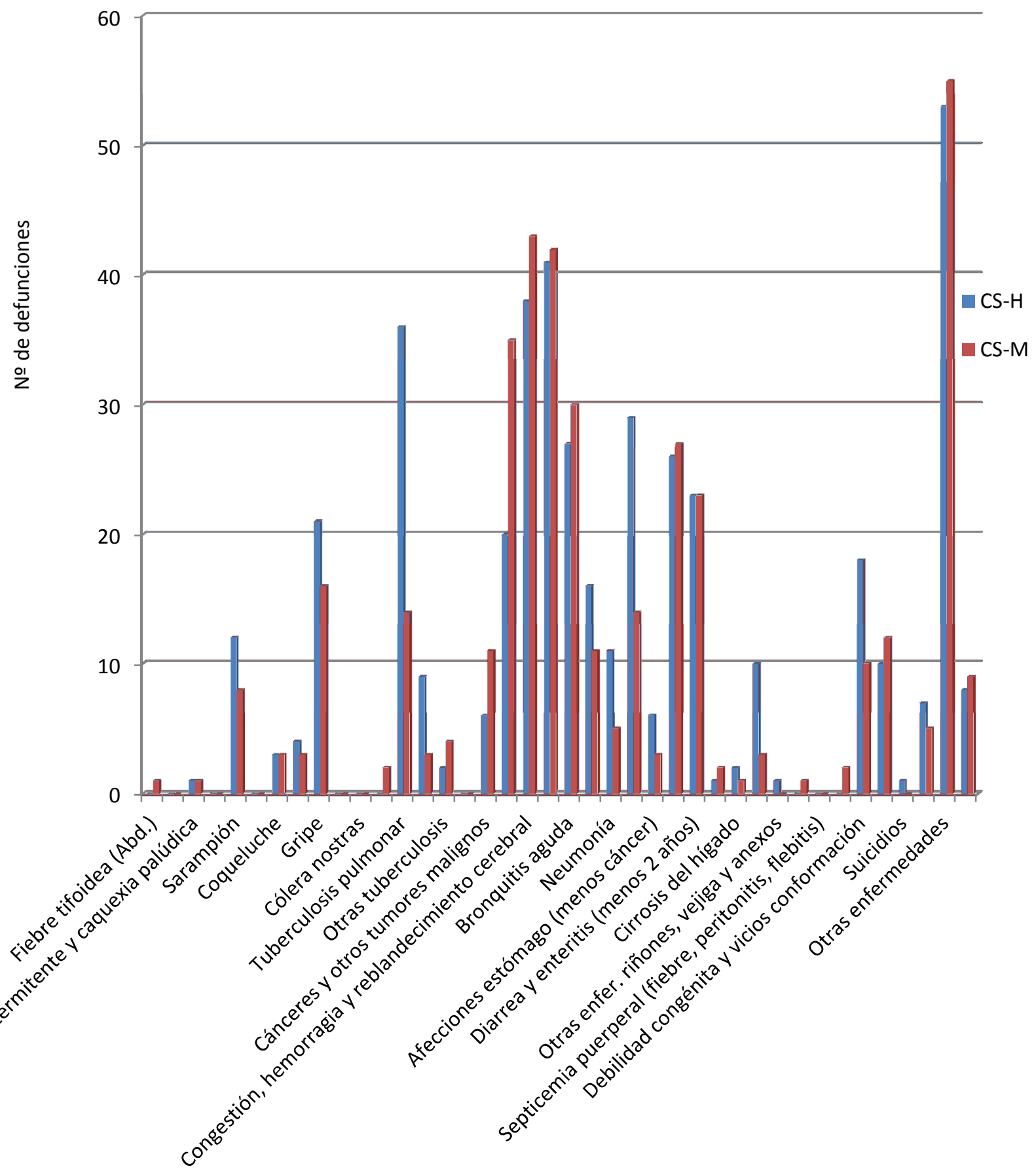

Fuente: Instituto Nacional de Estadística. Elaboración propia. 
Tabla 19 Causas de mortalidad en 1904 en la ciudad de Castellón

\begin{tabular}{|c|c|c|}
\hline CAUSAS & CS-H & CS-M \\
\hline Fiebre tifoidea (Abd.) & 0 & 1 \\
\hline Tifus exantemático & 0 & 0 \\
\hline Fiebre Intermitente y caquexia palúdica & 1 & 1 \\
\hline Viruela & 0 & 0 \\
\hline Sarampión & 12 & 8 \\
\hline Escarlatina & 0 & 0 \\
\hline Coqueluche & 3 & 3 \\
\hline Difteria y Crup & 4 & 3 \\
\hline Gripe & 21 & 16 \\
\hline Cólera asiático & 0 & 0 \\
\hline Cólera nostras & 0 & 0 \\
\hline Otras enfermedades epidémicas & 0 & 2 \\
\hline Tuberculosis pulmonar & 36 & 14 \\
\hline Tuberculosis de las meninges & 9 & 3 \\
\hline Otras tuberculosis & 2 & 4 \\
\hline Sífilis & 0 & 0 \\
\hline Cánceres y otros tumores malignos & 6 & 11 \\
\hline Meningitis simple & 20 & 35 \\
\hline Congestión, hemorragia y reblandecimiento cerebral & 38 & 43 \\
\hline Enf. Orgánicas del corazón & 41 & 42 \\
\hline Bronquitis aguda & 27 & 30 \\
\hline Bronquitis crónica & 16 & 11 \\
\hline Neumonía & 11 & 5 \\
\hline Otras enfer. apar. Respiratorio & 29 & 14 \\
\hline Afecciones estómago (menos cáncer) & 6 & 3 \\
\hline Diarrea y enteritis (más 2 años) & 26 & 27 \\
\hline Diarrea y enteritis (menos 2 años) & 23 & 23 \\
\hline Hernias, obstrucciones intestinales & 1 & 2 \\
\hline Cirrosis del hígado & 2 & 1 \\
\hline Nefritis y mal de Brigth & 10 & 3 \\
\hline Otras enfer. riñones, vejiga y anexos & 1 & 0 \\
\hline Tumores no cancerosos y enf. O genitales mujer & 0 & 1 \\
\hline Septicemia puerperal (fiebre, peritonitis, flebitis) & 0 & 0 \\
\hline Otros accidentes puerperales & 0 & 2 \\
\hline Debilidad congénita y vicios conformación & 18 & 10 \\
\hline Debilidad senil & 10 & 12 \\
\hline Suicidios & 1 & 0 \\
\hline Muertes violentas & 7 & 5 \\
\hline Otras enfermedades & 53 & 55 \\
\hline Enf. Desconocidas o mal definidas & 8 & 9 \\
\hline Total & 442 & 399 \\
\hline
\end{tabular}

Fuente: Instituto Nacional de Estadística. Elaboración propia. 


\section{Gráfica 15.Defunciones en 1904 en la provincia de Castellón}

Enf. Desconocidas o mal definidas Otras enfermedades Muertes violentas

Suicidios

Debilidad senil

Debilidad congénita y vicios conformación

Otros accidentes puerperales Septicemia puerperal (fiebre, peritonitis,.. Tumores no cancerosos y enf. O genitales...

Otras enfer. riñones, vejiga y anexos Nefritis y mal de Brigth Cirrosis del hígado Hernias, obstrucciones intestinales Diarrea y enteritis (menos 2 años)

Diarrea y enteritis (mas 2 años) Afecciones estómago (menos cáncer) Otras enfer. apar. Respiratorio Neumonía Bronquitis crónica Bronquitis aguda Enf. Orgánicas del corazón Congestión, hemorragia y... Meningitis simple Cánceres y otros tumores malignos Sífilis

Otras tuberculosis Tuberculosis de las meninges Tuberculosis pulmonar Otras enfermedades epidémicas Cólera nostras Cólera asiático Gripe Difteria y Crup Coqueluche Escarlatina Sarampion Viruela

Fiebre Intermitente y caquexia palúdica Tifus exantemático Fiebre tifoidea (Abd.)
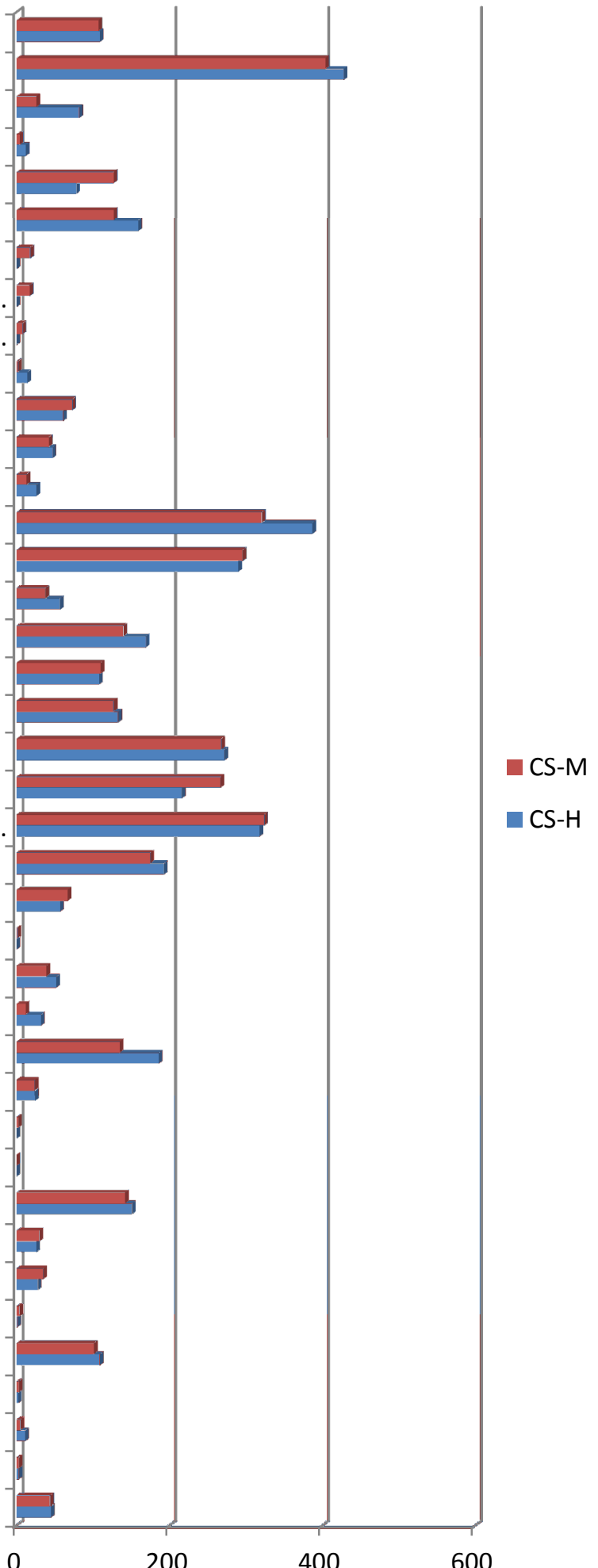

№ de defunciones

Fuente: Instituto Nacional de Estadística. Elaboración propia. 
Tabla 20. Causas de mortalidad en 1904 en la provincia de Castellón

\begin{tabular}{|c|c|c|}
\hline CAUSAS & CS-H & CS-M \\
\hline Fiebre tifoidea (Abd.) & 45 & 44 \\
\hline Tifus exantemático & 3 & 3 \\
\hline Fiebre Intermitente y caquexia palúdica & 11 & 5 \\
\hline Viruela & 2 & 3 \\
\hline Sarampión & 109 & 101 \\
\hline Escarlatina & 1 & 4 \\
\hline Coqueluche & 28 & 35 \\
\hline Difteria y Crup & 26 & 30 \\
\hline Gripe & 151 & 142 \\
\hline Cólera asiático & 0 & 0 \\
\hline Cólera nostras & 0 & 2 \\
\hline Otras enfermedades epidémicas & 24 & 24 \\
\hline Tuberculosis pulmonar & 186 & 135 \\
\hline Tuberculosis de las meninges & 32 & 12 \\
\hline Otras tuberculosis & 52 & 39 \\
\hline Sífilis & 0 & 1 \\
\hline Cánceres y otros tumores malignos & 57 & 67 \\
\hline Meningitis simple & 193 & 175 \\
\hline Congestión, hemorragia y reblandecimiento cerebral & 318 & 324 \\
\hline Enf. Orgánicas del corazón & 216 & 267 \\
\hline Bronquitis aguda & 272 & 268 \\
\hline Bronquitis crónica & 133 & 127 \\
\hline Neumonía & 108 & 110 \\
\hline Otras enfermedades aparato . Respiratorio & 169 & 140 \\
\hline Afecciones estómago (menos cáncer) & 57 & 38 \\
\hline Diarrea y enteritis (más 2 años) & 290 & 296 \\
\hline Diarrea y enteritis (menos 2 años) & 387 & 321 \\
\hline Hernias, obstrucciones intestinales & 26 & 13 \\
\hline Cirrosis del hígado & 47 & 42 \\
\hline Nefritis y mal de Brigth & 61 & 73 \\
\hline Otras enfer. riñones, vejiga y anexos & 14 & 2 \\
\hline Tumores no cancerosos y enf. O genitales mujer & 0 & 8 \\
\hline Septicemia puerperal (fiebre, peritonitis, flebitis) & 0 & 17 \\
\hline Otros accidentes puerperales & 0 & 18 \\
\hline Debilidad congénita y vicios conformación & 159 & 127 \\
\hline Debilidad senil & 78 & 127 \\
\hline Suicidios & 12 & 4 \\
\hline Muertes violentas & 82 & 26 \\
\hline Otras enfermedades & 428 & 404 \\
\hline Enf. Desconocidas o mal definidas & 109 & 107 \\
\hline Total & 3886 & 3681 \\
\hline
\end{tabular}

Fuente: Instituto Nacional de Estadística. Elaboración propia. 
El descenso observado en Castellón es comparable con los datos que arrojan Valencia y su capital, (gráfica 16 y tabla 21).

Gráfica 16. Defunciones en 1904 en la cuidad de Valencia

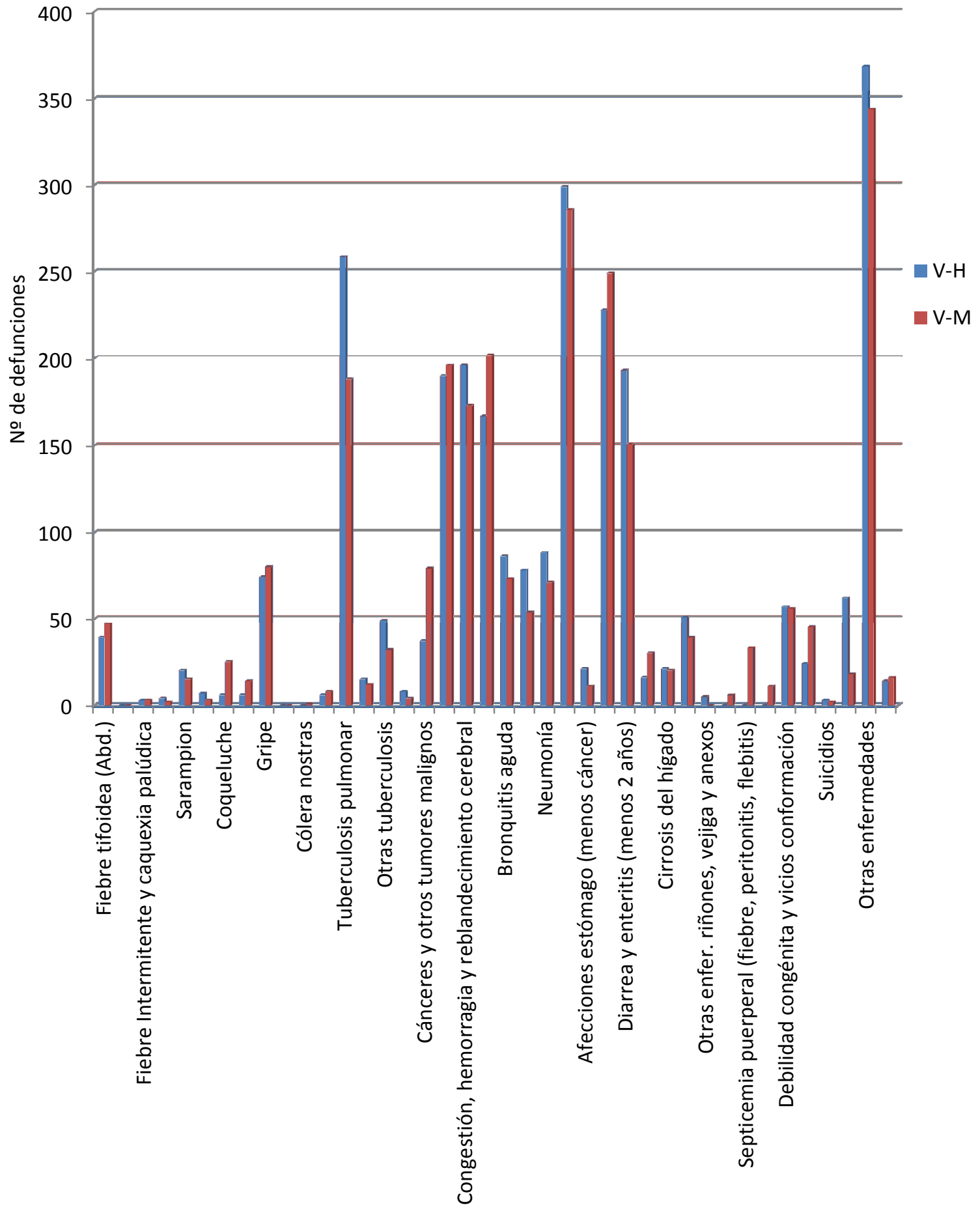

Fuente: Instituto Nacional de Estadística. Elaboración propia. 
Tabla 21. Causas de mortalidad en 1904 en la ciudad de Valencia

\begin{tabular}{|c|c|c|}
\hline CAUSAS & V-H & V-M \\
\hline Fiebre tifoidea (Abd.) & 39 & 47 \\
\hline Tifus exantemático & 0 & 0 \\
\hline Fiebre Intermitente y caquexia palúdica & 3 & 3 \\
\hline Viruela & 4 & 2 \\
\hline Sarampión & 20 & 15 \\
\hline Escarlatina & 7 & 3 \\
\hline Coqueluche & 6 & 25 \\
\hline Difteria y Crup & 6 & 14 \\
\hline Gripe & 74 & 80 \\
\hline Cólera asiático & 0 & 0 \\
\hline Cólera nostras & 0 & 1 \\
\hline Otras enfermedades epidémicas & 6 & 8 \\
\hline Tuberculosis pulmonar & 259 & 188 \\
\hline Tuberculosis de las meninges & 15 & 12 \\
\hline Otras tuberculosis & 49 & 32 \\
\hline Sífilis & 8 & 4 \\
\hline Cánceres y otros tumores malignos & 37 & 79 \\
\hline Meningitis simple & 190 & 196 \\
\hline Congestión, hemorragia y reblandecimiento cerebral & 196 & 173 \\
\hline Enf. Orgánicas del corazón & 167 & 202 \\
\hline Bronquitis aguda & 86 & 73 \\
\hline Bronquitis crónica & 78 & 54 \\
\hline Neumonía & 88 & 71 \\
\hline Otras enfer. aparato Respiratorio & 299 & 286 \\
\hline Afecciones estómago (menos cáncer) & 21 & 11 \\
\hline Diarrea y enteritis (más 2 años) & 228 & 249 \\
\hline Diarrea y enteritis (menos 2 años) & 193 & 151 \\
\hline Hernias, obstrucciones intestinales & 16 & 30 \\
\hline Cirrosis del hígado & 21 & 20 \\
\hline Nefritis y mal de Brigth & 51 & 39 \\
\hline Otras enfer. riñones, vejiga y anexos & 5 & 0 \\
\hline Tumores no cancerosos y enf. O genitales mujer & 0 & 6 \\
\hline Septicemia puerperal (fiebre, peritonitis, flebitis) & 0 & 33 \\
\hline Otros accidentes puerperales & 0 & 11 \\
\hline Debilidad congénita y vicios conformación & 57 & 56 \\
\hline Debilidad senil & 24 & 45 \\
\hline Suicidios & 3 & 2 \\
\hline Muertes violentas & 62 & 18 \\
\hline Otras enfermedades & 369 & 344 \\
\hline Enf. Desconocidas o mal definidas & 14 & 16 \\
\hline Total & 2701 & 2599 \\
\hline
\end{tabular}

Fuente: Instituto Nacional de Estadística. Elaboración propia. 


\section{Gráfica 17. Defunciones en 1904 en la provincia de Valencia}

Enf. Desconocidas o mal definidas Otras enfermedades Muertes violentas Suicidios Debilidad senil Debilidad congénita y vicios... Otros accidentes puerperales Septicemia puerperal (fiebre,..

Tumores no cancerosos y enf. 0 .. Otras enfer. riñones, vejiga y anexos Nefritis y mal de Brigth Cirrosis del hígado Hernias, obstrucciones intestinales Diarrea y enteritis (menos 2 años)

Diarrea y enteritis (mas 2 años) Afecciones estómago (menos cáncer)

Otras enfer. apar. Respiratorio Neumonía Bronquitis crónica Bronquitis aguda Enf. Orgánicas del corazón Congestión, hemorragia y.. Meningitis simple Cánceres y otros tumores malignos Sífilis

Otras tuberculosis Tuberculosis de las meninges Tuberculosis pulmonar Otras enfermedades epidémicas Cólera nostras Cólera asiático Gripe Difteria y Crup Coqueluche Escarlatina Sarampion Viruela

Fiebre Intermitente y caquexia...

Tifus exantemático Fiebre tifoidea (Abd.)

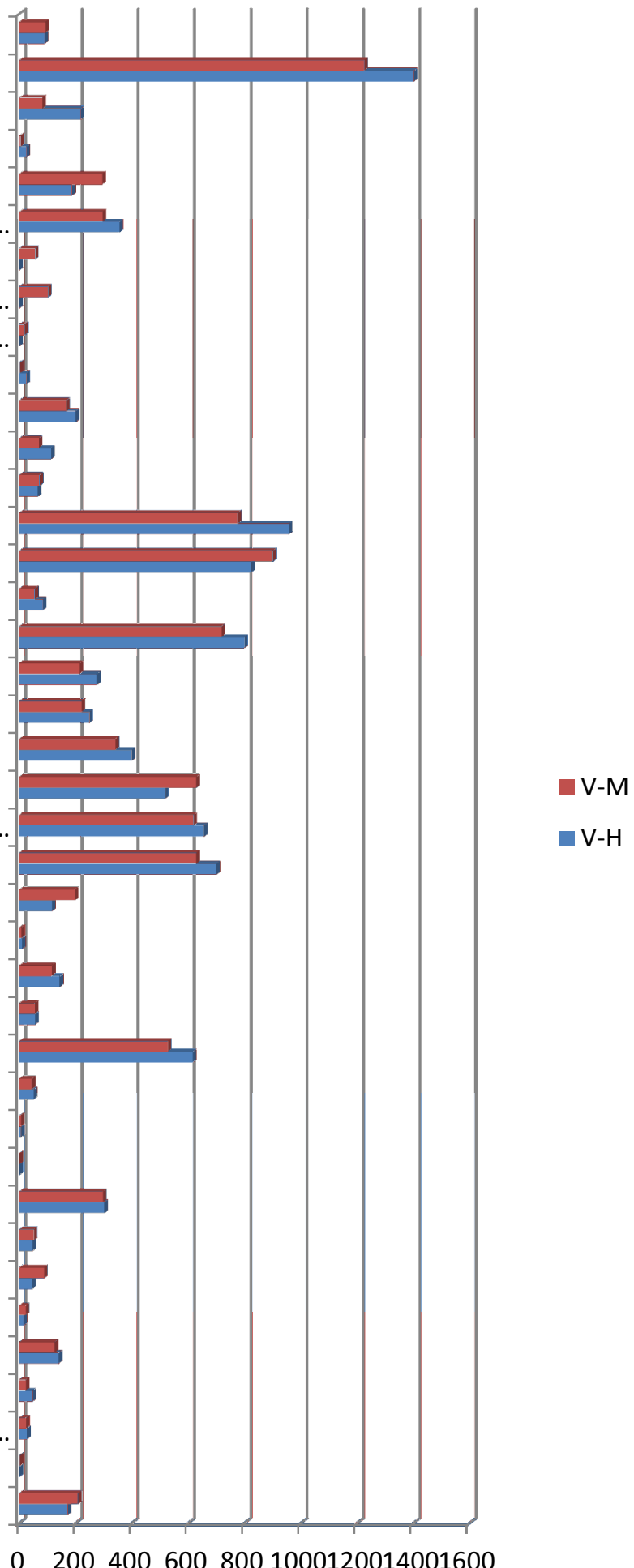

№ de defunciones

Fuente: Instituto Nacional de Estadística. Elaboración propia. 
Tabla 22. Causas de mortalidad en 1904 en la provincia de Valencia

\begin{tabular}{|c|c|c|}
\hline CAUSAS & V-H & V-M \\
\hline Fiebre tifoidea (Abd.) & 172 & 209 \\
\hline Tifus exantemático & 0 & 2 \\
\hline Fiebre Intermitente y caquexia palúdica & 26 & 24 \\
\hline Viruela & 47 & 23 \\
\hline Sarampión & 139 & 125 \\
\hline Escarlatina & 15 & 23 \\
\hline Coqueluche & 46 & 88 \\
\hline Difteria y Crup & 47 & 51 \\
\hline Gripe & 302 & 297 \\
\hline Cólera asiático & 0 & 0 \\
\hline Cólera nostras & 7 & 6 \\
\hline Otras enfermedades epidémicas & 51 & 45 \\
\hline Tuberculosis pulmonar & 616 & 528 \\
\hline Tuberculosis de las meninges & 56 & 55 \\
\hline Otras tuberculosis & 144 & 115 \\
\hline Sífilis & 10 & 7 \\
\hline Cánceres y otros tumores malignos & 116 & 197 \\
\hline Meningitis simple & 700 & 629 \\
\hline Congestión, hemorragia y reblandecimiento cerebral & 656 & 619 \\
\hline Enf. Orgánicas del corazón & 518 & 629 \\
\hline Bronquitis aguda & 399 & 341 \\
\hline Bronquitis crónica & 249 & 221 \\
\hline Neumonía & 276 & 215 \\
\hline Otras enfer. aparato Respiratorio & 799 & 718 \\
\hline Afecciones estómago (menos cáncer) & 83 & 55 \\
\hline Diarrea y enteritis (más 2 años) & 824 & 901 \\
\hline Diarrea y enteritis (menos 2 años) & 957 & 776 \\
\hline Hernias, obstrucciones intestinales & 65 & 72 \\
\hline Cirrosis del hígado & 113 & 69 \\
\hline Nefritis y mal de Brigth & 200 & 167 \\
\hline Otras enfer. riñones, vejiga y anexos & 25 & 2 \\
\hline Tumores no cancerosos y enf. O genitales mujer & 0 & 19 \\
\hline Septicemia puerperal (fiebre, peritonitis, flebitis) & 0 & 102 \\
\hline Otros accidentes puerperales & 0 & 56 \\
\hline Debilidad congénita y vicios conformación & 356 & 296 \\
\hline Debilidad senil & 187 & 294 \\
\hline Suicidios & 25 & 5 \\
\hline Muertes violentas & 218 & 82 \\
\hline Otras enfermedades & 1401 & 1225 \\
\hline Enf. Desconocidas o mal definidas & 90 & 92 \\
\hline Total & 9935 & 9380 \\
\hline
\end{tabular}

Fuente: Instituto Nacional de Estadística. Elaboración propia.

Mientras que es muy llamativa la escasa incidencia de las defunciones en Alicante y su provincia por ésta enfermedad (tablas 23 -24 y gráficas 18-19). 
Tabla 23. Causas de mortalidad en 1904 en la ciudad de Alicante

\begin{tabular}{|c|c|c|}
\hline CAUSAS & A-H & A-M \\
\hline Fiebre tifoidea (Abd.) & 4 & 2 \\
\hline Tifus exantemático & 0 & 0 \\
\hline Fiebre Intermitente y caquexia palúdica & 0 & 3 \\
\hline Viruela & 0 & 1 \\
\hline Sarampión & 19 & 17 \\
\hline Escarlatina & 0 & 0 \\
\hline Coqueluche & 1 & 0 \\
\hline Difteria y Crup & 5 & 0 \\
\hline Gripe & 7 & 9 \\
\hline Cólera asiático & 0 & 0 \\
\hline Cólera nostras & 0 & 0 \\
\hline Otras enfermedades epidémicas & 0 & 2 \\
\hline Tuberculosis pulmonar & 56 & 33 \\
\hline Tuberculosis de las meninges & 1 & 1 \\
\hline Otras tuberculosis & 10 & 7 \\
\hline Sífilis & 2 & 3 \\
\hline Cánceres y otros tumores malignos & 7 & 12 \\
\hline Meningitis simple & 31 & 22 \\
\hline Congestión, hemorragia y reblandecimiento cerebral & 28 & 23 \\
\hline Enf. Orgánicas del corazón & 40 & 60 \\
\hline Bronquitis aguda & 37 & 36 \\
\hline Bronquitis crónica & 35 & 25 \\
\hline Neumonía & 29 & 30 \\
\hline Otras enfer. aparato Respiratorio & 40 & 43 \\
\hline Afecciones estómago (menos cáncer) & 7 & 0 \\
\hline Diarrea y enteritis (más 2 años) & 53 & 41 \\
\hline Diarrea y enteritis (menos 2 años) & 40 & 36 \\
\hline Hernias, obstrucciones intestinales & 3 & 4 \\
\hline Cirrosis del hígado & 5 & 4 \\
\hline Nefritis y mal de Brigth & 12 & 9 \\
\hline Otras enfer. riñones, vejiga y anexos & 0 & 1 \\
\hline Tumores no cancerosos y enf. O genitales mujer & 0 & 0 \\
\hline Septicemia puerperal (fiebre, peritonitis, flebitis) & 0 & 7 \\
\hline Otros accidentes puerperales & 0 & 0 \\
\hline Debilidad congénita y vicios conformación & 16 & 10 \\
\hline Debilidad senil & 19 & 26 \\
\hline Suicidios & 0 & 0 \\
\hline Muertes violentas & 21 & 7 \\
\hline Otras enfermedades & 109 & 91 \\
\hline Enf. Desconocidas o mal definidas & 25 & 13 \\
\hline Total & 662 & 578 \\
\hline
\end{tabular}

Fuente: Instituto Nacional de Estadística. Elaboración propia. 


\section{Gráfica 18. Defunciones en 1904 en la ciudad de Alicante}

Enf. Desconocidas o mal definidas Otras enfermedades

Muertes violentas

Suicidios

Debilidad senil

Debilidad congénita y vicios..

Otros accidentes puerperales

Septicemia puerperal (fiebre,

Tumores no cancerosos y enf. O..

Otras enfer. riñones, vejiga y anexos

Nefritis y mal de Brigth

Cirrosis del hígado

Hernias, obstrucciones intestinales

Diarrea y enteritis (menos 2 años)

Diarrea y enteritis (mas 2 años)

Afecciones estómago (menos cáncer)

Otras enfer. apar. Respiratorio

Neumonía

Bronquitis crónica

Bronquitis aguda

Enf. Orgánicas del corazón Congestión, hemorragia y...

Meningitis simple

Cánceres y otros tumores malignos

Sífilis

Otras tuberculosis

Tuberculosis de las meninges

Tuberculosis pulmonar

Otras enfermedades epidémicas

Cólera nostras

Cólera asiático

Gripe

Difteria y Crup

Coqueluche

Escarlatina

Sarampion

Viruela

Fiebre Intermitente y caquexia..

Tifus exantemático

Fiebre tifoidea (Abd.)

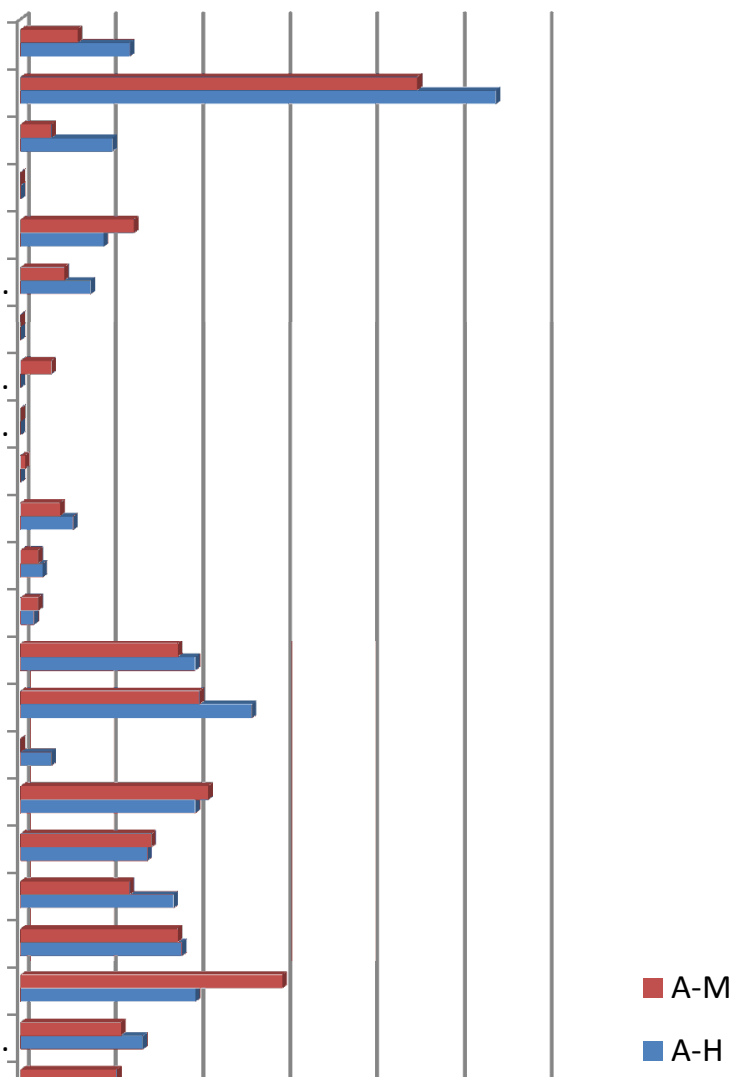

$\mathrm{A}-\mathrm{H}$

Fuente: Instituto Nacional de Estadística. Elaboración propia. 
Tabla 24. Causas de mortalidad en 1904 en la provincia de Alicante

\begin{tabular}{|c|c|c|}
\hline CAUSAS & A-H & A-M \\
\hline Fiebre tifoidea (Abd.) & 83 & 97 \\
\hline Tifus exantemático & 1 & 0 \\
\hline Fiebre Intermitente y caquexia palúdica & 58 & 75 \\
\hline Viruela & 9 & 2 \\
\hline Sarampión & 276 & 268 \\
\hline Escarlatina & 5 & 3 \\
\hline Coqueluche & 42 & 67 \\
\hline Difteria y Crup & 29 & 19 \\
\hline Gripe & 212 & 200 \\
\hline Cólera asiático & 0 & 0 \\
\hline Cólera nostras & 3 & 6 \\
\hline Otras enfermedades epidémicas & 37 & 44 \\
\hline Tuberculosis pulmonar & 306 & 260 \\
\hline Tuberculosis de las meninges & 10 & 11 \\
\hline Otras tuberculosis & 73 & 58 \\
\hline Sífilis & 5 & 3 \\
\hline Cánceres y otros tumores malignos & 78 & 115 \\
\hline Meningitis simple & 258 & 181 \\
\hline Congestión, hemorragia y reblandecimiento cerebral & 363 & 386 \\
\hline Enf. Orgánicas del corazón & 224 & 297 \\
\hline Bronquitis aguda & 295 & 252 \\
\hline Bronquitis crónica & 211 & 149 \\
\hline Neumonía & 193 & 133 \\
\hline Otras enfer. aparato Respiratorio & 307 & 307 \\
\hline Afecciones estómago (menos cáncer) & 61 & 38 \\
\hline Diarrea y enteritis (más 2 años) & 413 & 413 \\
\hline Diarrea y enteritis (menos 2 años) & 464 & 404 \\
\hline Hernias, obstrucciones intestinales & 36 & 30 \\
\hline Cirrosis del hígado & 47 & 43 \\
\hline Nefritis y mal de Brigth & 84 & 61 \\
\hline Otras enfer. riñones, vejiga y anexos & 25 & 8 \\
\hline Tumores no cancerosos y enf. O genitales mujer & 0 & 17 \\
\hline Septicemia puerperal (fiebre, peritonitis, flebitis) & 0 & 42 \\
\hline Otros accidentes puerperales & 0 & 21 \\
\hline Debilidad congénita y vicios conformación & 174 & 140 \\
\hline Debilidad senil & 161 & 241 \\
\hline Suicidios & 3 & 0 \\
\hline Muertes violentas & 95 & 32 \\
\hline Otras enfermedades & 855 & 800 \\
\hline Enf. Desconocidas o mal definidas & 180 & 165 \\
\hline Total & 5676 & 5388 \\
\hline
\end{tabular}

Fuente: Instituto Nacional de Estadística. Elaboración propia. 


\section{Gráfica 19. Defunciones en 1094 en la provincia de Alicante}

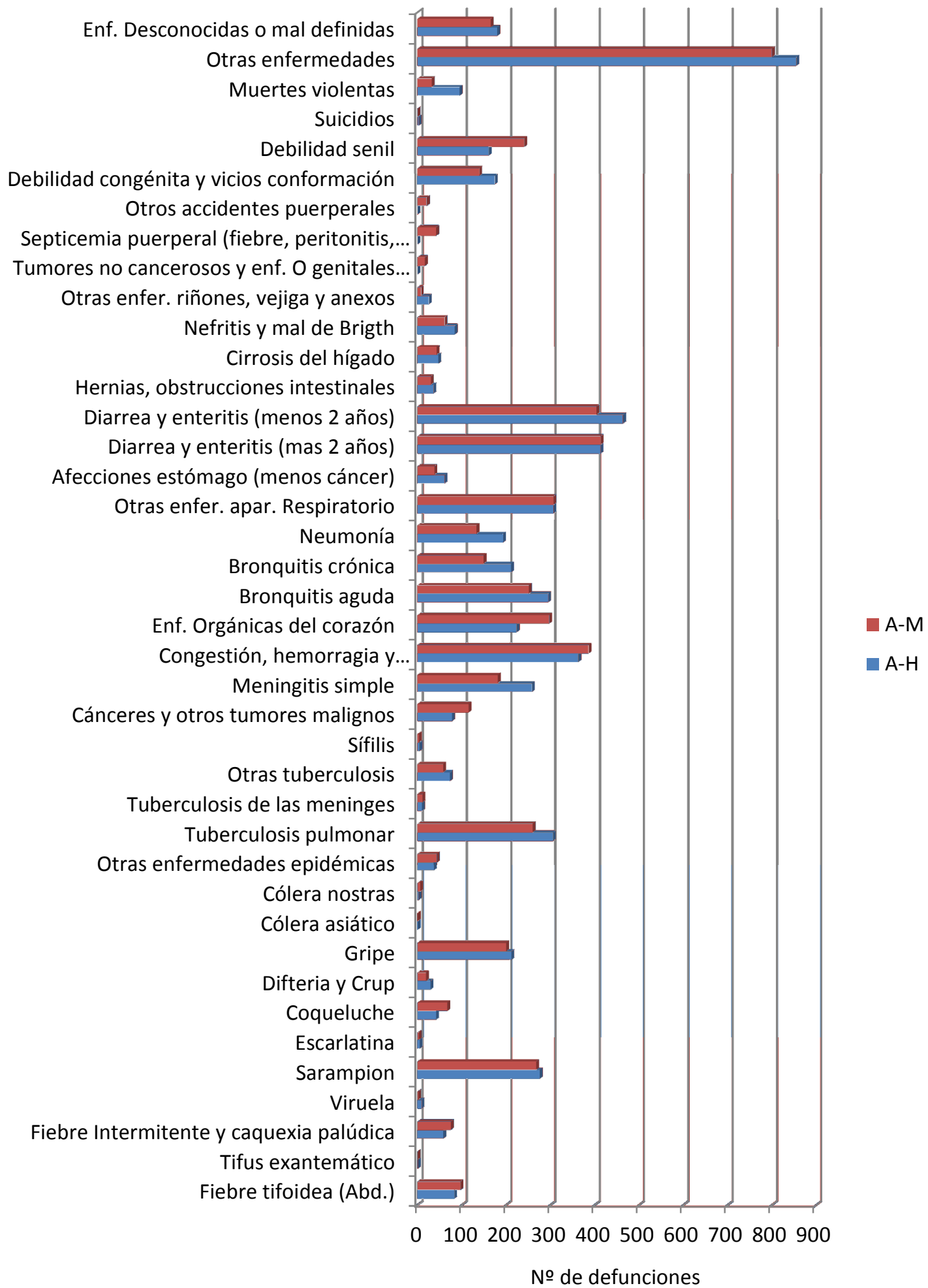

Fuente: Instituto Nacional de Estadística. Elaboración propia. 
En las estadísticas de 1901 a 1905, destacan las enfermedades puerperales de la mujer, basta citar para ello la cifra de 33 muertes en Castellón en 1905, en Valencia 169, y en Alicante 69; datos todos provinciales muy significativos, ya que en la actualidad lo que llama la atención es la no mortalidad por complicaciones post-parto. (Tablas 26, 28 y 30 ).

\section{Gráfica 20. Defunciones en 1905 en la ciudad de Castellón de la Plana}

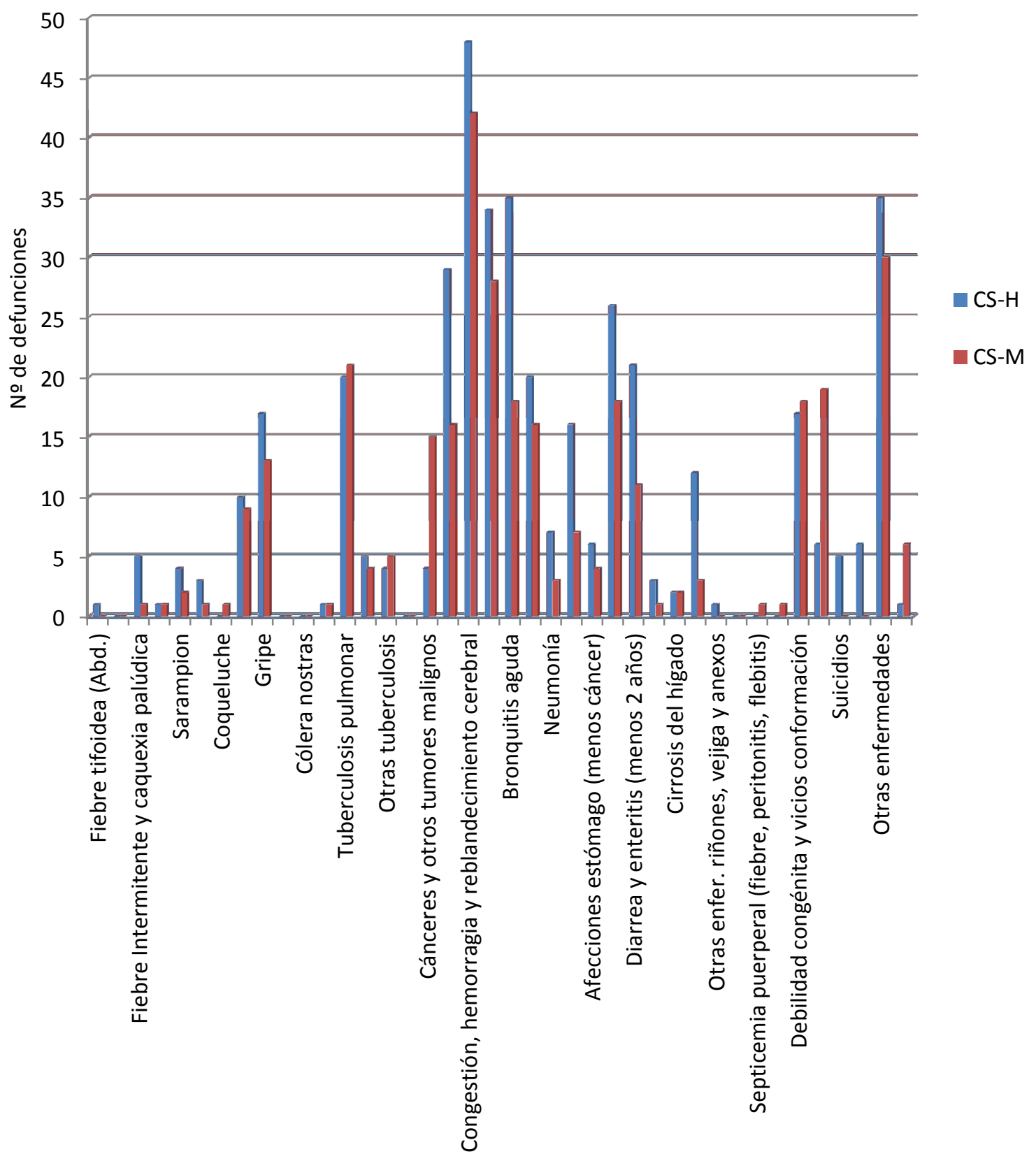

Fuente: Instituto Nacional de Estadística. Elaboración propia. 
Tabla 25. Defunciones clasificadas por causa de enfermedad en 1905 en Castellón

\begin{tabular}{|c|c|c|}
\hline CAUSAS & CS-H & CS-M \\
\hline Fiebre tifoidea (Abd.) & 1 & 0 \\
\hline Tifus exantemático & 0 & 0 \\
\hline Fiebre Intermitente y caquexia palúdica & 5 & 1 \\
\hline Viruela & 1 & 1 \\
\hline Sarampión & 4 & 2 \\
\hline Escarlatina & 3 & 1 \\
\hline Coqueluche & 0 & 1 \\
\hline Difteria y Crup & 10 & 9 \\
\hline Gripe & 17 & 13 \\
\hline Cólera asiático & 0 & 0 \\
\hline Cólera nostras & 0 & 0 \\
\hline Otras enfermedades epidémicas & 1 & 1 \\
\hline Tuberculosis pulmonar & 20 & 21 \\
\hline Tuberculosis de las meninges & 5 & 4 \\
\hline Otras tuberculosis & 4 & 5 \\
\hline Sífilis & 0 & 0 \\
\hline Cánceres y otros tumores malignos & 4 & 15 \\
\hline Meningitis simple & 29 & 16 \\
\hline Congestión, hemorragia y reblandecimiento cerebral & 48 & 42 \\
\hline Enf. Orgánicas del corazón & 34 & 28 \\
\hline Bronquitis aguda & 35 & 18 \\
\hline Bronquitis crónica & 20 & 16 \\
\hline Neumonía & 7 & 3 \\
\hline Otras enfer. aparato Respiratorio & 16 & 7 \\
\hline Afecciones estómago (menos cáncer) & 6 & 4 \\
\hline Diarrea y enteritis (más 2 años) & 26 & 18 \\
\hline Diarrea y enteritis (menos 2 años) & 21 & 11 \\
\hline Hernias, obstrucciones intestinales & 3 & 1 \\
\hline Cirrosis del hígado & 2 & 2 \\
\hline Nefritis y mal de Brigth & 12 & 3 \\
\hline Otras enfer. riñones, vejiga y anexos & 1 & 0 \\
\hline Tumores no cancerosos y enf. O genitales mujer & 0 & 0 \\
\hline Septicemia puerperal (fiebre, peritonitis, flebitis) & 0 & 1 \\
\hline Otros accidentes puerperales & 0 & 1 \\
\hline Debilidad congénita y vicios conformación & 17 & 18 \\
\hline Debilidad senil & 6 & 19 \\
\hline Suicidios & 5 & 0 \\
\hline Muertes violentas & 6 & 0 \\
\hline Otras enfermedades & 35 & 30 \\
\hline Enf. Desconocidas o mal definidas & 1 & 6 \\
\hline Total & 405 & 318 \\
\hline
\end{tabular}

Fuente: Instituto Nacional de Estadística. Elaboración propia. 


\section{Gráfica 21. Defunciones en 1905 en la provincia de Castellón}

Enf. Desconocidas o mal definidas

Otras enfermedades

Muertes violentas

Suicidios

Debilidad senil

Debilidad congénita y vicios conformación

Otros accidentes puerperales

Septicemia puerperal (fiebre, peritonitis,..

Tumores no cancerosos y enf. O genitales..

Otras enfer. riñones, vejiga y anexos

Nefritis y mal de Brigth

Cirrosis del hígado

Hernias, obstrucciones intestinales

Diarrea y enteritis (menos 2 años)

Diarrea y enteritis (mas 2 años)

Afecciones estómago (menos cáncer)

Otras enfer. apar. Respiratorio

Neumonía

Bronquitis crónica

Bronquitis aguda

Enf. Orgánicas del corazón

Congestión, hemorragia y reblandecimiento...

Meningitis simple

Cánceres y otros tumores malignos

Sífilis

Otras tuberculosis

Tuberculosis de las meninges

Tuberculosis pulmonar

Otras enfermedades epidémicas

Cólera nostras

Cólera asiático

Gripe

Difteria y Crup

Coqueluche

Escarlatina

Sarampión

Viruela

Fiebre Intermitente y caquexia palúdica

Tifus exantemático

Fiebre tifoidea (Abd.)
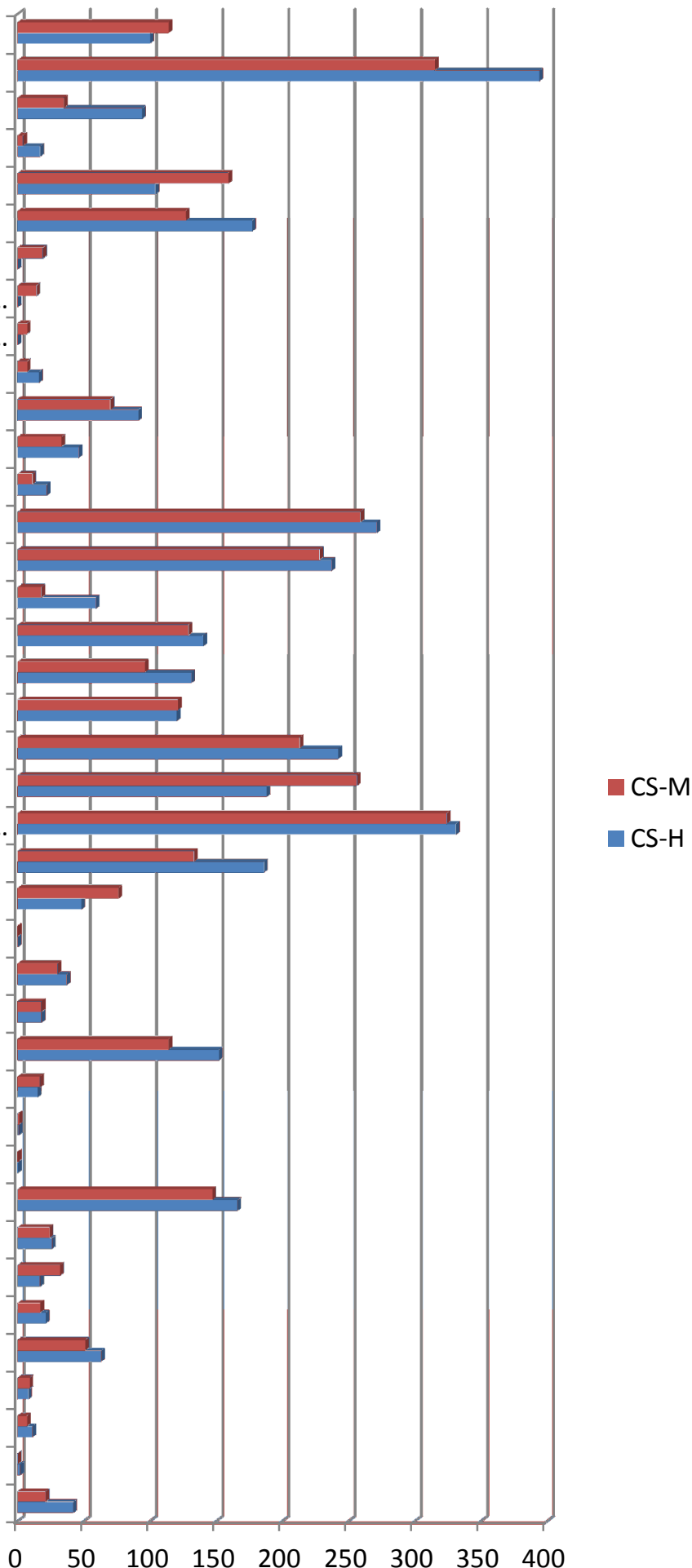

№ de defunciones

Fuente: Instituto Nacional de Estadística. Elaboración propia. 
Tabla 26. Defunciones clasificadas por causa de enfermedad en 1905 Castellón

\begin{tabular}{|c|c|c|}
\hline CAUSAS & CS-H & CS-M \\
\hline Fiebre tifoidea (Abd.) & 42 & 21 \\
\hline Tifus exantemático & 2 & 0 \\
\hline Fiebre Intermitente y caquexia palúdica & 11 & 7 \\
\hline Viruela & 8 & 9 \\
\hline Sarampión & 63 & 51 \\
\hline Escarlatina & 21 & 17 \\
\hline Coqueluche & 17 & 32 \\
\hline Difteria y Crup & 26 & 24 \\
\hline Gripe & 166 & 147 \\
\hline Cólera asiático & 0 & 0 \\
\hline Cólera nostras & 1 & 1 \\
\hline Otras enfermedades epidémicas & 15 & 17 \\
\hline Tuberculosis pulmonar & 152 & 114 \\
\hline Tuberculosis de las meninges & 18 & 18 \\
\hline Otras tuberculosis & 37 & 30 \\
\hline Sífilis & 0 & 0 \\
\hline Cánceres y otros tumores malignos & 48 & 76 \\
\hline Meningitis simple & 186 & 133 \\
\hline Congestión, hemorragia y reblandecimiento cerebral & 331 & 324 \\
\hline Enf. Orgánicas del corazón & 188 & 256 \\
\hline Bronquitis aguda & 242 & 213 \\
\hline Bronquitis crónica & 120 & 121 \\
\hline Neumonía & 131 & 96 \\
\hline Otras enfer. aparato Respiratorio & 140 & 129 \\
\hline Afecciones estómago (menos cáncer) & 59 & 18 \\
\hline Diarrea y enteritis (más 2 años) & 237 & 228 \\
\hline Diarrea y enteritis (menos 2 años) & 271 & 259 \\
\hline Hernias, obstrucciones intestinales & 22 & 11 \\
\hline Cirrosis del hígado & 46 & 33 \\
\hline Nefritis y mal de Brigth & 91 & 70 \\
\hline Otras enfer. riñones, vejiga y anexos & 16 & 7 \\
\hline Tumores no cancerosos y enf. O genitales mujer & 0 & 7 \\
\hline Septicemia puerperal (fiebre, peritonitis, flebitis) & 0 & 14 \\
\hline Otros accidentes puerperales & 0 & 19 \\
\hline Debilidad congénita y vicios conformación & 177 & 127 \\
\hline Debilidad senil & 104 & 159 \\
\hline Suicidios & 17 & 4 \\
\hline Muertes violentas & 94 & 35 \\
\hline Otras enfermedades & 394 & 315 \\
\hline Enf. Desconocidas o mal definidas & 100 & 114 \\
\hline Total & 3593 & 3256 \\
\hline
\end{tabular}

Fuente: Instituto Nacional de Estadística. Elaboración propia. 


\section{Gráfica 22. Defunciones en 1905 en la ciudad de Valencia}

Enf. Desconocidas o mal definidas

Otras enfermedades

Muertes violentas

Suicidios

Debilidad senil

Debilidad congénita y vicios conformación

Otros accidentes puerperales

Septicemia puerperal (fiebre, peritonitis,

Tumores no cancerosos y enf. O genitales..

Otras enfer. riñones, vejiga y anexos

Nefritis y mal de Brigth

Cirrosis del hígado

Hernias, obstrucciones intestinales

Diarrea y enteritis (menos 2 años)

Diarrea y enteritis (mas 2 años)

Afecciones estómago (menos cáncer)

Otras enfer. apar. Respiratorio

Neumonía

Bronquitis crónica

Bronquitis aguda

Enf. Orgánicas del corazón

Congestión, hemorragia y reblandecimiento..

Meningitis simple

Cánceres y otros tumores malignos

Sífilis

Otras tuberculosis

Tuberculosis de las meninges

Tuberculosis pulmonar

Otras enfermedades epidémicas

Cólera nostras

Cólera asiático

Gripe

Difteria y Crup

Coqueluche

Escarlatina

Sarampion

Viruela

Fiebre Intermitente y caquexia palúdica

Tifus exantemático

Fiebre tifoidea (Abd.)
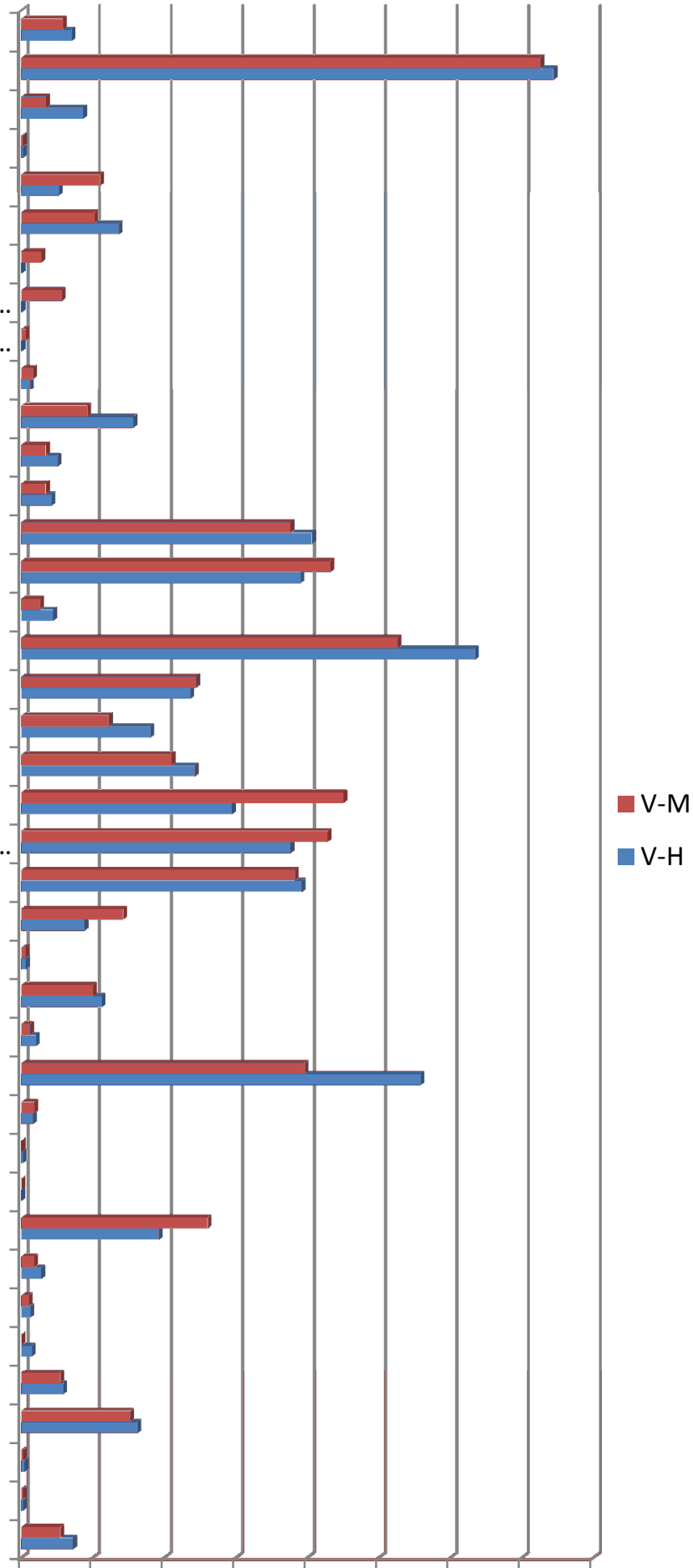

$\begin{array}{lllllllll}0 & 50 & 100 & 150 & 200 & 250 & 300 & 350 & 400\end{array}$

№ de defunciones

Fuente: Instituto Nacional de Estadística. Elaboración propia. 
Tabla 27. Defunciones clasificadas por causa de enfermedad en 1905 en Valencia

\begin{tabular}{|c|c|c|}
\hline CAUSAS & V-H & V-M \\
\hline Fiebre tifoidea (Abd.) & 36 & 27 \\
\hline Tifus exantemático & 1 & 1 \\
\hline Fiebre Intermitente y caquexia palúdica & 2 & 1 \\
\hline Viruela & 81 & 76 \\
\hline Sarampión & 29 & 27 \\
\hline Escarlatina & 7 & 0 \\
\hline Coqueluche & 6 & 5 \\
\hline Difteria y Crup & 14 & 9 \\
\hline Gripe & 96 & 130 \\
\hline Cólera asiático & 0 & 0 \\
\hline Cólera nostras & 1 & 0 \\
\hline Otras enfermedades epidémicas & 8 & 9 \\
\hline Tuberculosis pulmonar & 279 & 198 \\
\hline Tuberculosis de las meninges & 10 & 6 \\
\hline Otras tuberculosis & 56 & 50 \\
\hline Sífilis & 3 & 3 \\
\hline Cánceres y otros tumores malignos & 44 & 71 \\
\hline Meningitis simple & 196 & 191 \\
\hline Congestión, hemorragia y reblandecimiento cerebral & 188 & 214 \\
\hline Enf. Orgánicas del corazón & 147 & 225 \\
\hline Bronquitis aguda & 121 & 105 \\
\hline Bronquitis crónica & 90 & 61 \\
\hline Neumonía & 118 & 122 \\
\hline Otras enfer. aparato Respiratorio & 317 & 263 \\
\hline Afecciones estómago (menos cáncer) & 22 & 13 \\
\hline Diarrea y enteritis (más 2 años) & 195 & 216 \\
\hline Diarrea y enteritis (menos 2 años) & 203 & 188 \\
\hline Hernias, obstrucciones intestinales & 21 & 17 \\
\hline Cirrosis del hígado & 25 & 17 \\
\hline Nefritis y mal de Brigth & 78 & 46 \\
\hline Otras enfer. riñones, vejiga y anexos & 6 & 8 \\
\hline Tumores no cancerosos y enf. O genitales mujer & 0 & 3 \\
\hline Septicemia puerperal (fiebre, peritonitis, flebitis) & 0 & 28 \\
\hline Otros accidentes puerperales & 0 & 14 \\
\hline Debilidad congénita y vicios conformación & 68 & 51 \\
\hline Debilidad senil & 26 & 55 \\
\hline Suicidios & 1 & 1 \\
\hline Muertes violentas & 43 & 17 \\
\hline Otras enfermedades & 372 & 363 \\
\hline Enf. Desconocidas o mal definidas & 35 & 29 \\
\hline Total & 2945 & 2860 \\
\hline
\end{tabular}




\section{Gráfica 23. Defunciones en 1905 en la provincia de Valencia}

Enf. Desconocidas o mal definidas

Otras enfermedades

Muertes violentas

Suicidios

Debilidad senil

Debilidad congénita y vicios conformación

Otros accidentes puerperales

Septicemia puerperal (fiebre, peritonitis,...

Tumores no cancerosos y enf. O genitales...

Otras enfer. riñones, vejiga y anexos

Nefritis y mal de Brigth

Cirrosis del hígado

Hernias, obstrucciones intestinales

Diarrea y enteritis (menos 2 años)

Diarrea y enteritis (mas 2 años)

Afecciones estómago (menos cáncer)

Otras enfer. apar. Respiratorio

Neumonía

Bronquitis crónica

Bronquitis aguda

Enf. Orgánicas del corazón Congestión, hemorragia y...

Meningitis simple

Cánceres y otros tumores malignos

Sífilis

Otras tuberculosis

Tuberculosis de las meninges

Tuberculosis pulmonar

Otras enfermedades epidémicas

Cólera nostras

Cólera asiático

Gripe

Difteria y Crup

Coqueluche

Escarlatina

Sarampión

Viruela

Fiebre Intermitente y caquexia palúdica

Tifus exantemático

Fiebre tifoidea (Abd.)

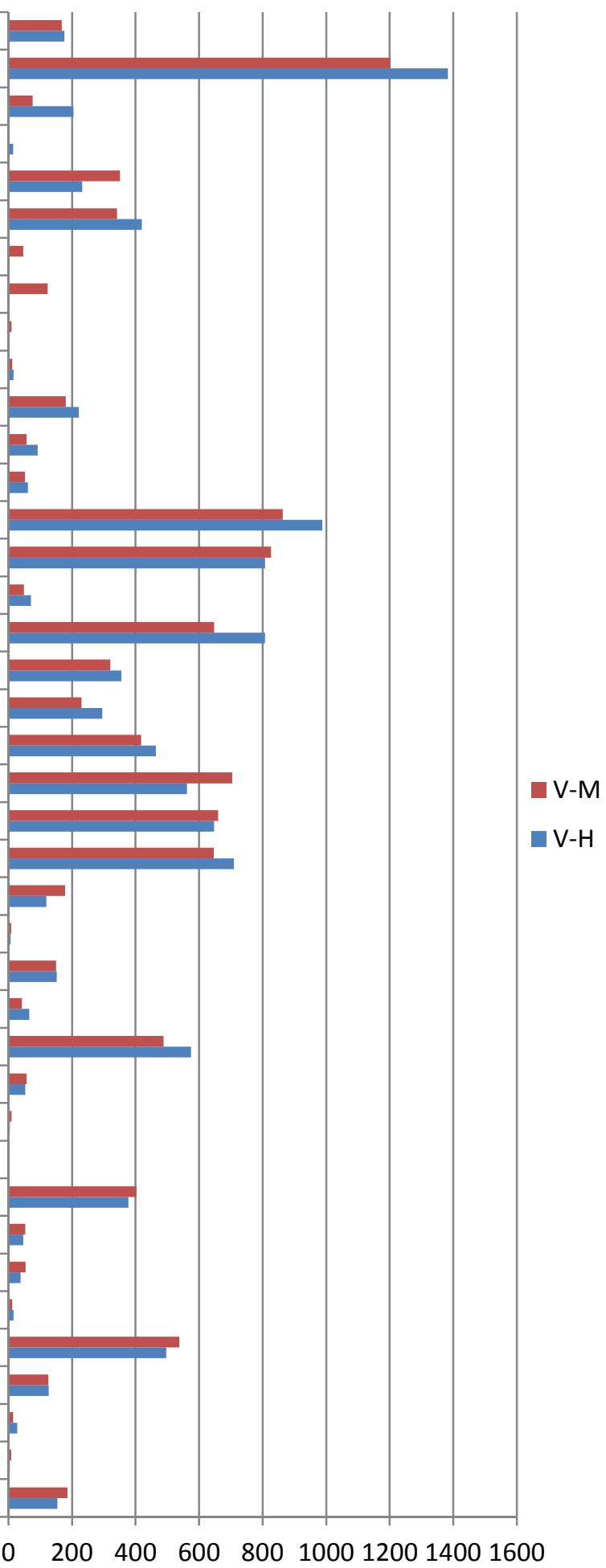

№ de defunciones

Fuente: Instituto Nacional de Estadística. Elaboración propia. 
Tabla 28. . Defunciones clasificadas por causa de enfermedad en 1905 en Valencia

\begin{tabular}{|c|c|c|}
\hline CAUSAS & V-H & V-M \\
\hline Fiebre tifoidea (Abd.) & 154 & 186 \\
\hline Tifus exantemático & 4 & 8 \\
\hline Fiebre Intermitente y caquexia palúdica & 27 & 15 \\
\hline Viruela & 127 & 125 \\
\hline Sarampión & 496 & 538 \\
\hline Escarlatina & 16 & 12 \\
\hline Coqueluche & 38 & 54 \\
\hline Difteria y Crup & 46 & 53 \\
\hline Gripe & 377 & 403 \\
\hline Cólera asiático & 0 & 0 \\
\hline Cólera nostras & 4 & 9 \\
\hline Otras enfermedades epidémicas & 53 & 57 \\
\hline Tuberculosis pulmonar & 574 & 488 \\
\hline Tuberculosis de las meninges & 65 & 42 \\
\hline Otras tuberculosis & 152 & 150 \\
\hline Sífilis & 6 & 8 \\
\hline Cánceres y otros tumores malignos & 119 & 178 \\
\hline Meningitis simple & 709 & 646 \\
\hline Congestión, hemorragia y reblandecimiento cerebral & 647 & 660 \\
\hline Enf. Orgánicas del corazón & 562 & 704 \\
\hline Bronquitis aguda & 464 & 417 \\
\hline Bronquitis crónica & 295 & 230 \\
\hline Neumonía & 355 & 320 \\
\hline Otras enfer. aparato Respiratorio & 808 & 647 \\
\hline Afecciones estómago (menos cáncer) & 71 & 48 \\
\hline Diarrea y enteritis (más 2 años) & 807 & 827 \\
\hline Diarrea y enteritis (menos 2 años) & 988 & 863 \\
\hline Hernias, obstrucciones intestinales & 61 & 52 \\
\hline Cirrosis del hígado & 92 & 57 \\
\hline Nefritis y mal de Brigth & 221 & 180 \\
\hline Otras enfer. riñones, vejiga y anexos & 16 & 12 \\
\hline Tumores no cancerosos y enf. O genitales mujer & 0 & 9 \\
\hline Septicemia puerperal (fiebre, peritonitis, flebitis) & 0 & 123 \\
\hline Otros accidentes puerperales & 0 & 46 \\
\hline Debilidad congénita y vicios conformación & 420 & 342 \\
\hline Debilidad senil & 232 & 351 \\
\hline Suicidios & 15 & 1 \\
\hline Muertes violentas & 205 & 76 \\
\hline Otras enfermedades & 1383 & 1202 \\
\hline Enf. Desconocidas o mal definidas & 176 & 168 \\
\hline Total & 10785 & 10307 \\
\hline
\end{tabular}

Fuente: Instituto Nacional de Estadística. Elaboración propia. 


\section{Gráfica 24.Defunciones en 1905 en la ciudad de Alicante}

Enf. Desconocidas o mal definidas Otras enfermedades

Muertes violentas

Suicidios

Debilidad senil

Debilidad congénita y vicios conformación

Otros accidentes puerperales

Septicemia puerperal (fiebre, peritonitis,..

Tumores no cancerosos y enf. O genitales..

Otras enfer. riñones, vejiga y anexos

Nefritis y mal de Brigth

Cirrosis del hígado

Hernias, obstrucciones intestinales

Diarrea y enteritis (menos 2 años)

Diarrea y enteritis (mas 2 años)

Afecciones estómago (menos cáncer)

Otras enfer. apar. Respiratorio

Neumonía

Bronquitis crónica

Bronquitis aguda

Enf. Orgánicas del corazón

Congestión, hemorragia y reblandecimiento...

Meningitis simple

Cánceres y otros tumores malignos

Sífilis

Otras tuberculosis

Tuberculosis de las meninges

Tuberculosis pulmonar

Otras enfermedades epidémicas

Cólera nostras

Cólera asiático

Gripe

Difteria y Crup

Coqueluche

Escarlatina

Sarampion

Viruela

Fiebre Intermitente y caquexia palúdica

Tifus exantemático

Fiebre tifoidea (Abd.)
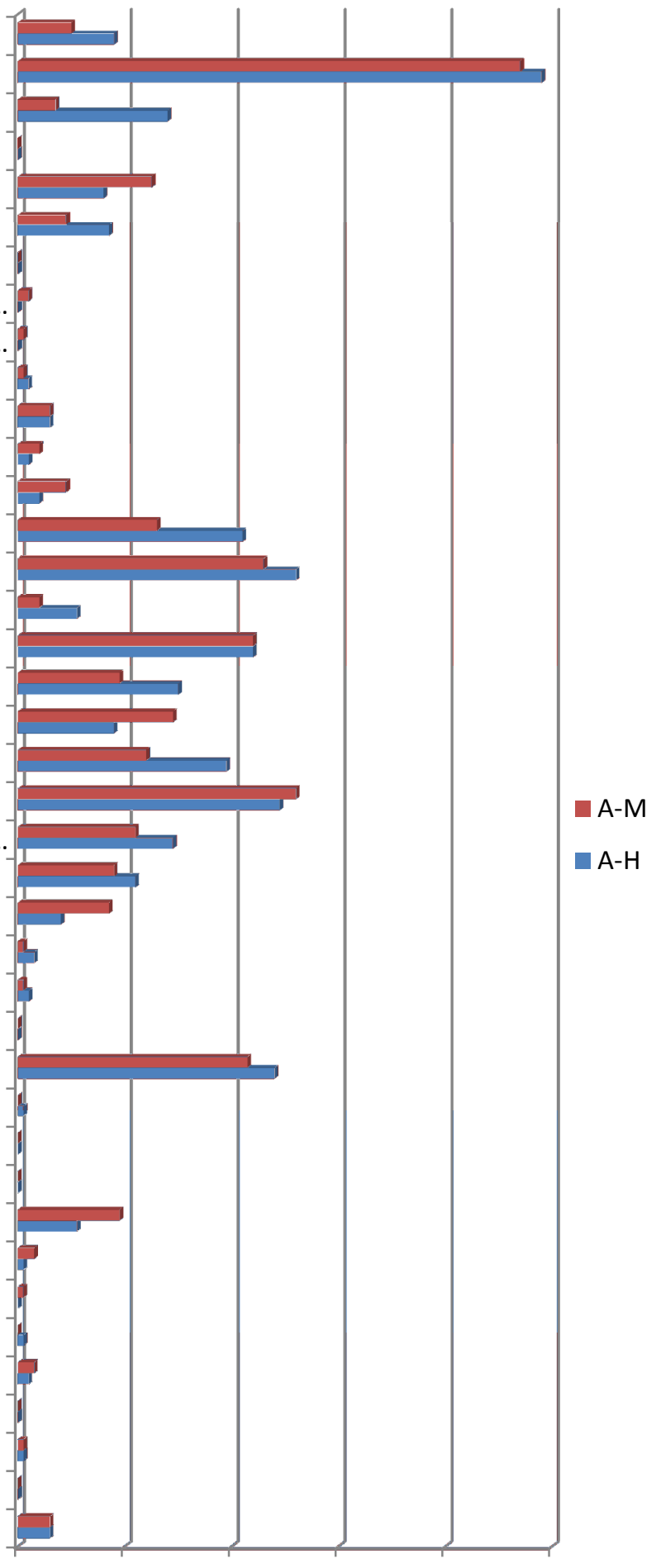

№ de defunciones

Fuente: Instituto Nacional de Estadística. Elaboración propia. 
Tabla 29. Defunciones clasificadas por causa de enfermedad en 1905 Alicante

\begin{tabular}{|c|c|c|}
\hline CAUSAS & A-H & A-M \\
\hline Fiebre tifoidea (Abd.) & 6 & 6 \\
\hline Tifus exantemático & 0 & 0 \\
\hline Fiebre Intermitente y caquexia palúdica & 1 & 1 \\
\hline Viruela & 0 & 0 \\
\hline Sarampión & 2 & 3 \\
\hline Escarlatina & 1 & 0 \\
\hline Coqueluche & 0 & 1 \\
\hline Difteria y Crup & 1 & 3 \\
\hline Gripe & 11 & 19 \\
\hline Cólera asiático & 0 & 0 \\
\hline Cólera nostras & 0 & 0 \\
\hline Otras enfermedades epidémicas & 1 & 0 \\
\hline Tuberculosis pulmonar & 48 & 43 \\
\hline Tuberculosis de las meninges & 0 & 0 \\
\hline Otras tuberculosis & 2 & 1 \\
\hline Sífilis & 3 & 1 \\
\hline Cánceres y otros tumores malignos & 8 & 17 \\
\hline Meningitis simple & 22 & 18 \\
\hline Congestión, hemorragia y reblandecimiento cerebral & 29 & 22 \\
\hline Enf. Orgánicas del corazón & 49 & 52 \\
\hline Bronquitis aguda & 39 & 24 \\
\hline Bronquitis crónica & 18 & 29 \\
\hline Neumonía & 30 & 19 \\
\hline Otras enfer. aparato Respiratorio & 44 & 44 \\
\hline Afecciones estómago (menos cáncer) & 11 & 4 \\
\hline Diarrea y enteritis (más 2 años) & 52 & 46 \\
\hline Diarrea y enteritis (menos 2 años) & 42 & 26 \\
\hline Hernias, obstrucciones intestinales & 4 & 9 \\
\hline Cirrosis del hígado & 2 & 4 \\
\hline Nefritis y mal de Brigth & 6 & 6 \\
\hline Otras enfer. riñones, vejiga y anexos & 2 & 1 \\
\hline Tumores no cancerosos y enf. O genitales mujer & 0 & 1 \\
\hline Septicemia puerperal (fiebre, peritonitis, flebitis) & 0 & 2 \\
\hline Otros accidentes puerperales & 0 & 0 \\
\hline Debilidad congénita y vicios conformación & 17 & 9 \\
\hline Debilidad senil & 16 & 25 \\
\hline Suicidios & 0 & 0 \\
\hline Muertes violentas & 28 & 7 \\
\hline Otras enfermedades & 98 & 94 \\
\hline Enf. Desconocidas o mal definidas & 18 & 10 \\
\hline Total & 611 & 547 \\
\hline
\end{tabular}

Fuente: Instituto Nacional de Estadística. Elaboración propia. 


\section{Gráfica 25. Defunciones en 1905 en la provincia de Alicante}

Enf. Desconocidas o mal definidas

Otras enfermedades

Muertes violentas

Suicidios

Debilidad senil

Debilidad congénita y vicios conformación

Otros accidentes puerperales

Septicemia puerperal (fiebre, peritonitis,

Tumores no cancerosos y enf. O genitales..

Otras enfer. riñones, vejiga y anexos

Nefritis y mal de Brigth

Cirrosis del hígado

Hernias, obstrucciones intestinales

Diarrea y enteritis (menos 2 años)

Diarrea y enteritis (mas 2 años)

Afecciones estómago (menos cáncer)

Otras enfer. apar. Respiratorio

Neumonía

Bronquitis crónica

Bronquitis aguda

Enf. Orgánicas del corazón Congestión, hemorragia y reblandecimiento...

Meningitis simple

Cánceres y otros tumores malignos

Sífilis

Otras tuberculosis

Tuberculosis de las meninges

Tuberculosis pulmonar

Otras enfermedades epidémicas

Cólera nostras

Cólera asiático

Gripe

Difteria y Crup

Coqueluche

Escarlatina

Sarampion

Viruela

Fiebre Intermitente y caquexia palúdica

Tifus exantemático

Fiebre tifoidea (Abd.)

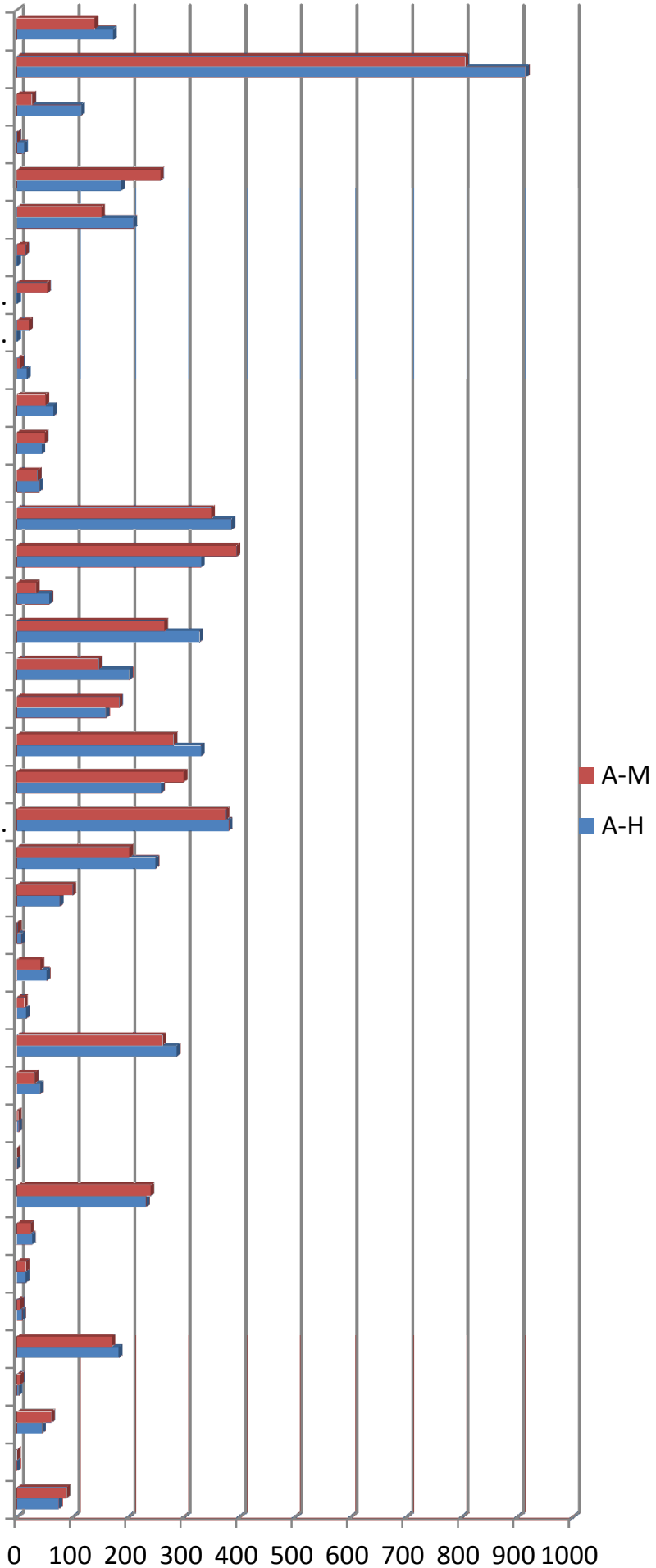

№ de defunciones

Fuente: Instituto Nacional de Estadística. Elaboración propia. 
Tabla 30. Defunciones clasificadas por causa de enfermedad en 1905 en Alicante

\begin{tabular}{|c|c|c|}
\hline CAUSAS & A-H & A-M \\
\hline Fiebre tifoidea (Abd.) & 75 & 89 \\
\hline Tifus exantemático & 0 & 0 \\
\hline Fiebre Intermitente y caquexia palúdica & 45 & 62 \\
\hline Viruela & 3 & 6 \\
\hline Sarampión & 183 & 170 \\
\hline Escarlatina & 9 & 6 \\
\hline Coqueluche & 16 & 16 \\
\hline Difteria y Crup & 27 & 24 \\
\hline Gripe & 232 & 240 \\
\hline Cólera asiático & 0 & 0 \\
\hline Cólera nostras & 3 & 2 \\
\hline Otras enfermedades epidémicas & 41 & 32 \\
\hline Tuberculosis pulmonar & 287 & 262 \\
\hline Tuberculosis de las meninges & 16 & 13 \\
\hline Otras tuberculosis & 53 & 42 \\
\hline Sífilis & 8 & 1 \\
\hline Cánceres y otros tumores malignos & 77 & 100 \\
\hline Meningitis simple & 249 & 202 \\
\hline Congestión, hemorragia y reblandecimiento cerebral & 381 & 376 \\
\hline Enf. Orgánicas del corazón & 259 & 300 \\
\hline Bronquitis aguda & 331 & 282 \\
\hline Bronquitis crónica & 160 & 184 \\
\hline Neumonía & 202 & 147 \\
\hline Otras enfer. aparato Respiratorio & 328 & 265 \\
\hline Afecciones estómago (menos cáncer) & 58 & 34 \\
\hline Diarrea y enteritis (más 2 años) & 331 & 395 \\
\hline Diarrea y enteritis (menos 2 años) & 386 & 349 \\
\hline Hernias, obstrucciones intestinales & 40 & 37 \\
\hline Cirrosis del hígado & 44 & 50 \\
\hline Nefritis y mal de Brigth & 65 & 51 \\
\hline Otras enfer. riñones, vejiga y anexos & 17 & 6 \\
\hline Tumores no cancerosos y enf. O genitales mujer & 0 & 21 \\
\hline Septicemia puerperal (fiebre, peritonitis, flebitis) & 0 & 54 \\
\hline Otros accidentes puerperales & 0 & 15 \\
\hline Debilidad congénita y vicios conformación & 210 & 152 \\
\hline Debilidad senil & 187 & 258 \\
\hline Suicidios & 13 & 0 \\
\hline Muertes violentas & 115 & 27 \\
\hline Otras enfermedades & 915 & 806 \\
\hline Enf. Desconocidas o mal definidas & 173 & 140 \\
\hline Total & 5539 & 5216 \\
\hline
\end{tabular}

Fuente: Instituto Nacional de Estadística. Elaboración propia. 
Tanto a nivel nacional como en Castellón hay que constatar que una de las enfermedades con más consecuencias sociales importantes es la tuberculosis pulmonar, que afectaba en especial a la población de 20 a 40 años, sector demográfico en pleno rendimiento productivo, más si comprobamos que afectaba en mayor medida al sexo masculino.

Después del estudio de las enfermedades que afectaron más a la población española y al País Valenciano durante los años de 1901 a 1905, vamos a centrarnos en un estudio comparativo entre las defunciones por fiebre tifoidea, gripe y viruela, las tres enfermedades que después de la tuberculosis pulmonar, tienen más incidencia en la mortalidad producida en las tres capitales del País Valenciano (gráfica 26) y en España en el periodo de 1901 a 1915.

\section{Gráfica 26. Defunciones por enfermedades infecciosas de 1901 a 1915 en las capitales del País Valenciano}

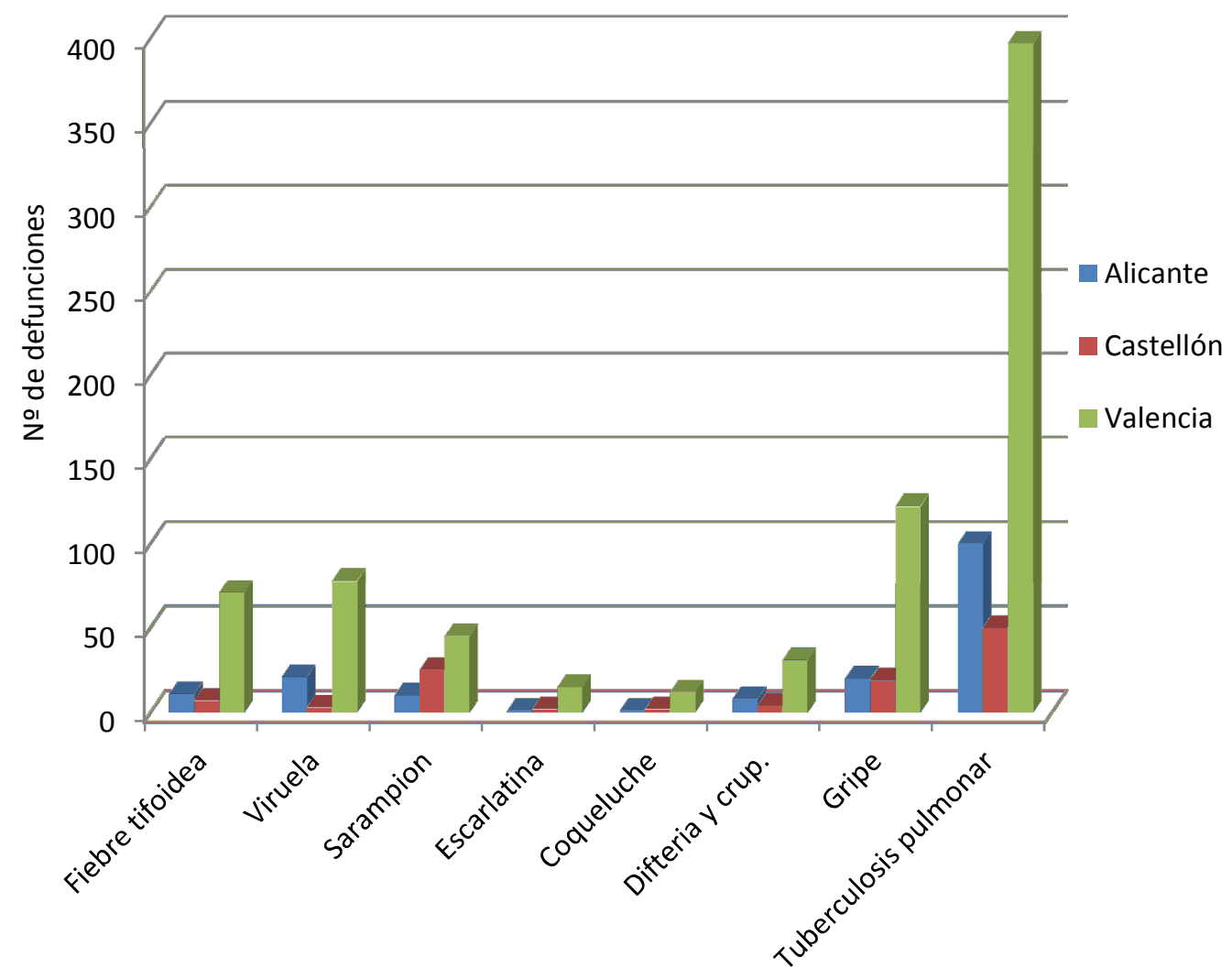

Fuente: Instituto Nacional de Estadística. Elaboración propia.

Podemos observar que la fiebre tifoidea no presenta una disminución en las tres capitales del País Valenciano (Tabla 31 y gráfica 27). 
Tabla 31. Defunciones por fiebre tifoidea de 1901 a 1915 en capitales del País Valenciano

\begin{tabular}{|c|c|c|c|c|c|}
\hline AÑNOS & Alicante & Castellón & Valencia & Total P. V. & España \\
\hline 1901 & 9 & 5 & 66 & 80 & 1604 \\
\hline 1902 & 24 & 3 & 91 & 118 & 1456 \\
\hline 1903 & 6 & 6 & 100 & 112 & 1333 \\
\hline 1904 & 6 & 1 & 86 & 93 & 1398 \\
\hline 1905 & 12 & 1 & 63 & 76 & 1133 \\
\hline 1906 & 8 & 6 & 86 & 100 & 1343 \\
\hline 1907 & 7 & 8 & 58 & 73 & 1263 \\
\hline 1908 & 11 & 8 & 62 & 81 & 1214 \\
\hline 1909 & 9 & 3 & 75 & 87 & 1534 \\
\hline 1910 & 5 & 8 & 60 & 73 & 995 \\
\hline 1911 & 14 & 6 & 65 & 85 & 969 \\
\hline 1912 & 11 & 12 & 71 & 94 & 1069 \\
\hline 1913 & 10 & 9 & 53 & 72 & 983 \\
\hline 1914 & 12 & 13 & 55 & 80 & 2612 \\
\hline 1915 & 21 & 10 & 71 & 102 & 1069 \\
\hline Total & 165 & 99 & 1062 & 1326 & 19975 \\
\hline
\end{tabular}

Fuente: Instituto Nacional de Estadística. Elaboración propia 
Gráfica 27. Defunciones por fiebre tifoide de 1901 a 1915 en las capitales del País Valenciano

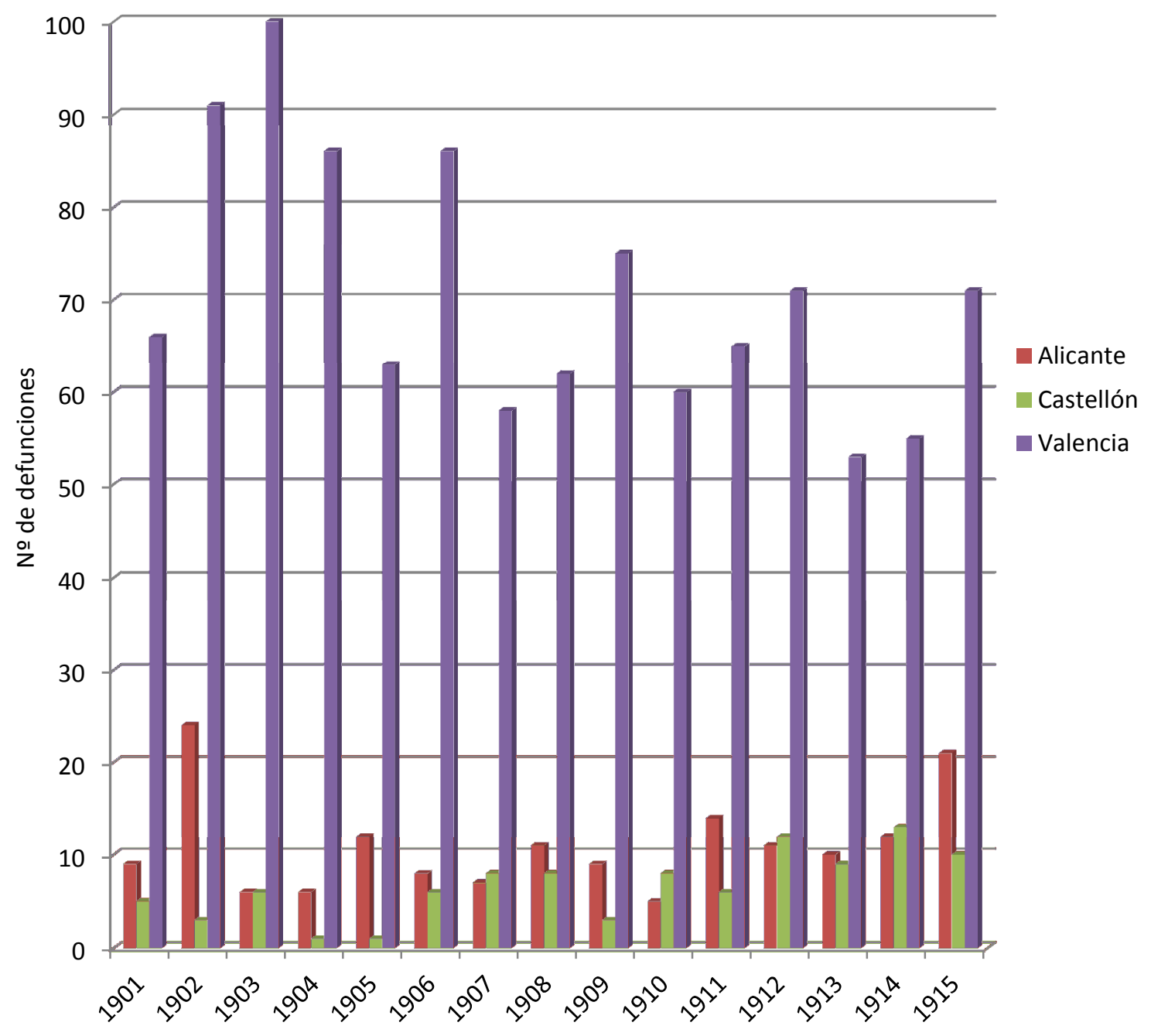

Fuente: Instituto Nacional de Estadística. Elaboración propia.

Se puede deducir que quizás sea debido a una aglomeración urbana, puesto que el proceso urbanizador en España va aumentando en el primer tercio del siglo XX.

En cuanto a la gripe, hasta que no hace su aparición la penicilina, hemos constatado una continuidad en el proceso de la enfermedad. (Tabla 32 y gráfica 28). 
Tabla 32. Defunciones por gripe de 1901 a 1915 en capitales del País Valenciano

\begin{tabular}{|c|c|c|c|c|c|}
\hline AÑNOS & Alicante & Castellón & Valencia & $\begin{array}{l}\text { Total } \\
\text { P. V. }\end{array}$ & España \\
\hline 1901 & 26 & 38 & 107 & 171 & 1885 \\
\hline 1902 & 18 & 29 & 114 & 161 & 1442 \\
\hline 1903 & 18 & 14 & 122 & 154 & 1346 \\
\hline 1904 & 16 & 37 & 154 & 207 & 1521 \\
\hline 1905 & 30 & 30 & 226 & 286 & 1190 \\
\hline 1906 & 13 & 13 & 186 & 212 & 1527 \\
\hline 1907 & 21 & 39 & 247 & 307 & 2448 \\
\hline 1908 & 12 & 10 & 125 & 147 & 1149 \\
\hline 1909 & 22 & 16 & 136 & 174 & 1376 \\
\hline 1910 & 28 & 16 & 99 & 143 & 1308 \\
\hline 1911 & 17 & 21 & 59 & 97 & 981 \\
\hline 1912 & 15 & 11 & 71 & 97 & 1022 \\
\hline 1913 & 22 & 1 & 71 & 94 & 1131 \\
\hline 1914 & 18 & 6 & 59 & 83 & 1003 \\
\hline 1915 & 29 & 8 & 52 & 89 & 899 \\
\hline Total & 305 & 289 & 1828 & 2422 & 20228 \\
\hline
\end{tabular}

Fuente: Instituto Nacional de Estadística. Elaboración propia. 
Grafica 28. Defunciones por gripe de 1901 a 1915 en las capitales del País Valenciano

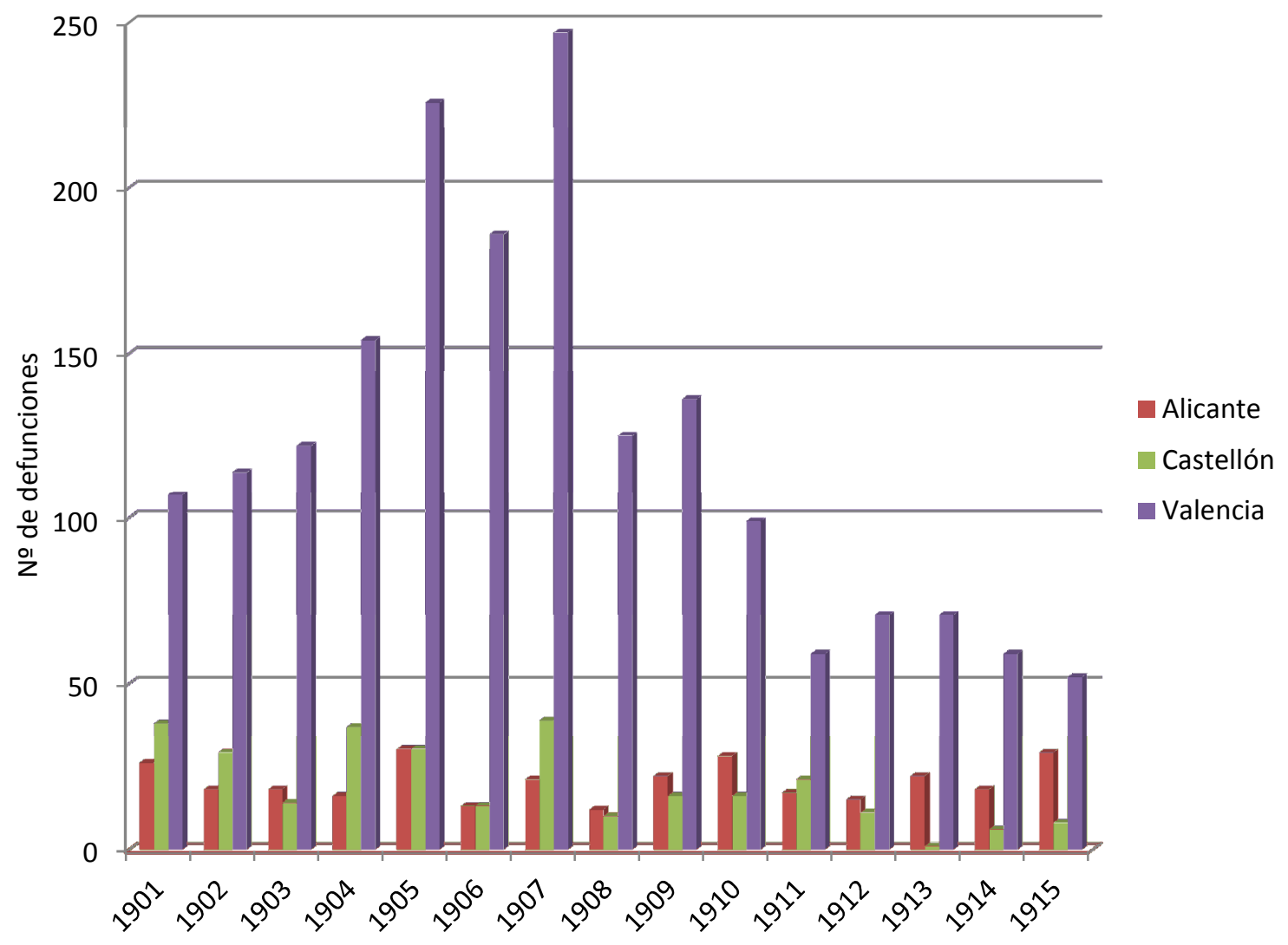

Fuente: Instituto Nacional de Estadística. Elaboración propia.

Sin embargo, en la viruela sí que hemos notado un descenso considerable, ya que basta citar que a nivel del País Valenciano en el año 1901 se produjeron 372 muertes por viruela, se llega a 7 en 1910, para rebrotar en 1914 con 59 muertes y en 1915 hay 191 defunciones (quizás esta última cifra está condicionada por la primera guerra mundial). (Tabla 33 y gráfica 29). 
Tabla 33. Defunciones por viruela de 1901 a 1915 en capitales del País Valenciano

\begin{tabular}{|c|c|c|c|c|c|}
\hline AÑOS & Alicante & Castellón & Valencia & Total P.V. & España \\
\hline 1901 & 101 & 0 & 271 & 372 & 1985 \\
\hline 1902 & 30 & 6 & 150 & 186 & 1674 \\
\hline 1903 & 0 & 2 & 13 & 15 & 1691 \\
\hline 1904 & 1 & 0 & 6 & 7 & 1077 \\
\hline 1905 & 0 & 2 & 157 & 159 & 959 \\
\hline 1906 & 10 & 8 & 20 & 38 & 1177 \\
\hline 1907 & 74 & 0 & 105 & 179 & 797 \\
\hline 1908 & 14 & 1 & 100 & 115 & 529 \\
\hline 1909 & 0 & 0 & 20 & 20 & 1396 \\
\hline 1910 & 7 & 0 & 0 & 7 & 456 \\
\hline 1911 & 6 & 2 & 36 & 44 & 570 \\
\hline 1912 & 5 & 0 & 63 & 68 & 958 \\
\hline 1913 & 54 & 0 & 14 & 68 & 1199 \\
\hline 1914 & 14 & 5 & 40 & 59 & 742 \\
\hline 1915 & 2 & 15 & 174 & 191 & 742 \\
\hline Total & 318 & 41 & 1169 & 1528 & 15952 \\
\hline
\end{tabular}

Fuente: Instituto Nacional de Estadística. Elaboración propia. 
Grafica 29. Defunciones por viruela de 1901 a 1915 en las capitales del País Valenciano

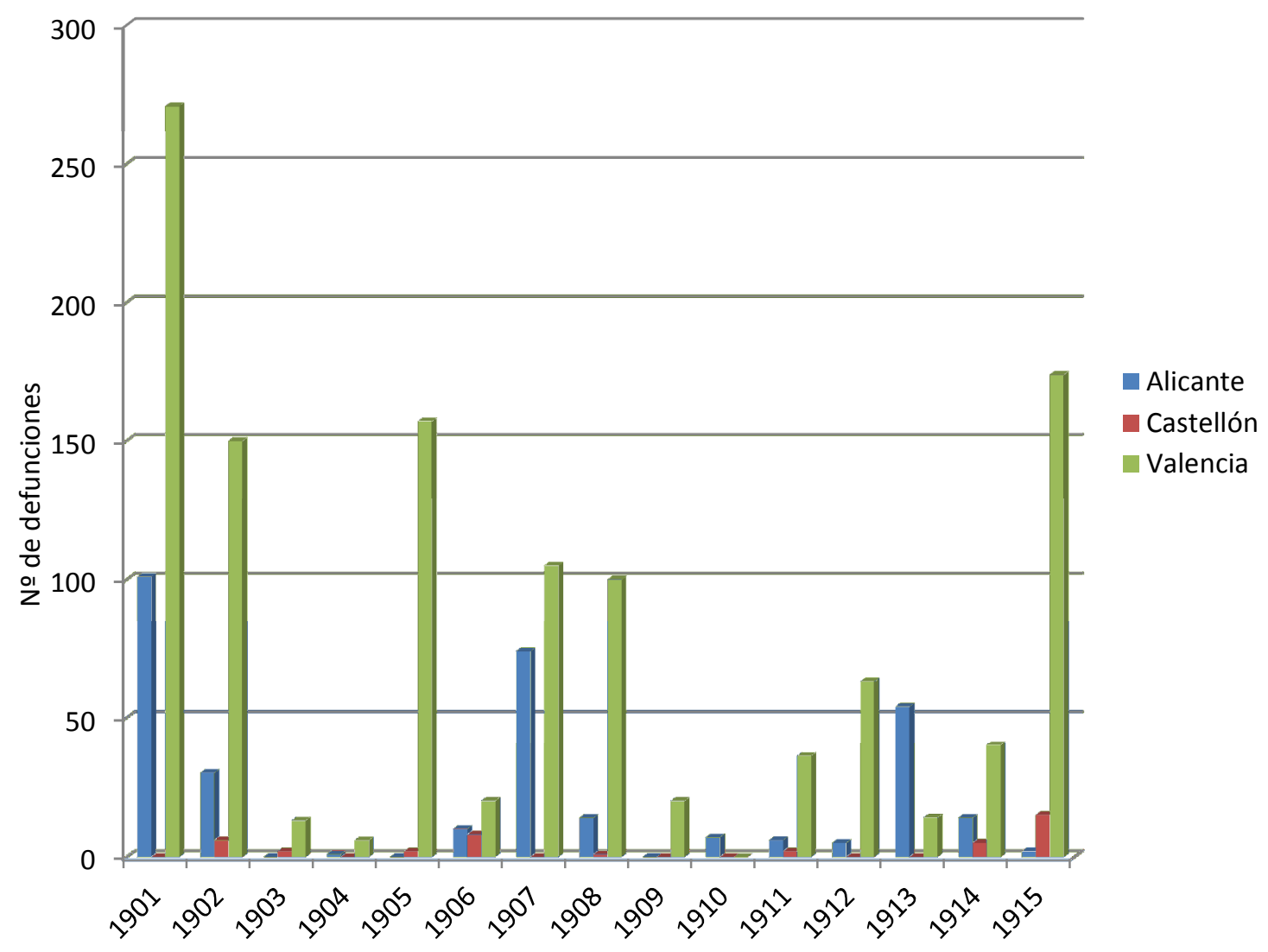

Fuente: Instituto Nacional de Estadística. Elaboración propia.

La misma pauta encontramos en las cifras nacionales que si en 1901 nos presentan 1.985 muertes, en 1910 se han reducido a 456 defunciones, llegando en 1914 y 1915 a tener 742 muertes en ambos años. (Tabla 33).

Por último presentamos un resumen estadístico de las defunciones por causa de enfermedad en la ciudad de Castellón de la Plana, desde 1914 a 1918 (tabla 34 y gráfica $30)$. 
Tabla 34. Defunciones clasificadas por causa de enfermedad de 1914 a 1918 Castellón de la Plana

\begin{tabular}{|c|c|c|}
\hline CAUSAS & Hombres & Mujeres \\
\hline Fiebre tifoidea (abdominal) & 32 & 29 \\
\hline Tifus exantemático & 0 & 0 \\
\hline Fiebre intermitente y caquexia palúdica & 11 & 7 \\
\hline Viruela & 10 & 12 \\
\hline Sarampión & 38 & 42 \\
\hline Escarlatina & 9 & 6 \\
\hline Coqueluche & 5 & 6 \\
\hline Difteria y Crup & 7 & 3 \\
\hline Gripe & 169 & 166 \\
\hline Cólera asiático & 0 & 0 \\
\hline Cólera nostras & 0 & 0 \\
\hline Otras enfermedades epidémicas & 16 & 12 \\
\hline Tuberculosis pulmonar & 195 & 123 \\
\hline Tuberculosis de las meninges & 14 & 9 \\
\hline Otras tuberculosis & 31 & 26 \\
\hline Cánceres y otros tumores malignos & 49 & 64 \\
\hline Meningitis simple & 80 & 76 \\
\hline Hemorragia y reblandecimientos cerebrales & 155 & 212 \\
\hline Enfermedades orgánicas del corazón & 141 & 227 \\
\hline Bronquitis aguda & 100 & 101 \\
\hline Bronquitis crónica & 63 & 88 \\
\hline Neumonía & 30 & 22 \\
\hline Otras enfermedades del aparato respiratorio & 118 & 72 \\
\hline Afecciones del estómago (excepto cáncer) & 30 & 13 \\
\hline Diarrea y enteritis (menores de 2 años) & 136 & 97 \\
\hline Apendicitis y Tiflitis & 3 & 2 \\
\hline Hernias y obstrucciones intestinales & 14 & 17 \\
\hline Cirrosis del hígado & 24 & 24 \\
\hline Nefritis y mal de Bright & 58 & 51 \\
\hline $\begin{array}{l}\text { Tumores no cancerosos y otras enfermedades de los órganos } \\
\text { genitales de la mujer }\end{array}$ & 2 & 2 \\
\hline Septicemia puerperal (fiebre, peritonitis, flebitis) & 0 & 6 \\
\hline Otros accidentes puerperales & 0 & 6 \\
\hline Debilidad congénita y vicios de conformación & 62 & 48 \\
\hline Senilidad & 51 & 143 \\
\hline Muertes violentas (excepto suicidios) & 31 & 11 \\
\hline Suicidios & 11 & 2 \\
\hline Otras enfermedades & 359 & 326 \\
\hline Enfermedades desconocidas o mal definidas & 28 & 40 \\
\hline Total & 2.082 & 2.091 \\
\hline
\end{tabular}

Fuente: Boletín de Estadística de Castellón 1914-1918. Elaboración propia. 


\section{Gráfica 30. Defunciones por causa de enfermedad de 1914 a 1918 en la ciudad de Castellón de la Plana}

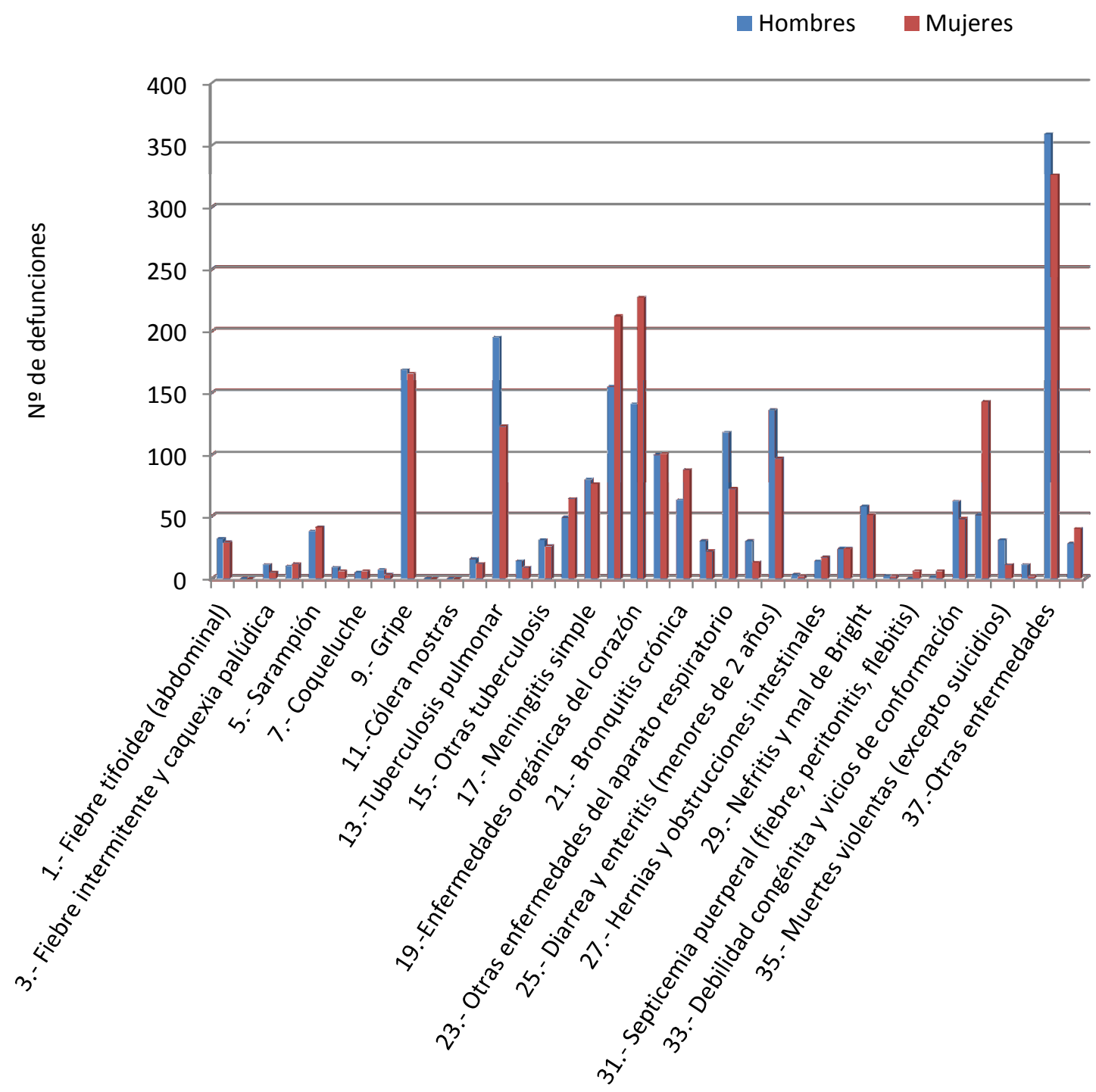

Fuente: Boletín de Estadística de Castellón 1914-1918. Elaboración propia.

En la tabla 34 y gráfica 30 podemos observar una notable incidencia de la tuberculosis, que por lo que vemos afectó más a los hombres que a las mujeres. A raíz de esta incidencia se amplió el Hospital Provincial, recién inaugurado en 1907, con pabellones independientes para alojar la demanda de enfermos tuberculosos.

La segunda enfermedad que más afectó a la ciudad de Castellón fue la gripe, que estudiamos en otro capítulo. 
Si nos fijamos en las enfermedades infantiles, la que más defunciones produjo fue el sarampión, disminuyendo con respecto a años anteriores, la escarlatina, la tosferina, la difteria y la viruela. Otras enfermedades que afectaron con mayor frecuencia a los niños y niñas menores de dos años fueron las enfermedades intestinales.

Tambien hemos consultado los libros de Registro general de enterramientos del Cementerio municipal de Castellón para ver el número de fallecimientos infantiles y sus causas.

Anterior a 1885 no consta documentación alguna. De 1885 a 1912 existen ya libros de registro que recogen los siguientes datos: fecha de enterramiento; nombre y apellidos; pueblo de naturaleza; casa en la que fallece; clase y número de sepultura e importe de lo satisfecho por arbitrios municipales.

A partir de 1920 figuran ya las causas de fallecimiento en estadillo independiente del libro General de registo de enterramientos.

Hemos confeccionado una tabla que recoge el número de defunciones por edades comprendidas entre 0 y 40 años, en el periodo 1912 a 1930.

Podemos observar el alto porcentaje de defunciones de niños y niñas, que se producen de 0 a 12 meses, llegando a doblarse de 1 a 5 años. Entre 0 a 5 años, de 19121915 este porcentaje está en el 28,25, descendiendo sensiblemente en las décadas siguientes, pasando a 19,50 en 1920 y al 16,25 por ciento a partir de la tercera década.

De esta edad hasta los 18-20 años, desciende de una manera acusada el porcentaje de fallecimientos, volviendo a subir ligeramente de los 20 a los 40 años, lo que puede estar relacionado con la enfermedad de la tuberculosis que afecta más a la población en estas edades,

El año de la gripe de 1918 el número total de defunciones que consta en los registros de enterramientos es de 1.341, casi el doble de los demás años consultados. 
Tabla 35. Fallecimiento por edades y años según el Registro general de enterramientos del Cementerio municipal de Castellon

\begin{tabular}{|l|l|l|l|l|l|l|l|l|l|l|l|l|}
\hline $\begin{array}{l}\text { Registro general } \\
\text { enterramientos }\end{array}$ & $\mathbf{1 9 1 2}$ & $\mathbf{1 9 1 3}$ & $\mathbf{1 9 1 4}$ & $\mathbf{1 9 1 5}$ & $\mathbf{\%}$ & $\mathbf{1 9 2 0}$ & $\mathbf{1 9 2 1}$ & $\mathbf{\%}$ & $\mathbf{1 9 2 9}$ & $\mathbf{1 9 3 0}$ & $\mathbf{1 9 3 1}$ & $\mathbf{\%}$ \\
\hline Fallecimientos & 720 & 847 & 760 & 755 & & 771 & 685 & & 674 & 710 & 699 & \\
\hline Fetos & 15 & 30 & 22 & 35 & $\mathbf{3 , 5}$ & 27 & 21 & $\mathbf{3 , 2 5}$ & 16 & 18 & 12 & $\mathbf{2 , 2 5}$ \\
\hline $\mathbf{0 - 1 2}$ meses & 70 & 91 & 79 & 71 & $\mathbf{9 , 5}$ & 59 & 55 & $\mathbf{8}$ & 46 & 43 & 31 & $\mathbf{5 , 7 5}$ \\
\hline $\mathbf{1 - 5}$ años & 159 & 196 & 111 & 80 & $\mathbf{1 8 , 7}$ & 67 & 102 & $\mathbf{1 1 , 7}$ & 59 & 113 & 45 & $\mathbf{1 0 , 5}$ \\
\hline $\mathbf{5 - 1 0}$ años & 28 & 25 & 17 & 16 & $\mathbf{3}$ & 16 & 15 & $\mathbf{2 , 1 5}$ & 11 & 8 & 12 & $\mathbf{1 , 5 0}$ \\
\hline $\mathbf{1 0 - 1 5}$ años & 13 & 10 & 6 & 15 & $\mathbf{1 , 7 5}$ & 17 & 7 & $\mathbf{1 , 6 5}$ & 9 & 15 & 13 & $\mathbf{1 , 5}$ \\
\hline $\mathbf{1 5 - 2 0}$ años & 21 & 18 & 25 & 10 & $\mathbf{2 , 4}$ & 8 & 21 & $\mathbf{2}$ & 21 & 21 & 25 & $\mathbf{3}$ \\
\hline $\mathbf{2 0 - 3 0}$ años & 26 & 24 & 23 & 27 & $\mathbf{3 , 2 5}$ & 38 & 36 & $\mathbf{5}$ & 27 & 18 & 23 & $\mathbf{3 , 2 5}$ \\
\hline $\mathbf{3 0 - 4 0}$ años & 34 & 29 & 32 & 35 & $\mathbf{4 , 2 5}$ & 32 & 30 & $\mathbf{4 , 1 5}$ & 25 & 28 & 31 & $\mathbf{4}$ \\
\hline
\end{tabular}

$28,25 \%$ fallecen antes de los 5 años en 1912-1915

19,50 fallecen antes de los 5 años en 1920-1921

16,25 fallecen antesde los 5 años en 1929- 1931 


\section{CAPÍTULO V: EL CÓLERA MORBO EN CASTELLÓN, UNA ENFERMEDAD TEMIDA}




\section{INTRODUCCIÓN}

En las primeras décadas del siglo XIX, cuando Europa no padecía desde hacía casi doscientos años epidemias de peste y empezaba a controlarse la viruela gracias a la vacuna de Jenner, llegó por primera vez a nuestro continente la enfermedad que fue llamada «cólera asiático», por oposición al cholera nostras, ya conocido desde la Grecia clásica. El agente causal del cólera es el Vibrio cholerae, diferenciable por análisis antigénico en varios biotipos, entre los que figuran el descubierto por Koch en 1883, el localizado el año 1905 en la estación cuarentenaria egipcia de El Tor y el 0139, aislado en 1992.

A diferencia de la peste, el único reservorio del vibrión colérico es el cuerpo humano enfermo, convaleciente o portador asintomático. El contagio se produce habitualmente a través del agua o los alimentos contaminados, y la enfermedad tiene también síntomas inequívocos, ya que la intoxicación intestinal causada por el germen produce unas diarreas riciformes que, en ausencia de tratamiento, conduce a la muerte por deshidratación.

El foco endémico originario está situado en el sur del valle del Ganges, en la India, a partir del cual se han desarrollado las siguientes pandemias:

- La iniciada el año 1826 en la India, que llegó, a través de Persia y Siberia, a la Europa oriental (1830), Alemania y Gran Bretaña (1831), Francia (1832) y España (1833).

- La desarrollada entre 1840 y 1862, que afectó a España en los años 18531856 y $1859-1860$.

- La de 1863-1875, que España sufrió en 1865.

- La de 1883-1894, que produjo en España la epidemia de 1884-1885 y un pequeño brote en 1890 .

- La de 1899-1922, cuya única epidemia europea fue la padecida por los países balcánicos en 1918 .

- Posteriormente la iniciada en la India en el año 1961.

Con gran alarma social, alcanzó a los países del sur de Europa, produciendo brotes en Italia (1973), Portugal (1974) y España (1971 y 1974-1976). Más tarde ha 
vuelto a amenazarlos desde la epidemia padecida por los países africanos. En América, donde no había habido cólera desde finales del siglo XIX, se inició en 1991 otra grave epidemia que produjo más de un millón de casos y casi quince mil muertos, mientras que la de África, con la mitad aproximadamente de casos, causó cerca de cuarenta mil fallecimientos. En ambas, el agente patógeno es el biotipo El Tor, al que ha venido a sumarse el Vibrio cholerae 0139, descubierto en Asia el año 1992.

Las principales causas de la desaparición del cólera en Europa como enfermedad social son de carácter sanitario, principalmente la instalación de sistemas modernos de abastecimiento de aguas y alcantarillado, así como la elevación del nivel de vida. También han contribuido la terapéutica, sobre todo la de la deshidratación, y la vacunación anticolérica, ideada por Jaime Ferrán y aplicada por primera vez en la epidemia padecida en Valencia en $1885 .^{451}$

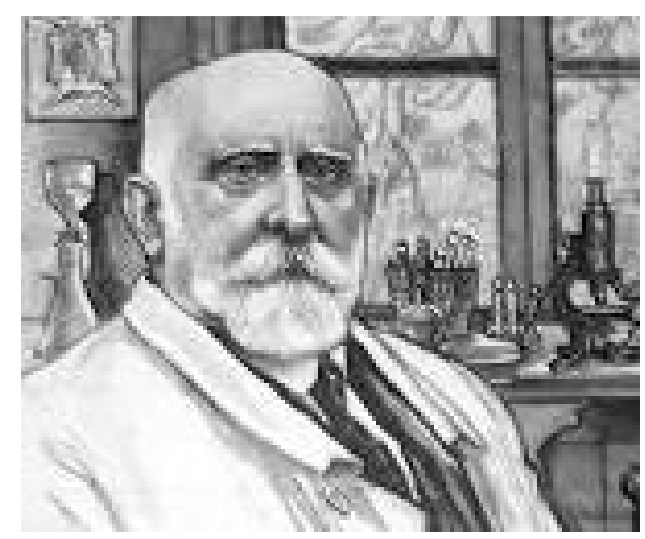

Jaime Ferrán. Fuente:

http://www.biografiasy

vidas.com/biografia/f/ferran.htm .

$[29 / 06 / 2015]$

El cólera morbo se extiende por primera vez a través de Europa en 1830, y desde esta misma fecha el Gobierno Español pone en funcionamiento todo el dispositivo de información sobre su curso y de control de fronteras. Existe una considerable masa de correspondencia diplomática de los años 1830 a 1833, procedente de toda Europa y buena parte de América y norte de África, con abundante información consular sobre la marcha del cólera a través de los distintos Estados. La primera noticia recibida por las autoridades españolas procede de Toscana, y es la única fechada en 1830. Al año siguiente informan ya de la enfermedad los delegados del gobierno a quienes se pide información en Suecia, Dinamarca, Inglaterra, Francia, Portugal, Italia, Austria, Rusia y,

\footnotetext{
451 LÓPEZ PIÑERO, José María (2002): La medicina en la historia. La Esfera de los Libros, Madrid, pp. 649-650.
} 
fuera de Europa, las potencias berberiscas, Egipto y los Estados Unidos. De las mismas zonas se repite la información a lo largo del año 1832. En julio de ese mismo año, el higienista español, Mateo Seoane, que por entonces se encuentra en Londres en el exilio, envía al gobierno un detallado informe impreso sobre la experiencia que de la enfermedad se acaba de tener en Inglaterra y Escocia.

Aunque se ha dado la fecha de enero de 1833 como la de entrada del cólera en España, cuando hace su aparición en Vigo procedente de los puertos portugueses, sobre todo de Oporto, probablemente no se trató todavía más que de algunos casos individuales. Será a finales de agosto de 1833 cuando el cólera morbo, franqueando los límites de Portugal invade territorio español, por Huelva y Ayamonte.

Según Pérez Moreda, las sucesivas invasiones del cólera, exceptuando la de 1853-56, no ocasionaron nunca a nivel nacional una mortalidad específica superior al 1 por 100 de la población total existente en el país en cada momento. Únicamente, la mortalidad por el cólera en torno a 1855 significaría a nivel general una pérdida de un 15 o un 16 por 1.000 de la población, aproximadamente un 50 por 100 de aumento adicional a la cifra de mortalidad ordinaria de esa época.

Las cifras oficiales de victimas atribuidas al cólera en las dos últimas epidemias de 1865 y 1885, que supondrían, respectivamente, una mortalidad específica de un 3 y un 7 por 1.000, quedaron reflejadas en la elevación de la tasa bruta de mortalidad a escala nacional en cada una de las fechas: este indicador se elevó en 1865 a 33 por 1.000 , y a 37,9 por 1.000 en $1885 .^{452}$

La epidemia de 1885 produjo 21.613 muertes en la provincia de Valencia, casi todas entre la segunda quincena de junio y la primera de julio, con días de más de doscientos fallecimientos. Por otra parte, las epidemias de cólera afectan a las zonas geográficas y a las clases pobres de forma muy superior a las ricas, haciendo patente la desigualdad socioeconómica ante la enfermedad, pero acaban atacando a toda la población, con lo que se pone de relieve la inutilidad de medidas que no sean colectivas $^{453}$.

Las condiciones de vida de las clases trabajadoras eran tan lamentables que la llamada «cuestión social» había provocado a nivel nacional tímidos intentos de reforma

\footnotetext{
452 PÉREZ MOREDA, Vicente (1980): Las crisis de mortalidad en la España interior. Siglo veintiuno de España, Madrid. pp.392-398.

${ }^{453}$ LÓPEZ PIÑERO, José María (2002). op, cit. pp. 649-650.
} 
que evitasen la ruptura y la confrontación entre clases sociales. En este marco la Comisión de Reformas Sociales se planteó, en 1883, una encuesta con el fin de conocer mejor la realidad de las condiciones de vida del proletariado. Según Enrique Perdiguero y Josep Bernabeu, las contestaciones dadas por la Junta Provincial de Alicante estuvieron basadas sobre todo en la información proveniente de Alcoy y en algunas informaciones sobre la situación del obrero agrícola. En el caso de este último se menciona como grave problema la emigración de muchos braceros para huir del hambre y de la miseria que provocaba la irregularidad de las cosechas debida a la mala distribución de los recursos hídricos. En el centro fabril de Alcoy se hace referencia a dificultades higiénicas de todo tipo, especialmente por el hacinamiento en el que trabajaban y vivían los trabajadores, por los problemas de seguridad en el trabajo que habían de afrontar las obreras y los obreros. ${ }^{454}$

El año 1885 tuvo lugar en Valencia un acontecimiento médico internacional: la aplicación de la vacuna anticolérica de Jaime Ferrán, la primera que se empleó en el mundo para inmunizar a un población humana frente a un enfermedad bacteriana.

La cabeza de los profesores experimentalistas valencianos era Amalio Gimeno, muy receptivo a los avances de la naciente microbiología médica, se convirtió en el dirigente de un grupo de profesores de la Facultad de Medicina de Valencia igualmente interesados por la nueva disciplina, entre ellos el ginecólogo Manuel Candela. A este grupo se asociaron Pablo Colvée Roura y Vicente Peset Cervera, que venían publicando desde los años setenta artículos y libros destinados a informar de las novedades bacteriológicas y realizando trabajos de laboratorio con los que verificaron las investigaciones extranjeras y consiguieron algunos hallazgos originales.

A Amalio Gimeno y su grupo se debió una importante serie de aportaciones. En primer término, la inmediata asimilación del descubrimiento del vibrión colérico por Koch (1883) y la publicación, en el verano de 1884, de la traducción anotada del principal texto que el gran bacteriólogo alemán le había dedicado; en otoño del mismo año, la observación y el posterior cultivo de vibriones en las deposiciones de enfermos del brote de la localidad de Beniopa, antecedente inmediato de la gran epidemia padecida por Valencia en 1885; a finales de marzo, el diagnóstico bacteriológico del

\footnotetext{
454 PERDIGUERO, Enrique y BERNABEU, Josep (1999): «Un reto a la modernización: el control de la enfermedad y de la muerte», en MATEO MARTíNEZ, Carlos (Coord.): Los inicios de la modernización en Alicante, 1882 - 1914. p. 141.
} 
comienzo de dicha epidemia en Játiva, en el que ya participó Ferrán; por último, la defensa de la vacunación anticolérica de éste, en la que colaboraron, además de forma decisiva. $^{455}$

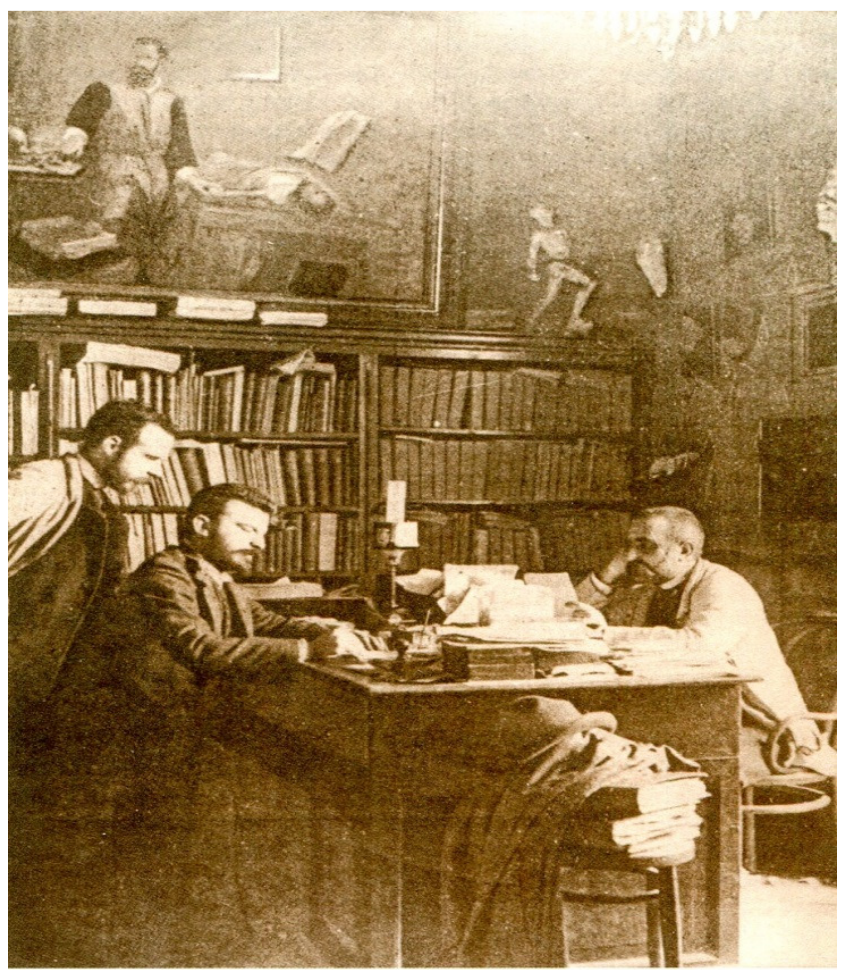

Jaime Ferrán en su despacho de Tortosa junto a Inocente Paulí y Amalio Gimeno. Fotograbado de su libro La inoculación preventiva contra el cólera morbo asiático (1886). En LÓPEZ PIÑERO, José María (2006): Santiago Ramón y Cajal

Jaime Ferrán nació en 1852, el 2 de febrero de 1852 en Corbera, pequeña localidad de la Terra Alta tarraconense, donde ejercía de médico su padre. Comenzó a dedicarse a la bacteriología en 1880 movido al principio por su admiración hacia los trabajos de Pasteur. La actividad científica de Ferrán fue típicamente extraacadémica, en relación siempre difícil con los representantes del saber universitario y las instituciones oficiales.

Ferrán se convirtió durante el lustro 1880-1884 en un diestro bacteriólogo, trabajando en colaboración con el químico Inocente Paulí. Estuvo en contacto directo con Pasteur, preparó las vacunas pasteurianas contra el carbunco y el mal rojo del cerdo, que tuvieron amplia difusión en España y el sur de Francia, y la Real Academia de

\footnotetext{
${ }^{455}$ LÓPEZ PIÑERO, José María. (2006). Santiago Ramón y Cajal. PUV, Valencia. pp 178-180.
} 
Medicina de Madrid premió su Memoria sobre el parasitismo bacteriano (1884). En agosto de este último año fue nombrado miembro de una comisión que el Ayuntamiento de Barcelona envió a Marsella, con motivo de haberse desencadenado el cólera en el sur de Francia. Junto a Paulí, que se desplazó a su costa, trabajó en los hospitales para coléricos de Marsella y Tolón, donde se relacionó con el propio Koch y varios microbiólogos franceses, hasta conseguir aislar y cultivar el vibrión.

A su regreso a Tortosa, en octubre, investigó la acción del germen en animales de laboratorio, encontrando que los cobayas supervivientes a la inyección de cultivos virulentos resistían después a la administración de dosis elevadas. Este hallazgo fue el punto de partida de su vacunación anticolérica, que experimentó inoculándose dosis progresivas del cultivo puro a sí mismo, a Paulí y a una serie de voluntarios, en gran parte médicos y estudiantes de medicina. La vacuna consistía al principio en la inyección de gérmenes vivos, aunque algunos meses más tarde Ferrán los sustituyó por muertos, después de haber propuesto que la acción patógena del germen era debida a la toxina que producía. En enero de 1885 comunicó su descubrimiento a la Real Academia de Medicina de Barcelona, que emitió un dictamen favorable, y en marzo y en julio envió dos notas a la Académie des Sciences de París, que ésta publicó en sus actas. A finales del mismo mes de julio y en enero siguiente informó también a la Académie parisina acerca de la toxina producida por el vibrión y del uso en la vacuna de gérmenes muertos. 456

Además de la vacuna, Ferrán creía haber descubierto que el «coma-bacilo» colérico descubierto por Koch era uno de los estadios del complejo ciclo vital de una criptógama microscópica perteneciente a las Peronosporáceas, familia a la que entonces dedicaban gran atención los fitopatólogos. La llamó Peronospora barcinonae y, aparte de la forma en «coma», describió en su ciclo «espirilos», esporas, «oogonios», «oosferas»y «cuerpos muriformes». 457

\footnotetext{
456 Ibídem, pp. 180-182.

${ }^{457}$ La familia de las Peronosporáceas pertenece al reino de los Hongos. En esta familia se incluyen especies que producen el Mildiu de las plantas.

Los oogonios son órganos sexuales femeninos donde se forman las oosferas de ciertas `plantas Talofitas; y las oosferas, son las células sexuales femeninas de las plantas Angiospermas y que se encuentran en el saco embrionario.

El cuerpo muriforme está compuesto por esporas con varios septos transversales y longitudinales que las dividen en numerosas células, dándoles el aspecto de una pared de ladrillos.
} 


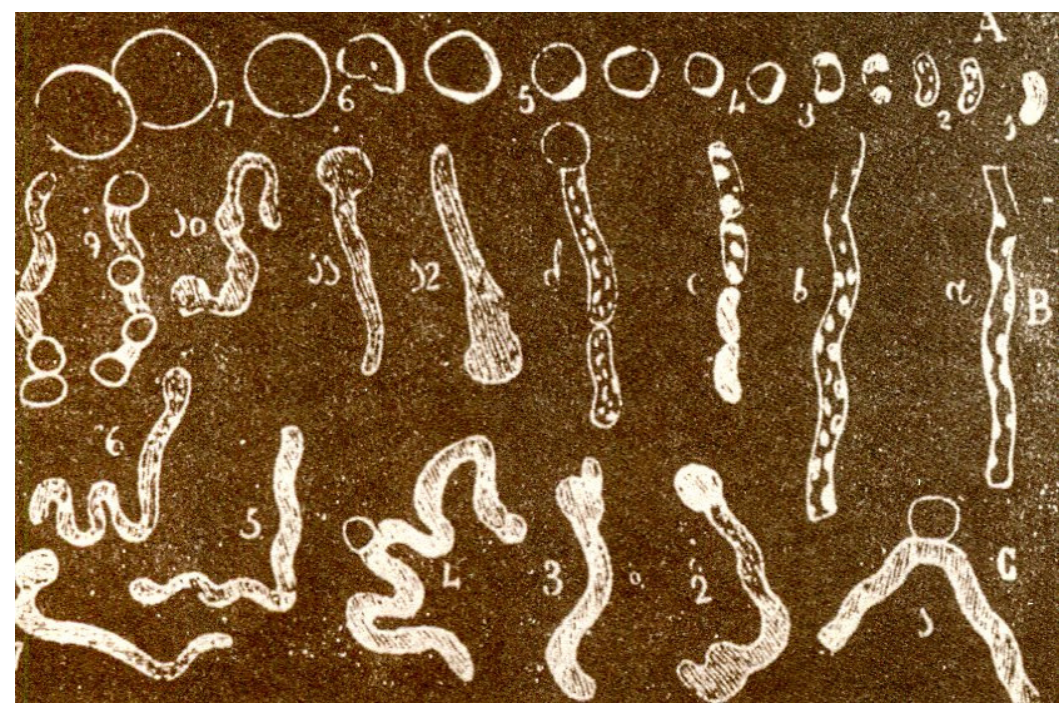

Grabado del artículo (1885) en el que Cajal defendió que las fases del vibrión colérico propuestos por Ferrán eran «formas involutivas y monstruosas». En LÓPEZ PIÑERO, José María (2006): Santiago Ramón y Cajal

En Valencia, Amalio Gimeno dio a conocer este ciclo evolutivo y las bases de la vacuna de Ferrán en sendos artículos que aparecieron a comienzos de 1885 en $L a$ Crónica Médica. Tras el diagnóstico bacteriológico del comienzo de la epidemia en Játiva y la comprobación del primer caso en la ciudad de Valencia, comenzó la vacunación a mediados de abril. Ferrán montó su laboratorio en una casa propiedad de Candela y tuvo como colaboradores, además de Paulí, a Gimeno y a varios miembros de su grupo, entre ellos, el propio Candela, Colvée, y Peset Cervera. Hasta finales de julio se vacunaron más de cincuenta mil personas, figurando entre los primeros inoculados muchos profesores de la Facultad de Medicina, uno de los cuales fue Santiago Ramón y Cajal. La vacunación se convirtió en un acontecimiento de amplia repercusión internacional, que motivó que acudieran a Valencia comisiones y personalidades científicas del resto de España y de Portugal, Francia, Bélgica, Italia, Gran Bretaña, Estados Unidos, Brasil, Rusia y Turquía, así como corresponsables de la prensa de muchos países. 


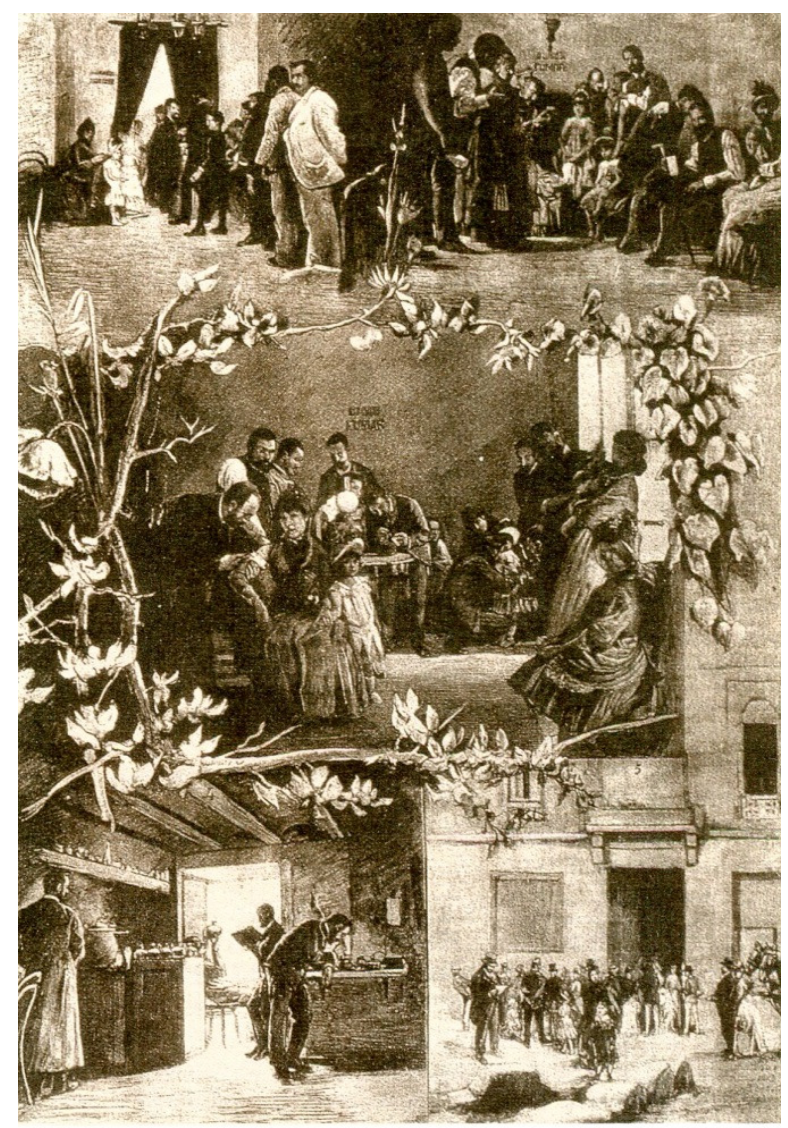

Vacunación anticolérica de 1885 en una casa valenciana propiedad de Manuel Candela. Grabado en la Ilustración Española y Americana (1885).1. Sala de inscripción. 2. Sala de preparación. 3. Sala de inoculación. 4. Laboratorio de Ferrán. 5. Exterior del edificio. En López Piñero, José María (2006): Santiago Ramón y Cajal

Este descubrimiento científico condujo a una encarnizada polémica, condicionada por factores muy complejos. En España se produjo una polarización ideológica en cierto modo paralela a la ocasionada por teorías científicas como el darwinismo, en principio, «ferranista» fue sinónimo de liberal o progresista y «antiferranista», de conservador o inmovilista. En algunas comisiones extranjeras pesó el nacionalismo y el perjuicio de que en un país de escaso nivel científico como entonces era España se produjera un descubrimiento de tanta importancia. ${ }^{458}$

Hubo autores que destacaron la importancia de la contribución, pero plantearon la necesidad de estadísticas controladas para verificar el valor profiláctico de la vacuna. Los primeros controles estadísticos válidos no han sido realizados hasta mediados del siglo XX, y ha sido G.H. Bornside el que ha demostrado en 1981 la eficacia de la vacunación de 1885 mediante un análisis post hoc de los datos numéricos de la época.

${ }^{458}$ Ibídem, p. 182. 
El talante extraacadémico de Ferrán quedó de manifiesto cuando no supo admitir que el propio Koch desmintiera el supuesto ciclo vital de la Peronospora barcinonae en el discurso inaugural del Segundo Congreso Internacional sobre el cólera (mayo de 1885), poniendo de relieve que se basaba en una interpretación errónea de formas involutivas del vibrión colérico. ${ }^{459}$

\section{AlARMA EN CASTEllón ANTE El CÓlera A PARTIR DE 1882. PRECAUCIONES Y MEDIDAS PREVENTIVAS}

Todos los años en septiembre y octubre se recibían noticias preocupantes en España por la invasión del cólera en las naciones extranjeras.

En septiembre de 1882, la prensa de Castellón alertaba sobre la existencia de cólera morbo en el mar Rojo, en Suez, y hacía hincapié que en Gibraltar los ingleses depositaban los heridos e infestados del cólera.

Existía preocupación porque la Casa Provincial de Misericordia era insuficiente para contener higiénicamente a la mitad de los allí depositados, que podía servir de foco epidémico al cólera morbo tan pronto se le ocurriera visitar Castellón. Y como en los meses de septiembre y octubre es cuando acostumbraba a viajar por España «este huésped terrible» la prudencia aconsejaba que se despejaran de personal los dormitorios donde pernoctaban hacinados las personas que allí habitaban, y ocupar otros edificios dedicados también a obras humanitarias que prestarían mejor servicio.

Por otra parte, la higiene de la población era muy deficiente, pues existían estercoleros que perjudicaban considerablemente las condiciones higiénicas de la capital.

Y en los cercanos pueblos de la Plana, estas costumbres estaban fomentadas en mayor escala, pues en los patios de todas las casas existían permanentes y abundantes depósitos de brozas y paja a los que se arrojaban de exprofeso aguas para hacer estiércol. La prensa hacía llamadas al gobernador civil para que evitara la existencia de semejantes focos de infección que tan graves consecuencias pudieran producir.

\footnotetext{
${ }^{459}$ Ibídem, pp. 182-185.
} 
«Y ya que aquí solo nos acordamos de Santa Bárbara cuando truena, como suele decirse, no olvidemos que la tempestad ya está a la vista.» 460

Al año siguiente, la prensa de Castellón llamaba la atención del Gobierno para que adoptara medidas y precauciones necesarias. La agencia Fabra enviaba telegramas acerca de la existencia de cólera en Egipto y pedía al Gobierno que tomara las medidas oportunas por la cercanía del mal, «cuyo solo nombre horroriza en nuestro País». Según dicen el Gobierno se preocupaba muy poco del problema que se avecinaba; en el Senado cuando se dirigió una pregunta sobre el cólera al vizconde de Campo Grande «resultó que no tenía más noticias que las publicadas por la prensa».

Y sin embargo, el caso merecía llamar la atención porque llegaban a España los partes de que el cólera había aparecido en Alejandría, y toda la prensa internacional se hacía eco del problema.

En París el periódico Le Temps hablando del cólera, dice que esta terrible epidemia se había presentado en Bombay el 12 de mayo de 1883 y que en vista de esto, el Consejo Internacional de Constantinopla dictó medidas rigurosas. Añade que el delegado inglés del Consejo hizo fracasar estas medidas alegando que los intereses del comercio eran tan respetables como los de la salud pública.

El Consejo de Constantinopla dispuso, aunque en vano, medidas preventivas contra los peregrinos musulmanes de Java, cuyas procedencias se consideraban sospechosas.

Todas las potencias mediterráneas dictaron rigurosas medidas sanitarias para evitar el contagio.

Se negaba el carácter colérico de la epidemia, fundándose en los síntomas cerebrales ajenos al cólera que presentaban los atacados; pero el dictamen de los facultativos que fueron a la zona, no dejaba duda alguna sobre el particular. ${ }^{461}$

La preocupación por la aparición del cólera en Egipto era debida a la corta distancia que mediaba entre aquél país y el continente europeo, y de la facilidad de comunicaciones que ligaban a los puntos infestados con los pueblos de esta parte del Mediterráneo.

Los representantes de las potencias europeas en Egipto gestionaban intensamente cerca de aquel gobierno para que adoptaran enérgicas medidas sanitarias,

\footnotetext{
${ }^{460}$ El Clamor, 3/09/1882.

${ }^{461}$ La Provincia, 1/07/1883.
} 
a fin de evitar la propagación del cólera, cuya aparición en las orillas del Nilo había producido la alarma en todos los puertos del Mediterráneo.

Muchos médicos enviados oficialmente a Damieta y Mausonrath, dudaban que la enfermedad fuera cólera, más bien pensaban que se trataba de tifus.

En Europa, se tomaron todas las disposiciones oportunas en los puertos del Mediterráneo, para someter a cuarentena a todas las procedencias de la India, Egipto, Malta y Chipre.

En España las disposiciones tomadas por el Consejo de Sanidad fueron declarar sucias a todas las procedencias de Egipto, las cuales quedaron sujetas a la cuarentena de rigor; se acordó que las procedencias de Túnez y Marruecos, Malta, Gibraltar y otros puertos ingleses, y en general, las de todos los puntos del Mediterráneo que no adoptasen medidas sanitarias, quedaran sometidas a las observaciones de tres a cinco días establecidas para los lugares sospechosos.

El Gobierno español decidió enviar médicos inspectores a todos los lazaretos y a varios puertos del litoral, para que dispusieran, los primeros, de las mejores condiciones sanitarias, y que vigilaran y observaran, en los segundos, cuanto pudiera tener relación con la enfermedad, y enviaran instrucciones a los gobernantes para el cumplimiento de las prescripciones sanitarias.

Asimismo, el Gobierno vigilaba de cerca a Inglaterra para que no infringiera los acuerdos adoptados en la Conferencia Sanitaria Internacional de Constantinopla. ${ }^{462}$

\footnotetext{
${ }^{462}$ La Conferencia Sanitaria Internacional de Constantinopla (septiembre de 1866) fue impulsada por el Gobierno Francés intentando excluir la participación de sanitarios y restringiendo la representación a los representantes diplomáticos. Más que prevenir la llegada a Europa de las epidemias, el objetivo de Francia era afrontar el problema en los lugares de origen de la enfermedad. A la Conferencia asistieron 31 países. El principal objetivo que proponía Francia, principal impulsor de la Conferencia, era adoptar medidas que atacaran el cólera morbo asiático en los lugares de nacimiento, más que centrar los esfuerzos en prevenir su expansión mediante un sistema coordinado de cuarentenas u otras medidas similares de aislamiento. Los representantes españoles en Constantinopla fueron el cónsul español en la capital francesa, Antonio María Segovia y el médico higienista y catedrático Pedro Felipe Monlau. La primera parte de la Conferencia estuvo dedicada a analizar el origen y los mecanismos de transmisión del cólera. Las pruebas científicas que se aportaban a la Conferencia eran escasas, la teoría microbiológica todavía no aclaraba la causa infecciosa y las vías acuáticas o aéreas de transmisión estaban aún en discusión. El programa de la Conferencia abarcaba también un segundo bloque relacionado con las estrategias de prevención. Las medidas sobre las restricciones al comercio y las normas de sanidad internacional se justificaban con el objetivo de preservar al continente europeo de epidemias mediante medidas de higiene y salud pública. Afectaban en especial al tráfico marítimo, con referencias específicas a las grandes masas de población que se desplazaban durante las peregrinaciones a la Meca y a la organización de un servicio sanitario sobre el litoral del Mar Rojo. La Conferencia acabó con la aprobación de unas resoluciones sobre patentes de salud y las condiciones que debían reunir las revisiones sanitarias a los barcos. BARONA, Josep L y BERNABEU MESTRE, Josep (2008): La salud y el Estado. El movimiento sanitario internacional y la administración española (1851 - 1945), Universitad de Valéncia, Valéncia. pp. 38-40.
} 
También decidió pedir un crédito a las Cortes de un millón de pesetas para los gastos que se ocasionaran. «Las precauciones propuestas y aceptadas son como se ve, bastantes completas, y si se cumplen, quitan todo pretexto de alarma». ${ }^{463}$

Más adelante la prensa de Castellón, comenta que la energía y precauciones que despliegan otros gobiernos, quisieran verlo también en el de España; hacen hincapié en las medidas adoptadas por Francia para evitar la invasión del cólera, prohibiendo la importación de ciertas sustancias o productos considerados como más susceptibles de producir el contagio. Las instrucciones concernientes a la cuarentena de buques no eran solamente aplicables a los puertos del Mediterráneo, sino a todos los puertos del litoral francés, a fin de evitar las contravenciones de interesados en abreviar la descarga de sus buques.

Según dice La Provincia, «las medidas de rigor adoptadas por todos los países ribereños en el Mediterráneo, han sido bastante enérgicas para que podamos tener alguna esperanza».

Argelia y Túnez prohibieron la peregrinación a la Meca y se organizaron nuevos lazaretos.

Las medidas de precaución que la prensa de Castellón señalaba como más prioritarias para evitar el cólera eran la limpieza de las alcantarillas, girar una visita a las casas de los más pobres, visitar ciertos corrales donde había depósitos de excrementos humanos que se recogían por la vía pública, mandar que se proceda a la limpieza de las cuadras, prohibir los estercoleros en las casas y en las inmediaciones de la población, inspeccionar las tiendas, tabernas, mercados y carnicerías con escrupuloso detenimiento, recogiendo y arrojando al sumidero cuantas frutas verdes o pasadas se presentaran a la venta:

No basta que por el Ayuntamiento se acuerden medidas de salubridad pública, es necesario, que en las difíciles circunstancias porque pasamos y el peligro que corremos, que el cólera visite nuestra Península, sean una realidad los acuerdos tomados y se ponga en Castellón en las mejores condiciones higiénicas. En una palabra, deseamos que se obre mucho y se hable poco. ${ }^{464}$

\footnotetext{
${ }^{463}$ La Provincia, 5/07/83.

${ }^{464}$ La Provincia, 8/07/1883
} 
A mediados de julio de 1883, continuaban siendo alarmantes las noticias de cólera en Egipto ya que el número de defunciones aumentaba considerablemente.

El gobierno inglés no quiso establecer cuarentenas porque eran dañosos para el comercio y admitía todos los buques y mercancías de países infestados con solo la precaución de hacer algunas fumigaciones.

Inglaterra al negarse a imponer cuarentena a los barcos que llegaban de los puertos infestados, los viajeros y las mercancías que venían al continente podían eludir las cuarentenas tomando la vía de Inglaterra. ${ }^{465}$

En España, la Dirección General de Sanidad dirigió una circular a todos los gobernadores de las diferentes provincias españolas para que tomasen precauciones con el fin de evitar del cólera los puertos que tenían relación con los que se hallaban invadidos por la enfermedad.

La circular dirigida a los gobernadores de provincia les ordenaba que mandaran a la Junta de Sanidad Provincial y la Junta de Sanidad Municipal cumplir las leyes que a estos casos se refiere, y sobre todo, cuanto estaba mandado en la circular de 18 de septiembre de 1882, que ordenaba a los gobernadores dispusieran que los empleados de sanidad permanecieran en sus puestos constantemente y «cumplan dignamente $\mathrm{y}$ lealmente el cargo que se les tiene encomendado».

A los gobernadores de las provincias marítimas se les encargaba vigilar más estrechamente las costas, «que la negligencia o una confianza criminal ha abierto alguna vez a enfermedades contagiosas» ${ }^{466}$.

También se les pide a los gobernadores que den pronta y detallada cuenta a la Dirección General de Sanidad de la más mínima sospecha de la invasión de la epidemia, «que se cumplan exactamente las leyes sanitarias, que es el medio más poderoso y eficaz para contener su desarrollo, cosa que, ante todo y sobre todo, hemos de procurar no reparando en sacrificios de ninguna especie [...]» 467

\footnotetext{
${ }^{465}$ La Provincia, 15/07/1883.

${ }^{466}$ Circulares publicadas por la Dirección General de Sanidad en las Gacetas de 10, 24 y 29 de septiembre de 1881 .

${ }^{467}$ La Provincia, 12/07/1883.
} 
El 12 de julio de 1883 se reunió la Junta Local de Sanidad de Castellón y acordaron limpiar el alcantarillado, los lavaderos públicos, así como visitar a las tenerías y prohibir la entrada de carnes muertas sin previo reconocimiento pericial. ${ }^{468}$

La Dirección de Sanidad dispuso que los directores de sanidad marítima de acuerdo con los capitanes del puerto, designaran un punto de la playa, el más distante de los muelles de carga y descarga, donde esperaran los buques hasta que recibieran la visita de Sanidad, habiendo sido señalado para este servicio en el Grao, la punta del Pinar. ${ }^{469}$

El Ayuntamiento de Castellón, en sesión ordinaria de 15 de Septiembre de 1883, quedó enterado de un oficio del Gobernador civil sobre sanidad, en la que participaba del acuerdo tomado por la Junta provincial de Sanidad para adoptar las medidas higiénicas necesarias con el fin de prevenir la invasión colérica. ${ }^{470}$

El 22 de noviembre de 1883 se leyó en el Ayuntamiento un oficio del Gobernador civil de la provincia en el que notificaba los acuerdos tomados por la Junta Provincial de Sanidad. El primer acuerdo era llamar la atención del Ayuntamiento y Junta Local de Sanidad para que adoptara la medidas más convenientes con el fin de evitar el estancamiento de las aguas perjudiciales para la salud; el segundo acuerdo era que los ganados existentes en la ciudad se establecieran fuera de la capital, concediendo a los ganaderos un espacio para tal fin. Para la consecución de esta medida, el Ayuntamiento acordó que se consultara a la Junta Local de Sanidad si la permanencia de los ganados de la población era perjudicial para la salud pública. ${ }^{471}$

\section{CONSEJOS HIGIÉNICOS EN LA PRENSA DE CASTELLÓN CONTRA EL CÓLERA EN 1883}

Aunque el estado sanitario en Europa era satisfactorio, la prensa de Castellón publicaba las medidas preventivas contra el cólera: evitar la aglomeración de personas en los sitios sospechosos y sanear convenientemente las ciudades; establecer visitas

\footnotetext{
${ }^{468}$ Ibídem.

${ }^{469}$ La Provincia, 19/07/1883.

${ }^{470}$ AACS, $15 / 09 / 1883$.

${ }^{471}$ AACS, 22/11/1883.
} 
médicas preventivas para atajar la marcha de la epidemia; curar los desarreglos digestivos y las diarreas para atajar la enfermedad; desinfectar las ropas de las habitaciones y de los lugares escusados. Para esto último se aconsejaba mezclar hierro y carbón pulverizado; para la ropa y las habitaciones se recomendaban las lociones de cloruro de cal. La ventilación y la limpieza general y particular representaban un papel primordial en las medidas preventivas contra las epidemias.

Recomendaban la calma y la tranquilidad de espíritu para hacer frente a la epidemia. El atolondramiento, el miedo irreflexivo, según decían, influían en el desarreglo de los intestinos, y consideraban que en tiempo de cólera se debía evitar en lo posible la diarrea y todo aquello capaz de provocarla.

Otras reglas eran no contraer la embriaguez y huir de todo exceso en la comida; no comer carne de cerdo ni embutidos; evitar las conservas; los alimentos crudos; las frutas que no están bien maduras y las bebidas heladas; rechazar todo alimento indigesto. Como más saludable se recomendaba comer sopa, arroz, carne asada y solamente aquellas legumbres que fueran de fácil digestión.

También se recomendaba evitar las bebidas heladas y las bebidas irritantes, como sidra, licores y bebidas alcohólicas, debiendo, eso sí, beber buen vino con agua mineral natural o agua hervida y enfriada después. Asimismo se aconsejaba la infusión de manzanilla o de té.

Había que evitar las corrientes de aire y la humedad, llevar sobre el vientre una faja de franela muy ajustada al cuerpo y ropas que proporcionaran algún abrigo; buscar el aire y la luz, atender a la higiene de la piel, de los cabellos y de los dientes y tomar con frecuencia baños tibios.

Los individuos que padecían afecciones crónicas de las vías digestivas, de dolores de estómago o de los intestinos, debían doblar el tratamiento y el régimen que les hubiese impuesto el médico; y los que usaban medicamentos estimulantes debían abandonarlos en tiempos de cólera.

Desde los primeros síntomas del mal se aconsejaba ponerse a dieta y tomar a cortas dosis una infusión de té mezclada con una cucharada de jarabe de éter y diez 
gotas de Láudano de Sydenham, ${ }^{472}$ un lavatorio de almidón con la misma dosis de Láudano y aplicar sobre el vientre unos sinapismos. ${ }^{473}$

Friccionar la piel con lana empapada en vinagre o alcohol alcanforado, para aumentar la circulación sanguínea.

Una vez tomadas estas precauciones, se recomendaba esperar la llegada del médico en una cama bien caliente, y se decía que el médico no tenía que hacer otra cosa que proseguir el uso de los anteriores medios, que eran verdaderamente curativos. En los casos más rebeldes, se recomendaba recurrir a los astringentes, los excitantes, los narcóticos y los vómitos.

La ipecacuana, ${ }^{474}$ aplicada en un principio, se consideraba un medicamento antídoto, lo mismo que el opio. Los sinapismos repetidos y multiplicados, las botellas de agua caliente, las fricciones de amoniaco, los baños con mostaza o los baños de aire caliente, y el ron helado etc., decían que daban buenos resultados en un periodo más avanzado del mal y lograban salvar muchas vidas.

Y añadían que la convalecencia del cólera era muy larga y penosa, y que debía ser atendida, paso a paso, con la más cuidadosa vigilancia. ${ }^{475}$

También se publican las precauciones sanitarias de la Sociedad de Medicina Pública de Paris, la cual nombró una comisión de médicos prestigiosos para que estudiaran las precauciones de higiene privada y pública, que debían tomarse en el caso de que se presentase la epidemia de cólera.

Del dictamen fue ponente el doctor Vallín, y sus conclusiones fueron aprobadas en la sesión de 11 de julio de 1883.

El dictamen decía que no se había observado ningún caso de cólera en Europa y que el peligro no era inmediato y podía ser evitado. Pero por prudencia se difundían entre el público consejos higiénicos que tendieran a prevenir o impedir la propagación del cólera.

\footnotetext{
${ }^{472}$ Jarabe de éter o éter sulfúrico, llamado así porque se obtiene por la acción del ácido sulfúrico sobre el alcohol. Es un antiespasmódico y calmante en las distintas afecciones. Láudano de Sydenham, es una preparación líquida de opio, azafrán, canela, clavo de especia y vino. Se usaba para combatir el insomnio y calmar los dolores.

${ }^{473}$ Sinapismo: Tópico o cataplasma a base de semillas de mostaza negra

${ }^{474}$ Ipecacuana: Nombre brasileño de la raíz de la planta rubiácea Cephaelis ipecacuana, de la que existen distintas variedades y cuyo principio activo es la emetina (alcaloide de la raíz de Ipecacuana), emética (vomitiva), y expectorante.

${ }^{475}$ La Provincia, 19/07/83.
} 
La primera medida higiénica que debían tomar las personas en estado de salud era conservar la tranquilidad de espíritu, porque las que tienen miedo resistían menos la enfermedad que los demás; Evitar la fatiga exagerada, el exceso de placeres y trabajo, las veladas largas, los baños fríos y de duración; en una palabra todo lo que producía cansancio.

Se recomendaba evitar el enfriamiento del cuerpo, sobre todo por las ventanas abiertas durante el sueño, los vestidos muy ligeros por la noche después de un día caluroso y beber agua fría en gran cantidad. Evitar toda variación en el modo de vivir y las indigestiones.

También se decía que usar agua de mala calidad es una de las causas más comunes del cólera. Porque el agua del pozo, río, arroyo, frecuentemente recibe las filtraciones del suelo, de las alcantarillas y de los residuos de las fábricas. Se recomienda hervir muchos litros de agua por las noches para el consumo del día siguiente, cuando no hay seguridad de la calidad de la misma.

Se encomendaba hacer una infusión en el agua hirviendo de té u otra planta aromática y mezclar la infusión con vino; vigilar el agua de mesa por fabricarse con agua mala en los mismos sitios donde se exportan; los tahoneros debía renunciar a fabricar el pan con agua de pozo, ensuciada muchas veces por las alcantarillas vecinas.

Uso moderado de frutas buenas y maduras, debiendo antes pelarla y mejor cocerlas; esto último se recomienda, sobre todo para las legumbres, ensaladas, rábanos, etc., porque podrían algunas guardar gérmenes peligrosos.

También se aconseja no tomar bebidas alcohólicas porque algunos pensaban que para preservarse del cólera era preciso beber más que de costumbre aguardiente y licores alcohólicos; y no tomar helados o bebidas con hielo rápidamente en plena digestión o sudando, pues podían determinar indisposiciones parecidas al cólera.

Las precauciones en caso de enfermedad se aconsejaban no descuidar la menor perturbación digestiva y llamar inmediatamente al médico porque un tratamiento rápido podía evitarlo o detenerlo.

Al considerar que el cólera se propagaba por los vómitos y las deposiciones se aconsejaba desinfectar la habitación y quitarlos lo más pronto posible, pues se podía envenenar toda la casa si se arrojaban al excusado sin desinfección previa. 
Por cada litro de estas materias se debía mezclar una taza pequeña, de café, de cloruro de cal en polvo (80 gramos), o bien un vaso grande de una solución de color azul: sulfato de cobre 30 gramos, más 1 litro de agua.

La habitación debía estar ventilada, tanto en invierno como en verano, pues la corrupción del aire era más peligrosa que el enfriamiento, que por otra parte, debía evitarse calentando o cubriendo bien la cama.

Se debía depositar el desinfectante de antemano en el vaso de noche. El ácido fénico y el sulfato de hierro, considerados muy buenos en otras circunstancias, eran ineficaces en el caso del cólera.

Las ropas del enfermo o de la cama, ensuciadas por los vómitos o deposiciones, debían ser metidas, antes de sacarlas del cuarto, en un cubo de 20 litros de agua, a la cual se mezclaba, con cuatro litros del citado color azul, o con dos tazas pequeñas de cloruro de cal. Se mantenían en el cubo media hora, se retorcían y se sacaban, y todavía húmedas, se entregaban a las lavanderas que las metían en agua hirviendo antes de pasarlas a la lejía.

Las piezas de los trajes se lavaban también como queda dicho, y las de paño o lana eran enviadas a la estufa de desinfección. También se podían desinfectar estas piezas, del modo siguiente: se colgaban en un cuarto vacío, cuyas puertas y ventanas estaban bien cerradas, se regaba el suelo con agua para humedecer un poco la atmosfera, y se quemaban 30 gramos de azufre en flor por cada metro cubico de espacio. El azufre se ponía en un vaso de metal metido en un cubo que estaba medio lleno de arena húmeda. Había que marcharse del cuarto enseguida que se encendiera el azufre y no se habría hasta que pasaran veinticuatro horas.

Todas las manchas en el suelo o en las alfombras se debían quitar con un trapo mojado con el líquido azul citado o con leche de cloruro de cal, obtenida por la mezcla de una cucharada de cloruro seco con un litro de agua. Después se quemaba el trapo.

Los colchones manchados eran humedecidos con un trapo o con un pedazo de algodón con la solución de cloruro de cal (una cucharada pequeña por litro de agua). También podían ser sacados sin peligro en carros especiales y desinfectarlos en estufas, ya por aire calentado a 110 grados.

Si no había aparatos para esto, los colchones eran extendidos en un cuarto cerrado y expuestos veinticuatro horas a los vapores resultantes de la combustión de 30 gramos de azufre por metro cúbico. 
En la casa donde hubiera un colérico, dos veces al día se debían tirar en los excusados dos litros del licor azul o dos tazas pequeñas de cloruro de cal disuelto en dos litros de agua.

En los tubos y cañerías de aguas sucias debía verter diariamente una taza pequeña del licor azul o de cloruro de zinc líquido, a 45 grados.

Se aconsejaba poner en todos los tubos y cañerías que iban a parar a la letrina, sifones o tubos de plomo doblados en $U$ para impedir el reflujo de los gases de aquella en el interior de las casas.

También los restos de cocina y de la limpieza se debían guardar en un recipiente cerrado, y diariamente verter sobre él medio vaso del líquido azul o dos cucharaditas de cloruro de cal en polvo. Dichos restos se debían bajar todos los días a un caja metálica bien cerrada en el patio de la casa, y al anochecer se mojaría con cloruro de cal. Esta caja seria vaciada en los carros de la limpieza, que después de vaciarla tirarían en ella algo de cloruro de cal.

En cuanto a la higiene pública, se recomendaba que en tiempo de cólera debiera evitarse la aglomeración de personas en un mismo punto, porque estas multitudes podían ser fácilmente un foco propagador de la epidemia; las ferias, las corridas de caballos, etc., debían en lo posible suspenderse.

También la acumulación de inmundicias, muladares y residuos industriales en los patios y cerca de las casas debían ser rigurosamente prohibidas, y los montones de descomposición que hubiera, no debían ser revueltos y transportados hasta haberlos mojado con una disolución de ácido sulfúrico (1\%), y regar con el mismo líquido el suelo cuando quedara libre.

Más que nunca debía evitarse el estancamiento en las alcantarillas, sobre todo junto a las bocas que daban a la calle, que debían lavarse con una mezcla de ácido sulfúrico con grandes cantidades de cloruro de cal.

Las letrinas debían desocuparse en aparatos cerrados herméticamente, desinfectándose el depósito por la proyección de una mezcla de cloruro de zinc (1\%) o de leche de cal obtenida por la mezcla de dos kilogramos de cal en cincuenta litros de agua.

La administración pública debía vigilar todo lo relacionado con las letrinas.Se debían declarar a la autoridad los casos de cólera que ocurrieran en una casa. La declaración debía hacerse a la alcaldía antes de las veinticuatro horas, bajo la 
responsabilidad de los que rodearan al enfermo; por su parte el médico debía limitarse a indicar a estos la enfermedad.

Cuando se presentara un caso en una fonda o casa de huéspedes, debía hacerse la declaración inmediatamente para que enseguida fuera llevado el enfermo a un hospital especial.

El cuarto que había ocupado el colérico no podía servir a otra persona sin una completa desinfección, quemando 30 gramos de azufre por metro cúbico. Se recomendaba trasladar al enfermo a un hospital «porque hay más probabilidades de curar que en un cuarto donde todo falta».

En la casa donde se presentara un caso de cólera, debía un funcionario especial hacer una rápida inspección, ante todo para hacer constar la realidad del caso y luego para asegurarse de que se habían tomado todas las medidas de desinfección.

Cuando no bastaran las garantías de ejecución y seguridad, las operaciones de desinfección debían hacerse por la administración.

Se consideraba el mejor desinfectante el calor húmedo de 110 grados centígrados, que no era peligroso para los tejidos y primeras materias. Los municipios podían fácilmente improvisar estufas, estableciendo hornos calentados al rojo.

Bastaría para ello poner perchas donde colgar los objetos. Los hornos tenían que alimentarse desde fuera, y por una vidriera poder vigilar la operación.

En cada prevención debía haber un depósito de materiales desinfectantes por paquetes o frascos, dosificados de un modo uniforme y con una etiqueta impresa, indicando el modo de servirse. Con un bono de un médico, un agente sanitario o individuo de una comisión de higiene, debían entregar desinfectantes a todo el mundo.

Los lavaderos públicos debían ser objeto de especialísima vigilancia para que la ropa sucia de los coléricos no se lavara en común. Debía haber en ellos grandes depósitos de cloruro de cal o de sulfato de cobre.

Debían establecerse ambulancias de socorro, cuartos bien aislados en los hospitales generales, hospitales o grandes barracones para coléricos, coches de transporte especiales para el momento en que hiciera su primera aparición el cólera, «que siempre estallaba bruscamente». ${ }^{476}$

${ }^{476}$ La Provincia, 22/07/1883. 
También La Provincia en su número 25 de julio de 1883, publica que «Aunque la salud pública en España es excelente y no hay ningún temor de invasión colérica, si se observan con rigor las medidas sanitarias, hemos creído oportuno reproducir las instrucciones para la preservación del cólera morbo y curación de sus primeros síntomas, dados por la Real Academia de Medicina de Madrid, en octubre de 1865».

La Academia recomendaba la higiene de las casas, evitando la acumulación de basuras, desperdicios de legumbres, frutas, restos de comida etc.; limpiar o blanquear las paredes, barrer suelos, ventilar las alcobas, y cuartos interiores; proporcionar libre salida al humo y a los vapores que en las cocinas produce la preparación de las comidas; hacer que no se detengan las aguas sucias; verter lo más pronto posible las que han servido para fregar y lavar; limpiar bien los orinales y letrinas, echando, si es posible, todos los días por éstas muchos cubos de agua o bien cierta cantidad de agua o cal de una disolución de la caparrosa, y procurando que estén perfectamente tapadas; no arrojar a los patios o corrales aguas o materias capaces de producir olor y humedad; observar la misma limpieza con respecto a las cuadras, portales y buhardillas, sacando a menudo el estiércol; barriendo, abriendo las puertas, desatascando los sumideros y no permitiendo que habiten animales domésticos en mayor número de los que permita su capacidad, si no se pudiera prescindir de ellos.

Regar moderadamente las habitaciones con agua de cal o clorurada, especialmente cuando haya algún enfermo u ocurriese algún fallecimiento. En este caso recomienda renovar bien el aire y hacer fumigaciones con cloro o también poniendo en una taza una onza de ácido nítrico (agua fuerte) en unión con un pedazo de cobre, que podía ser una moneda. Durante las fumigaciones había que tener cuidado de no respirar directamente los gases que se desprendiesen.

Se hacía hincapié en la pureza del aire como una de las primeras condiciones de salubridad; no someterse a las corrientes de aire; no ventilar las habitaciones hasta después de haberse vestido; no dormir con los balcones o ventanas abiertas, ni con poca ropa; salir de los dormitorios con suficiente abrigo; y por último, no exponerse a la eliminación del sudor en ningún caso.

El abrigo es otro de los cuidados que debían tenerse muy presentes. El ir muy abrigado, como el andar muy ligero de ropas, debía evitarse sobre todo en época de epidemia. 
El que hace uso de almillas, elásticas, camisas o chaquetas interiores durante el invierno, convendrá que se ponga estas prendas desde luego. El vientre, sobre todo, debe llevarse preservado con una faja; pues la acción del aire y del frío sobre esta parte del cuerpo es más perjudicial que en las demás, por la facilidad con que le destempla y ocasiona dolores, diarreas, etc. los pies exigen también especial cuidado con respecto al cólera y en estaciones frías; de aquí la necesidad de ir bien calzado, a fin de evitar la acción del frío y de la humedad. Es perjudicialísimo el andar descalzo por la casa. ${ }^{477}$

Con los niños debían tenerse las mismas precauciones; y las mujeres debían redoblar estos cuidados, principalmente durante las épocas menstruales.

La limpieza del cuerpo es otro de los cuidados que recomendaba la Academia en todo tiempo pero más en época de epidemia.

Recomienda un buen régimen alimenticio como el mejor preservativo del cólera; los alimentos debían ser de buena calidad y en cantidad proporcionada a las necesidades del individuo, según su edad, oficio, estado de salud, etc., evitando todo exceso en más o en menos. Aconseja, no comer a menudo, ni tampoco estar en ayunas mucho tiempo. La cena o comida de la tarde debían ser moderadas. No salir por la mañana de casa sin haber tomado algún alimento. No beber agua entre comida y comida, o por lo menos hasta pasadas cuatro horas de haber comido; y aun así se recomendaba mezclarla con un poco de cerveza o de vino, o añadirle unas gotas de aguardiente o de algún espirituoso. Tampoco era bueno correr, acalorarse u ocuparse mentalmente después de las comidas. Estas debían componerse en general, de sustancias sanas y de fácil digestión; «el régimen observado comúnmente por la mayor parte de las familias de buenas costumbres, es el que debe seguirse. Las carnes frescas de vaca, ternera y carnero, así como las de gallina, pollo o pichón, cocidas o asados, y los pescados frescos de carne blanca, pueden y deben usarse sin peligro». Había que abstenerse de tomar legumbres y ensaladas crudas. Las frutas en general se consideran nocivas, principalmente las ácidas y las que no están en sazón, o por verdes o por pasadas, y en todo caso debían comerse en poca cantidad. Se considera peligroso comer melón, sandía, pepinos, higos, tomates, cebollas, pimientos y calabazas. También debía prohibirse los condimentos fuertes, y renunciar a desayunar frutas y otras sustancias frías y de difícil digestión.

\footnotetext{
${ }^{477}$ La Provincia 25/0771883.
} 
Los que fueran estreñidos de vientre no debían omitir el uso de alguna lavativa de agua tibia para facilitar esa función, pero sí abstenerse de purgantes sin consejo del médico.

Con relación a las bebidas, se recomendaba para beber el agua pura de fuente, no usándola nunca en exceso. El abuso de vino y bebidas espirituosas eran perjudiciales; pero el que tuviera la costumbre de beber en las comidas un poco de vino no debía dejarlo; no se recomendaba la toma de helados.

Se hacía hincapié en observar un régimen alimenticio regular y los que no lo tuvieran debían corregirse, si no querían exponerse a ser las primeras víctimas.

Se recomendaba hacer ejercicio, pero sin llegar a cansarse ni menos experimentar fatiga, «porque es tan perjudicial como la quietud demasiado prolongada». No hacer ejercicio después de comer; evitar la acción prolongada al sol, sobre todo en la cabeza.

No acostarse tarde, pues el sueño es el que mejor restaura las fuerzas; no dormir al aire libre con poca ropa y menos con las ventanas abiertas. En las alcobas o dormitorios procurar que no hubieran orinales, ropa sucia, calzado sudado, flores ni objetos que contaminen el ambiente, y no debían dormir más que una o dos personas en cada pieza según su capacidad.

Pero lo que a toda costa debía evitarse era el miedo, porque predisponía a la enfermedad, produciendo inapetencia, malas digestiones, tristeza y abatimiento. No había motivo para temer tanto al cólera; «pues observando un buen régimen de vida y acudiendo con tiempo a remediarlo, es una enfermedad de la que la ciencia triunfa en el mayor número de casos, con los medios eficaces y bien experimentados de que dispone».

Sin embargo, el exceso mayor que predisponía a sufrir la enfermedad era el que se cometía contra la castidad, pues «durante el tiempo del cólera no hay cosa que predisponga más a sufrir la enfermedad que el abuso en esta parte».

Tal es el régimen de vida que debía observarse siempre para conservar la salud; pero muy especialmente mientras durara la epidemia. Los enfermos, los achacosos, los ancianos y personas delicadas habían de redoblar cuidados en semejantes circunstancias, correspondiendo al médico disponer lo que cada uno, en concreto, necesitase. 
Por otra parte la Academia advertía que las personas que quisieran abandonar una población atacada de la epidemia, lo hicieran desde los primeros casos, y que no regresaran hasta 15 o 20 días después de haber desaparecido la enfermedad, porque «el salir cuando la epidemia está en el periodo de desarrollo, expone al peligro de llevar incubado el mal que no dejará por la fuga de aparecer a su debido tiempo; y el volver antes de la completa purificación de la localidad, ofrece el riesgo de sentir la influencia con intensidad y de sufrir del padecimiento del que huía». ${ }^{478}$

Los consejos para prevenir el cólera se multiplicaban continuamente en la prensa, así, El 12 de agosto de 1883, La Provincia publicaba los consejos que el doctor Pasteur recomendaba contra el cólera.

Partiendo de la hipótesis de que el cólera no penetraba en el organismo humano por las vías respiratorias, sino por las digestivas, Pasteur aconsejaba una serie de precauciones contra el cólera.

Una de las primeras recomendaciones era no beber agua de la localidad invadida sin hervir el agua y, posteriormente, agitarla tres minutos después de que se haya enfriado en una botella medio llena y bien tapada;

Beber el vino haciéndolo pasar por botellas calentadas hasta 55 o 60 grados, y en vasos templados;

Cocer bien los alimentos y tomar frutas naturales bien lavadas con agua hirviendo;

Tomar pan cortado en rebanadas delgadas tostadas hasta una temperatura de 150 grados;

Todos los vasos y vasijas que se usaran en el servicio de mesa tenían que estar a una temperatura de 150 grados;

Las ropas de cama y las de uso interior se debían colocar en agua hirviendo y después secarlas muy bien antes de usarlas;

El agua para la limpieza, después de haberla hervido, se le debía añadir, ya fría, ácido thymico en la proporción de 1-500 o ácido fénico en la de 1-50;

Lavarse la cara y las manos varias veces al día con agua caliente mezclada con ácido thymico disuelto en alcohol o ácido fénico disuelto en agua;

${ }^{478}$ Ibídem. 
Y en el caso de haber en la casa cadáveres de coléricos o ropas sucias y usadas por los atacados, cubrir la nariz y la boca con una mascarilla de tela metálica rellena de una capa de algodón en rama de un centímetro de espesor. Esta mascarita debería tener siempre 150 grados de temperatura. ${ }^{479}$

\section{LA LLEGADA DEL CÓlERA A EUROPA EN 1884. PRECAUCIONES PARA EVITAR SU DIFUSIÓN EN ESPAÑA}

A mediados de junio de 1884, el cólera se había presentado en Tolón y la prensa critica el abandono que en los primeros días tuvo el Gobierno en el acordonamiento de las fronteras; el descuido de los lazaretos; el desembarco en Cádiz de buques procedentes de puntos infestados; la presentación en Valencia de individuos que habían burlado la vigilancia de la frontera; los lamentos de algunas poblaciones pidiendo al gobierno persiga a los «matureros» de la salud.

El Clamor crítica la vigilancia que se ejercía en la frontera para impedir que las personas procedentes de Francia entraran en España sin sufrir antes la cuarentena reglamentaria. Proponen que el dinero que se gastaba en acordonar la frontera sirviera para socorrer a la clase obrera que es «la única que hasta ahora va sintiendo los efectos de la epidemia que ha invadido la vecina República.» 480

Ante el peligro de invasión colérica, se hablaba de presentar una proposición de ley a las cámaras, por medio de la cual se declarasen incapacitados perpetuamente para desempeñar cargos retribuidos por el Estado, las Diputaciones y los Municipios a los funcionarios públicos que abandonasen sus destinos si por desgracia se llegaba a presentar el cólera morbo en España. El objetivo de la medida era redoblar el rigor de las leyes para que los servidores públicos no dieran motivo a aumentar el pánico que indudablemente se apoderaría de la gente, si se tuviera la desgracia que afligía a Marsella y a Tolón. ${ }^{481}$

En la segunda quincena de junio de 1884, se confirma oficialmente la noticia de la aparición del cólera en el arsenal de Tolón. La Dirección de Beneficencia y Sanidad

\footnotetext{
${ }^{479}$ La Provincia, 12/08/1883.

${ }^{480}$ El Clamor, 20/06/1884.

${ }^{481}$ Ibídem.
} 
comenzó a adoptar todas las disposiciones convenientes para prevenir y evitar la invasión colérica en España.

Telegráficamente, se declararon por dicha Dirección «sucias» las procedencias de los puertos franceses, se comunicaron ordenes e instrucciones a los gobernadores de las provincias para que tomaran las medidas que la ciencia y la experiencia aconsejaban en esos casos, exigiéndoles la más estrecha responsabilidad a los encargados de su cumplimiento.

El 15 de junio de 1884 se reunió el Real Consejo de Sanidad para deliberar sobre las medidas, que tanto por tierra como por mar, debían adoptarse en vista de la aparición del cólera en Tolón.

El Consejo adoptó aprobar la cuarentena de diez días en Lazareto sucio, impuesta por la dirección a las procedencias marítimas de Francia.

Investigar si alguno de los estados de Europa, Norte de África y Asia, dejaba de adoptar medidas contra las procedencias de Tolón, para sujetarlos a cuarentena de observación.

Con respecto a la procedencias por tierra, aunque partiendo que la incomunicación era la única medida que la ciencia reconocía eficaz para evitar que la epidemia se propagase, se declaró que no se estaba en el caso de llegar al acordonamiento de la frontera, pero sí, de sujetar a cuarentena a las personas, animales y mercancías que vinieran de pueblos infestados, y de prohibir la importación por mar y por tierra de las lanas sucias y de las pieles sin curtir, procedentes de todos los puntos de Francia, como materiales contumaces. ${ }^{482}$

Telegráficamente se comunicó a las provincias los acuerdos del Consejo de Sanidad para que tomaran las precauciones reglamentarias en la defensa y contra la llegada del cólera.

En España se tomaron medidas preventivas desde las zonas fronterizas. La Junta Provincial de Sanidad de Pamplona, que estaba más cerca de la frontera francesa, se reunió el 25 de junio de 1884, bajo la presidencia del Gobernador, y tomó los acuerdos siguientes: establecer un cordón sanitario en las 22 leguas de la frontera; establecer lazaretos provisionales en cinco pueblos de la frontera, por donde debían entrar todos los viajeros y mercancías de Francia, a los que se sujetaban a cuarentena de ocho días.

${ }^{482}$ El Clamor, 29/06/1884. 
Estos lazaretos deberían estar bajo la dirección del alcalde, médico y farmacéutico de las respectivas localidades; también se tomó el acuerdo de comunicar las instrucciones necesarias a los alcaldes de la provincia.

Estos acuerdos fueron sometidos a la aprobación del Gobierno. También se dispuso que en Port Bou se fumigara la correspondencia procedente de Francia.

El 26 de junio de 1884 celebraron una entrevista el presidente del Consejo de Sanidad y los ministros de la Guerra y de Gobernación, para tratar del acordonamiento de toda la frontera en previsión de que la epidemia se propagara. Si desgraciadamente llegara a suceder así, el gobierno llevaría a cabo inmediatamente aquella medida.

Todos los países, excepto Inglaterra, adoptaron grandes precauciones, distinguiéndose Italia y Portugal. ${ }^{483}$

En España, La Gaceta publicó, el 24 de junio de 1884, una circular del Director de Beneficencia y Sanidad, encaminada a adoptar medidas contra la invasión del cólera en nuestro país. «La presencia del cólera morbo asiático en Tolón (Francia), importado según las noticias recibidas del Tonkín, por medio del transporte Sarthe, colocan en inminente peligro la salud pública de España, por la proximidad al punto infestado y fáciles medios de comunicación en el mismo».

La Dirección de Beneficencia y Sanidad, después de adoptar las primeras medidas, ordenaba a todos los gobernadores que convocaran las Juntas Provinciales de Sanidad para discutir y acordar las medidas de precaución, y en su caso de represión, para evitar o combatir la transmisión y desarrollo del cólera, teniendo presente la Real Orden de 11 de julio de 1865 que puso en vigor la recopilación de instrucciones remitidas al Gobierno en circular de 9 de agosto de 1865, y las medidas para la preservación del cólera morbo y tratamiento de primeros síntomas, redactadas por la Real Academia de Medicina.

Asimismo se disponía que todos los alcaldes reunieran a su vez las Juntas Municipales para los mismos fines que se indicaban para las Juntas Provinciales.

Se hacía hincapié a los gobernadores para que reclamaran de los alcaldes el parte diario de la salud pública de los términos municipales, para posteriormente, aquellos, lo remitieran a la Dirección de Sanidad.

\footnotetext{
${ }^{483}$ Ibídem.
} 
También se pedía a los facultativos parte diario de las enfermedades que asistieran, y, por último, se dieron por terminadas las licencias en que se hallaran disfrutando los facultativos, con la obligación de presentarse inmediatamente en las dependencias a que pertenecieran. ${ }^{484}$

Las críticas circunstancias por las que atravesaba la Península con motivo del cólera en Francia, imponían a las autoridades y a las juntas de sanidad tomar todas las medidas que la higiene y la ciencia aconsejaban. Tener reunidos los elementos necesarios para constituir un hospital de coléricos, si fuese preciso; visitas diarias a los establecimientos públicos, mercados y puntos de venta, inspeccionando los artículos que se expenden al público; prohibir los depósitos de estiércol en las casas y en las inmediaciones de la capital. Vigilar las fábricas de jabón, velas y otros establecimientos donde se acumulaban grandes depósitos de sustancias nocivas para la salud del vecindario. Según la prensa de Castellón eran medidas cuyo cumplimiento urgía y pedían a las autoridades que no se olvidaran de actuar a su debido tiempo. ${ }^{485}$

El 3 de julio de 1884 la prensa anuncia la aparición del cólera en Marsella. Todas las naciones europeas adoptaron enérgicas medidas y precauciones sanitarias. También añaden que la salud en España es muy satisfactoria, declarándose sucias todas las procedencias de Marsella. ${ }^{486}$

En la misma fecha se reunió el Consejo de Ministros para ocuparse exclusivamente de la cuestión sanitaria y dispuso que se guardaran con todo el rigor posible las disposiciones referentes a la observación de los buques y demás procedencias de Francia.

No obstante, llegaban desde Tolón y Marsella noticias esperanzadoras de que la enfermedad iba remitiendo

Después de terminado el consejo de Ministros, Cánovas se entrevistó con el Gobernador y el Alcalde de Madrid para tratar los recursos de personal y material de que se podía disponer para el caso, por «fortuna improbable» de que el estado sanitario llegara a sufrir alteración.

\footnotetext{
${ }^{484}$ Ibídem.

${ }^{485}$ Ibídem.

${ }^{486}$ La Provincia, 3/07/1884.
} 
En dicha conferencia se convino en los medios de saneamiento de la capital, y que en los hospitales establecidos dentro de la población no se albergara los coléricos. ${ }^{487}$

Se había extendido la noticia que en Barcelona, Sevilla y Port Bou habían algunos casos de cólera. El Director de Beneficencia y Sanidad envió un telegrama a los Gobernadores provinciales desmintiendo estos hechos exhortándoles a calmar toda alarma, «pues adoptadas las medidas más enérgicas y cumplidas con el mayor rigor para evitar la invasión, no hay motivo alguno racional para la intranquilidad que se ha tomado en alguna población». ${ }^{488}$

\section{ACUERDOS TOMADOS POR EL AYUNTAMIENTO DE CASTELLÓN PARA COMBATIR EL CÓLERA EN 1884}

En Castellón, empezaron las Juntas Sanitarias de Distrito, a practicar las visitas domiciliarias, encontrando en algunas casas tan malas condiciones higiénicas, que se plantearon desalojar a sus habitantes. «Toda severidad en estas circunstancias es poca.» 489

También se hablaba de establecer el hospital de coléricos en «El improbable caso de que fuese visitada esta ciudad por el terrible huésped» los almacenes de vino que había cerca de la estación, o en su defecto aprovechar el edificio donde estaba establecido el ingenio de azúcar, en el paseo del mar.

La prensa hace un llamamiento a la Junta de Sanidad y comisiones auxiliares sobre la situación de las cárceles, que por el sitio céntrico que ocupaban, por sus malísimas condiciones, por el crecido número de presos, que encerraban y por la imposibilidad de mantener en ellas la higiene conveniente, eran un peligro y un foco de infección para la ciudad: «Se nos figura, pues, que el Ayuntamiento, el Gobernador y la Audiencia de común acuerdo, deberían encontrar el medio de resolver esta dificultad, y esperamos que lo harán en provecho de todos» ${ }^{490}$.

\footnotetext{
487 Ibídem.

${ }^{488}$ Ibídem.

${ }^{489}$ Ibídem.

${ }^{490}$ Ibídem.
} 
La Junta Local de Sanidad, para prevenir la posible invasión colérica, tomó los siguientes acuerdos: - Avisar a los facultativos de la capital para que dieran parte de los casos de cóleras esporádico o epidémico que pudieran presentarse- nombrar cinco comisiones o juntas de distrito compuestas de un teniente de alcalde, un médico, un farmacéutico, un veterinario, dos contribuyentes y un empleado de secretaría que hiciera las veces de secretario - nombrar para asociarse a la Junta Superior Local dos vocales supernumerarios de la clase facultativa, recayendo las propuestas para el nombramiento en Eliseo Soler y Odilón Girones ${ }^{491}$ - Asociar a la Junta Local Superior la Comisión de Beneficencia y Sanidad del Ayuntamiento - Nombrar vicepresidente de la Junta Local Superior a don Manuel Segarra ${ }^{492}$ - asociar a la Junta Local Superior el secretario del Ayuntamiento que haría las veces del alcalde en ausencia o enfermedad del mismo considerar la juntas de salubridad pública las comisiones de distrito - participar a las comisiones de distrito todas las disposiciones insertas en el Boletín Oficial de julio de 1884 - publicar un bando recomendando la limpieza general de calles y casas de la población, hacer desaparecer las aguas estancadas y sucias, y demás prescripciones higiénicas, privadas y públicas que «previene la repetida circular en su párrafo $5^{\circ}$ de precauciones higiénicas» - recomendar a los vecinos que hicieran dentro de sus casas las fumigaciones que para estos casos aconsejaba la ciencia y que tomaran en cuenta cuantas prescripciones higiénicas les recomendaran las juntas de distrito; trasladar los depósitos de trapos viejos fuera de la población a un kilómetro de distancia, dentro del plazo de ocho días, y obligar a las fábricas insalubres y demás establecimientos públicos a fumigaciones continuas. ${ }^{493}$

El Ayuntamiento acordó autorizar a la Junta Local de Sanidad la construcción de un hospital provisional de coléricos en el sitio destinado al tiro de palomo, facultándola para satisfacer del capítulo de imprevistos del presupuesto municipal el importe que originara su construcción. ${ }^{494}$

\footnotetext{
${ }^{491}$ Eliseo Soler Breva era médico cirujano, fue presidente del Colegio de Médicos desde 1917 a 1919. En: I Centenario del Colegio de Médicos de Castellón (2000). Ilustre Colegio Oficial de Médicos de Castellón. Odilón Girones era farmacéutico en la ciudad de Castellón.

${ }^{492}$ Agustín Segarra también era farmacéutico en la ciudad de Castellón.

493 Ibídem.

${ }^{494}$ AACS, 3/07/1884.
} 
Posteriormente se acordó que en lugar del hospital se construyeran barracones a medida que las necesidades lo exigieran, para doce camas, con un presupuesto de 1.600 pesetas cada barracón para enfermos y 900 cada barracón para dependencias. ${ }^{495}$

El Ayuntamiento ofreció al Gobernador militar de la provincia un departamento para coléricos militares en el hospital provisional que tenía determinado construir en el caso que Castellón fuera invadido por el cólera. El hospital debía estar a la mayor distancia del cuartel dentro de los 800 metros, y las subvenciones deberían abonarlas los enfermos militares hospitalizados.

$\mathrm{Al}$ rechazarse el proyecto de construir un hospital para coléricos y en su defecto se decidiera construir barracones para ocho o diez camas según necesidades, el Alcalde manifestó al Gobernador militar que no era posible atender en ellos a los militares atacados de cólera, pudiendo en cambio construir para ellos y por cuenta del Estado los barracones que se necesitaran dentro de la zona designada para levantar los del Municipio.

El Ayuntamiento acordó pedir una subvención a la Diputación provincial para la construcción de barracones con el fin de albergar allí a los enfermos pobres del Hospital provincial y los asilados en los demás establecimientos provinciales, en el caso de ser atacados por el cólera, ya que si tenían derecho a ser tratados en el Hospital, tenían derecho a que se les facilitase camas, botiquín con medicamentos y los recursos humanos necesarios. ${ }^{496}$

Ante la proximidad del cólera, el alcalde propuso que la Junta local de Sanidad dispusiera de las medidas higiénicas que estimara prudentes a fin de evitar la invasión colérica, invirtiendo en ellas las cantidades de dinero que se necesitasen, pues consideraba que la rapidez en tomar dichas medidas no era compatible con la morosidad que llevaría en sí someterlas antes a la aprobación del Ayuntamiento.

La solicitud del alcalde fue desestimada por mayoría de votos, pues se consideraba que tal proposición debía ser aprobada antes por el pleno del Ayuntamiento. La autorización a la Junta de Sanidad para llevar a efecto sus proyectos higiénicos, anta la amenaza de la epidemia, fue aprobada después por unanimidad. ${ }^{497}$

\footnotetext{
495 AACS, 17/07/1884.

${ }^{496}$ Ibídem.

497 Ibídem.
} 
El alcalde expuso al Ayuntamiento el deseo de los vecinos del Grao de que, en el caso de ser invadidos por la epidemia colérica, se les facilitara un médico para su asistencia ya que carecía de él y que los contribuyentes le abonaran cierta cantidad y otra igual el Ayuntamiento por la asistencia a los pobres. Dicha solicitud fue aprobada por unanimidad..$^{498}$

Parece ser que las comisiones sanitarias de distrito no realizaban las visitas domiciliarias con la frecuencia necesaria. Por ello, la prensa critica que si las visitas domiciliarias que practicaban dichas comisiones no hacían cumplir las leyes sanitarias, era inútil que se tomaran dicho trabajo.

La Provincia denuncia que las casas de las calles Barracas y Enchin (hoy calle Vera) debían ser desalojadas por sus malas condiciones higiénicas, y recomienda además que las comisiones realicen por lo menos una visita a la semana para dar algún resultado. ${ }^{499}$

Se encomendaba vigilar los canales de agua denominada «acequia Mayor y Cequiol», en la primera, el trayecto inmediato a Santo Domingo, se veía todos los días «fematers» y algún soldado, bañándose en sus aguas que después servían para beber el vecindario. En el «Cequiol», por donde circulaban las aguas que llenaban las cisternas, había necesidad de que se limpiara, pues los vecinos lavaban y arrojaban basuras y era un abrevadero de caballerías: «Hay que tener presente que el agua es el gran medio de infección según el doctor Koch, y la que bebemos en Castellón, viniendo como viene por canales abiertos, es muy susceptible de que se empuerque y con ella bebamos el veneno del cólera. Con que mucha severidad en este asunto».

En los pueblos de la provincia no se tomaban las medidas higiénicas que aconsejaban las circunstancias. La Provincia llama la atención sobre este asunto porque «el cólera puede invadir lo mismo el llano que la montaña, las grandes capitales que los pueblos de escaso vecindario». ${ }^{500}$

El 14 de julio se reunieron en la alcaldía los médicos y farmacéuticos de Castellón convocados por el Alcalde con objeto de ver si alguno de ellos se encargaría voluntariamente de la asistencia facultativa en los barracones que para enfermos coléricos se proyectaba construir en caso de epidemia.

\footnotetext{
498 AACS,. 11/09/1884.

${ }^{499}$ La Provincia 6/07/1884.

${ }^{500}$ La Provincia, 13/07/1884.
} 
No se sabía el carácter que tendrían esos barracones si serían municipales o de la provincia, porque en este último caso no solo deberían encontrar albergue los pobres de la capital, sino también cuantos vivían al amparo de la Diputación.

Pero la construcción de los barracones iba a cargo del Municipio. En la citada reunión se dio lectura a un oficio del Capitán general de Valencia aceptando el ofrecimiento del Ayuntamiento para albergar a los individuos de tropa en los proyectados barracones; esto hacía suponer que en dichos barracones se extendería el servició a algo más que a los pobres de la localidad. Además el médico mayor del Hospital Provincial reusó socorrer a los pobres que la Diputación tenía el deber de auxiliar.

Parece ser que la caridad municipal debía prestar socorro a todo colérico pobre, fuera de Castellón o forastero, estuviera o no, bajo el amparo de la Diputación.

El Ayuntamiento no tenía suficientes recursos para hacer frente a tantas necesidades y la Diputación no podía declinar sus atribuciones en el Ayuntamiento. ${ }^{501}$

Saltaba la alarma de que el alcalde de Villarreal no adoptaba ninguna medida encaminada a impedir que el cólera visitara dicha población. Al contrario, hacia oídos sordos a las continuas quejas de algunos vecinos que denunciaban el asqueroso hedor que desprendían los cadáveres expuestos en los zaguanes de las casas, y que después de transcurridos veinticuatro horas fueran paseados por las calles más céntricas, introduciéndolos en la iglesia parroquial donde se celebraban las exequias fúnebres.

También las caballerías bebían en la acequia Mayor, que es de donde se surtía el vecindario para los usos domésticos. ${ }^{502}$

Por otra parte, el Ayuntamiento de Villarreal suspendió la feria que anualmente se celebraba del 1 al 10 de agosto.

Además se realizaban las operaciones del enriamiento del cáñamo, que se consideraba un peligro para la salud. ${ }^{503}$

En una crónica de La Provincia se comenta que Castellón estaba sitiado de estiércol, pues se habían vaciado los corrales y las letrinas en los alrededores de la ciudad formando un cordón contagioso y epidémico «que apesta la atmosfera y envenena la población». En el llano de San Francisco se vaciaban cajas de estiércol de

\footnotetext{
${ }^{501}$ La Provincia ,20/07/1884.

${ }^{502}$ Ibídem.

${ }^{503}$ Ibídem.
} 
letrina que se envolvía con paja y una ligera capa de tierra. Dicho punto estaba a cincuenta pasos de la carretera de Valencia, inmediata al camino de Almazora, y a medio kilómetro del cuartel y de la población. «Si esto se tolera y así se cumplen las leyes sanitarias entendemos que el remedio es peor que la enfermedad». 504

Un peligro para la salud de los pueblos era tener el cementerio dentro de las ciudades, como lo tenían: Artana, Almazora, Arañuel, Catí, Cirat, Canet lo Roig, Castell de Cabres, Corachar, Fanzara, Ballester, Gaibiel, Vallibona y Zucaina, total 13.

Tenían el cementerio a la distancia de uno a cien metros, 55 pueblos; de cien a doscientos metros 14; de doscientos a trescientos, 13; de trescientos a cuatrocientos, 5; de cuatrocientos a quinientos, 23; de quinientos a setecientos, 5; de setecientos a ochocientos, 3; de ochocientos a novecientos, 1; de novecientos a mil, 16; y a más de mil metros, sólo tres pueblos.

Con lo expuesto anteriormente basta para que se vea el peligro que se corre si nos invadiera el cólera, por lo que llamamos particularmente la atención del señor Gobernador a fin de que se tomen las medidas convenientes en todos los pueblos de la provincia para que los enterramientos se verifiquen con las debidas precauciones y se tomen aquellas medidas sanitarias indispensables para hacer menos peligrosa la proximidad de los cementerios. ${ }^{505}$

En el cuartel de San Francisco, las ventanas estaban ribeteadas con aguas sucias, y rodeado de un foso infecto, «todo preparado para que los pobres microbios, hoy tan perseguidos, puedan vivir a sus anchas». ${ }^{506}$

El 4 de septiembre de 1884, volvió a reunirse la Junta de Sanidad para continuar ocupándose de las medidas sanitarias por la proximidad de la epidemia del cólera. Una comisión de la Junta tenía formuladas las bases para el acordonamiento de la capital.

Las bases eran las siguientes: todo el que se presentara en alguna de las puertas de la ciudad para penetrar en ella sería detenido. Si exhibiese el pase o acreditase que procede y residido durante los últimos siete días consecutivos en sitio limpio, se le

\footnotetext{
504 Ibídem.

${ }^{505}$ Ibídem.

${ }^{506}$ La Provincia ,27/07/84.
} 
concedería libre entrada; en caso contrario, sería conducido al lazareto, donde permanecería en observación siete días.

Los dependientes de la autoridad entregarían a todos los que salieran por las puertas de la capital un pase que deberían conservar para presentarlo a su regreso, a los efectos de la base anterior. Los pases mencionados eran válidos sólo para el día de su expedición y además personales e intransferibles.

También una comisión autorizada esperaba en la estación la llegada de todos los trenes, para examinar a todos los viajeros.

Respecto a las mercancías, se examinaba su procedencia. Si provenían de puntos infestados o sospechosos, serían conducidos inmediatamente a un depósito de efectos sucios donde permanecerían indefinidamente aislados o serían destruidos por el fuego si la autoridad lo estimase conveniente. Los efectos que proviniesen de puntos no infestados, permanecerían 24 horas en los almacenes de la estación, donde serían revisados por los consignatarios.

Los efectos contumaces de materiales como lanas, pieles, salazón, etc., se someterían a operaciones más eficaces y durante más tiempo.

Aparte del acordonamiento, se tomaron los siguientes acuerdos: que los viajeros procedentes de puntos sospechosos, y las mercaderías y efectos de igual origen, fueran al lazareto establecido en Lidón, con personal, camas y los útiles necesarios, sin perjuicio de la cuarentena que habían de sufrir en Almenara y Vinaroz los que entraran en la provincia por aquellos puntos; que continuaran cerradas la escuelas públicas y la privadas; sacar de la población el ganado de cerda; y construir un barracón para coléricos en el llano denominado «Tiro de palomo», y otro para dependencias de aquél. 507

En virtud del acuerdo del Ayuntamiento la comisión de Sanidad dictó las órdenes convenientes para que cuanto antes estuviera instalado el hospital de coléricos.

Los encargados de dejar instalado el lazareto de Almenara fueron Emilio Gascó, administrador, el médico José Clará; un farmacéutico, Ernesto Soler; José Gómez, celador; y dos asilados de la Casa Provincial de Misericordia, que harían el papel de

${ }^{507}$ La Provincia, 4/09/1884. 
mozos de servicio, dos hermanas de la Consolación y personal de enfermeros y sirvientes, que se considerara necesario. ${ }^{508}$

Habían empezado casos de cólera en Novelda donde ocurrieron algunas defunciones de la enfermedad sospechosa; en el resto de España, según la prensa, no ocurría novedad.

Se sometió a observación, la playa de Torre- Nostra, entre Torreblanca y Alcalá, para evitar el desembarco de algún viajero procedente de punto infestado, y toda la playa que correspondía a la comandancia de carabineros de la provincia; también las barcas pescadoras fueron objeto de todas las medidas necesarias para conseguir el objetivo deseado. 509

Para el lazareto de Almenara, se nombró al médico, farmacéutico y administrador del Hospital Provincial, con lo cual este establecimiento se quedó con tres empleados menos. Dos de ellos, según dice la prensa, de difícil reemplazo. El descontento venía sobre todo porque la botica del Hospital Provincial quedaba en manos de un practicante.

Ante la expectativa de una epidemia, el Hospital se quedaba sin farmacéutico y con un médico menos, teniendo en cuenta el escaso número de facultativos de aquel establecimiento.

El lunes, 8 de septiembre de 1884, empezó el acordonamiento de la capital; el servicio se hizo por los vecinos, comenzando por el barrio de Santa María.

Cuantos salían por los portales recibían una contraseña o salida, la cual habían de conservar si no querían exponerse a ser a su regreso trasladados al ermitorio de Lidón, en donde se había establecido el lazareto.

Algunas personas se resistieron el primer día a servirse de la salida que se les entregaba. 510

Había muchas contradicciones en cuanto a la invasión epidémica, algunos periódicos negaban su existencia asegurando ser la enfermedad creación del Gobierno para fines particulares, y otros aseguraban su existencia, dando cuenta del número de invasiones y bajas que diariamente producía la enfermedad.

\footnotetext{
${ }^{508}$ La Provincia, 7/0918/1884.

${ }^{509}$ La Provincia, 11/09/1884.

${ }^{510}$ La Provincia 11/09/1884.
} 
Las precauciones que se tomaban para impedir la invasión en muchísimos lugares, reflejaban el desconcierto que reinaba en España; la prensa comenta «que si esto sigue así, España quedará muy en breve declarada en tantos cantones como localidades, con notorio perjuicio del ministro de Hacienda, a quien ha de ser difícil realizar el cobro de las contribuciones».

Por ejemplo, el alcalde del Escorial comunicó al Gobernador de la provincia que no permitiera salir de Madrid trenes de recreo para aquel real sitio, porque él no dejaría que entrara en el pueblo ni uno solo de los viajeros.

Asimismo en la estación de Alcázar de San Juan, no se permitía descender de los coches ni a un solo viajero de los trenes. En Alcázar no se permitía a nadie la entrada, y las avenidas de la población estaban guardadas por hombres armados que a nadie permitían pasar, y rodeada del mismo modo la estación que era precisamente el empalme de todas las líneas del mediodía. Al vecino del pueblo que por curiosidad o por necesidad iba a la estación, ya no se le permitía volver a entrar en el pueblo.

En todos los pueblos de la comarca pasaba lo mismo. Cogidos por gente armada las avenidas, a ningún forastero, aunque fuera de poblaciones cercanas, se le permitía entrar bajo ningún pretexto, como no se consentía que entraran verduras ni frutas destinadas al consumo. «Persona ha habido que ha salido del pueblo a dar un paseo por el campo y al volver a poco rato le ha costado mil angustias el que se le permita entrar en la población» ${ }^{511}$.

En Castellón, La Provincia critica que el lazareto de observación establecido en el confín de la provincia, junto a Almenara estaba emplazado en un lugar muy insano. La Casa Blanca que era el edificio utilizado como lazareto se encontraba en una comarca pantanosa, en medio de unos arrozales cuyas emanaciones eran el azote de los habitantes de Almenara y puntos limítrofes. Las fiebres intermitentes eran endémicas en aquellos lugares, y mantenían en estado caquéctico a muchos individuos causando gran mortalidad en aquella zona. «Establecer lazaretos en tales puntos, es exponer a enfermedades a sus empleados y a los viajeros que por razones del régimen sanitario, se vean obligados a permanecer más o menos tiempo en sitio tan insalubre como La Casa Blanca». 512

\footnotetext{
${ }^{511}$ La Provincia, 11/09/1884.

${ }^{512}$ Ibídem.
} 
En un principio se acordó establecer el lazareto de Vinaroz en el Molino de Noguera, pero surgieron algunas dificultades y posteriormente se decidió instalarlo en el Ermitorio de San Sebastián, de la citada ciudad.

Había prisa por instalar los lazaretos, pero no se esperaba que se abrieran tan pronto como las circunstancias exigían. ${ }^{513}$

Los vecinos que formaba el cordón sanitario en las puertas de la ciudad abandonaban la vigilancia sin más guardia que la de los dependientes del resguardo de consumos, que ni tenían cédulas de las que se proveía a los vecinos que salían al campo, ni el encargo de impedir la entrada a los forasteros que carecían de la sanidad correspondiente.

Es decir, por aquellas puertas se entraba y salía por espacio de horas, sin inconveniente alguno. Con lo que se pedía se suprimiera el cordón sanitario si no es necesario y si lo fuera, se hiciera de verdad. ${ }^{514}$

Las noticias del cólera recibidas en el Gobierno civil de la provincia eran alarmantes. Había casos en la provincia de Alicante, en la de Lérida y en la provincia de Tarragona. ${ }^{515}$

La Provincia, pide al alcalde que suprimiera el cordón sanitario que tanto molestaba a la población, o impidiese que lo que «con él se adelanta no se pierda por otro lado». En el lazareto de Lidón tenían fácil acceso personas que luego entraban sin obstáculo alguno en la capital; y aun los dependientes de aquel establecimiento entraban en la capital sin encontrar inconveniente alguno.

Esto aparte de que por las puertas de la capital, a pesar del cordón, entraban cosas y personas cuya procedencia podría ser sospechosa. ${ }^{516}$

En los periódicos salían nuevos caso de cólera esta vez en Barcelona, y la Junta de Sanidad, en vista de los informes facultativos, declaró el caso de cólera morbo europeo.

El 2 de octubre de 1884 continuaba el cordón sanitario en la ciudad, aunque con las quejas de los vecinos que lo consideraban una molestia y nada más. ${ }^{517}$

\footnotetext{
${ }^{513}$ La Provincia, 14/09/84.

${ }^{514}$ Ibídem.

${ }^{515}$ La Provincia, 18/09/84.

516 Ibídem.

${ }^{517}$ La Provincia, 2/10/1884.
} 
La Junta Provincial de Instrucción Pública acordó, en sesión del 30 de septiembre de 1884, aconsejar al Gobernador Civil de Castellón la conveniencia de que se abrieran las escuelas de la provincia de Castellón. ${ }^{518}$

El 16 de octubre de 1884, el Gobernador civil suprimió los lazaretos provinciales de Almenara y Vinaroz, y se ordenó que todo el personal asignado a dichos lazaretos volviera a Castellón.

Según parece con la misma precipitación que se establecieron quedaron suprimidos dichos lazaretos que, en opinión general, únicamente sirvieron para gastar infructuosamente unos cuantos miles de pesetas «sacadas de la Caja provincial».

En el lazareto de Vinaroz, todos los pasajeros indocumentados que llegaban a dicha población eran detenidos y conducidos en una tartana al lazareto establecido en la ermita de San Sebastián y los tartaneros regresaban después a la ciudad.

El administrador del lazareto y los diputados provinciales de Castellón salían y entraban a la población; las monjas bajaban a oír misa, el ermitaño iba a recoger las limosnas, etc.

Los carros con las caballerías cargados de frutas y verduras llegaban a la población y sin embrago los carreteros eran detenidos y llevados al lazareto. ${ }^{519}$

Mientras tanto, seguían llegando noticias alarmantes de la propagación del cólera en París y los periódicos insertaban algunas medidas preventivas que se debían adoptar para librarse del cólera, y los cuidados que debían darse a los enfermos.

\subsection{MEDIDAS, CONSEJOS Y REMEDIOS A LA POBLACIÓN PARA LA PREVENCIÓN DEL CÓLERA EN 1884}

En la prensa, mientras había noticias sobre si llegaba el cólera, se daban consejos ya difundidos en meses anteriores. Para prevenir el cólera había que evitar todas las causas de debilidad o de depresión física o moral, así como evitar todas las causas de enfriamiento (llevar vestidos de abrigo, particularmente un cinturón o faja de franela y no dejar abiertas las ventanas de la habitación, por la noche etc.).

\footnotetext{
518 Ibídem.

${ }^{519}$ La Provincia, 16/10/1884.
} 
También se decía que las aguas de bebida habían de ser puras, mejor las aguas minerales naturales, y si esto no fuera posible, beber una infusión ligera de quinina. De igual modo se podía beber en el almuerzo té o cerveza, y en la comida vino puro y abstenerse de bebidas heladas.

Debían evitarse las ensaladas, las uvas y los rábanos, y las frutas tomarlas bien peladas y mejor cocidas. Asimismo debía hervirse el agua de tocador y en particular para uso de la boca. Y, por último echar agua todos los días en los excusados y especialmente por la mañana dos o tres litros con 50 gramos de sulfato de cobre o cloruro de zinc.

Para cuidar a los enfermos se decía que el cólera ataca rara vez de una manera fulminante. Casi siempre le precedía un periodo prodrómico, caracterizado por la diarrea, abatimiento, nauseas, etc. Si esto ocurría era preciso llamar al médico, acostarse, calentarse, especialmente los pies, con botellas de agua caliente y franela y colocarse una cataplasma caliente sobre el vientre.

El enfermo si no vomitaba, podía beber en pequeñas dosis té con ron o aguardiente. Si vomitaba, era mejor champagne helado. Para las diarreas, después de cada deposición, debía tomar 15 o 20 gotas de elixir paregórico ${ }^{520}$ en una cuchara mezclado con alcohol de menta o de 15 a 20 gotas de «tintura etérea de valeriana, 10 gramos; Laudanum de Sydenham, 4 ; alcohol de melisa, 6 ; Iodoformo, 0,50; esencia de menta inglesa, 10 gotas». ${ }^{521}$

El cuarto del enfermo debía estar ventilado, y no debían entrar en él más que las personas necesarias para su cuidado.

Para las deposiciones, se aconsejaba tener en el vaso de noche una solución de sulfato de cobre o cloruro de zinc, 50 gramos por litro de agua; arrojarse pronto estas materias y volver a poner la solución en el vaso. Los lienzos que se hubieran usado debían meterse en un cubo de la misma solución, o a poder ser quemados cuanto antes.

Después de la curación o defunción del atacado había que proceder a la desinfección del cuarto.

A las personas que estaban al cuidado del enfermo, se les aconsejaba lavarse frecuentemente las manos, la cara y la boca, con una solución de ácido búrico o ácido

\footnotetext{
${ }^{520}$ El elixir paregórico es una mezcla de opio y alcohol. Su uso básico era como antidiarreico.

${ }^{521}$ La Provincia, 20/11/1884.
} 
fénico y quitar inmediatamente la ropa salpicada por las deyecciones y lavarlas con una solución de sulfato de cobre.

Se decía que el cólera atacaba a las personas debilitadas o delicadas, y que la calma de espíritu y las condiciones higiénicas, permitían la mayor parte de las veces, evitar el contagio. ${ }^{522}$

Un elemento que se creía tener algún efecto para prevenir el cólera era el cobre. Se tenía que aplicar en el estómago una lámina muy delgada del referido metal, de unos diez centímetros de ancho por quince de longitud.

Tal procedimiento se fundaba en que todas las personas que directamente manejaban dicho metal, como los forjadores, caldereros, músicos, etc., no eran atacadas por la enfermedad epidémica. Se observó que en una banda de música, cuando reinaba el cólera, fallecían algunos de los que tocan instrumentos de percusión, mientras que permanecían libres los músicos que tocaban instrumentos de metal, por ser estos en su mayoría fabricados con cobre y otro metal formando aleación.

Otro remedio que publicaba la prensa para prevenir el cólera era tomar por la mañana, antes del desayuno, dos dedos de agua, diluyendo en ella dos gotas de cloroformo, y seguir la toma en la misma dosis mientras durara la epidemia.

Con tan sencillo procedimiento, unido a un régimen higiénico, lograron, según dicen, algunos individuos en la invasión de 1854 y 1865, no verse atacados, a pesar de estar cuidando y asistiendo a coléricos.

La prensa de Castellón también publicaba las noticias que sobre prevención del cólera publicaban los periódicos franceses, uno de ellos era Le Figaro que explicaba el medio para combatir el cólera, consistente en primer lugar, no cambiar los hábitos ordinarios, no tomar medicamentos y seguir el consejo de un tal doctor Vulpian que consistía en hacer uso durante la epidemia, del ácido salicílico a la dosis de un gramo por día distribuido en varias tomas en una bebida cualquiera (café, té, vino o licor). Según explican, la acción del ácido salicílico eliminaba completamente el microbio del cólera.

También se aconsejaba como preservativo del cólera el ron, «bebido discretamente» pues en Marsella y Tolón se tomaba en abundancia. ${ }^{523}$

\footnotetext{
522 Ibídem.

${ }^{523}$ La Provincia, 10/07/1884.
} 
Los remedios contra el cólera proliferaban, por ejemplo para la diarrea se recomendaba una infusión de menta sazonada con pimienta, y beber cada cuarto de hora, media taza muy caliente y convenientemente azucarada, añadiéndole dos cucharadas de ron o coñac viejo, y veinte gotas de extracto de canela. Inmediatamente, si el enfermo se sintiera con fuerzas para ello, debía pasearse aprisa, procurando con un ejercicio violento llamar el sudor; pero si estuviese débil y abatido, debía acostarse y administrarle medio vaso de agua fresca y una cucharadita de éter sulfúrico. Después debía abrigarse bien para sudar, y seguir tomado cada cuarto de hora la citada infusión hasta que las deposiciones desaparecieran; en la mayoría de los casos, se conseguía en menos de tres horas.

Si la bebida producía embriaguez al enfermo, indicaba que estaba fuera de peligro.

Si tenía vómitos, en lugar de la infusión se le daba a beber, cada cuarto de hora, una copita de coñac viejo; y si tuviera sed, se le da bocanadas de agua seltz o bien pedacitos de hielo que debía dejar derretir en la boca. Además se le debía aplicar sinapismos en el estómago y el vientre, no quitándolos hasta que la piel empezara a enrojecer y el enfermo a sentir un vivo escozor.

Con estos medicamentos sencillos se combatía los primeros síntomas de la enfermedad.

En el periodo álgido de la enfermedad, se recomendaba bebidas o infusiones aromáticas alcoholizadas, ayudas de agua fresca con bastante éter sulfúrico, fricciones con bayeta bien enjuta, o bien con extracto de alcanfor, de espliego, etc., y empleando el calor artificial, es decir, de cuanto pueda reanimar la circulación de la sangre y castigar el sistema nervioso.

En la convalecencia del enfermo aparte de comer ligero para no sobrecargar el estómago, los hombres debían tomar después de la comida, una copita de licor, y las mujeres una infusión de menta por la noche, precedida de ocho gotas de éter en un terrón de azúcar. ${ }^{524}$

Como vemos proliferaban todo tipo de consejos y preservativos; muchos de los medicamentos contra el cólera se vendían a la población por personas sin escrúpulos. Tanto es así que los farmaceúticos veian usurpados sus derechso por una multitud de

\footnotetext{
${ }^{524}$ La Provincia, 31/08/1884.
} 
vendedores que aprovechándose, por causa de la epidemia colérica, del miedo y alarma del pueblo, vendían toda clase de sustancias medicinales, incluso las más activas y venenosas. Éstos profesionales elevaron al Gobernador de la provincia una solicitud para que hiciera cumplir la Real Orden de 16 de junio de 1885. En dicha solicitud se experesaba que los farmaceúticos eran los únicos profesionales responsables ante la ley que podían vender los medicamentos, y los únicos que al expenderlos podían ofrecer garantías sólidas de buena calidad y de buena preparación. ${ }^{525}$

\section{1885, SE CUMPLEN LOS TEMORES DE LA DIFUSIÓN DEL CÓLERA}

El 20 de noviembre de 1884 aparece en la prensa la declaración oficial del cólera en el pueblo de Beniopa, allí estuvieron el Gobernador civil y los doctores Amalio Gimeno y Manuel Candela que confirmaron la enfermedad del cólera.

De esta declaración se levantó acta, y en la misma consta que las trece defunciones ocurridas anteriormente habían sido producidas por el cólera.

De cómo se había importado la epidemia a este pueblo, nada se sabía en definitiva.

Lo que se decía es que la primera invasión ocurrió en una mujer que se dedicaba a la venta de ropas, y que por motivo del tráfico que se dedicaba, estuvo algunos días ausente del pueblo.

Se sospechaba también que pudo llevarlo un grupo de gitanos que se cobijó en una cueva inmediata al pueblo. ${ }^{526}$

Empieza la alarma en la ciudad de Játiva por haberse presentado una enfermedad contagiosa, y los enfermos morían mientras los médicos discutían si era cólera morbo o nostras 527

El último parte de Játiva era poco tranquilizador, pues había muchas enfermedades del aparato digestivo. Se esperaba un diagnostico por parte de la comisión

\footnotetext{
${ }^{525}$ Revista Médico-Farmacéutica, 17/11/1885 pp. 306-307.

526 Ibídem.

${ }^{527}$ La Provincia, 29/03/1885.
} 
enviada por el Gobernador de Valencia, entre los miembros de dicha comisión figuraba los doctores Amalio Gimeno y Manuel Candela.

La primera autoridad civil de la provincia de Valencia dirigió una circular al ayuntamiento de Játiva, con gran número de copias para que se trasladara también a todos los pueblos del distrito, previniendo que los facultativos, bajo su responsabilidad, comunicaran el parte diario de los enfermos a los que asistían.

Seguidamente ordenaba que se reuniera la Junta de Sanidad de cada uno de los pueblos, acordando las medidas y precauciones que juzgaran oportunas adoptar.

También mandaba que la comisión de Salubridad pública se dividiese en subcomisiones, recorriendo las calles, cárceles, casas, investigando los focos perjudiciales a la salud pública, al mismo tiempo, debían inspeccionar los alimentos y las casas de comidas y bebidas. ${ }^{528}$

La Provincia se pregunta qué medidas de policía sanitaria se han tomado en Castellón y demás pueblos de la provincia ante la existencia del cólera en algunos pueblos de Valencia. ${ }^{529}$

Las medidas higiénicas dictadas por la Junta Provincial de Sanidad en 1884, bastaron para disminuir la mortalidad de las enfermedades ordinarias.

Pero los consejos higiénicos cayeron en desuso, a pesar del peligro de ser invadidos por la enfermedad sospechosa, ni se habían reproducido los acuerdos de las juntas, ni se hacía nada para prevenir la epidemia. Se llama la atención del Gobernador. $^{530}$

El 31 de mayo La Provincia anuncia la salida para Valencia del doctor Ferrán, y con él la comisión que el Gobierno enviaba para estudiar la enfermedad calificada de sospechosa, que se había extendido en algunos pueblos de la Ribera, para emitir su dictamen sobre el descubrimiento del doctor tortosino.

Dicha comisión, la presidia el doctor Francisco Alonso y Rubio, presidente de la Facultad de Medicina de la Real Casa, y formada por otros médicos como Maestre de San Juan, Sanmartín y Mendoza, llevaban instrucciones concretas redactadas por el ministro de la Gobernación, de acuerdo con la Academia de Medicina y el Consejo Superior de Sanidad. Su misión consistía en examinar y decidir si era o no el cólera

\footnotetext{
${ }^{528}$ La Provincia, 5/04/1885.

${ }^{529}$ La Provincia, $9 / 04 / 1885$.

${ }^{530}$ La Provincia 28/05/1885.
} 
morbo asiático la enfermedad reinante en determinados pueblos de la provincia de Valencia; dar audiencia a cierto número de vacunados para hacerles las preguntas que estimaran convenientes; examinar los cultivos preparados por el doctor Ferrán; decidir si habían de practicar nuevas inoculaciones experimentales en animales o en personas y caso de decidirse por esto último, habían de ser mayores de edad que se prestaran al ensayo y quedarán al cuidado de la comisión durante el periodo necesario para su examen.

Quedaba facultado el gobernador de la provincia para agregar a la comisión aquellos médicos que por su práctica y por su ciencia pudieran auxiliarla en sus estudios, lo cual hacía suponer que no se trataba de excluir ni de rechazar las opiniones que contra las inoculaciones habían emitido doctores tan reputados como Grean, Moliner, Crous y otros que como ellos opinaban.

La prensa de Castellón se congratula de que llegara el momento de decidir lo que se había dado en llamar enfermedad sospechosa que tanta alarma producía y que tanto daño hacia al comercio y que tan poco favorecía a la ciencia médica.

«Pronto sabremos pues, a qué atenernos sobre este particular, y al propio tiempo se logrará que brille al Dr. Ferrán si su invento tiene la sanción que de verdad le deseamos, en bien suyo y de la humanidad». ${ }^{531}$

Según decía El Mercantil Valenciano, (publicado por La Provincia) la Comisión continuaba el 3 de junio en Valencia, sin novedad en su importante salud.

«Así llevamos perdidos cuatro días, que a razón de cinco mil reales diarios, calculando por lo bajo, importan mil duros. Lo más importante no son los mil duros, sino el tiempo que se pierde para calmar la expectación general y hacer la luz».

La opinión pública necesitaba saber tres cosas y una de ellas con urgencia. La primera era el diagnostico que se pudo hacer el primer día; la segunda, si el procedimiento de la inoculación Ferrán podía o no causar perjuicios a la salud de los vacunados y, por último, si el preservativo de Ferrán era preservativo o no.

Una vez comprobado el carácter inofensivo de la vacuna, debía levantarse la prohibición que sobre ella pesaba, «salvando de esa manera el Gobierno la inmensa responsabilidad moral que pudiera contraer».

${ }^{531}$ La Provincia, 31/05/1885. 
El día 4 de junio de 1885, a las diez de la mañana se reunieron en el laboratorio de la Facultad de Medicina de Valencia los individuos que componían la comisión oficial para hacer el análisis de los líquidos atenuados del microbio del cólera, procediendo a sembrar cultivos puros de vírgula y someterlos posteriormente a observación. Fueron guardados, bajo llave, unos cincuenta gramos de líquido vacuna de Ferrán. $^{532}$

Una carta de Valencia del 13 de junio de 1885 relata que iba en aumento el apasionamiento de los ánimos por la cuestión Ferrán y la comisión encargada de estudiarlos. Crecía el número de los partidarios de la inoculación, porque las estadísticas arrojaban resultados muy favorables. Eran en aquellos momentos más doce mil los inoculados, y después de los cinco días que pedía el doctor Ferrán para que haga efecto la operación, no había muerto nadie. No sólo en los pueblos donde se habían hecho las inoculaciones en mayor escala, como Alcira, Alberique y Algemesí, sino también en Valencia, eran muchos los que clamaban porque se les permitiera vacunarse. Cuando la comisión oficial pidió cien conejillos de las Indias para hacer este experimento, el Ateneo científico y literario ofreció, en vez de aquellos animales, cien de sus socios. Y solemnemente, ante la comisión, cien ateneístas, entre los que se encontraban eminencias del foro, de la catedra de las letras y las artes del periodismo, la flor y nata de la Valencia intelectual presentaron su brazo a la jeringuilla del doctor Ferrán.

Generalmente se criticaba que dicha Comisión Oficial, tan respetable por las eminencias médicas que la componían, careciera de la libertad de acción que necesitaba. Aparecía constantemente cohibida por el señor Castellote, delegado administrativo, que había puesto a su lado el ministro de la Gobernación, y por el Gobernador de Valencia, que no eran favorables al doctor Ferrán. La comisión se propuso ir a algunos pueblos, se hizo pública su resolución, y después tuvo que prescindir de ella por inconvenientes que se les pusieron. Las gentes pedían que dicha comisión pronunciara pronto su dictamen sobre la inocuidad de las inoculaciones para que, si era favorable, las permitiera el Gobierno, y que después siguiera estudiando la cuestión de su eficacia profiláctica, «más difícil de resolver». 533

\footnotetext{
${ }^{532}$ Ver el acta de la reunión para el análisis de los líquidos atenuados de Ferrán en el Apéndice Documental No 2. La Provincia, 4/06/1885.

${ }^{533}$ La Provincia, $18 / 06 / 1885$.
} 
En La Provincia del 21 de junio de 1885, viene un artículo sobre la vacuna de Ferrán, que transcribe las opiniones que en el periódico La Época emite el doctor La Granja, de Boston, según la publican los periódicos de Paris.

Dice que el doctor La Granja, había llegado de Valencia acompañando a los individuos de la comisión designados por el Gobierno para estudiar el cólera. Éste médico había asistido personalmente a todas las experiencias de la comisión y declara que la epidemia no es otra que el verdadero cólera asiático, que se presenta bajo una forma particularmente maligna.

En cuanto al tratamiento profiláctico por la vacuna según el sistema del doctor Ferrán, La Granja cree a ese médico español «hombre absolutamente de conciencia y de honradez», pero no tiene ninguna confianza en su pretendido descubrimiento. Explica el hecho de haber disminuido el número de fallecimientos entre las personas inoculadas, por el estado de fuerza moral como resultado de la confianza que inspira el tratamiento del doctor Ferrán a los enfermos, y que ayuda considerablemente a la obra del médico.

El doctor La Granja opina que, la inoculación no ofrece peligro alguno a condición de que se practique por medio de inyecciones subcutáneas, pero que es en extremo peligrosa desde el momento en que transporta materias fecales e infectantes en cuerpos que están sanos.

Considera como los mejores medios profilácticos el empleo exclusivo de agua hervida y de una alimentación bien cocida y predice un fuerte aumento de la epidemia en otoño, cuando haya comenzado la exportación de los frutos recolectados en los distritos contaminados.

La Provincia publica una carta de un médico notable, el doctor Pulido, dirigida a Romero Robledo, ministro de la Gobernación, sobre el brillante resultado que da en Alcira la vacuna de Ferrán. Describe que entre la población inoculada hubo por debajo de una cuarta parte menos de invasiones que en la no inoculada, así mismo hubo menos muertos entre los vacunados que entre los que no lo hicieron, viniendo a confirmar la eficacia de la vacuna de Ferrán. ${ }^{534}$

\footnotetext{
${ }^{534}$ La Provincia, 28/06/1885. Ver Apéndice documental No 3
} 


\subsection{CONOCIMIENTO DEL ORIGEN DEL CÓLERA EN 1885}

Después de pasada la epidemia del cólera, la Revista Médico-Farmacéutica, comenta lo que se sabía en aquel año sobre el origen del cólera. Según dice, mientras algunos periódicos insignes cantaban los milagros de la vacuna colérica obtenidos por Ferrán, otros no menos significativos como el corresponsal del Britisch Medical Journal, denigraban este medio profiláctico.

En realidad, no se sabía a ciencia cierta la patología del cólera, se intentaba explicar de una manera racional sus síntomas.

Los médicos se planteaban las siguientes cuestiones:

¿Es el cólera una gastroenteritis específica? ¿Depende este trastorno gastrointestinal de la acción del bacilo sobre la túnica intestinal, o es del todo consecutiva a trastornos vaso-motores? ¿Pueden todos los síntomas explicarse, admitiendo estos trastornos neuro-vasculares?

Determinada la cual indican el valor que pueden tener en la terapéutica del cólera la enteroclisis ${ }^{535}$ y la hipodermoclisis. ${ }^{536}$

Estaba indudablemente demostrado que el agente engendrador del cólera era el bacilo-coma de Koch y que la vía por la cual este germen morboso penetraba en el organismo, era la del tubo gastrointestinal.

Cuando el bacilo entra en el intestino, el punto en que se localiza es el intestino; aquí hallan los medios favorables para su cultivo y empieza su maravilloso desarrollo. Pacini, y gran parte de patólogos, admiten que se produce entonces un catarro extenso, rapidísimo, específico, del tubo gastro-intestinal con brusco y extenso desprendimiento epitelial, que Bouillaud llama irritación secretoria, ClotBey verdadera gastroenteritis, y del cual opinan que depende la forma clínica del cólera.

Se preguntan si es posible que el cuadro sintomatológico del cólera -diarrea abundante, opresión epigástrica, vómitos, sed intensa, cianosis, enfriamiento, éxtasis del

\footnotetext{
${ }^{535}$ Enteroclisis: Inyección de un líquido en el intestino por vía rectal.

${ }^{536}$ Hipodermoclisis: Introducción en el tejido subcutáneo de gran cantidad de líquido, especialmente de solución salina fisiológica. Es una manera de reemplazar los líquidos que se han perdido a través del vómito, sudor o diarrea.
} 
círculo sanguíneo- podía depender de la simple acción del bacilo. Cuando en la autopsia de los coléricos, se abría el intestino, se hallaban gran número de alteraciones, que no tenían que ver con los trastornos que se encontraban en los enfermos. Según veían había una falta de concordancia ente los síntomas morbosos y los hechos necroscópicos.

Pensaban que el cólera no era una enfermedad local, sino general, cuyo foco de intoxicación estaba localizado en el tubo intestinal.

Había muchos casos de cólera en los que faltaba la diarrea y los vómitos, o eran posteriores a los demás síntomas generales.

Eran comunes los casos de cólera con pérdidas acuosas mínimas, con graves fenómenos morbosos, faltando en la mitad de los casos el vómito.

Admitían muchos autores que el solo desecamiento de los tejidos, debido al espesamiento de la sangre por las grandes pérdidas de suero, mataba al enfermo colérico.

La explicación de todos los síntomas era la intoxicación de la sangre. Pero aquí surgía la pregunta ¿era el mismo bacilo, que absorbido y penetrando en la sangre, la altera en términos de producir un estímulo anormal sobre el sistema nervioso, en especial sobre el simpático en sus ramificaciones vasomotoras; o era un veneno segregado por el bacilo, o una ptomaina ${ }^{537}$ que de él toma origen, o es una intoxicación por otros principios anormales que se mezclan con la sangre? ${ }^{538}$

Hoy en día se define el cólera como una enfermedad infecto-contagiosa aguda de origen bacteriano, endémico de la zona del Golfo de Bengala pero poco frecuente en nuestro medio. Evoluciona con diarreas abundantes que pueden comportar la deshidratación, el estado de choque y la muerte.

El agente etiológico es un bacilo denominado Vibrio cholerae, que se clasifica dentro del género Vibrio por el hecho que tiene una forma muy alargada y delgada, y porque está dotado de gran movilidad. El hábitat natural de este bacilo es el organismo de las personas infectadas. La fuente de infección está determinada por los alimentos y aguas contaminadas con materias fecales de personas infectadas, enfermos, y sobretodo, portadores. La vía de contagio es fecal-oral.

\footnotetext{
${ }^{537}$ Nombre con que se designa una serie de substancias originadas, principalmente en los cadáveres en putrefacción, por la degradación bacteriana de las materias albuminoideas.

${ }^{538}$ Revista Médico-Farmacéutica, 17/11/1885 pp. 312-314.
} 
Después de ingresar en el organismo por vía digestiva, el germen se establece y se multiplica en la mucosa intestinal. En esta localización, el bacilo produce una enterotoxina muy potente, denominada coleragen, que origina una activación enzimática de las células intestinales, que provoca la salida de importantes cantidades de agua y minerales desde la pared hasta la luz del intestino; esta es la causa de las diarreas abundantes y acuosas que caracterizan el trastorno. En muchos casos, después de remitir la sintomatología, los bacilos continúan eliminándose con las materias fecales durante unos meses o un año; en casos poco frecuentes, la persona infectada se puede convertir en eliminador permanente del germen al situarse éste en su vesícula biliar, de manera que se convierte en un portador sano que puede transmitir la enfermedad a través de sus deposiciones. La inmunidad que genera el proceso infeccioso protege el organismo solo unos meses.

El cólera es endémico en Pakistán, la India y Bangladesh.

El periodo de incubación es de 12 a 48 horas.

La enfermedad se inicia con diarreas intensas. Las deposiciones son abundantes, frecuentes y acuosas, y se pueden expulsar hasta un litro cada hora. Tienen una tonalidad y aspectos similares al agua de arroz. También son frecuentes los vómitos, que se producen con espontaneidad, ya que no son precedidos por nauseas. Al contrario de otros procesos infecciosos digestivos, el cólera no cursa con síndrome febril ni dolor abdominal. Después de unas cuantas deposiciones, es habitual que el enfermo comience a experimentar algunas manifestaciones debidas a la incipiente deshidratación, como la sensación de hormigueo, debilidad y calambres en las extremidades.

Si se procede al tratamiento antibiótico adecuado durante las fases iniciales, las manifestaciones suelen remitir al cabo de tres o cuatro días de aparecer. En el resto de los casos es habitual que se presente un estado de deshidratación completo que, en los casos graves, puede ocasionar el choque, el coma y la muerte.

La diagnosis se realiza a partir de las características de las deposiciones y los antecedentes de exposición al contagio, y la confirman aislando y cultivando el germen a partir de las materias fecales.

El tratamiento se ha de realizar en una unidad hospitalaria, y hay que ingresar el enfermo de forma urgente para que siga hidratado con rapidez, como también aislarlo en una habitación individual. La terapéutica consiste en la administración de diversos tipos de antibióticos durante una semana aproximadamente. Paralelamente se prevé o se trata 
la deshidratación con la administración de líquidos y de sales por vía intravenosa. Durante el tratamiento, el reposo en la cama ha de ser absoluto, y la dieta blanda y antidiarreica.

La profilaxis se basa en evitar el consumo de agua o de alimentos contaminados. En épocas de epidemias y en áreas endémicas conviene no consumir agua ni alimentos sospechosos; previamente a ingerir, hay que hervir o clorar las bebidas, como también conviene hervir o limpiarse con agua clorada los alimentos. Además hay que aislar a los enfermos en habitaciones individuales y garantizar la correcta higiene y la desinfección de las deposiciones, objetos de uso personal y la ropa, como también detectar y tratar los portadores sanos, administrar antibióticos a las personas que entran en contacto con el enfermo, y procurar que, a los alimentos, no lleguen moscas. Por otra parte hay una vacuna anticolérica elaborada con bacilos muertos que se administran en dos dosis separadas por un intervalo de entre una semana a cuatro, y se aplica a las personas que tienen planificado un desplazamiento a zonas endémicas en un periodo de entre un mes a seis, que es el lapso de tiempo durante el cual persiste la inmunidad que genera esta vacuna. $^{539}$

\subsection{SÍNTOMAS Y TRATAMIENTO MÉDICO DEL CÓLERA}

El concepto que se tenía del cólera morbo-asiático es que era un envenenamiento producido por un agente morboso atmosférico, que la física y la química no habían llegado a descubrir como tampoco habían demostrado estas ciencias la causa de la gripe, el sarampión, etc.

La causa determinante del cólera, siendo externa y contagiosa necesitaba, sin embargo, del concurso de otras causas para desarrollar su acción.

La entrada en el organismo del agente colérico tenía lugar al inspirar el aire atmosférico, y al ingerir los alimentos y bebidas.

La mucosa del tubo digestivo es la que tiene mayor aptitud para absorber el agente morboso.

\footnotetext{
539 VERGER I GRAU, Guillem (1991): «Enfermedades infecciosas» en DEL HOYO I CALDUCH, Josep (Coord.): Enciclopedia de Medicina i Salut. Malalties infeccioses. Sistema immunitari. Genética. Vol. 7. Enciclopedia Catalana, Barcelona. pp. 146-147.
} 
La intensidad y rapidez del mal estaban en razón directa de la mayor o menor fuerza del agente del cólera, o de la mayor o menor resistencia del organismo para rechazarle.

Los vómitos y la diarrea eran los esfuerzos que hace la naturaleza para eliminar el agente morboso.

Si por medio de los vómitos y deposiciones albinas se conseguía la total expulsión del principio venenoso, la enfermedad no pasaba más allá del primer periodo, que se conocía con el nombre de colerina, el cual no era otra cosa que un catarro gastrointestinal.

Si no se eliminaba completamente el agente colérico, entonces se absorbía, presentándose enseguida las alteraciones de la circulación, respiración, inervación, etc., es decir, el mal entraba ya en su segundo periodo, denominado algidez.

Los casos de cólera seco no eran más que «la absorción directa del agente morboso por la sangre que se encuentra en las últimas ramificaciones que constituyen el árbol pulmonar».

Los medios para combatir el cólera iban dirigidos a expulsar el agente venenoso, prevenir la absorción, y cuando ésta ya hubiese tenido lugar, a activar todas las funciones vitales para que reaccionaran contra el principio morboso, y de esta manera ver de lograr su completa eliminación de la economía.

Se aconsejaba el aceite esencial de trementina (resina de los pinos, abetos, alerces y terebintos) para favorecer el vómito, modificar la mucosa gastrointestinal, haciéndola menos apta para la absorción, desarrollando, por último, una actividad mucho mayor en todas las funciones vitales, principalmente en la circulación, respiración y diaforesis (sudor).

La dosis a que debía administrarse la esencia de trementina debía variar entre treinta centigramos a quince gramos según la intensidad del mal. Si no se toleraba el aceite se aconsejaba emplearlo en enemas. ${ }^{540}$

Para aminorar los estragos de la posible invasión del cólera, el Gobierno aconsejaba diversos desinfectantes, ya nombrados anteriormente. Para desinfectar las habitaciones y lugares insanos se recomendaba, como más eficaz, la pólvora, que «quemada, por la mezcla compleja de gases que produce, responde perfectamente al

\footnotetext{
${ }^{540}$ Revista Médico-Farmacéutica, 27/06/1884 pp. 104-105.
} 
objeto». Para la desinfección de letrinas, depósitos de aguas sucias, etc., el sulfato ferroso del comercio (caparrosa verde), tranquilidad de ánimo y no alterar en nada las costumbres de cada uno, evitando los enfriamientos repentinos y el abuso de helados y bebidas alcohólicas. ${ }^{541}$

Entre los muchos folletos y libros, nacionales y extranjeros que se publicaban sobre el tratamiento y profilaxis del cólera, figuraba uno titulado Tratamiento específico del cólera, escrito por el doctor Tunisi, coronel del cuerpo de sanidad militar italiano, en el cual recomendaba eficazmente el láudano, (citado anteriormente: preparación a base de vino blanco, opio y azafrán; extracto de opio) en el tratamiento del cólera.

Las conclusiones de dicho trabajo fueron que el cólera confirmado va siempre precedido de la diarrea llamada premonitoria; la diarrea premonitora, a pesar de su aparente benignidad, es el verdadero cólera, confirmado en sus primeras manifestaciones; vencida la diarrea premonitoria no es posible que siga el cólera confirmado; la diarrea premonitoria se vence, y se cura con facilidad con los opiáceos, a la cabeza de los cuales figura el láudano, «medicamento que todas las familias debían tener siempre a mano»; el cólera, una vez dominado el primer estadio, es siempre curable, y se reduce a los límites de una simple indisposición.; el cólera fulminante no existe, por lo menos no ha sido bien observado; el primer estudio del cólera (diarrea premonitoria) suele designarse con el nombres de cólera leve, mientras que se llama grave y gravísimo en los estadios siguientes; administrado a tiempo y a dosis especiales, el láudano es el específico del cólera. ${ }^{542}$

Otro método en el tratamiento del cólera morbo-asiático eran las inyecciones subcutáneas de morfina para combatir las diarreas y calmar el dolor; las de sulfato de atropina para combatir el colapso en esta enfermedad. Con estos dos medicamentos se evitaban los vómitos y los mareos; las inyecciones de taninos recomendadas también para combatir la diarrea; el sulfato de quinina; el uso de las inyecciones de éter para combatir la algidez y el colapso, el aceite esencial de mostaza, etc. ${ }^{543}$

\footnotetext{
${ }^{541}$ Revista Médico Farmacéutica, 17/07/84 pp. 118-119.

542 Ibídem, pp. 134-135.

${ }^{543}$ Ibídem, pp. 135-138.
} 
Un desinfectante considerado importante era el «ácido hiponítrico», destructor del microorganismo patógeno, que además era considerado como regenerador del ozono, que a su vez combatía rápidamente la asfixia. ${ }^{544}$

Otro tratamiento terapéutico era el carbón vegetal de pino de Flandes o de álamo, en polvo, bien tamizado en una infusión de manzanilla o salvia para facilitar su deglución.

Según se explicaba, el carbón vegetal actuaba sobre los intestinos como antiséptico y como absorbente, primero, ejerciendo una acción especial sobre el parasito por sus propiedades antisépticas, y segundo, absorbiendo y neutralizando los líquidos que bien el parásito, o bien la mucosa segregaban. ${ }^{545}$

Proliferaban fórmulas diversas para el tratamiento del cólera o como preservativo entre las principales figuraban:

El ácido tímico 12 gramos al día, en capsulas de 2 gramos

Desinfectantes para las letrinas:

Sulfato ferroso, 500 gramos

Agua, 10 litros

Ácido Fénico, 100 gramos

Etc.

Otro tratamiento que se recomendaban contra el cólera era la administración de calomelanos (protocloruro de mercurio sublimado, es un purgante, vermífugo y antisifilítico.) seguida inmediatamente de una ducha fría repetida varias veces. Con ello, según decían, se suspendían las diarreas, y se conseguía la reacción. ${ }^{546}$

El sulfato de estricnina como anticolérico se recomendaba para combatir las diarreas blandas. Se decía también que la estricnina, además de su acción sobre la medula espinal y sobre el sistema simpático podía matar al microbio del cólera teniendo también una acción parasiticida. ${ }^{547}$

\footnotetext{
${ }^{544}$ Ibídem, p. 142.

${ }^{545}$ Revista Médico-Farmacéutica, 7/08/84 pp. 151-152.

${ }^{546}$ Revista Médico-Farmacéutico,.27/08/1884 pp. 168-169.

${ }^{547}$ Ibídem, pp.170-171.
} 
La Revista Médico-Farmacéutica se preocupa por difundir los remedios médicos y publica un artículo que comenta los consejos y opiniones de Robert Koch.

En una conferencia sobre el cólera que Robert Koch dio en el hospital de Pharo en Francia, afirmó que el microbio del cólera era un organismo que se reproducía por escisión, y vivía en un líquido que debía ser alcalino, se destruía con los ácidos y sobre todo, con la sequedad. Tres horas de desecación bastaban para matarlo con las deyecciones. Sus vías de ingestión eran la boca, las vías digestivas y los intestinos.

Si existía en el aire, formando una especie de polvo, penetraba en los intestinos y se reproducía rápidamente.

Preguntado por las medidas profilácticas, Koch respondió que viviendo el microbio, si las materias que lo contienen van a parar al agua, el germen virulento se propaga. Se propagaba, pues, por el agua que sirve para lavar las ropas, las legumbres y los alimentos. La primera medida higiénica consistía en prescribir rigurosamente el uso de los alimentos cocidos, en los cuales el microbio no existe.

El tratamiento que prescribía Koch era el opio en el primer periodo; en el periodo álgido recomendaba suspender el opio y dar un castrante.

Consideraba como desinfectantes ineficaces el cloruro de zinc, el sulfato de hierro y las sales de mercurio.

Preguntado acerca de los medios personales para librarse de la epidemia, contestó que él se lavaba las manos con licor de Van Sweten (este licor era un solución de «bicloruro de mercurio», que era considerado por él mismo como ineficaz), comía alimento cocidos y bebía agua hervida. 548

Koch explicaba que el microbio del cólera se hallaba rara vez en el estómago. Durante la epidemia se perturbaban las funciones digestivas, la pesadez de estómago hacía que el microbio no se hallara bien en él y que se refugiara en el intestino grueso. En este se multiplicaba hasta el infinito, tanto en los tejidos como en los líquidos. Por esta causa sobrevenían las deposiciones y vómitos, y como consecuencia, una coagulación de la sangre que llegaba a no poder circular.

Después llegaba el espasmo. El microbio además segregaba un humor que era un verdadero veneno, y este producía el cólera que terminaba con la muerte del individuo:

\footnotetext{
${ }^{548}$ Revista Médico-Farmacéutica, 17/07/84 pp. 119-120.
} 
Me decís que con estas indicaciones el microbio debería ser pronto destruido: pero yo no curo observo. A otros toca aplicar lo que descubro y aconsejo. La infección, como ya he dicho, no se propaga por el aire, sino por la absorción de los microbios en el tubo digestivo con las comidas y las bebidas.

Por ello, aconseja a las autoridades cerrar los pozos de agua de beber, y al público de beber agua hervida, o agua de manantiales situados lejos de centros infestados, o agua ligeramente mineral. De ahí también la necesidad de comer cosas que hayan pasado por una alta temperatura, principalmente las verduras; y en cuanto a la fruta, conviene pelarla o hervirla.

El microbio muere si se le expone a una temperatura alta y sobre todo seca. Se transmite solo únicamente en las deposiciones o en los objetos que éstas manchan. La primera precaución, por consiguiente, es exponer las ropas de los enfermos a un calor seco, o desinfectarlas con una solución algo fuerte de ácido fénico, o exponerlas en un aire muy seco.

Cualquier prenda de ropa, una vez seca, no ofrece peligro, porque el microbio ha muerto y no puede reproducirse. Por esto recomienda cerrar por unas horas las habitaciones infestadas y secarlas. Desaconseja regar las calles porque crea las mejores condiciones para la reproducción y desarrollo del microbio.

También considera que el desinfectar a los viajeros, sus equipajes y las cartas, es una precaución ilusoria; «no comprendo cómo puede tomarse en serio».

En cuanto al origen de la epidemia, Koch creía que la había traído algún buque inglés, «pues no tienen estos escrúpulos en ocultar las muertes ocurridas durante la travesía y falsificar los libros de abordo».

Afirma que es contrario a las grandes aglomeraciones de gente en las ferias y mercados y que deberían suspenderse. ${ }^{549}$

La misma revista publica que el cónsul español en Marsella remitió a la Dirección de Sanidad la traducción de una Memoria pedida por aquel consulado al doctor F. Fiouppe, antiguo interno de los hospitales de Paris, en la que se describe la sintomatología del cólera.

\footnotetext{
${ }^{549}$ Revista Médico-Farmacéutica, 27/08/84 pp. 178-180.
} 
Según esta memoria, el cólera que se desarrolló en Marsella se presentó bajo tres formas que se designaron con los nombres de cólera mucoso, cólera seroso y cólera asfíctico.

La forma mucosa era la menos grave y la más frecuente, se presentaba con diarrea y sin cólicos, apareciendo la fiebre por la mañana temprano, falta de apetito, lengua blanca y espesa, sed y nauseas. Este estado duraba de uno a dos días y después se volvía a la normalidad. Si persistía la diarrea, la enfermedad se transformaba en cólera seroso o colerina.

En el cólera seroso, las deposiciones son muy líquidas. A la diarrea siguen rápidamente los vómitos una gran opresión y fuertes dolores de estómago, sofocación y una sed insaciable. Si la enfermedad continua haciendo progresos sobrevienen los calambres en los miembros, la piel se pone viscosa o fría, las uñas tienen un color azulado, la orina disminuye o cesa y la voz se extingue. Tres casos suelen presentarse; o bien cesa la diarrea a las doce horas o un día, desaparecen los vómitos, se restablece el calor en el cuerpo y el enfermo recupera la salud, o bien, y es la marcha que siguió la enfermedad durante esta epidemia, sobreviene una mejoría que no es más que aparente y termina en la tercera forma, el cólera asfíctico.

En esta fase terminan las diarreas y persiste la sed y los calambres, los ojos se hunden en las orbitas, la piel se enfría y endurece, la voz se extingue y el pulso cesa.

Todos los enfermos que llegaban a esta fase morían en el intervalo de dos a treinta y seis horas. El enfermo se salvaba si era tratado al principio de la enfermedad, pero moría cuando el mal ya había tomado cierto incremento.

Por eso se recomendaba adoptar un buen régimen higiénico, evitando los desórdenes gastrointestinales y tratar como si fuese una enfermedad seria la menor alteración de las funciones digestivas.

Se recomendaba que, fuera del sistema clásico (opio, hielo, bebidas gaseosas, champagne, acetato de amoniaco, fricciones con esencia de trementina, sobre el vientre) no se conocían otros remedios que pudieran producir resultados satisfactoritos. ${ }^{550}$

Un médico de Castellón, el doctor Félix Roig, director del Hospital Provincial de Castellón, escribió en el periódico La Provincia, cinco artículos sobre consideraciones generales e higiene del cólera. En ellos da a conocer lo que se sabe del cólera y los

\footnotetext{
${ }^{550}$ Ibídem.
} 
recursos que tiene la ciencia como más eficaz para combatirlo y evitar el empleo de drogas específicas y amuletos casi siempre perjudiciales.

Se limita a ordenar y a razonar las ideas de las personas más competentes en este tema.

Comenta que la higiene es la única garantía contra la epidemia. No sabe que es el cólera, pues «después de tantos estudios y observaciones prolijas, en realidad no lo sabemos». Sin embargo dice que «la opinión que cada día gana terreno, es la que considera al principio morbífico como un ser vivo, dada su evolución y reproducción».

Continua diciendo que se conocen los efectos de la enfermedad y «que no es tan mortífera como el miedo lo pinta, y la medicina tiene, respecto a esta dolencia, la certeza que en otras muchas enfermedades».

El doctor Félix Roig estaba al día sobre la naturaleza del cólera, los medios por donde se transmite y los agentes directos o indirectos que podían servir para atacar su evolución.

Su objetivo al hacer estos escritos no era decir novedades después de cuanto habían publicado los periódicos, sino inculcar en el ánimo las ventajas de los preceptos higiénicos, exponiéndolos de manera que lo entendiera toda la gente. ${ }^{551}$

\subsection{COMIENZO DEL CÓLERA EN CASTELLÓN}

A mediados de Junio la salud de Castellón continuaba siendo inmejorable, y según dice La Provincia no había motivo de alarma. Había algunos casos de cólicos que todos los veranos se repetían.

El 14 de junio de 1885, La Provincia daba cuenta de los muertos habidos en Castellón haciendo hincapié que de 32 muertos (22 párvulos y 10 adultos), tan solo uno murió de cólicos. Para afirmar de una manera absoluta que la salud que reinaba en Castellón era excelente, copia el número de defunciones habidas durante los días del mes de junio, en una población de 30.000 habitantes: ${ }^{552}$

\footnotetext{
${ }^{551}$ La Provincia, 13/07/1884, 17/07/1884, 24/07/1884, 27/07/1884, 3/08/1884. Véase en Apéndice Documental $\mathrm{N}^{\mathrm{o}} 4$, los cinco artículos del doctor Félix Roig sobre consideraciones generales e higiene del cólera.

${ }^{552}$ La Provincia, 14/06/1885.
} 
Tabla 1. Defunciones durante el mes de junio en Castellón.

\begin{tabular}{|c|c|c|}
\hline Días & Párvulos & Adultos \\
\hline 1 & 4 & 2 \\
\hline 2 & 1 & 2 \\
\hline 3 & 2 & 0 \\
\hline 4 & 1 & 1 \\
\hline 5 & 4 & 0 \\
\hline 6 & 4 & 1 \\
\hline 7 & 1 & 0 \\
\hline 8 & 0 & 0 \\
\hline 9 & 0 & 0 \\
\hline 10 & 1 & 2 \\
\hline 11 & 2 & 1 \\
\hline 12 & 1 & 10 \\
\hline 13 & 22 & 0 \\
\hline Total & $140 / 185$ & 0 \\
\hline
\end{tabular}

Fuente: La Provincia, 14/06/1885. Elaboración propia

La impresión que se tenía era que la epidemia no era tan contagiosa como el cólera morbo asiático, pero que había mayor proporción de los muertos entre los invadidos.

En los pueblos de la provincia había preocupación por los casos de enfermedad sospechosa.

En Burriana, muchas familias abandonaban la población dirigiéndose a los pueblos del Maestrazgo, y al Santuario de Nuestra Señora del Socorro, en la villa de Calig. También en Nules ocurría otro tanto, las familias huían a Alcora y Lucena.

En Villareal había del 13 a la madrugada del día 14 de junio, 18 invasiones y 13 defunciones; en Nules, 12 y 2; en Villavieja, 5 y 1; en Soneja, 4 y 2; 4 invasiones en Navajas y 2 en Burriana sin ninguna defunción. ${ }^{553}$

Una carta de Villarreal de 13 de junio de 1885 habla de que «el huésped del Ganges cierne sus negras alas sobre esta desgraciada población y que hace más de 8

${ }^{553}$ Ibídem. 
días que tuvo lugar la primera invasión colérica y que, sin embargo, el mal no ha tomado proporciones ni en su intensidad ni en su propagación».

Los invadidos pertenecían a las clases más pobres, cebándose en los jornaleros que habitaban en tugurios en donde la humedad y la falta de limpieza daban fácil acceso a la epidemia; se añadía a esto que la alimentación de estos vecinos era insana, escasa e impropia de la estación.

Se describen las viviendas de los pobres, donde la desolación, el dolor y la miseria se destacaban. Se narra como en un rincón de una casa, sobre un saco de escasa superficie, en cuyo interior había unos puñados de paja, yacía una joven de 18 años con las piernas acurrucadas, so pena de tenerlas sobre el suelo mojado por la humedad, con los ojos hundidos, demacrado el color, y el marmóreo frio de la muerte en su derredor. Para consuelo de tanta angustia, no había en la casa fuego siquiera, ni medicamentos, ni medios con que adquirir unos y otros. «A remediar esta clase de males tiende el Ayuntamiento que con plausible actividad tiene en construcción un hospital de coléricos en un solar cercado de pared, que se cubre de madera, y reunirá condiciones higiénicas».

Según se afirma el mal no tenÍa las proporciones que equivocadamente o maliciosamente se le atribuían, ya que el día que más defunciones hubo fueron 13 en una población de 3.000 habitantes y que en esas defunciones se incluían las causadas por enfermedades ordinarias.

La ciudad de Castellón negaba toda comunicación con Villarreal y Burriana, en donde la epidemia hacía mayores estragos.

Relatan que las exageraciones del pánico daban un aspecto grotesco a la triste situación en que se encontraban, según lo demuestra el hecho de que un peatón que conducía la correspondencia a Onda fue detenido a 500 metros de aquella población a los gritos de algunos de sus vecinos, exigiéndole que dejase la valija y se retirase, a cuya exigencia se negó el peatón repetidas veces. ${ }^{554}$

Otra carta esta vez desde Vinaroz del 13 de junio de 1885 dice que con el objeto de poder atender a la buena higiene de la población, se nombraron dos comisiones encargadas de la vigilancia para que las reglas dictadas tuvieran el debido cumplimiento, una para el interior del casco y otra para los barrios extremos y cercanías.

\footnotetext{
${ }^{554}$ La Provincia, 18/06/1885.
} 
Al mismo tiempo el Ayuntamiento y la Junta de Sanidad dictaron cuantas medidas eran necesarias para evitar que llegara la enfermedad sospechosa a la población. A tal efecto, los vigilantes empezaron a prestar el servicio a la llegada de los trenes, y montaron lazaretos y departamentos a propósito para las fumigaciones de los géneros y observación de pasajeros.

También dice que el comandante de Marina esperaba un vapor para que se encargara de la vigilancia marítima durante «las actuales circunstancias».

Y acaba indicando el corresponsal que «La salud en esta población no puede ser hoy más excelente; baste consignar que en doce días no han ocurrido más de tres fallecimientos de enfermedades ordinarias».

El gobernador decidió mandar delegados de sanidad a inspeccionar los pueblos de Burriana, Nules y Villareal, donde existía la enfermedad sospechosa, y donde la higiene estaba bastante descuidada. ${ }^{55}$

En Burriana además del cólera, había gran miseria, la prensa llama la atención del Gobernador para que distribuyera alguna cantidad de las 10.000 pesetas concedidas por el Gobierno para remediar este problema. ${ }^{556}$

La enfermedad en Burriana se había desarrollado con violencia, la gente pudiente abandonó la población, y los pobres quedaban no solo sin trabajo, sino sin los auxilios sanitarios que necesitaba. No se aislaban los focos, ni se saneaban las viviendas, «ni se hace nada para levantar el espíritu de la población abatida». En los días 9 y 10 de junio ocurrieron 23 invasiones que determinaron 23 defunciones, y en los días 12 y 13 ocurrieron 24 invasiones que determinaron 21 defunciones. ${ }^{557}$

Otra población que sufrió los estragos de la enfermedad reinante era Segorbe que causaba de ocho a diez defunciones diarias. Con este motivo, el obispo de la diócesis dirigió a sus diocesanos una pastoral que constaba de dos partes: una religiosa y otra médica. En la primera se exhorta al pueblo a la práctica de la religión, y al efecto, dispuso que las imágenes de la Virgen de la Cueva Santa y San Roque se veneraran en la catedral, celebrándose misas y otras funciones, a fin de que intercedieran por la salud del vecindario.

\footnotetext{
${ }^{555}$ La Provincia, 18/06/1885.

${ }^{556}$ Ibídem.

${ }^{557}$ La Provincia, 18/06/1885.
} 
En la segunda parte se recomienda la fe en los médicos, «llamados por vocación y estudio a conocer las enfermedades del cuerpo». Particularmente el obispo pidió al pueblo que no acogiera las supercherías que se propagaban contra los facultativos. Por último, recomendó algunas reglas higiénicas que debían observarse antes y después de la enfermedad. ${ }^{558}$

Otra carta de Villarreal del 21 de junio de 1885 dice que no hay casos sospechosos, ni otra mistificación con que se pretende encubrir el verdadero mal, «sino que no hay más que cólera morbo asiático, tal como suena, con toda su desnudez y con todas sus deplorables consecuencias».

Si bien la epidemia había fluctuado en los primeros días en número escaso de víctimas, «en los últimos, se ha despojado de la careta y nos ataca de frente con verdadera saña». Sobre Villarreal los datos estadísticos que constaban de una forma oficial eran:

Tabla 2. Invasiones y defunciones en junio en Villarreal

\begin{tabular}{|c|c|c|}
\hline Día & Invadidos & Defunciones \\
\hline 5 & 19 & 0 \\
\hline 6 & 11 & 5 \\
\hline 7 & 8 & 3 \\
\hline 8 & 4 & 13 \\
\hline 9 & 18 & 18 \\
\hline 10 & 20 & 9 \\
\hline 11 & 23 & 12 \\
\hline 12 & 13 & 12 \\
\hline 13 & 31 & 5 \\
\hline 14 & 23 & 7 \\
\hline 15 & 25 & 21 \\
\hline 16 & 53 & 21 \\
\hline 17 & 30 & 29 \\
\hline 18 & 41 & 156 \\
\hline Total & 319 & \\
\hline & & \\
\hline
\end{tabular}

Fuente: La Provincia, 18/06/1885. Elaboración propia

\footnotetext{
${ }^{558}$ Ibídem.
} 
Como podemos comprobar en la tabla 2, en el mes de junio murieron en Villarreal 156 personas de 319 invasiones, lo que representa un $48.9 \%$ de muertes.

Según continua el corresponsal de Villarreal «el total de esta cifras merecen la atención del Gobierno».

Sigue diciendo que la epidemia continuaba haciendo proezas en la clase proletaria, «si bien va salpicando a alguna víctima de la clase media acomodada».

Las transacciones mercantiles estaban paralizadas a consecuencia de la incomunicación a que estaba sometida la población, los artículos de primera necesidad empezaban a escasear y la miseria se dejaba sentir. ${ }^{559}$

El luto es general; el terror en nadie tiene excepción: cada cual procura por el prójimo con lo que buenamente puede, pero el miedo contrae el brazo que la caridad alarga.

El ayuntamiento ha elevado una sentida solicitud a la Diputación provincial en demanda de socorros para los pobres; ¡Dios quiera que aquella Corporación se haga eco de estas miserias!

La Diputación Provincial remitió a los ayuntamientos de Bechí y Villareal, invadidos por la epidemia, la cantidad de 300 y 500 pesetas respectivamente. Y el gobernador de la provincia, de los cuarenta mil reales consignados por el Gobierno, dos mil reales al primero, y cuatro mil al segundo. ${ }^{560}$

Circulaban noticias alarmantes acerca del estado de salud en Castellón, pero la prensa publicaba que no había nada que temer pues el estado de salud de la capital era excelente, si se exceptuaba que fueron trasladados al barracón, simplemente como sospechosos, cuatro enfermos del Hospital, un enfermero y tres niñas.

La sala de enfermos del Hospital Provincial fue desalojada y desinfectada con ácido sulfuroso. Después de picadas las paredes se blanquearon añadiendo a la cal cierta cantidad de deuto-cloruro-mercurio. ${ }^{561}$

El presidente de la Diputación Provincial telegrafió al obispo, pidiéndole que mandara a Castellón para el servicio de hospitales ocho hermanas de la Consolación. ${ }^{562}$

\footnotetext{
${ }^{559}$ La Provincia, 21/06/85.

${ }^{560}$ Ibídem.

${ }^{561}$ Ibídem.
} 
Mientras tanto continuaba la invasión en otras poblaciones, el gobernador y el alcalde visitaron Almazora, donde había dos casos sospechosos, decidiendo acordonar el pueblo. ${ }^{563}$

El 25 de junio de 1885, La Provincia sigue diciendo que en Castellón se disfruta de excelente salud, ocurriendo menos defunciones que de costumbre en esta época, «es el mejor dato para desvirtuar las noticias que circulan los alarmistas. Los casinos, cafés, centros políticos, reuniones particulares y otros lugares, y nada todo es expansión, alegría y jolgorio. Nadie llora la muerte de un pariente, un amigo [...]».

El Hospital Provincial quedó incomunicado, y el nuevo director Félix Roig trabajaba para extinguir todo foco en dicho establecimiento. ${ }^{564}$

El 26 de junio de 1885 salieron para Villarreal el gobernador de la provincia y el subdelegado de medicina de Castellón, Eduardo Portales. En las cuatro o cinco horas que permanecieron en dicho pueblo, reunieron la Junta de Sanidad, visitaron el hospital de coléricos, y entre las disposiciones que acordaron fueron rellenar de tierra la sequieta que cruza la población, en donde lavaban la ropa de sanos y enfermos y se fregaban al mismo tiempo los utensilios de cocina; que se fumigara la iglesia y que se abrieran grandes ventanales para que fuera mayor la circulación del aire. También el gobernador entregó 1.000 pesetas para atender las necesidades más urgentes. ${ }^{565}$

Aparecen los primeros casos en Alcora y Costur, y en todos los pueblos de la provincia donde existía el cólera se observaba un notable decrecimiento, excepto Villarreal donde estaba estacionado. ${ }^{566}$

El 2 de julio continuaba la salud en Castellón, que no llegaba a tres defunciones diarias de toda clase de enfermedades. ${ }^{567}$

Parece ser que el tiempo era poco normal para la época, porque llovía como si fuera otoño, dando un aspecto más tétrico a la ciudad, «que comienza a tomar el aspecto sombrío de la calamidad que nos aflige». 568

Descendía la enfermedad reinante en los pueblos invadidos de la provincia, pero en Alcora tomaba un carácter más alarmante 569

\footnotetext{
562 Ibídem.

${ }^{563}$ Ibídem.

${ }^{564}$ La Provincia, 25/06/1885.

${ }^{565}$ La Provincia, 28/06/1885.

${ }^{566}$ La Provincia, 28/06/1885.

${ }^{567}$ La Provincia, 2/07/1885.

${ }^{568}$ Ibídem.
} 
El 5 de julio había mejorado bastante el estado sanitario en los pueblos de la provincia, si bien la epidemia se había extendido en los pueblos de Alcora y Costur donde estaba causando muchas víctimas, especialmente en Alcora.

Sin embargo, en Castellón la salud continuaba siendo buena sin haber ocurrido ninguna invasión los día 3 y 4 de julio. ${ }^{570}$

Nules también fue otra población donde se cebó la enfermedad de un modo alarmante, siendo las invasiones tan numerosas que hubo días en que más de la mitad de la población estuvo afectada. Desde que empezó la enfermedad hasta el día 2 de julio murieron 193 personas. ${ }^{571}$

En Segorbe las invasiones coléricas concentradas en un barrio, se extendieron a todos los puntos de la ciudad; la Casa de Socorro de las Hermanas de la Caridad se trasladó de la calle Larga al palacio episcopal, como lugar más céntrico, en donde se expedían los remedios para los enfermos y los caldos y sopas para los necesitados. ${ }^{572}$

El 6 de julio de 1885, se reunieron el secretario del Gobierno Civil, el alcalde de Castellón y dos concejales de la villa de Alcora, para tratar la situación en que se hallaba aquella población como consecuencia del estado sanitario de la misma.

Los dos médicos que había en Alcora visitaban los enfermos de la población sin descanso día y noche; no eran suficientes para toda la población, máxime si la enfermedad se extendía a las aldeas anexas a dicho pueblo.

Los dos farmacéuticos de la población se hallaban enfermos y como la enfermedad no decrecía, había la necesidad de adoptar medidas convenientes para prever cualquier eventualidad.

El secretario del gobernador, en representación del mismo, entregó al alcalde de Alcora 750 pesetas de los fondos que el Gobierno destinó a esta provincia. ${ }^{573}$

A principios de julio aún había pocos casos de la enfermedad en Castellón. Los casos aparecían fulminantes dado el poco tiempo que transcurría desde la invasión aparente hasta el fin de la enfermedad que casi siempre tenía un desenlace funesto.

En la segunda mitad de julio la salud pública en la capital, según la prensa, seguía siendo satisfactoria aunque el Boletín había acusado algún aumento en los casos

\footnotetext{
569 Ibídem.

${ }^{570}$ La Provincia, 5/07/1885.

${ }^{571}$ Ibídem.

${ }^{572}$ Ibídem.

${ }^{573}$ La Provincia, 9/07/1885.
} 
sospechosos, sin embargo la enfermedad no tomaba las proporciones que «eran de temer». «Si para atajarle los pasos al terrible mal se redoblan los esfuerzos de todos, y, principalmente, si se da unidad a los trabajos y se armonizan con los intereses de la familia, tenemos confianza de vencer al terrible huésped».

El 12 de julio de 1885, se reunió el gobernador con la Comisión Provincial para tratar temas de salubridad pública. Esta reunión estaba motivada por un caso de «enfermedad sospechosa» que aquella mañana se había declarado en la Casa Provincial de la Misericordia. El gobernador y la Comisión visitaron el establecimiento tomando algunos acuerdos. 574

Una de las medidas que tomó la Comisión Provincial a consecuencia del caso sospechoso ocurrido en la Casa de Misericordia fueron, dar licencia temporal a todos los albergados que la solicitaran, acordar la salida definitiva de los varones mayores de 20 años y de las mujeres mayores de 22; enviar a su provincia respectiva los albergados que no eran de ésta, y estudiar la formación de un campamento al que pudieran trasladarse todos los asilados en dicha Casa en el caso de que la epidemia se desarrollara en ella.

También se aprobaron las medidas que desde un principio había adoptado el director del establecimiento, de acuerdo con los facultativos del mismo. Había aquél ordenado sacar al enfermo, que fue conducido a su casa; fumigar, desinfectar y blanquear convenientemente la habitación que aquél ocupó; aislar a los que le habían asistido y quemar las ropas que usaron entregándoles otras nuevas. ${ }^{575}$

Según los últimos partes del estado de la enfermedad en los pueblos de la provincia en que más se desarrolló fueron: ${ }^{576}$

\footnotetext{
${ }^{574}$ La Provincia, 16/07/1885.

${ }^{575}$ Ibídem.

${ }^{576}$ Ibídem.
} 
Tabla 3. Pueblos de la Provincia de Castellón donde más se desarrolló el cólera durante los días 12 y 13 de julio

\begin{tabular}{|c|c|c|c|c|}
\hline \multirow{2}{*}{ Julio } & \multicolumn{2}{|c|}{ Día 12 } & \multicolumn{2}{c|}{ Día 13 } \\
\cline { 2 - 5 } & Invasiones & Defunciones & Invasiones & Defunciones \\
\hline Alcalá & 10 & 1 & 20 & 2 \\
\hline Alcora & 7 & 6 & 9 & 4 \\
\hline Almazora & 13 & 3 & 19 & 7 \\
\hline Burriana & 10 & 3 & 0 & 1 \\
\hline Castellón & 9 & 3 & 13 & 3 \\
\hline Nules & 3 & 5 & 5 & 3 \\
\hline Segorbe & 13 & 8 & 18 & 6 \\
\hline Villarreal & 2 & 3 & 8 & \\
\hline
\end{tabular}

Fuente: La Provincia, 16/07/1885. Elaboración propia

El 19 de julio aparecen casos de cólera en los presos de la cárcel. A consecuencia de esto fueron trasladados la mayor parte de estos al ermitorio de San Isidro, procediéndose a la fumigación de aquella en la que quedaron solo los presos por causas graves. ${ }^{577}$

A partir de la segunda quincena de julio la epidemia iba bajando en intensidad en casi todos los pueblos donde existía desde hacía algunos días, pero se iba extendiendo por algunos otros que hasta ahora se habían visto libres de ella. En los últimos boletines se declara aquella en los pueblos de Onda, Alcalá, Cabanes y Vall de Uxó, en algunos de ellos con bastante intensidad. ${ }^{578}$

Las últimas noticias sobre el estado de salud los días 15 y 16 en los distintos pueblos de la provincia de Castellón fueron los siguientes:

${ }^{577}$ La Provincia, 19/07/1885.
${ }^{578}$ Ibídem. 
Tabla 4. Desarrollo del cólera en distintos pueblos de la provincia de Castellón durante los días 15 y 16 de julio

\begin{tabular}{|c|c|c|c|c|}
\hline \multirow[b]{2}{*}{ Julio } & \multicolumn{2}{|c|}{ Día 15} & \multicolumn{2}{|c|}{ Día 16} \\
\hline & Invasiones & Defunciones & Invasiones & Defunciones \\
\hline Alcalá & 31 & 8 & 30 & 9 \\
\hline Alcora & 14 & 2 & 4 & 4 \\
\hline Almazora & 11 & 2 & 7 & 6 \\
\hline Altura & 8 & 3 & 0 & 0 \\
\hline Artana & 9 & 4 & 0 & 0 \\
\hline Barracas & 0 & 0 & 0 & 0 \\
\hline Bechí & 0 & 0 & 0 & 0 \\
\hline Borriol & 6 & 4 & 5 & 4 \\
\hline Burriana & 7 & 2 & 2 & 1 \\
\hline Cabanes & 3 & 1 & 0 & 0 \\
\hline Castellón & 15 & 9 & 13 & 17 \\
\hline Chilches & 0 & 0 & 0 & 0 \\
\hline Costur & 0 & 0 & 0 & 0 \\
\hline Figueroles & 0 & 1 & 0 & 0 \\
\hline Gátova & 0 & 0 & 0 & 0 \\
\hline Geldo & 1 & 0 & 0 & 0 \\
\hline Gérica & 3 & 2 & 0 & 0 \\
\hline Moncófar & 2 & 1 & 0 & 0 \\
\hline Nules & 2 & 5 & 2 & 0 \\
\hline Onda & 13 & 6 & 2 & 0 \\
\hline Segorbe & 10 & 5 & 2 & 0 \\
\hline Soneja & 3 & 1 & 2 & 0 \\
\hline Teresa & 0 & 0 & 1 & 0 \\
\hline Vall de Almonacid & 6 & 1 & 6 & 1 \\
\hline Vall de Uxó & 7 & 2 & 21 & 2 \\
\hline Villarreal & 4 & 4 & 11 & 6 \\
\hline Villavieja & 0 & 1 & 4 & 0 \\
\hline Viver & 8 & 3 & 8 & 3 \\
\hline
\end{tabular}

Fuente: La Provincia, 19/07/1885. Elaboración propia

El cólera estaba haciendo estragos en Alcalá y el gobernador acompañado por dos diputados y el alcalde de Castellón marcharon a esa ciudad con el objeto de socorrer a dicha población afligida por la epidemia, y adoptar las medidas convenientes para evitar los estragos que estaba causando.

Según la prensa, las impresiones recibidas por dicha comisión fueron desoladoras. Para el Ayuntamiento de Alcalá, perteneciente en su mayoría al partido carlista, eran letra muerta las circulares del Gobierno de provincia disponiendo se adoptasen medidas conducentes a evitar la propagación del contagio. En dicha población no se había observado ninguna prescripción sanitaria, a pesar de que la 
epidemia estaba causando horribles estragos. Allí ni se llevaba registro de invasiones y defunciones, ni se prestaba asistencia a los enfermos pobres, muchos de los cuales estaban abandonados por sus familias, ni la alcaldía atendia las indicaciones de los facultativos de que adoptara ciertas medidas sanitarias y tampoco se desinfectaban las casas y las ropas de los fallecidos.

Las ropas de los fallecidos se lavaban y se dejaban secar en los tejados de las casas como único medio de desinfección, y las deyecciones de los coléricos se arrojaban a la calle, convirtiéndose estas en verdaderos focos de infección colérica. El Ayuntamiento había adquirido desinfectantes, pero no hizo uso de ellos porque creía eran perjudiciales a la salud pública.

La comisión reunió al Ayuntamiento y a los facultativos y el gobernador les hizo ver la necesidad de adoptar enérgicas medidas para combatir la epidemia; les entregó como recurso para atender a dichas necesidades 1.250 pesetas (750 pesetas del fondo de calamidades y 500 por cuenta de la provincia). También les ofrecieron proporcionar enfermeras para asistir a los coléricos abandonados. Parece ser que el Ayuntamiento recibió el ofrecimiento con frialdad. ${ }^{579}$

El 23 de julio, La Provincia dice que en la capital no ha empeorado la situación sanitaria y no tiene por lo tanto gravedad. «En los demás pueblos donde se ha cebado hasta hace poco, ha mejorado muchísimo el estado de la salud pública. Únicamente en Alcalá se deja sentir con intensidad».

La epidemia se iba extendiendo por Morella, Castellfort, Forcall, Ortells, Villafranca y Zurita, donde hubo varios casos sospechosos. ${ }^{580}$

Por otra parte, la situación en Alcalá era muy grave. Las autoridades de la villa continuaban sin preocuparse de la epidemia que estaba amenazando acabar con todo el vecindario. Se pide al Gobierno que ponga coto al mal que podría envolver a todos los pueblos vecinos de aquél. Por falta de recursos y desinfección habían muerto muchas personas.

El Ayuntamiento no toma medidas, la Junta Local de Sanidad que contempla con estúpida indiferencia los progresos de la epidemia; el alcalde a quien incomoda hasta el dinero que se le da para atender a las necesidades más

\footnotetext{
${ }^{579}$ La Provincia, 23/07/1885.

${ }^{580}$ Ibídem.
} 
apremiantes, todos continúan en sus puestos sin haber sufrido siquiera una multa por su punible y criminal abandono. ${ }^{581}$

Otra carta del 29 de julio de 1885, dirigida al director de La Provincia daba cuenta del estado de la población de Alcalá con motivo de la epidemia colérica; según dice a pesar de las proporciones aterradoras que alcanzó la epidemia desde los primeros momentos, no se hizo nada por parte del Ayuntamiento y Junta de Sanidad para atajar la epidemia. Ni desinfectantes, ni fumigaciones, ni auxilios, ni socorros a los pobres, nada de esto se organizó, y lo que es peor, la policía urbana empeoraba, pues crecía con la enfermedad la suciedad pública, hasta el punto de parecer las calles un inmenso estercolero.

Por otra parte se cuenta que por iniciativa de un guardia civil, se creó una sociedad de socorros que abrió una suscripción y produjo muy pronto mil cien pesetas con las cuales se remediaron muchas necesidades, pues el Ayuntamiento, manifestó no necesitar dinero que la Diputación y el Gobernador le entregaron. ${ }^{582}$

Al mismo tiempo se iba extendiendo la epidemia por toda la provincia, entrando al asalto en muchos pueblos a pesar de los cordones «con que han pretendido escudarse». Ayodar, Cortes, Campos, Cervera, Chert, Montanejos, Castellfort, Forcall, Ortells, Villafranca y Zurita, fueron visitados por el terrible huésped. A excepción de Alcalá, en donde la epidemia hacia estragos, en todos los demás pueblos se presentaba con relativa benignidad, o se hallaba en periodo descendente. En Castellón, la epidemia se había estacionado: ${ }^{583}$

Tabla 5. Invasiones y defunciones en Castellón en la segunda quincena de julio

\begin{tabular}{|c|c|c|}
\hline Día & invadidos & defunciones \\
\hline 17 & 9 & 7 \\
\hline 28 & 16 & 6 \\
\hline 29 & 7 & 4 \\
\hline
\end{tabular}

Fuente: La Provincia, 30/07/1885. Elaboración propia

\footnotetext{
${ }^{581}$ La Provincia, 26/07/1885.

${ }^{582}$ La Provincia, 30/07/1885.

${ }^{583}$ Ibídem.
} 
El 30 de julio la prensa seguía diciendo que la salud continuaba estacionada en la capital y en algunos pueblos de la provincia como Villarreal se había recrudecido algo y disminuía en Alcora, Alcalá; y entre los recientemente invadidos estaba Vinaroz. ${ }^{584}$

\subsubsection{El cólera en la ciudad de Castellón de la Plana: temor de la población al aislamiento}

Hacia mediados del mes de junio llamaban la atención pública los casos de cólera que se habían presentado en Nules, los cuales se reprodujeron más tarde en los pueblos de Burriana y Villarreal.

Por la posibilidad de ser invadida Castellón las autoridades asesoradas por la Junta de Sanidad se plantearon establecer las medidas del año anterior, acordonaron la ciudad y se estableció un lazareto en la ermita de Lidón.

Este cordón fue encomendado a los vecinos, pero la tolerancia unas veces y el descuido de los encargados de alimentarlo otras, hicieron que su utilidad fuera en ocasiones problemática.

El lazareto de Lidón fue calificado de purgatorio por la prensa local. Pocos días sirvió dicho ermitorio de lazareto, pues el terror que se apoderó de las personas recluidas, a consecuencia de dos invasiones ocurridas en la persona de la ermitaña y otra mujer procedente de la huerta de Castellón, hizo que se instalaran aquellas en un almacén contiguo a la estación del ferrocarril.

Las medidas se completaban con la instalación de un barracón de madera de poca capacidad y de muy escasas condiciones higiénicas, emplazado junto a la muralla, por la parte de poniente, destinado a hospital de coléricos, el cual ya había sido construido y desmontado el año anterior, al no ser invadida la ciudad por el cólera. ${ }^{585}$

El día 14 o 15 en la calle Falcó, un labrador, jornalero, que había cuidado a su mujer, era víctima del cólera, y a la caída de la tarde una masa de gente, con el ansia de curiosear este suceso, invadió las inmediaciones de la casa. Allí entraron y salieron multitud de médicos, hombres, mujeres, niños, el alcalde, el gobernador y monjas de la Caridad que fueron llamadas para asistir al enfermo, el cual falleció aquella noche de

\footnotetext{
${ }^{584}$ Ibídem.

${ }^{585}$ Revista Médico-Farmacéutica, 7/07/1885 pp. 96-101.
} 
«cólico maligno» según el parte facultativo, a pesar de haber afirmado algunos médicos que se trataba de un caso típico de cólera. La familia de esta víctima fue trasladada a la casa de las hermanas de la Consolación que habitaban frente al Hospital Provincial y de allí, a este establecimiento, en cuyas salas se presentó un caso de muerte por diarrea en una enferma ingresada por una fractura de huesos. A este caso siguieron otros varios, entre ellos un sirviente del Hospital, los cuales fueron trasladados al barracón, donde había otros casos que fallecieron de la «enfermedad reinante».

En la ciudad se hablaba ya de algunos casos sospechosos en diversos puntos de la capital, viéndose en las puertas de las casas de los atacados a la guardia municipal encargada de hacer efectivo el aislamiento.

La ansiedad del público crecía por momentos; el miedo se difundía por la ciudad y las personas con poca cultura secundaron la calumnias esparcidas en Valencia contra los médicos, llegándose a crear con esto tal atmosfera, que la autoridad eclesiástica, desde el pulpito, «hubo de poner las cosas en su sitio», como también el alcalde publicando un bando encaminado a tranquilizar los ánimos y a deshacer los errores que tenía el vulgo con respecto a los médicos.

Aparte de aislar las casas también se aisló el Hospital Provincial lo cual produjo tal indignación entre la gente que se apoderó de ellos un miedo terrible a llamar a los médicos.

\subsection{ACUERDOS Y MEDIDAS DE LAS AUTORIDADES MUNICIPALES Y PROVINCIALES PARA PREVENIR DEL CÓlERA A LA POBLACIÓN DE CASTELLÓN}

Declarada oficialmente la existencia del cólera morbo en la provincia de Valencia el Ministro de la Gobernación formó un plan completo de medidas de inmediata aplicación una y otras que se irían poniendo en práctica según aconsejaran las circunstancias.

Entre esas medidas estaban: la declaración oficial del cólera nada más se supusiese las conclusiones de la comisión científica que había ido a estudiar la eficacia de la vacunación de Ferrán; precauciones y medidas sanitarias en la capital de Valencia, aislando y fumigando las casas donde ocurrieran casos, formar las correspondientes 
juntas para la aplicación de auxilios y facilitar habitaciones en los hospitales; todo lo debía organizar el gobernador con la Junta de Sanidad. ${ }^{586}$

En Castellón el alcalde y la Junta Local de Sanidad empezaron a tomar todas las medidas convenientes para librar a la ciudad del cólera; también las juntas de distrito y comisiones de barrio se preparaban para practicar visitas domiciliarias. ${ }^{587}$

En la provincia empezaba haber preocupación, pues el día del Corpus fue un día de pánico para los habitantes de Nules, en donde hubo por la noche siete invadidos de la enfermedad sospechosa, de los que fallecieron tres.

También en Villarreal hubo un atacado y el Gobernador, Eleuterio Villalba, salió para dicho pueblo y el de Nules, a fin de tomar las medidas convenientes de aislamiento y enterarse del estado de aquellos pueblos que por entonces no eran alarmantes. ${ }^{588}$

En Bechí, pueblo inmediato a Nules, había seis invadidos y tres muertos. ${ }^{589}$

El 11 de junio de 1885, La Provincia publicaba que aunque no en proporciones alarmantes, seguía la enfermedad sospechosa en los pueblos de Villarreal, Nules, Alquerías del Niño Perdido, Villavieja, Bechí, Burriana, Mascarell y Segorbe. ${ }^{590}$

Se quería establecer un lazareto en el ermitorio de Santa Quiteria, para las procedencias de Valencia y demás pueblos infestados. El punto elegido recibió muchas críticas porque estaba situado a la orilla misma del Mijares por «donde pasan las aguas que abastecen a esta ciudad y Almazora»y, como consecuencia se corría el peligro de contagio, ya que podían arrojarse aguas sucias al río, o porque podrían con ciertas precauciones lavarse la ropa. 591

Por otra parte, se estaba construyendo el barracón de coléricos en el Tiro de Palomo pero, había preocupación porque la alcaldía aún no disponía de los desinfectantes necesarios para el servicio sanitario; faltaba disponer las brigadas de limpieza y los enfermeros.

Mientras tanto la prensa anunciaba cólera en Alicante, Murcia, Valencia, Castellón y Madrid, donde había ya algunos casos.

\footnotetext{
${ }^{586}$ La Provincia, 7/06/1885.

${ }^{587}$ Ibídem.

${ }^{588}$ Ibídem.

${ }^{589}$ Ibídem.

${ }^{590}$ La Provincia, 11/06/1885.

${ }^{591}$ Ibídem.
} 
Las críticas al acordonamiento en Castellón eran continuas, puesto que los coches de la Vall de Uxó que pasaban por Nules y Villarreal eran admitidos, así como los de Burriana. Se descargaban en la puerta de San Francisco sacos de patatas procedentes de Villarreal para el suministro de la tropa. Las mujeres que vendían fruta y verdura, salían todos los días a recoger la mercancía, que procedentes de Villarreal estaban en depósitos en diferentes puntos. Los viajeros de Valencia tomaban el billete para Benicasim y regresaban por la tarde a la ciudad. «En un palabra, reina en esta asunto un desbarajuste y una confusión inenarrable». «Nosotros creemos que este servicio debía perfeccionarse remediando muchos de los inconvenientes que ya se palpan y que podría solicitarse también el auxilio de la guardia civil para la vigilancia de puertas». «Y en el lazareto de Lidón faltan camas $[\ldots] » .{ }^{592}$

La impresión sobre el estado sanitario en Castellón era buena, según la prensa no había casos sospechosos y se confiaba «en la misericordia divina, en las condiciones higiénicas de la ciudad y en las medidas que toman las autoridades, que no las habrá». Las noticias del cólera no producían tanta alarma como el año anterior. ${ }^{593}$

«El domingo se trasladaron muchísimas personas al Grao, y al anochecer veíanse regresar alegres grupos que al son de la popular guitarra cantaban y bailaban como si no hubiera microbios en el mundo».

Las llamadas de atención sobre la higiene pública en Castellón eran continuas, puesto que faltaba policía urbana.

El año 1884 fue un año muy duro para Castellón por la pérdida de cosechas, debido a los temporales que hubo aquel año. La pobreza unida a la invasión del cólera amenazaba con arruinar la provincia. El presupuesto provincial se encontraba impotente para hacer frente a tantas necesidades; por este motivo la Comisión Provincial expuso una petición al Gobierno en demanda de recursos con que poder socorrer a las personas que sufrieran la enfermedad y las consecuencias que conllevaría de paralización de toda la actividad económica. ${ }^{594}$

\footnotetext{
${ }^{592}$ Ibídem.

${ }^{593}$ Ibídem.

${ }^{594}$ La Provincia, 14/06/1885. Ver Apéndice Documental. № 5.
} 
Más tarde, para atender el auxilio de los enfermos que causaba la epidemia, se concedieron por el gobierno 10.000 pesetas a la provincia de Castellón, y 5.000 a la de Murcia. ${ }^{595}$

En los lazaretos establecidos en Castellón y Valencia se acordó que los trenes que llegaran se dividieran en limpios y sucios según su procedencia. A los viajeros de puntos limpios someterlos a una observación y fumigación ligera, continuando su viaje; a los de puntos sucios someterlos a una detenida observación, fumigándose sus equipajes y habilitando cuartos para la fumigación de las ropas que llevaran puestas. Después de esta operación podían continuar su viaje. Asimismo los viajeros que se observase algún síntoma sospechoso serían trasladados al lazareto a sufrir cuarentena.

Como se ve, se renunció a la cuarentena general para todos los viajeros procedentes de puntos infestados, y para ello se alegaba como razón que habiendo dejado pasar ya a mucha gente, no parecía justo detener a los que salían de las zonas donde la epidemia existía sino era en caso extremo. ${ }^{596}$

Más adelante, el servicio cuarentenario se sustituyó por el de inspección para los viajeros de Valencia, Castellón y Murcia. Para los procedentes de las dos primeras provincias, la inspección se estableció en La Encina, y para los que procedan de Murcia dicho servicio se estableció en Pozo de la Cañada. Únicamente los enfermos eran conducidos al lazareto. ${ }^{597}$

En Castellón, el Ayuntamiento acordó por unanimidad: organizar una brigada de desinfección compuesta de un médico titular, el practicante municipal, tres peones como auxiliares; adquirir la cantidad de ácido muriático que el médico titular considerara conveniente para las desinfecciones en el caso que ocurriera algún fallecimiento de enfermedad sospechosa proceder a la fumigación y de cremación de los objetos que hubieran servido para uso del enfermo; construir el barracón para hospital de coléricos en el mismo sitio que el año pasado, autorizar al alcalde el gasto para las medidas sanitarias de hasta 3.700 pesetas; establecer el lazareto de observación en el ermitorio de Lidón; solicitar del director de la Casa Provincial de Misericordia 20 camas completas para dicho lazareto y autorizar al alcalde para adquirir el material necesario para el mismo; publicar un bando a fin de que tengan conocimiento los habitantes de los

\footnotetext{
${ }^{595}$ La Provincia, 14/06/1885.

${ }^{596}$ Ibídem.

${ }^{597}$ Ibídem.
} 
acuerdos tomados en lo relativo a vigilancia sanitaria y pasar una circular a los alcaldes de los pueblos de la provincia participándoles el acuerdo de la Junta prohibiendo la entrada en la población al que no acreditase por medio del oportuno documento que procedía de pueblo en que no existía enfermedad epidémica. ${ }^{598}$

Los médicos titulares se ofrecieron espontáneamente y desinteresadamente para dirigir las brigadas de desinfección y prestar todos los servicios sanitarios que se les ordenase. El Ayuntamiento dio las gracias a los facultativos, agradeciendo el acto de abnegación y desprendimiento de los sanitarios. 599

Al declararse sucio el puerto de Valencia, se debían establecer almacenes para expurgar y fumigar los géneros contumaces que procedían del puerto de dicha ciudad, pero como las importaciones eran insignificantes, el Ayuntamiento decidió no instalarlos y ahorrarse la subvención, ya que los gastos que debía hacer el municipio en medidas sanitarias para proteger a la ciudad de la epidemia colérica, eran muy elevados. ${ }^{600}$

Se acordó también que los soldados atacados de cólera fueran ingresados temporalmente en el Hospital de coléricos mientras se estaba construyendo el de la Diputación provincial.

El Ayuntamiento concedió un terreno a la Comisión Provincial para la instalación de un barracón de madera con destino al hospital de coléricos contiguo al establecido por el Ayuntamiento. ${ }^{601}$

La Diputación Provincial, al ser invadidas algunas personas en el Hospital, acordó aislar completamente el edificio, no permitiendo la entrada ni salida en él con el fin de exterminar el foco colérico y para llevar a efecto este acuerdo solicitó al Ayuntamiento el local de la escuela de párvulos para el tratamiento de las enfermedades comunes de individuos que hubieran de entrar en el Hospital y en éste establecer las oficinas. El Ayuntamiento acordó cederlo temporalmente. ${ }^{602}$

Se autorizó a la Comisión Provincial a utilizar el barracón para coléricos establecido en el cuartel de San Francisco, alojándose la tropa en otro edificio que

\footnotetext{
598 AACS, 6/06/1885.

599 AACS, $11 / 06 / 1885$.

${ }^{600}$ AACS, $11 / 06 / 1885$.

${ }^{601}$ AACS, $13 / 06 / 1885$.

602 AACS, 25/06/1885.
} 
proporcionaría el Ayuntamiento, siendo por cuenta de la Diputación los gastos de instalación y tratamiento.

El Ayuntamiento para alojar a los coléricos disponía de un barracón instalado en el llamado Tiro de Palomo por carecer de otro local apropiado. El rechazo a ser trasladados a dicho barracón por parte de los enfermos fue tal, que las autoridades municipales tuvieron que cambiar de procedimiento facilitando en el propio domicilio de los enfermos, de médico, enfermero, medicinas y alimentos. ${ }^{603}$

La municipalidad propone también adquirir el líquido profiláctico del doctor Ferrán para inocular pobres. ${ }^{604}$

La Junta Provincial de Sanidad convino el acordonamiento en los límites de la provincia que comunican con la de Valencia, así como el establecimiento de lazaretos.

El gobernador de la provincia para prevenir en lo posible la invasión del cólera, envió una circular el 11 de junio de 1885 a todos los alcaldes de los pueblos de la provincia en la que daba consejos sobre salud pública ante la proximidad de la epidemia. Recuerda las prevenciones que desde el verano de 1884 venía aconsejando para evitar la invasión colérica. Expone que ningún medio profiláctico es tan eficaz para combatir el contagio epidémico y aminorar sus consecuencias como la higiene individual y pública.

La invasión de algunos pueblos de la provincia se estaba produciendo por haber desoído la voz de alarma que hace meses daba el periódico oficial, y por haber cogido con tibieza los consejos que los médicos daban a la población.

Para evitar un mayor desarrollo de la epidemia en la provincia, el gobernador recomienda se cumplan las reglas que la Dirección General de Beneficencia y Sanidad dictó en 1884, y las instrucciones de la Real Academia de Medicina como medio de apartar y hacer que desaparezcan de los pueblos las causas que contribuían a su insalubridad.

Recuerda a las autoridades locales el cumplimiento exacto de todas las prevenciones contenidas en anteriores circulares, ampliarlas y completarlas.

Aconseja que tan pronto aparezca o se descubra un foco que indique la existencia de la epidemia colérica, procedan las autoridades locales, asesoradas por las Juntas municipales de Sanidad, a establecer el aislamiento absoluto de la casa y de la

\footnotetext{
${ }^{603}$ AACS, $25 / 06 / 1885$.

${ }^{604}$ AACS, $2 / 07 / 1885$.
} 
familia en que ocurra la invasión, o de la calle o manzana en que radique el foco, a fin de evitar el contagio y la difusión de la enfermedad por todo el pueblo, y que se acordonara la población entera para procurar que la epidemia quede localizada y que no se propague por toda la comarca.

También recomienda poner en práctica todas las medidas de desinfección y saneamiento que los médicos aconsejaban, como fumigar las habitaciones, lavar los suelos, desinfectar las ropas, enseres y utensilios y destruyendo las deyecciones de los enfermos por medio de ácido hiponítrico y enterrándolas después sin perder tiempo.

Considera como uno de los más enérgicos y eficaces desinfectantes, el uso de cloruro de mercurio, ya sea unido a la cal para el blanqueo de las habitaciones, o mezclado con agua para el lavado de los suelos.

Sobre los cadáveres, fallecidos por la enfermedad, recomendaba aspersiones de agua clorurada, trasladándolos cuanto antes a los depósitos de los cementerios y darles luego enterramiento en sepulturas profundas, y arrojar cal viva.

Para la eficaz ejecución de estas precauciones y de todas la que repetidamente he recomendado a los alcaldes, parte principalísima han de ser el celo y la actividad de las mismas autoridades, de las Juntas locales y de los Subdelegados de Sanidad, sobre quienes pesan como obligación ineludible el cuidado y la preservación de la salud pública en las jurisdicciones respectivas; pero infinitamente más fecundo en buenos resultados habrán de ser sus esfuerzos infatigables, si cuentan con la buena voluntad y con el concurso decidido de todas las clases sociales, para que lleven a la práctica en los pueblos las medidas sanitarias que aconseja una bien entendida higiene. ${ }^{605}$

Ninguna persona de los pueblos infestados de la provincia de Valencia, según órdenes circulares de su autoridad superior civil, podía salir de cualquiera de ellos sin que previamente hubiera sufrido siete días de observación cuarentenaria en sus respectivos lazaretos, donde se les expedía una certificación que lo acreditara. Como consecuencia, el gobernador de Castellón, ordenaba a los alcaldes de los pueblos de la provincia, y principalmente los limítrofes a la de Valencia, rechazaran o sujetaran a observación de siete días a todo viajero que no presente dicha certificación, si

${ }^{605}$ AACS, $15 / 06 / 1885$. 
procediese de punto infestado, o que no justifique llegar de pueblo limpio con la correspondiente cédula sanitaria, expedida a su nombre, firmada por el alcalde del punto de origen, con expresión de la fecha de salida y en la cual constara que el portador había residido más de siete días consecutivos en el pueblo limpio del cual procedía.

Se ordenaba también a los alcaldes de los pueblos de la provincia invadidos, establecer en locales apropiados lazaretos municipales donde los vecinos que se propusieran salir de la población habían de ser sometidos a una observación de siete días, trascurridos los cuales y en el supuesto de que no hubieran sufrido alteración en su salud, les sería expedida la correspondiente certificación de sanidad, bajo la responsabilidad del facultativo y del alcalde que la debían autorizar con su firma y sello y con apercibimiento de la sanción penal a que se hicieran acreedores con arreglo al código si certificaban una falsedad. ${ }^{606}$

El ministro de la Gobernación, con fecha 12 de junio de 1885, comunicó a todos los gobernadores de las provincias españolas, la Real Orden instando a todos que hicieran cumplir los preceptos de la higiene pública y la disposiciones dictadas en el año anterior con objeto de evitar la difusión de los gérmenes morbosos y conseguir su extinción en los focos existentes.

Según parece no fueron todo los eficaces que era de esperar las disposiciones que desde los primeros momentos de la aparición de la enfermedad dictó el ministro de la Gobernación. ${ }^{607}$

Como medio más eficaz aconsejado por la higiene, se mantenía el acordonamiento y la instalación de lazaretos en los pueblos invadidos a cargo de los municipios y con los agentes y fuerzas de que dispusieran las autoridades civiles.

\subsubsection{Medidas económicas para socorrer a los epidemiados}

La mayoría de los municipios de la provincia atravesaban una difícil situación a consecuencia de las calamidades que la afligieron durante el año anterior y principalmente por el nuevo plan del ministro de Hacienda. Éste con el fin de asegurar lo necesario para el sostenimiento de las cargas del Estado, fue mermando los ingresos

\footnotetext{
${ }^{606}$ Ibídem.

${ }^{607}$ Se recuerda la exacta aplicación de lo prevenido en Real Orden de 24 de junio de 1884, publicado en Gaceta de 25, las órdenes 2,6, 7 y 17 de julio siguientes, insertas en Gaceta de 3, 7, 8, y 18 del referido mes de julio y la circular de 28 de agosto.
} 
que podían obtener los municipios por los medios ordinarios. El aumento en los consumos, la refundición de la sal en la contribución, la disminución de lo que podían recargar los ayuntamientos sobre la industria, eran otros tantos inconvenientes para que los municipios pudieran ingresar en sus arcas lo necesario para cubrir sus más urgentes atenciones.

Las circunstancias sanitarias que atravesaba la provincia exigía de los ayuntamientos grandes sacrificios para hacer frente a la epidemia y aminorar sus estragos, y esto únicamente podía conseguirse contando con abundantes recursos. Estos no abundaban y los municipios no podían hacer frente a las necesidades de sus administrados, únicamente podían socorrer a los necesitados recurriendo al patriotismo y a la caridad de los vecinos. Para vencer a la epidemia se necesitaba dinero que es lo que más faltaba a los ayuntamientos. ${ }^{608}$

La Provincia llama la atención del gobernador hacia la necesidad de que se provea de recursos para que en el caso de que ocurrieran casos de la enfermedad reinante en personas que no contaran con los recursos suficientes para procurarse el servicio doméstico que su estado reclamara, no se encontraran completamente abandonadas.

Las personas que querían auxiliar a los vecinos enfermos, una vez entraban en la casa de los epidemiados, no se les permitían salir. Para evitar los inconvenientes del aislamiento, la prensa propone que el Ayuntamiento tuviera unas cuantas personas que, convenientemente retribuidas, prestaran voluntariamente y cuando fuera necesario sus servicios a los enfermos.

Las personas acomodadas podrían utilizarlas quedando obligadas a renumerarlas en la cantidad fijada por la autoridad; y los pobres que no quisieran salir de sus casas, podrían ser asistidos, según reclamara su estado, por personas pagadas por el Ayuntamiento. «Afortunadamente, el estado de salud pública es regular, pero si por desgracia tomara incremento la enfermedad, sería muy ventajoso que nos encontrara prevenidos en cuanto sea posible» ${ }^{609}$

A principios del mes de julio de 1885, la Junta directiva del Círculo Católico y Protectorado de Obreros, acordó abrir una suscripción entre los socios protectores del mismo, con objeto de socorrer a las familias de los socios obreros atacados, en el caso

\footnotetext{
${ }^{608}$ La Provincia, 19/07/1885.

${ }^{609}$ La Provincia, 9/07/1885.
} 
de que la epidemia se agravara. La cantidad que se debía entregar a cada familia sería a juicio de una comisión del mismo Círculo, que había de informar previamente respecto al grado de pobreza y necesidades de cada una. ${ }^{610}$

Los ayuntamientos de los diferentes pueblos de la provincia pidieron al gobierno de la provincia y de la Diputación Provincial, que se les entregara alguna cantidad del fondo de calamidades del presupuesto del Estado y de lo consignado a este efecto en el provincial, para socorrer a los epidemiados. ${ }^{611}$

Parece ser que el Ayuntamiento de Castellón aún no había pedido ninguna ayuda.

\subsubsection{Medidas sanitarias cuando se propagó el cólera en Castellón}

Por la Dirección General de Inspección Pública se ordenó al gobernador presidente de la Junta Provincial de Instrucción Pública la clausura de todos los establecimientos de enseñanza de los pueblos de la provincia invadidos por la epidemia. $^{612}$

Por cuenta de la Diputación Provincial, y para albergar y asistir a los asilados en los establecimientos de beneficencia que pudieran contraer la enfermedad sospechosa, «en el desgraciado caso de que la epidemia invadiera la ciudad», se construyó un barracón inmediato al que levantó el Ayuntamiento en el llano conocido por Tiro del Palomo. ${ }^{613}$

El 25 de junio de 1885 un bando del alcalde de Castellón José Tárrega Torres, hizo saber que el Ayuntamiento y la Junta Local para atender a las necesidades sanitarias de Castellón y con el objeto de que nadie careciera de asistencia facultativa, acordaron construir un barracón como hospital de coléricos, solo para aquellas personas que viéndose atacados del cólera quisieran ser trasladados a él.

El enfermo que no quisiera ir al barracón u hospital, no iría; y si careciera de medios de asistencia, el Ayuntamiento le facilitaría desde el médico, hasta las medicinas necesarias para la curación y los mejores alimentos; y serían cuidados en su propia casa «con todo el interés y esmero posible».

\footnotetext{
${ }^{610}$ Ibídem.

${ }^{611}$ La Provincia, 16/07/1885.

${ }^{612}$ La Provincia, 5/07/1885.

${ }^{613}$ La Provincia, 14/06/1885.
} 
Los médicos no tienen otro deseo que el de curar; las medicinas que se dan son también para curar, y si no curan muchos es porque no se llama a tiempo a los médicos, y cuando estos acuden, el enfermo están muriendo ya.

Las autoridades velan siempre por la salud del pueblo; tened confianza en ellas y no os dejéis engañar por los que os digan que los médicos tratan de perjudicar a nadie, pues lo que ellos desean es salvar a todos, absolutamente a todos si es posible.

Creo prudente adoptar este lenguaje, para que este bando sea comprendido por la clase a quien principalmente se dirige. ${ }^{614}$

El capitán general de Castellón dispuso que se montara una enfermería militar para coléricos, en previsión de que por lo reducido del local construido por la Diputación, no pudieran ser bien atendidos los militares si llegasen a ser atacados. ${ }^{615}$

La Comisión Provincial acordó el 22 de junio que se aislaran en el Hospital Provincial los practicantes del mismo, y que respecto a los médicos se tomaran las oportunas medidas para evitar el contagio.

Habiéndose negado los practicantes al aislamiento fueron suspendidos de sueldo.

Por prohibirse el ingreso de enfermos en el Hospital Provincial, se estableció en la escuela de párvulos un hospital provisional.

La Diputación Provincial, al ser invadida alguna persona en el Hospital, acordó aislar completamente el edificio, no permitiendo la entrada ni salida en él con el fin exterminar el foco colérico y para llevar a efecto este acuerdo solicitó el local de la escuela de párvulos para el tratamiento de las enfermedades comunes de individuos que hubieran de entrar en el Hospital y en este establecer las oficinas. El Ayuntamiento acordó cederlo temporalmente. ${ }^{616}$

La prensa recomienda al alcalde que prohíba terminantemente la exhibición del carruaje fúnebre que nada más porque sí cruzaba las principales calles y el paseo Ribalta a horas de más concurrencia. «Cualquiera que no supiese el estado de salud de esta población creería que estábamos en Murcia, y por eso creemos que de ningún modo debe tolerarse alarma tan escandalosa como inconveniente». 617

\footnotetext{
${ }^{614}$ La Provincia, 28/06/85.

${ }^{615}$ La Provincia, 2/07/1885.

${ }^{616}$ La Provincia, 2/07/85; AACS, 25/06/85.

${ }^{617}$ Ibídem.
} 
Los carros fúnebres que conducían los cadáveres de coléricos penetraban en la capital sin sufrir desinfección en el cementerio. La crítica que se hacía era que se prohibía la entrada a las personas procedentes de pueblos infestados o se les sometía a cuarentena para que no importaran el germen colérico, y se toleraba que «el carro que conducía los microbios penetrara en la capital». ${ }^{618}$

Había preocupación porque pronto empezarían los labradores la siega del cáñamo; La Provincia llama la atención de las autoridades y de la Junta de Sanidad para que dictara las disposiciones más acertadas al objeto de que la operación se llevara a efecto con todas las precauciones necesarias para que, sin ocasionar perjuicios a los cosecheros, no se tuvieran que deplorar fatales consecuencias, «hoy más que nunca probables dada la epidemia que aflige al país». ${ }^{619}$.

El sistema de aislamiento de los enfermos era muy criticado por su carácter inhumano, pues la familias quedaban aisladas sin cuidados ni protección. Las personas que entraban en las casas para auxiliar a los epidemiados no se les dejaban salir a llamar al médico, buscar medicinas, comestibles etc.

La Provincia dice que está conforme con el aislamiento pero que se plantee en la forma debida; pide que se organice la brigada sanitaria que preste los cuidados necesarios a los aislados, «despojando así de los, que de inhumano tiene el sistema, y desaparecerán las quejas y las resistencias que de otro modo crecerán de día a día». ${ }^{620}$

En una carta al director de La Provincia fechada el 13 de julio de 1885, un vecino denuncia el sistema de aislamiento de los enfermos de cólera adoptado en la capital en las casas de los invadidos. Pues mientras por un lado se extremaban las precauciones adoptadas en el aislamiento de las casas, no se habían desarrollado las medidas preventivas por medio de juntas o comisiones de distrito o barrio que podrían evitar la propagación y aumento de focos de infección, por medio de visitas a los barrios donde la enfermedad iba en aumento. ${ }^{621}$

Por la Comisión Provincial se estaba habilitando un espacioso almacén inmediato a la carretera de Alcora, para hospital de coléricos ${ }^{622}$.

\footnotetext{
618 Ibídem.

${ }^{619}$ La Provincia, 5/07/1885.

${ }^{620}$ La Provincia, 12/07/1885.

${ }^{621}$ La Provincia, 16/07/1885.

${ }^{622}$ La Provincia, 16/07/1885.
} 
El Ayuntamiento buscó enfermeras que se encargaran del cuidado y asistencia de todos aquellos que la necesitaran. ${ }^{623}$

La prensa se quejaba porque en muchas provincias de España se encendían hogueras o fogatas en las calles dónde el contagio era mayor, de las fumigaciones en gran escala y con abundancia de reactivos que se empleaban en todos los sitios peligrosos, y en fin, de las varias medidas que en presencia del mal se adoptaban por las juntas de distrito o de barrio. Urgía que esta actuación de las autoridades locales se hiciera ostensible también en Castellón, pues había llegado el caso de presentarse varios casos en edificios contiguos de una calle céntrica, lo cual parecía acusar la presencia de un foco que requería mayores medidas que las adoptadas hasta el presente para hacerlo desaparecer. Nadie mejor que esas comisiones podían informarse de la calidad de los alimentos que se consumían por el vecindario, dictar reglas y consejos higiénicos donde fuera preciso, facilitar el servicio facultativo cuando fuera necesario, cambiando las preocupaciones poco científicas que muchas personas tenían, y administrando la asistencia domiciliaria: «Sería de desear que de una vez se estableciera este régimen sanitario que ofrece las mayores facilidades y cuyos servicios pueden ser muy importantes en las presentes circunstancias y aún más digno en las eventualidades del porvenir».

El 20 de julio de 1885 se reunió en la Casa Capitular en sesión extraordinaria el Ayuntamiento, la Junta Local de Sanidad y el cuerpo médico de la capital presididos por el gobernador, para tratar de la necesidad de continuar con energía las medidas sanitarias acordadas por el Gobierno. En esta sesión se acordó dar un voto de confianza al alcalde José Tárrega para que continuara con el celo e interés que tenía en la grave cuestión sanitaria; que se publicara un bando para desvanecer ciertas preocupaciones de las gentes sencillas, advirtiéndoles que el aislamiento iba seguido de recursos de todo género; que se hiciera constar en acta el agradecimiento al gobernador Eleuterio Villalta, por el celo e interés y abnegación que demostraba en las difíciles circunstancias que atravesaba la provincia. ${ }^{624}$

\footnotetext{
${ }^{623}$ Ibídem.

${ }^{624}$ La Provincia, 23/07/1885.
} 
Una denuncia de la prensa eran los enterramientos de los muertos de cólera que se realizaban con precipitación, por lo que algunas veces se enterraba a personas que no habían fallecido. ${ }^{625}$

En lugar de esperar las ordenes de la autoridad competente para practicar la inhumación de los cadáveres conducidos al cementerio, se verificaba sin pasar aquella por el depósito, faltando de este modo a lo prescrito en las disposiciones relativas a sanidad y a las mismas por las que se regía el Registro Civil, que prohibía terminantemente los enterramientos antes de veinte y cuatro horas siguientes a las que el facultativo certificara el fallecimiento.

Por otra parte, por el apresuramiento seguido para sacar de casa los cadáveres, por razón de higiene era más fácil cometer la equivocación de tomar por una muerte cierta la que solo era aparente.

Muchas veces se presentaban los enterradores con el coche mortuorio en casa del colérico varias veces antes de que falleciera el enfermo.

También se prohibía el enterramiento de los que morían de cólera en nichos y panteones de propiedad particular, con lo que se producían muchas protestas, pues constituía un ataque a la propiedad privada.

La profundidad de los hoyos comunes distaba mucho de reunir las condiciones que las leyes de sanidad exigían. ${ }^{626}$

En una sesión del Ayuntamiento, el concejal Eliseo Soler (médico) expuso a la consideración del Ayuntamiento algunos abusos que se cometían en el cementerio, como era el entierro de los cadáveres sin orden del juez municipal y sin estar depositados las veinte y cuatro horas que disponía la ley del registro civil y el reglamento del cementerio; y estas infracciones estaban castigadas por otra ley y por el código penal. Tampoco se giraba la visita diaria al cementerio según exigía el reglamento, para lo cual era necesario establecer turno entre los concejales; y por último el concejal Soler añadió que no se registraba la cantidad de cadáveres que se enterraban al día.

La Corporación, en vista de todos y oídos otros concejales, acordó que se visitara diariamente el cementerio para vigilar el cumplimiento de las leyes y del reglamento del mismo; que se permitiera la inhumación en panteones y nichos, y que no

\footnotetext{
${ }^{625}$ La Provincia, 9/07/1885.

${ }^{626}$ La Provincia ,16/07/1885.
} 
se hiciera ningún depósito de cadáveres hasta las veinte y cuatro horas de haber fallecido. ${ }^{627}$

\subsection{ESTUDIO ESTADÍSTICO DE LA TRANSMISIÓN DEL CÓLERA EN LA CUIDAD DE CASTELLÓN DE LA PLANA}

Los primeros casos de la enfermedad en la ciudad de Castellón de la Plana aparecen en la segunda quincena del mes de junio. Las estadísticas que daban la Gaceta de Madrid, el Boletín Oficial de la Provincia y el Registro Civil, reflejan mucha confusión, pues no coinciden en el número de invasiones y defunciones:

Tabla 6. Invasiones y defunciones del cólera en la segunda quincena de junio

\begin{tabular}{|c|c|c|c|c|c|}
\hline \multirow{2}{*}{ Dia } & \multicolumn{2}{|c|}{ Gaceta de Madrid } & \multicolumn{2}{c|}{ Boletín Oficial } & Registro Civil \\
\cline { 2 - 6 } & Invasiones & Defunciones & Invasiones & Defunciones & Defunciones \\
\hline 19 & 6 & 4 & 2 & 0 & 0 \\
\hline 20 & 6 & 3 & 5 & 5 & 3 \\
\hline 21 & 6 & 0 & 0 & 0 & 3 \\
\hline 22 & 6 & 0 & 0 & 0 & 0 \\
\hline 23 & 7 & 3 & 7 & 3 & 2 \\
\hline 24 & 3 & 6 & 3 & 6 & 6 \\
\hline 25 & 1 & 2 & 1 & 2 & 0 \\
\hline 26 & 6 & 0 & 6 & 0 & 0 \\
\hline 27 & 6 & 0 & 3 & 0 & 1 \\
\hline 28 & 4 & 2 & 4 & 1 & 4 \\
\hline 29 & 7 & 7 & 7 & 7 & 3 \\
\hline 30 & 4 & 2 & 4 & 2 & 24 \\
\hline Total & 50 & 29 & 45 & 45 & \\
\hline
\end{tabular}

Fuente: Revista Médico-Farmacéutica, 17/07/1885, pp. 113-121

Según los datos publicados en prensa, el número de fallecimientos no era suficiente para declarar la epidemia en una población de 30.000 almas.

${ }^{627}$ La Provincia, 23/07/1885. 
La estadística por sexo, edad y profesión de los fallecimientos por cólera en éste periodo arrojaba los siguientes datos: ${ }^{628}$

Tabla 7. Estadística por sexo, edad y profesión de los fallecimientos por cólera en la segunda quincena de junio

\begin{tabular}{|c|c|c|c|c|}
\hline Días & Sexo & Edad & Profesión & Diagnostico \\
\hline 20 & Hembra & 44 & & Cólera morbo. \\
\hline "6 & "6 & “" & & $\begin{array}{l}\text { Enfermedad reinante en el hospital de } \\
\text { coléricos. }\end{array}$ \\
\hline “" & “" & 13 & & $\begin{array}{l}\text { Enfermedad reinante en el hospital de } \\
\text { coléricos. }\end{array}$ \\
\hline 21 & Varón & 66 & Labrador & Cólera morbo. \\
\hline “" & “" & 18 & Jornalero & $\begin{array}{l}\text { Enfermedad reinante en el hospital de } \\
\text { coléricos. }\end{array}$ \\
\hline "6 & “" & 12 & "“ & $\begin{array}{l}\text { Enfermedad reinante en el hospital de } \\
\text { coléricos. }\end{array}$ \\
\hline 22 & “" & “6 & “" & $\begin{array}{l}\text { Enfermedad reinante en el hospital de } \\
\text { coléricos. }\end{array}$ \\
\hline 23 & “" & 50 & “" & Cólera morbo. \\
\hline " & “" & 35 & Labrador & $\begin{array}{l}\text { Enfermedad reinante en el hospital de } \\
\text { coléricos. }\end{array}$ \\
\hline 24 & Hembra & 65 & & Cólera morbo esporádico. \\
\hline "6 & 6 & 35 & & Cólera morbo. \\
\hline "6 & “" & 56 & & Cólera morbo. \\
\hline “6 & “" & 50 & & Cólera esporádico. \\
\hline “" & “6 & 12 & & Cólera morbo. \\
\hline "6 & “" & 73 & Pastor & Cólera morbo epidémico. \\
\hline 25 & Varón & 46 & Labrador & Cólera esporádico. \\
\hline "“ & Hembra & 28 & & Cólera morbo. \\
\hline 26 & 66 & “ & & Cólera morbo. \\
\hline 27 & "“ & "6 & & Cólera morbo. \\
\hline 28 & Varon & 56 & “" & Cólera morbo asiático. \\
\hline 29 & “ & 30 & Sangrador & Cólera. \\
\hline "6 & Hembra & 56 & & Cólera morbo asiático. \\
\hline “6 & Varón & 38 & Jornalero & $\begin{array}{l}\text { Cólera, por referencias de la familia y } \\
\text { por las señales exteriores del cadáver. }\end{array}$ \\
\hline “ & Hembra & 50 & & Cólera morbo. \\
\hline 30 & 6 & 56 & & Cólera morbo asiático. \\
\hline “ & Varón & 38 & Labrador & $\begin{array}{l}\text { Cólera a juzgar por los signos exteriores } \\
\text { y antecedentes dados por la familia. }\end{array}$ \\
\hline “6 & “" & 50 & Jornalero & Cólera morbo. \\
\hline
\end{tabular}

Fuente: Revista Médico-Farmacéutica, 17/07/1885, pp. 113-121

${ }^{628}$ Revista Médico-Farmacéutica, 17/07/1885, pp. 113-121. 
Las invasiones y defunciones ocasionadas en el primer decenio de julio eran las siguientes, según los datos publicados por la Revista Médico-Farmacéutica recogidos de la Gaceta, el Boletín Oficial y el Registro Civil: ${ }^{629}$

Tabla 8. Invasiones y defunciones ocasionadas en el primer decenio de julio

\begin{tabular}{|c|c|c|c|c|c|}
\hline \multirow{2}{*}{ Julio } & \multicolumn{2}{|c|}{ Gaceta de Madrid } & \multicolumn{2}{c|}{ Boletín Oficial } & Registro civil \\
\cline { 2 - 6 } & Invasiones & Defunciones & Invasiones & Defunciones & Defunciones \\
\hline 1 & 5 & 2 & 5 & 2 & 1 \\
\hline 2 & 4 & 3 & 4 & 3 & 2 \\
\hline 3 & $\cdots$ & 1 & $\cdots$ & 1 & “ \\
\hline 4 & 4 & 1 & 4 & 1 & 6 \\
\hline 5 & 5 & 3 & 5 & 3 & 3 \\
\hline 6 & 7 & 6 & 7 & 6 & 3 \\
\hline 7 & 6 & 2 & 6 & 2 & 5 \\
\hline 8 & 15 & 5 & 15 & 5 & 5 \\
\hline 9 & $\cdots$ & $\cdots$ & 6 & 6 & 4 \\
\hline 10 & 13 & 5 & 15 & 5 & 33 \\
\hline Total & 59 & 28 & 67 & 34 & 4 \\
\hline
\end{tabular}

Fuente: Revista Médico-Farmacéutica, 17/07/1885, pp. 113-115

Los datos referentes a la población fallecida por cólera aparecen en la tabla siguiente:

Tabla 9. Estadística por sexo, edad y profesión de los fallecimientos por cólera en el primer decenio de julio

\begin{tabular}{|c|c|c|c|c|}
\hline Días & Sexo & Edad & Profesión & Diagnostico \\
\hline 1 & Varón & 66 & & Cólera. \\
\hline 2 & “ & 10 & & Cólera morbo. \\
\hline “ & “ & 44 & Labrador & Cólera morbo. \\
\hline 3 & “ & “ & Cólera morbo. \\
\hline
\end{tabular}

${ }^{629}$ Revista Médico Farmacéutica, 17/07/85, pp. 113-115. 


\begin{tabular}{|c|c|c|c|c|}
\hline 4 & " & " & " & Cólera morbo asiático. \\
\hline “" & Hembra & 43 & & Cólera morbo. \\
\hline " & Varón & 34 & Labrador & Cólera morbo asiático. \\
\hline "“ & "“ & 70 & Albañil & Cólera morbo asiático. \\
\hline "6 & " & 48 & Labrador & Enfermedad sospechosa. \\
\hline " & " & 23 & " & Cólera. \\
\hline 5 & " & 9 & “" & Cólera morbo asiático. \\
\hline " & " & 64 & “" & Cólera morbo asiático. \\
\hline " & " & 24 & " & Cólera morbo asiático. \\
\hline 6 & Hembra & 46 & & Cólera morbo asiático. \\
\hline “" & " & 3 & & Cólera morbo. \\
\hline “" & Varón & 79 & Labrador & Cólera morbo. \\
\hline “" & " & 7 & " & Cólera morbo asiático. \\
\hline 7 & Hembra & 65 & & Cólera morbo. \\
\hline “" & Varón & 32 & Labrador & Cólera morbo asiático. \\
\hline “" & Hembra & 34 & & Cólera morbo asiático. \\
\hline 8 & Varón & 16 & Labrador & Cólera morbo. \\
\hline “" & " & 10 & 6 & Cólera morbo asiático. \\
\hline "6 & " & 35 & "6 & Cólera morbo asiático. \\
\hline "“ & " & 52 & " & Cólera morbo. \\
\hline " & Hembra & 42 & & Cólera morbo asiático. \\
\hline 9 & Varón & 43 & Labrador & Cólera morbo epidémico. \\
\hline " & Hembra & 48 & & Cólera morbo. \\
\hline " & " & 50 & & Cólera morbo. \\
\hline " & " & 60 & & Cólera. \\
\hline "“ & " & 37 & & Cólera morbo epidémico. \\
\hline 10 & " & 60 & & Cólera. \\
\hline " & " & 50 & & Cólera morbo. \\
\hline “" & " & 48 & & Cólera morbo. \\
\hline " & Varón & "6 & Labrador & Cólera morbo epidémico. \\
\hline
\end{tabular}

Fuente: Revista Médico-Farmacéutica, 17/07/1885, pp. 113-115 
Comparando los datos de la primera decena de julio con los referentes a los últimos quince días de junio, aumentaron los casos de cólera en Castellón. Y como se ve afectaron a la clase humilde de la ciudad.

En la segunda decena de julio las defunciones aumentaron el doble, según arrojan los datos publicados en prensa: ${ }^{630}$

Tabla 10. Invasiones y defunciones ocasionadas en el segundo decenio de julio

\begin{tabular}{|c|c|c|c|c|c|}
\hline \multirow{2}{*}{ Julio } & \multicolumn{2}{|c|}{ Gaceta de Madrid } & \multicolumn{2}{c|}{ Boletín Oficial } & Registro civil \\
\cline { 2 - 6 } & Invasiones & Defunciones & Invasiones & Defunciones & Defunciones \\
\hline 11 & “ & “ & 8 & 8 & 10 \\
\hline 12 & “ & 9 & 13 & 8 & 3 \\
\hline 13 & “ & 6 & 15 & 6 & 6 \\
\hline 14 & 15 & 9 & 15 & 9 & 8 \\
\hline 15 & 15 & 7 & 13 & 7 & 10 \\
\hline 16 & 13 & 7 & 9 & 7 & 3 \\
\hline 17 & 9 & 4 & 6 & 4 & 7 \\
\hline 18 & 6 & 3 & 8 & 3 & 9 \\
\hline 19 & 5 & 9 & 12 & 9 & 64 \\
\hline 20 & 12 & 45 & 108 & 64 & 2 \\
\hline Total & 75 & & 9 & 3 & 6 \\
\hline
\end{tabular}

Fuente: Revista Médico-Farmacéutica, 27/07/1885, pp. 129-131

Tabla 11. Estadística por sexo, edad y profesión de los fallecimientos por cólera

\begin{tabular}{|l|l|l|l|l|}
\hline Días & Sexo & Edad & Profesión & Diagnostico \\
\hline 11 & Hembra & 19 & & Cólera morbo asiático. \\
\hline$“$ & Varon & 24 & & Cólera. \\
\hline “ & Hembra & 2 & & Cólera morbo epidémico. \\
\hline “ & Varon & 32 & Labrador & Cólera morbo. \\
\hline ( & Hembra & 45 & & Cólera morbo asiático. \\
\hline
\end{tabular}

${ }^{630}$ Revista Médico Farmacéutica, 27/07/85 PP. 129-131. 


\begin{tabular}{|c|c|c|c|c|}
\hline " & Varon & 25 & Labrador & Cólera morbo asiático. \\
\hline " & Hembra & 45 & & Cólera morbo asiático. \\
\hline “ & Varon & 50 & Labrador & Cólera morbo. \\
\hline " & Hembra & 32 & & Cólera. \\
\hline " & “ & 28 & & $\begin{array}{l}\text { Cólera complicado con } \\
\text { fiebre tifoidea. }\end{array}$ \\
\hline 12 & " & 45 & & Cólera indiano. \\
\hline “" & Varón & 6 & & Cólera morbo asiático. \\
\hline “" & “" & 6 & & Cólera. \\
\hline 13 & Hembra & 76 & & Cólera morbo asiático. \\
\hline " & " & 27 & & Cólera morbo asiático \\
\hline "“ & " & 46 & & Cólera morbo. \\
\hline " & Varon & 60 & Labrador & Cólera. \\
\hline " & " & 67 & " & Cólera. \\
\hline “" & Hembra & 55 & & Cólera morbo. \\
\hline 14 & “" & 66 & & Cólera morbo asiático. \\
\hline “ & " & 41 & & Cólera. \\
\hline " & " & 48 & & Cólera morbo asiático. \\
\hline “ & Varón & 30 & Curtidor & Cólera morbo asiático. \\
\hline " & “" & 5 & & Cólera morbo asiático \\
\hline “" & “ & 25 & Jornalero & Cólera morbo. \\
\hline “ & “" & 43 & Labrador & Cólera morbo. \\
\hline " & " & 36 & " & Cólera morbo \\
\hline 15 & Hembra & 50 & & Cólera morbo asiático. \\
\hline " & " & 42 & & $\begin{array}{l}\text { Sin asistencia y al parecer } \\
\text { cólera. }\end{array}$ \\
\hline " & “ & 50 & & Cólera morbo. \\
\hline “ & “" & 60 & & Cólera morbo. \\
\hline “ & Varon & 2 & & Cólera morbo. \\
\hline “ & " & 48 & Labrador & Cólera morbo. \\
\hline 16 & " & 20 & " & Cólera morbo. \\
\hline “ & Hembra & 78 & & Cólera morbo epidémico. \\
\hline
\end{tabular}




\begin{tabular}{|c|c|c|c|c|}
\hline “" & “" & 50 & & Cólera morbo asiático. \\
\hline "“ & Varón & 3 & & Cólera morbo asiático. \\
\hline "“ & Hembra & 31 & & Cólera morbo asiático. \\
\hline "“ & “" & 34 & & Cólera morbo asiático. \\
\hline "“ & Varón & 48 & Jornalero & Cólera morbo asiático. \\
\hline “" & Hembra & 21 & & Cólera. \\
\hline "“ & "“ & 18 & & Cólera morbo epidémico. \\
\hline " & " & 15 & & Cólera morbo. \\
\hline 17 & Varon & 60 & Labrador & Cólera morbo. \\
\hline "“ & Hembra & 2 & & Cólera morbo asiático. \\
\hline “" & “" & 60 & & Cólera morbo. \\
\hline 18 & “" & 35 & & Cólera. \\
\hline "“ & Varón & 38 & D.e consumos & Cólera morbo asiático. \\
\hline " & “" & 7 & & Cólera. \\
\hline “" & “" & 60 & Labrador & Cólera morbo asiático. \\
\hline "“ & "“ & 18 & Albañil & Cólera morbo. \\
\hline "“ & Hembra & 40 & & Cólera morbo asiático. \\
\hline “" & "“ & 59 & & Cólera morbo asiático. \\
\hline 19 & " & 84 & & Cólera morbo asiático. \\
\hline "“ & "“ & $8 \mathrm{~ms}$. & & Cólera morbo asiático. \\
\hline 20 & Varón & 13 & Labrador & Cólera. \\
\hline " & Hembra & 70 & & Cólera morbo. \\
\hline "“ & Varón & 43 & Empleado & Cólera. \\
\hline " & Hembra & 25 & & Cólera morbo asiático. \\
\hline "“ & " & 32 & & Cólera morbo asiático. \\
\hline “" & Varón & 20 & Jornalero & Cólera morbo. \\
\hline " & Hembra & 66 & & Cólera morbo. \\
\hline "“ & “" & 28 & & Cólera morbo asiático. \\
\hline “" & “" & 77 & & Cólera indiano. \\
\hline
\end{tabular}

Fuente: Revista Médico-Farmacéutica, 27/07/1885, pp. 129-131 
La enfermedad se presentaba con manifestaciones diversas que la alejaban del carácter típico con que hasta la fecha se la conocía, sin embargo, no era menos mortífera que en epidemias anteriores.

La epidemia en el último decenio de julio, no aumentó, pues el número de defunciones no era mucho mayor que en los días anteriores. ${ }^{631}$

Los datos que corresponden a la incidencia de la epidemia desde el 21 al 31 de julio se pueden observar en las siguientes tablas:

Tabla 12. Invasiones y defunciones ocasionadas en el tercer decenio de julio

\begin{tabular}{|c|c|c|c|c|c|}
\hline \multirow{2}{*}{ Días } & \multicolumn{2}{|c|}{ Gaceta de Madrid } & \multicolumn{2}{c|}{ Boletín Oficial } & Regist.civil \\
\cline { 2 - 6 } & Inv. & Def & Inv. & Def. & Def. \\
\hline 21 & 8 & 7 & 8 & 7 & 8 \\
\hline 22 & “ & “ & 4 & 3 & 3 \\
\hline 23 & 11 & 4 & 11 & 4 & 1 \\
\hline 24 & 15 & 6 & 15 & 6 & 10 \\
\hline 25 & 22 & 2 & 22 & 2 & 4 \\
\hline 26 & 15 & 10 & 15 & 10 & 7 \\
\hline 27 & 20 & 5 & 20 & 5 & 6 \\
\hline 28 & 16 & 9 & 16 & 9 & 9 \\
\hline 29 & 9 & 8 & 9 & 10 & 5 \\
\hline 30 & 16 & 7 & 16 & 7 & 6 \\
\hline 31 & 21 & 13 & 21 & 13 & 13 \\
\hline Total & 153 & 71 & 155 & 80 & 72 \\
\hline
\end{tabular}

Fuente: Revista Médico-Farmacéutica, 7/08/1885, pp. 145-147

Tabla 13. Estadística por sexo, edad y profesión de los fallecimientos por cólera en el tercer decenio de julio

\begin{tabular}{|l|l|l|l|l|}
\hline Días & Sexo & Edad & Profesión & Diagnostico \\
\hline 21 & Hembra & 32 & & Cólera asfíctico. \\
\hline “ & Varón & $18 \mathrm{~m}$. & & Cólera morbo asiático. \\
\hline “ & Hembra & 30 & & Cólera morbo asiático. \\
\hline “ & “ & 40 & & Cólera morbo epidémico. \\
\hline
\end{tabular}

${ }^{631}$ Revista Médico- Farmacéutica, 7/08/1885 pp. 145-147. 


\begin{tabular}{|c|c|c|c|c|}
\hline “ & Varón & 32 & & Cólera morbo epidémico. \\
\hline “ & “ & 25 & Albañil & Cólera morbo. \\
\hline “ & Hembra & 70 & & Cólera morbo asiático. \\
\hline “ & “ & & & Cólera morbo epidémico. \\
\hline 22 & Varón & 77 & Labrador & Cólera. \\
\hline “" & “ & 7 & & Cólera asfíctico. \\
\hline “ & “ & 45 & Alpargatero & Cólera morbo asiático. \\
\hline 23 & “ & 40 & & Cólera morbo asiático. \\
\hline 24 & Hembra & 15 & & Cólera morbo. \\
\hline “ & Varón & 18 & & $\begin{array}{l}\text { Cólera complicado con fiebre } \\
\text { tifoidea. }\end{array}$ \\
\hline “ & “ & 36 & Labrador & Cólera. \\
\hline “ & “ & 45 & & Cólera morbo. \\
\hline “ & Hembra & 14 & & Cólera morbo. \\
\hline “ & Varón & 5 & & Cólera morbo asiático. \\
\hline “ & Hembra & 38 & & Cólera morbo asiático. \\
\hline “ & “ & 40 & & Cólera morbo. \\
\hline “" & Varón & 61 & Pastor & Cólera morbo asiático. \\
\hline “ & “ & 50 & Labrador & Cólera morbo. \\
\hline 25 & Hembra & 32 & & Cólera morbo asiático. \\
\hline “" & Varón & 37 & Comerciante & Cólera morbo asiático. \\
\hline “، & “ & 28 & Labrador & Cólera morbo asiático. \\
\hline “" & " & 36 & Alpargatero & Cólera morbo asiático. \\
\hline 26 & “ & 46 & Fabricante & Cólera morbo epidémico. \\
\hline “6 & Hembra & 60 & & $\begin{array}{l}\text { Sin asistencia y a juzgar por signos, } \\
\text { C.M.A. }\end{array}$ \\
\hline “" & “ & 2 & & Cólera morbo asiático. \\
\hline “" & “ & 4 & & Cólera morbo. \\
\hline “6 & Varón & 60 & Labrador. & Cólera morbo asiático. \\
\hline “" & Hembra & 3 & & Cólera morbo. \\
\hline “ & “" & 65 & & Cólera morbo. \\
\hline 27 & Varón & 74 & & Cólera morbo asiático. \\
\hline “6 & Hembra & 2 & & Cólera morbo asiático. \\
\hline ““ & Varón & 49 & Sastre & Cólera morbo asiático. \\
\hline
\end{tabular}




\begin{tabular}{|c|c|c|c|c|}
\hline “ & Hembra & 80 & & Cólera morbo asiático. \\
\hline “ & “ & 75 & & Cólera morbo asiático. \\
\hline “ & “ & 46 & & $\begin{array}{l}\text { Cólera por falta de asistencia } \\
\text { facultativa. }\end{array}$ \\
\hline 28 & “ & 60 & & Cólera morbo epidémico. \\
\hline “ & “ & 3 & & $\begin{array}{l}\text { C. por faltar a las prescripciones } \\
\text { facultativas }\end{array}$ \\
\hline “ & “ & 76 & & Cólera morbo asiático. \\
\hline “ & Varón & 39 & & Cólera asfíxico. \\
\hline “" & Hembra & 16 & & $\begin{array}{l}\text { Cólera por falta de asistencia } \\
\text { facultativa. }\end{array}$ \\
\hline “ & Varón & 50 & Capitán & Cólera morbo fulminante. \\
\hline “ & Hembra & 70 & & Cólera. \\
\hline “" & Varón & 2 & & Cólera morbo asiático. \\
\hline “6 & Hembra & 45 & & Cólera morbo. \\
\hline 29 & “" & 44 & & Cólera morbo. \\
\hline “ & “ & 14 & & Cólera morbo asiático. \\
\hline “6 & “ & 64 & & Cólera morbo asiático. \\
\hline “ & " & 11 & & Cólera morbo. \\
\hline “6 & “ & 16 & & Cólera morbo. \\
\hline 30 & “" & 65 & & Cólera morbo. \\
\hline “ & Varón & 3 & & Cólera morbo. \\
\hline “6 & Hembra & 22 & & Cólera morbo asiático. \\
\hline “ & Varón & 11 & & Cólera morbo. \\
\hline “ & “ & 9 & Jornalero & Cólera morbo. \\
\hline “6 & Hembra & 28 & Modista & Cólera morbo asiático \\
\hline 31 & “ & 6 & & Cólera morbo. \\
\hline “" & “ & 60 & & Cólera morbo. \\
\hline “ & Varón & 10 & & Cólera morbo asiático. \\
\hline “ & “ & 53 & Alpargatero & Cólera morbo epidémico. \\
\hline “ & Hembra & 47 & & Cólera. \\
\hline “" & Varón & 19 & Barbero & Cólera morbo. \\
\hline “ & Hembra & 18 & & Cólera. \\
\hline “" & “ & 20 & & Cólera morbo asiático. \\
\hline “" & “" & 3 & & Cólera morbo asiático. \\
\hline
\end{tabular}




\begin{tabular}{|l|l|l|l|l|}
\hline “ & “ & & & Cólera morbo asiático. \\
\hline “ & Varón & 40 & & Cólera morbo. \\
\hline “ & Hembra & 7 & & Cólera morbo. \\
\hline “ & “ & 7 & & Cólera morbo. \\
\hline
\end{tabular}

Fuente: Fuente: Revista Médico-Farmacéutica, 7/08/1885, pp. 145-147

Los datos que corresponden al decenio del 1 al 10 de agosto, siempre extraídos de las publicaciones en prensa que hacen referencia a las instituciones oficiales, figuran en las tablas siguientes: ${ }^{632}$

Tabla 14. Invasiones y defunciones ocasionadas en el primer decenio de agosto

\begin{tabular}{|c|c|c|c|c|c|}
\hline \multirow{2}{*}{ Días } & \multicolumn{2}{|c|}{ Gaceta de Madrid } & \multicolumn{2}{c|}{ Boletín Oficial } & Registro civil \\
\cline { 2 - 6 } & Inv. & Def. & Inv. & Def. & Def. \\
\hline 1 & 13 & 7 & 13 & 7 & 11 \\
\hline 2 & 7 & 6 & 7 & 6 & 7 \\
\hline 3 & 14 & 5 & 14 & 5 & 3 \\
\hline 4 & 14 & 12 & 14 & 12 & 8 \\
\hline 5 & 10 & 6 & 10 & 6 & 8 \\
\hline 6 & 10 & 7 & 10 & 7 & 7 \\
\hline 7 & 14 & 4 & 14 & 4 & 5 \\
\hline 8 & 10 & 7 & 10 & 7 & 5 \\
\hline 9 & 5 & 4 & 5 & 4 & 4 \\
\hline 10 & 9 & 3 & 9 & 3 & 66 \\
\hline Totales & 106 & 61 & 106 & 61 & \\
\hline
\end{tabular}

Fuente: Revista Médico-Farmacéutica, 17/08/1885, pp. 161-163

${ }^{632}$ Revista Médico-Farmacéutica, 17/08/85. pp. 161-163. 
Tabla 15. Estadística por sexo, edad y profesión de los fallecimientos por cólera en el primer decenio de agosto

\begin{tabular}{|c|c|c|c|c|}
\hline Días & Sexo & Edad & Profesión & Diagnostico \\
\hline 1 & Varón & 33 & Sereno & Cólera. \\
\hline “ & “ & 40 & & Cólera asfíctico. \\
\hline “" & “" & 54 & & Cólera morbo asiático. \\
\hline “ & “ & 35 & Zapatero & Cólera morbo \\
\hline “ & “ & 20 & & Cólera \\
\hline “ & “ & 5 & & Cólera morbo asiático \\
\hline “ & Hembra & 2 & & Cólera morbo asiático \\
\hline “ & “ & 24 & Pescadera & $\begin{array}{l}\text { Cólera morbo asiático según } \\
\text { antecedentes. }\end{array}$ \\
\hline “ & “ & 2 & & Cólera morbo. \\
\hline “ & Varón & 67 & Jornalero & Cólera morbo. \\
\hline “ & Hembra & 28 & & Cólera morbo. \\
\hline 2 & “ & 60 & & Cólera morbo asiático. \\
\hline “ & “ & 42 & & Cólera morbo asiático. \\
\hline “ & Varón & 11 & & Cólera. \\
\hline “ & Hembra & 76 & & Cólera morbo. \\
\hline “ & Varón & 20 & Cortante & Cólera morbo asiático. \\
\hline “ & “ & 60 & & Cólera azul. \\
\hline “ & “ & 54 & Jornalero & Cólera morbo. \\
\hline 3 & “ & 2 & & Cólera morbo. \\
\hline “ & “ & 28 & & Cólera morbo asiático. \\
\hline “" & Hembra & 3 & & Cólera morbo. \\
\hline 4 & Varón & 29 & & Cólera morbo. \\
\hline “ & Hembra & 71 & & Cólera. \\
\hline “ & Varón & 76 & Labrador & Cólera morbo. \\
\hline “ & Hembra & 7 & & Cólera morbo epidémico. \\
\hline “" & “ & 56 & & Cólera. \\
\hline “ & “ & 40 & & Cólera morbo. \\
\hline “ & Varón & 34 & Alpargatero & Cólera morbo asiático. \\
\hline “ & Hembra & 54 & & Cólera morbo. \\
\hline 5 & “" & 54 & Monja & Cólera morbo. \\
\hline
\end{tabular}




\begin{tabular}{|c|c|c|c|c|}
\hline “6 & “ & 75 & & Cólera morbo asiático. \\
\hline “ & “ & 60 & & Cólera morbo epidémico. \\
\hline “ & “ & 50 & & Cólera morbo. \\
\hline “ & “ & 58 & & Cólera morbo epidémico. \\
\hline “" & Varón & 37 & Soguero & Cólera morbo epidémico. \\
\hline “ & Hembra & 40 & & Cólera morbo asiático. \\
\hline “" & “ & 6 & & Cólera morbo asiático \\
\hline 6 & Varón & 40 & Alpargateo & $\begin{array}{l}\text { Calentura tifoidea } \\
\text { consecutiva al cólera. }\end{array}$ \\
\hline “ & “ & 3 & & Cólera morbo asiático. \\
\hline “ & “ & 40 & Jornalero & Cólera. \\
\hline “" & Hembra & 13 & & Cólera morbo asiático. \\
\hline “" & “" & 23 & & Cólera morbo. \\
\hline “ & “ & 19 & & Cólera morbo. \\
\hline “ & “ & 22 & & Cólera morbo asiático. \\
\hline 7 & “" & 10 & & Cólera morbo asiático. \\
\hline “ & Varon & 52 & Labrador & Cólera morbo. \\
\hline ““ & Hembra & 52 & & Cólera morbo asiático. \\
\hline “ & “ & 72 & & Cólera morbo asiático. \\
\hline “ & " & 56 & & Cólera morbo. \\
\hline 8 & “" & 24 & & Cólera morbo. \\
\hline ““ & “" & 28 & & Cólera morbo asiático. \\
\hline ““ & “" & 2 & & Cólera morbo asiático. \\
\hline “ & Varón & 28 & Labrador & Cólera morbo asiático. \\
\hline “" & “ & 60 & “" & Cólera morbo. \\
\hline 9 & Hembra & 46 & & Cólera morbo epidémico. \\
\hline ““ & “" & & & Cólera morbo. \\
\hline “" & Varón & 29 & Soguero & Cólera. \\
\hline “ & “" & 50 & Labrador & Cólera. \\
\hline 10 & “" & 60 & “" & Cólera morbo epidémico. \\
\hline “" & Hembra & 72 & & Cólera. \\
\hline “ & Varón & 63 & Tejedor & Cólera. \\
\hline “" & “" & 55 & Labrador & Cólera morbo. \\
\hline “" & Hembra & 2 & & Cólera morbo. \\
\hline
\end{tabular}




\begin{tabular}{|l|l|l|l|l|}
\hline “ & “ & 10 & & Cólera morbo asiático. \\
\hline “ & Varón & 50 & Labrador & Cólera morbo asiático. \\
\hline & Hembra & 33 & & Cólera morbo. \\
\hline
\end{tabular}

Fuente: Revista Médico-Farmacéutica, 17/08/1885, pp. 161-163

En la segunda decena del mes de agosto, la epidemia decreció de una manera notable.

Según la prensa, las buenas condiciones higiénicas de la población, los auxilios de todas clases prestados a la clase proletaria y los socorros a los enfermos fueron la causa de que la enfermedad no se cebase en Castellón de la Plana tanto como en otras poblaciones vecinas. ${ }^{633}$

Los datos referentes a los días de 11 a 20 de agosto fueron:

Tabla 16. Invasiones y defunciones ocasionadas en el segundo decenio de agosto

\begin{tabular}{|c|c|c|c|c|c|}
\hline \multirow{2}{*}{ Días } & \multicolumn{2}{|c|}{ Gaceta de Madrid } & \multicolumn{2}{c|}{ Boletín Oficial } & Registro civil \\
\cline { 2 - 6 } & Inv. & Def. & Inv. & Def. & Def. \\
\hline 11 & 4 & “ & 4 & “ & 5 \\
\hline 12 & 4 & 2 & 4 & 2 & 2 \\
\hline 13 & 8 & 6 & 8 & 6 & 6 \\
\hline 14 & 3 & 1 & 3 & 1 & 1 \\
\hline 15 & 5 & 4 & 5 & 4 & 4 \\
\hline 16 & 2 & $\cdots$ & 2 & $\cdots$ & $\cdots$ \\
\hline 17 & 4 & 3 & 4 & 3 & 3 \\
\hline 18 & $“$ & 2 & $\cdots$ & 2 & 2 \\
\hline 19 & 2 & $“$ & 2 & $\cdots$ & 3 \\
\hline 20 & 4 & 3 & 4 & 3 & 26 \\
\hline Total & 36 & 21 & 36 & 21 & \\
\hline
\end{tabular}

Fuente: Revista Médico-Farmacéutica, 27/08/1885, pp. 177-178

La estadística por sexo, edad y profesión de los fallecimientos por cólera en éste periodo arrojaba los siguientes datos publicados en prensa: ${ }^{634}$

${ }^{633}$ Revista Médico-Farmacéutica, 27/08/1885. pp. 177-178.
${ }^{634}$ Ibídem. 
Tabla 17. Estadística por sexo, edad y profesión de los fallecimientos por cólera en el segundo decenio de agosto

\begin{tabular}{|c|c|c|c|c|}
\hline Días & Sexo & Edad & Profesión & Diagnostico \\
\hline 11 & Varón & 66 & Jornalero & Cólera morbo. \\
\hline " & Hembra & 9 & & Cólera morbo. \\
\hline “" & " & 30 & & Cólera morbo. \\
\hline " & Varón & 25 & & Cólera morbo asiático \\
\hline " & " & 36 & Labrador & Cólera \\
\hline 12 & Hembra & 30 & & Cólera morbo. \\
\hline " & " & 66 & & Cólera morbo asiático. \\
\hline 13 & “" & 34 & & Cólera morbo. \\
\hline " & " & 76 & & Cólera morbo asiático. \\
\hline " & " & 25 & & Cólera morbo asiático. \\
\hline “" & " & 26 & & Cólera morbo. \\
\hline 14 & “6 & 34 & & Cólera morbo epidémico. \\
\hline " & Varón & 56 & Escultor & Cólera morbo epidémico. \\
\hline “" & Hembra & 50 & & Cólera morbo epidémico. \\
\hline 15 & Varón & 15 & & Cólera morbo asiático. \\
\hline " & "6 & 31 & Empleado & Cólera indiano. \\
\hline " & Hembra & 5 & & Cólera morbo asiático. \\
\hline 16 & “" & 66 & & Cólera morbo asiático. \\
\hline 17 & “" & " & & Cólera morbo asiático. \\
\hline 18 & " & " & & Cólera morbo asiático. \\
\hline 19 & " & “" & & Cólera morbo asiático. \\
\hline 20 & Varón & 1 & & Cólera infantil. \\
\hline " & “" & 51 & & Cólera. \\
\hline "6 & " & 50 & & Cólera morbo asiático. \\
\hline “6 & Hembra & 78 & & Cólera asiático. \\
\hline
\end{tabular}

Fuente: Revista Médico-Farmacéutica, 27/08/1885, pp. 177-178

A mediados de agosto, a pesar del descenso considerable del número de casos, en el mercado de la ciudad se prohibió la venta de algunas frutas como el melón y la 
uva. Se suprimieron los cordones y los lazaretos; sólo quedaba el aislamiento «en simulacro», contra el cual se pronunciaron algunos concejales del Ayuntamiento, aún aquellos que más confianza tuvieron en la virtud profiláctica del procedimiento.

La Gaceta de Madrid y el Boletín Oficial de la Provincia de Castellón, desde el día 24 de agosto omitían dar cuenta de las invasiones y defunciones, únicamente el Registro Civil figuran defunciones por cólera en los días 25, 27, 29 y 31, según se puede ver en la tabla siguiente: ${ }^{635}$

Tabla 18. Invasiones y defunciones ocasionadas en el tercer decenio de agosto

\begin{tabular}{|c|c|c|c|c|c|}
\hline \multirow[t]{2}{*}{ Días } & \multicolumn{2}{|c|}{ Gaceta de Madrid } & \multicolumn{2}{|c|}{ Boletín Oficial } & \multirow{2}{*}{$\begin{array}{c}\text { Reg. Civil } \\
\text { Def. }\end{array}$} \\
\hline & Inv. & Def. & Inv. & Def. & \\
\hline 20 & 4 & 3 & 4 & 3 & “" \\
\hline 21 & “" & 2 & “6 & 2 & 2 \\
\hline 22 & " & " & " & " & " \\
\hline 23 & 2 & “" & 2 & “" & “" \\
\hline 24 & "“ & “" & “" & "“ & "“ \\
\hline 25 & " & " & “" & “" & 5 \\
\hline 26 & "“ & “" & “" & "“ & "“ \\
\hline 27 & " & " & " & “" & 1 \\
\hline 28 & "6 & "“ & "6 & "“ & "“ \\
\hline 29 & “" & “" & "“ & “" & 3 \\
\hline 30 & “" & “" & “" & “" & “" \\
\hline 31 & “" & “" & “" & “" & 1 \\
\hline Total & 6 & 5 & 6 & 5 & 12 \\
\hline
\end{tabular}

Fuente: Revista Médico-Farmacéutica, 7/09/1885, pp. 193-194

${ }^{635}$ Revista Médico-Farmacéutica, 7/09/1885, pp. 193-194. 
Tabla 19. Estadística por sexo, edad y profesión de los fallecimientos por cólera en el tercer decenio de agosto

\begin{tabular}{|c|c|c|c|c|}
\hline Días & Sexo & Edad & Profesión & Diagnostico \\
\hline 21 & Hembra & 66 & & Cólera morbo. \\
\hline "“ & " & 15 & & Cólera morbo. \\
\hline 25 & “" & 44 & & Cólera morbo. \\
\hline "“ & "“ & 16 & & Cólera morbo asiático. \\
\hline "“ & Varón & 35 & Militar & Cólera morbo asiático. \\
\hline "“ & Hembra & 67 & & Cólera morbo. \\
\hline "“ & " & 38 & & Cólera morbo asiático. \\
\hline 27 & "“ & 7 & & Cólera morbo asiático. \\
\hline 29 & “" & 22 & & Cólera morbo asiático. \\
\hline " & " & 59 & & Cólera morbo. \\
\hline " & " & 66 & & Cólera. \\
\hline 31 & " & 36 & & Cólera. \\
\hline
\end{tabular}

Fuente: Revista Médico-Farmacéutica, 7/09/1885, pp. 193-194

En septiembre se considera terminada la epidemia en Castellón de la Plana.

La Revista Médico-Farmacéutica publicó algunos datos (tablas 20, 21, 22) de la epidemia en la ciudad de Castellón, «no entreteniéndonos en trabajos de alcance estadístico, por creer que la escrupulosidad en aquellos deja algo que desear» ${ }^{636}$

Tabla 20. Evolución de la epidemia en Castellón de la Plana

\begin{tabular}{|c|c|c|c|c|c|c|c|c|c|c|c|c|c|}
\hline \multirow[b]{2}{*}{ Días } & \multicolumn{2}{|c|}{ Junio } & \multicolumn{2}{|c|}{ Julio } & \multicolumn{2}{|c|}{ Agosto } & \multirow[b]{2}{*}{ Días } & \multicolumn{2}{|c|}{ Junio } & \multicolumn{2}{|c|}{ Julio } & \multicolumn{2}{|c|}{ Agosto } \\
\hline & I & D & I & D & I & D & & I & D & I & D & I & D \\
\hline 1 & “ & “ & 5 & 2 & 13 & 7 & 17 & “" & “" & 9 & 7 & 4 & 3 \\
\hline 2 & “ & “ & 4 & 3 & 7 & 6 & 18 & “6 & “" & 6 & 4 & “ & 2 \\
\hline 3 & “ & “ & “ & 2 & 14 & 3 & 19 & 3 & “" & 8 & 3 & 2 & “ \\
\hline 4 & “ & “ & 4 & 1 & 14 & 13 & 20 & 4 & 5 & 12 & 9 & 4 & 3 \\
\hline 5 & “ & “ & 5 & 3 & 10 & 6 & 21 & 4 & 2 & 8 & 7 & “" & 2 \\
\hline 6 & “ & “ & 7 & 6 & 10 & 7 & 22 & “ & “" & 4 & 4 & “ & “ \\
\hline
\end{tabular}

${ }^{636}$ Revista Médico-Farmacéutica, 7/10/1885 pp. 242-244. 


\begin{tabular}{|c|c|c|c|c|c|c||c|c|c|c|c|c|c|}
\hline 7 & “ & “ & 6 & 2 & 14 & 4 & 23 & 7 & 3 & 12 & 4 & “ & “ \\
\hline 8 & “ & “ & 15 & 4 & 10 & 7 & 24 & 3 & 6 & 15 & 6 & “ & “ \\
\hline 9 & “ & “ & 6 & 6 & 5 & 4 & 25 & 1 & 2 & 22 & 5 & “ & “ \\
\hline 10 & “ & “ & 13 & 5 & 9 & 8 & 26 & 6 & “ & 15 & 11 & “ & “ \\
\hline 11 & “ & “ & 8 & 8 & 5 & 1 & 27 & 3 & “ & 20 & 5 & “ & “ \\
\hline 12 & “ & “ & 9 & 2 & 4 & 2 & 28 & 4 & 2 & 16 & 9 & 3 & 3 \\
\hline 13 & “ & “ & 13 & 8 & 8 & 6 & 29 & 4 & 7 & 9 & 10 & “ & “ \\
\hline 14 & “ & “ & 15 & 6 & 3 & 1 & 30 & 4 & 2 & 16 & 7 & “ & “ \\
\hline 15 & “ & “ & 15 & 9 & 5 & 3 & 31 & “ & “ & 21 & 13 & “ & “ \\
\hline 16 & “ & “ & 13 & 7 & 2 & “ & Total & 43 & 29 & 330 & 178 & 148 & 93 \\
\hline
\end{tabular}

Fuente: Revista Médico-Farmacéutica, 7/10/1885, pp. 242-244

Tabla 21. Invasiones y defunciones por estado civil de los afectados

\begin{tabular}{|c|c|c|c|c|c|c|c|c|c|c|c|}
\hline \multirow{6}{*}{ Invasiones } & \multirow[t]{2}{*}{ Meses } & \multicolumn{2}{|c|}{ Casados } & \multirow[b]{2}{*}{$\begin{array}{l}\text { Tota } \\
1\end{array}$} & \multicolumn{2}{|c|}{ Viudos } & \multirow[b]{2}{*}{$\begin{array}{l}\text { Tota } \\
1\end{array}$} & \multicolumn{2}{|c|}{ Solteros } & \multirow[b]{2}{*}{$\begin{array}{l}\text { Tota } \\
1\end{array}$} & \multirow[b]{2}{*}{ Totales } \\
\hline & & $\mathrm{V}$ & $\mathrm{H}$ & & V & $\mathrm{H}$ & & $\mathrm{V}$ & $\mathrm{H}$ & & \\
\hline & Junio & 12 & 9 & 21 & 1 & 6 & 7 & 8 & 7 & 15 & 43 \\
\hline & Julio & 50 & 85 & 135 & 10 & 34 & 44 & 70 & 81 & 151 & 330 \\
\hline & $\begin{array}{l}\text { Agost } \\
\text { o }\end{array}$ & 24 & 34 & 62 & 5 & 23 & 28 & 14 & 44 & 58 & 148 \\
\hline & Total & 86 & 132 & 218 & 16 & 63 & 79 & 92 & $\begin{array}{l}13 \\
2\end{array}$ & 224 & 521 \\
\hline \multirow{4}{*}{ Defuncione } & Junio & 8 & 7 & 15 & 1 & 5 & 6 & 4 & 6 & 10 & 31 \\
\hline & Julio & 33 & 48 & 81 & 8 & 22 & 30 & 37 & 37 & 74 & 185 \\
\hline & $\begin{array}{l}\text { Agost } \\
\text { o }\end{array}$ & 16 & 20 & 36 & 4 & 16 & 20 & 7 & 21 & 28 & 84 \\
\hline & Total & 57 & 75 & 132 & 13 & 43 & 56 & 48 & 64 & 112 & 300 \\
\hline \multirow{4}{*}{ Curaciones } & Junio & 4 & 2 & 6 & 0 & 1 & 1 & 4 & 1 & 5 & 12 \\
\hline & Julio & 17 & 37 & 54 & 2 & 12 & 14 & 33 & 44 & 77 & 145 \\
\hline & $\begin{array}{l}\text { Agost } \\
0\end{array}$ & 8 & 18 & 26 & 1 & 7 & 8 & 7 & 23 & 30 & 64 \\
\hline & Total & 29 & 57 & 80 & 3 & 20 & 23 & 44 & 68 & 112 & 221 \\
\hline
\end{tabular}

Fuente: Revista Médico-Farmacéutica, 7/10/1885, pp. 242-244 
Como se observa, había más invasiones en las mujeres que en los hombres:

-Entre los casados: 132 invasiones de mujeres, frente a 86 de varones.

-Entre los viudos: 63 de mujeres frente a 16 de varones.

-Entre los solteros: 132 mujeres, frente a 92 varones.

También había más muertes de mujeres que de varones:

-Casados: 75 mujeres, frente a 57 varones.

-Viudos: 43 mujeres frente a 13 varones.

-Solteros: 64 mujeres frente a 48 varones.

Sin embargo, había más curaciones en mujeres que en hombres:

-Casados: 57 mujeres frente a 29 varones.

-Viudos: 20 mujeres frente a 3 varones.

-Solteros: 68 mujeres frente a 44 varones.

Nuestra hipótesis es que al ser la mujer la que hacía de cuidadora y de enfermera, estaba más expuesta al germen colérico, que el hombre

Por otra parte, si nos fijamos en la edad del cuadro siguiente, la franja más afectada era la comprendida entre 40 a 60 años; seguida de los 25 a 40 años, y después, menores de 15 años.

Las personas de 25 a 40, y de 40 a 60 eran gente que trabajaba en su mayoría, en el campo, que no observaban una estricta higiene en el agua que bebían ni en los alimentos que tomaban.

Tabla 22. Invasiones, defunciones y curaciones por edades

\begin{tabular}{|c|c|c|c|c|c|c|c|}
\hline & Meses & $\begin{array}{l}\text { Menores de } \\
15 \text { años }\end{array}$ & $\begin{array}{l}\text { De } 15 \text { a } \\
25 \text { años }\end{array}$ & $\begin{array}{l}\text { De } 25 \text { a } \\
40 \text { años }\end{array}$ & $\begin{array}{l}\text { De } 40 \text { a } \\
60 \text { años }\end{array}$ & $\begin{array}{l}\text { De más de } \\
60 \text { años }\end{array}$ & Totales \\
\hline & Junio & 5 & 7 & 11 & 16 & 4 & 43 \\
\hline \multirow{3}{*}{ Invasiones } & Julio & 89 & 41 & 78 & 79 & 43 & 330 \\
\hline & $\begin{array}{l}\text { Agost } \\
\mathrm{o}\end{array}$ & 28 & 20 & 37 & 41 & 22 & 148 \\
\hline & Total & 122 & 68 & 126 & 136 & 69 & 521 \\
\hline \multirow[b]{3}{*}{ Defunciones } & Junio & 3 & 5 & 7 & 12 & 4 & 31 \\
\hline & Julio & 43 & 20 & 39 & 49 & 34 & 185 \\
\hline & $\begin{array}{l}\text { Agost } \\
0\end{array}$ & 16 & 8 & 20 & 23 & 17 & 84 \\
\hline
\end{tabular}




\begin{tabular}{|l|l|l|l|l|l|l|l|}
\hline & Total & 62 & 33 & 66 & 84 & 55 & 300 \\
\hline \multirow{5}{*}{ Curaciones } & Junio & 2 & 2 & 4 & 4 & 55 & 12 \\
\cline { 2 - 9 } & Julio & 46 & 21 & 39 & 30 & 9 & 145 \\
\cline { 2 - 8 } & $\begin{array}{l}\text { Agost } \\
\text { o }\end{array}$ & 16 & 35 & 17 & 18 & 5 & 64 \\
\cline { 2 - 8 } & Total & 64 & 58 & 60 & 52 & 14 & 221 \\
\hline
\end{tabular}

Fuente: Revista Médico-Farmacéutica, 7/10/1885 pp. 242-244

A mediados de septiembre ya nadie se acordaba del cólera; los ácidos y el láudano y cuantas sustancias se conservaban como talismán que había de proteger las vidas de los ciudadanos, fueron retirados por inservibles.

\subsection{ESTUDIO COMPARTIVO DE LA EPIDEMIA DE CÓLERA DE 1885 EN LA CIUDAD DE CASTELLÓN DE LA PLANA Y PROVINCIA}

A continuación hemos elaborado las gráficas de la evolución del cólera en Castellón y en los pueblos de la provincia, según los datos que figuran en el Boletín Oficial de la Provincia, desde el 24 de junio de $1885 .{ }^{637}$

\section{Gráfica 1. Cólera en Castellón de la Plana. Junio de 1885}

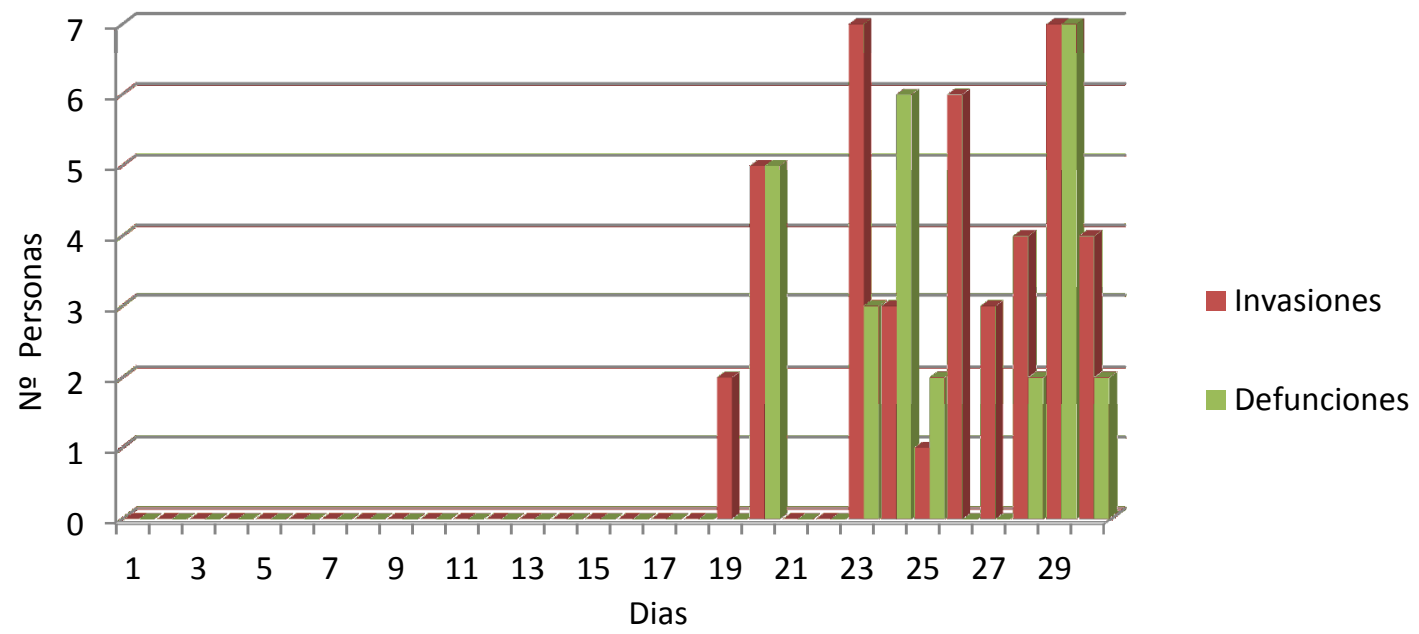

Fuente: BOP CS, 1885. Elaboración propia

\footnotetext{
${ }^{637}$ BOPCS, 1885 . Ver las tablas de las invasiones y defunciones por causa del cólera de 1885 en Castellón en el Apéndice Documental $N^{\circ} 6$.
} 
En la gráfica 1 observamos que las invasiones, en Castellón de la Plana, comienzan el día 19 de junio sin ninguna defunción, aumentando el día 20 con 5 invasiones y 5 defunciones, y siendo el día de mayor incidencia el 29 de junio con 7 invasiones y 7 defunciones. En total hubo en el mes de junio 42 invasiones y 27 defunciones.

Gráfica 2. Porcentaje total de invasiones y defunciones por cólera en Castellón de la Plana. Junio de 1885

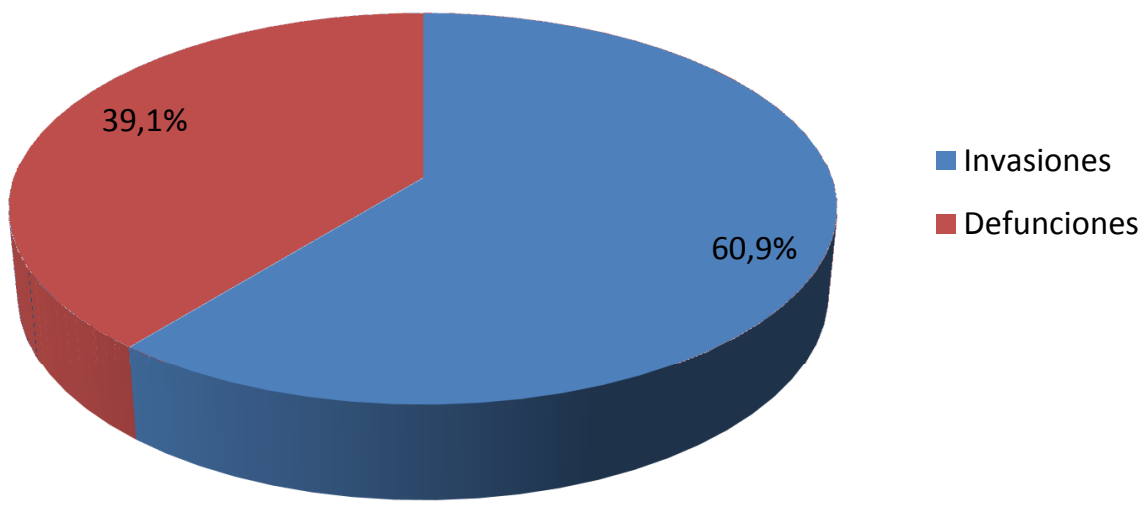

Fuente: Fuente: BOP CS. 1885. Elaboración propia

Gráfica 3. Cólera en Castellón de la Plana. Julio de 1885

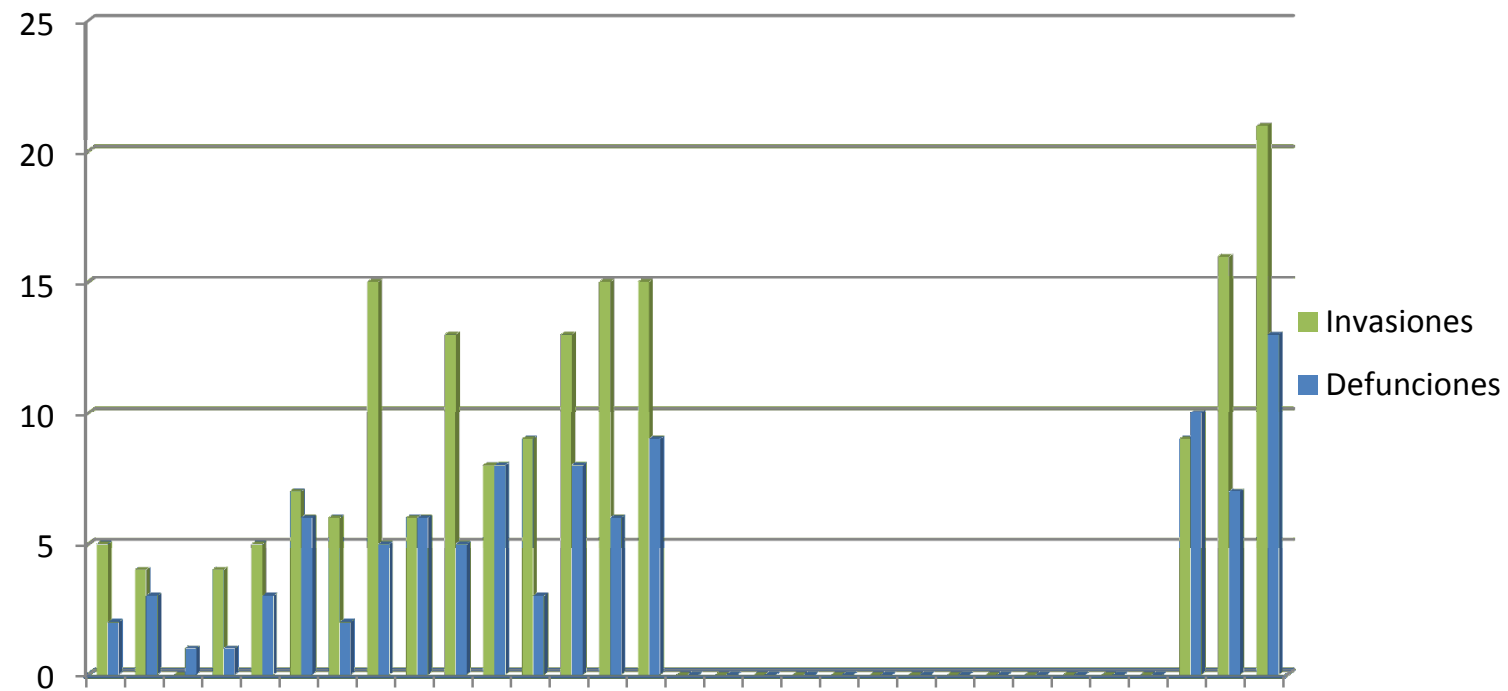

$122 \quad 3 \quad 4 \quad 5 \quad 6 \quad 7 \quad 8 \quad 910111213141516171819202122232425262728293031$

Días

Fuente: BOP CS. 1885. Elaboración propia 
Desde el 16 al 28 de julio no figuran en el Boletin Oficial de la Provincia de Castellón las invasiones y defunciones, esto puede ser porque no se informara al Gobernador Civil de la marcha de la enfermedad en esos días. En total en el mes de julio hubo 171 invasiones y 98 defunciones.

\section{Gráfica 4. Porcentaje total de invasiones y defunciones por cólera en} Castellón de la Plana. Julio de 1885

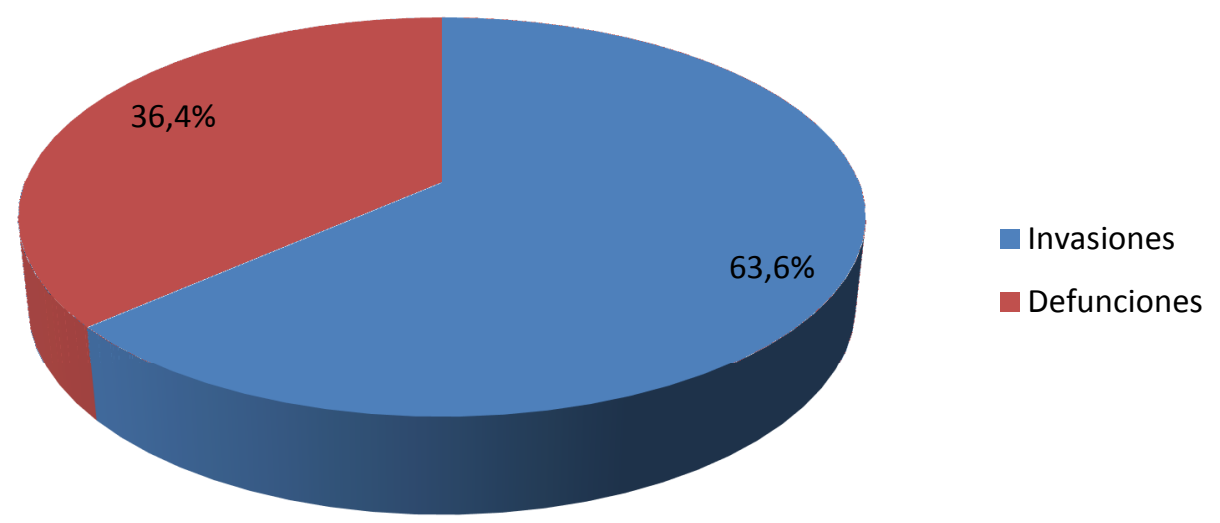

Fuente: BOP CS. 1885. Elaboración propia

Gráfica 5. Cólera en Castellón de la Plana. Agosto de 1885

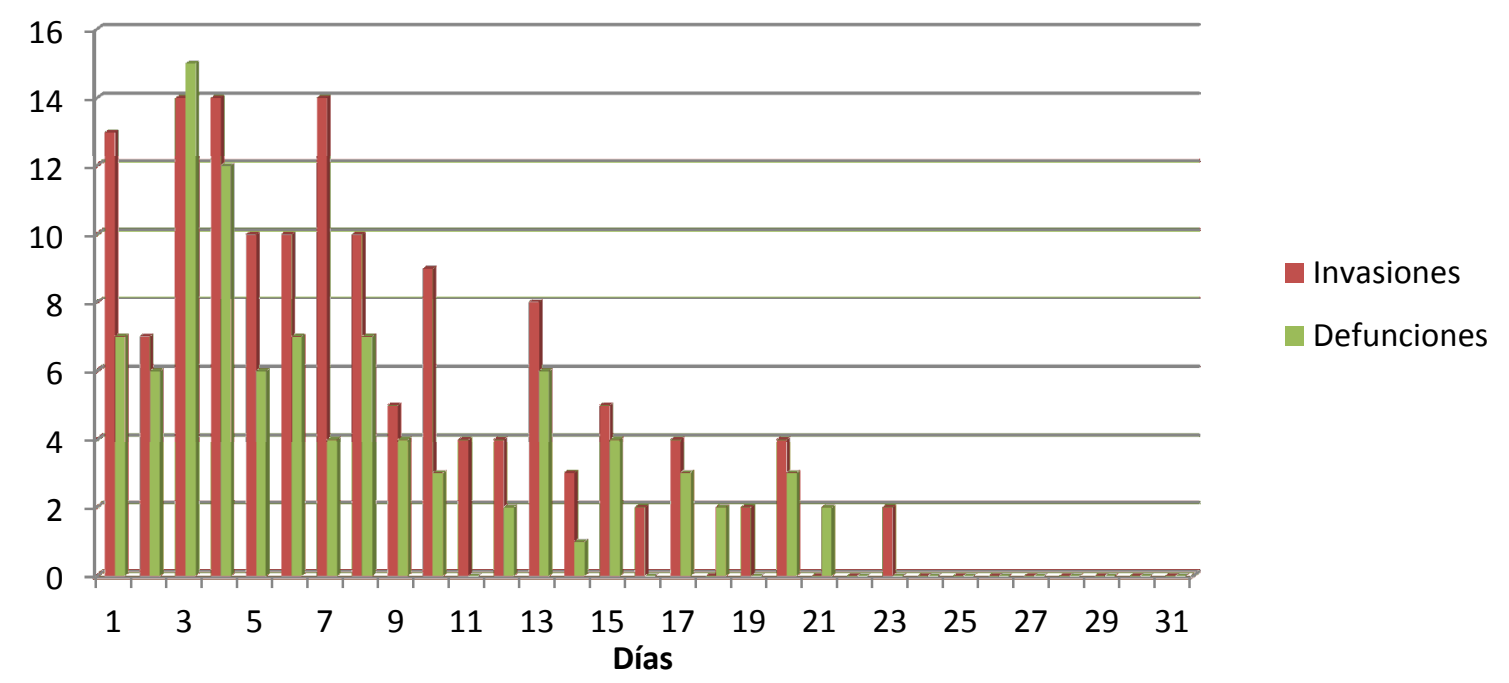

Fuente: BOP CS. Elaboración propia 
En agosto fue decayendo la enfermedad a partir de la segunda quincena y en total hubo 144 invasiones y 94 defunciones.

\section{Gráfica 6. Porcentaje total de invasiones y defunciones por cólera en}

Castellón de la Plana. Agosto de 1885

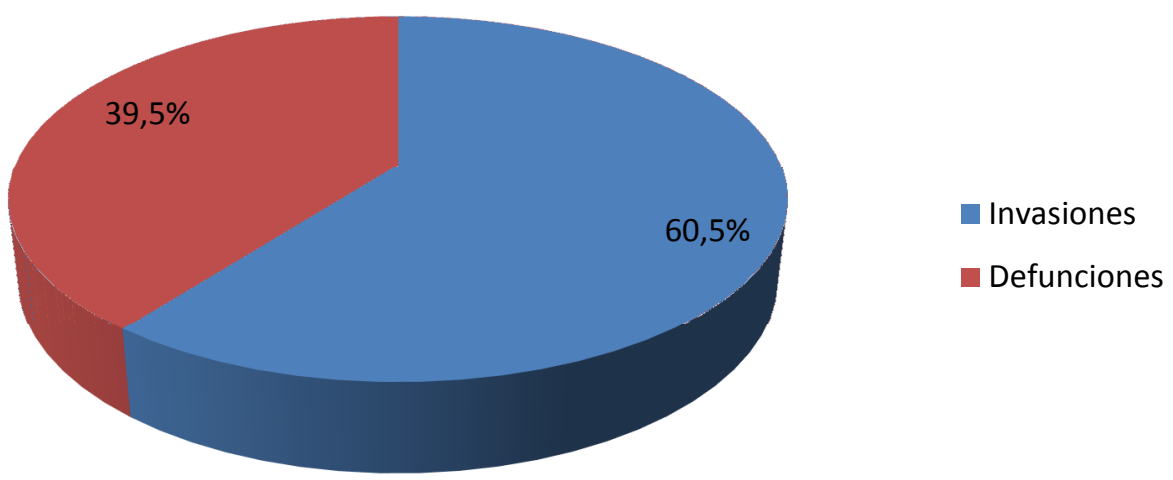

Fuente: BOP CS. Elaboración propia

El 17 de septiembre, habiendo transcurrido más de veinte días sin que ocurriese novedad en Castellón, el gobernador Eduardo Fernández de la Roda, declara libre de la epidemia la ciudad. ${ }^{638}$

Castellón tuvo en total 357 invasiones y 219 defunciones entre junio, julio y agosto.

Comparando la ciudad de Castellón de la Plana con otras poblaciones importantes de la provincia que se vieron afectadas por la epidemia, obtenemos las siguientes gráficas que recogen el número de defunciones:

${ }^{638}$ BOP, $18 / 09 / 1885$ 
Gráfica 7. Defunciones por causa del cólera en 1885. Gráfica comparativa de la incidencia en algunos pueblos de la provincia de Castellón

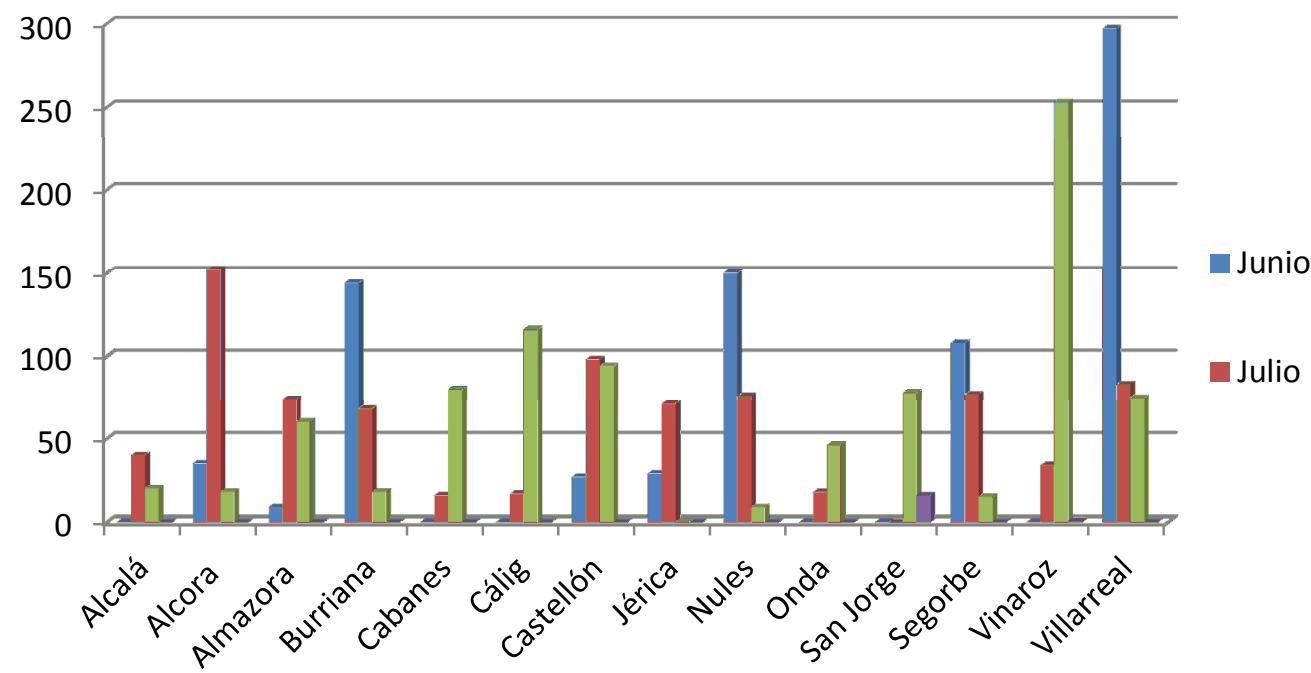

Fuente: BOP CS. Elaboración propia

Villarreal fue la población donde más defunciones hubo (455), seguida de Vinaroz, Nules, Burriana, Castellón y Alcora, (todas por encima de 200 defunciones). ${ }^{639}$

Gráfica 8. Porcentaje de defunciones por causa del cólera en algunos pueblos de la provincia de Castellón

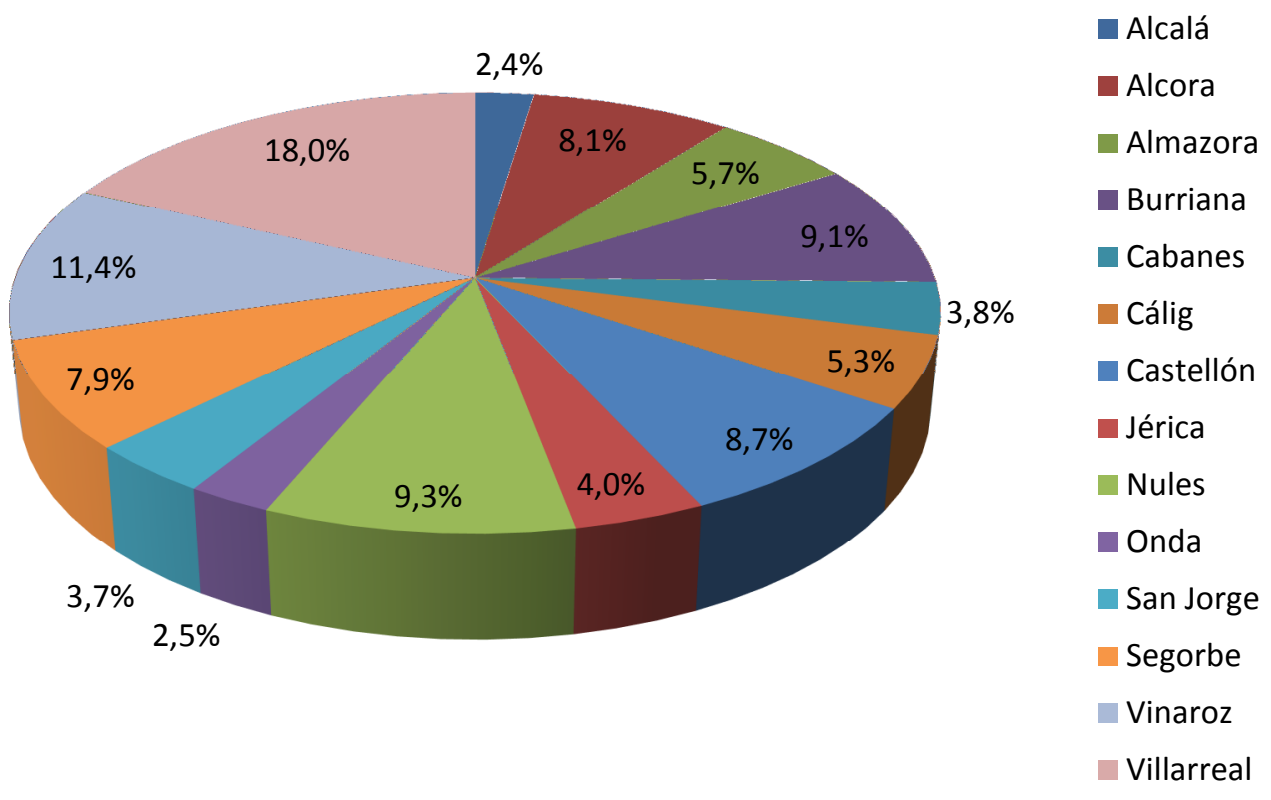

Fuente: BOP CS. 1885. Elaboración propia

${ }^{639}$ Ver tabla 26 del Ápéndice Documental No 7. 


\subsection{ACTUACIONES DE LOS MÉDICOS ANTE EL CÓLERA: CALUMNIADOS Y TEMIDOS POR EL VECINDARIO}

Ni la reflexión, ni la calma presidieron constantemente las resoluciones de los poderes públicos durante la epidemia de cólera de 1885. En nombre de la ley y de la ciencia fue acordonada la ciudad, y en nombre de la ley y de la ciencia se levantó el cordón. Se estableció el aislamiento de los enfermos, y con esta medida cundió la alarma entre las familias, y el terror se apoderó del enfermo en los momentos en que precisamente necesitaba mayor ayuda.

Dos lazaretos, uno de observación y otro sucio, completaban el orden de medidas preventivas. Las condiciones higiénicas eran muy defectuosas. Se tenía el convencimiento que el miedo era el mejor auxiliar de una epidemia.

El primer caso oficial ocurrió en una casa pobre de la calle Falcó (que luego resultó ser un caso de cólico maligno) en la persona de un jornalero. Acudieron médicos y autoridades, policías y alguaciles, camilleros y hermanas de la Consolación, carruajes y gran número de gente.

Las autoridades dispusieron enseguida el traslado del caso a una dependencia del Hospital Provincial en donde ocurrieron otros casos calificados de sospechosos.

Semejante medida fue duramente censurada por mucha gente. Al poco tiempo ocurrieron nuevas invasiones en distintos puntos de la capital, y la Junta de Sanidad aconsejó el aislamiento como la única medida capaz de extinguirla.

Como las primeras invasiones recayeron en personas humildes, por ser las que menos higiene tenían, y se tenía gran fe en el aislamiento planteado rigurosamente por alguaciles, en un principio tuvo mala acogida por parte de los enfermos que se vieron sin el cuidado de sus parientes, alejados de vecinos y amigos, y lo que era más cruel, sin poder atender a la manutención de la familia, al no poder ganar el jornal diario.

Como consecuencia de lo descrito, las disposiciones oficiales producían verdadero terror en la población. Tanto, que ya lo de menos era la enfermedad, sino la guardia. Los médicos que visitaban las casas invadidas, presenciaban situaciones de congoja y amargura; eran vistos como agentes de la exigencia oficial, en lugar de ser vistos como profesionales que iban a dar consuelo y mitigar el dolor de los enfermos.

El sentimiento popular se pronunció contra el aislamiento, y el ejercicio de la medicina se convirtió en una labor ardua y difícil, abocado a conflictos desagradables. El enfermo deseaba eludir esta medida y a tal efecto ocultaba los síntomas, disimulaba 
su estado; «los productos naturales del enfermo eran arrojados a propósito y el diagnóstico tardaba en confirmarse con grave disgusto de la autoridad local, con peligro evidente del enfermo y deshonra del profesional de la medicina que era mal visto y desacreditado». ${ }^{640}$

Los médicos consideraban que el aislamiento racional y científico consistía en dejar con el enfermo, tan sólo las personas necesarias para su cuidado, evitando la comunicación con los demás, y en hacer salir a los que gozaban de salud para que no se contaminaran; pero en realidad se hacía al revés, no se permitía la salida a los sanos quienes continuaban habitando en el foco de infección.

Sin embargo, las puertas del aislado estaban abiertas para el alcalde, desinfectadores, médicos, capellanes, sepultureros y blanqueadores, los que se ponían en contacto con sus familias, amigos y subordinados.

Otro de los males que impedía el ejercicio profesional a los médicos y pudo ocasionar algunas víctimas, era la opinión que el público tenía formado del cólera y de los medios para combatirlo.

Se publicaron gran cantidad de folletos y artículos médicos que confundieron a la gente no preparada, poniendo el veto a la medicación propuesta por el médico de cabecera, si ella no era del gusto del paciente.

Convertido el enfermo en médico era, además, farmacéutico. Muchas personas tenían que ser asistidas por el médico por causa del uso imprudente e inoportuno del láudano.

En Castellón, donde tantas cosas se realizaron por la salud del pueblo, se toleraron faltas graves a las disposiciones y leyes sanitarias en menosprecio de la clase médica.

Muchos facultativos fueron acusados del delito de morosos o descuidados en el deber de dar partes de invasiones o defunciones a la alcaldía.

Entre ellos estaban acusados los concejales Soler, Llansola y Forns, los tres médicos, denunciados por el incumplimiento de deberes impuestos por el Ayuntamiento y Junta de Sanidad.

\footnotetext{
${ }^{640}$ Revista Médico-Farmacéutica, 17/09/1885, pp. 211-214.
} 
A partir de esa denuncia, parece ser que el alcalde, José Tárrega, médico también, denunció a los tres compañeros de profesión al gobernador, sin comprobar la veracidad de los hechos que se les imputaba.

En una sesión del Ayuntamiento, los tres facultativos después de negar la certeza de los hechos objeto de la denuncia, pidieron que se abriera expediente en el que interviniera el síndico del Ayuntamiento, un teniente de alcalde y el secretario, con el objeto de depurar la verdad de los hechos.

El concejal conservador, José Núñez, propuso como solución que se retirara la comunicación dirigida por el alcalde al gobernador, si esto podía dar satisfacción a los denunciados, y reconocer que los facultativos acusados no habían faltado a su deber. El Ayuntamiento así lo aceptó y acordó que constara en acta.

Los médicos continuamente eran juzgados por su actuación, la mayoría de las veces eran opiniones calumniosas, carentes de fundamento. ${ }^{641}$

Se consideraba que la epidemia en Castellón no había tenido la gravedad que había tenido en otros pueblos de la provincia y, como consecuencia, los médicos no tuvieron la ocasión de distinguirse. Todos cumplieron con su deber; sin embargo se olvidaron los nombres de «tantos héroes como ha habido en la familia médica entre los profesores de la provincia». ${ }^{642}$

A principios de julio había aún pocos casos de cólera en Castellón, pero los pocos que había eran fulminantes, es decir, acababa con la muerte de los enfermos. Esto, según la prensa, era debido a que no se avisaba al médico cuando aparecían los primeros síntomas, que es cuando se podía curar, y solo llamaban a éstos cuando aquella ya no tenía remedio.

Se tenía la absurda creencia en que los médicos aplicaban remedios que producían la muerte, por este motivo no se les llamaba cuando aparecían los primeros síntomas. ${ }^{643}$

La Provincia llama la atención a sus lectores y toda clase de personas sobre la necesidad de llamar al facultativo cuando se presentaran los primeros síntomas de la enfermedad sospechosa. El descuido en ese punto era causa de muchas muertes, especialmente en las personas poco acomodadas, que miraban dichos accidentes como

\footnotetext{
${ }^{641}$ Revista Médico-Farmacéutica, 27/09/1885, pp.225-228.

${ }^{642}$ Revista Médico-Farmacéutica ,7/10/1885. pp. 241-242.

${ }^{643}$ La Provincia, 9/07/1885.
} 
cosa insignificante, y solo se acordaban de llamar al médico, cuando la enfermedad hacía estragos en el organismo, cuando se veía la imposibilidad de poder combatirla con esperanza de éxito. ${ }^{644}$

La prensa alaba el trabajo desarrollado por los facultativos en el cumplimiento de su deber, y resalta que en la clase médica todos cumpieron con su su obligación. ${ }^{645}$

El Ayuntamiento de Castellón dio las gracias de oficio a todos los facultativos médicos y señaló la cantidad de 2.000 reales para un obsequio a la clase médica, que parece ser no se llevó a cabo. A los farmacéuticos no se les dio ni «las gracias». ${ }^{646}$

Por los servicios extraordinarios prestados en la epidemia, se recompensó a los médicos del Hospital Provincial con una cantidad equivalente a casi seis meses de paga; y también los de la Casa de Misericordia fueron renumerados, aunque no tan espléndidamente, «Siendo así que en dicho establecimiento no hubo, por parte de ellos, servicio extraordinario que prestar».

En cambio, nadie se acordó de los médicos que ejercieron en Alcalá, Nules, Villavieja, Almazora, Burriana y otros muchos puntos donde la epidemia les obligó a prestar los servicios extraordinarios. ${ }^{647}$

\subsection{LA VACUNA DE FERRÁN EN CASTELlón, PROHIBICIONES Y APLICACIONES}

El Instituto de Vacunación castellonense, que presidía el oftalmólogo Antonio Forns, nombró al médico de la Beneficencia Municipal, Agustín Segarra y a José Clará, médico del Hospital Provincial, representantes de dicho Instituto para felicitar a Ferrán por sus trabajos, y estudiar el modo de propagar la vacuna del cólera en Castellón.

A tal efecto dichos facultativos fueron a Valencia el 18 de abril de 1885, y después de saludar a Ferrán y a Paulí, que les dispensaron una gran acogida, obtuvieron el cultivo para las inoculaciones, recibiendo de él las instrucciones oportunas para usar el preservativo y, además, fueron vacunados por el mismo Ferrán.

\footnotetext{
${ }^{644}$ La Provincia, 12/07/1885.

${ }^{645}$ Ibídem.

${ }^{646}$ Revista Médico Farmacéutica, 7/11/85 pp. 290-291.

${ }^{647}$ Revista Médico-Farmacéutica, 17/11/85 p. 306.
} 
El día 21 de abril comenzaron las vacunaciones en el Instituto Médico de Castellón, habiendo sido vacunados veinte individuos. Los días 22, 23, 24 y 25 de abril continuaron las vacunaciones.

El cultivo que se proporcionaba era atenuado, pues se seguía el método de dos inoculaciones, una débil y otra menos débil, ocho días después de la primera, los síntomas experimentados por los que se sometieron a la vacunación fueron sensación de dolor local, malestar general, fiebre, náuseas y algún ligero calambre.

Una vez cumplido el plazo fijado por Ferrán (en su sistema gradual de inoculación) para vacunar con el segundo caldo, se procedió a esta segunda operación dando como resultado que en los individuos de mayor receptividad, se presentaron los fenómenos de la vacunación colérica más pronunciados y en la mayoría de casos fueron menos intensos y de menor duración. ${ }^{648}$

En las personas inoculadas se presentaron los síntomas descritos más arriba, en alguno casos se presentaron vómitos violentos, lipotimias, y calambres, cuyos síntomas desaparecieron espontáneamente al poco tiempo de haberse presentado.

Se daba el caso que en sujetos más débiles y hasta enfermizos no experimentaron síntomas tan acentuados. Esto se atribuía a las condiciones personales de los sujetos.

Los médicos Agustín Segarra y José Clará fueron reinoculados después de un mes y no sufrieron ninguno de los síntomas que experimentaron con la primera inoculación.

Una comisión de médicos notables compuesta de los doctores Pulido y Serret en representación del Siglo Médico y de la Academia de Medicina de Madrid visitaron a Ferrán con el objeto de felicitarle y enterarse de los trabajos sobre la inoculación del cólera.

Como las vacunaciones practicadas en Valencia eran pocas y el resultado de ellas desconocido, Ferrán aconsejó a los doctores Pulido y Serret visitaran el Instituto de Vacunación de Castellón, que era el primer centro que había practicado la inoculación colérica, con el fin de recabar los resultados obtenidos de las muchas inoculaciones practicadas.

${ }^{648}$ Revista Médico-Farmacéutica, 7/05/85 pp. 6-8. 
A la comisión médica se le facilitaron los resultados de los trabajos de inoculación practicados por el Instituto.

El 26 de Mayo, el presidente del Instituto de Vacunación Anticolérico de Castellón, recibió un oficio de la alcaldía transcribiendo una comunicación del gobernador que decía:

El Excmo. Señor ministro de la Gobernación, en telegrama que acabo de recibir me dice lo siguiente: Hallándose comprendido el anticolérico del doctor Ferrán entre los remedios secretos a que se refiere el artículo 14 de la ley de Sanidad en el ínterin no se cumpla con las prescripciones de los artículos 85 y siguientes de dicha ley, prohíba V.S. su aplicación en esa provincia. Si fuese autorizado, este ministro cuidará de participarlo a V.S.

Y lo traslado a V.S. para su más inmediato cumplimiento en cuanto se refiere al Instituto de Vacunación Anticolérico que existe en esta capital.

La noticia cayó como una bomba en los médicos y muy particularmente en la prensa de Castellón que llamaba «el doctor»al ministro de la Gobernación Romero Robledo.

El Consejo de Sanidad se reunió para informar sobre los extremos de la Real Orden en cuyo texto había dos cuestiones diferentes:

La primera se refiere a si las inoculaciones de los líquidos cultivados por Ferrán eran o no remedios secretos; el cuerpo consultivo resolvió que no eran remedios porque no curaban el cólera y que lo único que podía constituir secreto era el procedimiento de atenuación, pues el «bacillus coma» era un elemento morfológico conocido y de ningún modo un agente misterioso.

La segunda parte, la más esencial para el ministro, fue la de si debían o no consentir las inoculaciones anticoléricas.

El 9 de junio de 1885 el gobernador Eleuterio Villalva mandó una circular a los alcaldes y subdelegados de Sanidad de la provincia de Castellón comunicándoles que el Ministro de la Gobernación le había enviado un telegrama prohibiendo la inoculación del líquido profiláctico del cólera, y le daba la autorización para destruir las preparaciones.

El Gobernador dice en la circular, que mientras el Gobierno de España, en vista de los informes que emitieran los centros científicos, no resolviera sobre la inocuidad de 
la vacuna, la prudencia aconsejaba el mayor rigor en la prohibición de dicha vacuna, «pues si bien la vacunación pudiera resultar un gran bien para la salud pública, debe prevenirse el caso de que sea un medio de propagación del mal que se combate». ${ }^{649}$

Y previene a los alcaldes y subdelegados de Sanidad de la provincia que por todos los medios de investigación a su alcance, averiguaran si en sus respectivas jurisdicciones se introducía la preparación profiláctica a que se refería el telegrama, destruyendo e inutilizando dicho líquido, si en efecto existiese, e impidiesen, bajo su responsabilidad, la práctica de las inoculaciones colerígenas, dándole cuenta de cuanto hicieran en «este importante asunto». 650

La clase médica de Castellón se reunió el 24 de junio de 1885 en el local del Instituto Médico de Vacunación para establecer un Centro de Colerización Ferrán. Esperaban practicar las inoculaciones nada más las autorizara el Gobierno.

La junta general de este Centro remitió al doctor Ferrán el siguiente telegrama: «Dr. Ferrán: Valencia.

Reunida la clase médica en Centro de inoculación, apresurase a felicitarle por el favorable informe de la Comisión oficial, permitiéndose rogarle venga a inaugurar sus trabajos.- La Comisión, Aliaga, Clará, Desbertrand, Segarra».

La Diputación Provincial acordó solicitar de Ferrán caldo para inocular todos los albergados de los establecimientos benéficos. ${ }^{651}$

Más tarde, el 27 de junio de 1885, el Gobernador comunicaba la Real Orden autorizando al doctor Ferrán para continuar aplicando la vacuna contra el cólera en los pueblos de las provincias invadidas por dicha enfermedad.

El Excmo. Ministro de la Gobernación, comunicaba al director general de Beneficencia y Sanidad, la Real Orden que decía que:

Vista la memoria presentada por la Comisión Científica que se nombró por Real Orden de 27 de Mayo último para el estudio de la virtud profiláctica del procedimiento empleado por el Dr. Ferrán en que se declara que la inoculación anticolérica es inofensiva para la salud pública y sin perjuicio del informe que emita la Academia de Medicina de esta Corte, en virtud de los preceptuado en aquella Real disposición, su Majestad el Rey se ha servido autorizar al referido Dr. Ferrán para

\footnotetext{
${ }^{649}$ BOPCS, 10/06/1885.

${ }^{650}$ Ibídem.

${ }^{651}$ La Provincia, 26/06/1885.
} 
que pueda continuar aplicando su procedimiento preventivo contra el cólera en los pueblos de las provincias invadidas por dicha enfermedad.-De Real Orden lo comunico a V.I. para su conocimiento y demás efectos. Lo que traslado a V.S. para iguales fines. $^{652}$

Hallándose pendiente el informe de la Real Academia de Medicina la conveniencia o inconveniencia de aplicar el método de Ferrán para la curación del cólera morbo asiático, el Ministro de la Gobernación envió un telegrama el 6 de julio de 1885 a los gobernadores civiles prohibiendo la práctica de la vacunación a toda persona que no fuera el doctor Ferrán y ni siquiera al mismo Ferrán fuera de los pueblos infestados. El Gobernador ordena a los alcaldes y subdelegados de Sanidad de la provincia el cumplimiento de la prohibición. ${ }^{653}$

En una sesión del Ayuntamiento de 2 de julio de 1885, el concejal Agustín Forés, manifestó que el Ayuntamiento debía obtener el líquido del doctor Ferrán para inocular a aquellas personas que carecían de medios para sufragar los gastos. Explica que la vacuna es un medio que llamaba la atención del mundo entero, cuyas personas de más saber en la medicina y singularmente de la microbiología, luego de serios estudios, habían reconocido su eficacia. Pide que se solicite al doctor Ferrán se digne facilitar gratis el caldo necesario para las inoculaciones de los pobres.

El alcalde expuso que al hacer la petición no debía ésta limitarse para los pobres de solemnidad, pues hay unos miles de personas que sin serlo no le es posible desprenderse de cincuenta reales, pues son míseros jornaleros que viven de un jornal. ${ }^{654}$

Muchos de los inoculados en la capital escribieron una carta al doctor Ferrán rogándole viniera a Castellón a practicar la reinoculación de los mismos. Según parecía eran 200 personas las que se encontraban en esa situación. ${ }^{655}$

El 8 de julio de 1885 algunos médicos de Castellón escribieron una carta de protesta al periódico La Provincia, en la que expresaban que la orden expedida por el ministro de la Gobernación prohibiendo a los médicos la práctica de la inoculación Ferrán era un atentado al decoro profesional:

\footnotetext{
${ }^{652}$ BOPCS, 29/06/1885.

${ }^{653}$ BOPCS, 6/07/1885.

654 .AACS, 2/07/1885.

${ }^{655}$ La Provincia, 9/07/1885.
} 
Restringido por el ministro el ejercicio de nuestra profesión, los derechos de la ciencia han venido a menoscabarse de lastimosa manera y ante tan inaudito proceder, los profesores médicos que suscriben protestan enérgicamente contra el atropello de que son víctimas, sin perjuicio de entablar la acción que les compete a fin de recabar sus derechos profesionales tan lastimosamente hollados. ${ }^{656}$

Firmaban: Pedro Aliaga; José Clará; Francisco Rambla; Eduardo Portalés; Nicolás Forés; José Pachés; Agustín Segarra; Manuel Sánchez; Manuel Segarra; José Llansola; Eliseo Soler; Luis Provinciale; Joaquín Fabregat; Francisco Gimeno; José Cazador; Andrés Puig; Francisco Esteve; Félix Roig.

El 11 de julio de 1885, el Gobernador Eleuterio Villalba, envía una circular diciendo que por orden del Ministerio de la Gobernación de 25 de mayo de 1885, quedaron prohibidas en esta provincia, como en las demás de la Península, las inoculaciones anticoléricas por el procedimiento del doctor Ferrán, y posteriormente fue ratificada aquella prohibición por las comisiones que habían recibido el encargo de estudiar dicho procedimiento en la provincia de Valencia.

Continua diciendo que como tuviera noticia la superioridad de que burlando la vigilancia de algunas autoridades y las ordenes de aquel Ministerio, algunos facultativos practicaran las inoculaciones anticoléricas con líquidos preparados por Ferrán, el Ministro de la Gobernación, en telegrama de 9 de julio de 1885, reitera la prohibición existente previniendo a los gobernadores de nuevo que sólo el doctor Ferrán estaba autorizado para practicar personalmente las inoculaciones en los pueblos invadidos por la epidemia.

El gobernador previene a los alcaldes, juntas locales de Sanidad y subdelegados de Sanidad en medicina y farmacia de la provincia del cumplimiento de la prohibición. También expresa que si se aplicaba en algún pueblo el citado medio profiláctico por otra persona que no fuera su inventor, el mismo doctor Ferrán, la autoridad local debía incautar inmediatamente el líquido profiláctico, remitiéndolo sin dilación, convenientemente lacrado y sellado al gobernador.

Un defensor acérrimo de Ferrán y su vacuna fue el médico de Albocacer Joaquín Chillida Meliá que lo defiende a ultranza, se declara ferranista y lamenta los problemas de los científicos en España:

${ }^{656}$ La Provincia 12/07/1885; también ver la Revista Médico-Farmacéutica, 17/07/85 pp.115-116. 
[...] España, la triste y mísera España, ésta olvidada nación rechazada por su bajo nivel intelectual hacia el África por toda Europa, escupe vilmente a sus hijos estudiosos, les rodea de obstáculos, los que debieran tender su mano al sabio, procuran hundirle en el precipicio del olvido, infundiendo en la clase ignorante esas supersticiones que suelen terminar siempre por el cruento sacrificio del Redentor.

$\mathrm{Y}$ este hombre que merece una carta paternal y cariñosa del eminente Pasteur alentándole con entusiasmo, este hombre que recibe fraternales homenajes de Van-Emergen, ese célebre histólogo belga que ha llenado el mundo con su científica fama; y este español que llama poderosamente la atención de todas las naciones de Europa las que se apresuran a estudiar sus trascendentales trabajos, su madre patria convertida en cruel madrastra, coloca sobre su frente la corona de espinas de todos los sinsabores disgustos y contrariedades. ${ }^{657}$

Por su parte, los vecinos de algunos pueblos de la provincia invadidos unos por el cólera y otros libres todavía de la epidemia, manifestaron sus deseos de someterse a la inoculación anticolérica del doctor Ferrán. ${ }^{658}$

En San Mateo se recibió un telegrama para averiguar si la población quería someterse a la inoculación anticolérica de Ferrán. Reunida la Junta de Sanidad designó varias comisiones para que consultara sobre el particular a todo el vecindario, haciendo comprender a éste la inocuidad del expresado procedimiento.

El resultado de la consulta fue que un gran número de hombres y de mujeres invadiera la plaza pública, agrupándose frente a la Casa Consistorial en donde se encontraba deliberando dicha junta, y prorrumpió en desaforada gritería, dando voces de fuera, y lanzando improperios contra el citado doctor y su procedimiento, hasta el extremo de verse la autoridad local en el caso de reclamar el auxilio de la fuerza de la guardia civil, que inmediatamente se presentó entre la multitud aconsejando a todos se retiraran a sus hogares, lo que se consiguió cuando el alcalde hizo el ofrecimiento de que no sería San Mateo el pueblo en que el doctor Ferrán hiciera las experiencias de su invento. $^{659}$

\footnotetext{
${ }^{657}$ Revista Médico-Farmacéutica ,17/07/1885 pp. 115-116.

${ }^{658}$ La Provincia, 9/08/1885.

${ }^{659}$ La Provincia, 13 /08/1885.
} 
En una carta al director de la Provincia desde Cervera, del 27 de agosto de 1885, se comenta que Ferrán llegó a dicho pueblo el 21 de agosto a las ocho de la noche, acompañado por el médico de Castellón José Segarra y otro señor, y que fue recibido por el segundo alcalde, por hallarse indispuesto el primero, con el secretario y diez o doce personas más de las principales del pueblo.

El día 22 de agosto se les facilitó el salón de sesiones para practicar el alistamiento de todos los que desearan ser inoculados, habiendo antes advertido que no comenzaría esta operación hasta que llegara a esta la Comisión Oficial, que probablemente sería al anochecer del mismo día 22. En efecto, se comenzó el alistamiento y se alistaron más de 900 personas. Pasó la noche y la Comisión no vino; y el día 23 de agosto, por la mañana recibió Ferrán un telegrama del jefe de la Comisión diciéndole que no creía necesaria la inoculación en esta villa porque no estaba bastante invadida, y por consiguiente que debía irse a otro punto. Enseguida lo manifestó al pueblo, y éste le suplicó que no se marchara sin inocular a los alistados, contestando Ferrán que no podía acceder a los deseos del pueblo sin que se telegrafiase al Presidente del Consejo de Ministros y así lo hizo el alcalde.

Esperando contestación de dicho telegrama, recibió otro del jefe de la Comisión Oficial, manifestándole que por fin vendrían; al recibir este telegrama ya se había comenzado la operación, que se suspendió cuando tenían unas cien personas inoculadas. El día 24 cuando esperaba la Comisión, recibió otro telegrama de la misma, insistiendo en que este pueblo no estaba bastante invadido y que podía retirarse.

En vista de esto y el estado de la población, empezó de nuevo la operación y se inocularon hasta el número 530, habiéndose retraído sobre 400 de los alistados, este retraimiento era debido a los padecimientos de los 100 inoculados, que contrarios a la inoculación, aprovecharon para hablar en contra. El día 25 sobre la una de la tarde marchó Ferrán con sus acompañantes.

Durante su estancia en Cervera, vinieron comisiones de las Cuevas de Vinromá, de Salsadella y de Rosell, que solicitaban a Ferrán que inoculara a sus vecinos. ${ }^{660}$

La Provincia informa que en Cambrils, una mujer, esposa del alcalde, había muerto víctima de la epidemia estando inoculada; a otro inoculado le tuvieron que

${ }^{660}$ La Provincia, 30/08/1885. 
operar el brazo para evitar la gangrena, quedando varios de los vacunados en cama y hallándose dos de ellos en estado grave.

El periódico llama la atención sobre el asunto «a fin de que todos, con sus noticias de verdad contribuya a poner en claro el valor de la virtud profiláctica del procedimiento Ferrán».

La Plana publica que el 27 de agosto fue inoculado en Salsadella, por la Comisión Segarra de Castellón, el alcalde de San Mateo, muriendo días después de cólera morbo asiático. Era el primer caso de cólera en San Mateo; el alcalde era un «entusiasta partidario de la vacuna de Ferrán siendo la primera víctima de dicho pueblo». ${ }^{661}$

\footnotetext{
${ }^{661}$ La Provincia, 30/08/1885. En el Apéndice Documental $\mathrm{n}^{\circ} 5$ hemos insertado la conferencia de Amalio
} Gimeno en Madrid sobre la inmunidad. 


\section{CAPÍTULO VI: LA GRIPE DE 1918 EN CASTELLÓN}




\section{ORIGEN DE LA GRIPE Y DESARROLLO EN ESPAÑA}

La evolución histórica de las epidemias gripales, si hacemos un retroceso en la historia, desde la pandemia de 1530, hasta la del año 1889 que afectó a toda Europa, han presentado un retroceso en su frecuencia.

A partir de la epidemia gripal de 1889 aparecen diversos brotes epidémicos en 1893, 1915, que más tarde terminaron produciendo la gran pandemia de 1918. En este año se produjeron tres ondas epidémicas que se alargaron hasta bien entrado 1919. Los primeros meses de 1918 no registraron un aumento en la incidencia gripal. En abril se produjo la primera onda epidémica, de carácter benigno, detectándose casos en Europa, en las tropas francesas, inglesas y americanas. En mayo se detecta en la Península Ibérica, finalizando en agosto, pero es en los meses de septiembre, fundamentalmente octubre, cuando se produce su mayor incidencia, decreciendo posteriormente en noviembre y finalizando en diciembre y enero de 1919, produciendo en su conjunto una alta mortalidad del 6-8\%. La tercera onda se presenta en febrero y marzo de 1919 y termina en mayo del mismo año.

En conjunto, se calcula que afectó al $50 \%$ de la población mundial, con una tasa media de mortalidad del 3\% y más de 20 millones de defunciones, por lo que ha sido calificada como «el más grave conflicto epidémico que ha sufrido el mundo en todos los tiempos».

El origen es desconocido, siendo calificada erróneamente de «gripe española», cuando ha quedado demostrado que la gripe llegó del exterior, mediante emigrantes enfermos, fundamentalmente soldados y trabajadores portugueses afectados por la gripe, que se extendía ya por Europa, y atravesaban España camino de Portugal, así como vendimiadores españoles, que regresaban a sus hogares, tras la recogida de la uva en Francia.

La alarma empieza en mayo y se acentúa paulatinamente, aunque dada la benignidad de las anteriores, a la segunda onda epidémica,-la más importante-, no se le da la debida importancia en sus inicios. Es cuando se presenta una elevada morbilidad/mortalidad en los meses de septiembre, octubre y noviembre, con gran frecuencia de complicaciones bronconeumónicas, cuando se empiezan a difundir las medidas terapéuticas y profilácticas. 
Esta alta tasa de morbilidad/mortalidad desencadenará una auténtica conmoción en la vida social española, con repercusiones políticas y económicas, así como médicas, como queda reflejado en la prensa profesional y en las circulares oficiales.

Se empiezan a adoptar medidas en la zona fronteriza con Francia, incluso se llegó a cerrar la frontera. Se persigue a los portugueses como a verdaderos apestados. ${ }^{662}$

A nivel nacional la situación no era boyante, porque escaseaban las subsistencias, proliferaban la huelgas y los empleados de correos, en paro; ponían al país en un aprieto. Su majestad el rey Alfonso XIII había amenazado con renunciar al trono si no se solucionaba la crisis política; los más pesimistas pronosticaban una dictadura militar, pero Antonio Maura consiguió formar su «Gobierno Nacional» y las gentes de orden respiraron satisfechas. ${ }^{663}$

En el mes de octubre la epidemia se agravó en toda España y se extendió a localidades que aún no habían sido invadidas; la mortalidad, si no en aumento, siguió en la misma proporción. La prensa de Castellón se hace eco del optimismo oficial sobre el estado sanitario de España: «El optimismo oficial sobre el estado sanitario del país es por completo infundado. La salud pública no ha experimentado una mejoría que lo justifique, y es, a nuestro juicio, contraproducente ocultar la verdad con pretexto de evitar alarmas».

Se había establecido una polémica sobre la naturaleza y causas de la enfermedad entre los políticos, los profesionales de la medicina y los periodistas, no se sabía si la enfermedad era gripe, tifus o alguna otra enfermedad, que lejos de dominarse, continuaba produciendo estragos en todo el país.

Aunque las referencias de prensa hacían hincapié en la gravedad de la epidemia, los poderes oficiales le restaban importancia; pero sin embargo, un acto llamó la atención de los periódicos y alertó que la enfermedad iba en serio: el aplazamiento del Congreso Nacional de Medicina por sus más constantes organizadores. ${ }^{664}$

Desde las esferas oficiales se decía que la situación no justificaba alarma alguna, y que las precauciones sanitarias se observaban escrupulosamente.

\footnotetext{
${ }^{662}$ GACÍA-FARIA DEL CORRAL, Francisco .Javier. (1995). La epidemia de gripe de 1818 en la provincia de Zamora. Estudio estadístico y social. Instituto de Estudios Zamoranos Florian Ocampo. Salamanca. Diputación de Zamora. pp. 67-68.

${ }^{663}$ PADILla BOLIVAR, Antonio (1974): «La gripe de 1918. Veintiún millones de muertos», Historia y vida, $\mathrm{n}^{\mathrm{o}} 72$, Madrid. p. 93.

${ }^{664}$ Ibídem, p. 99.
} 
No obstante, nada se decía de haberse instalado en los sitios que constituían peligrosos focos de infección, hospitales para atacados, ni acordonamiento o santuario para los no invadidos. En cuanto a las precauciones observadas en la frontera tampoco merecían confianza las manifestaciones oficiales, concediendo bastante crédito a las denuncias de los periódicos del Norte de España, que, con toda clase de datos, demostraban la insuficiencia del acordonamiento sanitario de los puertos fronterizos.

$\mathrm{Si}$ todos esto optimismos, encubridores de imprudencias y faltas de organización, ocurrieran en otro país mejor defendido sanitariamente que el nuestro, no habría que dar ciertamente gran importancia a las cosas. Pero en España, sí. Hay que pensar como estarán atendidos esos servicios en provincias, cuando en la propia capital del Estado no pueden ser más lamentables donde se carece de hospitales, asilos, maternidades, etc.

$\mathrm{Y}$ es que, cuando no el caciquismo, es la ignorancia la que preside y rige todos los asuntos de interés público, y en especial la salud, «cosa» que aquí no interesa grandemente a nuestros gobernantes. ${ }^{665}$

La prensa española censuraba duramente al Gobierno por no haber adoptado a tiempo las medidas higiénicas oportunas, contribuyendo con su pasividad a que se difundiera por toda la península la epidemia de gripe.

El periódico madrileño $A B C$ denunciaba que las sacas de correspondencia no se desinfectaban debidamente; que en Vallecas no había agua para las necesidades del vecindario, y que en Galicia se propagaba la epidemia entre el elemento militar pues solo en el cuartel de Alfonso XII de La Coruña había dos mil atacados constituyendo un verdadero peligro para la salud pública. ${ }^{666}$

La enfermedad, tanto en su génesis de 1818 como en su evolución y propagación, no puede separarse en ningún momento de los efectos de la I Guerra Mundial. La fatiga, la alimentación deficiente, el frío y la miseria ofrecían a la plaga un abono inmejorable. Únicamente en España en 1918, y a pesar de mantenerse ajena al conflicto, causó 147.000 defunciones. ${ }^{667}$

\footnotetext{
${ }^{665}$ El Clamor, 2/10/1918.

${ }^{666}$ Ibídem.

${ }^{667}$ REINHARD-ARMENGAUD (1966): Historia de la población mundial. Ariel, Barna. p.108.
} 
Las discusiones sobre «el incognito microbio» enfrentaron a los médicos especialistas. Mientras los doctores Gustavo Pittaluga y Gregoorio Marañon sostenían tesis contrapuestas. José Alberto Palanca y Luis Rodriguez Illera trataban de aislar el germen en los laboratorios del Instituto de Higiene Militar y en el Alfonso XIII. ${ }^{668}$

La gripe que se caracteriza por una fiebre alta y dolores intensos y difusos, está causada por la penetración a nivel de las vías respiratorias de un virus. Éste pertenece a tres grupos diferentes: A, B y C. Los dos primeros son patógenos para el hombre, el tipo A, el más peligroso, tiene la particularidad de modificarse con el tiempo, de manera que el organismo no está preparado para defenderse contra él. Un individuo no inmunizado puede infectar a otro, por ejemplo después de un estornudo. Cada año pueden verse afectados varios centenares de miles de personas.

Richard Shope, de Estados Unidos, aisló por primera vez el virus de tipo A en el cerdo. Era el año 1930. Sus trabajos movieron a los investigadores a identificar un virus similar en el hombre. Lo consiguieron en 1933 Wilson Smith, Christopher Andrewes y Patrick Lidlaw, de Inglaterra. Luego, Thomas Francis y T.P. Magill, en 1940, y R.M. Taylor, de Estados Unidos, en 1949, aislaron respectivamente un segundo y un tercer tipos de virus, llamados B y C.

Las proteínas que llevan en su superficie, la hemoglutinina y la neuraminidasa, determinan el poder infeccioso de cada uno de estos tipos víricos. Estas proteínas son antígenos, es decir, que provocan la formación de anticuerpos específicos en el organismo infectado. La composición o la estructura de estos antígenos se modifican sin cesar (variación antigénica). De ahí el origen de virus variantes; a su vez, estas variaciones generan dos subtipos víricos. La gripe de 1918 fue causa por el subtipo H1N1 del tipo A.

La lucha contra esta enfermedad epidémica implica conocer sus modos de transmisión. Pero si bien la transmisión entre los seres humanos no ofrece duda alguna desde los años cincuenta, en cambio no puede, por sí sola, explicar por qué comunidades a veces muy alejadas entre sí se ven afectadas simultáneamente por el mismo virus, como ocurrió en 1918.

Ciertos aspectos fundamentales de la epidemiología de la gripe son todavía controvertidos. ¿Dónde reside el virus durante los periodos no epidémicos? ¿Cuáles son

${ }^{668}$ NADAL OLLER, Jordi (1976): La población española, siglos XVI-XX. Ariel, Barna. p. 108. 
los elementos estacionales y climáticos que determinan la aparición y la desaparición de las epidemias? ¿Cuáles son los factores que provocan las modificaciones antigénicas de los virus?

La falta de respuestas a todas estas preguntas no impide, sin embargo, la lucha contra las epidemias de gripe. Actualmente disponemos de dos armas: la inmunoprofilaxis, que se basa en la vacunación, y la quimioprofilaxis con medicamentos antivíricos específicos de la gripe. ${ }^{669}$

\section{LA APARICIÓN DE LA GRIPE EN CASTELLÓN. LA GESTIÓN DECIDIDA DEL ALCALDE JOSÉ FORCADA Y EL DOCTOR CLARÁ FRENTE A LA PASIVIDAD DEL GOBIERNO}

A lo largo del primer cuarto de siglo XX el País Valenciano arrastró una honda crisis agraria. El optimismo agrario de la I Guerra Mundial se quebró en 1917 con la implantación del bloqueo alemán. La crisis económica repercutió sobre el campesinado al provocar el desempleo y las migraciones. La producción cerealista descendió notablemente a partir de 1917. La lógica consecuencia fue la subida de precios que experimentaron las cosechas, con lo cual los realmente dañados fueron las clases menesterosas $^{670}$

La crisis naranjera que se originó como consecuencia del bloqueo y que impidió la exportación y la llegada de fertilizantes fue muy importante. El bloqueo alemán se inició el 1 de febrero de 1917 y tuvo una doble repercusión: de un lado, paro, hambre, miseria y desarticulación económica y social en el ámbito del País Valenciano; de otro, manifestaciones de protesta y huelgas, que fueron a concluir en la huelga revolucionaria de agosto. Las huelgas iniciaron su intensidad a partir de marzo (Borriana, Alzira, VilaReal, Algemesi, etc.). El 31 de enero de 1917 se difundió la declaración de Alemania en la que anunciaba que prescindía de todas las limitaciones que impuso a su lucha en el mar, era debida la nota al fracaso de su oferta de paz el 12 de diciembre de 1916; según

\footnotetext{
${ }^{669}$ QUÉNEL, Philippe y DAB, William (1994): «Las epidemias de gripe», Mundo científico, N 152 , Vol. 14. pp. 1008-1011.

670 PATUEl ChUST, Pascual y OBIOL MENERo, Emilio (1887): «La gripe de 1918 en Vila-Real. Reconstrucción temporal y análisis demográfico». Boletín de la Sociedad Castellonense de cultura. Tomo LXIII. Enero Marzo, pp. 127.128.
} 
la nota Alemania impediría el tráfico en determinadas zonas alrededor de Gran Bretaña, Francia e Italia y en el mediterráneo oriental. Para el País Valenciano significaba el colapso del comercio exterior y la paralización de la industria. ${ }^{671}$

Como consecuencia de la Gran Guerra la situación económica de Castellón era muy delicada. Faltaban alimentos básicos como el pan, la harina y los huevos. La prensa continuamente llamaba la atención sobre el estado de los más necesitados e instaba a las autoridades a acudir, con todos los medios en auxilio de los pobres, ya que el Gobierno hacia oídos sordos a las apremiantes demandas que se le hacían. Se solicitaba que las autoridades pidieran a las personas ricas y pudientes de la ciudad dinero para socorrer a los desheredados de la fortuna, por sentimiento de humanidad y hasta por egoísmo de los demás que se verían en peligro si la epidemia continuaba.

Ante esta situación de falta de alimentos básicos, el alcalde, José Forcada, ruega a la Junta de Subsistencias, que prohibiera la salida de todos los artículos de comer beber y arder, es decir, que se llevaran las subsistencias a otros pueblos; que la vigilancia para impedir la salida de géneros se encargara no solo a los carabineros sino también a la guardia civil a fin de hacer imposible que por las carreteras y caminos se llevaran las subsistencias a otros pueblos desde donde por la vía férrea o marítima se trasladaran a otras provincias.

La Junta de Subsistencias tasaba todos los artículos para que no se vendieran más caros fuera de la capital al no estar vigilados. Esto ocurría por ejemplo con el carbón, que adquiría un precio más elevado fuera de Castellón. La ciudad quedaba desabastecida porque los comerciantes vendían sus productos fuera de la capital a mejor precio. Eso pasó con los huevos, que primero eran almacenados en cámaras frigoríficas y cuando se podía exportar a otras poblaciones que pagaban mejor, se desabastecía de dicho artículo a la ciudad. ${ }^{672}$

Como pasaba el tiempo y el Ayuntamiento no disponía de recursos para hacer frente a la epidemia, el alcalde dirigió una carta a los Diputados y Senadores por la provincia de Castellón, recabando su ayuda para conseguir se remitiera a la capital la

\footnotetext{
671 ROMEU ALFARO, Fernanda (1964): «La crisis de 1917 y sus consecuencias económicas y sociales en la Región Valenciana». Saitabi, no XIV, pp. 111-122. PATUEL CHUST, Pascual y OBIOL MENERO, Emilio, opus, cit., p. 128. Ver ABAD GARCÍA, Vicente (1984): Historia de la naranja, 1781-1939: Comité de la Gestión de la Exportación de Frutos Cítricos, Valencia. pp. 133-134.

${ }^{672}$ AACS., 9/01/1918.

El 1 de enero de 1918 fue proclamado Alcalde, José forcada Peris, por mayoría absoluta, siendo el alcalde saliente, el republicano Fernando Gasset Lacasaña.
} 
mayor cantidad de trigo argentino. Asimismo agradeció la actuación del diputado por Castellón Emilio Santa Cruz, el cual se puso en contacto con los demás representantes y conferenció con el ministro de Abastecimientos para lograr se diera satisfacción a los justos deseos de Castellón. ${ }^{673}$

José Forcada ordena para evitar la propagación de la epidemia de gripe, que se inspeccionen todas las viviendas de los pobres para dotarlas de condiciones higiénicas. Como el plan de higienización era muy amplio y, había que invertir muchos millones de pesetas por parte del Ayuntamiento, se decide que el gasto se realizará poco a poco.

La higiene de las casas era una constante preocupación del alcalde. Ante el desarrollo que iba adquiriendo la epidemia en el mes de septiembre en Castellón, visitó varias casas de los enfermos en la calle de la Pólvora que estaba situada en uno de los barrios extremos de la población, donde se hallaba más arraigada la enfermedad, sacando la impresión de que estaba justificado el desarrollo de la epidemia por las pésimas condiciones de las casas. Añadió que en sus visitas había presenciado cuadros de tristeza tal que no quería narrar pero lo que sí dijo es que urgía que el Ayuntamiento acudiera pronto en socorro de aquellos desgraciados que necesitaban no solamente medicinas que ya tenían de la beneficencia municipal, sino de recursos económicos para procurarse un poco de higiene y los alimentos necesarios. Propuso que se destinase una cantidad hasta donde pueda el Ayuntamiento para socorrer a los verdaderos necesitados y enfermos a fin de evitar mayores males

La Corporación municipal acordó por unanimidad que se autorizara al alcalde para disponer de toda la consignación de Imprevistos del presupuesto vigente invirtiendo la cantidad necesaria, y si dicha consignación no fuese suficiente o no bastasen los recursos del Ayuntamiento para remediar las necesidades más apremiantes, en tal caso, se recurriera a los sentimientos caritativos del pueblo. ${ }^{674}$

Asimismo, el alcalde ordenó a la guardia municipal que vigilara a los mendigos ambulantes que, según decían, eran los que generalmente llevaban encima el germen de las enfermedades infecciosas. Todos los albergues fueron inspeccionados entre ellos los de la antigua batería de San Roque, «masets»... ${ }^{675}$

\footnotetext{
${ }^{673}$ AACS., 27/09/1918.

${ }^{674}$ Ibídem.

${ }^{675}$ AACS., 8/05/1918.
} 
En la sesiones del Ayuntamiento se prestó especial atención al Grao por ser zona marginal, pobre y puerto. Las casas carecían de pozo negro, y los retretes desaguaban en las acequias, y ante las circunstancias que atravesaba Castellón, se pide la higienización de las viviendas y que los dueños de las referidas casas las pongan en las debidas condiciones de salubridad. ${ }^{676}$

Algunos vecinos del Grao rogaron al Ayuntamiento que facilitara gratuitamente los medicamentos a los enfermos que acudían al dispensario porque el vecindario era pobre y existían más de 200 atacados de la gripe. El Ayuntamiento acordó que el suministro de medicamentos gratuitos a los enfermos del Grao pasara a estudio y dictamen de la Comisión de Beneficencia y Sanidad.

Algunos concejales opinaban que el camino a seguir era la formación de un presupuesto extraordinario, dedicado exclusivamente a la extirpación de la enfermedad.

En octubre los farmacéuticos de Castellón encargados del suministro de medicamentos a los pobres inscritos en el padrón de pobres, reconocen el esfuerzo del Ayuntamiento para satisfacer lo que se les adeuda y deciden continuar la prestación por espacio de 40 días, que es el plazo que consideraban suficiente para que desapareciera la epidemia. $^{677}$

Asimismo el alcalde, José Forcada, indicó a los médicos de la Beneficencia municipal que en casos extremos, recetaran con fórmula municipal dando además cuenta a la alcaldía «de la situación de las viviendas que visitaran». ${ }^{678}$

Forcada gestionó con la Asociación Castellonense de Caridad y Junta Provincial de Sanidad la forma de llevar los necesarios socorros a los enfermos pobres. Dichas entidades tenían dificultades por carecer de fondos y opinaban que por tratarse de una epidemia de carácter general era el Ayuntamiento el llamado a tomar aquellas resoluciones que las circunstancias demandaban.

Finalmente hallándose agotado el crédito votado por el Ayuntamiento en la sesión anterior y siendo urgente y necesaria seguir facilitando socorros a los enfermos pobres, sometía el asunto a la Corporación al objeto de que resolviese acerca de la forma de aportar dinero para remediar enseguida la situación angustiosa y peligrosa para todos, de infinidad de familias pobres haciéndose al efecto un llamamiento a los

\footnotetext{
${ }^{676}$ AACS., 20/09/1918.

${ }^{677}$ AACS., 4/10/1918.

${ }^{678}$ El Clamor, 12/10/1918.
} 
contribuyentes apelando al altruismo de las personas pudientes a fin de que se dieran cuenta de las gravísimas circunstancias que atravesaba la población y aportaran su donativo cuando no por otras razones, por egoísmo propio.

El Ayuntamiento acordó invitar al vecindario a que diera un donativo equivalente a un semestre del impuesto de Inquilinato, recabándose una mayor suma de las personas pudientes; solicitar el concurso del Clero, autoridades y Centros y Sociedades de la Capital, para que designara el personal que había de formar parte de las comisiones encargadas de la recaudación voluntaria y, que, el alcalde, dirigiera una alocución al pueblo para que cooperara en la humanitaria obra que tomaba la Corporación Municipal. ${ }^{679}$

El remedio según la prensa era el dinero, que debía darlo el que lo tenía, entregándolo al Ayuntamiento que sería el que se encargara de distribuirlo equitativamente entre los pobres enfermos y más necesitados. ${ }^{680}$

Más tarde García Prieto, ministro de la Gobernación, envió un telegrama al gobernador participándole que enviaba 1.000 pesetas para atenciones sanitarias en Castellón y su provincia y cuyo texto se publicó en primera plana por El Clamor.

\footnotetext{
[...] para que todos los pueblos conozcan su contenido y juzguen de la burla que supone el donativo del Gobierno, de ese Gobierno que después de haber desoído las demandas de harinas y carne, se complace en escarnecer esbozadamente a la pobreza y miseria de este pueblo.

Es una acción imperdonable que no olvidamos ni olvidaremos, 1.000 pesetas para unos 370 mil habitantes que tiene la provincia de Castellón, equivale a más que si no hubiérase contestado a las peticiones formuladas.

Creemos que las autoridades deben apresurarse a devolver dicha irrisoria cantidad, diciéndole al ministro de la Gobernación que preferimos morirnos de miseria y de hambre que soportar resignadamente burla tan indigna. ${ }^{681}$
}

En una carta dirigida a El Clamor del alcalde de Castellón José Forcada, agradecía el interés del periódico por la publicación de las medidas que debían tomar las

\footnotetext{
${ }^{679}$ AACS., 16/10/1918.

${ }^{680}$ El Clamor, $15 / 10 / 1918$.

${ }^{681}$ Ibídem; AACS, 16/10/1918.
} 
autoridades locales para luchar contra la epidemia, y que coincidían con los acuerdos y determinaciones adoptadas por la Corporación Municipal en la sesión del 16 de octubre.

En dicha sesión se pusieron de manifiesto las condiciones higiénicas que las comisiones nombradas por el Ayuntamiento, presididas por concejales, pudieron advertir en muchas casas de la población, presenciando casos de verdadera miseria, como el encontrarse en una misma cama dos y hasta tres enfermos, en habitaciones sin ventilación y con ropas sucias. Los individuos de la misma familia, sanos, se encontraban depauperados por la falta de alimentación, y por consiguiente, candidatos a sufrir la enfermedad.

Para combatir estos males la Corporación Municipal acordó la aprobación de una transferencia de crédito destinado a paliar la miseria de las familias, conforme se iba recaudando dinero; también se acordó visitar a corporaciones y personas de relieve para que formaran parte de las comisiones que saldrían a recaudar fondos en forma de donativo voluntario equivalente a un semestre del impuesto sobre inquilinato, adoptándose este medio como el más rápido para poder empezar a remediar la miseria que las comisiones presenciaron y que según la opinión del Inspector de Sanidad era uno de los medios más eficaces para evitar la propagación de la epidemia. ${ }^{62}$

El Clamor insistía en que había que llevar a cabo las iniciativas del alcalde y de los acuerdos del Ayuntamiento para que se diera el resultado que la gravedad del momento reclamaba. Según el periódico, era indispensable el dinero para higienizar las viviendas pobres, socorrer la miseria y combatir con energía y actividad «la maldita epidemia que tantos estragos está causando en nuestra ciudad».

Y añadía que la fórmula para acabar con la epidemia era higiene, alimentos y medicamentos, y para eso, se necesitaban «DINERO, DINERO, Y DINERO». ${ }^{683}$

El Ayuntamiento pidió al gobernador militar y al cura párroco que una comisión de cada estamento formara parte de las que habían de proceder a la recaudación para el socorro de enfermos.

Inmediatamente, el alcalde recibió los donativos destinados al humanitario fin. Uno de los primeros fue el gobernador civil, que dio 500 pesetas. $^{684}$

\footnotetext{
${ }^{682}$ El Clamor, 17/10/1918.

${ }^{683}$ Ibídem.

${ }^{684}$ Ibídem.
} 
La carestía de las subsistencias, el elevado precio de los artículos y la propagación de la gripe, dificultó mucho la vida en Castellón y la situación empeoró.

En vista de que la carestía de artículos de primera necesidad aumentaba, el diputado por Castellón Emilio Santa Cruz, telegrafió al ministro de Abastecimientos pidiéndole con urgencia el envío de trigo argentino, telegrama al que contestó el ministro Juan Ventosa con otro, prometiéndole interesarse en el asunto.

La alcaldía, no solo hizo lo propio sino que remitió al citado ministro una carta en la que se demostraba la agudeza de la crisis económica y de subsistencias que atravesaba Castellón, la primera a causa del desastre de la naranja y la segunda por el abandono en que se tenía por los poderes públicos a esta provincia.

La bancarrota económica de Castellón determinó la carencia de trabajo, y como consecuencia la falta de medios de la clase proletaria y aún las clases medias para abastecerse de lo más esencial para su supervivencia, máxime con los precios alcanzados por los artículos de primera necesidad. En Castellón la penuria era grave y se pasaba hambre.

El alcalde, en una entrevista dada a los redactores de El Clamor y El Heraldo, dio los siguientes datos para demostrar el estado de penuria en que se encontraba Castellón: En los meses de julio, agosto y septiembre, de 1914 se sacrificaron en Castellón 687 cerdos, 4.295 carneros y 1.141 corderos; en los mismos meses de 1918 se sacrificaron191 cerdos, 1.256 carneros y 487 corderos.

Es decir, que el consumo de carne ha quedado reducido a mucho menos de la mitad, casi a la tercera parte. Y lo que digo de la carne se puede aplicar al pan. Los 200 sacos de harina que con poca variante se elaboraban diariamente en 1914, hoy han quedado reducidos a un centenar. Así sucesivamente, iríamos señalando la misma baja en el consumo de los demás productos alimenticios. ${ }^{685}$

De modo que el alcalde, José Forcada, mostraba con estos datos que en Castellón no se comía, que en Castellón se padecía hambre. Por ello podía decirse que la epidemia de gripe se cebaba en las clases pobres proletarias por encontrarlas sin las necesarias condiciones de resistencia a causa de la depauperación.

${ }^{685}$ El Clamor, 25/10/1918; Heraldo de Castellón, 26/10/1918. 
Por ello Forcada escribió al ministro de abastecimiento, exponiéndole tan terrible situación y encareciéndole que procurara con toda rapidez los medios de abaratar las subsistencias; la harina, las carnes, «cuanto es en fin indispensable para combatir el hambre que tantos estragos causa en Castellón».

La alcaldía, con la ayuda de la Junta de subsistencias y de todos los concejales, luchó por evitar que no faltasen las provisiones y que no subieran los precios del pan, de la carne, de las patatas, etc., pero todos esos esfuerzos no pudieron evitar «que los egoísmos de los comerciantes, de los vendedores y la incuria de los pudientes y miembros del Gobierno camparan en gran parte a su gusto, abusando de los consumidores». ${ }^{686}$

El alcalde solicitaba a la prensa su colaboración para que el pueblo de Castellón supiera que es lo que estaba haciendo el Ayuntamiento por sus vecinos «y no hayamos de cargar con las responsabilidades los que ninguna culpa tenemos de ello; los que hemos trabajado sin descanso para evitar llegáramos a tan desesperado extremo».

Forcada se quejaba que el mismo pueblo de Castellón hiciera el vacío a la labor de la alcaldía y del Ayuntamiento. La prueba es que se convocaron dos asambleas, una para aminorar la crisis del trabajo y la otra para estudiar la solución que podía darse a la cuestión del pan. A una y a otra, solo respondieron muy pocas personas y representaciones de entidades. Los demás hicieron el vacío, mostrándose indiferentes.

Mientras Valencia, Barcelona y Madrid conseguían todo el trigo que deseaban, Castellón se le negaba, determinando la carestía de harinas de precios económicos, causa de que tuvieran que adquirir el pan a precios escandalosos, que imposibilitaban a los pobres consumirlo.

Sólo se pudieron conseguir 92 toneladas para toda la provincia y 700 de los 5.000 sacos que de Barcelona ofreció el ministro de Abastecimientos Juan Ventosa.

Sin embargo, en Valencia se estaba repartiendo un cargamento bastante considerable de trigo argentino. El Clamor hace una crítica de éste hecho diciendo:

Fundándose en una injusta e irritante distribución, escudándose en que en nuestra provincia no hay más que dos fábricas de harina, nos darán como de limosna otra ínfima cantidad de dicho cereal que apenas bastará para las necesidades de tres

\footnotetext{
${ }^{686}$ Ibídem.
} 
o cuatro días, en tanto en Barcelona y Valencia tendrán satisfecho su consumo por tiempo ilimitado. ${ }^{687}$

Por otra parte, el Ayuntamiento pidió insistentemente ayuda; telegrafió innumerables veces al ministro de Abastecimientos, envió escritos a senadores y a diputados por la provincia que contestaron prometiendo ayuda, prestó su ayuda el diputado por Castellón Emilio Santa Cruz yendo a Madrid, para hablar con el ministro de Abastecimientos. A pesar de esto, continuó la indiferencia y el abandono del Gobierno y como consecuencia se agravó la situación y se acrecentó el hambre y la miseria que favorecieron la propagación de la epidemia de gripe.

El alcalde describía algunos cuadros presenciados en humildes viviendas visitadas por él, donde se veía familias enteras postradas en míseros lechos, sin medios no solo de alimentación, ni siquiera aquellos más elementales para la asistencia, que tenía que prestarse por los vecinos compasivos. «Esta es a grandes rasgos, la situación de Castellón. Si no nos dan carnes y trigo en abundancia que hagan bajar los precios, la depauperación de ahora, aumentará considerablemente, llegando al colmo, está ya angustiosa y desesperada situación».

Forcada Peris, quien detentaba la alcaldía, solicitó nuevamente la ayuda de los periódicos «con el fin de ver si así somos oídos y se presta desde el Gobierno alguna atención a nuestras justas demandas». Solicitó también de la prensa que dieran a conocer el estado de miseria de las clases humildes de la ciudad:

Es indispensable que aquellos y estos se enteren. El invierno que se avecina va a ser terrible, cruel. En previsión de la mayor agravación del mal y en evitación de lo que puede ser, peor, mucho peor que lo de ahora, precisa que los gobernantes, acordándose de que existe un pueblo en la mayor necesidad, le presten su ayuda, y los que no han sufrido aquí aún las consecuencias de esa miseria y disponen de medios o de influencias, lo pongan a disposición de las aludidas víctimas del hambre y de la gripe. ${ }^{688}$

\footnotetext{
${ }^{687}$ El Clamor, 25/10/1918.

${ }^{688}$ El Clamor, 25/10/1918.
} 
Castellón se encontraba sin medicamentos suficientes y sin dinero para hacer frente a la epidemia de gripe. La prensa se quejaba del deplorable estado sanitario de la nación española, víctima de la epidemia reinante.

El Ayuntamiento repartía mantas entre las familias pobres que tenían enfermos; se les daba carne, arroz y pan diariamente con el fin de mejorar su salud, víctimas de la gripe y de la miseria. ${ }^{689}$

Hay que destacar sobre todo, el comportamiento del alcalde de Castellón, ante la gravedad de la epidemia. En una carta dirigida a todos los castellonenses, publicada en El Clamor, El 19 de octubre de 1918, dice que la epidemia reinante no es un enemigo a quien se abaten y rinden tan solo la terapéutica del médico y la eficacia de las medicinas, es un enfermedad traidora que anida en la miseria del hogar y se nutre y mata en el depauperado organismo del que la padece. ${ }^{690}$

Por otra parte, el doctor José Clará, ante la escasez de médicos, pidió a Madrid el envío de médicos para los pueblos que carecían de ellos.

Efectivamente, hacían falta médicos, dinero para socorrer a los pobres enfermos e higienizar sus viviendas. Pero no recibió contestación por parte del Gobierno; solamente el ministro de la Gobernación envió mil pesetas para atenciones sanitarias de toda la provincia, como hemos indicado más arriba.

Por eso El Clamor, escribe:

No hay que esperar pues del Gobierno nada, absolutamente nada. Precisa que, teniendo esto en cuenta sean el señor Clará, los médicos de aquí, la junta de Sanidad, el Gobernador y el Alcalde los que toman a sus cargo toda iniciativa, toda labor que sea necesaria para encontrar medios, dinero, lo que haga falta para impedir que la gripe siga causando tantos estragos.

Del Gobierno como si no hubiera de García Prieto, de este funesto gobernante ni nombrarlo. Hay que hacerle el único honor que merece, despreciarlo y devolverle las miserables e indignas mil pesetas de referencia. ${ }^{691}$

\footnotetext{
${ }^{689}$ El Clamor, 29/10/1918.

${ }^{690}$ El Clamor, 19/10/1918. Ver Apéndice Documental No 8.

${ }^{691}$ Ibídem.
} 
La actitud del Ayuntamiento, del alcalde y de cuantos colaboraron en la labor humanitaria, dio motivos a muchos elogios que contrastaron con las censuras que la opinión pública dedicó a la Cruz Roja, que no dio señales de vida. ${ }^{692}$

\section{EVOLUCIÓN DE LA EPIDEMIA EN CASTELLÓN}

La primera onda de gripe que afectó a España no tuvo gran incidencia en la provincia. Concretamente en Castellón no hubo ninguna defunción a causa de la gripe durante los meses de primavera. En la prensa de Castellón las noticias referidas a la «epidemia reinante» comienzan a aparecer desde el mes de mayo y hacen referencia sobre todo a las ciudades de Madrid y Barcelona.

En el mes de septiembre comienzan a aparecer noticias de la epidemia referidas a la provincia.

En mayo de 1918 la afección gripal que había invadido varias capitales de España, hizo su aparición en Castellón donde se registraron sesenta casos.

Según los médicos, el vecindario no tenía por qué alarmarse porque además de tener el carácter benigno, se habían adoptado las medidas necesarias para impedir su desarrollo. ${ }^{693}$

Durante todo el mes de junio los casos de gripe en Castellón continuaron siendo benignos.

Los datos que entregaba el doctor Clará al Gobernador indicaban que en Castellón existían 600 atacados de «la enfermedad de moda» no siendo ninguno grave, es más, la enfermedad seguía su curso pero con carácter de descenso. ${ }^{694}$

Se iban generalizando las noticias de la enfermedad de moda en otros países como Alemania y Portugal, donde fueron muchos los atacados, sobre todo en Alemania que revistió alguna gravedad en los atacados. ${ }^{695}$

De todas maneras, la opinión de las autoridades sobre el estado sanitario en Castellón, era buena, aunque sí existía preocupación de los habitantes de la capital. El gobernador conferenciaba muy a menudo con, el Inspector de Sanidad, José Clará,

\footnotetext{
${ }^{692}$ El Clamor, 22/10/1918; Heraldo de Castellón, 26/1071918.

${ }^{693}$ El Clamor, 29/05/1918.

${ }^{694}$ El Clamor, 15/06/1918.

${ }^{695}$ El Clamor, 17/06/1918.
} 
sobre el estado sanitario de la capital y, éste, con datos irrevocables, le comunicaba que no había motivos de alarma.

En el mes de septiembre comienzan a aparecer noticias de la segunda onda epidemia.

Ante la amenaza de invasión de la enfermedad, el 2 de septiembre de 1918, el prestigioso médico republicano de Castellón, Vicente Gea, escribe un artículo en El Clamor, ya comentado en otro capítulo, en el que describe la situación de la higiene en la ciudad, y afirma que para defender la salud «se necesita dinero para instruir, para destruir y para construir». ${ }^{696}$

En la población de Castellón había cundido la alarma, pues se habían presentado varios casos de fiebres tifoideas.

El inspector Clará salió al paso de los comentarios en la prensa diciendo que los casos de fiebres tifoideas en la población no debía ser motivo de alarma, pues durante los meses de agosto y septiembre aumentaban los números de invasiones de esta enfermedad. ${ }^{697}$

El 18 de septiembre, el inspector Clará, dio cuenta a la Junta Provincial de Sanidad, de que la epidemia de gripe que tiempo atrás había aparecido en todos los pueblos de la provincia, «había de un mes a esta parte vuelto a presentarse en la mayoría de estos con mayor intensidad y difusión que la primera vez».

Añadió que aunque algunos casos graves hayan ocurrido en emigrantes del mediodía de Francia, «no cabe la menor duda de que se trata de gripe agravada por circunstancias especiales de los individuos invadidos».

Y seguía diciendo que pocos eran los pueblos en los que no se había presentado la epidemia en la provincia:

En la mayoría, aunque son muchos los casos, el número de graves ha sido hasta hoy muy reducida y la mortalidad por tanto también muy reducida, pero en algunos muy pocos por fortuna, la difusión de la enfermedad ha sido rapidísima, y se ha presentado esta con una virulencia desusada, siendo menos los casos graves y

\footnotetext{
${ }^{696}$ El Clamor, 3/09/1918.

${ }^{697}$ El Clamor, 3/09/1918.; Heraldo de Castellón, 9/09/1918.
} 
extremada la mortalidad, teniendo en cuenta lo exigua que suele ser de ordinario en la gripe epidémica. ${ }^{698}$

Los casos graves en su inmensa mayoría eran bronconeumonías.

Los pueblos más castigados por la gripe en el mes de septiembre fueron Las Alquerías de Villarreal, Useras, Chert, Torreblanca y Catí.

El doctor Clará visitó esto pueblos disponiendo las medidas más convenientes. A Torreblanca se envió un médico y un practicante y se dispuso de todos los recursos para acudir inmediatamente a donde fuera preciso con los medios y personal necesario.

Esta segunda onda de la epidemia de gripe fue general en toda España sobre todo en Levante.

En Castellón, aparte de la gripe que ha vuelto a presentarse, aunque no con gran intensidad, la situación sanitaria actual no es para causar alarmas infundadas; la fiebres tifoideas frecuentes en esta época parece ser, son más leves y en mucho menor número que en años anteriores y descontando el paludismo «por desgracia inevitable solo tenemos que preocuparnos de la gripe que con toda probabilidad no ha de adquirir graves proporciones». ${ }^{699}$

Circuló la noticia hasta en Madrid de que se había desarrollado una epidemia en Albocacer de disentería; el Inspector Provincial se trasladó de inmediato a dicho pueblo, en donde no había otra epidemia que la gripe de forma ligera.

La Junta Provincial de Sanidad concedió un voto de confianza al Inspector de Sanidad para que adoptara las medidas que creyera convenientes a fin de evitar la propagación de la epidemia.

Por disposición del Gobernador Civil, Clará volvió a visitar Torreblanca, desplazándose también a los pueblos de Alcalá de Chivert, San Mateo, Salsadella, Catí y Borriol, donde la epidemia de gripe tomó gran intensidad.

En Castellón y en el Grao también se fue incrementando la epidemia. ${ }^{700}$

\footnotetext{
${ }^{698}$ El Clamor, 18/09/1918; Heraldo de Castellón, 17/09/1918

${ }^{699}$ Ibídem.

${ }^{700}$ Ibídem.
} 
En Villarreal, existían por esa fechas 500 atacados, pero siendo la casi totalidad de carácter benigno.

En Castellón continuaban ocurriendo invasiones, todos los días, aunque no tomaban gran virulencia. ${ }^{701}$

Diariamente el doctor Clará daba noticias a la prensa sobre el desarrollo de la epidemia La enfermedad decrecía bastante en Torreblanca y Catí, «pues en el primero de estos pueblos no ocurrió ayer ninguna invasión y es muy probable que mañana o pasado pueda regresar a esta capital el personal facultativo que se envió para auxiliar al de dicha población».

En Catí no ha ocurrido tampoco ninguna invasión durante los últimos tres días.

En Villafamés y San Jorge se extiende, pero con carácter benigno y en Alcalá de Chivert se ha estacionado la epidemia.

Nos ha confirmado el doctor Clará que en Villarreal se ha extendido la gripe, pero también con carácter benigno.

En Alquerias del Niño Perdido, se ha recrudecido la enfermedad.

Del distrito de Morella, apenas se tiene noticia de haber ocurrido algún caso y en los demás pueblos de la provincia, se sabe han ocurrido algunas invasiones.

En San Mateo y Borriol, ha mejorado bastante y en la capital, aunque se ha extendido, parece que por ahora se muestra muy benigna la enfermedad gripal. ${ }^{702}$

En vista de todo esto, el doctor Clará afirmaba que la epidemia tendía a mejorar en toda la provincia, y recomendaba la prohibición de festejos para evitar la aglomeración de público.

No obstante, la gripe en Castellón y en la provincia iba en aumento; el 24 de septiembre El Clamor daba una cifra para la ciudad de más de 500 atacados, siendo muy escasos los enfermos de bronconeumonía.

Asimismo en las fuerzas del regimiento de Tetuán, el número de atacados era considerable. $^{703}$

\footnotetext{
${ }^{701}$ El Clamor, 20/09/1918; Heraldo de Castellón, 9/09/1918.

${ }^{702}$ El Clamor, 21/09/1918; Heraldo de Castellón, 17/09/1918.
} 
Al mismo tiempo que decrecía la enfermedad en las Fuerzas de Tetuán, aumentaban las fiebres palúdicas; y en un plazo de ocho días ingresaron en el Hospital

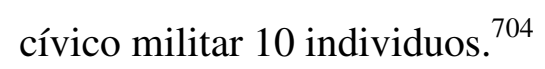

En la provincia, la situación del Forcall era difícil pues había más de 400 invasiones, siendo bastantes de carácter grave.

Los médicos de Forcall se encontraban enfermos y por ello se encargó al doctor Ángel Sánchez Gozalbo que se hiciera cargo de prestar los servicios médicos. ${ }^{705}$

En Forcall, hubo un primer brote epidémico sin complicaciones broncopulmonares a mediados de junio, que atacó a muy pocos vecinos, después y coincidiendo con la llegada de los primeros inmigrantes, aparece el llamado foco de Levante, que se va difundiendo y aparecen en Forcall los primeros casos a mediados de septiembre; queda invadido todo el pueblo y reviste la gripe unos caracteres de gravedad inusitados, con predominio del síndrome neumónico-septicémico. Siguen ocurriendo nuevas invasiones y cuando ya estaba todo el vecindario invadido, cesa la gripe a fines de octubre porque están inmunizados todos sus habitantes, y ya no vuelve a repetirse. $^{706}$

El 30 de septiembre iba aumentando la epidemia gripal, especialmente en los barrios extremos de Castellón, siendo especialmente altos los casos de bronconeumonía. Gracias a la intensa labor de los médicos, no fueron mayores las consecuencias de la gripe.

En los pueblos de la provincia, destacaba sobre todo el Forcall con 400 invasiones, aunque según dice la prensa «parece que la enfermedad se ha estacionado, pues apenas ocurren defunciones».

En Useras donde había unas 2.000 invasiones con más de 60 atacados graves, ha mejorado la situación, pues ha decrecido extraordinariamente; en las Alquerías del Niño Perdido, ha recrudecido bastante la epidemia, causando algunas defunciones; en Eslida ha mejorado mucho la situación, desapareciendo la gravedad; en Villarreal se ha estacionado la epidemia; en Nules ha aparecido la enfermedad con bastante virulencia; en Artana, la situación es bastante grave, habiendo ocurrido

\footnotetext{
${ }^{703}$ El Clamor, 24/09/1918;

${ }^{704}$ El Clamor, 28/09/1918.

705 Ibídem.

${ }^{706}$ SÁNCHEZ GOZALBO, Ángel. (1919). Contribución al estudio de la Grippe de 1918 en la provincia de Castellón. Hijos de J. Armengot, Castellón. p. 10.
} 
algunas defunciones; en el Desierto de las Palmas había ayer 28 atacados entre frailes legos y trabajadores. ${ }^{707}$

Entre las visitas que el doctor Clará hizo por toda la provincia y las que $E l$ Clamor hacía referencia en la sección «La salud pública», está la del 30 de septiembre cuando junto con el Gobernador Civil visitó las localidades de Villarreal, Nules, Villavieja, Eslida y Artana.

A principios de octubre la prensa sigue diciendo que la gripe se halla estacionada en Castellón, «que por ahora no toma mayor incremento»; según dice la mortalidad es mayor que en igual mes del año anterior pero «insistimos en afirmar que, afortunadamente, no es proporcional al número de atacados».

En cuanto a las demás provincias, «ocurre lo propio habiéndose ordenado las medidas rigurosas de higiene, especialmente en asilos, penales y cuarteles». ${ }^{708}$

A fin de evitar el consiguiente sobresalto que la noticia de las defunciones producía se realizaban los entierros con la menor publicidad posible.

El 8 de octubre el Inspector de Sanidad informó a la Junta Provincial de Sanidad que la gripe se había extendido por toda la provincia, siendo muy contados los pueblos en los que no hubiera casos, «pero solo en 38 había la infección adquirido gran expansión e intensidad»; también informó que la infección se propagaba rápidamente por todo el vecindario y se extinguía después de haber invadido en ocasiones el 80 por cien de la población, y añadió, que la mortalidad no había llegado aún en las poblaciones de más intensidad invadidas, al 2 por cien de los enfermos.

La infección era intensa en Artana, Forcall, Almedijar, Segorbe, Cabanes y Todolella; en las demás poblaciones según Clará, iba decreciendo; también añadía que en Useras, Catí, Chert, Eslida y Salsadella, donde la epidemia cursó con mucha intensidad, podía darse por terminada. ${ }^{709}$

En el Grao de Castellón la gripe hacia grandes estragos, había casas que tenía ocho atacados por carecer de toda clase de medios para combatir la enfermedad. En un acuerdo del Ayuntamiento en sesión de 9 de octubre, se aprueba facultar al alcalde para

\footnotetext{
${ }^{707}$ El Clamor, 2/10/1918; Heraldo de Castellón, 2/10/1918.

${ }^{708}$ Ibídem.

${ }^{709}$ El Clamor, 9/10/1918.
} 
que gestione de la autoridad competente se facilite al Ayuntamiento el material de desinfección que tenía el Servicio de Sanidad. ${ }^{710}$

A mediados de octubre, el número de fallecidos no aumentó pero tampoco decrecía el número de atacados. Según la prensa era debido a la perturbación atmosférica que se desarrollaba esos días, que venía a agravar los estragos de la miseria entre las familias pobres que tenían la desgracia de ser visitadas por «la maldita gripe».

El Clamor pedía al gobernador, Inspector Provincial de Sanidad, al alcalde o quienes tuvieran autoridad para ello, que prohibieran los entierros, el viatico y cuantos actos pudieran contribuir a sembrar las alarma en el vecindario «alarma, que causa tantos daños como la propia enfermedad».

Recomendaban esto porque el traslado de los muertos al cementerio en la forma de costumbre y el continuo recorrer de las calles por el cura que acudía a viaticar a los enfermos más o menos graves, daban motivo a que la gente creyeran que los estragos eran tan grandes que en Castellón morían a docenas.

Corría la versión de que fallecían 20 o 23 diariamente, sin embargo El Clamor lo negaba, según decía, «el promedio de los muertos en los últimos diez días (entre niños y adultos), incluyendo los fallecidos en el hospital, no excedía de 12 o $13 »$.Y añadía que exagerar estos números era «criminal».

Asimismo daba una indicación a los médicos diciendo que sería muy conveniente que se firmaran las papeletas de defunciones con la mayor prontitud a fin de evitar que la gente, al ver acumulados en el depósito cadáveres de dos días, se asuste de la mortalidad creyendo que tales bajas pertenecen a un solo día.

El alcalde se desplaza al Grao, visitando la mayor parte del caserío marítimo y enterándose de la marcha que seguía la epidemia que, al parecer, iba decreciendo. También reunió en el Ayuntamiento a los comisionados de distrito a los que expuso la necesidad de girar una minuciosa inspección a las casas de la ciudad para enterarse del estado higiénico de las mismas, hacer a sus habitantes las indicaciones sanitarias oportunas y recoger los datos que crean precisos para tomar cuantas medidas sean indispensables para atajar la enfermedad reinante.

\footnotetext{
${ }^{710}$ Ibídem.
} 
Finalmente, en el Boletín Oficial de la Provincia del 14 de octubre se publicó una circular del gobernador civil, declarando oficialmente por acuerdo de la Junta Provincial de Sanidad, la existencia de la gripe en toda la provincia. ${ }^{711}$

Empezaron las comisiones y subcomisiones de los respectivos distritos a girar la anunciada visita de inspección a todas las viviendas de Castellón, a fin de conocer el estado higiénico de las casas, número de enfermos y remedios que deben aplicarse. ${ }^{712}$

Los pueblos de Altura, Vall de Almonacid y Toga, carecían de asistencia facultativa a causa de hallarse enfermos sus respectivos médicos.

En vista de esto y que los médicos de Castellón no podían ausentarse por exceso de trabajo, el doctor Clará pidió telegráficamente a la Inspección general de Sanidad enviara médicos para la asistencia facultativa de dichos pueblos.

A Chilches y La Llosa marchó el médico de Castellón, Leandro Ureña, para sustituir al de aquellos pueblos que se encontraba enfermo. ${ }^{713}$

El 16 de octubre la epidemia seguía por todo lo alto. En España, estaba invadiendo los pueblos donde no había atacados en general.

En cuanto a Castellón y su provincia se refiere, Clará declaró a El Clamor, que la epidemia crecía en la Capital. Diariamente se registraban unas 200 nuevas invasiones, siendo del total de ellas un 2 o un 3 por cien de bronconeumonía, incluyendo el caserío marítimo, y añadía que existían 150 enfermos de gripe complicada. ${ }^{714}$

En la segunda quincena de octubre la enfermedad empezaba a decrecer en Castellón y la provincia, pues si aún había defunciones se debía a la existencia de enfermos graves.

Los vecinos de Castellón pedían al gobernador civil que se suprimieran los entierros y el toque de difuntos, que continuamente ofrecían las parroquias de la Trinidad y la Sangre, porque con el continuo desfile de entierros y el repiqueteo de las campanas, se alarmaba considerablemente el vecindario, preocupado por el desarrollo que adquiría la enfermedad. ${ }^{715}$

Continuamente regresaban obreros procedentes de Francia. Los trenes iban sobrecargados. En todas las estaciones del tránsito se iban quedando inmigrantes que

\footnotetext{
${ }^{711}$ El Clamor, 14/10/1918; BOP, 14/10/1918.

${ }^{712}$ El Clamor, 15/10/1918.

${ }^{713}$ Ibídem.

${ }^{714}$ El Clamor, 16/10/1918.

${ }^{715}$ El Clamor, 17/10/1918.
} 
iban esparciendo por los pueblos los gérmenes de la epidemia procedente de la frontera. En la estación de Barcelona, hacinados en un inmenso montón confundidos entre los sucios equipajes, esperaban la formación del tren, al que subían mezclados con todos los demás viajeros.

El Clamor se quejaba, pues según decían, había suficiente número de obreros para que se formen trenes especiales para ellos «y no produjera el trastorno que significa emplear dos máquinas y un convoy de catorce o más vagones». ${ }^{716}$

El alcalde y las autoridades eclesiásticas se pusieron de acuerdo en ordenar que no tocaran a muertos las campanas de las parroquias de la Sangre y Trinidad; también se dispuso que los entierros se realizaran por el trayecto más corto, desde la casa mortuoria al cementerio, dejando de pasar por la iglesia. ${ }^{717}$

En Castellón continuaba la epidemia y El Clamor hace una crítica de la epidemia que se desarrolló en el invierno de 1889-1890 igual que la de la gripe, que entonces se llamó dengue, trancazo, influenza y, recuerda que igual que ahora, el desconcierto era grande no había higiene ni caridad y los médicos tampoco sabían cuál era el origen de la enfermedad. ${ }^{718}$

A partir del 21 de octubre la prensa comenta que en Castellón disminuían las invasiones, aunque la mortalidad seguía igual debido al número de enfermos graves de los días anteriores. En la provincia, Burriana y Almazora aumentaban las invasiones y el número de defunciones. En Nules, donde apenas se registraban invasiones, estaba adquiriendo la gripe gran virulencia. ${ }^{719}$

Todos los días el Ayuntamiento recibía donativos de los contribuyentes para paliar los estragos de la enfermedad en los pobres. ${ }^{720}$

El 24 de octubre, el doctor Clará daba cuenta a la Junta Provincial de Sanidad de la evolución de la gripe en la provincia. Según afirmaba se observaba una notable disminución en la intensidad de la epidemia en la mayoría de los pueblos, y en la capital la disminución era bastante acentuada. ${ }^{721}$

\footnotetext{
${ }^{716}$ Ibídem.

${ }^{717}$ El Clamor, 19/10/1918.

${ }^{718}$ El Clamor, 21/10/1918.

${ }^{719}$ Ibídem.

${ }^{720}$ El Clamor, 23/10/1918.

${ }^{721}$ El Clamor, 25/10/1918.
} 
La Junta se ocupó de la falta de algunos medicamentos en las farmacias de la capital y en la mayoría de las de la provincia acordándose rogar al gobernador que en la forma más conveniente y juntamente con el alcalde e inspector de sanidad «intervengan en este grave asunto para solucionarlo como mejor se pueda». ${ }^{722}$

El Clamor hace una crítica al ministro de la Gobernación, García Prieto, porque gracias a su «irresponsabilidad» la epidemia se había extendido por toda España. La crítica venía al caso porque se había licenciado a los reclutas contaminados, el Gobierno no tenía datos exactos de la extensión de la epidemia ni de las víctimas que producía, y, además, destaca la incapacidad del Gobierno para organizar el servicio médico y la falta de consideración hacía la clase médica. ${ }^{723}$

El 28 de octubre el ministerio de la Gobernación facilitaba una nota sobre la mejoría de la salud pública en toda España.

En Castellón seguía mejorando la situación, el 28 de octubre solo hubo 14 invasiones. Las defunciones aún eran respetables, pero obedecía a los casos graves de días anteriores.

Según la prensa, la baja señalada, en invasiones y defunciones, «son prueba evidente que ha contribuido mucho al mejoramiento actual la asistencia prestada a las familias pobres, gracias al dinero que han donado y siguen entregando al Ayuntamiento los castellonenses pudientes y de sentimientos humanitarios». ${ }^{724}$

El 30 de octubre la situación mejora en toda España. En Castellón sigue el decrecimiento iniciado, tanto en cuanto a invasiones como defunciones.

En Burriana, de dos practicantes que había, falleció uno, y el doctor Clará envió otro, en vista de que aún había 200 atacados de la gripe.

El gobernador recibió un telegrama del ministerio de la Gobernación diciendo que habían sido libradas 2.000 pesetas para atenciones sanitarias de la provincia.

Las invasiones y defunciones que salen en la prensa, el 30 de octubre en una nota oficiosa, están reflejadas en la siguiente tabla: ${ }^{725}$

\footnotetext{
${ }^{722}$ Ibídem.

${ }^{723}$ El Clamor, 28/10/1918.

${ }^{724}$ El Clamor, 29/10/1918.

${ }^{725}$ El Clamor, 30/10/1918.
} 
Tabla 1. Invasiones y defunciones ocurridas el día 30 de octubre

\begin{tabular}{|c|c|c|}
\hline Pueblos & Invasiones & Defunciones \\
\hline Alcalá & 4 & 0 \\
\hline Alcora & 8 & 0 \\
\hline Alfondeguilla & 9 & 0 \\
\hline Algimia & 3 & 1 \\
\hline Almazora & 14 & 2 \\
\hline Almenara & 10 & 2 \\
\hline Altura & 8 & 3 \\
\hline Ayodar & 4 & 1 \\
\hline Bechi & 8 & 1 \\
\hline Benasal & 4 & 1 \\
\hline Benicarló & 3 & 0 \\
\hline Benicasim & 9 & 0 \\
\hline Borriol & 5 & 2 \\
\hline Burriana & 58 & 4 \\
\hline Cabanes & 9 & 2 \\
\hline Castellón & 28 & 13 \\
\hline Cervera & 7 & 0 \\
\hline Cinctorres & 1 & 0 \\
\hline Cuevas & 5 & 0 \\
\hline Chilches & 5 & 1 \\
\hline Eslida & 2 & 0 \\
\hline Figueroles & 6 & 0 \\
\hline Gátova & 2 & 1 \\
\hline La Llosa & 3 & 0 \\
\hline Lucena & 5 & 0 \\
\hline Moncofar & 0 & 1 \\
\hline Navajas & 0 & 1 \\
\hline Nules & 16 & 0 \\
\hline Onda & 17 & 4 \\
\hline Oropesa & 4 & 1 \\
\hline San Mateo & 2 & 0 \\
\hline Santa Magdalena & 4 & 2 \\
\hline Segorbe & 2 & 0 \\
\hline Soneja & 1 & 0 \\
\hline Sueras & 11 & 2 \\
\hline Torás & 2 & 0 \\
\hline Traiguera & 0 & 1 \\
\hline Vall de Almonacid & 6 & 2 \\
\hline Vall de Uxó & 16 & 1 \\
\hline Villafranca & 4 & 0 \\
\hline Villarreal & 35 & 1 \\
\hline Vinaroz & 5 & 2 \\
\hline Vistabella & 2 & 0 \\
\hline Viver & 5 & 1 \\
\hline
\end{tabular}

Fuente: el Clamor, 30/10/1918 
En la Provincia disminuían las invasiones y defunciones. El mayor número de invasiones se registraban en Burriana, Onda, Almazora, y decrecía el número de defunciones.

En Castellón decrecían no solo las invasiones sino también las defunciones, en general, según la prensa, la situación de la provincia mejoró notablemente.

El 31 de octubre la epidemia en España decrece, exceptuando en Badajoz, donde estaba causando verdaderos estragos. ${ }^{726}$

El 2 de noviembre, la situación de la provincia sigue mejorando, aunque aún se sigue produciendo algunas invasiones y defunciones, pero el número de unas y otras es bastante reducido; en 48 horas, se registraron 12 defunciones, incluidas las de gripe y otras enfermedades. Nueve de ellas pertenecían a las primeras 24 horas y las 3 restantes a las segundas. $^{727}$

En El Clamor de 2 de noviembre sale una crónica donde compara las defunciones habidas en años anteriores con las habidas en 1918:

En septiembre de 1917 ocurrieron 58 defunciones, en igual mes de 1918, 120; en el mes de octubre de 1913, hubo 68 defunciones; en 1914, 38; en 1915, 54; 1916, 66; 1917, 67. En el mes de octubre de 1918 se registró «la horrorosa cifra de 487 defunciones», es decir 420 más que en igual mes del año anterior.

Las 487 defunciones habidas en el mes de octubre fueron 179 varones adultos, y 220 mujeres.

Nosotros hemos realizado las gráficas de la epidemia de la gripe en Castellón, con los datos extraídos del Boletín de Estadística Municipal de Castellón de 1918-1921.

En la gráfica 1 podemos comprobar cómo durante el año 1918, concretamente en el mes de octubre, se produjo un elevado número de defunciones. Murieron casi el mismo número de mujeres que de hombres. ${ }^{728}$

\footnotetext{
${ }^{726}$ El Clamor, 31/10/1918.

${ }^{727}$ El Clamor, 2/11/1918.

${ }^{728}$ Boletín de Estadística Municipal de Castellón de 1918-1921. Ver Tabla 1 en Apéndice.Documental. $\mathrm{N}^{\circ} 9$.
} 
Gráfica 1. Mortalidad por gripe en 1918. Castellón capital

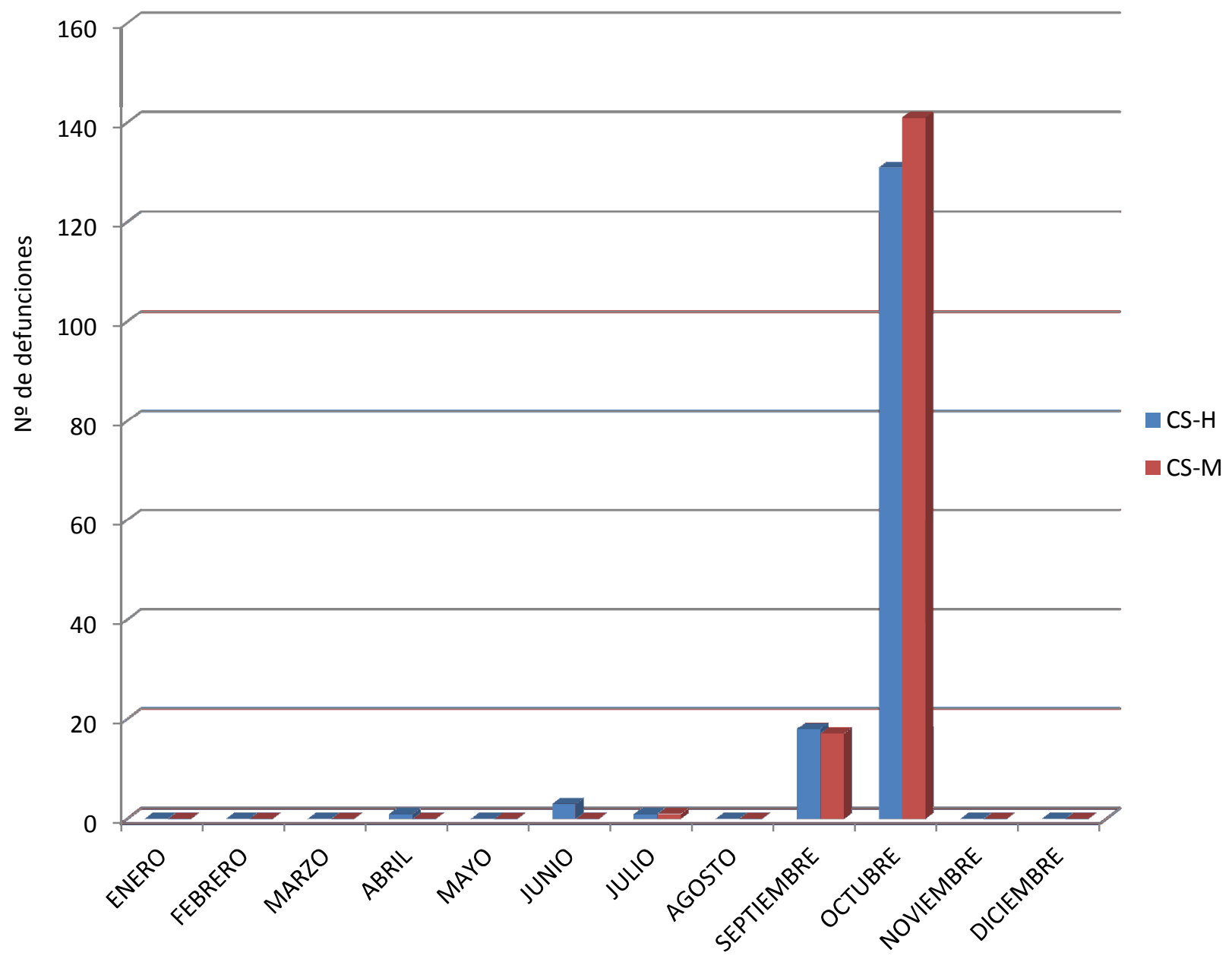

Fuente: Boletín de Estadística Municipal de Castellón de 1918-1921. Elaboración propia

Las gráficas 2 y 3 muestran que en el mes de septiembre murieron más mujeres y hombres por causa de la gripe que por otras enfermedades. ${ }^{729}$

${ }^{729}$ Ibídem. Ver las tablas del Apéndice Documental No 10 , Tabla 2 y Apéndice Documental No 11 , Tabla 3. 
Gráfica 2. Mujeres fallecidas por enfermedad en septiembre de 1918. Castellón capital

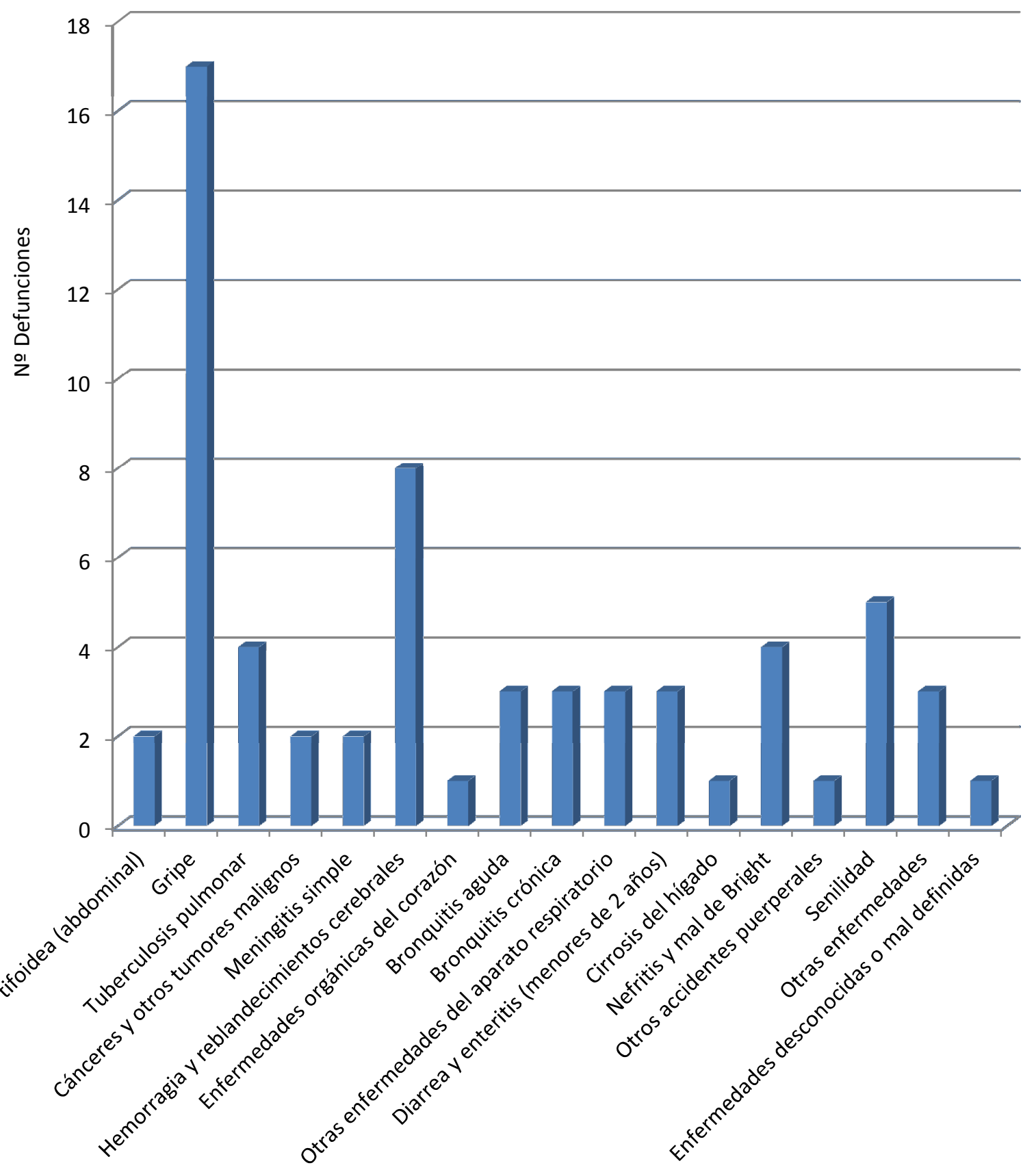

Fuente: Boletín de Estadística Municipal de Castellón de 1918-1921. Elaboración propia 
Gráfica $n^{\circ}$ 3. Varones fallecidos por enfermedad en septiembre de 1918. Castellón capital

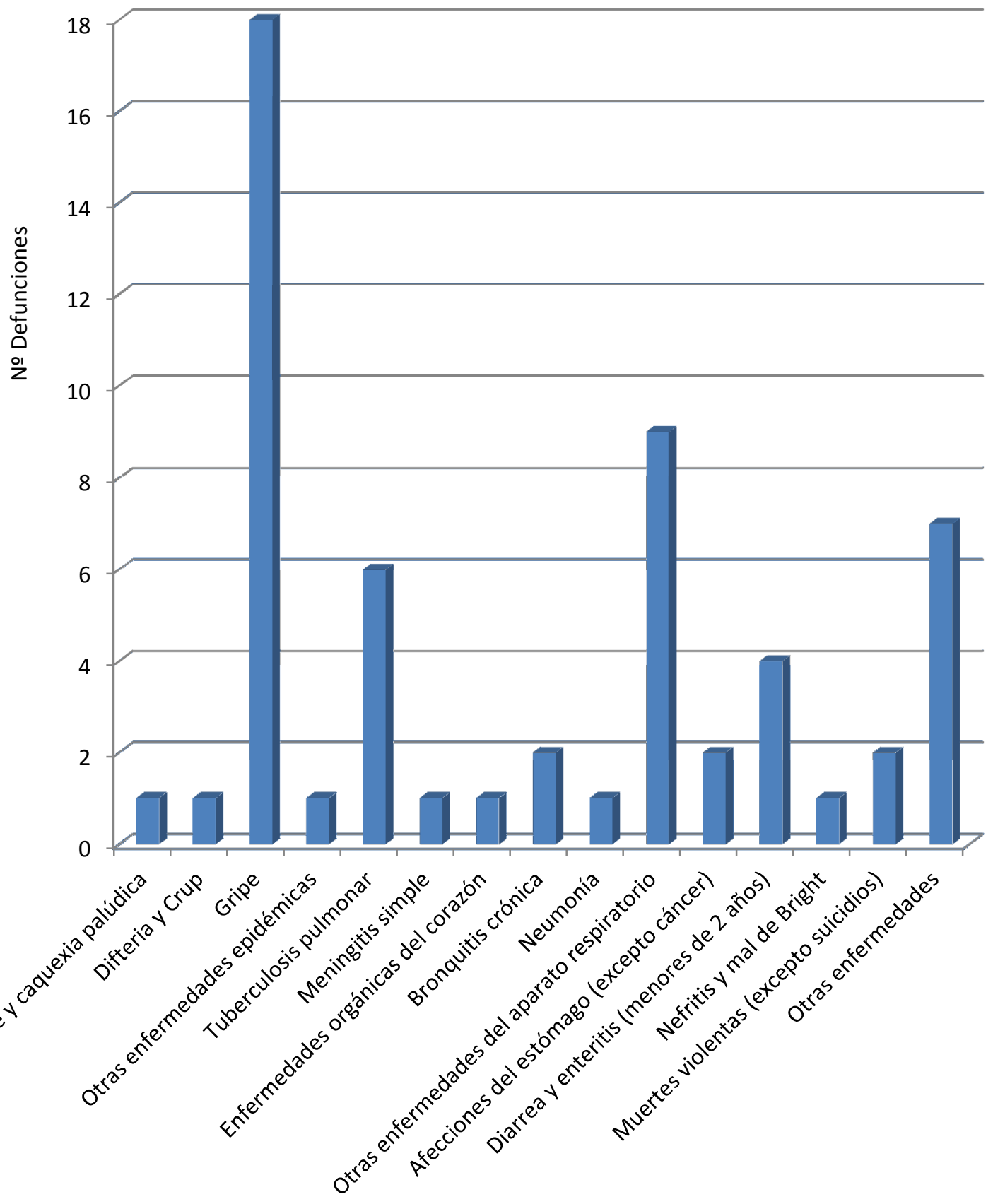

Fuente: Boletín de Estadística Municipal de Castellón de 1918-1921. Elaboración propia

Asimismo en el mes de octubre ocurre lo mismo, mueren más mujeres y hombres por causa de la gripe que por causa de otras enfermedades como podemos ver en las gráfica 4 y 5. 
Gráfica $n^{\circ} 4$. Mujeres fallecidas por enfermedad en octubre de 1918. Castellón capital

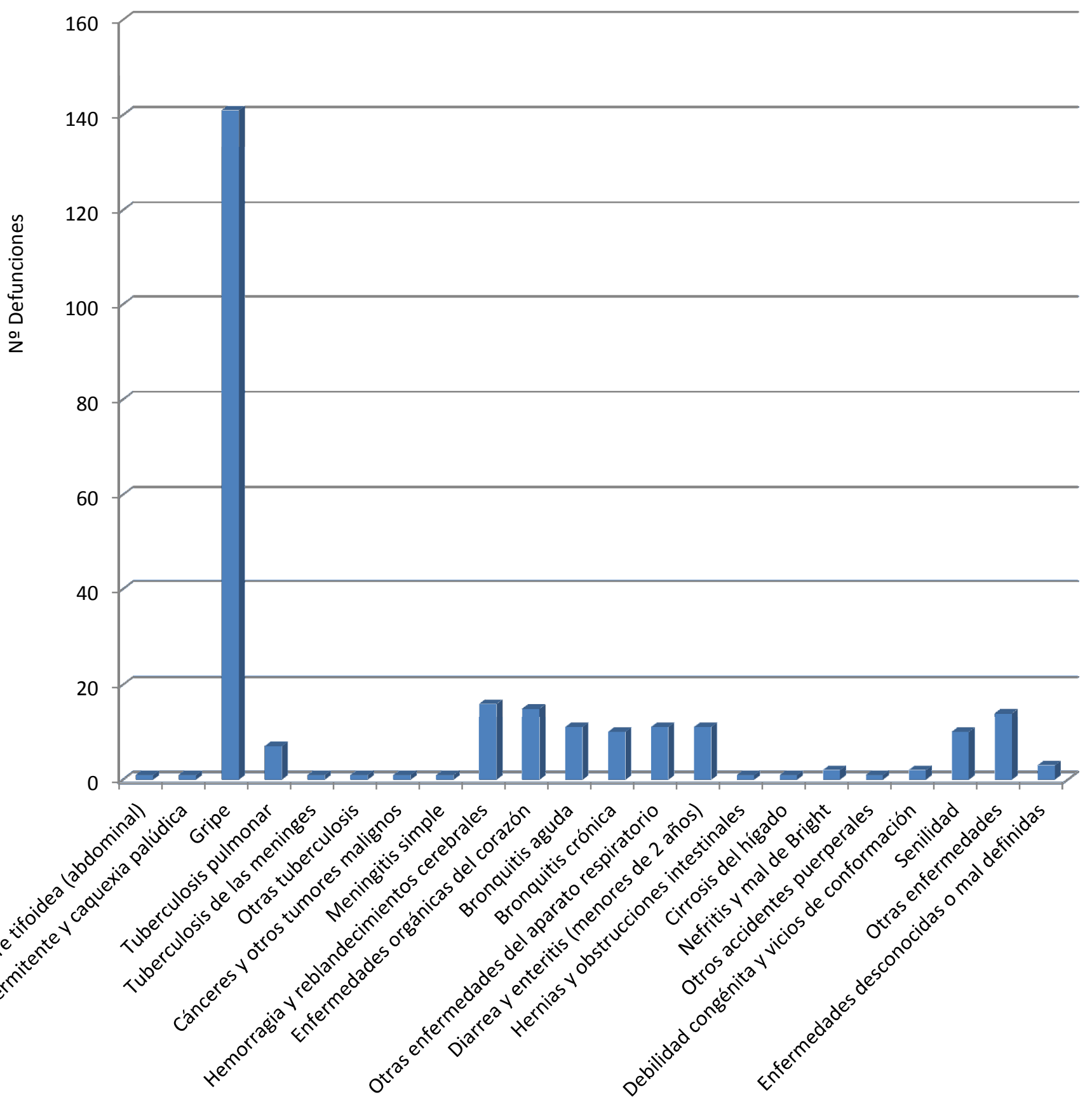

Fuente: Boletín de Estadística Municipal de Castellón de 1918-1921. Elaboración propia 


\section{Gráfica $\mathrm{n}^{\circ}$ 5. Varones fallecidos por enfermedad en octubre de 1918.} Castellón capital

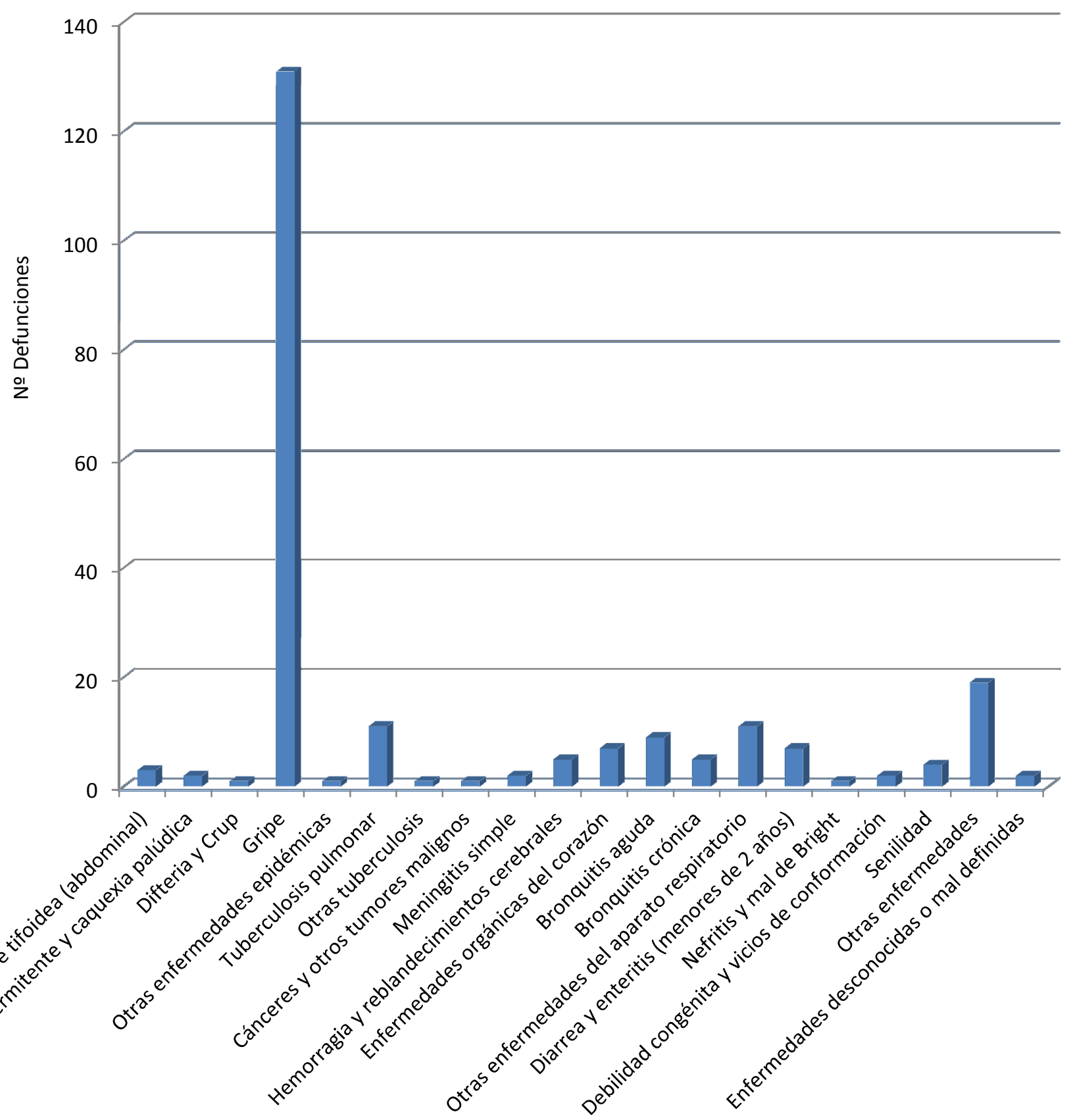

Fuente: Boletín de Estadística Municipal de Castellón de 1918-1921. Elaboración propia

En las gráficas 6 y 7 observamos que la gripe afectó al colectivo más joven, pues las personas mayores que pasaron la gripe de 1889-1890, quedaron inmunizadas. ${ }^{730}$

${ }^{730}$ Ibídem, Ver Apéndice Documental No 12, Tabla 4 y Apéndice Documental № 13, Tabla 5. 
Gráfica $n^{\circ} 6$. Fallecimientos por gripe en septiembre de 1918 según edad. Castellón capital

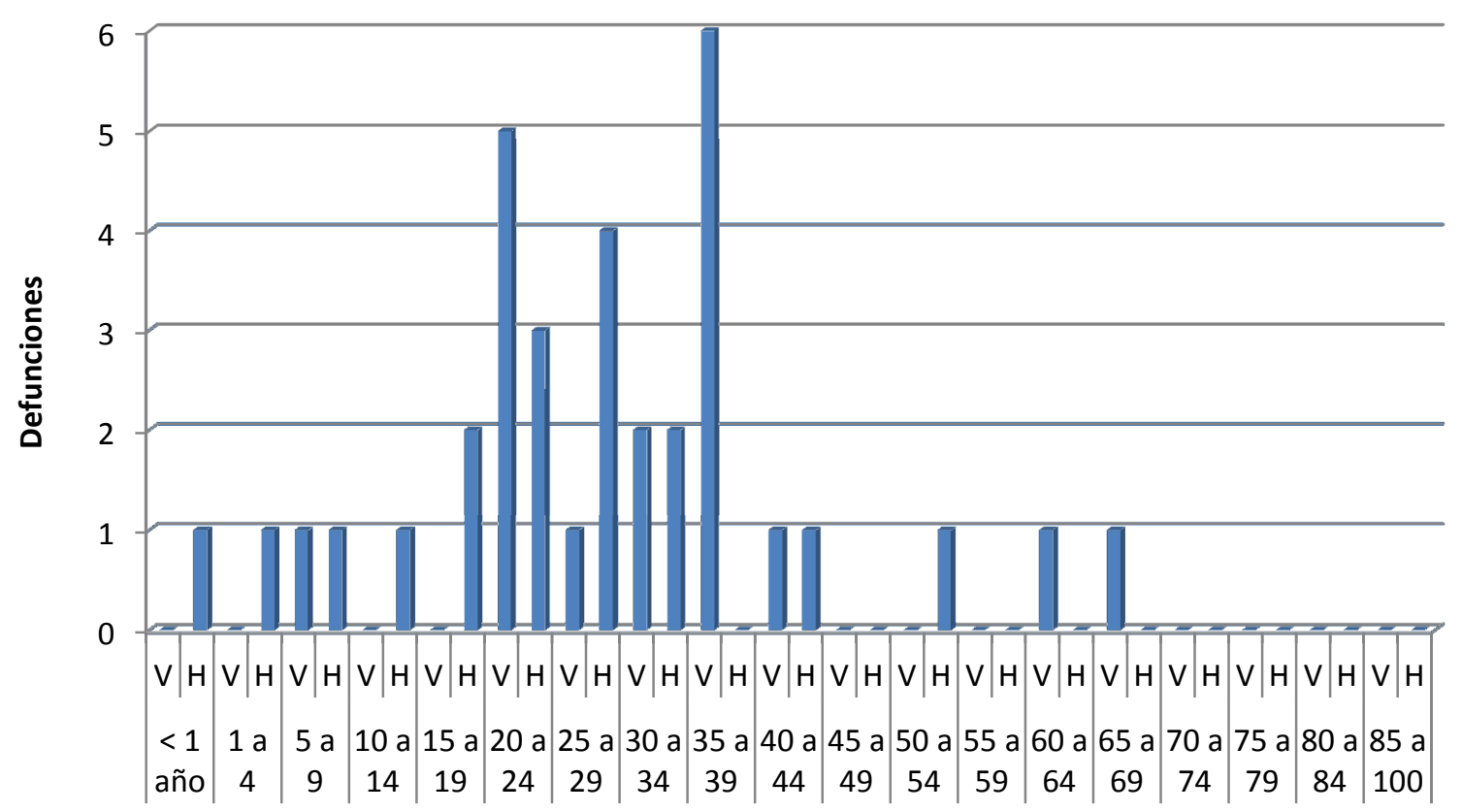

Fuente: Boletín de Estadística Municipal de Castellón de 1918-1921. Elaboración propia

Gráfica $n^{\circ}$ 7. Fallecimientos por gripe en octubre de 1918 según edad. Castellón capital

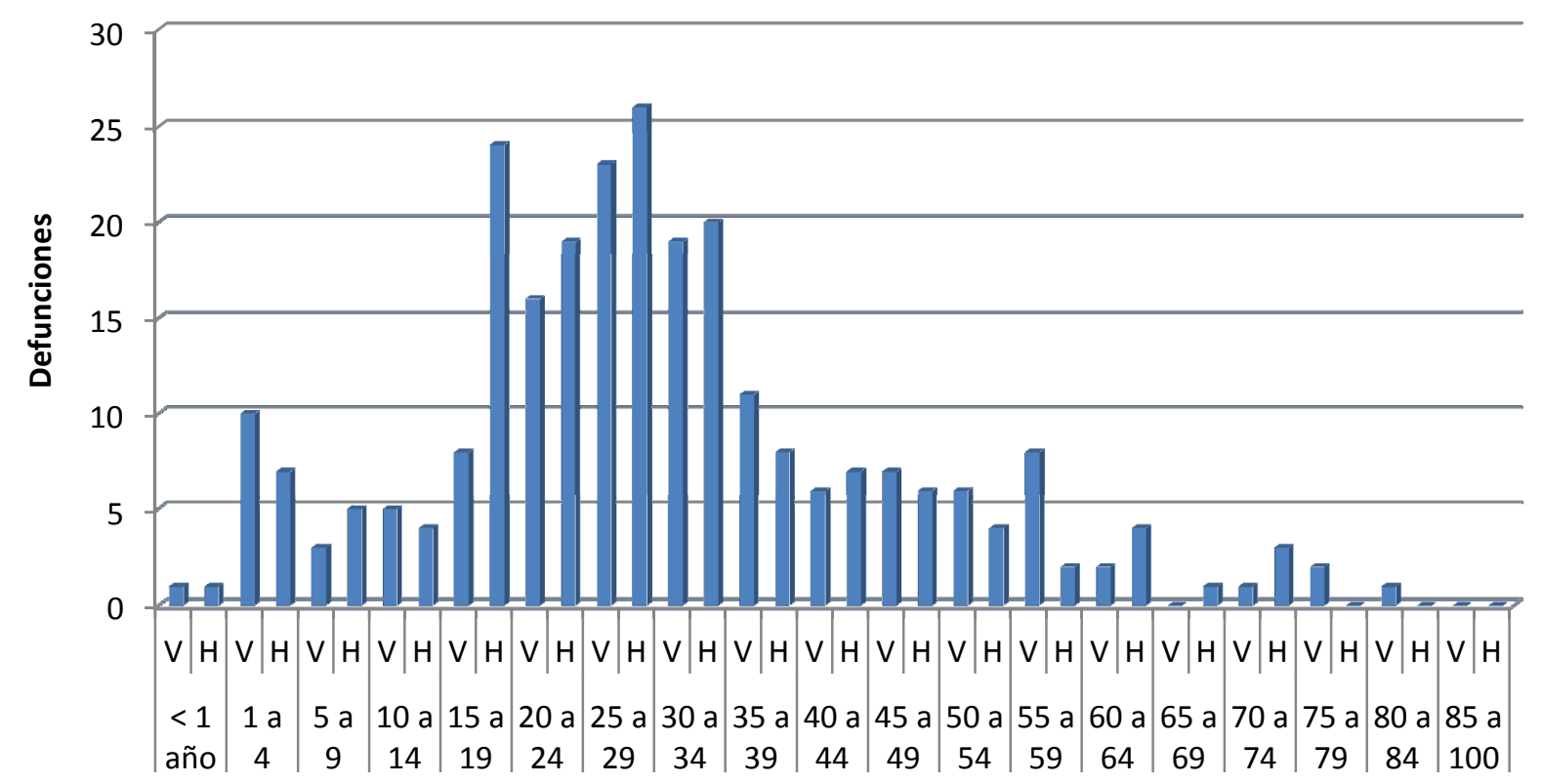

Fuente: Boletín de Estadística Municipal de Castellón de 1918-1921. Elaboración propia 
La enfermedad ataca a todas las edades, pero sobre todo a los niños, más sensibles a la infección y que son las primeras víctimas de una epidemia. En este grupo de edad, la tasa de morbilidad es alta, aunque la mortalidad es baja. En cambio, en las personas de edad, la situación es a la inversa, por lo que la mortalidad es elevada.

Habitualmente, en una población infectada por un virus, los individuos desarrollan anticuerpos específicos dirigidos contra la cepa infecciosa. Por otra parte, cuando se produce un contacto con una nueva variante vírica de estructura antigénica parecida, la inmunidad de la población aumenta (la tasa global de anticuerpos neutralizadores se eleva). Como la inmunidad de los individuos infectados neutraliza los virus, la probabilidad de contagio de los individuos susceptibles de ser infectados disminuye. Este modelo general postula, pues, que las epidemias son el resultado de una disminución de la resistencia a la infección en la comunidad humana y, por lo tanto, de la tasa de anticuerpos.

En la tabla 2 podemos observar como en España en el año 1918 hubo más defunciones por gripe que por otras enfermedades, tanto en hombres como en mujeres.

Tabla 2. Estadística de las causas de mortalidad, en España en 1918

\begin{tabular}{|l|c|c|c|}
\hline ENFERMEDADES & Hombres & Mujeres & Total \\
\hline 1.-Fiebre tifoidea (Abad.) & 3691 & 3709 & 7400 \\
\hline 2.-tifus exantemático & 46 & 27 & 73 \\
\hline 3.-Fiebre Recurrente y caquexia palúdica & 1244 & 1103 & 2347 \\
\hline 4.-Fiebre Intermitente y caquexia palúdica & 315 & 267 & 582 \\
\hline 5.-Viruela & 1568 & 1401 & 2969 \\
\hline 6.-Sarampión & 2936 & 2661 & 5597 \\
\hline 7.-Escarlatina & 376 & 403 & 779 \\
\hline 8.-Tos ferina (Coqueluche) & 1147 & 1309 & 2456 \\
\hline 9.-Difteria y Crup & 1979 & 1865 & 3844 \\
\hline 9 (bis).-Difteria y Crup & 385 & 332 & 717 \\
\hline 10.-Gripe & 70681 & 76433 & 147114 \\
\hline 11.-Sudor miliar & 1 & 2 & 3 \\
\hline 12.-Cólera asiático & 0 & 0 & 0 \\
\hline 13.-Cólera nostras & 74 & 53 & 127 \\
\hline 14.-Disentería & 735 & 673 & 1408 \\
\hline 15.-Peste & 1 & 2 & 3 \\
\hline 16.-Fiebre amarilla & 0 & 0 & 0 \\
\hline 17.-Lepra & 77 & 41 & 118 \\
\hline 18.-Erisipela & 424 & 424 & 848 \\
\hline 19.-Otras enfermedades epidémicas & 18 & 17 & 35 \\
\hline 20.-Infección purulenta y septicemia & 1074 & 873 & 1947 \\
\hline 21.-Muermo y lamparón & 0 & 0 & 0 \\
\hline 22.-Pústula maligna y carbunclo & 216 & 127 & 343 \\
\hline
\end{tabular}




\begin{tabular}{|c|c|c|c|}
\hline 23.-Rabia & 15 & 8 & 23 \\
\hline 24.-Tétanos & 375 & 208 & 583 \\
\hline 25.-Micosis & 3 & 1 & 4 \\
\hline 26.-Pelagra & 70 & 85 & 155 \\
\hline 27.-Beriberi & 0 & 0 & 0 \\
\hline 28.-Tuberculosis de los pulmones & 17047 & 16439 & 33486 \\
\hline 29.-Tuberculosis miliar aguda & 261 & 299 & 560 \\
\hline 30.-Tuberculosis de las meninges & 1183 & 1044 & 2227 \\
\hline 31.-Tuberculosis Abdominal & 1358 & 1847 & 3205 \\
\hline 32.-Mal de Pott & 213 & 207 & 420 \\
\hline 33.-Tumores blancos & 90 & 61 & 151 \\
\hline 34.-Tuberculosis de otros órganos & 631 & 652 & 1283 \\
\hline 35.-Tuberculosis generalizada & 405 & 491 & 896 \\
\hline 36.-Raquitismo & 4644 & 3887 & 8531 \\
\hline 37.-sífilis & 488 & 378 & 866 \\
\hline 38.-Cháncro blanco.- Gonococia & 12 & 9 & 21 \\
\hline 39.-Cáncer o tumor de cavidad bucal & 365 & 109 & 474 \\
\hline 40.-Cáncer o tumor de estómago, hígado & 2738 & 2144 & 4882 \\
\hline $\begin{array}{l}\text { 41.-Cáncer o tumor de peritoneo, intestino, } \\
\text { recto }\end{array}$ & 343 & 488 & 831 \\
\hline 42.-Cáncer o tumor de órganos genitales mujer & 0 & 1462 & 1462 \\
\hline 43.-Cáncer o tumor de los pechos & 0 & 444 & 444 \\
\hline 44.-cáncer o tumor de la piel & 271 & 297 & 568 \\
\hline 45.-Cáncer o tumor de los otros órganos & 1901 & 1712 & 3613 \\
\hline $\begin{array}{ll} & \text { Total } \\
\end{array}$ & 119401 & 123994 & 243395 \\
\hline
\end{tabular}

Fuente: Instituto Nacional de Estadística de Castellón. Elaboración propia

\section{ACTUACIÓNES MÉdicas Y MEDIDAS PÚBLICAS PARA REFORZAR LA HIGIENE ANTE LA GRIPE}

Según García Faría del Corral, la actuación médica sobre el proceso Epidemial de septiembre, octubre y noviembre de 1918, se puede esquematizar en tres apartados:

1. En la colaboración con los Estamentos Oficiales.

2. Su aportación en conocimientos científicos.

3. El sufrimiento personal que puede provocar el contacto con los enfermos. 
En cuanto a la colaboración con los estamentos oficiales, el personal médico realizo una gran labor, pues además de ejercer su función puramente curativa, tuvo que actuar un poco como inspector o policía, comunicando cada uno de los casos que asistía.

Esta inspección no se centró solamente en la población residente en cada localidad, sino que abarcó también a las gentes de paso.

Todas estas medidas de actuación médica, fueron más evidentes y rigurosas a nivel de fronteras, con actuaciones de tipo sanitario.

Pero no sólo se les pidió desde los Estamentos Oficiales una función puramente burocrática de comunicar los casos diagnosticados, sino también realizar una entrega total a su profesión, no decayendo en el desánimo y no abandonando por ningún motivo sus puestos de trabajo.

También los médicos aportaron conocimientos científicos que fueron utilizados por diferentes estamentos y deferentes formas. Y según como fue utilizado, tuvo diferentes manifestaciones:

Pero hubo otros autores, médicos y periodistas, que con sus publicaciones en prensa intentaron informar a la sociedad de sus conocimientos, con la intención a de que dicha sociedad luchara con más acierto contra el mal reinante. ${ }^{731}$

No obstante, la actuación médica, no sólo se dirige a dar a conocer la gripe y actuar a nivel de la sociedad y el paciente, sino que también se dirigió hacia la investigación, buscando métodos y sistemas para luchar contra la enfermedad.

Además los médicos se arriesgaban a contraer la enfermedad y sufrir personalmente las consecuencias del contacto con los enfermos.

Está claro que la Epidemia Gripal produjo una alta tasa de mortalidad, pero lo que es evidente es que a todo ello se antepuso una altísima morbilidad.

Morbilidad que conllevó un excesivo trabajo por parte de los médicos, que tuvieron que atender a los innumerables enfermos de gripe.

Pero la epidemia gripal no afectó sólo a los médicos, en un excesivo y agobiante trabajo, sino que también se produjeron innumerables casos de contagio de pacientes a médicos, algunos de ellos llevaron al fallecimiento de sus médicos. ${ }^{732}$

\footnotetext{
${ }^{731}$ GARCÍA FARÍA DEL CORRAL, F.J. op. cit. p.176.

${ }^{732}$ Ibídem.
} 
En Castellón, mucho antes de que se desatara la epidemia gripal, el alcalde José Forcada y el inspector provincial de sanidad José Clará, se ocuparon de las medidas higiénicas que convenía adoptar en vista del desarrollo que adquirían determinadas enfermedades en otras provincias españolas.

Convinieron en la necesidad de montar una estación de desinfección e higiene con destino a los pobres transeúntes según ordenaba la superioridad. El alcalde dio órdenes terminantes para que sin demora alguna se realizaran las obras necesarias a fin de implantar enseguida dicho importante servicio.

En los solares de la antigua batería de San Roque se instalaron una piscina de higienización y un cuarto de desinfección para cumplimentar los acuerdos de la superioridad. $^{733}$

Forcada ordenó a los dueños de carnicerías, ultramarinos y puestos de frutas que cubrieran con gasas, durante el verano, los comestibles destinados a la venta y procuraran tenerlos en las debidas condiciones higiénicas; asimismo, recomendó el mayor celo de sus subordinados en cuanto afectaba a la higiene y sanidad en la capital. $^{734}$

Por la brigada de peones municipales se procedió a la limpieza de las bocas de alcantarilla de varias calles de la ciudad. ${ }^{735}$

De todas maneras, la opinión de las autoridades sobre el estado sanitario en Castellón era buena, aunque sí existía preocupación de los habitantes de la capital. El gobernador conferenciaba muy a menudo con el inspector Clará sobre el estado sanitario de la capital y, éste, con datos irrevocables, le comunicaba que no había motivos de alarma.

Todos los años había casos de fiebres tifoideas, aunque ésta, según Clará era benigna. De todas maneras el doctor. José Clará, tenía órdenes del gobernador de adoptar las medidas sanitarias que creyera convenientes en esta época. ${ }^{736}$

Se recibió la grave noticia de que en el Mediodía de Francia existían focos de tifus exantemático; inmediatamente se dieron órdenes necesarias para organizar el

\footnotetext{
${ }^{733}$ La antigua batería de San Roque se encontraba en la actual calle San Roque, y ya estaba en 1852. Según figura en el «Atlas de España y sus posesiones de ultramar» del Teniente Coronel Capitán de Ingenieros Francisco Coello y que fue auxiliado por Pascual Madoz, en las notas estadísticas e históricas. ${ }^{734}$ El Clamor, 13/06/1918.

${ }^{735}$ El Clamor, 15/06/1918.

${ }^{736}$ El Clamor, 28/08/1918.
} 
servicio de vigilancia sanitaria en todos los pueblos de la provincia y se registraron todos los pasajeros e inmigrantes de aquel país en cuanto llegaban a sus pueblos de residencia.

El doctor Clará continuamente daba a conocer la situación sanitaria de Castellón, enumerando aquellas causas que pudieran perjudicar a la salud, especialmente la falta de agua u otras causas de insalubridad.

El alcalde dio cuenta de los trabajos que realizaba el Ayuntamiento para aprovechar el manantial del Molí de la Font, por ser el más cercano a la ciudad y del que con menos coste rápidamente podía ponerse en condiciones de ser utilizable, sin olvidar el arreglo de los motores de los pozos que facilitaban el agua que Castellón consumía a fin de asegurar el regular abastecimiento.

También ofreció subsanar otras deficiencias que se observaban en la capital como la limpieza del Albañal ${ }^{737}$.

Un problema grave era el conflicto planteado por los farmacéuticos que no querían facilitar medicamentos a los pobres de la Beneficencia municipal, si no se les pagaba lo que el Ayuntamiento les adeudaba. El alcalde y los representantes dentro de la Junta de Sanidad Municipal, llegaron al fin a un acuerdo que hizo innecesario la revuelta social, nada apropiada para las circunstancias que imperaban en aquellos momentos. $^{738}$

El doctor Clará recomendaba que el vecindario evitara, dentro de lo posible, el contagio con los atacados de gripe, dando la mano a quienes llevaban consigo el microbio. $^{739}$

Desde la prensa también se daban consejos a la población como El Clamor, que recomendaba a los fabricantes de bebidas gaseosas, desinfectaran los sifones y botellas de gaseosas, tantas veces como las devolvieran los parroquianos o sean recogidos por los mismos, para contribuir a impedir la propagación de «la enfermedad reinante». ${ }^{740}$

El Gobernador Civil publicó por recomendación de la inspección de sanidad una circular en el Boletín Oficial recordando a los alcaldes las medidas acordadas para evitar la intensidad de la gripe, haciéndoles presente que el hacinamiento de personas, sobre todo en los locales cerrados, influye en su propagación.

\footnotetext{
${ }^{737}$ Albañal es la red de evacuación horizontal de aguas sucias.

${ }^{738}$ El Clamor, 18/09/1918.

${ }^{739}$ Ibídem.

${ }^{740}$ El Clamor, 19/09/1918.
} 
Por indicación de la Inspección provincial, el gobernador prohibió las corridas de vaquillas pues se comprobó que en muchos pueblos donde se celebraron fiestas, que llevan en si la aglomeración de gente, hubo una gran intensidad en la enfermedad gripal después de verificarse las corridas.

Así, en San Mateo, Burriana, Navajas, y otras poblaciones, no se verificaron las corridas. $^{741}$

El Inspector Provincial de Sanidad, doctor Clará, recomendó al gobernador que impidiese la celebración de fiestas en los pueblos, con objeto de frenar la afluencia de gente, tanto en las funciones religiosas como los festejos populares, que tienen lugar en las plazas o calles públicas. ${ }^{742}$

Prácticamente quedaron paralizados las instituciones oficiales y los espacios de ocio.

El gobernador firmó las órdenes clausurando las escuelas públicas, cines teatros y demás espectáculos públicos, prohibiendo también las fiestas y las corridas y festejos en la plazas, tanto de los pueblos como de la capital, hasta que cesara la epidemia gripal. $^{743}$

Al objeto de evitar la aglomeración de gente, la alcaldía suprimió temporalmente el alumbrado extraordinario de la calle González Chermá. ${ }^{744}$

El Rector de la Universidad de Valencia recibió del ministro de Instrucción la orden de aplazar la apertura del curso 1918-1919 de todos los centros docentes del distrito universitario dependiente de su autoridad, hasta que los informes de las inspecciones técnicas y de las autoridades provinciales y locales consintieran el comienzo de las tareas docentes. ${ }^{745}$

En las órdenes circuladas no aparecían incluidas el cerrar las iglesias, y $E l$ Clamor, periódico republicano, llamaba la atención de las autoridades sobre tal omisión «sabiendo que constituyen mayor foco de infección que los centros de enseñanza, cines y teatros». ${ }^{746}$

\footnotetext{
${ }^{741}$ El Clamor, 20/09/1918.

${ }^{742}$ El Clamor, 21/09/1918.

${ }^{743}$ El Clamor 25/09/1918; El Heraldo de Castellón, 27/09/1918.

${ }^{744}$ El Clamor, 26/09/1918.

745 Ibídem.

${ }^{746}$ Ibídem.
} 
Aparte de recomendar el cierre de las iglesias, se hacía también hincapié, en suprimir el agua bendita «por ser un medio muy a propósito para transmitir el contagio».

Más adelante, El Clamor publica un artículo titulado «A Medias» donde el articulista, Agustín Miralles, decía que las cosas se habían hecho a medias, pues quedaban muchos «caserones por cerrar»:

Ojala lo fueran para una eternidad-quedan aún esos edificios en los cuales tan raro y ruin olor se respira, obscuros como boca de lobo, que se llaman iglesias.

En ellos se congrega mucha gente: gente de todas las edades ¿Puede haber allí dentro atacado por la epidemia? Sí. ¿Puede haber contagio? También. Luego al salir a la calle y juntarse con su familia, con los amigos, con el demonio-aunque sea imposible que esa gente se tropiece con ese buen señor. La enfermedad tomará incremento y se sucederán las bajas. ${ }^{747}$

Parece ser que se tenía mucha tolerancia con las iglesias, pues en Villarreal se permitió la celebración de la novena del Rosario que congregaba diariamente en la parroquia a centenares de personas. ${ }^{748}$

Por otra parte, el presidente de la Audiencia, José Font, como medida de previsión, ordenó que se limitara el número de personas asistentes a los juicios orales que se celebraban en dicho centro de justicia. ${ }^{749}$

El Boletín Oficial de la Provincia publicó una circular recordando a todos los alcaldes el más exacto cumplimiento de lo prevenido en las circulares publicadas con fecha de 9 a 20 del mes de septiembre y de las comunicaciones que con fecha 3 y 23 del mismo mes, se remitieron sobre el servicio de vigilancia sanitaria en los emigrantes procedentes de Francia para evitar el contagio.

Prevengo pues, de nuevo a los señores alcaldes, secretarios, inspectores de Sanidad y demás funcionarios y facultativos sanitarios, que no admitiré excusas de ningún género para atenuar la corrección con la que quedan conminados por faltas

\footnotetext{
${ }^{747}$ El Clamor, 30/10/1918.

${ }^{748}$ El Clamor, 4/10/1918.

${ }^{749}$ El Clamor, 2/10/1918.
} 
en los servicios sanitarios, aunque se trate tan solo de simples retardos en su cumplimiento

Los señores alcaldes que no han acusado recibo de las comunicaciones sobre inmigrantes que antes se ha mencionado, quedan conminados con la multa reglamentaria, si en el plazo del quinto día no han cumplido este servicio.

Una vez más recomiendo a todos el mayor interés y celo en el cumplimiento de cuanto se ha prescrito en defensa de la salud pública, seriamente amenazada en la actualidad. ${ }^{750}$

Según el Gobernador, algunos alcaldes no cumplían estos servicios, como su importancia y la extrema gravedad de las circunstancias exigía.

En Castellón se cumplieron las órdenes emanadas de la circular, pues el gobernador y el inspector de Sanidad trabajaron siempre juntos para defender la salud pública

Así, pues, para evitar que los emigrantes que regresaban de Francia pudieran propagar la enfermedad gripal a los pueblos donde esta no había aparecido aún, el gobernador y el inspector de Sanidad ordenaron extremar la vigilancia en las estaciones del tranvía y línea del Norte y en el Grao, en los días que hacía escala en el puerto, el vapor que traía pasaje de la ciudad condal.

Se estableció el servicio sanitario en todas las estaciones del Norte, enclavadas en la provincia. En Castellón prestaba el servicio un médico en los trenes de la mañana y en los de la tarde. Los sospechosos que llegaban eran trasladados al Hospital para su reconocimiento, y los que resultaban infectados se quedaban hasta su curación. ${ }^{751}$

El gobernador civil, de acuerdo con el inspector Clará, pidió a su colega de Tarragona que ordenara a los emigrantes que regresaban de Francia viajar en coches separados de los demás, en la cola del tren, a fin de hacer más fácil el reconocimiento y desinfección de los mismos.

Asimismo se encargó a los interventores de la línea del Norte se informaran de los viajeros que estaban enfermos para poder realizar también, con más prontitud, su desinfección y atenderles con mayor rapidez

\footnotetext{
${ }^{750}$ BOP, 30/09/1918, El Clamor, 3,10/1918.

${ }^{751}$ El Clamor, 5/10/1918.
} 
El número de emigrantes venidos de Francia, pertenecientes a distintos pueblos de la provincia, eran numerosos, estaban atacados la mayoría de gripe complicada, y algunos en estado grave. ${ }^{752}$

Más tarde, el obispo de la diócesis, en vista de la comunicación que le dirigió la Junta provincial de Sanidad, publicó un número extraordinario del Boletín eclesiástico dirigido a los párrocos, en el que se recomienda pongan en prácticas, en sus respectivas iglesias, todos los medios de desinfección precisos para evitar la propagación de la gripe. $^{753}$

Por otra parte, el alcalde dictó las oportunas órdenes para que no se abrieran las puertas del cementerio en los días de las almas y de todos los santos, ni se autorizara la colocación de flores, coronas, etc., sobre las tumbas como era costumbre. ${ }^{754}$

El gobernador civil y el doctor Clará realizaron gestiones para que desde Madrid se enviaran medicamentos y elementos de desinfección. ${ }^{755}$

A finales de octubre se reunió la Junta Provincial de Sanidad, en la que el inspector dio cuenta a la junta, de que se habían recibido algunas cantidades de desinfectantes, y estaba anunciado el envío de más desinfectantes y otros medios para aplicarlos en le epidemia de gripe.

Se acordó teniendo en cuenta que el servicio de vigilancia sanitaria reglamentario era deficiente en lo que respecta a los inmigrantes procedentes de Francia por la naturaleza de la epidemia, dirigirse al excelentísimo señor ministro de la Gobernación, indicándole la conveniencia a juicio de la junta de instalar un Asilo en el límite de la provincia donde pudieran aislarse por un plazo prudencial a todos los inmigrantes sanos o enfermos. ${ }^{756}$

También la prensa recomendaba que se extremaran las medidas higiénicas y que las autoridades oficiales ordenaran al vecindario observar la mayor limpieza de sus domicilios, obligando a los que tienen sus casas convertidas en basureros, se apresuraran a extraer el estiércol y blanquear inmediatamente los locales.

Asimismo indicaban que los dueños de las vaquerías limpiaran diariamente los corrales. «Todo esto es más importante que cerrar escuelas, y trinquetes»

\footnotetext{
${ }^{752}$ El Clamor 11/10/1918.

${ }^{753}$ Ibídem.

${ }^{754}$ El Clamor, 12/10/1918.

${ }^{755}$ El Clamor, 16/10/1918.

${ }^{756}$ El Clamor, 25/10/1918.
} 
También el gobernador civil, Vicente Martínez, teniendo en cuenta el estado sanitario de la provincia y al objeto de evitar en lo posible la propagación de la epidemia gripal, ordenó a todos los alcaldes de su jurisdicción que prohibieran la visita anual a los cementerios en la festividad de Todos los Santos y Día de Difuntos, mientras durara le epidemia gripal. ${ }^{757}$

\section{REMEDIOS CONTRA LA GRIPE APARECIDOS EN LA PRENSA}

La alta tasa de mortalidad de la Epidemia Gripal produjo una angustia y un pánico colectivo en la sociedad, que unido a la falta de un medicamento específico contra este mal, llevó a la población a la búsqueda de toda clase de medios, para combatir esta horrible enfermedad, fundamentalmente por la prensa, único medio de comunicación existente en la época.

Y aparte de las recomendaciones higiénicas promulgadas por las autoridades sanitarias, surgieron toda clase de ideas y experiencias de unos y de otros. Un poco cada uno hablaba de la Epidemia según le iba, le había ido o sabía que le había ido a alguien. $^{758}$

Así El Clamor, a principios de octubre, publicó las bases presentadas y aprobadas, en la Junta Provincial de Sanidad de Madrid y firmada por el doctor. J. Call. En estas decía, que la única profilaxis es la higiene, colectiva y personal; procurar entonar moralmente a los enfermos, recomendándoles principalmente la higiene de los órganos que más delicados tengan, según sean catarrosos cardiacos, diabéticos, etc.

Atender con más cuidado que de ordinario a la asepsia y limpieza de la cavidad bucal y fosas nasales.

Cuidar del normal funcionamiento del aparato gástrico intestinal.

Recomendar los paseos al aire libre y la vida en atmosferas puras que no sean confinadas.

Evitar el contacto de los enfermos y de los objetos de su pertenencia.

\footnotetext{
757 Ibídem.

${ }^{758}$ Florián Ocampo, op. cit. p.159.
} 
Desinfectar su ropa de uso y camas y renovar prudentemente el aire de las habitaciones en que se encuentran.

Cuidar con todo esmero cualquier indisposición sobre todo de carácter catarral, por leve que sea, como si se tratase de una enfermedad grave y buscar la pronta reacción del organismo en caso de enfriamientos bruscos.

Recomendaba como medida general contra la gripe la quinina, principalmente como tónico, el salicilato de sosa, y la aspirina; y sobre todo, dejar al buen criterio del médico el tratamiento especial de cada caso. ${ }^{759}$

La prensa de Castellón, continuamente publicaba medidas profilácticas para combatir la gripe.

Así, recomendaba suprimir las innecesarias visitas a los enfermos a fin de no fomentar la propagación de la epidemia.

Lavarse la cara muy a menudo; limpiarse la nariz, boca y garganta con agua caliente a la que puede agregarse por 100 partes de ésta, dos gramos de borato de sosa o diez gramos de agua oxigenada.

Lavar la ropa de los enfermos con agua caliente y desinfectante en el propio domicilio.

Los más propensos a la gripe o los que tuvieran que relacionarse con los atacados, debían darse diariamente un toque a la garganta, con un pincel apropiado y con la siguiente solución: ioduro sódico, dos gramos; glicerina neutra 100 gramos. ${ }^{760}$

Más adelante, El Clamor añadía más remedios contra la epidemia gripal recomendaba, aseo personal con preferencia boca y nariz, con una solución de fenosalol al 5 por 1.000 , y permanecer el menos tiempo posible en lugares cerrados.

\footnotetext{
${ }^{759}$ La quinina es un alcaloide principal de los muchos que contiene la corteza de quino. Sustancia, blanca amorfa, inodora, de sabor muy amargo, muy poco soluble en el agua fría y más en agua caliente, alcohol y éter. Ingerida a pequeñas dosis, estimula el sistema nervioso $\mathbf{y}$ hace muy lento el pulso; a mayores dosis cogestiona el cerebro, disminuye la excitabilidad refleja de la médula espinal y baja la temperatura de los febricitantes, algunas veces con producción de vértigo y sordera. Tiene numerosas aplicaciones en terapéutica, siendo la principal contra el paludismo en todas sus formas, del que es el medicamento específico. Se usa también como antipirético en la fiebre tifoidea, neumonía, etc.; como tónico en gran número de estados de debilidad y agotamiento; como estimulante de las contracciones uterinas en el parto, etc. Sólo se emplea en forma de sales: bromhidrato, clorhidrato, etilcarbonato. Fosfato, salicilato, sulfato, tanato, valerianato, etc. Vid. Diccionario terminológico de ciencias médicas (1984). Salvat, Barcelona. p.952. Salicilato de sosa: sal de ácido salicílico; las principales son las de amonio, bismuto, mercurio metilo y sodio. Vid. Diccionario terminológico de ciencias médicas (1984). Salvat, Barcelona. p.1004. El Clamor, 7/10/1918.

${ }_{760}$ El Clamor, 10/10/1918.
} 
Recomendaba como medida contra el contagio, el uso del aceite mentolado al 2 por 100 , en las fosas nasales.

Desde el momento en que se sintieran los escalofríos, picazón de garganta, dolores de cabeza o cuerpo, guardar cama, procurando sudar con infusiones calientes.

Como alimentación, en las primeras 48 horas dieta absoluta y después leche o caldos vegetales sin sal.

En el caso de fiebre alta, una papeleta de aspirina de medio gramo, tomando a continuación una infusión de café caliente.

En casos de dolores de costado, pecho o espalda, aplicaciones de agua caliente, cataplasmas, sinapizadas o sinapismos en el sitio del dolor.

Pasada la enfermedad, se recomendaba evitar los enfriamientos, indigestiones y humedades.

Guardar por lo menos diez días de convalecencia, después de haber padecido la gripe.

Las complicaciones de la enfermedad debían ser tratadas siempre por el médico.

Recomendaba desinfectar las ropas, retretes y habitaciones de los enfermos con una solución de creolina al 5 por $100 .^{761}$

También la prensa publicaba los consejos de los médicos de Castellón.

Así el médico de la Beneficencia Provincial, Francisco Badenes, en una entrevista con el periodista de El Clamor, recomendaba los recursos higiénicos más necesarios, más eficaces y menos molestos y costosos que evitaran el ataque del microbio de Feiffer.

Recomendaba sobre todo, la higiene, que se practicara una sencilla desinfección. Decía que había que desinfectar bien las cavidades naturales boca y nariz, «con buches y duchas respectivas»: «Hay que desinfectar las cavidades naturales boca y nariz, éstas han de ser objeto de buches y duchas respectivas. Teniéndolas bien desinfectadas estas cavidades por las cuales tiene que penetrar el germen de la gripe habremos evitado el estallido de la infección».

\footnotetext{
${ }^{761}$ El feno-salol, liquido siruposo espeso, antiséptico y desinfectante. Compuesto de fenol (8 gramos), ácido salicílico (1 gramo), mentol (0,5 gramo) y ácido láctico (3 gramos). Ver Diccionario terminológico de ciencias médicas (1984). Salvat, Barcelona. p.451; Sinapismos: tópico o cataplasma a base de semillas de mostaza negra, también señal que deja en la piel la aplicación de un sinapismo; sinapizado, que contiene mostaza. Ibídem, p. 1040; Creolina: preparación líquida, negruzca, espesa, de creosota de hulla y jabones resinosos; desodorizante, antiséptica, parasiticida. Ibídem, p.276. El Clamor, 11/10/1918.
} 
El doctor Badenes, decía también, que bastaba dos veces al día de desinfección, valiéndose de alguno eficaz, «que bien pudiera ser agua oxigenada adicionada con dos partes de agua hervida».

Y sobre todo, hacía hincapié en la necesidad de que la prensa divulgara las recetas de higiene. ${ }^{762}$

En aquellos momentos de intranquilidad no se sabía qué partido tomar para no caer bajo las garras de la gripe. No se sabía si abandonarse a los brazos del destino o seguir al pie de la letra todas las reglas, prescripciones, consejos, recomendaciones y advertencias que los señores doctores escribían esos días.

Así en el número 19 de octubre de 1918 en El Clamor, se publica un artículo de T. Mendive titulado «Cartilla del doctor Salustio», que da una serie de recomendaciones como alimentarse bien y con manjares sanos, limpios y que no estén adulterados. Las chuletas asadas, el pescado fresco y las aves; beber poco alcohol, aunque si recomendaba beber champañ con moderación.

Otros consejos que se daban en dicha «Cartilla», era que no vivieran varias familias numerosas en un solo piso; tener cuarto de baño; los vestidos nuevos, y de abrigo cuando hace frio; no llevar el calzado roto, de modo que penetre el agua o la humedad en los pies.

También se decía que el trabajo no fuera excesivo, sino más bien un recreo que entretenga y produzca; por eso añade que las personas que suben a los andamios, que bajan a la mina, que va al taller o que trabajen a la intemperie, no pueden cuidarse.

Aconseja no dar la mano para saludar a los amigos; no tomar ninguna bebida en establecimientos como cafés, tabernas y bares, «porque en la misma taza o copa que se bebe, bebió antes un tuberculosos, un asmático, un escrofuloso, o todos, uno detrás de otro.»

También recomendaba no empujar las puertas para abrirlas con las manos, ni tampoco agarrar de sus tiradores.

No entrar en ningún local cerrado con más de tres personas, ni permanecer cerca de alguien que tosa, escupa o carraspee; tampoco era conveniente visitar enfermos de gripe, ni menos dormir con ellos.

\footnotetext{
${ }^{762}$ El Clamor, 12/10/1918.
} 
Hacía hincapié en el riesgo que significaba recoger desperdicios del suelo, colillas y papeles sucios.

Se decía también que no era higiénico madrugar, y menos aún trabajar por la noche: «La noche se ha hecho para dormir, y el día para pasear, si hace buen tiempo; si no, para estar en la cama».

Finalmente se recomiendan rogativas, novenas y misas para preservarse de la epidemia, aunque según decían: «el único defecto de este sistema profiláctico es que suele ponerse en práctica un poco tarde cuando la enfermedad ha hecho de las suyas». ${ }^{763}$

Otros remedios fueron:

El iodo que fue muy recomendado para prevenir la gripe. Así en El Clamor sale un artículo del doctor Balaustegigoitia de Bilbao, en el que describía los resultados beneficiosos de la utilización del mismo.

El iodo se consideraba ideal para el tratamiento gripal, indicado en todos los enfermos con fiebre, aun ignorando su naturaleza. Según decían, este medicamento acortaba el periodo de las grandes infecciones, por ser antitóxico, tónico y antiséptico «que une a la menor ofensividad el máximo de acción».

Aparte de utilizarse en las infecciones generalizadas y en las localizaciones intestinales, se utilizaba específicamente en las pulmonías y bronconeumonías.

Se consideraba que la preparación ideal de iodo era la tintura de iodo recién preparada, y tomada disuelta en leche. Primero se debía tomar un purgante como era el sulfato de sosa, se continuaba con dieta láctea y unas gotas de tintura de iodo: cinco gotas en la comida y cinco en la cena. ${ }^{764}$

Para desinfectar las fosas nasales recomendaba: disolver una cucharada de las de café de Biclorol en medio litro de agua templada, preferentemente hervida; a continuación llenar el cuenco de la mano con esta disolución y sorberla por la nariz, devolviéndola una veces por la boca y otras sonándose con el pañuelo. Esto se repetía

\footnotetext{
${ }^{763}$ El Clamor, 19/10/1918.

${ }^{764}$ El Clamor, 21/10/1918.

El iodo, elemento halógeno sólido con escamas negras, con brillo metálico, olor peculiar y con sabor acre; símbolo I. Es soluble en el alcohol; se volatiliza a la temperatura ordinaria, produciendo vapores de color violáceo. Es esencial para la nutrición y existe especialmente en el cuerpo tiroides. Se empleó en uso interno como alterante en la sífilis, escrofulismo, raquitismo, hipertrofia ganglionar, afecciones de las membranas mucosas y serosas, etc., y en uso externo, actualmente, como antiséptico, modificador y caustico en formas de tintura, pomada o solución yodoyodurada. Ver Diccionario terminológico de ciencias médicas (1984). Salvat, Barcelona. p.1204.
} 
varias veces al día, pero especialmente antes y después de haber estado cerca de un enfermo de gripe o en locales contaminados.

Después de la limpieza se recomendaba introducir en las fosas nasales varia gotas de Oleumnol.

Esto se hacía impregnando en oleumnol dos bolitas de algodón del tamaño de un garbanzo, los cuales se introducían en las fosas nasales. A continuación se inclinaba la cabeza hacia atrás y en esta posición se apretaban las alas de la nariz para que el algodón se exprimiera y el líquido embardunara el interior de la nariz, «en cuyo momento se sacan y se tiran los algodones».

Como precaución se hacía hincapié no tapar las dos fosas de la nariz al sonarse, sino cerrar alternativamente la una y la otra y no sonarse con fuerza para evitar que llegue el aire al oído y lo infecte.

En cuanto a la desinfección de la boca y la garganta se debía gargarizar y enjuagarse la boca varias veces al día con la disolución de biclorol. Este se utilizaba también como dentífrico.

El tratamiento con la disolución de biclorol, según se pensaba entonces, ayudaba a evitar complicaciones en los oídos y en el aparato respiratorio. ${ }^{765}$

Se utilizó mucho el suero antidiftérico en el tratamiento de la gripe, hasta tal punto que las farmacias se quedaron sin existencias

En La Junta de Sanidad, celebrada del 24 de octubre se dio cuenta de un telegrama del ministro de la Gobernación dirigido al gobernador en el que se llama la atención de todos, especialmente de los médicos en ejercicio, acerca de la falta casi absoluta en toda España de suero antidiftérico, ocasionada por el abuso que indebidamente se había hecho de este agente curativo para el tratamiento de todas las formas de gripe aún las más ligeras, con evidente perjuicio de los casos en los que el suero antidiftérico estaba plena y únicamente indicado.

La Junta encuentra justificada la moción del ministro y acuerda dirigirse a todos los médicos de la provincia, para indicarles la conveniencia de no emplear el suero antidiftérico más que en los casos en que realmente debe emplearse, para no desproveer la población de este único remedio contra la difteria y a los farmacéuticos indicándoles

\footnotetext{
${ }^{765}$ El Clamor, 22/10/1918. El biclorol está compuesto de partes iguales de cloruro de sodio y el oleumnol se compone de aceite gomenolado al 1por 100. Ver Diccionario terminológico de ciencias médicas (1984). Salvat, Barcelona. p. 506.
} 
que debían guardar siempre alguna cantidad de suero para los casos de esta enfermedad: «[...] pues sería altamente sensible que en un momento dado no se encontrara en una población el único medio de reconocida eficacia para salvar a un enfermo de una muerte fatal, por haber agotado en otros enfermos en que no es de utilidad absoluta y cuya acción puede ser substituida con iguales ventajas por otros medios terapéuticos».

El 25 de octubre de 1918, el gobernador de Castellón, Vicente R. Martínez envió una circular ordenando a los alcaldes que informasen a los médicos de sus municipios, sobre la limitación del empleo del suero antidiftérico a neumónicos graves, no prodigando su uso en cualquier forma de gripe, incluso en las formas benignas. Y asimismo procuraran que en las farmacias hubiera siempre suero antidiftérico para atender a las necesidades de la población. ${ }^{766}$

Según Angel Sanchez Gozalbo, en su tesis doctoral Contribución al estudio de la gripe de 1918 en la provincia de Castellón; de todas las medidas adoptadas en una epidemia de gripe hay algunas que solo tienen un valor teórico, pero otras son de verdadera eficacia práctica, entre ellas destaca:

El diagnostico precoz. A la menor sospecha clínica (dolor de cabeza, fiebre ligera, constricción de garganta, cansancio, etc.), se examine al enfermo y una vez hecho un diagnostico precoz se proceda a su aislamiento.

El aislamiento de enfermos. Con el aislamiento del enfermo se consigue que no contagie directamente o que no contagie a un gran número de personas, que convertidas en portadores de gérmenes, difunden la enfermedad.

Desinfección. No es necesaria la desinfección, según dice Sánchez Gozalbo, es más bien inútil. El agente causal es tan poco resistente que basta con el lavado de la ropa. Es también inútil la desinfección de la habitación con líquidos antisépticos. Basta recomendar la limpieza, ventilación y soleamiento de las habitaciones.

Higiene. Es necesario el aseo personal, de lavado y desinfección de la boca y fosas nasales y las de limpieza y ventilación de las viviendas.

\footnotetext{
${ }^{766}$ El Clamor, 25/10/1918.
} 
Vacunación. Los ensayos acerca de una vacunación profiláctica estaban en plena prueba experimental. Los doctores Ferrán, Peset, Colvée y Rincón de Arellano, aislaron el neumococo en un 61 por 100 de casos y experimentaron en el ratón que la inmunidad conseguida con uno de los gérmenes aislados servía para los otros, prepararon una vacuna con muchas muestras de los gérmenes aislados que mataban por el éter o por el calor a $58^{\circ}$ durante una hora.

El doctor Salvat practicó en el sur de España 5.000 vacunaciones con la vacuna por él preparada.

Legroux, del Instituto Pasteur, preparó una vacuna mixta de neumococo, estreptococo y bacilo de Pfeiffer, para evitar las complicaciones broncopulmonares basándose en el éxito obtenido por Vrigt en 1912 con vacunas neumocócicas, en los negros de las minas de diamantes del África del Sur, en las experiencias de 1914 de los autores americanos sobre vacunaciones profilácticas antineumocócicas en las complicaciones broncopulmonares del sarampión, y en la frecuencia con que se ha encontrado el neumococo en los caso graves de la epidemia de gripe de 1918.

La conferencia de Londres del 14 de octubre de 1918 en el War Office, bajo la presidencia de Sir William B. Leishman, aprobó una vacuna mixta de neumococo, estreptococo y bacillus influenzae en las proporciones siguientes:

\begin{tabular}{|l|l|l|}
\hline Bacterias & Primera dosis & Segunda dosis \\
\hline Bacullus influenzae & 30 millones & 60 millones \\
\hline Neumococo & 100 millones & 200 millones \\
\hline Estreptococo & 40 millones & 50 millones \\
\hline
\end{tabular}

La Sección de Epidemiología del Instituto Nacional de Higiene de Alfonso XIII preparó una vacuna mixta con neumococos, estreptococos y cocobacilos de Pfeiffer españoles. Pero todas estas pruebas estaban, entonces, en fase de experimentación. ${ }^{767}$

\footnotetext{
${ }^{767}$ Véase más ampliamente en SÁNCHEZ GOZALBO, Ángel. (1919). Contribución al estudio de la Grippe de 1918 en la provincia de Castellón. Hijos de J. Armengot, Castellón. pp. 28-30.
} 


\section{CONOCIMIENTO DEL ORIGEN DE LA GRIPE EN 1918}

De la gripe no se ofrecían noticias concretas. Se ignoraba su origen, su desarrollo, sus causas, y los medios para combatirla. Muchos médicos, aprovechando la actualidad del tema, escribían largos artículos sobre la enfermedad, pero no decían nada definitivo. Lo único que decían, es que cuando se notara algo se llamara, al médico.

Con fecha 2 de octubre de 1918 en un artículo de El Clamor titulado «la Epidemia reinante la contagia el tercero», se dice que la gripe es una enfermedad exótica en España, que lo único parecido a dicha enfermedad es el llamado «Trancazo, que además, tiene tendencia y aficiones militaristas»:

La gripe es una enfermedad exótica en España. Lo único análogo que se ha conocido de esa enfermedad es la llamada «trancazo». Pero la gripe, «propiamente dicha», como dicen los diccionarios, es nueva en España. Probablemente, esta peste es siempre, su tendencia y aficiones militaristas. Hay además, detalles disciplinistas y autoritarios que confirman su condición militar.

Además sigue diciendo, la gripe no permite grupos:

Como en aquellos bandos famosos de Sousa, en cuanto ve unas personas reunidas, hace fuego. Se basa en la teoría del «tercero». Dos personas no pueden comunicar la epidemia; pero llega un tercero y ese la propaga. Este tercero puede ser un amigo, una pulga, una mosca, un casero, un diputado nacionalista o un perro vagabundo. Para evitar el contagio hay que huir del tercero. Y mucho más el tercero del cuarto y siguientes. Los mayores focos de infección son los locales donde se reúne mucho público.

Se trataba de una enfermedad «moderna» en España, y la ciencia no estaba preparada para combatirla. Además, no se sabía ni siquiera cómo se escribía, si con una «p o con dos».

Las recomendaciones que daba el articulista era que hasta saber lo que pasa no convenía asustarse y recomendaba serenidad. 
Finalmente dice que la gripe responde a manejos germanófilos. «Mientras la opinión se distrae hablando de la epidemia, no se ocupa de comentar los éxitos de los países aliados ni del último discurso de Wilson». ${ }^{768}$

En 1892 Richard Pfeiffer publicó sus observaciones sosteniendo que el agente causal de la gripe era el cocobacilo, microrganismo de forma intermedia entre un bacilo y un coco.

Sin embargo, muchos autores dudaban de la especificidad del cocobacilo, porque encontraron en sus investigaciones gérmenes distintos como agentes causantes de la gripe.

El doctor. Sánchez Gonzalbo, en los esputos de 8 enfermos diagnosticados de bronconeumonía descubrió los bacilos tipo Pfeiffer,

Después de la epidemia de 1889-90, el cocobacilo empezó a encontrarse más rara vez, y su presencia fue negada en muchos brotes epidémicos y en casi todos los casos de gripe endémica.

En Valencia las investigaciones bacteriológicas llevadas a cabo por los doctores Peset y Rincón de Arellano, convergieron con las efectuadas por el doctor Colvée en que el germen aislado era el Micrococcus pasteuri de Stenberg más frecuentemente conocido por neumococo de Talmon Fraenkel. Estas investigaciones fueron hechas en material recogido de piezas necrópsicas de enfermos bronconeumónicos de evolución rapida y terminación mortal

Estas observaciones eran las mismas que realizaban todos los bacteriólogos de España y del extranjero y que afirmaban la hipótesis de que estreptococos y neumococos sobrepasarían y dominarían a los bacilos de Pfeiffer que son gérmenes dotados de escasa resistencia.

Jules Renault en su Note sur la grippe en Suisse afirma la existencia del cocobacilo en las formas simples, que desaparece en las formas complicadas cediendo el paso al neumococo y a un estreptococo que fueron evidenciados en los hemocultivos.

Según el doctor Gozalbo en las complicaciones de la gripe el bacilo de Pfeiffer juega un papel muy secundario y en cambio las infecciones por estreptocócicas y neumocócicas adquieren una violencia extremada.

\footnotetext{
${ }^{768}$ El Clamor, 3/10/1918.
} 
Muchos autores creían que la gripe nada tenía que ver con el cocobacilo, opinaban que la enfermedad estaba producida por un germen desconocido hasta entonces.

Legroux, opinaba que el primer germen que se encuentra en las vías respiratorias dotado de acción patógena es el cocobacilo de Pfeiffer, al cual se sobreponen rápidamente neumococos y estreptococos.

Estudiando la patogenia, contagiosidad y epidemiología de la gripe se admitía como probable la existencia de un virus filtrable. Según Sánchez Gonzalvo, «la existencia del virus filtrable es hoy admitida y estudiada por todos y son muchos los investigadores que comenzaron sus experimentos sobre él, dada la relativa inconstancia del hallazgo del bacilo de Pfeiffer sobre todo en las formas complicadas y de larga duración». 769

Según el doctor Gozalbo el comienzo de la infección se manifestó, en la mayoría de los enfermos, de un modo súbito, con fiebre alta, sensación de abatimiento, escalofríos, cefalalgia intensa, pulso lento, congestión faríngea, ligera congestión conjuntival, coriza, algunas veces epistaxis y ausencia de síntomas del tractus respiratorio:

Con una diaforesis intensa y un purgante remiten la fiebre y todos los demás síntomas a los tres o cuatro días, y el enfermo se cura como lo atestiguan centenares de observaciones; otras veces el comienzo es lento y el enfermo siente una laxitud y un abatimiento grande durante varios días y a la postre aparece todo el cortejo sintomático que acabamos de esbozar; en muchos casos hay tos, con sensación de dolor traqueal y estertores mucosos diseminados; otros disnea intensa con ausencia de signos de auscultación.

Otras veces, los síntomas eran apenas reconocibles, y el enfermo después de algunos días de cefalea, de fiebre ligera y gran postración se curaba.

Se observaron bronquitis aguda, bronconeumonías, formas gastrointestinales de gripe y complicaciones cardiacas y renales. ${ }^{770}$

Como vemos, en 1918 se desconocía el origen de la gripe. Los médicos opinaban que se trataba de una plaga neumónica y algunos que se trataba de una

\footnotetext{
${ }^{769}$ SANCHEZ GOZALBO, Angel, op. cit., pp. 18-22.

${ }^{770}$ Ley de Pfluger Edward Fredrich w. Pfluger fisiólogo alemán, 1829-1910. Ibídem, p. 23.
} 
verdadera arma biológica relacionada con la guerra en curso. En Alemania Richard Pfeiffer, bacteriólogo discípulo de Robert Koch encontró un bacilo en los enfermos de influenza y lo denominó Bacillus influenzae, considerándolo como el agente causal de la influenza (hoy se denomina Haemophilus influenzae), varios científicos intentaron encontrar una relación causal entre este bacilo y la enfermedad, sin embargo, si bien se encontraba en un alto número de pacientes fallecidos por influenza, había casos en donde no se encontraba o bien se identificaba otra bacteria como el neumococo y el estreptococo.

El virus de la influenza de 1918 no se aisló en esa época. Ni siquiera se sospechó que el germen era un virus. El virus de la influenza humana fue aislado por primera vez en 1933 por Wilson Smith y colaboradores. Los anticuerpos de los sobrevivientes demostraron que estaba relacionado a un virus porcino aislado después en los Estados Unidos. $^{771}$

${ }^{771}$ QUÉNEL, Philippe, DAB William (1994), opus cit., pp. 1008-1011. 


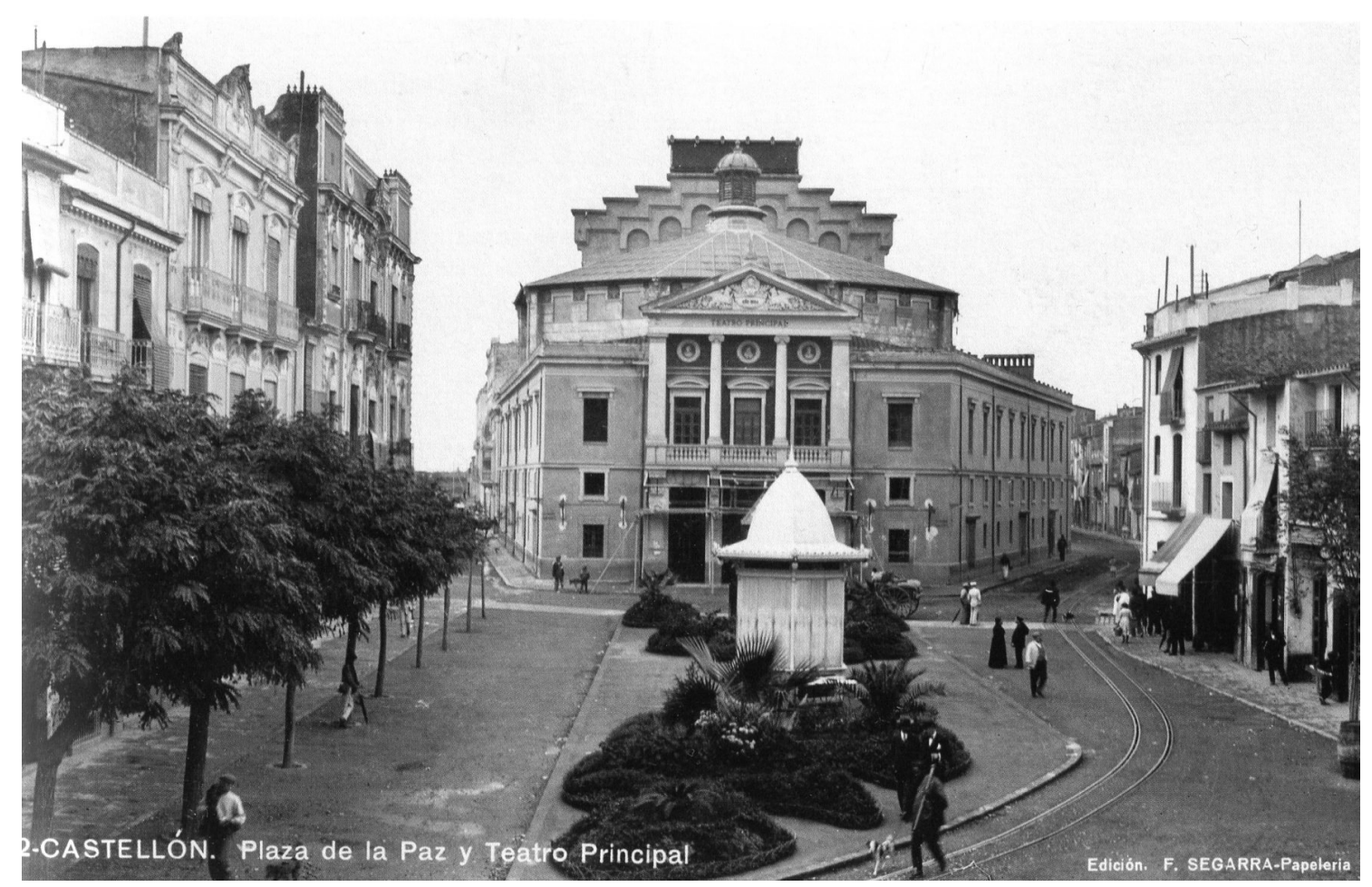

\section{Castellón hacia la modernidad. Salud, educación y debate científico (1880-1918) \\ Volumen II}

Tesis doctoral dirigida por: Dra. Rosa Monlleó Peris

Realizada por: Concepción Calvo Mas

Castellón, diciembre de 2015

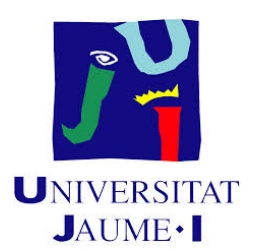

Facultad de Ciencias Humanas y Sociales

Departamento de Educación 

INDICE

PARTE III: EDUCACIÓN SECUNDARIA Y ENSEÑANZA-

APRENDIZAJE DE LAS CIENCIAS NATURALES. EL DEBATE CIENTIFICO SOBRE DARWIN

CAPÍTULO VII: EL INSTITUTO RIBALTA, FUERZA

IMPULSORA DE LA CIENCIA Y LA EDUCACIÓN EN

CASTELLÓN (1880 - 1918)

1. EL INSTITUTO RIBALTA FUERZA IMPULSORA DE LA

CIENCIA Y LA EDUCACIÓN EN CASTELLÓN (1880-1918).

1.1. LA APERTURA DEL CURSO EN EL INSTITUTO DE

CASTELLÓN, UN ACONTECIMIENTO PÚBLICO.

2. LAS CONFERENCIAS DE LOS PROFESORES DEL

INSTITUTO DE SEGUNDA ENSEÑANZA DE CASTELLÓN

3. LA DOCENCIA DE LAS CIENCIAS NATURALES EN EL

INSTITUTO DE SEGUNDA ENSEÑANZA. PROFESORADO Y

RECURSOS DE ENSEÑANZA-APRENDIZAJE 544

3.1. ALGUNAS BIOGRAFÍAS DESTACADAS DE LOS

PROFESORES DE CIENCIAS NATURALES DEL

INSTITUTO DE SEGUNDA ENSEÑANZA (1880-1918) ... 544

3.1.1. CATALINO ALEGRE. 544

3.1.2. FRANCISCO DOMENECH BUESO 546

3.1.3. ANTIMO BOSCÁ SEYTRÉ. 549

3.2. RECURSOS PARA LA ENSEÑANZA-APRENDIZAJE UTILIZADOS POR LOS PROFESORES DE CIENCIAS NATURALES: LIBROS, EXCURSIONES Y GABINETE DE CIENCIAS NATURALES 550

3.2.1. Los libros de texto de Ciencias Naturales 550

3.2.2. Los libros de texto utilizados por los profesores de ciencias naturales del instituto de Castellón (1880 - 1918) 556

3.2.3. Las excursiones científicas 650 
3.2.4. El Gabinete de Historia Natural del Instituto de Castellón

4. POLÉMICA EN LA IMPLANTACIÓN DE LA ESCUELA

NORMAL DE MAESTRO.

CAPÍTULO VIII: UN EJEMPLO DE DEBATE CIENTÍFICO

EN TORNO AL DARWINISMO EN CASTELLÓN (1880-1909) 687

1. LA RECEPCIÓN DEL DARWINISMO EN ESPAÑA. 691

2. EL DARWINISMO EN VALENCIA 697

3. EL DARWINISMO EN CASTELLÓN .... 702

3.1. LA POSTURA ENFRENTADA DE CATÓLICOS Y REPUBLICANOS .708

4. CENTENARIO DEL NACIMIENTO DE DARWIN EN 1909 EN CASTELLÓN 715

\section{PARTE IV: HIGIENE, EDUCACIÓN SANITARIA Y COLONIAS ESCOLARES.PROPUESTAS PARA CONSEGUIR UNA EDUCACIÓN INTEGRAL}

CAPÍTULO IX: HIGIENE, SALUD Y EDUCACIÓN ESCOLAR 733

1. DE LA CARIDAD PÚBLICA AL RECONOCIMIENTO DEL DERECHO A LA EDUCACIÓN Y A LA SALUD POR PARTE DEL ESTADO

2. LAS PROPUESTAS DE LOS MÉDICOS HIGIENISTAS

PARA MEJORAR LA SALUD EN LA ESCUELA

3. LA INTRODUCCIÓN DE LA INSPECCIÓN MÉDICOESCOLAR EN EUROPA Y EN ESPAÑA

4. UN MODELO DE ESCUELA PARA CONSEGUIR UNA EDUCACIÓN INTEGRAL

5. LA LEGISLACIÓN QUE REGULABA EN ESPAÑA LA HIGIENE DE LOS EDIFICIOS ESCOLARES 
6. LOS TRATADOS DE HIGIENE Y LA EDUCACIÓN

SANITARIA EN LA ESCUELA

7. SITUACIÓN DEPLORABLE DE LA ENSEÑANZA Y DE LA HIGIENE EN LAS ESCUELAS PÚBLICAS DE CASTELLÓN A FINALES DEL SIGLO XIX

8. MEJORA DE LA ENSEÑANZA EN CASTELLÓN EN LA

SEGUNDA DÉCADA DEL SIGLO XX.

8.1. ANÁLISIS COMPARATIVO ENTRE LAS DISTINTAS

ESCUELAS Y ESTAS CON LA NORMATIVA VIGENTE.

9. ENTREVISTAS A MÉDICOS Y PERSONALIDADES EN LA PRENSA DENUNCIAN LA TRISTE Y MÍSERA REALIDAD DE LA INFANCIA

\section{CAPÍTULO X: LAS COLONIAS ESCOLARES EN}

CASTELLÓN

1. LA DIFUSIÓN DE LAS COLONIAS ESCOLARES EN

EUROPA

2. LAS COLONIAS ESCOLARES VALENCIANAS

3. GESTIÓN DE LA PRIMERA COLONIA ESCOLAR

CASTELLONENSE POR EL DOCTOR JOSÉ CLARÁ Y EL INSPECTOR JOSÉ SENENT

3.1. PREPARACIÓN DE LA COLONIA.

3.2. LAS ACTIVIDADES EN LA COLONIA

3.3. RESULTADOS DE LA COLONIA

3.4. LA PRENSA SE INTERESA POR LA PRIMERA

COLONIA ESCOLAR EN CASTELLÓN.

3.5. DESARROLLO DE LA SEGUNDA Y TERCERA

COLONIA ESCOLAR 866

3.6. LOS BAÑOS ESCOLARES, OTRO MEDIO DE

DESARROLLAR LA SALUD 869

3.7. LA ESCUELA-BOSQUE. 873 
1. PRIMERA PARTE. SOCIEDAD URBANA. MODERNIDAD

Y POLÍTICAS DE HIGIENE EN CASTELLÓN. 879

2. SEGUNDA PARTE: MEDICINA, ENFERMEDAD Y MUERTE EN CASTELLÓN .886

3. TERCER PARTE: EDUCACIÓN SECUNDARIA Y

ENSEÑANZA-APRENDIZAJE DE LAS CIENCIAS

NATURALES. EL DEBATE CIENTÍFICO SOBRE DARWIN 904

4. CUARTE: PARTE. HIGIENE, EDUCACIÓN SANITARIA Y COLONIAS ESCOLARES. PROPUESTAS PARA CONSEGUIR UNA EDUCACIÓN INTEGRAL 921

FUENTES Y BIBLIOGRAFÍA..............................................................933

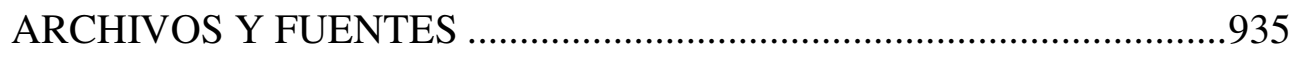

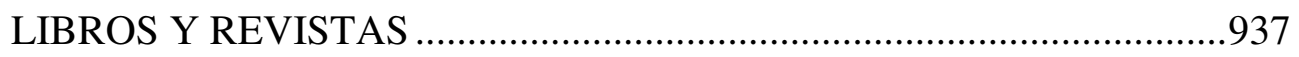

APÉNDICE DOCUMENTAL ........................................................................949 


\title{
PARTE III: EDUCACIÓN
}

\section{SECUNDARIA Y ENSEÑANZA-}

APRENDIZAJE DE LAS

\author{
CIENCIAS NATURALES.
}

\section{EL DEBATE CIENTIFICO}

SOBRE DARWIN 
Castellón hacia la modernidad. Salud, educación y debate científico (1880-1918)

Parte III 


\section{CAPÍTULO VII: EL INSTITUTO RIBALTA, FUERZA IMPULSORA DE LA CIENCIA Y LA EDUCACIÓN EN CASTELLÓN. (1880 - 1918)}




\section{EL INSTITUTO RIBALTA FUERZA IMPULSORA DE LA CIENCIA Y LA EDUCACIÓN EN CASTELLÓN (1880-1918)}

El Instituto de Enseñanza Media se creó en 1846, acondicionando el exconvento de las monjas de Santa Clara, situado en la calle Mayor. El nuevo edificio se construyó a principios del siglo XX, sobre los terrenos de lo que fuera la antigua plaza de Toros de Castellón, según el proyecto del arquitecto Francisco Tomás Traver. ${ }^{772}$ Las obras comenzaron el 28 de febrero de 1912, inaugurándose el centro el 14 de enero de 1917.

A la inauguración del nuevo Instituto asistieron los catedráticos valencianos Eduardo Boscá y José Marti, acompañando al rector de la Universidad de Valencia Rafael Pastor. Según la prensa momentos antes de celebrarse la ceremonia los alrededores del Instituto estaba invadido por numeroso público que pugnaban por penetrar en el edificio, ansiosos de recorrer sus dependencias y presenciar el acto.

A las doce en punto, hora señalada, penetraron en el salón de actos las autoridades, representaciones de los claustros del Instituto, Normal de Maestras, Escuelas de Artes, Diputación, Ayuntamiento, Asociación de Maestros, etc.

Ocuparon la presidencia el rector, el gobernador, el obispo, coronel de Tetuán, presidente de la audiencia, el alcalde de la capital y el director del Instituto, Martí Blat.

El catedrático Damián Alcón, como secretario, dio lectura de la memoria en la que se hace historia de las gestiones y trabajos realizados para conseguir la construcción del edificio, hasta verlo terminado y llegar «al momento actual en que se darán las clases en locales decorosos y dignos de la enseñanza».

Alcón dedicó alabanzas a los que se interesaron por la realización de la obra, de manera particular a los ministros Amalio Gimeno, Alba y Burull, a José Canalejas y a los diputados Vicente Cantos y Emilio Santa Cruz. Habló también del arquitecto Francisco Tomás, autor del proyecto al que alabó por su proyecto.

El director del Instituto, Martí Blat, pronunció un discurso en el que habló de la trascendencia del acto que se celebraba y que señalaba para Castellón el comienzo de una nueva era. Expuso que la instrucción y el trabajo son las dos fuerzas con que cuentan los pueblos para hacerse grandes y prósperos. Resaltó el que la Normal de

\footnotetext{
772 MONLLEÓ PERIS, Rosa (1992): Del Sexenio Democrático a la Guerra Civil, en ORTELLS CHABRERA, Vicente (Coord.): La Ciudad de Castellón de la Plana. Excmo. Ayuntamiento de Castellón de la Plana. Castelló. pp. 302.
} 
Maestras y la Escuela de Artes estuvieran en el Instituto, «cumpliendo así con una misma finalidad, la de instruir a la mujer, al obrero y a los que han de ejercer las profesiones liberales en la cátedra y en el laboratorio».

Continuó su discurso ensalzando el trabajo del profesorado del Instituto, Normal de Maestras y Escuela de Artes. Recabó el apoyo del rector para alcanzar del Gobierno su ayuda para poder dotar a dichos establecimientos del material de que carecían, «evitando así que se tenga un grandioso edificio desprovisto de medios de enseñanza».

El rector después de agradecer el honor que se le había dispensado al invitarle para que presidiera «un acto tan grandioso», recogió las indicaciones del director, Martí Blat, y aseguró que el ministro de Instrucción pública, «cuyo entusiasmo por la cultura ha quedado probado con la creación de innumerables escuelas, atenderá los deseos del profesorado y pueblo de Castellón concediendo el apoyo que de él se solicita».

Después de algunas frases del obispo, el rector declaró inaugurado el edificio y abiertas las clases en los nuevos locales del Instituto, Escuela de Artes y Normal de Maestras.

En la memoria que leyó el secretario del Instituto se omitió cuanto hacía relación con los orígenes del proyecto «como si el Instituto hubiera surgido por generación espontánea». La prensa critica este hecho pensando que fue motivada por ignorancia y describe todos los hechos hasta conseguir la realización del proyecto, para que Damián Alcón, tomara nota y« no incurriera en injustas e injustificadas omisiones»:

En una reunión celebrada en el Gobierno Civil para hacer frente a una crisis obrera, Fernando Gasset, entonces diputado a Cortes, propuso que la Diputación y Ayuntamiento cedieran los terrenos de la antigua plaza de toros y los inmediatos para construir el Instituto y aceptando las dos corporaciones interesadas se tomaron los acuerdos necesarios y una comisión presidida por Gasset recabó del ministro de la Gobernación Bernabé Dávila en el gabinete del general López Domínguez la necesaria real orden y después de Amalio Gimeno por mediación de José Canalejas, que ordenara la redacción de bases para el concurso del proyecto. ${ }^{773}$

Llamó también mucho la atención que no asistiera a la inauguración del nuevo Instituto el autor de las obras, el arquitecto castellonense Francisco Tomás Traver. La

${ }^{773}$ El Clamor, 16/01/1917. 
prensa comenta que éste no asistió porque por omisión o por causas desconocidas, no se le invitó.

Otro hecho que llamó la atención fue que el obispo hablara después que el Rector. Los que estaban allí presentes consideraron que el rector debía hablar el último como representante del Gobierno y del Rey, «hoy por hoy la más elevada jerarquía del Estado español, pero trastocar los términos, es decir, hablar la autoridad eclesiástica después de hacerlo el rector, eso no es, a nuestro criterio, lo procedente y lo justo». ${ }^{774}$

La contestación del director del Instituto a la crónica de El Clamor no se dejó esperar. Martí Blat expone que la omisión que se advirtió en la memoria leída por el secretario referente a la moción hecha en una reunión por el ilustre patricio Fernando Gasset, siendo diputado a Cortes, se debió a la ignorancia del funcionario que no tenía el relato de los hechos en la secretaria de su cargo.

«Que a don Fernando Gasset le corresponde buena parte de gloria en la mejora alcanzada, ¡quién lo duda! por eso figura su nombre, en la memoria, entre los que perdurarán en los anales de aquella».

Sigue diciendo que era cierto que a Francisco Tomás Traver no se le invitó como arquitecto autor del proyecto y director de las obras. La culpa, según dice, era suya, como también el no haber invitado al pintor castellonense Vicente Castell, autor de los lienzos y donante del retrato del rey que daban relieve al salón de actos. Lo que realmente ocurrió fue que ambos fueron invitados como director y como profesor de la Escuela de Artes, respectivamente, es decir «como compañeros de profesión en la enseñanza».

« [...] he pretendido dejar inmaculado el recuerdo de una fiesta que inicia una Era de progreso en la Historia de Castellón y que todos estamos obligados a procurar que no se tuerza». ${ }^{775}$

Preocupaba que la escuela de Artes no tuviera el apoyo necesario para ser una verdadera universidad del obrero. El director en su discurso de inauguración del nuevo Instituto, hizo referencia a que la Escuela merecía toda clase de apoyo a fin de hacer de ella una verdadera Universidad del Obrero donde éste pudiera encontrar la cultura artística que necesitaba para ser aún más provechoso a la patria. La prensa excita a que la Junta del patronato acuda a la Diputación y a los representantes en Cortes para hacer

\footnotetext{
${ }^{774}$ El Clamor, 15/01/1917.

${ }^{775}$ El Clamor, 16/01/1917.
} 
que la primera contribuyera a su sostenimiento y los segundos a conseguir del Gobierno una subvención permanente que permitiera proveer a la Escuela del material necesario, «sin el cual, resultarán poco menos que inútiles los esfuerzos de su abnegado profesorado». ${ }^{776}$

Durante la guerra civil, el Instituto fue destinado a Hospital Militar del ejército de Levante. Años más tarde se procedió a realizar varias obras de mejora. En 1948 se transformó el antiguo jardín de ensayos agrícolas en patio de deportes, pavimentándolo.

En el Instituto se impartía la Enseñanza Secundaria completa. En 1849 se creó el gabinete de Física e Historia Natural. El jardín botánico comenzó a plantarse en 1848.

Otros servicios que ofrecía el Instituto eran la biblioteca, la Escuela de dibujo, que acogía alumnado de fuera y de dentro, y el colegio de internos, establecido en 1851.

El plan de 1850 contemplaba la posibilidad de establecer en los institutos estudios especiales que estuviesen de acuerdo con el trabajo de la provincia ${ }^{777}$ y la de crear escuelas especiales encaminadas al fomento de la agricultura, artes y comercio, y al perfeccionamiento necesario para el ejercicio de cargos públicos que no tuviesen una carrera específica previa. ${ }^{778}$

El director del Instituto pidió al Ayuntamiento y a la Junta de Agricultura que solicitasen una Escuela de Agricultura elemental para Castellón. Este deseo no se haría realidad hasta la publicación de la Ley Moyano.

La Ley Moyano divide los estudios en Generales, la enseñanza secundaria propiamente dicha, y de Aplicación, aquellos que preparan para el ejercicio de una actividad profesional y conducen a la obtención del título que habilita para ejercerla.

La creación de los estudios de Aplicación llevó a la provincia de Castellón a solicitar que se estableciesen en el Instituto las cátedras necesarias para la obtención del título de agrimensor, resaltando lo necesario que eran estos estudios para sacar la agricultura de la rutina y el atraso en que se encontraba en esta provincia. En 1859 la Reina autorizaba la creación de una catedra de Agricultura teórico-práctica, una de Topografía y otra de Dibujo topográfico.

\footnotetext{
${ }^{776}$ El Clamor, 17/01/1917.

${ }^{777}$ Exposición de motivos, arts. 5 y 75. Col. Legisl., t. 50, pp. 776, 778 y 792. en ALTAVA RUBIO, Vicenta. (1993): Aportaciones al estudio de la Enseñanza Media en Castellón, 1846-1900. Tesis inédita. Universidad de Valencia Facultad de Filosofía y Ciencias de la Educación. Departamento de Educación Comparada e Historia de la Educación. Valencia. p. 25.

${ }^{778}$ Art. 84, Col. Legisl., t. 50, p. 793, en ALTAVA RUBIO, Vicenta, op. cit.
} 
En la apertura del curso 1867-68, el director del centro señalaba la necesidad de los estudios de Aplicación al Comercio en esta provincia. Dichos estudios se establecieron después de la Revolución del 1868, al amparo de la libertad concedida a las Corporaciones provinciales y locales para establecer cátedras libres. ${ }^{779}$

La acción de los profesores del Instituto con respecto a la enseñanza popular fue muy positiva, pues, según la prensa, las clases para obreros establecidas en 1869 contaron con una asistencia masiva.

En el Instituto se celebraban las «conferencias agrícolas», que según la ley debían participar en ellas los profesores y darse de forma gratuita los domingos

El Instituto de Castellón era una de las instituciones que ostentaba un mayor nivel cultural. El salón de actos servía para realizar veladas musicales, conferencias y exposiciones como la que organizó en 1887 el Casino de Artesanos.

Así, la inauguración de la sociedad titulada Circulo Cooperativo y protectorado de obreros se realizó en el Instituto Provincial y fueron invitados los representantes más significativos de la sociedad castellonense por el catedrático de Ciencias Naturales Catalino Alegre. ${ }^{780}$

También en 1909, en el salón de actos, se celebró una asamblea para pedir al Gobierno mejoras en la enseñanza y sanidad.

Según la prensa el acto revistió excepcional importancia por las representaciones que a la asamblea concurrieron, viéndose en el salón a muchísimos castellonenses y en la tribuna pública a «una nutrida representación del sexo femenino».

Por la repercusión que tuvo esta asamblea en la prensa, desarrollamos aquí el contenido de la misma.

Los organizadores fueron los representantes de Valencia, siendo esperados en la estación por varios profesores, maestros y escolares de Castellón.

A las nueve y media comenzaba la asamblea, cuya presidencia se le cedió al joven maestro Eleuterio Pérez Solernou.

En dicha asamblea se leyeron algunas adhesiones y cartas de Cambó, Canalejas, Moret y Sol y Ortega, en las que contestando a las peticiones que les hizo la Casa del Pueblo de Valencia, exponían que comprendían lo justas y necesarias que eran las

\footnotetext{
${ }^{779}$ ALTAVA RUBIO, Vicenta, op. cit p. 29.

${ }^{780}$ El Clamor, 21/01/1883.
} 
peticiones que se les hacía de pedir al Gobierno aumento en los presupuestos de instrucción e higiene y harían todo lo posible en favor de ellas.

Después pronunciaron discursos el maestro Carlos Selma, Benjamín Ballester, auxiliar de las escuelas públicas de Castellón, que dio lectura de unos escritos en los que constaba la adhesión de la Asociación provincial del Magisterio público; el director de El Heraldo de Castellón, José Castelló y Tárrega, el médico José Albiñana Sanz; en representación de la liga contra la ignorancia, el médico Vicente Gea Mariño, y finalmente, el catedrático del Instituto José Albiñana Mompó.

En todos los discursos, los oradores hicieron resaltar el estado deplorable de la enseñanza y la necesidad que había de que se crearan nuevos centros, mejorando los que habían, aumentando el material científico, dotando mejor al profesorado y «haciendo que se coloque en España la instrucción a la altura de las naciones que estiman como galardón de su poderío la cultura de sus hijos».

Hablaron asimismo de lo que son «hoy las escuelas públicas en nuestro país y de la poca consideración y estima que se tiene al maestro, sujetándoles a instruir a los pequeñuelos en locales insanos donde no hay ni sol ni aire y con una remuneración irrisoria y vergonzosa».

Se trató también por varios oradores del estado de la higiene en España, de lo que eran en este sentido las viviendas, los asilos y los hospitales. Se habló de la necesidad de que los gobiernos y el pueblo se preocupen de este asunto de tan vital importancia para el bienestar, «ya que el progreso de los pueblos solo se mide por la cultura y por la salud que disfrutan».

Según la prensa todos los oradores fueron muy aplaudidos, pero mereció especial mención las aclamaciones con que se saludó el contenido de unos escritos que, alusivos al acto, envió para su lectura la joven profesora valenciana Natividad Domínguez. El escrito de esta profesora constituia un profundo estudio de lo que eran las escuelas, de la situación del magisterio público y de lo que había que hacer para que España fuera grande y prospera por la cultura y por la higiene.

«Resumió los discursos con uno muy elocuente, lleno de sana doctrina pedagógica el maestro Eleuterio Pérez Solernou cuyo discurso fue interrumpido distintas veces con salvas de aplausos por el público».

Como resultado del acto se aprobaron por aclamación las siguientes conclusiones: 
1. Adherirse a los acuerdos adoptados en la asamblea de la Casa del Pueblo de Valencia, pidiendo al Estado la realización de un empréstito de 100 millones para cultura y sanidad.

2. Recomendar a los jefes de todos los grupos parlamentarios que presentaran y defendieran un proyecto de ley encaminado a conseguir esa aspiración de «mejoras patrias».

3. Nombrar una comisión para que, junto con otra de-Valencia y Alicante, hiciera entrega al jefe del Estado «en su próximo viaje a la vecina capital», de un mensaje pidiendo el mencionado empréstito.

El articulista sigue diciendo que necesitada como está España de cultura e higiene, cuanto se haga por que el analfabetismo desaparezca y la salud se disfrute, bien merece el apoyo y el entusiasmo al menos de los hombres amantes de la humanidad; «por eso hemos acudido a la Asamblea y dispuestos estamos a cooperar con fe siempre en la conquista de cuanto signifique bienestar, progreso y justicia». ${ }^{781}$

En el número siguiente de El Clamor aparece un artículo titulado «Sinceridades» en el que el autor, Enrique Dávalos Segarra, critica que lo que pedían los asambleístas para mejorar la enseñanza y la sanidad no se iba a cumplir.

[...] es inútil que ejercitéis el derecho de petición. Yo os aseguro que no seréis atendidos.

Desde 1898, cuando lo dijo el gran Costa, hasta hoy, todo el pueblo culto sabe de memoria que la instrucción, la despensa y la higiene, son la trinidad de la educación integral en que se basa toda grandeza y todo progreso, y desde entonces acá el pueblo culto español no pide más que eso.

No esperéis que se os atienda. No hay nada tan revolucionario como instruir. Instruir es emancipar conciencias, despertar las facultades críticas en el campo de las especulaciones científicas y fomentar la duda cuando menos en materia religiosa. ¿Y creéis vosotros ilusos, que os va a dar todo esto un régimen en cuyo poder se turnan varios gobiernos de jesuitas y palaciegos?

${ }^{781}$ El Clamor, 10/05/1909. 
Ellos viven de la ignorancia del pueblo y ya se cuidaran muy mucho de no vigorizar el brazo que le ha de dar el golpe de gracia. Ellos saben muy bien que dar cultura es apresurar el hundimiento del régimen actual; ellos comprenden ellos ven que si todas las poblaciones de España fuesen tan cultas como Madrid, Barcelona, Valencia, Sevilla, Coruña y Castellón mismo, ya tiempo que sin grande estrepito, pero de una manera segura y definitiva se habría venido abajo el funesto tinglado de la Restauración. ${ }^{782}$

\subsection{LA APERTURA DEL CURSO EN EL INSTITUTO DE CASTELLÓN, UN ACONTECIMIENTO PÚBLICO}

El proceso de expansión de la educación secundaria estatal que tuvo lugar en el segundo tercio del siglo XIX, se realizó utilizando el modelo organizativo centralista, y su peso recayó, en las provincias, sobre los jefes políticos y diputaciones, con el apoyo de algunos ayuntamientos de localidades importantes y de diversas entidades culturales (sociedades económicas), de grupos de padres interesados en la creación de centros docentes en el nivel secundario y de algunas destacadas individualidades del mundo cultural y social de las capitales de provincia o de dichas localidades importantes. Los actos públicos en los institutos y escuelas Normales (inauguraciones o fines de curso, exámenes públicos) se convirtieron en acontecimientos públicos con relieve y resonancia socio-cultural y, de alguna forma, para muchas poblaciones, la aparición de estos centros docentes debió significar una cierta efervescencia cultural. ${ }^{783}$

La apertura del Instituto de Castellón fue siempre un acontecimiento social, cultural y educativo. La prensa recoge el acto, resaltando la asistencia de las autoridades y de las personas más influyentes de la ciudad, se adornaban los claustros, participaba una orquesta para amenizar el acto. En ella, el director daba cuenta del estado del Instituto el curso anterior, como las variaciones en el profesorado, número de alumnos matriculados y examinados, resultados obtenidos en la enseñanza, mejoras en el edificio, etc., según lo dispuesto por el artículo 96 del reglamento de segunda enseñanza de 1859 (R.D. 22-V). Al comienzo de la Restauración, los directores de este centro acompañaban la exposición de estos datos de una serie de reflexiones encaminadas a

\footnotetext{
${ }^{782}$ El Clamor, 11/05/1909.

${ }^{783}$ VIÑAO FRAGO, Antonio. (1982): Política y educación en los orígenes de la España contemporánea. Examen especial de sus relaciones en la enseñanza secundaria. Siglo XXI de España editores, Madrid. p. 478.
} 
mejorar la acción educativa de los padres y la aplicación de los alumnos. A partir de 1877, la redacción y lectura de la Memoria corrió a cargo del secretario y se redujo a la simple exposición de los datos estadísticos sobre la enseñanza y a su comparación con los del curso anterior. ${ }^{784}$

Algunos directores en la inauguración del curso académico disertaban sobre los temas de actualidad como el director y profesor de Ciencias Naturales del Instituto, Catalino Alegre, que en el curso 1885-1886, habló del cólera, de la higiene de Ferrán, de los ministros que ponen obstáculos al sabio tortosino, «- estupefacción en el gobernador- continuó hablando de las Carolinas, del patriotismo, de Covadonga, de la guerra de la Independencia, de los invitados, de los estudiantes premiados y no premiados; coronando su discurso, que fue muy aplaudido, con frases galantes a las bellas que ocupaban la tribuna.» ${ }^{785}$

En la apertura de curso del año siguiente: 1886-87, Catalino se ocupó de la epidemia de cólera, del fallecimiento de Alfonso XII, del porvenir de los hijos del monarca, de la enseñanza.

El secretario del instituto se encargaba de leer la memoria del curso del año anterior. Ese año era el profesor de Historia Sanz de Bremón, que según la prensa « leía una bien escrita memoria». El acto era amenizado por la banda de música «Guadalajara». ${ }^{786}$

\section{LAS CONFERENCIAS DE LOS PROFESORES DEL INSTITUTO DE SEGUNDA ENSEÑANZA DE CASTELLÓN}

Los profesores del Instituto ocuparon un espacio político y cultural importante en Castellón. Colaboraron en la prensa o revistas especializadas como La Revista de Castellón o la Unión Médica, donde escribieron Francisco Llorca y Pedro Aliaga.

También el catedrático de Ciencias Naturales del Instituto Catalino Alegre, escribió varios artículos en La Revista de Castellón sobre el tema: Riegos del Mijares ${ }^{787}$

\footnotetext{
${ }^{784}$ ALTAVA RUBIO, Vicenta, op. cit p.158.

${ }^{785}$ El Clamor de Castellón, 5/11/1885.

${ }^{786}$ El Clamor de Castellón, 3/10/1886.

${ }^{787}$ El Clamor de la Democracia, 26/02/1885.
} 
El ingeniero y profesor de agricultura del Instituto, Antonio Maylin publicó innumerables artículos en la prensa sobre la enfermedad del mildiu o moho de la vid. ${ }^{788}$

Domingo Herrero fue diputado a Cortes desde 1879 en varias legislaturas y nombrado alcalde en 1876. Gracias a él se construyó el paseo de la Alameda y fue uno de los dirigentes más importantes del Círculo de Labradores. También Teodoro Tena fue diputado a Cortes y concejal, al igual que Pedro Aliaga, uno de los militantes republicanos de mayor peso en Castellón. ${ }^{789}$

Los profesores del Instituto colaboraron en los espacios de sociabilidad del Castellón dando conferencias sobre temas de arte, ciencias naturales, higiene, educación política o economía, con la finalidad de elevar la cultura de los castellonenses.

Ocupan un lugar preferente los cursos y conferencias, canalizados a través del Ateneo Obrero y del Casino de Artesanos.

El primero, a pesar de su vinculación al partido republicano, en lo relativo a la organización y realización de actos culturales y educativos estaba abierto a personas de ideologías muy diversas

El Casino de Artesanos tenía como principal actividad la organización de conferencias semanales. Algunas de ellas de carácter científico, político o social, corrieron a cargo de profesores del Instituto como el catedrático Pedro Aliaga, que pronunció una conferencia sobre «Las condiciones higiénicas de Castellón y sus escuelas» en diciembre de $1888,{ }^{790}$ con ella se inician una serie de acciones, organizadas por el mencionado Casino, que culminan con la presentación de un estudio sobre la situación de las escuelas de Castellón y con la mejora de sus condiciones que permitiese hacer realidad las exigencias de la Ley de 1857 con respecto a la enseñanza primaria.

Una de las conferencias que se dieron en el Ateneo Obrero fue la del catedrático del Instituto, Luis Parral, sobre el tema «Teoría del arte: su utilidad».Comentamos a continuación un resumen de dicha conferencia:

Después de indicar la distancia que media entre el hombre y los animales irracionales, indicó dos caracteres físicos, a saber: la posición de la cabeza y los ojos y la mano del hombre con el dedo pulgar oponible a los demás, «cuyos miembros sintetizan las dos grandes esferas de actividad social, la ciencia y el arte».

\footnotetext{
${ }^{788}$ El Clamor de Castellón, 11/10/1885-

${ }^{789}$ MONLLEÓ PERIS, Rosa (1992) op. cit. pp. 302.

790 El Clamor de Castellón, 13/12/1888.
} 
«Las facultades que principalmente las desarrollan: la razón y la imaginación, cuyo cultivo nos da los sabios la primera y los genios, los artistas, la segunda»:

Que ambas facultades se ayudan y que en su consorcio se funda el desarrollo del tema, porque si el hombre obrase por instinto sus obras no serían capaces de progresar y sería imposible la ciencia y el arte; más la inteligencia es susceptible de mejorar auxiliando en sus investigaciones la razón a la imaginación y éstas a aquella estableciéndose íntima relación entre las dos esferas. ${ }^{791}$

Exaltó el movimiento intelectual «que se ha despertado en nuestro siglo y el cuidado que se pone en todas las naciones para la educación popular».

Que el que aprende a leer posee un instrumento para instruirse, que de nada le servirá si no lo usa y que de usarlo, ya que la vida es breve, debe hacerlo en aquella clase de conocimientos que le pueden auxiliar en su profesión.

Hizo una recorrido por las industrias y artes útiles más conocidas demostrando los adelantos que ha hecho la teoría recordando la transformación que ha causado en la tintorería la anilina; el desarrollo de la industria azucarera por la refinación debida a la aplicación hecha por Figuier el profesor de Montpelier en 1845 de la coloración de las materias de origen vegetal por el carbón animal descubierta por el químico ruso Howar en 1781 .

La revolución causada por el descubrimiento y aplicación de la pólvora a la construcción que «desgaja con barrenos las canteras como caen las costillas de naipes al soplo de una débil criatura».

Se ocupó igualmente de la aplicación de las máquinas cuyos adelantos son debidos a los conocimientos teóricos de las ciencias aplicadas a las artes.

«Estos fueron los puntos principales que el señor Parral con palabra fácil y seguridad en los conceptos expuso en el desarrollo de un tema, mereciendo al término repetidos aplausos del numeroso público que poblaba el salón de sesiones del Ateneo». ${ }^{792}$

Los conferenciantes, al comenzar su discurso, advertían siempre que lo desarrollarían con claridad para mayor entendimiento de la clase obrera.

\footnotetext{
${ }^{791}$ El Clamor, 20/11/1881.

792 Ibídem.
} 
Asimismo los profesores de ciencias naturales del Instituto dieron varias conferencias en el mismo Centro como Francisco Llorca ${ }^{793}$ que desarrolló el tema: «Importancia de los conocimientos más elementales de la Geología para los progresos de la agricultura y de las artes cerámicas». Dividió la conferencia en dos partes: una se ocupó de la historia cósmica y geológica de la tierra, y otra de las aplicaciones, «pues no se podían comprender éstas sin tener conocimientos, aunque sean elementales, de aquella».

Explicó que el espacio y la materia fueron creados por la voluntad del «Supremo Hacedor»: materia muy difundida que ocupaba la inmensidad de los espacios y en quietud o sin movimiento alguno. Y por la acción del Creador, esta materia recibió el movimiento, fue condensándose, y obedeciendo a las leyes que acababa de recibir de la mano de Dios, formó una inmensa nebulosa dotada de movimiento rápido y uniforme sobre su eje:

[...] y a la manera como se demuestra por el experimento de Plateau que unas gotas de aceite, suspendidas en un vaso de agua ligeramente alcoholizada para darle la densidad conveniente, si se mueven rápidamente, forman núcleos, y anillos alrededor que a la vez se convierten en otros glóbulos y otros anillos, así la inmensa nebulosa al moverse sobre sí dio origen a infinitas nebulosas, de los globos y anillos que iban sucesivamente desprendiéndose. Una de estas nebulosas fue la vía láctea, de la que por la misma causa se formó un colosal anillo con su inmenso globo o núcleo central que constituyó luego otros anillos con sus respectivos centros, y de estos otros más pequeños que dieron origen al sol y a los diferentes planetas y satélites.

Uno de estos núcleos fue la tierra; su anillo dio lugar a la luna, su compañera; y desde entonces la tierra terminó su historia cósmica, empezando su historia geológica. ${ }^{794}$

\footnotetext{
${ }^{793}$ Francisco Llorca era médico y fue director del Instituto de Castellón, en varias etapas: desde 1857 a 1858; 1864 a 1865; 1866 a1868; 1875 a1879; 1881 a1884, año en que murió, después le sustituyó, en la cátedra de Ciencias Naturales, Catalino Alegre. En ALTAVA RUBIO, Vicenta, op. cit p. 146. Doctor y Regente de primera clase en las facultades de Ciencias y Medicina, Caballero de la Real Orden de Carlos III, Médico condecorado con la Cruz de Epidemias, Socio correspondiente de la Real Academia de la Historia e individuo de la Comisión provincial de Monumentos históricos y artísticos, Vocal de las Juntas provinciales de Estadística, de Sanidad, de Beneficencia y de Instrucción pública, Socio de mérito de la Academia Médico-Quirúrgica-Matritense, y de la Sociedad Médica de Lisboa, Socio corresponsal de otras varias sociedades científicas y catedrático de Física y Química. En Memoria acerca del estado del Instituto de Segunda Enseñanza de Castellón 1867-1868. Imprenta y Librería de la Viuda de V. Perales. ${ }^{794}$ El Clamor, 28/11/1881.
} 
Expuso que esta historia no está escrita sino «en los monumentos de restos de seres que pasaron» y que puede determinarse por cambios «que actualmente se suceden y que teniendo conocidas causas por la analogía de efectos se comprenderán causas desconocidas». ${ }^{795}$

Después habló sobre la edad de la tierra, dando a conocer las diferentes opiniones sobre el particular. Indicó que la edad que se atribuye es un error, pues la tierra debe ser muchísimo más antigua, «debiendo haberse necesitado millares de siglos para la larga serie de los fenómenos que se han sucedido; y por consiguiente, que los cinco días de que habla Moisés antes de la creación del hombre debe mirarse como cinco grandes épocas». A continuación habló del calor central de la tierra y de la formación de las montañas, los dos principios fundamentales de la geología, «probando luego con multitud de datos y con ejemplos su poderosa influencia».

Explicó después la historia de la Tierra, empezando por los terrenos más primitivos, anterior a la aparición de los seres organizados. Siguió hablando de la aparición de los vegetales sobre la tierra y la aparición de los animales marinos, en la Era Secundaria; En la Era Terciaria la aparición de los tetrápodos sobre la Tierra y aguas dulces del Globo; y en la Era Cuaternaria, la aparición del hombre sobre la Tierra, rodeados de animales marinos y terrestres.

Hablando de la historia de la Era Cuaternaria, intentó demostrar el diluvio universal. Según explicó, los inmensos depósitos de cantos rodados, de peñas errantes, la dirección de los valles, la presencia de fósiles de grandes mamíferos en las regiones «hoy frías» y la aparición de aerolitos, fue la causa de esta gran catástrofe que atribuyó al choque oblicuo de la tierra con algún planeta; hipótesis que le sirvió para explicar todos los fenómenos de esta época. ${ }^{796}$

\footnotetext{
${ }^{795}$ Francisco Llorca se refiere a los fósiles y a la teoría del «Actualismos Geológico»: los autores más clásicos admitían la teoría cataclísmica, según la cual las deformaciones de la corteza terrestre y las formas del terreno se deben a fenómenos bruscos de un tipo desconocido en el mundo actual. Charles Lyell y Constant Prévost expusieron una teoría muy diferente: el uniformismo o actualismo. Considerando, con Hutton «que el presente es la clave del pasado», Lyell (Principles of Geology, 18301833) halló en cada periodo geológico los mismos fenómenos, realizados por los mismos agentes e idéntico mecanismo. Constant Prévost fue más lejos, al decir que las causas antiguas no eran diferentes de las actuales y que producían efectos idénticos a los que podemos estudiar en la Naturaleza actual. TATON, René Direc. (1973): Historia General de la Ciencias. Vol. III «La Ciencia contemporánea I El siglo XIX» Destino, Barcelona, P.428.

${ }^{796}$ Francisco Llorca estudia las diferentes Eras en la que se divide la Historia de la Tierra. Durante los siglos XVII Y XVIII, la mayoría de los sabios de la época aceptaban que los fósiles son la prueba del diluvio
} 
«Después de enunciar la existencia de varios diluvios parciales, concluyó por probar la conformidad de los hechos geológicos con el génesis; escuchando una salva de aplausos del numeroso público que le oía y espera con igual gusto escucharle en las siguientes noches que acabará su interesante y bien expuesto tema». ${ }^{797}$

También los profesores de la asignatura de agricultura desarrollaron una labor muy positiva para elevar los conocimientos de agricultura de los labradores.

El ingeniero agrónomo y profesor de agricultura del Instituto, Antonio Maillyn, ${ }^{798}$ daba conferencias sobre el ramio ${ }^{799}$ en Castellón, Nules y Villarreal:

Esta creemos debe ser la verdadera misión de los ingenieros agrónomos recorrer las poblaciones y dar conferencias para difundir las luces entre la clase labradora. Si nuestro ruego había de encontrar eco, pediríamos al señor Maillyn, que dilatara sus correrías hasta nuestro país, en donde hay bastante huerta y en donde se haría fácil ensayo de la plantación del ramio. ${ }^{800}$

universal. Los fósiles marinos hallados en las tierras altas y en las montañas fueron llevados allí por la subida de las aguas con ocasión del diluvio universal. Algunos van incluso más lejos: el diluvio no es solo una explicación de los fósiles, sino también un elemento que permite comprender la historia de la tierra, y algunos geólogos llegan a veces a datar ese acontecimiento. Según el geólogo inglés Whiston (1708), el diluvio se habría producido el 18 de noviembre del año 2349 a. de C.

El primer ataque serio y argumentado contra la doctrina del diluvio universal proviene de Buffon, que explica en su Histoire de la Terre (1744) que la explosión de un astro provocó la formación de los planetas; que al principio la Tierra fue una bola incandescente, y que su enfriamiento ha determinado la formación de un núcleo central muy caliente y de una corteza sólida en la que se han originado las altas montañas; que el vapor de la atmosfera, condensada, ha sido el origen de un océano universal en el que vivieron los animales que se han hallado fosilizados; seguidamente, especifica que las aguas del océano han bajado y que, en los continentes así formados, han aparecido grandes animales; por último, poco a poco, la Tierra tomó su configuración actual y apareció el ser humano.

Esta teoría, atrevida para su época, borra y prescinde de la idea del diluvio. Además, incorpora dos elementos fundamentales para la idea de la evolución: el tiempo (Buffon habla de setenta y cuatro mil años como edad de la Tierra) y la idea de que, en la historia del planeta, se han producido cambios profundos, en particular, grandes transformaciones de la superficie terrestre. La historia de la tierra propuesta por Buffon merece la indefectible condena de la Facultad de Teología de la Sorbona en 1751, y tiene que retractarse. GIORDAN, André; HOST, Victor; TESI, Delfo; CAGLIARDI, Raul. (1988): Conceptos de Biología 2. La teoría celular. La fecundación los cromosomas y los genes. La evolución. MEC Y Labor, Madrid, Barcelona. pp. 163-164.

${ }^{797}$ El Clamor, 28/11/1881.

798 Antonio Maylin fue catedrático interino de Agricultura del Instituto de Cabra en 1882. En 1884, fue nombrado Ingeniero Agrónomo de la Provincia de Castellón, y en el mismo año, se encargó de la catedra de Agricultura del Instituto de Castellón. Cesó en este destino en 1888.En Hoja de servicios de Antonio Maylin Alonso.

${ }^{799}$ El Ramio es una especie de la familia de las Urticáceas, de su corteza se obtiene una fibra textil llamada ramio.

${ }^{800}$ El Clamor de Castellón, 7/10/1886. 
Bajo la dirección de Mailyn, se procedió, en el campo de prácticas del Instituto, a la plantación del «ramio» con objeto de ver los resultados que el cultivo de dicha planta producía. ${ }^{801} \mathrm{Y}$, al mismo tiempo, daba conferencias en la catedra de Física del Instituto y en el Círculo Católico sobre el mismo tema. ${ }^{802}$

Mailyn se lamentaba del abandono e indiferencia con que en la provincia de Castellón se contemplaba la invasión de la filoxera. ${ }^{803}$

Asimismo, escribió un libro titulado: Instrucciones prácticas para reconocer y combatir algunas enfermedades de la vid donde describía las principales plagas que amenazan al cultivo de la misma, utilizando un lenguaje sencillo al alcance de los labradores cuando era director de la Granja Escuela de Tarragona. ${ }^{804}$

También el ingeniero agrónomo, profesor interino de agricultura del Instituto de Castellón, Ramón Rivas Moreno, descubrió una enfermedad en el ramio ocasionada por un arácnido que ataca las partes verdes de dicho vegetal y especialmente la parte terminal del tallo, donde muchos millares de arácnidos forman una red impidiendo el desarrollo de la planta en cuestión y ocasionando en pocos días su muerte. «Tanto las costumbres como la organización especial del arácnido serán objeto de una memoria que publicará en mejor ocasión el señor Rivas Moreno. Es pues de gran importancia el asunto que nos ocupa por la novedad que ofrece, $y$ atendiendo al fomento que en pocos años ha adquirido el cultivo de dicha planta en algunas localidades de España». ${ }^{805}$

Parece ser que Manuel Sanz de Bremon escribió una cartilla sobre «el Mildiu y su tratamiento escrito al alcance de todas las inteligencias». El objetivo era popularizar estos conocimientos y hacerlos prácticos para que se apliquen en primavera a fin de evitar el desarrollo de la plaga. ${ }^{806}$

Por otra parte, el médico y profesor ayudante del Instituto Antidio Desbertrand dio una conferencia en el Casino de Artesanos sobre «Pasteur: su vida y trabajos».

Explicó los primeros trabajos de Pasteur «que le crearon una reputación por lo acabado de sus experimentos: la división de los cuerpos en simétricos y asimétricos».

\footnotetext{
${ }^{801}$ El Clamor de Castellón, 9/05/1886.

${ }^{802}$ El Clamor de Castellón, 30/01/1887.

${ }^{803}$ El Clamor, 10/03/1889.

${ }^{804}$ El Clamor, 7/07/1889.

${ }^{805}$ El Clamor, 14/06/1888.

${ }^{806}$ El Clamor, 17/03/1889.
} 
Más lo que le creó verdadera reputación, decía el conferenciante, fue su teoría de las fermentaciones. «Se disputaban el predominio de la ciencia dos teorías para explicarlas las sostenidas por Liebig y Berzelius, que aunque muy en boga admitida, no dejaban de ser absurdas. A ellas opuso las suyas Pasteur» ${ }^{807}$.

También en el Casino de Artesanos dio una conferencia acerca de la Higiene en Castellón el profesor Pedro Aliaga ${ }^{808}$.Explicó las diferentes causas que influyen para que Castellón no estuviera a la altura que debiera en cuestión de higiene, comparando las cifras de mortandad en los diversos países de Europa con las de España, y Castellón «que arroja datos que dicen bien poco en pro de nuestra ciudad». ${ }^{809}$

Entrando a examinar las principales causas, se fijó en las condiciones en que se suministra a Castellón el agua del río Mijares, criticando a los que con su «apatía» permitían que fuera un peligro constante para la salud pública.

Llamó la atención sobre el estado de las calles en Castellón y de la limpieza que en las mismas se efectuaba, enumerando los múltiples peligros a que estaban expuestos los ciudadanos.

Habló sobre los terrenos pantanosos situados en puntos no lejanos de Castellón, ocupándose de las consecuencias que reportan bajo el doble punto de vista de la higiene y la riqueza, «pues que ellos son causa de que los labradores permanezcan en la ciudad en vez de vivir en las tierras que cultivan».

Y por último, se ocupó de los establecimientos públicos. Se felicitó que estuvieran en construcción el hospital y la cárcel, «para sustituir a los malos edificios que a estos objetos están destinados». También hizo observar las deficiencias de que adolecían las escuelas públicas, que ya comentamos en otro capítulo. ${ }^{810}$

En el Casino de Artesanos se reunieron algunos catedráticos del Instituto, junto con exdiputados, exsenadores a Cortes, concejales, ingenieros, etc., para aprobar y firmar una exposición sobre instrucción primaria, que según decían estaba a la cola de las demás provincias de España. ${ }^{811}$

\footnotetext{
${ }^{807}$ El Clamor, 29/11/1888.

${ }^{808}$ Pedro Aliaga fue presidente de la Junta gestora del Casino de Artesanos. En el Casino se miraba por ilustrar al obrero, dando conferencias sobre diversos temas, clases de taquigrafía, dibujo, etc. El Clamor, $01 / 01 / 1889$.

${ }^{809}$ Ibídem.

${ }^{810}$ El Clamor, 8/12/1888, La Provincia, 13/12/1888.

${ }^{811}$ El Clamor, 2/02/1889.
} 
En el Instituto se celebraban conferencias nocturnas para obreros. Por ejemplo en el curso 1911-1012, se daban clases de Lengua Castellana y Lengua Francesa por Damian Alcón; Física y Química por José Sanz; Caligrafía por Martin Rodríguez e Higiene de enfermedades evitables y de Educación Física por el médico Luis Sanz de Andino. Lo jueves y los sábados había gimnasio. ${ }^{812}$

Cuando fue nombrado director del Instituto en 1914, Miguel Marti Blat, una comisión de la Junta local del Centro Obrero le visitó con el fin de agradecerle la atención que con las sociedades proletarias había tenido participándoles su toma de posesión y felicitarle por su nombramiento de director del Instituto.

La misma comisión le expuso a Martí Blat los deseos del Centro Obrero de que el profesorado del Instituto diera en el local del mismo algunas conferencias instructivas a fin de elevar en los posible la cultura de la clase obrera castellonense «ansiosa siempre de saber».

El director del Instituto manifestó a los comisionados que no faltaría la colaboración de los catedráticos a la campaña instructiva que deseaban realizar, «doblemente tratándose de obreros manuales compañeros al fin del profesorado». ${ }^{813}$

La conferencia inaugural del curso 1914 a 1915, organizada por las sociedades obreras, estuvo a cargo del profesor del Instituto de Ciencias Naturales Antimo Boscá, que desarrolló el tema «Leyes biológicas», hablando de la Lucha por la existencia, Adaptación al medio, Selección natural, Herencia, Atavismo, etc. ${ }^{814}$

Las personalidades que prometieron dar conferencias en el Centro Obrero durante el curso 1914/1915 fueron los profesores del Instituto General y Técnico: Miguel Martí Blat, Antimo Boscá, José Albiñana, Fernando Martínez Checa, Luis del Arco, Luis Sanz de Andino; y otras personalidades de Castellón como el inspector provincial de educación José Senent; el jefe de los republicanos de Castellón Fernando Gasset; los médicos Juan Marco Salvador, Ramón Penichet, Vicente Gea, José Gil Valero, etc. Salvador Guinot, Tiburcio Martín, Miguel Alonso, Manuel Bellido abogado, José Martínez, Manuel Breva (abogado), Antonio Ten, Maximiliano Alloza, Emilio Santa Cruz, Juan Carbó, Vicente Gimeno Michavila, Agustín Betoret y Carlos Selma.

\footnotetext{
${ }^{812}$ El Clamor, 2/10/1911.

${ }^{813}$ El Clamor, 13/11/1914.

${ }^{814}$ El Clamor, 25/11/1914.
} 
A la conferencia de Antimo Boscá asistieron todos los profesores del Instituto, estudiantes y personalidades de Castellón. Fue un acto multitudinario en la que Boscá al dirigirse a los allí presentes les hizo una advertencia que no venía a desarrollar dotes oratorias sino a enseñar, considerándose satisfecho si al terminar había podido lograr aportar algo para la obra de cultura que realizaba el Centro Obrero. ${ }^{815}$

Antimo Boscá dio también en el Círculo Mercantil otra conferencia sobre «Los microbios», sus medios de existencia, formas, enfermedades que causan, etc. durante la conferencia proyectó una película sobre el tema desarrollado. ${ }^{816}$

Según dice la prensa el salón del Círculo estaba atestado de público «que nos fue imposible ocupar sitio adecuado para tomar notas del discurso pronunciado por el conferenciante».

Boscá habló de los microbios, que enumeró y clasificó, exponiendo las funciones que ejercen en la vida de los seres animados, señalando varias de las enfermedades que ocasionan. Acompañando las explicaciones con proyecciones dio a conocer las distintas formas que adquieren, no sin antes exponer la razón de la existencia de los microbios y medios de que se sirven para ejercer sus funciones, beneficiosas unas y perjudiciales otras.

También describió el microscopio, enseñando su funcionamiento y ensalzando la misión que tal aparato desempeña en la labor científica que realizan los sabios. Dedicó alabanzas a los grandes naturalistas, algunos de los cuales perecieron por su amor a la Ciencia. «El señor Boscá empleó más de hora y media en el desarrollo de su tema, oyendo muchos aplausos y recibiendo al terminar entusiastas felicitaciones». ${ }^{817}$

El profesor de Ciencias Naturales dio otra conferencia en el mismo Centro y en el mismo mes, en la que presentó 24 proyecciones de reino hominal y animal con ejemplares «que llamaron poderosamente la atención». A cada una de las proyecciones acompañaba la correspondiente explicación, «quedando el público muy satisfecho y aplaudiendo la labor del señor Boscá» ${ }^{818}$

Otros temas que desarrollaron algunos profesores del Instituto en el Centro Obrero fueron los relacionados con la guerra europea de 1914.

\footnotetext{
${ }^{815}$ El Clamor, 28/11/1914.

${ }^{816}$ El Clamor, 3/02/1916.

${ }^{817}$ El Clamor, 5/02/1916.

${ }^{818}$ El Clamor, 24/02/1916.
} 
El catedrático de latín del Instituto José Albiñana Mompó fue uno de los primeros que desarrollo una conferencia sobre la guerra, con el tema titulado «El conflicto europeo con relación a España».

Después de ensalzar la obra de cultura que realizaba el Centro Obrero con las conferencias, entró en el tema estudiando las virtudes y los defectos de los pueblos en lucha, «lucha que arranca de las Universidades, de los laboratorios, de las fábricas y del campo a esa valiosa juventud para que perezca en una guerra sin precedentes en la historia».

Estudió el conflicto europeo, deduciendo las consecuencias que había de reportar a todos los Estados del viejo continente y particularmente a España. ${ }^{819}$

También, sensible a la problemática de la crisis de la naranja, disertó en el Círculo Mercantil sobre «La crisis del hambre». En esta conferencia afirma que España debería industrializarse, pues un país agrícola es un país pobre. Por eso defendía la industrialización de la naranja para que los productos que de ella se obtengan, «nos den mejores rendimientos que nos da el fruto ahora».

«Alemania ha logrado sacar muy buenos productos del carbón y nosotros sacaríamos de la naranja ácido cítrico, azúcar y otros productos, empleando para ello buena cantidad de fruto que, al no acudir al mercado, haría que consiguiesen mejores precios las cajas que se exportaran».

Afirma que la mutualidad, la cooperación y el crédito son las grandes palancas para salvar a los pueblos, y critica al Banco de España y ferrocarriles «que son los únicos dueños del gobierno de España» y combate al caciquismo que «ha sufrido y sufre esta provincia». Terminó su conferencia diciendo que «debemos pedir al Estado laboratorios, escuelas industriales y ferrocarriles, con lo que lograremos salir de la atonía, del marasmo en que vivimos, convirtiendo a España en una nación de primer orden». 820

\footnotetext{
${ }^{819}$ El Clamor, 5/12/1914.

${ }^{820}$ Ibídem.
} 


\section{LA DOCENCIA DE LAS CIENCIAS NATURALES EN EL INSTITUTO DE SEGUNDA ENSEÑANZA. PROFESORADO Y RECURSOS DE ENSEÑANZA-APRENDIZAJE}

\subsection{AlgunAS BIOGRAFÍAS DESTACADAS DE LOS PROFESORES DE CIENCIAS NATURALES DEL INSTITUTO DE SEGUNDA ENSEÑANZA (1880-1918)}

Dada nuestra especialidad en Ciencias Naturales hemos creído conveniente hacer un estudio pormenorizados de los profesores de Ciencias Naturales que desarrollaron su labor en nuestra época de estudio: Catalino Alegre Renau, Francisco Domenech Bueso y Antimo Boscá Seytré, en donde se demuestra su amplia formación y las actividades que realizaban. También haremos un estudio de dos de los libros de texto que más utilizaron dicho profesores.

\subsubsection{CATALINO ALEGRE}

Catalino Alegre y Renau nació en Castellón de la Plana, en 1837 y murió en 1891. Catedrático de Historia Natural y de Fisiología e Higiene del Instituto, también desempeñó la catedra de Agricultura agregada a la de Historia Natural.

Catalino Alegre era bachiller en Filosofía, en Ciencias y Derecho y licenciado en Derecho Canónico. Fue socio corresponsal de la Sociedad de Amigos del País de Valencia. Formó parte de la Junta de Agricultura, Industria y Comercio de la provincia de Castellón y de la Beneficencia de ídem. Fue presidente del Sindicato de riegos de Castellón y Comisario Regio de agricultura de la provincia y ostentaba el título de comendador de Isabel la Católica.

En 1867 fue nombrado secretario del Instituto de Castellón por el Rector del Distrito cuyo cargo desempeñó nueve meses y diez y siete días.

Encargado por la junta de Agricultura, Industria y Comercio de las conferencias agrícolas dominicales.

Catalino Alegre obtuvo la alcaldía en las primeras elecciones realizadas en la Restauración y desempeñó el cargo desde $1^{\circ}$ de marzo de 1877 hasta el $1^{\circ}$ de julio de 1879, por real orden de 20 de febrero de 1877. Sus principales actividades están 
encaminadas a remediar la falta de agua del campo y a organizar el riego. Bajo su presidencia, el Ayuntamiento hizo el acuerdo de construir un teatro y, en su sesión del 20 de enero de 1879, tomó la decisión de comenzar su construcción. ${ }^{821}$

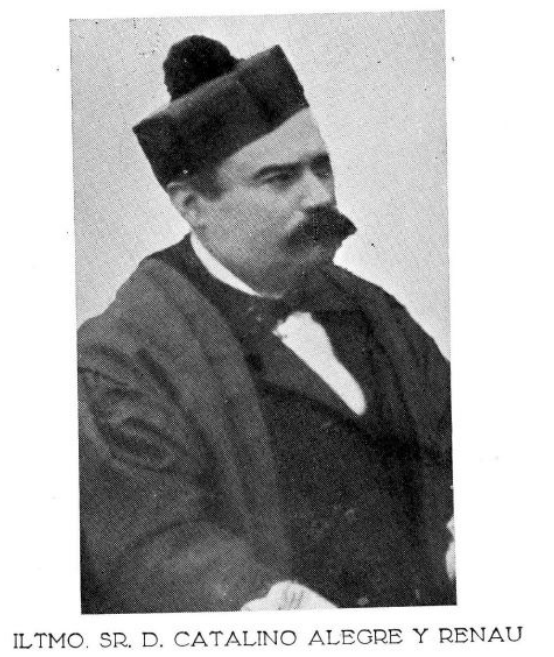

Catalino Alegre Renau (1837-1891) Profesor de Ciencias Naturales del Instituto de Segunda Enseñanza de Castellón. Fuente:http://3.bp.blogspot.com/.Q7bwTjbYrVg/UjXyfslfSNI/ $[23 / 08 / 2015]$

Fue presidente del Círculo Cooperativo y Protectorado de obreros. A finales de 1882, como decimos en otro capítulo, Alegre pronunció un discurso en la inauguración de dicho Círculo, en el que pretendía rebatir la teoría Darwinista ${ }^{822}$.

Juez en distintas ocasiones, y presidente del tribunal de oposiciones a escuelas de Instrucción primaria

Fue nombrado director del Instituto el 10 de marzo de 1884 hasta el 15 de febrero de 1891, cuando murió.

Redactó el reglamento y ordenanzas para el régimen y gobierno del Sindicato y jurado de riegos de Castellón.

Autor de artículos sobre agricultura publicados en los periódicos de Valencia $L a$ agricultura Valenciana y Las Provincias.

Redactó el reglamento de la «Asociación de cosecheros de naranja de la provincia de Castellón».

Intervino en las «Conferencias Agrícolas», en las que según la ley sobre la enseñanza de la Agricultura de $1^{\circ}$ de Agosto de 1876, estaban obligados a participar.

\footnotetext{
821 Sesión 20 enero de 1879. Actas sesiones del Ayuntamiento, 1877. (A.H.M.), en ALTAVA RUBIO, Vicenta, op. cit. p.61

${ }^{822}$ GARRIDO, Samuel (1986): Los trabajadores de las derechas, Diputación de Castellón, Castellón. pp. 117-118.
} 
Estas tenían lugar los domingos y trataban sobre temas fijados de antemano por la Junta Provincial de Agricultura, Industria y Comercio. El director como el catedrático de Agricultura eran vocales natos de la mencionada Junta. ${ }^{823}$

\subsubsection{FRANCISCO DOMENECH BUESO}

Nació en Castellón en 1843 y murió en la misma ciudad en 1914.

Fue nombrado catedrático numerario de Historia Natural en el Instituto de Ciudad Real en 1869, pasó luego por permuta al Instituto de Albacete en 1876, y posteriormente cesó por traslado al de Almería en 1878. Por último, fue Catedrático de Historia Natural del Instituto de Castellón en virtud de concurso en 1895.

Domenech era Bachiller en Artes por el Instituto de Castellón en 1861, Bachiller en la Facultad de Ciencias en 1869, Bachiller en Sagrada Teología en 1882. Se licenció y doctoró en Ciencias Naturales en la Universidad Central.

En 1882 se le expidió el título de comendador de la Real Orden de Isabel la Católica. Fue socio de la Sociedad Económica de Amigos del País de Almería y la de Albacete, y Vocal de la Comisión de Estadística de esta última ciudad, nombrado por el gobernador en 1876 .

Pero fue en Almería donde con mayor fuerza desarrollo su labor y social y docente que le llevaron a ser muy apreciado por quienes le trataron.

Fue Concejal Síndico del Ayuntamiento de Almería desde 1881 a 1886. Vocal de la Comisión de Monumentos históricos y artísticos, Vocal de la Junta del Censo de Almería, nombrado en 1885. Vocal de la Sección de Comercio, Vocal naturalista de la Junta de pesca, Presidente de la Sección de Ciencias Naturales, Físicas y Exactas del Ateneo de Almería, bibliotecario del Círculo Católico de obreros, etc.

En el curso 1871-1872 creó en el Instituto de Ciudad Real una cátedra de Geología, recibiendo felicitaciones del Rectorado por su interés en el fomento de la enseñanza.

Desempeñó las Cátedras de Aritmética y Algebra, Fisiología e Higiene, Geometría y Trigonometría y Nociones de Agricultura, en el seminario de Almería desde 1880 a 1884. Representó al Instituto de Segunda Enseñanza de Almería y a la

\footnotetext{
${ }^{823}$ Hoja de Servicios Catalino. Alegre. Expedientes personales.
} 
Escuela Normal de la misma, por acuerdo de los respectivos Claustros, en el congreso pedagógico Hispano-Portugués-Americano, con motivo del centenario de Colón.

En 1880 fue nombrado director del Instituto de Almería. Su gestión en el cargo fue muy valorada. Unas veces contribuyendo con sanos consejos y disposición a la fundación y fomento de varios centros de enseñanza en la provincia; otras reconstruyendo, reformando y embelleciendo el edifico del Instituto, y «siempre, como Jefe de Establecimiento, velando con gran celo e interés por la prosperidad y engrandecimiento del mismo».

En 1885 con motivo de la terminación de las obras del Instituto de Almería, el rector del distrito le manifestó su satisfacción por el interés con que llevó a efecto sus gestiones en pro de la reconstrucción del edificio y de los derechos del profesorado.

Gran aficionado a la agricultura publicó varias conferencias sobre la Filoxera en La Crónica Meridional de Almería. También publicó un libro de texto con el nombre de Programa razonado de un curso de Historia Natural con principios de Fisiología e Higiene, y un catálogo de plantas determinadas de la provincia de Almería.

Perteneció a las sociedades económicas de Amigos del País de Santiago y de Jaén.

Francisco Domenech fue profesor Auxiliar de la Sección de Ciencias en el Instituto de Castellón en 1867 hasta que fue nombrado catedrático del Instituto de Ciudad Real en 1869

Domenech era un gran aficionado al mundo de las plantas, siendo auxiliar en el Instituto de Castellón, elaboró un herbario con más de seis mil plantas recolectadas y clasificadas por él.

En 1868, fue nombrado catedrático sustituto de las asignaturas de Agricultura teórica-práctica del Instituto de Castellón y dirigió la escuela de Prácticas agrícolas del mismo.

Francisco Domenech fue nombrado director del Instituto de Castellón en $1907 .{ }^{824}$

${ }^{824}$ Hoja de Servicios Francisco Domenech. Expedientes personales. 


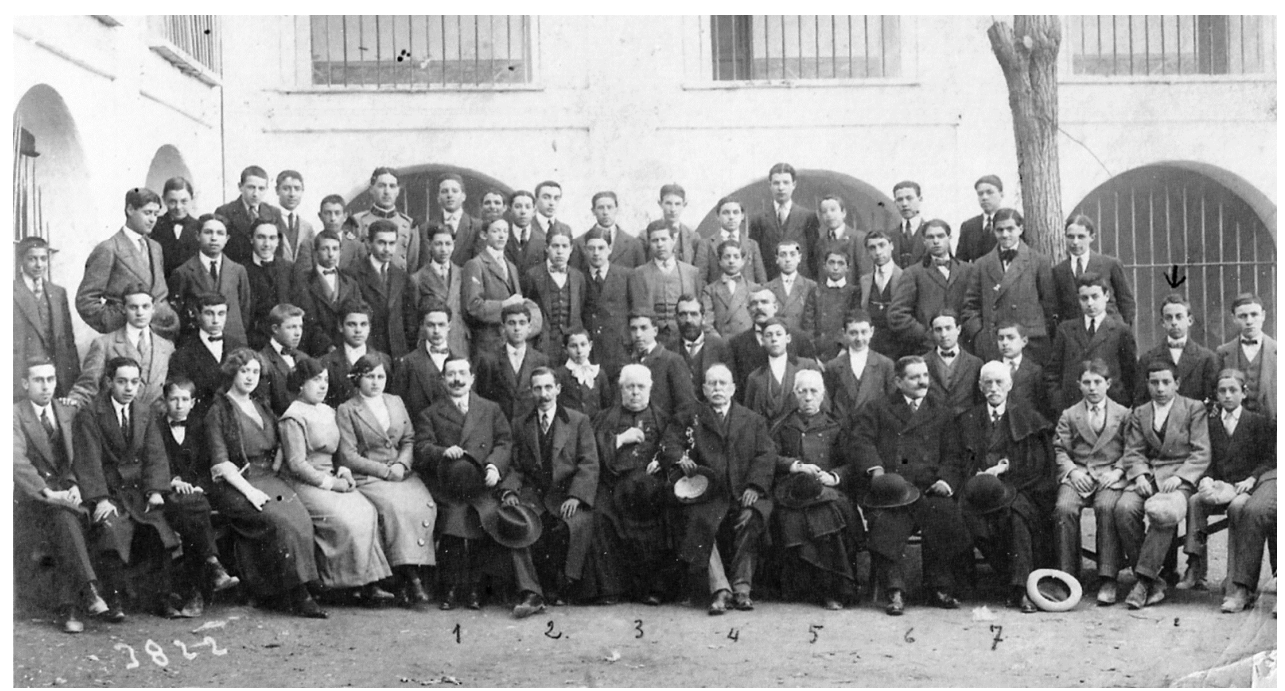

Profesores del Instituto: 1. Luis del Arco; 2. Miguel Martí Blat; 3. Manuel Pascual Pérez; 4. Francisco Doménech; 5.Alejo Prats; 6. Damián Alcón, secretario; 7. Ismael Fabra. Foto conjunta de los cursos $5^{\circ}$ y $6^{\circ}$; se distingue entre el alumando al geólogo Vicente Sos Baynat, segunda fila, a la derecha, marcado con una flecha (1913-1914). Fuente: SOS PARADINAS, Alejandro (2013): Biografía del profesor Dr. D. Vicente Sos Baynat

En 1911, recibió el real decreto sobre la construcción de un nuevo edificio para la habilitación del Instituto:

Aprobado por real decreto de 16 de julio de 1910 el proyecto de construcción de un edificio con destino a Instituto general y técnico, Escuela Normal y escuelas de Bellas Artes y Artes industriales en Castellón de la Plana, redactado por el arquitecto don Francisco Tomás Traver, por su presupuesto de contrata que asciende a 1.190 .000 pesetas 91 céntimos; consultado el ministerio de Hacienda con arreglo a lo que preceptúa la real orden circular de dicho departamento y reales decretos que en la misma se citan; el rey (q.D.g.) de acuerdo con el consejo de ministros se ha servido autorizar la ejecución de las obras comprendidas en dicho proyecto con imputación a loe ejercicios de 1912, 1913 y 1914 por iguales partes.

Lo que tengo el honor de poner en conocimiento de U.S. para su satisfacción y efectos consiguientes. ${ }^{825}$

La prensa agradece también las gestiones que hasta llegar a conseguir este real decreto realizaron los diputados Vicente Cantos y Emilio Santa Cruz.

${ }^{825}$ El Clamor, 10/08/1911. 


\subsubsection{ANTIMO BOSCÁ SEYTRÉ}

Nació en Valencia en 1875, era hijo del científico valenciano Eduardo Boscá.

Boscá ocupó la plaza de Ayudante por oposición de las clases prácticas de la Facultad de Ciencias de Valencia (Sección de Naturales), en 1900. Más tarde se hizo cargo de la plaza de Auxiliar en la misma Facultad en 1902. Posteriormente, en 1903, fue nombrado por oposición catedrático numerario de Historia Natural, Fisiología e Higiene del Instituto General y Técnico de Baeza, pasando luego por concurso, en octubre del mismo año, al Instituto de Teruel. A la muerte de Francisco Domenech, en 1914, se hizo cargo de la cátedra de Historia Natural del Instituto General y Técnico de Castellón.

Antimo Boscá obtuvo el grado de Bachiller en el Instituto de Valencia en 1891. Licenciado en Ciencias Naturales en 1897 y Doctor en Ciencias Naturales en el mismo año.

Estuvo pensionado en el Laboratorio Biológico de Santander durante el curso 1895-1896 a propuesta de la Facultad de Ciencias Naturales. También estuvo pensionado por la Junta de Ampliación de Estudios para el extranjero en 1910, y fue Delegado por la Junta para estudiar las colecciones y ejemplares de mamíferos fósiles de Buenos aires, La Plata y Las Pampas de América.

Publicó una Memoria Geológica-minera de la Provincia de Teruel. También fue muy celebrada la publicación de su obra titulada Fauna Valenciana, que consta de nueve capítulos en los cuales trata, respectivamente, del medio ambiente valenciano y sus límites naturales, de los diversos tipos de animales, como los Protozoos, Espongiarios, Cnidarios, Equinodermos, Gusanos, Artrópodos, Moluscos y Vertebrados. La obra iba ilustrada con 148 grabados originales. Boscá editó varios ejemplares para enviarlos a las repúblicas sudamericanas donde el catedrático y su padre contaban con gran número de admiradores. ${ }^{826}$

Boscá fue nombrado subdirector del Instituto de Castellón en 1915

En el desarrollo de su profesión recibió gran número de premios, como por ejemplo, el Gran Premio, con distintivo especial y medalla de oro en la Exposición

\footnotetext{
${ }^{826}$ El Clamor, 24/11/1916.
} 
Hispano-Francesa de Zaragoza en 1908, Medalla de Plata «con su título del Centenario de los sitios de Zaragoza» etc.

Ostentó los títulos de director encargado del Observatorio Meteorológico de Teruel, de Socio de la Real Sociedad Española de Historia Natural, de la Sociedad Económica de Amigos del País de Teruel, etc. Encargado colector del distrito Minero de Teruel. $^{827}$

Con Antimo Boscá se comenzaron a impartir clases prácticas en el laboratorio del Instituto y llevó a los alumnos a varios lugares de excursión: al Desierto, para herborizar y clasificar; al Grao de Castellón a recoger algas y conchas marinas; a Ribesalbes para recoger yesos y fósiles; a la cueva de las Maravillas del pantano de María Cristina, etc. Antimo los llevaba al mercado, donde obtenía ejemplares para su estudio posterior en el laboratorio, o al puerto, donde algunos pescadores le solían entregar peces poco frecuentes. ${ }^{828}$

\subsection{RECURSOS PARA LA ENSEÑANZA-APRENDIZAJE UTILIZADOS POR LOS PROFESORES DE CIENCIAS NATURALES: LIBROS, EXCURSIONES Y GABINETE DE CIENCIAS NATURALES}

\subsubsection{Los libros de texto de Ciencias Naturales}

Hasta 1868 todos los textos tenían que pasar por una comisión administrativa que dictaminaba su idoneidad. Se demandaba un tipo de enseñanza más práctica en la que el profesorado tomara parte más activa. Por fin en 1868, se dio plena libertad al profesorado para utilizar en sus enseñanzas aquellos textos que mejor se acomodaban a sus doctrinas y métodos. El decreto de 21 de octubre de 1868 manifestó una política pedagógica en aras a la libertad de enseñanza, pues «los profesores deben ser también libres en la elección de métodos y libros de texto y en la formación de su programa.» Según vemos, el profesor podía tener un sistema y método propio. ${ }^{829}$

\footnotetext{
${ }^{827}$ Hojas de servicio de Antimo Boscá. Expedientes personales.

${ }^{828}$ SOS PARADINAS, Alejandro (2013): Biografía del profesor Dr. D. Vicente Sos Baynat. Diputació de Castelló, Castelló. p. 42.

829 CAPITAN DÍAZ, Alfonso (1994): Historia de la educación en España. Tomo II. Pedagogía Contemporánea. Dykinson, Madrid p. 331.
} 
Las Ciencias Naturales debían apoyarse para su estudio en el método experimental, en el que sus pilares más importantes son: primero la observación de los fenómenos y, después, el paciente análisis de los mismos. Desde la antigüedad hasta nuestros días, se ha seguido esta línea en el estudio de las ciencias en general y de las Ciencias Naturales en particular.

A partir de 1868 comienza la diversificación de las materias de Ciencias Naturales en los planes de estudios de segunda enseñanza. En el plan de 1873 se impartió Biología, que ya se consideraba en el Plan anterior de 1868, Uranografía y Geología, Botánica, Zoología y, Fisiología e Higiene.

Los contenidos en Biología versaban sobre la vida en general y sus leyes, especialmente de la vida humana. La Uranografía y Geología comprendían la teoría general la formación de los cuerpos celestes, la descripción de nuestro cielo y, en especial, del sistema solar, con nociones de Geogenia y Elementos de Mineralogía. La Fisiología e Higiene se impartían junto a Nociones de Medicina. ${ }^{830}$

En esta década de los setenta se tiene en cuenta la prioridad de los programas sobre los libros de texto. Estos programas eran explicados por el catedrático de la asignatura todo el año. A partir de la publicación del Decreto de 3 de junio de 1873, ${ }^{831}$ se abrió un concurso público para premiar el mejor y más adecuado programa de las asignaturas

En 1875, el Consejo de Instrucción Pública es el encargado de aprobar el catálogo de las obras de texto, así como los programas oficiales de las asignaturas, ${ }^{832}$, por lo que una vez más se limitaba la libertad de elección de texto mediante el sistema de listas, según la Circular Orovio, a los rectores, de 26 de febrero de 1875.

Los debates sobre los libros de texto se sucedían entre el profesorado. Unos opinaban que contribuían únicamente al desarrollo de una enseñanza memorística, mientras que otros se pronunciaban en sentido contrario. A este respecto, la Institución Libre de Enseñanza presenta una marcada oposición a la utilización del libro de texto por su mecanización del proceso de aprendizaje, pronunciándose por corrientes

\footnotetext{
830 HERNÁNDEZ NIEVES, Purificación. (2009): La evolución de las Ciencias Naturales en la Segunda Enseñanza. Universidad de Extremadura, Cáceres. pp.246-249.

${ }^{831}$ Decreto de 3 de junio de 1873. Colección Legislativa de 1873. Colección Legislativa de España de 1873.t. CX.

${ }^{832}$ Real Decreto de 26 de febrero de 1875. Colección Legislativa de Instrucción Pública de 1875, p. 250.
} 
metodológicas más innovadoras fundamentadas en Pestalozzi, Herbart, Froebel o Rousseau $^{833}$.

En el Plan de 1868 se incorporó la asignatura de Nociones de Higiene, por lo que muchos libros de texto añadieron a la parte de anatomía y fisiología humanas unos conceptos fundamentales de Higiene, en los que se tenía en cuenta la higiene de los alimentos, del vestido, del entorno y sobre todo la higiene de los diferentes órganos y aparatos.

La asignatura de Agricultura, que se encontraba en los estudios de aplicación de 1858 o en el «bachillerato técnico» del Plan de 1868, se incluyó en los estudios generales, después de promulgarse el Plan de 3 de junio de 1873. Es la ley de 1 de agosto de 1876 la que estableció a la Agricultura como asignatura obligatoria en los estudios de segunda enseñanza. Los conocimientos de esta materia no iban encaminados a la discusión de las teorías de la Agricultura moderna, sino al estudio de los múltiples y variados detalles del cultivo para formar agricultores prácticos.

Al principio, el estudio de la asignatura de Historia Natural giró en torno a las clasificaciones mineralógicas, botánicas y zoológicas, lo cual provocaba en el estudiante el estar frente a un árido catálogo de nombres raros que olvidaba más tarde porque la sola clasificación no le era útil en su vida social. Algunos autores combatieron esta tendencia, no solo los catedráticos en sus programas y autores de libros de texto, sino los responsables de libros especializados.

En el último tercio del siglo XIX, aún se mantenía en los libros de texto la denominación de Historia Natural y su división en las tres ramas de: Zoología, Botánica y Mineralogía.

Cada vez, el profesor de Ciencias Naturales estaba más convencido de que había que facilitar el aprendizaje al alumno. Así, algunas obras iban acompañadas de cuadros sinópticos que comprendían cada una de las clasificaciones de un reino de la Naturaleza, pues, a golpe de vista, se disponía de las divisiones, subdivisiones en tipos, clases, ordenes, subórdenes, familias, tribus y especies de los animales, vegetales y minerales. Se acompañaba con ellos una concisa relación de los principales caracteres distintivos de cada tipo, clase y orden. Estos cuadros sinópticos se colgaban en los gabinetes de Historia Natural para facilitar la clasificación de los ejemplares y conseguir una buena

\footnotetext{
${ }^{833}$ VEGA GIL, Leoncio (1997): Pedagogía Institucionista y educación social en Castilla León. Historia de la Educación. Revista interuniversitaria. Universidad de Salamanca. Núm. 16. P. 268.
} 
ordenación taxonómica de las colecciones. Algunos libros siguen una metodología basada en el sistema de preguntas y respuestas.

El objetivo de introducir en los libros de texto grabados, láminas, cuadros sinópticos y diálogos a modo de preguntas y respuestas, no fue otro que el de conseguir una buena metodología para la enseñanza-aprendizaje al alumno.

Se pretendió llegar a la motivación y fácil aprendizaje del alumno a través de sencillas estrategias metodológicas que facilitaran este objetivo. Hubo profesores que concibieron para estas Ciencias una metodología didáctica en función de la metodología investigadora.

En algunas obras, el estudio de la Historia Natural comienza por la Zoología, seguida de la Botánica y más tarde de la Mineralogía. Otros autores prefieren en sus libros comenzar por la Mineralogía, seguida de la Botánica y luego de la Zoología. Según el profesor Felipe Picatoste, este orden parece más lógico y científico, se pasa de lo sencillo a lo más complicado, para que el alumno vaya adquiriendo conocimientos nuevos y ampliando el mundo de las ideas de una manera progresiva.

La Fisiología e Higiene se concibió como asignatura independiente de la Historia Natural desde 1868. En ella se ha procurado conciliar las vulgaridades de la Higiene, dándole cierto carácter científico, con el conocimiento de la Fisiología Humana. En los textos donde se abordan estas enseñanzas se analizan las principales funciones del organismo-nutrición, relación, reproducción-, así como los preceptos que deben seguirse para una correcta higiene privada y pública.

Según el Real Decreto de 16 de septiembre de 1894, las asignaturas de Historia Natural y de Agricultura del Plan de 1880 tienen su equivalencia en el Plan de 1894 con las siguientes materias: la primera, con Nociones de Organografía y Fisiología Humanas y con los Cuadros de Historia Natural, y la segunda, con lo Elementos de Agronomía y Nociones de las principales Industrias.

En los planes de estudios anteriores se venía detectando una cierta preocupación por la metodología. Por fin, en el Plan Groizard (1894) aparecen una serie de orientaciones metodológicas que el legislador denomina el concepto de asignatura, que en el caso de las Ciencias Naturales fue el siguiente: los contenidos en los Cuadros de Historia Natural debían responder a un estudio sintético de las clasificaciones y grupos fundamentales correspondientes a los reinos de la naturaleza, según el orden biológico correspondiente. 
Los contenidos de la asignatura de Nociones de Organografía y Fisiología Humana debían responder al conocimiento descriptivo del cuerpo humano, con referencias al estudio de la Morfología general biológica, procurando que estos conocimientos fueran los más experimentales y prácticos posibles. Para este cometido, el decreto anteriormente citado remite a la utilización de ciertas materias contenidas en los gabinetes y laboratorios de los institutos, tales como el hombre clástico y diversas piezas anatómicas «claras y sencillas». Después del estudio anatómico se debía seguir un estudio fisiológico, con el carácter elemental que caracterizaba a este tipo de enseñanza

Se aprecia a finales del siglo XIX un cambio en la transmisión de los contenidos de Historia Natural, que debían realizarse en dos cursos alternos: uno de Mineralogía y Geología con base química, y otro de Botánica y Zoología con base anatómica y fisiológica. La importancia del asunto es que debía exponerse con un sentido más biológico y menos descriptivo y externo, para lo cual deberían ir acompañados de las prácticas y experiencias suficientes realizadas en los gabinetes de Historia Natural. ${ }^{834}$

A comienzos de siglo XX se notaba ya un cambio en la concepción del profesorado a la hora de elaborar los libros de texto, pues el tratamiento de cada una de las ramas de las Ciencias Naturales, abandonaba, en parte, su carácter enciclopédico.

También desde las filas gubernamentales se propugnaba un cambio en estos libros y en el Real Decreto de 20 de julio de 1900 se indicaba que los programas y libros de texto de la asignatura debían ser «sencillos y concretos».

Se venía observando que los libros de texto no se escribían con fines didácticos, sino para dar contestación a las preguntas de los exámenes, por lo que le Plan Romanones, de 1901, se decidió no poner un libro único, ni tampoco que el profesor señalara un determinado número de ellos para la enseñanza de sus alumnos, los cuales eran libres para decidir estudiar por aquel que mejor le conviniese. ${ }^{835}$

En los libros de Historia Natural ya se constata una diversificación más amplia de las materias: Zoología, Botánica, Mineralogía, Geología, Anatomía Humana y Fisiología e Higiene

En general, la exposición de los contenidos en los libros de texto de Fisiología e Higiene, Historia Natural y Agricultura, es clara y sencilla. Son libros didácticos que

\footnotetext{
${ }_{834}^{834}$ HERNÁNDEZ NIEVES, Purificación (2009), op. cit. pp. 250-258.

${ }^{835}$ Ibídem, pp.262-263.
} 
utilizan algunas estrategias para facilitar el estudio a los alumnos, como grabados, esquemas y tipo de letra con dos tamaños diferentes - la mayor para los contenidos fundamentales y la menor para los complementarios -.

El interés por la metodología práctica de la clase impartida en el gabinete de Historia Natural, fue potenciado desde el Ministerio, ya que en el examen de ingreso al Instituto, de los tres ejercicios exigidos, en el oral se incluyeron las denominadas Nociones generales de conocimientos útiles, entre las que se encontraban algunos conceptos de Naturaleza y en el ejercicio práctico podía describirse algún objeto natural. ${ }^{836}$

En cuanto a los cursos, las disposiciones administrativas contemplaban que debían abordarse con carácter experimental, práctico y aplicado mediante el trabajo desarrollado en los gabinetes y laboratorios, así como en casa y en el aula a través de la resolución de ejercicios prácticos, lo que significaba un descenso en la fundamentación teórica, en pro de ese marcado carácter experimental con el que se querían tildar estas disciplinas.

En el Instituto-Escuela de Madrid, creados en 1918 y fiel a los principios pedagógicos de la Institución Libre de Enseñanza, el aprendizaje de las Ciencias Naturales en el ciclo elemental se afrontaba de una manera más práctica y menos memorística, en la que los alumnos carecían de libros de estudio. El libro de texto es sustituido por el cuaderno de clase, como instrumento en el que se reflejaban los resúmenes de las explicaciones del profesor y una serie de problemas, ejercicios y cuestiones prácticas.

Había calado ya en la enseñanza de las Ciencia Naturales el desarrollo de las clases prácticas en los gabinetes y laboratorios. Los gabinetes eran sustituidos por laboratorio de trabajo donde se llevaban a cabo una serie de destrezas y habilidades de investigación, como la construcción y manejo de determinados materiales sencillos con los que realizar las diferentes experiencias de laboratorio, empleo del microscopio, realización de preparaciones de seres naturales e identificación de estos seres.

El desarrollo de las actitudes se trabajaba en el área de las Ciencias Naturales a través de la observación de la Naturaleza, también se facilitaba el interés y motivación

\footnotetext{
${ }^{836}$ Real Decreto de 12 de abril de 1901. Colección Legislativa de España de 1901, vol. 2ª.arts. 3-5.
} 
por la Ciencia y se fomentaba el trabajo de forma cooperativa, como fuente de creación de hábitos sociales solidarios.

La programación de los contenidos en el Instituto-Escuela tenía marcado carácter cíclico y su planteamiento didáctico supuso un cambio radical con respecto a los anteriores. El Informe elaborado por la Institución Libre de Enseñanza en 1919, propuso una ordenación concéntrica de los contenidos y la Revista de Pedagogía, fundada en 1922, llevaba desde sus páginas, a los lectores españoles, el pensamiento de los pedagogos más innovadores y sus experiencias más significativas. ${ }^{837}$

\subsubsection{Los libros de texto utilizados por los profesores de ciencias naturales del instituto de Castellón (1880 - 1918)}

Según la profesora Vicenta Altava: «Más allá de la política y desde los límites impuestos por ella, los libros, como recurso didáctico, tienen una influencia directa sobre la enseñanza: determinan y configuran los procesos instructivos que tienen lugar en el aula por medio de su acción sobre los contenidos y sobre los métodos.

El contenido de la enseñanza, lo que se enseña en realidad, depende de los textos. Ellos trasladan a las aulas las propuestas de los planes de estudios, reinterpretadas desde la formación científica e ideológica de sus autores. Por otra parte, los principios didácticos en que se apoya el autor de un manual, las características epistemológicas de la materia que contiene, el modo de presentarla y los ejercicios que proponen determinan la forma de trabajar los profesores $\mathrm{y}$, por medio de ella, el nivel de conocimientos adquiridos por los alumnos y el desarrollo de sus procesos mentales.

Los manuales pueden actuar como elemento innovador, difundiendo ideas científicas y pedagógicas nuevas entre los profesores. Sin embargo, la permanencia de los mismos textos puede entorpecer las reformas de la enseñanza». ${ }^{838}$

Los profesores de Ciencias Naturales del Instituto de Castellón optan por manuales nuevos y de calidad, aunque en la enseñanza de esta asignatura sigan propuestos dos manuales de la era Isabelina, como el de Sandalio de Pereda y el de Manuel María José de Galdo y López.

\footnotetext{
${ }^{837}$ CAPITAN DÍAZ, Alfonso (1994), op. cit. pp.474-477.

838 ALTAVA RUBIO, Vicenta (1993): Aportaciones al Estudio de la Enseñanza Media en Castellón, 1846-1900.Universidad de Valencia. Facultad de filosofía y Ciencias de la Educación. Valencia. pp. 396397.
} 
Al principio de su carrera profesional, Catalino Alegre utilizo el texto de Manuel María José de Galdo, para posteriormente, a partir de los años setenta, cambiarlo por el de Sandalio de Pereda, hasta su muerte en 1981.

El libro adoptado se siguió usando mientras permaneció en la catedra el profesor que lo eligió, la continuidad de los textos guardó un relación muy estrecha con la estabilidad del profesorado.

El libro de texto más utilizado por los profesores que sustituyeron a Catalino Alegre en la cátedra de Ciencias Naturales, fue el Emilio Ribera Gómez.

Los libros de texto de la época que estudiamos pertenecen a una etapa en la que predomina la descripción de los conocimientos de la disciplina de Historia Natural. Es una etapa que abarca todo el siglo XIX y principios del siglo XX. Predomina en ella la gran extensión de los conocimientos en densos libros de texto.

Los contenidos responden más a un aspecto descriptivo de los seres vivos que a un aspecto más evolucionado. Abundan las descripciones de los órganos, aparatos y sistemas de estos seres (Organografía), el funcionamiento y los mecanismos que utilizan (Fisiología) y el estudio de la clasificación de los seres vivos (Taxonomía) desde el punto de vista puramente descriptivo. Se le da una gran importancia a la Taxonomía vegetal, animal y mineralógica, basada en la búsqueda de diferencias entre los organismos para poderlos encasillar en taxones. ${ }^{839}$

A continuación, comentaremos los libros de texto que utilizaron los catedráticos de Ciencias Naturales que ejercieron en nuestra época de estudio.

Programa razonado de un curso de Historia Natural con nociones de Fisiología e Higiene por Sandalio de Pereda y Martínez (1870) 840

La primera edición del libro escrito por el catedrático de Historia Natural del Instituto de primera clase de San Isidro, Sandalio de Pereda y Martínez, es de 1858. Con posterioridad a esta fecha publicó cinco ediciones más. Comentaremos a continuación la quinta edición de 1870

\footnotetext{
${ }^{839}$ HERNÁNDEZ NIEVES, Ma Purificación (2009): op. cit. p. 325.

${ }^{840}$ PEREDA Y MARTÍNEZ, Sandalio (1870): Programa razonado de un curso de Historia Natural con nociones de Fisiología e Higiene. $5^{\text {a }}$ Edición. Imprenta de A. Gómez Fuentenebro, Madrid. Consultado en el Instituto Francisco Ribalta de Castellón.
} 


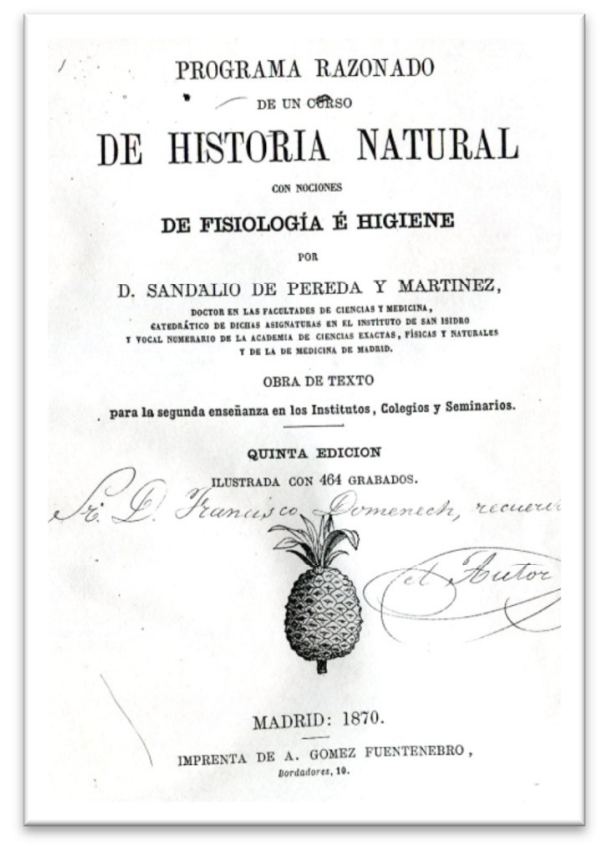

Sandalio de Pereda y Martínez, Programa Razonado de un curso de Historia Natural con nociones de Fisiología e Higiene. $5^{\text {a }}$ edición, 1870

A partir de 1850, los autores de la época mantenían tres partes fundamentales en la organización de los contenidos de la disciplina de Historia Natural: Zoología, Botánica y Mineralogía. En esta edición Pereda añade Nociones de Fisiología e Higiene

La obra consta de 441 páginas, destinadas las 368 primeras a Programa razonado de un curso de Historia Natural, y las 73 restantes a Nociones de Fisiología e Higiene, con sus correspondientes índices de materias y unos párrafos de advertencias de la quinta edición que se examina. Advierte el autor que además de mejorar el papel y la parte tipográfica, se intercalan 464 grabados (117 más que en la última edición), renovando con otros mejores todos los respectivos a Zoología y Fisiología y algunos de Botánica, Mineralogía y Geología, «para que la enseñanza, esencialmente intuitiva en ciencias naturales, se funde en el conocimiento práctico de los objetos en las aulas y en los gabinetes, auxiliado todo lo que sea posible por su significación en las obras de estudio».

Varia poco, según dice, el texto de Historia Natural, pero bajo idéntico plan añade unas nociones de la nueva asignatura de Fisiología e Higiene, «no resumiendo iguales materias de la facultad de Medicina, sino redactándolas bajo el concepto 
especial y propio que, deben tener siempre los estudios generales de segunda enseñanza». ${ }^{841}$

Sandalio de Pereda mantiene los cuatro apartados citados anteriormente, que analizamos según el orden dispuesto por el catedrático.

Comienza la Historia Natural por unas Nociones preliminares en las que expone la división de los seres, indicando los caracteres diferenciales entre los orgánicos y los inorgánicos, composición química, estructura, forma, etc., diferencias entre los seres vivientes: animales y vegetales, advirtiendo de la dificultad de deslindarlos. Un cuadro de los seres, y una «tabla comparativa del profesor Dumas», de las diferencias químicas entre vegetales y animales, completan estos preliminares.

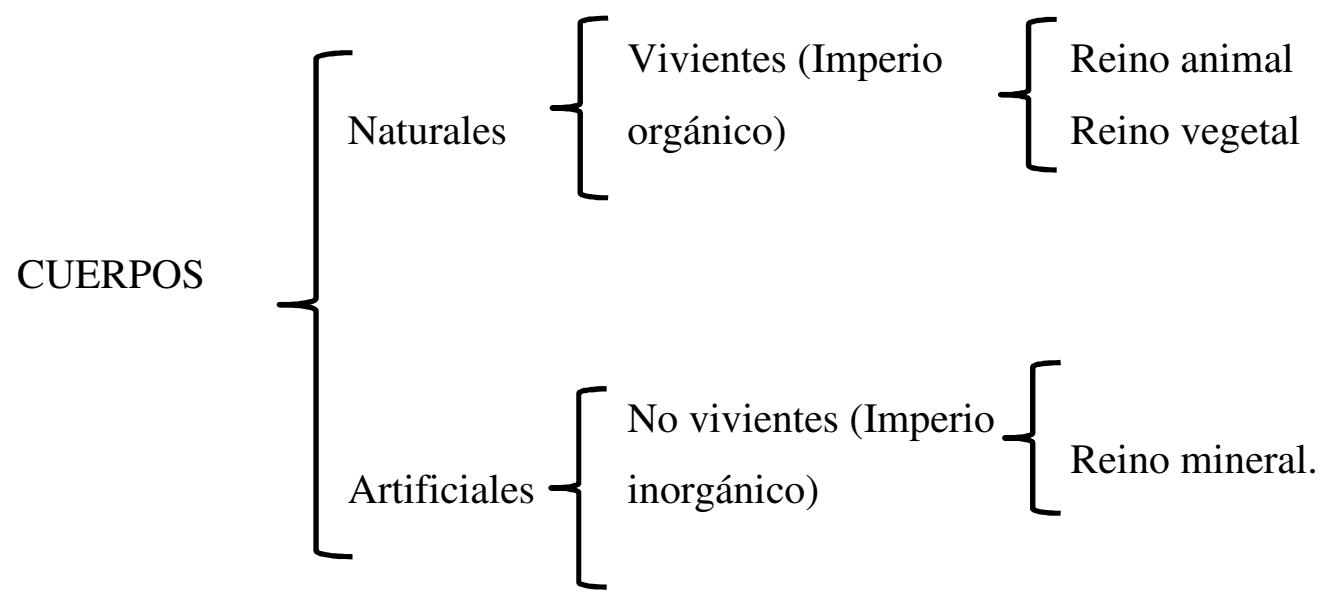

\section{BALANZA QUÍMICA ENTRE ANIMALES Y VEGETALES}

\begin{tabular}{|l|l|}
\hline El vegetal & El animal \\
\hline Es un aparato inmóvil de reducción & Es un aparato móvil de combustión. \\
\hline Reduce el carbono e hidrógeno & Quema el carbono e hidrógeno. \\
\hline Fija el ácido carbónico. & Desprende el ácido carbónico \\
\hline Desprende oxígeno. & Consume oxígeno \\
\hline Toma sus elementos del aire y de la tierra. & Da sus elementos al aire y a la tierra. \\
\hline Transforma la materia inorgánica en & Transforma la materia orgánica en \\
\hline
\end{tabular}

${ }^{841}$ Ibídem, p. 1. 


\begin{tabular}{|l|l|}
\hline orgánica & inorgánica \\
\hline Absorbe el calor. & Produce calor \\
\hline Conduce la electricidad & Produce electricidad. \\
\hline
\end{tabular}

Desde la página 5 hasta la página 88, aborda el estudio de la Zoología. Define ésta y explica los elementos químicos, orgánicos y anatómicos que componen el ser animal. Los elementos químicos (carbono, hidrógeno, oxígeno, nitrógeno, etc.) constituyen los orgánicos (urea, fibrina, albúmina caseína, gelatina.), y estos a su vez, forman los anatómicos (glóbulo, fibra, celdilla y tubo), y por último define lo que son humores, tejidos (añade un cuadro analítico de los tejidos principales que componen el cuerpo de un animal), órganos, aparatos y sistemas.

A continuación define la vida y fuerza vital y, por último, el autor divide la Zoología en Anatomía, Fisiología y Zoografía. El estudio de la anatomía precede al de la Fisiología haciendo especial hincapié en el hombre, sin perjuicio de indicar las principales diferencias que se advierten cuando se trata de otros animales. Añade un cuadro analítico de las funciones en los animales: orgánicas (de nutrición y de reproducción), y de relación, exclusivas de los animales: Sensaciones, Instinto y Facultades intelectuales, Actitudes y movimientos, Actos de significación y Sueño.

En la página 89 comienza la Zoografía que comprende todo lo relativo a principios generales y cuadro de la clasificación que adopta el autor, conforme con la de Cuvier, para continuar con la Zoología descriptiva que llega hasta la página 200.

La parte correspondiente a la Botánica, (72 páginas), contiene los mismos bloques temáticos que el de Zoología, separando la parte de Organografía y Fisiología que lo distribuye de manera independiente. Las 4 páginas de Generalidades hacen referencia a los elementos, tejidos, componentes y partes esenciales de los vegetales. La organografía (32 páginas) trata los órganos de nutrición (raíz, tallo, rizomas, bulbos, tubérculos, hojas y yemas) y de reproducción (la flor y sus partes, la semilla y el fruto) de los vegetales. La Fisiología (13 páginas) incluye el funcionamiento de los órganos estudiados anteriormente, realizando un estudio de la absorción, circulación, respiración, asimilación, secreción, fecundación, diseminación, germinación y maduración.

En la Clasificación vegetal (22 páginas) describe los caracteres de las clases del sistema sexual de Linneo y los de las clases y subclases del método de De Candolle. Las 
4 últimas páginas están destinadas a la Geografía botánica donde se reflejan las causas que influyen en la estación de las plantas y zonas diferentes de vegetación.

La Mineralogía (62 páginas), comienza con los Caracteres físicos y químicos de los minerales. Entre los primeros, las formas de concreciones irregulares y orgánicas, su estructura, caracteres mecánicos como la dureza y la tenacidad, caracteres ópticos, electro-magnéticos y organolépticos. Entre los segundos, su composición química. Una vez realizado el estudio comparativo de los caracteres físicos y químicos, se establece la Clasificación mineralógica. El autor sigue la clasificación de Haüy. Después de describir las principales clases y órdenes adjunta un apéndice en el que incluye a la turquesa, el guano, el nitrógeno, el hidrógeno y el agua, en sus estados sólidos, líquidos y gaseosos. Finaliza el apartado con un estudio mineralógico de las rocas, las cuales agrupa, según la Clasificación de Halley, en tres clases: la primera corresponde a las rocas metálicas, la segunda a las rocas lipídicas y la tercera a las rocas combustibles. Tanto en el caso de los minerales como en las rocas, hace referencia a los lugares en los que se encuentran estos ejemplares.

El apartado de Geología, (34 páginas), estudia la Geognosia y la Geogenia. Entre los primeros se estudia la forma, densidad y composición de la tierra, las características mineralógicas de los terrenos, la distribución y relaciones de los fósiles con ellos y una clasificación basada en el origen o clasificación de J. D'Omalins d'Halley, en la que aparecen divididos en dos clases: acuosos o neptúnicos e ígneos o plutónicos. Entre los segundos se tratan los fenómenos geogénicos acuosos de la época actual (acción del agua y del aire) y los fenómenos ígneos, volcánicos y sísmicos.

Para terminar aborda el estudio de la Higiene (71 páginas), con dos secciones. En la Sección I, trata el Sujeto de la Higiene (razas, sexo, edad, temperamento, constitución, idiosincrasia, herencia, hábitos, profesiones), y la Sección II, comprende los agentes modificadores de la vida orgánica (Circumfusa, Ingesta, Excreta, Aplicata), y de relación (Gesta y Percepta).

\section{Análisis del texto}

\section{Zoología}

Cuando describe los elementos anatómicos, en el estudio de la Zoología, el autor no alude a la teoría celular y habla del glóbulo, la fibra, la celdilla y el tubo como elementos anatómicos: 
De la combinación y desagregación de principios inmediatos resultan los elementos anatómicos; formándose estos por diminutos cuerpos, libres o contiguos, de caracteres físicos y químicos propios y con una estructura distinta de los cuerpos inorgánicos. El glóbulo, la fibra, la celdilla y el tubo son elementos anatómicos; existiendo otros amorfos, o sin forma determinada, que rellenan los huecos que dejan los primeros.

Los elementos orgánicos y anatómicos reunidos constituyen la materia organizada, que se denomina humor, si es líquida; tejido, si es sólida.

Los tejidos, son para el autor, «factores inmediatos del ser animal»:

[...] se distinguen por su textura o especial agregación de sus elementos; por sus propiedades físicas y químicas, como la consistencia, elasticidad, higrospicidad, etc.; cualidades inherentes a la vida, cual la absorción, incremento, regeneración e inervación. ${ }^{842}$

Hasta entrado el siglo XIX se admitía que los organismos estaban constituidos por una materia especial peculiar de ellos «la fuerza vital» propia tan solo de los seres vivos.

Los biólogos del mundo moderno, a la hora de enfrentarse con el problema materia-vida propenden a una interpretación vitalista de tipo descriptivo de la estructura orgánica .La unicidad de los seres vivos, dicen, debe ser adscrita a propiedades vitales, a capacidades o predisposiciones, inexplicables pero naturales, en una sustancia primigenia que constituye a los cuerpos vivos, confiriéndoles primera estructura.

En un sentido estricto y riguroso, el que prevalece durante los siglos XVIII y XIX, el vitalismo designa aquella doctrina que expresa que la diferencia entre lo viviente y lo no-viviente ha de ser atribuida a un peculiar principio constitutivo y operativo, «el principio vital», el cual, a su vez, es concebido como una fuerza específica, la «fuerza vital» ontológica y operativamente superior a las restantes fuerzas de la naturaleza cósmica -mecánica, térmica, eléctrica, magnética, química- y, en consecuencia, esencialmente irreductiblemente a ellas, pero específicamente activa, como tal fuerza,

${ }^{842}$ Ibídem, pp. 5-6. 
en la dinámica real de los entes materiales en que existen, en los que llamamos «seres vivos».

Desde comienzos del mundo moderno, se ha considerado a la fibra el elemento último estructural de los tejidos corporales. La mayor parte de los biólogos va a pensar que la actividad vital de los órganos, y el conjunto de éstos, tiene su principio y causa en las partes sólidas del organismo vivo; en definitiva en sus fibras, que se hallarían animadas en sí mismas por una vis o fuerza específica.

Parte de los biólogos de los años finales del siglo XVIII comienzan a preguntarse si será realmente la fibra el último elemento formal de nuestras partes. Se inicia así el paradigma de los glóbulos que, en principio, no trata de substituir la estructura fibrilar por la globular, sino de introducir, dentro de la primera, un nuevo punto de vista: la génesis de la fibra -todavía elemento formal portador de la fuerza vital- a partir de unos globulitos que ya habían sido considerados por varios autores en el siglo XVII, Swammerdam, Malpighio, Leeuwenhoeck, y vistos también en el siglo XVIII por Monro, Wolff, Hewson y Fontana.

Se admite la existencia de estos glóbulos en tanto que precedentes genéticos de la fibra, que sigue siendo el elemento estructural esencial del organismo, sede de la fuerza vital Será poco después, en los primeros decenios del siglo XIX, cuando comience un nuevo paradigma verdaderamente globular, con la consideración del glóbulo como unidad elemental de la vida, portadora en sí de la «fuerza esencial» que desde el seno mismo de la materia viva, específicamente propia de ella, impulsa y rige los fenómenos vitales de la nutrición y el crecimiento. Tan cerca nos encontramos ya de la teoría celular que, cuando en 1838 eleve Schwann a principio general la estructura celular de vegetales y animales, habrá «globulistas» que reclamen la prioridad del descubrimiento. ${ }^{843}$

Más adelante, Pereda, añade un cuadro analítico de los tejidos principales que componen el cuerpo de un animal.

${ }^{843}$ ALBARRACIN TEULÓN, Agustín. (1983): La teoría celular, Alianza Editorial. Madrid. pp. 14-19. 


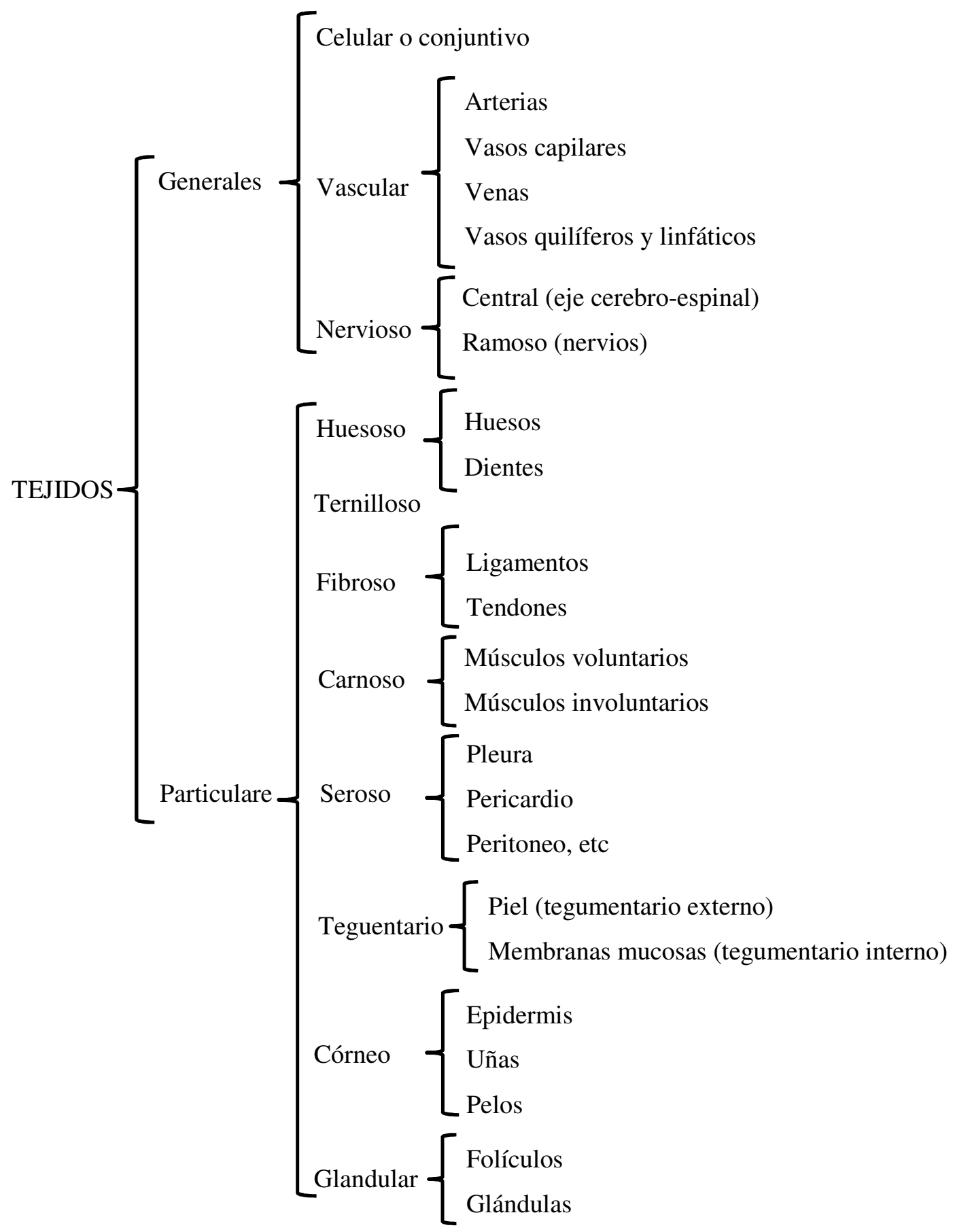


Define la vida y la fuerza vital:

La vida, resultado de la íntima unión de una fuerza con la materia organizable, es el conjunto de funciones que en una época limitada se suceden en un ser organizado; y fuerza vital es la actividad por la cual este modifica la materia bruta en materia organizable.

Como hemos señalado anteriormente, aborda primero el estudio de la anatomía, «que analiza la forma, estructura y relaciones de las partes que componen la máquina de un animal»; y la «fisiología, que nos da a conocer los diferentes actos que constituyen la vida animal»:

Necesario el conocimiento de las partes que forman la máquina de los animales para comprender los actos de su vida, al describir estos en fisiología enumeraremos las principales partes que los desempeñan. Debe, pues, preceder en cada función el hecho anatómico al fisiológico. ${ }^{844}$

Divide las funciones de la manera que expresa el cuadro analítico siguiente:

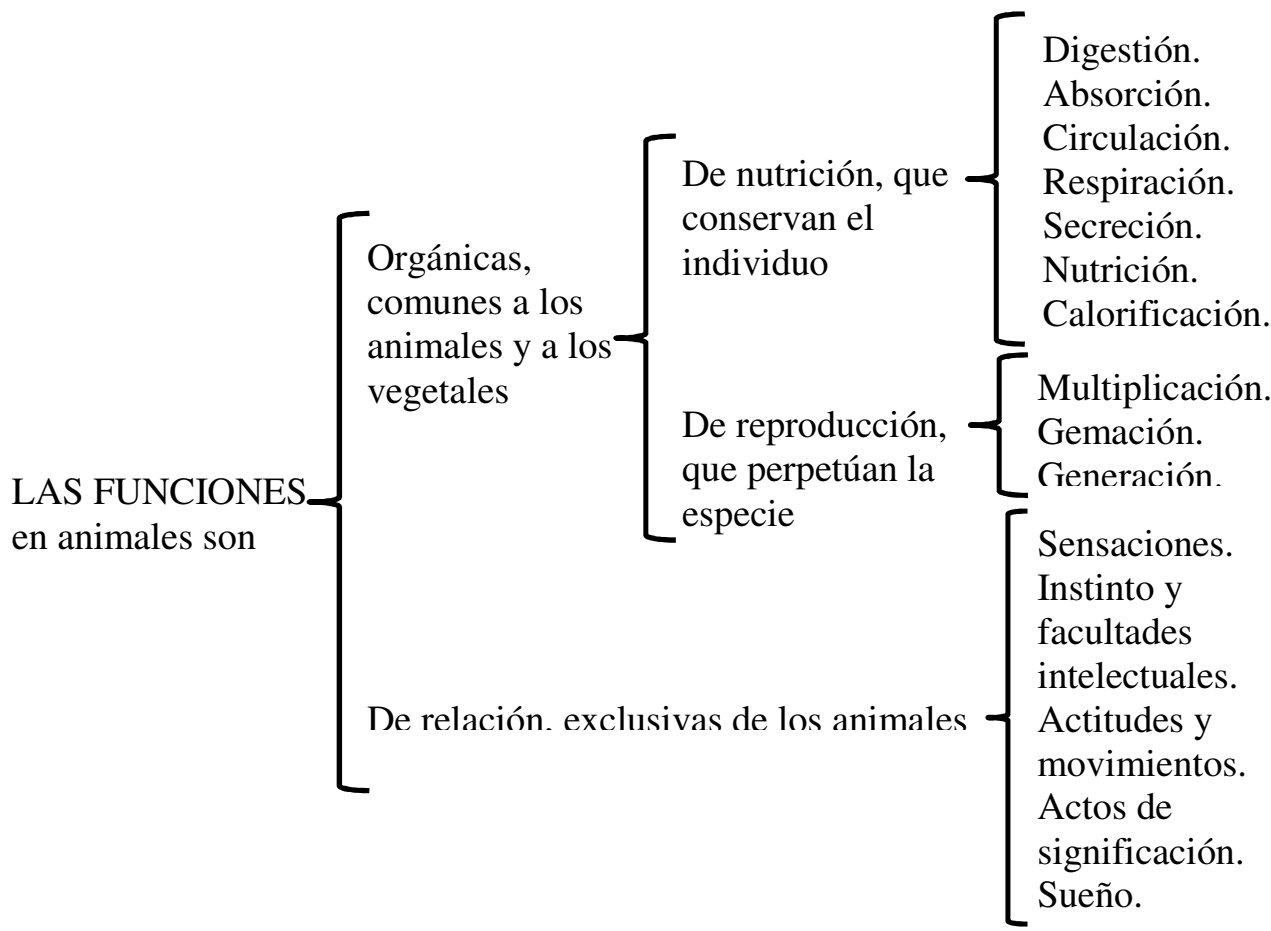

${ }^{844}$ PEREDA Y MARTÍNEZ, Sandalio (1870): op. cit. pp. 7-8. 


\section{Función de nutrición}

En la función de nutrición define la digestión y las sensaciones internas que le preceden, el hambre y la sed. ${ }^{845}$

A continuación define los alimentos como «productos susceptibles de activar el calor animal o de proporcionar materia reparadora de los tejidos y humores vivientes» .Los que cumplen el primer objetivo los llama respiratorios, los que atienden al segundo plásticos:

Sustancias abundantes en carbono e hidrógeno, sin nitrógeno, grasas, azucaradas o feculentas, son las que forman los alimentos respiratorios; materias nitrogenadas neutras, como la gelatina, fibrina y albúmina, constituyen los alimentos plásticos.

Clasifica las bebidas en acuosas, acídulas, aromáticas o fermentadas, «reuniendo, no pocas veces, iguales condiciones nutritivas que los alimentos».

Explica los actos de la digestión: prehensión de los alimentos, masticación, e insalivación, deglución, quimificación, quilificación, defecación

En el acto de la masticación e insalivación, nombra la tialina o diastasa salivar, destinada a transformar los productos harinosos e insolubles, en otros azucarados y solubles:

La lengua y los carrillos colocando el alimento entre las muelas, favorecen la masticación; y esta fuerza incompleta, si a la vez aquel no se ablandara por la saliva, humor que por otra parte modifica los alimentos, no siendo grasientos o nitrogenados, mediante la tialina, especie de fermento destinado para transformar los productos harinosos e insolubles, en otros azucarados y solubles.

Pereda nombra como facilitadores de la quimificación o digestión estomacal, los movimientos, el calor, la fuerza vital y la pepsina del jugo gástrico, que transforma las sustancias albuminosas en productos solubles:

845 Ibídem, pp.8-17. 
Lleno el estómago de alimentos, ciérranse sus orificios durante la digestión estomacal, facilitando esta los movimientos, calor y fuerza vital de aquél órgano, unido a la poderosa acción del jugo gástrico. Este líquido modifica los alimentos mediante la pepsina, principio que, si tiene un ácido, transforma las sustancias albuminosas en productos solubles, fáciles de ser así absorbidos.

En el duodeno, el quimo se mezcla con el jugo intestinal, la bilis y el fluido pancreático y, bajo «la acción de la vida» se transforma en quilo y en excremento:

El quimo en el intestino duodeno se mezcla con el jugo intestinal, la bilis y el fluido pancreático: este último humor, más activo aún que la saliva, completa la transformación de las sustancias amiláceas en otras azucaradas, favoreciendo además la solubilidad de las grasientas; la bilis excita los actos digestivos, y disuelve o emulsiona también las grasas; y el jugo intestinal interviene con los expresados líquidos en los cambios del alimento. Bajo la acción de la vida y la influencia de tales agentes, el quimo, al correr por el tubo digestivo mediante los movimientos vermiformes o peristálticos de los intestinos, se transforma en quilo y en excremento.

\section{Mecanismo de la absorción}

La capilaridad, y «la dependencia de la vida» son las causas de la absorción:

Las leyes de la capilaridad influyen en la facultad absorbente de los tejidos orgánicos; pudiéndose considerar estos como un sistema de cavidades capilares, cuyas paredes obran sobre los fluidos adyacentes a la manera de los tubos de igual nombre y bajo la dependencia de la vida, que en todo y por todo rige y gobierna los actos orgánicos.

La capilaridad puede explicarnos la imbición de los sólidos por los fluidos, pero no las corrientes que se establecen entre los líquidos separados por un cuerpo poroso, según se demuestra por el endosmómetro de Dutrochet. 


\section{Y explica cómo funciona el endosmómetro de Dutrochet:}

Si en un vaso lleno de líquido, por ejemplo agua, sumergimos otro, con un tubo y cuyo fondo esté cerrado por una membrana, que contenga, v.gr., disolución de azúcar, se observan dos corrientes: una mayor, endósmosis o corriente ósmica, del agua hacia la disolución; otra menor, exósmosis o corriente de difusión, de la disolución hacia el agua, resultando de la mezcla desigual de ambos líquidos, que ascenderá el contenido en el tubo y vaso interior, y al contrario, descenderá el que se halla dentro del exterior. El movimiento será opuesto, es decir, que excederá la corriente exosmósica a la endosmósica, invirtiendo la colocación de los expresados líquidos.

Estos fenómenos dependen de la propiedad física llamadas difusión: por ella, juntando dos líquidos capaces de mezclarse, se penetran mutuamente sus moléculas; pero si un cuerpo poroso los separa, en la tendencia a mezclarse se reconoce además una corriente predominante en virtud de la fuerza que se llama ósmosis, que es la endósmosis de Dutrochet, siendo la que este denominó exósmosis no una fuerza especial, sino simple resultado de la difusión de los líquidos. ${ }^{846}$

El médico y naturalista Henri Dutrochet da un enérgico impulso a las investigaciones fisiológicas, tanto en el terreno teórico como en el de los hechos concretos. Antivitalista convencido, Dutrochet desarrolla una concepción unitaria de la naturaleza orgánica y mineral, considerándolas gobernadas por leyes físico-químicas de un mismo tipo. En 1837, Dutrochet afirma que no existe más que una sola Fisiología, ciencia general de las funciones de los seres vivos, y espera, según sus propios términos, que sus primeros ensayos permitan un día nacer a «una ciencia nueva, la Fisiología general».

Los trabajos de Dutrochet atraen la atención general por uno de los descubrimientos más notables del siglo, la ósmosis (1827), y por las aplicaciones que su autor hace de dicho principio a varias manifestaciones vitales inexplicadas hasta entonces. Dutrochet había observado:

$1^{\circ}$. Que ciertas membranas orgánicas tienen la propiedad de dejar pasar el agua pura, mientras detienen las moléculas de los cuerpos disueltos en ellas.

${ }^{846}$ Ibídem, pp. 17-20. 
$2^{\circ}$. Que entre dos soluciones mezclables y de concentración (corriente de endósmosis) que va desde la solución menos concentrada a la más concentrada.

Las condiciones en las que operó Dutrochet no le permitieron alcanzar mucha precisión; las membranas que pudo utilizar eran sólo muy groseramente semipermeables, y la endósmosis quedaba contrapesada, en parte, por la corriente de exósmosis. Pero Dutrochet se esforzó por explicar lo esencial del fenómeno mediante pacientes experimentos en condiciones determinadas y cada vez diferentes. Construyó un osmómetro con objeto de poder medir la presión osmótica e ideó un aparato más perfecto en el cual la membrana podía ser no orgánica y de superior calidad. También tuvo la idea de asimilar la célula a un osmómetro, y de esto infirió un elemento de explicación de la circulación y la ascensión de la savia en la plantas. ${ }^{847}$

Describe la función de la respiración en sus hechos más ostensibles, pues admite que los íntimos o vitales son desconocidos:

La respiración en sus hechos ostensibles, pues los íntimos o vitales son desconocidos, es un fenómeno de disolución y desprendimiento de gases, subordinado a otro, que es el consumo de oxígeno y la producción de ácido carbónico, en la masa de los órganos; y como esto es un acto nutritivo, tendremos que los fenómenos de la respiración serán de dos clases, unos locales, limitados a los pulmones, la respiración propiamente tal; otros generales a todos los tejidos, que consumen el oxígeno absorbido, y producen en cambio ácido carbónico, el cual unido a la sangre venosa se exhala después mediante el pulmón o la piel. ${ }^{848}$

\section{Secreción}

«La secreción es un acto por el cual los órganos separan o forman de la sangre productos independientes de los elementos que les nutren».

Pereda clasifica los órganos secretores en «exhalantes, foliculares y glandulares». Pertenecen a este último los riñones, «glándulas de color rojo oscuro que forman la orina».

\footnotetext{
${ }^{847}$ TATON (1973): La Ciencia Contemporánea I. El siglo XIX. Ediciones Destino, Barcelona. .pp. 510-511.

${ }^{848}$ PEREDA Y MARTÍNEZ, Sandalio (1870): op. cit. pp. 30-31.
} 
Según el autor: «Los materiales urinarios, y principalmente la urea, son proporcionados a los riñones por la sangre, cuyo humor pierde, al atravesar estos órganos, una gran parte de su fibrina, sin que este principio se halle en la orina».

Pereda dice que se ha querido explicar el modo de eliminar los productos urinarios contenidos en la sangre por diálisis; «pero aunque tal fenómeno se confirme siempre desconoceremos la acción de los riñones sobre la sangre, como la de todos los actos moleculares del organismo viviente». ${ }^{849}$

Se ha querido explicar el modo de eliminarse dichos productos por diálisis, o sea la separación que se efectúa entre sustancias disueltas, en presencia del agua y de gelatina o de un tabique albuminoso, según son cristalizables o no cristalizables; pero aun cuando tal fenómeno se confirme en la secreción de que hablamos, siempre en su esencia desconoceremos la acción de los riñones sobre la sangre, como la de todos los actos moleculares del organismo viviente.

El autor denomina Glándulas imperfectas a ciertas partes del cuerpo, de funciones desconocidas y sin conductos excretorios. Corresponden a este grupo los órganos siguientes: el tiroides, las cápsulas suprarrenales, los ganglios mesentéricos y glándulas linfáticas y el bazo; de este último dice: «Se desconocen los usos del bazo, suponiendo el mayor número de fisiólogos que está destinado: $1{ }^{\circ}$ a ser un reservorio de la sangre, por lo que es muy elástico y extensible; 2. ${ }^{\text {o }}$ para eliminar, destruir o transformar los glóbulos rojos». ${ }^{850}$

\section{Nutrición}

Define que es la nutrición: «La nutrición es un acto por el cual los tejidos adquieren de la sangre arterial los elementos precisos para su incremento, eliminando a la vez otros inútiles, que se incorporan con la sangre venosa, la linfa, o los productos excrementicios». 851

\footnotetext{
${ }^{849}$ Ibídem, p.35.

${ }^{850}$ Ibídem.

${ }^{851}$ Ibídem, p. 35.
} 
Nombra los dos tipos de reacciones que constituyen el metabolismo: asimilación (anabolismo) y el de eliminación o descomposición (catabolismo).

El objeto de las funciones que hemos descrito no es otro que el de preparar productos necesarios en los actos nutritivos; y para que estos sean completos, es preciso que en lo íntimo de los tejidos haya un doble movimiento molecular: el de asimilación, que incorpora elementos; el de eliminación o descomposición, que los elimina. $^{852}$

La parte fluida de la sangre arterial, es decir, «el plasma y no los glóbulos», es el producto esencial en los actos de incremento de los tejidos. Para el autor es un fenómeno fisiológico oscuro y admirable.

Siendo un fenómeno fisiológico tan importante como oscuro y admirable, el que con un mismo líquido se forme tanta variedad de tejidos, tantos humores diversos: fuerzas propias de la vida, fuerzas independientes y distintas de las físicas y químicas, que son solo sus auxiliares, intervienen en el movimiento, arreglo y afinidad molecular de la nutrición; y como se ignoran las leyes de tales actos, nunca el hombre podrá conocer la esencia del fenómeno, jamás producirá el órgano más sencillo, las partes con las que el Creador formó y dispuso la complicada máquina de un ser vivo. ${ }^{853}$

La utilización de los alimentos y del oxígeno por los tejidos, lo explica de la siguiente manera:

El plasma de la sangre empapa los tejidos, porque trasuda por las paredes de los vasos continentes; y para que el líquido sea reparador, es preciso que esté en movimiento en las mallas de aquellos, es necesario que se renueve adquiriendo los productos que pierde en sus continuas transformaciones.

Las materias que por diversas funciones se agregan a la sangre, pueden separarse de tres modos diferentes: $1 .^{\circ}$ eliminándose de este humor, sin cambio alguno y por

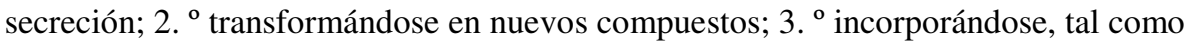
son, a los tejidos orgánicos, como sucede con la rubia en los huesos, según hemos

\footnotetext{
${ }^{852}$ Ibídem.

${ }^{853}$ Ibídem, pp. 35-36.
} 
dicho en la absorción intersticial. El agua se elimina de la primera manera, y al filtrarse por los tejidos facilita el trabajo de la nutrición, la solubilidad y dispersión de ciertos cuerpos, evitando a la vez los efectos perjudiciales que resultan de la desecación de los órganos. De igual modo son eliminadas la mayor parte de las sales; y la común que es la más necesaria, además de favorecer las secreciones, da la suero de la sangre, en que está disuelta, la propiedad de conservar inalterable los glóbulos, impidiendo que estos se descompongan por la maceración del líquido. Otras sustancias, las que constituyen realmente el alimento, se agregan a la sangre, pero se modifican y dan origen a productos nuevos, teniendo lugar una combustión fisiológica en los tejidos, siendo comburente el oxígeno adquirido por la respiración y combustible las sustancias unidas a dicho humor. Los glóbulos rojos se pueden considerar como cuerpos conductores y condensadores del expresado gas, y el plasma un necesario intermedio entre la sangre y los glóbulos, entre la parte combustible y la comburente. ${ }^{854}$

Los fenómenos catabólicos, (combustión fisiológica), son para Pereda, complejos y desconocidos:(la famosa reacción de oxidación de la glucosa):

Los fenómenos de la combustión fisiológica son a cual más complejos; y si bien se explica en general el trabajo orgánico, es lo cierto que ignoramos cómo y porqué la materia se agrega en formas y texturas tan diversas, qué transformaciones se suceden en sus elementos anatómicos y orgánicos, hasta ser expelida fuera del cuerpo en estado de ácido carbónico, urea y otros compuestos muy oxidados. Atribúyese el origen de la urea a la oxidación de los productos albuminosos o nitrogenados; y el de los grasos, amiláceos o harinosos y azucarados a combustiones incompletas. Como hemos dicho en la digestión, el hígado elabora una especie de azúcar (glucosa), la cual quemándose por el oxígeno adquirido en los actos respiratorios, produce, según algunos, agua y ácido carbónico, cuyo origen lo atribuyesen otros al ácido láctico.

Las leyes vitales propias de los seres vivos, son las causantes de que la sangre arterial produzca glóbulos, células, fibras y las demás partes de los tejidos.

${ }^{854}$ Ibídem. 
La sangre arterial es el humor nutritivo que, por las transformaciones indicadas, produce glóbulos, células, fibras y las demás partes de los tejidos, mediante las leyes vitales propias de los seres vivientes. La fuerza asimilatriz de estos excede a la descomposición cuando están creciendo: al contrario, domina la última en la vejez; y en el estado adulto ambas fuerzas están equilibradas [..... . $^{855}$

\section{Calorificación}

El autor define el calor animal como «resultado del conjunto de acciones moleculares respectivas a todas las funciones de nutrición y de la influencia del sistema nervioso, demostrada por los trabajos de Chossat y Brodie». «Hay calor animal en todas las partes del cuerpo en que se verifica combustión fisiológica, donde hay oxígeno, cuerpo carburante y materias combustibles que, por él quemadas, producen ácido carbónico, urea y otros productos». 856

La temperatura del cuerpo procede de dos órdenes de causas que obran en sentido contrario: unas, las de combustión, productoras de calor, otras de enfriamiento, como la evaporación del sudor y la radiación del calórico en la superficie del ser. Estas causas, según Pereda, están coordinadas por «la fuerza vital propia de los seres vivientes, junto con la sangre».

Estas causas coordinadas por la fuerza vital propia de las partes vivientes, junto con la sangre, el líquido con más calor que por ellas circula, tiende a equilibrar las irregularidades de temperatura en los órganos, por ser más o menos diatermos o atermos los sólidos y líquidos que los constituyen.

Claude Bernard (1813-1878), estudia y renueva toda la Fisiología: la de los jugos digestivos ante todo, saliva (1847), jugo gástrico (1843), pancreático, etc. Pone de manifiesto el papel del páncreas, en la digestión de las grasas $(1848,1856)$, analiza la digestión de los azúcares, lo cual le lleva a descubrir algo muy importante, la función glucogénica del hígado (1848), así como aislar el glucógeno (1855). Establece la constancia de la dosis de glucosa en la sangre, y cómo las perturbaciones de ese

\footnotetext{
${ }^{855}$ Ibídem, p.37.

${ }^{856}$ Ibídem, p. 38.
} 
equilibrio constituyen la diabetes, (1877), y refuta, mediante experimentos decisivos, las objeciones hechas contra sus conclusiones. La función glucogénica del hígado es el primer ejemplo de las secreciones internas que renovaron, desde entonces, la Fisiología General y la Patología. La glucosa se presenta como el combustible que circula por la sangre y se quema en los tejidos, y es la fuente del calor animal cuyo estudio habían emprendido Lavoisier y Laplace; pero la sede de esta combustión no es el pulmón, como ellos creyeron, sino los diversos tejidos; la sangre, vehículo de la glucosa y del oxígeno, es el regulador del calor animal. ${ }^{857}$

\section{Funciones de reproducción.}

El autor niega la generación espontánea:

Reproduciéndose ciertos animales de un modo no bien conocido, creyéndose por los antiguos y aún por algunos modernos, que existía la generación espontánea, en virtud de la cual las carnes corrompidas, el mantillo y otros productos orgánicos muertos o vivos, podían, bajo la influencia del calor, el aire y el agua, formar seres que no fueran engendrados por otros. La materia muerta y bruta no puede por sí constituir un ser vivo: siempre se engendra y nace de otro ser o seres vivientes; y el ignorarse cómo y de qué manera se reproducen algunos animales y vegetales, son hechos negativos pero no pruebas que demuestren, bajo ningún concepto, las generaciones espontáneas, tanto más disminuyendo el número de especies con reproducción desconocida, desde que la fisiología, auxiliada por medios de investigación más poderosos, confirma que todo ser viviente es producido por otro ser vivo e idéntico en su especie. ${ }^{858}$

Describe a continuación los tres modos de perpetuarse la especie en el reino animal: multiplicación, gemación y generación. De este último estudia la reproducción ovípara, ovovivípara y la vivípara. Con relación al origen de la vesícula germinativa dice que «es esencial materia fecundante y productos aptos de ser fecundados»:

${ }^{857}$ TATON, René Coord. (1973): la Ciencia contemporánea I. El siglo XIX, pp. 427.
${ }^{858}$ Ibídem, p. 39. 
Es esencial para el origen de la vesícula germinativa, materia fecundante y productos aptos de ser fecundados: si ambas sustancias se forman en un individuo, el animal es hermafrodita; siendo formadas en dos individuos distintos se llama sexual, masculino el que tiene órganos que elaboran materia fecundante, femenino aquel donde se hallan órganos (los ovarios) que dan productos aptos de ser fecundados. ${ }^{859}$

\section{Funciones de relación.}

El animal, además de los actos de nutrición y reproducción destinados a conservar el individuo, desempeña otros que sirven para comunicar sus órganos entre sí y con el mundo físico, que le relacionan con los objetos que le rodean. El autor afirma que «el sistema nervioso es el tejido necesario en estas comunicaciones; y para que sean completas es preciso, como en una red telegráfica, que haya centros o estaciones que reciban o hagan partir corrientes, y nervios o hilos que lleven o transmitan estas».

Las funciones de relación, según Pereda son: sensaciones; instintos y facultades intelectuales; actitudes y movimientos; actos de significación; sueño.

El autor describe el sistema nervioso y lo divide en: centro nervioso, nervios y ganglios. Los elementos que constituyen el sistema nervioso son los tubos y las células; estas, esféricas o polares, se hallan en los ganglios respectivos a los nervios de la sensibilidad; y los tubos reunidos constituyen la fibra nerviosa, y estas agregadas entre sí los cordones nerviosos

Pereda considera que la inervación, es un fenómeno fisiológico tan desconocido como complejo y oscuro.

La inervación considerada en su esencia, es decir, en el modo que tienen los nervios de recibir las impresiones o de transmitir la excitación necesaria para el movimiento, es un fenómeno fisiológico tan desconocido como oscuro y complejo: ningún cambio material, ninguna modificación perceptible, se puede apreciar, tanto en los nervios como en los centros nerviosos, cuando están funcionando; y sorprende seguramente ver materialmente ileso tal sistema en sus numerosos desarreglos y en los continuos o temporales desordenes intelectuales. No es menos curioso observar que la sensibilidad de ciertos órganos no corresponde al número y

\footnotetext{
${ }^{859}$ Ibídem, p.40.
} 
volumen de sus nervios, como el que es o llega a ser accidentalmente, muy viva en tejidos donde no se ha confirmado la existencia del sistema nervioso. ${ }^{860}$

Admite las analogías entre la acción nerviosa y la electricidad, pero reconoce que no pueden compararse las fuerzas propias de la vida con las fuerzas físico y químicas:

No es de extrañar, a la vista de estos hechos, que por hipótesis se explique la inervación; y que entre ellas sea muy admitida la de suponer un fluido nervioso, incoercible e imponderable como el eléctrico. Ciertas son las analogías entre la acción nerviosa y la electricidad, cuyos efectos fisiológicos más comunes son dolor y tirantez en las articulaciones, hormigueo en la piel y contracciones, como calambres, en los músculos; pero por ningún concepto pueden ser idénticos fenómenos dependientes, unos de fuerzas propias de la vida, otros de propiedades físicas y químicas. ${ }^{861}$

Diversas son las funciones de inervación en el centro nervioso cerebro-espinal y Pereda reconoce que se ignora los usos que tienen las múltiples y complejas partes de que se compone. Explica las funciones del cerebro, el cerebelo, la médula espinal y el bulbo raquídeo.

[..... el cerebro es el instrumento principal del alma, el encargado de percibir las impresiones y de provocar, mediante la voluntad, los estímulos necesarios para los actos de movimiento o de significación; que el cerebelo sirve, según unos, para regularizar los movimientos, y según otros, es el foco de los instintos de reproducción. La médula espinal, además de su acción propia o refleja, es un centro que recibe y comunica al cerebro las impresiones de los nervios de la sensibilidad, que recibe del cerebro y comunica a los nervios los estímulos de los del movimiento. El bulbo raquídeo, junto con las acciones de la médula, reúne las respectivas a un foco central y regulador de los movimientos respiratorios. ${ }^{862}$

\footnotetext{
${ }^{860}$ Ibídem, p. 46.

${ }^{861}$ Ibídem, p. 47.

${ }^{862}$ Ibídem, p. 47-48.
} 
El autor explica los sentidos y los divide en afectivos e instructivos: «afectivos como el gusto y el olfato, si la impresión da por único resultado placer o dolor; instructivos, como el tacto, vista y oído, si a estos efectos se agrega instrucción y conocimiento».

Pereda, declara que se ignora en gran parte las funciones propias de cada órgano de la audición sobre todo de los receptores de la función auditiva, el llamado órgano de Corti situado en una parte del oído interno, el caracol, que recibe este nombre por ser un tubo enrollado en espiral cónica:

Ignoramos en gran parte las funciones propias de cada una de las partes del órgano de la audición. Está sin embargo, confirmado: $1^{\circ}$. Que la oreja por su forma, desigualdades y elasticidad, reúne las ondas sonoras en un foco que corresponde al conducto auditivo externo; $2^{\circ}$. Que el tímpano, la cadenilla y las membranas respectivas a las ventanas oval y redonda, son susceptibles, por su estructura, de tensión y vibraciones con arreglo a las leyes con que vibran las cuerdas; $3^{\circ}$. Que la trompa de Eustaquio, renovando el aire de la caja, favorece la audición mediante el calor conveniente de dicho gas y a la tensión de este en la cara interna del tímpano, que contrarresta los efectos de la presión atmosférica en la externa; $4^{\circ}$. Que el vestíbulo y los conductos semicirculares favorecen la propagación y dirección de las ondas sonoras mediante los líquidos que contienen, interviniendo su materia caliza en las impresiones acústicas; $5^{\circ}$. Que la compleja y delicada estructura del caracol, el número de fibras de Corti que hay en sus escalas (más de 3000, según algunos) induce a creer que es la parte más esencial del órgano de la audición. ${ }^{863}$

Actualmente se sabe que los receptores de la función auditiva están en el llamado órgano de Corti que se apoya sobre la membrana basilar del caracol. El órgano de Corti presenta una serie de células epiteliales de sostén alargadas entre las que se insinúan las células sensitivas que poseen en su extremo un penacho de cilios, y por el otro establecen conexión con la rama coclear del nervio acústico. Encima de los cilios y casi rozando con ellos se halla la llamada membrana tectoria, que cuando vibra como consecuencia de las ondas sonoras, dobla los cilios de las células sensoriales, desencadenándose así el impulso nervioso auditivo.

${ }^{863}$ Ibídem, p. 56. 
El autor describe la pared del globo ocular formada por tres capas que de fuera a dentro son las siguientes: la esclerótica, la coroides y la retina. En esta última se hallan los receptores visuales, los conos y los bastones; Pereda nombra solo los bastones y no explica su función.

La retina es una cubierta formada por varias capas a cual más delicadas: la exterior, membrana de Jacob o de los bastoncitos, está compuesta por la agregación de infinidad de cilindros perpendiculares al plano de la retina, cuyas extremidades libres figuran mosaico, cual los panales, de superficies capaces de modificarse por la luz de un modo diferente. El nervio óptico, terminación de la retina, que solo se afecta por la acción de la luz, transmite al cerebro las impresiones de las imágenes de los objetos en dicha membrana. ${ }^{864}$

La estructura histológica de la retina es muy compleja, ya que se sabe desde los memorables trabajos de Cajal que está formada por diez capas de células de las cuales las más importantes son cuatro: la más externa está formada por células epiteliales pigmentarias, cuya misión es elaborar un pigmento rojizo llamado «púrpura visual» fundamental para la visión. La segunda capa, situada a continuación de la anterior, está constituida por los verdaderos receptores visuales, que son células de dos clases: los bastones de forma cilíndrica alargada y los conos, menos abundantes y en forma de botella. La tercera capa está formada por células nerviosas bipolares cuyas dendritas se relacionan con los conos y bastones y cuyo cilindroeje lo hace con las células de la siguiente capa. Esta última, formada por células nerviosas multipolares, establece contacto entre sus dendritas y los axones de las células bipolares, y sus cilindroejes se reúnen para formar el nervio óptico. ${ }^{865}$

Describe con acierto la visión practicada con los dos ojos o visión binocular:

La visión sencilla a pesar de ser doble la imagen, una en cada ojo, depende de la coincidencia de la impresión en puntos idénticos de ambas retinas: si no coinciden, como sucede al elevar con los dedos un ojo, aquella se duplica, con la

\footnotetext{
${ }^{864}$ Ibídem, p. 59.

${ }^{865}$ LÓPEZ PIÑERO, José María (2006): Santiago Ramón y Cajal, Universitat de València, p. 269.
} 
particularidad de ir aproximándose ambas imágenes hasta confundirse, aun cuando persista, conforme el órgano se va acomodando al cambio normal del eje visual. ${ }^{86}$

\section{Instintos y facultades intelectuales.}

El autor define los instintos y las facultades intelectuales.

Los sentidos, los nervios y el encéfalo, partes esenciales en las funciones por las que el ser se comunica con el mundo físico, se hallarán orgánicamente en relación con el desenvolvimiento de las facultades intelectuales; y si bien nunca podremos reconocer la esencia de estas por las cualidades propias a la materia componente de dichos órganos, se ha intentado, sin embargo, hacerlo respecto a la cantidad, mediante los medios cefalométricos y los principios frenológicos y craneoscópicos. ${ }^{867}$

\section{Zoografía}

La Zoografía es la parte de la Zoología que tiene por objeto clasificar y describir los animales

El autor adopta la clasificación animal de Cuvier por ser, según dice, la más sencilla y la mejor conocida:

No ignoramos que la clasificaciones adoptadas por Linneo, Blainville, Carus. Lamarck, Milne-Edwars, Bonaparte, etc. son tal vez más naturales, más completas y algunas muy filosóficas. Si preferimos la del célebre naturalista francés es por ser la más sencilla y la mejor conocida, teniendo en cuenta además que en un curso como este lo importante es conocer los grupos principales y los seres más comunes y característicos, objeto que puede cumplirse con cualquiera clasificación. esta tiene mucha importancia cuando estudiando más la ciencia, se quiere investigar el orden natural de relaciones, las afinidades y subordinación entre el mayor número de especies. ${ }^{868}$

\footnotetext{
${ }^{866}$ PEREDA Y MARTÍNEZ, Sandalio (1870): op. cit p. 62.

${ }^{867}$ Ibídem, pp. 63- 64.

${ }^{868}$ Ibídem, p.91.
} 
Expone detalladamente los cuatro tipos de Cuvier. En la explicación de los mamíferos, llama la atención la reseña que inserta de las muertes de animales carniceros ocurridas en aquellos años: «Como prueba de la abundancia de esta y otras especies de carniceros, diremos, según datos oficiales, que en 1864 se mataron en España: 34.725 zorros; 5.394 lobos; 3.488 garduñas; 1915 gatos monteses; 1588 tejones y 953 turones».

Cita los miriápodos como una clase distinta de la de los insectos, y de los zoófitos afirma «que por los progresos de la ciencia se ha demostrado que muchos zoófitos son verdaderos moluscos o articulados»; refiriéndose a los infusorios dice:

El observador puede comprobar en tan diminutos seres la prodigiosa divisibilidad a que llega la materia orgánica viviente; y por poco que reflexione, contemplar las maravillas del Creador en lo pequeño como en lo grande: Magnus in magnis, maximus in minimis. ${ }^{869}$

\section{Botánica}

Pereda tampoco alude a la teoría celular cuando habla de la constitución de las planta, El carbono, el hidrógeno, y el oxígeno son los elementos químicos del vegetal, reunidos los elementos químicos se forman los elementos orgánicos o principios inmediatos, combinados a su vez los elementos orgánicos se forman los tejidos; y estos se reducen a uno solo, el tejido celular.

El tejido celular vegetal, parecido en su aspecto a la espuma del jabón, constituye la trama orgánica de las plantas, observándose en él mediante el microscopio, cavidades circunscritas por paredes propias, y espacios o huecos entre estos colocados. La formas de dichas cavidades, o lo que es lo mismo, las del tejido celular, se pueden reducir a tres: celdillas, fibras y vasos. ${ }^{870}$

Explica que son las celdillas, fibras y vasos:

\footnotetext{
${ }^{869}$ Ibídem, p. 197-198.

${ }^{870}$ Ibídem, p. 202.
} 
Celdillas: Saquillos o vejiguillas esféricas, ovoideas, poliédricas o irregulares, aplicadas más o menos íntimamente entre sí, conforme los tejidos de las plantas sean más o menos duros. Entre las celdillas quedan huecos, que contienen el aire o la savia, denominados espacios intercelulares.

Fibras: son análogas a las celdillas, diferenciándose en su forma, que es prolongada o filiforme, y en ser leñosas sus paredes.

Vasos: tubos membranosos más o menos largos, rara vez ramificados, interpuestos en los tejidos vegetales $[\ldots . . .]^{871}$

Las celdillas, fibras y vasos se unen de manera que siempre hay una comunicación mutua entre estos elementos anatómicos; conteniendo en sus cavidades aire, savia, aceites, resinas, materias colorante verde (clorofila), fécula, sales cristalizadas, etc.

La epidermis de las plantas está formada por tejido celular. La diversa reunión de los tejidos elementales forman los órganos compuestos, cuyo conjunto constituye un vegetal. Este en su primer estado es una celdilla, multiplicada después en otras nuevas en las plantas de sencilla organización, y además en vasos cuando esta es complicada.

Describe los órganos de nutrición y reproducción de los vegetales

El autor añade un cuadro analítico de las funciones de los vegetales:

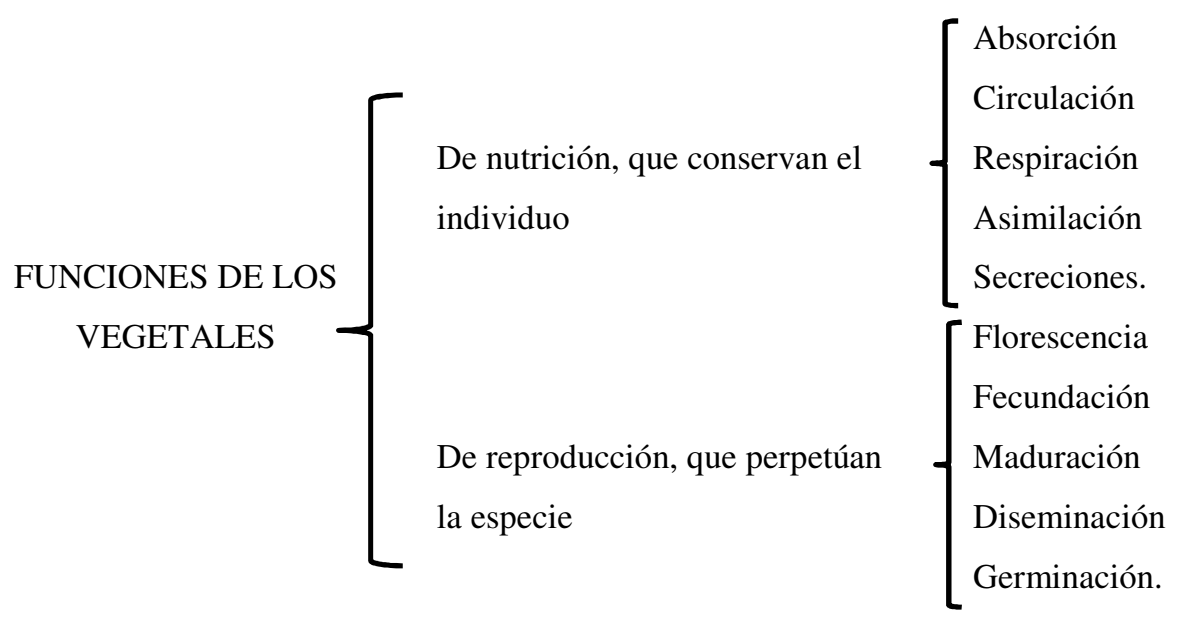

Empieza por explicar la absorción, que según el autor es un acto por el cual los tejidos hacen penetrar en su masa los fluidos con quienes están en contacto. Los tejidos

${ }^{871}$ Ibídem, p. 203-204. 
vegetales, además de chupar líquidos por sus propiedades higroscópicas, pueden absorber, mediante la fuerza ósmica. Las plantas, mediante la osmosis, pueden absorber los líquidos que los rodean, una vez que estos son más fluidos o menos densos que los contenidos entre las mallas de sus tejidos

No hay en las raíces la propiedad de elegir determinadas sustancias, pues estas penetran indistintamente con tal de que queden disueltas. El agua, aire y ácido carbónico, los fosfatos alcalinos disueltos por este ácido, las sales amoniacales y combinaciones minerales solubles, son los productos habitualmente absorbidos; tanto el mantillo, como el humus o tierra vegetal y la atmósfera, son manantiales de donde las plantas sacan las grandes cantidades que consumen de carbono y nitrógeno.

El líquido absorbido por un vegetal, y que recorre sus tejidos, llamado savia, es puesto en movimiento mediante la circulación, Pereda explica que el ascenso de la savia se verifica, a través del tejido celular, por la albura o madera nueva y por las partes tiernas del vegetal. Modificada la savia ascendente, mediante los fenómenos de la respiración, se convierte en savia elaborada o savia descendente.

Explica muy someramente la respiración de las plantas diciendo que es distinta según se verifique de día o de noche. «Las partes no verdes durante el día y la noche, absorben oxígeno y exhalan ácido carbónico. Las partes verdes, durante la noche, absorben oxígeno y exhalan ácido carbónico, y durante el día descomponen el ácido carbónico, exhalando su oxígeno y apropiándose el carbono».

\section{Higiene}

La higiene comprende 60 lecciones, (de la 36 a la 60), en las cuales, en la introducción, se define la misma con una reseña histórica y explica los caracteres más comunes de un estado de salud. Siguiendo el plan de Halle, hace dos secciones: $1^{\mathrm{a}}$. Sujeto de la Higiene; $2^{\text {a }}$. Objeto de la Higiene.

En la sección primera estudia las modificaciones que obran, en el hombre, según las condiciones siguientes: raza, sexo, edad, temperamento, naturaleza o constitución, idiosincrasia, herencia, hábitos, profesiones. Comprende la sección segunda el estudio de los agentes que intervienen en la salud. 


\section{Introducción}

El autor define la higiene «como la ciencia que tiene por objeto conservar la salud. Como ciencia investiga las causas, como arte da reglas para evitar las dolencias que afligen al hombre».

Pereda, afirma que la higiene es muy diferente de la medicina: «esta cura la enfermedad, aquella la previene: el objeto de la primera es el hombre sano, el de la segunda el hombre enfermo».

Divide la higiene en privada y pública. Cada una se divide respectivamente en higiene de la infancia, de la mujer, de los viejos, etc., rural, urbana, industrial, naval, militar, etc. «según sus especiales aplicaciones».

En la reseña histórica, resalta la importancia que la higiene ha tenido y tiene en todas las legislaciones dictadas para el gobierno de los pueblos, haciendo especial hincapié en la importancia que las leyes del Evangelio tienen para el bienestar físico y moral del hombre:

La importancia de la higiene se reconoce en todas las leyes dictadas para el gobierno de los pueblos, en los antiguos como en los modernos tiempos. Ya la mitología llamó Higia a la salud, suponiéndola hija de Esculapio y Lampecia, adorándose su estatua cubierta de ancho velo, coronada de yerbas y con una copa en la mano. En los libros de Moisés (el Deuteronomio y el levítico en particular), en el Eclesiastés, en los Proverbios, se hallan un sin número de preceptos higiénicos, como en los de Zoroastro, Confucio y el Coran. No pocos hay en las leyes de Solon para Grecia, en las dictadas por Licurgo para formar el aguerrido y varonil pueblo espartano, en las de roma durante sus reyes, cónsules, tributos, decemviros, triunviratos y emperadores. El cristianismo regenerando el mundo con las divinas leyes del evangelio, proclamando la unidad de la especie humana, elevando a preceptos consejos higiénicos aplicables a toda la humanidad, en todos los climas y condiciones, anatematizando el vicio, fuente de enfermedad, enalteciendo la virtud, foco de donde irradia la salud, reformó las costumbres y fomentó en el hombre los más puros sentimientos, las más nobles aspiraciones para su bienestar físico, moral e intelectual. $^{872}$

${ }^{872}$ Ibídem, p.369-370. 
Para el autor «la sanidad del cuerpo representa un estado de concierto, armonía y equilibrio de las funciones, de actividad en el organismo, que no es posible definir, pero que de todos es conocido». No hay un tipo real y absoluto de salud: siempre es relativo con las condiciones de los individuos:

Así vemos estados de salud muy diferentes: coincide en unos con naturaleza fuerte y robusta, en otros delicada y floja; y mientras los primeros por causas leves pierden a veces la salud, no pocos endebles poseen un temple orgánico, un grado de resistencia tal, que resisten impunes agentes insalubres, y débiles, como achacosos, alcanzan longevidad $[\ldots . .]^{873}$

Pereda clasifica los caracteres más comunes de un estado de salud:

$1^{\circ}$. Armonía de los órganos con el temperamento, la edad y el sexo; $2^{\circ}$. Ordenada y regular sucesión de las funciones; $3^{\circ}$. Relación entre los productos absorbidos y los segregados; $4^{\circ}$. Sueño tranquilo y reparador de las fuerzas gastadas por el ejercicio; $5^{\circ}$. Íntegro uso de los sentidos y sensaciones internas. ${ }^{874}$

Tiene un concepto positivo de salud, no es solo ausencia de enfermedad sino que a su vez, es fuente de bienestar individual y social: «La salud es fuente de donde mana alegría y bienestar para el individuo, fomento, paz y trabajo en la familia, bienes físicos y morales en los pueblos; con razón fundada dicen los ingleses: salud nacional es riqueza nacional». ${ }^{875}$

\section{Sección I}

\section{Sujeto de la Higiene}

Los modificadores de la raza humana son, según Pereda: la raza, sexo, edad, temperamento, naturaleza o constitución, idiosincrasia, herencia, hábitos, profesiones.

\footnotetext{
${ }^{873}$ Ibídem, p. 370.

${ }^{874}$ Ibídem.

${ }^{875}$ Ibídem.
} 


\section{Raza}

La raza, según el autor, «son a la especie humana lo que a la constitución al individuo: sus diferencias cefalométricas de color y formas significan un conjunto de modificaciones exteriores e internas, la acción del clima, el sello de la herencia, estados sociales, políticos y religiosos de nacionalidades».

\section{El sexo}

Los autores de los libros de texto que analizamos sostienen que la acción de los modificadores higiénicos es distinta en el hombre y en la mujer, y esta diversidad nace de las diferencias que existen entre ambos sexos: la constitución física, la sensibilidad y la misión de cada sexo

Sandalio de Pereda señala que el desarrollo físico y moral de las niñas se adelanta al de los niños. Cuando los niños y niñas alcanzan la pubertad la diferencia es radical: «En el hombre se significa la fuerza, en la mujer la delicadeza y blandura. Cada sexo se distingue por su respectiva belleza, en la mujer las formas de la Venus de Médicis, en el hombre las de Apolo de Belveder». ${ }^{876}$

La mujer es considerada más sensible, imaginativa y expresiva, las edades más tempranas: «La sensibilidad en la mujer es más exquisita, la imaginación veloz, el lenguaje más expresivo, mayor perspicacia. En el sexo masculino las edades son más tardías y graduadas, en el femenino menos regulares y más precoces».

Los desarreglos de la sensibilidad son más comunes en la mujer y la afectan de manera diferente las lesiones orgánicas:

Un disgusto, una conmoción, olores fuertes, temperaturas extremadas y desapacibles, etc., la afectan más que al hombre, mientras éste padece más a menudo de lesiones del sistema circulatorio, de la respiración y muscular. La resistencia a los agentes exteriores es mayor en la mujer que en los hombres; la mortandad, las epidemias alcanzan comúnmente más a los segundos que a las primeras. ${ }^{877}$

${ }^{876}$ Ibídem, p. 372.
877 Ibídem. 


\section{Edad}

\section{Infancia}

El frío, las variaciones de la temperatura, los abusos de la alimentación, la lactancia mercenaria, el abandono o cuidados imprudentes de los padres, son causas de los desarreglos de la salud, y que ocasionan, según el autor, una mortalidad horrorosa en la infancia, «tal que en España en 1864 fue desde el nacimiento hasta el primer año de 1 por 5,07 y desde igual época a los 5 años de 1 por 2,3, lo cual equivale respectivamente a 20 o 40 defunciones por cada 100 nacimientos».

Pereda recomienda que el régimen lácteo deba ser único en los primeros meses de la vida, pudiéndose agregar al cuarto o quinto mes otros alimentos. Hace hincapié en el deber de las madres de criar a sus hijos:

No hacerlo así, entregar ésta a nodrizas que al fin y al cabo descuidan una obligación propia por el aliciente de la ganancia, es ocasionar a los niños numerosos males, es no fomentar en su origen el amor materno, tan puro como previsor, lleno de sacrificios y molestias, pero también de emociones y sentimientos que ennoblecen a la mujer. ${ }^{878}$

Resalta la obligación de la mujer como educadora de sus hijos y ángel del hogar:

Una madre prudente y cariñosa dirige mejor que nadie la educación de estos: de ella depende el medro de los hijos, sus costumbres, gustos e inclinaciones. Cuidar al hombre cuando es niño, formar su corazón y aconsejarle cuando es mozo, dar consuelos y cubrir de flores el camino de la vida es la obligación de la mujer. ${ }^{879}$

\section{Puericia}

Comprende el periodo que media desde la segunda dentición hasta la adolescencia. A los cuidados higiénicos respectivos al organismo, el autor, añade los de

${ }^{878}$ Ibídem, p. 374.

${ }^{879}$ Ibídem. 
instrucción, esta debe siempre ser arreglada al desarrollo físico, como debe también variar en las niñas «conforme a su distinta organización, diversas facultades y destinos».

\section{Adolescencia}

Comprende desde los 13 o 15 años hasta los 21024 en cuyo término comienza la mayoría de edad. La higiene, en tal edad, se dirige especialmente a procurar el desarrollo orgánico y afectivo.

La higiene en esta etapa se dirige además de procurar el desarrollo orgánico y afectivo, a evitar que los vicios germinen:

La higiene en tal edad se dirige especialmente a procurar que unido vaya el incremento orgánico con el desarrollo de los afectos, a evitar que los vicios germinen y crezcan en un organismo débil, a oponer, con un cuerpo robusto, muro firme que, bajo la égida de la Religión y la moral, resista al embate de las pasiones $[\ldots$.

Las indisposiciones de la infancia desaparecen en la adolescencia, pero en cambio se adquiere predisposición a enfermedades graves, que por lo común corresponden al pecho, como la tisis, hemorragias pulmonares y lesiones del corazón, etc. $^{880}$

\section{Virilidad}

Completa el desarrollo físico en el hombre a los 22 o 25 años, en la mujer a los 20 o 22 años. Pereda, describe las divisiones de la virilidad que hizo Hallé: virilidad creciente, confirmada y decreciente. La virilidad confirmada es el tipo al cual se ajustan los preceptos higiénicos generales.

\section{Vejez}

El autor dice que «esta edad es el invierno de la vida, comprende tres periodos: vejez incipiente, de los 60 a los 70 años; vejez confirmada, hasta los 80 años;

\footnotetext{
${ }^{880}$ Ibídem, 375.
} 
decrepitud, de los 80 hasta la muerte senil». La vejez incipiente, según dice el autor, «es la edad del viejo verde porque se conservan gustos, costumbres e inclinaciones de las precedentes, pero sin fuerzas y robustez suficientes para satisfacerlas sin daño».

En la vejez se recoge lo que se ha sembrado en épocas anteriores, Pereda dice que las molestias de esta son tanto menores cuanto antes anticipemos las costumbres y vida propias de la senectud; y añade este proverbio «quien quisiere ser mucho tiempo viejo, comiéncelo presto».

Los preceptos higiénicos principales de esta edad tienen por objeto:

Reanimar las fuerzas con aire puro, ejercicio moderado, tranquilidad y alimentación suficiente, evitando los excesos de la gula; respetar los hábitos inveterados, precaverse del frío y la humedad, y de los cambios repentinos en la atmósfera, consejos que Reveille-Parise reduce a esta cuatro reglas: $1^{\circ}$. Saber ser viejo; $2^{\circ}$. Conocerse bien a sí mismo; $3^{\circ}$. una vida arreglada; $4^{\circ}$.combatir, desde su comienzo, cualquier enfermedad. ${ }^{881}$

Como resultado de la mayor o menor duración de las edades del hombre. El autor hace unas consideraciones sobre la longevidad; y a «esto se dirige la Macrobiótica, o arte de prolongar la vida, objeto esencial de la higiene».

\section{Longevidad}

La longevidad se puede considerar bajo dos conceptos, colectivo uno, individual el otro. Las personas alargan su vida si observan los preceptos higiénicos, ayudadas por la herencia recibida. El autor afirma que la longevidad es más larga en la mujer que en el hombre, en las zonas templadas que en las frías; la indigencia como la riqueza, las profesiones y oficios, las costumbres, la vida en el campo o en la ciudad, son también causas que intervienen directamente en la longevidad individual. En la longevidad colectiva, objeto de la Demografía, hay que tener presentes: la mortalidad, la vida probable y la vida media.

El autor dice que las causas principales que aumentan la mortalidad son:

${ }^{881}$ Ibídem, p. 376. 
La carestía y alto precio de los alimentos, las epidemias, los pantanos, las industrias insalubres, el exceso de población en pueblos y habitaciones reducidas, la desigualdad del temple atmosférico por frío, calor o humedad, la guerra, los trastornos políticos, etc. ${ }^{882}$

En España en aquellos años, según Pereda, la mortalidad por término medio era muy alta, de 1 por 34, frente a Francia que era de 1 por 42 e Inglaterra de 1 por 52.

Pereda, añade una tabla que indica que de 1000 nacimientos, en España («según datos estadísticos publicados»), la longevidad, como el número de defunciones era por término medio como sigue:

De 1000 nacidos al cabo de 1 año existen 782; al cabo de 5: 525; de 10: 477; 20: 431; 30: 374; 40: 284; 50: 255; 60: 186; 70: 97; 80: 31; 90: 4; 100: 1.

El autor define la vida probable ${ }^{883}$ y Vida media ${ }^{884}$, y explica que el aumento de población estriba en el mayor número de años que alcanza la misma en los individuos; «siendo esta el mejor dato para conocer el mejoramiento de los pueblos, los resultados de las influencias higiénicas»:

Estas causas, como la de mortalidad que hemos señalado, son las que cambian la vida media: desde el siglo XVI, que era de 18 años y medio, ha crecido hasta ser casi doble en el actual; elevándose a 35 años en Prusia, 34 en Francia, y a poco más de 29 en España, alcanzando 31 años en algunas zonas septentrionales en nuestro país. $^{885}$

\section{Temperamentos}

Las diferencias individuales, compatibles con la salud, que resultan del predominio de los sistemas o aparatos orgánicos determinan el temperamento:

\footnotetext{
${ }^{882}$ Ibídem, p. 377.

${ }^{883}$ Es la edad en que cierto número de individuos, nacidos al mismo tiempo, se encuentran reducidos a la mitad.

${ }^{884}$ La Vida media resulta de un cociente cuyo dividendo es la suma de años que, en un periodo dado, han vivido cierto número de individuos y el divisor total de estos. Si 100 personas, por ejemplo, vemos en una tabla de mortalidad, que le corresponde la suma de 3100 años, su vida media será 31 años =3100/100.

${ }^{885}$ Ibídem, p.380.
} 
Tal predominio, considerado sea en materia o actividad, corresponde a diversas partes: $1^{\circ}$. Al sistema vascular, temperamento sanguíneo; $2^{\circ}$. A los nervios $\mathrm{y}$ sus centros, temperamento nervioso; $3^{\circ}$. Al aparato digestivo, temperamento bilioso; $4^{\circ}$. Al sistema absorbente, temperamento linfático. ${ }^{886}$

El temperamento sanguíneo, según Pereda, es el que está más en armonía con la salud, aun cuando predisponga a enfermedades del sistema vascular. Es de gran imaginación, tan apasionado como voluble. El temperamento atlético es una variedad del sanguíneo en que predomina el sistema muscular, «con frecuencia a expensas de la sensibilidad y de las facultades intelectuales».

El temperamento nervioso, según el autor, se manifiesta por una sensibilidad exquisita, más subjetivos que objetivos, les interesa más las bellas artes que las ciencias de observación; predomina en las profesiones literarias que en las mecánicas, y las enfermedades dominantes son las relacionadas con los desórdenes de la inervación, o con excesos del placer o del dolor.

Rostro pálido, ojos brillantes, mirada viva, músculos pequeños y bien torneados. Sensibles y exagerados, ávidos de emociones ideales, lo subjetivo les agrada más que lo objetivo, las bellas artes, la música, la poesía encuentran en ellos mejor acogida que las ciencias de observación según dice Pereda, en las mujeres es común que esté unido al linfático. Predomina más en los cortesanos que en los labriegos, en las profesiones literarias que en las mecánicas; predisponiendo a numerosas enfermedades, cuyo origen se enlaza a desordenes de la inervación, o con excesos del placer o del dolor.

Las pasiones en los biliosos son grandes y vehementes; más dispuestos para las ciencias abstractas que a las estéticas. Ester temperamento es habitual en los grandes hombres

Los linfáticos llamados también flemáticos, son de escasa imaginación y memoria frágil. Este temperamento degenera en obesidad con el aliciente de la gula. El temperamento linfático predispone a enfermedades escrofulosas y humorales.

${ }^{886}$ Ibídem, p. 381. 


\section{Herencia}

El autor habla de la herencia y le produce admiración la transmisión de los caracteres permanentes e inmutables de la especie:

En esta sucesión, admirable siempre como incomprensible, ¡ $\tan$ misteriosos son los arcanos de la generación! Hallamos unas veces la acción directa, paterna o materna, de los progenitores, otras la indirecta de los abuelos, ya la colateral por ambas líneas. ${ }^{887}$

Pereda explica que heredamos modificaciones compatibles unas veces con la salud, pero no pocas nos predisponen a sufrir un gran número de enfermedades: [...] alteraciones en los humores, la tisis, la gota, el cáncer, las escrófulas, desarreglos de la inervación, etc. son afecciones que llevan «el triste privilegio de sucederse en las familias».

Heredamos la belleza, fuerza física e inteligencia, pero también se sustraen a la herencia los atributos más elevados de espíritu: «El genio, como dice, Lordat, es célibe e inclusero: muy común es que los hijos no alcancen o sobrepujen el talento de los padres, cual raro que las cualidades de estos sean todos iguales en aquellos. El hijo de Cicerón y los de Pericles fueron unos necios».

\section{Hábitos}

Los hábitos siempre imperan en nosotros, $\mathrm{y}$ de tal modo que se convierten a veces en verdaderas necesidades. El autor afirma que «adquirir los menos posibles y fomentar los hábitos buenos, siempre es norma de la moral y de la higiene». De los buenos hábitos depende en gran parte la salud.

${ }^{887}$ Ibídem, p. 385. 


\section{Profesiones}

La ocupación diaria del hombre tiene una gran influencia en la salud: «La ocupación habitual del hombre influye directamente en su organismo: la conservación de la salud se halla unida a su modo y manera de vivir; siendo consecuencia del hábito la acción que en las personas tienen las profesiones u oficios».

Pereda, inserta la tabla de las profesiones con relación al trabajo y a la higiene de Descuret; «las profesiones se pueden comprender en dos grupos: $1^{\circ}$. Las que ejercitan el ingenio (profesiones liberales); $2^{\circ}$.las que ejercitan el cuerpo (profesiones mecánicas)»:

El literato y el labrador son respectivamente ejemplos de dichos grupos, siendo las más convenientes para la salud aquellas en que a la vez existen ambas clases de ejercicios. En cada profesión suele haber diversas modificaciones, cualidades, defectos, ventajas e inconvenientes. ${ }^{888}$

\begin{tabular}{|l|l|l|}
\hline & LITERATOS & LABRADORES \\
\hline CUALIDADES & Benignos, generosos, afables. & $\begin{array}{l}\text { Amor a la familia y al trabajo, } \\
\text { sobriedad. }\end{array}$ \\
\hline DEFECTOS & $\begin{array}{l}\text { Orgullo, envidia, murmuración, } \\
\text { intemperancia, lujuria. }\end{array}$ & Astucia, desconfianza, rusticidad. \\
\hline VENTAJAS & Placeres del espíritu, independencia. & Salud, alegría, longevidad. \\
\hline INCONVENIENTES & $\begin{array}{l}\text { Crítica, enfermedades del cerebro y de las } \\
\text { entrañas, propensión a la melancolía. }\end{array}$ & $\begin{array}{l}\text { Resabios, daños del tiempo, } \\
\text { reumas, lesiones físicas. }\end{array}$ \\
\hline
\end{tabular}

\section{Sección II.}

\section{Objeto de la Higiene}

Corresponde a esta sección el estudio de los agentes que intervienen en la salud; el autor inserta un cuadro analítico donde están comprendidos aquellos en seis grupos:

${ }^{888}$ Ibídem, p. 387. 


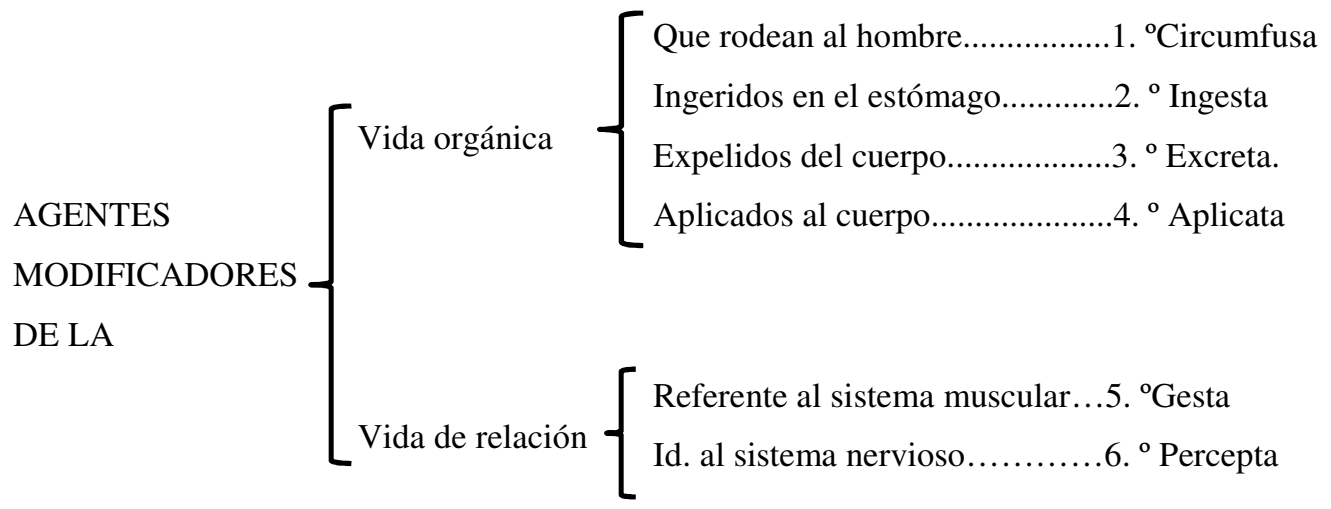

\section{Circumfusa}

Cuando rodea al hombre e influye en su salud comprende órdenes diferentes de causas, según se indica a continuación:

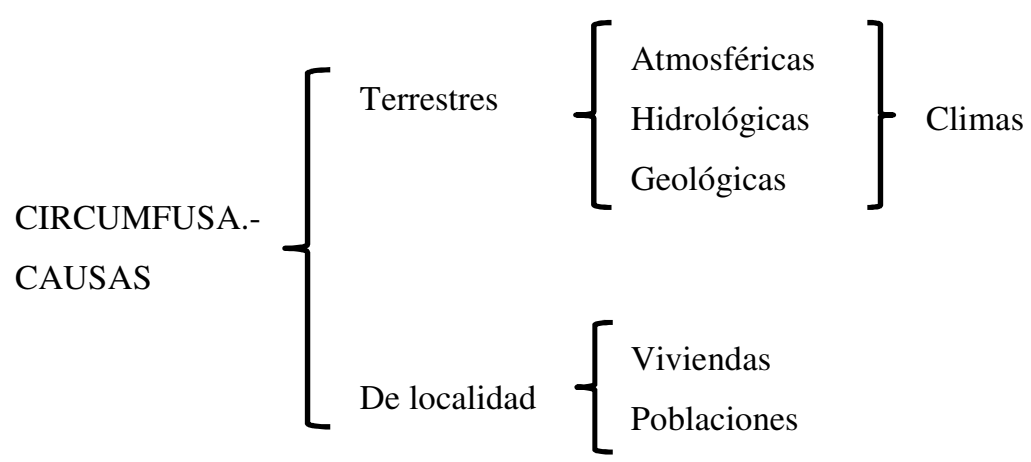

Las causas atmosféricas se refieren al calor, la electricidad, la luz y el aire. En la influencia de este distingue acciones físicas y químicas: a las físicas corresponde los efectos de la presión, de los vientos y de la humedad; a las químicas los que resultan: $1^{\circ}$. Del aire puro; $2^{\circ}$. Del aire viciado o impuro

Pereda explica los efectos de todos estos agentes, y hace especial hincapié en los del aire

Afirma que los efectos del aire imprimen huella en el organismo, influyen directamente en la salud porque son continuos y constantes, «porque alcanzan más pronto y de un modo más inmediato que los de la alimentación, a los elementos constitutivos de la sangre». Establece diferencias en la respiración del aire en el pobre y el rico y dice que la salud de este último resulta más dañada por inspirar aire viciado:

El pobre y desvalido suele respirar buen aire y comer mal: el rico, al contrario, come bien y respira aire impuro; y si comparamos en ambos los resultados, veremos que la salud del último es más quebrantada que en el primero, 
siendo los daños orgánicos mayores y más rápidos en quien inspira un aire viciado que en aquél cuya alimentación es insuficiente en cantidad y calidad. ${ }^{889}$

El aire, según el autor, se puede alterar: $1^{\circ}$. Por desproporción entre los elementos que lo compone; $2^{\circ}$. Por adición de principios químicamente definidos; $3^{\circ}$. Por adición de principios no definidos químicamente.

En el aire viciado por principios no definidos químicamente, explica los principios que dañan el organismo, inapreciables por el análisis químico que comprenden: $1^{\circ}$.las emanaciones de aguas estancadas; $2^{\circ} .10 s$ productos de fermentaciones pútridas, $3^{\circ}$. Los miasmas específicos.

La causa de que las enfermedades surgían como consecuencia de misteriosas influencias externas fue atribuida durante largo tiempo a una alteración del aire, a cuyas desconocidas impurezas se aplicó el nombre de miasmas. Algunas dolencias que solamente se desarrollaban en determinados lugares, como el paludismo, por ejemplo, se achacaron a la acción de ciertos miasmas que en forma de vapores emanaban de las aguas estancadas. El concepto de miasma era completamente arbitrario, pero no el de contagio, con el cual se expresaba la posibilidad de que una substancia segregada de un organismo enfermo podía producir la misma enfermedad en un individuo sano al pasar al cuerpo de éste. Admitiendo la existencia de tales substancias se trató de explicar el fenómeno de la infección. El pus y otros líquidos orgánicos fueron considerados como portadores de las substancias contagiosas. La idea de que muchas enfermedades podían ser provocadas por diminutos e invisibles seres fue expresada ya en el siglo I a. J.C. por Varro; pero fue Henle quién en 1840, observando principalmente en el organismo humano la facultad que las supuestas sustancias contagiosas tienen de crecer, dedujo la clara conclusión de que la sustancia contagiosa es una materia dotada de vida individual que puede reproducirse a la manera como lo hacen las plantas y los animales, multiplicarse por asimilación de sustancias orgánicas, y que vive parásita en el organismo enfermo. La primera demostración directa (por observación del microscopio) de la existencia de bacterias en el organismo enfermo se logró en 1855 en un caso de carbunco, enfermedad maligna del ganado vacuno, carneros cerdos, caballos, etc., que puede transmitirse al hombre; pero el descubridor de estos gérmenes, el veterinario

\footnotetext{
${ }^{889}$ Ibídem, p.389.
} 
Pollender, comenzó por hallarlos únicamente en la sangre de animales muertos a consecuencia de la enfermedad. Mas cuando fueron descubiertos también en animales enfermos todavía vivos y se logró transmitir la enfermedad a individuos sanos inyectándoles sangre de reses enfermas, surgió la idea de que el bacilo en cuestión era realmente el agente productor de la dolencia. Pero la prueba no era decisiva, lo cual dio pie a los adversarios de la teoría para afirmar que las bacterias representaban elementos accesorios de la enfermedad y que, además de ellas, debía existir en la sangre una sustancia especial, un veneno, por ejemplo. ${ }^{890}$

A todas estas dudas puso fin Louis Pasteur y Robert Koch.

Louis Pasteur, a partir de 1866, poco antes de ser nombrado profesor de química de la universidad de Paris, se dedicó a investigar la etiología microbiana en enfermedades contagiosas de los animales, entre ellas las del gusano de seda, el cólera de las gallinas y el carbunco de los óvidos, y, desde 1875, en las padecidas por el organismo humano. Descubrió el estafilococo en el pus de los forúnculos y en los focos de la osteomielitis, el estafilococo en la fiebre puerperal y el vibrión séptico anaerobio (Clostridium septicum) en algunos casos de septicemia.

Desde 1881 hasta 1886, Pasteur se dedicó a resolver el problema de la rabia. Con Chamberland, Roux y Thuillier, confirmó que el virus de la rabia se propaga a lo largo de los nervios del miembro mordido y llega al sistema nervioso central; elaboró la inoculación de médula rábica y practicó el primer tratamiento el 6 de julio de 1885, con el joven alsaciano Joseph Meister. A fines de 1885 había tratado 350 casos de rabia, con una sola muerte. Aunque al final de su vida le fue imposible aislar el agente etiológico de la rabia, cuya condición de virus se comprobó más tarde, consiguió obtener la vacuna antirrábica. $^{891}$

Robert Koch (1876) cultivó el agente patógeno del carbunco en caldo de carne. La cantidad de sangre infectada que se introducía en el líquido de cultivo era pequeñísima, y además se diluía extraordinariamente al practicar repetidas infecciones en nuevas porciones de líquido nutritivo (caldo de carne), hasta el punto de que podía considerarse prácticamente como inexistente. No obstante, los cultivos conservaban la facultad, no debilitada, de producir el carbunco en un animal sano. Koch descubrió

\footnotetext{
${ }^{890}$ KRAEPELIN-SCHÄFFER. (1942); Curso y prácticas de Biología. Para uso de las Escuelas superiores y para la Enseñanza autodidáctica, Labor, Barcelona, pp. 266-267.

${ }^{891}$ LÓPEZ PIÑERO, José .María. (2002); La medicina en la historia, La Esfera de los Libros, Madrid, p. 536.
} 
además que el bacilo del carbunco era capaz de formar esporas muy resistentes cuando se hallaba en presencia del oxígeno atmosférico.

La segunda enfermedad en que se logró poner de manifiesto la existencia de un agente patógeno determinado fue la tuberculosis. Ya en 1865 había demostrado el francés Villemin que esta dolencia es de naturaleza infecciosa, mientras que hasta entonces se había creído en su carácter constitucional, es decir, se había atribuido a condiciones innatas del organismo. Esta demostración se llevó a cabo observando la aparición de la enfermedad en conejos a los que se había inyectado el contenido de tubérculos pulmonares de individuos tuberculosos. Robert Koch descubrió en 1882 que la coloración con azul de metileno es un medio seguro para la demostración de bacilos tuberculosos en los tejidos. Más adelante consiguió preparar cultivos puros del mencionado germen patógeno e inyectando una porción de estos cultivos en cobayas, provocar la tuberculosis en estos animales. Con ello quedó descubierta la causa de la temible enfermedad infecciosa a consecuencia de la cual, «conforme enseñan las estadísticas (dice el propio Koch), mueren la séptima parte de los seres humanos». ${ }^{892}$

En la lucha contra los gérmenes patógenos se destacan por su importancia los métodos curativos y preventivos que colectivamente se designan con el nombre de vacunas. La más antigua de las vacunas es la de la viruela. Esta vacuna se comenzó a practicar en 1796, es decir, en una época en que todavía no se sabía nada acerca de los gérmenes productores de enfermedades.

La historia de la vacuna antivariólica comienza mucho antes de 1796. De antiguo se practicaba un método de vacunación, ideado en oriente, que se apoyaba en las siguientes observaciones: $1^{\mathrm{a}}$. Que existen epidemias de viruela leves, seguidas de pocos casos mortales, así como también epidemias graves; 2. a, Que las personas que habían padecido una vez la enfermedad casi nunca la contraían por segunda vez; 3. a, Que incluso la afección variolosa de carácter leve basta para impedir un segundo ataque de la misma dolencia. Como además se comprobó que eran muy escasas las personas respetadas por la viruela, cada cual deseaba padecer la enfermedad en su forma leve; ésta fue la causa de que se comenzase a practicar una vacunación, que se realizaba con éxito, aun cuando no dejaba de ser peligrosa, consistente en depositar en una herida de la piel de un individuo sano el contenido de pústulas variolosas de un enfermo leve.

${ }^{892}$ KRAEPELIN-SCHAFFER. Op. cit., pp. 267-268. 
Este procedimiento primitivo fue objeto, a partir de 1796, de un perfeccionamiento radical sugerido por la observación de que en las ubres de las vacas aparecen a veces unas pústulas semejantes a las variolosas y que la persona encargada de ordeñar a estas vacas, si se infectaba con tal "viruela-vacuna" quedaba libre del ataque de la viruela humana. El médico inglés Jenner llevó a cabo en 1796 un experimento en grande: aplicó a la piel de un muchacho el líquido procedente de la viruela-vacuna, lo que motivó la aparición en aquella de las pústulas correspondientes, y entonces Jenner vacunó a 15000 personas con la linfa obtenida de dichas pústulas. Cuando ulteriormente aplicó a 5000 de estos individuos, líquido de auténtica viruela humana, ninguno de ellos contrajo la enfermedad. ${ }^{893}$

Durante el último cuarto del siglo XIX y los primeros lustros del XX fue descubierta la mayoría de las bacterias patógenas, principalmente por miembros de las escuelas de Pasteur y de Koch. En este terreno significó una novedad cualitativa la comprobación de la existencia de otros microorganismos que no eran visibles con el microscopio óptico y atravesaban los filtros de porcelana porosa, por lo que fueron llamados virus filtrables. El primero de ellos, el causante del mosaico del tabaco, lo dio a conocer en 1892 el botánico ruso Dimitri A. Ivanovski. Con la excepción de los más grandes, como el de la vacuna, no fueron visualizados hasta la invención del microscopio electrónico. ${ }^{894}$

En 1865, en el diccionario de Littré y Robin, se lee que el virus no existe como cuerpo ponderable o aislable, que solamente existen estados virulentos de los humores o tejidos cuando han sufrido una modificación hasta ahora desconocida por catálisis isomérica

De Vauréal, los define como: fermentos específicos que determinan enfermedades, y que se caracterizan por ser fácilmente inoculables mediante humores o productos patológicos extraídos del organismo infectado ${ }^{895}$

Las emanaciones palúdicas (efluvios), según Pereda, son las que más daños ocasionan al hombre, «teniendo en cuenta cuanto abundan las charcas, lagunas, pantanos y otros depósitos de aguas estancadas y aún corrientes, de las que se desprenden las indicadas emanaciones».

\footnotetext{
${ }^{893}$ Ibídem, pp. 270-271.

${ }^{894}$ LÓPEZ PIÑERO, José María (2002), op. cit., p.538.

895 GIORDAN, A; RAichVARG, D; Drouin, J. M.; GAgliardi, R; CANAY, A. M. (1988); Conceptos de Biología. 1. La respiración. Los microbios. El ecosistema. La neurona. Labor, Madrid. pp. 104-105.
} 
Estas alteran lenta, gradual y profundamente el organismo; y si agregamos tales daños a los de la edad, los trabajos excesivos y una alimentación insuficiente, tendremos causas poderosas de despoblación y de enfermedades, como de que disminuya la vida media de un país. ${ }^{896}$

Hace referencia a las condiciones necesarias para la existencia de miasmas palúdicos y a la posibilidad de que estas dependan de un veneno producido por animales microscopios.

Las condiciones necesarias para la existencia de miasmas palúdicos en la atmósfera (malaria) son productos vegetales muertos sumergidos en agua pura o salobre y acción del aire con temperatura elevada. Es opinión muy admitida que dependen de un veneno producido por animales microscopios abundantes en la fermentación de las materias pantanosas. ${ }^{897}$

El descubrimiento de la naturaleza del paludismo y del mecanismo de su transmisión fue el resultado de una larga serie de trabajos que van desde la primera observación del hematozoo en la sangre de un palúdico por Laveran (1880), hasta el reconocimiento definitivo por G.B. Brassi (1898) de la transmisión del agente de la malaria por mosquitos del género Anopheles. Este descubrimiento iba a tener consecuencias de trascendental importancia en la lucha contra la malaria, en la cual tomaron predominante parte los científicos italianos. ${ }^{898}$

Da consejos para evitar los miasmas:

Dar curso corriente a las aguas; desecar los charcos, lagunas, pantanos, etc., o hacer, si esto no es posible, que siempre estén anegados; evitar la mezcla, siempre perjudicial, de aguas pluviales con las saladas; hacer plantaciones convenientes;

\footnotetext{
${ }^{896}$ PEREDA Y MARTÍNEZ, Sandalio (1870): op. cit. p. 396.

${ }^{897}$ Ibídem.

${ }^{898}$ TATON, R. (1973): La Ciencia Contemporánea.1. El siglo XIX. Vol. 3. Destino, Barcelona. pp. 649650.
} 
regularizar el trabajo de modo que no sea excesivo ni se verifique en las horas del día en las cuales el aire es más frío [.... ${ }^{899}$

Emanaciones pútridas. Con este nombre designa el autor, «ciertos productos diseminados en el aire, resultado de transformaciones moleculares orgánicas o fermentos que se forman bajo la acción de la vida de los infusorios»; y cita los materiales antisépticos más importante:

El cloro, las sales de cobre, zinc, plomo, y plata, el ácido arsénico y el fénico, deben la cualidad de antipútridos o antisépticos a su afinidad con el hidrógeno y las materias amoniacales, a la propiedad de destruir los infusorios que pululan en los productos de la putrefacción. ${ }^{900}$

Los miasmas específicos son para el autor: «Las partículas materiales que, procedentes de un enfermo, se transmiten por el aire a otro individuo sano, determinando en este una enfermedad análoga a la del primero».

Establece las diferencias entre los miasmas y las emanaciones palúdicas; e indica la inmunidad que producen las enfermedades como las viruelas, el sarampión, la escarlatina, etc. en el organismo del que las sufre:

Los miasmas se distinguen de las emanaciones palúdicas: $1^{\circ}$. En que estas son resultado de alteración de las plantas y aquellas proceden de animales; $2^{\circ}$. En que las miasmas específicos, y no las emanaciones, se propagan por las personas. Las viruelas, el sarampión, la escarlatina, el tifo, la fiebre amarilla, el cólera, la peste, etc. son enfermedades miasmáticas: casi siempre comunican al organismo de los que sufren sus daños aptitud suficiente para resistir su acción, disposición para no enfermar de nuevo por la misma causa. ${ }^{901}$

Y nombra los desinfectantes más acreditados:

\footnotetext{
${ }^{899}$ PEREDA Y MARTÍNEZ, Sandalio (1870): op. cit. p. 396.

${ }^{900}$ Ibídem.

${ }^{901}$ Ibídem, p.397.
} 
El cloro, hipocloritos alcalinos, álcalis, ácido clorhídrico y nítrico, el carbón la sal, fumigaciones aromáticas o resinosas, la deflagración del nitro o pólvora, han sido los desinfectantes más acreditados; pero no tan seguros como la ventilación, y aún y más eficaz la dispersión, que un refrán antiguo expresas de esta manera: huir de la peste con tres 1.1.1.; luego, lejos, y largo tiempo.

Las patentes de sanidad (limpias, tocadas, sospechosas o sucias), los lazaretos, cuarentenas, expurgos y cordones sanitarios, son en globo los medios administrativos e higiénicos empleados con más o menos éxito, con mayor o menor diligencia, para prevenir las enfermedades que invaden a un gran número de individuos. ${ }^{902}$

Define la palabra virus como «un humor elaborado por enfermedad y transmisible por inoculación» y describe dos, especialmente, el virus de la vacuna y el de la rabia, «cuya inoculación tantos beneficios ocasiona el primero, como una enfermedad cruel e incurable el segundo».

La vacuna es un virus, que preserva de la viruela. Según el autor, «el cow-pox, formado en las ubres de las vacas (procedentes a su vez del gabarro del caballo), es el virus que preserva de la viruela». Nombra a Jenner, como el médico inglés que descubrió la vacuna en 1776

La vacuna no solo se propaga de la vaca sino también de un hombre a otro; Pereda, aconseja la vacunación para preservar de la viruela:

La utilidad del virus es tan grande, su propagación tan sencilla, que la higiene debe aconsejar: $1^{\circ}$. Que sea obligatoria la vacunación; $2^{\circ}$. Que se vacune con precaución en el modo de inocular y en la procedencia del virus, para conseguir que este prenda en el cuerpo sin daño ulterior; $3^{\circ}$. Que se renueve a menudo el virus, porque degenera después de haberse propagado por varias y sucesivas inoculaciones; $4^{\circ}$. Que la revacunación es conveniente, aun cuando no tenga otro objeto que distinguir los individuos preservados de los que no lo están por inoculaciones anteriores. ${ }^{903}$

\footnotetext{
${ }^{902}$ Ibídem.

${ }^{903}$ Ibídem, pp. 397-398.
} 
La rabia (hidrofobia) es una enfermedad transmitida por la inoculación de un virus desarrollado en varios animales, y muy particularmente en las especies del género Cannis:

Desenvuelta la enfermedad no hay por desgracia esperanza alguna de curación, y los medios eficaces de prevenirla, que deben ser siempre aconsejados por el médico, son los que impiden la absorción del virus lísico o rabífico. La destrucción por el fuego rojo (cauterización) de los tejidos mordidos es el mejor, no dejando también de tener importancia los cáusticos líquidos, fuertes ligaduras por encima de las heridas, y la aplicación de ventosas sobre estas, cuyo efecto es evitar sea absorbida el humor [...... ${ }^{904}$

\section{Localidades}

El examen de las localidades, con relación a la higiene, deberá ser individual o colectivo, formando el hombre familia o pueblo: en el primer caso examina las condiciones higiénicas de las viviendas; en el segundo las de las poblaciones.

Pereda, afirma que el hacinamiento de muchas personas en poblaciones cuyas viviendas sean bajas, reducidas y mal ventiladas, la acumulación de habitantes en reducidos perímetros, produce más estragos aún que la carestía y mala calidad de los alimentos, que las epidemias y contagios; «causas que por desgracia son muy poderosas en nuestro país».

El ejercicio de las industrias debe poner a cubierta la salud, seguridad y comodidad del público; y a fin de salvar derechos colectivos muy sagrados, se han dividido, para la reglamentación conveniente, los establecimientos industriales en insalubres, peligrosos e incómodos: «Insalubre es, por ejemplo, una fábrica de albayalde, de guano artificial, de curtidos, etc.; peligrosos, las fábricas de fósforos, de pólvora, los altos hornos, los almacenes de petróleo, etc.; incómodos, las fábricas de almidón y de bujías, las cerrajerías, telares, etc.».

En la industria agrícola hay también labores que afectan mucho a la salud pública, como la del arroz cuando se cultiva por medio del riego: «Males sin cuento ocasionan los arrozales en las poblaciones rurales, por los miasmas palúdicos que se forman; pero males que el hombre soporta, y consiente, por el incentivo de la riqueza de sus cosechas».

\footnotetext{
${ }^{904}$ Ibídem.
} 


\section{Ingesta}

Trata de la higiene de los alimentos. Comprende: $1^{\mathrm{o}}$. Examen de la especie y calidad de los alimentos, condimentos y bebidas; $2^{\circ}$. Régimen alimenticio conveniente para la salud.

Describe las cualidades nutritivas de los alimentos; de las hortalizas como la patata, dice que deben los pobres su principal sostenimiento; la leche es uno de los alimentos que más se adulteran: «el agua, que es lo menos malo, harina, fécula, sales más o menos nocivas y la nata son la sofisticaciones comunes».

Los efectos nutritivos de los alimentos son distintos según el estado del organismo; Pereda, inserta un cuadro de los productos alimenticios y su digestibilidad según la constitución y temperamento de las personas:

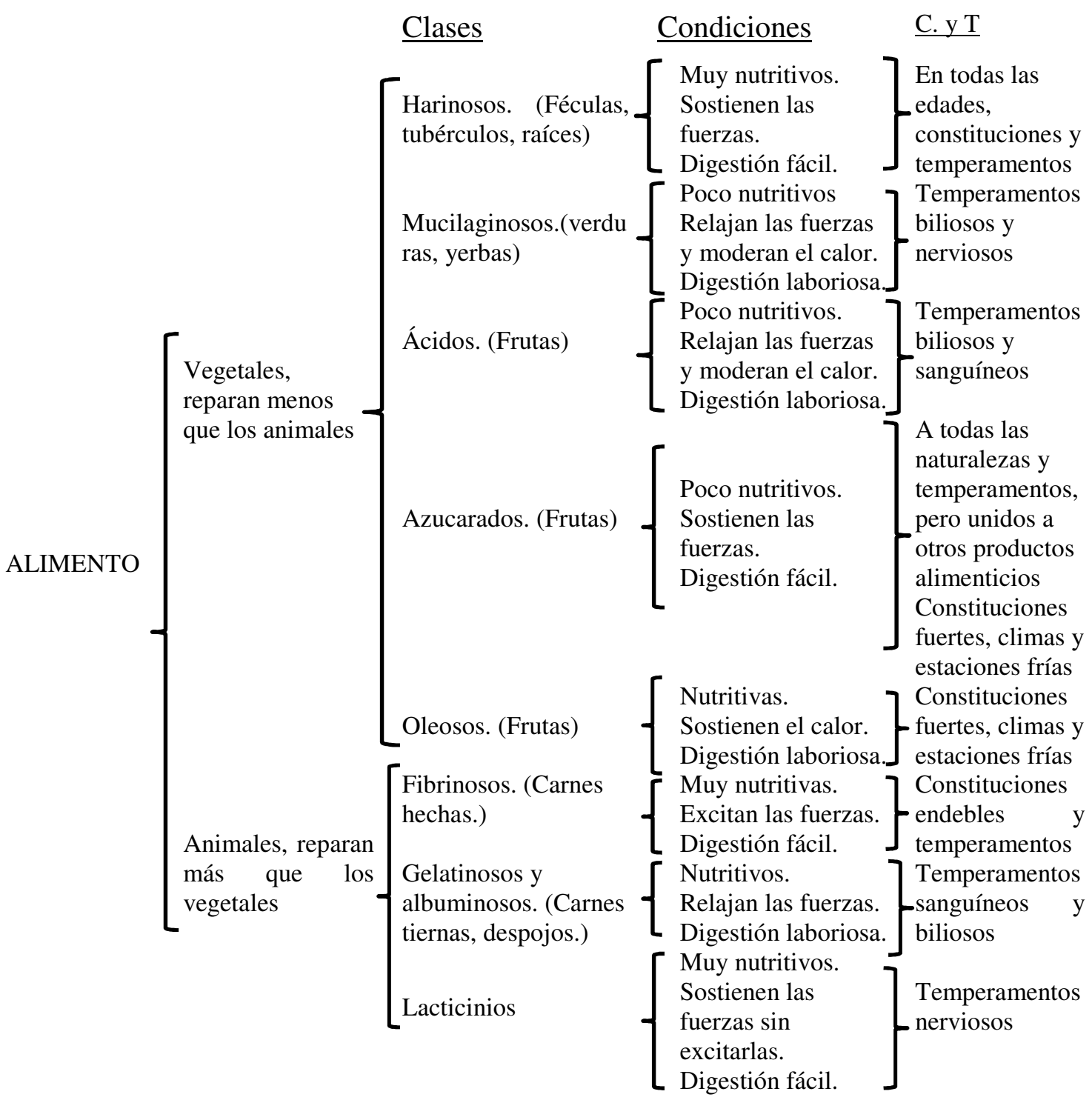




\section{Bebidas}

El autor compara las aguas de fuentes con las de río y dice que estas deben preferirse por tener mayor cantidad de aire y proporción de principios salinos, aun cuando apetezcan más las primeras por su transparencia, temperatura y pureza; las de pozo, aljibes, lagunas, pantanos, etc., no son tan buenas, unas por su escasa aireación, otras por las materias minerales u orgánicas que reúnen

En cuanto a la naturaleza de los recipientes que contenga el agua, dice que son preferibles los recipientes de barro, hormigón, piedra etc. a los metálicos; hace referencia a los recipientes de plomo y afirma que «se ha exagerado mucho su acción nociva, una vez que está confirmado no formarse sales plúmbicas en las aguas siempre que haya en ellas carbonato de cal».

Describe la bebidas aromáticas: el café y el té; las fermentadas: el vino, la sidra, la cerveza; las espirituosas: los aguardientes y los licores.

De las bebidas espirituosas afirma:

Estimulan pronto y de un modo intenso el organismo: gastan las fuerzas, irritan los órganos, perjudican la nutrición y anticipan la vejez. Si a tales efectos agregamos los resultados de la vida sedentaria, los vicios, las pasiones fuertes, etc. tendremos una de las causas principales de la degradación física, moral e intelectual de la especie humana. ${ }^{905}$

El aguardiente y los licores no son bebidas higiénicas; el vino y los demás líquidos fermentados, pero no destilados, son útiles para robustecer las naturalezas débiles y más convenientes en los linfáticos que en los sanguíneos y nerviosos.

\section{Régimen alimenticio}

La intemperancia en el comer y la mala calidad de los alimentos y bebidas son manantiales de las enfermedades que afligen a la humanidad como alteran al hombre físico. El apetito no pervertido y desenvuelto naturalmente, y sin estímulo alguno, es la

905 Ibídem, pp. 404-420. 
guía mas segura para conocer la ocasión oportuna de tomar alimento ; y si bien teniendo en cuenta las condiciones individuales, no es fácil determinar su cantidad (que por término medio se fija de 1 a 3 kilogramos la ración diaria de carnes, pan y legumbres), es lo cierto que la mejor regla consiste en evitar los extremos: la sed y el hambre normales son suficientes para ordenar el cumplimiento de tales necesidades.

Hace referencia a la alimentación de los pobres:

Si los alimentos son excesivos en cantidad pero insuficientes en calidad, lo cual ocurre a menudo en los pobres, se producen también graves daños en el organismo: abundan en este los humores blancos, predomina el temperamento linfático; y varias enfermedades, como las escrófulas, la tisis, los flujos, etc., aniquilan el cuerpo. ${ }^{906}$

\section{Proporción de los alimentos}

El régimen alimenticio más saludable es aquél en que hay debida proporción, según las condiciones del individuo y las que le rodean, entre los productos alimenticios de ambos reinos: debe predominar el vegetal sobre el animal en los climas cálidos, estaciones calurosas y naturalezas ardientes; al contrario el animal en opuestas condiciones.

Recomienda que el régimen alimenticio no sea uniforme: «A excepción del pan y del agua, la mayor parte de los alimentos, cuando se toman diariamente y sin variar en nada su preparación, causan molestia, hastió y hasta perturbación en las funciones gástricas».

Da consejos para una buena digestión:

Ponerse a la mesa en hora fija, comer despacio y masticar bien, libre de cuidados y con la tranquilidad, moderación y dulces placeres del hogar doméstico, satisfacer la necesidad con mesura y no con ansia, son condiciones que, como es sabido, influyen muchísimo en las buenas digestiones.

${ }^{906}$ Ibídem, p.421. 
Más ligeros que la comida deben ser el desayuno y la cena; y esta, además de convenir se efectúe algún tiempo antes del descanso, es también muy saludable el que sea parca, recordando el refrán: más mató la cena que sanó Avicena. ${ }^{907}$

\section{Excreta}

El autor afirma que la salud del hombre se conserva no solo por lo que se asimila sino por lo que se excreta de su cuerpo: el equilibrio de ambos actos, asimilación y excreción, es preciso para la salud.

Debemos evitar retener mucho tiempo la orina en la vejiga ; abstenerse de productos que estriñan o relajen el vientre.

\section{Aplicata}

En esta sección explica los cuidados higiénicos respectivos a los vestidos y los cosméticos; en los vestidos distingue su materia, textura, color y forma.

Sobre la moda afirma: «La costumbre, la veleidosa moda, y no la higiene, son las que han gobernado y gobiernan siempre la forma y configuración de los vestidos».

Los vestidos influyen en la salud:

La forma de los vestidos, además de favorecer el calor, según sean estrechos u holgados, influyen en la salud por la constricción que producen en los órganos, constricción promovida por el ilusorio y perjudicial empeño de sujetar el cuerpo al vestido y no el vestido al cuerpo, por el afán temerario de cambiar las formas naturales a fuerza de ligaduras, talabartes, corsés, cascos, cinturones calzado estrecho, etc. inventados por la moda para cilicio, tormento y daño de la especie humana. ${ }^{908}$

Sobre los cosméticos considera que son higiénicamente perjudiciales casi siempre:

907 Ibídem, p. 422.
908 Ibídem, p. 427. 
Unos por el estímulo y enfermedades que en el cutis provocan, otros porque se oponen a la exhalación cutánea, y los hay que absorbidos por la piel obran como sustancias venenosas. El agua pura, el jabón sencillo y alguna sustancia oleosa o grasienta para limpiar la piel y sus anejos, son los mejores cosméticos; teniendo presente que la belleza que se pretende dar por estos, es una quimera cuando solo atendemos a mejorar el cutis por fuera sin seguir a la vez un método higiénico, que modifique el cuerpo interiormente, con sobriedad, ejercicio y calma de lo físico y moral, que son las fuentes de donde manan raudales de salud. ${ }^{909}$

Y más adelante añade: «Como ilusorios o perjudiciales deben tenerse los medios para reponer o disimular las ruinas de la edad, que como la hiedra del muro antiguo, engalanan y enverdecen el cuerpo para luego derruirlo o aumentar más su grietas y quiebras».

\section{Gesta}

Se comprenden en esta sección los preceptos higiénicos respectivos al ejercicio, al sueño y vigilia.

Con respecto al ejercicio dice que siempre que sea moderado y se una a un régimen alimenticio reparador, influye poderosamente en la salud: «Porque fortifica los órganos facilitando sus funciones, y muy particularmente la digestión, secreciones y exhalación cutánea; distribuye uniformemente el calor en el organismo, da amplitud a la cavidad torácica haciendo más expedito los actos respiratorios, y modera o impide los desarreglos de la inervación».

Hace referencia a los ejercicios y la salud de los indigentes y el trabajo de los niños:

Los ejercicios perjudican a la salud por ser excesivos, escasos o nulos. Siendo excesivos trastornan la circulación y respiración, producen cansancio y debilidad muscular, enflaquecimiento, demacración orgánica, abatimiento de todos los actos funcionales y vejez anticipada con tanta más seguridad si a tal abuso, muy común en las clases indigentes y en los infelices niños entregados a trabajos y

${ }^{909}$ Ibídem, p. 428. 
oficios muy superiores a sus fuerzas, se añaden alimentos insuficientes, aire impuro y el fuego devorador del deseo y de pasiones comprimidas. ${ }^{910}$

Según Pereda, en el ejercicio debemos considerar: $1^{\circ}$. Respecto a la actividad de los músculos en los diferentes movimientos que estos producen; $2^{\circ}$. Relativos a los actos de fonación; $3^{\circ}$. A la gimnasia.

Los diversos medios de locomoción pueden ser activos o pasivos. El autor explica los activos como la marcha, baile, carrera, salto, caza, esgrima, natación, lucha, y esfuerzos; y los pasivos como montar a caballo, ir en carruaje, en lancha, buque etc.

Fonación. Los ejercicios del órgano vocal comprenden la conversación, lectura en voz alta, el canto y la declamación. Los efectos, según el autor, sobre los órganos correspondiente son: «En la laringe y en las partes del tubo aéreo resultan sus efectos inmediatos; los mediatos en los pulmones, órganos abdominales, oído, sistema nervioso y en los sentimientos».

Leer o declamar, con fuerza expresiva y ritmo de acento y tiempo, favorece el desarrollo del aparato respiratorio; «y son por cierto ejercicios harto descuidados en la educación. El canto requiere mayores esfuerzos: su influencia en los afectos es muy viva».

La gimnasia, se propone perfeccionar nuestros órganos, particularmente los del movimiento, para el completo desarrollo de sus facultades. Pereda opina:

No es ni debe ser su objeto aumentar las fuerzas físicas formando hércules y atletas, tan forzudos y corpulentos como rudos, estúpidos y flojos de espíritu; tampoco emplear medios bárbaros, como la lucha, el pugilato y la manopla de los juegos olímpicos; se dirige a procurar que el hombre sea vigoroso, ágil y veloz en los movimientos, fuerte de ánimo, duro en la intemperie, animoso en las privaciones y contrariedades de la vida; goce, en fin, de salud. ${ }^{911}$

Pero por otra parte:

${ }^{910}$ Ibídem, p. 429.
911 Ibídem, p. 432. 
Téngase en cuenta que no es, como creen algunos apasionados, un medio exclusivo: otros agentes son tan necesarios como los gimnásticos para el bienestar físico, moral e intelectual del hombre a que enderezarse debe toda buena educación. Descuidos muy grandes y de tristes resultados vemos en esta; y no es pequeño el abandono en que se tiene el desarrollo físico, formándose así, especialmente en los centros de población, constituciones endebles y delicadas, jóvenes pusilánimes ante el peligro, como ávidos de la sensualidad y débiles para resistir borrascas de las pasiones. $^{912}$

Pereda añade un cuadro analítico de los ejercicios gimnásticos:

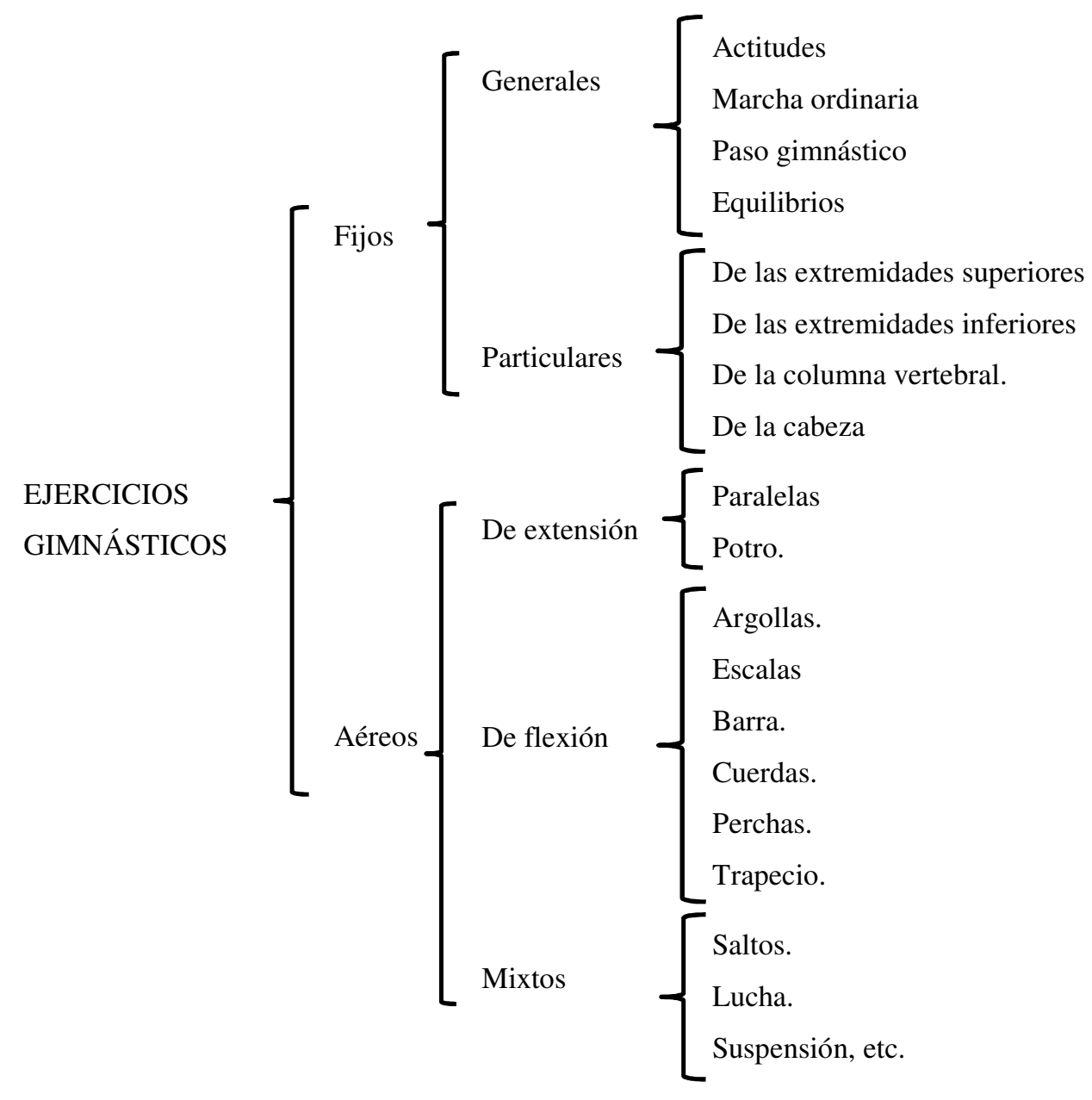

\footnotetext{
912 Ibídem.
} 


\section{Sueño y Vigilia}

Para el autor, «el sueño tranquilo y reparador es una de las necesidades de la vida, uno de los caracteres de la salud».

Pereda hace referencia a las condiciones que debe tener un sueño reparador

El sueño por la noche, en tiempo fijo, y en sus primeras horas, es más reparador y saludable que durante el día, a horas irregulares o en la madrugada: uno de los males de nuestras costumbres en las ciudades, además de la espina del deseo o de la ambición, es madrugar poco, trasnochar mucho, y sujetarnos a la influencia de la luz artificial, que por ningún concepto iguala a la natural. ${ }^{913}$

El autor, señala las precauciones higiénicas que hay que tomar con respecto al sueño:

Los dormitorios, piezas en que se desliza el tercio de nuestra vida, no deben ser los oscuros y mal ventilados cuartos, tan contrarios a la higiene, llamados alcobas, sino viviendas que reúnan más que ninguna otra las condiciones señaladas ya anteriormente. Es conveniente que el lecho esté alzado sobre el suelo, más bien duro que blando, con cubiertas variables según la estación y circunstancias individuales. Limpieza exquisita, esmerado aseo, separar toda causa de emanaciones, no dormir muchas personas en un cuarto ni varias en una cama, tanto más siendo de edad y constitución diferentes, y permanecer poco en un dormitorio o lecho después de un sueño reparador. ${ }^{914}$

\section{Percepta}

El hombre, según afirma el autor, es un ser formado de cuerpo y alma:

El cuerpo agregado de órganos que funcionan por la vida; el alma, causa de que sienta, piense y quiera. Para obrar el bien ha de recibir reglas de sus acciones: de la Ética para sus costumbres; de la Psicología, moral de su inteligencia; de la higiene, norma del bien fisiológico, que es la salud. Si ha de conservar ésta, si ha de

\footnotetext{
${ }^{913}$ Ibídem, p. 434.

${ }^{914}$ Ibídem.
} 
haber un todo ordenado, es preciso que concurran a un fin, que no se disocien. Lo físico y lo moral. ${ }^{915}$

Pereda, dice que «estamos obligados a conservar nuestro cuerpo, pero no hacer de él un ídolo, sino un fiel y pronto servidor de nuestra alma; a este resultado se encamina la higiene, apoyada en la religión y la moral». En la parte llamada Percepta describe la higiene del placer y el dolor, como determinantes extremos de la sensibilidad; de los sentidos (olfato y gusto, tacto oído y vista), las pasiones y las facultades intelectuales.

Divide los sentidos en afectivos e instructivos, «el uso ordenado de los primeros influirá más directamente en las funciones de nutrición, el de los segundos en las de la inteligencia».

Sobre el olfato y el gusto dice: «Perturba el regular uso de estas facultades los olores, sabores y condimentos fuertes y muy continuados: el olfato y el gusto se anulan o no funcionan en armonía con los actos respiratorios o digestivos; afectando algunos productos, como el tabaco, a los centros de inervación».

Describe los efectos del hábito de fumar:

Por el hábito de fumar, además de exponernos a estos daños, hay los inconvenientes de gastar inútilmente saliva, humor tan necesario en la digestión, ennegrecer y destruir los dientes, viciar el aire y dar mal olor al aliento, tanto mas si la costumbre es mascar el tabaco o tomarlo en polvo por las narices. Los perjuicios de fumar son mayores en constituciones débiles y enfermizas, en temperamentos nerviosos e irritables y en las primeras edades. Haciendo caso omiso de los resabios y mala educación que tal hábito expresa en ellas, solo citaremos con respecto a la higiene las observaciones hechas por el Dr. Decaisne: de 28 niños que fumaban, 22 tenían malas digestiones, latidos en el corazón, inercia intelectual o propensión a la bebidas alcohólicas, 8 menor cantidad de glóbulos sanguíneos, 12 hemorragias, 10 ensueños o desarreglos de la inervación, 4 úlceras en la boca y 1 tisis pulmonar. ${ }^{916}$

Con respecto a las precauciones generales de la higiene del oído afirma: «Procurar la limpieza del conducto auditivo externo, cuidar más de lo que se hace el

\footnotetext{
${ }^{915}$ Ibídem, p. 435.

${ }^{916}$ Ibídem, pp. 436-437.
} 
abrigo de la garganta, origen de no pocas enfermedades de la caja del tambor, evitar los ruidos fuertes, desordenados y sin ritmo».

Explica los efectos que sobre el órgano de la vista produce la luz natural y artificial; aconseja no leer libros cuyos caracteres de imprenta sea muy pequeña y de papel muy blanco y satinado, no cansar nunca la vista, el reposo del ojo en la oscuridad y por el sueño, etc.

Las pasiones, constitutivo esencial de la humana naturaleza, no son en sí buenas ni malas: «son incentivos de virtud y de salud cuando hacemos normal uso de ellas, focos del vicio y de la enfermedad si no las encauzamos».

Los medios higiénicos para dominar las pasiones son ineficaces si no los unimos con los de la Religión, si no se contrarresta con la virtud, con los deberes para con Dios:

Para combatir las pasiones necesario es señalar que los medios higiénicos aconsejados para dominar con fruto sus extravíos, reducidos a sustituir unas causas por otras opuestas, son ineficaces no aunándolos con los de la Religión; si la pasión, origen del exceso y del vicio, no se contrarresta con la virtud, fuente de salud, con los deberes que el hombre tiene para con Dios, consigo mismo y con sus semejantes; si no existe templanza en todos sus afectos, una buena educación física, moral y religiosa. $^{917}$

La cultura intelectual, siempre que sea moderada por el desarrollo físico es favorable a la fuerza, salud y belleza: «el estudio es para el alma lo que la nutrición y el ejercicio para el cuerpo».

Los trabajos intelectuales excesivos perjudican la salud:

Los trabajos intelectuales excesivos, que incluyen siempre los peligros de la vida sedentaria, perjudican a la salud: desarreglan la inervación, promueven el temperamento nervioso, debilitan el sistema muscular como las funciones digestivas, con perjuicio del incremento del cuerpo y de la calorificación. El hombre

${ }^{917}$ Ibídem, p. 439-440. 
no está evidentemente formado para meditar de continuo, y si lo hace destruirá su organismo, se volverá estúpido o maniático [...]. ${ }^{918}$

El trabajo intelectual moderado, aparte del placer que puro y metódico que produce: «Comunica a los órganos actividad favorable para las funciones del organismo. Conservarlo en saludable armonía con las facultades morales e intelectuales del hombre es objeto final de la higiene, objeto significado con estas sabias palabras: Mens sana in corpore sano».

Pereda, hace referencia a la mala educación cuando ésta fomenta el desarrollo intelectual sin tener en cuenta el desarrollo orgánico:

Uno de los males más graves de la educación es fomentar el desenvolvimiento de la inteligencia y de la sensibilidad moral sin su compensador, que es el desarrollo orgánico. La vanidad, la ambición, el error de creer que todos tenemos igual talento, el desacierto de no seguir las especiales aptitudes e inclinaciones, la pasión indiscreta y a menudo ciega de los padres, concurren a estados cuyos frutos se recogen en las medianías e ineptitudes, o en jóvenes instruidos sí pero débiles y enfermizos, que desfallecen luego ante el torrente de los deseos, al ser incapaces de resistirlos por una razón firme y un organismo vigoroso. 919

\section{Elementos de Historia Natural de Emilio Ribera Gómez}

El siguiente libro que analizamos se titula Elementos de Historia Natural ${ }^{920}$ del catedrático Emilio Ribera Gómez. Se trata del libro de texto más importante en nuestra época de estudio

Emilio Ribera Gómez (1853- 1921) sucedió en 1877 a Salustiano Sotillo en la cátedra de historia natural del Instituto de Segunda Enseñanza de Valencia. Había nacido en Madrid, estudiado en la Universidad Central y, antes de venir a Valencia, fue catedrático de la misma asignatura en el Instituto de Almería. No solo convirtió el

\footnotetext{
918 Ibídem, p. 440.

919 Ibídem, p.441.

920 RIBERA GÓMEZ, Emilio (1897): Elementos de Historia Natural. (5 ${ }^{\mathrm{a}}$ ed.). Imprenta de Manuel Alufre, Valencia. Libro consultado en la Biblioteca Provincial de Castellón.
} 
museo de ciencias naturales del instituto en uno de los mejores de su género en España sino que sirvió de enlace con la Universidad. En varias ocasiones se encargó de la enseñanza de la zoología y la mineralogía en la Facultad de Ciencias. Viajero incansable, recorrió numerosas zonas europeas y americanas, recogiendo abundantes ejemplares, que fue incorporando al museo del Instituto de Valencia. Publicó trabajos sobre temas biológicos, geológicos y agronómicos en varias revistas científicas, así como artículos de divulgación en la prensa diaria de Valencia y de Madrid. Estaba principalmente interesado en la didáctica de las ciencias naturales, motivo por el cual participó en numerosos congresos pedagógicos y científicos. Ello explica también el esfuerzo que dedicó a las publicaciones en torno a la enseñanza de la historia natural en el bachillerato. En 1904 renunció temporalmente a la cátedra por razones de salud y pasó a ser conservador mayor del museo madrileño de ciencias naturales. A partir de entonces declinó su actividad y en su testamento legó un fondo económico destinado a una beca para estudiantes pobres que cursaran el doctorado en ciencias naturales. Fue el final consecuente de una vida dedicada con entusiasmo a la enseñanza.

Entre sus libros destacan Nociones de Higiene Privada y Social, que tuvo nueve ediciones entre 1880 y 1909, y sobre todo Elementos de Historia Natural, del que aparecieron quince ediciones entre 1879 y 1926. Tan amplia y continuada pervivencia corresponde al prestigio y la difusión de la obra, no solo en España, sino en Latinoamérica. Corrigiendo y actualizando el contenido de sus elementos, no solo mantuvo al día la información, sino que superó los planteamientos tradicionales de la Historia Natural agrupando las partes de su compendio relativas a los seres vivos bajo el concepto general de biología. Rechazó rotundamente el racismo consecutivo al darwinismo social iniciado por Herbert Spencer.

La integración de Ribera en el ambiente científico valenciano le condujo a recoger en sus manuales aportaciones como los parásitos que Pablo Colvée acababa de descubrir, los trabajos de Ferrán sobre la vacunación anticolérica y los de Cajal que fundamentaron la teoría de la neurona. ${ }^{921}$

Analizamos la $5^{\text {a }}$ edición, de 1897, consultada en el Instituto Francisco Ribalta de Castellón.

\footnotetext{
921 LÓPEZ PIÑERO, José María y TERREDA FERRANDIS, María Luz. (2007): El libro médico y biológico Valenciano (Siglos XV-XIX). Generalitat Valenciana. Valencia. pp. 168-169.
} 
El libro que examinamos titulado Elementos de Historia Natural escrito por Emilio Ribera Gómez fue informada favorablemente por el Consejo de Instrucción pública y por la Real Academia de Ciencias de Madrid; premiada con medalla de oro en la Exposición Universal de Barcelona de 1888. Ilustrada con 357 grabados y seis láminas.

Fue editada en Valencia por primera vez en 1879 y la quinta edición- que es la que nos ocupa- en 1897.

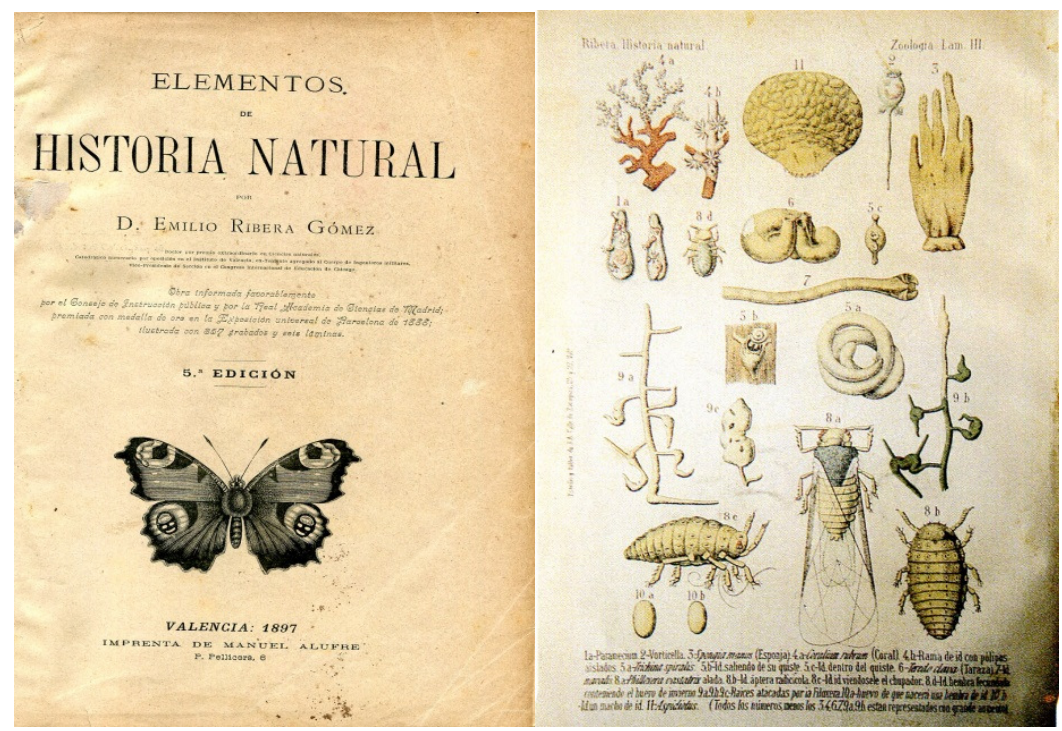

Emilio Ribera Gómez, Elementos de Historia Natural 5a ed., 1897. La foto de la derecha es una lámina cromolitográfica dedicada a ejemplificar la anatomía comparada de los invertebrados, utilizando especies de Paramecium, Vorticella, Trichina, Teedo, Phillorea y Aspiodotus. Incluye novedades científicas de la época e incluso un avance de la investigación: el parásito Aspiodotus oleae, cuya primera descripción publicó Pablo Colvée Roura en 1880.Fuente: LÓPEZ PIÑERO, José María (2008): El darwinismo valenciano del siglo XIX y su fundamento histórico

En el prólogo de la primera edición, el autor expresa la idea culminante que ha presidido la redacción de su obra, que no es otra que la de proporcionar los conocimientos indispensables históricos-naturales para que los alumnos que no se dediquen a estudios superiores, encuentre en el libro los suficientes para representar el papel del hombre ilustrado que la época exigía; y añade una idea muy en boga en aquellos años, y es la de la aplicación de los conocimientos físico- naturales a las necesidades de la sociedad:

La idea culminante que he procurado presida a la redacción de mi obra, ha sido la de proporcionar bajo el menor volumen posible la suma de conocimientos histórico-naturales, necesaria para que un alumno, que no se dedique a estudios 
superiores de la bellísima ciencia de la naturaleza, encuentre sin embargo en este libro los suficientes para representar dignamente el papel del hombre ilustrado, que tan difícil es hoy cumplir, sin la posesión de nociones algo detalladas sobre todas las ramas de las ciencias de observación. Esta idea fija, este fin preconcebida me han obligado a no hacer tan solo un libro de texto, sino a intentar escribir un tratado, en el que, resumido en un tipo de letra algo gruesa los conocimientos puramente precisos para aprobar en un examen, vayan además contenidos en otro tipo más pequeño aquellos otros detalles, que aunque no tan indispensables, son sin embargo muy convenientes, lo mismo para aspirar a una calificación más honrosa que la de aprobado, que para adquirir una idea general de las aplicaciones, que el hombre puede hacer de los múltiples y riquísimos materiales, que la naturaleza puso entre sus manos; en una palabra, he querido reunir los puramente científico con lo verdaderamente útil y aplicativo a las necesidades de la sociedad, aspirando a que mi libro pueda servir tanto para el estudiante como para el hombre de mundo (según dicen los franceses), que no desee poseer más nociones elementales sobre la Historia Natural $[\ldots]$

La quinta edición del libro, obedece al mismo plan que el anterior, con algunas mejoras que según su autor, son «demandadas por el continuo progreso de la Ciencia»:

La quinta edición de este libro, obedece a plan idéntico al de su anterior, sin que por ello haya dejado de procurarse mejora en el texto con algunas adiciones y algunas enmiendas, demandadas por el continuo progresar de la Ciencia, mejorando también la parte material con algunos grabados nuevos y con fotograbados de verdadera novedad científica, cual los correspondientes a las figuras 300 y 313

Con ello, con la formación de más extenso índice alfabético, y con intentar que la edición resulte lo más cuidada posible, procuro seguir demostrando mi gratitud a las sabias corporaciones que han favorecido a esta obra con sus informes, a los profesores, que se han dignado recomendarla para la enseñanza de la Historia Natural y al público que tanto me ha honrado consumiendo en tiempo relativamente corto las ediciones anteriores. ${ }^{922}$

922 RIBERA GÓMEZ, Emilio, op. cit, p. XI. 
Después del prólogo, se cita la Real Orden del Ministerio de Fomento y a continuación los informes del Consejo de Instrucción Pública y la Real Academia de Ciencias de Madrid.

Entre los asistentes a la sección $3^{\mathrm{a}}$ que dictaminó favorable la obra de Ribera, figuraba Ignacio Bolívar y Urrutia, ilustre científico que tuvo una gran influencia en el Consejo de Instrucción Pública.

El Informe describe someramente la obra y subraya «el lenguaje correcto que se emplea y su estilo sencillo a la par que severo son en extremo a propósito para los fines didácticos a que esta obra se destina». Refiriéndose a los contenidos el informe añade: «En la parte doctrinal se puede asegurar que revela tener el autor un conocimiento exacto de todos los adelantos de actualidad y gran juicio para la discusión de los más arduos problemas; así es que se trata con discreción suma los puntos más difíciles de la Biología, sin ir más allá de los límites señalados a una obra elemental». Y sigue «por estas consideraciones, cree la Sección que esta obra es acreedora a que se considere como mérito digno de ser tenido en cuenta para los ascensos de este ilustre profesor».

El Informe de la Real Academia describe con mayor profundidad el desarrollo de la obra. En la última parte del informe alaba las excelentes dotes del autor:

La obra toda revela las excelentes dotes que adornan al $\mathrm{Sr}$ Ribera, acreditado ya de escritor castizo y correcto y de eximio catedrático, que sabe combinar con raro acierto la claridad y riguroso método didáctico en provecho de sus discípulos, con el progreso científico que tanto aquilata sus propios merecimientos, sin dejarse llevar por esto, como otros muchos, por las exageraciones que dañan a la Ciencia misma, como a los encargados de enseñarla y definirla.- Por todas estas razones, la Academia opina que la obra de que se trata es digna del más sincero aplauso y, por su fondo de doctrina y método de exposición, de gran utilidad para la propagación y vulgarización de los conocimientos de Historia Natural.

\section{Desarrollo del programa}

La obra consta de 546 páginas, destinadas las 447 a Elementos de Historia Natural, y las 99 restantes a Nociones de Higiene Privada y Social, con sus correspondientes índices de materias y alfabético, unos párrafos del prólogo de la 
primera edición, el prólogo de la quinta edición, que se examina, y la introducción a la misma, en la que se define la Historia Natural, se valora su importancia, y se traza brevemente su reseña histórica. Ilustran el texto figuras intercaladas. Advierte el autor en los párrafos del prólogo de la primera edición, que ha introducido en la obra una novedad, reducida a resumir todo lo que necesita el alumno para aprobar en el examen, en un tipo de letra algo mayor y completar con caracteres más pequeños, los detalles que no son tan indispensables pero sí muy convenientes, lo mismo para conseguir una calificación más alta, que para hacerse cargo de las aplicaciones útiles que pueden hacerse de los variados materiales que la naturaleza nos suministra.

Comienza la Historia Natural (páginas 1-8) por unas nociones preliminares en las que expone la división de los seres, indicando los caracteres diferenciales entre los orgánicos y los inorgánicos, composición química, estructura, forma, etc., subdivisión del reino orgánico en dos sub-reinos, animal y vegetal, advirtiendo la dificultad de separarlos. División del reino inorgánico en fósiles y minerales, siguiendo a Beudant. Dos cuadros comprensivos de los seres y de las ciencias, que los estudian completan estos preliminares que comprenden también unas breves nociones químicas indispensables para comprender la clasificación mineralógica.

Sigue por la Biología o ciencia de la vida, donde explica la constitución de la materia organizada, la organización del ser vivo y la vida; así como el estudio de los medios vitales, sinónimo de medio ambiente, las fuerzas que intervienen en la vida, origen de ésta, en la que rechaza la autogenia, cuerpos simples que forman la materia orgánica, principios inmediatos, elementos anatómicos, célula, fibra y tubo, y por último define lo que son tejidos, humores, órganos, sistemas, aparatos y función.

En la página 21 comienza la Botánica, que se extiende hasta la página 114. Divide el autor su estudio en: Anatomía, Fisiología y Fitografía. El «libro primero», titulado Anatomía vegetal (21-54), comprende dos capítulos. El primero destinado a dar una idea general de los elementos constituyentes de las plantas, tejidos y humores. El segundo describe los principales órganos de nutrición y reproducción de los vegetales. La Fisiología vegetal (55-68) se expone en el «libro segundo», que comprende tres capítulos: funciones de nutrición, funciones de reproducción y fenómenos independientes y auxiliares de los vegetales. «El libro tercero» trata acerca de la Fitografía (69-114), donde se estudia Taxonomía vegetal, Botánica descirptiva y Geografía botánica. Para la descripción de los vegetales se adopta una clasificación que 
comprende desde las Criptógamas- algas, hongos y helechos- a las Fanerógamasgimnospermas y angiospermas- con sus clases, órdenes y familias correspondientes. Finaliza el apartado con unos conocimientos de Geografía botánica, en la que se realiza una distribución de los vegetales tratando de inculcar al alumno el respeto por los mismos.

Pasa luego a desarrollar la Zoología (115-388). Los conocimientos se agrupan también en anatómicos, fisiológicos y zoográficos. La Anatomía comprende 49 páginas dedicadas a Anatomía general y Anatomía descriptiva. Esta última explica los principales órganos, aparatos y sistemas referidos al hombre. La Fisiología animal, ocupa 82 páginas, se encuentra subdividida en «funcional»y «de organismo», en las que describe las funciones de nutrición, relación y reproducción, las edades de la vida, constituciones, temperamento y muerte.

La Zoografía está distribuida en dos capítulos. El primero, dedicado a la Taxonomía, comprende todo lo relacionado con los principios generales y el cuadro de la clasificación de Claus y Gegenbaur, más evolucionada que la de Cuvier. El segundo, a la Zoología descriptiva, donde Ribera expone las ideas referentes a la clasificación en general y su división en artificiales y naturales. Comienza la Zoología descriptiva por una clasificación de los animales más evolucionada, comenzando por los más sencillos o inferiores, como los protozoos, celentéreos, equinodermos, gusanos, artrópodos, etc., hasta llegar a los más complejos, vertebrados y por último, al hombre. Es una clasificación basada en las relaciones de parentesco entre las especies, y, por tanto, evolucionada. Finaliza con la Geografía zoológica (4 páginas)

El tercer apartado del libro lo dedica a la Geología (189-478), definiendo que se entiende por Geología general, la cual divide en cinco libros: Fisiografía, Litología, Geología dinámica, Geogenia y Geología histórica. En Fisiografía (4 páginas) aborda la forma y dimensiones de la Tierra. La litología (56 páginas) aparece dividida en dos secciones: Mineralogía y Petrología. La Mineralogía comprende desde la página 393 hasta la 443 y la Petrología, las 5 siguientes. En Mineralogía, después de comentar los caracteres físicos y químicos de los minerales, se incluyen unas nociones de Sistemática para pasar a describir los minerales según la clasificación Lapparent, clasificación natural basada en conocimientos geológicos y en rasgos físicos y químicos que agrupa a los minerales en cuatro clases: Clase I: sílice y silicatos, Clase II: minerales de 
precipitación química, clase III: minerales metálicos y clase IV: combustibles minerales.

La Geología dinámica (11 páginas) trata de la acción de la atmosfera, del calor central, del agua en sus tres estados y de la acción de los organismos. La Geogenia, con 4 páginas, trata de la hipótesis de Laplace y Faye, completada con algunas consideraciones acerca del porvenir de la Tierra. Por último, la Geología histórica (15 páginas) aborda la clasificación de los terrenos, la aparición sucesiva de las especies y el origen de las mismas, explicando detalladamente el transformismo y las hipótesis de las creaciones sucesivas. Concluye que no es posible explicar la aparición de los seres orgánicos sobre el haz de la tierra, se sea transformista o no, sin la intervención de una potencia sobrenatural creada, Dios, causa y origen de todo lo que existe.

Las nociones de Higiene privada y social (97 páginas) comprende la última parte del libro.

Comienza con una introducción en la que se define la ciencia de la salud, y hace hincapié en la importancia de su estudio.

El capítulo primero estudia los modificadores físico-químicos: el calor, la luz, la electricidad, el aire atmosférico, el suelo, los climas, el sonido, el agua y la alimentación. Habla primero de la acción modificadora del agente de que se trata; luego de su acción fisiológica seguido de la influencia patogénica; y de las reglas de higiene, así privadas como sociales que conviene adoptar para prevenir los efectos perniciosos.

El capítulo segundo trata de los modificadores biológicos, de las edades, de los temperamentos, de la herencia y del hábito, dando las reglas que deben adoptarse en los distintos periodos de la vida por los que pasa el hombre, lo mismo que para combatir las aptitudes patógenas propias del temperamento y las heredadas que es fruto del hábito.

En el tercer y último capítulo, se exponen los modificadores sociales, modificadores que dependen de la constitución de las sociedades empezando por el individuo, familia, tribu y nación: modificadores que dependen de la actividad de las sociedades, representadas por la Demografía, las habitaciones colectivas, grandes y pequeñas poblaciones, edificios públicos, las profesiones, enfermos y enfermedades, epidemias y endemias, y por último, la legislación sanitaria. 


\section{Análisis del texto}

Analizaremos solo los aspectos más significativos del libro.

Comienza la Biología con la descripción de la materia viva y su organización.

Define de una manera muy sencilla que es «la vida». «La vida es la organización en actividad, es la acción propia de los seres organizados sobre sí mismos y sobre lo que les rodea: vivir es obrar y reaccionar; los seres vivos se distinguen porque son activos, obran por sí y cada uno forma un centro de acciones [...]» ${ }^{923}$

Como se puede ver es una definición bastante simplista. Actualmente la vida no se presta a una definición sencilla, la realidad es, que nuestros conocimientos actuales sobre la vida son aún insuficientes para poderla definir satisfactoriamente, y es posible que nunca podamos llegar a conseguirlo.

Ante la imposibilidad de definir la vida, nos debemos limitar a poner de manifiesto los aspectos más característicos de los proceso vitales, que son precisamente los que distinguen a los seres vivos de la materia no viva que carece de tales atributos. Tales aspectos son los siguientes: capacidad reproductora, metabolismo y sensibilidad e irritabilidad.

Más adelante Ribera cita la «fuerza vital», esa fuerza que hace que la materia orgánica se mueva; se trata, como dijimos anteriormente, de un concepto muy en boga en el siglo XIX y dice así:

La fuerza vital es un principio admitido, pero indefinible, un algo cuya necesidad creen muchos evidente, pero que no solo no se puede definir, sino que ni se conoce su naturaleza, ni el sitio de la organización en que reside; en una palabra, es una fuerza desconocida por lo que se trata de explicar multitud de fenómenos orgánicos, cuya esencia se ignora y que se atribuye a ella. ${ }^{924}$

La Biología moderna ha desterrado la existencia de misteriosas fuerzas vitales y admite que los fenómenos que caracterizan la vida se pueden explicar dentro de los campos de la física y de la química.

En 1860 Luis Pasteur refutaba la «generación espontánea».

\footnotetext{
923 RIBERA GÓMEZ, Emilio. op. cit. p. 16.

924 Ibídem, p. 17.
} 
El experimento de Pasteur con el frasco abierto por un tubo en forma de $\mathrm{S}$ demostró concluyentemente que la fermentación y la putrefacción resulta de microbios y puso fin a la larga controversia sobre la generación espontánea.

Ribera hace referencia al descubrimiento de Pasteur cuando describe el origen de la vida:

Por largo tiempo han estado discutiendo los autores si la vida podía originarse espontáneamente, si de un ser inorgánico podía nacer otro orgánico, o por el contrario, si para que un ser orgánico exista es preciso que haya habido otro $\mathrm{u}$ otros de su especie, que le hayan formado y dado el ser. Hoy por multitud de experimentos, entre ellos los muy notables del sabio químico y biólogo francés Mr. Pasteur, está plenamente demostrado, que la generación espontánea de los seres orgánicos no existe $[\ldots]^{925}$

Más adelante niega que el primer ser orgánico naciera de la materia inorgánica, «no pudiendo explicarse la aparición de dicho primer ser orgánico, más que por intervención divina en el acto de la creación».

La definición de célula también es muy sencilla pues muchas de sus estructuras y orgánulos aún no habían sido descubiertas, por ejemplo, un año después de la edición de este libro, en 1898, Benda y Golgi descubrieron las mitocondrias y el aparato de Golgi.

No obstante, sí que hubieron a partir de 1870, algunos descubrimientos que contribuyeron al conocimiento de la estructura celular por ejemplo, en 1870 Miescher a partir de células de pus consiguió demostrar en los núcleos ciertas sustancias ricas en fósforo, los ácidos nucleicos, que están asociados con proteínas, formando nucleoproteínas. Posteriormente, estas moléculas complejas han constituido el centro de atención de importantes investigaciones bioquímicas sobre las propiedades químicas de los genes, con amplias implicaciones para una mejor comprensión del crecimiento herencia y evolución. ${ }^{926}$

\footnotetext{
${ }^{925}$ Ibídem.

${ }^{926}$ CleVeland, P. HICKMAN (1967): Principios de Zoología. Ediciones Ariel, Barcelona. pp. 984.
} 
En 1873, en su descripción de la división celular, Schneider mostró estructuras nucleares que denominó «filamentos nucleares». Varios años después, en 1888, se les dio el nombre de cromosomas (cuerpos coloreados) por Waldeyer. ${ }^{927}$

Ribera no menciona a los cromosomas cuando define las células, quizá por desconocimiento o, porque en el siglo XIX era difícil divulgar los últimos conocimientos científicos que venían de Europa.

La definición de la célula según Ribera, es la siguiente: «Definimos las células, diciendo que son elementos anatómicos, constituidos, ya por una cubierta exterior continente, y una materia interior contenida, llamada protoplasma, en la que suele aparecer un núcleo, o ya tan sólo por un grumo de protoplasma, sin cubierta ni núcleo» ${ }^{928}$

A continuación describe la reproducción celular sin tener en cuenta la función del núcleo:

La reproducción celular es de dos modos: por escisión y endógena; la primera se verifica dividiéndose una célula en dos por una estrangulación, y la segunda, por la formación en el interior de una célula, que se llama madre, de otras varias denominadas células hijas; una vez formadas éstas, se rompe la primera y quedan en libertad las segundas. ${ }^{929}$

El fenómeno de la división celular fue aclarado entre los años 1870 y 1890 gracias a la elaboración de técnicas precisas que permiten examinar las células al microscopio. Los grandes protagonistas de este tipo de investigaciones fueron: Strasburger (1844-1912), Guignard (1852-1928), Fleming (1843-1915, Beneden (18461910) etc.

Vuelve a nombrar la fuerza vital cuando describe la contractilidad celular: «La contractilidad celular es la aptitud que tienen las células o las partes que las forman, para ejecutar determinados movimientos. Todos estos fenómenos se producen por la acción de fuerzas físicas y químicas a las que muchos agregan la fuerza vital». ${ }^{930}$

\footnotetext{
927 Ibídem, p. 985.

${ }^{928}$ Ibídem, p. 18.

${ }^{929}$ Ibídem, p. 19.

${ }^{930}$ Ibídem.
} 
En las clasificaciones de los animales y vegetales el autor emplea las llamadas «Clasificaciones Naturales»:

Las cuales se establecen por el conjunto de todos los caracteres, que los seres naturales presentan, y tienden a reflejar al método natural o sea a una clasificación en que los seres naturales se distribuyeran de tal modo por sus analogías y diferencias, que todos los grupos establecidos en ella fuesen perfectos, sin poderles añadir ni quitar un solo ser: el método natural, por lo tanto, representa fielmente el plan que la naturaleza ha seguido en la creación de todos los seres presentes y pasados, y por desgracia faltan aún muchísimo para llegar a él en historia natural. Las clasificaciones naturales ofrecen grandes dificultades para su formación, pero en cambio son verdaderamente importantes, puesto que tienden a la investigación del método natural, al que deben aproximarse cuanto sea posible, si quieren ser bien recibidos por la ciencia. ${ }^{931}$

Como vemos Ribera no adopta una clasificación evolutiva, sino que adopta las antiguas clasificaciones, construcciones formales y arbitrarias, que intentaban agrupar a los animales según sus semejanzas y diferencias; concedían especial importancia a los caracteres superficiales y al modo de vida. Esta concepción inducía a errores, los cuales se deben, en gran parte, a una confusión entre órganos análogos y órganos homólogos.

La noción de evolución, que estaba en esos momentos en pleno desarrollo, iba a dar un vigoroso impulso a todas las clasificaciones; desde aquel momento, una clasificación evolutiva basada en la filogenia sustituirá a las clasificaciones naturales.

Esa lenta transformación utilizará para realizarse los documentos aportados por las diversas disciplinas: Paleontología, Morfología y Anatomía, Embriología.

Las diversas concepciones acabarán por armonizarse en el siglo XX.

Una de las dificultades de la sistemática estriba en la definición de cada uno de los grupos sistemáticos, y sobre todo en la definición de la especie. Uno de los mejores intentos de definición de la especie se debe a Cuvier: «La especie es una colección de todos los cuerpos orgánicos nacidos los unos de los otros o de padres comunes y de todos los que se les parecen tanto como ellos se parecen entre sí». ${ }^{932}$

\footnotetext{
${ }^{931}$ Ibídem, p.69-70.

932 TATON, René (coord.) (1973): La Ciencia contemporánea I. El siglo XIX, en Historia General de las Ciencias. Vol. III. Destino, Barcelona. p. 447.
} 
Ribera está de acuerdo con el concepto de especie dado por Cuvier y dice:

Numerosas definiciones se han dado del concepto de la especie en Biología, y entre todas ellas la menos defectuosa es la de Cuvier, que algo modificada dice, que la especie orgánica es el conjunto de individuos orgánicos, que se parecen más entre sí que a ningunos otros, y cuyos principales caracteres de semejanza se conservan por la reproducción, en tanto que no varía la forma del tipo específico. ${ }^{933}$

Pero el criterio morfológico de especie es insuficiente. Buffon lo había comprendido ya perfectamente. Los sistemáticos modernos se esforzaran por establecer una definición más precisa de la especie, basada en varios criterios.

Ribera, expresa varias veces en el libro su creencia en Dios, como Hacedor de todo lo creado y muestra influencias bíblicas cuando describe, en la geología histórica, el periodo cuaternario:

Al concluirse la época terciaria y comenzar la cuaternaria, existían ya en su mayor parte los actuales continentes, pero por causas aún no bien demostradas, estaban cubiertos en parte en el hemisferio boreal por enormes masas de hielo, que constituían extensos glaciares, esparcidos principalmente por todos los valles estrechos del Norte y centro de Europa: estos glaciares transportaron gravas y enormes cantos erráticos y produjeron otros accidentes de consideración hasta que inmensas inundaciones y gravísimas lluvias les hicieron desaparecer. Estas lluvias e inundaciones constituyeron el diluvio de la historia de la humanidad y de los libros sagrados (sic). Verificado el Diluvio y habiendo tomado los mares su nivel actual comenzó el periodo histórico $[\ldots]^{934}$

Ribera explica de forma muy clara, las dos teorías que explicaban el origen de las especies: El transformismo y las creaciones sucesivas. El autor del libro no se decanta hacia ninguna de las dos teorías y dice, se sea transformista o no, Dios es causa y origen de todo lo que existe:

\footnotetext{
933 RIBERA GÓMEZ, Emilio, op. cit. p.70.

934 Ibídem, p.473
} 
Vemos en conclusión, que siendo en el estado actual de la ciencia absolutamente inadmisible la generación espontánea, no es posible explicar, que se sea transformista o que no, la aparición de los seres orgánicos sobre el haz del globo, sin lo que decíamos sobre el origen de la vida, sin la intervención de una potencia sobrenatural creadora, Dios causa y origen de todo lo que existe. ${ }^{935}$

En el siglo XX, el experimento de Miller en 1953, demostró que las descargas eléctricas como los rayos en una atmosfera primitiva de amoniaco, metano e hidrógeno, pudieron dar lugar a la producción de algunas de las complejas moléculas de los sistemas vivos y este descubrimiento abrió un nuevo campo de investigación: la síntesis experimental de los constituyentes químicos de la vida bajo « las condiciones de la tierra primitiva». A partir de 1953, muchos de estos experimentos se realizaron con varias mezclas gaseosas y fuentes de energía que podrían haber estado presentes al principio de la historia de la tierra. Tales experimentos casi han logrado sintetizar cada constituyente principal de los sistemas vivos.

Todos estos estudios han conducido a los científicos a considerar un tiempo primitivo en las historia de la tierra, en el cual la superficie estaba cubierta por los océanos o lagos, ricos en moléculas producidas no biológicamente y fundamentales para la vida. las aguas de estos océanos o lagos se han descrito a menudo como un caldo orgánico diluido, concepto desarrollado en la década de 1920-30 por el biólogo inglés Haldane y el bioquímico ruso Oparin, primeros investigadores del origen de la vida. El interés por estos temas, que se despertó después del experimento de Miller, hizo que las ideas de Haldane y Oparin se ampliaran enormemente, y hoy día, diversas hipótesis especulativas intentan explicar el desarrollo de los primeros organismos con autorreproducción, a partir de bloques no vivos formados en el caldo orgánico primitivo. $^{936}$

\footnotetext{
935 Ibídem, pp. 476-477.

${ }^{936}$ MCLESTER, A. Lee. (1973): La historia de la vida, Omega, Barcelona. pp. 4-8.
} 


\section{A continuación pasamos a comentar con detalle el apartado de la}

\section{Higiene.}

Las nociones de higiene privada y social comprenden 97 páginas, en las cuales se incluyen una ligera advertencia de la primera edición y la Introducción en la que se define la ciencia de la salud, se encarece la importancia de su estudio, y tras de ligera reseña histórica, traza el autor el plan a que obedece su desarrollo, dando la preferencia al estudio de los diferentes modificadores que obran lo mismo sobre el hombre aislado que sobre las agrupaciones humanas. Estos modificadores son astronómicos, físicosquímicos, biológicos, individuales y complejos o sociales; prescinde Ribera de los del primer grupo, por su menor importancia y expone todo lo referente a los restantes modificadores higiénicos, siguiendo el plan de Lacasagne, modificado por el profesor Gómez Reig, de valencia, y por él mismo.

Comprende en el capítulo primero entre los modificadores físico-químicos el calor, la luz, la electricidad, el aire atmosférico, el suelo, los climas, el sonido, el agua y la alimentación; adoptando en la exposición de todos ellos un plan uniforme que facilita su comprensión, hablando primero de la acción modificadora del agente de que se trata; luego de su acción fisiológica seguido de la influencia patogénica, y de las reglas de Higiene, tanto privada como social, que conviene adoptar. Trata en el capítulo segundo, titulado modificadores biológicos, de las edades, de los temperamentos e idiosincrasias, de la herencia y del hábito, dando las reglas que deben adoptarse en los distintos períodos de la vida por que pasa el hombre, lo mismo que para combatir en lo posible las aptitudes patogénicas propias de temperamentos e idiosincrasias y las heredadas que son fruto del hábito.

En el capítulo $3^{\circ}$. Expone el autor los modificadores sociales: en primer lugar, los modificadores que dependen de la constitución de las sociedades que comienzan con el individuo, siguen con la familia, la tribu o nación, y terminan por la raza; y en segundo lugar los que dependen de la actividad de las sociedades, representada por la demografía, las habitaciones colectivas, grandes y pequeñas poblaciones, edificios públicos, las profesiones, enfermos y enfermedades, epidemias y endemias, y por último, por la Legislación sanitaria.

En sus observaciones a la primera edición afirma, que esta obra es de las más modernas que sobre higiene se han publicado en España y en el extranjero; y que ha 
procurado reunir los conocimientos higiénicos más importantes que necesitan adquirir los alumnos de segunda enseñanza, y todo aquél que no habiendo de seguir la carrera médica desee poseer conocimientos básicos de la misma.

Escrita esta obra en vista de la mejores y más modernas que sobre higiene se ha publicado en España y en el extranjero, he procurado que forme un conjunto de los conocimientos higiénicos, que más importa adquirir a los alumnos de la segunda enseñanza y aún a todo aquél que, no habiendo de seguir la carrera médica, desee poseer las más precisas nociones sobre ciencia de tanta utilidad práctica, como la Higiene lo es. Feliz me consideraré si mi modesto trabajo obtiene el favor del público en general, y de mis comprofesores en particular, demostrándose de este modo que he conseguido hacer un libro útil para la enseñanza, único fin que al publicarlo me he propuesto.

En las observaciones a la quinta edición, agradece el recibimiento recibido por los profesores y público en general; pero sobre todo, el dictamen favorable emitido por la Real academia de Ciencias de Madrid.

Honra grande ha recibido este pequeño libro al ocuparse de él la Real Academia de Ciencias de Madrid, emitiendo en su favor un Dictamen por todo extremo laudatorio, juzgándole a 31 de Marzo de 1891, en unión con el de Elementos de Historia Natural, del mismo Autor. Por otra parte, muchos profesores y el público le han protegido, hasta el punto de agotar en poco tiempo sus ediciones anteriores. Tales éxitos, lejos de envanecer al que lo ha escrito, sírvenle, si de la legítima satisfacción, también de poderoso incentivo y de continuo estímulo para aspirar a merecerlo, poniendo en esta quinta edición el mayor cuidado para, conservando el plan general de las anteriores, mejorar todos aquellos detalles y hacer todas aquellas ediciones que el progreso continuo de la higiene demanda y el perfeccionamiento de sus enseñanzas requiere.

\section{Introducción}

En la introducción define la higiene y su importancia y realiza una breve reseña histórica de la misma, citando los autores más destacados del siglo XIX como Hallé, Parent Duchatelet, Tissot, Levy, Malgaigne, Monlau, Pasteur, Bert, Paulier y 
Lacassgne, «sabios ilustres, cuyos trabajos tanto han enriquecido a la ciencia higiénica actual».

Hace una reseña de. Pedro Felipe Monlau: «D. Pedro Felipe Monlau, arrebatado pocos años há a las ciencias médicas españolas, ha sido uno de los higienistas más notable de nuestro siglo, como lo prueban sus numerosas obras, algunas de ellas traducidas con universal aplauso a diversos idiomas europeos.» ${ }^{937}$

Adopta la clasificación de los modificadores de Eleury modificada por Lacassagne con ligeras alteraciones del Dr. Gómez Reig ${ }^{938}$ : «El Dr. Gómez Reig, Catedrático de Higiene en la Facultad de Medicina de Valencia, ha expuesto por medio brillante y acabado esta excelente clasificación en una introducción al Manual de Higiene pública y privada de Paulier, traducción de Arnau, publicado en Valencia en 1882 por la librería de Pascual Aguilar.

\section{Capítulo primero}

En el capítulo primero aborda los modificadores físico-químicos:

\section{Calor}

Adoptando para el estudio de casi todos los agentes higiénicos el plan de Lacassagne, divide el del calor en las siguientes partes: $1^{\circ}$. El calor como modificador;

\footnotetext{
${ }^{937}$ RIBERA GÓMEZ, Emilio, op. cit. p.8.

${ }^{938}$ Constantino Gómez Reig (1846-1931), que ocupó la cátedra de higiene de la facultad de Medicina de Valencia desde 1878 hasta su jubilación en 1907, fue un temprano seguidor de la teoría microbiana de la infección. En 1880, a pesar de que se carecía aún de datos indiscutibles, defendió la condición "parasitaria de la difteria. En su discurso Carácter de la higiene contemporánea (1887) subrayó la importancia de la teoría bacteriana como fundamento de la epidemiología y de las medidas preventivas, destacando asimismo el interés de las investigaciones químicas aplicadas a la higiene realizadas por Pettenkofer y otros autores. Su producción escrita se ocupó de problemas como la ventilación de edificios públicos, la mortalidad por enfermedades infecciosas en la ciudad de valencia y las medidas preventivas que reclamaban la peste bubónica de Oriente Próximo. Gómez Reig dedicó sus trabajos más importantes al problema de las aguas residuales. En 1880 publicó en el Journal d'Hygiene un artículo sobre su utilización para el riego en la huerta de Valencia y, dos decadas más tarde, presentó al IX Congreso Internacional de higiene y demografía (1898) una comunicación en la que expuso un análisis comparado de la mortalidad por enfermedades infecciosas de los habitantes de Ruzafa que vivían en terrenos irrigados con aguas sucias y de la del resto de la población del distrito.

Gómez Reig contribuyó decisivamente a la creación del Cuerpo de Sanidad Municipal de Valencia, primero de su clase en España, del que redactó el proyecto (1882) y después el reglamento (1883). Como "Inspector General" del mismo en 1885 fue uno de los responsables de la memoria El cólera en Valencia en 1885, editada por la Junta Municipal de sanidad el año siguiente. En José María López Piñero y María Luz Terrada Ferrandis (2007): El Libro Médico y Biológico Valenciano (siglos XV - XIX), Biblioteca Valenciana, Generalidad Valenciana, Valencia. p. 186.
} 
$2^{\circ}$. Su acción fisiológica; $3^{\circ}$. Su acción patogénica; $4^{\circ}$. Reglas de higiene privada; $5^{\circ}$. Reglas de higiene social.

\section{Acción patogénica del calor.}

Entre las enfermedades producidas por el calor nombra la lepra y la elefantiasis, las disenterías crónicas, insolaciones, apoplejías por calor y hemorragias cerebrales.

Ribera afirma que las enfermedades producidas por el frío, atacan más a las clases menesterosas y a la jornalera del campo, por estar sometidos a una alimentación insuficiente en calidad o en cantidad. Sin embargo numerosas enfermedades se presentan bajo la acción del frío, en toda clase de individuos como por ejemplo los reumas y congestiones sanguíneas de las extremidades (sabañones, congelaciones), catarros, pulmonías, pleuresías, etc., por bien alimentados que estén, especialmente si se exponen a cambios bruscos de temperatura.

\section{Reglas de higiene privada sobre el calor}

En este punto, Ribera explica las prácticas que el hombre debe ejecutar para dirigir convenientemente la acción del calor como agente higiénico, que pueden dirigirse a auxiliar la producción de éste en la economía o a disminuir las pérdidas del producido en ella: las primeras se refieren a la alimentación, ejercicio muscular y respiración, y las segundas consisten en los medios de protección, que busca contra las pérdidas caloríficas, o sea los vestidos y la viviendas.

El autor recomienda la siesta como medida higiénica cuando hace mucho calor:

Bajo la acción de los grandes calores el reposo y la inmovilidad se recomiendan altamente, siempre fuera de la acción directa de los rayos solares, puesto que harto elevada es entonces la temperatura de la economía, para que se aumente con el ejercicio del tejido muscular; de aquí lo higiénica que es la práctica de la siesta en el centro del día durante el verano, y lo conveniente que sería en este 
tiempo no salir fuera de las habitaciones desde las once de la mañana a las cuatro de la tarde. ${ }^{939}$

Ribera, estudia los vestidos (materia, textura, color, forma, etc.) como medio de protección contra las pérdidas del calor.

Con relación a la forma de los vestidos habla de un enemigo terrible de la higiene: la moda:

Tiene sin embargo la Higiene un enemigo terrible y con frecuencia indomable cuando de forma de los vestidos se trata y del que ya hemos hablado anteriormente, la moda, tirano avasallador que con sobrada razón hacía decir a nuestro eminente Monlau; «pero lo cierto y lo más lamentable es que en tan importante materia sirve casi siempre de legislador una caprichosa moda, inspirada con harta frecuencia por artistas ignorantes y codiciosos o por señoritas tontas y desocupadas. ¡Cuántas incomodidades y cuantas dolencias se evitarían los hombres, si, desentendiéndose de los decretos de la tiránica moda, vistiesen cual reclama la naturaleza de su organización!»

He aquí por qué a pesar de los preceptos de la higiene no se modifica la forma de los vestidos en provecho de nuestro organismo, como la sana razón y el sentido común lo reclaman, y he aquí por qué son inútiles casi por completo cuantas reglas se dan sobre este punto; trataremos sin embargo de indicar las principales para satisfacción de nuestra propia conciencia, examinando ligeramente las diferentes prendas que más se usa hoy en los países civilizados para vestir la cabeza, cuello, tronco y extremidades. ${ }^{940}$

Afirma que es pernicioso que los niños lleven sombreros pesados y gorras apretadas o de excesivo abrigo, porque predisponen a deformaciones de su delicado cráneo. En los adultos acarrean la calvicie, dolores de cabeza, etc., los sombreros militares (cascos, tricornios, etc.). Las gorras sin visera o los sombreros con ala estrecha predisponen a enfermedades de los ojos y no resguardan del sol ni de la lluvia; y sobre todo hace hincapié en los ridículos sombreros del sexo femenino, «unidos a sus variables y a veces enormes peinados», que no responden a ninguna necesidad orgánica

\footnotetext{
${ }^{939}$ RIBERA GÓMEZ, Emilio, op. cit. p.11.

${ }^{940}$ Ibídem, p. 15.
} 
y que solo tratan de satisfacer a la moda. Los sombreros higiénicos, según el autor, son los de fieltro o castor blandos, de ancha ala, los de paja o algodón. Hace una crítica del sombrero de copa:

Una de las prendas menos higiénicas es el sombrero de copa, cuya altura, ridícula forma, poca resistencia a los golpes, facilidad de ser llevado por el más suave viento, y estropeado por la más ligera lluvia, estrechas y duras alas y absoluta impermeabilidad, apenas bastan para justificar los numerosos padecimientos cefálicos a que predispone y lo incómodo que es su uso, impuesto por desgracia por la moda desde fines del siglo pasado; pueden aminorarse sus defectos, como los de todo sombrero duro o impermeable, abriéndole uno o más pequeños orificios ventiladores en la copa. ${ }^{941}$

En el cuello, según dice, lo verdaderamente higiénico es prescindir de todo abrigo, por lo menos en los países templados y cálidos, con lo cual se evitarían las anginas y otras enfermedades de la faringe y laringe, porque al estar siempre protegidos estos órganos por las prendas de abrigo, son más impresionables al frío

La ropa exterior, según Ribera, es la que más sujeta se halla a la moda, haciendo referencia a los complicadísimos vestidos de las señoras, afirma que siempre perderá la higiene y ganará la moda; con respecto a los «perjudicalísimos» corsés dice:

Basta para comprender lo pernicioso que es el corsé, considerar que le tórax es cónico con la base hacia abajo y que el corsé tiende a volverle cónico con la base hacia arriba, dificultando con esto las funciones de los pulmones y del corazón, aparte de lo que comprime al estómago, hígado y demás vísceras abdominales. ¡Cuántas tisis, enfermedades del corazón y del hígado tiene a su cargo esta prenda! Y sin embargo, las mujeres de las ciudades no consienten en abandonarlo, ni aun sustituyéndola con los cómodos e higiénicos justillos sin ballenas de las campesinas. Ya que se use, debe procurarse que no sea muy alto, no tenga ballenas o aceros muy fuertes y sobre todo no se apriete más que lo necesario para que conserve su posición y forma, sin dificultar en nada las funciones del tórax y del abdomen. ${ }^{942}$

\footnotetext{
${ }^{941}$ Ibídem, p. 16.

${ }^{942}$ Ibídem, p. 17
} 
Lo mismo ocurre con el calzado:

De poco sirve decir que el más higiénico lo constituyen las botinas de piel suave y flexible, con la punta ancha, el tacón de un par de centímetros y la caña alta y que comprima solo muy suavemente; siempre se llevará como quieran los zapateros de París, y la humanidad irá muy contenta yendo de moda, aunque se despeñe de lo alto de unos tacones o se torture los pies dentro de unas botas acabadas en punta como los de una espada. ${ }^{943}$

En aquellos años ya se consideraba un problema la capacidad de la vivienda, pues Ribera reflexiona sobre la misma en los siguientes términos:

La capacidad de las habitaciones por desgracia está muy lejos de satisfacer la higiene, en las grandes poblaciones por lo menos, pareciendo nuestras casas más bien armariadas de oficina, donde se amontonan pisos y aposentos como si fueran cajones para guardar papeles, que moradas dónde han de vivir multitud de seres humanos. Téngase presente sobre esto la necesidad de que haya siempre aire puro en cantidad bastante para las necesidades respiratorias de las personas, que cada habitación deba contener de ordinario, cuando esté incomunicado con el exterior: ello se consigue únicamente con habitaciones de 15 a 30 metros cúbicos de capacidad por individuo $[\ldots . . .]^{944}$

Explica los medios de calefacción más usados: braseros, estufas, chimeneas y caloríficos y afirma que ninguno es tan pernicioso como el brasero, «puesto que el ácido carbónico y demás gases originados por la combustión del carbón o leña, que en él se queman van a viciar el ambiente de la habitación». De los caloríferos opina que son medios muy costosos de calefacción, casi imposibles de sostener en las casas particulares, pero son los preferibles desde el punto de vista higiénico; desde el económico los medios de calefacción más recomendados por los higienistas son las estufas alimentadas con cok. Nombra, como reciente, la construcción de estufas para gas del alumbrado.

\footnotetext{
943 Ibídem.

${ }^{944}$ Ibídem, pp. 19-20.
} 


\section{Luz}

\section{Ribera describe la acción de la luz sobre nuestro organismo}

La luz obra de un modo notable sobre toda nuestra economía, pero principalmente sobre el desarrollo en general y sobre la piel, cuando es luz natural, y sobre el sentido de la vista, sea natural o artificial. Influyendo sobre el desarrollo, imprime al organismo modificaciones tan profundas como el raquitismo, flojedad de carnes, linfatismo y debilidad general, que se nota en los individuos privados por mucho tiempo de recibir la luz del sol mineros, presos, vigilantes de alcantarillas, etc. y que contrastan con la robustez de los que viven recibiéndola naturalmente en los alternados períodos de oscuridad y claridad de la noche y del día. ${ }^{945}$

La luz influye en la estética de los habitantes de los países meridionales:

Como efecto notable de la acción de la luz solar sobre el más perfecto desarrollo orgánico, cuando éste no está retrasado por un calor o humedad excesivos, puede citarse dentro de la raza blanca la belleza y regularidad de formas de los habitantes de los países meridionales, comparadas con el poco gracioso y con frecuencia desproporcionado aspecto de los individuos pertenecientes a los pueblos del Norte. ${ }^{946}$

Sobre las reglas de higiene privada aconseja la exposición del organismo a la luz natural durante el día, aunque no de un modo directo de continuo, y al uso de medios protectores de la cara y de los ojos, cuando por necesidad haya que sufrir una luz muy viva.

Comenta las perniciosas costumbres del hombre de ciudad de vivir durante la noche:

Debe desecharse las perniciosas costumbres del hombre de las ciudades en la parte que tienden a vivir durante la noche, pasear al anochecer y dormir durante el día, invirtiendo el orden natural del descanso y la vigilia y convirtiéndola en ser

\footnotetext{
945 Ibídem, p.22.

${ }^{946}$ Ibídem.
} 
nocturno cuando la naturaleza le formó para vivir durante el día y respirar el aire libre, sobre todo el de la mañana y tarde en verano y del centro del día en invierno. $^{947}$

Realiza un breve repaso de los medios que se usan para el alumbrado: sólidos (teas, velas de sebo o cera, bujías, de estearina, etc.; líquidos (aceite común, nafta, petróleo, etc.); gaseosos (gas del alumbrado); y luz eléctrica.

Sobre la luz eléctrica afirma:

La luz eléctrica es sin disputa la luz del porvenir y comienza a serlo del presente, porque realiza el ideal de la higiene de alumbrar sin viciar ni calentar sensiblemente el ambiente en que luce: resulta aún más cara que el gas, donde no se disponga de fuerza barata para producirla vapor, caídas o corrientes de agua, etc. o dónde no se la produzca muy en grande, pero donde existan cualquiera de estas dos condiciones es mucho más barata que él y aún que el petróleo; se produce con mayor facilidad y no ofrece peligro alguno, si se toman con ella las precauciones debidas $[\ldots . . .]^{948}$

\section{Aire atmosférico}

Estudia el aire atmosférico bajo tres aspectos distintos: como medio atmosférico, como cuerpo que ejerce presión sobre nosotros (presión atmosférica) y como alimento que penetra por las vías respiratorias.

Sobre la acción fisiológica de los vientos afirma que los impetuosos perturban todas las funciones del organismo, y si además son muy secos y cálidos, llegan a causar notables alteraciones en la salud del hombre y de los animales, como sucede con el poniente en el reino de Valencia, el levante en la costa del sur de España, el siroco, en Italia, etc.

La acción de los vientos cálidos y secos produce la excitación nerviosa que conduce a cometer más crímenes, pendencias y suicidios:

\footnotetext{
${ }^{947}$ Ibídem, p. 23.

${ }^{948}$ Ibídem, pp. 24-25.
} 
En el reino de Valencia y en las provincias de Almería, Granada y Málaga, son más frecuentes los crímenes y las pendencias en los días en que soplan el Poniente y el Levante respectivamente; y en Londres según Lacassagne, se dá el nombre de viento de los ahorcados al viento del Norte, que allí es muy seco, porque coincide con un notable aumento en el número de suicidios. ${ }^{949}$

En el aire como alimento, estudia el aire puro y el aire viciado

Según dice, el autor, es muy importante respirar el aire puro y convenientemente renovado.

Por desgracia ésta es una de las necesidades de nuestro organismo que más desatendida suele estar, y que mayor número de víctimas cuesta a la humanidad, de las grandes poblaciones sobre todo, donde las clases media y menesterosa viven hacinadas en pequeños edificios, raquíticas calles y plazas y pocos ventilados pisos entresuelos, bajos o sótanos que no solo no tienen el aire bastante para las necesidades respiratorias de las personas que albergan sino que carecen de medios para que este mismo aire se renueve convenientemente. ${ }^{950}$

Ribera nombra los componentes del aire impuro y define por primera vez que son los microbios:

Puede el aire estar alterado por la presencia entre su masa de gases distintos de los que deben componerle, de partículas finísimas (polvo) de diversas substancias animales, vegetales, o minerales, o de cuerpos vivos o sus gérmenes, principalmente microbios

Microbios son pequeños organismos vegetales microscópicos, muchas de cuyas especies viven sobre el hombre o los animales, produciendo en ellos a veces enfermedades graves, y con frecuencia mortales. Botánicamente pertenecen a las clases de las Algas y de los Hongos. ${ }^{951}$

El autor afirma que «el estudio de estos pequeños organismos es recientísimo y su conocimiento se debe principalmente a Tyndall, Pasteur y Koch, que han tenido

\footnotetext{
${ }^{949}$ Ibídem, p.27.

${ }^{950}$ Ibídem.

${ }^{951}$ Ibídem, p. 31.
} 
numerosos discípulos e imitadores, entre los que ocupa lugar distinguido el médico español doctor Ferrán». ${ }^{952}$.

Ribera expone algunas generalidades sobre los microbios, «por ser la primera vez que en esta obra hay necesidad de ocuparse de su existencia y acción sobre el organismo humano»:

Preséntanse los microbios constituidos por una o varias células con estructura muy simple, aunque susceptible muchas veces de metamorfosis, hasta el punto de que formas transitorias de muchas especies han sido tomadas por especies distintas; viven la mayor parte flotantes en los líquidos en que hay materia orgánica o sobre otros cuerpos orgánicos vivos o muertos; se nutren a expensas de elementos determinados, constantes para cada especie, y por lo tanto cada una de ellas solo puede vivir allí donde encuentre los principios de que se nutre. Se reproduce como todo ser vivo muy pequeño con una fecundidad y rapidez extraordinarias, y sus gérmenes, que son celulillas microscópicas, y muchas veces ellos mismos, son arrastrados por agentes diversos, por el agua o por el aire principalmente, desde la superficie de los medios en que viven o desde los residuos de la desecación de los líquidos en que se desarrollaron; llevados por tales agentes caen sobre mil objetos o sobre otros seres; si en estos no hay condiciones para que evolucionen y continúen su vida, permanecen inertes perecen; pero si hallan las circunstancias que cada uno ha de menester para su vivir, crecen, se nutren y se reproducen como los individuos de que procedieron. Con esta facilidad de vivir y extenderse, resulta que todo resto orgánico, todo líquido procedente de cuerpos orgánicos, grandísimo número de seres

\footnotetext{
952 Jaime Ferrán Clúa (1852-1929), nacido en Corbera del Ebro, era hijo de un médico rural e inicio su formación en Tortosa y Tarragona. Estudió después medicina en la Facultad de Barcelona, donde obtuvo el título de licenciado el año 1873. Tras una breve temporada en Plá de Penedés, se afincó en Tortota, localidad en la que simultaneó el ejercicio de la clínica general con el de la oftalmología. El interés de Ferrán por la microbiología se debió inicialmente a su admiración por la obra de Pasteur, cuyos trabajos pudo estudiar en la biblioteca de Landerer, sobre todo los publicados en las Comtes Rendus de l'Academie des Sciencies. El microscopio de petrógrafo que tenía el propio Landerer le sirvió para realizar sus primeros ensayos prácticos en 1880, que prosiguió después con otro que adquirió en la capital francesa. Pronto se convirtió en un diestro microbiólogo, que consiguió preparar las vacunas pasteurianas contra el carbunco y mal rojo del cerdo por primera vez en España y que la real academia de medicina de Madrid premiara su memoria sobre el parasitismo bacteriano (1884). Este mismo año fue nombrado miembro de una comisión que el ayuntamiento de Barcelona envió a Marsella, , con motivo de haberse desencadenado el cólera en el sur de Francia. Trabajó en los hospitales para coléricos de Marsella y Tolón hasta conseguir aislar y cultivar el vibrión que Robert Koch había descrito meses antes. A su regreso a Tortosa, gracias a disponer de un cultivo virulento de vibrión colérico, Ferrán pudo provocar un cólera experimental en el cobaya y comprobar la acción inmunizadora que provocaba su inyección. Esta fue la base de su vacuna anticolérica, consistente en la inyección subcutánea de gérmenes vivos que al principio consideró preferible a la inmunización con vibrioenes atenuados o muertos. Tras aplicársela a sí mismo y a una serie de voluntarios, comunicó su descubrimiento a la Academie des Sciencies de Paris. López Piñero y Terrada Ferrandis (2007): El libro médico y biológico valenciano (siglos XV - XIX) op. cit., pp. 182-183.
} 
vivos, hasta algunos minerales, sirven de alimento a miríadas de legiones de microbios, que sobre ellos y a su costa viven, produciendo alteraciones profundas en su composición, y en los animales y plantas modificaciones tales en su vida, que con frecuencia la alteran y desequilibran, llegando a suprimirla y, por tanto, causándoles la muerte. ${ }^{953}$

La calvicie, el carbunco, la rabia, la caries dentaria, las fiebres intermitentes, fiebres tifoideas, fiebre amarilla, el cólera morbo, la escarlatina, la viruela, la difteria, la lepra, la tisis, la infección purulenta y otras enfermedades, son consecuencia de la presencia en el organismo humano de microbios determinados.

Y explica a que se llamaba «efluvios o miasmas»:

Hasta ahora se creía que estas enfermedades las adquiría el hombre de los medios que le rodeaban o de los animales o de otros hombres que las padecían, propagándose ya por contacto directo, ya por la acción de unos principios desconocidos a que se llamaba efluvios o miasmas, a los cuales se suponía flotantes en el aire, adheridos a las ropas, contenidas en el agua, etc.; hoy parece evidenciado que los adquiere porque el aire, el agua, las ropas u otro vehículo llevan hasta un organismo sano los gérmenes del microbio productor de cada enfermedad [..... $]^{954}$

\section{Agua}

El Autor explica las consecuencias que pueden tener para la salud las aguas estancadas

Las fiebres intermitentes, son acompañamiento obligatorio de las agua estancadas, las que también suelen favorecer el desarrollo del tifus, cólera y muchas otras epidemias. Los ríos y arroyos de escasa corriente auxilian la propagación de las mismas enfermedades que las aguas estancadas, y en los países cálidos son muy perniciosos, cuando con sus infiltraciones forman pantanos, o terrenos periódicamente inundados.

953 RIBERA GÓMEZ, Emilio, op. cit. pp. 32-33

${ }^{954}$ Ibídem, pp. 33-34. 
Tan conveniente y necesaria como es el agua cuando es potable, tan perjudicial se torna cuando se emplea como bebida sin reunir todas las condiciones necesarias para ello: las principales causas de su acción perniciosa en este caso son su temperatura, la cantidad en que se ingiere y los cuerpos que contiene... ${ }^{955}$

Entre los preceptos higiénicos que sobre el agua pueden darse, recomienda la desaparición de las aguas estancadas, y cuando esta no sea posible, plantar bosques en su cercanías y en su interior; los árboles que deben preferirse son los eucaliptos, «que además de sanear los suelos pantanosos, desprenden una sustancia balsámica (eucaliptol) que destruye la vitalidad de muchos microbios y sus gérmenes cuando flotan en el aire».

Explica los preceptos higiénicos más importantes sobre el agua potable, y afirma que el agua que mejor cumple las condiciones de potabilidad, es la de fuente natural, arroyo o río, cuando no está impurificada por las sustancias, que se le agrega naturalmente o que el hombre arroja en su curso (residuos de industrias, alcantarillas, etc.).

Da la siguiente regla práctica para el conocimiento a primera vista de la salubridad de las aguas de campo: «Aquellas en que crezcan los berros y las verónicas de excelente calidad: aquellas otras en que se vea juncos, cañas, mentas, ninfeas no son tan buenas y las ricas en algas y otras criptógamas o bordeadas de tierra parda o negruzca deben desecharse por completo».

Cuando el hombre no puede hacer uso de aguas naturales puras, debe purificarlas antes de beberlas: el autor, explica los principales procedimientos para conseguirlo como son la sedimentación, la filtración y la destilación; así como su transporte a los hogares.

955 Ibídem, p. 43. 


\section{Alimentos}

Ribera, explica que son los principios nutritivos y los alimentos e inserta un cuadro analítico de los principios nutritivos y de la división de los alimentos modificado por él:
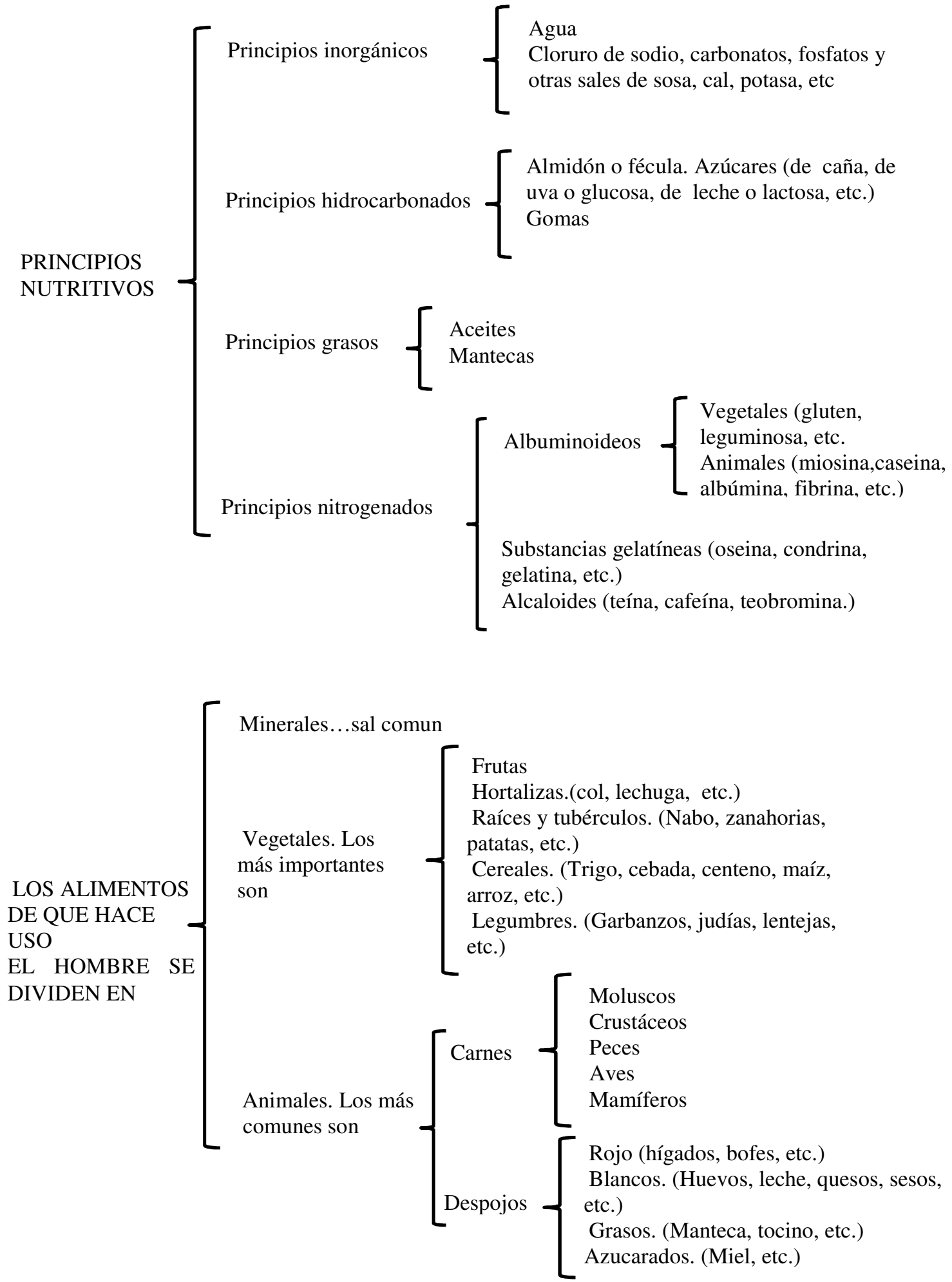
Añade un cuadro del poder nutritivo de los alimentos más usados según Beaunis o Dujardín-Beaumetz

Describe los diferentes grupos de alimentos y la cantidad de estos que debe formar diariamente la ración alimenticia de una persona

La ración que toma como tipo es la de Dujardin-Beaumetz para el ejército francés en tiempos de paz:

\begin{tabular}{|c|c|c|c|c|}
\hline & & Nitrógeno & $\underline{\text { carbon }}$ & grasa \\
\hline Pan & 1000 gramos & 12,00 & 300,00 & 15,00 \\
\hline Carne (de vaca) & 300 gramos & 5,41 & 19,80 & 3,60 \\
\hline $\begin{array}{l}\text { Raíces y tubérculo (patata, } \\
\text { zanahoria, nabo) }\end{array}$ & \multirow[t]{2}{*}{100 gramos } & \multirow[t]{2}{*}{0,24} & \multirow[t]{2}{*}{5,60} & \multirow[t]{2}{*}{0,10} \\
\hline Hortalizas (col principalmente) & & & & \\
\hline $\begin{array}{l}\text { Legumbres secas (habas, judías, } \\
\text { etc, cocidas }\end{array}$ & 30 gramos & 1,02 & 12,60 & 0,60 \\
\hline Total & 1430 gramos & 18,67 & 338,00 & 19,30 \\
\hline
\end{tabular}

Según explica el autor, las cantidades de nitrógeno y carbono que proporciona esta ración exceden de las necesarias para un hombre de 65 kilogramos de peso y «sin embargo algunos higienistas aún consideran mal alimentado al soldado francés».

Explica los condimentos (salinos, ácidos, azucarados etc.), la preparación de los alimentos (vegetales y animales) y la bebidas (alcohólicas, aromáticas, y ácidas)

En las reglas de higiene social sobre la alimentación considera que las entidades gobernantes (ministerios, cuerpos consultivos, autoridades gubernativas, municipios, etc.,) no se preocupan todo lo que deben de un asunto tan importante. Los objetivos preferentes de la legislación y de la vigilancia oficial debe ser la investigación constante de los alimentos y bebidas; vigilancia estrecha de los establecimientos comerciales para que los pesos y medidas de venta sean los debidos; y abaratamiento y mejora de condiciones para la vida de las clases pobres, proporcionándoles sobre todo trabajo continuo, habitación sana y comida nutritiva y barata, para que no sientan la necesidad de embriagarse para olvidar su suerte. 


\section{Excreciones}

En este apartado estudia las excreciones cutáneas y las excreciones bucales, alvinas y urinarias.

Las principales cuestiones que considera en la higiene de la piel del hombre son las secreciones sudoríparas y sebáceas; la producción de los órganos epidérmicos (pelos y uñas), y los medios de sostener la integridad de todas las funciones del tegumento externo (baños y cosméticos).

Con relación a los cosméticos, el autor considera que la mayoría impiden la excreción cutánea y que son toxicas muchas de las sustancias que entran en su composición:

Con este nombre se designa a una porción de substancias que se aplica sobre la piel y sus anexos, para conservarlos, embellecerlos o disimular sus defectos, la higiene no puede ni debe admitir los cosméticos más que para el primer uso; los otros dos tienden a corregir la naturaleza y a sostener una belleza mentida, que a cambio de no engañar más que al que la usa y se cree restaurado con ella, es siempre origen de daños mucho mayores que los que trata de corregir, a causa de que la mayoría de los cosméticos impiden la excreción cutánea y de que son tóxicas muchas de las substancias que en su composición entran. ${ }^{956}$

Y describe los cosméticos más usados:

Los polvos de arroz, que si son sólo harina finísima de arroz pueden emplearse en pequeña cantidad para secar por completo la piel y suavizarla algo después de las lociones, pero que mezclados como casi siempre se venden con polvos minerales (albayalde, blanco de zinc, blanco bismuto, creta, etc.) son verdaderamente nocivos y a la larga estropean el cutis;-los ácidos (vinagrillos de tocador), que muy diluidos en agua se pueden emplear para limpiar la piel y aromatizarla;-los aceites esenciales, disueltos en alcohol $[\ldots . . .]^{957}$

${ }^{956}$ Ibídem, pp. 70-71.
${ }^{957}$ Ibídem. 
En cuanto a la higiene de los dientes recomienda la limpieza continúa, esta se efectúa de la siguiente manera:

$1^{\circ}$. Procurando después de las comidas dejar expeditos los espacios interdentarios por medio de mondadientes blandos (de pluma o madera), pues los duros arañarían al esmalte, y enjuagando toda la boca con agua tibia pura $o$ mezclada con algunas gotas de cualquier tintura alcohólica, para que fortalezca las encías; $2^{\circ}$. Frotándose diariamente dientes y encías con un cepillo suave empapado en agua, el cual de vez en cuando puede usarse con jabón o con algunos polvos dentífricos, que actúen solo físicamente, como el carbón vegetal, coral, hueso de jibia molidos, etc. conviene también para la mejor conservación de los dientes no exponerlos a cambios muy bruscos de temperatura, para evitar que se pasen, como vulgarmente se dice, y no mascar o beber substancias que, como el tabaco y los ácidos pueden atacar al esmalte. ${ }^{958}$

\section{Capítulo segundo}

\section{Modificadores biológicos}

En este capítulo, el autor estudia las edades, temperamentos, Idiosincrasias, Herencia y Hábito

\section{Herencia}

Ribera hace referencia a la herencia como una disposición especial en virtud de la que ciertos estados fisiológicos o patológicos se transmiten de padres a hijos por la generación.

Afirma la herencia de muchas enfermedades:

Negada por algunos la herencia patológica, es hoy ya un hecho perfectamente demostrado y hasta vulgar, efecto de los numerosos ejemplos que de ella se ve todos los días en ciertas familias, en las que todos o la mayor parte de sus

${ }^{958}$ Ibídem, pp. 71-72. 
individuos sucumben de la misma enfermedad hacia una misma época de su vida, o se presentan ciegos, sordomudos, jorobados, bizcos o con cualquier otro defecto orgánico. Las enfermedades, cuya, predisposición a padecerlas más comúnmente, se transmiten por la herencia, son: la apoplejía, reumatismo, gota, cáncer, tisis, asma, parálisis, hernias, sordomudos, locura, idiotismo, epilepsia, histerismo, escrofulismo, sífilis y enfermedades cutáneas. ${ }^{959}$

\section{Capítulo tercero}

\section{Modificadores sociales}

\section{Modificadores que dependen de la constitución de las sociedades.}

Para Ribera la salud de la colectividad pasa por la salud del individuo

Considera la familia el embrión de la sociedad, la base de una colectividad humana, si se suprime este miembro del organismo social desaparece la humanidad: «La base de la familia es la unión conyugal del hombre y de la mujer, el matrimonio, que cuanto más racional y perfectamente esté constituido, más perfecta hace a la familia y por consiguiente a la sociedad».

Hace una crítica de la poligamia y ensalza el cristianismo que da igualdad de derechos al hombre y la mujer en el matrimonio, y hacen de la segunda una compañera y no una sierva

Y en el campo de la higiene las consecuencias del matrimonio para la sociedad, afirma que hay mucho menor número de hijos en las naciones polígamas que en las cristianas, y pone ejemplos como Persia ,Turquía, Marruecos, etc. que no aumentan de población y hasta disminuyen con mayor o menor rapidez, mientras que Inglaterra, Alemania, España, etc. aumenta rápidamente; en segundo término, el progreso y la civilización son tanto mayores, cuanto más perfectamente esté constituida la familia ( el occidente de Europa, aventaja en civilización a Rusia, a los estados Danubianos y a otras naciones, en las que la mujer no ha llegado aún por completo a ser la compañera del hombre); por último los crímenes y ciertas enfermedades (locura, hipocondría, etc.)

${ }^{959}$ Ibídem, p. 82. 
se presentan con frecuencia mucho mayor en los célibes, no consagrados a las órdenes religiosas, que en los viudos, y en estos que en los casados, notándose además que en los dos últimos casos ejercen beneficiosa influencia los hijos, lo prueba con los datos que toma de Lacassagne:

En un 1000000 de individuos se cuenta por término medio anual 1.014 criminales distribuidos de esta forma:

\begin{tabular}{|c|c|c|c|}
\hline Hombres célibes & 405 & mujeres célibes & 88 \\
\hline Hombres viudos & 242 & mujeres viudas & 43 \\
\hline Hombres casados & 200 & mujeres casadas & 36 \\
\hline
\end{tabular}

Tomados en conjunto los dos sexos y en un millón de individuos se cuenta cada año por término medio:

\begin{tabular}{|l|l|}
\hline Esposos sin hijos & 175 acusados de crímenes y 314 suicidas \\
\hline Esposos con hijos & 109 acusados de crímenes y 125 suicidas \\
\hline
\end{tabular}

\section{Modificadores que dependen de la actividad de las sociedades.}

El autor estudia en este punto la demografía (población relativa, mortalidad, vida probable y vida media), habitaciones colectivas, profesiones, enfermos y enfermedades.

\section{Profesiones}

El Autor, resume las principales profesiones indicando los inconvenientes que presentan y las enfermedades a que predisponen.

\section{Profesión escolar.}

Describe la influencia que tiene en el organismo el régimen escolar: 
No puede precisarse ni aún para cada país la edad conveniente para el comienzo de la educación intelectual colectiva: debe ésta tener principio cuando cada niño presente ya un desarrollo físico suficiente para que se pueda estimular su cerebro, pidiéndole el desenvolvimiento de sus facultades intelectuales: por no hacerlo así resultan muchos jóvenes de ambos sexos, o raquíticos y enfermizos porque se provocó en ellos una precocidad cerebral que amortiguó y quizás impidió la evolución de los demás órganos; o torpes y de poca inteligencia, porque se cayó en el extremo opuesto dejando que los otros sistemas orgánicos, tomaran delantera al sistema nervioso, y sobre todo al cerebro, que difícilmente luego puede recobrar el tiempo que se le dejó perder. Ingresado el niño en la escuela, debe procurar conservarse a todo trance el equilibrio entre estos dos órdenes de desarrollo, físico e intelectual, graduando lentamente sus estudios de menos a más y alternándolos siempre con ejercicios corporales (gimnasia de salón, excursiones escolares, ejercicio militar para los niños en los límites de la adolescencia, ejercicios manuales para las niñas, juegos que exijan destreza y gasto de fuerza, etc.) y con vacaciones durante las fiestas y los calores estivales. Las grandes aglomeraciones de niños y de jóvenes son muy perjudiciales, principalmente por la facilidad que proporcionan al desarrollo de las enfermedades contagiosas, sobre todo a la terrible difteria, y solo pueden tolerarse cuando se trate ya de adolescentes, que sigan régimen escolar como externos en un establecimiento, situado en edificio de buenas condiciones higiénicas, con tal que no permanezcan en un mismo local muchas horas seguidas. ${ }^{960}$

Cuanto la higiene enseña sobre los modificadores físicos y biológicos debe cumplirse cuidadosamente con los escolares, «pues en ninguna edad se paga más caro los errores higiénicos que en la puericia y adolescencia, por lo mismo que el organismo es en ellas blanda cera, que se deja fácilmente moldear por toda clase de agentes».

Así que la situación, capacidad (12 a 15 metros cúbicos de aire puro por individuo y por hora en las clases); ventilación y calefacción de los edificios escolares, que deben estar construidos expresamente para el objeto; las letrinas absolutamente inodoras; la luz natural recibida por la izquierda cuando haya que escribir o Zenital en los demás casos y siempre muy abundante; el alumbrado artificial, eléctrico o de otro sistema, siempre muy abundante y fijo, que alumbre al libro, y no a los ojos directamente; el agua potable; la alimentación, vestidos y dormitorios en el régimen como internos; la limpieza personal y de los locales; la higiene de los sentidos, en especial de la vista; el mobiliario, que muchas veces es

${ }^{960}$ Ibídem, pp. 92. 
potro cruel que atormenta al alumno y le hace aborrecible el estudio en vez de cómodo medio de aficionarlo a él; la vigilancia moral ejercida de modo que no se aperciba de ella el escolar sino en determinados casos, con objeto de que no procure eludirla; la discreción en los castigos, que nunca deben ser a costa de la higiene, y la práctica de métodos de enseñanza agradables que realicen el docere delectando justamente preconizado por la Higiene, son otras tantas cuestiones que requieren atención continua por parte de los Profesores, y vigilancia estrecha por los organismos gobernantes, ejercida con el auxilio de Inspectores médicos muy inteligentes. $^{961}$

\section{Profesiones agrícolas.}

Las profesiones agrícolas son las que mayor número de individuos ocupan y las que pueden reputarse como más higiénicas: el aire puro, el trabajo metódico y constante, la menor corrupción moral de las poblaciones rurales y la alimentación abundante, son otros tanto factores, que contribuyen a la salud del hombre de campo, cuya vida de ordinario es más larga que la del habitante de las ciudades, efecto de lo cual la mortalidad es menor en aquél, y cuyas casi únicas enfermedades son las que dependen de las injurias atmosféricas (reumas, catarros crónicos, oftalmias, etc), y las fiebres palúdicas. Un inconveniente grave tiene sin embargo la profesión agrícola y es, el poco apego que los campesinos tienen a la instrucción, lo que les hace rutinarios, suspicaces, astutos, supersticiosos y hasta egoístas, avaros y poco escrupulosos. Por eso el principal precepto higiénico para las gentes del campo estriba en que debe favorecerse por todos los medios posibles su instrucción moral e intelectual.

\section{Enfermos y enfermedades}

\section{Enfermedades contagiosas}

Ribera afirma que todas las enfermedades contagiosas son microbianas y como no se conocen las especies de estos pequeños seres que originan muchas de ellas, la mejor defensa es la evitación del contacto con organismos que las padezcan; la

${ }^{961}$ Ibídem, p. 93. 
destrucción de sus animales o sus microbios productores; alimentación sana, limpieza extremada en habitaciones, ropas, menajes y utensilios de cocina, y sobre todo con la desaparición de los focos de infección

El autor da unas breves ideas de la higiene ante las principales enfermedades contagiosas: las fiebres palúdicas, la rabia y la viruela:

De las fiebres palúdicas puede el hombre librarse muchas veces usando una buena alimentación, vestidos que excitan las funciones de la piel y bebidas aromáticas y alcohólicas en cantidad moderada, procurando además evitar la residencia o el paso cerca de pantanos o aguas estancadas durante los crepúsculos o la noche, y el beber agua de los países en que reinan fiebres sin filtrarla convenientemente

Contra la viruela el único medio preventivo eficaz es la vacunación o inoculación en la sangre del hombre de un virus ${ }^{962}$ que vulgarmente recibe el nombre de linfa vacuna y está tomada o de una especie de viruela de las vacas, el cow pox, que se forma en las ubres, o de pústula originaria por la vacunación en otro individuo humano. La vacunación preferible es la directamente tomada de la vaca, debe ser obligatoria para todos los niños dentro del primer año del nacimiento, renovada a los siete años y más tarde cada ocho o diez. ${ }^{963}$

Con respecto a la hidrofobia, Ribera recomienda que toda persona mordida por perro rabioso acuda a laboratorios donde se practique inoculaciones preventivas contra el desarrollo de esta enfermedad por el sistema descubierto por el eminente Pasteur, «que tan buenos resultados da cuando se aplica bien y pocos días después de la mordedura».

\footnotetext{
${ }^{962}$ Ribera llama virus a los líquidos que llevan en disolución o suspensión gérmenes de una enfermedad o sustancias animales venenosas

${ }_{963}$ Ibídem, p. 96.
} 


\subsubsection{Algunas conclusiones de los 2 libros de texto}

El manual de Sandalio de Pereda es muy didáctico, intercala 464 grabados con la finalidad de que la enseñanza intuitiva se funde en el conocimiento práctico de los objetos en las aulas y en los gabinetes.

Pereda define el glóbulo, la fibra, la celdilla y el tubo como elementos anatómicos y expone que los fenómenos que caracterizan la vida se explican mediante la fuerza vital.

Desconoce la respiración interna de los tejidos, la acción de los riñones sobre la sangre y el bazo.

Sandalio de Pereda pertenecía al grupo de naturalistas españoles formados en el Cuvierismo, modelo metodológico y rector de la Historia Natural de la primera mitad del siglo XIX, partidario del Fijismo, con una concepción tipológica y esencialista de las especies, de las que despreciaba su variabilidad y sólo buscaba los ejemplares tipo.

Niega la generación espontánea y reconoce a un ser superior como origen de todo el universo.

Emilio Ribera cuestiona en su libro la existencia de misteriosas fuerzas vitales y admite que los fenómenos que caracterizan la vida se pueden explicar dentro de los campos de la física y de la química

Dedica al «transformismo, la teoría de la descendencia o darwinismo» una detallada exposición, mientras que la «doctrina de las creaciones sucesivas» las resume en menos de seis líneas. Su adhesión al evolucionismo se manifestó también en el empleo de la taxonomía zoológica de Carl Gegenbaur, basada en la morfología comparada darwinista, y en el rechazo de un reino humano, que había sido defendido desde el fijismo. Sin embargo, consideró necesaria la intervención creadora divina en la biogénesis o aparición de los seres orgánicos.

Digno de mención es que rechaza el racismo consecutivo al darwinismo social iniciado por Herbert Spencer.

En el manual dedicó, ya a partir de su primera edición, amplio espacio a los parásitos que Pablo Colvée acababa de descubrir y también dio noticias de los trabajos de Ferrán sobre la vacunación anticolérica y de los del Cajal que fundamentaron la teoría de la neurona. 
Emilio Ribera recoge dos novedades científicas del momento, la primera de ellas es una fotografía del esqueleto de un ratón, hecha por la acción de los rayos Roentgen en los laboratorios del Instituto de Valencia.

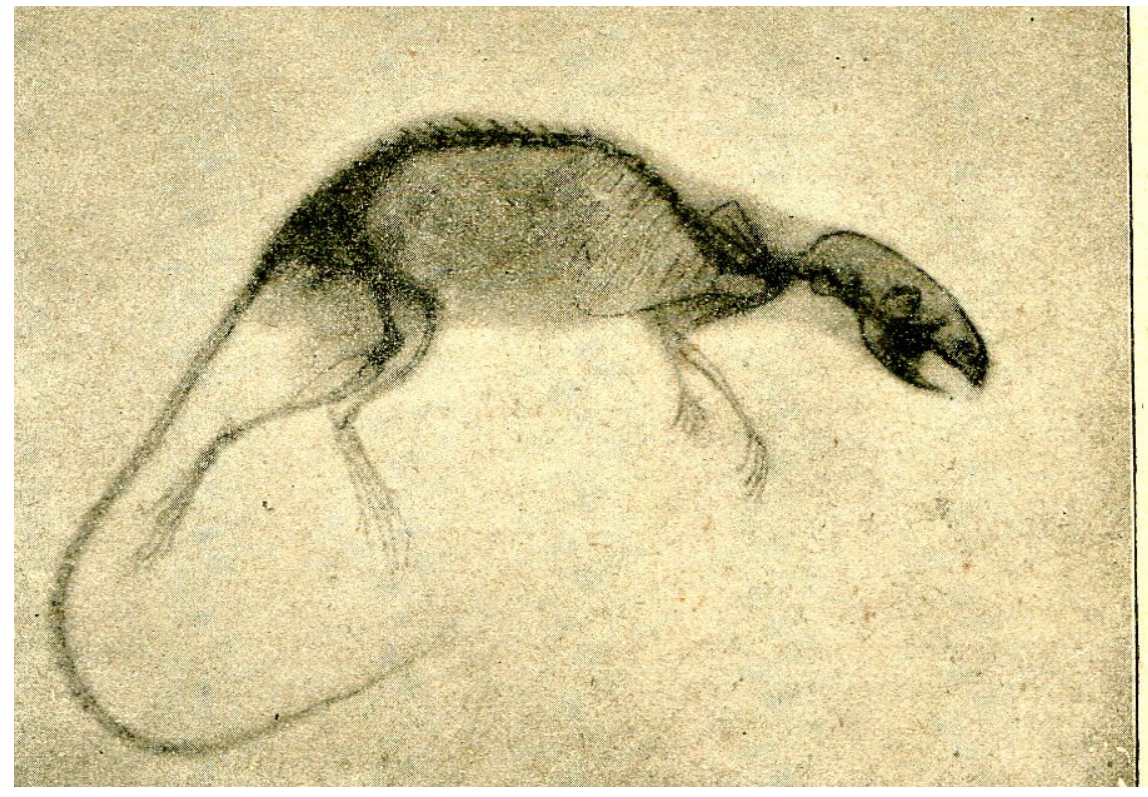

Fotografía del esqueleto de un ratón, hecha por la acción de los rayos Roentgen. Fuente: Elementos de Historia Natural de Emilio Ribera Gómez (1897)

El autor en una nota a pie de página agradece al doctor Colvée el haberle permitido copiar su trabajo:

Este fotograbado es copia exacta de una fotografía, hecha por la acción de los rayos Roentgen en los laboratorios del Instituto de Valencia. La impresión fotográfica original y la prueba que han servido para este grabado han sido hechas por el Dr. Colvée, quien amablemente ha permitido copiarlas para este libro. Por ello el autor le tributa gratitud, ya que esto le ha permitido insertar una novedad científica, mediante la que los alumnos no solo reciben idea bastante clara del esqueleto de un ratón, tipo del de los roedores, sino que la reciben también de la colocación de los huesos dentro de las masas musculares, y hasta del resultado que se puede obtener con el sorprendente descubrimiento de Roentgen para fotografiar los huesos a través del cuerpo de los animales o del hombre.

Efectivamente se trataba de una novedad científica, pues en 1895, Roentgen descubrió los rayos $\mathrm{X}$. este gran descubrimiento fue rápidamente seguido de su aplicación a la interpretación de las estructuras y procesos corporales y constituye uno 
de los más grandes instrumentos en la investigación biológica. Roentgen fue premio Nobel en 1901.

La segunda novedad que Ribera recoge en su libro es la representación gráfica de las relaciones entre la superficie, la altura y la profundidad de las tierras firmes y del fondo de los mares, la llamada «curva hysográfica de la corteza terrestre».

Ribera copia esta gráfica del libro Lecons de Geographie Physique cuyo autor es A. de Lapparet, editado en Paris en 1896.

Refiriéndose a la gráfica dice: « [...] Es sin duda alguna la mejor representación gráfica hacha hasta el día, de las relaciones entre la superficie, la altura y la profundidad de las tierras firmes y del fondo de los mares $[\ldots] »$.

En el estudio de la higiene resumió los planteamientos renovadores de Contantino Gómez Reig, tanto lo relativo a la microbiología como a los sociales y ambientales.

Ribera ilustra su libro con reproducciones de la serie de figuras didácticas que tenían las grandes editoriales, sobre todo francesas, y también láminas independientes propias.

\subsubsection{Las excursiones científicas}

En la Restauración se concedió mayor importancia a los métodos de enseñanza con la finalidad de incrementar su calidad. Al llegar al poder los liberales en 1881, necesitan cambiar la formación que se da en los institutos por otra más útil y práctica y optan por introducir nuevos procedimientos de enseñanza, en lugar de modificar los contenidos del plan de estudios. De esta forma, los métodos dejan de ser considerados un simple medio de transmisión de conocimientos y podemos situarlos dentro del proceso de modernización que ya se inició en el Sexenio Democrático.

Para conseguirlo el Real Decreto. de 16 de noviembre de 1883 del marqués de Sardoal manda establecer, en todos los institutos, ejercicios prácticos agregados a las asignaturas de la sección de Ciencias y ejercicios verbales, escritos o gráficos, adecuados a la índole de la asignatura, en las de letras. Dentro del primer bloque, los ejercicios de Matemáticas y Física y Química, consisten en resolver problemas de la vida diaria propios de la disciplina, formulados del mismo modo que se presentan en la realidad. La enseñanza de la Historia Natural y de la Agricultura, se apoya en la observación de los fenómenos de la naturaleza y de las actividades laborales. En la 
primera se proponen las excursiones como medio idóneo para conocer de forma directa las especies animales y vegetales del entorno. En la segunda, las visitas a los lugares de trabajo son el procedimiento recomendado para aprender las principales operaciones relacionadas con el cultivo de la tierra y con el aprovechamiento de los productos del campo. $^{964}$

Con toda esta serie de ejercicios se trataba de transformar la enseñanza teórica y memorística, sin aplicación inmediata en otra más práctica y positiva, en que la Ciencia se considera el solo medio de explicación del mundo real y el único modelo de progreso humano.

La prensa de Castellón se hace eco de este Real Decreto, y publica:

El consejo de instrucción pública ha terminado el estudio sobre el proyecto de reformas en la segunda enseñanza. Según el dictamen aprobado se establecen con el carácter de obligatorias, prácticas en las asignaturas de aritmética y álgebra, geometría y trigonometría. En la asignatura de Historia Natural, determinación de objetos, con especialidad de aquellos que son de mayor aplicación, y en los últimos meses del curso se harán excursiones para que los alumnos, bajo la dirección del profesor, hagan estudios prácticos que completen los teóricos anteriores. Los alumnos de agricultura deberán visitar los establecimientos agrícolas con el mismo objeto.

La física y la química, que antes formaban una sola asignatura, se divide en dos, y en ambas será también obligatoria la práctica». ${ }^{965}$

Las excursiones en 1884 y 1885 tuvieron lugar en el mes de mayo, organizadas por la cátedra de Historia Natural, bajo la dirección de Catalino Alegre. El río Mijares, Benicasim y los terrenos situados más allá «dels Mestrets» fueron los lugares elegidos. En las dos excursiones de 1884 participaron veintiséis y veintisiete alumnos respectivamente, y en la de 1885, veinticuatro. El objetivo del profesor no era recoger y clasificar cuantos seres animados e inanimados encontrara, sino estudiar «in situ la materia dada a los alumnos en la catedra». Las excursiones se aprovechaban para estudiar la flora, la fauna y la geología de los terrenos, y para conocer las obras de

\footnotetext{
${ }^{964}$ Arts. 1 y 2, Col. RR.DD., T. II, pp. 337-338, en ALTAVA RUBIO, Vicenta (1993). op. cit. pp. 381-382.

${ }^{965}$ El Clamor de la Democracia, 8/11/1883.
} 
ingeniaría y de arte de los lugares que visitaban. De esa forma, Catalino les concedía un carácter interdisciplinar semejante al que reclamaría para ellas la reforma de 1894.

Dispuestas por el gobierno estas instructivas romerías para los escolares de Historia natural, a semejanza de las que verifica la Institución Libre de Enseñanza; el Instituto de esta capital acordó tuvieran lugar las excursiones escolares en el mes de mayo, después que los alumnos han estudiado en la catedra, durante el curso, los tres ramos de la ciencia vasta de la naturaleza. La excursión se verificó por la tarde la primera expedición dirigida por el catedrático de la asignatura D. Catalino Alegre. 966

Los estudiantes recorrieron entre ida y vuelta alrededor de 12 kilómetros, durante el mismo recibieron lecciones prácticas de organografía y fisiología vegetal, observando y clasificando las plantas por el sistema de Linneo y método de Decandolle algunas gramíneas, leguminosas, liliáceas, labiadas y dos ejemplares de monocotiledóneas, un hongo y el culantrillo del pozo.

Tuvieron también ocasión de examinar y estudiar las metamorfosis de los anfibios ranas y sapos, en un cauce contiguo a Almazora, clasificando al paso algunos insectos pertenecientes a varias familias. El profesor les explicó que la caliza compacta servía para fabricar la cal. Examinaron las laderas del Mijares, y el procedimiento, «por cierto desconocido», de que se vale la naturaleza para la formación de las pudingas, o masas minerales formadas por la reunión de cantos. Estos, con las gravas, arenas y demás materiales de que se halla compuesto el lecho del río Mijares, hicieron que los alumnos se formaran una idea de los terrenos de aluvión y de la procedencia de tales materiales

Sería prolijo enumerar todos los detalles de la expedición, pero lo mencionado es bastante para comprender el partido que, bajo el punto de vista científico, se puede de ellas sacar, organizándolas con otros medios y recursos.

No creemos que con ello saldrían hombres sabios de los Institutos, pues que el estudio de los tres reinos de la naturaleza, no puede hacerse sino en un sentido muy elemental, pero al menos, contribuirían estas excursiones a despertar en la

\footnotetext{
966 ALTAVA RUBIO, Vienta, op. cit. p. 385.
} 
juventud estudiosa la afición y el amor a los estudios de la naturaleza, harto olvidados por desgracia en nuestra España. . ${ }^{967}$

La segunda expedición científica de Catalino Alegre, se realizó el 18 de mayo de 1884, a Benicasim, riberas del Mediterráneo, cuestas y desmontes de Oropesa.

Las excursiones se realizaban los domingos para que los estudiantes no perdieran otras clases a las que estaban obligados a asistir. En la segunda excursión salió la comitiva a las 9 horas de la mañana en ferrocarril hasta Benicasim, y regresaron en el tren de las cinco de la tarde.

Magnífico era el panorama que ostentaba la naturaleza a la vista de todos los compañeros; a mano izquierda una cadena de montañas, de color azulado derivación de las de Peñagolosa, con todos los caracteres del terreno cretáceo: más allá otra cordillera de intrincados montes de color oscuro, cuyas crestas y picos elevados señalan el terreno triásico derivación de la Sierra de Espadán, que dejamos a nuestra espalda.

El desierto de las Palmas, se destaca en su fondo con varios ermitorios situados en su recinto cual blancas palomas; a la derecha dilatados campos cubiertos de verdes plantas, y en lontananza, la interminable faja del Mediterráneo. Tal es lo que se distingue al paso rápido del tren. ${ }^{968}$

Cuando llegaron a Benicasim, tras un breve descanso, se dirigieron rumbo hacia el mar. En el transcurso del camino observaron olivos, algarrobos, plantas de huerta, etc., plantas típicas del monte mediterráneo como jaras aliagas lentisco gramíneas...

En Benicasim echamos pie a tierra, y tras breve descanso, dirigimos nuestro rumbo hacia el mar. ¿Que variedad de planas en este trayecto! Los olivos y algarrobas forman a un lado bosques, aquí el trigo, cebada y jeja, allá habas, guisantes, algarroba, garbanzos y otras plantas de huerta: entre las espontáneas, amapolas, aliagas, lentisco, jaras y varias gramíneas. ${ }^{969}$

\footnotetext{
${ }^{967}$ La Provincia, 18/05/1884.

968 Ibídem.

${ }^{969}$ Ibídem.
} 
Observaron la Torre de los carabineros que en otro tiempo tenía como misión la vigilancia y defensa de la costa de los ataques de los corsarios y berberiscos.

Contemplamos un momento la torre que hoy sirve de albergue a los carabineros, y en otro tiempo de atalaya para distinguir las galeotas africanas, azote de estas costas. A la izquierda mano, mirando al Mediterráneo se ve la olla de Benicasim, sitio que servía de refugio a aquellas embarcaciones. Sobre la pared de la torre se yergue majestuosamente una higuera; ejemplo vivo de que las raíces en muchos casos, fijan y no absorben, cual sucede a esta planta que toma todos sus elementos de la atmosfera. ${ }^{970}$

En la orilla del mar vieron los restos de animales marinos y algas arrojados a la playa por el mar, aves marinas, etc.; También vieron lagartos, mariposas, rocas calizas y silíceas; por las cuestas y lomas contemplaron el madroño, la retama, el romero, el espliego, la adelfa y el guarda lobo;

« ¡La orilla del mar! ¡Cuánto despojos, objeto de estudio, han amontonado las olas de estas playas! El cardium, pinnas, patelas, cañadillas, ortigas de mar, variedades de elix, algas y varios fucus; ejemplos de moldes; muchas especies de cáncer [...]». ${ }^{971}$

Catalino Alegre realizo una tercera excursión escolar el 19 de Mayo de 1885, con los alumnos de Historia Natural, que reproducimos más extensamente.

El Clamor de la Democracia se encargó de la descripción de la expedición científica. $^{972}$

Se reunieron a las 3 horas de la tarde en el Paseo de Ribalta.

Según el redactor, era un día nublado que hacia la tarde fresca y deliciosa, y «puestos en marcha por la vía férrea y camino dels Mestrets, nuestro paseo se convirtió desde aquel momento en una continua lección práctica».

Antes de emprender la marcha, en el propio paseo de Ribalta, Catalino les dirigió la palabra manifestando que la finalidad no era herborizar, ni recoger y clasificar animales, vegetales y minerales, sino que la misión de la excursión era poner en práctica la materia teórica explicada en la cátedra durante el curso.

\footnotetext{
${ }^{970}$ Ibídem.

${ }^{971}$ La Provincia, 25/05/84.

${ }^{972}$ El Clamor de la Democracia, 24/5/1885.
} 
Empezaron a recoger plantas, estudiando la organización de las raíces, tallos y hojas, así como flores y frutos. Con tal motivo examinaron las raíces fibrosas de la Poa annua, planta monocotiledónea, las de la Euforbia comunis, dicotiledónea; las hojas sencillas y pendulinas del chopo, las compuestas de acacias y algarrobo; la flor crucífera del Alisum espinosum; la amariposada de la Trifolium ocroleutum; las hojas acuminadas de la Agave con sus variedades americana y variegata; las radicales y enteras del Arum maculatum; las biternado-divididas de la Peonia oficinal; las flores tetradinamos de la Escabiosa y del Plantago; el fruto llamado cono de la Tuya y el Ciprés, y otros órganos más o menos importantes de las plantas encontradas al paso hasta llegar al cauce del llamado río seco.

A continuación exponemos las imágenes de algunos organismos vegetales observados en la tercera excursión de Catalino Alegre:

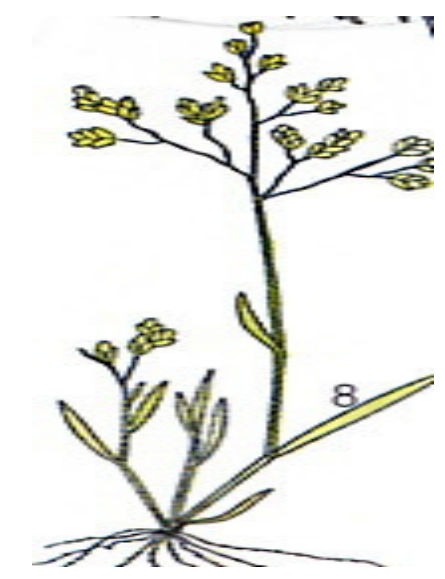

Poa annua

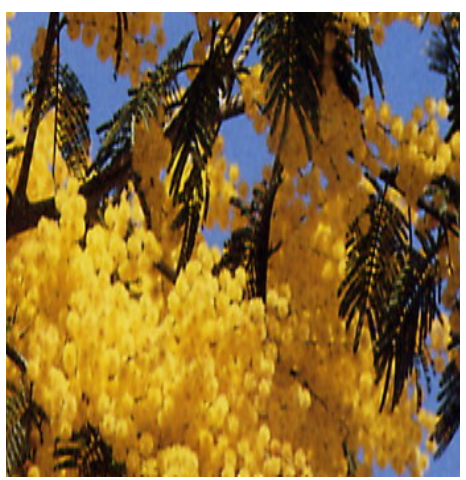

Acacia dealbata

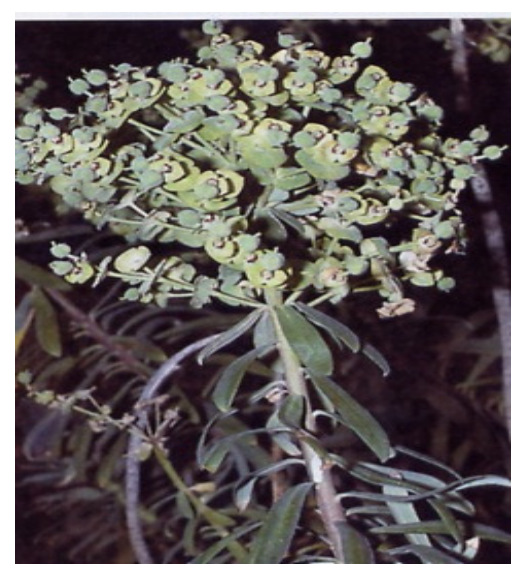

Euphorbia s

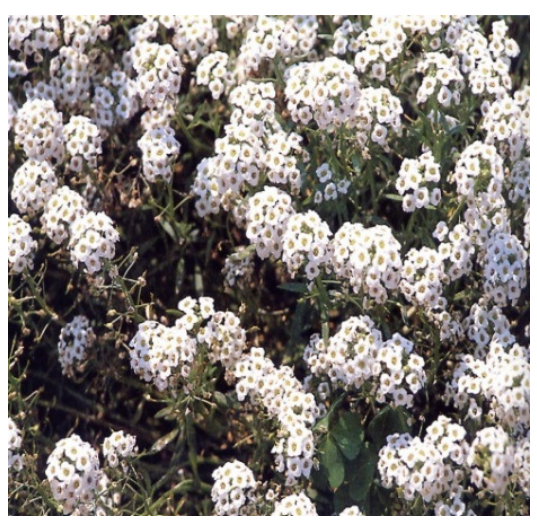

Alissum maritimum 


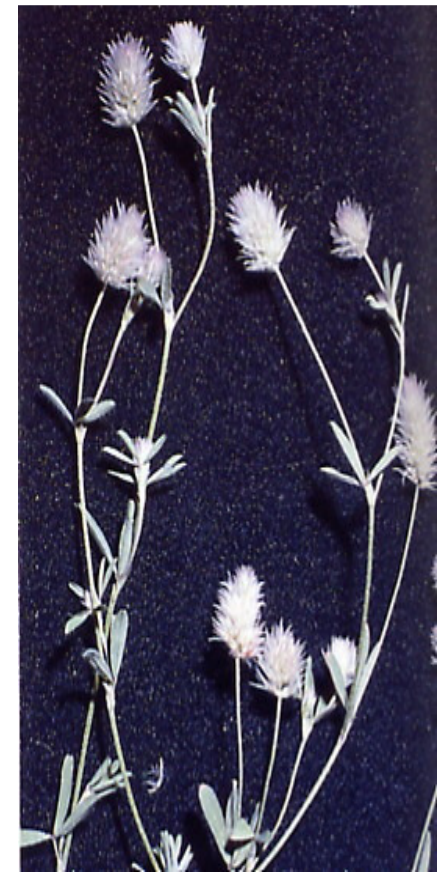

Trifolium pratense

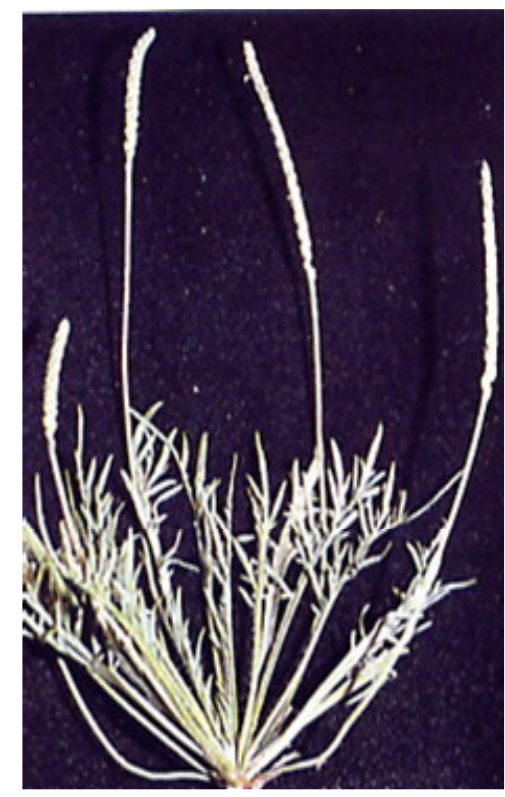

Plantago coronupus

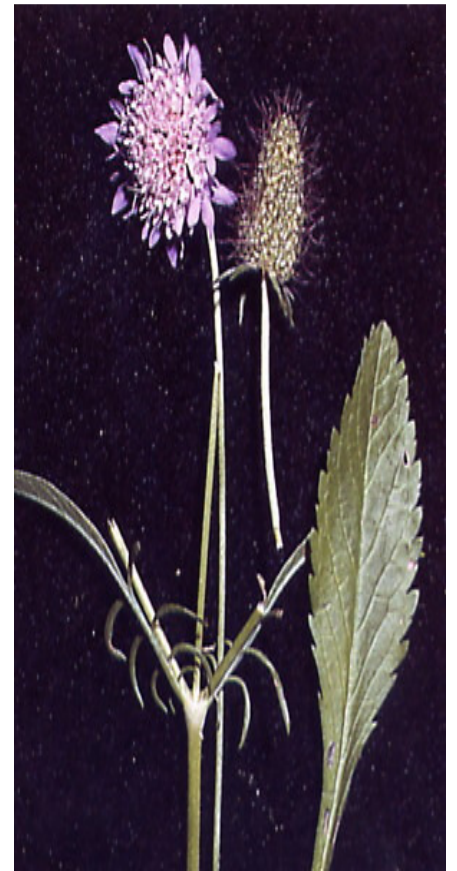

Escabiosa maritima

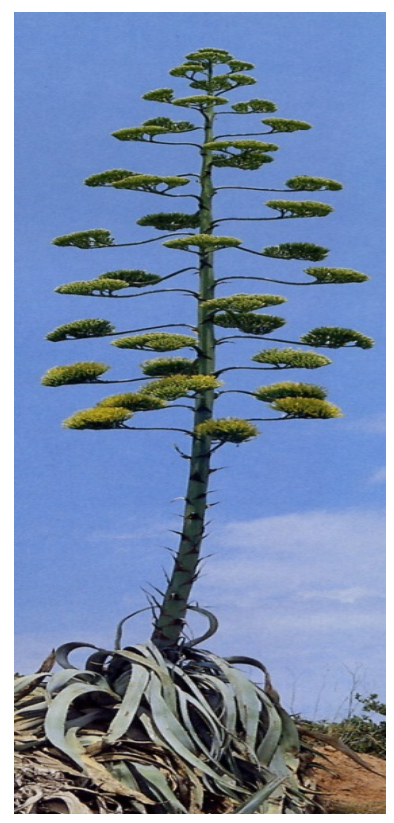

Agave americana

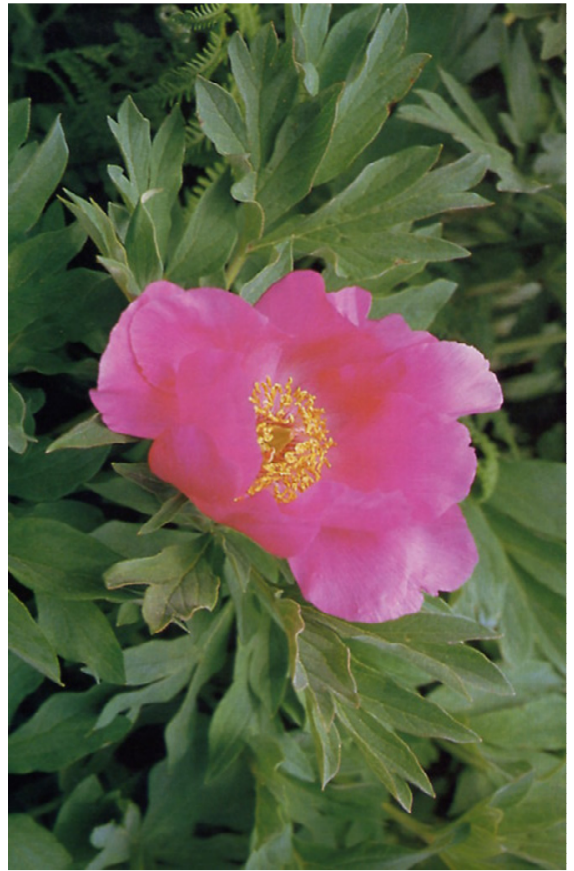

Paeonia officinalis

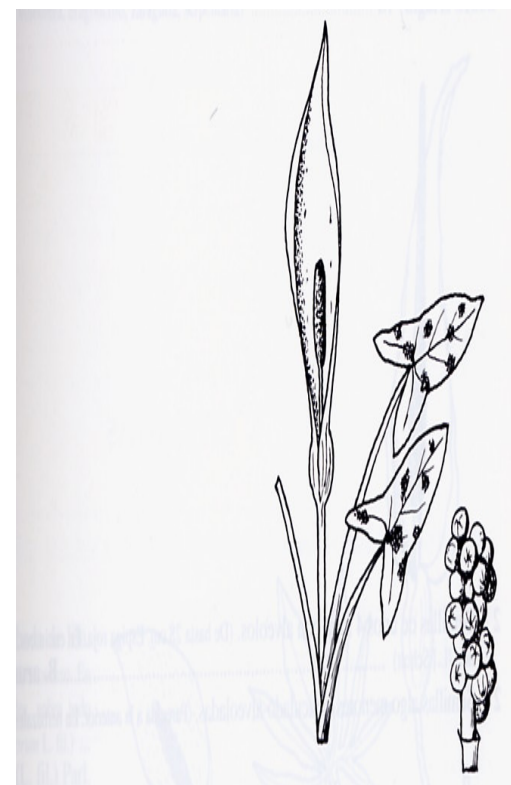

Arum maculatum 


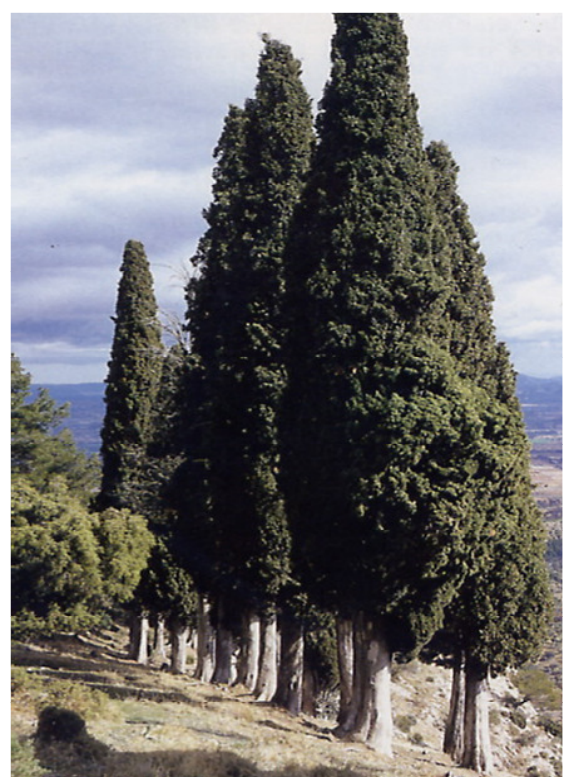

Cupressus sempervirens

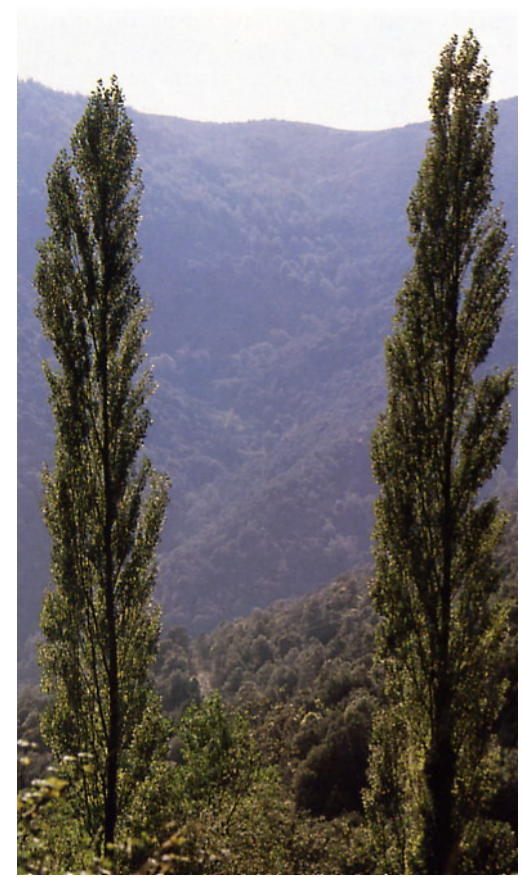

Populus nigra

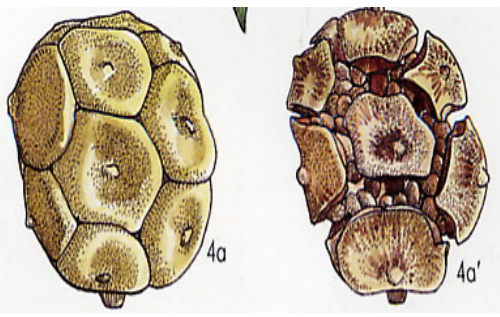

conos del ciprés

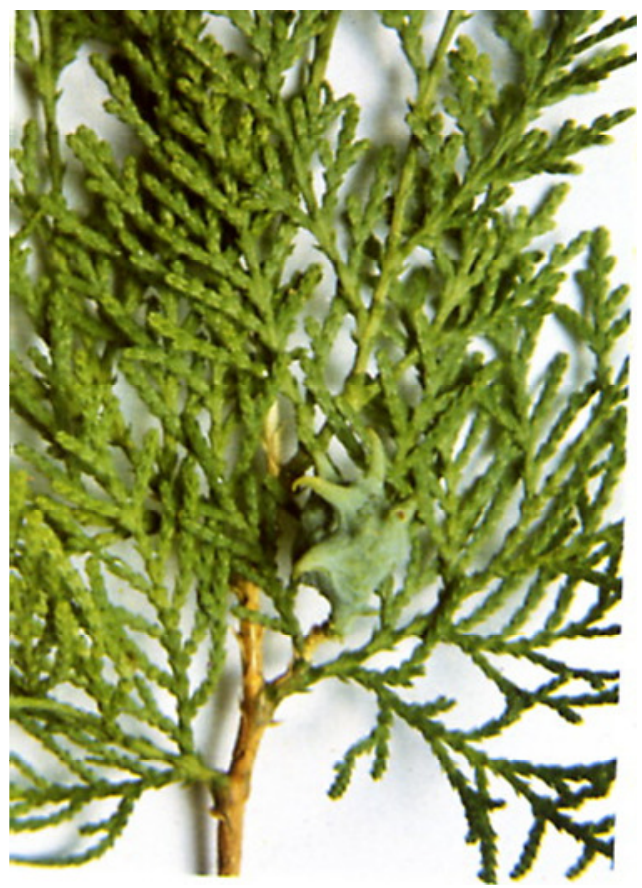

Thuja occidentalis

En el cauce del río seco Catalino explicó a los estudiantes la geología del terreno:

Detuvímonos allí breves momentos en la ladera derecha para escuchar algunas palabras del profesor, indicándonos el curso y terrenos que atraviesa el referido barranco o río seco, que naciendo en la cuesta de Puebla Tornesa, derivación de los montes triásicos del Desierto de las Palmas, entra en el valle de 
Borriol, de naturaleza cretácea, que lo atraviesa en toda su extensión de norte a sur, pasa al término de Castellón, torciendo su curso hacia oriente, y socavando su lecho en el terreno cuaternario, desciende hacia el mediterráneo, sin que jamás sus aguas tengan fácil acceso al mar en su último trayecto, ya por los arrastres acumulados en las partes bajas, ya por codicia del cultivo que ha ido mermando al lecho natural su anchura y extendiendo las plantaciones; de donde proceden las inundaciones de estos últimos años, que destruyendo diques por unos lados, invadiendo cultivados campos en otros, ha llegado a amenazar la vida de los moradores del Grao de esta capital. ${ }^{973}$

\section{En el cauce del río estudiaron las rocas sedimentarias:}

La caliza pura, la variedad cristalina llamada espato, la sílice compacta, fácil de confundir por su aspecto con la anterior, pero que se distingue por dar chispas con el eslabón; en la ladera la marga; más allá, cantos rodados, gravas, arenas, tanto calizas como silíceas y muchas pudingas y areniscas formadas por aglutinación de materiales redondeados, gruesos en el primer caso y pequeños en el segundo. ${ }^{974}$

Saliendo del cauce ascendieron hacia el norte hasta llegar a las estribaciones de los montes que «en forma de anfiteatro circuyen a la capital por aquella parte».

A doscientos metros sobre el nivel del mar, se observaba la fértil llanura de la Plana, cubierta de bosques de naranjos, olivos, algarrobos, y demás frutales. Desde allí se divisaba la capital a los pies y a lo lejos las poblaciones de Villarreal, Almazora, Burriana y Nules.

A través de esta vasta llanura se distinguía una línea que la cruza de noroeste a sureste: es el Mijares cuyas abundantes aguas repartidas por mil canales de riego, dan vida y lozanía a toda aquella vegetación. ${ }^{975}$

Torciendo hacia la derecha y ladeando los montes, continuaron los ensayos prácticos sobre la Historia Natural:

\footnotetext{
${ }^{973}$ Ibídem.

${ }^{974}$ Ibídem.

${ }^{975}$ Ibídem.
} 
Muchas plantas en flor cayeron en nuestras manos, que después de recorrer brevemente el campo de la descripción anatómica de sus raíces, hojas, flores y frutos, clasificábamos primero por el sistema Lineano y luego por el método de Decandolle: examinamos las flores didinomas del Isopus oficinal, menta y marrubio y algunas tetradinamas pertenecientes a los géneros Lepidium e Isatis; con tal motivo pudimos ver las relaciones que existen entre la clase didinamia y tetradinamia de Lineo y las familias denominadas labiadas y crucíferas, respectivamente de Decandolle. ${ }^{976}$

Encontraron un fósil perteneciente al cretácico: Conus verneulli, fósil perteneciente al cretácico y un «curioso mineral consistente en la creta recubierta de una capa ferruginosa».

Recogieron insectos coleópteros como la Cicindela campestris, la Pimelia septena-puntata, carábidos, sílfidos y escarabeidos; entre los ortópteros el grillo, la Mantis religiosa y el saltamontes; entre los himenópteros, varias especies de hormigas y avispas; dos especies del género vanesa entre los lepidópteros; entre los hemípteros otras dos especies de chinche de campo y un abejorro entre los dípteros.

Entre los reptiles, alcanzaron dos lagartijas y entre los anfibios unos «escuerzos que sobrenadaban en un charco del barranco o río seco de Borriol» en estado de metamorfosis apuntando las extremidades abdominales.

Fueron finalmente objeto de estudio, algunos arácnidos de los géneros Epeira y Folcus, la cochinilla de humedad entre los crustáceos y una abubilla y varias tórtolas que «vimos volar y que nos hicieron recordar a los paseres y palomas».

Presentamos a continuación las fotografías de algunos animales observados en la excursión:

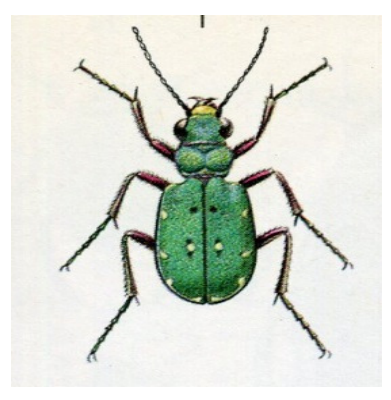

Cicindela campestris

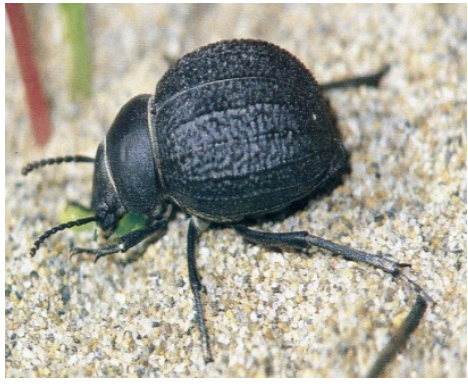

Pimelia septempuntata

${ }^{976}$ Ibídem. 


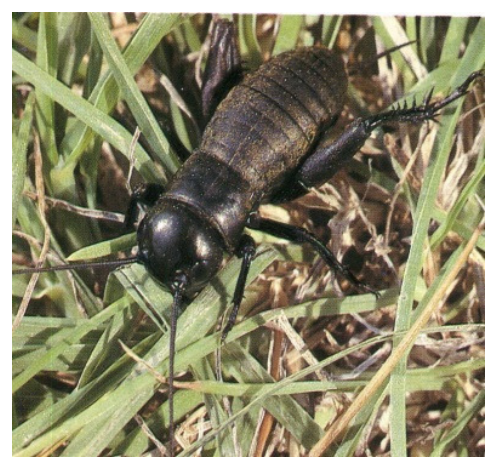

Grylllus campestris

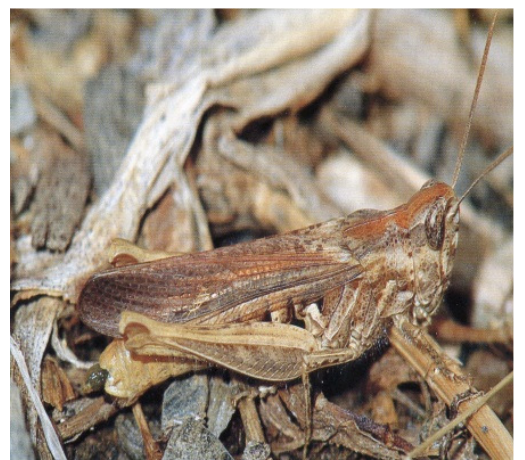

Chorthippus brunneus

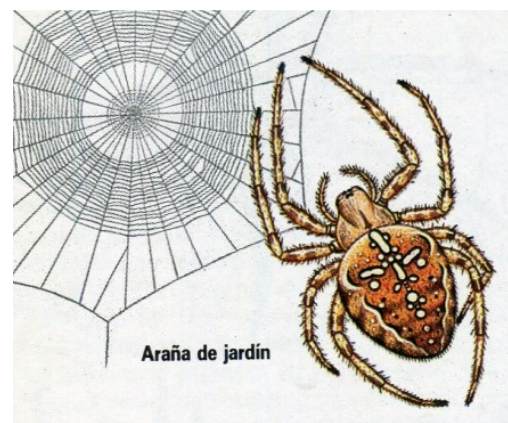

Araneus diadematus

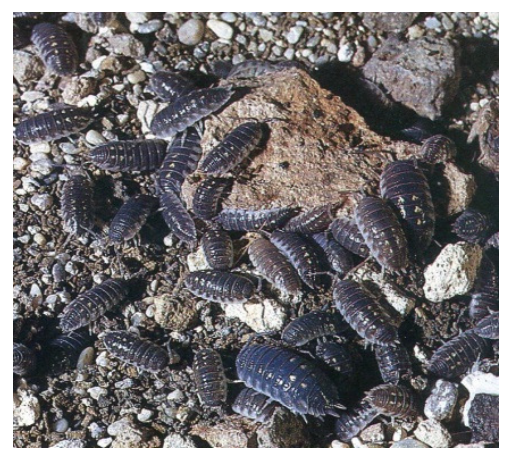

Oniscus asellus

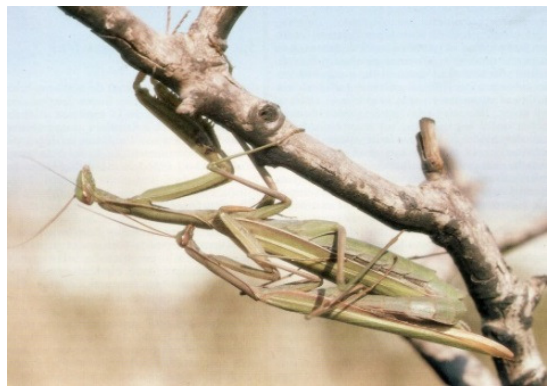

Mantis religiosa

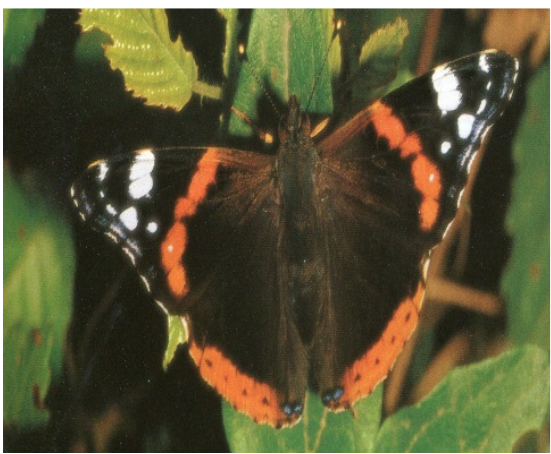

Vanesa atalanta

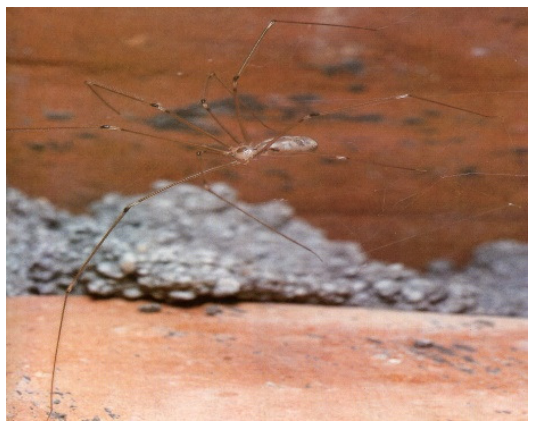

Pholcus phalangioides

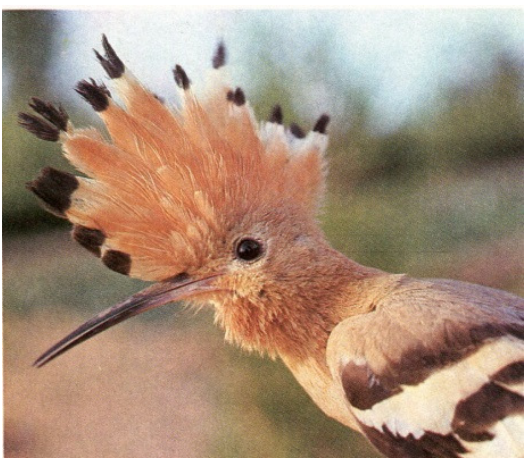

Upupa epops 
«Entre tanto el sol declinaba. Nos hallábamos separados de la ciudad unos cuatro kilómetros y bien a pesar nuestro, tuvimos que emprender viaje de regreso por el camino llamado de Borriol, porque la noche se nos echaba encima.»

El redactor lamenta que se terminara la breve, pero instructiva expedición científica. Reflexiona sobre la acumulación de asignaturas, la falta de medios y recursos en los establecimientos de segunda enseñanza y sobre todo la deficiencia de la ley y reglamento, no permitan dar mayor extensión a estas lecciones prácticas «que tanto contribuirían a despertar la afición de la juventud a tales estudios, cuyo progreso señala el nivel intelectual de las naciones que por desgracia con tal descuido se miran en nuestra España».

En el primer tercio del siglo XX, surgió un gran interés por la metodología llevada a cabo en la impartición de la clase de Historia Natural, los profesores vieron la necesidad de la salida al campo como complemento de los conceptos desarrollados en el aula. Nada mejor que la propia Naturaleza para la observación de los fenómenos naturales. En esta época, la excursión cobra un sentido más didáctico, no sólo sirve para recolectar seres naturales, sino como lección dada «in situ» para observar las distintas formaciones geográficas y geológicas, el hábitat de los seres vivos y su relación con el medio ambiente. ${ }^{977}$

Después de Catalino Alegre, su sucesor y director del Instituto Francisco Domenech, realizó una excursión a la Torreta de Castellón para «conocer todas las especies de plantas y minerales que en ella se encuentran».

Según la prensa la excursión resultó tan provechosa como amena y distraída, «poniendo de relieve el digno director de este Instituto, el celo que tiene porque sus alumnos sepan tanto la asignatura teórica como prácticamente.» ${ }^{978}$

Domenech llevaba a los alumnos del último curso de Historia Naturtal a un jardín botánico dependiente del Instituto, situado en el camino del Mar, en el llamado Hort del Sord, que pertenecia a la familia Tirado de Castellón, donde les daba lecciones de botánica. ${ }^{979}$

\footnotetext{
977 HERNÁNDEZ NIEVES, Ma Purificación (2009), op. cit. pp. 216-217.

${ }^{978}$ El Clamor, 04/05/1910.

${ }^{979}$ SOS PARADINAS, Alejandro (2013): Biografía del Dr. D. Vicente Sos Baynat. Diputació de Castelló. p. 40 .
} 
En 1915, con el catedrático de ciencias naturales Antimo Boscá, marcharon a Valencia los alumnos de sexto curso del Bachillerato con el fin de visitar los museos de Historia Natural de la Universidad y Centro de Segunda Enseñanza, Granja experimental, Observatorio Meteorológico y Jardín Botánico. Permanecieron dos días en Valencia para poder examinar detenidamente los objetos que encerraban los «centros de cultura práctica».

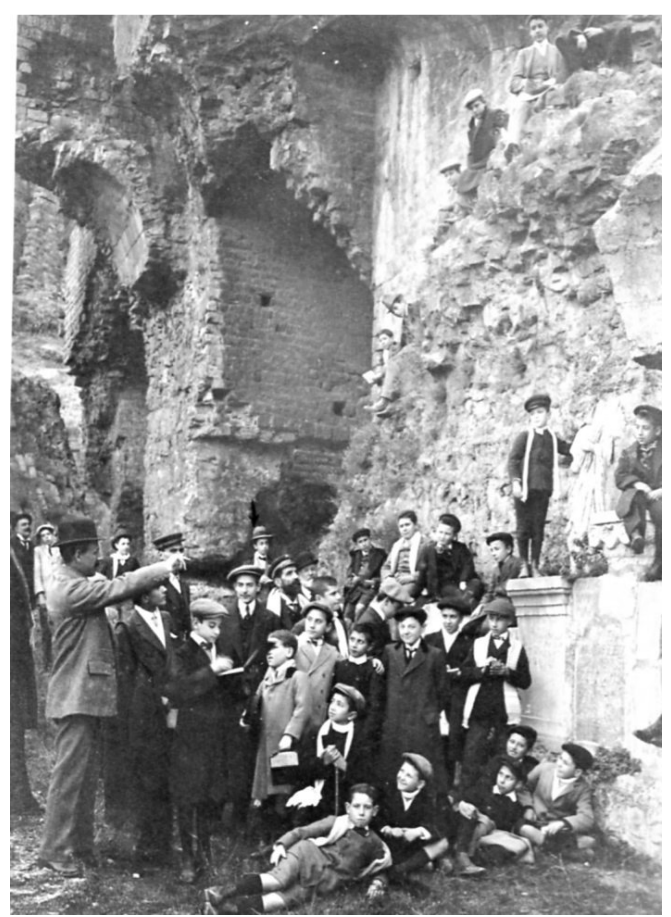

Excursión a Sagunto de Antimo Boscá. Noviembre de 1911. Alumnos del 3er curso. Fuente: SoS PARADINAS, Alejandro (2013): Biografía del profesor Dr. D. Vicente Sos Baynat

Uno de los centros que más impresionaron a los excursionistas fue la «Granja Escuela Agrícola», de Burjasot, de la que era director el que fuera profesor del Instituto, Antonio Maylin. Llamó la atención de los visitantes el aparato del análisis de los vinos por electricidad y que «consiste en esencia, en un aparato fundado en la medida de las resistencias, estableciéndose cierto equilibrio entre las de la muestra sometida al análisis, y las desarrolladas en una cajita de resistencias».

Está compuesto sencillamente de un puente de Wiston en el cual, en vez de emplear corriente continua como se hace para la electrolisis, se hace uso de la corriente alterna para mantener cierto equilibrio móvil entre los iones; para más claridad, supongamos que se trata de averiguar la cantidad de sulfatos que hay en el vino; estos sulfatos, juntamente con las demás sales, darán lugar a unos iones 
electronegativos, como el radical (SO2) y otros electropositivos, si se pone en el aparato, agua de barita, los iones $\mathrm{SO} 2$ se unen a los del bario disminuyendo la conductibilidad a causa de sulfato bárico (SO4 Ba) insoluble, de este modo se van quitando iones $\mathrm{SO} 2$ hasta que quitados todos, al añadir más agua de barita sube la conductibilidad a causa de no poderse formar sulfato barico por la falta de radical SO2 y quedando así determinada la cantidad de sulfatos que tenía la muestra. También se pueden determinar los cloruros, para lo cual se substituye el agua de bario por nitrato argéntico (NO3 Ag); se aprecia la marcha de la operación por el ruido que produce el desequilibrio de las resistencias, cuyo ruido desaparece al restablecer el equilibrio; de modo que la principal ventaja del aparato en cuestión está en la rapidez con que se opera, pues en cinco minutos se hace lo que por procedimientos ordinarios se necesita lo menos cuatro o cinco horas.

Este es a grandes rasgos el gran adelanto del análisis químico aludido y que entre otros muchos conocimientos forma parte de los adquiridos en la provechosísima excursión del jueves. ${ }^{980}$

«Nuestro querido profesor, como se ve, educado a la moderna, desterrando las viejas prácticas, encauza la enseñanza de su ciencia por los derroteros del verdadero provecho y sentido práctico de las cosas haciendo excursiones científicas como la presente.» ${ }^{981}$

El Desierto de las Palmas fue un aula de naturaleza para los centros docentes de la capital provincial. La proximidad era un aliciente a la hora de programar excursiones de estudio y reconocimiento de un entorno enormemente instructivo. A menudo estas experiencias docentes fuera del aula dependían del impulso del profesor. Sin ánimo exhaustivo, he aquí una muestra de excursionismo reglado por el Desierto.

A finales de mayo de 1915, dirigidos por el catedrático de Historia Natural Antimo Boscá, 14 estudiantes del Instituto Ribalta acompañados de un fotógrafo, cogieron el ferrocarril en Castellón de buena mañana para dirigirse a Benicasim. Durante el trayecto Antimo Boscá explicó los hechos más destacados de los árboles cultivados que iban observando. A partir de la estación de Benicasim iniciaron la marcha hacia el convento del Desierto. A lo largo del camino, profesor y estudiantes iban identificando «el algarrobo (Ceratonia silicua), el palmito (Chamaerops humilis), el

\footnotetext{
${ }^{980}$ El Clamor, 26/05/1915.

${ }^{981}$ Ibídem.
} 
enebro, el brezo, la ginesta, la coscoja, el orobranquio; animales, la lagartija, el Pshamodromus hispanicus, el mil pies...». El ilustre naturalista también les explicó el predominio de los yesos vinosos triásicos y de las rocas calcáreas dolomíticas (Muschelcalk). Después de descansar en la fuente del «Poll» e impresionar varias placas fotográficas, continuaron hacia «la font de la Teula» donde identificaron un ejemplar de adiantus capilum veneris. Después pasaron por la orilla del convento viejo y finalmente llegaron al convento nuevo donde vieron un alcornoque (Quercus suber). Después de comer, visitaron las dependencias conventuales y de inmediato tomaron el tren que les devolvió a Castellón. ${ }^{982}$

Al año siguiente, de nuevo a mediados de mayo, el profesor Antimo Boscá volvió al Desierto con la nueva promoción de estudiantes de Ciencias Naturales del Instituto de Castellón. El esquema de la jornada fue muy parecido a la del curso anterior, con explicaciones naturalísticas durante el trayecto hacia Benicasim, numerosos reconocimientos geológicos, botánicos y faunísticos durante el ascenso al convento y diversas comprobaciones barométricas. ${ }^{983}$

Y así poco a poco, viendo y aprendiendo fuimos llegando al convento. Sentados en los bancos de la ermita de los desamparados contemplamos el estupendo panorama...Peñas abruptas y elevados montes cubiertos de vegetación, pinos y enebros (coníferas) embalsaman el ambiente. El ancho valle (al pie) con la carretera blanca como una estela de luz más allá el mar tranquilo, esfumado por las nubes del cielo, que nos dejó ver la las islas Columbretes. La brisa mueve blandamente los árboles. Suenan las doce en el reloj del convento... ${ }^{984}$

Años después, también los estudiantes de la Normal de Castellón fueron de excursión al Desierto. El objetivo de la visita guiada por el profesor de Ciencias Naturales era conocer «bien los terrenos, pasar en plena naturaleza, despertando con ello el amor al ejercicio alpinista». Después de visitar el convento, los excursionistas iniciaron el reconocimiento de diversos afloramientos y las causas de su compleja estructura. El profesor Rafael Balaguer explicó los resultados de la reciente

\footnotetext{
982 BELlÉS MATEU, Joan F: El Paisatge del Desert de las Palmes: la seua imatge cultural (1900-1936). Boletín de la Sociedad Castellonense de Cultura. Tomo LXXXI. Enero- Junio 2005. Cuad. I-II pp. 89-90. 983 Ibídem.

${ }^{984}$ El estudiante - cronista, Canos, 1916, describe con admiración las vistas panorámicas.
} 
investigación geológica realizada por Vicente. Sos Baynat. Después los estudiantes recogieron muestras de pizarras y gres, mientras el guía continuaba explicando los procesos de metamorfismo, el sial y la sima además de la teoría de Wegener. En conclusión, un instructivo viaje a la naturaleza durante el cual los estudiantes de la Normal tuvieron ocasión de observar la relevancia de los fenómenos geológicos que «nos enseñan a contemplar los paisajes, desde una perspectiva menos conocida y particularmente interesante». ${ }^{985}$

A últimos de 1912 y primeros de 1913, nacieron los exploradores o «boyscouts» de Castellón, delegación de una asociación patriótica juvenil de instrucción moral y física. Entre sus actividades, los días festivos hacían «excursiones campestres y, mientras oxigenan sus pulmones con el aire puro del campo o de la mañana, se les enseña prácticamente un sinfín de cosas que no se hallan en los libros» ${ }^{986}$.

Obviamente el Desierto estaba muy lejos para las salidas dominicales ordinarias, no obstante, a veces, también iban a este bonito paraje.

Así, el mes de octubre de 1916, un grupo de exploradores de Castellón-guiados por el director del Instituto y el catedrático de Historia Natural, Antimo. Boscá, hicieron una excursión al Desierto de las Palmas. El objetivo era establecer comunicación telegráfica desde el castillo de Montornes y desde el Bartolo con la estación receptora localizada en el observatorio del Instituto Ribalta. El día convenido había un grupo de exploradores en el Bartolo con el director del Instituto y otro en el castillo de Montornes con Antimo. Boscá. Poco después de mediodía salió el sol y los exploradores telegrafistas y semaforistas del Desierto pudieron comunicarse y saludar la estación receptora y recibir la respuesta. ${ }^{987}$

\subsubsection{El Gabinete de Historia Natural del Instituto de Castellón}

El Instituto disponía de suficientes recursos materiales para realizar las clases prácticas. Contaba con colecciones de animales, plantas, rocas y minerales, maquetas y modelos anatómicos, suficientes para hacer una enseñanza intuitiva.

\footnotetext{
985 BELLÉS MATEU, Joan F. op. cit. pp. 89-90. Otro estudiante, Pérez 1936, describe las explicaciones que les hacía el profesor Rafael Balaguer, sobre la geología del terreno.

${ }^{986}$ Ibídem.

${ }^{987}$ Ibídem.
} 
Catalino Alegre utilizaba estos recursos para desarrollar las clases prácticas. El Gabinete poseía una gran mesa de experimentos y alrededor de la misma se situaban los alumnos para observar como el profesor realizaba la práctica, es decir, los alumnos no intervenían solo observaban. ${ }^{988}$

El material del gabinete de Historia Natural fue aumentando progresivamente por donativos de personas interesadas en el engrandecimiento del Instituto. En 1865, José Navarro, Coronel de la media brigada de provinciales, donó al Instituto, una colección de conchas procedentes de los mares de Filipinas. También se concedió por un particular, colección de minerales de los principales distritos mineros de la península. $^{989}$

En el año 1866-1867 Jaime Bellver y Torres, regaló tres ejemplares de estrellas de mar y varios ejemplares de piedras de construcción de diversos puntos de la provincia $^{990}$

Durante el curso de 1867 a 1868, los objetos que se adquirieron para el gabinete de Historia Natural fueron los siguientes:

1 Serranus gigas, Gm

1 Uranoscopus scaber. Lin

2 Trigla lyra. Lin

1 Scorphaena porcus. Lin

1 Scorphena scropha. Lin

1 Peristedion conmuni

1 Sparus hurta. Lin

1 Pagellus erythrinus. Lin

2 Labrus turdus. Lin

1 Zeus faber. Lin

1 Box talpa. Cuv.

1 Brama rayi. B1.

\footnotetext{
988 ALTAVA RUBiO, Vicenta (1993): Aportaciones al estudio de la enseñanza Media en Castellón, 18461900. op. cit. p. 385.

${ }^{989}$ Memoria acerca del estado del Instituto de Segunda Enseñanza de Castellón, leída el día 16 de Septiembre de 1866 por el doctor en Ciencias y Medicina, director y catedrático del mismo D. Francisco Llorca, en el acto solemne de la apertura del curso 1866 a 1867. Castellón, 1866, Imprenta y librería de la viuda de Vicente Perales, p. 15

${ }^{990}$ Ibidem, curso, 1867-1868, p.15
} 
1 Clupea major. Lin

1 Chaetodon pistratus. Lin

1 Syngnathus acus. Lin

1 Xiphias gladius. Lin.

1 Sargus vulgaris. Lin

1 Barbus communis. Lin

1 Squalus unistelus. Lin

1 Torpedo galvanii. Riis.

Los objetos regalados fueron Strix vulgaris. Lin., regalo de D Joaquin Bañon. Un herbario 800 plantas de Francisco Doménech Bueso, auxiliar de la Sección de Ciencias del Instituto; y dos ejemplares de mármol negro de la provincia de Castellón, regalo de Victorino Fabra. ${ }^{991}$

A partir de los cursos 71-72, 72-73, 73-74, 74-75, el Instituto tuvo problemas para hacer frente a los pagos del profesorado y subalternos, así como adquirir nuevo material para los gabinetes, porque la Diputación no recaudaba el dinero que le adeudaban los pueblos invadidos por la guerra carlista. En julio de 1875, vino la paz a la provincia, y el curso 75-76 transcurrió con tranquilidad, pero con escasos recursos para la compra de nuevo material.

En el curso 76 a 77, el material científico que se adquiere para los gabinetes es poco y de escasa importancia. Se pudo satisfacer los haberes del personal y material más indispensable.

En el Real Decreto de 10 de agosto de 1877, se establecen los derechos académicos, destinados en parte al aumento y mejora del material científico, y auxiliar a los jóvenes poco pudientes, que sean sobresalientes. De este modo, con un pequeño recargo a cada alumno, apenas sensible, se consiguió que la enseñanza no careciera de los medios indispensables para su propagación y mejoramiento, y que los alumnos más inteligente y aplicados, pero faltos de recursos, contaran con medios para seguir una carrera.

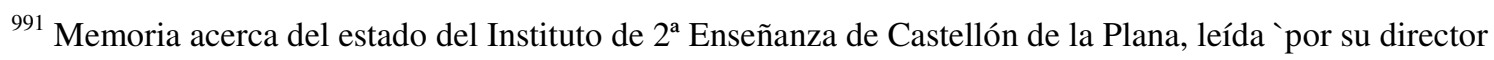
y catedrático Romualdo Arnal, en la solemne apertura del curso de 1868 a 1869. Castellón, 1868. Imp. Y Lib. de Rovira Hermanos, pp. 26-27.
} 
Se adquirieron durante el curso 78-79, tanto de fondos destinados en el presupuesto del Instituto para material científico, como de la parte de derechos académicos, destinados a dicho objeto, 14 láminas de anatomía de cartón piedra de anatomía descriptiva para el estudio de la fisiología.

El material que contenía el Gabinete de Historia Natural, en el curso 79-80 era el siguiente:

\section{MINERALOGÍA}

1.- 186 Especies mineralógicas

2.- 108 ejemplares de rocas

3.- 240 fósiles.

\section{BOTÁNICA}

4.- 760 Plantas disecadas

\section{ZOOLOGÍA}

5.- Un esqueleto humano

6.- Cuatro cuadrumanos

7.- Un quiróptero

8.-Tres insectivoros

9.- Seis fieras

10.- Un pinnipedo

11.- Cuatro roedores

12.- Dos desdentados

13.- Tres rumiantes

14.- Un diente de hipopótamo

15.- Un delfín

16.- Un marsupial

AVES

17.- Tres rapaces

18.- Cinco trepadoras

19.- Nueve pájaros

20.- Dos palomas

21.- Tres gallinas

22.- Cinco zancudas 
23.- Dos palmípedas.

24.- Un esqueleto.

REPTILES

25.- Un esqueleto

26.- Tres quelonios

27- Cuatro saurios

28.- tres ofidios

BATRACIOS

29.- Un esqueleto

30.- Tres especies de batracios

PECES

31.- Un esqueleto

32.- Diez acantopterigios

33.- Un malacopterigio

34.- Un lofobranquio

35.- Cuatro selacios

36.- Un ciclóstoma

MOLUSCOS

37.- Ciento seis conchas.

ARTICULADOS

38.- Cinco especies.

ZOÓFITOS

39.- Seis ejemplares.

\section{ANATOMÍA}

40.- Una colección de 14 láminas o figuras en relieve para el estudio de la anatomía humana descriptiva.

41.- Una oreja anatómica.

En el curso 80-81 se adquirieron una escala de dureza y 26 modelos de cristales, 23 ejemplares de miriápodos, arácnidos, etc., una colección de insectos en tres cajas, y cuatro preparados de filoxera. 
En el 81-82, se adquirieron una colección de 16 piedras preciosas en Strass, 10 modelos para la demostración de la talla de los diamantes. Un esqueleto de cuadrumano y otro de ave.

82-83, ídem que el curso anterior.

83-84, varios frascos y tubos de moluscos y crustáceos, 21 ejemplares de aves y mamíferos. ${ }^{992}$

De tiempos de Francisco Doménech data el llamado Gabinete de Historia Natural, con colecciones de minerales, rocas, fósiles, moluscos, reptiles, aves y mamíferos cuidadosamente clasificadas.

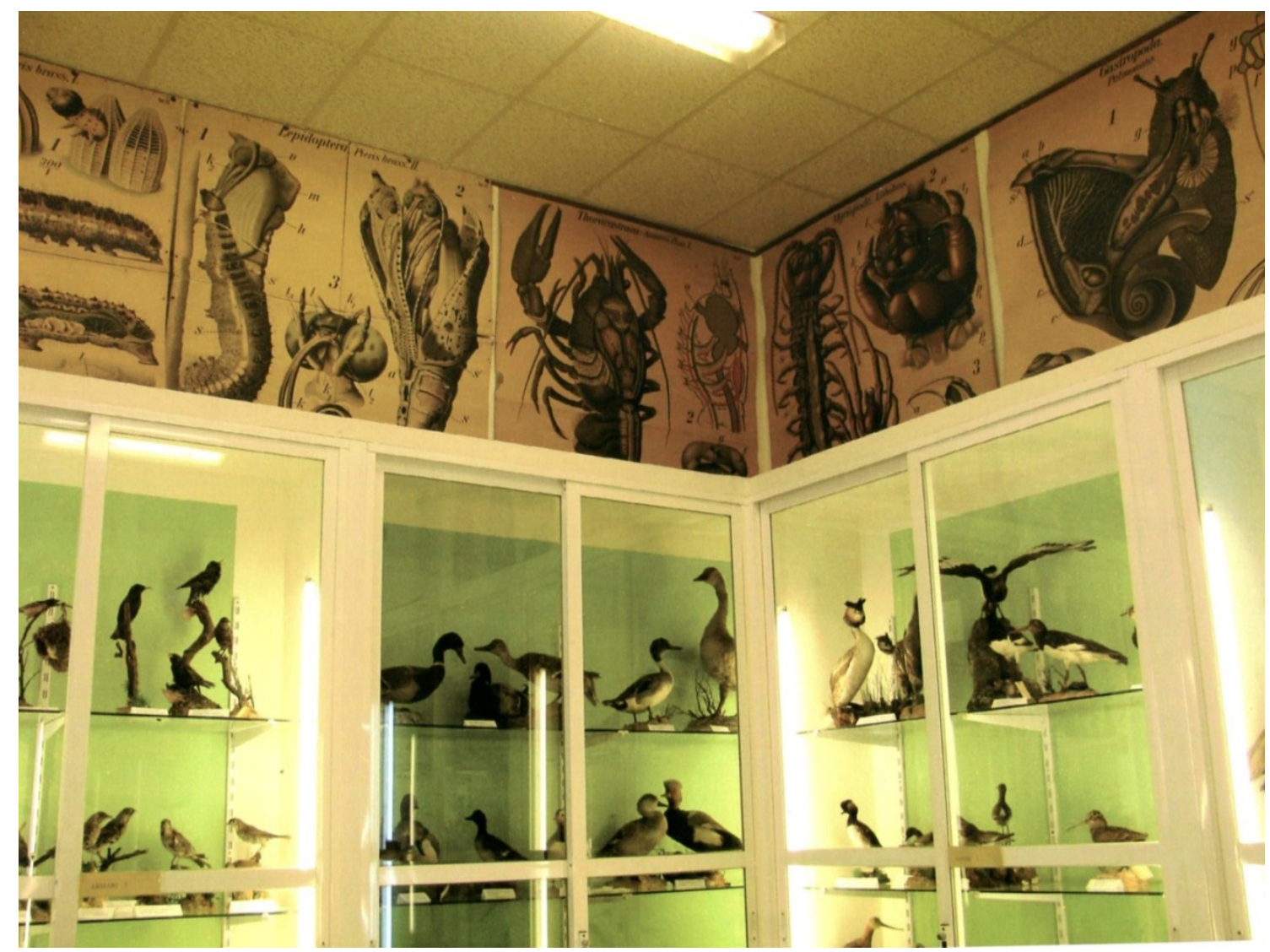

Gabinete de Historia Natural. Procede del antiguo Instituto General y Técnico. Hoy constituye un importante aporte al Gabinete del Instituto Ribalta. Fuente: SOS PARADINAS, Alejandro (2013): Biografía del profesor Dr. D. Vicente Sos Baynat

Su sucesor, Antimo Boscá incrementó las colecciones del Instituto: insectos, minerales, rocas, fósiles, etc. Destacaba la colección de peces de las costas de Levante, importante colección desde el punto de vista científico, y que fue mencionada en

992 Memorias del Instituto de Castellón de los años 1867- 1915. 
comunicaciones publicadas por la Sociedad Española de Historia Natural. Publicó muchos trabajos, de entre los cuales destacó uno titulado Fauna Valenciana, donde describe desde protozoos marinos a los animales superiores. ${ }^{993}$

\section{POLÉMICA EN LA IMPLANTACIÓN DE LA ESCUELA NORMAL DE MAESTRO}

No queremos acabar este capítulo sin comentar la repercusión que tuvo en la sociedad castellonense, incluido el Instituto, por la supresión de las estudios de Maestro en dicho centro.

El Instituto de Segunda Enseñanza siempre estuvo preocupado porque el centro sirviera para educar a todas las clases sociales como ya hemos comentado en párrafos anteriores. Los directores al comienzo de curso, señalaban la necesidad de los estudios de Aplicación: Comercio, Artes, Agricultura, por ello, la supresión de la Escuela Normal de Maestros provocó una gran polémica en todos los estamentos sociales, incluido el profesorado del Instituto, que siempre abogaba por la educación del obrero, y, estaba claro que, al suprimir dicha escuela, repercutía en la clase menos pudiente que no podía seguir sus estudios en Castellón.

También fue demandada por la sociedad castellonense, otros centros de enseñanza, entre ellos, la Escuela Pericial, pues la juventud castellonense necesitaba de ciertos estudios que los capacitase para ejercer en la industria, agricultura y en el comercio. La Escuela Pericial fue propuesta por el médico republicano, Vicente Gea, en una sesión de la Diputación Provincial, celebrada en mayo de 1916.

En 1904 fueron agregados a los estudios de bachillerato los del Magisterio, pudiéndose desde entonces cursar en el Instituto las enseñanzas de la carrera de maestro.

Años después, el Decreto de 30 de agosto de 1914 suprimía los estudios de magisterio en el Instituto General y Técnico. ${ }^{994}$

\footnotetext{
993 SOS PARADINAS, Alejandro (2013): Biografía del profesor Dr., D. Vicente Sos Baynat. Diputació de Castelló. p.41.

${ }^{994}$ El Real Decreto de 30 de agosto de 1914, en su artículo $5^{\circ}$, disponía que las provincias que quisieran establecer Escuelas Normales, debían solicitarlo del ministerio de Instrucción pública y Bellas Artes, obligándose a ingresar en el Tesoro el importe de los gastos de su instalación y sostenimiento. El Decreto no declaraba obligatorio su establecimiento, como se hizo en 1901 para el grado elemental. El Clamor, 27/10/1914
} 
El primero de octubre de 1914 cesaban dichas enseñanzas y gran número de estudiantes pertenecientes a las clases menos pudientes tuvieron que interrumpir sus estudios, no pudiendo seguir la carrera de maestros unos y menos ingresar en ella otros.

Esto y el deshonor que significaría para una provincia como la de Castellón el carecer de Centro docente de tanta importancia es lo que inclinó a la prensa local de Castellón a iniciar la campaña a favor de la creación de la Escuela Normal de Maestros. Todos los diarios locales, de todas las ideologías, contribuyeron a la campaña en pro de la creación de dicha Escuela; además de El Clamor, La Provincia y El Heraldo, colaboraron también los semanarios El Tradicionalista y El Maestrazgo. ${ }^{995}$

Refiriéndonos al profesorado que ha de componer el claustro de la Escuela ya decíamos hace días que por lo pronto no había que atender a los sueldos de los profesores de Pedagogía, Religión, Derecho, Legislación, Francés, Caligrafía y Dibujo, porque de estas materias se encargarían los del Instituto, cuyos sueldos ya perciben del Estado. De modo que con poco aumento de profesorado estaría el claustro completo y Castellón tendrá Escuela Normal, hasta sin pagar nada, dentro de poco tiempo, por la causa antes indicada. ${ }^{996}$

Además, 21 sociedades obreras de que se componía el Centro Obrero de la Ronda del Mijares, la Cámara de Comercio, Círculo Mercantil, Casino de Artesanos, Dependencia de Comercio, Comisión de estudiantes, el Claustro de profesores del Instituto, La directora de la Normal de Maestras, Ayuntamiento y otras entidades y personas, dirigieron comunicaciones a la Diputación ofreciendo algunas sus servicios y en demanda de que se fundara la referida Normal las restantes.

Una carta abierta publicada en El Clamor, los estudiantes del Magisterio, dan las gracias a la prensa de Castellón por la brillante defensa que hacen en pro de la creación de la Escuela Normal. ${ }^{997}$

La directora de la Escuela Normal de Maestras, Leonor Velao, también escribe una carta en El Clamor dirigida a los diputados, defendiendo la creación de dicha Escuela. ${ }^{998}$

\footnotetext{
995 El Clamor, 4/09/1914; La Provincia, 3/09/1914; El Heraldo de Castellón, 2/0971914.

${ }^{996}$ El Clamor, 4/09/1914.

${ }^{997}$ Ver Apéndice Documental No 14.

${ }^{998}$ Ver Apéndice Documental No 15.
} 
La creación en Castellón de una Escuela Normal de maestros, interesó por completo a la opinión pública.

El Círculo Mercantil, acordó, desde sus juntas directivas, pedir la fundación de dicho Centro docente dirigiendo oficios a la Diputación en tal sentido.

La Comisión del Centro Obrero, visitaban a los diputados recabando su voto para que se llevara adelante el proyecto.

Los semanarios el Tradicionalista y El Maestrazgo dedicaron también grandes espacios en varios números a exponer la necesaria instalación de la Escuela Normal de Maestros y pedían a la corporación provincial que satisfaciera el deseo de la capital y su provincia.

El segundo de los mencionados periódicos añadía que el Ayuntamiento debía ayudar en cuanto le fuera posible al sostenimiento de la referida Escuela.

Una comisión, en representación de los estudiantes del Magisterio, secundó la campaña de la prensa local, y dirigió a los ayuntamientos y maestros de la provincia, una circular pidiéndoles que prestaran su cooperación, para que la creación de la Normal fuera obra de todos.

«En resumen esto va bien, y todo hace presumir que el anhelo popular será una realidad después de la sesión que la Diputación celebrará el día 19 del corriente y a la que deben asistir como público, representantes de escolares, sociedades obreras, círculos, etc».

También el claustro de profesores del Instituto, el director accidental Miguel Martí Blat, secretario Damián Alcón y sacerdote Manuel Pascual, como catedráticos y en representación del claustro, visitaron al presidente de la Diputación Provincial Arcadio Porcar, para ofrecer el local del Instituto, material científico y los servicios del profesorado de segunda enseñanza, para facilitar la creación en Castellón de la Escuela Normal de Maestros. ${ }^{999}$

«[...] el proceder de los catedráticos del Instituto es merecedor del aplauso de cuantos sepan apreciar el valor de ofrecimiento tan noble y desinteresado [...].

Después de esto no cabe excusa ninguna. La Escuela Normal de Maestros será un hecho dentro de pocos días».

\footnotetext{
${ }^{999}$ El Clamor, 14/09/1914.
} 
Las dificultades para llevar a efecto esta obra eran muchas, pues la Diputación no disponía de dinero para para llevar a efecto dicha obra.

Para el sostenimiento de la Escuela Normal, El Clamor explica el presupuesto de los gastos que podía reportar el referido Centro, y también hace los cálculos de donde y como podía la Diputación atender a ellos, sin necesidad de gravar a los pueblos. ${ }^{1000}$

Cuando el nuevo gobernador de Castellón, Ángel Pérez tomó posesión de su cargo, los periodistas le recomendaron el asunto de la Normal de Maestros, prometiendo éste, hacerse cargo para que su fundación fuera una realidad. ${ }^{1001}$

El 19 de septiembre la Diputación convocó una reunión extraordinaria con el fin de resolver respecto a lo que determinaba el Real Decreto de 30 de agosto de 1914, por lo cual desaparecían del Instituto los estudios del magisterio en perjuicio de las clases modestas y pobres que son las que surtían de estudiantes las Escuelas Normales.

La sesión era pública y podía asistir todo el público que quisiera y sobre todo los alumnos que eran los más interesados. También, las sociedades obreras enviaron una numerosa comisión, así como la directiva de la Asociación provincial del magisterio.

En dicha sesión solo se trató el Real Decreto y no de la creación de la Escuela Normal de Maestros, lo que ocasionó un gran disgusto a la prensa de Castellón.

La Diputación acordó solicitar del Gobierno civil nueva convocatoria para tratar de la Escuela Normal y elevar a la superioridad una comunicación pidiendo continuar en el Instituto los estudios del Magisterio. Parece ser que no se cumplieron los acuerdos. ${ }^{1002}$ Algunos diputados se oponían a la creación de la Escuela, argumentando que no querían aumentar el contingente. ${ }^{1003}$

Al hilo de esta solicitud el Inspector de Primera Enseñanza, José Senent, expuso su opinión sobre la supresión de la Escuela Normal de Primera Enseñanza de Maestros:

No dudamos que los señores diputados secundarán la opinión unánime y clamorosa por la Normal y que pronto tendrá Castellón, al igual que las otras provincias que le limitan, su centro de formación del Magisterio, plantel de maestros, los que han de educar al pueblo haciéndole sentir fuertemente el amor a la tierra como condición primera para el mejoramiento moral y material de esta bella

\footnotetext{
1000 El Clamor, 15/09/1914. Ver Apéndice Documental № 16.

${ }^{1001}$ El Clamor, 15/09/1914. Ver Apéndice Documental № 17.

1002 El Clamor, 21/09/1914 y 24/09/1914.

${ }^{1003}$ El Clamor, 18/09/1914.
} 
región castellonense. La provincia que desee tener buenas escuelas debe preocuparse en formar primeramente buenos maestros. ${ }^{1004}$

La prensa de Castellón pedía a todos los que tuvieran interés porque continuara los estudios del Magisterio en esta capital, se dirigieran al ministro de Instrucción pública para pedir que continuaran en el Instituto un año más los referidos estudios, con el objeto de que la Diputación estudiara detenidamente la manera de implantar en Castellón la Escuela Normal de Maestros.

El presidente del Círculo Mercantil José Varela, y la sociedad Casino de Artesanos, dirigieron un telegrama al ministro de Instrucción pública rogando que autorizara la continuación de los estudios de Magisterio en el Instituto un año más con el fin de dar tiempo a la Diputación a estudiar la creación de la Escuela Normal de Maestros.

El ministro Bergamín envió una carta al alcalde accidental Gimeno Michavila, contestando al telegrama que le dirigió el Ayuntamiento pidiendo que continuara un año más los estudios de Magisterio en el Instituto, diciendo que no podía acceder a la petición, y añadiendo que la Diputación debía acordar sin demora alguna la creación de la Escuela Normal que tantos beneficios reportaría a la capital y provincia.

Asimismo se invitó a los diputados a cortes y senadores de los diferentes partidos políticos y a la alcaldía, para que segundaran estas gestiones. ${ }^{1005}$

Se esperaba una matrícula en el curso de 1915 a 1916 de 140 alumnos de magisterio, habiendo sido en el curso 1914-1915 de 100 alumnos. ${ }^{1006}$

El 8 de octubre de 1914, se celebró un mitin «por la cultura», organizado por el Centro Obrero para pedir a la Diputación provincial la creación de la referida Escuela en Castellón.

El mitin fue muy concurrido, acudieron todos los periódicos de la capital así como maestros, profesores y catedráticos del Instituto, concejales, elementos de todos los partidos políticos, estudiantes, etc.

Se leyeron las adhesiones firmadas por las principales entidades, entre ellas la de la directora de la Normal de Maestras, Leonor Velao.

\footnotetext{
${ }^{1004}$ El Clamor 19/09/1914.Ver la carta de José Senent en Apéndice Documental No 18.

1005 El Clamor, 25/09/1914.

${ }^{1006}$ El Clamor, 28/09/1914.
} 
Todos los representantes de las fuerzas vivas de Castellón hablaron en favor de la creación de la Escuela Normal de Maestros.

El jefe de los republicanos de Castellón, Fernando Gasset, además de pedir a la Diputación la Escuela Normal de Maestros, creía asimismo necesario solicitar del Gobierno la Escuela de Comercio, ambos centros igualmente necesarios para el engrandecimiento de la capital y su provincia.

El diputado a Cortes Emilio Santa Cruz, expuso lo poco que se había hecho en España por la enseñanza y lo mucho que faltaba por realizar, y añadió que los pueblos solo pueden ser grandes y poderosos por la enseñanza. Defendió la creación de la Escuela Normal de Maestros y de lo indispensable que era para Castellón la creación de dicho Centro, «cosa que debe hacer la Diputación sin miramiento a sacrificio alguno, pues cuanto se gaste por la cultura es lo mejor invertido y lo más fructífero». También defendió la creación de la Escuela de Comercio.

Después del mitin, nadie dudaba que todo el pueblo de Castellón y su provincia quisieran el establecimiento de la Escuela Normal de Maestros y que la Diputación provincial debiera acordar su creación en la sesión que había de celebrar el 14 de octubre de 1914.

Hubo en el mitin miles de personas, representaciones de todas las tendencias políticas, sociedades, profesorado, prensa, maestros, cuanto era y significaba en Castellón.

Todos acordaron dirigirse a la Diputación en demanda de que se creara en la capital la referida Escuela.

También se mandó al ministro de Instrucción pública un extenso telefonema en el que en nombre de todas las entidades y prensa se pedía la instalación en la ciudad de Castellón de una Escuela de Comercio. ${ }^{1007}$

Las solicitudes, mitin, etc., cuanto se hizo en pro de la creación de la Normal resulto tiempo y trabajo perdido pues la Diputación se negó a crear la Escuela. ${ }^{1008}$

Existía el miedo que en la sesión que debía celebrar la diputación el 20 de octubre, no solo se denegase la creación de la Normal de Maestros, sino que se suprimiera también la de Maestras sustituyéndola por la creación de unas 60 becas de

\footnotetext{
${ }^{1007}$ El Clamor, 9/10/1914.

${ }^{1008}$ El Clamor, 16/10/1914.
} 
500 pesetas anuales para facilitar a 30 alumnas su estancia en otras capitales de provincia donde existían esos centros.

Precisa, pues, estar alerta y tener en cuenta, para cuando llegue el momento, que la Normal de Maestras, ya creada, no puede, legalmente, suprimirla la diputación; que llevar los alumnos a otras capitales es restarle medios de progreso a Castellón; que lejos de favorecer con ello a los estudiantes del Magisterio se les perjudica gravemente, y por último, que si llegara a proponerse y a aprobarse esa atrocidad (así como suena) sería para favorecer a aquellos escolares cuyos deudos y amigos actuaran de caciquillos en la provincia. ${ }^{1009}$

Finalmente, la Diputación provincial resolvió, en la sesión de 14 de octubre, no crear la Escuela Normal de Maestros por la imposibilidad material de atender al sostenimiento de la misma.

Parece ser que la oposición de la mayoría de la Diputación obedecía a algo ocurrido con la Normal de Maestras.

En efecto, La Diputación solicitó la creación de la citada Escuela en mayo o junio del año 1913, y como no hubo presupuestos generales del Estado en 1914, no pudieron pasar a ellos los gastos de la Normal de Maestras y tuvo la Diputación que pagar durante año y medio, sin ver un céntimo de beneficio.

Es de destacar la labor del Centro obrero en pro de la cultura y del interés general de la provincia; según decían no querían avergonzarse el día de mañana, «cuando por España se diga que Castellón debe ser un insignificante villorrio, por cuanto no ha podido implantar un Escuela Normal de Maestros». El Centro estaba atravesando una crisis económica, pero su prioridad era apoyar cualquier acto público que se iniciara por la creación de la Normal de Maestros. ${ }^{1010}$

El problema venia porque el Estado encargó a las diputaciones provinciales el sostenimiento de las Escuelas Normales, y la Diputación no disponía de recursos para ello.

\footnotetext{
${ }^{1009}$ El Clamor, 19/10/1914.

${ }^{1010}$ El Clamor, 27/10/1914.
} 
En Castellón se culpaba a los diputados liberales de no transigir con lo de la Normal, siendo ellos los mayores culpables de que la provincia no tuviera ese centro de cultura. ${ }^{1011}$

«La mayoría de las capitales españolas tienen Normal de Maestros, una de las contadísimas que no tiene Normal de Maestros, CASTELLÓN. ¿No constituye esto una vergüenza?» ${ }^{1012}$

Eran 43 provincias con Normal de Maestros y seis que no la poseían figurando entre las últimas Castellón.

Castellón con 32.000 habitantes no había conseguido crear la Normal de Maestros y sin embrago lo hicieron ya en 1914, Soria que solo poseía 8.000, Teruel con 10.000, Cáceres, Zamora, etc.

El periódico El Clamor llama a la movilización para conseguir la Normal de Maestros, a los estudiantes del magisterio, las entidades progresivas de la ciudad, los periódicos locales la sociedad obrera, Cámaras, Círculos, y cuantos ansiaban cultura e instrucción. ${ }^{1013}$

Al constituirse la nueva Diputación, el Centro obrero, propone presentar otra instancia pidiendo la Normal de Maestros para que los nuevos diputados estudiaran el caso de poder implantar este Centro de cultura. «El proletariado de Castellón, ante todo y sobre todo, quiere instrucción, pan y trabajo.» ${ }^{1014}$

Otro centro de estudio muy demandado en la ciudad era la Escuela de Comercio.

La Cámara de Comercio acordó pasar a estudio de la Comisión de Enseñanza, el Real Decreto sobre la creación y organización de escuelas de esta clase, y ver si, por cuenta propia, o con la ayuda de otras corporaciones, era factible el sostenimiento de un Escuela Elemental o Pericial de Estudios Mercantiles.

El Ayuntamiento aprobó también la fundación de una Escuela Elemental de Comercio, que podría sostenerse con un presupuesto de 6.000 pesetas participando la Cámara y la Diputación.

Según la prensa con tan exigua cantidad como de 6.000 pesetas, es decir, 2.000 por cada una de dichas entidades, podría formarse un cuadro de tres profesores, uno para idiomas, otro para Cálculos Mercantiles y Teneduría de Libros y otro para

\footnotetext{
${ }^{1011}$ El Clamor, 19/11/1914.

${ }^{1012}$ El Clamor, 22/11/1914.

${ }^{1013}$ El Clamor, 15/04/1915.

${ }^{1014}$ El Clamor, 3/05/1915.
} 
Geografía Comercial, Economía y Derecho, con un haber de 1.500 pesetas cada uno, que serían 4.500 pesetas, y un conserje con 800 , que suman 5.300. Las 700 restantes podrían invertirse para gastos de material y una pequeña gratificación al director.

El alquiler del local se ahorraría, habilitando dos o tres salas en los distintos edificios de las dependencias a su cargo.

La cantidad presupuestaria de 6.000 pesetas, vendría reducida anualmente por el aumento de ingresos proporcionados por las matrículas, derechos de examen donativos, etc.

«La Cámara de Comercio y el ayuntamiento, abogando por la implantación de este nuevo Centro de enseñanza, hacen meritísima labor en pro de los intereses morales y materiales de toda esta región».

Según la prensa, Castellón se iba haciendo grande a pasos agigantados. Desde hacía veinte años que se notaba un aumento en su censo de población; se habían establecido nuevas industrias; la agricultura se hallaba en un floreciente estado; se había multiplicado el comercio, sobre todo el marítimo, extraordinariamente, «hasta el punto que el número de buques de vapor excede de 400 que efectúan sus operaciones en el puerto, ya próximo a terminarse, y que, por la solidez y originalidad de su construcción, será, sin duda alguna, de los mejores de España».

Con la finalización del puerto, coincidirá la afluencia, hasta él, de varias líneas férreas hoy en proyecto, Alcañiz, Chert, Lucena y otras, para facilitar la explotación de minerales, tan abundantes en esta comarca, que, juntamente con la naranja, almendra, cebolla y cáñamo, constituirán los principales productos del comercio de exportación.

El inusitado movimiento que le proporcionará su puerto que, a la vez que sirve de abrigo seguro a los buques y embarcaciones de toda clase, es poderoso auxiliar en las operaciones de carga y descarga, economizando tiempo, capital y trabajo, indispensables factores en la producción de riqueza, hará de Castellón capital de segunda clase y tal vez no esté lejano el día en que, alcanzando desmedidas proporciones los ramos todos de nuestra actividad, llegue a figurar nuestra ciudad entre las de primera categoría. . ${ }^{1015}$

${ }^{1015}$ El Clamor, 11/06/1915. 
La divulgación de los estudios de Comercio, pues, se hacía necesaria para Castellón que veía como se desarrollaba el fenómeno comercial.

Por su parte el médico republicano, Vicente Gea, propone en una sesión de la Diputación Provincial celebrada en mayo de 1916, la creación de una Escuela Pericial.

Vicente Gea expone que faltan en la provincia centros de enseñanza a donde pueda acudir el joven trabajador en busca de todos los conocimientos científicos que sirven de base para poder tener un conocimiento técnico necesario para la práctica de varias profesiones, que son «la fuente de la riqueza del mundo.»

Hace referencia a la fuente principal, fuente de riqueza como es la agricultura. «Las condiciones climáticas generales de nuestra región y las químicas del suelo son lo bastantes variadas para que aquí puedan obtenerse con facilidad todos los cultivos de la península».

Afirma que la agricultura provincial ha vivido y continúa viviendo solo y exclusivamente con la pobre savia de la tradición oral.

El agricultor moderno necesita una preparación científica muy corta si se quiere, pero muy sólida. Necesita tener a su alcance medios, centros, instituciones a donde pueda ir a aprender una sana teoría deducida de un somero estudio de las Ciencias Naturales, que pueda luego servirle de sólida base para una razonada práctica agrícola que le permita intensificar los cultivos y sacar rendimientos mayores que los actuales. ${ }^{1016}$

Sigue diciendo que la industria va desarrollándose en Castellón de manera lenta pero continua, sin que nadie haya formado al obrero en los conocimientos generales de mecánica, que le pudieran facilitar una rápida comprensión de las nuevas actividades que tiene que desarrollar.

Además de las muchas fábricas que aquí ya existen, son muchos los obreros encargados del manejo de motores, sobre todo destinados a la elevación de agua para el riego; son miles los encargados de trabajar con material eléctrico en fábricas y en instalaciones; y sin embargo esa falange se mueve a sus propios impulsos, sin dirección, sin maestro, sin nadie que les haya orientado en sus primeros pasos y les

\footnotetext{
${ }^{1016}$ Ibídem.
} 
haya indicado las reglas fundamentales en que se basan todos los posteriores desarrollos y las vastas aplicaciones de los conocimientos de la Mecánica y Electrotecnia. ${ }^{1017}$

Expone que el desarrollo de la industria y las variadas producciones de la agricultura castellonense, lleva consigo la necesidad del desarrollo del comercio; comercio nacional y sobre todo comercio de exportación de «nuestros frutos y productos industriales».

Naturalmente que no se puede aspirar a que todo el mundo sea un genio comercial, pero si hay la obligación por parte de los organismos directores de velar por la instrucción del pueblo procurándole todas las facilidades, poniendo a su disposición centros e instituciones a donde pueda acudir a pertrecharse de todos los conocimientos necesarios para poder dedicarse con fruto a cualquiera de las ramas del comercio.

Nuestra provincia, tan relacionada comercialmente con Francia e Inglaterra, no tiene ningún centro de enseñanza en donde pueda adquirir quien lo desee el conocimiento práctico de los idiomas de dichas naciones. ${ }^{1018}$

Según dice el pequeño comerciante no encuentra centro ni institución de enseñanza a donde poder ir él o mandar a sus hijos para que aprendan los conocimientos necesarios de contabilidad comercial y legislación mercantil con el fin de conocer en profundidad su negocio.

Asimismo el pequeño exportador desconoce dónde está la población con la cual trafica, no halla sitio en donde le puedan enseñar Geografía comercial y de producción o zonas productoras.

«Es, pues, bien notoria la necesidad de que el trabajador, el que no puede aspirar a poseer un título facultativo, tenga centros, instituciones de enseñanza, en donde pueda adquirir el caudal de conocimientos que precisa para poder entrar con una base sólida al ejercicio de la Agricultura, la Industria y el Comercio.»

\footnotetext{
1017 Ibídem.

${ }^{1018}$ Ibídem.
} 
Según Gea, en los centros de enseñanza de nuestro País no se enseñan conocimientos para la vida práctica. No es allí donde puede acudir el joven que piensa dedicarse a cualquiera de los tres ramos de la actividad que antes se señalan para recibir la instrucción teórico-práctica que necesita. «Allí se enseña la ciencia y el arte oficial, con gran ampulosidad, en sus menores detalles, con mucha escrupulosidad en los razonamientos, pero sin ese sabor práctico necesario para que todo ello se desprenda la inmediata aplicación».

Sigue diciendo que en la escuela de instrucción primaria no hay más finalidad que la preparación para el ingreso en segunda enseñanza. En los Institutos generales y técnicos se dan conocimientos muy generales, muy teóricos, muy poco técnicos, muy poco prácticos. Su finalidad es la preparación para seguir carreras facultativas.

«Tiene el Estado creadas en algunos sitios Escuelas de Comercio y de Industria de donde se sale con pomposos títulos facultativos, pero la especial enseñanza de estos centros no le sirve de instrucción al obrero.»

Y continúa exponiendo que en las Escuelas de Artes y Oficios, aparte de la enseñanza del dibujo, sólo se dan los mismos conocimientos que en la escuela de primera enseñanza y aún éstos tan teóricos, tan desprovistos de finalidad que para nada sirven al alumno.

Convencido, pues, el diputado que suscribe de la necesidad de que al pueblo trabajador se le facilite la instrucción suficiente y convencido al propio tiempo de que ninguna de las instituciones de enseñanza, creadas en esta provincia, sirven al fin que persigue el firmante y que demostrado queda en la anterior exposición, es de razón proponer a la excelentísima Diputación la creación de una Institución de enseñanza teórico-práctica en donde se cursen los estudios de aplicación necesarios; (ahora los estrictamente necesarios) más adelante los suficientes para que pueda considerarse la obra educativa de la Corporación como una magna Escuela de Agricultura, Industria, (artes y oficios) y Comercio.

La modesta aspiración actual del que suscribe se reduce, pues, a facilitar el estudio de las nociones suficientes para que pueda luego el alumno dedicarse con provecho al Comercio, a la Industria y a la Agricultura. ${ }^{1019}$

\footnotetext{
1019 , Ibídem.
} 
Así pues, Gea propone el siguiente plan de enseñanza dividido en tres secciones:

\section{SECCIÓN COMERCIAL}

Primer curso

Gramática castellana, diaria.

Aritmética práctica, alterna.

Geografía comercial, alterna.

Segundo curso

Francés primer curso, alterna.

Contabilidad, alterna.

Legislación comercial, alterna.

Tercer curso

Francés segundo curso, alterna.

Práctica mercantil, alterna..

Inglés, diaria.

\section{SECCIÓN INDUSTRIAL}

\section{Primer curso}

Aritmética práctica, alterna,

Geometría, alterna.

Segundo curso

Elementos de Física y Química, alterna.

Mecánica primer curso, alterna.

Tercer curso

Mecánica segundo curso, diaria.

Electrología y Electrotecnia, diaria.

\section{SECCIÓN AGRÍCOLA}

Primer curso

Elementos de Física y Química, alterna. 
Elementos de Historia Natural, alterna.

Segundo curso

Agricultura, diaria.

Tercer curso

Prácticas agrícolas, discrecional.

Para la sección comercial proponía un profesor de Gramática, otro de Aritmética, otro de Geografía y Legislación, otro de Francés, otro de Contabilidad y Práctica mercantil y otro de Inglés.

En la sección Industrial proponía uno de Elementos de Física y Química que sería el de Electrología y otro de Mecánica primero y segundo curso. La Aritmética se cursaría junto con los de la sección comercial y el mismo profesor explicaría la Geometría.

La sección Agrícola tendría un profesor de Agricultura que sería el mismo tiempo de elementos de Historia Natural, y los Elementos de Física y Química se cursarían junto con los de la sección Industrial. Las prácticas agrícolas serían discrecionales y motivadas por las circunstancias, por lo tanto el profesorado práctico sería en cada época el necesario. Todas las clases serían por la tarde y de una hora de duración.

La Diputación elegiría a un diputado para el cargo de director de la Escuela, que sería el jefe administrativo de la misma y el encargado de la custodia del material y orden administrativo y sostendría las relaciones de este Centro con la Corporación provincial.

«La instrucción será sólida y eminentemente práctica, pues no ha de perderse de vista nunca que la finalidad de la instrucción es solo y exclusivamente dar a quien no ha de poseer título facultativo los conocimientos precisos y bien cimentados para que puedan siempre regir la práctica posterior de cada alumno.»

Propone que la escuela sea instalada, al principio, en el piso alto del palacio de la Diputación, habilitando cuatro locales para cátedra, uno para para sala de profesores otro pequeño para secretaría y dirección y otro para museo y almacén, material de enseñanza y biblioteca. 
Gea expone un acabado estudio del presupuesto probable de los gastos que conllevaría la instrucción. Los gastos de luz, limpieza y cuidado de las habitaciones de la Escuela que correrían a cargo de la Diputación.

Asimismo afirma que aun aumentando la extensión de la escuela provincial más, no implicaría mayores gastos para la Corporación, pues si bien el presupuesto de entonces sería mayor, también podría la escuela al desarrollarse más recabar una subvención del Estado y otra del Ayuntamiento de la capital y con todo ello poder ayudar ampliamente a las necesidades de dicho centro de instrucción, que «nacido modesto podría llegar a tener gran importancia y ser un núcleo de diseminación de conocimientos, no sólo de los que ahora se proponen, sino llegar a ser la escuela politécnica del obrero, del trabajador, del que vive y vivirá sin necesidad de título profesional, que pudiera escudar más de una vez en ignorancia y aptitudes.»

En resumen: para las Corporación provincial un gasta anual de 16.000 pesetas como máximo. Para la provincia de Castellón tener desde el primer día un Centro en donde poder aprender por hoy lo necesario para poder seguir el paso del progreso en las tres manifestaciones de la actividad humana que se llaman Agricultura, Industria y Comercio, que son ya de sí las tres sólidas bases de riqueza y de bienestar del país: Mañana quiere él tener este boceto convertido en una Escuela general de instrucción y educación técnica hasta el más pequeño detalle, en donde puedan adquirirse todos los conocimientos necesarios para la vida, excepto los que forman los estudios de las carreras especiales y facultativas.

El presupuesto de la Diputación es lo suficiente grande para encontrar con facilidad partidas de donde sacar la cantidad que importa el pequeño presupuesto de la institución que se propone.

Con este proyecto será siempre la corporación la que dirige la escuela, y no poca cosas será conseguir que, en parte al menos, la enseñanza provincial se vea desligada del férreo y atávico cuadro de la enseñanza oficial, pues convencido va estando todo el mundo de que la educación e instrucción para ser práctica y útil debe en absoluto desligarse de todo lo que lleve etiqueta universitaria.» ${ }^{1020}$

${ }^{1020}$ El Clamor, 4/05/1916. 
Después de leer Gea su proposición consiguió que fuera tenida en consideración y que pasara al estudio de la comisión provincial. Pero pasaron los meses y la comisión no dio señales de vida sobre lo referente a la Escuela Pericial.

La prensa comenta que: «hubiese sido cuestión política obra de compadrazgo, y a buen seguro que cada uno de sus miembros hubiese desplegado incalculable energía por conseguir el privilegio de chupar la breva. La actividad sería su característica.»

Pero se trata de lo que el obrero y, en general, todos cuantos requieren medios de ilustración necesitan, se trata de enseñanza, y esto ya es otra cosa. Hay que caminar con pies de plomo, poner mil inconvenientes y si, cuando alguna vez, llega a acordarse la urgente necesidad de querer reformar lo antiguo para dar paso a las teorías modernas, al método, al estudio...nos encontramos con que el cerebro se ha atrofiado y no puede asimilarse los adelantos de la ciencia.

Entonces es ya tarde...y así no se progresa.» ${ }^{1021}$

No se tomó ningún acuerdo sobre la proposición de la escuela pericial porque implicaba un aumento de gastos en el presupuesto provincial y hasta el año siguiente no podía tomarse ningún acuerdo. ${ }^{1022}$

\footnotetext{
${ }^{1021}$ El Clamor, 13/09/1916.
}

${ }^{1022}$ El Clamor, 4/05/1916. 
Parte III Capítulo VIII

\section{CAPÍTULO VIII: UN EJEMPLO DE DEBATE CIENTÍFICO EN TORNO AL DARWINISMO EN CASTELLÓN (1880-1909)}


Castellón hacia la modernidad. Salud, educación y debate científico (1880-1918) 
En España estaba prohibido el darwinismo hasta bien entrado el siglo XX, igual que lo sigue estando hoy en muchos países, como es el caso de EE.UU. El resurgir del creacionismo en la principal potencia científica del momento parece presagiar que este argumento sobre la separación de ciencia y religión no va a ser aceptado por ciertos sectores políticos muy poderosos en el mundo actual. ${ }^{1023}$

La teoría darwinista fue atacada desde el puro fanatismo religioso, pero hubo opositores legítimamente movidos por sus creencias en algunos casos, y por unas motivaciones completamente alejadas de la religión o de las ideologías en muchos otros, que estudiaron a fondo las teorías de Darwin y las combatieron con argumentos sólidos y estilo educado.

La revolución darwinista tiene su raíz en el origen de las especies. Sin embargo ésta ortodoxia ha recibido objeciones. Algunos autores más radicales, como Peter Bowler, ${ }^{1024}$ plantearon en su día que hubo revolución, pero no darwinista. Éste historiador sostiene que no se puede encontrar un evolucionista en el último tercio del siglo XIX que sea íntegramente darwinista, en el sentido de haber aceptado todas las partes de la propuesta de Darwin. Muchos de los que se proclamaban darwinistas, lo hacían porque defendían la realidad de la evolución, pero con mecanismos explicativos que no se correspondían con la selección natural y el gradualismo, y aún más por oponerse al pensamiento tradicional dominante hasta entonces.

En efecto, había muchos puntos ligados a la teoría de la evolución por selección natural de Darwin que estaba en abierta confrontación con la tradición católica. Tal y como demostraron Thomas F. Glick y Diego Nuñez, Darwin se conoció en España a través del naturalismo germánico (Haeckel, Büchner y Vogt), que la impregnaron de materialismo y ateísmo. Inmediatamente, los grupos de opinión tomaron posición a favor o en contra. Para unos, parecía que el darwinismo se relacionaba bien con las

\footnotetext{
${ }^{1023}$ La historiadora Janet Browne ha escrito la biografía más completa hasta el momento de Charles Darwin En una entrevista realizada en Valencia con motivo de la celebración del congreso bienal de la Sociedad Española de Biología Evolutiva (SESBE), se le preguntó sobre los problemas de la sociedad americana para admitir la teoría de la evolución. Browne afirmó que el problema está en los evangelistas, que son especialmente refractarios a admitir las teorías de Darwin. Según dice, el problema no es tanto aceptar la teoría de la evolución como un problema de aceptar los avances científicos y tecnológicos de la sociedad, es decir, no están en contra de la teoría de la evolución sino contra la ciencia y la modernización de la sociedad.CATALÁ, Jesús I, y PERETó, Juli.: «Entrevista a Janet Browne», en Métode, 2009, nº 64, p. 44.

${ }^{1024}$ BOWLER, Peter. (1988): The Non-Darwinian Revolution. Reinterpreting a Historical Myth, Baltimor: The Johns Hopkins University Press. En CATALÁ GORGUES, Jesús I.:«La dificil influéncia de Darwin». L'avenç, 351, Noviembre 2009, pp. 48-49.
} 
teorías anarquizantes y las pretensiones secularizadoras del republicanismo. Para otros, había que quitarle importancia o desacreditar el darwinismo.

Actualmente nos hacemos la pregunta siguiente: en qué se basan hoy las críticas al darwinismo? La teoría de Darwin tiene dos componentes. El primero es la confirmación del hecho en sí de que la evolución ha ocurrido y todos los seres vivos que pueblan la tierra descienden de un antecesor común. El segundo es una explicación de cómo ha tenido lugar esa evolución: la teoría de la selección natural. Sobre el primer punto, la unanimidad de la comunidad científica es total, la evolución es un hecho tan demostrado como lo pueda estar la existencia del átomo o que la Tierra gira alrededor del Sol. Respecto al segundo, sí existe alguna controversia, que es utilizada junto con los avances conseguidos durante los últimos años en campos como la biología molecular, la genética y la biología del desarrollo, para defender que el darwinismo está acabado y que es necesaria una nueva teoría. Curiosamente son bastantes los científicos que apoyan esta postura, pero nadie ha sugerido una teoría alternativa a la selección natural para explicar cómo se produce la evolución de las especies. Se acepta el hecho de la evolución pero se critica el mecanismo de funcionamiento propuesto por Darwin, la selección natural.

Las personas, e inclusive muchos biólogos que no han tenido la formación adecuada, suelen tener la sensación de que la teoría evolutiva sólo se puede estudiar mirando el pasado desde un marco histórico. Según Manuel Soler, Presidente de la Sociedad Española de Biología Evolutiva (SESBE), las hipótesis evolutivas también se pueden poner a prueba en un escenario completamente actual, tanto en estudios de campo como de laboratorio. La evolución es algo real, tangible y patente en nuestros días, sin necesidad de tener que considerar el pasado remoto, su utilización está favoreciendo un rápido avance en diversos temas aplicados entre los que podemos mencionar la lucha contra las enfermedades infecciosas y epidémicas (las investigaciones sobre el sida son un claro ejemplo), la biología de la conservación, la lucha contra las plagas de la agricultura, etc. ${ }^{1025}$

La biografía y la obra de Darwin no sólo sufre fabulaciones y mitificaciones falseadas procedentes de la tosca historiografía de las grandes figuras y del patrioterismo, como sucede con Einstein, Newton, Claude Bernard, Pasteur, Cajal o

\footnotetext{
1025 MORENO, Juan. (2008): Los retos actuales del darwinismo ¿Una teoría en crisis? Síntesis, Madrid.
} pp. 12-13. 
Cavanilles. Darwin padece sobre todo las resultantes de la polarización ideológica entre el evolucionismo y el creacionismo, que se hizo patente con motivo del primer centenario de su nacimiento.

\section{LA RECEPCIÓN DEL DARWINISMO EN ESPAÑA}

Conviene subrayar que la presencia del evolucionismo en España ya se dio antes de 1868, aunque presentado siempre con afanes refutatorios. Tenemos como ejemplo las conferencias del catedrático de la Universidad de Santiago, José Planellas y Giralt en 1859 y de José de Letamendi en el Ateneo barcelonés en 1867, pero quizá el acto de mayor importancia fue la recepción de Miguel Colmeiro en la Academia de Ciencias en 1860. Tanto su discurso como la contestación de Mariano Graells versaron sobre los argumentos evolucionistas.

El director del Jardín Botánico, Miguel Colmeiro, pronunció en la Academia de Ciencias de Madrid en 1861 una conferencia con el título: «Estabilidad de las especies en el reino vegetal» en la que presenta por primera vez el argumento que ya Louis Agassiz había enunciado en Boston: la inestabilidad y casualidad de la variación adquirida. Todas las variaciones adquiridas por influencia ambiental en los organismos son pasajeras; en este sentido la adaptación al medio puede influir en la forma orgánica, pero nunca hasta el punto de ser instancia creadora de nueva organización. Ésta, como Mariano Graells precisa a continuación, está limitada a un pequeño número de tipos fijos, cuya armonía interna y externa (interactiva) manifiesta constantemente una economía en la naturaleza viva. En su conjunto la fauna actual no difiere de la pasada y cualquier pretensión de que existan nuevas creaciones pone en peligro la certeza de los procedimientos de anatomía comparada y de la paleontología. ${ }^{1026}$

Sin embargo, el director del Museo de Historia Natural, Mariano Graells, no sólo rechazaba cualquier veleidad evolucionista, sino incluso estaba en contra de los diferentes sucedáneos teóricos que a lo largo de la década central del siglo XIX se proponían para salvar el paradigma fisiológico.

\footnotetext{
${ }^{1026}$ CATALÁ SALA, José. (1987): Ideología y ciencia biológica en España entre 1860 y 1881. La difusión de un paradigma, CSIC, Madrid, pp. 43-44.
} 
Fueron los krausistas españoles los primeros en aceptar el evolucionismo y en promover su difusión organizada entre las elites intelectuales.

La primera valoración krausista positiva de las ideas evolucionistas la realizó Francisco Giner de los Ríos en un artículo publicado en la Revista de España, «Psicología comparada. El alma de los animales», que apareció en 1871. Los discípulos de Francisco Giner iniciaron un estudio sistemático del tema que duró desde finales de 1872 a principios de 1874, años en los que Alfredo Calderón, Augusto González de Linares, y Enrique Serrano Fatigati publican trabajos sobre el tema. Al principio la mención a la obra de Darwin se sitúa en una argumentación muy antropocéntrica, tendente a demostrar la unidad formal de la persona humana con el resto de los seres vivos. $^{1027}$

A partir de 1872 los krausistas españoles aceptan el evolucionismo biológico, pero tras depurarlo y adaptarlo a sus peculiares ideas filosóficas. La aceptación oficial se produce en 1873 en la obra Ensayo de una introducción al estudio de la Historia Natural, escrita por el discípulo predilecto de Francisco Giner, Augusto González de Linares. A partir de esta obra, el krausismo científico, al admitir la evolución orgánica como una ley general de la naturaleza, da un nuevo paso hacia su positivación.

La mejor exposición del evolucionismo krausista la realizará Enrique Serrano en su libro La Evolución en la Naturaleza, publicado en Madrid en 1874. En él examina las distintas manifestaciones de la evolución, aceptando la gradación evolutiva de las formas y la variabilidad de las mismas dependiendo de acciones exteriores. Como afirma, sus convicciones hacia un evolucionismo teleológico refuerzan la creencia de los krausistas en la generación espontánea. No obstante, a través de los trabajos de González de Linares y Enrique Serrano, los krausistas asimilan el evolucionismo biológico con un grado suficiente de precisión que les permite pasar a investigaciones prácticas. Han entendido el papel creador del entorno ambiental para todo lo viviente, así como la viabilidad de las formas; también presuponen que el proceso se realiza en un orden teleológico. ${ }^{1028}$

La expansión en Europa del positivismo en la segunda mitad del siglo XIX, supondrá la apertura a nuevas versiones del evolucionismo. La aparición pública del

\footnotetext{
${ }^{1027}$.HERNÁNDEZ NIEVES, Purificación. (2009): La evolución de las Ciencias Naturales en la Segunda Enseñanza española. (1836-1970). Universidad de Extremadura, Cáceres. p. 160.

${ }^{1028}$ CATALÁ SALA, José. (1987). op. cit. pp. 60-63.
} 
grupo positivista tuvo lugar en el Ateneo de Madrid con motivo del comienzo de sus cursos de 1875 y 1876. La sección de Ciencias Naturales propuso como tema de debate « [...] si la vida orgánica es una transformación de la energía universal». José del Perojo, Luis Simarro, Manuel de la Revilla, Carlos María Cortezo, Pompeyo Gener y Pedro Estasen, intervinieron reivindicando lo que Revilla en sus crónicas llamó «filosofía crítica»; Moreno Nieto y Urbano González Serrano defenderán posiciones filokrausistas.

Manuel de la Revilla unifica con el término filosofía crítica componentes del positivismo naturalista de la filosofía de Spencer y del neokantismo alemán.

Mientras que para los krausistas la libertad de la ciencia alumbraría una armonía cada vez mayor entre los diversos resultados de la investigación y de la vida, los positivistas críticos no se preocupan de esa armonía; para ellos la libertad de la ciencia supone la aceptación de la responsabilidad de la investigación para determinar aquello que es cierto frente a lo que solamente puede ser creíble.

Esa autoconciencia filosófica del grupo descrita por Manuel de la Revilla es obra de José del Perojo, discípulo del neokantiano alemán Kuno Fisher. Sin embargo, ya sea por la exigencia del ambiente cultural o por sus propias convicciones, del Perojo transmite una concepción de la evolución biológica y de la ciencia desde los problemas antropológicos. $^{1029}$

José del Perojo desde el periódico La Europea, publicado en Madrid, presenta la obra de Georgr Gerland, discutiendo el problema del eslabón perdido entre los simios y los humanos, así como el principio de variación, punto flaco del darwinismo. Desde la publicación de la Revista Contemporánea, que fundó en 1875, José del Perojo presenta una extensa traducción de Wensmister Review titulada «Origen y desarrollo del hombre» que resume las opiniones de Darwin, Lyell y Lubbok sobre el tema. Estudia también la crítica de Hartmann a las teorías de Haeckel. Por último, también analiza el artículo de Spencer «Psicología comparada del hombre».

Del Perojo, a la altura de 1875, ha publicado un conjunto temático que reúne muchas inquietudes intelectuales de grupos españoles que vienen trabajando desde hace tiempo por la renovación científica de la nación. El ideal de una antropología científica fundada en una psicología experimental, de fuerte inspiración fisiológica, y en una

${ }^{1029}$ Ibídem, pp. 67-68. 
teoría de la evolución humana, coherentemente fundada también en esos supuestos, va a ser la aspiración teórica común de los positivistas madrileños opuestos al krausismo. ${ }^{1030}$

En cuanto a los autores que critican el evolucionismo, el médico José de Letamendi fue uno de los primeros antidarwinistas en Cataluña, en 1867. Sus conferencias en el Ateneo barcelonés se publicaron en forma de libro con el título Discurso sobre la naturaleza y origen del hombre. Letamendi parte de una crítica general del positivismo, según la cual no se puede prescindir del elemento racional en el conocimiento, ya que ello supondría una concepción de la Naturaleza puramente materialista y, por tanto, un Panteísmo acorde con la doctrina de la unidad de la sustancia. Éste autor prefiere la tesis de la pluralidad substancial puesto que así puede explicar las diversas individualidades de los seres y sobre todo la persona humana. Critica la mutabilidad de las especies naturales y la teoría de la generación espontánea, teorías básicas del evolucionismo krausista; pero además, procede a descalificar la Fisiología en su pretensión de describir el fenómeno humano; para Letamendi la Anatomía comparada del sistema nervioso arroja el resultado de que el encéfalo humano está formal y substancialmente constituido y como tal distinto de los otros seres. No hay en este autor una crítica científica del evolucionismo, solo crítica especulativa desde una particular visión antropológica.

En Madrid, en 1867, había iniciado la restauración de la filosofía tomista el fraile dominico Ceferino González. En el marco de un enfrentamiento general con el positivismo, hace una crítica pormenorizada del darwinismo, sobre todo desde el interés de separar al hombre de los animales. Niega que el hombre acumule adaptaciones ventajosas de los simios, así como la selección natural de los valores morales; también presenta rebatiéndola, por no comprobada, la teoría de la selección sexual y la aplicación de la selección natural a la Humanidad.

Pero la voz más autorizada entre los polemistas católicos del evolucionismo es el catedrático de Geología y Paleontología de la Universidad Central, Juan de Vilanova y Piera. Él será el que represente la refutación científica desde posiciones y publicaciones independientes. Rebate la posibilidad de una explicación actualista del registro fósil, acepta como expediente explicativo de la naciente biogeografía fósil la

${ }^{1030}$ Ibídem, pp. 81-82. 
opinión de Agassiz y de la Teología natural inglesa de un plan o designio del Creador para la duración y vida de cada especie.

También fueron de mucho interés sus conferencias en el Ateneo Científico y Literario de Madrid, agrupadas en sus cursos de «Ciencia Prehistórica», en los que desde 1874 presenta y divulga con alto nivel todos los temas y teorías referentes al origen del hombre y su primitiva evolución. ${ }^{1031}$

También hay que destacar, dentro de los polemistas católicos, la obra de Emilia Pardo Bazán Reflexiones críticas contra el darwinismo, donde afirma que combate esta teoría no por motivos religiosos sino porque «carece de pruebas directas para ser racional y empíricamente establecida».

En 1878 desde una posición ecléctica entre los requerimientos del dogma católico y los de la ciencia paleontológica moderna, destacan José Joaquin Landerer, director del Observatorio Astronómico de Tortosa, su discípulo, el canónico y profesor del Seminario conciliar de Barcelona, Jaime Almera, y el colaborador de éste, Arturo Bofill y Poch.

La obra de Jaime Almera, Cosmogonía y Geología, aparecida en 1878, incorpora el actualismo geológico de Lyell, desechando las teorías catastrofistas o incluso la interpretación literal del Génesis. A la vez plantea la necesidad de investigar la historia de la tierra con el objetivo de hallar las causas segundas de la misma, bien diferenciadas de la Causa Primera. Almera incluye también en su discusión el tema del evolucionismo; los capítulos sobre paleontología serán tratados por José Joaquín Landerer que de un modo matizado, pero seguro, cambia sus anteriores posiciones cerradamente antievolucionistas.

En 1879, Arturo Bofill y Poch utiliza criterios evolucionistas de clasificación, se inaugura así la primera investigación evolucionista catalana. Ya desde 1884 Jaume Almera se incorporará con Bofill a la misma línea de investigación, juntándose así los esfuerzos de las dos pequeñas instituciones que ellos dirigen.

Almela planteará una cosmovisión laplaciana presidida por un principio de evolución abarcante de todos los seres y dirigido hacia un fin providencial. ${ }^{1032}$

\footnotetext{
${ }^{1031}$ Ibídem, pp. 94-98.

1032 BOHIGAS MAYNEGRE, Jordi: «Reacciones antidarwinianas en Cataluña», en L'Avenç 351, Noviembre 2009, p. 51.
} 
El materialismo científico denostado por los neotomistas y los krausistas induce a Ceferino González a pedir una alianza con los krausistas para combatirlo conjuntamente. El evolucionismo, aprendido en fuentes francesas y alemanas, será un componente esencial de esta tendencia ideológica diferente tanto del racionalismo armónico de los krausistas como del positivismo crítico madrileño y tendrá sus principales expositores en las ciudades de la periferia.

En Sevilla, Antonio Machado ${ }^{1033}$, entre los años 1871 y 1872, será un temprano difusor de la versión francesa del darwinismo entre la intelectualidad sevillana.

En Granada, el catedrático del Instituto de Segunda Enseñanza, Rafael García Álvarez, fue el que asumió públicamente la defensa del evolucionismo ganándose una condena eclesiástica por parte del obispo de la ciudad.

En Barcelona, destaca Joaquin María Bartrina, que fue el primer traductor de Darwin. En 1876 publicó en Imprenta de la Reinaxensa Origen del hombre. La selección natural y la sexual. También Leandro Pons y Dalmau traducía al catalán la primera obra de Darwin Viatge d'un naturalista al voltant del món. 1831 a $1836 .{ }^{1034}$

A comienzos del siglo XX numerosos naturalistas y biólogos partidarios del evolucionismo darwinista, tales como Ignacio Bolívar, Enrique Rioja, Odón de Buen o José Royo, tuvieron que exiliarse por su vinculación a la Segunda República.

El evolucionismo -identificado como darwinismo- fue rechazado por motivos políticos y religiosos, al parecer vinculados a corrientes, ideologías e instituciones proscritas como el krausismo y la Institución Libre de Enseñanza. En la segunda década del siglo XX, la proyección editorial del darwinismo decayó, comenzando la divulgación del evolucionismo de Lamarck. ${ }^{1035}$

\footnotetext{
${ }^{1033}$ Antonio Machado y Núñez. Catedrático de Ciencias Naturales en la Universidad Hispalense, activo militante del krausismo y amigo de Francisco Giner de los Ríos. Explicó y tradujo las teorías evolucionistas de Darwin y monista de Haeckel. En BaltanÁs, Enrique. (2006): Los Machado, Fundación José Manuel Lara, Sevilla. pp. 25-71; GIBSON, Ian. (2006): Ligero de equipaje, Santillana Editores G, Madrid. p 90.

${ }^{1034}$ CATALÁ SALA, José. (1987), op. cit. pp. 129-131.

${ }^{1035}$ Según Lamark, las modificaciones experimentales en el entorno de una especie generaba cambios en ésta, idea que se resume en la célebre frase: «la función crea el órgano». Estos cambios podían ser transmitidos a los descendientes: «Herencia de los caracteres adquiridos». HERNÁNDEZ NIEVES, $\mathbf{M}^{\mathrm{a}}$ Purificación. (2009), op. cit. p.161.
} 


\section{EL DARWINISMO EN VALENCIA}

Para situar históricamente el darwinismo en Valencia conviene tener en cuenta dos aportaciones valencianas: la introducción en España de la enseñanza de la anatomía comparada por Tomas Villanova Entraigues y la de la zoología, ya institucionalizada por Laureano Pérez Arcas.

Villanova Entraigues nació en Valencia en 1769 y estudió medicina en su ciudad. En 1819 impartió en el Museo de Ciencias Naturales el primer curso de anatomía comparada que se dio en España. Aparte de su dedicación a la enseñanza y de enriquecer las colecciones de zoología y anatomía comparada, redactó una serie de estudios científicos, entre ellos figuran una memoria sobre la enseñanza de la anatomía comparada (1822), un compendio de zoología (1824) y varios informes de insectos.

Laureano Pérez Arcas nació en Requena en el año 1824 y se formó como naturalista en Madrid, principalmente junto a Mariano Graells. Como investigador, se dedicó fundamentalmente a la entomología, sobre todo a los coleópteros.

Publicó el primer compendio universitario de zoología en 1861, titulado Elementos de Zoología, en el que incluyó no solamente sus propios materiales, sino también los de otros naturalistas españoles, entre ellos los del valenciano Ignacio Vidal y Cros relativos a las aves de la Albufera. En las ediciones posteriores fue actualizando sus contenidos. En la tercera (1872), asimiló plenamente los presupuestos de la teoría celular y puso al día el sistema de clasificación, que en la primera había basado en el de Cuvier con ligeras modificaciones. ${ }^{1036}$

La mayoría de los médicos y naturalistas valencianos no aceptaban la teoría de la evolución darwinista que se manifestó en las obras de José María Gómez Alamá, Salustiano Sotillo y Juan Vilanova Piera.

José María Gómez Alamá se opuso al evolucionismos darwinista en su Discurso sobre la importancia de la anatomía humana (1872), defendiendo la fijeza de las especies y la existencia de un «reino humano» de acuerdo con las ideas de Cuvier. ${ }^{1037}$

\footnotetext{
1036 LÓPEZ PIÑERO, José María. (2008): Charles Darwin, PUV, Valencia, pp. 187-193.

1037 José María Gomez Alamá (1815-1874) fue el principal responsable de la recuperación de la enseñanza anatómica. Nacido en Valencia, estudió medicina en su Universidad. En 1836 fue nombrado ayudante de disector y, tras varios años de profesor sustituto y agregado, consiguió en 1848 una de las dos cátedras anatómicas de la Facultad de Medicina de Valencia. Su compendio de Anatomía (1867-1868) cuya segunda edición ampliada tituló Tratado elemental de Anatomía humana descriptiva, general y
} 
El catedrático de Historia Natural en el Instituto Provincial de Segunda Enseñanza, Salustiano Sotillo Rodríguez, también defendió en las tres ediciones de su manual de la asignatura $(1868,1870,1877)$ la concordancia de la Biblia con la ciencia.

También se opuso a las teorías evolucionistas el médico y geólogo Juan Vilanova y Piera (1821-1823). Desde su condición de paleontólogo, Vilanova se interesó por la antropología prehistórica y realizó aportaciones de relieve al estudio del hombre fósil en la península Ibérica. Su oposición al evolucionismo la manifestó desde posturas variables casi siempre conciliadoras, constantemente basadas en una ideología concordista entre la ciencia y la religión. ${ }^{1038}$

No obstante, hubo científicos valencianos que defendieron el darwinismo incorporándolo como supuesto de sus investigaciones. Entre ellos están Rafael Cisternas Fontseré (1818-1876), nacido en Barcelona, fue catedrático en la Universidad de Valencia desde 1861 hasta su muerte. Orientó sus investigaciones de acuerdo con el darwinismo, estudiando los peces pobladores de cuencas determinadas desde el punto de vista de la «lucha por la existencia» en relación con las condiciones ambientales, sobre todo en su Catálogo de los peces comestibles que se crían en las costas españolas del Mediterráneo y en los ríos y lagos de la provincia de Valencia (1867).

El sucesor de Cisternas en la Facultad de Ciencias fue José Arévalo Baca. En 1877 ganó las oposiciones a la cátedra de Historia Natural, que ocupó hasta su muerte en 1890. Expuso su actitud ante el darwinismo en La Vida, discurso inaugural del curso académico 1878-79 de la Universidad de Valencia. En su disertación afirmó que la multitud de datos reunidos por la anatomía comparada, la embriología y la paleontología demuestran las relaciones que ligan a los organismos entre sí. Sin embargo, opinaba que la teoría de la evolución desarrollada por Darwin no se había comprobado en hechos positivos.

Serrano Cañete (1832-1892), profesor de patología médica durante el periodo revolucionario del Sexenio Democrático (1868-1875), también aceptó la teoría de

\footnotetext{
microscópica (1872), además de sintetizar de forma clara y rigurosa la anatomía descriptiva, fue el primer manual español de la asignatura que incluyó un resumen de anatomía microscópica basado en la teoría celular. Ibídem, pp. 194-198. Ver también LOPÉZ PIÑERO, José María. (2008): El darwinismo valenciano del siglo XIX y su fundamento histórico. Consell Valencià de Cultura, Valencia. pp. 114-119.

${ }^{1038}$ Juan Vilanova Piera nacido en Valencia, estudió en su Universidad las licenciaturas de medicina y de ciencias. Empezó a ejercer como médico, pero abandonó pronto la práctica clínica para dedicarse por completo a la geología y la paleontología. LóPEZ PIÑERO, José María. (2008): Charles Darwin, PUV, Valencia, pp. 194-198.
} 
Darwin. Fue presidente del Ateneo Científico-Literario y Artístico de Valencia, asociación fundada en 1870 por universitarios valencianos.

En el Ateneo de Valencia se organizó en 1878 un ciclo de cinco conferencias sobre el evolucionismo. La primera la pronunció Serrano Cañete, que reiteró que la importancia de la contribución de Darwin consistía en haber basado sólidamente la teoría de la evolución en la selección natural. ${ }^{1039}$

Un importante integrante del Ateneo fue Amalio Gimeno Cabañas, cabeza destacada de la corriente experimentalista. Nació en Cartagena en 1850 y cursó sus estudios en Valencia, pero por motivos políticos terminó los de medicina en Madrid. ${ }^{1040}$

En sus tres conferencias de 1878 en el Ateneo Científico- Literario y Artístico, expuso las pruebas morfológicas y fisiológicas del evolucionismo, destacando como núcleo teórico la «ley biogenética fundamental», en la que el alemán Erns Haekel había basado su Anthropogenie oder Entwcklungsgeschichte des Menschen (1874). Gimeno defendió en sus conferencias la compatibilidad entre el evolucionismo y las creencias religiosas.

La cuarta conferencia la dio José Arévalo Baca, que aludió a la persecución política que dos años antes habían sufrido los profesores españoles seguidores del darwinismo y se centró en la variabilidad de las especies como otro de sus núcleos doctrinales. Cerró el ciclo el psiquiatra José María Escuder, defendiendo el antagonismo entre darwinismo y creacionismo. ${ }^{1041}$

Otro científico valenciano, Eduardo Boscá, aplicó el darwinismo de modo sistemático en su obra científica porque era un evolucionista radical que lo consideraba un fundamento para explicar todos los aspectos de la realidad. Su principal obra zoológica Catalogo de los reptiles y anfibios observados en España, Portugal e Islas

\footnotetext{
${ }^{1039}$ Ibídem, pp. 198-206.

1040 Amalio Gimeno ganó en 1875 la cátedra de Patología General de la Facultad de Santiago de Compostela y después volvió a Valencia en 1877, como catedrático de Terapéutica. En 1888, se trasladó a Madrid donde primero fue catedrático de Higiene y más tarde de Patología General. Interrumpió a partir de entonces su actividad científica, que había desarrollado en Valencia, para dedicarse a la política como personalidad destacada del liberalismo encabezado por Canalejas. Desde 1906 hasta 1919 ocupó distintos ministerios, promoviendo diversas campañas y leyes sanitarias, así como la Fundación de la Junta para Ampliación de Estudios e Investigaciones Científicas. Murió el 9 de septiembre de 1936, poco después de iniciarse la guerra civil. FERNÁNDEZ SANTARÉN, Juan Antonio. (2014): Santiago Ramón y Cajal. Epistolario. La Esfera de los Libros. pp. 240-241; LÓPEZ PIÑERO, José María. (2008), op. cit. pp. 198-206. 1041 Ibídem.
} 
Baleares (1877), se tradujo al francés y se publicó en Bulletin de la Societé Zoologique de France (1880). ${ }^{1042}$

Peregrín Casanova Ciurana (1849-1919), nació en Valencia, estudió medicina en su Universidad, donde tuvo profesores experimentalistas opuestos al evolucionismo como Gómez Alamá, pero también seguidores de la teoría de Darwin, en especial Cisternas y Serrano Cañete, que le enseñaron respectivamente historia natural y patología médica en los años en torno a la revolución de 1868, cuando el darwinismo se convirtió en el tema polémico de moda. Ganó la cátedra de Anatomía en 1875, vacante tras el fallecimiento de Gómez Alamá. Seguidor de Erns Haeckel, mantuvo con él una larga relación epistolar a partir de 1876, aparte de asistir a sus cursos en Jena. En 1877 publicó el artículo «La morfología humana del porvenir», cuya tesis central era que «la ciencia anatómica del hombre» después de una fase descriptiva, había pasado a otra explicativa mediante leyes causales basadas en teorías evolucionistas, como la ley biogenética fundamental. A finales del mismo año apareció su libro La biología general, en el que ofreció una síntesis de los fundamento teóricos de la morfología de acuerdo con las ideas de Haeckel.

Casanova envió esta obra a Carl Gegenbaur, autentico fundador de la anatomía comparada evolucionista y responsable de su aplicación a la anatomía humana.

Peregrín Casanova presidió los actos de homenaje a Darwin que los estudiantes de medicina valencianos organizaron en febrero de 1909, con motivo del centenario de su nacimiento. Además de Miguel de Unamuno participaron numerosos médicos y científicos. ${ }^{1043}$

Luis Simarro Lacabra (1851-1921) se ocupó, desde una perspectiva evolucionista, de temas concretos de anatomía comparada, embriología e histología, sobre todo del sistema nervioso, basándose especialmente en los trabajos de Haeckel y

\footnotetext{
${ }^{1042}$ Eduardo Boscá Casanoves (1843-1924) nació en Valencia, estudio medicina y ciencias naturales en su Universidad. Fue profesor auxiliar en la Escuela de Agricultura de la Diputación de Valencia (18691874), catedrático de historia natural de los Institutos de Segunda Enseñanza de Játiva y de Ciudad Real (1874-1882), jardinero mayor del Botánico de la Universidad de Valencia (1883-1892) y catedrático de historia natural de la misma Universidad desde 1892 hasta su jubilación en 1913. LÓPEZ PIÑERO, José María. (2008), op. cit. p. 208.

${ }^{1043}$ Ibídem, pp. 212-215.
} 
Gegenbaur. En sus publicaciones, cursos y conferencias, Simarro se presentó como un seguidor del darwinismo, influido principalmente por la obra de Haeckel. ${ }^{1044}$

Santiago Ramón y Cajal (1852-1934), nació en Petilla de Aragón. En 1883 obtuvo las oposiciones a una de las dos cátedras de Anatomía en la Facultad de Medicina de Valencia. La ocupó hasta el 2 de noviembre de 1887, fecha en la que pasó a la de Histología y Anatomía Patológica en la Facultad de Barcelona.

Al principio Cajal rechazó el darwinismo, pero en sus años que residió en Valencia le influyeron no solo su compañero de Claustro Peregrín Casanova, sino también sus amigos médicos y naturalistas, seguidores o simpatizantes del darwinismo.

El magisterio de Simarro reforzó su adhesión al darwinismo. En el más importante de sus textos teóricos, la comunicación «Consideraciones generales sobre la morfología de la célula nerviosa», que envió al Congreso Internacional de Medicina celebrado en Roma el año 1894, dijo que la ontogenia o desarrollo embrionario del sistema nervioso reproduce de modo abreviado, con algunas simplificaciones y saltos, su filogenia, de acuerdo con la ley biogenética fundamental, núcleo de la morfología darwinista.

Solamente se planteó dudas tras la crisis de la teoría darwinista original durante el periodo de entreguerras, al estudiar la organización del ojo de los vertebrados e invertebrados y su exquisita adaptación orgánica. ${ }^{1045}$

Emilio Ribera Gómez (1853-1921), sucedió a Salustiano Sotillo en la cátedra de Historia Natural del Instituto de Segunda Enseñanza de Valencia. Nació en Madrid, estudio en la Universidad Central y, antes de venir a Valencia, fue catedrático de la misma asignatura en el Instituto de Almería. Publicó trabajos sobre temas biológicos, geológicos y agronómicos en varias revistas científicas, así como artículos de divulgación en la prensa diaria de Valencia y de Madrid. Ribera fue autor del libro titulado Elementos de Historia Natural, del que aparecieron quince ediciones entre 1879 y 1926. En este libro, que mantuvo al día en sucesivas ediciones, dedicó al transformismo, teoría de la descendencia o darwinismo, una detallada exposición,

\footnotetext{
${ }^{1044}$ Luis Simarro Lacabra, nació en Roma, estudió medicina en la Facultad de Valencia. Fue uno de los dirigentes de la juventud republicana local, estuvo en las barricadas durante el levantamiento de 1869, dio cursos sobre higiene laboral en el Centro Republicano de la Clase Obrera (1870-71) Trabajo en Paris junto a grandes figuras como Mathias Duval, Louis Antoine Ranvier, Jean Martín Charcot y Valentin Magnan. Durante este periodo parisino, Simarro ingresó en la masonería. FERNÁNDEZ SANTARÉN, Juan Antonio, op. cit. pp. 292-294; LÓPEZ PIÑERO, José María. (2008), op. cit. pp. 215-218.

${ }^{1045}$ LÓPEZ PIÑERO, José María. (2008), op. cit. pp. 226-230;
} 
mientras que la «doctrina de las creaciones sucesivas» la resumió en menos de seis líneas. Su adhesión al evolucionismo se manifestó también en el empleo de la taxonomía zoológica de Carl Gegenbaur, basada en la morfología comparada darwinista, y en el rechazo de la existencia de un «reino humano», que había sido defendido desde el fijismo. Sin embargo, consideró necesaria la intervención creadora divina en la biogénesis o aparición de los seres orgánicos. ${ }^{1046}$

\section{EL DARWINISMO EN CASTELLÓN}

En Castellón las posiciones opuestas al darwinismo vienen representadas por los neocatólicos, que no se limitaron a descalificaciones meramente ideológicas sino que fueron cultivadores rigurosos de las ciencias biológicas. Los principales fueron el jesuita castellonense Antonio Vicent y el catedrático de Ciencias Naturales del Instituto de Castellón Catalino Alegre Renau.

Antonio Vicent nace en Castellón, el 2 de octubre de 1837, en el seno de una familia acomodada. Su padre era dueño de una empresa de alpargatas. Cursa los estudios elementales y el bachillerato en Castellón. En 1859 se licencia en Derecho y en Filosofía y Letras en la Universidad de Madrid. En 1861 ingresa en la Compañía de Jesús. Hace el noviciado en el Puerto de Santa María y en 1865 se licencia en Ciencias en la Universidad de Sevilla, inaugurando una pasión por la biología que le dará un lugar relevante entre los científicos españoles del siglo XIX, siendo discípulo de Ramón y Cajal ${ }^{1047}$.

Ramón y Cajal lo citó en sus Recuerdos:

Organicé [...] en Valencia, con mayor éxito todavía que en Zaragoza, un curso práctico de Histología normal y patológica, al cual acudieron bastantes

\footnotetext{
${ }^{1046}$ Ibídem, pp. 231-236.

${ }^{1047}$ En una carta que escribió Ramón y Cajal a Antonio Vicent, el 1 de enero de 1885, cuando éste se encontraba en Lovaina estudiando junto a Jean Baptiste Carnoy, le habla de las observaciones micrográficas que estaba realizando para su Manual de Histología, en especial de las relativas al núcleo y la membrana celulares y al tejido muscular. En la carta asegura Ramón y Cajal que había comprobado la estructura reticular del protoplasma del núcleo y del nucleolo. Vicent asistía a las clases prácticas que Ramón y Cajal daba en su casa de Histología y de Bacteriología. Ver LÓPEZ PIÑERO, José María. (1995): Història de la Ciència al País Valencià. Edicions Alfons el Magnànim, Valencia, pp, 201-203; 206; 505506.
} 
médicos que cursaban libremente el doctorado, y algunos doctores deseosos de ampliar sus conocimientos en Histología y Bacteriología...Por cierto, que uno de mis discípulos fue el fogoso, culto y activo jesuita Padre Vicent. ${ }^{1048}$

Aunque Ramón y Cajal opinaba que Antonio Vicent, según ocurre en la mayoría de los eclesiásticos polemistas, no buscaba en la Ciencia sino argumentos en pro de sus arraigadas creencias, ambos mantuvieron una cordial relación hasta la muerte del jesuita, como se refleja en las dos cartas que reproducimos en el apéndice documental. ${ }^{1049}$ La primera, muy extensa, la envió Santiago Ramón y Cajal el 1 de enero de 1885. La otra carta es de Vicent Dolz, a Ramón y Cajal, el 28 de enero de 1901.

De Sevilla sus superiores lo trasladan a Manresa, donde enseña ciencias en el Colegio de San Ignacio. Funda allí el primer Círculo Católico de España. De Manresa pasa a Tortosa, aquí pasa la Revolución de 1868 que, contraria a sus ideas, lo empuja al exilio francés. Este hecho tendrá suma importancia porque le dio la oportunidad de entrar en contacto con el catolicismo social centroeuropeo. Al volver se dedicará a expandirlo por España. Según parece regresa en 1879, (Llorens, 1954), yendo a vivir a Tortosa hasta ser destinado al Colegio de San José de Valencia en 1883. Tras el verano de 1884 los superiores lo enviarán a Bélgica a completar los estudios de biología, y en 1885 se establece definitivamente en Valencia, donde muere en $1912 .^{1050}$

A parte de las tareas relacionadas con los círculos y patronatos de obreros católicos, creó en el colegio un laboratorio donde desarrolló una gran actividad didáctica que fue después consolidada por otros biólogos jesuitas, de entre los cuales sobresale Ignacio Sala Castellarnau. La principal publicación científica de Vicent fue el libro Estudios biológicos (1892). Al círculo del laboratorio de Vicent perteneció el médico Vicent Guillent Marco, dedicado principalmente al estudio de la flora del territorio valenciano. ${ }^{1051}$

\footnotetext{
1048 Ibídem, p. 175.

1049 FERNÁNDEZ SANTARÉN, Juan Antonio. (2014), op. cit. pp. 298-300. Ver Apéndice Documental No 19.

1050 GARRIDO, Samuel. (1986): Los trabajadores de las derechas, Diputación de Castellón, pp. 32-34.

${ }^{1051}$ LÓPEZ PIÑERO, José María. (1995), op. cit. pp. 513-514.
} 
El pensamiento social del padre Vicent se refleja en su obra teórica más importante: Socialismo y anarquismo, donde plantea el tema de la cuestión social de los obreros.

La filosofía de los Círculos fundados por Vicent es que la pobreza ha existido siempre, si bien hubo un tiempo en que los humildes la aceptaban con resignación gracias al estar el mundo organizado según los dictados de la Iglesia, ello no les representaba excesivas penalidades. Empieza el problema social cuando la iglesia ve puesta su autoridad en tela de juicio, y la irreligiosidad de las naciones conduce al triunfo del liberalismo.

En los círculos católicos deberán entrar en contacto patronos y asalariados para dirimir amistosamente sus diferencias y adquirir conciencia de los deberes que mutuamente los obligan, la caridad para los primeros y la aceptación de las jerarquías sociales para los segundos. Su principal preocupación será recristianizar a los obreros y apartarlos de los vicios que los echan en brazos del socialismo, mientras que las inquietudes propiamente laborales casi no existen: no dan cabida a posturas reindivicativas y su labor económica se reduce a fomentar entidades de previsión y cooperación.

En 1887 Vicent redacta un «reglamento-tipo» que presenta el modelo más elaborado de estas sociedades. Básicamente, define al Círculo como una asociación de patronos y obreros que desarrolla cuatro tipos de actividades: religiosas, económicas, instructivas y recreativas.

Los socios obreros (numerarios) pagaban una cuota semanal que les daba derecho en caso de enfermedad a una ayuda económica. Los socios no obreros (protectores) aportaban una cuota mensual, pero sin gozar del derecho a socorro. Podían existir señoras protectoras y esposas de los numerarios (copartícipes).

El gobierno de la sociedad lo ejercía la junta directiva, formada por protectores y numerarios. Dentro de ella tenía especial importancia el cargo de consiliario, sacerdote nombrado por el obispo para vigilar la sujeción a la más estricta ortodoxia.

Los Círculos de Vicent tomaron cierto auge en el País Valenciano durante las dos primeras décadas de la Restauración, en unos momentos en los que las relaciones sociales capitalistas están aún en pleno proceso de implantación. Pero a finales de siglo, con un capitalismo ya consolidado, les será mucho más difícil atraer a los obreros con 
sus posturas paternalistas y los propios patronos, viendo su ineficacia, dejaran de financiarlas. ${ }^{1052}$

La educación del obrero es una de las principales preocupaciones del catolicismo social valenciano. En los círculos la educación es siempre sinónimo de educación cristiana, es decir, moralizante y salvaguarda del orden social. Se trata ante todo, no de proporcionar al proletariado unos conocimientos que seguramente no sabrá utilizar de forma correcta, sino de difundir la idea de Dios. Las escuelas que no atienden a estos principios elementales son las llamadas escuelas neutras. Las escuelas nocturnas aparecen en todos los Círculos casi al mismo tiempo de ser fundados. Se daban clases gratuitas, a los socios y sus hijos, de lectura, escritura, doctrina cristiana, historia sagrada, aritmética y los estudios de aplicación a las artes e industrias. ${ }^{1053}$

Las charlas edificantes son la actividad más potenciada en todos los Círculos. Las conferencias pronunciadas siempre por eclesiásticos o protectores, se centraban en predicar la moralidad de las costumbres y prácticamente nunca aludían aspectos sociales o laborales. La maldad de las blasfemias, la santificación de los domingos o motivos piadosos semejantes son los temas más socorridos. ${ }^{1054}$

Con el tiempo la gran mayoría de los Círculos se dedicaron a potenciar el fin recreativo. Las Juntas directivas, especialmente el consiliario, son los encargados de erradicar el menor asomo de inmoralidad en los actos recreativos. En Vila-Real, en 1895 se crea una banda de música; en Alcora se dispone de un gimnasio, y en Castellón, el padre Vicent acudía de vez en cuando con algún microscopio para ilustrar a sus paisanos con conocimientos de biología. ${ }^{1055}$

En 1881, para desmarcarse de los carlistas, el Círculo Católico de Obreros pasa a llamarse Círculo Cooperativo y Protectorado de Obreros para que los carlistas no abusaran de la palabra católico, considerándola sinónimo de carlista.

La preside el sacerdote Juan Cardona Vives (1814-1890), antiguo Arcipreste de Castellón, siendo otro de sus miembros Catalino Alegre Renau.

Catalino Alegre había ocupado la alcaldía entre 1877 y 1879, formando parte de una candidatura labradora apoyada por los propietarios católicos. Licenciado en ciencias

\footnotetext{
1052 GARRIDO, Samuel. (1986), op. cit. pp. 38-39.

1053 Ibídem, pp. 102, 104.

${ }^{1054}$ Ibídem, p. 107.

1055 Ibídem, p. 111.
} 
$\mathrm{y}$ derecho, era catedrático $\mathrm{y}$, por entonces, secretario del Instituto Provincial de Enseñanza Media. Gozaba de gran prestigio debido a que, siendo presidente del Consejo Provincial de Agricultura, había organizado la Comunidad de Regantes. En 1884, después de la entrada de Alejandro Pidal en el gabinete de Cánovas, pasa a ser director del Instituto Provincial de Enseñanza Media de Castellón, cargo que ocupa hasta su muerte en 1891.

La defensa del darwinismo en Castellón fue llevada a cabo por los republicanos. Muchas de las conferencias que se daban en el Centro Republicano y en la Juventud Republicana, trataron sobre la teoría darwinista. El médico y concejal Vicente Gea, Gil Valero, jefe de los republicanos villarrealenses y el redactor de El Clamor y jefe de las Juventudes Republicanas, Agustín Betoret, fueron los principales conferenciantes sobre esta temática. ${ }^{1056}$

Los republicanos con una clara vocación de intervención en la vida de sus seguidores, disponían de una red institucional diversificada como prensa o intensa actividad asociativa.

La red institucional y asociativa que desplegaron los republicanos castellonenses muestra bien a las claras la voluntad de presencia, lo más intensa posible en la vida social castellonense. La base de todas las actividades era el Centro Republicano (que podía ir cambiando de nombre según el que adoptara el partido en cada coyuntura). Éste actuaba como sede central de los diferentes partidos y comités que conformaban el republicanismo castellonense, y contaba con una junta directiva propia escogida entre todos los organismos que la componían. El Centro Republicano estaba situado en el corazón mismo de la capital, en la calle de Ruiz Zorrilla, esta sede fue inaugurada el 20 de diciembre de 1894 por Nicolás Salmerón, en sustitución de la antigua situada en la Plaza de Vilaroig. El Centro desplegaba un conjunto de actividades que lo convirtieron en algo más que una sede de partido político, ya que en la práctica funcionaba como

\footnotetext{
${ }^{1056}$ Vicente Gea era republicano perteneciente a los federalistas integrados junto con los unionistas en la Federación Provincial Republicana de Castellón. Ver ARCHILES CARDONA, Ferrán. (2002): Parlar en nom del poble. Cultura política, discurs $i$ mobilització social al republicanisme castellonec (18911909).Excm. Ayuntamiento de Castellón de la Plana, p.37.; LlANSOLA GIL, Gerard. (2006): Republicanisme, identitat popular i hegemonia municipal.Castelló de la Plana, 1913-1917. Publicaciones de la Universidad Jaume I, pp. 61-64. En 1899, Vicente Gea fue nombrado concejal junto con Enrique Gimeno (que era presidente de los federales).Gea era masón del Capitulo Integridad, en USÓ I ARNAL. Joan Carles, (1982): La masonería castellonense contemporánea (1874-1939). Tesina de licenciatura inédita. Universidad de Valencia. Facultad de Geografía e Historia.
} 
casino republicano y centro social, donde tenían lugar acontecimientos de la vida social como las fiestas de Carnaval y el año nuevo. Disponía de una biblioteca y las actividades culturales y educativas eran funciones muy destacadas de este Centro.

Antes de 1908 existían dos centros republicanos más, dependientes del Centro Republicano de la calle Ruiz Zorrilla, situados en el Raval de San Félix y en el Grao.

Desde 1882 existía El Centro Democrático-Instructivo, una entidad que perduró a lo largo de la primera década del siglo XX. La actividad desarrollada por este centro fue muy intensa y su importancia dentro de la red del partido era notable. En 1892 su presidente era Enrique Perales, uno de los intelectuales del partido, y en 1893 sería Fernando Gasset, jefe de la Federación Provincial Republicana de Castellón.

Con sede en el mismo Centro Republicano estaba la Juventud Republicana Propagandista, que fue fundada con esta denominación en 1893. Su militancia era numerosa y su presencia en los actos del partido era destacada. A excepción de Gaeta Huguet Segarra, que fue presidente en 1906, y que sería una de las figuras más destacadas del partido, Josep Castelló Soler, que fue concejal y Vicente Gimeno Michavila que fue vicepresidente en 1893, ningún miembro destacado del organigrama del partido ocupó cargos previamente en las juventudes.

En 1910 fue creada una Juventud Radical, distinta a la Juventud Propagandista y vinculada al partido radical de Lerroux, y que contaba con una sede propia en la calle González Chermá. Entre 1909 y 1912 se fundó el Ateneo Radical, una institución que perduró hasta la Guerra Civil y que fue una de las más características de los republicanos castellonenses. En La Juventud Republicana Radical, que compartía también la sede del Centro Republicano, se organizaban actos políticos y sociales. ${ }^{1057}$

Otra institución de la ciudad de Castellón pero, sin depender directamente de la red organizativa del partido, fue el Casino de Artesanos, institución fundada en 1879 y que perduró a lo largo de los años veinte. Durante muchos años este centro fue complementario de las actividades republicanas y le dio cobertura a muchas actividades cuando los republicanos no podían o no querían efectuarlas en sus sedes. Fue especialmente destacada durante muchos años la función ejercida por el Casino de Artesanos actuando como primer centro obrero de la ciudad y desde el cual los republicanos aseguraron su predominio en el movimiento obrero castellonense. Según

\footnotetext{
1057 ARCHILÉS CARDONA, Ferrán, op. cit. pp. 62-63.
} 
Joan Carles Usó ${ }^{1058}$, el Casino era un centro de la masonería en estrecha relación con el mundo del republicanismo castellonense.

Además de las relaciones con el mundo obrero, los republicanos castellonenses mantuvieron una estrecha relación con otras instituciones de la vida ciudadana vinculadas a las clases medias. Los republicanos mantuvieron una notable presencia en la liga de contribuyentes (de la que fueron presidentes Gaeta Huguet y Fernando. Gasset) y el Círculo Mercantil (con los presidentes Enrique Santa Cruz, Carlos González Espressati o Serrano). Esta institución, creada en 1897, era clave porque dio lugar a la creación de la Cámara de Comercio en 1901 y ésta, a su vez, constituyó la Junta de Obras del Puerto. Estas últimas instituciones fueron presididas por Carlos González Espressati el cual hasta su expulsión en 1904, era miembro del partido republicano.

El Círculo Mercantil, más allá de sus funciones económicas, fue el centro recreativo por excelencia de los republicanos. Una de las actividades más habituales, además de las relacionadas con la acción política (mítines, asambleas, etc.), era la realización de diferentes tareas de carácter educativo dirigidas a un público amplio, pero mayoritariamente obrero. El Centro Democrático Instructivo y el Centro Republicano eran las instituciones donde tenían lugar campañas de alfabetización dirigidas a un público mayoritariamente adulto o que por causa del trabajo no podía asistir.

En el Centro Republicano se creó, además, en los primeros años de siglo XX una sección dedicada a las actividades educativas. El Centro Instructivo, en 1906, impartía clases, no solo de alfabetización, sino de agricultura, aritmética, geometría, geografía, historia e idiomas. Destaca, sobretodo, la existencia de una escuela nocturna, por tanto, dirigida a los sectores trabajadores bajo la titularidad de la Juventud Republicana.

\subsection{LA POSTURA ENFRENTADA DE CATÓLICOS Y REPUBLICANOS}

Durante los primeros meses la vida del Círculo Cooperativo transcurre sin especiales incidencias. Se encuentran entre sus protectores individuos de todos los partidos, en su mayoría de procedencia liberal, y gran parte de los numerarios son artesanos que nunca se han mezclado en acto político alguno. Catalino Alegre, a través

${ }^{1058}$ USÓ I ARNAL, Joan Carles. (1982), op. cit. 
de numerosas charlas reseñadas por La Provincia, lo presenta como una fundación típica del padre. Vicent destinada a moralizar, instruir y socorrer. Comienza a fundar escuelas y promete establecer una Caja de Ahorros, pero sobre todo, insiste en el apoliticismo.

A finales de 1882, ante el crecido número de socios, el Círculo Cooperativo se traslada a unos locales más amplios y celebra el 21 de enero la inauguración oficial en los salones del Instituto Provincial de Enseñanza Media de Castellón.

Asisten los presidentes de la Diputación y de la Audiencia. Alegre, haciendo gala de profesor de ciencias naturales, pronuncia un discurso en el que pretende rebatir la teoría darwinista. ${ }^{1059}$

La Provincia publica un artículo sobre la conferencia que dio Catalino Alegre en el Círculo Cooperativo, haciendo hincapié en la perturbación que producen en las conciencias las nuevas escuelas filosóficas, así lo describe el periodista:

[...] Pero en donde rayó a mayor altura el Sr. Alegre, fue al ocuparse del estado actual de la sociedad; las varias escuelas filosóficas, las diferentes sectas que en otras naciones se han desarrollado, producen tal perturbación en las conciencias, que hace indispensable que el verdadero católico, el creyente sincero, viva apercibido para no llegar a contagiar con doctrinas y enseñanzas tan funestas como impropias. Con vehemencia y enérgico acento declaró que era verdadero católico, y que sus principios son los que inculcará siempre a sus hijos; y que si éstos había de correr riesgo algún día de caer en alguna de aquellas aberraciones elevaba desde luego sus súplicas al cielo para que se los llevara de este mundo, antes que apartarse de nuestra bendita y santa religión. ${ }^{1060}$

Por otra parte la prensa demócrata progresista se hace eco de este discurso. En $E l$ Clamor se publica un artículo sobre la inauguración del Círculo Católico Cooperativo en el Instituto de Segunda Enseñanza:

Un dosel con una virgen de Lidón: un obispo que abre el acto con una bendición y un «Ave María»; un joven abogado que en un discurso en que habla de todas las cosas y de muchas más, sostiene que, en el siglo de la revolución francesa, el fanatismo religioso creaba libertad y la revolución entronizaba la tiranía; que hay

\footnotetext{
${ }^{1059}$ USÓ I ARNAL, Joan Carles. (1982), op. cit. pp. 116-118.

${ }^{1060}$ La Provincia 15/7/1882.
} 
progreso bueno y progreso malo; que casi todos los adelantos se deben a los frailes: y que donde no hay religión no hay progreso posible; un catedrático de instituto que combate sin razones la escuela positivista y las doctrinas de Darwin sobre el origen de la especies [...] ${ }^{1061}$

En otro número de El Clamor se ruega a Catalino Alegre que publique el discurso que leyó la noche de la inauguración del Círculo Cooperativo «para combatirlo con las formas corteses que acostumbramos a usar en esta clase de polémicas».

La prensa critica el discurso de Catalino Alegre por considerarlo que no estaba a la altura de la ciencia moderna:

[...] Y eso no puede ser. D. Catalino Alegre, el ilustrado profesor de Historia Natural y de Fisiología e Higiene de este Instituto, posee, estamos seguros de ello, cuantos conocimientos modernos puedan referirse a las ciencias que enseña. Podrá no estar conforme con algunas teorías nuevas, pero tenemos la convicción de que a sus alumnos se las expone con claridad y les deja libres para que las acepten o no, sacrificando sus creencias particulares a la instrucción de sus discípulos. ${ }^{1062}$

También otro colega, El Clamor de la Democracia, recoge el discurso de Catalino Alegre:

El presidente del Círculo Don Catalino Alegre leyó un discurso acerca de los orígenes de la vida y las especies orgánicas. Combatió la escuela materialista y el transformismo de Darwin. Dijo que estas teorías son puramente hipotéticas y calificó de más fundadas y seguras las que acerca del punto debatido resultan de los sueños de Jacob. ${ }^{1063}$

Los liberales criticaban las ideas políticas del Círculo por considerar que allí nunca sonaba la voz de la Ciencia y de la civilización moderna:

${ }^{1061}$ El Clamor, 28/1/1883.

1062 El Clamor, 4/3/1883.

${ }^{1063}$ El Clamor de la Democracia, 25/1/1883. 
La conferencia es allí la apoteosis del retraso. Darwin fue un malvado, Spencer un criminal, Krause un embaucador, Buchner un trapacero, Fourrier un brigante, Voltaire un pillo, Rousseau un mohicano....y todos purgan o purgarán en eterna condenación su empeño atrevido en dar vueltas a la razón... ${ }^{1064}$

Asimismo en La Revista de Castellón apareció un artículo ensalzando la figura de Darwin. El autor Tomas Michelena lo describe como un «cerebro elegido, de un guiador y maestro, de un espíritu luminoso»: « [...].Es una nueva idea o de una idea antigua esclarecida por un genio, por uno de esos seres privilegiados que surgen de cuando en cuando para subir muy por encima de la colectividad». ${ }^{1065}$

Más adelante el articulista continúa diciendo del gran naturalista, «que viene a convencer a las multitudes ignorantes, a los que embargó la fantasía tradicional, a sacar del error»:

Es Darwin, uno de los espíritus elegidos. Sacerdote de la naturaleza, es en tan espléndidas aras que rinde su culto a Dios. Paciente en la observación y activo en el estudio, consagró su existencia al más noble objeto, y con la perseverancia del genio llegó al esclarecimiento de los fenómenos biológicos. ${ }^{1066}$

Por otra parte, considera el autor que no se le debe inculpar a Darwin como preconizador del materialismo y señalarle así el estigma del ateísmo porque la teoría de la evolución es tan extensa cuanto que abarca todas las Ciencias Naturales y mal puede ser juzgada si no se estudia en todas sus fases:

Ella no se refiere únicamente a un movimiento de desarrollo de las especies, a sus relaciones íntimas de parentesco, a la herencia y a la adaptación, al combate por la vida, y a la selección. Abarca en un solo e inmenso horizonte los dos grandes reinos de la naturaleza animada, hermanando la Botánica y la Zoología, penetra con la observación en la Embriología; desentraña la Paleontología; va así hasta la Geología, que relacionada íntimamente con la Astronomía, por la similitud de la materia cósmica, se remonta a la consideración de las grandes leyes universales, y funda, en fin, sobre bases científicas un criterio más perfecto sobre la

\footnotetext{
${ }^{1064}$ El Clamor de Castellón, 8/6/1884.

${ }^{1065}$ Revista de Castellón, 15/7/1884. no 86, pp. 215-218.

1066 Ibídem.
} 
generación de los seres(...) el transformismo informa y relaciona la Historia, la Política, la Filología, la Moral y la Sociología. 1067

Darwin al final de su obra El Origen de las Especies alude al Creador, por eso el articulista afirma que Darwin no es materialista; tampoco es positivista porque el positivismo no acepta un primer principio inteligente, luego Darwin es espiritualista: «Cree en Dios, en un creador, y como agentes de su designio en la naturaleza, las leyes las cuales obran tanto en lo físico como en lo moral para resolver el problema misterioso de la vida, en su génesis, desarrollo y variación, por el cambio evolutivo». ${ }^{1068}$

En otro número, La Revista de Castellón publica un resumen de la vida de Darwin, destacando su genio analítico y sintético y comentando que «la revolución causada por sus teorías aún no ha encontrado reposo». ${ }^{1069}$

La tarea educativa era, sin duda, una de las prioridades de los republicanos castellonenses. Los republicanos organizaron desde antiguo ciclos de charlas y conferencias sobre los aspectos más diversos en todas las instituciones republicanas. El Centro Democrático Instructivo, el Centro Republicano y el Casino de Artesanos, fueron en los primeros años las instituciones encargadas de estas actividades. Después fue la Juventud Republicana, con conferencias varias veces por semana y el Círculo Mercantil (especialmente a partir de la presidencia de Salustiano Serrano) con ritmo semanal, los que las organizaban con más asiduidad. También el Centro Obrero fue una institución implicada a menudo en las actividades republicanas.

Los temas preferidos solían ser de carácter científico. En realidad las actividades realizadas en el Casino de Artesanos o por las Juventudes Republicanas en el Centro Republicano solían ir más dirigidas a los sectores populares y trabajadores, con un carácter más divulgativo y temas más prácticos como las matemáticas, los avances de la mecánica o electricidad experimental.

En el Círculo Mercantil, en cambio, las conferencias iban dirigidas al público burgués y profesional de las capas medias con mayor formación intelectual, podían abrazar desde la evolución del comercio y la posición de las clases mercantiles en la sociedad moderna hasta una conferencia dada por el médico y concejal Vicente Gea

\footnotetext{
${ }^{1067}$ Ibídem.

1068 Ibídem.

${ }^{1069}$ Revista de Castellón, 6/3/1887. Tomo VI no 147, p. 18.
} 
sobre darwinismo. A veces, este tipo de temas llegaban a provocar la polémica, como cuando en febrero y marzo de 1909 se impartieron dos charlas sobre el origen de la vida de contenido darwinista y que fueron contestadas por la prensa católica. ${ }^{1070}$

Un aspecto que hay que destacar de los republicanos es su vinculación con la masonería. Según Joan Carles Usó la mayoría de los republicanos que tuvieron importancia en la historia política de Castellón pertenecían a la masonería.

La masonería castellonense centró muchos de sus fines en la enseñanza laica, lo más interesante fueron las «tenidas de instrucción» celebradas en la logia Perfecta Razón, con asistencia de numerosos obreros. Los trabajos y ponencias perseguían una finalidad ilustrativa y, a la vez, informativa. ${ }^{1071}$

En los periódicos neocatólicos como La Verdad, se expone en muchos de sus números la conveniencia de formar una Liga antimasónica. Tal proyecto no pudo llevarse a cabo hasta 1897, bajo los auspicios de Pedro Rocamora, Obispo de la Diócesis, Tomas Costas, Arcipreste de Santa María, y el padre Antonio Faulí. Uno de los compromisos que imponía la Liga antimasónica a todas aquellas personas interesadas en formar parte de ella era combatir la escuela neutra o laica y, por el contrario, favorecer las obras y asociaciones antimasónicas: academias católicas, círculos católicos, asociaciones religiosas, etc. ${ }^{1072}$

Una de las manifestaciones del anticlericalismo en la retórica del republicanismo castellonense se produjo con la polémica que mantuvieron el cura Antonio Fauli y Agustín Betoret ${ }^{1073}$ en agosto de 1896. La polémica tenía como fondo el materialismo darwiniano.

Antonio Faulí, un sacerdote de Villarreal, publicó una serie de cartas abiertas a Agustín Betoret desde El Heraldo de Castellón. Faulí era un ejemplo de cura periodista ya que estaba vinculado al diario de La Plana, periódico activista de la propaganda católica. Faulí escogió las páginas del periódico con más tirada de la capital, lo cual indica que se trataba de una ofensiva en toda regla.

\footnotetext{
${ }^{1070}$ ARCHILÉS CARDONA, Ferrán, op. cit. pp. 68-69.

${ }^{1071}$ USÓ I ARNAL, Joan Carles. (1982), op. cit. p. 84.

1072 Ibídem, pp. 130-132.

${ }^{1073}$ Antonio Faulí era profesor de religión del Instituto Provincial de Enseñanza Media y de la Escuela Normal de Castellón, y Agustín Betoret era redactor de El Clamor y presidente de las juventudes del partido republicano. Ver Diario de La Plana, 25/3/1898.
} 
El motivo presentado por Faulí fue una crítica a Agustín Betoret por el artículo que éste había escrito en El Clamor, sobre la muerte de González Chermá ${ }^{1074}$, titulado «Ha muerto». Betoret había escrito:

La naturaleza, esa soberbia ignorante que todo lo envuelve y domina, esa diosa olímpica que pone todo su afán en crear, en multiplicar los seres sin curarse de los medios adecuados para que esos seres desenvuelvan su existencia en su justa medida ... y que todo lo hace mal... ${ }^{1075}$

Estas palabras servían a Faulí para desarrollar una serie de artículos criticando el materialismo que en sus teorías filosóficas sostenía El Clamor:

[...] El Clamor es un impío, esclavo maniatado del materialista Hegel, que en sus teorías filosóficas sostiene «que no hay más vida que la presente» y de su discípulo Kraué que dice «Las ilusiones de la inmortalidad ya no engañan más que algunas almas débiles, a los espíritus serviles» porque El Clamor en su artículo dice: «Si más allá de la tumba existiera un mundo para los muertos...; pero la ley ciega de la materia cierra nuestras esperanzas». ${ }^{1076}$

Hace una crítica del materialismo darwinista:

El Clamor es un materialista darwiniano, quien afirma en su filosofía no existir más que la naturaleza con su fuerza y materia, con las que los vegetales se transforman en animales, estos los perfecciona en monos, los que llegan a perfeccionarse gradualmente y convertirse en hombres. ${ }^{1077}$

Faulí reta a El Clamor a que responda si no son éstas sus teorías y si no es ésto lo que afirma en su artículo: «[...] Viene a decir de González Chermá que sus antepasados fueron o algún mono, o algún mulo, o algún árbol de los que florecen en

\footnotetext{
${ }^{1074}$ En 1896 moría Francesc González Chermá, el líder de los republicanos castellonenses. Fue alcalde, diputado a Cortes y periodista. Ver MONLLEó PÉRIS, Rosa. (1995): Los diputados valencianos en la $i$ República. Federalismo y levantamiento carlista en las comarcas de Castellón. Diputación de Castellón. pp. 168-174.; CARDONA ARCHILES, Ferrán. (2002): Parlar en nom del poble.Cultura política, discurs $i$ mobilització social al republicanisme castellonec (1891 - 1909) Ayuntamiento de Castellón de la Plana. ${ }^{1075}$ El Clamor, 3/8/1896.

${ }^{1076}$ El Heraldo de Castellón, 3/8/1896.

${ }^{1077}$ Ibídem.
} 
nuestros campos y bosques; en fin, dice del señor González, que ya nada de él subsiste, y todo aquel genio se ha reducido a un montón de gusanos». ${ }^{1078}$

Faulí acusaba a El Clamor de propagar las ideas materialistas en el artículo de referencia, de empañar la brillante catolicidad de Castellón y de mancillar «con borrón indeleble» el nombre de los republicanos honrados de Castellón:

[...] porque al leer las gentes El Clamor, (órgano del numeroso partido de Castellón) creerán que la mayor parte de los castellonenses rechazan como un delirio el milagro de la creación para abrazar la generación espontánea de Darwin, y la ley de casualidad del alemán Eckel: creerán que los castellonenses no aceptan la filosofía cristiana que nos enseña ser el alma el principio vital del hombre. ${ }^{1079}$

En sucesivos números de El Heraldo, Faulí siguió defendiendo el dogma de la creación y atacando las ideas materialistas de los republicanos, defendidas por Betoret desde El Clamor.

\section{CENTENARIO DEL NACIMIENTO DE DARWIN EN 1909 EN CASTELLÓN}

Con motivo del centenario del nacimiento de Charles Darwin la prensa de Castellón recoge que la Institución Libre de Enseñanza, por invitación del Ministro de Inglaterra acreditado en Madrid, inició una suscripción para levantar un modesto monumento a Darwin en cuya suscripción figuraban entre otras personalidades españolas, los señores Moret, Echegaray, Riaño, Uña, Pedregal, Azcárate y Giner de los Ríos:

Tales honores y distinciones tributados a Darwin, por tantos hombres eminentes, de tan opuestas creencias y opiniones científicas, son la prueba más elocuente del gran mérito del genial naturalista, uno de los sabios más renombrados

\footnotetext{
1078 Ibídem.

${ }^{1079}$ El Heraldo de Castellón, 20/3/1896.
} 
del actual siglo, cuya memoria vivirá eternamente en la historia de la ciencia y de la humanidad. ${ }^{1080}$

En la polémica en torno al darwinismo la prensa republicana de Castellón daba inequívocamente la gloria a Darwin «por destruir el viejo concepto de la naturaleza y levantar sobre las ruinas del pasado el grandioso edificio de la ciencia actual». Se resalta la biografía del gran naturalista, destacando su obra magna On the origen of Species by Means of natural Selection que tan gran sensación causó en el mundo científico: «Libro que hará época en la historia de las ciencias por lo atrevido y trascendental de la doctrina, la sencillez de la exposición y el riquísimo caudal de hechos y datos en su mayor parte desconocidos, que tan interesante hacen el hermoso trabajo del ilustre naturalista inglés». 1081

En sesión de 12 de febrero de 1909, los republicanos que gobernaban el Ayuntamiento de Castellón decidieron dar el nombre de Darwin a la calle del Rey don Jaime. Fue propuesto por el concejal Valero por cumplirse cien años del nacimiento del ilustre naturalista.

La prensa católica reaccionó con fuertes críticas a tal decisión diciendo que «en Castellón era costumbre sustituir los santos y los héroes por los revolucionarios y canallas que no hicieron feliz a su patria».

Según El Cruzado la teoría de la evolución espontánea fue un plagio de la de Lamarck, quien a su vez, lo copió de los antiguos materialistas refutados y triturados por Aristóteles en su libro Ánima. También se pregunta si no es más práctico averiguar el origen de las enfermedades que «calentarse los cascos en la inquisición del origen próximo de la especie humana». ${ }^{1082}$

Compara las figuras del naturalista inglés, antirreligioso e impío y la del Rey don Jaime, católico y fundador de Castellón:

El odio de secta no deja ver a los darwinizantes que por honrar a un antirreligioso, escupen a la ciencia verdadera, y además pisotean nuestra Religión, rasgan nuestra historia, desprecian nuestras gloriosas tradiciones y profanan la

\footnotetext{
${ }^{1080}$ El Clamor, 12/2/1909.

1081 Ibídem.

${ }^{1082}$ El Cruzado, 27/2/1909.
} 
memoria del gran fundador de Castellón, del más ilustre y esclarecido Rey de Aragón, sino de España entera. ${ }^{1083}$

Por otra parte, la Junta directiva de la Juventud Republicana de la ciudad de Castellón proyectó honrar la figura de Darwin invitando a diferentes personalidades en el campo de la ciencia para que dieran conferencias sobre Darwin y su teoría evolucionista. Aceptaron esta invitación los catedráticos de las Universidades de Barcelona y Valencia respectivamente: Odón de Buen y Peregrín Casanova. También iban a tomar parte Vicente Gea y José Gil Valero. ${ }^{1084}$

Las restricciones ideológicas propias de la época impidieron la divulgación e incluso la defensa abierta del darwinismo, pero en Castellón había cultivadores de las ciencias de mentalidad progresista que lo aceptaron, enseñándolo en los círculos republicanos. Ésta fue la actitud del doctor Vicente Gea y el redactor de El Clamor, Agustín Betoret.

El doctor Gea dio dos conferencia sobre «Darwin y su escuela» en el Círculo Mercantil. En la primera, tras exponer las doctrinas dualistas de Linneo, Cuvier y Agassiz, se ocupó del lamarckismo. Sintetizó la doctrina de Darwin basada en la selección natural y la lucha por la existencia como medios naturales de producción de tipos nuevos. Se extendió en la generalización de estos hechos al estudio del hombre y demostró ya por el desarrollo filogenético como por el ontogénico y paleontológico el origen animal de la especie humana.

El clamor se expresa así sobre la conferencia del doctor Gea:

Hizo exposición de la doctrina monista o mecánica enfrente de la doctrina dualista o vital.

Presentó a la naturaleza como nueva fuente de conocimientos y rindió ferviente homenaje a los grandes hombres que dedicando sus esfuerzos al descubrimiento de verdades eternas son los santos de la ciencia y patronos de la humanidad.

\footnotetext{
1083 Ibídem.

${ }^{1084}$ Vicente Gea y Gil Valero, como hemos dicho anteriormente, eran médicos de Castellón y de Villarreal respectivamente. Ambos pertenecían al partido republicano. El Clamor, 7/4/1909.
} 
Es la oratoria de señor Gea sencilla, clara, elocuente, llena de luminosos juicios y pertinentes citas; es la oratoria fácil del que tiene un gran fondo de conocimientos de donde sacar sin esfuerzo ideas y enseñanzas. ${ }^{1085}$

Las críticas en la prensa católica a la conferencia del doctor Gea fueron numerosas, en un artículo de El Cruzado se critica a los monos sabios de Castellón, «al empeñarse en desenterrar a título de progreso y civilización una teoría por repugnante, absurda y ridícula sepultada en la fosa del más profundo desprecio».

Compara el empeño de negar el origen divino del hombre para apellidarse hijo del mono con:

Ciertos chiquillos del arroyo que olvidando por unos momentos la nobleza de su humana condición se esfuerzan por imitar en sus juegos a los animales, «bien andando a cuatro patas o colgando de su cuello un cabestro» ¡Si se descuelgan cualquier día con que nuestro padre común es el mismísimo asno cuya quijada (hipparión de la Garriga) fue como la puntilla solemne dada por el gran sportman del darwinismo Odón de Buen! ${ }^{1086}$

En otro apartado dice que demostrará en una serie de artículos que el hombre no es un mono transformado, «sino ser nobilísimo hecho a imagen y semejanza de Dios». Según dice el periódico católico todos los conocimientos humanos evidencian que el hombre no ha pasado por una serie de transformaciones, sino que siempre ha tenido «iguales atributos y propiedades esenciales». ${ }^{1087}$

El Cruzado también afirma que la Antropología y la Arqueología demuestran la falsedad del transformismo y hace una referencia al profesor Wirchow, que en una reunión de la sociedad alemana en Munich en el verano de 1877, decía que:

[...] cuando examinamos al hombre cuaternario fósil el cual debe acercarse a nuestros antepasados en la serie ascendente o descendente, hallamos siempre un hombre como nosotros.

\footnotetext{
${ }^{1085}$ El Clamor, 26/2/1909. No hemos podido encontrar la conferencia desarrollada, pues El Clamor sólo la resume. Parece ser que Vicente Gea quería, según este periódico, publicar en un folleto sus conferencias.

${ }^{1086}$ El Cruzado, 13/3/1909.

${ }^{1087}$ Ibídem.
} 
Ha poco más de seis años, que al hallar un cráneo en la turba en los parajes palustres o las antiguas cavernas, creíase ver en él caracteres singulares que indicaban un estado salvaje no bien desarrollado. Nada casi faltaba para juzgar que fuese de mono, pero desvaneciéndose esta ocurrencia del todo, y cada día se ve desacreditando más [...].

[.... debo decirlo nunca se ha encontrado un cráneo fósil de mono o hombre mono que haya pertenecido realmente a hombre alguno [...]. ${ }^{1088}$

También La Cruz de Castellón y El Restaurador de Tortosa se ocuparon de la conferencia que el doctor Gea dio en el Círculo Mercantil acerca de Darwin y su escuela. Lanzan un reto dirigido al doctor Gea para discutir las teorías que expuso en su disertación.

La persona elegida para rebatir las teorías darwinistas, en la misma tribuna del Círculo Mercantil, fue el doctor Rafael Tarín Juaneda, profesor de la Universidad de Valencia que también fue profesor del Instituto Provincial de Castellón. ${ }^{1089}$

La Cruz de Castellón dice que «como dos y dos son cuatro demostrará el sabio profesor que el hombre no desciende ni puede descender del mono, haciendo añicos de paso la falsa teoría evolucionista o transformista de Darwin». ${ }^{1090}$

En el mismo periódico sale desarrollada la conferencia del Doctor Tarín en el Círculo Mercantil. De gran altura intelectual, la conferencia el doctor Tarin se limitó a rebatir los tres argumentos en favor del origen simiano del hombre «según la obra del evolucionista Metchnikoff titulada La nature humaine»: argumento morfológico, basado en la semejanza de los órganos del hombre con los de los animales; argumento fisiológico, tomado de la supuesta inutilidad de muchos órganos del hombre llamados rudimentarios, y argumentos patológicos, que se fundan en los inconvenientes y desequilibrios que en la salud del hombre producen la existencia de esos órganos incompletos que existen en virtud de la herencia y que están en vías de desaparición por adaptación al medio.

\footnotetext{
1088 Ibídem.

1089 Rafael Tarín fue auxiliar numerario de la Universidad de Valencia. Se inició en los trabajos de laboratorio de la mano del padre Antonio Vicent, antidarwinista, que desde 1885 desarrolló su tarea docente e investigadora en el Colegio de San José de Valencia. Del trabajo de Rafael Tarín destacan las preparaciones microscópicas que acompañaron la memoria de Antonio Vicent sobre las aguas del río Turia durante la epidemia de cólera de 1890, y sus estudios de botánica sobre plantas fanerógamas. Ver SÁNCHEZ SANTIRÓ, Enrique. (1998): Científics i Professionals. La Facultad de Ciències de València (1857-1939). Universidad de Valencia.

${ }^{1090}$ La Cruz de Castellón, 20/3/1909.
} 
En el primer argumento, hace referencia a los órganos homólogos que son los que conservan cierta semejanza de forma, aunque las distintas especies de animales en que se observan hagan distinto uso de ellos: ${ }^{1091}$

Esta semejanza de forma sirve de fundamento a la escuela evolucionista para sostener el parentesco entre todas las especies comparadas, y como la homología entre los órganos del hombre y los de ciertos monos llamados antropomorfos existe, de ahí que los evolucionistas afirmen que el hombre procede del mono. ${ }^{1092}$

El doctor Tarín continua diciendo que no se ha podido completar la serie de todas las formas de los seres vivientes ni la de los animales solos, y que experimentalmente no ha podido confirmarse la descendencia de unas especies de otras. Además, en el terreno de los hechos, aún no se ha visto confirmada la hipótesis de que la semejanza sea debida al parentesco. Experimentalmente no ha podido confirmarse la descendencia de unas especies de otras. La Escuela Evolucionista ha ideado la manera de obviar este inconveniente:

Ha establecido una comparación entre el desarrollo de un ser desde que es óvulo hasta el estado completo, y el desarrollo sucesivo de todas las especies. Así para establecer esta comparación en la serie animal ideó Haeckel que el embrión del hombre durante su desarrollo presenta 22 formas (o estadios como él las llama) que equivalen a otras tantas especies típicas de la serie zoológica. Tales formas, como la mónera, amiba, gástrula, turbelaria, scolex, ascidia, amphioxus, lamprea, etc. Son las representaciones, durante el desarrollo embrionario del hombre, de otras tantas especies típicas que al frente de grandes grupos zoológicos nos ofrece la serie de todos los animales que existen y han existido en la tierra. La serie embrionaria, llamada ontogenia, aseguran los transformistas que es una reproducción abreviada de la otra serie, llamada filogenia. Según esto, viendo lo que sucede en el desarrollo de un ser, podemos saber el camino que recorrieron todas las especies que son

\footnotetext{
${ }^{1091}$ Richard Owen (1804-1892) en su libro On the Archetype and Homologies of the Vertébrate Skeleton (1848) precisó los conceptos básicos de la moderna anatomía comparada. Diferenció entre «analogía» o mera semejanza funcional, y «homología» o autentica semejanza anatómica. Por ejemplo, las alas de un murciélago son análogas a las de un insecto y un ave, mientras que son homólogas a las aletas anteriores de un pez, a las patas delanteras de un cuadrúpedo y a las extremidades superiores del cuerpo humano. Estos conceptos fueron generalmente aceptados, pasando luego a ser una de las bases metodológicas de la anatomía comparada evolucionista. Ver LÓPEZ PIÑERO, José María. (2008): Charles Darwin, Universidad de Valencia, pp. 102-103.

${ }^{1092}$ La Cruz de Castellón, 20/3/1909.
} 
términos anteriores al lugar que ocupa en la escala la especie cuyo desarrollo embrionario estudiamos. ${ }^{1093}$

Tarín comenta que muchos darwinistas aseguran que para dar como un hecho la descendencia de unas especies de otras, faltan documentos. Continua diciendo que ninguna objeción ha formulado contra el primer argumento de Darwin, los mismos darwinistas se han encargado de proporcionar argumentos en contra ${ }^{1094}$ :

Ellos confiesan que no hay hechos a favor de la tesis que sienta que de la semejanza de las especies se deduce el parentesco entre ellas y por lo tanto la descendencia de unas de otras; y al cabo algunos de ellos más sinceros, señalan como hipótesis mal fundadas lo que otros menos escrupulosos querían presentar al mundo científico como ley. ${ }^{1095}$.

El segundo argumento llamado fisiológico, describe la función de los órganos rudimentarios «que creen los transformistas que existen en el hombre, solamente por ley de herencia aunque para nada le sirvan». Han sido transmitidos hasta la persona a través de la serie animal, y aunque por adaptación al medio y por no usarlos se vayan atrofiando, aún quedan restos de ellos en nuestra especie:

El total de estos órganos se eleva, según Metchnikoff, a más de cien y pueden dividirse para su estudio en dos categorías: $1^{\circ}$ órganos tan rudimentarios que solamente son vestigios, a veces microscópicos, que se encuentran en los adultos y apenas si pueden compararse a órganos homólogos existente en algún supuesto

\footnotetext{
${ }^{1093}$ Ibídem. Estudiando los embriones y las larvas de muchos animales se observó que las homologías se podían descubrir en ellos con mayor facilidad, porque durante las fases del desarrollo embrionario tales órganos se parecen más entre sí que en los adultos respectivos. Ello indujo a Haeckel a pensar que durante el desarrollo embrionario se repetían sucesivamente, aunque de forma abreviada, las distintas etapas de la evolución, enunciando en consecuencia en 1866 su famosa Ley biogenética fundamental, la cual afirma que la ontogenia, es decir, el desarrollo de un ser vivo, es una recapitulación abreviada de la filogenia, es decir, de su historia evolutiva. Ver LóPEZ PIÑERO, José María. op. cit. pp. 169-173.

${ }^{1094}$ Debe tenerse en cuenta que la paleontología ofrece grandes lagunas, porque ni todos los seres vivos fosilizaron, ni todos los fósiles se han conservado, ni todos se han logrado encontrar. La fosilización sólo es posible cuando los organismos presentan partes duras (esqueletos, conchas, etc.) y por tanto de los primeros seres vivos que carecían de tales formaciones no existen fósiles; además, los fenómenos de magmatismo y metamorfismo a que se han visto sometidas muchas rocas sedimentarias, han destruido los que podían contener. Por ello, las aportaciones de la paleontología a la evolución, aunque son importantísimas, en muchos casos son fragmentarias, aunque en buen número de ocasiones suficientes si se saben interpretar correctamente. Los hallazgos paleontológicos, que de forma más evidente apoyan el hecho evolutivo, son aquellos que han permitido reconstruir series filogenéticas o localizar formas intermedias.

${ }^{1095}$ La Cruz de Castellón, 20/3/1909.
} 
antepasado. $2^{\mathbf{o}}$ órganos bien determinados cuya función en el hombre adulto es desconocida. $^{1096}$

Según dice el doctor Tarín, los primeros provienen de la atrofia de ciertos órganos que fueron útiles en un momento dado de la vida embrionaria y que al parecer los órganos definitivos no desempeñan ya función y por regresión van desapareciendo, aunque alguna vez dejen pequeños vestigios:

Estos vienen a ser como las construcciones provisionales que se necesitan durante la edificación de un gran monumento arquitectónico.

La función, pues, que han desempañado tales órganos durante el desarrollo embrionario es bien manifiesta y no pueden, por lo tanto, llamarse órganos sin oficio. $^{1097}$

En la segunda categoría se incluyen una porción de órganos bien definidos como el coxis, los músculos de las orejas, etc. que no se puede asegurar que en el desarrollo del individuo hayan sufrido regresión. «Más de ellos no puede asegurarse que no tienen función asignada en el estado adulto»:

Cuvier demostró que existe entre todos los órganos de un cuerpo una tan estrecha solidaridad de construcción, que al menor cambio de forma de uno de ellos, entraña necesariamente una serie tal de modificaciones en todas los demás que queda por precisión modificado el individuo entero. ${ }^{1098}$

\footnotetext{
${ }^{1096}$ Ibídem. En muchos vegetales y animales se descubren órganos o porciones de los mismos que, por causas diversas, son inútiles y se hallan degenerados, de tamaño reducido, carentes de alguna porción esencial, si son comparados con órganos homólogos de especies afines. En el cuerpo humano hay más de cien órganos vestigiales entre los que están comprendidos el apéndice vermiforme, cóccix (conjunto de vértebras caudales reunidas), muela del juicio, membrana nictitante, pelo en la superficie del cuerpo y músculos que mueven las orejas y la nariz. Órganos vestigiales son los remanentes de otros que fueron o son funcionales en animales antecesores. Debido a las alteraciones ambientales que modificaron a su vez el modo de vivir de una especie, el órgano se convirtió en inútil para la supervivencia, de modo que, poco a poco, dejó de ser funcional. ¿Corresponde esto al concepto de Lamark sobre el papel del uso y falta de uso en la evolución? Ocurren mutaciones constantes que disminuyen el tamaño y función de varios órganos; en caso de que dichos órganos sean necesarios para la supervivencia, son eliminados los organismos que experimentan estas mutaciones. Si los órganos no son necesarios para la supervivencia, se reducirán de tamaño, llegaran a ser «vestigiales» y finalmente serán eliminados.

${ }^{1097}$ La Cruz de Castellón, 20/3/1909.

${ }^{1098}$ Ibídem. Cuvier en su obra Leçons d'anatomie comparée (1800-1805 2º ed., 1835-1845), expuso el «principio de la correlación de las partes orgánicas»: en los seres vivos no existen todas las combinaciones de órganos que son posibles en abstracto porque los órganos se influyen mutuamente al cooperar en su conjunto, dependiendo las funciones que realizan de todas las demás. Esta concepción del
} 
Hay órganos pasivos cuyas funciones no se advierten y sin embargo determinarían notables cambios en la forma y funcionamiento del organismo si se suprimiesen:

Relacionadas con estas doctrinas están las nuevas enseñanzas del anatómico Houssay acerca de los que él llama rozamiento. Este fenómeno funcional, por cuya virtud ciertos órganos impiden un desarrollo ilimitado a otros cuya actividad los lleva a la hipertrofia, es el que explica la existencia de un límite en las formas externas que pudiera adquirir un cuerpo obligado a poner en actividad excesiva solamente algunos de sus miembros. ${ }^{1099}$

Continúa diciendo que no deben estudiarse tan solo las funciones de los órganos por el aspecto de la cinemática sino también por el de la estática, «como acredita la nueva rama de la Anatomía comparada, llamada Mecánica del Crecimiento»:

Destinada a mostrar con gran claridad el error de los evolucionistas que suponen que carecen de importancia funcional los órganos cuya función no es bien visiblemente conocida por ahora.

[...].Está demostrado por los anatómicos más eminentes que muchos de los órganos que se creían inútiles desempañan importante papel, activo o pasivo, en el funcionamiento del organismo humano. Tal se observa en los músculos de las orejas, ciertos otros de los pies, los onceavos y doceavos pares de costillas y el coxis. $^{1100}$

Acaba resumiendo que los órganos llamados rudimentarios no son ni inútiles, ni heredados del mono. «Ellos tienen asignados funciones bien definidas, y activos o pasivos, son indispensables para dar al cuerpo humano la forma armónica que la caracteriza».

El tercer argumento se funda en la supuesta existencia de grandes desequilibrios producidos en la salud del cuerpo humano, debidos a la presencia de órganos rudimentarios.

organismo como totalidad integrada ha sido uno de los supuestos básicos de la ciencia médica y biológica contemporánea. Ver LÓPEZ PIÑERO, José.María. op. cit. p. 87.

${ }^{1099}$ La Cruz de Castellón, 20/3/1909.

${ }^{1100}$ Ibídem. 
Según afirma Tarín las desarmonías del cuerpo humano tan frecuentemente invocadas por los transformistas, no puede negarse que existen; pero los órganos llamados por ellos rudimentarios no son los únicos que las producen:

Pretenden los médicos que militan en el transformismo que si fuera extirpar los órganos, que según ellos para nada sirven, la vida del hombre sería más equilibrada. Esto equivale a decir, que los mencionados órganos no solamente son inútiles, sino además perjudiciales. Entre los muchos de esos órganos que el doctor Metchnikoff menciona, llaman sobre todo la atención el intestino grueso con su parte llamada ciego y su apéndice vermiforme. La exageración de los transformistas llega a suponer que sin tales partes del tubo digestivo viviría el hombre mejor, pues bastaría que el intestino delgado, encargado de absorber los alimentos, vertiera directamente al exterior los restos de la digestión. ${ }^{1101}$

Continua diciendo que ni el ciego del intestino ni el apéndice vermiforme son órganos inútiles, ni son producto de la herencia que hemos recogido de nuestros supuestos ancestrales:

Es un hecho que los mencionados órganos sirven para evitar grandes molestias, pues las secreciones que en ellos tienen lugar regulan y facilitan la importante función de la defecación. Bien se observa esto en los animales eminentemente herbívoros, en los que el ciego del intestino y el apéndice vermiforme alcanzan gran desarrollo, en armonía con el régimen alimenticio y el género de vida que el animal lleva. ${ }^{102}$

El Clamor se hace eco de la conferencia del Doctor Tarín en el Círculo Mercantil sobre la creación del hombre. Según el cronista «había expectación por oír al orador que han traído de fuera de la provincia algunos elementos para contrarrestar las doctrinas que sobre el transformismo expuso en la tribuna libre del Círculo Mercantil el doctor Vicente Gea». ${ }^{1103}$

El cronista hace un resumen de la conferencia y resalta la labor científica y discreta del doctor Tarín que fue premiada con aplausos «testimoniadores de las tolerancias de los que ordinariamente concurren a las conferencias del Círculo

\footnotetext{
1101 Ibídem.

1102 Ibídem.

${ }^{1103}$ El Clamor, 22/3/1909.
} 
Mercantil»: «No tenemos inconveniente en dar testimonio de las prudencias del conferenciante y de su buen acuerdo de apartarse, generalmente, de todo empeño teológico y dogmático estudiando el asunto en el terreno puramente científico». ${ }^{1104}$

Después de la disertación del profesor Tarín, el doctor Vicente Gea volvió a dar una segunda conferencia, en el Círculo Mercantil, sobre el transformismo. Según el cronista había mucha expectación después de la polvareda levantada alrededor de la cuestión, resultando muy pequeño el salón del Círculo para la gran masa de oyentes que acudieron a escuchar «al sabio médico»: «Su discurso fue una maravilla de erudición y un formidable ariete que destruyó las vanas contradicciones de quienes a título de la fe pretenden detener la incesante marcha de las ideas». ${ }^{1105}$

El doctor Gea concluyó que las verdades científicas han de estar siempre por encima de la tradición y la mentalidad primitiva «porque de otra suerte las ciencias se ahogarían y el progreso humano sería imposible».

Parece ser que esta segunda conferencia tuvo un gran éxito por lo que se desprende del articulista de El Clamor:

Pocas ovaciones habrá oído el señor Gea tan espontáneas, entusiastas y ruidosas como la que al terminar su notabilísima conferencia le tributó el numeroso público congregado anteayer en el Círculo Mercantil.

Todo lo merecía, porque fue una conferencia magistral, de las que forman época por el reguero que dejan. ${ }^{1106}$

Sin embargo El Cruzado en una crónica que titula «El Doctor Gea de cuerpo presente» hace una crítica a la conferencia:

El sábado dio en el Círculo Mercantil otra conferencia sobre el transformismo el médico de éste Sr. Gea, y como nunca segundas partes fueron buenas, resultó lo que debía de resultar, el más fenomenal de los descalabros imaginables, el tras pies más sensible que pueda dar hombre alguno como científico y como católico, porque ni demostró saber filosofía, ni historia natural, ni paleontología, ni geología, no dando un pasito ni siquiera en el camino de la ciencia,

\footnotetext{
${ }^{1104}$ El Clamor, 21/03/1909.

1105 El Clamor, 5/4/1909.

${ }^{1106}$ Ibídem.
} 
ni formulando argumento alguno no ya nuevo y original, si que ni siquiera con novedad. ${ }^{1107}$

Gea confundió en su conferencia el Batybius Haeckel con el primer viviente en el fondo de los mares que después se demostró que era un precipitado de sales marinas:

Podrá ser el Sr Gea medio ilustrado, pero no dio pruebas de ser hombre de ciencia, ni mucho menos, como lo demostró al confundir el Batybius Haeckel de Uxley con el primer viviente en el fondo de los mares, cuando no es sino un precipitado de sales marinas, y otros mil y mil lapsus en que incurrió, como demostraremos cuando tengamos tiempo para hacerlo.

....Nada digamos de su empeño en empequeñecer la grandiosa figura de Pasteur que está a cien codos sobre algún doctor que conoce el Sr. Gea. ${ }^{1108}$

El Cruzado compara a Gea con Lamarck, Darwin, Haeckel, Huxley, Vogt, Spinosa, es decir, lo define como «un racionalista radical y extremado».

Gea, en la conferencia, negó la creación y afirmó que de la materia procede todo lo que existe. Afirmó que la narración mosaica de la creación del hombre, salida de las manos de Dios, es una fábula, el hombre es hermano carnal del mono antropomorfo, hace millones de años este gran tronco se dividió en dos ramas, una permaneció estancada en la rama simia, otra desarrolló el órgano de la inteligencia, el de la sociabilidad y el del lenguaje, y pasó a ser hombre.

Éste no se distingue esencialmente de los animales, no tiene alma, y si la tiene es puramente animal, y no espiritual, no tiene libertad y todo en él se rige por las leyes mecánicas y la fuerza de la materia.

También añadió que entre los principios indestructibles de la Ciencia y los dogmas de la religión, él se quedaba con los primeros y rechazaba los últimos.

El Cruzado se escandaliza de las afirmaciones emitidas por Gea, escribiendo:

\footnotetext{
${ }^{1107}$ La Cruz de Castellón, 8/4/1909.

${ }^{1108}$ Ibídem.
} 
[...].Es decir, un horror, una serie de herejías, un cúmulo de blasfemias, el consumatum est de la apostasía.

Y como el Sr. Gea dijo todas estas impiedades en público, y como el Sr. Gea hablaba seriamente y con calor y convencido y alardeando de científico, y como el Sr. Gea fue aplaudido (aunque no mucho ni por muchos) en sus herejías, nosotros protestamos con toda la fuerza de nuestra alma contra las impiedades de este nuevo apóstol de la nueva religión, de este precursor del anticristo, de este hombre sin fe que la arrebata, valiéndose del predicamento de la ciencia, del corazón de los castellonenses. $^{1109}$

Y sigue lamentándose de las teorías antitéticas a la religión católica:

Protestamos enérgicamente contra tamaños radicalísimos, casi nunca oídos en Castellón; protestamos contra esas teorías, muerte y antítesis de nuestra religión.

¡Pobre Castellón! ¡Pobre España! Señor, Señor, perdón por lo impíos que te blasfeman, por los cobardes que te niegan, por los traidores que te venden, por las turbas que piden tu muerte, por los poderes que te desamparan y sentencian, por el Sr. Gea y los que le aplauden! ${ }^{1110}$

Por su parte el redactor de El Clamor, Agustín Betoret, dio otra conferencia sobre el origen del hombre en Villarreal y repitió la misma en Burriana a petición del Centro de Sociedades Obreras. ${ }^{1111}$

Era tal el interés que suscitaba este tema que después de 1909 siguieron celebrándose conferencias en el Círculo Mercantil y otros centros republicanos, sobre más transformismo, a cargo de Gea, Gil Valero, Betoret y otros médicos de Castellón.

El médico de Villarreal Gil Valero dio una conferencia en el Círculo Mercantil el 22 de enero de 1910 sobre Darwin que según dice La Cruz de Castellón: «A pesar de su fácil verbo no acertó a entusiasmar al auditorio que está ya harto de Darwin, de monos, micos, monadas y monerías». Y continúa: «El Sr Gil Valero, de seguro que vive dentro de la botella o redoma del brujo Marqués de Villena. ¡iNo se ha enterado

\footnotetext{
1109 Ibídem.

${ }^{1110}$ Ibídem.

${ }^{1111}$ El Clamor, 24/5/1909.
} 
todavía de que los pontífices máximos del darwinismo han inventado una nueva columna dorsal humana con dos costillas!!». ${ }^{112}$

En 1911 la Juventud Republicana Propagandista invitó al sabio catedrático de Historia Natural de la Universidad de Barcelona Odón de Buen para dar una conferencia en el Centro Republicano sobre «Darwin y sus teorías sobre la evolución». Odón de Buen era muy apreciado en Castellón por la competencia que en esa materia poseía el ilustre catedrático, y porque en alguna ocasión defendió alguna causa del pueblo de Castellón cuando era alcalde Carlos González Espresati.

Según la prensa la llegada de Odón de Buen fue todo un acontecimiento, pues fue recibido por gran número de republicanos y representantes de los diferentes organismos del Partido. ${ }^{1113}$

El Clamor afirma que pocas veces se vio el local republicano tan concurrido de señoras y señoritas que con su presencia, «patentizaban de una manera evidente que la mujer castellonense ha comenzado a interesarse por las trascendentales teorías de las ciencias modernas».

Las palabras de bienvenida las pronunció el presidente de la Juventud Republicana, Cayetano Huguet Segarra, quien dijo que el ilustre conferenciante no necesitaba presentación, pues era de sobra conocido por haber tenido la dicha los castellonenses de haberle escuchado en dos ocasiones más, y por su fama mundial como hombre de ciencia y como político sobresaliente de las filas democráticas españolas. Cayetano Huguet le dio las gracias por el sacrificio que supone abandonar sus ocupaciones de sabio profesor para venir a Castellón y «satisfacer con sus luminosas enseñanzas, el deseo de saber de este pueblo culto y amante del progreso en todas sus varias y complejas manifestaciones».

Al ocupar la tribuna Odón de Buen agradeció al pueblo de Castellón la calurosa acogida y continúa diciendo que:

[...] a pesar de los sinsabores y asperezas de las luchas políticas y sociales existe en el fondo del alma humana un sedimento de bondad y pureza de ideales, que hacen que, los hombres que batallamos a diario por el triunfo de las ideas modernas de verdad y razón, encontramos siempre, como ahora en estos momentos me ocurre

\footnotetext{
${ }^{1112}$ La Cruz de Castellón, 22/1/1910.

${ }^{1113}$ El Clamor, 5/1/1911.
} 
a mí, un oasis donde se espacia el espíritu y se fortalece el ánimo para proseguir con más entusiasmo que antes si cabe, la lucha pertinaz e incesante en pro de la verdad científica que en plazo no lejano acabará, para siempre con esa otra ciencia fantasma dualista que tanto mal ha hecho a la humanidad retardando su progreso y evolución hacia su perfeccionamiento social e intelectual. ${ }^{114}$

Dedicó grandes elogios a la Juventud Republicana de Castellón por la labor realizada con la serie de conferencias políticas, sociales y científicas que se daban en su casa social, y a continuación expuso el tema objeto de su conferencia, haciendo un estudio psicológico del carácter de Darwin:

[...] autor de la más grande de las teorías modernas que había de revolucionar totalmente las creencias de todos los hombres de ciencia de su época y había al propio tiempo de destruir la falsa doctrina dualista, que aún por desgracia hoy existen hombres en España que la defienden sin poder demostrarlo científicamente, como lo demostramos nosotros en los laboratorios y de una manera incontrovertible y sin lugar a dudas. ${ }^{1115}$

Refirió como Darwin después de muchos años de estudio llegó al convencimiento de que todo se transforma: «[...] de que toda planta, de que toda materia evoluciona incesantemente hasta llegar a su completo desarrollo, al perfecto estado de su característico modo de ser». ${ }^{1116}$

\footnotetext{
1114 Ibídem.

1115 Ibidem.

${ }^{1116}$ El Clamor, 7/1/11. Ver la conferencia desarrollada en el Apéndice Documental. № 20.
} 
Castellón hacia la modernidad. Salud, educación y debate científico (1880-1918) 


\title{
PARTE IV: HIGIENE, \\ EDUCACIÓN SANITARIA Y COLONIASESCOLARES.
}

\author{
PROPUESTAS PARA
}

CONSEGUIR UNA EDUCACIÓN INTEGRAL 
Castellón hacia la modernidad. Salud, educación y debate científico (1880-1918)

Parte IV 


\section{CAPÍTULO IX: HIGIENE, SALUD Y EDUCACIÓN ESCOLAR}




\section{DE LA CARIDAD PÚBLICA AL RECONOCIMIENTO DEL DERECHO A LA EDUCACIÓN Y A LA SALUd POR PARTE DEL ESTADO}

Durante la transición al siglo XX la sociedad española fue escenario de un amplio debate en torno a la penosa situación en que se desenvolvía la vida de los niños. El debate estaba estrechamente vinculado, por una parte a la crisis de 1898 y a la sensación de decadencia que ésta provocó en los diversos sectores de la sociedad española y, por otra parte, a un movimiento internacional que buscaba mejorar las condiciones de vida y supervivencia de la infancia. La opinión pública española acuñó así el problema de la infancia y su análisis y resolución se convirtieron en una de las piedras angulares del programa de modernización y regeneración social durante el primer tercio del siglo XX. Resolver la penosa situación de la infancia representaba uno de los retos principales para la transformación de la sociedad española.

Por estas razones en las primeras décadas del siglo XX el problema de la infancia alcanzó un amplio eco social y político. La dimensión sanitaria del problema fue analizada por higienistas y médicos comprometidos con la medicina social. La dimensión pedagógica fue impulsada por maestros y pedagogos que consideraban la educación como instrumento de modernización y progreso. Médicos y pedagogos fueron los dos principales arquitectos del diseño y la construcción del problema de la infancia. $^{1117}$

El problema de la infancia adquirió también una dimensión laboral, moral y delictiva en la transición al siglo XX, delimitándose en España alrededor de cuatro dimensiones principales. Una dimensión sanitaría sustentada en unos indicadores de mortalidad y morbilidad infantil escandalosos y en las profundas deficiencias en las condiciones de vida y alimentación de los niños. Una dimensión educativa, caracterizada por un sistema de escolarización deficiente, tanto por las malas condiciones higiénicas de las escuelas como por los métodos docentes anticuados y la escasez de recursos materiales y didácticos. Y eso sucedía precisamente en unos

\footnotetext{
1117 BARONA, Josep Lluís (2007): « ¿Por qué mueren los niños? El debate ideológico sobre la salud infantil en la sociedad española (1904-1939)», en Campos, Ricardo y otros (eds.): Medicina, ideología e historia en España (siglos XVI - XXI), Consejo Superior de Investigaciones Científicas, Madrid. pp. 287288.
} 
momentos en que el debate sobre la escuela y su potencial regenerador era ampliamente valorado y debatidos en la sociedad española, tanto en el seno de la Institución Libre de Enseñanza como en las reformas planteadas por Ferrer y Guardia, el padre Manjón y otros representantes del reformismo pedagógico y la escuela moderna. Una tercera dimensión laboral abundaba en el carácter abusivo del trabajo infantil, que debilitaba la salud e impedía la escolarización. Finalmente, una cuarta dimensión delictiva se refería a la mendicidad, al abandono, la vagancia y el delito. Ello planteaba un problema de orden público que con tribuyó a configurar el arquetipo marginal y psicopatológico del niño golfo. ${ }^{1118}$

La Ley de Protección a la Infancia y Represión de la Mendicidad de 12 de agosto de 1904 aportaba una novedad fundamental: la implicación y el compromiso del Estado. En el siglo XIX, el Estado no había ido en España más allá de asumir una función legislativa y en las políticas públicas (sanidad, asistencia social, educación) no se había comprometido en la financiación ni en la ejecución, delegando de forma subsidiaria en la administración periférica (diputaciones, ayuntamientos) o en la acción social de la iglesia. Durante las dos primeras décadas del siglo XX esta actitud se transformó no solo en relación con el problema de la infancia, sino también con respecto a la educación, la salud pública, la actividad científica y la asistencia social. El compromiso del Estado se convirtió así en un factor ideológico que permitió superar las limitaciones de la caridad pública en favor del reconocimiento del derecho a la educación y a la salud, y también al compromiso en afrontar la represión de la delincuencia. Una de las causas de ese cambio fue la internacionalización del movimiento sanitario y la influencia de la Sociedad de Naciones. No hay que olvidar que España se integró en la política internacional a través de las conferencias sanitarias internacionales que venían desarrollándose desde $1851 .^{1119}$

La Ley de Protección a la Infancia y Represión de la Mendicidad se publicó el 12 de agosto de 1904 (Gaceta de 17 de agosto de 1904) y hasta el 24 de enero de 1908 (Gaceta de 25 de enero de 1908) no se publicó el Reglamento para su desarrollo. El principal impulsor de una política activa del Estado para resolver el problema de la infancia fue el médico Manuel Tolosa Latour.

\footnotetext{
1118 Ibídem, pp. 288-289.

${ }^{1119}$ Ibídem, 289-290.
} 
Según José Luis. Barona, las estrategias de acción social y sanitaria que puso en marcha el Consejo Superior de Protección a la Infancia y Represión de la Mendicidad expresan la ideología social del reformismo conservador, representado por las autoridades económicas y políticas de la burguesía y la Iglesia católica. El movimiento obrero no tuvo ninguna participación. ${ }^{1120}$

Todos los testimonios acerca de las condiciones de vida y salud de la infancia en la sociedad española a comienzo del siglo Xx indican la existencia de una gran preocupación social. Tanto los testimonios políticos como los literarios, los eclesiásticos como los del movimiento obrero, los pedagógicos como los sanitarios, coinciden en denunciar las penosas condiciones de vida de una gran parte de la población infantil. No solo preocupaba la incidencia de enfermedades infantiles y la muerte prematura de los niños, sino también las deficientes condiciones higiénicas del medio urbano y rural, las lamentables condiciones de las escuelas, el abandono, la orfandad, la marginalidad y el vagabundeo, la explotación y el trabajo infantil, los abusos sexuales y la delincuencia. $^{1121}$

Muchas de las enfermedades estaban relacionadas con deficiencias graves en la alimentación, los espacios públicos, las viviendas y las condiciones laborales. En una primera etapa el problema llegó a ser especialmente dramático en los contextos urbanos e industriales, y menos en las áreas rurales, pero, desde finales del siglo XIX, se extendió entre la opinión pública la imagen de una sociedad rural poco higiénica y atrasada. El hacinamiento y la convivencia con animales e inmundicias, la falta de sistemas de eliminación de aguas sucias y de instalaciones higiénicas en las viviendas ponía en riesgo la vida de los niños.

El testimonio de los médicos acerca de las condiciones higiénicas de las escuelas es demoledor y aparece en la mayoría de las topografías médicas. En el medio rural los niños abandonaban la escuela a los diez años para ayudar en las faenas del campo y cuidar de los animales domésticos. Las niñas ejercían como niñeras y asistentas en el servicio doméstico de la burguesía urbana hasta que se casaban a los quince o dieciséis años. Las tasas de alfabetización eran muy bajas, alrededor del 50 por cien, y el analfabetismo era significativamente más alto entre las mujeres.

\footnotetext{
${ }^{1120}$ Ibídem, p. 291.

${ }^{1121}$ Ibídem.
} 
El Real Decreto de 25 de mayo de 1900 creó las escuelas para niños obreros en fábricas y talleres. El Decreto establecía que los patronos tenían obligación de conceder una hora diaria a los menores de 18 años para su instrucción. Además tenían que costear una escuela elemental en cada establecimiento industrial, dotado de personal competente y materia indispensable para la instrucción de los niños y jóvenes obreros. En estos establecimientos se debía de enseñar lectura, escritura, gramática, aritmética y la doctrina cristiana. Al concluir el obrero recibiría un certificado. ${ }^{1122}$

En 1909, las Cortes aprobaron un Proyecto de Ley que establecía la enseñanza obligatoria entre los 6 y los 12 años. Los dos últimos años, la enseñanza se hacía compatible con el trabajo, ya que sólo eran obligatorios seis meses para los niños de 10 a 11 años que estuvieran escolarizados desde los 6 años, y solo tres meses para los de 11 a 12 años. La inspección de centros escolares se organizó en 1910 mediante comisiones específicas de las juntas locales, con separación de niños y niñas, vigilancia de las condiciones higiénicas, regulación del contenido de las enseñanzas que incluían gimnasia y manualidades y la segregación de los deficientes.

La importancia del fenómeno de la mendicidad infantil provocó que la mayoría de las Juntas provinciales de protección a la infancia creadas a partir de 1909 pusieran en marcha de inmediato su sección de mendicidad y vagancia. ${ }^{1123}$

Al final de la primera década del 1900 el Gobierno español realizó una intensa labor diplomática a través del Ministerio de Estado, con el objetivo de impulsar la creación de la Unión Internacional para la Protección de los Niños en la Primera Infancia. La iniciativa de crear un organismo internacional de protección a la infancia se adoptó en el Primer Congreso de Gotas de Leche celebrado en Paris en 1905 y el proyecto de estatutos en el Segundo Congreso (1907).

La trama institucional era compleja. La Ley creaba un Consejo Superior de Protección a la Infancia en el Ministerio de la Gobernación, unas Juntas Provinciales presididas por el gobernador y unas Juntas Locales presididas por el alcalde con participación de obispos, gobernadores, presidentes de diputaciones, inspectores de sanidad, representantes de academias científicas, culturales y literarias, sociedades civiles, ateneos y agrupaciones empresariales, maestros y otras asociaciones civiles, en cambio, los sindicatos obreros carecían de representación.

\footnotetext{
${ }^{1122}$ Ibídem, pp. 293-294.

${ }^{1123}$ Ibídem, 294.
} 
El Consejo Superior de Protección a la Infancia creó cinco secciones:

1. Puericultura y primera infancia: era para atender a las mujeres trabajadoras durante la gestación, el parto y el puerperio, y regular la lactancia mercenaria.

2. Higiene y Educación Protectora: para mejorar las condiciones de escuelas y asilos, elaborar estadísticas sanitarias, velar por la educación de los niños en las escuelas, crear dispensarios de salud infantil y casas de maternidad.

3. Mendicidad y vagancia: para investigar la situación de los niños abandonados, fomentar la asistencia al trabajo y el socorro a domicilio a los padres indigentes, registrar a los niños amparados y combatir la mendicidad y la vagancia.

4. Patronatos y corrección paternal: para denunciar los malos tratos y la corrupción de menores, proteger a los niños mártires y delincuentes, favorecer las instituciones benéficas, velar por el cumplimiento de las leyes laborales y combatir la desmoralización y la perversión de la infancia.

5. Sección jurídica y legislativa: encargada de las reformas legislativas y la actualización bibliográfica. ${ }^{124}$

Además de las «gotas de leche» (1913) y la regulación de la lactancia mercenaria, se proyectó la creación de un Instituto Nacional de Maternología y Puericultura, se crearon dispensarios de salud materno-infantil y se organizaron colonias y comedores infantiles.

La preocupación por los problemas de higiene en la infancia se refleja en el Primer Congreso de Higiene Escolar que se iba a celebrar en Barcelona en 1912. Dicho Congreso se proponía estudiar los problemas de higiene en la educación y mejorar las condiciones materiales de la escuela, dar impulso a la educación física en nuestro país y aplicar los preceptos de la ciencia a los programas y métodos de enseñanza.

En la exposición del Real Decreto declarando oficial el Primer Congreso Español de Higiene Escolar, Amalio Gimeno, Ministro de Instrucción Pública, declaraba a su majestad el Rey Alfonso:

Es indudable que conviene en alto grado fomentar, por todos los medios posibles, el desarrollo de iniciativas tan útiles y estimables. Recientemente se han dictado disposiciones generales referentes a los problemas relacionados con la Higiene escolar, entre ellas el Real decreto de 16 de Junio de 1911, que estableció la

${ }^{1124}$ Ibídem, pp. 295-296. 
inspección médica en la Escuelas, referida a los locales y a los alumnos; y allí donde la acción particular puede coadyuvar, con la celebración de Congresos y Exposiciones como los proyectados, a la realización de tan elevados fines, debe el Estado prestar su decidido apoyo. ${ }^{1125}$

La filosofía de la Junta organizadora era que la escuela, como continuación de la familia, debía vigilar el crecimiento del niño y evitar los defectos que aparecen en un ser que se amolda a todo y al propio tiempo debía enseñarle bien, dándole lo que pueda comprender, lo que pueda asimilar en relación con su edad.

El hombre tiene una individualidad propia, gracias al conjunto de elementos que con él concurren, los cuales son el resultado de las fuerzas hereditarias, del medio ambiente, de su desarrollo físico y psíquico, modificado todos ellos por la educación, que es el factor que los rige y los encamina.

Tiene la educación un tipo ideal que corresponde al máximo desiderátum de belleza en todos los órdenes, y a este ideal debe procurar en todo lo posible acercarse, identificarse la escuela.

Y ¿cómo puede lograrlo? Por medio de la higiene. En consecuencia de este raciocinio se decía en una circular anterior que la higiene informadora de la enseñanza es la que hace a las naciones fuertes y poderosas. ${ }^{1126}$

La Junta organizadora estaba constituida por representantes de todas las sociedades de médicos, maestros, profesores, arquitectos y dentistas de Barcelona.

El Congreso se dividía en tres secciones: Higiene física escolar; Higiene psíquica escolar e Higiene de edificios y material escolar. Aneja al Congreso, se celebraba una Exposición Internacional de Higiene Escolar y Trabajos Escolares. Lo que se quería era demostrar los esfuerzos ignorados de muchos maestros por llevar a cabo un buen método didáctico de la higiene en las escuelas. Concurrían a ella desde la escuela nacional de párvulos hasta las cátedras universitarias.

La Junta organizadora afirmaba que la escuela en España estaba en un lamentable estado higiénico y gracias a personas eminentes, «amantes de la patria se

\footnotetext{
${ }^{1125}$ Primer Congreso Español de Higiene Escolar. Declarado oficial por Real Decreto de $1^{\circ}$ de Marzo de 1912, pp. 9-10.

${ }^{1126}$ Ibídem, pp. 15-16.
} 
han puesto al descubierto estas miserias, estas faltas en la escuela, y así ha brotado la necesidad de hacer en España una escuela higiénica».

A dicho Congreso iban a acudir de toda España personas eminentes especializadas en la materia para crear la higiene escolar, «aún sin historia en esta nación». ${ }^{1127}$

\section{LAS PROPUESTAS DE LOS MÉDICOS HIGIENISTAS PARA MEJORAR LA SALUD EN LA ESCUELA}

Los objetivos de los médicos que publicaban tratados de higiene escolar eran dictar reglas para el perfeccionamiento físico, intelectual y moral del niño. Se proponían popularizar conocimientos de higiene infantil, criticar malas costumbres, destruir los errores borrar prácticas anticientíficas, deshacer preocupaciones del vulgo y combatir ideas extraviadas sobre la higiene de las personas desde su nacimiento.

En el prólogo que realiza el profesor Brouardel ${ }^{1128}$ en el libro de Higiene Escolar del doctor Jules Delobel ${ }^{129}$, decía que al ser recibido un alumno en un establecimiento de instrucción, el maestro toma a su cargo al mismo tiempo que su educación, la protección de su vida y de su salud. Moralmente establece un contrato con la familia que le ha confiado esta doble misión. Debe hacer del alumno un hombre instruido y vigoroso, y no puede ni debe faltar a las obligaciones que dicho compromiso le impone.

Sigue asegurando Brouardel que el maestro se preocupaba principalmente de la instrucción del alumno y dejaba en un segundo lugar la educación para la salud, sin embargo, después se notaba que estos jóvenes que poseían todos los recursos intelectuales para desarrollarse en la vida no obtenían ningún provecho de ella por faltarles el vigor físico necesario.

El maestro debía preocuparse de la salud de los niños pues «los alumnos enclenques y pálidos carecen de resistencia para evitar enfermedades contagiosas.»

\footnotetext{
${ }^{1127}$ Ibídem, p.21.

${ }^{1128}$ P. Brouardel, Decano honorario de la Facultad de Medicina de Paris, Miembro del Instituto y de la Academia de Medicina.

${ }^{1129}$ DELOBEL, Jules (1876): Higiene escolar. Traducción de Avilés Rodríguez, Ángel, médico de la Beneficencia municipal de Cartagena. Saturnino Calleja, Madrid. Delobel, Jules, Médico Inspector de Niños y de las Escuelas públicas de París.
} 
La limpieza de la escuela, del alumno, la higiene de los locales, el cuidado de la salud a cargo de médicos competentes, el desarrollo del cuerpo por medio de ejercicios reglamentados, eran las indicaciones de los médicos higienistas.

También consideraban que en la escuela, aún más que en la familia, «es preciso hacer una obra de higiene, porque la higiene es el arte de conservar la salud» ${ }^{1130}$

Los temas que trataba el doctor Delobel en su manual incluían la higiene de la escuela y del escolar y, sobre todo, nociones elementales de higiene personal.

Después de la pérdida de las colonias en 1898, Tolosa Latour decía en un prólogo del libro Higiene y Educación del Niño, escrito por el doctor Vicente Miró Laporta, que un pueblo se regenera lentamente, evitando la mortandad en la primera infancia, vigilando la instrucción física y mental, perfeccionando la educación en todos sus variados aspectos y sobre todo «protegiendo al niño, el cual está por redimir en esta época de redentores y redenciones».

Se legisla acerca de muchas cosas nimias y ridículas para velar por las sagrados intereses de la industria y el comercio, y nada se dice respecto a esa industria y a ese comercio llamado lactancia mercenaria, origen de tantas irremediables desventuras; se trata de legislar en cambio sobre vacunación, instrucción y hasta religión obligatoria, y no se garantiza de modo científico la bondad de las vacunas, ni se tiene escuelas en condiciones de salubridad, ni se evita que la desmoralización más corrosiva vaya emponzoñando la juventud lentamente. 1131

Latour consideraba que el niño que tenía familia se hallaba relativamente desamparado por causas de deficiencias remediables pues tenían su principal origen en la ignorancia de las gentes.

El niño que tiene familia se halla relativamente desamparado, a causa de tantas deficiencias remediables, en cierto modo, pues tienen su principal origen en la ignorancia de las gentes ¿Qué diremos del pobre aprendiz, del espósito: enfermizo y

\footnotetext{
1130 Ibídem.

1131 MIRÓ LAPORTA, Vicente (1899): Higiene y Educación del niño, Librería de Victoriano Suarez, Madrid, pp. 14-15.
} 
del desventuradísimo degenerado, víctimas de vergonzosas explotaciones, los cuales en talleres, asilos, calles y cárceles, sufren las consecuencias de este punible indiferentismo? ${ }^{1132}$

Los temas tratados en el libro de Miró Laporta, versaban sobre el alimento, la lactancia, la limpieza, el vestido, la cuna, ejercicio corporal, gimnasia y juegos, el niño obrero, los sentidos, el ejercicio intelectual, la educación moral, las pasiones, educación religiosa, la voluntad y la educación estética. ${ }^{1133}$

Los médicos daban mucha importancia a la higiene de los sentidos en las escuelas. Una obra premiada por la sociedad Española de Higiene en el concurso público de 1887 fue escrita por el médico Nicasio Mariscal y García, con el título Higiene de la vista en las Escuelas. ${ }^{1134}$

En su libro, Mariscal afirma que las escuelas son una fábrica de miopes. Su objetivo al escribir esta obra era que la leyesen los gobernantes, el padre de familia, y el maestro de primera enseñanza.

El libro se desarrolla en varios capítulos que tratan de la anatomía y fisiología del ojo, de la visión, de las enfermedades que ocasionan en la vista las escuelas y métodos de enseñanza imperfectos, por las malas condiciones higiénicas que reúnen, de los requisitos que debe tener una buena escuela para considerarla como tal, especialmente de la vista, y de cuál puede ser el mejor método pedagógico para los niños en las escuelas de primera enseñanza, por lo que respecta a la higiene del órgano visual. $^{1135}$

Asimismo los médicos higienistas consideraban que el tipo de enseñanza que se daba en las escuelas repercutía negativamente en la salud de los niños.

\footnotetext{
1132 Ibídem, pp. 2-3.

${ }^{1133}$ Ibídem, pp. 9-247.

${ }^{1134}$ MARISCAL Y GARCIA, Nicasio:(1888): Higiene de la vista en las Escuelas. Editorial El Cosmos. Madrid. Doctor Nicasio Mariscal y García. Antiguo alumno interno, por oposición, de la Facultad de Medicina de Madrid; premio extraordinario de la Universidad Central; Ex subdelegado de Sanidad; premiado por su Memoria sobre la profilaxis de la difteria por la Sociedad Española de Higiene (1886), y con medalla de oro en la Exposición de Higiene de la Infancia de Paris de 1887; Socio correspondiente de la sociedad.

${ }^{1135}$ Ibídem, pp.29-30.
} 
En una conferencia pronunciada por el doctor Eduardo Masip Budesca ${ }^{1136}$ en el Claustro de la Universidad Central, el 24 de febrero de 1910, expuso la importancia de la medicina y la higiene para atender al estado físico del educando «El cerebro del niño, a semejanza de una máquina complicada, necesita actividad regular y constante, es decir que debe sometérsele a un trabajo adecuado a su desarrollo: ni tan escaso que le enmohezca por falta de ejercicio, ni tan excesivo que le desgaste».

El doctor Masip daba mucha importancia para el correcto desarrollo del cerebro del niño, que en los programas escolares no se amontonasen demasiadas asignaturas que exijan del niño un trabajo superior a sus fuerzas, sino más bien darle ideas generales y en armonía con su desarrollo cerebral.

Según decía Eduardo Masip el desarrollo prematuro de las facultades intelectuales producía perturbaciones en el organismo, «perturbaciones que en el orden intelectual engendran hasta la locura, la epilepsia, la depresión mental, etc.» ${ }^{137}$ También, consideraba que lo importante en la educación del niño no es el cuánto, sino el cómo «pues lo mismo el cerebro que el estómago no se nutren con exceso de sustancias, sino con las precisas y convenientes para su funcionamiento normal».

Para que el trabajo intelectual fuera higiénico, había que tener en cuenta las asignaturas que exigían del escolar mayor esfuerzo, para graduar la enseñanza según la dificultad de las materias. La asignatura que según los higienistas ocasionaba mayor cantidad de fatiga eran las matemáticas en el cerebro del niño. Según esto recomendaba que las clases abstractas se dieran por la mañana, alternando con alguna concreta, reservando la tarde para ejercicios corporales, trabajos manuales y excursiones.

Igualmente consideraban los médicos higienistas que el reparto de las horas de clase debía ser: para los alumnos comprendidos entre los 7 y los 10 años, lecciones de 15 a 20 minutos con un rato de descanso entre cada dos lecciones y recreo al final de cada hora. Y para los de 10 a 14, lecciones de 30 a 40 minutos con el mismo descanso, y «las escuelas de párvulos deben ser Escuelas Maternales en donde el niño no haga más que jugar.» 1138

\footnotetext{
1136 Inspector Médico Municipal de Higiene y Salubridad Pública, de la Beneficencia Municipal de Madrid.

${ }^{1137}$ MASIP BUDESCA, Eduardo (1910): Higiene Escolar, Tip. y Pap. M Payá y compa ${ }^{\text {a }}$ Zaragoza.

${ }^{1138}$ Ibídem, p. 4.
} 
Si importante se considera la higiene del cuerpo, no lo era menos la higiene del alma «que también se halla expuesta a padecimientos de que a todo trance debemos preservarla.» La escuela es considerada el sitio donde niños y niñas se hacen adultos, donde se forma el ciudadano, el patriota, el ser moral, en ella deben crearse hábitos buenos y corregirse o reformarse los malos o viciosos.

Por razones de higiene se recomienda tener cautela con las recompensas para que no obliguen al niño a esforzarse en el trabajo intelectual más de lo que le permitan sus aptitudes y su desarrollo físico, por el afán de conseguir el galardón.

El médico Eduardo Masip hace una crítica a los centros de enseñanza porque daban mayor importancia a la instrucción teórica que a la práctica, «por más que teóricamente convengamos todos en que es el principal elemento de la regeneración de un país- tal es el descuido en que se tiene la educación física.» Consideraba que se había olvidado por completo el esparcimiento del alumno y las ventajas que reporta la vida en el campo. Esto con las malas condiciones del local escolar, sobre todo en los referente a ventilación, y el antihigiénico mobiliario que se usaba, eran las causas determinantes de las enfermedades que diezmaban la población escolar, o por lo menos la inutilizaban para el trabajo.

Las enfermedades que con más frecuencia se presentaban en la escuela eran la miopía, originada por los malos hábitos del escolar para escribir y leer, por la deficiencias de iluminación de las salas de la clase y el mobiliario que obligaba al niño a forzar el aparato de acomodación más de lo conveniente.

Solamente en 14 escuelas que por encargo mío visitó un médico el pasado curso, encontró más de un 32 por cien de miopes entre los niños y hasta un 60 por cien de anomalías visuales entre las niñas, haciendo notar que estas anomalías visuales dependían de la inconveniente posición en que para escribir y dibujar se colocaban los niños, por la falta de adaptación de las mesas y bancos a su talla y de las delicadas labores que se obligaba a ejecutar a las niñas.

Se impone, pues, para evitar tamaños males la inspección oculista en las escuelas. $^{1139}$

${ }^{1139}$ Ibídem, p. 7. 
Otra enfermedad frecuente en la escuela era la escoliosis o desviación de la columna vertebral, producida por la utilización de mobiliario defectuoso. Para evitar estas torceduras y desviaciones vertebrales, no bastaba desterrar el antiguo mobiliario, era preciso además colocar a los alumnos acertadamente, teniendo en cuenta la estatura y evitando que permanezcan mucho tiempo en la misma postura, vigilando sus actitudes para corregir las viciosas y no olvidando que el «ejercicio muscular es altamente recomendable para este objetivo».

También el nerviosismo podía ser combatido en la escuela, que según Masip Budesca, «proviene principalmente del exagerado intelectualismo de la escuela y se manifiesta en los niños de tres maneras distintas:»

Hay entre los escolares algunos que padecen excitación nerviosa constante; su imaginación es tan viva y su inteligencia tan clara que se asimilan cuanto escuchan, pero que a la edad adulta no sirven para nada. Estos niños prodigio no son sino enfermos a causa del excesivo trabajo intelectual a que se les ha sometido para hacerlos hombres antes de tiempo con grave perjuicio de su voluntad y de su vida.

El nerviosismo se manifiesta otras veces en los niños haciéndoles indolentes y apáticos; todo les aburre, todo les produce indiferencia, como si fueran personas desengañadas del mundo. Esto que a menudo se castiga y se atribuye a holgazanería, es un estado morboso que merece serios cuidados y mucha atención por parte del médico y del pedagogo.

También hemos observado que esta afección suele otras veces hacer al niño extraordinariamente voluble y variable; tan pronto desea una cosa como la rechaza; hoy quiere a una persona y mañana la aborrece; ahora goza con un juguete y a los pocos minutos le ha arrinconado. No es esto, pues, una manía caprichosa de la infeliz criatura; es un caso patológico muy corregible en la escuela. ${ }^{1140}$

Asimismo, consideraba que las «cefalalgias» en los niños eran debidas al excesivo trabajo al que le sometía la escuela pues alteraba con frecuencia la salud por obligar a sus órganos antes de tiempo a realizar funciones para las cuales no tienen la preparación debida, ni la necesaria madurez.

\footnotetext{
${ }^{1140}$ Ibídem, pp. 7-9.
} 
Otra enfermedad que según el doctor Massip era frecuente en la escuela era el adenoidismo, que pasaba muchas veces inadvertido en la escuela, y «que prende casi siempre en las naturalezas débiles y enfermizas, preparando el organismo para enfermedades graves.»

Se presenta esta afección en forma de excreciones fungosas en la nasofaringe, excreciones que si no se extirpan a tiempo impiden el desarrollo del niño, causándole serios trastornos. ¡Cuántas veces el retardo intelectual, el raquitismo, la sordera y la pereza del niño son debidos a las vegetaciones adenoideas! $!^{1141}$

También, consideraba que la falsa idea que tenía la gente del valor alimenticio del alcohol era causa de algunas afecciones entre los escolares, debilitando y desgastando no solo el cuerpo del niño, sino sus facultades morales e intelectuales. «Contra el alcoholismo pueden hacer mucho médico y maestro de común acuerdo».

Sobre las enfermedades escolares de índole contagiosa, era necesaria la inspección médica a fin de que tan pronto como aparecieran los primeros síntomas, se tomaran las medidas profilácticas convenientes en cada caso para atajar el mal en su origen, evitando el contagio.

El deseo de difundir los preceptos higiénicos se estrellaba ante la ignorancia e incultura del pueblo y en los escasos medios materiales con que contaba la clase obrera para mejorar sus condiciones de vida «No es fácil resolver el problema higiénico sin resolver antes el económico. Mientras haya niños con hambre, la higiene no puede hacer todo eso, toda vez que la falta de alimentos trae consigo la degeneración de la raza». ${ }^{1142}$

\section{LA INTRODUCCIÓN DE LA INSPECCIÓN MÉDICO-ESCOLAR EN EUROPA Y EN ESPAÑA}

En los últimos años del siglo XVIII, se comenzó en Alemania a dar importancia a la higiene escolar, gracias a una obra que con el título de Sistema de una policía médica

\footnotetext{
${ }^{1141}$ Ibídem.

${ }^{1142}$ Ibídem.
} 
completa escribió Johann Peter Frank, donde se tratan los principales problemas higiénicos que pueden presentarse en la escuela. En 1905 estaba totalmente establecida la inspección médico-escolar en cien ciudades, siendo 550 el número de médicos encargados de esta especialidad. En Francia se inició la idea en 1793, pero tardó más en implantarse, pues los maestros se oponían por creer que con la implantación de la inspección se mermaban sus atribuciones. Más tarde se convencieron de que no había motivos para sus temores y vieron en el médico un auxiliar para cumplir su misión, mientras él se ocupaba del desenvolvimiento físico del educando, el pedagogo atendía a su cultura intelectual.

En el extranjero el médico higienista intervenía en la distribución del tiempo y del trabajo y en la formación de los programas escolares, para que el niño se desenvolviera en las mejores condiciones de salud. A él incumbía señalar la edad en la que el niño podía, sin inconveniente alguno, comenzar a trabajar, cuánto tiempo podía dedicar cada día al trabajo, etc.

En Paris se organizó sistemáticamente la inspección médica de las escuelas en 1883, dividiéndose para este objetivo la ciudad en 126 circunscripciones, encargándose cada médico de 30 o 40 clases, con obligación de visitarlas dos veces al mes. En Inglaterra se estableció la inspección médico-escolar por Ley de $1^{\circ}$ de enero de 1908. También Dinamarca, Suecia y Suiza organizaron este servicio, así como Italia, Rusia, Austria, Rumania y Portugal.

En España, es en el año 1879 cuando se ordena por vez primera, que un médico visite diariamente la Escuela Froebel, y en 1884, cuando se dispone que todas las escuelas municipales de Madrid disfruten de un servicio médico.

El Real Decreto de 2 de septiembre de 1902 y el de 7 de febrero de 1908, son una prueba inequívoca de que la idea de la Inspección Médica no era olvidada por los legisladores, pues tanto en una como en la otra disposición, se ordena que el médico forme parte de las Juntas de Enseñanza, y en el segundo hasta se le marcan ya sus atribuciones, el Real Decreto de febrero de 1908 organizando las Juntas de Primera Enseñanza hace figurar en cada Junta Local un vocal Médico Inspector de Sanidad.

Posteriormente, en agosto de 1909 se encargó a la Junta Municipal de Primera Enseñanza de Madrid la redacción de unas bases para reorganizar las escuelas públicas y en una de ellas se trataba del servicio higiénico de las escuelas, diciendo entre otras cosas, lo siguiente: 
La revisión higiénica de nuestras escuelas se impone como la primera, la más fundamental y la más fructífera de la numerosa serie de reformas apuntadas antes, para librar y vencer ya la armónica batalla que se está dando del analfabetismo que nos devora y deshonra, y el analfabetismo enclenque que nos caracteriza en perjuicio de la raza. ${ }^{1143}$

La Junta Municipal acordó proponer la creación de diez médicos, uno por cada distrito, que formando un cuerpo, estuviesen organizados y en función constante bajo la dirección del Vocal Médico de la Junta.

La Inspección Médico-Escolar fue creada con carácter general por Amalio Gimeno, ministro de Instrucción Pública, en virtud de un Real Decreto publicado en la Gaceta 18 de Junio de 1911. Dada la falta de fondos con la que se abordaba esta creación, eran frecuentes las apelaciones a la voluntariedad de los doctores españoles. La base de la institución serían los vocales médicos de la Juntas Locales de Primera Enseñanza, los cuales debían procurar la colaboración de sus compañeros y elaborar un plan de trabajo que remitirían a la Dirección General de Primera Enseñanza. No parece que el anterior Real Decreto tuviese una respuesta inmediata en el territorio nacional. ${ }^{144}$

Los objetivos que perseguía la Inspección Médico-Escolar, eran vigilar el adecuado desarrollo físico y moral del niño, la higiene de los locales y prevenir las enfermedades contagiosas.

En 1912, la Inspección Médica en Madrid estaba formada por 41 médicos encargados de la inspección de las 168 escuelas nacionales de primera enseñanza, pues en las privadas no se había establecido el servicio todavía.

Esta Inspección abarcaba vigilar los locales escolares, el mobiliario y material escolar desde el punto de vista higiénico; cuidar el desarrollo armónico y normal del educando, estableciendo con este objeto la ficha sanitaria; profilaxis de las enfermedades contagiosas; instrucción sanitaria de alumnos y maestros, y estudios relativos a cuestiones especiales durante la edad escolar.

\footnotetext{
1143 MASIP BUDESCA, Eduardo, op. cit. pp. 9-12.

1144 DEL POZO ANDRÉS, María del Mar (2012): Salud, higiene y educación: origen y desarrollo de la Inspección Médico-Escolar (1900-1931). Revistas.um.es Núm. 20 Universidad de Alcalá [5/08/2015].
} 
Había un médico encargado de visitar cada uno de los 10 distritos en que se dividía la capital para llevar a cabo la vigilancia higiénica de los locales, cuyo resultado era anotado por el médico-inspector en un libro que al efecto llevaba y posteriormente dar cuenta a la Secretaría General. ${ }^{145}$

Para la formación de la ficha sanitaria de los escolares, éstos acudían acompañados de sus profesores y familiares que desearan al local que ocupaba la Inspección Médica, donde existían los aparatos necesarios para realizar el examen antropométrico-fisiológico.

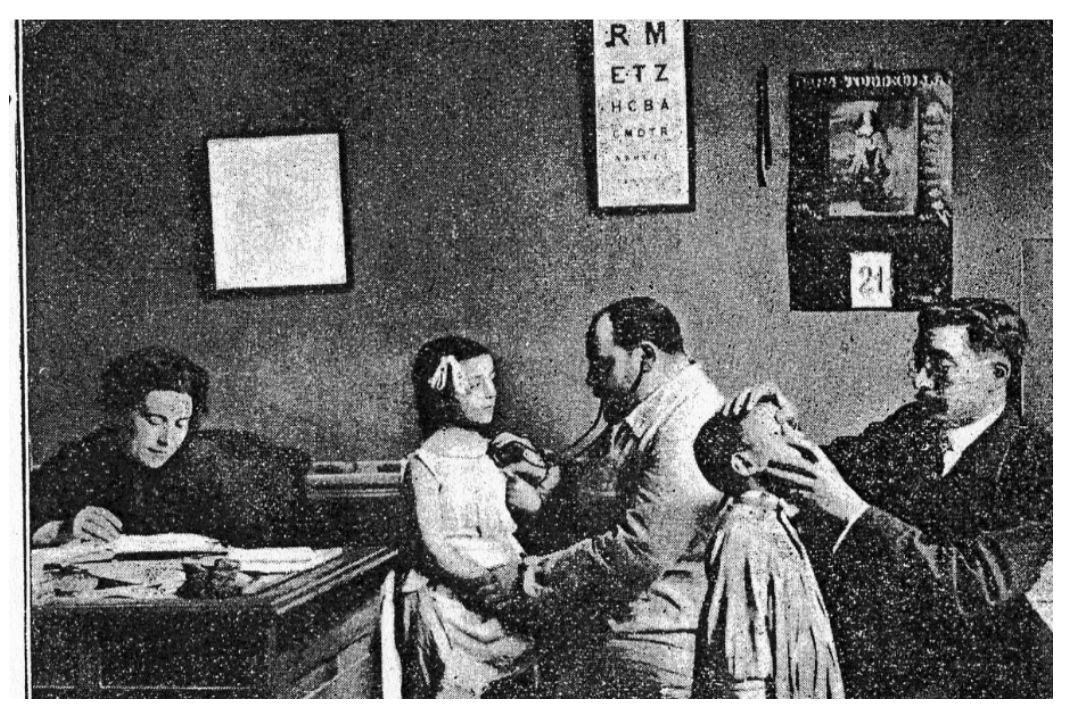

Formación de la ficha sanitaria. Fuente: MASIP BUDESCA, Eduardo (1912): Memoria presentada a los Excmos. Sres. Ministro de Instrucción Pública y Bellas Artes y Director General de Primera Enseñanza. Imprenta y Litografía de Policarpo Sáez

Cada día de la semana se destinaba a un determinado distrito, y allí eran recibidos los niños y niñas por el Secretario de la Inspección Médica, el médico del distrito correspondiente, los médicos especialistas cuando eran necesarios y el personal subalterno. Los maestros llevaban cada día los alumnos que determinaba la Inspección Médica. El resultado de este examen se consignaba en una ficha especial, cuyo modelo era el siguiente:

\footnotetext{
1145 MASIP BUDUESCA, Eduardo (1912): Memoria presentada a los Excmos. Sres. Ministro de Instrucción Pública y Bellas Artes y Director General de Primera Enseñanza. Imprenta y Litografía de Policarpo Sáez, Madrid. pp. 26-28.
} 


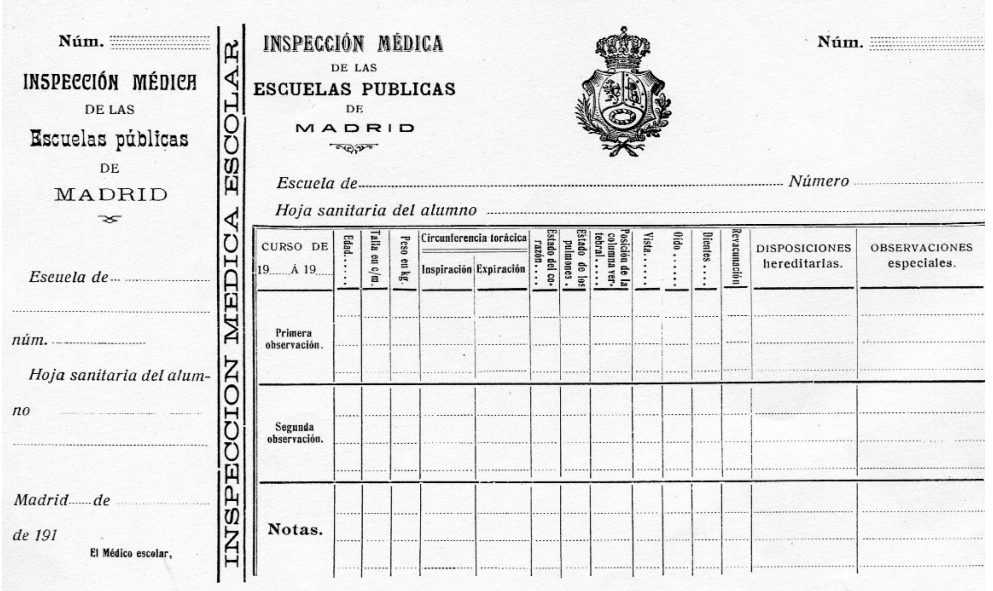

Ficha de la Inspección Médica de las Escuelas públicas de Madrid. Fuente: MASIP BUDESCA, Eduardo (1912): Memoria presentada a los Excmos. Sres. Ministro de Instrucción Pública y Bellas Artes y Director General de Primera Enseñanza. Imprenta y Litografía de Policarpo Sáez

El médico debía anotar en ella el peso, talla, circunferencia torácica, esqueleto vista, oído, conformación de pecho y abdomen, enfermedades padecidas, vacunación, estado general, etc.

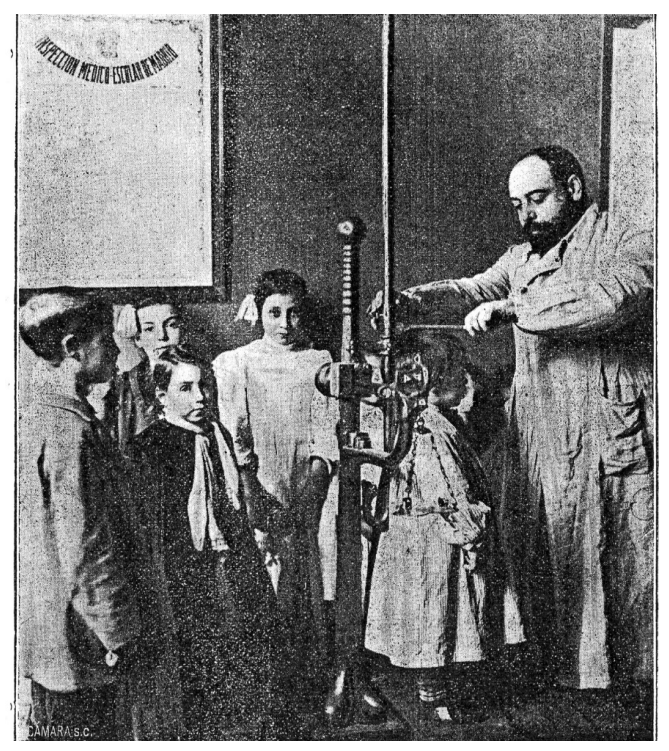

Peso y Talla. Fuente: MASIP BUDESCA, Eduardo (1912): Memoria presentada a los Excmos. Sres. Ministro de Instrucción Pública y Bellas Artes y Director General de Primera Enseñanza. Imprenta y Litografía de Policarpo Sáez

En los casos dudosos los niños eran remitidos a los especialistas correspondientes. También contaba la Inspección con un profesor dentista que empleaba el esquema siguiente: 


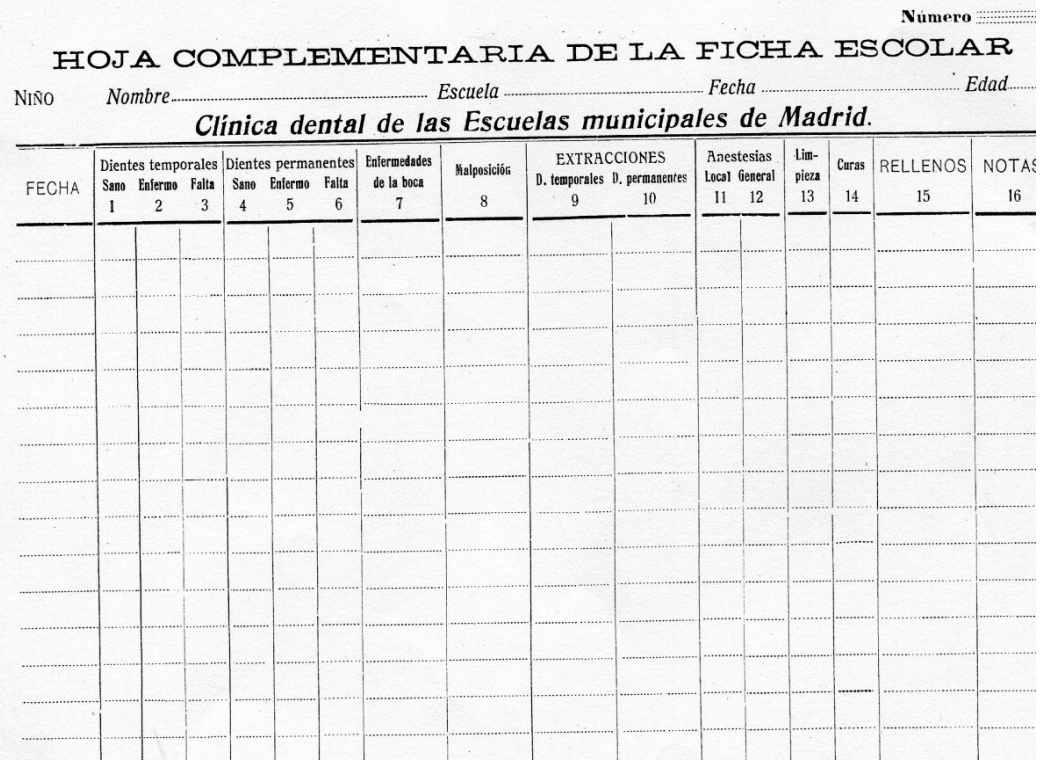

Ficha escolar del dentista para anotar las observaciones que hacía a los niños. Fuente: MASIP BUDESCA, Eduardo (1912): Memoria presentada a los Excmos. Sres. Ministro de Instrucción Pública y Bellas Artes y Director General de Primera Enseñanza. Imprenta y Litografía de Policarpo Sáez

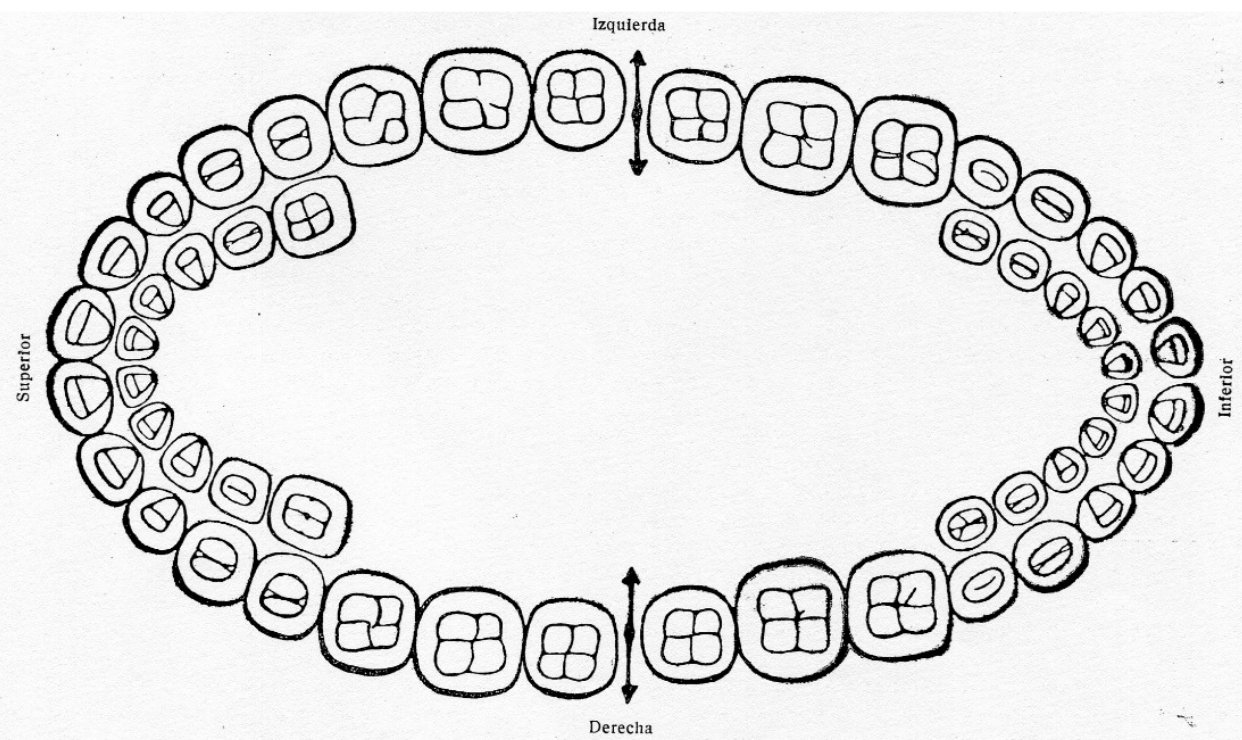

Inspección Médica Escolar de Madrid. Boca y dientes. Dr. Landete. Fuente: MASIP BUDESCA, Eduardo (1912): Memoria presentada a los Excmos. Sres. Ministro de Instrucción Pública y Bellas Artes y Director General de Primera Enseñanza. Imprenta y Litografía de Policarpo Sáez 


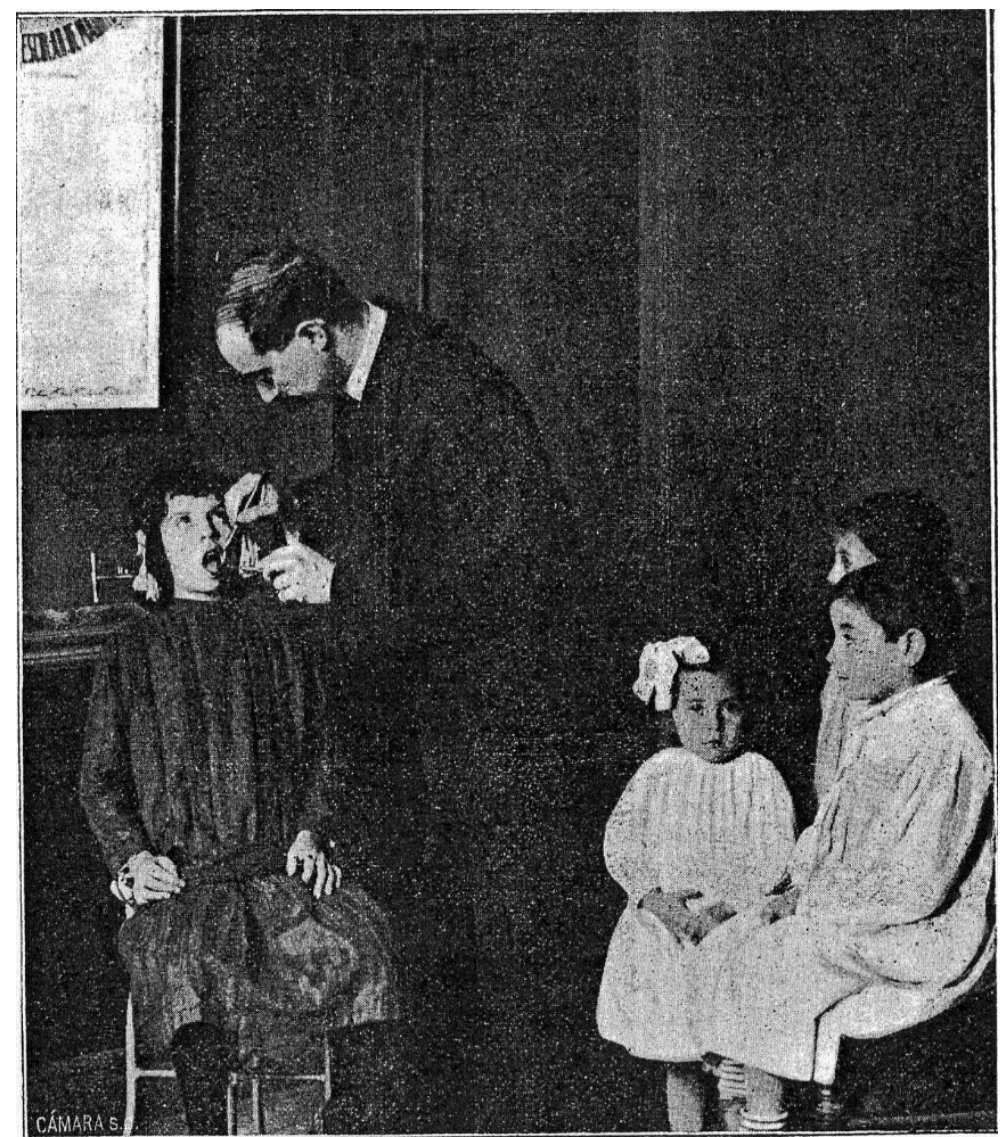

Examen de la boca y de los dientes. Fuente: MASIP BUDESCA, Eduardo (1912): Memoria presentada a los Excmos. Sres. Ministro de Instrucción Pública y Bellas Artes y Director General de Primera Enseñanza. Imprenta y Litografía de Policarpo Sáez

Una vez formada la ficha sanitaria individual, el niño pasaba a ser un número de registro, con el fin de mantener el secreto de las taras fisiológicas si las había.

Por último, según ordenaba el Reglamento de la Inspección Médica, se remitía a los médicos de distrito y a los especialistas el siguiente cuestionario para que enviraran sus informes al inspector jefe:

1. Número de escuelas visitadas.

2. Ídem de alumnos reconocidos.

3. Alumnos sanos.

4. Ídem tuberculosos.

5. Ídem con escoliosis.

6. Enfermos de la piel.

7.Ídem garganta, nariz y oído.

8. Ídem de la vista.

9. Enfermedades infecciosas. 
10. Deficiencias higiénicas observadas en las escuelas.

11. ¿Cuál es la enfermedad dominante entre los escolares?

12. Medidas sanitarias que convendría adoptar.

13. ¿Debe instalarse en las escuelas un servicio de baños-duchas?

14. Observaciones relativas a la Inspección Médica y mejoras que debían ser realizadas. ${ }^{1146}$

El especialista en otorrinolaringología informaba que había muchas infecciones del oído y respiración nasal insuficiente por obstrucciones nasales. Abundaban las vegetaciones adenoideas y las hipertrofias de las amígdalas. Estas últimas eran debidas a infecciones por bacterias comunes, y los casos de hipertrofia lenta crónica de las amígdalas palatinas, eran muchas veces debidas a la infección por bacilos de Koch. El médico otorrino insistía en la importancia de estas afecciones y en la necesidad de vigilarlos en el recinto escolar por ser una de las puertas de entrada de la tuberculosis pulmonar.

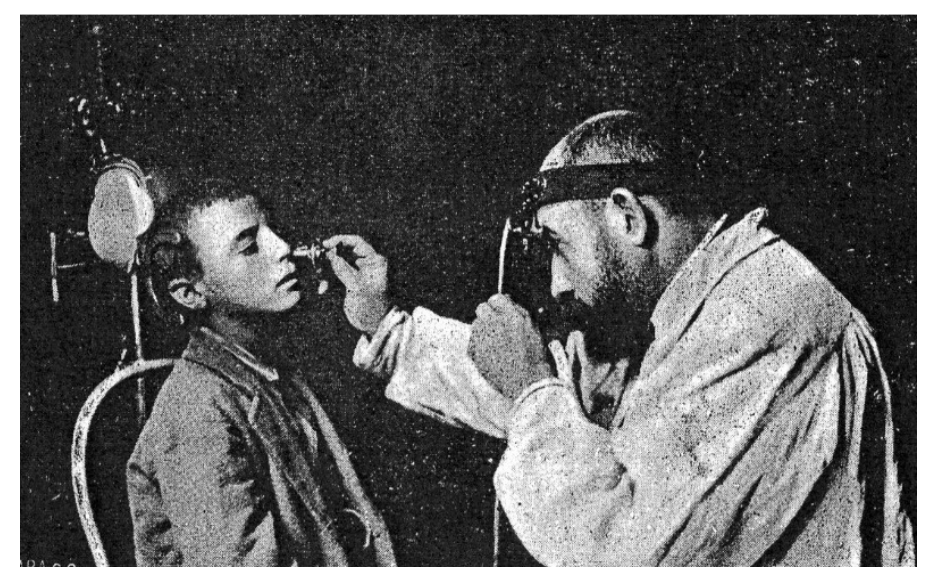

Examen de las fosas nasales. Fuente: MASIP BUDESCA, Eduardo (1912): Memoria presentada a los Excmos. Sres. Ministro de Instrucción Pública y Bellas Artes y Director General de Primera Enseñanza. Imprenta y Litografía de Policarpo Sáez

\footnotetext{
${ }^{1146}$ Ibídem, p.48.
} 


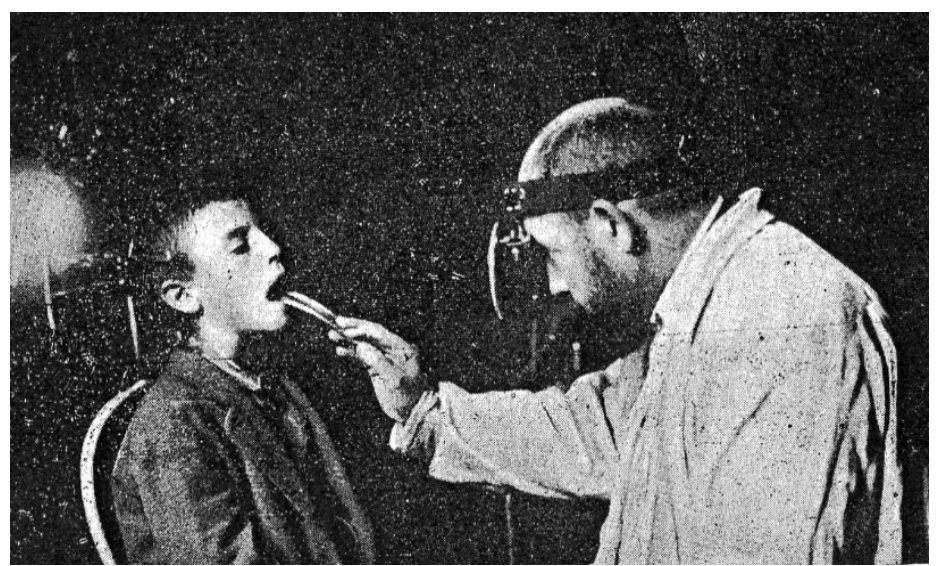

Examen faríngeo. Fuente: MASIP BUDESCA, Eduardo (1912): Memoria presentada a los Excmos. Sres. Ministro de Instrucción Pública y Bellas Artes y Director General de Primera Enseñanza. Imprenta y Litografía de Policarpo Sáez

Según el especialista en oftalmología, la miopía era la afección de la vista que predominaba en los escolares de edades comprendida entre los siete y nueve años.

En dermatología se recomendaban los baños-duchas en las escuelas, por pertenecer los niños que a ellas asistían a la clase más pobre, «pues carecían de medios que les permitiera cuidarse convenientemente. Había casos de piodermitis que se producían por la falta de limpieza.»

Los médicos-inspectores de distrito declaraban que en sus visitas habían encontrado gran número de deficiencias higiénicas en las escuelas visitadas, y que convendría vigilar las ropas de los alumnos desinfectándolas convenientemente. Piden que cada escuela disponga de una habitación amplia para ropero y que se higienicen los retretes. Se recomienda que el médico de cada distrito pronuncie conferencias de vulgarización de los preceptos higiénicos en las escuelas.

También se lamentan los médicos-inspectores del excesivo número de asistentes a la escuela, «porque de ese modo es bien exigua la cantidad de aire que a cada niño corresponde». Censuran que los locales-escuelas se hallen en calles estrechas por la poca luz que reciben y las malas condiciones higiénicas que tienen en general.

Asimismo califican de «puramente intelectual» el sistema pedagógico y preconizan las ventajas de la educación física. Una de las principales medidas sanitarias que se recomienda adoptar es la de proporcionar a los niños terrenos donde pudieran jugar y expansionarse.

Por otra parte entienden que la Inspección médica debía procurar el fomento de las cantinas escolares en beneficio de la salud de los niños, faltos en su mayoría de una alimentación sana y abundante. 
Preconizan las excelencias del campo, «cuya influencia educadora nadie pone ya en duda», ni las ventajas de la escuela al aire libre.

Según los inspectores médicos, las causas del linfatismo, los infartos ganglionares, el escrofulismo y la tuberculosis que reinaban entre los escolares, eran la falta de alimentación y de higiene, tanto en sus casas como en la escuela. ${ }^{1147}$

La escuela española debía sufrir una trasformación tal que el niño pudiera vivir en ella una vida sana, activa y perfectamente armónica con las necesidades que legítimamente reclaman la edad infantil. Por esto pedían que formaran parte del programa escolar los ejercicios físicos, que se establecieran los baños-duchas en las escuelas, que se atendiera como merecía a la educación sexual y que se le diera a la enseñanza de la higiene toda la importancia que tiene.

\section{UN MODELO DE ESCUELA PARA CONSEGUIR UNA EDUCACIÓN INTEGRAL}

Gracias a la Inspección Médico-Escolar, se pusieron de manifiesto todas las deficiencias higiénicas de los escolares y de las escuelas y, al mismo tiempo, la Inspección indicaba el medio de corregirlas para que de esta forma España se pudiéra colocar a la misma altura que las demás Naciones.

En una memoria de la Inspección Médica de las Escuelas de Madrid, remitida a la Delegación Regia de Primera Enseñanza, en noviembre de 1913, se informaba del estado de las escuelas que por carencia de condiciones de salubridad merecían clausurarse.

Los reconocimientos efectuados durante el año 1912 por la Inspección en los diferentes distritos de Madrid, indicaban que había un número excesivo de alumnos matriculados en relación con la capacidad de los locales. Este exceso de concurrencia agravaba las malas condiciones de la mayor parte de las escuelas.

Las escuelas no eran edificios aislados, como se recomendaba, no tenían iluminación ni ventilación adecuada. Muchos establecimientos carecían de urinarios y lavabos, y los retretes eran insuficientes. Asimismo los peldaños de las escaleras de los

${ }^{1147}$ Ibídem, pp. 55-61. 
edificios solían ser muy elevados, constituyendo un peligro para los niños que tenían que subir a gatas.

Hacían falta escuelas para que dejara de existir esa sobrecarga que hacía de los centros escolares un lugar malsano y antipedagógico, y para dar entrada a muchos niños que esperaban sitio vagando por las calles.

Las entradas a la escuela constituían muchas veces un peligro para los niños por tener que utilizar la misma puerta que el servicio de incendios, la Casa de Socorro, la Tenencia de alcaldía, etc. por ser sitios destinados a establecimientos insalubres y peligrosos.

Muchas escuelas estaban situadas en casas de vecindad, en barrios poco saludables, donde los vecinos depositaban los detritus, restos de la limpieza de las casas y excrementos, hasta que los carros de la limpieza pasaban a recogerlos una o dos veces al día.

Ya en 1899 Macías Picavea se lamentaba de los importantes defectos cuantitativos y cualitativos de un triste panorama escolar resaltando las imperfecciones y los vicios de la cultura nacional. Escuelas que son «cuadras destartaladas», con maestros ignorantes $\mathrm{y}$ «sin pagar», una escuela con escasa asistencia y peores resultados, y unas familias que mantienen una mentalidad negativa sobre los beneficios de aquélla.

Ese mismo año, 1899, la prensa y la revista La Escuela Moderna difunden una crítica realizada por Bartolomé Cossío en donde habla de la ignorancia como causa de nuestra catástrofe nacional, y de la incapacidad para salir del estado en el que de casi cuatros millones de niños de 3 a 12 años, dos millones y medio, no reciben ninguna enseñanza. $^{1148}$

Y hacen bien esos dos millones y medio de niños en no ir a la escuela, y sus padres obran muy cuerdamente en no enviarlos [...]. Perderían el tiempo, porque no hay en España ni escuelas en que meterlos, aunque fuesen almacenados, ni suficientemente número de maestros para educarlos de verdad; y perderían la salud, porque los que malamente cupiesen, irían a envenenarse en el pestífero ambiente de unos locales infectos, donde hoy mismo están ya hacinados los niños que asisten; y

\footnotetext{
1148 MAYORDOMO, Alejandro (2007): Regeneracionismo y educación: La construcción pedagógica de la sociedad y la política, en SALAVERT, Vicente, SUÁREZ CORTINA, Manuel eds. (2007): El regeneracionismo en España. Universidad de Valencia. pp. 169-170.
} 
con el tiempo y la salud perderían también la alegría y la despierta curiosidad que, en estas condiciones, no tardan en cambiarse en rutina servil y en horror a la escuela. ${ }^{1149}$

Un inspector médico, el doctor. Pin, expone que la Inspección Médico-Escolar no solo debía limitarse al reconocimiento y vigilancia sanitaria del alumnado y a la inspección y mejora de las condiciones higiénicas de los locales-escuela, sino que también entraban en sus atribuciones otros puntos que constituían problemas de suma trascendencia, cuya resolución aportaría enormes beneficios: la necesidad de limitar el número de asistentes a cada escuela; los inconvenientes que ofrecían las grandes agrupaciones escolares (grupos escolares, internados, etc.), que eran los que en caso de epidemias contribuían más a la propagación de éstas; la escasez de iluminación y ventilación en la mayoría de las clases; la conveniencia de establecer escuelas al aire libre y la de la creación de jardines; los perjuicios que ocasiona a la salud de los niños el horario de las escuelas; lo beneficioso que habría de resultar el fomento y perfecta organización de las instituciones benéficas circum-escolares y post-escolares (cantinas, desayunos, roperos, talleres, etc.).

En la práctica, era difícil encontrar locales apropiados, y además había que añadir los inconvenientes económicos y en algunos casos la resistencia que solían oponer los dueños de locales al arrendamiento de los mismos para escuela. ${ }^{1150}$

El doctor Pin recomendaba en la citada memoria evitar que las escuelas tuvieran que estar instaladas en casas de vecindad, pues el edificio que se destinara a escuela tendría que ser edificado especialmente para ello. Debería constar de una sola planta distribuida convenientemente para las distintas necesidades de la enseñanza, con separación completa de toda habitación y con espaciosos patios o jardines, en los que se pudieran dar las clases siempre que fuera posible. Con ello se corregiría la insana influencia que sobre la salud de los escolares ejerce el horario escolar que obliga a los alumnos a permanecer encerrados durante cinco o seis horas diarias, en una atmosfera confinada, que generalmente no se ventila durante las horas de clase, pues al disponer

\footnotetext{
${ }^{1149}$ COSSIO, Manuel Bartolomé: «Idilio pedagógico», en La Escuela Moderna, 1899, t. I, pp. 330-333. En MAYORDOMO, Alejandro (2007), op. cit. p. 170.

${ }^{1150}$ MASIP BUDESCA, Eduardo. (1913). Memoria presentada a los Excmos. Sres. Ministro de Instrucción Pública y Bellas Artes. Director General de Primera Enseñanza y Alcalde presidente del Excmo. Ayuntamiento de esta Corte. Imprenta litográfica de Policarpo Sáez, Madrid. P.17.
} 
de locales al aire libre, podría muy bien compensarse la quietud y encierro forzado, con la libre expansión y desentumecimiento que representaría la estancia al aire libre.

Además, se aconsejaba la iluminación unilateral, las dimensiones de las clases debían ser tales que tuvieran elevación por lo menos dos tercios de su anchura y los huecos o ventanas dispuestos en forma y en número que aseguraran una iluminación uniforme en todos los puntos del local.

El número de asistentes a cada escuela no debería pasar de cincuenta, pues además de lo mejorada que resultaría la labor educativa del maestro, teniendo solo que atender a un reducido número de alumnos, se evitarían los inconvenientes de la excesiva aglomeración de individuos en una atmosfera limitada. ${ }^{1151}$

Cada alumno debía disponer de una superficie de 1,25 metros cuadrados para poder moverse desahogadamente. Los suelos y paredes debían estar desprovistos de ángulos y aristas salientes y el material debía ser todo lo más sencillo y liso posible, sin depresiones ni almohadillados que pudieran servir de depósito al polvo y los gérmenes infecciosos.

El médico escolar debía contar, en primer lugar con la ayuda del maestro y con la aquiescencia de los padres. «El día que estos se convenzan de las grandes ventajas y de los beneficios que en la salud de sus hijos puede aportar la Inspección MédicoEscolar, se habrá dado un gran paso en la regeneración de la raza».

Para ello, el doctor Pin propone la creación de una serie de actos como conferencias, veladas, etc., con los cuales poner de relieve todas las ventajas de este organismo y así disipar los prejuicios y equívocos que existían sobre ella. También, propone publicar revistas, folletos y periódicos; crear cursos de gimnasia (sueca, atlética, etc.) y organizar excursiones; es decir, poner en práctica todos aquellos procedimientos que sirvan para que los padres, maestros y alumnado comprendan la necesidad y utilidad de la Inspección Médico Escolar, como garantía de la salud de los escolares y de la mejora y perfeccionamiento de la raza. ${ }^{1152}$

Como resultado de la inspección médico-escolar realizada en el Distrito de la Universidad de Madrid, durante el año 1912, el doctor García del Diestro, reconoció, desde $1^{\circ}$ de septiembre, a 419 niños y niñas con el fin de establecer su ficha escolar.

\footnotetext{
${ }^{1151}$ Ibídem, p 18.

${ }^{1152}$ Ibídem, pp.18-19.
} 
Estos 419 niños y niñas padecían las siguientes enfermedades por orden alfabético

Tabla 1. Enfermedades más frecuentes entre los escolares reconocidos en el Distrito de la Universidad de Madrid durante el año 1912

\begin{tabular}{|c|c|c|c|c|c|}
\hline Enfermedades & Niños & Niñas & Párvulos & Total & Observaciones \\
\hline Amígdalas & 41 & 1 & 9 & 51 & \\
\hline Anormales & 3 & 0 & 2 & 5 & $\begin{array}{l}\text { El informe detallado } \\
\text { corresponde al Psiquiatra }\end{array}$ \\
\hline Bronquitis & 20 & 2 & 9 & 31 & \\
\hline $\begin{array}{ll}\begin{array}{l}\text { Columna } \\
\text { (desviación) }\end{array} & \text { vertebral } \\
\end{array}$ & 27 & 12 & 7 & 46 & \\
\hline $\begin{array}{l}\text { Corazón (alteraciones } \\
\text { orgánicas del) }\end{array}$ & 5 & 1 & 2 & 8 & $\begin{array}{l}\text { Exceptuando las } \\
\text { congénitas }\end{array}$ \\
\hline $\begin{array}{l}\text { Deformidades } \\
\text { congénitas }\end{array}$ & 2 & 0 & 4 & 6 & \\
\hline Caries de los dientes & 5 & 8 & 32 & 45 & $\begin{array}{l}\text { Los detalles sobre este } \\
\text { punto corresponden al } \\
\text { odontólogo. }\end{array}$ \\
\hline Faringitis & 5 & 0 & 0 & 5 & \\
\hline $\begin{array}{l}\text { Ganglios (infarto de } \\
\text { los) }\end{array}$ & 100 & 2 & 20 & 122 & \\
\hline $\begin{array}{l}\text { Nariz } \text { (enfermedades } \\
\text { de la }\end{array}$ & 4 & 0 & 1 & 5 & \\
\hline $\begin{array}{l}\text { Nutrición (Trastornos } \\
\text { de la) }\end{array}$ & 16 & 0 & 20 & 36 & \\
\hline $\begin{array}{l}\text { Oído (enfermedades o } \\
\text { anomalías del) }\end{array}$ & 16 & 27 & 6 & 49 & \\
\hline $\begin{array}{l}\text { Piel (enfermedades de } \\
\text { la) }\end{array}$ & 8 & 4 & 3 & 15 & $\begin{array}{l}\text { El estudio detallado } \\
\text { corresponde al } \\
\text { dermatólogo. }\end{array}$ \\
\hline $\begin{array}{l}\text { Pulmón } \\
\text { (enfermedades no } \\
\text { tuberculosas del) }\end{array}$ & 3 & 0 & 0 & 3 & \\
\hline Raquitismo & 7 & 1 & 5 & 13 & \\
\hline Suciedad corporal & 12 & 4 & 24 & 40 & \\
\hline Tuberculosis & 9 & 2 & 14 & 25 & $\begin{array}{l}\text { Incluidos los escrofulosos } \\
\text { y pretuberculosos. }\end{array}$ \\
\hline $\begin{array}{l}\text { Vegetaciones } \\
\text { adenoideas }\end{array}$ & 14 & 5 & 2 & 21 & \\
\hline $\begin{array}{l}\text { Vista (enfermedades o } \\
\text { anomalías de la) }\end{array}$ & 6 & 3 & 12 & 21 & $\begin{array}{l}\text { El estudio detallado } \\
\text { corresponde al } \\
\text { especialista. }\end{array}$ \\
\hline
\end{tabular}

Fuente: MASIP BUDESCA, Eduardo. (1913). Memoria presentada a los Excmos. Sres. Ministro de Instrucción Pública y Bellas Artes. Director General de Primera Enseñanza y Alcalde presidente del 
Del examen efectuado se desprendía que las enfermedades más frecuentes entre los escolares reconocidos en el Distrito de la Universidad de Madrid durante el año 1912, eran por orden de frecuencia las siguientes:

$1^{\circ}$. Alteraciones del sistema linfático: infartos ganglionares, vegetaciones, adenoideas e hipertrofia de amígdalas.

$2^{\circ}$. Caries dentarias.

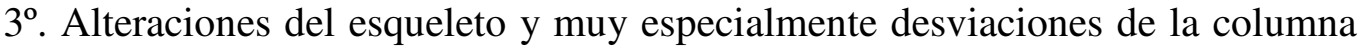
vertebral

$4^{\circ}$. Enfermedades no específicas del aparato respiratorio.

$5^{\circ}$. Formas diversas de tuberculosis o predisposición a padecerla.

En general, la morbilidad era bastante elevada, que según decía el doctor García del Diestro, se debía a múltiples causas, entre las cuales las más importantes eran:

1. La miseria y las malas condiciones higiénicas en que se desenvolvía la vida del proletariado.

Para remediar en parte esa primera causa, preconizaba la creación de nuevas cantinas escolares que permitieran atender a los niños de las familias más necesitadas. Asimismo, indicaba la urgente necesidad de instalar baños ducha en todas las escuelas, con el fin de suplir negligencias de las madres pobres.

2. Las pésimas condiciones higiénicas de los locales destinados a escuelas y la escasez de estas. Los locales que no carecían de luz o de ventilación suficientes se hallaban mal orientados o no tenían el número de retretes proporcional al número de niños, o se encontraban situados en inmediata comunicación con las clases, etc. 
3. La construcción deficiente desde el punto de vista higiénico del mobiliario escolar. Recomendaba la renovación de todo lo existente.

4. la imposibilidad material de practicar con espíritu científico la profilaxis de las enfermedades infecciosas tal como se ejercitaba la Inspección MédicoEscolar, en Madrid, y la escasez de medios con que contaba el médico para prevenir los contagios.

El doctor García del Diestro, indicaba que mientras no se crearan las escuelas al aire libre, donde puedan agruparse los niños y los maestros tuberculosos, mientras el médico se limite únicamente a formular el diagnóstico de esta enfermedad, sin tener autoridad moral ni material para prohibir la asistencia a la escuela a aquellos individuos (maestros o alumnos), que tienen la desgracia de padecerla, la salud de la colectividad escolar ha de verse comprometida y la difusión de tan terrible plaga tiene que ser un hecho inevitable.

Continua diciendo García del Diestro, el autor que estamos analizando, que sería necesaria la creación de un servicio médico-escolar a domicilio que evitase las ocultaciones de las familias y que permitiera con conocimiento de causa practicar aquellas reglas de profilaxis que requieren la mayoría de las enfermedades agudas de los niños, siendo el mismo Médico-Escolar quien fijase el periodo de aislamiento que para cada una de ellas conviene establecer, así como la oportunidad de conservar o destruir útiles escolares del enfermo, etc.

Abogaba también este autor por la creación de un laboratorio de investigación clínica, «sin el cual, nunca será posible llevar a cabo la inspección médica de las escuelas, intentar la resolución de muchos problemas de epidemiología, que hoy por hoy, o no se resuelven o se resuelven de modo diametralmente opuesto a lo que ordenan los cánones, porque debe regirse todo buen higienista».

Todo niño que padeciese una enfermedad contagiosa debería prohibírsele el reingreso en la escuela sin antes pasar por el Laboratorio, con el fin de eliminar el citado peligro; y en caso de epidemia hacer un examen global a la población escolar, y con el aislamiento de los sospechosos o peligrosos, desde el punto de vista del 
contagio, se conseguirían seguramente resultados más eficaces que los obtenidos hasta ahora con medidas tan radicales como la clausura de las escuelas. ${ }^{1153}$

Continuamente los inspectores médico-escolares denunciaban el estado de las escuelas y la falta de higiene de los niños pobres que habitaban en casas de malas condiciones higiénicas. Predominaban los niños escrofulosos, raquíticos y anémicos, que habitaban en casas poco higiénicas y al mismo tiempo estaban mal alimentados.

Había escuelas donde un noventa por ciento de los niños tenía parásitos (pediculus capitis), debido a la propagación de unos a otros, y a la falta de limpieza en sus casas.

La Inspección Médico-Escolar recomendaba la instalación de los baños-ducha en los grupos escolares, donde se llevaran a cabo todas las prácticas necesarias para la limpieza de los escolares.

\section{LA LEGISLACIÓN QUE REGULABA EN ESPAÑA LA HIGIENE DE LOS EDIFICIOS ESCOLARES}

En la primera mitad del siglo XIX asistimos a un único modelo de organización escolar: una escuela/ un aula /un espacio. ${ }^{1154}$ Desde el último tercio del siglo XIX y primera década del siglo XX las construcciones escolares evolucionaron desde la escuela-habitación, ubicada preferentemente en un piso o local de alquiler, a un edificio escolar construido ex profeso para tal uso.

La expansión de edificios escolares en la geografía española fue lenta y dificultosa, debido a los gastos de construcción y mantenimiento con cargo a los presupuestos municipales, aspecto que se daba también en otros países de Europa. ${ }^{1155}$ Desde la publicación del Real Decreto de 1844, se señaló que la habitación y la escuela debían ser propiedad del ayuntamiento, asumiendo todas las funciones. El gobierno

\footnotetext{
1153 Ibídem, pp.21-24.

${ }^{1154}$ LOPEZ MARTÍN, Ramón (1997): «La construcción y creación de escuelas en la España del primer tercio del siglo XX» en Historia de la Educación. Revista interuniversitaria. Ed. Universidad, Salamanca, p 65.

${ }^{1155}$ ORTUETA HILBERANTH, Elena (1997): «Modelos de escuelas de educación primaria pública avalados por el Ministerio de Instrucción Pública y Bellas Artes», Norva-Arte XVII, p. 171.
} 
central, para paliar estas carencias llevo a cabo una política de subvenciones, lo que permitió a ciertos municipios y a las capitales de provincia construir centros escolares.

El Estado del siglo XIX deja la Escuela en manos de los municipios, contra cuya labor clamarán Congresos y Asambleas pedagógicas desde 1895.

Con el Real Decreto del 21 de julio de 1900, el Estado asume el pago y obligaciones de personal y material de las escuelas públicas, y con el Real Decreto de 23 de septiembre de 1920, la escuela nacional pasara, en lo que respecta a construcciones escolares a manos del Estado, a través de la Oficina Técnica de Construcciones Escolares.

Los dos Ordenamientos decimonónicos que intentaron dignificar la escuela del siglo XIX, fueron el Plan Calomarde de 16 de febrero de $1825^{1156}$ y el Plan de Instrucción Primaria de 21 de julio de 1838, obra de Pablo Montesinos. El primero representa la ideología de un estado conservador y católico, y el segundo propugna las ideas de un estado liberal.

El reglamento del Plan Calomarde, impuso a los municipios la obligación de sostener una escuela pública que, además, no podía servir a otros usos públicos y estuviera alejada de cualquier lugar incómodo, prohibiendo la coeducación de sexos. Divide en clases y subclases la escuela en razón del número de habitantes, y señala los diversos textos y métodos de enseñanza de modo uniforme y obligatorio. En referencia al aula, se dispuso que la sala de enseñanza debía ser amplia y ventilada, sin especificar ningún otro aspecto de ocupación o de carácter métrico e higiénico.

El Plan de 1838, recopiló la normativa anterior añadiendo la necesidad de impartir las clases en local cubierto y con bastante luz. Incorporó algunas medidas higiénicas como prohibir la escolarización de los niños y niñas con enfermedades contagiosas o el control de la limpieza de la escuela por parte del maestro. ${ }^{1157}$ En el Título II, artículo séptimo, dice que, «todo pueblo que llegue a cien vecinos estará obligado a sostener un escuela primaria elemental completa»; y en el octavo y noveno

\footnotetext{
${ }^{1156}$ El Plan y Reglamento de Escuelas de Primeras Letras (16 de febrero de 1825) ordenaba la inspección de la enseñanza a través de la Junta superior de Inspección, las Juntas de capital de provincia, y las Juntas del Pueblo. Las Juntas provinciales tendrían una intervención decisiva en las oposiciones o exámenes para maestros de escuela. CAPITAN DÍAZ, Alfonso (1994): Historia de la educación en España II. Pedagogía Contemporánea. Dykinson, Madrid, p. 45.

1157 ORTUETA HILBERANTH, Elena (1997): op. cit. p. 169.
} 
expresa la necesidad de establecer escuelas de niñas, de párvulos y de adultos, respectivamente. $^{1158}$

La Real Orden de 1 de enero de $1839,{ }^{1159}$ y el Real Decreto de 23 de septiembre de $1847,{ }^{1160}$ insisten en que los ayuntamientos adquieran o construyan edificios para escuelas de primaria, o reparen los antiguos acomodándolos para estos fines.

Ninguna nueva consideración de tipo higiénico al respecto formulará la Ley de Instrucción Pública de 9 de septiembre de 1857, con la que Moyano cristalizó las disposiciones pedagógicas de la primera mitad del siglo XIX y estableció las bases para la nueva ordenación pedagógica.

Más moderno y realista se muestra -en cuanto a la construcción y adecuación de centros escolares- el Decreto Ley del 18 de enero de 1869, de Ruiz Zorrilla, ${ }^{1161}$ que recogiendo el espíritu revolucionario de los krausistas, inicia un primer paso para la estandarización y homogeneización de la arquitectura escolar, por el cual se convocó concurso en la Escuela de Arquitectura de Madrid para la redacción de varias escuelas modelo clasificadas según el número de alumnos. Del examen de propuestas se fijó por primera vez una normativa a seguir para los edificios escolares. Se determino que el número de alumnos por aula no podía exceder de 120; la relación superficial de 75 centímetros cuadrados por alumno si era regida por sistema simultaneo y de un metro cuadrado si se adoptaba el sistema mutuo. La relación cúbica de 3 metros por escolar para un sistema como para otro. ${ }^{1162}$ Incluso se determinaba la superficie de hueco de ventilación que no podía ser inferior a 14 centímetros por cada alumno, ${ }^{1163}$ sin olvidar que « los excusados o retretes para el servicio, se sitúen en una galería exterior». ${ }^{1164}$

\footnotetext{
${ }^{1158}$ CAPITAN DÍAZ, Alfonso (1994), op.cit. pp. 149-154.

${ }^{1159}$ Compilación Legislativa de Instrucción Pública. Tomo II. (1878): Primera Enseñanza. Imprenta de T. Fortanet, Madrid, pp. 39-44.

${ }^{1160}$ Ibídem, pp.45-54.

${ }^{1161}$ Ibídem, pp. 374-378.

${ }^{1162}$ ORTUETA HILBERANTH, Elena ( 1997): op.cit., p. 168.

1163 La superficie de 14 centímetros por alumno para ventilación es una dimensión muy generosa. Para una capacidad máxima de 120 alumnos y una relación superficial de aula de 1 metro por alumnos, en el supuesto de un ancho de aula de 7 metros, la dimensión longitudinal es de 17 metros. Suponiendo esta dimensión la que contiene las ventanas y para una altura de aula de 4 metros, la superficie de ventilación supone un $50 \%$ de la superficie de la fachada, suponiendo que se puede abrir toda ella, en caso contrario el hueco tendría que ser mayor. Esta proporción es al que hoy día suelen tener los nuevos centros escolares. La relación de 1 metro de superficie de aula por alumno también es generosa, si lo comparamos con otros países de Europa en esos años.

1164 ESTEBAN, León (1997): «Introducción a la Historia de la Escuela», en Historia de la Educación. Revista interuniversitaria. Ediciones Universidad, Salamanca. pp. 6-7.
} 
Poco a poco se fueron acondicionando mejor las edificaciones escolares a las necesidades pedagógicas. Mas avanzada podría calificarse la aprobación del Real Decreto de 5 de octubre de 1883, al señalar las obligaciones de los ayuntamientos respecto al proyecto y planos del edifico a construir, que debe constar al menos de «vestíbulo, sala, patio de recreo, jardín, local para biblioteca popular y dependencias necesarias para el aseo de los alumnos». También se limitó drásticamente la capacidad del aula a 60 alumnos frente a los 120 de la disposición anterior; la relación superficial en planta se aumentó sensiblemente, pasando en todos los casos a 1,25 metros cuadrados por alumno y la relación cúbica se elevó de 3 a 5 por escolar. Pero tal ordenación y especificaciones técnicas no tuvo visos de implantación, como lo demuestra la literatura contemporánea y las críticas formuladas por profesores y maestros en distintos congresos y en las diversas obras pedagógicas. ${ }^{1165}$

El Primer Congreso Español de Higiene Escolar (Barcelona 1912), en su Sección III: «Higiene de edificios y material escolar», acogió las conclusiones de figuras del prestigio de los doctores Tolosa Latour- siendo secretario de la Junta de Protección de la Infancia-, Luis Verdereu, Manuel Salvat, Prieto Pulpeiro, Sanz Aguilar y otros. ${ }^{1166}$

Como observamos, el Estado del siglo XIX deja la escuela en manos de los Municipios, la solución a la deficiencia y a la insuficiencia de escuelas tendrá lugar con el Estado del siglo XX que se hace cargo del pago de los maestros (1901), crea el Ministerio de Instrucción pública (1900), el Negociado de Arquitectura Escolar (1904) y la Dirección General de Enseñanza Primaria (1911) 1167

En el primer tercio del siglo XX, los procesos de modernización social y económica se van abriendo paso paulatinamente en una estructura escolar decimonónica. El crecimiento de la actividad industrial y de servicios en detrimento de las labores agrarias, en el marco de una notable explosión demográfica; el masivo éxodo a las ciudades con un importante desarrollo del urbanismo; el nacimiento de las grandes compañías industriales y bancarias del país a la sombra de nuestra neutralidad en la Primera Guerra mundial; la tecnificación social y económica producida por el automóvil, el teléfono, el gramófono, la radio, etc.; y, en definitiva un profundo cambio

\footnotetext{
1165 Ibídem, p. 7.

${ }^{1166}$ Primer Congreso Español de Higiene Escolar (1912), Barcelona. pp. 43-46.

${ }^{1167}$ ESTEBAN, León (1997): op. cit. p. 8.
} 
en los modos y costumbres de vida, son los parámetros que enmarcan una sociedad de progreso.

Este contexto, propicia una España de contrastes dominada por extremos arquetípicos: a la «revolución desde arriba», liberal y burguesa, se enfrenta la «revolución desde abajo», izquierdista y proletaria; a la creciente industrialización de la España urbana, el lento abandono de pueblos y villas, con notables desequilibrios interregional, y sobre todo a una inmensa mayoría de analfabetos, una élite cultural de elevado nivel que conformó una etapa gloriosa, la llamada «Edad de Plata de la cultura española»; al intelectual bucólico y desmoralizado del 98, el hombre activo, soñador y político de la generación de 1915; en definitiva, a una sociedad anacrónica amarrada al pasado y una España moderna que mira al exterior.

El ámbito educativo, no quedará al margen de dicho proceso modernizador, ni exento de significativos contrastes. El abandono de las viejas estructuras del Ministerio de Fomento, con la creación del de Instrucción Pública y Bellas Artes (1900), junto al nacimiento de las Direcciones Generales de Primera Enseñanza (1911) y de Enseñanza Secundaria y Superior (1925), conformarán una administración educativa cada vez más desarrollada y estatalizada. En el mundo escolar, se reduce la lacra del analfabetismo. El Estado asume el pago de haberes a los maestros, se prolonga la escolaridad obligatoria hasta los 14 años, comienza la implantación del modelo graduado, se arbitran fórmulas alternativas a la escuela como puerta de acceso a la cultura; por el contrario, la mayoría de los locales-escuela continúan en un estado miserable, el absentismo escolar apenas se reduce en el marco de una escuela escasamente atractiva, los aires de renovación pedagógica se encuentran muy alejados de la mayoría de nuestras escuelas, etc. ${ }^{1168}$

Con el nacimiento del Ministerio de Instrucción Pública, en los albores del siglo XX y la entrada en vigor del Real Decreto del 21 de julio de 1900, parece que el problema presupuestario entra en vías de solución. El Estado asume el pago de las obligaciones de personal y material de las escuelas públicas, poniendo así fin a una larga trayectoria de deficiencias, retrasos en el pago y legislación incumplida. Nada más lejos de la realidad, por cuanto el Real Decreto del 26 de octubre de 1901, por el que se ratifica el pago de las atenciones de personal y material escolar deja los gastos de

\footnotetext{
${ }^{1168}$ MARTÍN LOPEZ, Ramón (1997): «La construcción y creación de escuelas en la España del primer tercio del siglo XX» en Historia de la Educación. Revista interuniversitaria. Ediciones Universidad, Salamanca, pp. 66-67.
} 
arrendamientos de casa escuelas y habitaciones de los maestros, así como los de construcción y reparación de locales destinados a estos servicios, a expensas de los ayuntamientos.

La limitación de recursos de los ayuntamientos y la escasez en los auxilios del Estado, propician una radiografía de nuestras escuelas en locales alquilados, destartalados, sucios y faltos de condiciones higiénicos-pedagógicas.

Los municipios con menor población se ven incapaces de hacer frente no solo al desembolso del alquiler del edificio escolar y casa para el maestro, sino a tenerlos en buenas condiciones $\mathrm{y}$, sobre todo, a poder sustraer de cada presupuesto anual una cantidad para plantearse la construcción de una nueva escuela, aun con el recurso del exiguo auxilio estatal. ${ }^{1169}$

Los diversos emplazamientos de la institución escolar a lo largo de la historia han sido muy variados. Desde templos, calles o plazas, hasta palacios, monasterios, casas particulares o ayuntamientos, cualquier ubicación era válida hasta llegar a mostrarse como edificio independiente a principios del siglo XX.

Un salto cualitativo en las condiciones de los centros de enseñanza significó el Real Decreto de 28 de abril de 1905, firmado por Carlos Maria Cortezo, en el que junto al sistema de ayudas y subvenciones estatales, la reducción drástica del número de alumnos y alumnas, se aprobó la Instrucción Técnico-higiénica, que establece la necesidad de construir un edificio escolar en las mejores condiciones de salubridad e higiene, y en donde se recogen los postulados y las opiniones mas autorizadas del higienismo escolar importado de conferencias, viajes y congresos europeos por eminentes políticos liberales, médicos y pedagogos, muchos de ellos cercanos a la Institución Libre de Enseñanza ${ }^{1170}$ y la labor del Museo Pedagógico Nacional que desde 1882, se van abriendo paso en nuestra legislación de primera enseñanza, consolidándose en las dos primeras décadas de siglo. ${ }^{1171}$

\footnotetext{
${ }^{1169}$ Ibídem, pp. 68-69.

${ }^{1170}$ LOPEZ MARTíN, Ramón (1997): Op. cit, p 75; LAHOZ ABAD, P. (1992) «Higiene y Arquitectura Escolar en la España Contemporánea (1838-1936)», Revista de Educación, 298, 89-118. Ciertamente, las Instrucciones españolas de 1905 son algo tardías comparándolas con las francesas de 1850 o las Belgas de 1852.

${ }^{1171}$ CAPITAN DÍAZ, Alfonso (1994), op. cit. pp. 236-278.
} 
Los preceptos de esta instrucción establecen el correcto emplazamiento de la escuela, su orientación, extensión y construcción, distribución de sus locales y clases, adecuada ventilación, iluminación, calefacción y todo lo relativo al mueblaje escolar. ${ }^{1172}$

Reseñamos las instrucciones más significativas que puedan estar relacionadas con los edificios e instalaciones escolares de Castellón en este periodo.

Emplazamiento: Ubicadas en sitios altos, secos y bien soleados, de fácil acceso y próximas a campos. Estarán alejadas de lugares insalubres de tipo higiénico y moral.

Extensión: El del edificio tendrá, tres o cuatro metros de patio o jardín por alumno.

Orientación: Según el clima de cada localidad. «Al Norte en las regiones calidas, al Sur en las frías y al Nordeste y Este, en las templadas»

Construcción: Sólida y sencilla. Los materiales serán «ligeros y malos conductores del calor, impermeables y compactos, excluyendo, desde luego, los que resulten de puro lujo». Se aconsejo el uso de ladrillo y para los tejados estaba prohibido la azotea o terraza, se recomendaba el tejado de una o dos pendientes.

Locales: Estaba prohibido terminantemente las viviendas de los maestros en el mismo edificio de la escuela. Una escuela completa, por regla general, estaba compuesta de las siguientes dependencias: vestíbulo, guardarropía, salones de clase en relación al número de alumnos, despacho del maestro o de la maestra, patio cubierto para el recreo, campo arenado y con plantación de arboles, retretes y urinarios a razón de 1 por cada 20 y 15 alumnos/as, 1 lavabo por cada 20, biblioteca, museo escolar y salón de actos y exámenes.

${ }^{1172}$ Ibídem, p.74. 
Clases: Con capacidad para 25-40 niños o niñas en las graduadas y 60 en las unitarias. La superficie mínima será de 1,25 metros cuadrados por alumno. La altura de la techumbre alcanzará hasta cuatro metros. La forma geométrica aconsejada era la rectangular. Para evitar humedades se debía elevar el piso 0,80 metros sobre el nivel exterior. Las ventanas se ubicarán en los lados mayores elevados dos metros del suelo. La luz de mayor intensidad provendrá del lado izquierdo. Los vidrios serán transparentes. El color asignado al aula en tonos claros.

Ventilación: Se evitará el aire viciado, a ser posible con ventilación natural. «Para mover la atmósfera se recomiendan ventiladores giratorios periódicos alternados, o cualquier otro sistema que active o fomente el movimiento del aire y la ventilación cruzada. De entre ellos los alternados correspondientes que consisten en aberturas practicadas en los lados mayores del local y dispuestas de tal suerte que unas correspondan a la parte inferior y otros la superior de las paredes son muy recomendables. Las aberturas correspondientes a la parte inferior distaran 10 ó $15 \mathrm{~cm}$. del suelo, y la correspondiente á la superior se situará a ras de techo. Unas y otras estarán provistas de un enrejado metálico y de un registro regulador. El área de los orificios de entrada debe ser por lo menos igual a los de salida.»

Iluminación: A ser posible deberá ser natural, «abundante, constante, uniforme, difusa y no reflejada». No se tolerará la luz cenital pero si la «bilateral siempre y cuando predomine el foco de claridad procedente del lado izquierdo».

Mueblaje escolar: Mesas banco, siendo preferible de uno o dos asientos máximos. $^{1173}$

\footnotetext{
${ }^{1173}$ Ministerio de Instrucción Pública y Bellas Artes. Subvenciones para la construcción de edificios escolares, Madrid, Imprenta la Dirección General del Instituto Geográfico y Estadístico, 1905
} 
La realidad de las escuelas, sin embargo, transcurre por otros derroteros. Ante la insistente falta de edificios de nueva construcción, una gran mayoría de nuestras escuelas se encuentran ubicadas en locales alquilados de condiciones más que dudosas, y en muchos de los casos, las partes altas y anexos de los edificios concejiles son habilitados como aulas. Los municipios, además, que deben atender estos menesteres, se encuentran faltos de recursos y presupuestos para mejorar una red escolar vieja, ruinosa y sin condiciones higiénico-pedagógicas adecuadas.

La Instrucción Técnico-Higiénica de 1905, vino a completarse por una circular de la Subsecretaria del Ministerio de Instrucción Pública de 19 de noviembre de 1908, donde se vuelve a proponer una serie de planos-modelos de escuelas públicas, al objeto de facilitar a los municipios la construcción de nuevas escuelas. ${ }^{1174}$

La tipología de modelos, firmada por el arquitecto del Ministerio Luis Domingo de Rute, representa escuelas graduadas de dos o más salas, ubicadas en un solo piso, con capacidad para 42 alumnos, algunos con sala para trabajos manuales y sin casa para el maestro en el recinto escolar.

He aquí una muestra de los mismos: Edificio de corte ecléctico, materiales nobles y sólidas estructuras. Representa escuelas graduadas de varias clases, ubicadas en una o dos plantas. Ampliándose en $1911^{1175}$ estos modelos para graduadas de de 6 y 12 secciones por el arquitecto Julio Sáenz y Barés.

Las propuestas se ajustan a las Instrucciones Técnico-higienicas de 1905, que sirvieron de norma. Las aulas están proyectadas para una capacidad de 42 alumnos/as.

De los planos aportados y a partir de la escala gráfica que tiene, se deduce que la altura aproximada de suelo a techo es de 4,5 metros; la superficie en planta aproximadamente es $9 \times 7$ metros, dando como resultado una superficie de 63 metros y un volumen de 283 metros, lo que supone una relación superficial de 1,5 metros por alumno/a.

\footnotetext{
${ }^{1174}$ MARTÍN LÓPEZ, Ramón (1997), op. cit. pp. 75-76.

${ }^{1175}$ La Real Orden de 23 de septiembre de 1898, dictada por Germán de Gamazo fue el primer paso para una renovación pedagógica de la educación en pro de una enseñanza graduada. Posteriormente con la aprobación de la Real Orden de 25 de febrero de 1911 para el cumplimiento de la anterior y la circular del 14 de junio de 1911 fue una realidad la implantación de las escuelas graduadas en la geografía española. La mayor innovación residió en el cambio de concepto de Grupo Escolar; ya no se trataba de de una escuela capaz de contener una de niños y otra de niñas y, acaso, una de párvulos sino que el Grupo Escolar era una escuela graduada para 12 secciones, seis para cada sexo [...] Resultaba necesario por lo legislado diseñar nuevas escuelas modelo. Por ello el 16 de junio de 1911 se convocó un concurso a nivel nacional [...], en ORTUETA HILBERANTH, Elena (1997): op. cit., p. 181-182.
} 

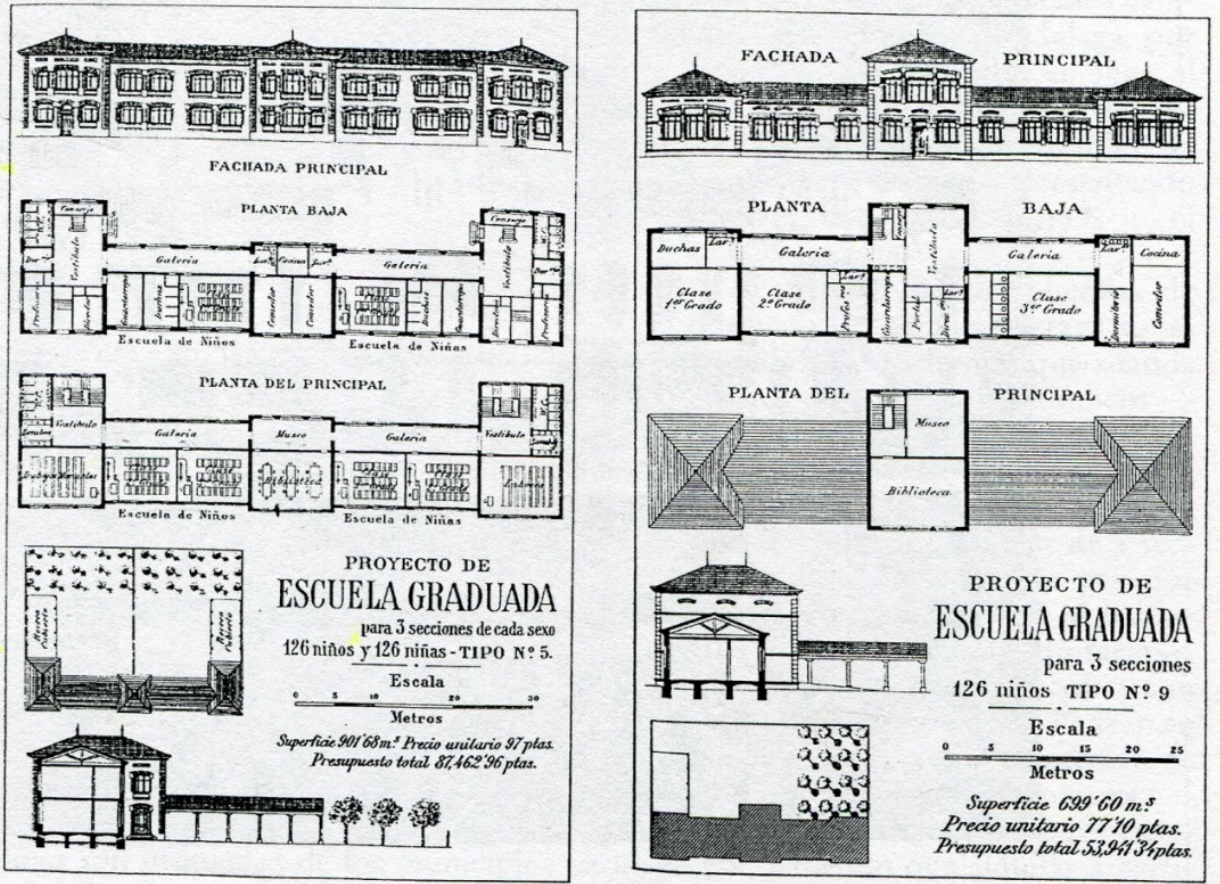

Tipología de modelos firmada por el arquitecto del Ministerio Luis Domingo de Rute.

Fuente: MARTÍN LOPEZ, Ramón (1997): «La construcción y creación de escuelas en la España del primer tercio del siglo XX» en Historia de la Educación. Revista interuniversitaria. Ediciones

Universidad, Salamanca, p. 77.

A pesar de todo, las estadísticas publicadas muestran que las escuelas no reúnen las condiciones higiénicas estipuladas con la legislación vigente; el 80\% no tenía el mínimo de condiciones pedagógicas exigidas.

Los presupuestos municipales no pueden hacer frente a la modernización de los locales que albergan sus escuelas y bastante hacen con seguir costeando el alquiler de los mismos, lo que supone una dura carga para sus reducidos capitales.

En el ámbito rural, el tema se agrava sustancialmente, a la escasez de recursos económicos, hay que añadir el retraso crónico en cuanto a infraestructura escolar, con locales ruinosos, faltos de material y en condiciones infrahumanas. ${ }^{1176}$

El Ministerio de Instrucción Pública para ensayar métodos de educación nuevos, y bajo la tutela de la Junta de Ampliación de Estudios e Investigaciones Científicas, crea en 1918 el Instituto-Escuela en Madrid. Para su funcionamiento se inspiró en los principios educativos de la Institución Libre de Enseñanza y en las corrientes

\footnotetext{
${ }^{1176}$ MARTÍN LÓPEZ, Ramón (1997), op. cit p.79.
} 
pedagógicas europeas más innovadoras de la época. Se componía de dos secciones que funcionaban con cierta independencia; una comprendía niños/as de cuatro a once años, sección primaria y otra de 11 a 17 años, sección secundaria. La primera con más de 1.000 alumnos de uno y otro sexo y la segunda con 800 . El número de alumnos/as en cada clase no pasa de 30 y el sistema de enseñanza era de carácter activo y cíclico. Con el tiempo llegó a establecer el intercambio escolar con Alemania, Francia e Inglaterra formando grupos internacionales que convivían en España y en esos países en la época veraniega. También era el Instituto Escuela lugar donde se formaba el profesorado primario y secundario. Se desarrolló con penuria de locales y estrechez de medios. ${ }^{1177} \mathrm{~A}$ partir de 1922 se empieza a construir el edificio para las diferentes secciones de primaria del arquitecto Francisco Javier Luque. De 1926 a 1931 es el edificio de secundaria, del arquitecto Carlos Arniches que mostramos aquí. Los dos modelos sirvieron de prototipo en la arquitectura escolar del periodo republicano. Del citado documento gráfico y tomando como elemento de medida la escala gráfica que figura en la parte inferior del plano, se desprende que las aulas tienen unas dimensiones próximas al cuadrado, aproximadamente $7 \times 6,5$ metros, es decir una superficie en planta de 45 metros., lo que supone para 30 alumnos/as por clase, que son las mesas individuales que aparecen dibujadas en el plano, la relación superficial de 1,5 metros por escolar.

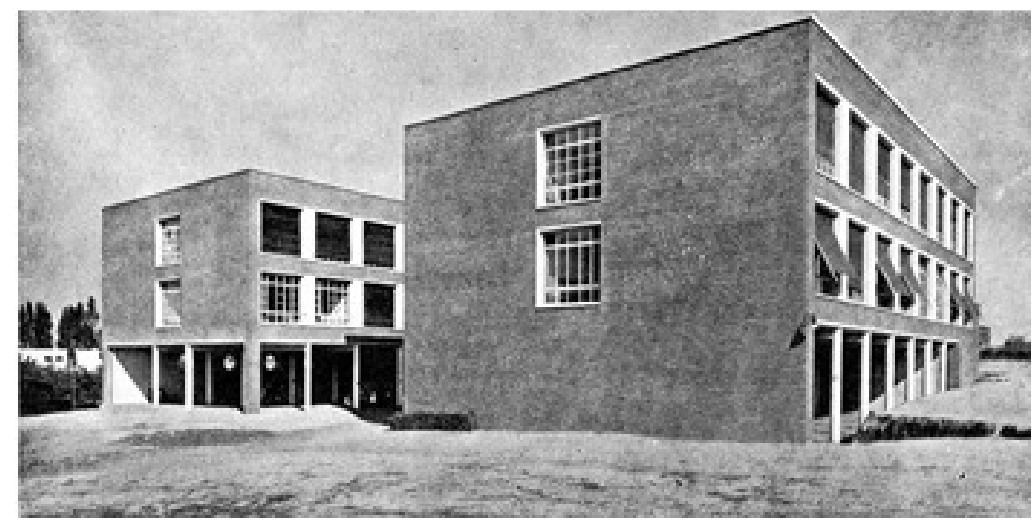

Edificio del Instituto Escuela de Segunda Enseñanza, Madrid. Fuente: ARNICHES, Carlos (1933): «Sección preparatoria del Instituto Escuela de Segunda Enseñanza-Madrid», en A.C.9. Revista Trimestral. Publicación del G.A.T.E.P.A.C. (1933)

1177 ARNICHES, Carlos (1933): «Sección preparatoria del Instituto Escuela de Segunda EnseñanzaMadrid», en A.C.9. Revista Trimestral. Publicación del G.A.T.E.P.A.C. (1933), año III. Barcelona. Madrid. San Sebastián. P. 27. 


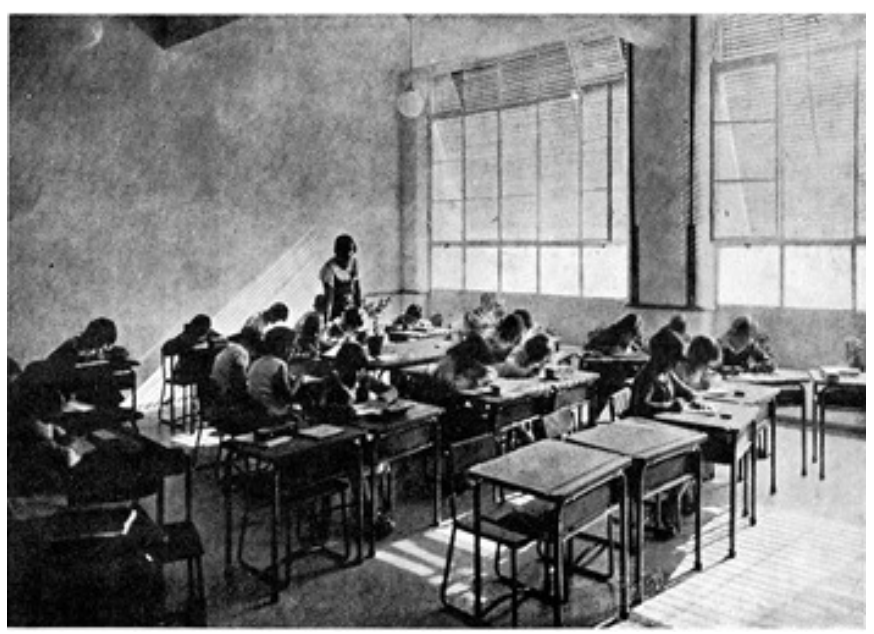

Aulas del Instituto Escuela de Segunda Enseñanza, Madrid. Fuente: ARNICHES, Carlos (1933): «Sección preparatoria del Instituto Escuela de Segunda Enseñanza-Madrid», en A.C.9. Revista Trimestral. Publicación del G.A.T.E.P.A.C. (1933)

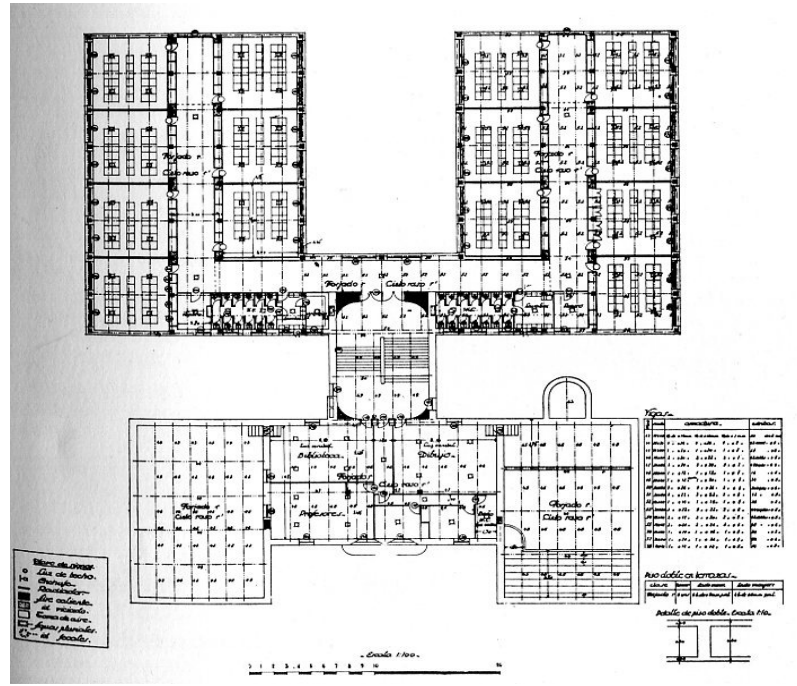

Plano Instituto Escuela Segunda Enseñanza-Madrid. Fuente: Arquitecto Carlos Arniches (1933).

Con la llegada de los años veinte se producen importantes cambios en la producción escolar. El Real Decreto del 23 de noviembre de 1920, implica al Estado en la financiación y construcción de escuelas; creándose la Oficina Técnica de Construcciones Escolares, en sustitución del Negociado de Arquitectura de principios de siglo, iniciándose una nueva fase en el diseño de modelos escolares.

Bajo la dirección de Antonio Flórez Urdapilleta y otros arquitectos cercanos a la ideología institucionista, como Leopoldo Torres Balbás, Bartolomé Giner de los Ríos o Joaquín Muro, imprimen a la construcción de escuelas un toque institucionista característico de arquitectura funcional y sencilla, atenta a la pedagogía moderna y a los presupuestos técnico-higiénicos. Cuya aportación más significativa fue la adecuación del edificio escolar a la climatología y a los distintos sistemas constructivos de cada 
región. Observando escrupulosamente la Instrucción Técnico-Higiénicas de 1905, reeditada por Real Orden. de 31 de marzo de 1923 con algunos cambios, adaptándola a los nuevos planteamientos de las escuelas graduadas. ${ }^{1178}$

Se adjuntan estas variaciones.

Extensión: Asignar a cada alumno entre seis y diez metros cuadrados.

Construcción: La altura se vuelve a situar en 4,5 metros, que recomendaba el Museo Pedagógico (1900).

Clases: Se vuelve a reduce a un máximo de 50 niños o niñas para las unitarias.

Iluminación: Relación entre la superficie de iluminación y la superficie del aula $1 / 3$.

El presente cuadro adjunto pretende resumir la evolución de los estándares higiénicos que desde mediados del siglo XIX ha ido exigiendo el Estado en la construcción y acondicionamiento de las escuelas públicas. Y que nos servirá de base para analizar la situación de las escuelas públicas de Castellón en el periodo de estudio (1880-1918).

\begin{tabular}{|l|c|c|c|l|l|l|}
\hline \multicolumn{7}{|c|}{ Parámetros higiénicos de las aulas en escuelas públicas. Su evolución } \\
\hline & Alumnos/as & Altura & $\begin{array}{l}\text { Superficie } \\
\text { de los patios }\end{array}$ & $\begin{array}{l}\text { Relación } \\
\text { superficial }\end{array}$ & $\begin{array}{l}\text { Relación } \\
\text { volumétrica }\end{array}$ & $\begin{array}{l}\text { Huecos de } \\
\text { ventilación }\end{array}$ \\
\hline Plan Ruiz Vila, 1869 & 120 & & & $\begin{array}{l}0,75 \text { simul. } \\
1,00 \text { mutuo }\end{array}$ & $3 \mathrm{~m}^{3} /$ alumno & $\begin{array}{l}1 / 7 \text { huecos/ } \\
\text { sup. aula }\end{array}$ \\
\hline Decreto de 1883 & 60 & & & $1,25 \mathrm{~m}^{2} / \mathrm{alum}$ & $3-5 \mathrm{~m}^{3} / \mathrm{alum}$. & \\
\hline $\begin{array}{l}\text { C.M.Cortezo, 1905 } \\
\text { Instrucciones } \\
\text { Técnico-higieneicas }\end{array}$ & $\begin{array}{l}25-40 \text { graduada } \\
60 \text { unitarias }\end{array}$ & $4 \mathrm{~m}$. & $3-4 \mathrm{~m}^{2} /$ alum. & $1,25 \mathrm{~m}^{2} / \mathrm{alum}$ & & $1 / 5$ \\
\hline Real Orden de 1923 & $\begin{array}{l}25-40 \text { graduada } \\
50 \text { unitarias }\end{array}$ & $4,5 \mathrm{~m}$. & $6-10 \mathrm{~m}^{2} / \mathrm{alum}$ & $1,25 \mathrm{~m}^{2} / \mathrm{alum}$ & & $1 / 3$ \\
\hline
\end{tabular}

Con el Real Decreto de 10 de julio de 1928 se modificaron algunas disposiciones anteriores. Paralelamente, en el ámbito catalán se apostó por una nueva política

\footnotetext{
${ }^{1178}$ LOPEZ MARTÍN, Ramón (1997), op. cit., p. 80.
} 
pedagógica. Se prefirió la construcción de pequeñas escuelas unitarias, siguiendo los modelos de Adolf Florensa o Antoni Folguera, evitando la construcción de grandes grupos escolares. Las clases, con capacidad para 40 estudiantes y $1,25 \mathrm{~m}^{2}$, por alumno/a, reúnen todos los adelantos higiénico-pedagógicos del momento. ${ }^{1179} \mathrm{Se}$ anuncia así el debate entre la Oficina Técnica de Construcciones escolares y el Grupo de Arquitectos del GATEPAC (1933) que consideraba la arquitectura escolar como cara, anacrónica y lujosa, decantandolo por los modelos racionalistas europeos. ${ }^{1180}$

El periodo de la Segunda República significó un gran impulso de la educación primaria pública, en detrimento de la enseñanza religiosa. En este contexto, como consecuencia de la disminución de plazas escolares, el Estado subvencionó escuelas en todo el territorio dando buenos resultados.

Pero al margen de estas nuevas construcciones, la realidad de la mayoría de las escuelas seguía siendo poco ejemplar, numerosas son las citas y testimonios de inspectores, informes de los delegados regios, juntas locales y provinciales, etc., que reflejan las condiciones precarias de nuestras escuelas, siendo, en ocasiones, necesario la clausura o traslado a otros locales. ${ }^{1181}$

Dispuesto a combatir de raíz tan importante problema, el Ministerio de Instrucción Pública, del Gobierno de la República, ordenó los créditos necesarios para la creación de gran cantidad de escuelas con el fin de reducir las deprimentes estadísticas del analfabetismo en España.

De la revista G.A.T.E.P.A.C/AC.9, del primer trimestre de 1933, podemos extraer datos estadísticos significativos de analfabetismo del periodo ${ }^{1182}$. El País Valenciano, con un $70 \%$ de analfabetismo en 1900 y un $55 \%$ en 1920 , se mantiene sensiblemente por encima de la media nacional, que era del $62 \%$ y $50 \%$ respectivamente, y con un $6 \%$ por debajo de las tres últimas, Andalucía, Canarias y Murcia.

Por provincias, en 1920, Valencia tiene el 55\% de analfabetos, Alicante el 58\% y Castellón el 63\%. Madrid y Barcelona entorno al 30, situándose la media nacional en el $50 \%$.

\footnotetext{
${ }^{1179}$ Ibídem, 78.

1180 «A.C. Documentos de actividad Contemporánea», GATEPAC, nº 10, 1933.

1181 ARNICHES, Carlos (1933), op. cit., p.82.

${ }^{1182}$ Ibídem, p. 16.
} 
Gráfica 1. Porcentaje de analfabetos en 1920 por provincias, y por regiones 1900-1920

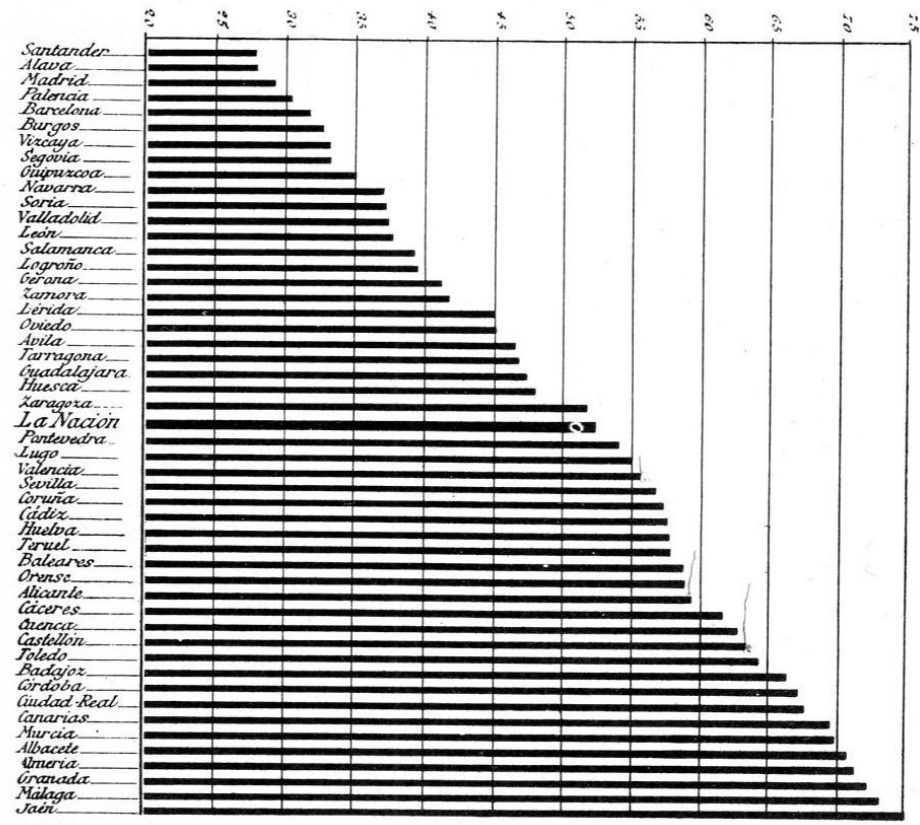

Fuente: «El problema escolar en España: Porcentaje de analfabetos en las provincias y en España con arreglo a los resultados del censo de población de 1920 (últimas oficiales). El analfabetismo por regiones, en AC.9. Revista Trimestral. Publicación del G.A.T.E.P.A.C. (1933)

\section{Gráfica 2. Porcentaje de analfabetos en 1920 por provincias, y por regiones 1900-1920}

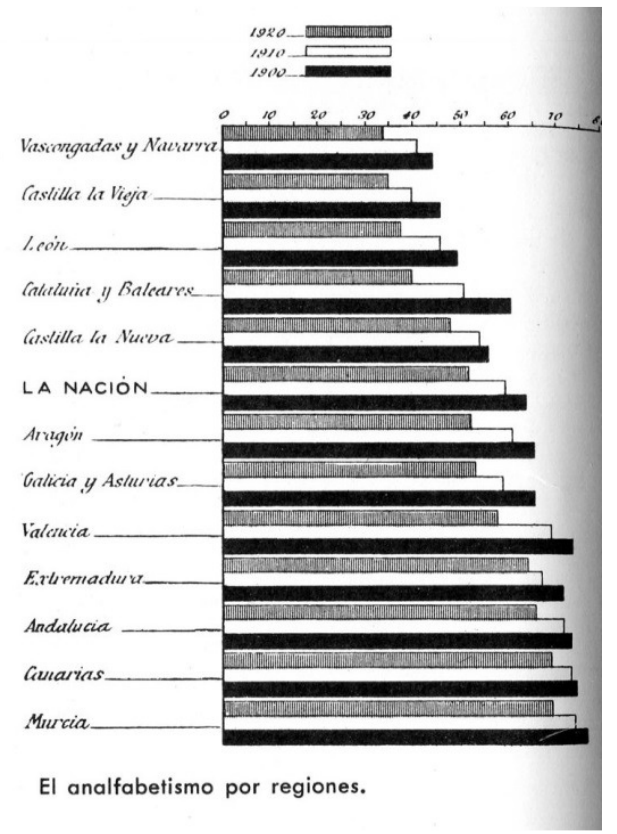

Fuente: «El problema escolar en España: Porcentaje de analfabetos en las provincias y en España con arreglo a los resultados del censo de población de 1920 (últimas oficiales). El analfabetismo por regiones, en AC.9. Revista Trimestral. Publicación del G.A.T.E.P.A.C. (1933) 
Los datos estadísticos facilitados por la revista G.A.T.E.P.A.C./AC.9 (primer trimestre de 1933) son bastante similares a los extraídos y reinterpretados en el capítulo «Educación» por Clara Eugenia Nuñez, en el libro: Estadísticas Históricas de España. Siglos XIX-XX. ${ }^{1183}$ También se puede observar en esta publicación que la alfabetización de las mujeres era sensiblemente inferior a la de los hombres. Diferencias que se van corrigiendo con los años, pasando del 67\% en 1860, al 23\% en 1920 y al 11\% en 1960.

Tabla 2: Tasas de alfabetización según los censos de población, 1860-1960

\begin{tabular}{|l|l|l|l|l|l|l|l|l|l|l|}
\hline $\begin{array}{l}\text { Tasa de } \\
\text { alfabetización } \\
\text { P. Valenciano }\end{array}$ & $\mathbf{1 8 6 0}$ & $\mathbf{1 8 7 7}$ & $\mathbf{1 8 8 7}$ & $\mathbf{1 9 0 0}$ & $\mathbf{1 9 1 0}$ & $\mathbf{1 9 2 0}$ & $\mathbf{1 9 3 0}$ & $\mathbf{1 9 4 0}$ & $\mathbf{1 9 5 0}$ & $\mathbf{1 9 6 0}$ \\
\hline Masculino & 24 & 26 & 33 & 40 & 45 & 58 & 72 & 86 & 94 & 96 \\
\hline Femenino & 8 & 12 & 16 & 22 & 29 & 42 & 55 & 74 & 83 & 85 \\
\hline Total & 16 & 19 & 25 & 31 & 37 & 50 & 63 & 80 & 88 & 91 \\
\hline $\begin{array}{l}\text { Tasa } \\
\text { alfabetización } \\
\text { España }\end{array}$ & $\mathbf{1 8 6 0}$ & $\mathbf{1 8 7 7}$ & $\mathbf{1 8 8 7}$ & $\mathbf{1 9 0 0}$ & $\mathbf{1 9 1 0}$ & $\mathbf{1 9 2 0}$ & $\mathbf{1 9 3 0}$ & $\mathbf{1 9 4 0}$ & $\mathbf{1 9 5 0}$ & $\mathbf{1 9 6 0}$ \\
\hline Masculino & 40 & 45 & 50 & 55 & 61 & 67 & 80 & 88 & 93 & 97 \\
\hline Femenino & 12 & 19 & 24 & 32 & 41 & 51 & 63 & 76 & 83 & 87 \\
\hline Total General & 26 & 31 & 37 & 43 & 50 & 59 & 71 & 82 & 88 & 92 \\
\hline
\end{tabular}

Fuente: Nuñez, Clara Eugenia ((2005): «Educación», en Carreras, Albert y TafunelL, Xavier (Coords.): Estadísticas Históricas de España. Siglos XIX -XX. Volumen I

Durante la Segunda República, las nuevas construcciones escolares tuvieron en cuenta los últimos conocimientos en materia de educación y sanitarias. Se partió de las Instrucciones Técnico-higiénicas de 1905 y las reeditadas y revisadas por Real Orden de 31 de marzo de 1923, para seguir indagando, principalmente, en la dimensión, organización y funcionamiento del aula, para adaptarla a las nuevas corrientes pedagógicas europeas. Pero las instrucciones (1905-1923) mantuvieron gran parte de su vigencia, realizándose interesantes experiencias y avances en los sistemas de

\footnotetext{
1183 NUÑEZ, Clara Eugenia ((2005): «Educación», en CARRERAS, Albert y TAFUNELL, Xavier (Coords.): Estadísticas Históricas de España. Siglos XIX - XX. Volumen I. Fundación BBVA, Bilbao. p.230.
} 
iluminación y ventilación del aula, aumentándose la superficie de iluminación de las normas anteriores.

Las dimensiones standard de la clase en la escuela primaria eran de 6,5 m. de ancho y $10 \mathrm{~m}$. de longitud, para una capacidad máxima de 50 alumnos. Estas dimensiones resultan de la ordenación en tres filas de dos pupitres fijos cada una.

La clase, como elemento de la escuela, debe adaptarse a los nuevos principios pedagógicos. Al pasar el profesor a la categoría de colaborador de sus alumnos deben desaparecer del aula los elementos rígidos que crean barreras, como los pupitres fijos, la tarima, para favorecer la disposición de la sala a todas las formas imaginables, además de cumplir con una serie de exigencias higiénicas.

En este sentido, las dimensiones del aula en planta deben aproximarse a la geometría del cuadrado, como preconizan los pedagogos del centro y norte de Europa, para favorecer la proximidad al profesor y la participación en grupo.

Un nuevo sistema de pupitres, según las últimas tendencias educativas, sustituyendo los bancos y escritorios fijos por mesas y sillas móviles, favoreciendo de esta forma los cambios de actividad y una mayor dinámica en el desarrollo de las clases.

Salida al exterior, con disposición de clases en la planta baja, lo que posibilitaba la comunicación inmediata y directa con el jardín o patio escolar, con ello se crean más posibilidades para la enseñanza. La finalidad era poder sacar las sillas y mesas al jardín. El contacto directo del niño con la naturaleza produce efectos saludables. ${ }^{1184,}$

Además se empezó a tener en cuenta, en la redacción de los proyectos técnicos, la desagradable y antihigiénica falta de adecuada aireación en el aula, con la incorporación de ventilación cruzada, mediante aperturas elevadas diametralmente dispuestas. El estudio del soleamiento, para la apropiada iluminación natural y protección solar. En la composición de las nuevas fachadas dominaba el hueco sobre la pared ciega, con persianas enrollable-abatibles o parasoles, para evitar las sombras perjudiciales, controlar la intensidad de la luz y la incidencia del sol, en función de la hora del día y de la orientación del aula. Las cortinas interiores colaboraban a dicho control de confort. La deseable relación entre superficie de iluminación y superficie pavimento se establecía en $1 / 3$, en comparación con las antiguas ordenanzas constructivas que fijaban un mínimo de 1/5.

\footnotetext{
${ }^{1184}$ MOSER, Werner M. (1933): «La escuela como construcción funcional» en A.C. 9. Revista Trimestral. Publicación del G.A.T.E.P.A.C. (1933), Año III. Barcelona. Madrid. San Sebastián. pp. 23-24.
} 
He aquí la comparación que se hace entre un aula mal iluminada y un aula con una buena iluminación que tenía en consideración los últimos conocimientos en materia de higiene y técnica constructiva:

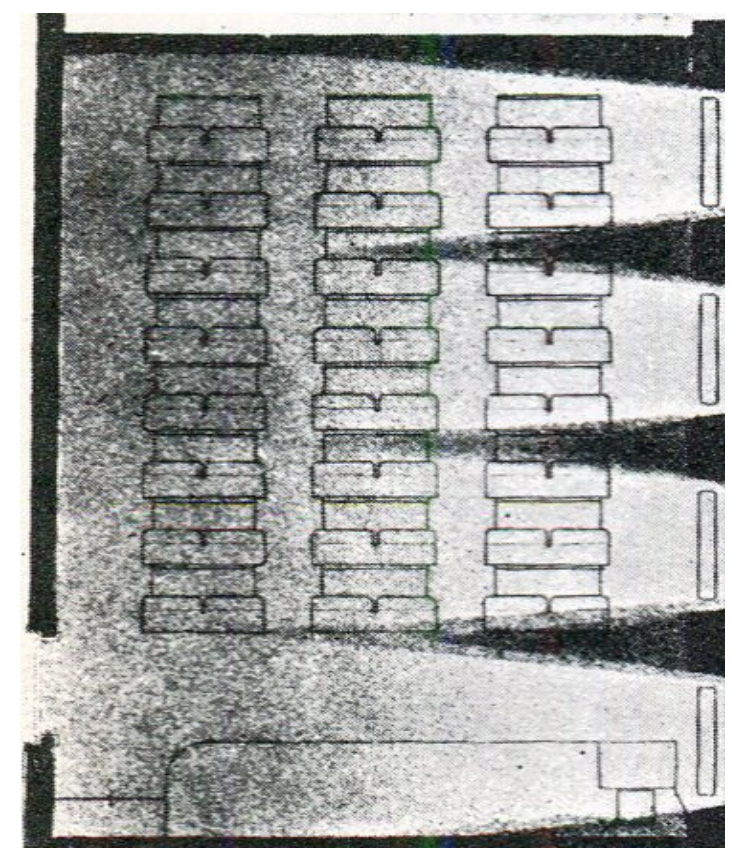

Iluminación defectuosa de una clase. Fuente: Moser, Werner M. (1933): «La escuela como construcción funcional» en A.C. 9. Revista Trimestral. Publicación del G.A.T.E.P.A.C. (1933)

- El contraste constante de la clara superficie vidriada, y los espacios obscuros de los pilares, fatiga la vista.

- Gran pérdida de luz hacía el fondo.

- La reducida altura del dintel de la ventana, obscurece el techo y disminuye la entrada de luz.

- El antepecho, más alto que las mesas sugiere al niño, la sensación de estar aprisionado.

- Una parte de las mesas, cae inevitablemente bajo la sombra arrojada por los muros que hay entre las ventanas. 


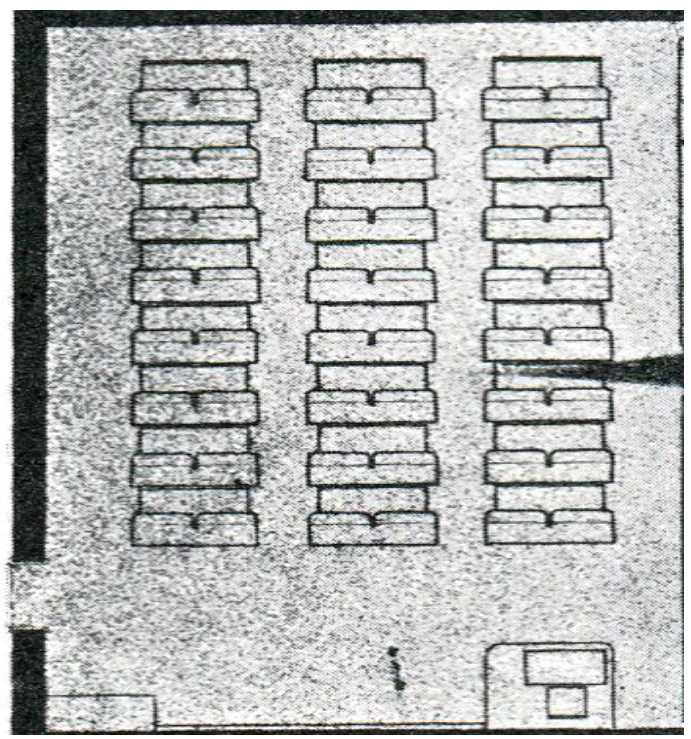

Clase con buena Iluminación. Fuente: Moser, Werner M. (1933): «La escuela como construcción funcional» en A.C. 9. Revista Trimestral. Publicación del G.A.T.E.P.A.C. (1933)

- La gran superficie vidriada proporciona luz uniforme y abundante.

- La ventana rasgada hasta el techo lo ilumina perfectamente, y hace penetrar luz hasta el fondo de la clase.

- La mínima altura del antepecho, sugiere la impresión de libertad y espacio.

A continuación se muestra la distribución de los pupitres según el patrón del aula antigua y la nueva disposición.

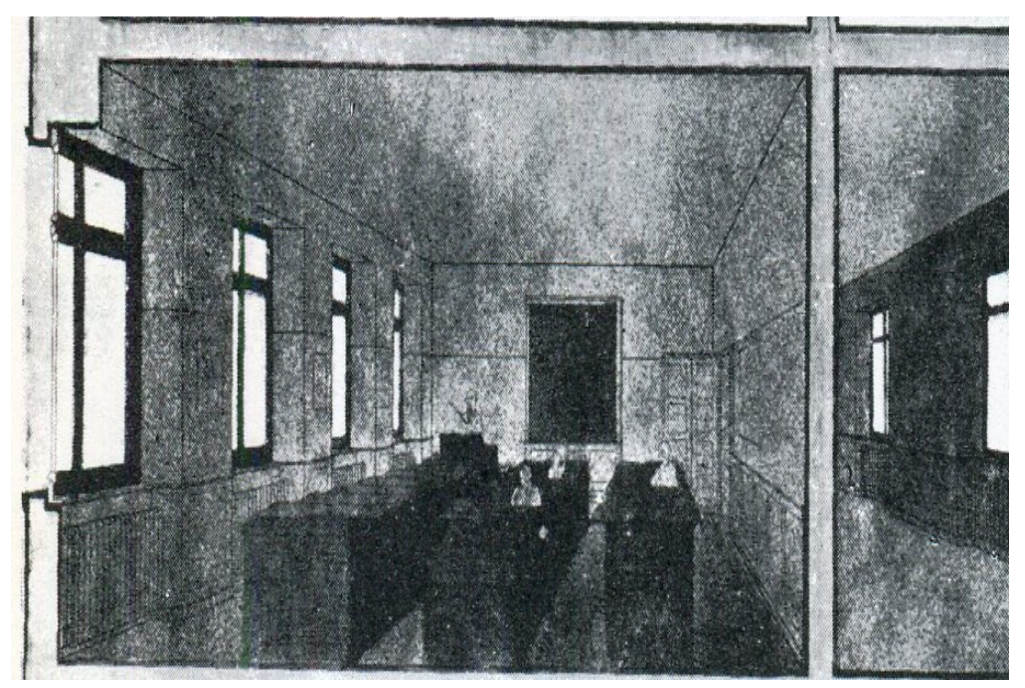

Disposición anticuada. Sistema rígido de pupitres. Fuente: Moser, Werner M. (1933): «La escuela como construcción funcional» en A.C. 9. Revista Trimestral. Publicación del G.A.T.E.P.A.C. (1933)

- Las mesas y pupitres fijos.

- Posibilitan solamente una única disposición de los alumnos y el profesor. 
- Excluye diversos aprovechamientos de la clase para otros fines.

- La inclinación del plano superior del pupitre excluye la posibilidad de otros usos (como trabajos manuales, juegos, etc.), excepto leer y escribir.

- La clase de forma alargada y con iluminación unilateral: Obliga a una gran separación entre los estudiantes y la pizarra; separa a los alumnos del profesor y entre sí; proporciona la luz clara y sin sombras, solamente en un sentido.

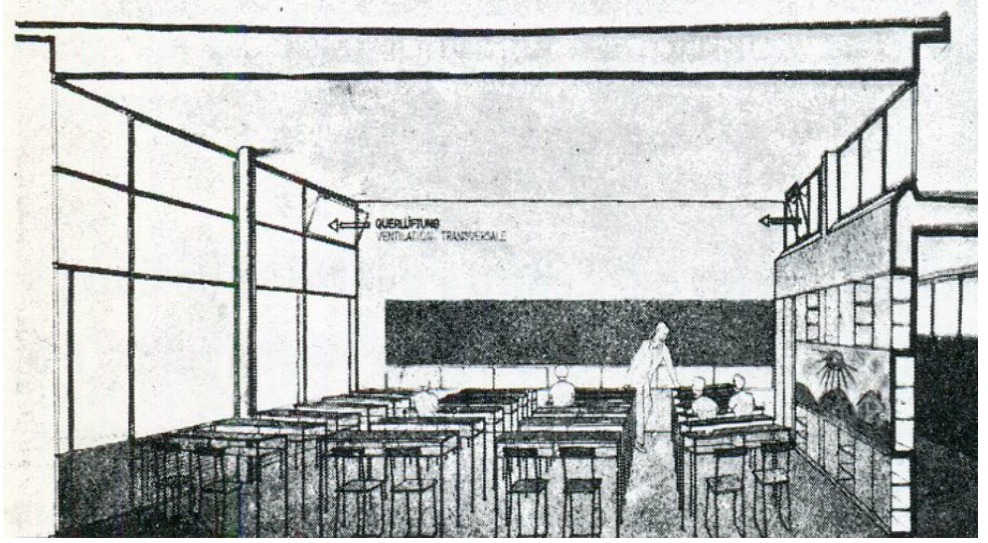

Moderno sistema de mesas y sillas libres, iluminación bilateral y ventilación cruzada. Fuente: Moser, Werner M. (1933): «La escuela como construcción funcional» en A.C. 9. Revista Trimestral. Publicación del G.A.T.E.P.A.C. (1933)

- Posibilita numerosas disposiciones según la actividad que haya de desarrollar el alumno, y a juicio del profesor.

- La superficie horizontal de las mesas proporciona las máximas facilidades para variadas clases de trabajo.

- La forma casi cuadrada de la clase, con iluminación bilateral es la aspiración de los pedagogos modernos, ya que: permite el mayor número de variaciones en la disposición de las mesas y las sillas; posibilita una mayor agrupación entre alumnos y con el profesor; la pizarra queda más próxima para todos los alumnos; proporciona para todos, luz clara y abundante. ${ }^{1185}$

Los importantes avances que se alcanzaron en higiene escolar en este corto periodo, no fueron superados en décadas.

\footnotetext{
${ }^{1185}$ Ibídem, p.23.
} 
Hoy día, los centros educativos se ajustan a la Ley 1/1990 de 3 de octubre, de Ordenación General del Sistema Educativo-LOGSE. Se establece para alumnos de ESO, aulas con capacidad máxima para 30 alumnos, con una superficie de $50 \mathrm{~m}^{2}$, y dimensiones aproximadas $8 \times 6,5 \mathrm{~m}$. Para alumnos de bachillerato, el aforo máximo es de 35 alumnos, la superficie de $55 \mathrm{~m}^{2}$, con dimensiones similares. Y una altura mínima de suelo a techo de 3,15 m. Cumpliéndose en los dos casos una relación de 1,6 m²/alumno. El mobiliario es móvil y constructivamente se exige la adecuada orientación de las aulas, el confort en la iluminación y protección solar, la ventilación cruzada y las clases al aire libre para párvulos. Podemos observar también como los parámetros de las aulas del Instituto Escuela, construido a finales de la década de los veinte, y los actuales centros escolares son similares en aforo, geometría, dimensiones y relación de ocupación.

A lo largo del primer tercio del siglo XX los estándares higienicos se van mejorando, teniendo su punto álgido en la República. Sin embargo, los actuales centros escolares de primaria y secundaria han mejorado extraordinariamente en equipamiento: laboratorios, talleres, aulas de apoyo, seminarios, despachos para el profesorado, biblioteca, gimnasio, campos deportivos y espacios de esparcimiento.

\section{LOS TRATADOS DE HIGIENE Y LA EDUCACIÓN SANITARIA EN LA ESCUELA}

En los últimos años del siglo XIX y principios del XX proliferaron los tratados de higiene para uso de las escuelas, escritos por médicos, que guiados por su vocación higienista, colaboraban con los maestros para ayudarles a completar su misión docente. Entre ellos figura el libro escrito por el doctor Juan Rosado Fernández en 1913. ${ }^{1186}$

Otro móvil que impulsaba a escribir éstos tratados era la convicción de que el problema nacional de falta de higiene en las escuelas, era un problema de educación, que tenían que solucionar la escuela, las madres y la sociedad.

Se perseguía la educación integral, es decir, la educación del cuerpo y del alma. La iglesia con su doctrina cristiana daba el carácter ortodoxo a la educación.

\footnotetext{
1186 ROSADO FERNÁNDEZ, Juan. (1913): Tratado Enciclopédico de Higiene y Terapéutica Escolar, Doméstica y Social, Tipografía de G. Casañal, Zaragoza. pp. 2-4.
} 
En los viajes que realizaban estos profesionales observaban la falta de higiene de las escuelas.

En algunos pueblos la escuela de niñas estaba instalada en la cuadra de un antiguo mesón sin luz ni ventilación «que las provenientes de un inmundo patio, en donde había una aljibe de unos diez metros de profundidad, con agua putrefacta en el fondo y sin un brancal en condiciones de proteger la vida de las alumnas». No había retretes ni urinarios. Y los dueños de los locales se negaban a subsanar los defectos higiénicos de los que adolecían dichos locales.

En la mayoría de los inmuebles escolares no había evacuatorios y, si existían, carecían de agua de inodoros, de desagüe higiénico, etc. y la construcción, orientación, iluminación, etc., de los mismos dejaban mucho que desear. Los muebles escolares eran antiguos y poco limpios. ${ }^{1187}$

Sin embargo, muchos colegios privados poseían patios para los ejercicios físicos, jardines, enfermería, local de aislamiento para los infecciosos, cuartos de baño y duchas, sistema evacuatorio completo, moblaje y material de enseñanzas excelente.

Las Juntas de Sanidad y de Instrucción no se constituían o no funcionaban y casi todas se hallaban supeditadas a la voluntad de los alcaldes.

Las escuelas carecían de material desinfectante decretadas por la ley de Sanidad, «y cuando los niños sufren un contagio se confía en que la Providencia velará porque no se propague a los demás».

Otro defecto que señalan los médicos, era que en ninguna población se verificaba la inspección médica.

Ante estas circunstancias expuestas, la asistencia a las escuelas no era grata con lo cual aumentaba el absentismo en las aulas. Como consecuencia de todo ello los niños estaban más atrasados en el curriculum académico y se contagiaban de enfermedades en los centros escolares. ${ }^{1188}$

El objetivo final que pretendía en su tratado el doctor Rosado, era que en las escuelas públicas, normales, seminarios, institutos, colegios particulares y domicilios familiares se crearan costumbres sanitarias. La moral era una parte integrante y fundamental de la higiene.

\footnotetext{
${ }^{1187}$ Ibídem, pp. 11-14.

${ }^{1188}$ Ibídem, pp. 15-17.
} 
Es curioso que este autor abogue por que el Estado implantara los tribunales para juzgar a los niños delincuentes, «cuya corrección debe tener lugar pedagógicamente en granjas o colonias agrícolas regidas por un médico, un sacerdote y un maestro». ${ }^{189}$

Relacionado con la salud y la higiene de los niños se recomendaban las excursiones rurales, según exigía las Reales órdenes del 29 de julio de 1883 y 1 de abril de 1890. La primera disponía que se excitara a las Juntas de Instrucción pública y las locales de primera enseñanza, para que recomendaran a los maestros y maestras que se esforzaran en inspirar a los niños sentimientos de protección para con los animales y las plantas como medio de cultura y conveniencia pública. Por la segunda Real Orden se convocó un concurso para premiar trabajos, que aportaran a las escuelas carteles, muestras, cartillas y libros, en que figuraran máximas y enseñanzas relacionadas con la agricultura, mejora del cultivo y protección a los animales útiles. ${ }^{1190}$

Los niños debían respirar el aire puro del campo, admirar su panorama, exponerse a la luz diáfana, y tomar el sol sin molestos interceptores como las sombrillas, que debían ser sustituidas por sombreros de paja, esparto o paja, y «solazarse con el infinito número de prodigios higiénicos, o de otras clases, que la naturaleza ofrece de una manera intuitiva y real.»

Los niños debían, sin esfuerzo intelectual, aprender en las excursiones, el valioso e indispensable concurso que para la vida prestan los vegetales y los animales. Las excursiones rurales debían servir para desarrollar la observación, para aprender a tener buen humor, a despertar el amor a la naturaleza, a resistir a la fatiga, etc. ${ }^{1191}$

La necesidad de educar a la población sobre asuntos que tienen que ver con el manejo de la salud y la enfermedad no fue una novedad sobrevenida con la llegada del siglo XX pero durante el primer tercio de este siglo se produjo la incorporación a esta tarea de medios de comunicación de masas como el cartelismo, el cine y la radio. Hasta entonces las conferencias, las charlas y los escritos habían sido los canales habituales. En el caso de estos últimos se puso especial énfasis a partir de la Ilustración y fue una constante durante todo el siglo XIX. Con la llegada del nuevo siglo y la necesidad de regeneración que se instaló en la sociedad española hubo varios intentos de organizar unos servicios sanitarios que tratasen de afrontar con éxito las deficientes condiciones

\footnotetext{
${ }^{1189}$ Ibídem, p. 32.

${ }^{1190}$ Ibídem, pp. 301-309.

${ }^{1191}$ Ibídem, p. 329.
} 
de salud percibidas por las autoridades, profesionales sanitarios, y diferentes entidades. En este marco, en el que la Instrucción General de Sanidad de 1904 fue la norma más sobresaliente, casi todos los intentos de dinamizar el panorama sanitario español trataron de fomentar la educación sanitaria de la población. Así, por ejemplo, la circular de 7 de mayo de 1901, sobre «Precauciones individuales sobre el paludismo» instaba a las autoridades de los pueblos pantanosos que difundieran algunas advertencias para hacer frente a la enfermedad del paludismo. ${ }^{1192}$

Que los alcaldes, médicos, curas y maestros de escuela de los lugares pantanosos difundan estas sencillas y muy contadas advertencias entre sus paisanos, con bandos, consejos, pláticas y lecciones y estén seguros que contribuirán a velar eficazmente por la salud pública de la comarca, que es siempre la primera de sus riquezas.

En el mismo sentido la circular del 4 de octubre de 1901 de la Dirección General de Sanidad sobre lucha antituberculosa al insistir en la importante dimensión de la enfermedad señalaba, que urgía difundir los conocimientos elementales acerca de cómo se produce el contagio y los medios de evitarlos y para conseguir este objetivo, los folletos, los artículos en la prensa periódica, las conferencias públicas, eran los medios de popularización a los que convendría recurrir. ${ }^{1193}$

En cuanto a la educación sanitaria en la escuela, se consideraba que el maestro debía tener conocimientos de higiene escolar y no solo los métodos y procedimientos de enseñanza, pues la falta o descuido del maestro podía dar origen a un trastorno que alterara la salud del alumno para toda la vida.

El carácter que debía revestir en las escuelas la enseñanza de la higiene debía tener carácter experimental y práctico. El maestro debía relacionar la Higiene con los conceptos de la fisiología, y no dar conocimientos mediante fórmulas escuetas redactadas en forma de máximas.

\footnotetext{
1192 PERDIGUERO, Enrique y otros (2007): «La propaganda sanitaria en España en la II República: La Sección de Higiene Social y Propaganda de la Dirección General de Sanidad», en Campos, Ricardo y otros (Coord.): Medicina, ideología e historia en España (siglos XVI-XXI), CSIC, Madrid. pp. 303-304.

${ }^{1193}$ Ibídem, p 305.
} 
El carácter que requiere en la escuela la cultura higiénica, tiene gran analogía con el que exige la cultura moral, que, al cabo, no es otra cosa, que una verdadera higiene del espíritu. Empeñarse en suministrar estas dos culturas de la manera abstracta que suponen las lecciones aprendidas de memoria en los libros o las máximas que a modo de formulario de recetas se ostentan, en las paredes de las clases, es desconocer la índole de ambas materias y las exigencias de toda buena educación y convertir en enseñanzas muertas las que más que ningunas otras deben ser enseñanzas vivas que den por resultado el hombre sano física y moralmente. Así entendida la enseñanza de la higiene en la escuela, puede ejercerse una influencia fecunda, no solo por lo que a los escolares respecta, sino también por lo que a las costumbres públicas atañe. ${ }^{1194}$

En los libros de higiene se destacaba la importancia del material de enseñanza por sus implicaciones en la salud del órgano de la vista. Se aconsejaba que el color del papel de los libros de lectura debiera ser amarillento o agarbanzado como más aventajado para la conservación de la vista. El papel muy delgado resulta también perjudicial porque hace el texto confuso. Los demás requisitos se refieren a los tipos de letra y a la longitud de las líneas, pues «la excesiva pequeñez de los caracteres de los libros de clase, es causa de una miopía.» La tinta para escribir, a la que mejor se acomoda la vista es la negra.

Se aconseja los encerados de pizarra por ser los que menos reflejos producen, en lugar de los de madera, que son nocivos para la vista. Los mapas y globos terrestres, las láminas y otros cuadros murales de las clases debían evitar el abigarramiento y los contrastes muy pronunciados de colores, la demasiada distancia y la mala colocación, la aglomeración y la confusión, etc., todo puede redundar en perjuicio de la vista de los escolares y debía colocarse de manera que no perjudicara a la vista de los escolares. ${ }^{1195}$

Se considera también importante para la salud de los escolares las excursiones y las colonias de vacaciones. Estas últimas que tuvieron su origen en Suiza y que fue importada más tarde a Alemania y Austria se generalizó en otros varios países. El nombre de colonias escolares de vacaciones, se dio a la residencia en los mejores lugares de la montaña o cerca del mar, durante los meses de verano, de los niños débiles

\footnotetext{
1194 RODRIGUEZ LÓPEZ, Isaac (1915): Apuntes de Higiene General comprendiendo la Higiene -Escolar, Tipo-Litografía Auber y Pla, Barcelona. P.122.

1195 Ibídem, pp. 164-165.
} 
o convalecientes que asistían a las escuelas urbanas y pertenecían familias poco acomodadas.

El resultado que se obtenían de estas colonias, desde el punto de vista de la salud y el desarrollo físico de los niños cuando regresaban a su hogar era muy positivo.

En España recibieron gran impulso las colonias escolares de vacaciones desde que en 1887 las inició el Museo de Instrucción primaria. Muchos ayuntamientos de capitales importantes las protegieron y las subvencionaron.

El maestro debía también tener algún conocimiento de cómo recoger los datos antropométricos, como la talla, el peso, la circunferencia torácica, las pulsaciones, sensibilidad táctil, agudeza visual y agudeza auditiva. ${ }^{1196}$

En 1882 aparece el libro Higiene de las Escuelas del médico de Albocacer (Castellón), Joaquín Chillida Meliá, ${ }^{1197}$ siendo una de las primeras obras que aparece en el mundo científico y que según el autor venía a ocupar un vacío en el terreno de la higiene.

Según este autor, los establecimientos de enseñanza habían ganado mucho en mejoras materiales, en grandiosas construcciones y lujoso mobiliario, pero no se cuidaba que el edificio y el mobiliario cumplieran las debidas reglas higiénicas, para asegurar la salud y contribuir al mayor desarrollo físico y moral, de los niños y las niñas.

Chillida Meliá denuncia que la gimnasia se realizaba por puro pasatiempo o recreo y no con fines higiénicos, que tanto beneficios reportaría a los niños.

En las escuelas, se obligaba a los niños a estudiar con luz artificial horas seguidas, «exponiendo a los niños a verdaderas catástrofes morbosas».

En los colegios de «señoritas» sucedía otro tanto con respecto a las labores. Las directoras, desconocían la gravedad que podía reportar a las alumnas cierta clase de bordados que podían estropear el órgano de la vista.

Lo mismo sucedía en las escuelas públicas y privadas de instrucción primaria, los libros de texto, carteles, mapas, etc., todos estos objetos eran enseres detestables bajo el punto de vista higiénico, «reclamando urgentes reformas, si no se quiere perjudicar la salud de los débiles seres que a ellas acuden.»

\footnotetext{
1196 Ibídem, pp. 166-169.

${ }^{1197}$ CHILlidA MELIÁ, Joaquín. (1882): Higiene de las escuelas, Centro editorial de la Asociación Tipográfica, Castellón. Licenciado en Medicina y Cirugía. Subdelegado de Sanidad, premiado por la Universidad de Valencia y el Instituto del Real Colegio de San Pablo. pp. 2-4.
} 
Según Chillida, se enseñaba a todos de la misma manera, sin pensar que los estudios de primera y aún los de segunda enseñanza, «no tienen por objeto la instrucción del individuo, sino, en la mayor parte, la preparación de la inteligencia, dándole un grado conveniente de desarrollo para superiores estudios».

El objetivo del libro era que fuera una guía fiel, un eco de la ciencia, que marcara las condiciones higiénicas de los establecimientos de enseñanza y de sus enseres; de los diversos departamentos de los mismos; y que al mismo tiempo, diera ligeras nociones de las facultades intelectuales, y de las reglas o preceptos oportunos para su desarrollo y perfección.

La obra iba destinada a los que no tenían noción del «arte higiénico», el autor, no emplea un lenguaje técnico, «por lo que más bien que un libro científico, es un conjunto de principios y preceptos expuestos con la mayor claridad y sencillez, para que puedan ser comprendidos intuitivamente, siendo de inmediata aplicación práctica».

Da frecuentes nociones de anatomía y fisiológica, «sin las que se haría confuso el texto, y sobre las que apoyo todas mis decisiones higiénicas». ${ }^{\mathbf{1 1 9 8}}$

\section{SITUACIÓN DEPLORABLE DE LA ENSEÑANZA Y DE LA HIGIENE EN LAS ESCUELAS PÚBLICAS DE CASTELLÓN A FINALES DEL SIGLO XIX}

En los años de estudio la política sanitaria de Castellón era bastante descuidada. La prensa consideraba de vital importancia atajar la falta de higiene ciudadana.

Uno de los aspectos en que más incide la prensa, de finales el siglo XIX, es la falta de condiciones higiénicas de los locales de las escuelas y la repercusión de esta circunstancia en la salud de los niños.

Ya en 1877 aparecen enunciados en la prensa los principales elementos de la higiene escolar: el aire, la luz, el material de las escuelas y los ejercicios moderados del cuerpo y del espíritu.

Las nefastas condiciones de higiene motivarían que en la población escolar se produjesen diversas epidemias como la viruela, el sarampión, el cólera y la difteria.

\footnotetext{
${ }^{1198}$ Ibídem.
} 
En muchas ocasiones la Junta Local de Sanidad optó por el cierre de las escuelas como en la gran epidemia del sarampión en $1883 .^{1199}$

En dicho año aparece reseñada por primera vez en la prensa la vacunación gratuita en la casa Ayuntamiento como medida profiláctica contra la viruela; y en 1884 la Junta Local de Sanidad decidió exigir a todos los alumnos de las escuelas de Castellón el certificado facultativo de haber sido vacunados en el caso de ser menores de siete años o revacunados en el caso de haber cumplido dicha edad. ${ }^{1200}$

Las escuelas públicas para niños y niñas eran locales donde la escasez de medios e infraestructuras se reflejaba en los aseos, mobiliario y en las propias condiciones de los edificios, además del hacinamientos en el que los niños estaban en las aulas y que analizaremos más adelante con algunos ejemplos concretos.

La prensa denunciaba que ninguna escuela municipal tenía la debida ventilación, distribución y capacidad para el contingente de alumnos que asistían a ellas. Los niños sufrían los rigores del calor en verano y del frío en invierno.

No hay en todo Castellón, triste es decirlo, ni siquiera una escuela municipal que tenga la debida ventilación, distribución y capacidad para el contingente de alumnos que a cada uno de ellas asisten. Casi podemos afirmar, sin temor a ser desmentidos, que difícilmente pueden contener de pie a los niños que, por rara coincidencia y quizá con una sola excepción, sufren todos los rigores del calor en verano y del frío en invierno, precisamente por la indicada falta de ventilación y confort. ${ }^{1201}$

La escuela del Hospital, según asegura La Provincia, parecía un «hediondo calabozo», declarada en estado ruinoso, era una constante amenaza para la vida del profesor y de los niños. «El ayuntamiento tiene en el más completo abandono una de sus primeras y más sagradas obligaciones».

También recomendaba al Ayuntamiento suprimir gastos superfluos, fomentar los ingresos, y destinar el producto que de ambas operaciones resultara a mejorar el local de

\footnotetext{
1199 AGUILAR RÓDENAS, Consol. (1986): La educación en Castellón a través de la Prensa (1868-1900), Diputación de Castellón, Castellón. pp.. 78-79.

${ }^{1200}$ La Defensa, 25/2/1883, citado por Aguilar Ródenas, op. cit. p. 79.

${ }^{1201}$ La Provincia, 20/12/1885.
} 
todas las escuelas municipales, dotándolas de aquellas condiciones que «la higiene reclama y la pedagogía recomienda» ${ }^{1202}$

Cuando se abría una escuela, el arquitecto municipal inspeccionaba la seguridad del local y la ventilación e higiene del mismo. Ya en 1881 el arquitecto municipal, Godofredo Ros de Ursinos, puso en conocimiento del Ayuntamiento el estado ruinoso y alarmante en que se encontraba el edificio destinado a escuela pública de niños del Hospital a cargo de don Eduardo Requena. El alcalde dispuso que se repararan los desperfectos que se observaran para conseguir la seguridad del mismo, evitando las desgracias que por abandono podían originarse; presentó la relación justificada de los gastos que se iban a ocasionar y ordenó la demolición y reedificación del edificio escuela en el mismo sitio que ocupaba. ${ }^{1203}$

La prensa de Castellón hacía hincapié en la necesidad de atender a la difusión de la primera enseñanza en la capital y la urgencia de que se crearan escuelas de ambos sexos en los barrios conocidos con los nombres de la Trinidad y San Félix.

Algunos vecinos de Castellón dirigieron un escrito al Ayuntamiento pidiendo que se aumentara el número de escuelas existentes, y se atendiera especialmente a la necesidad urgente de crear algunas en los arrabales a fin de facilitar la instrucción primaria a los niños de ambos sexos que en los mismos habitaban: «Que la creación de escuelas en los barrios extremos de Castellón es necesaria, es una verdad indudable; que el Ayuntamiento debe atender a dicha necesidad, lo es también, y no caben excusas fundadas en razones económicas, es para nosotros evidente». Y a continuación exponen algunas consideraciones del bajo nivel de la cultura intelectual de los habitantes de los barrios aludidos.

En estos centros docentes se establecían colegios electorales cuando se había de renovar parte del Municipio, y en algunas ocasiones, cuando la extensión del sufragio lo exigía, para las elecciones de diputados provinciales o para los representantes del pueblo en el Congreso. En muchas ocasiones el Ayuntamiento tenía que enviar auxiliares a las mesas porque las que las constituían eran incapaces de extender con claridad los nombres de los votantes.

Este hecho, acusa un gran abandono por parte de los municipios anteriores, que no han mirado con el debido interés la difusión de la instrucción primaria, base

\footnotetext{
${ }^{1202}$ La Provincia, 20/12/1885.

1203 AACS. 5/02/1881.
} 
de la verdadera moralidad, ni han atendido como era su deber proporcionar a sus administrados medios convenientes para salir de aquel estado de ignorancia, con la creación de centros de instrucción, y al propio tiempo demuestra el escasísimo interés que por la adquisición de la misma han tenido los habitantes de los mencionados barrios. Y no se crea que sea brillante la ilustración de los que viven en los restantes, la instrucción no está mucho más extendida en los demás barrios extremos, en los que no creemos que lleguen al diez por ciento los que saben leer y escribir. $^{1204}$

En una conferencia que dio el profesor del Instituto Provincial, Pedro Aliaga, ${ }^{1205}$ en el Casino de Artesanos, explicó las diferentes causas que influyen para que Castellón no estuviera a la altura que debiera en cuestión de higiene, comparando las cifras de mortandad en los diversos países de Europa con las de España y Castellón que «arrojan datos que dicen bien poco en pro de nuestra ciudad».

Aliaga hizo observar las deficiencias que tenían las escuelas públicas, no solo para la enseñanza, sino también para la salud de los niños que a ellas concurrían. En su discurso alentó a los oyentes a llevar a cabo un esfuerzo supremo con el fin de construir algún local adecuado destinado a la primera enseñanza. ${ }^{1206}$

Según la prensa, el médico Pedro Aliaga, realizó un detenido estudio de la situación de las escuelas en Castellón, lamentándose del abandono en que se encontraba la educación de la infancia, del escaso número de escuelas que había en la población, y de las pésimas condiciones de luz y capacidad de las mismas, de «donde resulta que son un peligro constante para la vida de la niñez»: «Con esta ocasión prorrumpió el orador en quejas conmovedoras que hicieron honda impresión en el público. La concurrencia salió sumamente complacida, tributándole calurosos aplausos». ${ }^{1207}$

En una segunda conferencia en el mismo centro social, insistió que a pesar del buen clima, Castellón es de las poblaciones de España en que la cifra de la mortalidad es más espantosa, llegando a la enorme proporción de treinta y cuatro por mil el número de las defunciones anuales, y siendo los niños de corta edad los que pagan mayor contingente a una muerte prematura. ${ }^{1208}$

\footnotetext{
${ }^{1204}$ La Provincia, 10/01/1886.

${ }^{1205}$ Pedro Aliaga era médico y profesor de Ciencias del Instituto de Enseñanza Media Francisco Ribalta.

${ }^{1206}$ El Clamor, 8/12/1888; La Provincia, 13/12/1888. Ver Apéndice Documental: № 21.

${ }^{1207}$ La Provincia, 13/12/1888.

${ }^{1208}$ Ibidem. Ver Apéndice Documental No 22.
} 
El 17 de enero de 1889 se publica en el periódico La Provincia, un artículo sobre «La Escuela Moderna» en el que se defienden los cambios propugnados por dicha escuela, tanto en el orden pedagógico como en el higiénico.

En dicho artículo se hace hincapié en las ventajas que reporta la escuela moderna en cuanto sustituye el aspecto triste de cárcel sombría y sus prácticas inquisitorias, por una escuela que hace más agradable la estancia de los niños y niñas en la escuela, según el sistema educativo de Montessori.

También se cita a Froebel cuando expresa que las mujeres son más idóneas para inculcar a los niños el amor a las personas encargadas de comunicarles los primeros conocimientos.

Se resalta el cambio sufrido por el material de la escuela, así como la arquitectura escolar, con salones amplios, bien ventilados y con luz, que sustituían a los estrechos y lóbregos recintos donde los escolares se apiñaban. Así, en la escuela moderna tiene tanta importancia la educación intelectual, como el desarrollo físico y la salud de los niños.

Sigue diciendo el articulista que en España, aunque se viene realizando lentamente este progreso, no basta para que se siga lamentando la falta de higiene en las escuelas de párvulos.

Comenta el periódico La Provincia que el mejor medio para atender las necesidades de la escuela moderna y para dotarla de las condiciones necesarias, es la creación de Cajas escolares como en Francia. Estas Cajas recibían ingresos de donativos particulares y de subvenciones del Ayuntamiento y del Estado. Sus fondos se destinaban a la asistencia de las escuelas, recompensas pecuniarias a los alumnos aplicados, y al socorro de los más pobres. ${ }^{1209}$

El 1 febrero de 1889 se reunió en el Casino de Artesanos numerosa concurrencia para mejorar las escuelas de la capital. Esta reunión fue convocada por Pedro Aliaga y había representaciones de la mayoría de las opiniones políticas de la capital:

[...] y nos congratulamos en alto grado de que así haya sucedido, pues al obrar de tal modo se ha demostrado el interés que inspira la educación de la juventud castellonense a los hombres que tienen el deber de patrocinar uno de los

${ }^{1209}$ La Provincia, 17/01/1889. Ver Apéndice.Documental No 23. 
primeros elementos del adelanto y bienestar de los pueblos, como lo es sin duda alguna la enseñanza elemental.

Aliaga en su discurso expuso la necesidad urgente de poner fin al abandono en que se encontraba la enseñanza en la capital, recabando para ello todas las mejoras que según la ley de 1857, la ley Moyano, y demás disposiciones vigentes, tenía derecho a pedir Castellón, tanto en lo referente al número de escuelas, como a las condiciones higiénicas y pedagógicas de las mismas; reproduciendo para aumentar el convencimiento del auditorio las notas estadísticas consignadas en la exposición por el profesor Germán Salinas. ${ }^{1210}$

La última parte del discurso de Aliaga estuvo encaminada a disipar las dudas que habían surgido respecto al carácter que tendrían las nuevas escuelas, manifestando que éstas tendrían las mismas características que las que costeaba hasta entonces el Ayuntamiento de Castellón « [...] pues habiendo de ser oficial la enseñanza que en ellas se diere, no podían en manera alguna dejar de estar sometidas a la legislación vigente las nuevas escuelas que al Ayuntamiento se solicitan». ${ }^{1211}$

El Acta se firmó por todos los concurrentes, entre ellos, además de Aliaga y Salinas, firmaron también: Hipólito Fabra, Francisco González Chermá, (jefe de los republicanos castellonenses), Vicente Ruiz Vila, José Antonio Balbás, Fernando Gasset, Antidio Desbertrand, (médico y profesor del Instituto), Vicente Sos, (padre del geólogo Vicente Sos Baynat), entre otros.

El periódico La Provincia, después de felicitar a todos los autores del proyecto, reiteró su adhesión para el mejoramiento en la ciudad de la enseñanza oficial.

\footnotetext{
${ }^{1210}$ Germán Salinas era profesor de Retórica del Instituto Provincial de Castellón.

${ }^{1211}$ En algunas conferencias dadas en los centros de sociabilidad de Castellón los profesores del Instituto de Enseñanza Media, Pedro Aliaga y Germán Salinas, se confesaron abiertamente partidarios de la Escuela neutra o laica.
} 
servicio público que mejor indemniza de los gastos que produce y uno de los sacrificios que mejor recompensados ha de ver nuestro Ayuntamiento. ${ }^{1212}$

En años posteriores siguió la lucha para la mejora de las escuelas y la salud. Un ejemplo lo tenemos en 1909 cuando se celebró en el salón de actos del Instituto General y Técnico, una asamblea para pedir al Gobierno mejoras en la enseñanza y sanidad.

El acto revistió excepcional importancia por las representaciones que a la asamblea concurrieron, viéndose en el salón a muchísimos castellonenses. La presidencia de la asamblea recayó sobre el maestro Eleuterio Pérez Solernou, asistiendo también el maestro Carlos Selma; Benjamín Ballester, auxiliar de las Escuelas públicas de Castellón, que dio lectura a unas cuartillas en las que se hacía constar la adhesión de la Asociación Provincial del Magisterio público; el director del Heraldo de Castellón José Castelló y Tárrega; en representación de la Liga contra la Ignorancia, el doctor Vicente Gea y el catedrático del Instituto José Albiñana Mompó. A la Asamblea acudieron también importantes personajes de Valencia como Francisco Moliner, hijo y Juan Bautista Guillén, presidente de la Casa del Pueblo de Valencia.

En todos los discursos los oradores hicieron resaltar el estado deplorable de la enseñanza y la necesidad que había de crear nuevos centros, mejorando los que ya había, aumentando el material científico, dotando mejor al profesorado y haciendo que se coloque en España la instrucción a la altura de las naciones europeas.

Hablaron asimismo de lo que eran las escuelas públicas en España y de la poca consideración y estima que se tenía del maestro, sujetándole a instruir a los niños en locales insanos donde no hay ni sol ni aire y con una remuneración irrisoria y vergonzosa.

Se trató también por varios oradores del estado de higiene en España, del estado de las viviendas, los asilos y los hospitales.

Como resultado del acto se aprobaron por aclamación las siguientes conclusiones: adherirse a los acuerdos adoptados en la Asamblea de la Casa del Pueblo de Valencia, pidiendo al Estado la realización de un empréstito de 100 millones para la cultura y sanidad; recomendar a los jefes de todos los grupos parlamentarios que presentaran y defendieran un proyecto de ley encaminado a conseguir esa aspiración

\footnotetext{
${ }^{1212}$ La Provincia, 7/02/1889.
} 
para mejorar la patria, y nombrar una comisión para, que junto con otra de Valencia y Alicante, entregara al jefe del Estado, en un viaje que tenía que hacer a Valencia, un mensaje pidiendo el mencionado empréstito. ${ }^{1213}$

El periódico El Clamor acudió a la asamblea porque, según afirmaba «España está necesitada de cultura e higiene, cuanto se haga porque el analfabetismo desaparezca y la salud se disfrute, bien merece el apoyo y el entusiasmo de los hombres amantes de la humanidad.» 1214

En otro artículo de El Clamor, titulado «Sinceridades», el autor, Enrique Dávalos Segarra, afirma que el derecho de petición es «como un arma sin municiones o la Carabina de Ambrosio», porque no implica en los poderes públicos el deber de hacer caso a lo que se pide, aun cuando sea universalmente reconocido como justo y necesario para el mejoramiento de todas las condiciones sociales.

Más adelante añade, haciendo referencia a Joaquín Costa en 1898, que todo el pueblo culto sabe de memoria que la «instrucción, la despensa y la higiene, son la trinidad de la educación integral en que se basa toda grandeza y todo progreso.»

[...] el pueblo culto español no pide más que eso ¿y qué se ha conseguido? Votar 200 millones para la construcción de una escuadra que ya bastante antes de hacerse a la mar aparece envuelto en la densa niebla de inmoralidades sin fin.

No esperéis que se os atienda. No hay nada tan revolucionario como instruir. Instruir es emancipar conciencias, despertar las facultades críticas en el campo de las especulaciones científicas y fomentar la duda cuando menos en materia religiosa $¿ \mathrm{Y}$ creéis vosotros ilusos, que os va a dar todo esto un régimen en cuyo poder se turnan varios gobiernos de jesuitas y palaciegos? ${ }^{1215}$

En 1910, El Clamor se hace eco de lo que decía el ministro de Instrucción pública acerca de los locales donde se daba la enseñanza a los niños en ciertos pueblos. Había escuelas donde los niños y niñas no podían entrar hasta que no sacaran las bestias que iban a pastar; escuelas tan reducidas que apenas hacía algo de calor se producían desvanecimientos por escasez de aire y falta de ventilación; otras eran depósito de estiércol en fermentación, «y se le ocurre alguna autoridad local decir qué de esta suerte

\footnotetext{
${ }^{1213}$ El Clamor, 10/05/1909.

${ }^{1214}$ Ibídem.

${ }^{1215}$ El Clamor, 11/05/1909.
} 
están los niños más calientes en invierno». Existían escuelas conviviendo con una cárcel; otra instalada entre un salón de baile y un café, y otra cuya única ventana se abría sobre un cementerio. Un inspector habló de un local escuela utilizado como toril cuando en el pueblo había capeas.

Al leer esto, es cosa de alegrarse de que falten más de diez mil escuelas para dar cumplimiento a la añeja Ley de Instrucción Pública de Moyano.

Porque si habían de estar en iguales condiciones que las descritas por el ministro, más vale que los muchachos estén sin instrucción. ${ }^{1216}$

Un dictamen aprobado por el Ayuntamiento de Castellón, el 3 de julio de 1912, figuraba el relativo a la reconstrucción de las Aulas de latinidad. Este edificio fue hasta la creación del Instituto Provincial centro donde se enseñaba el latín y más tarde fue habilitado para escuela de párvulos, abandonándose después por las malas condiciones que ofrecía. De centro de enseñanza se convirtió en ampliación del viejo Hospital, sirviendo de morada a las hermanas de la caridad y de estancia para muchos enfermos.

Al trasladarse el Hospital al nuevo edificio de la carretera Alcora, el Ayuntamiento solicitó de la Hacienda Pública su cesión. Habiendo accedido el Estado a la petición del Ayuntamiento, éste acordó realizar importantes obras, cuyo presupuesto ascendía a más de 13.000 pesetas.

El edificio viejo y destartalado era amplio y permitía la distribución de tres amplios salones, uno en la planta baja y dos en planta alta, con la debida orientación y necesaria luz. Tenía un patio amplio para esparcimiento de los párvulos. Se adecentó todo el exterior qué ofrecía muy mal aspecto. «Con esta reforma ganará mucho la instrucción, por lo que felicitamos cordialmente al Ayuntamiento.» 1217

En una sesión de la Junta Provincial de Sanidad, celebrada el 27 de mayo de 1913, se acordó solicitar del gobernador que en cumplimiento de lo prevenido en disposiciones vigentes, no autorizara los presupuestos municipales de los pueblos cuyos locales fueran defectuosos, mientras no se consignaran las cantidades necesarias para las reformas o traslados de las escuelas. ${ }^{1218}$

\footnotetext{
${ }^{1216}$ El Clamor, 11/06/1910.

${ }^{1217}$ El Clamor, 3/07/1912.

${ }^{1218}$ El Clamor, 28/05/1913.
} 


\section{MEJORA DE LA ENSEÑANZA EN CASTELLÓN EN LA SEGUNDA DÉCADA DEL SIGLO XX}

Tras la lucha llevada a cabo en Castellón de la Plana a finales del siglo XIX por políticos, maestros, médicos, intelectuales y periodistas para que mejorara la enseñanza y la higiene en las escuelas y se concedieran el número necesario de ellas, la situación en la ciudad mejoró sensiblemente en cuanto a la higiene escolar, además de aproximarse al número de escuelas oficiales que marcaba la ley. Estas dos circunstancias estaban reguladas por el Real Decreto de 23 de abril de 1905.

En 1914, gracias al periódico republicano El Clamor, siempre interesado por la educación, hemos podido conocer las características y estado de las diferentes escuelas en Castellón que describimos a continuación.

1. Existía la Escuela nacional de niñas dirigida por la maestra Carolina Ortega. Se hallaba enclavada en la plaza de Sixto Cámara (actualmente Plaza del Real), era propiedad del Ayuntamiento y ocupaba parte de la planta baja del edificio. El resto del mismo se destinaba a escuela de párvulos y habitación para la maestra.

Las dimensiones con que contaba el único salón de clase eran las siguientes: 9,65 metros de longitud, 6,23 metros de ancho y 4,20 metros de altura, siendo su cubicación de 252,50 metros.

Contaba con agua suficiente, luz y ventilación. El local carecía de jardín y de patio, «sin que haya medio de proporcionarle semejantes requisitos.»

La matrícula era de 114 alumnas y la existencia media fluctuaba entre las 75 a 80 alumnas. Había buen material escolar « [...] lo cual supone un esfuerzo supremo por parte de la señora maestra, si se tiene en cuenta que esa escuela comenzó a funcionar como tal desde hace pocos años, o mejor dicho, desde que se hizo el desdoble de las escuelas de la capital».

La maestra disfrutaba del sueldo anual de 1.375 pesetas y recibía gratificación en concepto de alquiler de casa. El autor del artículo comenta que la maestra tenía una buena preparación pero mucho esfuerzo debía hacer para poder soportar por sí sola el trabajo que representan 114 educandas. ${ }^{1219}$

${ }^{1219}$ El Clamor, 28/04/1914. 


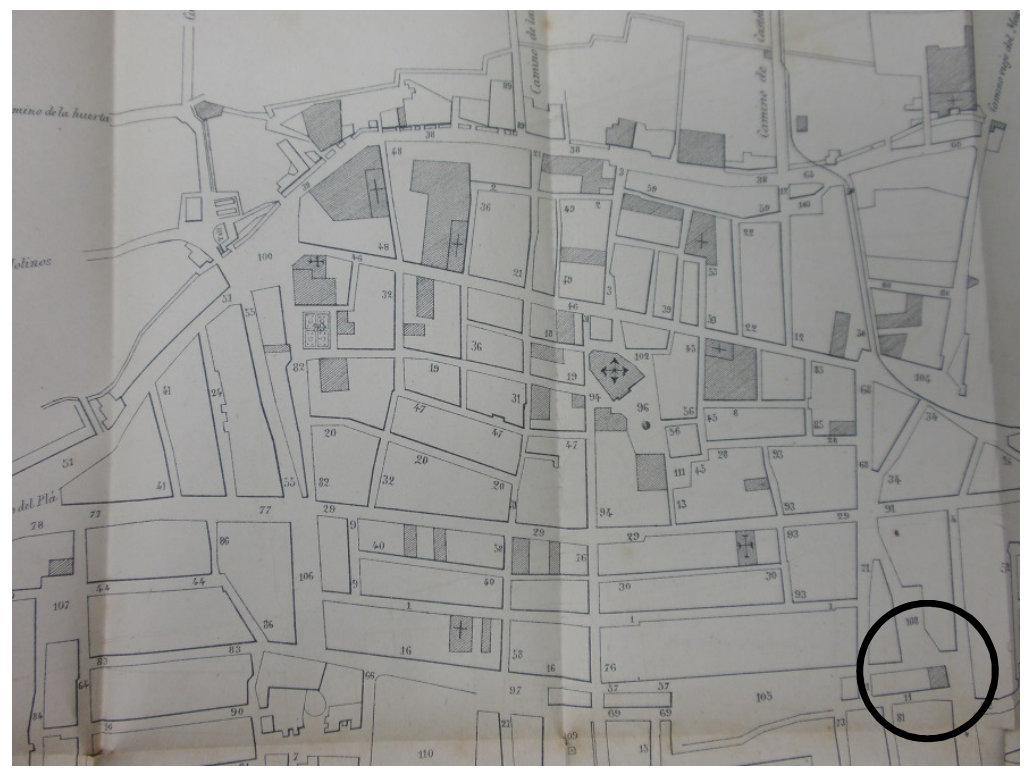

Emplazamiento de la Escuela del Real, en la plaza Sixto Cámara (actualmente Plaza del Real). Fuente: Guía Oficial de Castellón y su Provincia. Croquis de la Capital, 1890

La Escuela de párvulos, situada en el mismo edificio, ocupaba el resto de la planta baja y estaba atendida por la maestra Evarista Julia Andrés Castel; constaba de un salón para clase, un pequeño departamento pasillo que utilizaba la profesora para recreo de los párvulos, y además había una habitación para la maestra. El salón de clase tenía las siguientes dimensiones: 9,44 metros de longitud, 6 de ancho, y 4,20 de altura. Y el conjunto del edificio medía 10,84 metros por la parte este; 20 por el sur. Había agua, luz y ventilación en abundancia. Carecía de jardín y patio. Los retretes eran de «sólida construcción». El edificio era propiedad del municipio y desde antiguo estaba destinado a escuelas.

La escuela disponía de materiales adecuados a la enseñanza de párvulos. Poseía un museo con objetos pertenecientes a los distintos reinos de la naturaleza como semillas, frutos, algunos animales disecados y minerales. La enseñanza corria a cargo de la maestra Julia Andrés y de su hermana. Tenía la escuela 222 párvulos de ambos sexos de matrícula y la asistencia media era de 118 párvulos. La maestra figuraba en la

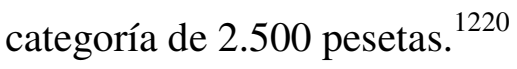

2. No todas las escuelas estaban mal dotadas, la Escuela que dirigía don Francisco Canos Sanmartín, estaba emplazada en la calle del Conde Pestagua número 5,

\footnotetext{
${ }^{1220}$ El Clamor, 7/05/1914.
} 
de propiedad particular, era considerada como una de las mejores de la capital. Su alquiler costaba 1.095 pesetas anuales.

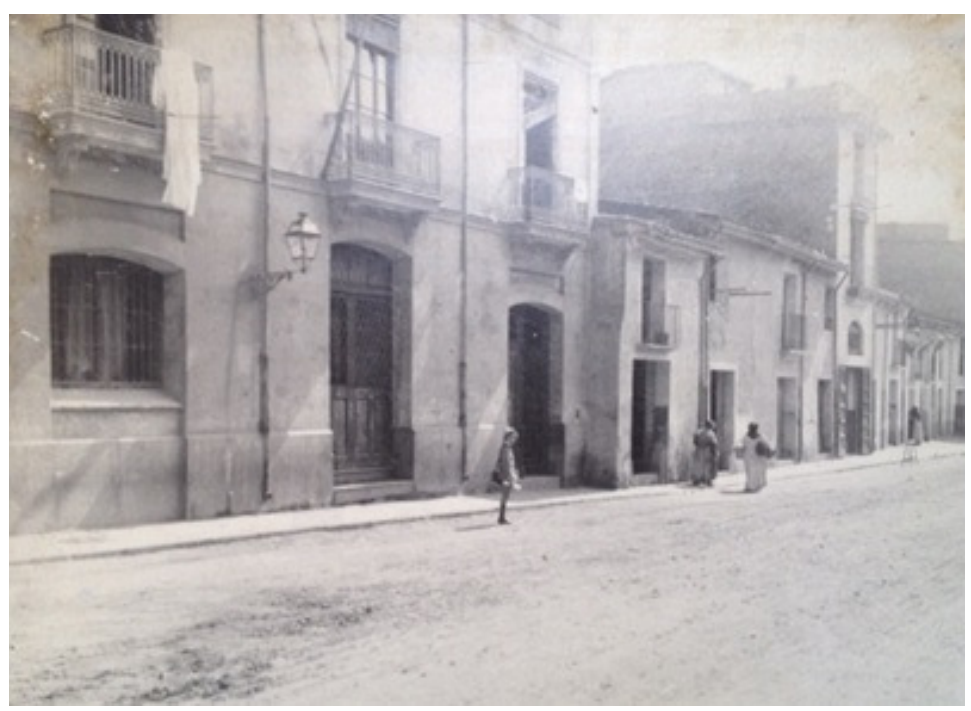

Escuela de Pestagua, en calle Conde Pestagua, 3. Fondo fotográfico: Colección José Prades

La enseñanza se daba en la planta baja del edificio, y según el plano de las reformas realizadas por el Ayuntamiento, constaba de las siguientes dimensiones: 14 metros de fachada y 17 de profundidad, o sea una superficie de 238 metros cuadrados, distribuidos en seis departamentos y un pequeño patio, en donde estaban los retretes y una fuente para beber.

Las tres salas de clase median: la primera, 10 metros de largo, 6 de ancho y 6 de alto; la segunda, 8 metros de largo, 4 de ancho y 4 de alto; y la tercera, 10 metros de largo, 7 de ancho y 6 de alto.

El profesor habitaba en el mismo edificio, en los pisos principal y segundo, «que son de excelentes condiciones».

Había agua en abundancia para el servicio de la escuela y para el maestro. Tenía un pequeño patio de 14 metros de largo y 2 de ancho y en él estaban instalados los retretes bien condicionados y una fuente de agua potable.

En las aulas primera y tercera, la luz que se recibía era cenital, y en la segunda la luz venía de la izquierda.

La matrícula escolar se elevaba a 262 alumnos y la asistencia media diaria era de 224. Esta escuela era graduada y en ella se verificaban las prácticas escolares para los alumnos del Magisterio que hacían sus estudios en el Instituto General y Técnico. El material escolar era bueno y completaban el mismo su correspondiente museo y muchos trabajos manuales. 
La dirección de la escuela corría a cargo de Francisco Canós, «quien por su ilustración, amor a la enseñanza y por los grandes entusiasmos que siente por la misma, no vacilamos en decir que los resultados responden a la acertada labor en los trabajos escolares». Colaboraban en la enseñanza con el director los maestros de sección Federico García y José Barrachina, «jóvenes y entusiastas por la misma enseñanza y de reconocido mérito dentro del profesorado».

Francisco Canós disfrutaba del sueldo de 2.500 pesetas y los maestros García y Barrachina tenían el sueldo respectivamente de 1.100 pesetas y recibían gratificación en concepto de alquiler por habitación y los tres tenían clases nocturnas. La escuela de Pestagua tenía mucha fama en la provincia, así como sus maestros. ${ }^{1221}$

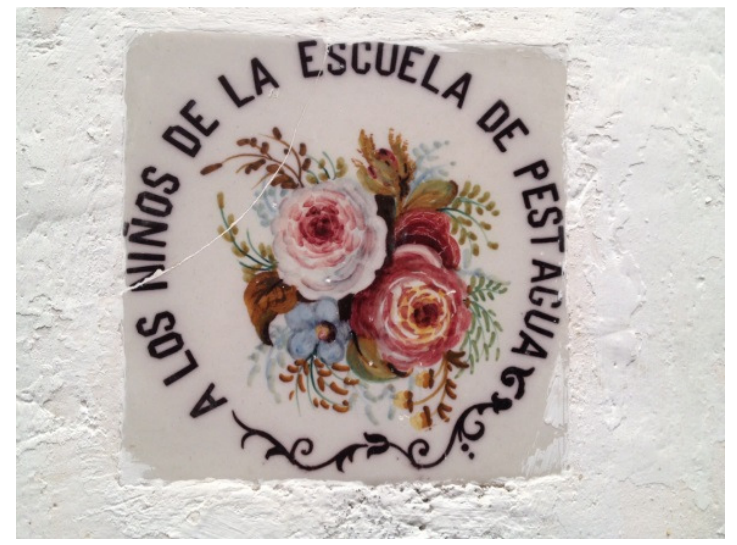

Cerámica que se conserva actualmente en el edificio donde estuvo la Escuela Pestagua. Foto: Concepción Calvo

3. Otra escuela que nos gustaría comentar sus características es la Escuela de niños de la Casa Provincial de Beneficencia. Se hallaba esta escuela situada en las afueras, mirando la fachada o puerta de entrada al norte y calle del Rosario, número 11. Era propiedad de la Diputación Provincial, «la que no escatima medios tanto para mejoramiento del local, como en lo relativo a material». Estaba instalada en la planta baja con abundante luz y ventilación y «con un aseo y limpieza envidiables». Medía la sala de clase 13,50 metros de longitud, 7 de ancho y 4,20 de altura, formando una cubicación de 396,90 metros. Contaba con un hermoso patio plantado de árboles.

La matrícula escolar era de unos 70 alumnos, siendo sus asistencia media sobre unos 66; además se daban clases nocturnas de adultos, que era la más concurrida de la capital. La enseñanza corría a cargo del maestro Francisco Soler y Fornás, que

\footnotetext{
${ }^{1221}$ El Clamor, 29/04/1914.
} 
disfrutaba del sueldo de 1.650 pesetas. «De modo que puede decirse que con el celo del maestro y la protección que le dispensa la Diputación Provincial, es modelo en su clase».

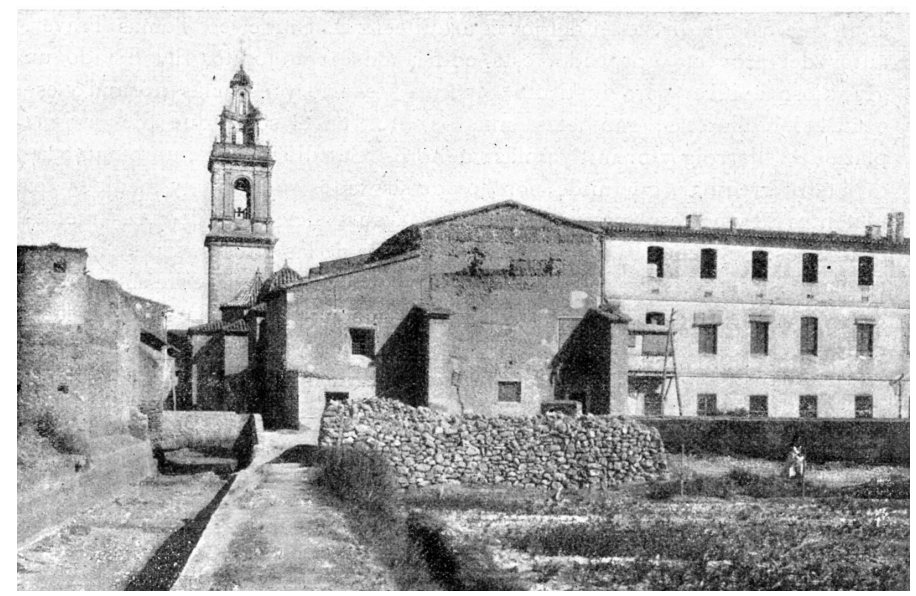

Escuela de niños de la Casa Provincial de Beneficencia. Fuente Sarthou Carreres, Carlos (1913): Geografía General del Reino de Valencia

No era una escuela graduada «convendría, no obstante para que los resultados fueran aún superiores a los excelentes, establecer la graduación, dividiendo por lo menos la escuela en tres secciones y quedando la dirección al frente del actual maestro».

No disponía siempre de agua, y el patio arbolado no se destinaba exclusivamente para los escolares ya que no estaba separado de otras dependencias. ${ }^{1222}$

4. Otra escuela digna de destacar era la Escuela graduada de niñas, aneja a la Escuela Superior de Maestras ya que servía para que hicieran prácticas las alumnas de magisterio. La escuela funcionaba bajo la dirección de la maestra Eladia Pedrós, que figuraba en el escalafón con el sueldo de 2.500 pesetas y como maestras de sección aparecían Petra Sanz y Julia Soriano, ambas propietarias y la maestra Mercedes Soriano, interina.

${ }^{1222}$ El Clamor ,4/05/1914. 


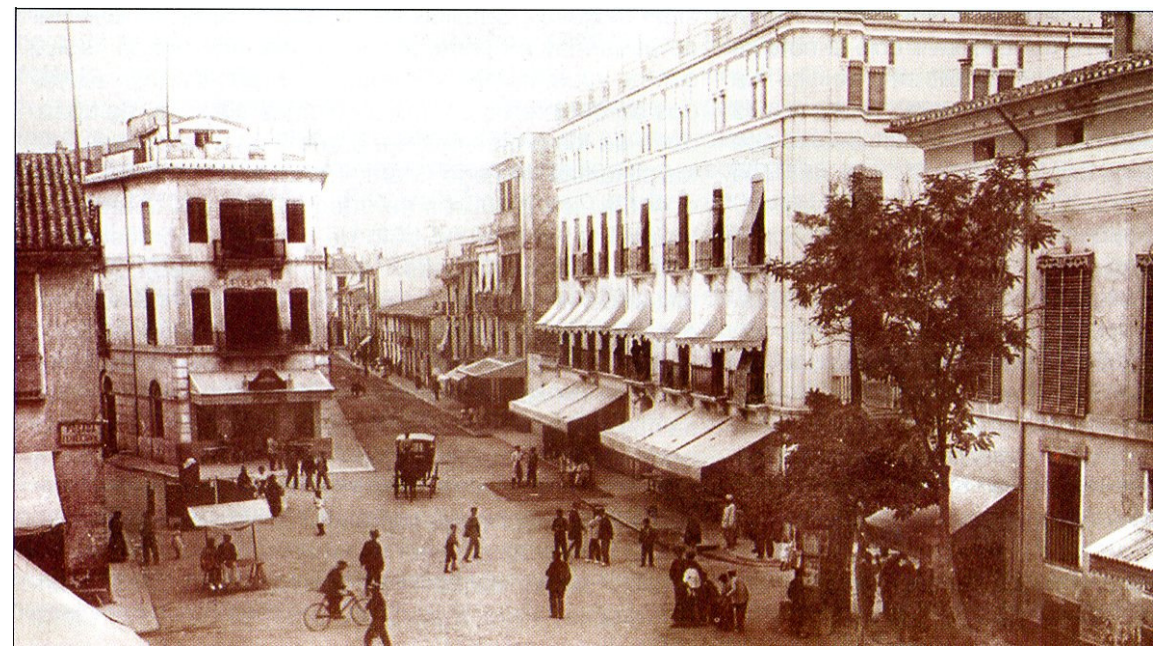

Escuela Centro, aneja de la Normal de Maestras, Plaza Castelar Fondo fotográfico: Colección José Prades

El establecimiento se hallaba situado en el centro de la capital, en la plaza Castelar (actualmente Puerta del Sol), esquina a las calles de Sixto Cámara y Ruiz Zorrilla. Este edificio era de propiedad particular y el Ayuntamiento pagaba por inquilinato $1.551,25$ pesetas anuales por la ocupación del $1^{\circ}$ y $2^{\circ}$ pisos destinados a enseñanza y habitación para la directora de la escuela. La planta baja, con entrada separada de la escuela, la tenía reservada su dueño para comercio.

El edificio, de forma trapezoidal medía 13 metros por la parte norte, 14 por la parte sur, 8 por el este, y 14 por el oeste, que distribuidos en los diversos departamentos «resultaban tres magníficos salones para enseñanza», con algunos accesorios y además habitación para la directora, que ocupaba la mitad del segundo piso. Había mucha luz y ventilación; no carecía de agua y «presentaba un aspecto más que agradable tanto en el interior como en su exterior», no tenía patio ni jardín. La matrícula escolar era de 208 alumnas y la asistencia media de 170 .

Tanto la directora como las demás maestras estaban muy bien consideradas como docentes. La escuela estaba muy bien dotada de material didáctico y, además, tenía un museo que completaba la obra educativa. El Ayuntamiento concedió los recursos necesarios para que no faltase nada a la escuela

La habitación de la directora no estaba en el local escolar. Tampoco era posible dotarlo de patio ni jardín. Estaba en proyecto trasladar la escuela al edificio en construcción del Instituto de Segunda Enseñanza y Escuela Normal; lo cual 
representaba además para el municipio una economía de 1.551,25 pesetas anuales, que le costaban al Ayuntamiento. ${ }^{1223}$

5. También existía la escuela que dirigía el profesor José Marco Cheza, decano de los maestros de la ciudad, y «verdadero campeón para la lucha contra la ignorancia».

La Escuela se hallaba situada en zona céntrica, calle González Chermá, no $52,{ }^{1224}$ (actualmente calle Enmedio), en un segundo piso, ocupándolo por completo; se componía de tres amplias salas de clase, una galería y los accesorios necesarios. Las dimensiones de cada una de las salas de clase eran: primera: 12,36 × 6,33 x 3,35; segunda: 12,11 x 5,10 x 4,24 y tercera: 10,45 x 7,70 x 4,24.

De propiedad particular el edificio, pagaba el Ayuntamiento por alquileres unas 900 pesetas anualmente. Contaba con agua abundante, luz suficiente y bastante ventilación, y se consideraba como de los mejores locales alquilados para escuela.

Funcionaba la escuela como graduada bajo la dirección de José Marco Cheza, que tenía una sección a su cargo y otras dos desempeñadas por los maestros Alejandro Orts y José María López. Contaba con material adecuado y «el director iba adquiriendo los objetos que mejor utilidad pudieran reportar sin reparar, en muchas ocasiones en el coste de los enseres que adquiría».

Las mesa-banco para los niños consistían en pupitres o mesas bipersonales y, en muchas ocasiones, el director, de su peculio particular, acometía algunas reformas y costeaba algunas reparaciones que suponía necesarias. Marco Cheza ascendió al sueldo de 2.500 pesetas y a 1.100 respectivamente ascendieron sus compañeros Orts y López. Los tres maestros tenían clases nocturnas de adultos y recibían cierta cantidad alzada en concepto de alquileres por casa habitación. ${ }^{1225}$

\footnotetext{
${ }^{1223}$ El Clamor, 5/05/1914.

${ }^{1224}$ Anteriormente esta escuela estuvo situada en la calle Mayor 126.Con el tiempo estas aulas dejaron de ser utilizadas como escuela pública. Juan Albert, nos cuenta que en 1957 estudiaba en la Escuela del Sindicato Textil que ocupaba éstos mismos locales.

${ }^{1225}$ El Clamor, 6/05/1914.
} 


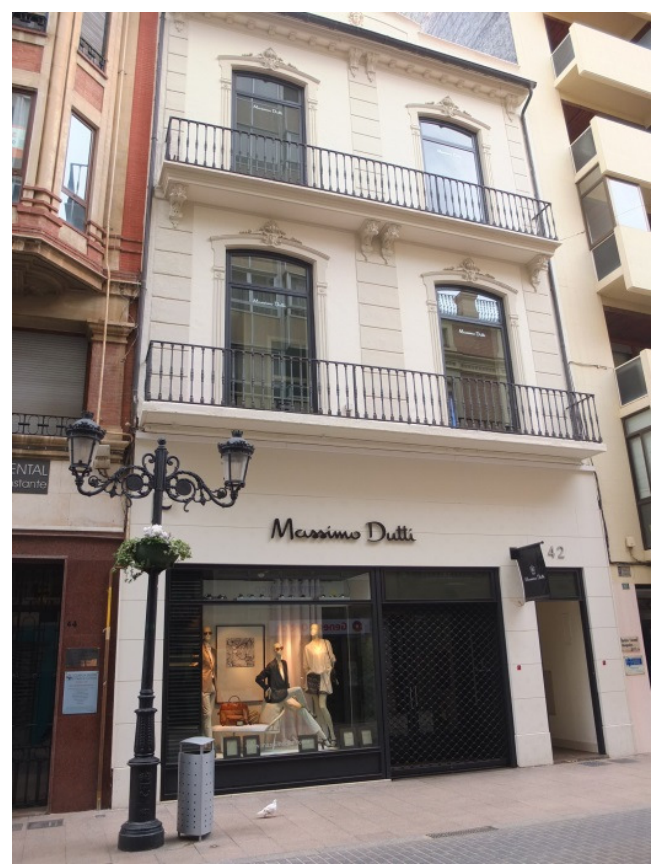

Edificio que alojaba la Escuela Centro de niños, que dirigía el maestro José Marco Cheza, en la calle Gonzalez Chermá, 52. Foto: Concepción Calvo

6. Otra Escuela de párvulos estaba dirigida por la maestra María de los Ángeles Piñón Carsí, que figuraba con el sueldo de 1.375 pesetas y la escuela que desempeñaba era unitaria.

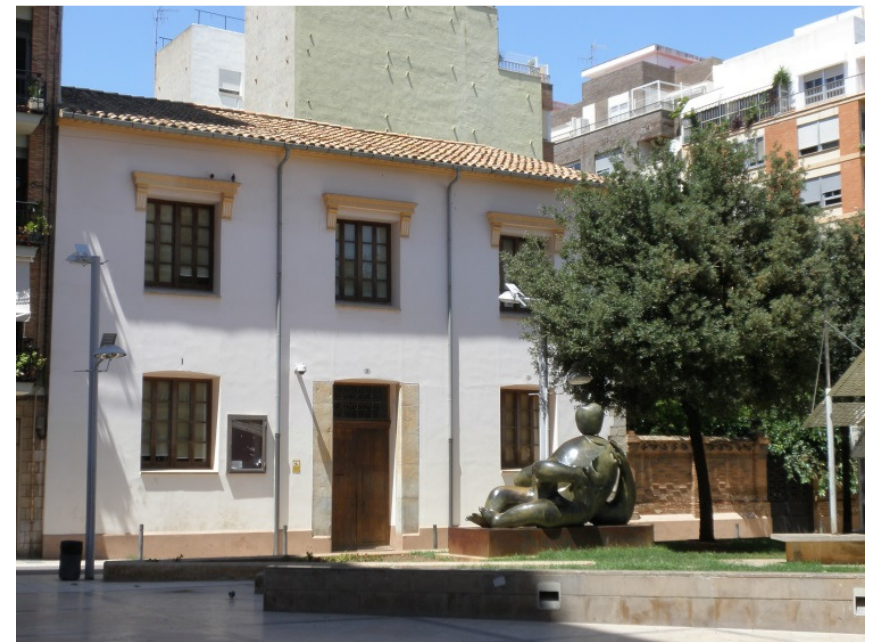

Escuela y parvulario de niñas en las antiguas Aulas de Latinidad. Foto: Concepción Calvo

Se hallaba en el local al final de la calle Caballeros, frente al nuevo edificio entonces en construcción, destinado a Diputación Provincial (actualmente Plaza de Las Aulas). Era propiedad del Ayuntamiento y se la consideraba como una de los mejores de la capital. El inspector de escuelas del distrito universitario manifestó que ese 
edificio estaba muy por encima del que en Valencia se tenía como modelo bajo el título de «Escuelas de Cervantes».

La escuela ocupaba la planta baja y se daba la enseñanza en un salón, cuyas dimensiones eran las siguientes: 15,75 metros de largo, 5,25 ancho y 4,40 alto, siendo su superficie total la de $82.6875 \mathrm{~m}^{2}$ aproximadamente y su capacidad de $363.825 \mathrm{~m}^{3}$; y las dimensiones de todo el edificio eran 28 metros de longitud, 26 de latitud y 12 de altura. En el piso alto y único había tres escuelas unitarias más.

Estaba bien surtida de agua, abundante luz y ventilación. Contaba con dos jardines de 15,10 metros de largo por 12 de ancho el uno y de 9 metros de largo y 9 de ancho el otro. La matrícula era de 180 párvulos y la asistencia media diaria de 96 . Tenía buen material escolar y abundante, acorde con la enseñanza que tenía que desarrollarse. En el edificio no había habitación para ninguna de las maestras que funcionaban en el mismo, y disponia de aseos en buenas condiciones. ${ }^{1226}$

En estre mismo edificio, además de la escuela de párvulos, funcionaban también tres escuelas unitarias ubicadas en el piso principal. El salón que ocupaba la maestra Ramona Fabregat media 13 metros de largo, 6,50 de ancho y 4,50 alto. Esta clase contaba con una matrícula de 58 alumnas y su asistencia era de 40. El salón que ocupaba la maestra María Valls tenía 15 metros de largo, 5,10 de ancho y 4,50 alto. Tenía una matrícula de 56 niñas y asistían a clase unas 40. El salón de la maestra Rosario Iroli tenía 13,50 metros largo, 5 de ancho y 4,50 alto. En esta clase había matriculadas 56 niñas y su asistencia era aproximadamente de 33 niñas.

Escuelas y maestros son los dos factores principales en la educación. De ello se van convenciendo los que se aman y aman a la patria.

Nuestras antiguas escuelas mejoran en su organismo y en su funcionamiento a pasos agigantados: los locales para la enseñanza, tan detestables como inútlies, son reemplazados por otros que reúnen condiciones apropiadas al objeto a que se destinan. $^{1227}$

7. El Grupo Escolar de niños estaba situado en la Ronda de la Magdalena, la dirigía el maestro Juan A. Bartual Ortiz, que gozaba del sueldo de 2.000 pesetas.

\footnotetext{
${ }^{1226}$ El Clamor, 12/05/1914.

${ }^{1227}$ El Clamor, 19/05/1914.
} 
Funcionaba la escuela como graduada, con tres secciones que corrían a cargo de los maestros Bartual, José Guitart y Francisco Fuertes Antonino, este último como interino.

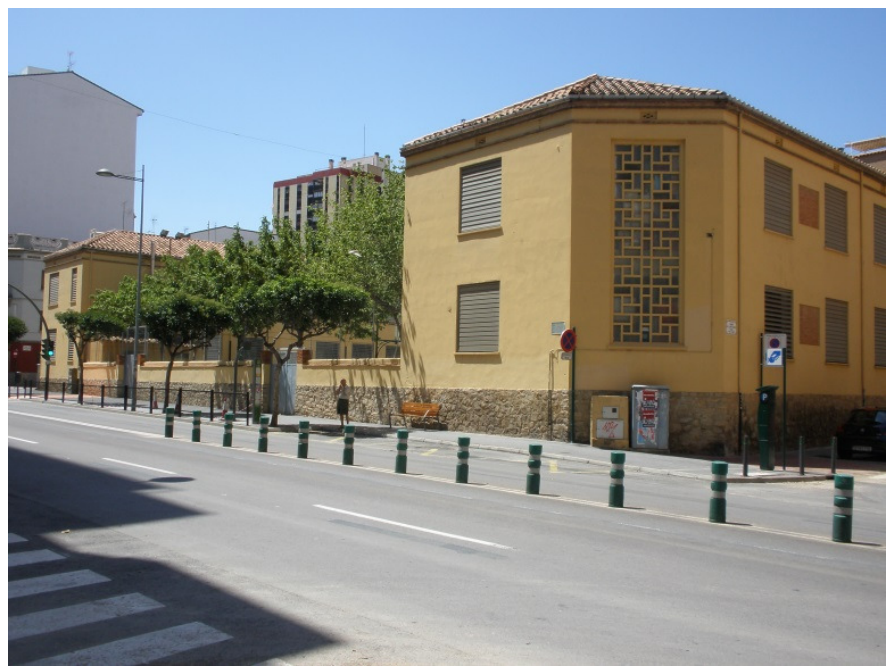

Lugar donde se encontraba el Grupo Escolar de la Ronda Magdalena (actualmente C.P. Cervantes). Foto: Concepción Calvo

El edificio escolar construido de nueva planta en 1906-1908 ${ }^{1228}$ por el Ayuntamiento con subvención del Estado, estaba resuelto en planta baja y se hallaba junto a otro de niñas, separados uno de otro por un tabique. Constaba de los siguientes departamentos: tres salas de clase de iguales dimensiones, un pasillo vestíbulo lateral, retretes y patio jardín. La superficie de cada sala de clase era de 9,4 m de largo por 7,5 $\mathrm{m}$ de ancho y la altura de $5 \mathrm{~m}$, sólo se destinaba el local para escuelas. Había agua en gran abundancia, luz y ventilación. La extensión del patio-jardín, era de $175 \mathrm{~m}^{2}$ y en él había variedad de árboles y plantas. La escuela contaba con abundante material moderno y objetos para hacer la enseñanza intuitiva. La matrícula ascendía a 196 alumnos matriculados, asistiendo unos 162 escolares.

Todos los maestros de este centro de enseñanza recibían gratificación en concepto de alquileres de casa-habitación y daban clases nocturnas de adultos. ${ }^{1229}$

Como hemos dicho anteriormente, en el mismo solar estaba la escuela de niñas. El edificio también fue construido por el Ayuntamiento con subvención del Estado. Funcionaba en este edificio tres escuelas unitarias aunque se dispuso su funcionamiento como enseñanza graduada.

\footnotetext{
${ }^{1228}$ GIMENO MICHAVILA, Vicente, op. cit. p. 60.

${ }^{1229}$ El Clamor, 13/05/1914.
} 
Ejercian las clases, la maestra Carmen Cava, con 2.000 pesetas de sueldo; Emilia Morer, con 1.650, y Desamparados García, con 1.375. Todas ellas disfrutaban de gratificación por alquileres de casa.

Las escuelas se hallaban en planta baja con tres salones destinados a la enseñanza, pasillo, vestíbulo, retretes y un patio con árboles.

Cada sala de clase media una extensión de 7,5 metros de ancho, por 9,4 metros de largo, por 5 metros de alto; el patio media $270 \mathrm{~m}^{2}$.

La matrícula por cada escuela era de 100 alumnas y la asistencia de 80 alumnas aproximadamente. ${ }^{1230}$

8 Existía también la escuela nacional de niñas dirigida por la maestra, Anita Colomer Cervelló, que gozaba de sueldo de 1.650 pesetas y además recibía gratificación por residencia. Funcionaba como escuela graduada, cuyas tres secciones de que constaba, estaban bajo la dirección de la maestra Colomer; figuraban como maestras de sección Francisca Ferrer y Luisa Ferrandis, con el sueldo cada una, de 1.100 pesetas anuales.

Estaba situado el Grupo Escolar en la calle Herrero y fue construido, ex profeso para colegio por el Ayuntamiento, con subvención estatal concedida en $1906 .{ }^{1231}$

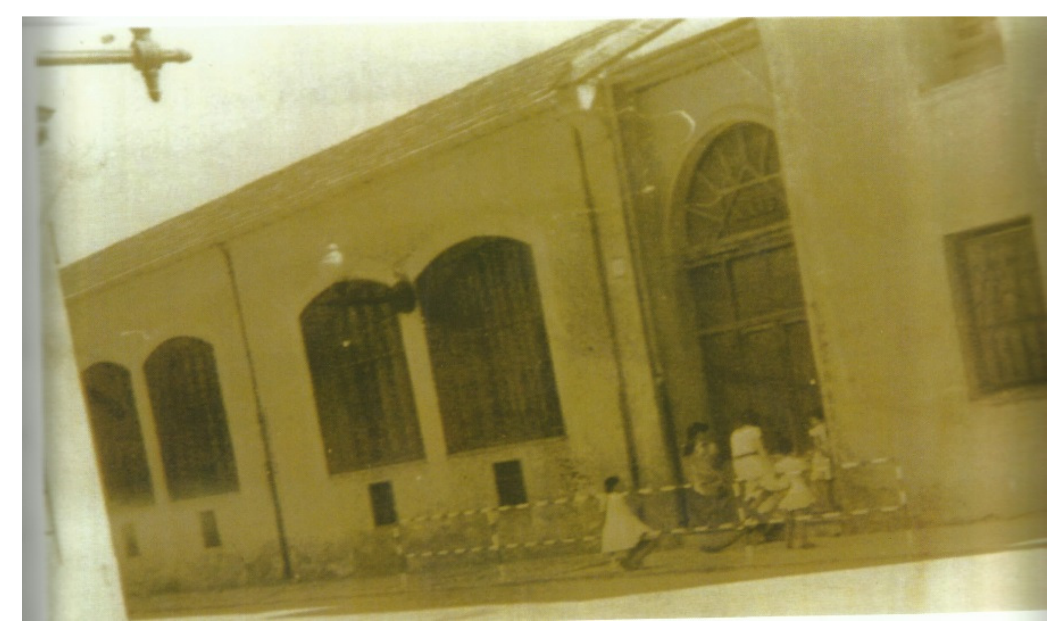

Grupo Escolar de la calle Herrero. Fondo fotográfico: Colección José Prades Se puede observar en la parte inferior de la fachada los huecos para la ventilación cruzada de las aulas.

\footnotetext{
${ }^{1230}$ El Clamor, /05/1914.

1231 GIMENO MICHAVILA, Vicente, op. cit. p. 60.
} 
Ocupaba la planta baja y un piso y las dimensiones del edificio, 44 metros de largo, 10 de ancho y 10 de altura, distribuido en tres salas de clase y un departamento para lavabo y retretes. En el piso único, había una sala para los trabajos manuales. Esta sala y las tres dedicadas a la enseñanza, eran de igual dimensión, constando cada una de 9 metros de largo, 7 de ancho y 5 de altura. No había en el local vivienda para la maestra.

Contaba la escuela con agua, luz y suficiente ventilación, «pudiendo graduarse ésta última por medio de procedimientos modernos», como se puede observar en los huecos inferiores de la fachada de la foto adjunta. Se trata del sistema de ventilación cruzada «alternadas correspondientes», ${ }^{1232}$ recomendado en las Instrucciones Técnicohigienicas, anexas al Real Decreto de 1905, que hemos reseñado en el apartado anterior.

Tambien disponía de ocho retretes de sistema moderno, un aseo y cuarto de limpieza.

Era un hermoso edificio, plantado de árboles y con las siguientes dimensiones: 45 metros de largo por 10 de ancho. Las alumnas matriculadas eran 233 y la asistencia diaria de 170. No faltaba material moderno y tenía objetos adecuados para la enseñanza y abundantes trabajos manuales. ${ }^{1233}$

9. Otra escuela digna de mención era la de la calle de Pi y Margall, (actualamente calle Trinidad), dirigida por el maestro Rafael Pardo, que disfrutaba del sueldo de 1.100 pesetas. El edificio era de propiedad particular y el Ayuntamiento pagaba por alquiler 1.000 pesetas. Ocupaba el primer y único piso y la planta baja estaba destinada a almacén de naranja. El acceso se realizaba por una larga y empinada escalera de dos tramos, por ello se la conocía con el nombre de «Escola de l’ escaleta».

\footnotetext{
1232 Ventilación: Se evitará el aire viciado, a ser posible con ventilación natural. «Para mover la atmósfera se recomiendan ventiladores giratorios periódicos alternados, o cualquier otro sistema que active o fomente el movimiento del aire y la ventilación cruzada. De entre ellos los alternados correspondientes que consisten en aberturas practicadas en los lados mayores del local y dispuestas de tal suerte que unas correspondan a la parte inferior y otros la superior de las paredes son muy recomendables. Las aberturas correspondientes a la parte inferior distaran 10 ó $15 \mathrm{~cm}$. del suelo, y la correspondiente á la superior se situará a ras de techo. Unas y otras estarán provistas de un enrejado metálico y de un registro regulador. El área de los orificios de entrada debe ser por lo menos igual a los de salida.» ${ }^{1233}$ El Clamor, 15/05/1914.
} 


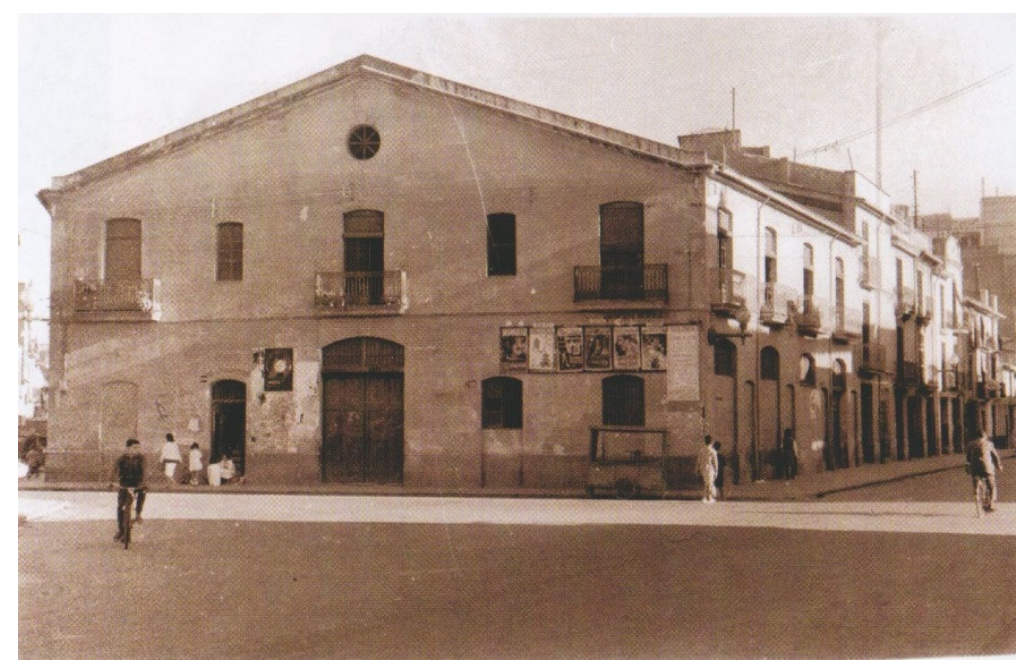

Escola de l'escaleta en la calle Pi y Margall. Foto: Colección José Prades

Las dimensioines del edificio eran 15 por 13 por 3,5 metros. Constaba de dos salas de clase, un corredor y espacio para los retretes. Tenía suficiente agua, ventilación y luz y carecia de jardín y patio. La primera de las salas de clase, media 82,50 $\mathrm{m}^{2}$ y la segunda $97,50 \mathrm{~m}^{2}$

La escuela era graduada y las dos secciones de que constaba, una se encargaba el maestro Rafael Pardo, que era interino y el director y otra era desempeñada interinamente por el maestro Manuel Pradells.

Había suficiente material didáctico, contaba con 98 matriculados y asistían a las clases diarias unos 80 .

Tanto el director Rafael Pardo, como el maestro interino Manuel Pradells recibían gratificación por enseñanza de adultos y en concepto de alquiler por casahabitación. ${ }^{1234}$

10. También existía la Escuela de niñas de la calle Enseñanza, dirigida por la maestra Natalia Gil que disfrutaba del sueldo de 1.375 pesetas anuales.

\footnotetext{
${ }^{1234}$ El Clamor, 22/05/1914.
} 


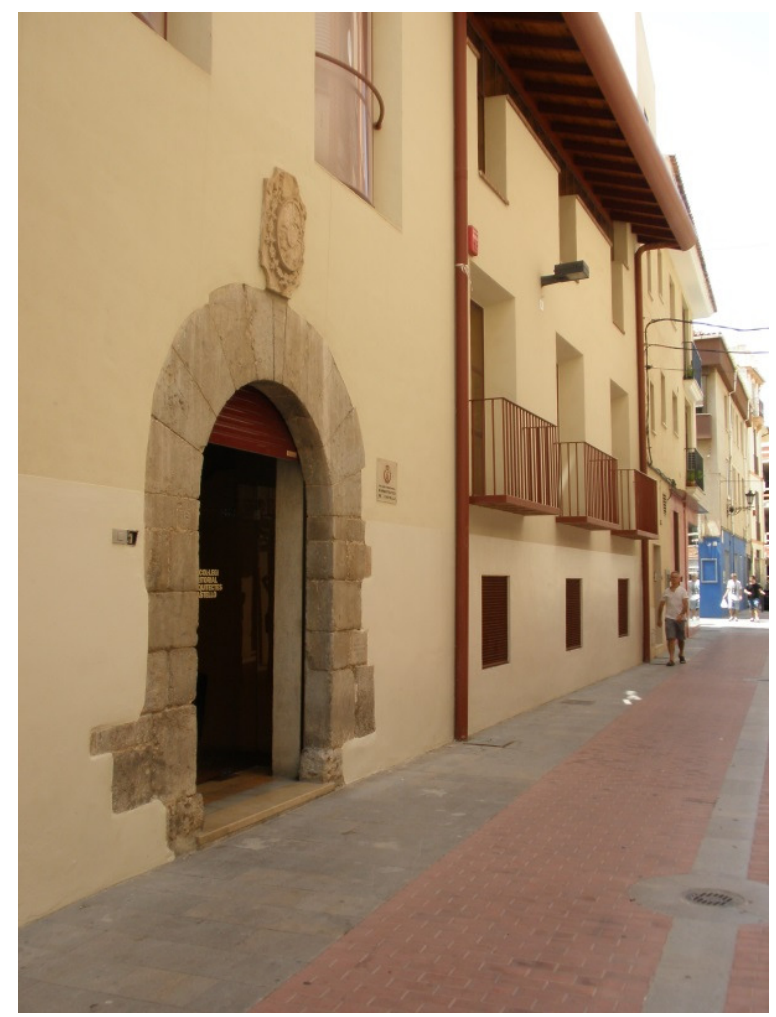

Escuela de niñas de la calle Enseñanza. Actualmente sede del Colegio de Arquitectos de Castellón. Foto: Concepción Calvo

El edificio era propiedad de la Junta de patronos y como patronato funcionaba la escuela. Se hallaba en el primer y único piso, siendo las dimensiones del edifico, 21 metros de ancho por 13 de largo.

Los salones de clase eran tres, midiendo cada uno de ellos: el primero, 7,05 metros de largo por 6,08 metros de ancho, por 4,35 metros de alto; el segundo, 9,08 por 9,55 por 2,45 metros y el tercero, 10,05 por 4,05 por $3,56 \mathrm{~m}$.

Había agua en abundancia, algunas antesalas y todo el edificio con suficiente luz y ventilación. Carecía de jardín y patio. La maestra vivía en el mismo edificio.

La matrícula escolar era de 179 alumnas y la asistencia de 150. Tenía material escolar suficiente y aunque unitaria, la maestra era auxiliada por la propia familia. ${ }^{1235}$

${ }^{1235}$ El Clamor, 30/05/1914. 


\subsection{ANÁLISIS COMPARATIVO ENTRE LAS DISTINTAS ESCUELAS Y ESTAS CON LA NORMATIVA VIGENTE}

Como hemos dicho anteriormente, entre abril y junio de 1914 se publica en el periódico El Clamor, una serie de artículos bajo el titulo Estadísticas de las escuelas públicas de Castellón, en el que se describen pormenorizadamente algunos colegios públicos de la capital. Los datos que allí figuran, que valoramos de gran interés y que en parte hemos transcrito, nos van a permitir aproximarnos al tipo de enseñanza que se impartía y a la configuración e higiene de los edificios que albergaban estas escuelas públicas en la segunda década del siglo XX.

De las 18 escuelas públicas que figuran en la Guía Oficial de Castellón y Provincia de 1914, conocemos con detalle 13 de ellas a través de los artículos anteriormente citados del periódico El Clamor de ese mismo año. Consideramos que es un número suficientemente representativo para valorar la situación escolar de la capital en esas fechas.

Para ello hemos confeccionado una tabla con datos extraídos de dichas descripciones: como es la situación y titularidad del edificio, el tipo de docencia, el número y dimensiones de las aulas, los alumnos matriculados por centro, el absentismo escolar, los nombres y el número de profesores que impartían docencia en cada colegio y los que daban clases nocturnas de adultos, lo que nos va a permite hacer un análisis comparativo entre las distintas escuelas y estas con la normativa vigente.

También hemos tenido en consideración la información que la Guía Oficial de Castellón y Provincia, del año 1914 aporta del resto de escuelas que no aparecen descritas en los artículos del periódico El Clamor. Se adjunta cuadro con dichos datos.

Como consecuencia del rápido crecimiento de la población en las últimas décadas del siglo XIX, el Ayuntamiento tiene que proveerse rápidamente de nuevos espacios para alojar la demanda escolar, y de profesores para satisfacer estas exigencias. Tanto la prensa de la época, los maestros y la población en general reclaman con insistencia mas y mejores escuelas. 


\begin{tabular}{|c|c|c|c|c|c|c|c|c|c|c|c|}
\hline & \multicolumn{11}{|c|}{$\begin{array}{l}\text { ALGUNAS ESCUELAS NACIONALES DE LA CIUDAD DE CASTELLÓN, AÑO } 1914 \\
\text { Extracto descripciones del periódico El Clamor }\end{array}$} \\
\hline & DENOMINACIÓN & EMPLAZAMIENTO & TITULARIDAD & DOCENTES & $\begin{array}{l}\text { AULAS /SUPERFICES } \\
\text { largo } x \text { ancho } x \text { alto }\end{array}$ & $\begin{array}{l}\text { ESPACIOS } \\
\text { ABIERTOS }\end{array}$ & $\begin{array}{l}\text { MATRICULA } \\
\text { Alum./aula }\end{array}$ & $\begin{array}{l}\text { ASISTENCIA } \\
\text { CLASE }\end{array}$ & $\begin{array}{l}\text { RELACION } \\
\text { sup. aula/alumno. }\end{array}$ & $\begin{array}{l}\text { RELACIÓN } \\
\text { volumen/alumno }\end{array}$ & $\begin{array}{l}\text { Absentismo } \\
\text { escolar }\end{array}$ \\
\hline & $\begin{array}{l}\text { R.D. } 1905 \\
\text { NORMATIVA }\end{array}$ & & & & $\begin{array}{l}\text { Lado mínimo } 9 \mathrm{~m} . \\
\text { Altura techo } 4 \mathrm{~m} .\end{array}$ & 3-4m2 /alum & $\begin{array}{l}25-40 \text { grado. } \\
60 \text { unitarias. }\end{array}$ & & 1,25 m2/alumno/a & 5 m3/alumno/a & \\
\hline & Escuelas de niñas & & & & & & & & & & \\
\hline 1 & $\begin{array}{l}\text { Escuela del Real } \\
\text { graduada de niñas }\end{array}$ & $\begin{array}{l}\text { Pza. Sixto Cámara, } 18 \\
\text { ( Pza.d.Real) }\end{array}$ & Municipal & 1 maestro & $\begin{array}{l}\text { 1 AULA /pl. baja } \\
9,65 \times 6,25 \times 4,20 \mathrm{mts} \text {. } \\
\text { Sup. } 60,30 \mathrm{~m} 2 / \text { aula }\end{array}$ & No & 114 grado & $75-80$ & $\begin{array}{l}\text { 0,5 m2/alumno. M } \\
0,8 \text { m2/alumno. } A\end{array}$ & $\begin{array}{l}\text { 2,2m3/alumno.M } \\
\text { 3,2m3/alumno.A. }\end{array}$ & $31 \%$ \\
\hline 2 & $\begin{array}{l}\text { Escuela aneja a } \\
\text { Esc. Superior } \\
\text { Maestras, } \\
\text { graduada de niñas } \\
\end{array}$ & $\begin{array}{l}\text { Plaza Castellar, esq. } \\
\text { Sixto Cámara y Ruiz } \\
\text { Zorrilla (Puerta del Sol) }\end{array}$ & Particular & 4 maestras & $\begin{array}{l}3 \text { AULAS/pl. primera y parte } \\
\text { segunda + viv. directora. } \\
\text { Sup. aprox } 60 / 70 \mathrm{~m} 2 / \text { aula }\end{array}$ & No & $\begin{array}{l}208 \text { grado } \\
70 \text { alum/aula }\end{array}$ & $\begin{array}{l}170 \\
56 \text { alum/aula }\end{array}$ & $\begin{array}{l}\text { 0,9 m2/alumno.M } \\
1,1 \mathrm{~m} 2 / \text { alumno.A }\end{array}$ & $\begin{array}{l}\text { 3,3 m3/alumno M } \\
\text { 4,0 m3/alumno A }\end{array}$ & $18,25 \%$ \\
\hline 3 & $\begin{array}{l}\text { Colegio de la } \\
\text { Enseñanza, } \\
\text { unitaria de niñas }\end{array}$ & C/Enseñanza, 30 & Particular, Patronato & 3 maestras & $\begin{array}{l}3 \text { AULAS/pl. primera } \\
7 \times 6 \times 4,35 ; 9 \times 9,50 \times 2,45 \\
10 \times 4 \times 3,55 \\
\text { Sup. aulas:42m2, 85m2,40m2 }\end{array}$ & No & $\begin{array}{l}179 \text { unitaria } \\
60 \text { alum/aula }\end{array}$ & $\begin{array}{l}150 \\
50 \text { alum/aula }\end{array}$ & $\begin{array}{l}\text { 0,9 m2/alumno. M } \\
1,1 \mathrm{~m} 2 / \text { alumno. } A\end{array}$ & $\begin{array}{l}\text { 3,0 m3/alumnoM } \\
\text { 3,5 m3/alumno.A }\end{array}$ & $16,15 \%$ \\
\hline 4 & $\begin{array}{l}\text { Escuela de las } \\
\text { Aulas, graduada de } \\
\text { niñas. }\end{array}$ & $\begin{array}{l}\text { C/ Caballeros, frente } \\
\text { nuevo edificio } \\
\text { Diputación. }\end{array}$ & Municipal & 3 maestras & $\begin{array}{l}3 \text { AULAS/pl. primera } \\
13 \times 6,5 \times 4,5 ; 15 \times 5,10 \times 4,5 ; 13 \times 5 \times 4,5 \\
\text { Sup. aulas:76 m2,84 m, } 65 \mathrm{~m} 2\end{array}$ & $\begin{array}{l}\text { Patio- jardín } \\
140 \mathrm{~m} 2 \\
0,80 \mathrm{~m} 2 / \mathrm{alum}\end{array}$ & $\begin{array}{l}168 \text { grado } \\
56 \text { alum/aula }\end{array}$ & $\begin{array}{l}113 \\
\text { 37alum/aula }\end{array}$ & $\begin{array}{l}1,4 \mathrm{~m} 2 / \text { alumno } \mathrm{M} \\
2,0 \mathrm{~m} 2 / \text { alumno } A\end{array}$ & $\begin{array}{l}\text { 6,0 m3/alumno.M } \\
8,9 \text { m3/alumno.A }\end{array}$ & $33 \%$ \\
\hline & Escuelas de niños & & & & & & & & & & \\
\hline 5 & $\begin{array}{l}\text { Escuela Pestagua, } \\
\text { graduada de niños }\end{array}$ & C/Conde Pestagua, 5 & Particular & 3 maestros * & $\begin{array}{l}\text { 3 AULAS/pl. baja } \\
\text { 10x6x6; } 8 \times 4 \times 4 ; 10 \times 7 \times 6 \mathrm{mts} \text {. } \\
\text { Sup. aulas:60m2;32m2;70 m2 }\end{array}$ & No & $\begin{array}{l}262 \text { grado } \\
87 \text { alum/aula }\end{array}$ & $\begin{array}{l}224 \\
75 \text { alum/aula }\end{array}$ & $\begin{array}{l}\text { 0,62 m2/alumno. M } \\
0,74 \text { m2/alumno.A }\end{array}$ & $\begin{array}{l}\text { 3.5m3/alumno.M } \\
4,05 \text { m3/alumno.A }\end{array}$ & $14,50 \%$ \\
\hline 6 & $\begin{array}{l}\text { Escuela de la } \\
\text { Beneficencia, } \\
\text { unitaria de niños }\end{array}$ & C/ Rosario,11 & $\begin{array}{l}\text { Diputación } \\
\text { Provincial }\end{array}$ & 1 maestro * & $\begin{array}{l}\text { AULA/pl. baja. } \\
13,50 \times 7 \times 4,20 \mathrm{mts} . \\
\text { Sup. aula: } 94,50 \mathrm{~m} 2 .\end{array}$ & Patio- jardín & 70 unitaria & 66 & $\begin{array}{l}\text { 1,3m2/alumno. M } \\
\text { 1,4m2/alumno.A }\end{array}$ & $\begin{array}{l}\text { 5,6 m3/alumno.M } \\
6,0 \text { m3/alumno.A }\end{array}$ & $5,75 \%$ \\
\hline 7 & $\begin{array}{l}\text { Escuela graduada } \\
\text { de niños } \\
\text { escola de } 1 \text {. escaleta }\end{array}$ & $\begin{array}{l}\text { Pi y Margall } \\
\text { (C/Trinidad) }\end{array}$ & Particular & 3 maestros * & $\begin{array}{l}2 \text { AULAS/pl. primera } \\
\text { Sup.82,50m2 (aprox.12x7m.) } \\
\text { Sup. } 97,50 \mathrm{~m} 2 \text { (aprox. } 12 \times 8 \mathrm{~m} . \text { ) }\end{array}$ & No & $\begin{array}{l}98 \text { graduada } \\
50 \text { alum/aula }\end{array}$ & $\begin{array}{l}80 \\
40 \text { alum/aula }\end{array}$ & $\begin{array}{l}\text { 1,80m2/alumno. M } \\
\text { 2,2 m2/alumno. A }\end{array}$ & $\begin{array}{l}\text { 5,9 m3/alumno.M } \\
\text { 7,1 m3/alumno.A }\end{array}$ & $18,40 \%$ \\
\hline 8 & $\begin{array}{l}\text { Escuela graduada } \\
\text { de niños }\end{array}$ & $\begin{array}{l}\text { C/ González Chermá, } 52 \\
\text { (C/ Enmedio) }\end{array}$ & Particular & 3 maestros* & $\begin{array}{l}\text { 3 AULAS/ pl. segunda } \\
78,25 ; 61,75 \text { y } 80,50 \mathrm{~m} 2\end{array}$ & No & & & & & \\
\hline & Nuevos grupos & & & & & & & & & & \\
\hline 9 & $\begin{array}{l}\text { Escuelas de la calle } \\
\text { Herrero, graduada } \\
\text { niñas. }\end{array}$ & C/ Herrero, & $\begin{array}{l}\text { Municipal, de nueva } \\
\text { planta y subvención } \\
\text { estatal }\end{array}$ & 3 maestras & $\begin{array}{l}\text { 3 AULAS/pl. baja } \\
9 \times 7 \times 5 \mathrm{mts} \text {. } \\
\text { Sup. } 63 \mathrm{~m} 2 / \text { aula }\end{array}$ & Patio - jardín & $\begin{array}{l}233 \text { grado } \\
77 \text { alum/aula }\end{array}$ & $\begin{array}{l}170 \\
57 \text { alum/aula }\end{array}$ & $\begin{array}{l}\text { 0,8 m2/alumno. M } \\
\text { 1,1 m2/alumno. A }\end{array}$ & $\begin{array}{l}\text { 4,0 m3/alumno.M } \\
5,5 \text { m3/alumno. A }\end{array}$ & $27 \%$ \\
\hline 10 & $\begin{array}{l}\text { Escuela de la } \\
\text { Ronda Magdalena } \\
\text { graduada niñas, }\end{array}$ & Ronda Magdalena & $\begin{array}{l}\text { Municipal, de nueva } \\
\text { planta y subvención } \\
\text { estatal }\end{array}$ & 3 maestras & $\begin{array}{l}3 \text { AULAS/pl. baja } \\
9,50 \times 7,40 \times 5 \text { mts. } \\
\text { Sup. } 70,3 \mathrm{~m} 2 / \text { aula }\end{array}$ & $\begin{array}{l}\text { Patio y jardín } \\
\text { de } 270 \mathrm{~m} 2 \\
2,7 \mathrm{~m} 2 / \text { alum. }\end{array}$ & $\begin{array}{l}100 \text { grado } \\
33 \text { alum/aula }\end{array}$ & $\begin{array}{l}80 \\
27 \text { alum/aula }\end{array}$ & $\begin{array}{l}\text { 2,2 m2/alumno. M } \\
\text { 2,6 m2/alumno. A }\end{array}$ & $\begin{array}{l}\text { 10,5m3/alumno.M } \\
\text { 13,1 m3/alumno.A }\end{array}$ & $20 \%$ \\
\hline 11 & $\begin{array}{l}\text { Escuela de la } \\
\text { Ronda Magdalena } \\
\text { graduada niños, } \\
\end{array}$ & Ronda Magdalena & $\begin{array}{l}\text { Municipal, de nueva } \\
\text { planta y subvención } \\
\text { estatal }\end{array}$ & 3 maestros & $\begin{array}{l}\text { 3 AULAS/pl. baja } \\
9,50 \times 7,40 \times 5 \mathrm{mts} \text {. } \\
\text { Sup. } 70,3 \mathrm{~m} 2 / \text { aula }\end{array}$ & $\begin{array}{l}\text { Patio - jardín } \\
\text { de } 175 \mathrm{~m} 2 \\
1,25 \mathrm{~m} 2 / \mathrm{alum}\end{array}$ & $\begin{array}{l}196 \text { grado } \\
65 \text { alum/aula }\end{array}$ & $\begin{array}{l}162 \text { alum/aula } \\
54\end{array}$ & $\begin{array}{l}\text { 1,0 m2/alumno. } \mathrm{M} \\
\text { 1,3 m2/alumno. A }\end{array}$ & $\begin{array}{l}\text { 5,4 m3/alumno.M } \\
6,5 \text { m3/alumno.A }\end{array}$ & $17,40 \%$ \\
\hline & Párvulos & & & & & & & & & & \\
\hline 21 & $\begin{array}{l}\text { Escuela del Real } \\
\text { párvulos niñas. }\end{array}$ & $\begin{array}{l}\text { Pza. Sixto Cámara, } 18 \\
\text { (Pza.d.Real) }\end{array}$ & Municipal & 2 maestras & $\begin{array}{l}1 \text { AULA /pl. baja } \\
9,50 \times 6 \times 4,20 \mathrm{mts} \text {. Sup. } 57 \mathrm{~m} 2\end{array}$ & No & 222 & 118 & $\begin{array}{l}\text { 0,3m2/alumno. } \mathrm{M} \\
0,5 \mathrm{~m} 2 / \text { alumno. A }\end{array}$ & $\begin{array}{l}\text { 1,8 m3/alumno } \mathrm{M} \\
\text { 2,0 m3/alumno A }\end{array}$ & $47 \%$ \\
\hline 13 & $\begin{array}{l}\text { Escuela las Aulas, } \\
\text { párvulos niñas }\end{array}$ & $\begin{array}{l}\text { C/ Caballeros, frente } \\
\text { nuevo edificio } \\
\text { Diputación }\end{array}$ & Municipal & 1 maestra & $\begin{array}{l}1 \text { AULA/pl. baja } \\
15,75 \times 5,25 \times 4,40 \mathrm{mts} \text {. } \\
\text { Sup. aprox } 82,70 \mathrm{~m} 2\end{array}$ & $\begin{array}{l}\text { Patio- jardín } \\
\text { de } 135 \mathrm{~m} 2 \\
0,80 \mathrm{~m} 2 / \mathrm{alum}\end{array}$ & 180 & 96 & $\begin{array}{l}\text { 0,4 m2/alumno. M } \\
0,7 \text { m2/alumno. } A\end{array}$ & $\begin{array}{l}\text { 2,0 m3/alumno.M } \\
\text { 3,7 m3/alumno A }\end{array}$ & $46,67 \%$ \\
\hline
\end{tabular}

Todos disponían de agua, iluminación y ventilación suficiente, según figura en los correspondientes artículos de El Clamor.

*Clases nocturnas de adultos; Matriculados=M; Asistencia $=A$; Los datos en cursiva corresponden a la asistencia a clase 


\begin{tabular}{|c|c|c|c|c|}
\hline \multicolumn{5}{|c|}{$\begin{array}{l}\text { ALGUNAS ESCUELAS MUNICIPALES, AÑO } 1914 \\
\text { Guía Oficial de Castellón y la Provincia }\end{array}$} \\
\hline Denominación & Emplazamiento & Titularidad & Docentes & aulas \\
\hline $\begin{array}{l}\text { Colegio de las Balsas } \\
\text { Unitaria, niñas }\end{array}$ & Plaza las Balsas, 26 & Municipal & 1 maestra & 1 aula \\
\hline $\begin{array}{l}\text { Colegio calle Ros de } \\
\text { Ursinos } \\
\text { Graduada,niños }\end{array}$ & c/ Ros de Ursinos, 2 & Particular & 1 maestro & 1 aula \\
\hline $\begin{array}{l}\text { Coleg. Caserío del Grao } \\
\text { Unitaria,niños y niñas }\end{array}$ & c/ San Cristóbal & Particular & $\begin{array}{l}1 \text { maestro } \\
1 \text { maestra }\end{array}$ & 2 aulas \\
\hline $\begin{array}{l}\text { Grupo escolar calle } \\
\text { Herrero } \\
\text { Graduada, niños }\end{array}$ & c/ Moyano,6 & Municipal & 3 maestros & $3 \mathrm{aulas}$ \\
\hline
\end{tabular}

Poco a poco estas diferencias se van corrigiendo. En la primera década del siglo XX aparecen tres nuevas escuelas y a finales de la misma década ya hay dos grupos escolares de nueva construcción y de subvención estatal. En la segunda década surgen tres nuevos grupos escolares, desapareciendo progresivamente las «escuelas-habitación» y mejorando la higiene y el hacinamiento en las aulas.

Un primer aspecto que observamos, es que en más de un 60 por ciento de los centros escolares se estaba impartiendo la enseñanza graduada, frente al 40 por ciento que continuaba con la enseñanza unitaria. Lo que suponía pasar del anterior sistema «escuela-aula» a la «escuela-colegio». La innovación pedagógica llevaba consigo más aulas y más maestros, además de un nuevo sistema de ordenación, diferente organización y recursos, la formación del profesorado y la difícil tarea de aplicar los criterios de «clasificación». Todo esto suponía por parte de la Corporación municipal transformar y ampliar centros y por parte de los profesores adaptarse al nuevo sistema educativo. Aunque con el Real Decreto de 26 de octubre de 1901, el Estado asume los gastos de personal y mantenimiento, los ayuntamientos, a cambio, tienden que duplicar y adecuar los centros escolares a su costa, ya que el Real Decreto de 1905, de Carlos María Cortezo, reduce drásticamente los alumnos por aula a 25-40 para la enseñanza graduada, y también en el mismo decreto se introducen las nuevas Instrucciones Técnico-higiénicas. Manteniendose los 60 alumnos/as para la enseñanza unitaria.

El Ayuntamiento y los profesionales de la docencia realizaron un gran esfuerzo para convertir en enseñanza graduada todas estas escuelas en fechas tan tempranas. Lo que denota por parte de la corporación municipal y maestros su predisposición a las innovaciones pedagógicas.

Debemos recordar, que pocos años antes, el Real Decreto de 23 de septiembre de 1898, de Germán de Gamazo, dicta las primeras normas que obligaban a convertir las 
escuelas en graduadas. El Decreto de 25 de febrero de 1911, estable su funcionamiento. Las sucesivas instrucciones, la de 1913 regula la transformación, y la de 1918 es el Primer Reglamento de Escuelas Graduadas. Para Antonio Viñao, ${ }^{1236}$ la introducción de la escuela graduada en el sistema público fue muy lento y constituyo casi exclusivamente un fenómeno urbano. En 1935 las escuelas unitarias representaban todavía el 82,4 por cien del total en España.

Se observa también, que en la segunda década del siglo $\mathrm{XX}$, en la ciudad de Castellón, casi la mitad de los centros escolares son aún escuela-habitación, instalados en locales propios o viviendas alquiladas, generalmente en planta piso. Lo que suponía la sistemática renovación de contratos cada cuatro o cinco años ${ }^{1237}$ o el cambio de emplazamiento, también para buscar mejores y más amplios establecimientos, como era el caso de la Escuela Centro de niños, que dirigía el maestro José Marco Cheza.

De las escuelas de propiedad municipal, algunas como la Escuela del Hospital, la Escuela de las Balsas, o la del Real, son antiguas y pequeñas construcciones de finales del siglo XVIII, algunas se cerraron, otras se reedificaron, remodelaron o ampliaron para adaptarse a las nuevas condiciones.

Tan solo hay dos grupos escolares municipales de reciente construcción y de subvención estatal, que cumplen con la reciente normativa Técnico-Sanitaria de 1905.

En general, tanto las escuelas situadas en locales alquilados, como las de propiedad municipal, son edificios aparentemente amplios, sólidos y en su conjunto relativamente recientes, con estancias capaces para albergar las aulas y otras dependencias escolares.

A excepción de las aulas de los citados grupos escolares, las clases del resto de escuelas públicas no reunian todas las exigencias higiénicas que las nuevas normas imponian en materia de ventilación, iluminación y orientación para la entrada de luz. Requisitos difíciles de cumplir si no se trata de construcciones escolares de nueva

\footnotetext{
1236 VIÑAO FAGO, Antonio: (1990): Innovación pedagógica y racionalidad científica. La escuela graduada pública en España (1898-1936), p. 46

1237 Entre los expedientes de Instrucción pública de centros escolares del Archivo Histórico del Ayuntamiento de Castellón, figuran actas de arriendos entre el Ayuntamiento y particulares para albergar escuelas públicas. De 26 de febrero de 1894 es el contrato de alquiler entre el Excmo. Ayuntamiento y Cristóbal Juan Mateu, por la cantidad de 1,50 pts., diarias, para trasladar a la casa de su propiedad, situada en la calle San Cristóbal, la Escuela de niñas del Grao. De 29 de septiembre de 1895 es el contrato de alquiler, por la cantidad de 2,25pts. diarias, de una casa en la calle de las Cruces $\mathrm{n}^{\circ} 6$, propiedad de Jaume Miralles Monfort, para trasladar la escuela de niñas de las Balsas, durante el periodo que dure el derribo y reconstrucción del viejo edificio escolar, que estaba situado en la plaza de las Balsas, 26.
} 
edificación. La mayoría de las escuelas ocupaban edificios antiguos de difícil adaptación o locales alquilados adecuados a la función docente.

Para profundizar en la higiene de estos centros docente, se han visitado los edificios existentes que alojaban estas escuelas, también se han buscado fotografías antiguas de sus fachadas, planos de sus interiores y se ha investigado su localización y orientación a través de planos de la ciudad de la época, para valorar las condiciones de habitabilidad que tenian. En la mayoría de los casos se trata de edificios de gran fachada, que solían hacer esquina a dos o tres calles, con abundantes ventanas de amplias dimensiones a las que recaían las aulas, como podemos observar en la ilustración adjunta de la Escuela de la calle Pi i Margall.

Más de la mitad de las escuelas no tenía patio o jardín, el emplazamiento de muchas de ellas en el centro de la ciudad impedía disponer de espacios abiertos de juego y las que lo tenían no cumplían con las dimensiones reglamentarias.

Las escuelas solían tener tres aulas, con un profesor por aula. En casi todos los casos, las superficies y alturas que se describen de las mismas eran las recomendadas, siendo la media no inferior a los 60 metros cuadrados y la altura próxima a los 4,5 metros. Pero como se puede apreciar en la tabla resumen anterior de escuelas, la alta escolarización que figura en todas las escuelas, sobrepasa en la mayoría de los casos el número de alumnos permitidos por aula. Mientras que en las escuelas unitarias es poco significativo, en las de enseñaza graduada es muy acusado, doblándose en ocasiones el número de alumnos permitidos. Debemos recordar que para las escuelas unitarias, desde el Real Decreto de 5 de octubre de 1883 la capacidad del aula se fijó en un máximo de 60 alumnos y en 1,25 metros cuadrados de aula por alumno, y para las escuelas graduadas, a partir del Real Decreto de 28 de abril de 1905, entre 25-40 alumnos.

Todo este hacinamiento se traduce en que la relación de superficie de aula por alumno no llega al mínimo establecido de 1,25 $\mathrm{m}^{2} /$ alumno, y en consecuencia, el volumen por alumno tampoco se alcanza. Incluso considerando la asistencia real, en el caso de las escuelas graduadas, tampoco se cumple, como podemos ver en apartado correspondiente de la citada tabla.

Otro tema preocupante que se detecta es el alto grado de absentismo escolar, que gira en torno al 20 por ciento, siendo más elevado en las niñas que en los niños. Llegando en los párvulos al 50 por ciento. 
Los nuevos grupos escolares de la calle Herrero y de la Ronda Magdalena se componen de tres aulas para niños y tres para niñas, además de los servicio de aseo y complementarios. Según los datos facilitados en los artículos de El Clamor, las dimensiones que figuran de las aulas y de los patios se ajustan a la normativa del Ministerio de Instrucción Pública. Pero mientras el Centro Escolar de la Ronda Mijares cumple con el número de alumnos y alumnas fijados para la enseñanza graduada, el de la calle Herrero aloja más alumnos y alumnas que fijaba la ley. En los dos casos se aprecia un alto índice de absentismo, siendo en los niños del 17,5\% y en las niñas llega al $24 \%$. Los edificios estaban alejados del centro de la ciudad y la población escolar debía proceder en su mayoría de los nuevos ensanches.

Por los datos analizados podemos concluir que a mediados de la última década del siglo XIX la enseñanza pública empieza a experimentar una sensible mejoría, tanto en el sistema pedagógico, en número de escuelas, como en las condiciones higiénicas. A mediados de la segunda década del siglo XX, que es cuando aparecen publicados los artículos estadisticas de las esuelas públicas en el periodico El Clamor, y que hemos analizado desde la normativa, las mejoras son significativas. Continuando en la misma dirección las décadas siguientes, con nuevos centros escolares graduados, y desapareciendo progresivamente las escuelas-habitación muchas de ellas de alquiler.

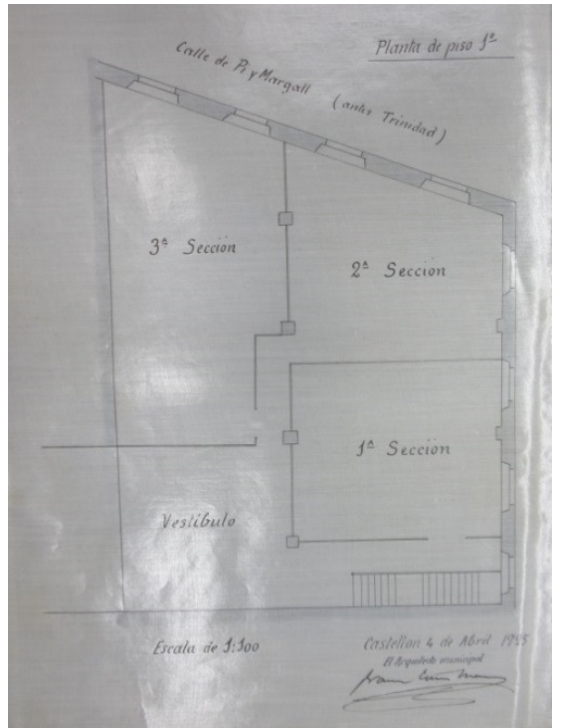

Plano de distribución de la tres aulas de la escuela pública de la calle Pi i Margall Fondo documental: Expedientes Instrucción Pública, Archivo Histórico Municipal de Castellón

También hemos constatado esta buena evolución en las declaraciones de políticos como el alcalde de la ciudad Fernando Gasset. En el salón de sesiones del Ayuntamiento se reunió el 14 de diciembre de 1917 una Asamblea de Primera 
Enseñanza. Asistieron la mayoría de los vocales de la Junta Local, el inspector provincial de Primera Enseñanza, todos los maestros y maestras de la capital y gran número de concejales. Fernando Gasset, alcalde y presidente de la Asamblea, pronunció un discurso haciendo historia de la evolución y progreso de la Primera Enseñanza en Castellón desde hacía treinta años, cuando por primera vez vino al Ayuntamiento como concejal. Comparó el estado de la instrucción en aquellos años en que existían solo ocho maestros y cuatro o cinco escuelas de pésimas condiciones con el de 1917 en que existían cerca de cuarenta maestros y diecinueve escuelas en «magníficos edificios unos y muy aceptables otros, con material a la altura de las modernas exigencias de la pedagogía». ${ }^{1238}$

Gasset visitó como alcalde la mayor parte de las escuelas, afirmando que a su juicio todos los maestros y maestras cumplían con sus deberes, siendo satisfactorio el estado general de la enseñanza. Estudió detenidamente la enseñanza de adultos en la que no se obtenían los resultados apetecidos y afirmó que era necesario reorganizar la enseñanza de adultos. Para esto convocó a todos los reunidos al objeto de estudiar los medios de llegar a esa reorganización e invitó a todos los presentes a que expusieran su opinión para ayudar a resolver el problema. Se acordó nombrar una ponencia formada por los maestros vocales de la Junta local para estudiar y proponer los medios de llegar a la reorganización deseada.

El alcalde se preocupaba por la falta de asistencia a las clases nocturnas, los maestros cumplían con su obligación, pero los vecinos miraban con indiferencia las clases que se daban por las noches en las escuelas oficiales. La presidencia pidió que se dieran clases de adultas en las escuelas de niñas, prestándose varias maestras a darlas en la escuela Herrero, en la Aulas y en la Enseñanza.

Otro tema que se trató fue el del horario de clase en los meses de invierno. A juicio del alcalde, la hora de entrada en la escuela debía ser a las nueve horas saliendo a las doce. Después de discutir este punto, se acordó que la entrada en invierno fuera a las nueve dejando en libertad a los maestros que no estuvieran de acuerdo con esta medida para entrar como siempre a las ocho horas. ${ }^{1239}$

\footnotetext{
${ }^{1238}$ El Clamor, 15/12/1917.

${ }^{1239}$ Ibídem.
} 


\section{ENTREVISTAS A MÉDICOS Y PERSONALIDADES EN LA PRENSA DENUNCIAN LA TRISTE Y MÍSERA REALIDAD DE LA INFANCIA}

El gran impacto de la elevada mortalidad infantil y la prevalencia de enfermedades de la infancia, que eran evitables, convirtieron a la infancia en un grupo social diana de las actividades de protección social y acción sanitaria.

La preocupación municipal por la atención a la infancia desprotegida había dado lugar a comienzos del siglo XX a la creación de la Gota de Leche en algunos municipios importantes (Barcelona, 1904; Valencia, 1910). Su objetivo era dar lactancia natural a los niños que por ser hijos de familias pobres no podían ser amamantados por la madre, bien por problemas físicos o laborales. Las gotas de leche proporcionaban la cantidad de leche necesaria para el crecimiento y desarrollo físico del niño, con las suficientes garantías higiénicas, que incluían el análisis bacteriológico y la esterilización de la leche. Por otra parte, como la mayoría de instituciones de comienzos del siglo XX, las gotas de leche incluían entre sus funciones la educación de las madres en el cuidado de sus hijos.

Unos años más tarde, la publicación del Reglamento Municipal de Sanidad (1925) transformó las anteriores gotas de leche en Institutos Provinciales de Puericultura (1927).

Los Institutos de puericultura constaban de un comedor para embarazadas y mujeres lactantes, una gota de leche y una casa-cuna. El despliegue de todas estas medidas encaminadas a atender la higiene y la salud de las madres y los niños tuvieron como consecuencia la fundación en Madrid de una Escuela Nacional de Puericultura (1923) que debía hacer frente a la formación de todo el personal especializado en maternología-infantil. Allí se estableció la especialización de médico puericultor, que marcó la etapa previa al nacimiento de la pediatría, como también de enfermeras y demás personal auxiliar. ${ }^{1240}$

Un problema crónico relacionado con los hijos de familias pobres lo constituía la falta de asistencia a la escuela, agudizado en el medio rural y menos grave en las

\footnotetext{
1240 BARONA VILAR, Josep Lluis (2002): Salud, enfermedad y muerte. La sociedad valenciana entre 1833 y 1939, Institució Alfons el Magnànim, Valencia. pp. 288-290.
} 
ciudades. A veces, se quejaban los maestros, había que arrancar al niño a sus padres y a la misma sociedad. Miseria y egoísmo se encontraban en la base del problema. La primera se convertía en una lacra irresoluble al no recibir las familias asistencia social apropiada, mientras el establecimiento en las escuelas de instituciones complementarias como cantinas y roperos se desarrollaba lentamente. Los intereses de los padres y de la propia sociedad, de otro lado, infringían o impedían la aplicación de la norma legal contra la explotación de los niños en el trabajo, lo que favorecía el absentismo escolar. $^{1241}$

En los locales-escuela de Castellón, se daban a menudo conferencias sobre la necesidad de implantar los roperos y las cantinas escolares. Un ejemplo lo tenemos en la conferencia que dio la maestra de párvulos de la escuela de Pestagua, Julia Andrés Castel en 1911.

El acto fue presidido por el director de El Heraldo, José Castelló Tárrega y el director de la mencionada escuela Francisco Canós, siendo un acto muy concurrido.

La maestra explicó cómo funcionaban los Roperos en el extranjero, tomando como tipo el instruido en Lille. Describió su organización, su funcionamiento y sus excelentes resultados:

«Los comienzos de todas las cosas son pesados, más si un día y otro aplicamos nuestras fuerzas al mismo fin, se van aligerando las dificultades: lo vencido sirve de auxilio para lo que queda por vencer».

Defiende las excursiones, las cantinas, los roperos, la mutualidad, como instituciones de educación social modernas que extienden la obra del maestro y la hacen interesarse íntimamente con los asuntos de los pueblos dando ocasión de adquirir alguna preponderancia en la vida de los jóvenes «porque el aislamiento en que hasta hoy vamos trabajando, encerrados en la Escuela fuera de la vista del público, contribuye a aislarnos y a que se nos olvide».

Andrés Castel, terminó diciendo: «Vengan cantinas, roperos escolares, la mutualidad escolar, bibliotecas y museos de enseñanza agregados a nuestras escuelas que deben ser cuna y semillero de virtudes sociales, haciendo así útil y simpática la escuela popular». ${ }^{1242}$

\footnotetext{
${ }^{1241}$ RUIZ RODRIGO, Cándido (1997): «Maestro, Escuela y Sociedad (de la Restauración a la II República», en Historia de la Educación, Revista interuniversitaria. Vol. 16, Universidad de Salamanca. p. 166.

${ }^{1242}$ El Clamor, 27/11/1911.
} 
En Castellón un redactor de El Clamor con seudónimo Crispín realizó una serie de entrevistas a personalidades de Castellón sobre obras benéficas. La obra benéfica que el Ayuntamiento trataba de instituir con los rendimientos proporcionados por el impuesto municipal que grababa la luz eléctrica.

Se quería proponer que el Ayuntamiento subvencionara los roperos y las cantinas escolares a través de los impuestos recaudados de la electricidad. Se iban a recaudar por dicho impuesto unas 8.000 pesetas y el reportero de El Clamor obsesionado con la idea de la creación de una obra benéfica, quiso pulsar la opinión de las personalidades, periodistas y organismos de la capital, para que manifestaran qué idea encajaría mejor en Castellón a fin de que se implantara y funcionara con el dinero de referencia que el Ayuntamiento cedía para tal objeto. ${ }^{1243}$

Las entrevistas realizadas por Crispín en El Clamor fueron realizadas al prestigioso médico republicano, Vicente Gea; al Inspector provincial de Sanidad, doctor Clará; al médico de la Beneficencia Provincial, Francisco Badenes; a prestigiosos republicanos como Vicente Tamaturgo; al director de La Provincia, Carlos Armengot... ${ }^{1244}$

El primero que entrevistó el periodista fue el ilustre médico republicano Vicente Gea. Éste defendía el sanatorio para tuberculosos, ${ }^{1245}$ para evitar tan terrible mal en la infancia: ${ }^{1246}$

\footnotetext{
${ }^{1243}$ La Asociación Castellonense de Caridad era la que se encargaba del Comedor, el Ropero de pobres y la Cantina Escolar. La Asociación consiguió establecer el comedor escolar de pobres, el ropero y la cantina escolar, extinguir la mendicidad callejera y acabar con el espectáculo poco edificante, impropio de una capital de provincia, que venían dando continuamente un enjambre de niños de corta edad en las calles más céntricas y hasta en los arrabales, saliendo al paso de los transeúntes, implorando la caridad pública descalzos, casi desnudos y sucios. Ësta asociación, cuando pasaba por problemas económicos, hacía un llamamiento a la ciudadanía para que con sus limosnas ayudara a mantener estas obras benéficas. En El Clamor, 20/07/1914.

${ }^{1244}$ Ver en apéndice documental $\mathrm{N}^{\circ} 24$ todas las entrevistas a personalidades de Castellón.

${ }^{1245}$ Hasta 1953 no se inaugura el sanatorio antituberculoso. Tienen que pasar más de cuarenta años para que sea una realidad las aspiraciones de estos médicos castellonenses. Está situado en las inmediaciones de la población, en zona alta y seca, a los pies de las estribaciones de la sierra de Borriol. El edificio es similar a otros construidos en la misma época a lo largo de la geografía española. El Ministerio, a través del arquitecto Sebastián Villalta Valls, diseña estos edificios a base de grandes terrazas corridas orientadas al sur, a las que dan frente las habitaciones, para disfrute del sol y del aire natural en la cura de reposo. La idea fue puesta en práctica por el doctor D.Sarasin en 1901 y fue recogida por el arquitecto Richard Döcker de Stuttgart, en 1926 para el sanatorio de Waiblengen, en PEVSNER, Nikolaus (1980): Historia de las tipológicas arquitectónicas, editorial Gustavo Gili.S.A., Barcelona, p. 188. Pero el sanatorio más paradigmático que recoge estos planteamientos, es el de Paimio (1929-33), en Finlandia, del arquitecto Alvar Aalto, en GIEDION S. (1980): Espacio, tiempo y arquitectura. Editorial Dossat, s.a. Madrid, p. 608.

${ }^{1246}$ El Clamor, 20/07/1914.
} 
También sería una obra humanitaria, el sanatorio para tuberculosos, pero no en la forma que apuntas- me decía el doctor- sino para evitar tan terrible mal en la infancia.

¿Cómo?... Sencillísimo. Bastaría recoger a los niños de padres tuberculosos y buscar matrimonios de honradez intachable que, por una modesta retribución, se encargarían de cuidarlos, de educarlos y hacerlos hombres, lejos de Castellón, en la montaña, en aquellos pueblos que por sus condiciones higiénicas lograsen destruir los gérmenes de tan terrible enfermedad.

¿Ventajas?... Muchísimas. Todos los tuberculosos, desgraciadamente pueden contagiar a los que les rodean, y su enfermedad aún no ha logrado dominarla la ciencia irremisiblemente, el tuberculoso ha de desaparecer del mundo de los vivos. Y calculo lo triste que resulta en la actualidad ver a aquellos inocentes niños, quizá contagiados por el contacto, y que muerto su padre no les queda otro recurso que la Casa de Beneficencia [....].

También para evitar que los niños deambularan por las calles, Vicente Gea abogaba por dar una pensión combinada con la gota de leche.

Hermosa idea es también la pensión para esa nube de criaturas que vemos abandonadas por nuestras calles, y mucho mejor si pudiéramos combinarla con la gota de leche, y es un asunto digno de estudio, pues seguramente que con esta institución disminuiría muchísimo la mortandad de la infancia en nuestras clases humildes; pero para ello se necesita una mayor subvención y tengo para mí que no puede implantarse por vía de ensayo, sino cuando se cuente con el dinero para hacer una obra definitiva $[\ldots]$.

Asimismo era partidario de crear una escuela nueva, una escuela semi al aire libre, con cantina escolar, que además de darle al niño «el pan del cuerpo, le daría el pan de la inteligencia»: «Yo crearía una escuela reducida, una escuela para tan solo 40 niños, que son los suficientes para un profesor, y estos 40 niños, recogidos entre los de las clases menesterosas encontrarían allí la comida y la educación».

Gea pensaba que esta nueva escuela podría ser municipal, y que en ella se diera la educación e instrucción que la moderna pedagogía reclamaba, «educación e instrucción racional todo lo racional y progresiva que los tiempos reclaman». 
Seguía diciendo que el ideal de escuela al aire libre tenia que estar dirigida siempre por el mismo maestro para un número determinado de años y, además, debía contar con cantina escolar. Con ella todo serían muchas las ventajas: $1^{\circ}$ se aseguraría la asistencia a la escuela de los niños pobres, libres de todo cargo y con la comida segura; $2^{\circ}$ los beneficios que reportaría la enseñanza planteada sobre el mismo grupo de niños, por un mismo profesor y $3^{\circ}$ las ventajas que reportaría la enseñanza al aire libre, estando los niños en contacto con la naturaleza, «gran maestra de los hombres».

No, no resultaría caro, Crispín. Calcula 40 niños con un gasto de 0,50 pesetas diarias durante los 240 días de clase anual que se pueden contar, solo alcanzaría el gasto de manutención unas 4.800 pesetas anuales. Añadamos a esto un maestro con 2.500 pesetas anuales de sueldo; 500 pesetas para material y 200 para imprevistos, y tendríamos el presupuesto de las 8.000 pesetas, ya que, por subasta encontraríamos quien se encargase de suministrar los alimentos en las buenas condiciones que, seguramente exigiría el maestro que ve hijos en sus discípulos.

Solo puede pararnos a meditar el gasto de la construcción y menaje de la escuela, gasto que yo juzgo cubierto con el primer año de subvención.

¿Lugar del emplazamiento?... Nuestro hermoso Paseo. Donde estaba el antiguo fielato de Morella, en la caseta del guarda, y mejor en el Gimnasio que se va a construir, podría edificarse la nueva escuela, sencilla, dos salones, una para clases y otro para comedor; cuatro paredes en las debidas condiciones higiénicas, sin lujos, serían lo suficiente.

La idea del doctor Gea no era separar los pobres de los ricos, sino en la misma escuela se podría admitir niños pudientes pagando una modesta pensión, y «seguramente serían muchos los ricos que aceptasen para sus hijos este internado.»

El doctor Gea, en alas de su poética concepción, ve el magnífico resultado que podría dar una escuela semi al aire libre y con cantina escolar.

Y con su insinuante, con su atractiva palabra, hace pasar por mi vista un plan nuevo, grande, cambiando poco a poco la manera de ser de las actuales escuelas, montando en todas las cantinas escolares, aunando, al esfuerzo del ayuntamiento, la subvención del Estado y hasta la de los particulares, que entonces, cuando todos podríamos ver los grandes resultados que se obtendrían en aquella escuela, sería hora de ampliar la idea, de pedir auxilios a todos y estableceríamos 
una magnifica forma de enseñanza cíclica e integral enseñanza obligatoria, que, gustaría indudablemente a los maestros porque podrían desarrollar un completo plan de enseñanza, que gustaría a los padres porque sus hijos, saldrían de la escuela con buen bagaje de cultura y bien educados física y moralmente y encantaría a los niños porque desaparecería lo mucho de cárcel que actualmente tiene la escuela para los pequeños $[\ldots]$.

Otro republicano, Vicente Tamaturgo, se decantaba también por las cantinas escolares, porque según decía había mucha hambre en Castellón y las clases humildes necesitaban el jornal de sus hijos por lo que estos no podían asistir a la escuela. ${ }^{1247}$

El director de La Provincia, Carlos Armengot, opinaba que las cantinas escolares y el sanatorio para tuberculosos eran proyectos a tenerse en cuenta. Pensaba que llegaría el día en que el Estado se haría cargo de ellos, y que los sanatorios antituberculosos debían extenderse por toda España.

Hace una crítica a las paseadoras de los niños «verdaderos verdugos inconsciente de las pobres criaturas que se les encomiendan a su cuidado a cambio de unas cuantas perras de salario».

Otro ilustre médico de Castellón, entrevistado por Crispín, fue al doctor José Clará, Inspector Provincial de Sanidad. Este dirigía la Asociación Castellonense de Caridad, y al ser preguntado su parecer por los temas que estamos tratando, opinaba que la Asociación era el único organismo laico que oficialmente debía acudir a remediar todas las necesidades, a practicar todas las obras de beneficencia.

La Asociación estaba dividida en comisiones. Hasta entonces sólo funcionaban dos, la del Comedor y la del Ropero, pero la intención de la Asociación era ampliarlas.

Según el doctor Clará, la Asociación estaba constituida por personas abnegadas pertenecientes a todas las clases sociales y a todos los matices de la población. Eran personas que trabajaban por altruismo, por amor al prójimo y no por obligación, solo así podía gobernarse una obra benéfica, pues si llegase a la municipalización del servicio, sería un mal porque «los concejales, al ser elegidos, lo son por sus condiciones políticas

${ }^{1247}$ El Clamor, 22/07/1914. 
y administrativas, no por el entusiasmo que puedan sentir para realizar una obra benéfica».

Sigue diciendo el doctor Clará, que la Asociación comprendía la acción tutelar del individuo desde que nace hasta que muere. «La Asociación tiende a acoger al recién nacido y darle la primera cucharada de leche y guiarle y ayudarle toda su vida hasta que, terminada esta, le deje en el ataúd. Todo está comprendido en el reglamento que estudiamos ahora, y todo confiamos alcanzarlo».

La gota de leche no estaba comprendida en la Asociación Castellonense de Caridad. Según Clará, la gota de leche podía ser subvencionada por el Ayuntamiento con el impuesto de la electricidad, estableciendo un consultorio donde un médico diera consejos para conservar la salud del niño y que vigilara su desarrollo, facilitando su crecimiento, haciendo disminuir «la horrorosa mortalidad que sufrimos en Castellón».

Según el inspector de Sanidad, un promedio de 200 niños morían al año en Castellón y añade que en 1913 fallecieron 220 evitables, todos ellos murieron de catarros, bronquitis, diarreas infantiles y meningitis derivados de las diarreas. Y todos por falta de higiene en los niños como consecuencia de la falta de educación sanitaria de las madres.

También se queja el doctor Clará que las clases más elevadas no seguían los consejos del médico: «desean enterarse antes de obedecer lo que se les aconseja, y como para convencerse han de estudiar, han de trabajar y no estudian, dificultan el trabajo de la ciencia», sin embargo, sigue diciendo, «la clase más humilde, es la que se hace cargo más pronto de las cosas y admiten como dogmático lo que aconseja el médico.

Más adelante añade que la Asociación de Caridad se haría cargo también de la segunda faceta de la vida del niño, es decir, de los niños destetados cuyos padres van a trabajar por el mundo y no pueden atenderles. Según afirma el inspector eran tres o cuatro mil los pequeños que iban por las calles tirados de cualquier modo, ya que no podían con ellos las niñeras.

Clará sostuvo conversaciones con el alcalde de Castellón, Forcada Peris, para solucionar el problema de los niños mendigos. El objetivo de ambos médicos era recoger en amplios almacenes a todas las paseadoras con las criaturas y ponerles bajo la dirección de las mujeres que hacían escuela en sus casas. Allí se les daría a todas almuerzos y meriendas y también clases de higiene. «Allí, limpios y aseados los niños, evitaríamos la propagación de la diarrea infantil que es la que más estragos produce». 
El objetivo de la Asociación de Caridad era establecer primero la cantina escolar por ser más barata, aunque Clará daba más importancia a la gota de leche para evitar la desesperante cifra de 200 niños que morían al año:«[...] que mueran los viejos es triste sí, pero es la selección natural. Lo que no debemos consentir es que mueran los niños, que son el porvenir, que son la esperanza...esto, esto es una cuestión social».

Sigue diciendo el inspector que con la Cantina escolar se resolvería el problema de la enseñanza obligatoria. Según sus cálculos, eran 300 niños los que necesitaban las cantinas. «Esto lo podía resolver el Comedor con menos que doblar lo que hacemos actualmente. Esto para nosotros resultaría muy barato, pues no puede usted imaginar lo económico que resulta dar bien de comer y por poco dinero cuando se administra bien».

Consideraba Clará que las colonias escolares no eran necesarias en la capital, «porque aquí se hace vida en el campo todo el año, y apenas llegan a media docena los niños raquíticos, sin embargo sí que serían necesarias en las grandes ciudades».

A todo quería atender la Asociación y como cúpula de su obra la asistencia a los pobres y el asilo para los ancianos. Y añade: «todo esto no podremos hacerlo sin el decidido apoyo de todos y sin la protección del Ayuntsamiento. Esta corporación debe encargar a la Asociación todos los servicios de beneficencia».

Otra idea que lanza el doctor Clará es que la protección del Ayuntamiento debía comenzar por dar a la Asociación de caridad un edificio, en lugar céntrico, donde instalar el Comedor, con un pequeño departamento para la gota de leche y un salón para las cantinas escolares. «La Bolsa del trabajo en construcción sería un local magnífico, donde podrían establecerse todos los servicios».

La finalidad del doctor Clará era trabajar para que Castellón entero viera aquella nube de mendigos que antes le molestaba continuamente, en el Comedor: «bien vestidos, correctos, sin hacer el menor ruido para comer y hasta sin beber... el caldo en el plato».

En un año de funcionamiento del Comedor, sólo murieron siete pobres. Castellón daba 800 pesetas mensuales al Comedor y cada vez llegaban un buen número de donativos: «Ya funcionan el Ropero y el Comedor, instituyamos ahora la gota de leche y pediremos luego la subvención al Estado para las cantinas escolares».

El objetivo del inspector era acabar con las 220 defunciones de niños que ocurrían al año en Castellón. Para este fin pedía que el Ayuntamiento dedicara la cantidad que daba a las nodrizas a la Asociación, «que no sabemos si lactan o no a los 
niños que son subvencionados por el municipio y con nuestra directa intervención sabrán los concejales todos que el dinero que vota va directamente al humanitario fin que los destinan $[\ldots] \gg .{ }^{1248}$

Otra de las entrevistas fue a Cayetano Huguet Breva, «entusiasta de la educación y adalid de la cultura» que fue el que cedió los terrenos para gimnasio y fábrica de luz eléctrica en beneficio de Castellón.

Cayetano Huguet se decantaba claramente por las cantinas escolares con el fin de extinguir el analfabetismo:

Si pretendemos que Castellón sea una ciudad progresiva y con aspiración a figurar entre las primeras de España. Y una de las causas principales de la ignorancia es, sin duda, la miseria y la inteligencia. Procuremos, pues, proporcionar al niño pobre vestido, alimento sano y abundante y libros y habremos removido uno de los principales obstáculos que le alejan de la escuela. Los ayuntamientos de Castellón vienen haciendo esfuerzos muy laudables en pro de la enseñanza del pueblo desde hace algunos años; pero no nos hagamos ilusiones: el número de analfabetos en Castellón es abrumador; y esto de ninguna manera se ve mejor en la práctica, porque a veces las estadísticas suelen resultar desiguales.

Cayetano Huguet apuntaba la idea de crear una asociación popular para atender a la alimentación higiénica e instrucción de los pobres, con el título de «Asociación popular de obras benéficas» cuyo objetivo sería realizar de una manera prudente y paulatina, pero segura y progresiva, todas las obras sociales, como la gota de leche, las cantinas escolares, las colonias infantiles, las escuelas al aire libre, etc., con atribuciones para albergar recursos por los medios que fueran necesarios, incluso el de una suscripción popular por unas 250 pesetas anuales, «todo sobre la base de la cantidad que ofrece el Ayuntamiento».

«Creo que en el estado depresivo porque pasa la Sociedad Española en los actuales momentos, donde no hay más ideal que la plaza de toros, debiéramos

${ }^{1248}$ El Clamor, 1/08/1914. 
esforzarnos en dar un ejemplo sano llegando a la realización de estos pensamientos propios de pueblos cultos y altruistas $\left[\ldots . .{ }^{1249}\right.$

Otro personaje entrevistado por Crispín, fue al abogado de Castellón Manuel Bellido Alba. Este también se decantaba por las cantinas escolares «porque sin ellas, la enseñanza obligatoria es ilusoria por irrealizable, porque sin pan y condumio para el cuerpo no puede haber alimento y cultura para el espíritu».

Según Bellido Alba, las familias pobres no podía mantener a su hijos con el menguo salario que ganaban, necesitaban la ayuda del trabajo de sus pequeños para comprar lo más necesario para poder sobrevivir.

Cierto es, que no se les podía pedir a esos padres que matricularan a sus hijos en la escuela, «porque antes que famélicos, y éticos, los prefieren analfabetos e ignorantes».

Los niños ganaban un pequeño jornal, recogiendo basura o colillas, «a menar en el Huerto de Sogueros», a vocear periódicos, etc.

Por las calles de Castellón pululaban, niñeras, «menaors», colmeneros, caracoleras, raterillos y toda clase de vagabundos y maleantes.

Según Bellido, la cantina escolar solucionaría esta cuestión, dando en alimentos el menguado jornal que ganaba el pequeño. «Y el analfabetismo que nos deprime, cedería con las cantinas escolares su puesto a la cultura que dignifica y a la ilustración que ennoblece».

Bellido compara lo que ocurre en Castellón con las provincias del norte de España, «donde la enseñanza obligatoria es un hecho, donde han desaparecido los analfabetos».

Continua diciendo que la Asociación Castellonense de Caridad, «obra altruista de iniciativa privada, ha limpiado en parte las calles de la ciudad de pordioseros y vagabundos, y digo en parte porque la extinción completa de la mendicidad es irrealizable $[\ldots] \gg$.

Manuel Bellido consideraba a las cantinas escolares, como el digno complemento y remate de la obra de la Asociación de Caridad, porque «barrerían de la

\footnotetext{
${ }^{1249}$ El Clamor, 22/08/1914.
} 
vía pública los golfillos de uno y otro sexo, desarropado de cuerpo y alma que en ella hacen vida de abandono y vagancia».

«Si abrir una escuela, es cerrar un presidio, abramos el estudio para los desheredados que son precisamente la masa ingente de que se forman los bollos del horno de nuestras cárceles y habremos conseguido restar a la criminalidad el más fuerte de sus contingentes». ${ }^{1250}$

Siguiendo con las entrevista de Crispín, le tocó el turno al médico de la Beneficencia provincial Francisco Badenes. Este era un médico muy preocupado por la mortalidad infantil, procurando por todos los medios, difundir aquellas ideas que podían conservar la vida a aquellos niños que morían nada más nacer.

El doctor Badenes defendía la Gota de Leche. Antes del acuerdo del Ayuntamiento, estudió con Fernando Gasset y su hermano Rafael Gasset, por si ellos con su influencia, podían dotar a Castellón de una obra benéfica social de tanta importancia.

También como Gea abogaba por una escuela al aire libre con cantina escolar, pero consideraba que llegaría a muy pocos niños el dinero que podía disponer el municipio. El problema principal era evitar la muerte a una porción de niños que desaparecían cada año. Según consideraba, el doctor Badenes, con las cantinas escolares se formaría al hombre del futuro, pero con la gota de leche se formaría al niño que necesitaría la cantina escolar para que el hombre gozara de aquellas condiciones físicas necesarias para ser útil a la sociedad. La idea era tomar al niño desde su nacimiento y acompañarlo durante toda su vida hasta dejarlo en el sepulcro.

Comenzar por la gota de leche, luego la casa cuna, a la que debía seguir la cantina escolar, y cuando fuera hombre y necesitara salud, construir sanatorios, y para el final de su vida preparar el asilo.

Un problema que remarca el médico de la Beneficencia, era que para evitar la muerte de tanto niño había que educar a las madres para que los cuidaran debidamente, y esto lo evitaría seguramente la gota de leche. «Esta sería una verdadera escuela de madres, actualmente, por regla general, las madres cuidan a sus hijos sin aquellos conocimientos necesarios para asegurarles la vida».

\footnotetext{
${ }^{1250}$ El Clamor, 12/09/1914.
} 
La falta de educación de las mujeres para cuidar a sus hijos, no solamente ocurría en las clases menos pudientes, sino también en las más elevadas que ignoraban si el alimento que tomaban sus hijos era apropiado a su edad, a sus necesidades y en cantidad conveniente. Badenes abogaba por que esa cantidad fuera administrada por la Asociación castellonense de caridad. Y que la institución debía inaugurarse de una manera modesta, «sin gastos personales, sin grandes vuelos».

«Una estufa, unas cuantas botellas, algo muy poco para el material indispensable, y nada más». Porque según dice no faltarían médicos que sin retribución alguna se encargasen de la dirección.

Debemos fijarnos en que cada niño que muere, es un sumando menos en el capital humano; es una merma en el banco vital de su pueblo, que pierde con el individuo un equivalente monetario, pues si las lágrimas afectan a la familia. Las defunciones hacen perder al Estado una cantidad que, durante un año, asciende a millones de pesetas.

Según el doctor Badenes con la gota de leche se salvarían muchos niños. Sería más fácil, con la alimentación mixta y hasta con una lactancia artificial bien estudiada en cada caso, defender con éxito la vida del niño.

La ignorancia de algunas madres llegaba hasta el extremo de dar al niño aún en los primero días de su vida, leche de vaca pura. «Naturalmente los niños no pueden digerirla y enferman». ${ }^{1251}$

Todas saben que el biberón se ha de limpiar, pero ¡cuán pocas tienen nociones sobre la cantidad de leche que han de suministrar, las horas en que han de efectuarlo y las restantes condiciones todas tan importantes como la limpieza! [...]

Instituyamos la gota de leche, donde pueden acudir las madres cuyos recursos no les permita consultar a un médico y habremos evitado muchísimas defunciones.

Sí, yo creo que con ello podría suprimir el municipio de sus presupuestos la cantidad que fija para nodrizas.

${ }^{1251}$ El Clamor, 19/09/1914. 
Instituyamos premios que satisfagan la vanidad de aquellas madres que criasen mejor a sus hijos, indudablemente que habría entre todas un pugilato digno de encomio que redundaría en beneficio no solo de los niños, sino también del municipio.

Otro personaje entrevistado, fue el presidente del Círculo Mercantil, José Varella. Este era partidario de las cantinas escolares y hace referencia al jornal que los niños llevan a casa para la subsistencia de la familia que «tiene como consecuencia la falta de instrucción de los niños, que desgraciadamente abundan tanto en Castellón».

Según asegura la redención de España está en la instrucción porque «con un pueblo culto, con un pueblo instruido no tratarían los gobiernos a sus administrados en la forma que lo hacen. Pueblo que lee no es esclavo de aquellos que abusan de su analfabetismo».

«Al instruir al pueblo debemos dedicar todos nuestros esfuerzos, y a este respecto he hecho, en la medida de mis fuerzas, cuanto me ha sido posible, Pero continuamente he tropezado con la falta de dinero».

La Cámara de Comercio tenía la intención de crear una Escuela de Comercio, y en el Círculo Mercantil hacía tiempo que se intentaba implantar las clases de contabilidad, francés e inglés, pero ambas entidades tropezaban con la falta de dinero.

En el Círculo Mercantil funcionaba en 1914 la clase de contabilidad, pero se pagaba mal al profesor, sin las debidas condiciones para que su labor fuera fructífera.

Varella se decantaba por las cantinas escolares porque así, se podría implantar la enseñanza obligatoria, y los padres no podrían escudarse en la necesidad del jornal de los pequeños para alimentarles. El Ayuntamiento financiaría una pequeña cantidad y el resto con la colaboración de los particulares.

«La Asociación Castellonense de Caridad ya tiene bastante con los servicios que mantiene. Estas cantidades deberían ser administradas por otra entidad, por una entidad creada exprofeso y que dedicara todo su entusiasmo al mejor desarrollo de las cantinas». 1252

${ }^{1252}$ El Clamor, 24/10/1914. 
Planteadas las cuestiones que estamos comentando al profesor de retórica del Instituto, Germán Salinas, se declaró partidario de que continuaran las obras benéficas ya establecidas y que podían peligrar si no se les subvencionaba, como era el comedor de los pobres y el asilo de las hermanas de los pobres. ${ }^{1253}$

Sin embargo, Cayo Gironés del Partido Liberal, disertó sobre la cultura del pueblo de Castellón. Opinaba que el Ayuntamiento debía crear escuelas nocturnas para adultos, tanto hombres como mujeres. Escuelas nocturnas que enseñaran el amor a la patria y al ejército, pues según decía los castellonenses eran refractarios a ir al ejército. «Tienen una idea tan contraria de lo que es la patria, que sienten verdadero pavor al pensar en que pueden ir al cuartel».

Opinaba que había que crear escuelas para que se educaran la clase humilde y que, juntamente con aquellos conocimientos indispensables para la vida, adquirieran una idea exacta de lo que es la patria y aprendieran a amarla como se merecía.

Sobre las mujeres decía, que obligadas durante el día a ganarse el sustento, estaban sin instrucción, tan atrasadas que no sabían leer ni escribir, y muchas no sabían «ni hacer un zurcido». Para las mujeres que trabajaban se precisaban escuelas nocturnas donde se les dieran todos aquellos conocimientos que tanta falta les hacían.

Para los hombres debían haber escuelas nocturnas, públicas o particulares, Gironés decía que debían ser distintas, porque los maestros de las públicas, «bastante tienen que hacer con las horas de clase que sobre ellos pesan»; y en las que tenían establecidas los Centros particulares, aparte de que en ellas podían darse una instrucción tendenciosa precisaba ser socio o hijo de socio de los mismos para acudir a sus clases. Debían ser estas escuelas sin ningún color político, y en las que no hubiera nada de sectarismo y completamente gratis.

Gironés propone que los profesores se escogieran entre tantos de los que había en espera de una interinidad y que pudieran dedicar las horas del anochecer a esta obra cultural.

Y para que los jóvenes de ambos sexos acudieran a las escuelas, para que tomaran afición al estudio, proponía, crear distinciones que les sirvieran de estímulo, que les invitaran a la asistencia; que una vez en la escuela, los profesores que tuvieran el

\footnotetext{
${ }^{1253}$ El Clamor, 21/11/1914.
} 
suficiente amor y cariño para tratarles, lograran elevar su inteligencia, y conseguir darles aquella cultura, aquella instrucción que tanta falta les hacía.

«Vengan termina diciendo Gironés, vengan esas escuelas en las que se instruya a la mujeres, en las que se eduque a los hombres en el santo amor a la patria, y crea usted que con ello habrá hecho el Ayuntamiento la mejor obra benéfico-social a que puede aspirar y habrá gastado el dinero engrandeciendo a nuestro pueblo [... ${ }_{\gg .}{ }^{1254}$

Un personaje importante en la labor educativa de Castellón fue El Inspector de Primera Enseñanza José Senent, dedicado a la enseñanza por vocación, realizaba una labor cultural intensa. Luchaba por implantar los métodos y sistemas más apropiados para la educación de los niños, propagaba y difundía los procedimientos para dar una juventud física, moral e intelectualmente preparada para la lucha de la vida.

Admirable me ha parecido llevar al plebiscito, a la escuela pública este asunto de la obra benéfica. Pocas veces ocurre esto con las entidades políticas y administrativas y al efectuarla así el Ayuntamiento de Castellón, ha añadido un nuevo timbre a su nombre por el respeto que ha tenido con el principio democrático que debe informar todas las obras para que tomando parte en ellas el mayor número de interesados, sean sus decisiones acatadas y defendidas por todo el pueblo.

He ahí el complemento de la obra de la confrontación, del choque de ideas que se presentan para que el público pueda cotejar y para que los directores de la cosa pública puedan fallar con mayor amplitud de miras y con mayor acierto.

Para el inspector Senent las obras benéficas que darían mejores resultados serían las colonias escolares y las escuelas al aire libre

Según el inspector, la gran cuestión de la obra benéfica es saber cual tendría más probabilidad de éxito, cual podía ser mejor administrada con el dinero de que dispondría el Ayuntamiento.

Las obras benéficas según Senent se podían dividir en dos grupos; «las que como la higiene son para prevenir y las que, como la medicina son para curar».

${ }^{1254}$ El Clamor, 28/11/1914. 
Senent decía que no se había hecho nada para acabar la brillante acción del municipio en favor de la cultura de la niñez. Y el complemento necesario, imprescindible, es la escuela al aire libre y la colonia escolar.

«Con esto no inventariamos nada. Bilbao, Barcelona y otras capitales tienen ya establecidas estas obras complementarias de cultura».

Allí por iniciativa y por formidable impulso de las izquierdas, no hay ni un niño que deje de ir a las escuelas allí está verdaderamente implantada la enseñanza obligatoria.

Y durante todo el año se organizan las colonias escolares. ¿Cómo?...Muy sencillo. La inspección de acuerdo con los maestros, va seleccionando a los niños que necesitan las colonias escolares, con los que se forman tres grupos: los que necesitan baños, los que necesitan colonias escolares y aquellos que, para recobrar la salud perdida, necesitan sanatorios.

«He ahí el complemento de la obra de cultura, de manera tan brillante de manera tan hermosa, ha llevado el municipio castellonense». ${ }^{1255}$

El inspector de Enseñanza Primaria, consideraba que los Baños, las Colonias y los Sanatorios son los complementos de la obra de cultura que el Ayuntamiento debía imponerse.

«Muchos son los niños que necesitan baños de mar. Y si estos baños están convenientemente dirigidos, convenientemente administrados, ¡Cuánto bien se podría hacer a los niños!»

«Mil niños son los que Bilbao lleva a los baños todos los años. Castellón podría hacer otro tanto, con muy poco gasto».

José Senent exponía que durante los dos meses de calor podrían organizarse dos expediciones de cien niños cada uno que, dirigidas por dos o tres maestros, pasarían un mes en la vecina playa del Pinar, «haciendo vida en plena naturaleza, pasando el día en la hermosa pinada». Y allí recibirían las lecciones y fortalecerían su cuerpo y su espíritu.

A las colonias escolares irían aquellos niños que necesitaran climas de altura «y no se necesitarían para organizar la colonia más de tres o cuatro mil pesetas».

${ }^{1255}$ El Clamor, 5/12/1914. 
Y para completar la obra, los sanatorios para aquellos niños cuya salud los requiriese a juicio del médico. «Una casa de campo en un pueblo de la montaña bastaría para convertirla en un sanatorio, donde encontrasen los niños la salud perdida».

¡Hablar de las ventas de la Colonias escolares! Calculad ese número importantísimo de criaturas anémicas que se regeneran con el ejercicio espontáneo en plena naturaleza, con buena alimentación, con una higiene bien dirigida, y, sobre todo, con el tónico de la alegría que sienten los niños al vivir a cielo abierto, en plena naturaleza!

Aquellos niños, con la propiedad grandísima que tienen sus cuerpos en formación para asimilarse raudales de vida, se trasforman en el transcurso de un mes, acumulan en sus organismos fuerza vital para todo el año.

Pero al lado de esta ventajas, con ser las más importantes, se puede lograr un desarrollo de sentimientos, de gustos e inclinaciones por la contemplación de la Naturaleza, por el goce de vivir libremente en medio de ella, por la constante novedad de escenas y objetos que les alejan de tantos placeres malsanos y de tantas causas de corrupción moral, se puede lograr que los niños adquieran sin esfuerzo alguno y de una manera intuitiva muchas nociones de Geografía, Historia Natural, Industria, Agricultura, Comercio, y finalmente, se pueden lograr también aquellas ventajas que nacen de la intimidad de la familia, cuya vida hacen los niños en la colonia, pudiendo el maestro dirigir, encauzar los gustos, las aficiones del niño [...].

Habla también de la escuela al aire libre, dedicando un cumplido elogio al doctor Gea, patrocinador de una escuela al aire libre con cantina escolar.

Comenta que las escuelas al aire libre tienen muchas de las ventajas de las colonias escolares, y sobre las actuales escuelas, «las de librar a los niños de esas cárceles a las que damos el nombre de escuelas». Allí el niño, como en las colonias, se educa en plena naturaleza, y el maestro saca de esta todas las grandes enseñanzas que le permiten el estar en contacto con los objetos reales. Allí el niño se educa con la mayor perfección intelectual y fisiológicamente. «La escuela al aire libre, aunque no con tantas ventajas, puede considerarse como una colonia escolar permanente». ${ }^{1256}$

${ }^{1256}$ El Clamor, 7/12/1914. 
Ahora bien, ¿convendría una sola escuela, con un maestro, o sería más conveniente construir en distintos puntos varios pabellones donde fueran por turno los alumnos de las escuelas a conseguir esta enseñanza intuitiva? [...].

Luchemos-termina diciendo el señor Senent-luchemos para crear hombres fuerte moral y fisiológicamente y así seguramente lograremos exterminar en Castellón esa plaga de pobres de cuerpo y de espíritu para cuya obra, con un desprendimiento digno de los ilustres hombres que rigen los destinos de esta capital, dedica el ayuntamiento la cantidad que le ha de producir el impuesto municipal sobre la luz eléctrica [...].

El reportero de El Clamor entrevistó esta vez al cura arcipreste de Castellón, Hermenegildo Muntaner.

La opinión del arcipreste era que en Castellón ya había muchas obras benéficas. Lo que creía el arcipreste más conveniente era que el Ayuntamiento atendiera a aquellas obras ya creadas para evitar que muriesen las existentes. Y entre las obras ya creadas había cuatro que merecían especial predilección: las Hermanitas de los Pobres, la Oblatas, el Colegio de Niños Huérfanos y el Comedor.

Las Hermanitas de los Pobres tenían cobijados a unos 50 ancianos. Su vida era tan precaria que apenas podían darles de comer.

Las Oblatas de Benicasim que recogían a gran número de muchachas y que tenían una sucursal en Castellón realizaban una obra social de gran importancia «al evitar se perdieran tantas y tantas mujeres de inclinación sospechosa, procurando infundirles hábitos de trabajo, fomentando sus ideas morales, regenerándolas en una palabra».

«Después tenemos el colegio de Niños Huérfanos que, como se apoderó el gobierno de su bienes vive hoy pobremente, ya que toda su riqueza es una lámina de 2.000 pesetas».

«Y últimamente el Comedor de los Pobres. Este parece que tiene vida más próspera, pero hay que desengañarse; esto durará poco».

Al fundarse el Comedor, Hermenegildo Muntaner y José Clará visitaron a gran número de familias castellonenses con el fin de lograr el mayor número de suscripciones, pero quedaron al poco tiempo reducidas a la mitad.

Sobre la instrucción opinaba que había mucho que hacer aún. Consideraba que daba lastima ver el número de analfabetos que había en Castellón, pero añadía que antes 
había que dar de comer al que necesita instrucción. De ahí la importancia de las cantinas escolares «que tanta falta nos hacen».

Según el arcipreste el problema no se resolvía con decretar la enseñanza obligatoria, puesto que los padres necesitaban lo jornales de sus hijos para poder comer.

¡Y qué alimentos...Durante el día cualquier cosa es buena y por la noche, un plato de olla, sin carne, sin ninguna substancia que fortalezca aquellos cuerpos.

Por eso hemos podido observar cómo disminuye en España la talla física de los hombres, disminución debida en gran parte a los vicios, pero indudablemente que en la depauperación de la raza interviene también muy directamente la poca alimentación.

Muntaner defendía también el establecimiento de una obra benéfica donde estuvieran cobijados los hijos de las mujeres que se ganaban el sustento en el almacén y en los talleres. ${ }^{1257}$

«Esos pobres niños que hoy vemos desparramados por esas calles, podrían allí- llámesele como se quiera, gota de leche, si lo pomposo del nombre puede cautivarnos-encontrar los cuidados que no tiene ahora y un mendrugo para comer».

Pero desgraciadamente, para estas obras son poco las 8.000 pesetas que vendrá a recaudar el municipio. Creo que debemos pensar, más que en crear obras nuevas en vivificar las que hoy tenemos, pues sería muy lamentable que desaparecieran.

Atendamos a las obras que hoy tenemos comenzadas, esta es mi humilde opinión, terminemos lo que tenemos comenzado, procuremos que vivan las obras benéficas que son hoy motivo de orgullo para Castellón y cuando esto lo hayamos logrado, pensaremos en obras nuevas, teniendo siempre presente que, sin la vida del cuerpo, no podemos avanzar el perfeccionamiento de la inteligencia.

Un personaje anónimo habla al reportero de El Clamor sobre la importancia de la enseñanza, dice que Castellón no es un pueblo de analfabetos y «podemos enorgullecernos de lo que actualmente tenemos». Pero añade que antes que la cultura

${ }^{1257}$ El Clamor, 12/12/1914. 
está «el tener hombres fuertes y sanos para que puedan conseguir la ilustración a que aspiramos».

«Si los maestros son trabajadores, si ponen en el cumplimiento de su deber aquellos entusiasmos que son precisos, indispensables para que su labor sea fructífera, conseguirán óptimos frutos, si su trabajo está empleado con niños sanos de cuerpo, con niños, sobre todo, alimentados».

Porque así como no podemos pedir a un maestro que se muere de hambre, que no tiene el sueldo que necesita para que la sociedad no le mire con desdén, sacrificios mayores que su sueldo, tampoco podemos obligar a aquellos trabajadores que no tienen pan para sus hijos a que les lleven a la escuela, a que renuncien al jornal, que, desde pequeños, pueden llevar a casa.

Este personaje anónimo defendía que con el dinero del impuesto de la electricidad, se subvencionara la construcción de casas para obreros para mejorar sus condiciones de salubridad. Además de vivir hacinados y en malas condiciones, pagaban un alquiler muy alto, con lo que no les quedaba mucho para alimentarse.

Hay que ver cómo viven; hay que pasar por aquellas calles de nuestros arrabales donde habitan, mejor dicho, donde se amontonan nuestros obreros. Hay que ver aquellas pocilgas a que se dan los pomposos nombres de casas, en las que no se sabe dónde termina el sitio de las personas para comenzar el lugar de los irracionales; hay que ver la asquerosa promiscuidad en que viven personas y bestias para apartarse con horror y con asco de aquellas viviendas...

Y por habitar en ellas, pagan mensualmente nuestros obreros un buen número de pesetas, pesetas que indudablemente han de restar a la alimentación de sus hijos. ¿Pueden, en estas condiciones, mandarlos a la escuela cuando tanta falta les hace su jornal?...

Hay que convenir en que mientras esto ocurra no se les puede obligar a que renuncien al jornal de sus pequeños.

Además de construir casas para los pobres, el Ayuntamiento les daría jornales, y casas habitables. Para completar más la obra benéfica del municipio, añade el interlocutor, aquellas casas que construyera el Ayuntamiento podría alquilarlas a los obreros por cantidades muy modestas. 
«Las casas baratísimas para los obreros darían salud a nuestro pueblo y alimentos para los niños pobres que bien los necesitan, pues antes que resolver los problemas de instrucción creo muy del caso que resolvamos el grande, el vaporoso problema de la higiene y la alimentación del pobre $[\ldots] .{ }^{1258}$

El director del Instituto de Castellón, Miguel Martí Blat, también intervino en este plebiscito.

Uno de los problemas de Castellón era la mendicidad callejera, Martí Blat soñaba con la extinción de los pobres. Abogaba por un cambio del modo de vivir de la población para que resultara imposible la pobreza material y moral en Castellón, dando a los jóvenes y a los niños una educación que les fortaleciera corporal y moralmente para luchar contra todos los obstáculos que les presentara la vida.

Martí Blat opinaba que la caridad, ejercida a medias no resuelve nada y dejarla confiada a los sentimientos individuales, es condenarla a perpetua desorganización, por eso debía ser función municipal.

La caridad debía estar organizada, y consideraba que la institución más idónea para hacerse cargo de la misma eran los municipios en contacto directo con las necesidades de pueblo; éstos, podían y debían tener a su cargo el remedio de aquellas necesidades.

Según decía para que el municipio se encargase de la caridad, bastaría una clasificación de los vecinos en dos grupos: vecinos que por sus rentas o profesiones pueden gobernarse sin auxilio ajeno; vecinos que carecen de bienes de fortuna. Estos a su vez, podían clasificarse en jornaleros y menesterosos.

A estos últimos debía atender la solicitud del municipio. Una vez conocido su número, sería fácil calcular la cantidad necesaria para atender a sus necesidades durante el año, cantidad que repartida entre los vecinos pudientes a título de Arbitrio de la Caridad, significaría un recargo de un 50 por 100.

«El 50 por 100 de recargo, constituiría un remanente con que atender a los jornaleros en tiempos calamitosos y el sobrante podría acumularse en años sucesivos hasta llegar, con el tiempo a constituir un capital cuyo interés aminorará el arbitrio y hasta llegará a extinguirlo».

\footnotetext{
${ }^{1258}$ El Clamor, 19/12/1914.
} 
La idea de Martí Blat era pensar en un palacio de Caridad con mesa, cama, ropero, escuelas y talleres. «No es sueño pensar en que Castellón pudiera afrontar esa cantidad para ponerse a la cabeza de todas las capitales españolas. No es sueño pensar en un Palacio de Caridad con vida propia y donde se mitigasen las necesidades de los menesterosos».

Y allí pensaba en instalar las escuelas para que esos niños que hoy acuden al Comedor y que no sabemos en qué pasan el día, pudieran instruirse, aprender a leer y escribir y allí también sus talleres para que aprendieran un oficio útil para sí y sus semejantes, allí sus talleres para evitar, en una palabra, que los niños de hoy, sean los pordioseros de mañana.

Un palacio con un jardín grande, donde los pobres vivieran con la satisfacción interior de quien ve, al final de su vida, cubiertas todas sus necesidades, amparados sus hijos, no por la caridad seca del Estado, sino por aquella otra de los particulares asociados a la obra del municipio.

Y añade que podría el Ayuntamiento constituirse en patronato de la gran obra de caridad y los señores que formaban la Asociación de Caridad ser los que intervinieran de manera directa en la buena marcha del palacio.

Pensaba que quizá el Monte de Piedad se encargaría de aportar al Ayuntamiento el capital necesario para la construcción del edifico, capital del que podría rembolsarse contando con el sobrante de Arbitrio de Caridad y con el 50 por 100 de recargo que hemos comentado más arriba.

Martí Blat estuvo al frente de la Asociación de Caridad, y deseaba que la gran obra benéfica de Castellón debiera estar en manos del Ayuntamiento. ${ }^{1259}$

Si el excelentísimo ayuntamiento de Castellón quiere hacer una obra grande, de perdurable y grato recuerdo, invierta esa 8.000 pesetas, las que le sigan del mismo origen y las que puede conseguir con implantar el Arbitrio de Caridad, en erigir el Palacio de la Caridad, y acepte el Patronato de la Asociación Castellonense, emancipándola de la fluctuante y mísera cuota mensual que, ni ayuda por gubernativos sablazos, basta para otra cosa que para mantener viva la necesidad de los pobres.

${ }^{1259}$ El Clamor, 9/01/1915. 
Francisco Giner Lila, jefe de los carlistas de la provincia, atendió al reportero de un periódico republicano «con la amabilidad de un hombre de mundo quien sabe respetar las opiniones contrarios, y lograr el mismo respeto para las propias».

En la entrevista, Giner Lila, hacia resaltar sus anhelos de ver convertido a Castellón en una capital que fuese envidia de los extraños y orgullo de sus hijos.

Todos los esfuerzos de Giner se dirigían a higienizar la capital porque entendía que la higiene es fuente de vida inagotable, porque sin higiene no hay salud, y pueblo que carece de salud es un pueblo triste.

Giner se preocupaba por las familias que vivían en casas antihigiénicas, en casas donde es inhumano que habitaran seres de la especie humana.

«Con la higiene se resolvería en gran parte el problema de la salud pública; con higiene se verían libres de esos azotes que en forma de epidemias aterran a los pueblos $[\ldots] \gg$.

Giner opinaba que lo más importante, lo más esencial para la vida de un pueblo es la higiene: «Cuánto dinero gaste el ayuntamiento para higienizar la población, me parecerá poco, porque dinero que se gasta en higiene, es dinero sumamente reproductivo, porque la higiene es fuente de vida».

Giner Lila era partidario de que el Ayuntamiento dedicara ese dinero a higienizar las viviendas de las clases proletarias haciendo desaparecer gran número de «casuchas» que carecían de condiciones para la vida de seres humanos. El municipio podía gastar esa cantidad procurando también la transformación del firme de las calles, evitando que sus arroyos se convirtieran en charcas cuando llovía o que tuvieran «un metro» de polvo en épocas de sequía. Podría también organizar brigadas de limpieza para las calles de Castellón, «como están en la actualidad las de las grandes capitales, a las que debemos imitar».

Y sobre todo, añade, podría el Ayuntamiento construir baños públicos donde pudieran lavarse todos los castellonenses, «baños de los que carecemos casi en absoluto».

«Todo esto que puede realizarse con poco dinero, sería también una obra benéfica, porque como decía antes, contribuiría a conservar, a aumentar la salud de nuestro pueblo».

Más adelante añade que podría instituirse un asilo donde se recogieran todos los necesitados, niños, ancianos y «personas inútiles». 
Giner era director de la Casa Provincial de Beneficencia y se quejaba de que no se podía atender a todos los necesitados de los pueblos y de la capital. La idea de Giner era que el Ayuntamiento creara un asilo de mayores vuelos que el de la Diputación, un asilo en el que además de toda clase de higiene y comodidades, encontrasen los albergados las necesarias escuelas, patios, recreos, talleres, etc.

Pero no como los que tiene actualmente la Diputación, sino con más amplia base. No limitándose, como ocurre en la actualidad en la Beneficencia, a dos o tres oficios, sino para el mayor número posible, con la que los niños podrían salir perfectamente instruidos y capacitados para ganarse la vida, sin que fuesen explotados por los patronos.

Y allí en el mismo asilo, una granja agrícola donde aprendiesen cuanto se refiere al cultivo de la tierra y cuyos productos se dedicarían a la alimentación de los asilados.

Giner Lila cree que una institución que tomase a los niños desamparados en los primeros años de la vida y que los abandonase cuando, en edad oportuna, pudiesen ser útiles a la sociedad y bastarse a sí mismos, sería la mejor obra de beneficencia que podría crear el Ayuntamiento. ${ }^{1260}$

El presidente del Casino de Artesanos recibió una carta del redactor de $E l$ Clamor que firmaba sus escritos con el seudónimos de Crispín, pidiendo la opinión de esta sociedad sobre la inversión que mejor pudiera darse a las cantidades que iba a recaudar el Ayuntamiento de la capital, por el impuesto de la electricidad.

El Casino de Artesanos entendía que se debía favorecer la obra de la Asociación Castellonense de Caridad, entregándole íntegra toda la cantidad para el funcionamiento del Comedor de los pobres.

También entendía que en el populoso arrabal de la Trinidad se debía habilitar o construir un edificio para otro comedor, evitando de este modo que los numerosos pobres de esta barriada, ancianos, ciegos o achacosos, hicieran todos los días dos veces un largo recorrido, para proporcionarse el cotidiano alimento. ${ }^{1261}$

\footnotetext{
${ }^{1260}$ El Clamor, 23/01/1915.

${ }^{1261}$ El Clamor, 6/02/1915.
} 


\section{CAPÍTULO X: LAS COLONIAS ESCOLARES EN CASTELLÓN}




\section{LA DIFUSIÓN DE LAS COLONIAS ESCOLARES EN EUROPA}

En el verano de 1876 un pastor evangelista suizo, Walter Bion, en unión de 10 maestros, llevó a 68 niños pobres del cantón de Appenzell al campo, donde pasaron dos semanas respirando aire puro y recibiendo una alimentación sencilla y fortificante. La experiencia de Bion tendría tanto éxito que en muy pocos años se extendería por toda Europa y América. El mismo sería considerado el fundador de las llamadas colonias escolares de vacaciones.

Once años después, en el verano de 1887, el Museo Pedagógico Nacional, a través de su director, Manuel Bartolomé Cossío, organizaba la primera colonia escolar de vacaciones en España en la localidad santanderina de San Vicente de la Barquera, con 20 niños de diferentes distritos de Madrid. ${ }^{1262}$

Antes de Bion ya habían existido experiencias de colonias (aisladas similares), aunque de carácter más bien terapéutico y médico. El primer sanatorio para niños se creó en Margate (Inglaterra), en 1796; También en ese país el reverendo Stenphen Hawtrey creó en 1861 una escuela a orillas del mar en la que reunía a niños de diferentes regiones. Poco antes, en 1859, la conferencia de San Vicente de Paul creaba en Montpellier (Francia) los Baños de mar. Análogas experiencias se extendieron por Alemania, Bélgica, Holanda y los Estados Unidos de América.

Bión, cuando tuvo que dejar su vicaría en el pueblo montañoso de Trogen para vivir en un pequeño apartamento de la industriosa Zurich, sus hijos enfermaron física y psicológicamente. Por ello resolvió llevarlos nuevamente, y por un verano, a Trogen. «Si mis hijos, que están sanos, comen bien y tienen una buena casa - se preguntaba-, tienen tanta necesidad de recuperarse, ¿cómo no la necesitarán los pobres?». Visitando los barrios marginales de Zurich comprobó que en ellos no existían posibilidades para una vida mínimamente sana; además, como los padres de estos niños no podían ocuparse de ellos durante las vacaciones, deambulaban por las calles, y cuando retornaban a las escuelas se encontraban disminuidos física y moralmente. Este fue su punto de partida para la creación de las colonias escolares de vacaciones que en muy

\footnotetext{
1262 PEREYRA, Miguel. (1982): «Educación, salud y filantropía: el origen de las colonias escolares de vacaciones en España». Revista Interuniversitaria $\mathrm{N}^{\circ} 1, \mathrm{p} .45$.
} 
poco tiempo se propagarían; los congresos nacionales e internacionales que se celebraron después de 1876 contribuyeron a divulgarlas por todo el mundo. ${ }^{1263}$

La Institución Libre de Enseñanza recogió con entusiasmo la idea de Bion porque ella respondía, entre otras cosas, a una de sus preocupaciones primordiales: el mejoramiento de la salud y las costumbres higiénicas del pueblo español. La Institución divulgó en España prácticas higiénicas y alimentarias desconocidas hasta aquel momento o sólo al alcance de la clase más pudiente (el baño diario, la permanencia del mayor tiempo posible de las casas con las ventanas abiertas, la práctica de la gimnasia al aire libre, la introducción de un gran número de deportes, etc.).

A partir de 1881 con la consolidación del liberalismo, al acceder Sagasta al poder, los institucioncitas van a poder realizar notables mejoras e innovaciones en el sistema de educación pública del país. La primera gran reforma fue el Museo Pedagógico Nacional, que se creó en 1882 siguiendo el ejemplo de similares instituciones europeas, y especialmente de Francia ${ }^{1264}$

En 1887, Cossío organizó la primera colonia escolar de vacaciones que ya estaban extendidas por todos los países más importantes del continente. España fue la última en organizar colonias escolares; además, la que ahora se creaba tenía carácter particular, porque era organizada y mayoritariamente financiada por la ILE. A partir de ese año se celebrarán regularmente colonias, pero hasta 1892 no serían oficialmente adoptadas. Un Real Decreto del 26 de julio de ese año (Gaceta de Madrid de 27 de julio) establecía su creación para niños pobres y necesitados de las grandes ciudades. A partir de ese año, irá apareciendo una legislación destinada a propagar las colonia en España. Sin embargo, habría que esperar a 1911 para que esta institución escolar recibiera un sustancial apoyo por parte del Ministerio de Instrucción Pública, que tenía en aquellos momentos a Rafael Altamira al frente de la Dirección de Instrucción Primaria.

Al terminar el siglo, son solo 1.313 los niños españoles que han disfrutado de un promedio de 29 días de vacaciones en colonias fundadas a partir de los esfuerzos del Museo Pedagógico, las Sociedades Económicas de Amigos del País, diputaciones provinciales y otras instituciones oficiales y filantrópicas, siendo Barcelona y Madrid las que más colonias organizaron.

\footnotetext{
${ }^{1263}$ Ibídem, pp. $155-156$.

${ }^{1264}$ CAPITÁN DíAZ, Alfonso (19949: Historia de la educación en España. Dykinson, Madrid. pp. 186-188.
} 
Fue precisamente en Barcelona, donde, con el paso de los años, el movimiento de las colonias escolares alcanzó el máximo esplendor. Hasta 1906, la tarea de las colonias recayó en la Sociedad Económica de Amigos del País de Barcelona. Cada año organizó diversas colonias, a la montaña, a la playa, habiendo atendido desde su creación hasta 1907 a 1.637 colonos. A partir de 1906 el Ayuntamiento de Barcelona inició sus colonias escolares. El compromiso del consistorio barcelonés fue importante. Constituyó una amplia red de colonias, semicolonias -actividad consistente en que los escolares pasaran el día en lugares cercanos a la ciudad, realizando las mismas actividades que en las colonias, pero volviendo a dormir a sus casas- y baños de mar, que durante los años de la Segunda República alcanzó a 12.000 escolares. Además de la obra municipal, existieron en Barcelona una docena de entidades privadas de distintos signos que organizaban sus propias colonias escolares. ${ }^{1265}$

Cossío conoció buena parte de la literatura pedagógica sobre las colonias de vacaciones que en esos momentos se estaba produciendo en Europa y que incluía las recomendaciones de los diversos congresos sobre las cuestiones de educación, higiene y sanidad de las colonias. En el Congreso Internacional de Colonias Escolares de Vacaciones de Zurich en 1887 participó el propio Cossío. De esa literatura se tomaron ideas para llevarlas a la práctica en España. Así, la Circular de la Dirección General de Instrucción Pública de 15 de febrero de 1894, en la que se fijan las condiciones que debían reunir las colonias que se crearan, incluía una ficha antropométrica y otra de carácter pedagógico para la orientación de las actividades educativas que se habrían de desarrollar en las colonias, que no se diferenciaban mucho de las que empleaban otras colonias europeas. ${ }^{1266}$

Muchos de los creadores de colonias de vacaciones estuvieron más preocupados por cuestiones instructivas y educativas que por las relacionadas con la salud. Así, junto a las simples preocupaciones sanitarias, las colonias fueron para algunos un medio para lograr escolares sanos, felices y relajados, capaces de rendir intelectualmente y de vivir en comunidad.

Otros, sin ignorar los valores terapéuticos que las mismas reportaban, las apoyaban porque de este modo contentaban a los padres de los niños, recibiendo a

\footnotetext{
1265 CRUZ J. Ignacio (1991): Las colonias escolares valencianas (1906-1936), Institut València de la Juventut, València. pp. 29.

1266 Ibídem, pp.158-159.
} 
cambio su agradecimiento y vinculación. Muchos también creyeron que, educando a los hijos en los buenos hábitos y costumbres, influirían decisivamente a su vuelta en sus padres, que eran totalmente incapaces de llevar a cabo una adecuada educación de sus proles; de ahí que no sólo se llevasen los niños al campo para que dejasen las malsanas ciudades, sino también para alejarlos de ellos. Otros añadieron un objetivo nacional: el mejoramiento de la raza o la fusión de las poblaciones urbanas con las campesinas; en el primer caso, las primeras colonias de vacaciones no tuvieron las intenciones exageradamente nacionalistas o agresivas que más tarde aparecerán con el advenimiento del nazismo y los régimenes fascistas.

Finalmente, las colonias de vacaciones fueron creadas también para la cura de almas. En muchas colonias católicas europeas la salud fue secundaria; lo importante era insistir en las lagunas morales y religiosas de los niños, imbuyéndoles el sentido de obediencia, que incluía, el respeto al orden establecido.

También en España las colonias fueron consideradas importantes para el porvenir físico de la raza, puesto que se trataba de educar de un modo «integral y armónico criaturas pobres de espíritu y de obtusa inteligencia».

Las colonias escolares de vacaciones catalizaron numerosas experiencias educativas alrededor del mundo. Pronto se vio que no era necesario esperar a que llegase el verano para poner al niño en contacto con la naturaleza. Por toda Europa surgirán escuelas al aire libre que fueron generalmente conocidas como «escuelas del bosque»o «escuelas del mar». En muchos casos llegaron a convertirse en núcleos de renovación pedagógica en torno a los cuales se formaría el movimiento de las escuelas nuevas.

Las circunstancias históricas de la nueva sociedad contemporánea fueron un impulso decisivo. El resultado del cambio de los patrones de vida rural en urbano, dentro de la sociedad industrial, obligó a que las naciones que iban surgiendo buscaran nuevas estrategias de adaptación. El desarrollo de la higiene fue en mayor medida debido a la consideración de que la salud pública no debía ser más un problema que resolviera una sola persona o su familia, sino un problema nacional. El descubrimiento del germen de la infección y su control a través de los antisépticos, al mismo tiempo que la mejora de la técnica quirúrgica, desembocaron en un generalizado movimiento de salud pública en Europa desde la segunda mitad del siglo XIX. Además para paliar la creciente mecanización de la vida y el trabajo que gradualmente reducía las necesidades 
y oportunidades para el ejercicio al aire libre y, al mismo tiempo, para solventar los problemas de tiempo libre que la nueva sociedad industrial generaba, los deportes, la actividad física y las vacaciones se hicieron populares. ${ }^{1267}$

\section{LAS COLONIAS ESCOLARES VALENCIANAS}

La labor socio-sanitaria en torno a la prevención de las enfermedades infantiles tuvo un desarrollo específico bajo la forma de las colonias escolares, que representaron una encrucijada de proyectos educativos, higiénicos y de mejora de la salud y la nutrición de muchos niños de las clases obreras y campesinas. Las colonias escolares se organizaban habitualmente durante los meses de vacaciones estivales a lugares montañosos o junto al mar, para buscar los beneficios del contacto con la naturaleza, su fortalecimiento físico mediante la práctica del ejercicio físico, una alimentación sana y suficiente, los baños en el mar y el efecto lúdico y pedagógico de los juegos en grupo.

Desde el último cuarto del siglo xix, la sociedad valenciana se vio favorecida por las propuestas de la Institución Libre de Enseñanza que fue la que promovió en España esta experiencia, imitando modelos semejantes que, con resultados satisfactorio, se estaba realizando en países de la Europa Central. Como hemos dicho en 1887, el Museo Pedagógico Nacional organizó la primera de ellas en San Vicente de la Barquera con niños madrileños. La creación oficial de las colonias escolares para niños pobres se estableció por Real Decreto de 26 de julio de 1882.

La ley de protección a la infancia y represión de la mendicidad (agosto de 1904) y su posterior desarrollo reglamentario de 1908 consolidaron una serie de iniciativas y aportaron un apoyo financiero e institucional más sólido a las colonias escolares. A partir de 1911 los ayuntamientos y las juntas municipales y provinciales de protección a la infancia buscaron apoyo financiero, asociaciones de protección a la infancia y ciertas entidades privadas como la Sociedades Económicas de Amigos del País.

Las colonias escolares llegaron a Valencia en 1893 con una colonia en el Cabañal formada por niños valencianos y madrileños organizada por la Sociedad Protectora de Niños de Madrid. En 1912, la Asociación para el Fomento de la Cultura y

\footnotetext{
${ }^{1267}$ Ibídem, 159-160.
} 
la Higiene, una entidad privada que agrupaba sobre todo a profesionales de la medicina y la enseñanza, estableció colonias en Buñol y Porta Coeli con alumnos de las escuelas municipales valencianas. Al año siguiente su vicepresidente, el médico Mariano Pérez Feliu, se dirigió al Ayuntamiento de Valencia para pedir una subvención para las colonias, destinadas a subsanar el deteriorado estado físico de los escolares que atribuía principalmente a las pésimas condiciones higiénicas de las viviendas familiares, a la degradación del entorno urbano, pero también a la miserable situación de las escuelas.

El Ayuntamiento organizó durante el verano de 1913 su primera colonia escolar en Porta Coeli y un año después se creó la Junta Valenciana de Colonias Escolares, organismo que agrupaba a varias instituciones como la Junta Provincial de Lucha contra la Tuberculosis, la Junta Provincial de Protección a la Infancia y la Asociación para el Fomento de la Cultura y la Higiene. En esta agrupación de instituciones sociales participaban algunos médicos de reconocido prestigio de la ciudad y profesores de la Facultad de Medicina, en estrecha colaboración con los maestros coordinadores de las actividades. Los niños eran seleccionados para las colonias con unos criterios principalmente médicos, de acuerdo con los registros antropométricos elaborados por la inspección médico escolar, que supuestamente reflejaban su estado general de salud y desarrollo corporal, buscando beneficiar los que estando sanos necesitaban de los beneficios derivados del régimen de vida de las colonias. Durante las dos semanas que solían durar las colonias, los niños recibían una alimentación adecuada para su desarrollo, realizaban excursiones a pie, practicaban ejercicios de gimnasia higiénica, juegos colectivos y deportes en grupo y se ejercitaban en los baños de agua y de sol. Cada año, la Junta publicaba unas memorias, que resumían los resultados obtenidos y la labor realizada.

Una de las ideas fundamentales que se reiteraba sistemáticamente en la retórica legitimadora de esta saludable iniciativa era el gran beneficio que el contacto con la naturaleza, la vida sana, la alimentación abundante, el ejercicio físico y la higiene, reportaban para la salud de los niños y más específicamente para prevenirlos de ser atacados por la amenaza de la tuberculosis.

El sanatorio de la Malvarrosa no sólo sirvió para el tratamiento y la prevención de la tuberculosis ósea infantil, sino que también fue escenario de la organización de colonias escolares durante el verano. Como se trataba de una institución de carácter 
estatal, acogía no sólo a niños valencianos, sino también del resto de España, especialmente de Madrid.

Cada uno de los niños que participaba en las colonias escolares organizadas por el Ayuntamiento de Valencia disponía de una ficha antropométrica, y las actividades que se realizaban durante las dos semanas estaban perfectamente programadas con criterios individuales y de grupos de edad, siempre de acuerdo con el nivel de desarrollo y con las condiciones físicas de los niños. La ficha recogía el tipo de ejercicio físico realizado, las excursiones por el campo y el resto de actividades realizadas. En el caso de niños que se encontrasen en una situación más débil o fuese diagnosticado como de constitución enfermiza, los médicos podían aconsejar una estancia más prolongada de las dos semanas habituales y podían ser acogidos en otras colonias. ${ }^{1268}$

\section{GESTIÓN DE LA PRIMERA COLONIA ESCOLAR CASTELlONENSE POR EL DOCTOR JOSÉ CLARÁ Y EL INSPECTOR JOSÉ SENENT}

En Castellón, la primera colonia escolar de vacaciones se organizó en el verano de 1915 gracias a las gestiones del Inspector de Sanidad Doctor. José Clará, y el Inspector de Primera Enseñanza Juan José Senent. Éste ya se había encargado de la organización de las colonias escolares en los años 1913 y 1914 en Serra (Valencia).

\subsection{PREPARACIÓN DE LA COLONIA.}

Como en los años 1913 y 1914, la Dirección general de Primera Enseñanza, en virtud de la Real Orden de 18 de Junio de 1915, encargó al Inspector Juan José Senent la organización y dirección de una colonia escolar.

Las primeras gestiones para organizar la colonia en Castellón fueron intervenidas y secundadas por el Gobernador Civil, Ángel Pérez Magnin y el Inspector Provincial de Sanidad, José Clará.

\footnotetext{
1268 BARONA, Josep. L. (2007), José: Chabás Bordehore (1877-1963). Tuberculosis y Medicina Social en la Valencia del primer tercio del siglo XX. Valencia, Consell Valencià de Cultura, pp. 69-72.
} 
La solicitud en demanda de subvención se basaba, entre otras razones, en la necesidad de promover el establecimiento de colonias en la provincia de Castellón, en la convencimiento de que la iniciativa de Estado había de ser motivo para que surgiese el interés y apoyo de las corporaciones y particulares, dando continuidad a la obra de la colonia; en los méritos contraídos por la capital de la provincia en favor de la enseñanza, sosteniendo mayor número de escuelas de las exigidas por la ley. El régimen técnico y administrativo de la nueva colonia tenía que ajustarse a las instrucciones de la Circular de 15 de Febrero de 1894, basadas en la obra realizada por el Museo Pedagógico y a lo preceptuado en el Real Decreto de 19 de Mayo de 1911. Obraban, además, en la Dirección General las memorias de las colonias dirigidas en los años 1913 y 1914 por Senent, y se contaba con las facilidades económicas de poseer el mobiliario y ajuar perteneciente a estas colonias. La petición de auxilio fue atendida por el Estado con la subvención de 2.000 pesetas.

En sesión celebrada por la Junta Provincial de Primera Enseñanza el 3 de Julio de 1915 se tomaron los acuerdos siguientes: prestar el mayor apoyo y poner bajo los auspicios de la Junta la obra de la colonia escolar; llevar a la opinión pública la significación social y carácter humanitario de la misma; como el auxilio del Estado era insuficiente para beneficiar a un mínimo de 30 niños y niñas, solicitar el concurso económico de las corporaciones y particulares para poder realizar y sostener la primera colonia escolar que se implantaba en la provincia. ${ }^{1269}$

El Gobernador Civil invitó a la sociedad castellonense a que cooperasen económicamente al sostenimiento de la colonia. Bien pronto respondieron las corporaciones y particulares, reuniendo en total la cantidad de 1.118 pesetas y 65 céntimos.

La Asociación Castellonense de Caridad, adelantándose a los deseos de la Junta Provincial, acordó conceder 100 pesetas para ayuda de la colonia y facilitar las prendas de vestir que necesitasen los niños más pobres.

Simultáneamente con estas gestiones, toda la prensa de Castellón promovía una campaña a favor de la colonia, dando a conocer el origen, desarrollo, finalidad y carácter popular de la institución.

\footnotetext{
${ }^{1269}$ SENENT IBÁÑEZ, Juan José: Memoria de la Primera Coloniza Escolar Castellonense en Lucena del Cid. 20 de julio a 20 de Agosto de 1915. Castellón, Imp. Joaquín Barberá pp.5-6; ver también El Clamor: 27/04/1915; 28/04/1915; 23/06/1915.
} 
Antes de empezar la colonia visitaron la misma el Gobernador Civil, el Alcalde accidental de Castellón Juán Carbó, el Inspector de Sanidad, José Clará, el de enseñanza, José Senent y el de policía José Gutiérrez. La visita tenía por objeto reconocer la casa elegida y preparar sus condiciones de alojamiento. ${ }^{1270}$

Reunidos los recursos suficientes para organizar la colonia de 30 escolares, acordada en principio por la Junta provincial, y previas reuniones para reglamentar la elección, equipo y viaje de los colonos, se procedió a elegir 15 niños y 15 niñas que fuesen de constitución débil, que no presentaran indicios de enfermedad contagiosa, que fueran de reconocida pobreza y cuya edad oscilase entre los ocho y doce años.

La selección de colonos fue encomendada al inspector de Sanidad José Clará, quien recorrió durante las horas de clase todas las escuelas de la capital, escogiendo, en colaboración con los maestros, aquellos alumnos más necesitados de los beneficios de la colonia. $^{1271}$

Una vez establecida la lista de colonos, los organizadores visitaron a los padres de los niños para recabar su conformidad en la designación de sus hijos; darles una serie de consejos higiénicos, relativos a los baños que debían tomar los niños, para mejor reaccionar después en la vida de montaña, y presentarles la relación de prendas de vestir y enseres que constituían el equipo de los colonos. Como el equipo representaba un sacrificio para las familias pobres, la comisión del Ropero de la Asociación de Caridad, proporcionó a muchos niños prendas de vestir, a otros equipos completos y a todos sombreros, blancos para las niñas y grises para los niños. ${ }^{1272}$

Antes de salir los niños y niñas de Castellón, fueron sometidos a las medidas antropométricas de peso, talla y capacidad torácica. Este acto tuvo lugar en el salón de sesiones del Ayuntamiento y fue presenciado por las autoridades municipales, por varios maestros y por las familias de los niños.

El 20 de julio, fecha convenida para la marcha de la colonia, los niños se reunieron en el Gobierno civil, donde acudieron los familiares, autoridades y maestros de la capital. Salieron en un automóvil grande de viajeros a las diez de la mañana, para llegar a Lucena a las dos horas de viaje. ${ }^{1273}$

\footnotetext{
${ }^{1270}$ Ibídem, pp. 6-7; El Clamor 12/07/1915.

${ }^{1271}$ El Clamor, 1/07/1915.

1272 SENENT IBÁÑEZ, Juan José, op. cit. p. 8.

1273 Ibídem, pp.7-9.
} 
Dirigía la colonia el Inspector de Primera Enseñanza, José Senent y las maestras Alfonsa Giménez y Julia Soriano, ayudados por el maestro de Lucena Vicente Artero. ${ }^{1274}$

El recibimiento dispensado fue el acto más importante que se vio en aquella población. A la entrada del pueblo esperaban a los niños, el alcalde, concejales, curas y demás autoridades.

Los niños de la escuela de Lucena con su maestro Vicente Artero ostentaban banderas nacionales. La banda de música acompañó a los niños hasta la plaza en donde se oyeron vítores a la Colonia.

A partir de entonces la prensa de Castellón publicaba el «Diario de las Colonias» para que los padres supieran el estado de los niños y las niñas y la labor que se realizaba. $^{1275}$

Entre los pueblos montañosos, Lucena del Cid, reunía las mejores condiciones para la instalación de una colonia de montaña. Lucena gozaba de excelentes aguas y clima; de una altura de 500 a 600 metros, preconizada para esta clase de colonias, y de las ventajas relativas al transporte cómodo de los niños, fácil comunicación con la capital, y además, contaba con un local espacioso y fácilmente adaptable para colonia.

Este edificio estaba situado en las afueras y parte alta del pueblo. Por delante de la casa pasaba un ramal de carretera, apenas transitada, y esta circunstancia ofrecía, dentro de lo accidentado del terreno, amplio campo de juego para los niños. La colonia ocupaba el primero y segundo pisos. Al primero se subía por una corta escalera y contenía el dormitorio grande de los niños y la sala que servía para comedor y clase. El segundo piso se dedicó exclusivamente para dormitorio de las niñas y contenía un vestíbulo para el aseo y una gran terraza, desde donde se divisaba un extenso panorama.

La independencia de la casa, su altura y orientación a Levante, daban a la colonia las mejores condiciones de luz y ventilación.

El servicio de aguas para el aseo e higiene estaba asegurado por los aljibes de la casa y para la bebida se traía el agua de la fuente de San Vicente, situada a un kilómetro escaso. El servicio de luz era eléctrico. ${ }^{1276}$

\footnotetext{
${ }^{1274}$ El Clamor, 20/07/1915.

1275 El Clamor, 21/07/15.

${ }^{1276}$ SENENT IBÁÑEZ, Juan José, op. cit. pp.9-10.
} 


\subsection{LAS ACTIVIDADES EN LA COLONIA}

La situación de la casa, un poco alejada del núcleo urbano, la distribución y separación de sus amplias dependencias y sus alrededores, anchos y libres para la expansión infantil, «permitieron establecer un régimen de vida fácil, independiente y sencilla».

Según Senent a las favorables condiciones del medio, se añadía la buena relación existente entre maestros y colonos, $y$, entre estos, dominaba una relación de hermanos que hicieron que la estancia en la colonia fuera muy placentera y distraída.

El horario de la colonia estaba dentro de un plan de vida estudiado de antemano, en relación con los cambios fisiológicos del niño en cuanto a salud, entrenamiento para los ejercicios físicos, trabajo mental etc. En este sentido, durante los primeros días, se impuso la moderación en las comidas y paseos, y, a medida que pasaba el tiempo, aumentaba gradualmente la alimentación, los ejercicios físicos y el trabajo mental.

El horario de la colonia era el siguiente: ${ }^{1277}$

\begin{tabular}{|l|c|c|c|}
\hline & Mañana & Tarde & Noche \\
\hline Levantarse & $6: 30 \mathrm{a} 7 \mathrm{~h}$ & & \\
\hline Desayuno & $8 \mathrm{~h}$ & & \\
\hline $\begin{array}{l}\text { Juego por los alrededores o } \\
\text { pequeño paseo }\end{array}$ & Hasta 10:30h & & \\
\hline Diario y correspondencia & $11: 30 \mathrm{~h}$ & & \\
\hline Comida & $12: 30 \mathrm{~h}$ & & \\
\hline Siesta y juegos & & Hasta las $15 \mathrm{~h}$ & \\
\hline Excursión y merienda & & Hasta las $19 \mathrm{~h}$ & \\
\hline Cantos & & & Hasta las $20 \mathrm{~h}$ \\
\hline Cena & & & $21: 30 \mathrm{~h}$ \\
\hline Sueño & & & \\
\hline
\end{tabular}

Para la administración de la casa se distribuyeron los cargos en relación a la diversidad de funciones de la colonia y atendiendo a la especialidad e interés de cada persona. De la parte administrativa-económica (gasto diario, adquisición de víveres,

${ }^{1277}$ Ibídem, pp. 11-12. 
limpieza en general) se encargó la maestra Alfonsa Giner. A las órdenes de ésta había una cocinera, dos sirvientas y una lavandera del pueblo. Una profesora auxiliar, Julia Soriano, atendía al cuido directo de las niñas, y un profesor, Vicente Nicolau, acompañaba siempre a los niños. La distribución del tiempo y el trabajo de los niños quedaron encomendados principalmente al director.

En las imágenes de la página siguiente pueden observarse la situación de la Casa Colonia en Lucena.

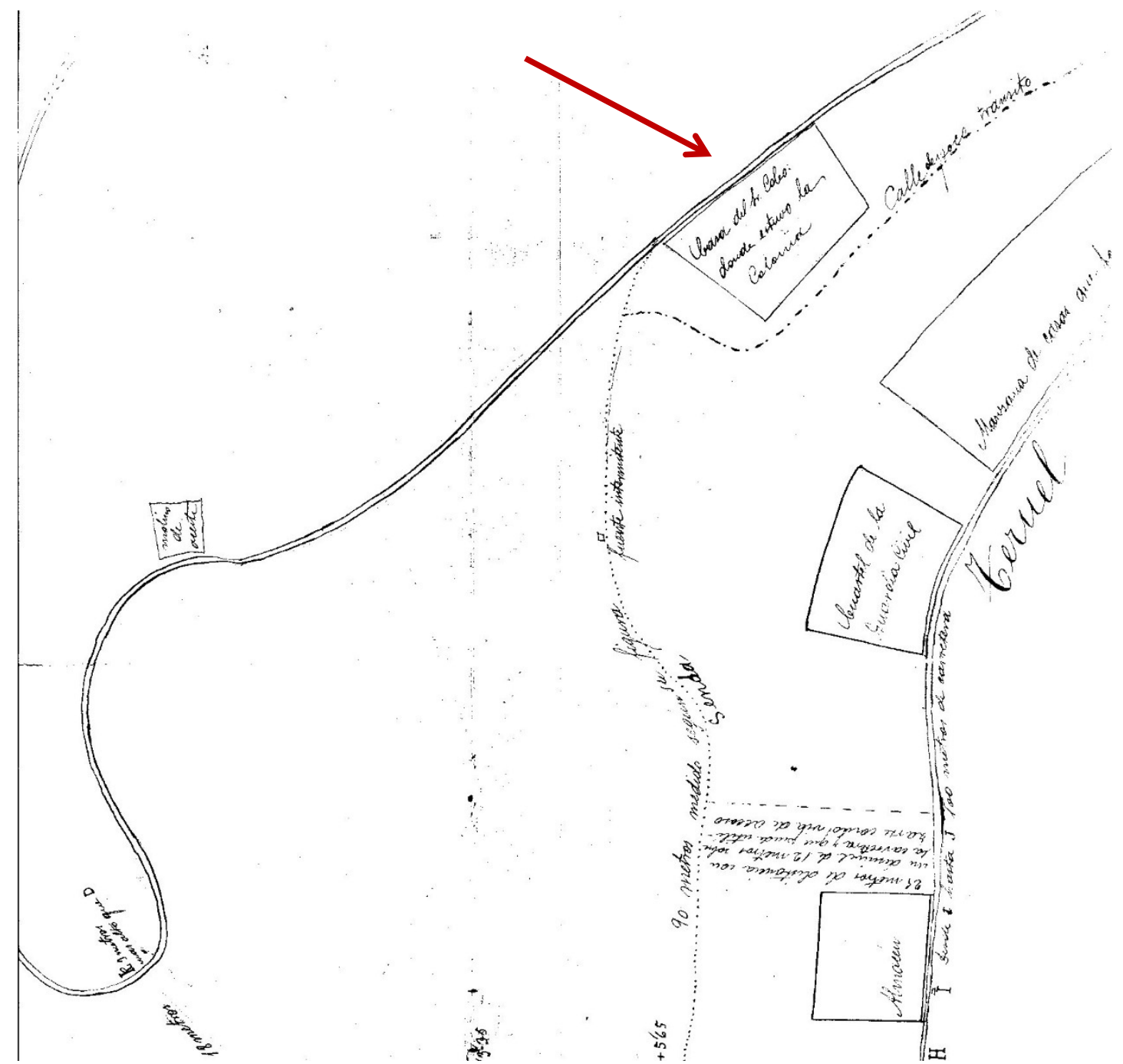

Croquis de la situación de la Casa Colonia (aproximadamente 1965). Fuente: Archivo Histórico del Ayuntamiento de Lucena del Cid 


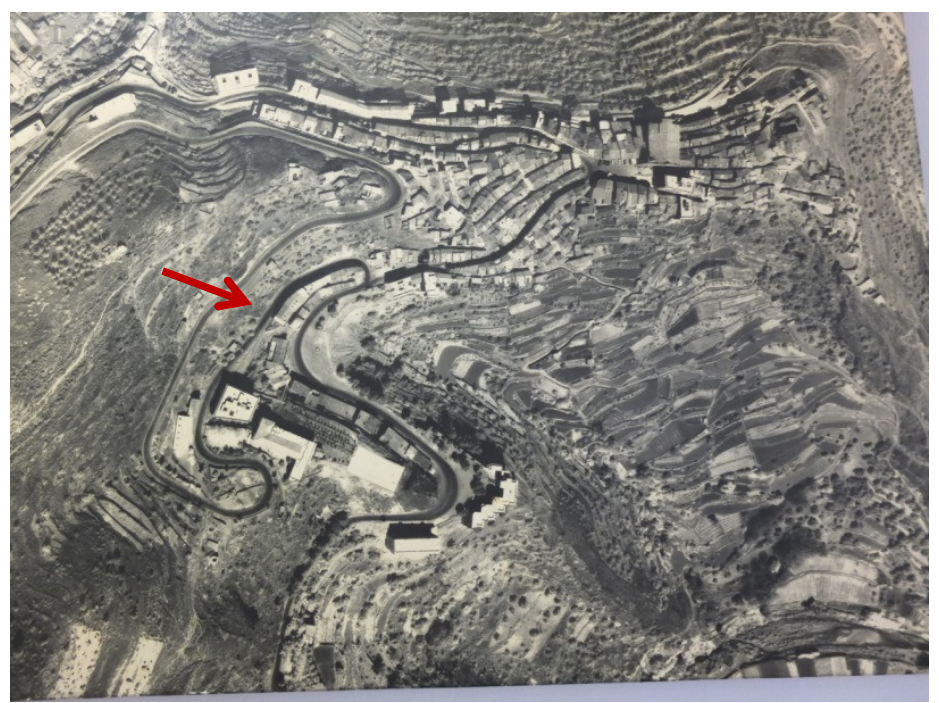

Foto aérea de Lucena. Fuente: Archivo Histórico del Ayuntamiento de Lucena del Cid

Al levantarse los niños por la mañana, plegaban sus camas, después bajaban a lavarse a un patio contiguo a la casa, donde existía un cobertizo. En éste se guardaba la palanganera, las jofainas, el jabón y los cubos de agua y, podían los niños dejar sus ropas y toallas mientras efectuaban el lavado. Este se hacía generalmente al aire libre, con el torso desnudo y siguiendo el ejemplo de los profesores. Después del lavado se procedía a la limpieza de la boca mediante cepillitos y usando bicarbonato de sosa.

Las niñas practicaban el lavado, limpieza de dientes y peinado, en el vestíbulo y terraza del segundo piso.

La limpieza de manos se repetía antes y después de cada comida.

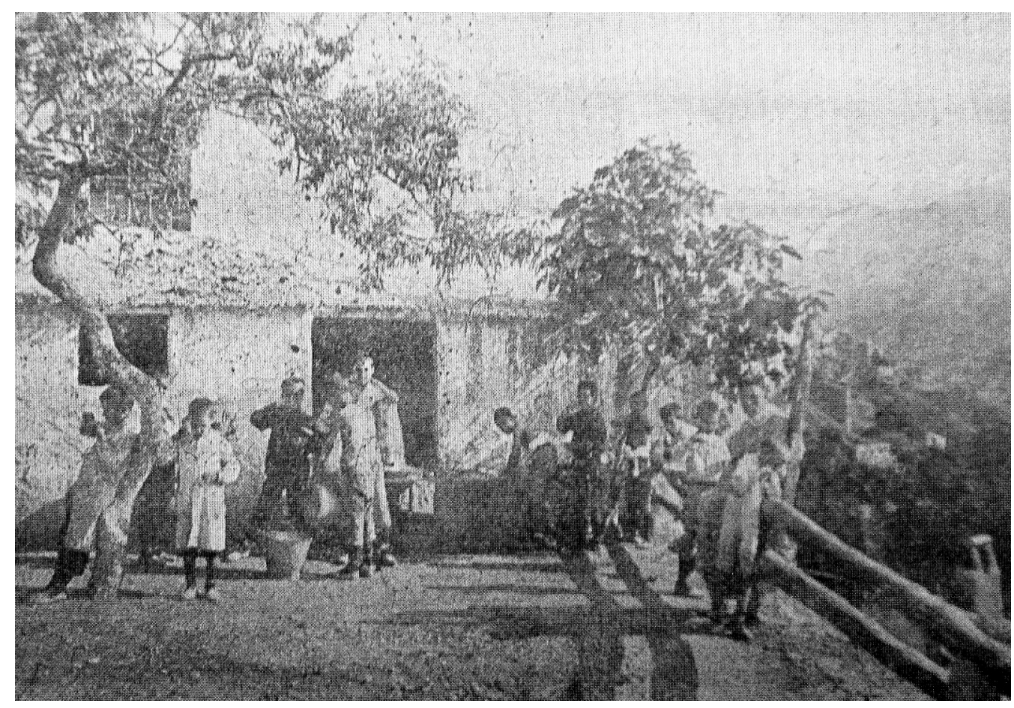

Aseo de los niños en el patio contiguo a la casa colonia. Fuente: Senent, Juan José (1915): Memoria de la primera colonia escolar castellonense en Lucena del Cid 
Los niños, acompañados de sus profesores, dedicaron muchas horas al ejercicio físico, «sin llegar a la fatiga excesiva».

Durante la primera semana los paseos fueron cortos, después fueron prolongándose hasta pasar todo el día fuera de casa, como en las excursiones a la mina de San Vicente y al Molino del Río.

Los paseos se dirigían generalmente a las fuentes de los alrededores, San Vicente, Prat, Molí, Montera”, Oms, Gatell, Coronetes, etc. En la fuente se merendaba y después se organizaban juegos en que tomaban parte los profesores.

Las excursiones se anunciaban y preparaban de antemano para hacer más interesante el camino y se variaban los itinerarios para encontrar siempre lecciones ocasionales.

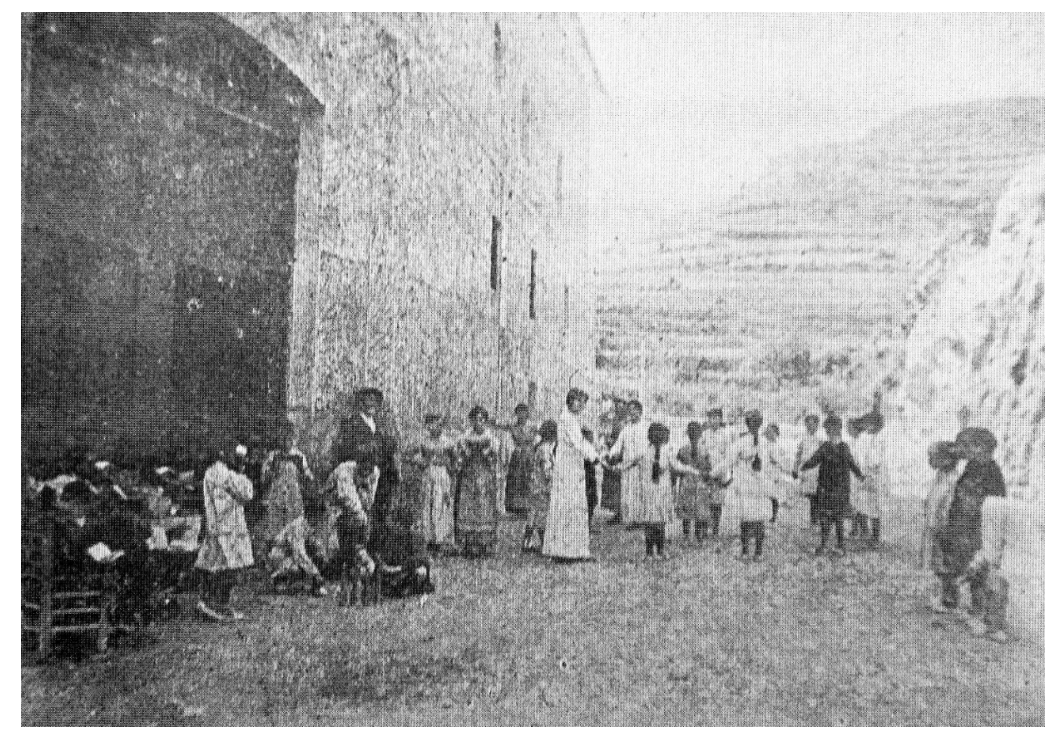

Ejercicios físicos en los alrededores de la Casa Colonia. Fuente: Senent, Juan José (1915): Memoria de la primera colonia escolar castellonense en Lucena del Cid

La colonia cultivó mucho el canto por su valor educativo estético y como elemento de disciplina y orden. Cantaban cuando volvían de las excursiones, al lado de una fuente, o cuando llegaban a la casa. Los cantos eran populares: gallegos, asturianos, castellanos y levantinos.

El principal objetivo de la colonia era fortalecer y educar para la salud a los niños y niñas, pero por otra parte, no podía dejar inactivas sus facultades mentales. A este fin fueron invitados los niños a redactar el Diario de la colonia. Acudieron doce, entre niños y niñas, los que escribían con mayor facilidad. 
En la redacción del Diario se procuraba respetar la espontaneidad del niño y de la niña. Después de corregir el escrito anterior, el director suscitaba una conversación entre los mismos niños y niñas sobre los recuerdos y observaciones más sobresalientes del día anterior y, luego, quedaban éstos en plena libertad de escribir lo que más interesaba a cada uno. El Diario se encabezaba con las anotaciones meteorológicas del mismo día, recogidas por los niños y niñas. Los que no escribían, se dedicaban, en la hora de trabajo, a leer, dibujar, hacer labores y trabajos manuales, mirar con el estereoscopio la colección Pestalozzi. Algunos niños recogieron pequeñas colecciones de minerales e insectos y formaron herbarios.

Durante la temporada, fue guía de las enseñanzas el cuestionario de excursiones y geografía local que había elaborado el Museo pedagógico.

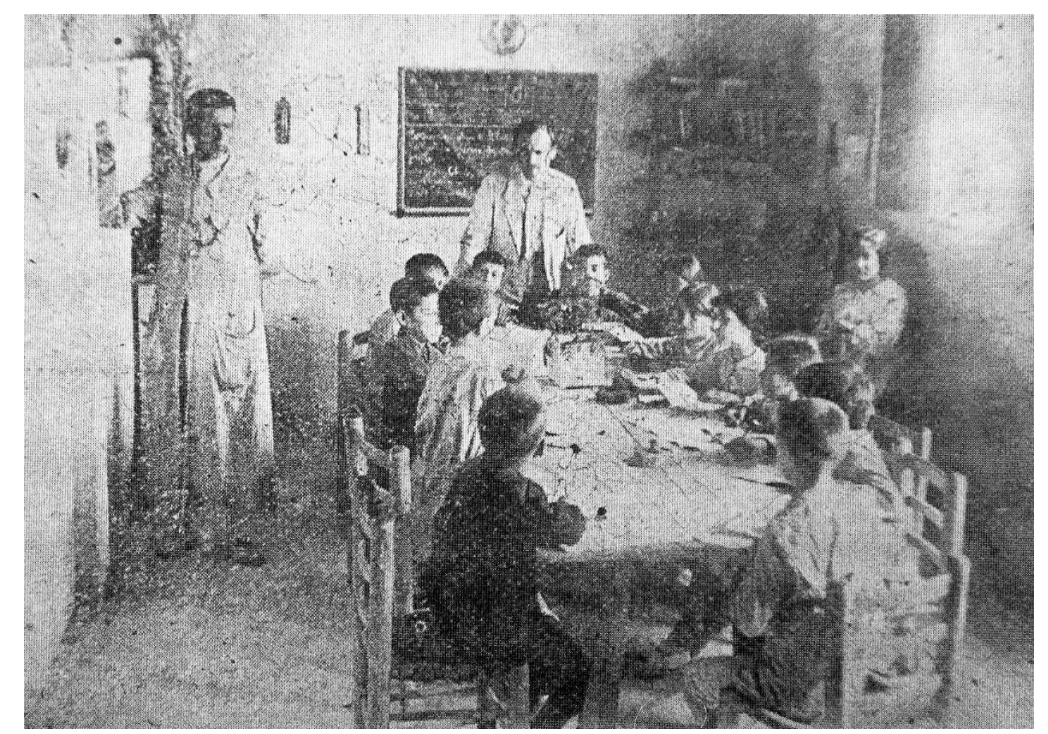

Redacción de los diarios en el aula. Fuente: Senent, Juan José (1915): Memoria de la primera colonia escolar castellonense en Lucena del Cid

La colonia vigilaba la calidad de los alimentos, y su proporción variable y creciente.

El desayuno constaba de un tazón de café con leche y pan a discreción. Algunos niños tomaban pan con queso o chocolate y jamón.

La comida de mediodía constaba de tres platos y postres. Cuatro días de la semana consistía en sopa de pastas o arroz, cocido, guiso de carne o embutidos, y postres. Otros dos días los platos eran los típicos del pueblo como arroz con verduras o bacalao, carne asada, queso o jamón y postres. Los domingos y días y festivos se hacía paella valenciana. La merienda consistía en pan y queso o algún dulce o chocolate, etc. 
La cena se componía de dos platos: sopa de pastas o judías, tortilla o carne con patatas cocidas y postres. Debido a la escasez de frutas que hubo aquel verano, el postre fue generalmente de galletas o dulce.

Cuando el sueño empezaba a iniciarse en la mayor parte de los niños, se daba la señal de retirada. Los profesores dormían al lado de los niños, en los ángulos que dominaban el salón. Éste quedaba ventilado, con las ventanas entreabiertas toda la noche.

Todas las semanas los niños acudían a misa; eran pesados y medidos con la misma báscula y escribían a sus casas.

Los niños tenían correspondencia con niños de otras colonias, y también, escribían a todas las personalidades que habían favorecido a la colonia. Entre las contestaciones recibidas, figuraban la del Ministro de Instrucción pública y Director General de Primera Enseñanza, Obispo de Barcelona, Rafael Altamira y los Diputados de la provincia, Vicente Cantos y Emilio Santacruz. ${ }^{1278}$

La Colonia de Lucena fue objeto de muchas visitas. La colonia estaba abierta para que los maestros pudieran observar de cerca el funcionamiento y régimen educativo de la misma. En este sentido ofreció hospedaje a varios maestros de Castellón, y, también, algunas madres viajaron de Castellón a Lucena para ver a sus hijos.

El 5 de agosto visitaron la Colonia el Gobernador Civil, Inspector provincial de Sanidad, Alcalde y concejales del Ayuntamiento de Castellón. Los niños fueron obsequiados por el gobernador con una merienda, el Alcalde les ofreció pasteles y dulces. José Clará regaló a cada niño una caja de pinturas y a las niñas unos pendientes.

Entre los obsequios que recibieron los colonos, figuran los paquetes de caramelos y dulces del Ayuntamiento de Lucena y la paella valenciana que un concejal del Ayuntamiento ofreció a los niños y niñas en una finca de su propiedad, llamada el Molino del Río.

La Colonia recibió otros donativos, principalmente de cajas de galletas, caramelos, pasteles, etc., de diferentes personalidades de Lucena y de Castellón, por ejemplo el juez y farmacéutico de Lucena; Leonor Velao, directora de la Normal de Castellón; el maestro Francisco Canós, prestó un fonógrafo y obsequió a los niños con

\footnotetext{
${ }^{1278}$ Las actividades las hemos resumido de la Memoria de Senent, José, op. cit. pp. 12-19.
} 
una sesión de cinematógrafo; el librero de Castellón, Benjamín Ballester regaló libretas para los Diarios y otros objetos de papelería, y un bienhechor de la colonia Emilio Zorita, dedicó un himno a la Colonia. ${ }^{1279}$

Los dos médicos de Lucena. Antonio Nebot y Lauro Hernández, visitaban constantemente la casa para ver de cerca el progreso de los niños y niñas. ${ }^{1280}$

El 20 de agosto regresaron los niños a Castellón. El pueblo de Lucena les tributó una cariñosa despedida.

Llegaron a Castellón a las tres de la tarde. En el Gobierno Civil esperaban sus familiares y autoridades. Reunidos los niños en un patio del edificio, fueron sucesivamente nombrados y entregados a sus respectivas familias. Poco después acudieron a la casa ayuntamiento de Castellón, donde fueron pesados y medidos en presencia de las autoridades y maestros. Los profesores rogaron a las madres que cuidaran de mantener en sus hijos las costumbres de higiene y orden practicadas por los colonos. $^{1281}$

\subsection{RESULTADOS DE LA COLONIA}

\section{EDUCATIVOS}

Las actividades en plena naturaleza fomentaron la educación ambiental, social y cultural de los colonos.

Con el cambio de medio, los niños aumentaron considerablemente sus conocimientos. Subiendo a la montaña, estudiaron la topografía del terreno y sus accidentes. Recorriendo la población, los niños redactaban el Diario, estudiaron la vida local en sus diferentes aspectos: civil, industrial, agrícola, comercial, histórica, artística, sus vías de comunicación, sus costumbres etc. Los objetos eran aprendidos por la observación directa y dentro de aquellas condiciones que más interés despertaban. La colonia despertó la curiosidad de algunos niños que asediaban con sus preguntas a los maestros; el contacto con la naturaleza, despertó la afición por la Historia Natural y el sentimiento de amor hacia la naturaleza. ${ }^{1282}$

\footnotetext{
${ }^{1279}$ Ver en Apéndice Documental No 26; La Escuela, 1915.

1280 SENENT IBÁÑEZ, Juan José, op. cit. pp. 19-20.

1281 Ibídem, p. 21; El Clamor, 21/08/1915.

1282 Ibídem, pp. 22-23. Ver la redacción de algunos diarios de la primera, segunda y tercera colonia escolar, en el Apéndice Documental. № 27.
} 
Los niños procedían de casas pobres donde era frecuente la desorganización familiar y el desapego social. La colonia fue un cambio absoluto de ambiente social. El ejemplo de sus profesores despertaron en los colonos sentimientos de respeto mutuo, corrigieron las maneras groseras y ruidosas que trajeron algunos niños; las burlas, riñas, la mentira, la brusquedad en el lenguaje y el comportamiento en la comida.

\section{FÍSICOS}

Los datos antropométricos tomados antes y después de la colonia revelaron, por término medio, el aumento de $1 \mathrm{k}$ de peso, por niño; $1,25 \mathrm{~cm}$ en estatura y $0,76 \mathrm{~cm}$ en amplitud torácica. La diferencia entre las circunferencias torácicas medias tomadas a la ida y a la vuelta, dio un aumento medio por niño de 2.50 centímetros. El aumento de peso fue mayor en los niños que en las niñas. En cambio, éstas, superaron a los niños en aumento de estatura y amplitud torácica. Como términos extremos, en la tabla de pesos, hubo niños que aumentaron 2.50 kilos y niñas que disminuyeron 0.50 kilos.

La ganancia de peso en los niños, según Senent, era debido al entrenamiento físico, «que supone mucho gasto de actividad muscular con el fin de fortificar y endurecer el organismo del colono»:

Tabla 1. Resultados antropométricos de la primera colonia escolar de 1915

\begin{tabular}{|l|l|l|l|l|l|l|l|}
\hline \multirow{2}{*}{ NIÑNOS } & \multirow{2}{*}{ ANOS } & \multicolumn{3}{|l|}{ Peso en kilógramos } & \multicolumn{2}{l|}{$\begin{array}{l}\text { Talla en } \\
\text { centímetros }\end{array}$} & \multicolumn{2}{l|}{$\begin{array}{l}\text { Amplitud en } \\
\text { centímetros }\end{array}$} \\
\cline { 2 - 9 } & & Ida & Vuelta & Ida & Vuelta & Ida & Vuelta \\
\hline Antonio Renau & 8 & 17,5 & 19,5 & 114 & 117 & 2 & 3 \\
\hline Ramón Soro & 8 & 23,5 & 24,5 & 124 & 125 & 2,5 & 3,5 \\
\hline Marcos Peñas & 8 & 21 & 22 & 115 & 116 & 3 & 4 \\
\hline $\begin{array}{l}\text { Ricardo } \\
\text { Cabrera }\end{array}$ & 8 & 22 & 23 & 119 & 119,5 & 2 & 2,5 \\
\hline $\begin{array}{l}\text { Vicente } \\
\text { Carnicer }\end{array}$ & 9 & 27 & 28 & 129 & 130 & 2 & 2,5 \\
\hline José Madrigal & 9 & 25 & 26 & 133 & 135 & 2 & 3 \\
\hline Pedro Sanchis & 9 & 20 & 23 & 122 & 124 & 2 & 3 \\
\hline Enrique Garcés & 9 & 24 & 26,5 & 125 & 125,5 & 4 & 5 \\
\hline Miguel Ibáñez & 9 & 22 & 23 & 122 & 123 & 2 & 2 \\
\hline José Igual & 10 & 26,5 & 28 & 127 & 129 & 2 & 3 \\
\hline José Guillén & 10 & 25 & 27 & 128 & 130 & 3,5 & 4 \\
\hline Francisco Vilar & 10 & 26 & 27 & 128 & 129 & 3,5 & 4 \\
\hline Jose'Llorens & 11 & 28 & 29 & 127 & 127 & 2 & 2,5 \\
\hline José Aparici & 11 & 30 & 32,5 & 144 & 145 & 1,5 & 3,5 \\
\hline José Monfort & 12 & 28 & 29 & 141 & 142 & 4,5 & 5 \\
\hline
\end{tabular}




\begin{tabular}{|l|l|l|l|l|l|l|l|}
\hline NIÑAS & & & & & & & \\
\hline $\begin{array}{l}\text { Vicenta } \\
\text { Herrando }\end{array}$ & 9 & 24,5 & 25 & 126 & 127 & 1,5 & 2 \\
\hline $\begin{array}{l}\text { Vicenta } \\
\text { Moliner }\end{array}$ & 9 & 22 & 22,5 & 120 & 122 & 1,5 & 2 \\
\hline Antonia Salas & 9 & 22 & 22 & 120 & 121 & 2 & 4 \\
\hline $\begin{array}{l}\text { Francisca } \\
\text { Fabregat }\end{array}$ & 9 & 22 & 22,5 & 119 & 120,5 & 2 & 3 \\
\hline Carmen Prades & 9 & 21,5 & 22 & 119 & 121 & 2 & 3 \\
\hline $\begin{array}{l}\text { Carmen } \\
\text { Campos }\end{array}$ & 9 & 21 & 22 & 118 & 119,5 & 2 & 3 \\
\hline $\begin{array}{l}\text { Bienvenida } \\
\text { Campos }\end{array}$ & 9 & 21,5 & 22 & 119 & 121 & 4,5 & 5 \\
\hline Carmen Fibla & 10 & 25,5 & 26 & 133 & 133 & 3,5 & 4 \\
\hline Carmen Roig & 10 & 28,5 & 28 & 130,5 & 132 & 2,5 & 3 \\
\hline Trinidad Diago & 10 & 24,5 & 25,5 & 129 & 131 & 0,5 & 2 \\
\hline $\begin{array}{l}\text { Ángela } \\
\text { Carceller }\end{array}$ & 10 & 20 & 19,5 & 113 & 114 & 2 & 3 \\
\hline $\begin{array}{l}\text { Consuelo } \\
\text { Verchili }\end{array}$ & 11 & 26,5 & 28 & 128 & 129 & 3 & 3 \\
\hline María Calvo & 11 & 25 & 26 & 128,5 & 129 & 4 & 4,5 \\
\hline $\begin{array}{l}\text { Angela } \\
\text { Martínez }\end{array}$ & 11 & 27 & 28 & 131 & 133,5 & 0,5 & 2 \\
\hline María Tirado & 12 & 25,5 & 26,5 & 131 & 131 & 3 & 3 \\
\hline
\end{tabular}

Fuente: Senent, Juan José (1915): Memoria de la primera colonia escolar castellonense en Lucena del Cid

Tanto como los datos antropométricos, se observó un cambio total en el aspecto externo de los niños y niñas. Con la temporada de colonia los niños parecían otros; «había crecido el apetito por el ejercicio realizado a cielo abierto, el tono de su piel de color tostado, sus movimientos firmes, y la alegría de vivir que expresaban sus ojos, denotaban la influencia positiva de su estancia en la colonia».

\subsection{LA PRENSA SE INTERESA POR LA PRIMERA COLONIA ESCOLAR EN CASTELLÓN}

La importancia que tuvo para Castellón la primera colonia escolar lo refleja bien la prensa.

Un redactor de El Clamor, ensalza a la ciudad de Castellón por sus ideas progresistas y sentimientos generosos al organizar la salida de la primera colonia escolar a Lucena. 
Escribe que entre las varias instituciones relacionadas con la escuela primaria, «la colonia escolar es indudablemente una de las más importantes. De aquí la necesidad de que se le mire con simpatía y se le apoye con entusiasmo».

Continúa diciendo que es conveniente apoyar las colonias escolares porque los niños serán «los estadistas, los gobernadores, los legisladores futuros, que han de regir la suerte de las naciones». ${ }^{1283}$

Y allá van los pequeñuelos enfermos, depauperados, anémicos, llenos el corazón de júbilo, la mente de ilusiones, el alma de esperanzas, para que el campo les devuelva a las ciudades sanas, fuertes y robustas. Hay que combatir la escrófula; que extinguir el raquitismo; que ahuyentar la tuberculosis, con objeto de que, fortalecido el cuerpo, elevado el espíritu, vigorizada la raza, puedan esos niños, cuando hombres mañana, ser útiles a la sociedad, a la familia, a la patria.

El Clamor publica un artículo titulado: «Después de la colonia escolar» en el que dice que ésta es una forma de compensación, ingeniosa y singular, con que las entidades oficiales y clases pudientes pagan también su tributo a los niños pobres y enfermos que necesitan su temporada de campo para renovar sus organismos, deleitarse con la naturaleza y aprovisionarse de energías. ${ }^{1284}$

Dentro del concurso social que prestaron las clases populares y la prensa local, destaca singularmente el apoyo personal y decisivo que mereció la colonia por las autoridades de Castellón.

Se indica la conveniencia de organizar una junta o patronato formado por personas dignas y celosas para dar mayor amplitud y desarrollo a las instituciones que protejan a los niños pobres y débiles. La obra y sus admirables resultados constituían una propaganda muy positiva para que en años sucesivos pudieran aumentar las facilidades y medios económicos. Para favorecer las colonias escolares se pide organizar fiestas, tómbolas, festivales en que tomen parte los niños, sesiones de cinematógrafo educativo, (poco conocidas en aquel tiempo en Castellón), para contribuir a favorecer estas instituciones escolares.

\footnotetext{
${ }^{1283}$ El Clamor, 28/07/1915.

${ }^{1284}$ El Clamor, 28/081915.
} 
La primera colonia debía ser la base para extender los beneficios de las vacaciones al mayor número de niños. No solo colonias sino también los baños escolares y con el tiempo el sanatorio indispensable para regenerar a los niños, «víctimas de fatales enfermedades». La ciudad de Castellón que sobresalía por su interés en la enseñanza, puesto que, según el inspector Senent, sostenía mayor número de escuelas de las exigidas por la ley y que puso su interés en el cuidado y bienestar de los niños enfermos, debía en lo sucesivo aprovechar, como otras ciudades españolas y muchas extranjeras, la época del verano y su proximidad al mar para que todos los niños, unos en la playa y otros en la montaña gozaran de los beneficios del campo, compensaran las fatigas del estudio, y adquirieran las energías suficientes para el trabajo escolar. Realizada esta empresa de promoción de la salud física, quedaría completa la labor de enseñanza de las escuelas de Castellón, y «la ciudad vería crecer una juventud fuerte y animosa inmunizada para las enfermedades, laboriosa y pacífica, amante y conocedora de su región, una juventud exigida más que nunca por los tiempos que seguirán a la guerra». ${ }^{1285}$

En otro número de El Clamor, otro redactor, defiende que los niños castellonenses pasen una temporada en la montaña, afirma que las colonias son ya imprescindibles. «Pero como la obra es incompleta precisa modificarla».

Subraya que existe una clase media abandonada por todos; una clase media que sufre las impertinencias de los de arriba y las necesidades de los de abajo:

«Los de arriba tienen sus masías, sus villas se levantan a orillas del mar; los balnearios están lujosamente montados para ellos. Los de abajo, los pobres, consiguen la colonia, consiguen el amparo oficial que cada día será mayor».

Según dice, los de la clase media están abandonados por todos, sus hijos no pueden gozar los beneficios que la naturaleza puede darles en la montaña o en la orilla del mar, porque su peculio particular no llega a cubrir estas necesidades, ni el municipio, ni el Estado acuden a subvencionarlas.

«La solución sería organizar el ahorro dirigido a este fin, el ahorro individual para que cada niño por su esfuerzo, por sus economías, cuando llegara el mes de julio, reuniera el suficiente dinero con el que trasladarse a la montaña o al mar».

\footnotetext{
${ }^{1285}$ El Clamor, 28/08/1915.
} 
Brinda la idea a los maestros, a los inspectores y a los profesionales, y se pregunta ¿la veremos realizada? ${ }^{1286}$

\subsection{DESARROLLO DE LA SEGUNDA Y TERCERA COLONIA ESCOLAR}

Vistos los resultados obtenidos en la primera colonia escolar, la Junta Provincial de Primera Enseñanza, en marzo de 1916, nombró una comisión formada por el Inspector Provincial de Sanidad José Clará, Inspectores de Primera Enseñanza Emilio Monserrat y José Senent, presididos por el Gobernador Teodoro Izquierdo, para que gestionara del Estado, el dinero suficiente para organizar, no solo una colonia con niños de la capital, sino también otra marítima compuesta de niños del interior de la provincia, necesitados de los baños y la vida en la costa.

No se consiguió la cantidad pedida de 6.000 pesetas; el Estado solo concedió 4.000 pesetas, y como consecuencia la Junta provincial, en sesión de 31 de julio de 1916, acordó la organización de una sola colonia con niños de la capital, ampliando el número hasta 40, 20 de cada sexo, en Lucena, por un mes, pero sin renunciar al proyecto de constituir a su tiempo la colonia marítima para lo cual se estudiaban los medios de arbitrar recursos para completar la ayuda del Estado.

La segunda colonia escolar castellonense estaba constituida por 20 niños y 20 niñas pertenecientes a las escuelas públicas de la capital. El Inspector Provincial de Sanidad, José Clará, a quien la Junta Provincial confió la dirección de la colonia, eligió los niños más necesitados por su salud y los más pobres, y entre éstos de los más asiduos a la escuela.

La estancia en Lucena se programó del 5 de agosto al 5 de septiembre.

A principios de agosto en el Ayuntamiento se efectuó la entrega de los equipos correspondientes a las niñas y niños que formaban parte de la segunda colonia escolar. Como en el año anterior, en el salón de sesiones del Ayuntamiento se verificó el acto de pesarlos y medirlos, al que acudía todo aquel que lo deseara.

La segunda colonia también se encargó el Inspector Senent, quien designó al maestro Vicente Nicolau y a la maestra Amelia Pérez del Cerro, número uno en la

\footnotetext{
${ }^{1286}$ El Clamor, 1/02/1916.
} 
oposiciones celebradas hacía poco en Valencia, de la inspección de los grupos de niños y niñas, respectivamente.

La segunda colonia escolar salió esta vez desde el Ayuntamiento en lugar del Gobierno Civil, acompañada del Inspector de Primera Enseñanza José Senent, del Inspector de Sanidad José Clará y de la Inspectora de Escuelas Asunción Playán.

En Lucena fueron recibidos por las autoridades y todo el pueblo que los acogían con gran entusiasmo.

Diariamente El Clamor informaba para conocimiento de los padres del estado de los niños y niñas, y publicaba un diario escrito por los mismos sobre la vida en la colonia. $^{1287}$

Muchos maestros visitaban Lucena para observar de cerca la colonia y dar a conocer semanalmente los progresos obtenidos en la educación del colono, «pues aunque siendo el objetivo primordial de la colonia fortalecer el organismo de los niños, no por ello se descuidaba su progreso intelectual» ${ }^{1288}$

Al llegar a Lucena se dirigían a la Casa colonia produciendo admiración la situación y orientación de la casa, que eran inmejorables: la distribución de sus dependencias, la ventilación, aseo, etc.

Para conocimiento y satisfacción de los padres ofrecían una idea de los beneficios obtenidos por los colonos en la primera semana de estancia en la colonia.

En una semana de estancia en la colonia los niños, por término medio aumentaron unos 600 gramos; con respecto a la talla, varios niños y niñas crecieron un centímetro, «nada despreciable si consideramos que se trata de niños de constitución débil».

Las colonias eran igual de beneficiosas para la educación intelectual y moral. Las continuas excursiones que realizaban los colonos se prestaban para la explicación de lecciones de botánica, zoología, mineralogía, agricultura, etc., los ejercicios de redacción al llevar su diario, las descripciones y cartas a las familias, desarrollaban el lenguaje y la escritura. Se les enseñaba a vivir en sociedad, a cumplir con sus deberes y a respetar y ser respetados en sus derechos y así ir formando su carácter y desarrollando su voluntad.

\footnotetext{
${ }^{1287}$ El Clamor, 3/08/1916.

${ }^{1288}$ Ver Apéndice Documental No 28.
} 
El objetivo de las colonias era, además de no descuidar la inteligencia y moralidad de los niños, llevarse a la sierra 40 candidatos a la tuberculosis, anemia y demás plagas de la humanidad y devolver organismos reconstituidos, sanos, robustos para hacer frente a las contingencias de la vida.

Se decía que con esta colonia se había atendido a los necesitados de salud de Castellón, pero los niños que vivían en las montañas también necesitaban la brisa del mar. Se estaban haciendo gestiones para lograr subvenciones suficientes para establecer una colonia marítima. ${ }^{1289}$

El 21 de Mayo de 1918 visitaron al Gobernador Civil, el Doctor Clará y el Inspector José Senent a fin de ponerse de acuerdo respecto a la organización de la tercera colonia escolar en Lucena.

Para dicha colonia el Estado concedió 3.000 pesetas. Se gestionó algún donativo más de entidades y corporaciones con el objeto de disponer de la cantidad necesaria para atender al mantenimiento de los cuarenta colonos de que se había de componer aquella. $^{1290}$

El Ayuntamiento de Castellón, acordó en sesión ordinaria del 26/06/1918 contribuir con 1.000 pesetas al sostenimiento de la tercera colonia escolar que iba a instalarse en Lucena. ${ }^{1291}$

En el Salón de sesiones del Ayuntamiento, como en años anteriores, el doctor Clará y el Inspector Senent midieron y pesaron a los niños para la tercera colonia escolar. A la talla y peso se añadió ese año otro dato, el de la capacidad respiratoria. ${ }^{1292}$

La tercera colonia escolar estaba formada por 21 niñas y otros tantos niños, de los cuales 40, mitad de cada sexo, pertenecían a las escuelas públicas de Castellón y 2, al Centro Obrero, a petición de éste. El 31 de julio se congregaron en la Casa Capitular para recibir las últimas instrucciones. A la reunión debían concurrir los pequeños colonos acompañados de sus respectivas madres, a fin de que éstas tuvieran conocimiento de los propósitos de los señores Senent y Clará, organizadores de la colonia.

\footnotetext{
${ }^{1289}$ El Clamor, 18/08/1916.

${ }^{1290}$ El Clamor, 21/05/1918; La Escuela, 18/05/1918.

${ }^{1291}$ El Clamor, 27/06/1918.

${ }^{1292}$ El Clamor, 1/07/1918, La Escuela, 3/07/1918.
} 
Los niños salieron de Castellón el día 1 de agosto, a las 6 horas de la mañana y las niñas salieron desde el Gobierno Civil, a las 10 horas. En Lucena se les preparó un gran recibimiento.

Se utilizó la misma casa que en los años anteriores, introduciendo las reformas que fueron necesarias.

Los castellonenses ayudaron a la colonia entregando dinero y especies, como, por ejemplo, todo el jabón necesario para el aseo de los colonos. ${ }^{1293}$

Regresaron a Castellón el 1 de septiembre, y días después, en el Salón de sesiones del Ayuntamiento, se procedió a la operación de pesar y medir a los niños y niñas por el Inspector de Sanidad, doctor Clará y el Inspector de Primera Enseñanza, José Senent.

\subsection{LOS BAÑOS ESCOLARES, OTRO MEDIO DE DESARROLLAR LA SALUD}

En 1915, el Inspector José Senent, presentó a la aprobación del Ayuntamiento de Castellón un Ensayo de un plan orgánico para el funcionamiento de los «Baños Escolares» en la playa de Castellón de la Plana durante el verano de 1915.

El objetivo de los baños escolares era también, la protección y cuidado de los niños, la educación física, el desarrollo y mejora fisiológica de los niños. ${ }^{1294}$

Dentro de la educación «moderna» se desarrolló un movimiento a favor de la educación física, naciendo a la vez instituciones que procuraban el desarrollo y la mejora fisiológica de los niños.

Entre estas instituciones de carácter higiénico hay que señalar aquellas obras de preservación social que tendían a contrarrestar las causas de degeneración física, tan persistentes y abundantes en las grandes poblaciones. El niño pobre de la ciudad vivía rodeado de condiciones antihigiénicas que minaban su salud. La vida en lugares estrechos, húmedos, oscuros, faltos de sol y aire, donde vivían los niños en peligro de contagio y sometidos a una alimentación escasa y artificial, eran la causa de que tuvieran peor salud. ${ }^{1295}$

\footnotetext{
${ }^{1293}$ El Clamor, 1/08/1918.

${ }^{1294}$ La Escuela, 9/07/1915.

${ }^{1295}$ El Clamor, 24/06/1915.
} 
Tres eran las obras escolares protectoras de la infancia que se realizaban principalmente dentro del verano, que atendían a los niños pobres y enfermos de las escuelas para devolverles la salud que necesitaban. Estas obras eran los «Sanatorios», las «Colonias Escolares de vacaciones»y finalmente los «Baños Escolares». Los niños debilitados, desnutridos y raquíticos, los predispuestos a la escrófula o a la tuberculosis, que formaban el 80 por 100 de las escuelas, eran atendidos, según la intensidad de su dolencia, por una de estas tres instituciones. La selección de los niños que habían de beneficiarse con estas obras dependía, entre otras circunstancias, del mayor o menor grado y calidad de la afección o tendencia morbosa de los niños.

Los baños escolares debían beneficiar a los niños de las escuelas públicas, que por su condición social, negligencia de los padres, estado de salud, etc., necesitaban durante el verano restaurar sus fuerzas físicas mediante ejercicios convenientes a plena luz y a pleno aire y con la acción tonificadora de los baños de playa. A los beneficios conseguidos por los niños en orden a la salud había que añadir los resultados pedagógicos de disciplina moral y de enseñanza bajo el influjo de la acción educadora de los maestros directores.

El sostenimiento y organización de los «Baños Escolares», se encomendaba principalmente a los Municipios y a la ayuda de los particulares e instituciones benéficas.

Teniendo en cuenta el carácter de ensayo que debían tener los «Baños Escolares» en el primer año de funcionamiento, debía limitarse a 100 niños el número de los que disfrutaran sus beneficios en el verano de 1916. Los cien escolares se repartirían en 50 niños y 50 niñas.

La elección de los niños debía correr a cargo de los médicos escolares municipales, los cuales debían elegir de las escuelas nacionales aquellos niños más pobres y más necesitados por su condición fisiológica de restaurar sus fuerzas con los «Baños Escolares».

La edad de los niños debía ser dentro del periodo escolar, entre los nueve y doce años. Los médicos fijarían la época de los baños pudiendo durar un mes la temporada de los mismos. 
El número de profesores se compondrían por un director y dos profesores auxiliares por grupo de 50 niños.

Los niños debían acudir a los baños con una toalla para secarse después del baño; solamente se les proporcionaría un sombrero grande y el traje de baño.

La distribución del tiempo debía ser la siguiente: la salida de los niños de 7 a 8 de la mañana. Al llegar a la playa tomarían el almuerzo que trajeran de sus casas. Descanso y juego. De 10 a 11 horas, los niños vestidos con su traje de baño harían ejercicios físicos por la playa. Terminada la gimnasia tomarían el baño de 11 a 12 horas. Después de vestirse y haberse secado los trajes de baño regresarían a la capital.

Para desnudarse los niños, se instalaría un barracón en la playa. Cuidarían del baño además de los profesores dos barqueros convenientemente situados para evitar todo peligro. $^{1296}$

La Junta Local de Primera Enseñanza sería la encargada de la administración del dinero destinado a los «Baños Escolares». Sus funciones principales serían las siguientes:

-Elaboración del horario de salida y vuelta de los niños y distribución del tempo en la playa.

-Elección del profesorado director y auxiliar.

- Intervenir cerca de los médicos escolares y de los maestros y convocar a los padres de familia para dar los oportunos avisos y resolver las dificultades que se presentaran.

-Gestionar los viajes por ferrocarril en las mejores condiciones de economía, seguridad y comodidad de los niños.

-Instalación de los barracones de playa y determinación de los barqueros auxiliares.

${ }^{1296}$ La Escuela, 9/07/1915, pp. 183-184. 
- Adquisición de sombreros y trajes de baños para los niños.

- Solicitar donativos de los particulares y de las sociedades benéficas y obtener otros recursos por medio de cuestaciones públicas, fiestas, tómbolas, etc.

-El alcalde, como presidente de la Junta local, era el encargado de vigilar y dirigir la implantación de esta institución escolar para darle efectividad en años sucesivos. $^{1297}$

-El secretario de la junta local, de acuerdo con el profesorado de los niños, presentaría una «memoria» terminada la temporada de baños, donde debían constar los resultados obtenidos con datos gráficos y fotografías y las variaciones que aconsejados por la experiencia habrían de introducirse para otros años.

La junta local quedaba así mismo encargada de la publicación de un reglamento que debía regir para lo sucesivo en los «Baños Escolares». ${ }^{1298}$

No se llegaron a organizar los baños escolares en 1916, como se esperaba, sin embargo, en Castellón, en la segunda quincena de julio, organizado por el director de la Beneficencia, Juan Aragonés, se realizaban los baños de los asilados en la casa de Beneficencia.

Durante nueve días los chicos se dirigían al Grao en el tranvía de las ocho de la mañana, permaneciendo en el Pinar hasta las cuatro, hora en que regresaban a la capital.

Tomaban los baños en la playa en grupos de 12 a 14, con el fin de poder cuidarlos debidamente y evitar desgracias.

Cada uno de los 150 asilados iba provisto de su correspondiente merienda y sombrero de paja.

Terminados los nueve días de baños de los chicos, comenzaban otro tanto las chicas del mismo establecimiento, procurando terminar el 14 de agosto.

Antes de comenzar, los baños se pesaban y medía a los asilados con el fin de conocer el desarrollo físico que experimentaran. ${ }^{1299}$

\footnotetext{
1297 Ibídem, p. 185.

${ }^{1298}$ El Clamor, 24/06/1915; La Escuela, 9/07/1915, pp. 183-185.
} 
En Castellón, a partir de 1917, se establecieron colonias que tenían una finalidad más educativa que higiénico-sanitaria. Podemos citar la escuela-bosque y la colonia escolar católica, inauguradas a partir de 1917. ${ }^{1300}$

\subsection{LA ESCUELA-BOSQUE.}

Las clases de la escuela-bosque se inauguraban durante la primera quincena de julio, en el Pinar de Castellón, en una villa del republicano José Gimeno

La escuela estaba dirigida por el maestro de la escuela del Centro Republicano, Vicente Vilar Miralles prestaba su protección el empresario Enrique Gimeno Tomás.

Asistían los hijos de las familias instaladas en las villas y «masets» cercanos y los hijos de los trabajadores de Gimeno Tomás, empresario republicano, afín al partido de Fernando Gasset.

En los meses de verano que duraba su funcionamiento se daban conferencias escolares a los niños por muchos republicanos ilustres invitados por Vilar. El sostenimiento de la escuela-bosque se debía a las familias Gimeno- Nebot. ${ }^{1301}$

\subsection{LAS COLONIAS ESCOLARES DESPUÉS DE 1918}

El final de la Primera Guerra Mundial demostró que los niños son los grandes perdedores de todas las guerras. Las consecuencias de ese gran conflicto entre la población infantil produjo una corriente de opinión favorable a ella y visible en las muchas ligas, comités y asociaciones que se crean para su apoyo y protección. Una de estas iniciativas, trascendental por lo que supuso en ese objetivo de salvaguardar la infancia, fue la Unión internacional de socorro a los niños, fundada en 1920. Dos años más tarde, esta asociación redacta la «Declaración de los derechos del Niño», o «Declaración de Ginebra», que hace suya en 1924 la V Asamblea de la Sociedad de Naciones, y que inspira otras manifestaciones como las contenidas en la «Carta sobre los Derechos de la Infancia», redactada en 1929 por el grupo madrileño de la Liga

\footnotetext{
${ }^{1299}$ El Clamor, 28/07/1915.

${ }^{1300}$ Ver: Colonia Educativa de Castellón de la Plana. Memoria presentada al Primer Congreso Nacional de Educación Católica y Exposición Pedagógica. Celebrado en Madrid en 1924. Imprenta de Juan Bta Más, Castellón.

${ }^{1301}$ El Clamor , 12/07/1918.
} 
Internacional de Educación Nueva. Promover la atención a la infancia en sus necesidades físicas, espirituales y morales era el objetivo perseguido por todas esas iniciativas. Salvar la infancia del niño es la llamada que hacen las declaraciones e investigaciones pedagógicas. El niño necesita vivir su niñez. Y la Primera Guerra Mundial vino a demostrar al mundo que la infancia sufrió las decisiones y vivió las preocupaciones de los adultos.

En la primavera de 1931 llega la República a España, ya había sonado la hora del niño. Por eso, en su artículo 43 la Constitución republicana recoge la obligación del Estado de proteger la infancia haciendo suya la «Declaración de Ginebra» o «Tabla de los Derechos del Niño» que, entre otros derechos contempla el de su normal desarrollo, tanto en lo material como espiritual, y el de ser el primero en recibir socorros en épocas de calamidad. $^{1302}$

En la guerra del 36 aumentaron casi todas las patologías, especialmente las derivadas de una alimentación deficiente y de los trastornos nutritivos y las enfermedades del aparato respiratorio que afectaron de manera particular a los niños. Estas patologías afectaron más a los niños de las zonas urbanas que a los de las rurales, ya que las ciudades acogen enormes contingentes de evacuados y de población transeúnte que huyen de las zonas de conflicto, provocando hacinamiento, insalubridad, escasez de alimentos, etc., que repercuten en los índices de mortalidad; ésto, unido a que las ciudades están más expuestas a acciones bélicas indiscriminadas que provocan numerosas muertes violentas, las convierten en un lugar poco aconsejable para los niños. La evacuación infantil hacia zonas más saludables y seguras, se convierte en una necesidad urgente que desde muy pronto quieren atender el Gobierno de la República y numerosas organizaciones culturales, políticas y sindicales.

En España las colonias se conocían desde que en 1882 echaran a andar de manos del Museo Pedagógico Nacional; pero ahora pierden su tradicional carácter temporal para convertirse en permanentes, y si antes pretendían casi exclusivamente mejorar la salud de los niños, ahora, sin perder esa finalidad, buscan un objetivo más ambicioso: configurar el germen de una nueva sociedad. Esta finalidad requiere convertir la colonia en un espacio escolar en el que la educación y los métodos pedagógicos sean tantos o

\footnotetext{
${ }^{1302}$ FERNÁNDEZ SORIA, Juan Manuel, en ESCRIVÁ MOSCARDÓ, Cristina; MAESTRE MARÍN, Rafael. (2011). De las negras bombas a las doradas naranjas. Colonias Escolares 1936-1939. Eixam Edicions, Valencia. p. 7.
} 
más importantes que el cuidado físico y el restablecimiento de la salud de los pequeños colonos. $^{1303}$

Muchas fueron las colonias que empiezan a funcionar; unas lo hacen auspiciadas por el gobierno de la República, otras por organizaciones políticas o sindicales; las hubo también apadrinadas por particulares y por organizaciones filantrópicas y comités extranjeros de muy variado signo y filiación, mostrando con su ayuda la corriente de solidaridad y de simpatía que generó la causa de la República.

A todas las colonias les unió un mismo afán: ofrecer protección y cuidado a los niños sin descuidar su formación, lo que también quiere decir que no tenían un objetivo esencialmente pedagógico ni prioritariamente sanitario. La finalidad de las colonias más que instruir fue educar, sin que eso implicara descuido de los objetivos intelectuales. Una de las finalidades de las colonias escolares era convertirlas en el origen de una nueva sociedad y en el vivero de una nueva persona, el ciudadano activo y consciente de la República. ${ }^{1304}$

En Benicasim se estableció La Colonia «Hogar de Huérfanos», el 12 de agosto de 1937, acogiendo a 57 niños y niñas, la mayoría de procedencia asturiana, hijos de combatientes fallecidos en el frente. ${ }^{1305}$

\footnotetext{
${ }^{1303}$ Ibídem, p. 8.

${ }^{1304}$ Ibídem, p. 9.

${ }^{1305}$ Ibídem, p. 183.
} 


\section{CONCLUSIONES}




\section{PRIMERA PARTE. SOCIEDAD URBANA. MODERNIDAD Y POLÍTICAS DE HIGIENE EN CASTELLÓN}

Después de haber partido de unos supuestos hipotéticos, que hemos planteado en la introducción y posteriormente hemos desarrollado en distintos capítulos, a partir de la consulta de fuentes y bibliografía, ahora vamos a desarrollar las conclusiones a que hemos llegado sobre el cumplimiento o no de las hipótesis planteadas.

En la primera parte del proyecto de tesis estudiamos el desarrollo urbano e higiene en Castellón durante el último tercio del siglo XIX y principio del XX.

En el capítulo I hemos considerado importante hacer una introducción histórica al periodo y en el capítulo II estudiamos la higiene urbana en la ciudad de Castellón.

Hemos podido observar en esta investigación que el problema higiénico y sanitario que más preocupaba a políticos y a ciudadanos era la eliminación de las aguas residuales y las basuras. Castellón padeció tres epidemias de cólera importantes, la primera de 1834 , la segunda de 1855 y la tercera de 1885 , cuyo origen en buena medida era la contaminación que las aguas del subsuelo recibían de los pozos ciegos. Para paliar este problema y otras prácticas poco higiénicas como echar aguas sucias a la calle o elaborar estiércol en los patios de las casas, el Ayuntamiento dicta algunas disposiciones o bandos, como el de 1871 o el Reglamento de Higiene Municipal de 1908, para prohibir e inspeccionar su cumplimiento. También se exigía la construcción de depósitos de letrinas en las casas, y como llevar a cabo la evacuación de estos depósitos, de los pozos negros y de la acumulación del estiércol de las cuadras.

La instalación de una red de alcantarillado público para conectar los desagües de las viviendas se inicia en la primera década del siglo XX, siendo su ejecución muy lenta. Consultados los expedientes de obras en el Archivo Municipal de Castellón, de las décadas 1920 y 1930, en diferentes zonas de la ciudad, sigue figurando entre la documentación para la concesión de licencias de obras de viviendas el plano de «obras del subsuelo», donde aparece aún representado para eliminar las aguas residuales el depósito de letrinas y el pozo ciego, sistema que se venía exigiendo en ordenanzas de décadas anteriores. Lo que hace suponer que aún no se había completado la red de alcantarillado con su sistema de depuración y vertido, o que el Ayuntamiento seguía permitiendo el antiguo sistema de evacuación. 
A mediados del siglo XIX, el abastecimiento de agua a la ciudad aún era por antiguos pozos existentes en el casco antiguo y barrios periféricos, y de las aguas procedentes del río Mijares, canalizada por la acequia Mayor. A partir del último tercio del siglo XIX empezaron a instalarse fuentes públicas con control sanitario, completándose en toda la ciudad en la primera década del siglo XX. La distribución de agua potable mediante canalización para dar servicio a las viviendas no se inicia hasta la última década del siglo XIX, continuándose las obras en las décadas siguientes. Por los expedientes de licencias de obras consultados, hasta mediados de la segunda década del siglo XX no empiezan a aparecer, en distintos puntos la ciudad, solicitudes de obras para la instalación de electro-bombas en las viviendas y en las industrias para elevar el agua.

También hemos estudiado el tipo de vivienda en Castellón. Entre los distintos tipos, conocemos por descripciones, que la vivienda de los agricultores era mayoritaria, tanto en el casco antiguo como en los arrabales. Solían ser casas unifamiliares de uno o varios pisos, con unas condiciones higiénicas muy deficientes, en donde las personas y el animal conviven en un espacio poco diferenciado. El proceso de evolución y mejora fue lento, prolongándose las malas condiciones de habitabilidad y ausencia de servicios higiénicos públicos hasta las primeras décadas del siglo XX. Se mantiene la casa tradicional, con el paso de carro y el animal hasta el patio o corral. La vida familiar se realizaba en la cocina, comedor y sala de estar, que solía ser un espacio único situado en contacto con el suelo de la planta baja. Estas habitaciones estaban separadas por un patio descubierto de la cuadra y del pajar, donde también estaba el retrete y las balsas para la elaboración del estiércol. Este tipo de vivienda y la del hábitat rural temporal, generaban cifras mas elevadas de enfermedades, especialmente las transmitidas por animales, que estudiamos en los capítulos que tratan las enfermedades de la ciudad de Castellón.

La vivienda burguesa adquiere mayor auge en el último tercio del siglo XIX, localizándose en las calles y zonas más céntricas de la ciudad, exhibiendo desde el primer momento unas mejores condiciones higiénicas que con el tiempo fueron mejorando. Las primeras viviendas por pisos solían compartir una habitación situada en planta baja para los servicios higiénicos mínimos, el comú. También en los espacios comunes habían tinajas o depósitos para acopiar el agua de consumo que traía el aguadero. Con el tiempo, y con la llegada del agua potable a las viviendas, se empiezan a instalar los retretes en cada piso y en cada vivienda. Igualmente empiezan a aparecer 
los primeros cuartos higiénicos completos en las familias con mayor poder adquisitivo. En la casa suburbana de recreo, de esta misma clase social, empieza a mejorar su higiene y confort a partir de la primera década del siglo XX.

Las viviendas obreras en Castellón empiezan a surgir con el inicio del nuevo siglo, recogiendo la herencia de las nuevas infraestructuras y los primeros reglamentos de salubridad y normativas urbanísticas. Su localización se generaliza en los nuevos ensanches y en los antiguos arrabales. En su mayoría son unifamiliares en hilera de uno o dos pisos, de reducidas dimensiones y con aspecto todavía de tradición agrícola. Las ordenanzas de habitabilidad municipal les garantizan iluminación y ventilación en todas sus estancias, con servicio higiénico mínimo individual en cada vivienda.

A través de los expedientes de licencias de obras, consultados en el Archivo Histórico Municipal de Castellón, hemos podido conocer el estado de habitabilidad de las viviendas que se construyeron en el periodo de estudio, las normas higiénicas y el control que el Ayuntamiento ejercía sobre estas viviendas.

Por los datos consultados sabemos, que hasta los primeros años del siglo XX no aparece documentación alguna de la distribución interior de la casa ni de las condiciones higiénicas de su interior. Solo figura el plano de fachada con la composición de los huecos, el número de pisos y la altura de la casa y otro plano con la situación de la parcela y su alineación a la calle. Se desprende que la concesión de licencia se centraba exclusivamente en las normas urbanísticas relacionadas con la anchura de calle y altura de la edificación, para preservar la ventilación y asoleo de las vías públicas y las habitaciones de las viviendas que recaen a ellas. Únicamnete en las autorizaciones de licencias de obras es donde consta por escrito la necesidad de «cumplir con las condiciones de los artículos 3 al 13 del bando de policía urbana de $1871 »$, así como la medida higiénica que hace referencia a que «se coloquen canales en los aleros de todos los tejados, provistos de los necesarios tubos de bajada de agua».También consta en la misma autorización, que terminada la obra, será la Comisión de policía urbana la que verifique si la obra realizada en el interior de la vivienda cumple con las condiciones higiénicas.

Con la aprobación del Reglamento de Policía de 26 de junio de 1901, se observa que la documentación que se presenta para la concesión de licencia de obras de construcción o reforma de viviendas es mucho más exhaustiva, mejorando cualitativamente en lo que respecta a las condiciones de habitabilidad del interior de la 
casa. En donde, junto a una memoria técnica de materiales y obras a realizar, figura una colección de planos explicativos de las condiciones higiénicas a cumplir en la nueva vivienda.

Además de los planos ya comentados de situación del solar y de fachada, figuran planos de cada uno de los pisos de la casa, en donde aparece dibujada la distribución de las distintas estancias con su nombre y dimensiones.

Se observa que «todas las habitaciones reciben luz y aire del exterior» a través de la fachada a la calle o de los patios interiores. También se constata una diferenciación de funciones, en donde la «cocina tiene iluminación natural suficiente y ventilación independiente del resto de la casa». El retrete figura casi siempre junto a la cocina, ocupando un pequeño cuarto ventilado al exterior. Las habitaciones pueden aislarse con puertas para respetar la intimidad. Estas condiciones higiénicas aparecen reseñadas en el Reglamento de Policía de 1901.

También figura en todos los expedientes de autorización de licencia de obras un plano denominado «obras subterráneas», en donde está dibujado el depósito de letrinas, que funciona a modo de cámara séptica y el pozo sumidero. Además hay una red de tuberías que recoge el agua de lluvia procedente de los patios interiores y de los tejados que recaen a ellos, que vierten al pozo ciego.

Con la Instrucción General de Sanidad de 1904 se plantea una importante descentralización del control higiénico y sanitario, y una restructuración de las antiguas juntas municipales y provinciales. Como consecuencia de ello, el Ayuntamiento, en 1908 aprueba el nuevo Reglamento de Higiene Municipal de Castellón de la Plana, introduciendo algunas nuevas condiciones sanitarias para la construcción o reforma de viviendas y establecimientos públicos y privados, como que los «patios interiores deben tener una superficie suficiente para que la luz del sol bañe su suelo en todas las estaciones» Es importante destacar el Artículo 7.3 para la concesión de licencia de construcción o reforma de viviendas y edificios públicos y privados, para lo cual se requiere la «autorización de la Junta de Sanidad, previo informe del proyecto de obras a realizar».Terminada la construcción se comprobará el «cumplimiento de las condiciones higiénicas por el Inspector de Sanidad y la Junta de Sanidad acordará la autorización de habitarla si cumple las condiciones del proyecto, como dispone el Art 115 de la Instrucción General de Sanidad.» 
Hemos comprobado que independientemente de la zona de la ciudad, la obligación de cumplir las normas de habitabilidad las nuevas viviendas era la misma.Ya que en los expedientes consultados la documentación y los planos son similares, reflejando en todos los casos las mismas condiciones higiénicas.

También se observa en los proyecto de construcción de viviendas de la segunda y tercera década del siglo XX, que las condiciones de habitabilidad que figuran en los planos, son semejantes a las que figuraban a principio de siglo. Lo que nos hace pensar que las ordenanzas de higiene no han variado sustancialmente desde entonces.

De todo ello se desprende que a partir de la última década del siglo XIX, pero especialmente a partir de 1900, el Ayuntamiento de Castellón apuesta por mejorar las condiciones de salubridad de la ciudad, el ornato publico, con calles y plazas ajardinadas y las infraestructura urbanas, acelerando las obras de pavimentación, red de agua potable, alcantarillado o cubriendo los mercados, para lo cual pide un préstamo de un millón de pesetas en 1913. También le preocupa el estado higiénico de muchas de las viviendas de la ciudad, que la prensa y médicos denuncian. Para elevar el nivel de habitabilidad de las nuevas viviendas y edificios públicos y privados, aprueba una serie de nuevos reglamentos de policía y de higiene municipal que supone desde 1901 mejoras importantes en el nivel de habitabilidad de las viviendas. Hasta el extremo de que en las décadas siguiente los proyectos de construcción exhiben similares condiciones higiénicas.

Será la Comisión de policía urbana, presidida por el técnico Municipal, la que se encarga de hacer cumplir escrupulosamente las ordenanzas municipales en la concesión de licencias de obras, como se constata por los informes que figuran de expedientes de obras. Asimismo, la Inspección y la Junta de Sanidad tuvieron un papel muy destacado en este periodo sobre el control de la higiene de las calles, de las viviendas y de los edificios públicos y privados.

Con relación a la actividad constructiva se ha detectado, que mientras que en las dos ultimas décadas del siglo XIX hay mas solicitudes de reformas de fachadas que de construcción de nuevas viviendas, en las dos primeras décadas del sigo XX esta situación se invierte, aumentado tambien progresivamente el número general de licencias de obras.

También hemos podido observar en esta investigación, la preocupación de la prensa por las condiciones higiénicas-sanitarias de la ciudad. Ante la presencia de 
epidemias insta a los ayuntamientos que adopten medidas encaminadas a sostener la salud pública. Para ello denuncia todos los abusos y faltas contrarias a la higiene.

Ya desde principios del siglo XIX los periódicos critican las costumbres antiguas de lanzar aguas sucias de fregar a la calle y basura por las puertas y ventanas, o también la costumbre de usar la calle para hacer la matanza del cerdo o para realizar los trabajos de los artesanos.

La prensa publica una crónica sobre la falta de higiene pública, dirigida al alcalde de Castellón. En ella denuncia los focos de inmundicias de los alrededores de la ciudad, la suciedad de las calles, los estercoleros, las aguas para el consumo y la falta de condiciones higiénicas de los mercados.

Asimismo recoge las quejas del público por las múltiples infracciones al bando de buen gobierno que se registraban en la capital. Se llama la atención de la alcaldía sobre los montones de basura que se extraían en pleno día de las casas de las calles más céntricas de la capital y sobre el escandaloso abuso de la mendicidad.

Una de las primeras medidas higiénicas que se realizan en la ciudad de Castellón es la construcción de aceras en las calles principales a partir de mediados del siglo XIX, siendo el pavimentado de las calzadas algo posterior. Hasta la segunda década del siglo XX no se completa en toda la población.

Otro organismo que estuvo muy volcado en la higiene urbana de Castellón fue la Junta Local de Sanidad. Después de la epidemia de cólera acordó redactar una memoria relativa a las mejoras que debían adoptarse en la salubridad pública para que el Ayuntamiento las tuviera presentes al confeccionar los nuevos presupuestos. Fue designado como ponente el doctor José Clará.

Existían en Castellón algunos ganados vacunos que durante el día pacían por el término municipal y por la noche los encerraban en el centro y arrabales de la población. Algunas de esas agrupaciones padecían la viruela, con lo que la Junta de Sanidad provincial acordó obligar a cerrar los ganados fuera de la ciudad, para evitar el roce continuado que los habitantes de la población pudieran tener con estos focos de infección.

El Ayuntamiento de Castellón tomó otras medidas higiénicas destinadas a observar la higiene del matadero y el transporte de reses desde el mismo a los puntos de venta. Acordó blanquear el matadero público y que el traslado de reses muertas, desde dicho establecimiento hasta las casas particulares o puntos de venta, se hiciera en 
carruajes construidos exprofeso completamente cerrados por telas metálicas según aconsejaban las reglas de ornato y limpieza que debían observarse en toda población y muy particularmente en una capital de provincia.

En Castellón, el público se quejaba del peso y calidad de muchos géneros alimenticios que se vendían en tiendas y puestos de venta, así como de los vinos y aguardientes, por las adulteraciones de que eran objeto. La prensa reiteradamente llamaba la atención de las autoridades competentes para que tomaran las medidas oportunas.

También los médicos contribuyeron a que Castellón mejorara sus aguas, así en las primeras décadas del siglo XX, el Inspector provincial de Sanidad, José Clará, se preocupó por estudiar las condiciones de las aguas que servían para abastecer los diferentes pueblos de la provincia, con objeto de que la autoridad gubernativa obligara a los municipios a realizar las mejoras indispensables para aumentar los caudales y que aquellas reunieran las condiciones de potabilidad.

Los gobernadores de la provincia de Castellón mandaban circulares a los ayuntamientos municipales para que cuidaran la higiene. Recomendaban vigilar constantemente la calidad de los alimentos que se vendían al público prohibiendo la venta y el tráfico de los que estuvieran alterados, por causa físicas o por la mala fe de los vendedores. Asimismo recomendaban el cuidado y reparación y limpieza de los conductos de aguas sucias, letrinas, sumideros, alcantarillas y arroyos; del aseo de las fuentes, calles, plazas y mercados; de la desaparición de los depósitos de materias animales y vegetales en putrefacción existentes dentro o en las cercanías de la población, prohibiendo de la manera más absoluta el establecimiento de estercoleros que estuvieran situados a menos de 40 metros de las viviendas. Igualmente debía procurarse la extinción de los efluvios pantanosos y vigilar escrupulosamente los cementerios, cuidando que las fosas tuvieran la profundidad conveniente que aconsejaban la ciencia y las leyes.

Para cumplir con todos estas obligaciones, los alcaldes contaban con el auxilio de las Juntas Municipales de Sanidad, de los Médicos titulares, Inspectores de carne y los Veterinarios.

Cuando aparece el periódico El Heraldo de Castellón en 1895, en su exposición de principios se hace eco de la preocupación por las medidas de higiene que compartía 
la ciudadanía, los políticos y la prensa en ese momento. Según dice su misión sería apoyar todas las mejoras por la que suspiraba el ciudadano de Castellón.

\section{SEGUNDA PARTE: MEDICINA, ENFERMEDAD Y MUERTE EN CASTELLÓN}

En la segunda parte abordamos el estudio del estado de la medicina en el siglo XIX y principios del XX, (capítulos III), y la incidencia de las enfermedades infectocontagiosas que con mayor frecuencia afectaron a Castellón, (capítulo IV), desarrollando en los capítulos V y VI, por su gran incidencia en la población, el cólera de 1885 y la epidemia de gripe de 1918.

A lo largo de nuestra investigación hemos podido comprobar que los médicos de Castellón tuvieron mucha influencia en la vertebración de la sociedad, en la conformación de una élite social a la cabeza de la ciencia necesaria para la ciudad, y un peso social y político indudable.

Un número importante de los profesionales de la medicina desarrollaron sus conocimientos científicos con sus conferencias en los centros de sociabilidad de Castellón y en sus escritos en la prensa, contribuyendo con ello a elevar la cultura científica de los castellonenses. Ejemplos los tenemos con Vicente Gea Mariño, José Gil Valero, Juan Marco Salvador, Francisco Badenes Champel y Ramón Penichet Delgado. Asimismo muchos licenciados en medicina fueron profesores del Instituto de Enseñanza Media de Castellón, citamos como ejemplo a Domingo Herrero, Pedro Aliaga, profesor de matemáticas y director del Instituto en 1896; Antonio Forns y Sanz de Andino.

Estos médicos también influyen en los planteamientos higienistas de la ciudad al plantear proyectos que desarrollaron nuevos ensanches y zonas verdes que cumplían una doble finalidad higiénica y educativa. Podemos citar a Domingo Herrero que fue alcalde de la ciudad en 1876. Propició la creación de lo que ahora es el Parque Ribalta y que en su día se planteó como jardín botánico siguiendo las tendencias culturales que proliferaban en toda Europa.

Asimismo estos intelectuales intervinieron profesionalmente en los momentos más graves para nuestra ciudad como fue en la epidemia de cólera en 1885 y en la 
epidemia de gripe de 1918. Podemos citar entre ellos a Félix Torres Roig, en la primera, y sobre todo al doctor, José Clará Piñol, que desarrolló una gran actividad en la segunda epidemia citada y, además, fue el que organizó junto al Inspector de Primera Enseñanza, José Senent, la Primera Colonia Escolar de Castellón.

Al principio del siglo XIX los médicos ejercían su actividad sin estar colegiados, pues el Colegio de Médicos, otro ejemplo de aplicar las leyes y controlar la profesión médica, fue creado en 1898. En el ritmo de colegiación de los médicos de Castellón lo podemos distinguir en varias etapas, la primera, que abarca desde la creación del Colegio en 1898 hasta 1902 coincidiendo con el final de la obligatoriedad de la colegiación, en todo este periodo se inscriben 31 médicos; la segunda, hasta el año 1920, cuando se impone definitivamente la obligatoriedad, aparecen 37 médicos que ejercen en Castellón; las tercera que llega hasta junio de 1938 cuando Castellón es ocupada por el general Franco, en la que se inscriben 50 médicos más, pero de la cual no sabemos exactamente las bajas, los traslados o las defunciones; y por último hasta 1944, que es la fecha hasta donde llegan las fuentes consultadas, en la cual aparecen 22 médicos más, con la misma salvedad de la etapa anterior. En total 140 médicos inscritos en el Colegio, pero no podemos asegurar que cubran a todos, por varias razones, una es la que ya hemos comentado sobre la colegiación. De los 140 médicos inscritos en el Colegio, 51 se licenciaron en la Facultad de Medicina de Valencia, le siguen Madrid con 10; Zaragoza y Barcelona con 6 cada una; Granada con 3, Salamanca y Santiago con 2 y Cádiz, Valladolid y la Habana con 1. Es decir, el factor geográfico era importante a la hora de escoger el lugar de estudio.

Una cuestión importante es saber la relación de médicos con el número de habitantes para ver hasta qué punto la sociedad estaba asistida. Tenemos dos datos importantes con los cuales podemos hacer alguna comparación: la primera es de 18981902, y la segunda, de 1920. En 1900, Castellón tenía 29.904 habitantes para los cuales ejercían 31 médicos; en 1900 Alicante tenía 62.546 habitantes para los cuales tenía 38 médicos. Las cifras de Castellón representan 964 habitantes/médico. En 1920, Castellón tenía 34.457 habitantes para los cuales había 37 médicos, resultando 931 habitantes/médico, en Alicante no hay cifras para 1920, pero en 1925 tenía 85 médicos. Todas estas cifras vienen a demostrar que el nivel asistencial por el número de profesionales era bueno y además la tendencia iba mejorando, había que ver si la 
educación sanitaria o las posibilidades económicas de los enfermos les permitían acceder a ello.

En el capítulo IV abordamos la incidencia de las enfermedades que con mayor frecuencia afectaron a Castellón y realizamos un estudio comparativo de las enfermedades infecciosas en el País Valenciano y España.

Una de las enfermedades endémicas que afectó a la población de Castellón en todas las épocas pasadas fue el paludismo o malaria. El foco más grande de emanaciones que tenía Castellón era el terreno conocido con el nombre de El Cuadro, que eran unos marjales muy extensos situados detrás del pinar del Grao. En todos los tiempos encontramos disposiciones encaminadas a remediar las fiebres palúdicas.

En Castellón había preocupación por saber el origen de las fiebres palúdicas. Así la prensa de Castellón publica un artículo sobre el descubrimiento de los microbios que producen las tercianas. También la Revista Médico-Farmacéutica de Castellón publica en diferentes números, la tesis doctoral de Manuel Lassala Emo titulada: Etiología del paludismo, en donde muestra lo que se sabía de dicha enfermedad en los años ochenta del siglo XIX.

En esos años no se sabía nada de la etiología del paludismo; existían multitud de investigaciones sobre las condiciones genésicas y cualidades peculiares de la malaria, pero cuando se trataba de determinar la causa intima o el verdadero agente físico, se entraba en la esfera de la conjetura y muchos autores preferían confesar que lo ignoraban, esperando que trabajos ulteriores dieran más luz sobre este asunto.

Los vecinos del Grao de Castellón eran los más castigados por la enfermedad, que según decían, era debido a las plantaciones de cáñamo en los predios situados junto a las acequias de los marjales.

Las playas no eran muy frecuentadas debido al temor de contagiarse de las «fiebres», y las familias buscaban otras zonas alejadas del litoral donde pasar el verano.

La opinión pública de Castellón reclamaba la solución a los problemas de salud que ocasionaban los cuadros y las aguas sin corriente de la marjalería. Si Castellón había de entrar en el camino del progreso, una de las mejoras era la desecación de los cuadros.

En la capital, los barrios más afectados fueron los del norte de la población, San Félix y San Roque, porque allí vivía una población eminentemente agrícola. La trilogía secano, huerta, marjal preside la historia económica de Castellón, aunque la huerta ha 
sido siempre el eje vital. A finales del siglo XVIII casi las tres quintas partes de los activos se dedican a la agricultura. Los jornaleros residen preferentemente en los arrabales, edificados como núcleos rurales pobres.

Hubo un proyecto de la sociedad La Fertilizadora para desecar y sanear los terrenos conocido como «El Cuadro y marjales adyacentes», que no llegó a ningún fin.

Otra enfermedad que causaba muchas víctimas en Castellón, en los años ochenta del siglo XIX, era la difteria. Como consecuencia de los muchos casos que se presentaban, la Junta de Sanidad Local acordó que además de las medidas de desinfección y aislamiento que se tomaran en cada caso particular, se pasaran con frecuencia visitas médicas a las escuelas de párvulos, para que no se admitieran en ellas a los niños que presentaran síntomas sospechosos de tan terrible enfermedad.

También, en los mismos años, se presentaban muchos casos de viruela en la ciudad. La Junta Local de Sanidad exigía a todos los alumnos el certificado facultativo de haber sido vacunados si tenían menos de siete años o revacunados en el caso de haber cumplido dicha edad. También la Corporación Municipal ordenaba a todos los médicos titulares que procedieran a la vacunación gratuita de los niños pobres de la ciudad, autorizándoles para adquirir los tubos o cristales de la linfa necesarios.

En el siglo XX, la viruela siguió haciendo estragos en la capital. Según el doctor Clará la incidencia de la enfermedad era debida al poco interés que se observaba en los servicios de vacunación y sobre todo de revacunación.

Los institutos de vacunación, creados para producir y distribuir vacuna, comienzan a proliferar por toda Europa a mediados del siglo XIX, en ocasiones serán financiados por la iniciativa privada y, en otras, por la administración pública o sanitaria y por instituciones médicas.

En la ciudad de Castellón existía un Instituto privado de vacunación que estaba situado en la calle Campoamor y después en la calle San Juan número 19 (hoy calle Colón) donde se propagaba la verdadera linfa vacuna contra la viruela, en dicha corporación se celebraban sesiones semanales. Hasta 1880 el Instituto Médico Valenciano fue el principal suministrador de vacuna al Instituto castellonense. En el mismo establecimiento se vendían los tubos de vacuna extraídos directamente de la ternera. 
Existía también el Instituto de Vacunación Antirrábico que fue instalado por la Diputación en el Hospital Provincial. En dicho Instituto fueron tratados gran número de personas mordidas por perros rabiosos.

El Gobierno tenía el proyecto de construir leproserías en número suficiente para recluir a todos los enfermos. En la segunda decena del siglo XX, el Hospital Provincial podía albergar mayor número de enfermos gracias a los dos pabellones que se construyeron para este fin, pudiendo recluirse todos los que en los pueblos no tenían las condiciones de aislamiento.

En el estudio comparativo que hemos realizado, nos centramos sobre todo en comentar las enfermedades que tuvieron más incidencia en los primeros años del siglo $\mathrm{XX}$, puesto que hasta entonces los censos que proporciona el Instituto Nacional de Estadística no detallan las diversas enfermedades comunes. No obstante, hemos creído conveniente hacer un análisis introductorio de los años 1869 y 1870, más el sexenio de 1886-92.

Los años $1869-1870^{1306}$ los debemos enmarcar en un periodo de crisis económica con malas cosechas, insuficiencia alimentaria iniciada en 1866 y que repercute en los años sucesivos que hemos estudiado. Una prueba de ello es que en 1869 tanto las enfermedades comunes como las epidémicas son más numerosas que en 1870, porque en este año y a partir de 1871 la crisis económica va disminuyendo.

Hay que notar una mayor mortalidad en el sexo masculino, frente al femenino tanto a nivel del País Valenciano como de España, mientras que por muerte senil debido a que hay más mujeres que hombres vivos mueren más personas del sexo femenino.

También hacemos notar que por muerte violenta es la sección de hombres los que presentan las cifras más elevadas, suponemos que al estar el hombre más integrado en el espacio público y ser cabeza de familia tiene responsabilidades más directas, lo cual puede llevarle al suicidio y a las reyertas.

Hemos podido comprobar que la mortalidad entre los años 1886-92 va disminuyendo siguiendo el modelo europeo típico de sociedades que inician la revolución industrial. No obstante, hay que destacar el año 1890-91 que, junto con el de 1818 , constituye el momento de mayor mortalidad por gripe. ${ }^{1307}$

\footnotetext{
${ }^{1306}$ Ver tablas 4, 5, 6,7 del capítulo IV.

${ }^{1307}$ Ver tablas 8 y 9 del capítulo IV.
} 
A nivel del País Valenciano la tendencia a la disminución progresiva de la mortalidad es mayor que a nivel nacional lo cual nos permite asegurar que el País Valenciano está situado en una de las zonas más desarrolladas de España, junto con Cataluña.

En cuanto al brote gripal de 1890-91 hemos advertido que el mayor aumento de la mortalidad en el País Valenciano ${ }^{1308}$ se debe a un mayor contacto comercial con otros países europeos (no hay que olvidar que los puertos de Valencia y Alicante representaban un peso económico mayor que otros puertos españoles) ya que nos relacionaban con puertos africanos y europeos.

Centrándonos en el año 1900 y la mortalidad por causa de enfermedad durante las estaciones del año en las capitales del País Valenciano ${ }^{1309}$ podemos comprobar que las enfermedades que más incidieron fueron las del aparato respiratorio y del aparato digestivo; les sigue las del sistema nervioso y sentidos; y destacar también la cuarta causa de mortalidad, la del aparato circulatorio.

Analizando los datos de mortalidad por enfermedad en el año 1900 en España, ${ }^{1310}$ podemos observar también la cifra correspondiente a enfermedades infantiles, dado que sólo afecta a un sector de la población, llegando en 1900 a 10.245 defunciones cuando la enfermedad del aparato respiratorio (con mayor número de muertes) llega a 100.847. Creemos que a pesar de los adelantos de la ciencia, un buen número de enfermedades están condicionadas por los cambios estacionales. Destacamos el mayor número de muertes en invierno, causadas por enfermedades del aparato respiratorio; sin embargo, es en la estación veraniega cuando las enfermedades del aparato digestivo aumentan de forma considerable debido a la falta de tratamientos de aguas y la no conservación de alimentos. ${ }^{1311}$

Continuamos en el País Valenciano en el año 1900 y observamos que las causas de mortalidad por enfermedad que más inciden en la población de sus provincias ${ }^{1312}$ y en la de sus capitales ${ }^{1313}$ son la gripe y el tifus, y el sarampión en la población infantil.

\footnotetext{
${ }^{1308}$ Ver tabla 9 del capítulo IV.

${ }^{1309}$ Ver tabla 10 y gráfica 3 del capítulo IV.

${ }^{1310}$ Ver tabla 11 y gráfica 4 del capítulo IV.

${ }^{1311}$ Ver gráfica 4 del capítulo IV.

${ }^{1312}$ Ver gráfica 5 del capítulo IV.

${ }^{1313}$ Ver tabla 12 del capítulo IV.
} 
Las estadísticas de los años 1901 y 1902 siguen la tónica de la de 1900 destacando el aumento de muertes por viruela, enfermedad que presentaba brotes discontinuos $^{1314}$

El estudio de los datos que nos ofrece el Instituto Nacional de Estadística sobre enfermedades causantes de mortalidad, nos ha sido muy útil para concretizar en otras enfermedades que en las estadísticas generales no aparecían, por ejemplo la tuberculosis pulmonar que nos da para Castellón capital ${ }^{1315}$ sólo en el año 1903, para varones 28 muertes y para mujeres 14; la provincia presenta 157 defunciones en varones y 151 en mujeres. $^{1316}$

En las ciudades de Valencia y Alicante las defunciones por tuberculosis pulmonar fueron, en la primera 258 varones y 197 mujeres y en la segunda 54 varones y 31 mujeres. Las provincias de Valencia y Alicante sumaron 548 varones y 508 mujeres y 335 varones y 273 mujeres, respectivamente. ${ }^{1317}$

En 1904 se aprecia el notable descenso de defunciones por sarampión en la ciudad de Castellón de la Plana ${ }^{1318}$ que había presentado unos elevados índices de mortalidad por esta enfermedad el año anterior. Éste descenso también es manifiesto en el resto de la provincia. ${ }^{1319}$ El descenso observado en Castellón es comparable con los datos que arrojan Valencia y su capital. ${ }^{1320}$ Mientras que es muy llamativa la escasa incidencia de las defunciones en Alicante y su provincia por ésta enfermedad. ${ }^{1321}$

En las estadísticas de 1901 a 1905, destacan las enfermedades puerperales de la mujer, basta citar para ello la cifra de 33 muertes en Castellón en 1905, en Valencia 169, y en Alicante 69; datos todos provinciales muy significativos, ya que en la actualidad lo que llama la atención es la no mortalidad por complicaciones postparto. $^{1322}$

Tanto a nivel nacional como en Castellón hay que constatar que una de las enfermedades con más consecuencias sociales importantes es la tuberculosis pulmonar, que afectaba en especial a la población de 20 a 40 años, sector demográfico en pleno

\footnotetext{
${ }^{1314}$ Ver gráficas 6 y 7 del capítulo IV.

${ }^{1315}$ Ver tabla 13 y gráfica 8 del capítulo IV.

${ }^{1316}$ Ver tabla 14 y gráfica 9 del capítulo IV.

${ }^{1317}$ Ver tablas 15. 16, 17, 18 y gráficas 10,11, 12 y 13 del capítulo IV.

${ }^{1318}$ Ver tabla 19 y gráfica 14 del capítulo IV.

${ }^{1319}$ Ver tabla 20 y gráfica 15 del capítulo IV.

${ }^{1320}$ Ver tablas 21 y 22 y gráfica 16 y 17 del capítulo IV.

${ }^{1321}$ Ver tablas 23 y 24 y gráficas 18 y 19 del capítulo IV.

${ }^{1322}$ Ver tablas 26,28 y 30 y gráficas $21,23,25$, del capítulo IV.
} 
rendimiento productivo, más si comprobamos que afectaba en mayor medida al sexo masculino quien era el que monopolizaba todos los sectores del trabajo, mientras las mujeres permanecían en el hogar, aunque las de las clases populares también trabajaban en la industria y el sector agrario.

Después del estudio de las enfermedades que afectaron más a la población española y al País Valenciano durante los años de 1901 a 1915, nos hemos centrado en un estudio comparativo entre las defunciones por fiebre tifoidea, gripe y viruela, las tres enfermedades que después la tuberculosis pulmonar, tienen más incidencia en la mortalidad producida en las tres capitales del País Valenciano ${ }^{1323}$ y en España en el periodo de 1901 a 1915.

Hemos observado que la fiebre tifoidea no presenta una disminución en las tres capitales del País Valenciano. ${ }^{1324}$ Se puede deducir que era debido a una aglomeración urbana, puesto que el proceso urbanizador en España va aumentando en el primer tercio del siglo XX. En cuanto a la gripe, hemos constatado una continuidad en el proceso de la enfermedad. ${ }^{1325}$

Sin embargo, en la viruela sí que hemos notado un descenso considerable, ya que basta citar que a nivel del País Valenciano en el año 1901 se produjeron 372 muertes por viruela, se llega a 7 en 1910, para rebrotar en 1914 con 59 muertes y en 1915 hay 191 defunciones (creemos que esta última cifra está condicionada por primera guerra mundial). ${ }^{1326}$

La misma pauta encontramos en las cifras nacionales que si en 1901 nos presentan 1.985 muertes, en 1910 se han reducido a 456 defunciones, llegando en 1914 y 1915 a tener 742 muertes en ambos años. ${ }^{1327}$

Por último, para completar nuestros datos, presentamos un resumen estadístico de las defunciones por causa de enfermedad en la ciudad de Castellón, extraído de los tres tomos del Boletín de Estadística Municipal de Castellón, desde 1914 a 1918. ${ }^{1328}$ Con esos datos, hemos podido observar una notable incidencia de la tuberculosis, que

\footnotetext{
${ }^{1323}$ Ver gráfica 26 del capítulo IV.

${ }^{1324}$ Ver tabla 31 y gráfica 27 del capítulo IV.

${ }^{1325}$ Ver tabla 32 y gráfica 28 del capítulo IV.

${ }^{1326}$ Ver tabla 33 y gráfica 29 del capítulo IV.

${ }^{1327}$ Ver tabla 33 del capítulo IV.

${ }^{1328}$ Ver tabla 34 y gráfica 30 del capítulo IV.
} 
determinó la ampliación del Hospital, inaugurado en 1907, con pabellones independientes para alojar la demanda de enfermos tuberculosos.

La segunda enfermedad que más afectó a la ciudad de Castellón fue la gripe, que afectó por igual a hombre y mujeres.

En cuanto a las enfermedades infantiles, la que más defunciones produjo fue el sarampión, disminuyendo con respecto a años anteriores, la escarlatina, la tosferina, la difteria y la viruela. Otras enfermedades que afectaron con mayor frecuencia a los niños y niñas menores de dos años fueron las enfermedades intestinales.

Consultados los libros de Registro general de Cementerio municipal de Castellón se desprenden los siguientes datos:

Hasta 1912 no figura la edad de la defunción, y a partir de 1920 figura en estadillo independiente de los libros de registro las causas de fallecimiento.

De los datos extraídos de varios años, comprendidos entre 1912 y 1930, los fallecimientos de niños y niñas es significativo entre 0 y 12 meses, llegando a doblándose el porcentaje entre 1 y 5 años. Entre 0 y 5 años, de 1912-1915 el porcentaje está en el 28,25, descendiendo sensiblemente en las décadas siguientes, pasando a 19,50 en 1920 y al 16,25 por ciento a partir de la tercera década. De esta edad hasta los 18-20 años desciende bruscamente el porcentaje de fallecimientos, volviendo a subir ligeramente de los 20 hasta los 40 años, lo que puede estar relacionado con la enfermedad de la tuberculosis, que afecta más a estas edades.

En el capítulo v estudiamos la epidemia del cólera en Castellón.

Ya desde 1882, la prensa de Castellón alertaba sobre la existencia de cólera morbo en el mar Rojo, en Suez, y hacía hincapié que en Gibraltar los ingleses depositaban los heridos e infestados del cólera. Desde el primer momento se preocupó para que las autoridades provinciales y municipales tomaran las medidas necesarias para prevenir la epidemia.

Ante la proximidad del cólera la gestión de Castellón fue pronta y eficaz. En 1883, la Junta Local de Sanidad acordó limpiar el alcantarillado, los lavaderos públicos, visitar las tenerías y prohibir la entrada de carnes muertas sin previo reconocimiento pericial.

La Junta Provincial de Sanidad acordó llamar la atención del Ayuntamiento y Junta Local de Sanidad para que adoptara las medidas más convenientes con el fin de 
evitar el estancamiento de las aguas superficiales para la salud y que los ganados existentes en la ciudad se establecieran fuera de la capital.

Al presentarse el cólera en 1884, en Tolón, en Castellón empezaron las Juntas Sanitarias de Distrito a practicar las visitas domiciliarias, encontrando en algunas casas tan malas condiciones higiénicas que se plantearon desalojar a sus habitantes. También se hablaba de establecer el hospital de coléricos en los almacenes de vino que había cerca de la estación, o en su defecto, aprovechar el edificio donde estaba el ingenio de azúcar en el paseo del mar.

La Junta Local de Sanidad, para prevenir la posible invasión colérica, tomó varios acuerdos, entre ellos, avisar a los facultativos de la capital para que dieran parte de los casos de cólera esporádico o epidémico que pudieran presentarse, nombrar cinco comisiones o juntas de distrito y publicar un bando recomendando la limpieza general de calles y casas de la población; hacer desaparecer las aguas estancadas y sucias y recomendar a los vecinos que hicieran dentro de sus casas las fumigaciones que para esto casos aconsejaba la ciencia.

El Ayuntamiento acordó autorizar a la Junta Local de Sanidad la construcción de un hospital provisional de coléricos. Posteriormente se convino que en lugar del hospital se construyeran barracones a medida que las necesidades lo exigieran.

En septiembre la Junta de Sanidad, ante la proximidad de la epidemia del cólera, acordó el acordonamiento de la ciudad y que se estableciera un lazareto en Lidón con personal, camas y los útiles necesarios. En octubre se levantó el cordón, que según decía la prensa no sirvió para otra cosa que para molestar a los vecinos.

Declarada oficialmente en 1885 la existencia de cólera morbo en la provincia de Valencia, el alcalde de Castellón y la Junta Local de Sanidad empezaron a tomar las medidas convenientes para librar a la ciudad del cólera; también las juntas de distrito y comisiones de barrio se preparaban para practicar las visitas domiciliarias.

El Ayuntamiento acordó por unanimidad organizar una brigada de desinfección, adquirir ácido muriático, construir el barracón para hospital de coléricos y establecer el lazareto de observación en el ermitorio de Lidón.

El lazareto de Lidón fue calificado de purgatorio por la prensa local. Pocos días sirvió dicho ermitorio de lazareto, pues el miedo que se apoderó de las personas recluidas, a consecuencia de dos invasiones acaecidas en la persona de la ermitaña y 
otra mujer procedente de la huerta de Castellón, hizo que se instalaran aquellos en un almacén contiguo a la estación del ferrocarril.

Los primeros casos de la enfermedad en la ciudad de Castellón aparecen en la segunda quincena de junio. Las estadísticas que daban la Gaceta de Madrid, el Boletín Oficial y el Registro Civil, reflejan mucha confusión, pues no coinciden en el número de invasiones y defunciones. De todas maneras no era suficiente el número de muertos que indicaba cada uno para declarar epidemia en una población de 30.000 habitantes.

Comparando los datos de la primera decena de julio con los referentes a los últimos quince días de junio, aumentaron los casos de cólera en Castellón, y afectaron a la clase humilde de la ciudad.

En la segunda decena de julio las defunciones aumentaron el doble. La epidemia en la decena siguiente, del 21 al 31 de julio, no aumentó gran cosa, pues el número de defunciones no era mucho mayor que el decenio anterior.

En la segunda decena del mes de agosto la epidemia decreció de una manera notable. Los auxilios de todas clases prestados a la clase proletaria y los socorros a los enfermos fueron la causa de que la enfermedad no se cebase en Castellón tanto como en otras poblaciones vecinas.

El 7 de septiembre se consideraba terminada la epidemia en Castellón.

La Gaceta de Madrid y el Boletín Oficial de la provincia de Castellón, desde el día 24 de Agosto omitían dar cuenta de las invasiones y defunciones, únicamente el Registro Civil acusaba algunas defunciones en los días 25, 27, 29 y 31.

En los trabajos estadísticos expuestos, hemos observado la inexactitud de los datos oficiales. Había diferencias entre las fuentes. Los datos de la alcaldía tampoco estaban de acuerdo con los del Estado.

Las consecuencias de la epidemia colérica es que hubo más invasiones en las mujeres que en los hombres.

También había más muertes de mujeres que de varones:

Sin embargo, había más curaciones en mujeres que en hombres:

Nuestra conclusión es que al ser la mujer la que hacía de cuidadora y de enfermera, estaba más expuesta al germen colérico, que el hombre.

Por otra parte, si nos fijamos por edades la franja más afectada era la comprendida entre 40 a 60 años; seguida de los 25 a 40 años, y después, menores de 15 años. 
Las personas de 25 a 40, y de 40 a 60 eran gente que trabajaba en su mayoría, en el campo, que no observaban una estricta higiene en el agua que bebían ni en los alimentos que tomaban.

Hemos elaborado unas tablas de la evolución de la epidemia en Castellón y sus comarcas sólo con los datos que figuran en el Boletín Oficial de la Provincia desde el 24 de junio de 1885 y observamos que la ciudad de Castellón tuvo en total 357 invasiones y 219 defunciones entre junio, julio y agosto. Villarreal fue la población donde más defunciones hubo (455), seguida de Vinaroz, Nules, Burriana y Alcora, todas por encima de 200 defunciones. ${ }^{1329}$

El 17 de septiembre, habiendo transcurrido más de veinte días sin que ocurriese novedad en Castellón, el Gobernador Eduardo Fernández de la Roda, declara libre de la epidemia la ciudad.

Hemos analizado también el trato y consideración que se les dio a los médicos, ya que en esta epidemia fueron juzgados por su actuación; la mayoría de las veces eran opiniones calumniosas, carentes de fundamento. Se tenía la creencia de que los médicos aplicaban remedios que producían la muerte, por este motivo no se les llamaba cuando aparecían los primeros síntomas.

Algunos médicos de Castellón fueron multados, por no dar parte de las invasiones de casos de cólera cuando eran reconocidos dichos enfermos en su visita particular. Sin embargo, muchos facultativos tenían fama de distinguirse por su trabajo en el cumplimiento de su deber y, en general, no se creía que la clase médica faltase a su obligación.

Por los servicios extraordinarios prestados en la epidemia, se recompensó a los médicos del Hospital Provincial con una cantidad equivalente a casi seis meses de paga, y también, con menos dinero, a los de la Casa de Misericordia.

También hemos estudiado los remedios populares de la época. Los que explotaban la epidemia eran muchos en todas partes, los inventores de remedios contra el cólera aumentaban de tal manera que era muy difícil recopilar el sin número de recetas, preservativos, específicos, secretos y medicamentos que se anunciaban.

En cuanto al concepto que se tenía del cólera morbo-asiático es que era un envenenamiento producido por un agente morboso atmosférico, que la física y la

\footnotetext{
${ }^{1329}$ Ver gráficas 1, 3, 5, 7 del capítulo v; y tablas 23, 24, 25 del Apéndice Documental No 6, y tabla 26, del Apéndice Documental No 7.
} 
química no habían llegado a descubrir como tampoco habían demostrado estas ciencias la causa de la gripe, el sarampión, etc.

En realidad, no se sabía a ciencia cierta la patología del cólera, se intentaba explicar de una manera racional sus síntomas.

Los médicos se planteaban las siguientes cuestiones:

¿Es el cólera una gastroenteritis específica? ¿Depende este trastorno gastrointestinal de la acción del bacilo sobre la túnica intestinal, o es del todo consecutiva a trastornos vaso-motores? ¿Pueden todos los síntomas explicarse, admitiendo estos trastornos neuro-vasculares?

Determinada la cual indican el valor que pueden tener en la terapéutica del cólera la enteroclisis ${ }^{1330}$ y la hipodermoclisis. ${ }^{1331}$

Estaba indudablemente demostrado que el agente engendrador del cólera era el bacilo-coma de Koch y que la vía por la cual este germen morboso penetraba en el organismo, era la del tubo gastrointestinal.

Se preguntan si es posible que el cuadro sintomatológico del cólera: diarrea abundante, opresión epigástrica, vómitos, sed intensa, cianosis, enfriamiento, éxtasis del círculo sanguíneo, podía depender de la simple acción del bacilo. Cuando en la autopsia de los coléricos, se abría el intestino, se hallaban gran número de alteraciones, que no tenían que ver con los trastornos que se encontraban en los enfermos. Según veían había una falta de concordancia ente los síntomas morbosos y los hechos necroscópicos.

Pensaban que el cólera no era una enfermedad local, sino general, cuyo foco de intoxicación estaba localizado en el tubo intestinal.

La explicación de todos los síntomas era la intoxicación de la sangre. Pero aquí surgía la pregunta ¿era el mismo bacilo, que absorbido y penetrando en la sangre, la altera en términos de producir un estímulo anormal sobre el sistema nervioso, en especial sobre el simpático en sus ramificaciones vasomotoras; o era un veneno segregado por el bacilo, o una ptomaina ${ }^{1332}$ que de él toma origen, o es una intoxicación por otros principios anormales que se mezclan con la sangre?

\footnotetext{
${ }^{1330}$ Enteroclisis: Inyección de un líquido en el intestino por vía rectal.

${ }^{1331}$ Hipodermoclisis: Introducción en el tejido subcutáneo de gran cantidad de líquido, especialmente de solución salina fisiológica. Es una manera de reemplazar los líquidos que se han perdido a través del vómito, sudor o diarrea.

${ }^{1332}$ Nombre con que se designa una serie de substancias originadas, principalmente en los cadáveres en putrefacción, por la degradación bacteriana de las materias albuminoideas.
} 
El preservativo del cólera era la vacuna de Ferrán que fue muy bien aceptada por los médicos de Castellón. Tanto es así que el Instituto de Vacunación castellonense que presidia el oftalmólogo Antonio Forns, nombró al médico de la Beneficencia municipal, Agustín Segarra y a José Clará, médico del Hospital Provincial, representantes de dicho Instituto para felicitar a Ferrán por sus trabajos, y estudiar el modo de propagar la vacuna del cólera en Castellón.

A tal efecto dichos facultativos fueron a Valencia el 18 de abril de 1885, y después de saludar a Ferrán y a Paulí, que les dispensaron una gran acogida, obtuvieron el cultivo para las inoculaciones, recibiendo de él las instrucciones oportunas para usar el preservativo y, además, fueron vacunados por el mismo Ferrán.

Más tarde el Gobierno prohibió la colerización Ferrán, fundándose en algunos artículos de la ley de Sanidad.

Posteriormente, al autorizar el Ministro de la Gobernación solo a Ferrán para practicar la inoculación en los pueblos de la provincia invadidos por la epidemia, vacunó en presencia de la Comisión Oficial que debía presenciarlo, a los vecinos que lo deseaban de Cervera y Peñiscola. Se alistaron más de 900 personas, de los cuales fueron inoculados 530. Durante su estancia en Cervera, vinieron comisiones de las Cuevas de Vinromá, de Salsadella y de Rosell, solicitando a Ferrán que inoculara a sus vecinos.

Un defensor acérrimo de Ferrán y su vacuna fue el médico de Albocacer, Joaquín Chillida Meliá que lo defiende a ultranza se declara ferranista y lamenta los problemas de los científicos en España.

Otra gran epidemia que sufrió Castellón fue la gripe de 1918 que abordamos en el capítulo VI. Como consecuencia de la Primera Guerra Mundial la situación económica de Castellón era muy delicada. Faltaban alimentos básicos como el pan, la harina y los huevos. La prensa llamaba la atención sobre el estado de los más necesitados e instaba a las autoridades a acudir, con todos los medios en auxilio de los pobres, ya que el Gobierno hacia oídos sordos a las apremiantes demandas que se le hacían. Se solicitaba que las autoridades pidieran a las personas ricas y pudientes de la ciudad dinero para socorrer a los pobres, por sentimiento de humanidad y hasta por egoísmo de los demás que se verían en peligro si la epidemia continuaba.

Ante esta situación de falta de alimentos básicos, el Alcalde, José Forcada, ruega a la Junta de Subsistencias, que prohibiera la salida de todos los artículos de comer beber y arder, es decir, que se llevaran las subsistencias a otros pueblos; que la 
vigilancia para impedir la salida de géneros se encargara no solo a los carabineros sino también a la guardia civil a fin de hacer imposible que por las carreteras y caminos se llevaran las subsistencias a otros pueblos desde donde por la vía férrea o marítima se trasladaran a otras provincias.

La Junta de Subsistencias tasaba todos los artículos para que no se vendieran más caros fuera de la capital al no estar vigilados. Esto ocurría por ejemplo con el carbón, que adquiría un precio más elevado fuera de Castellón. La ciudad quedaba desabastecida porque los comerciantes vendían sus productos fuera de la capital a mejor precio. Eso pasó con los huevos, que primero eran almacenados en cámaras frigoríficas y cuando se podía exportar a otras poblaciones que pagaban mejor, se desabastecía de dicho artículo a la ciudad.

Como pasaba el tiempo y el Ayuntamiento no disponía de recursos para hacer frente a la epidemia, el Alcalde dirigió una carta a los Diputados y Senadores por la provincia de Castellón, recabando su ayuda para conseguir se remitiera a la capital la mayor cantidad de trigo argentino. Asimismo agradeció la actuación del diputado por Castellón Emilio Santa Cruz, el cual se puso en contacto con los demás representantes y conferenció con el Ministro de Abastecimientos para lograr se diera satisfacción a los justos deseos de Castellón.

El alcalde, José Forcada ordena para evitar la propagación de la epidemia de gripe, que se inspeccionen todas las viviendas de los pobres para dotarlas de condiciones higiénicas. Como el plan de higienización era muy amplio y, había que invertir muchos millones de pesetas por parte del Ayuntamiento, se decide que el gasto se realice poco a poco.

La Corporación municipal acordó por unanimidad que se autorizara al Alcalde para disponer de toda la consignación de Imprevistos del presupuesto vigente invirtiendo la cantidad necesaria, y si dicha consignación no fuese suficiente o no bastasen los recursos del Ayuntamiento para remediar las necesidades más apremiantes, en tal caso, se recurriera a los sentimientos caritativos del pueblo.

José Forcada gestionó con la Asociación Castellonense de Caridad y Junta Provincial de Sanidad la forma de llevar los necesarios socorros a los enfermos pobres. Dichas entidades tenían dificultades por carecer de fondos y opinaban que por tratarse de una epidemia de carácter general era el Ayuntamiento el llamado a tomar aquellas resoluciones que las circunstancias demandaban. 
El Ayuntamiento acordó invitar al vecindario a que diera un donativo equivalente a un semestre del impuesto de Inquilinato, recabándose una mayor suma de las personas pudientes; solicitar el concurso del Clero, autoridades y Centros y Sociedades de la Capital, para que designara el personal que había de formar parte de las comisiones encargadas de la recaudación voluntaria y, que, el Alcalde, dirigiera una alocución al pueblo para que cooperara en la humanitaria obra que tomaba la Corporación Municipal.

En vista de que la carestía de artículos de primera necesidad aumentaba, el diputado por Castellón Emilio Santa Cruz, telegrafió al ministro de abastecimientos pidiéndole con urgencia el envío de trigo argentino, telegrama al que contestó el ministro Juan Ventosa con otro, prometiéndole interesarse en el asunto.

La alcaldía, no solo hizo lo propio sino que remitió al citado ministro una carta en la que se demostraba la agudeza de la crisis económica y de subsistencias que atravesaba Castellón, la primera a causa del desastre de la naranja y la segunda por el abandono en que se tenía por los poderes públicos a esta provincia.

La bancarrota económica de Castellón determinó la carencia de trabajo, y como consecuencia la falta de medios de la clase proletaria y aún las clases medias para abastecerse de lo más esencial para su supervivencia, máxime con los precios alcanzados por los artículos de primera necesidad. En Castellón la penuria era grave y se pasaba hambre.

Por ello José Forcada escribió al ministro de abastecimiento, exponiéndole tan terrible situación y encareciéndole que procurara con toda rapidez los medios de abaratar las subsistencias; la harina, las carnes y cuanto era indispensable para combatir el hambre en Castellón.

La ciudad se encontraba sin medicamentos suficientes y sin dinero para hacer frente a la epidemia de gripe. El Ayuntamiento repartía mantas entre las familias pobres que tenían enfermos; se les daba carne, arroz y pan diariamente con el fin de mejorar su salud, víctimas de la gripe y de la miseria.

El doctor José Clará, ante la escasez de médicos, pidió a Madrid el envío de doctores para los pueblos que carecían de ellos.

La primera onda de gripe que afectó a España no tuvo gran incidencia en la provincia. Concretamente en Castellón no hubo ninguna defunción a causa de la gripe durante los meses de primavera. En la prensa de Castellón las noticias referidas a la 
epidemia comienzan a aparecer desde el mes de mayo y hacen referencia sobre todo a las ciudades de Madrid y Barcelona.

En el mes de septiembre comienzan a aparecer noticias de la segunda onda epidemia y diariamente el doctor Clará daba noticias a la prensa sobre el desarrollo de la misma.

Finalmente, en el Boletín Oficial de la Provincia del 14 de octubre se publicó una circular del gobernador civil, declarando oficialmente por acuerdo de la Junta Provincial de Sanidad, la existencia de la gripe en toda la provincia.

Empezaron las comisiones y subcomisiones de los respectivos distritos a girar la anunciada visita de inspección a todas las viviendas de Castellón, a fin de conocer el estado higiénico de las casas, número de enfermos y remedios que deben aplicarse.

Para ver el desarrollo de la epidemia de gripe en Castellón hemos realizado unas gráficas con los datos extraídos del Boletín de Estadística Municipal de Castellón de 1918. ${ }^{1333}$

Podemos comprobar cómo durante el año 1918, concretamente en el mes de octubre, se produjo un elevado número de defunciones por gripe, Murieron casi el mismo número de mujeres que de hombres.

Observamos que la gripe afectó al colectivo más joven, pues las personas mayores que pasaron la gripe de 1889-1890, quedaron inmunizadas.

También en España podemos observar que en el año 1918, hubo más defunciones por gripe que por otras enfermedades tanto en hombres como en mujeres.

La enfermedad ataca a todas las edades, pero sobre todo a los niños, más sensibles a la infección y que son las primeras víctimas de una epidemia. En este grupo de edad, la tasa de morbilidad es alta, aunque la mortalidad es baja. En cambio, en las personas de edad, la situación es a la inversa, por lo que la mortalidad es elevada.

Habitualmente, en una población infectada por un virus, los individuos desarrollan anticuerpos específicos dirigidos contra la cepa infecciosa. Por otra parte, cuando se produce un contacto con una nueva variante vírica de estructura antigénica parecida, la inmunidad de la población aumenta (la tasa global de anticuerpos neutralizadores se eleva). Como la inmunidad de los individuos infectados neutraliza los virus, la probabilidad de contagio de los individuos susceptibles de ser infectados

\footnotetext{
${ }^{1333}$ Ver tablas 1, 2, 3 del Apéndice Documental Números: 9, 10 y 11; tabla 4 del Apéndice Documental $\mathrm{N}^{\mathrm{o}} 12$ y, tabla 5, del Apéndice Documental No 13; gráficas 1, 2, 3, 4, 5, 6, 7 del capítulo VI.
} 
disminuye. Este modelo general postula, pues, que las epidemias son el resultado de una disminución de la resistencia a la infección en la comunidad humana y, por lo tanto, de la tasa de anticuerpos.

La actuación médica sobre el proceso Epidemial de septiembre, octubre y noviembre de 1918, se puede esquematizar en tres apartados:

4. En la colaboración con los Estamentos Oficiales.

5. Su aportación en conocimientos científicos.

6. El sufrimiento personal que puede provocar el contacto con los enfermos.

En cuanto a la colaboración con los estamentos oficiales, el personal médico realizo una gran labor, pues además de ejercer su función puramente curativa, tuvo que actuar un poco como inspector o policía, comunicando cada uno de los casos que asistía.

Pero no sólo se les pidió desde los Estamentos Oficiales una función puramente burocrática de comunicar los casos diagnosticados, sino también realizar una entrega total a su profesión, no decayendo en el desánimo y no abandonando por ningún motivo sus puestos de trabajo.

También los médicos aportaron conocimientos científicos que fueron utilizados por diferentes estamentos y diferentes formas. Y según como fue utilizado, tuvo diferentes manifestaciones.

Asimismo hubo otros autores, médicos y periodistas, que con sus publicaciones en prensa intentaron informar a la sociedad de sus conocimientos, con la intención a de que dicha sociedad luchara con más acierto contra el mal reinante.

Además los médicos se arriesgaban a contraer la enfermedad y sufrir personalmente las consecuencias del contacto con los enfermos.

Está claro que la Epidemia Gripal produjo una alta tasa de mortalidad, pero lo que es evidente es que a todo ello se antepuso una altísima morbilidad.

Morbilidad que conllevó un excesivo trabajo por parte de los médicos, que tuvieron que atender a los innumerables enfermos de gripe.

Pero la epidemia gripal no afectó sólo a los médicos, en un excesivo y agobiante trabajo, sino que también se produjeron innumerables casos de contagio de pacientes a médicos, algunos de ellos llevaron al fallecimiento de sus médicos. 


\section{TERCER PARTE: EDUCACIÓN SECUNDARIA Y ENSEÑANZA- APRENDIZAJE DE LAS CIENCIAS NATURALES. EL DEBATE CIENTÍFICO SOBRE DARWIN}

En la tercera parte de la tesis, en el capítulo VII, abordamos el estudio del Instituto Ribalta como fuerza impulsora de la educación y la cultura en Castellón entre 1880 y 1918, y el debate científico que hubo en la ciudad sobre la teoría darwinista entre 1880 y 1909.

En el Instituto se impartía la Enseñanza Secundaria completa. En 1849 se creó el gabinete de Física e Historia Natural. El jardín botánico comenzó a plantarse en 1848.

Otros servicios que ofrecía el Instituto eran la biblioteca, la Escuela de dibujo, que acogía alumnado de fuera y de dentro, y el colegio de internos, establecido en 1851.

El plan de 1850 contemplaba la posibilidad establecer en los institutos estudios especiales que estuviesen de acuerdo con el trabajo de la provincia y la de crear escuelas especiales encaminadas al fomento de la agricultura, artes y comercio, y al perfeccionamiento necesario para el ejercicio de cargos públicos que no tuviesen una carrera específica previa.

El director del Instituto pidió al Ayuntamiento y a la Junta de Agricultura que solicitasen una Escuela de Agricultura elemental para Castellón. Este deseo no se haría realidad hasta la publicación de la Ley Moyano.

La Ley Moyano divide los estudios en Generales, la enseñanza secundaria propiamente dicha, y de Aplicación, aquellos que preparan para el ejercicio de una actividad profesional y conducen a la obtención del título que habilita para ejercerla.

La creación de los estudios de Aplicación llevó a la provincia de Castellón a solicitar que se estableciesen en el Instituto las cátedras necesarias para la obtención del título de agrimensor, resaltando lo necesario que eran estos estudios para sacar la agricultura de la rutina y el atraso en que se encontraba en esta provincia. En 1859 la Reina autorizaba la creación de una catedra de Agricultura teórico-práctica, una de Topografía y otra de Dibujo topográfico.

En la apertura del curso 1867-68, el director del centro señalaba la necesidad de los estudios de Aplicación al Comercio en esta provincia. Dichos estudios se establecieron después de la Revolución del 1868, al amparo de la libertad concedida a las Corporaciones provinciales y locales para establecer cátedras libres. 
La apertura de curso del Instituto de Castellón fue siempre un acontecimiento social, cultural y educativo. La prensa recoge el acto, resaltando la asistencia de las autoridades y de las personas más influyentes de la ciudad, se adornaban los claustros y participaba una orquesta para amenizar el acto. El director daba cuenta del estado del Instituto el curso anterior, como las variaciones en el profesorado, número de alumnos matriculados y examinados, resultados obtenidos en la enseñanza y las mejoras en el edificio. Al comienzo de la Restauración, los directores de este centro acompañaban la exposición de estos datos de una serie de reflexiones encaminadas a mejorar la acción educativa de los padres y la aplicación de los alumnos. A partir de 1877, la redacción y lectura de la Memoria corrió a cargo del secretario y se redujo a la simple exposición de los datos estadísticos sobre la enseñanza y a su comparación con los del curso anterior.

La acción de los profesores del Instituto con respecto a la enseñanza popular fue muy positiva, pues las clases para obreros establecidas en 1869 contaron con una asistencia masiva.

En el Instituto se celebraban las «conferencias agrícolas», que según la ley debían participar en ellas los profesores y darse de forma gratuita los domingos

El Instituto de Castellón era una de las instituciones que ostentaba un mayor nivel cultural. El salón de actos servía para realizar veladas musicales, conferencias y exposiciones como la que organizó en 1887 el Casino de Artesanos.

Así, la inauguración de la sociedad titulada Circulo Cooperativo y protectorado de obreros se realizó en el Instituto Provincial y fueron invitados los representantes más significativos de la sociedad castellonense por el catedrático de Ciencias Naturales Catalino Alegre.

Un ejemplo de la fuerza impulsora del Instituto fue la celebración de una asamblea en 1909 para pedir al Gobierno mejoras en la enseñanza y sanidad. El acto revistió excepcional importancia por las representaciones que a la asamblea concurrieron, viéndose en el salón a muchísimos castellonenses y a un gran número de mujeres.

En dicha asamblea se leyeron algunas adhesiones y cartas de Cambó, Canalejas, Moret y Sol y Ortega, en las que contestando a las peticiones que les hizo la Casa del Pueblo de Valencia, exponían que comprendían lo justas y necesarias que eran las peticiones que se les hacía de pedir al Gobierno aumento en el presupuestos de instrucción e higiene y harían todo lo posible en favor de ellas. 
Después pronunciaron discursos el maestro Carlos Selma, Benjamín Ballester, auxiliar de las escuelas públicas de Castellón, que dio lectura de unos escritos en los que constaba la adhesión de la Asociación provincial del Magisterio público; el director de El Heraldo de Castellón, José Castelló y Tárrega, el médico José Albiñana Sanz; en representación de la liga contra la ignorancia, el médico Vicente Gea Mariño, y finalmente, el catedrático del Instituto José Albiñana Mompó.

En todos los discursos, los oradores hicieron resaltar el estado deplorable de la enseñanza y la necesidad que había de que se crearan nuevos centros, mejorando los que había, aumentando el material científico y dotando mejor al profesorado.

Se trató también por varios oradores del estado de la higiene en España, de lo que eran en este sentido las viviendas, los asilos y los hospitales. Se habló de la necesidad de que los gobiernos y el pueblo se preocupen de este asunto de tan vital importancia para el bienestar.

Como resultado del acto se aprobaron por aclamación las siguientes conclusiones:

1. Adherirse a los acuerdos adoptados en la asamblea de la Casa del Pueblo de Valencia, pidiendo al Estado la realización de un empréstito de 100 millones para cultura y sanidad.

2. Recomendar a los jefes de todos los grupos parlamentarios que presentaran y defendieran un proyecto de ley encaminado a conseguir esa aspiración de mejoras.

3. Nombrar una comisión para que junto con otra de-Valencia y Alicante hiciera entrega al jefe del Estado de un mensaje pidiendo el mencionado empréstito.

Los profesores del Instituto ocuparon un espacio político y cultural importante en Castellón. Colaboraron en la prensa o revistas especializadas como La Revista de Castellón o la Unión Médica, donde escribieron Francisco Llorca y Pedro Aliaga.

También el catedrático de Ciencias Naturales del Instituto Catalino Alegre, escribió varios artículos en La Revista de Castellón sobre el tema: Riegos del Mijares.

El ingeniero y profesor de agricultura del Instituto, Antonio Maylin publicó innumerables artículos en la prensa sobre la enfermedad del mildiu o moho de la vid.

Domingo Herrero fue diputado a Cortes desde 1879 en varias legislaturas y nombrado alcalde en 1876. Gracias a él se construyó el paseo de la Alameda y fue uno de los dirigentes más importantes del Círculo de Labradores. También Teodoro Tena 
fue diputado a Cortes y concejal, al igual que Pedro Aliaga, uno de los militantes republicanos de mayor peso en Castellón.

También colaboraron en los espacios de sociabilidad de Castellón dando conferencias sobre temas de arte, ciencias naturales, higiene, educación política, etc., con la finalidad de elevar la cultura de los castellonenses.

Ocupan un lugar preferente los cursos y conferencias, canalizados a través del Ateneo Obrero y del Casino de Artesanos.

El primero, a pesar de su vinculación al partido republicano, en lo relativo a la organización y realización de actos culturales y educativos estaba abierto a personas de ideologías muy diversas.

El Casino de Artesanos tenía como principal actividad la organización de conferencias semanales. Algunas de ellas de carácter científico, político o social, corrieron a cargo de profesores del Instituto como el catedrático Pedro Aliaga, que pronunció una conferencia sobre «Las condiciones higiénicas de Castellón y sus escuelas» en diciembre de 1888, con ella se inician una serie de acciones, organizadas por el mencionado Casino, que culminan con la presentación de un estudio sobre la situación de las escuelas de Castellón y con la mejora de sus condiciones que permitiese hacer realidad las exigencias de la Ley de 1857 con respecto a la enseñanza primaria.

Asimismo los profesores de ciencias naturales del Instituto dieron varias conferencias en el mismo Centro como Francisco Llorca que desarrolló el tema: «Importancia de los conocimientos más elementales de la Geología para los progresos de la agricultura y de las artes cerámicas».

También los profesores de la asignatura de agricultura desarrollaron una labor muy positiva para elevar los conocimientos de agricultura de los labradores El ingeniero agrónomo y profesor de agricultura del Instituto, Antonio Mailyn, daba conferencias sobre el ramio en Castellón, Nules y Villarreal.

Bajo la dirección de Mailyn, se procedió, en el campo de prácticas del Instituto, a la plantación del «ramio» con objeto de ver los resultados que el cultivo de dicha planta producía. Y, al mismo tiempo, daba conferencias en la catedra de Física del Instituto y en el Círculo Católico sobre el mismo tema.

Mailyn se lamentaba del abandono e indiferencia con que en la provincia de Castellón se contemplaba la invasión de la filoxera. Asimismo, escribió un libro titulado: Instrucciones prácticas para reconocer y combatir algunas enfermedades de la 
vid donde describía las principales plagas que amenazan al cultivo de la misma, utilizando un lenguaje sencillo, al alcance de los labradores, cuando era director de la Granja Escuela de Tarragona.

Asimismo, el ingeniero agrónomo, profesor interino de agricultura del Instituto de Castellón, Ramón Rivas Moreno, descubrió una enfermedad en el ramio ocasionada por un arácnido que ataca las partes verdes de dicho vegetal y especialmente la parte terminal del tallo, donde muchos millares de arácnidos forman una red impidiendo el desarrollo de la planta en cuestión y ocasionando en pocos días su muerte.

Por otra parte, el médico y profesor ayudante del Instituto Antidio Desbertrand dio una conferencia en el Casino de Artesanos sobre «Pasteur: su vida y trabajos». También en el mismo centro disertó sobre la higiene en Castellón el profesor Pedro Aliaga.

En el Instituto se celebraban conferencias nocturnas para obreros y se daban clases de Lengua Castellana y Legua Francesa por Damian Alcón; Física y Química por José Sanz; Caligrafía por Martin Rodríguez e Higiene de enfermedades evitables y de Educación Física por el médico Luis Sanz de Andino. Lo jueves y los sábados había gimnasio.

La conferencia inaugural del curso 1914 a 1915 organizados por las sociedades obreras estuvo a cargo del profesor del Instituto de Ciencias Naturales Antimo Boscá, que desarrolló el tema «Leyes biológicas», hablando de la Lucha por la existencia, Adaptación al medio, Selección natural, Herencia y Atavismo.

A la conferencia de Antimo Boscá asistieron todos los profesores del Instituto, estudiantes y personalidades de Castellón. Fue un acto multitudinario en la que Boscá al dirigirse a los allí presentes les hizo una advertencia que no venía a desarrollar dotes oratorias sino a enseñar, considerándose satisfecho si al terminar había podido lograr aportar algo para la obra de cultura que realizaba el Centro Obrero.

Antimo Boscá dio también en el Círculo Mercantil otra conferencia sobre «Los microbios», sus medios de existencia, formas, enfermedades que causan, etc. durante la conferencia proyectó una película sobre el tema desarrollado, y describió el microscopio, enseñando su funcionamiento.

Otros temas que desarrollaron algunos profesores del Instituto en el Centro Obrero fueron los relacionados con la guerra europea de 1914. 
El catedrático de latín del Instituto, José Albiñana Monpó, fue uno de los primeros que desarrolló una conferencia sobre la Primera Guerra Mundial, con el tema titulado «El conflicto europeo con relación a España».

También, sensible a la problemática de la crisis de la naranja, disertó en el Círculo Mercantil sobre «La crisis del hambre». En esta conferencia afirma que España debería industrializarse, pues un país agrícola es un país pobre. Por eso defendía la industrialización de la naranja para que los productos que de ella se obtengan, dieran mejores rendimientos.

Hemos investigado también el tema de la didáctica de las Ciencias Naturales.

Los recursos que emplearon los profesores de Ciencias Naturales para la enseñanza-aprendizaje fueron las excursiones, el gabinete de Ciencias Naturales y los libros de texto.

En la Restauración se concedió mayor importancia a los métodos de enseñanza con la finalidad de incrementar su calidad. Al llegar al poder los liberales en 1881, necesitan cambiar la formación que se da en los institutos por otra más útil y práctica y optan por introducir nuevos procedimientos de enseñanza en lugar de modificar los contenidos del plan de estudios. De esta forma, los métodos dejan de ser considerados un simple medio de transmisión de conocimientos y podemos situarlos dentro del proceso de modernización que ya se inició en el Sexenio Democrático.

Para conseguirlo el marqués de Sardoal manda en 1883, establecer en todos los institutos ejercicios prácticos agregados a las asignaturas de la sección de Ciencias y ejercicios verbales, escritos o gráficos, adecuados a la índole de la asignatura, en las de letras. Dentro del primer bloque, los ejercicios de Matemáticas y Física y Química, consisten en resolver problemas de la vida diaria propios de la disciplina, formulados del mismo modo que se presentan en la realidad. La enseñanza de la Historia Natural y de la Agricultura, se apoya en la observación de los fenómenos de la naturaleza y de las actividades laborales. En la primera se proponen las excursiones como medio idóneo para conocer de forma directa las especies animales y vegetales del entorno. En la segunda, las visitas a los lugares de trabajo son el procedimiento recomendado para aprender las principales operaciones relacionadas con el cultivo de la tierra y con el aprovechamiento de los productos del campo.

Con toda esta serie de ejercicios se trataba de transformar la enseñanza teórica y memorística, sin aplicación inmediata en otra más práctica y positiva, en que la Ciencia 
se considera el solo medio de explicación del mundo real y el único modelo de progreso humano.

Las primeras excursiones en 1884 y 1885 tuvieron lugar en el mes de mayo, organizadas por la cátedra de Historia Natural, bajo la dirección de Catalino Alegre. El río Mijares, Benicasim y los terrenos situados más allá «dels Mestrets» fueron los lugares elegidos. En las dos excursiones de 1884 participaron veintiséis y veintisiete alumnos respectivamente, y en la de 1885, veinticuatro. El objetivo del profesor, no era recoger y clasificar cuantos seres animados e inanimados encontrara, sino estudiar «in situ la materia dada a los alumnos en la catedra». Las excursiones se aprovechaban para estudiar la flora, la fauna y la geología de los terrenos, y para conocer las obras de ingeniaría y de arte de los lugares que visitaban. De esa forma, Catalino les concedía un carácter interdisciplinar semejante al que reclamaría para ellas la reforma de 1894.

Las excursiones se realizaban los domingos para que los estudiantes no perdieran otras clases a las que estaban obligados a asistir. En la segunda excursión salió la comitiva a las 9 horas de la mañana en ferrocarril hasta Benicasim, y regresaron en el tren de las cinco de la tarde.

Posteriormente, en el primer tercio del siglo XX, surgió un gran interés por la metodología llevada a cabo en la impartición de la clase de Historia Natural, los profesores vieron la necesidad de la salida al campo como complemento de los conceptos desarrollados en el aula. Nada mejor que la propia naturaleza para la observación de los fenómenos naturales. En ésta época, la excursión cobra un sentido más didáctico, no sólo sirve para recolectar seres naturales, sino como lección dada «in situ» para observar las distintas formaciones geográficas y geológicas, el hábitat de los seres vivos y su relación con el medio ambiente.

Después de Catalino Alegre, su sucesor y director del Instituto Francisco Domenech, realizó una excursión a la Torreta de Castellón para conocer todas las especies de plantas y minerales de la zona.

En 1915, con el catedrático de ciencias naturales Antimo Boscá, marcharon a Valencia los alumnos de sexto curso del Bachillerato con el fin de visitar los museos de Historia Natural de la Universidad y Centro de Segunda Enseñanza, Granja experimental, Observatorio Meteorológico y Jardín Botánico. Permanecieron dos días en Valencia para poder examinar detenidamente los objetos que encerraban éstos centros. 
El Desierto de las Palmas fue un aula de naturaleza para los centros docentes de la capital provincial. La proximidad era un aliciente a la hora de programar excursiones de estudio y reconocimiento de un entorno enormemente instructivo. Antimo Boscá fue uno de los profesores de Ciencias Naturales que más utilizó el desierto de las Palmas para sus excursiones didácticas.

El Instituto de Castellón tenía suficientes recursos materiales para realizar las clases prácticas. Disponía de colecciones de animales, plantas, rocas y minerales, maquetas y modelos anatómicos, suficientes para hacer una enseñanza intuitiva.

Catalino Alegre utilizaba estos recursos para desarrollar las clases prácticas. El Gabinete poseía una gran mesa de experimentos y alrededor de la misma se situaban los alumnos para observar como el profesor realizaba la práctica, es decir, los alumnos no intervenían solo observaban.

El material del gabinete de Historia Natural fue aumentando progresivamente por donativos de personas interesadas en el engrandecimiento del Instituto. En 1865, José Navarro, Coronel de la media brigada de provinciales, donó al Instituto, una colección de conchas procedentes de los mares de Filipinas. También se concedió por un particular, colección de minerales de los principales distritos mineros de la península.

De tiempos de Francisco Doménech data el llamado Gabinete de Historia Natural, con colecciones de minerales, rocas, fósiles, moluscos, reptiles, aves y mamíferos cuidadosamente clasificadas.

Su sucesor, Antimo Boscá, incrementó las colecciones del instituto: insectos, minerales, rocas, fósiles, etc. Destacaba la colección de peces de las costas de Levante, importante colección desde el punto de vista científico, y que fue mencionada en comunicaciones publicadas por la Sociedad Española de Historia Natural. Publicó muchos trabajos, de entre los cuales destacó uno titulado Fauna Valenciana, donde describe desde protozoos marinos a los animales superiores.

Más allá de la política y desde los límites impuestos por ella, los libros, como recurso didáctico, tienen una influencia directa sobre la enseñanza: determinan y configuran los procesos instructivos que tienen lugar en el aula por medio de su acción sobre los contenidos y sobre los métodos.

El contenido de la enseñanza, lo que se enseña en realidad, depende de los textos. Ellos trasladan a las aulas las propuestas de los planes de estudios, 
reinterpretadas desde la formación científica e ideológica de sus autores. Por otra parte, los principios didácticos en que se apoya el autor de un manual, las características epistemológicas de la materia que contiene, el modo de presentarla y los ejercicios que proponen determinan la forma de trabajar los profesores y, por medio de ella, el nivel de conocimientos adquiridos por los alumnos y el desarrollo de sus procesos mentales.

Los manuales pueden actuar como elemento innovador, difundiendo ideas científicas y pedagógicas nuevas entre los profesores. Sin embargo, la permanencia de los mismos textos puede entorpecer las reformas de la enseñanza.

Los profesores de Ciencias Naturales del Instituto de Castellón optan por manuales nuevos y de calidad, aunque en la enseñanza de esta asignatura sigan propuestos dos manuales de la era Isabelina, como el de Sandalio de Pereda y el de Manuel María José de Galdo y López.

Al principio de su carrera profesional, Catalino Alegre utilizo el texto de Manuel María José de Galdo, para posteriormente, a partir de los años setenta, utilizar el de Sandalio de Pereda hasta su muerte en 1981.

El libro adoptado siguió utilizándose mientras permaneció en la catedra el profesor que lo eligió, la continuidad de los textos guardó un relación muy estrecha con la estabilidad del profesorado.

Los libros de texto utilizados por los profesores de Ciencias Naturales de nuestra época de estudio, recogen las teorías científicas más recientes y las últimas innovaciones pedagógicas.

El libro más utilizado por los profesores que sustituyeron a Catalino Alegre en la cátedra de Ciencias Naturales, fue el Emilio Ribera Gómez.

Los libros de texto de la época que estudiamos pertenecen a una etapa en la que predomina la descripción de los conocimientos de la disciplina de Historia Natural. Es una etapa que abarca todo el siglo XIX y principios del siglo XX. Predomina en ella la gran extensión de los conocimientos en densos libros de texto.

Los contenidos responden más a un aspecto descriptivo de los seres vivos que a un aspecto más evolucionado. Abundan las descripciones de los órganos, aparatos y sistemas de estos seres (Organografía), el funcionamiento y los mecanismos que utilizan (Fisiología) y el estudio de la clasificación de los seres vivos (Taxonomía) desde el punto de vista puramente descriptivo. Se le da una gran importancia a la Taxonomía 
vegetal, animal y mineralógica, basada en la búsqueda de diferencias entre los organismos para poderlos encasillar en taxones.

En éste trabajo, comentamos los libros de texto que utilizaron los catedráticos de Ciencias Naturales que ejercieron en nuestra época de estudio: Programa razonado de un curso de Historia Natural con Nociones de Fisiología e Higiene de Sandalio de Pereda y Martínez (1870) y Elementos de Historia Natural de Emilio Ribera Gómez (1897).

La primera edición del libro escrito por el catedrático de Historia Natural del Instituto de primera clase de San Isidro, Sandalio de Pereda y Martínez, es de 1858. Con posterioridad a esta fecha publicó cinco ediciones más. Hemos comentado la quinta edición de 1870

A partir de 1850, los autores de la época mantenían tres partes fundamentales en la organización de los contenidos de la disciplina de Historia Natural: Zoología, Botánica y Mineralogía. En esta edición Pereda añade Nociones de Fisiología e Higiene

El otro libro de texto que analizamos es del catedrático Emilio Ribera Gómez titulado: Elementos de Historia Natural es el más importante de nuestra época de estudio. Dicho libro del que aparecieron quince ediciones entre 1879 y 1926, tuvo una amplia y continuada pervivencia. La obra se difundió no solo en España sino en Latinoamérica. Corrigiendo y actualizando el contenido de sus Elementos, no solo mantuvo al día la información, sino que superó los planteamientos tradicionales de la Historia Natural agrupando las partes de su compendio relativas a los seres vivos bajo el concepto general de biología. Rechazó rotundamente el racismo consecutivo al darwinismo social iniciado por Herbert Spencer.

La integración de Ribera en el ambiente científico valenciano le condujo a recoger en sus manuales aportaciones como los parásitos que Pablo Colvée acababa de descubrir, los trabajos de Ferrán sobre la vacunación anticolérica y los de Cajal que fundamentaron la teoría de la neurona.

Como conclusión del análisis que hemos realizado de los dos libros de texto podemos decir lo siguiente:

El manual de Sandalio de Pereda es muy didáctico, intercala 464 grabados con la finalidad de que la enseñanza intuitiva se funde en el conocimiento práctico de los objetos en las aulas y en los gabinetes. 
Pereda define el glóbulo, la fibra, la celdilla y el tubo como elementos anatómicos y expone que los fenómenos que caracterizan la vida se explican mediante la fuerza vital.

Desconoce la respiración interna de los tejidos, la acción de los riñones sobre la sangre y el bazo.

Sandalio de Pereda pertenecía al grupo de naturalistas españoles formados en el Cuvierismo, modelo metodológico y rector de la Historia Natural de la primera mitad del siglo XIX, partidario del Fijismo, con una concepción tipológica y esencialista de las especies, de las que despreciaba su variabilidad y sólo buscaba los ejemplares tipo.

Niega la generación espontánea y reconoce a un ser superior como origen de todo el universo.

Emilio Ribera cuestiona en su libro la existencia de misteriosas fuerzas vitales y admite que los fenómenos que caracterizan la vida se pueden explicar dentro de los campos de la física y de la química

Dedica al «transformismo, la teoría de la descendencia o darwinismo» una detallada exposición, mientras que la «doctrina de las creaciones sucesivas» las resume en menos de seis líneas. Su adhesión al evolucionismo se manifestó también en el empleo de la taxonomía zoológica de Carl Gegenbaur, basada en la morfología comparada darwinista, y en el rechazo de un reino humano, que había sido defendido desde el fijismo. Sin embargo, consideró necesaria la intervención creadora divina en la biogénesis o aparición de los seres orgánicos.

Digno de mención es que rechaza el racismo consecutivo al darwinismo social iniciado por Herbert Spencer.

En el manual dedicó, ya a partir de su primera edición, amplio espacio a los parásitos que Pablo Colvée acababa de descubrir y también dio noticias de los trabajos de Ferrán sobre la vacunación anticolérica y de los del Cajal que fundamentaron la teoría de la neurona.

Emilio Ribera recoge dos novedades científicas del momento, la primera de ellas es una fotografía del esqueleto de un ratón, hecha por la acción de los rayos Roentgen en los laboratorios del Instituto de Valencia.

El autor en una nota a pie de página agradece al doctor Colvée el haberle permitido copiar su trabajo: 
Efectivamente se trataba de una novedad científica, pues en 1895, Roentgen descubrió los rayos $\mathrm{X}$. este gran descubrimiento fue rápidamente seguido de su aplicación a la interpretación de las estructuras y procesos corporales y constituye uno de los más grandes instrumentos en la investigación biológica. Roentgen fue premio Nobel en 1901.

La segunda novedad que Ribera recoge en su libro es la representación gráfica de las relaciones entre la superficie, la altura y la profundidad de las tierras firmes y del fondo de los mares, la llamada «curva hysográfica de la corteza terrestre».

Ribera copia esta gráfica del libro Lecons de Geographie Physique cuyo autor es A. de Lapparet, editado en Paris en 1896.

En el estudio de la higiene resumió los planteamientos renovadores de Contantino Gómez Reig, tanto lo relativo a la microbiología como a los sociales y ambientales.

Ribera ilustra su libro con reproducciones de la serie de figuras didácticas que tenían las grandes editoriales, sobre todo francesas, y también láminas independientes propias.

Otro apartado que tratamos en este capítulo de la tesis, por la repercusión que tuvo en la sociedad castellonense, es la supresión de los estudios de magisterio en el Instituto General y Técnico según el decreto del 30 de agosto de 1914.

En 1904 fueron agregados a los estudios de bachillerato los del Magisterio, pudiéndose desde entonces cursar en el Instituto las enseñanzas de la carrera de maestro. Años después, el decreto de 30 de agosto de 1914 suprimía los estudios de magisterio en el Instituto General y Técnico.

El primero de octubre de 1914 cesaban dichas enseñanzas y gran número de estudiantes pertenecientes a las clases menos pudientes tuvieron que interrumpir sus estudios, no pudiendo seguir la carrera de maestros unos y menos ingresar en ella otros.

Esto y el deshonor que significaría para una provincia como la de Castellón el carecer de Centro docente de tanta importancia es lo que inclinó a la prensa local de Castellón a iniciar la campaña a favor de la creación de la Escuela Normal de Maestros. Todos los diarios locales, de todas las ideologías, contribuyeron a la campaña en pro de la creación de dicha Escuela; además de El Clamor, La Provincia, El Heraldo con la cooperación de los semanarios El Tradicionalista y El Maestrazgo, hicieron lo propio. 
Además, 21 sociedades obreras de que se componía el Centro Obrero de la Ronda del Mijares, la Cámara de Comercio, Círculo Mercantil, Casino de Artesanos, Dependencia de Comercio, Comisión de estudiantes, el Claustro de profesores del Instituto, La directora de la Normal de Maestras, ayuntamiento y otras entidades y personas, dirigieron comunicaciones a la diputación ofreciendo algunos sus servicios y en demanda de que se fundara la referida Normal las restantes.

El 8 de octubre de 1914, se celebró un mitin «por la cultura», organizado por el Centro Obrero para pedir a la Diputación provincial la creación de una Escuela Normal de Maestros en Castellón.

El mitin fue muy concurrido, acudieron todos los periódicos de la capital así como maestros, profesores y catedráticos del Instituto, concejales, elementos de todos los partidos políticos, estudiantes, etc. Se leyeron las adhesiones firmadas por las principales entidades, entre ellas la de la directora de la Normal de Maestras, Leonor Velao.

Todos los representantes de las fuerzas vivas de Castellón hablaron en favor de la creación de la Escuela Normal de Maestros. El jefe de los republicanos de Castellón, Fernando Gasset, además de pedir a la diputación la Escuela Normal de Maestros, creía asimismo necesario solicitar del gobierno la Escuela de Comercio, ambos centros igualmente necesarios para el engrandecimiento de la capital y su provincia.

La Diputación provincial resolvió en la sesión de 14 de octubre no crear la Escuela Normal de Maestros por la imposibilidad material de atender al sostenimiento de la misma.

Otro centro de estudio que era muy demandado era la Escuela de Comercio.

La Cámara de Comercio acordó pasar a estudio de la Comisión de Enseñanza, el real decreto sobre la creación y organización de escuelas de esta clase, y ver si, por cuenta propia, o con la ayuda de otras corporaciones, era factible el sostenimiento de un Escuela Elemental o Pericial de Estudios Mercantiles.

El ayuntamiento aprobó también la fundación de una Escuela Elemental de Comercio, que podría sostenerse con un presupuesto de 6.000 pesetas participando la Cámara y la Diputación.

Castellón se iba haciendo grande a pasos agigantados. Desde hacía veinte años que se notaba un aumento en su censo de población; se habían establecido nuevas industrias; la agricultura se hallaba en un floreciente estado; se había multiplicado el 
comercio, sobre todo el marítimo, extraordinariamente, «hasta el punto que el número de buques de vapor excede de 400 que efectúan sus operaciones en el puerto, ya próximo a terminarse, y que, por la solidez y originalidad de su construcción, será, sin duda alguna, de los mejores de España».

Por su parte el médico republicano, Vicente Gea, propone en una sesión de la Diputación Provincial celebrada en mayo de 1916, la creación de una Escuela Pericial.

Vicente Gea expone que faltan en la provincia centros de enseñanza a donde pueda acudir el joven trabajador en busca de todos los conocimientos científicos que sirven de base para poder tener un conocimiento técnico necesario para la práctica de varias profesiones.

No se tomó ningún acuerdo sobre la proposición de la escuela pericial porque implicaba un aumento de gastos en el presupuesto provincial y hasta el año siguiente no podía tomarse ningún acuerdo.

Dentro del impulso educativo y cultural que el Instituto Ribalta dio a Castellón en los años objeto de nuestro estudio, nos ha parecido adecuado estudiar en este apartado, (en el capítulo VIII), el debate que hubo en Castellón en torno al darwinismo desde 1880 hasta 1909, año en que se celebró el centenario del nacimiento de Darwin.

En España estaba prohibido el darwinismo hasta bien entrado el siglo XX, igual que lo sigue estando hoy en muchos países, como es el caso de EE.UU. El resurgir del creacionismo en la principal potencia científica del momento parece presagiar que este argumento sobre la separación de ciencia y religión no va a ser aceptado por ciertos sectores políticos muy poderosas en el mundo actual.

La teoría darwinista sobre la evolución por selección natural, produjo, (y sigue produciendo), rechazos intensos. Lo que une a todos los críticos en contra de la teoría es que atenta contra los cimientos de la idea que ha sustentado todas las culturas y religiones hasta el presente, que no es otra que la diferencia inconmensurable entre el ser humano y el resto de los organismos.

Fueron los Krausistas españoles los primeros en aceptar el evolucionismo y en promover su difusión organizada entre las elites intelectuales.

La primera valoración Krausista positiva de las ideas evolucionistas la realizó Francisco Giner de los Ríos en un artículo publicado en la Revista de España, «Psicología comparada. El alma de los animales», que apareció en 1871. Los discípulos de Giner iniciaron un estudio sistemático del tema que duró desde fines de 1872 a 
principios de 1874, años en los que Alfredo Calderón, Augusto González de Linares, y Enrique Serrano Fatigati publican trabajos sobre el tema. Al principio la mención a la obra de Darwin se sitúa en una argumentación muy antropocéntrica, tendente a demostrar la unidad formal de la persona humana con el resto de los seres vivos.

A partir de 1872 los krausistas españoles aceptan el evolucionismo biológico, pero tras depurarlo y adaptarlo a sus peculiares ideas filosóficas. La aceptación oficial se produce en 1873 en la obra Ensayo de una introducción al estudio de la Historia Natural, escrita por el discípulo predilecto de Giner, Augusto González de Linares. A partir de esta obra, el Krausismo científico, al admitir la evolución orgánica como una ley general de la Naturaleza, da un nuevo paso hacia su positivación.

Para situar históricamente el darwinismo en Valencia conviene tener en cuenta dos aportaciones valencianas, la introducción en España de la enseñanza de la Anatomía comparada por Tomas Villanova Entraigues y la de la Zoología ya institucionalizada por Laureano Pérez Arcas.

La mayoría de los médicos y naturalistas valencianos no aceptaban la teoría de la evolución darwinista que se manifestó en las obras de José María Gómez Alamá, Salustiano Sotillo y Juan Vilanova Piera

No obstante, hubo científicos valencianos que defendieron el darwinismo incorporándolo como supuesto de sus investigaciones. Entre ellos están Rafael Cisternas Fontseré, José Arévalo Baca, Serrano Cañete, Amalio Gimeno Cabañas, cabeza destacada de la corriente experimentalista, Eduardo Boscá, Peregrin Casanova Ciurana, Luis Simarro Lacabra Santiago Ramón y Cajal y Emilio Ribera Gómez.

En Castellón las posiciones opuestas al darwinismo vienen representadas por los neocatólicos que no se limitaron a descalificaciones meramente ideológicas sino que fueron cultivadores rigurosos de las ciencias biológicas. Los principales fueron el jesuita castellonense Antonio Vicent, fundador del Círculo Católicos de Obreros, y El catedrático de Ciencias Naturales del Instituto de Castellón, Catalino Alegre Renau.

En 1881, para desmarcarse de los carlistas, el Círculo Católico de Obreros pasa a llamarse Círculo Cooperativo y Protectorado de Obreros para que los carlistas no abusaran de la palabra católico, considerándola sinónimo de carlista.

A finales de 1882, ante el crecido número de socios, el Círculo Cooperativo se traslada a unos locales más amplios y celebra el 21 de enero la inauguración oficial en los salones del Instituto Provincial. 
Asisten los presidentes de la Diputación y el de la Audiencia. Alegre haciendo gala de profesor de ciencias naturales, pronuncia un discurso en el que pretende rebatir la teoría darwinista. La prensa liberal critica el discurso de Catalino Alegre por considerarlo que no estaba a la altura de la ciencia moderna:

En el lado opuesto estaban los republicanos que defendían abiertamente el darwinismo en sus redes sociales. El médico y concejal del Ayuntamiento de Castellón Vicente Gea, Gil Valero, jefe de los republicanos villarrealenses, y el redactor de $E l$ Clamor y jefe de las Juventudes Republicanas, Agustín Betoret, fueron los principales defensores de la teoría darwinista.

En la polémica en torno al darwinismo la prensa republicana de Castellón daba inequívocamente la gloria a Darwin «por destruir el viejo concepto de la naturaleza y levantar sobre las ruinas del pasado el grandioso edificio de la ciencia actual». Se resalta la biografía del gran naturalista, destacando su obra magna On the origen of Species by Means of natural Selection que tan gran sensación causó en el mundo científico: «Libro que hará época en la historia de las ciencias por lo atrevido y trascendental de la doctrina, la sencillez de la exposición y el riquísimo caudal de hechos y datos en su mayor parte desconocidos, que tan interesante hacen el hermoso trabajo del ilustre naturalista inglés»

Al cumplirse el centenario de la muerte de Darwin en 1909, la Junta directiva de la Juventud Republicana de la ciudad de Castellón, proyectó honrar su figura invitando a diferentes personalidades en el campo de la ciencia. Aceptaron a esta invitación los catedráticos de las Universidades de Barcelona y Valencia respectivamente, Odon de Buen y Peregrin Casanova. También iban a tomar parte los médicos Vicente Gea y José Gil Valero.

El doctor Vicente Gea dio dos conferencia sobre «Darwin y su escuela» en el Círculo Mercantil En la primera, tras exponer las doctrinas dualistas de Linneo Cuvier y Agassiz, se ocupó del Lamarckismo. Sintetizó la doctrina de Darwin basada en la selección natural y la lucha por la existencia como medios naturales de producción de tipos nuevos. Se extendió en la generalización de estos hechos al estudio del hombre y demostró ya por el desarrollo filogenético como por el ontogénico y paleontológico el origen animal de la especie humana.

Las críticas en la prensa católica a la conferencia del doctor Gea fueron numerosas, en un artículo de El Cruzado se critica a los monos sabios de Castellón, «al 
empeñarse en desenterrar a título de progreso y civilización una teoría por repugnante, absurda y ridícula sepultada en la fosa del más profundo desprecio».

También La Cruz de Castellón y El Restaurador de Tortosa se ocuparon de la conferencia que el doctor Gea dio en el Círculo Mercantil acerca de Darwin y su escuela. Lanzan un reto dirigido al doctor Gea para discutir las teorías que expuso en su disertación.

La persona elegida para rebatir las teorías darwinistas, en la misma tribuna del Círculo Mercantil, fue el Doctor Rafael Tarín Juaneda, profesor de la Universidad de Valencia que también fue profesor del Instituto Provincial de Castellón.

En el mismo periódico sale desarrollada la conferencia del Doctor Tarín en el Círculo Mercantil. De gran altura intelectual, la conferencia el doctor Tarin se limitó a rebatir los tres argumentos en favor del origen simiano del hombre «según la obra del evolucionista Metchnikoff titulada La nature humaine»: argumento morfológico, basado en la semejanza de los órganos del hombre con los de los animales; Argumento fisiológico, tomado de la supuesta inutilidad de muchos órganos del hombre llamados rudimentarios, y argumentos patológicos, que se funda en los inconvenientes y desequilibrios que en la salud del hombre producen la existencia de esos órganos incompletos que existen en virtud de la herencia y que están en vías de desaparición por adaptación al medio.

Después de la disertación del profesor Tarin, El doctor Vicente Gea volvió a dar una segunda conferencia, en el círculo Mercantil, sobre el transformismo. Según el cronista había mucha expectación después de la polvareda levantada alrededor de la cuestión, resultando muy pequeño el salón del Círculo para la gran masa de oyentes que acudieron a escuchar «al sabio médico»: «Su discurso fue una maravilla de erudición y un formidable ariete que destruyó las vanas contradicciones de quienes a título de la fe pretenden detener la incesante marcha de las ideas»

El doctor Gea, concluyó que las verdades científicas han de estar siempre por encima de la tradición y la mentalidad primitiva «porque de otra suerte las ciencias se ahogarían y el progreso humano sería imposible».

Por su parte el redactor de El Clamor, Agustín Betoret, dio otra conferencia sobre el origen del hombre en Villarreal y repitió la misma en Burriana a petición del Centro de Sociedades Obreras. 
Después de 1909 siguieron celebrándose conferencias en el Círculo Mercantil y otros centros republicanos, sobre más transformismo, a cargo de Vicente Gea, Gil Valero, Agustín Betoret y otros médicos de Castellón.

En 1911, la Juventud Republicana Propagandista invitó al sabio catedrático de Historia Natural de la Universidad de Barcelona Odón de Buen para dar una conferencia en el Centro Republicano sobre «Darwin y sus teorías sobre la evolución». Odón de Buen era muy apreciado en Castellón por la competencia que en esa materia poseía el ilustre catedrático, y porque en alguna ocasión defendió alguna causa del pueblo de Castellón cuando era alcalde Carlos González Espresati. Dedicó grandes elogios a la Juventud Republicana de Castellón por la labor realizada con la serie de conferencias políticas, sociales y científicas que se daban en su casa social, y a continuación expuso el tema objeto de su conferencia, haciendo un estudio psicológico del carácter de Darwin:

Refirió como Darwin después de muchos años de estudio llegó al convencimiento de que todo se transforma: «de que toda planta, de que toda materia evoluciona incesantemente hasta llegar a sus completo desarrollo, al perfecto estado de su característico modo de ser».

\section{CUARTE: PARTE. HIGIENE, EDUCACIÓN SANITARIA Y COLONIAS ESCOLARES. PROPUESTAS PARA CONSEGUIR UNA EDUCACIÓN INTEGRAL}

En la cuarta parte de la tesis estudiamos la higiene de las escuelas, (capítulo IX), y las colonias escolares en Castellón, (capítulo X).

Durante la transición al siglo XX la sociedad española fue escenario de un amplio debate en torno a la penosa situación en que se desenvolvía la vida de los niños. El debate estaba estrechamente vinculado, por una parte a la crisis de 1898 y a la sensación de decadencia que ésta provocó en los diversos sectores de la sociedad española y, por otra parte, a un movimiento internacional que buscaba mejorar las condiciones de vida y supervivencia de la infancia. La opinión pública española acuñó así el problema de la infancia y su análisis y resolución se convirtieron en una de las piedras angulares del programa de modernización y regeneración social durante el primer tercio del siglo XX. 
Resolver la penosa situación de la infancia representaba uno de los retos principales para la transformación de la sociedad española.

Por estas razones en las primeras décadas del siglo XX el problema de la infancia alcanzó un amplio eco social y político. La dimensión sanitaria del problema fue analizada por higienistas y médicos comprometidos con la medicina social. La dimensión pedagógica fue impulsada por maestros y pedagogos que consideraban la educación como instrumento de modernización y progreso. Médicos y pedagogos fueron los dos principales arquitectos del diseño y la construcción del problema de la infancia.

El problema de la infancia adquirió también una dimensión laboral, moral y delictiva en la transición al siglo XX, delimitándose en España alrededor de cuatro dimensiones principales. Una dimensión sanitaría sustentada en unos indicadores de mortalidad y morbilidad infantil escandalosos y en las profundas deficiencias en las condiciones de vida y alimentación de los niños. Una dimensión educativa, caracterizada por un sistema de escolarización deficiente, tanto por las malas condiciones higiénicas de las escuelas como por los métodos docentes anticuados y la escasez de recursos materiales y didácticos.

Y eso sucedía precisamente en unos momentos en que el debate sobre la escuela y su potencial regenerador era ampliamente valorado y debatidos en la sociedad española, tanto en el seno de la Institución Libre de Enseñanza como en las reformas planteadas por Ferrer y Guardia, el padre Manjón y otros representantes del reformismo pedagógico y la escuela moderna. Una tercera dimensión laboral abundaba en el carácter abusivo del trabajo infantil, que debilitaba la salud e impedía la escolarización. Finalmente, una cuarta dimensión delictiva se refería a la mendicidad, al abandono, la vagancia y el delito. Ello planteaba un problema de orden público que con tribuyó a configurar el arquetipo marginal y psicopatológico del niño golfo.

La Ley de Protección a la Infancia y Represión de la Mendicidad de 12 de agosto de 1904 aportaba una novedad fundamental: la implicación y el compromiso del Estado. En el siglo XIX, el Estado no había ido en España más allá de asumir una función legislativa y en las políticas públicas (sanidad, asistencia social, educación) no se había comprometido en la financiación ni en la ejecución, delegando de forma subsidiaria en la administración periférica (diputaciones, ayuntamientos) o en la acción social de la iglesia. Durante las dos primeras décadas del siglo XX esta actitud se 
transformó no solo en relación con el problema de la infancia, sino también con respecto a la educación, la salud pública, la actividad científica y la asistencia social. El compromiso del Estado se convirtió así en un factor ideológico que permitió superar las limitaciones de la caridad pública en favor del reconocimiento del derecho a la educación y a la salud, y también al compromiso en afrontar la represión de la delincuencia. Una de las causas de ese cambio fue la internacionalización del movimiento sanitario y la influencia de la Sociedad de Naciones. No hay que olvidar que España se integró en la política internacional a través de las conferencias sanitarias internacionales que venían desarrollándose desde 1851.

Todos los testimonios acerca de las condiciones de vida y salud de la infancia en la sociedad española a comienzo del siglo Xx indican la existencia de una gran preocupación social. Tanto los testimonios políticos como los literarios, los eclesiásticos como los del movimiento obrero, los pedagógicos como los sanitarios, coinciden en denunciar las penosas condiciones de vida de una gran parte de la población infantil. No solo preocupaba la incidencia de enfermedades infantiles y la muerte prematura de los niños, sino también las deficientes condiciones higiénicas del medio urbano y rural, las lamentables condiciones de las escuelas, el abandono, la orfandad, la marginalidad y el vagabundeo, la explotación y el trabajo infantil, los abusos sexuales y la delincuencia.

Muchas de las enfermedades estaban relacionadas con deficiencias graves en la alimentación, los espacios públicos, las viviendas y las condiciones laborales. En una primera etapa el problema llegó a ser especialmente dramático en los contextos urbanos e industriales, y menos en las áreas rurales, pero, desde finales del siglo XIX, se extendió entre la opinión pública la imagen de una sociedad rural poco higiénica y atrasada. El hacinamiento y la convivencia con animales e inmundicias, la falta de sistemas de eliminación de aguas sucias y de instalaciones higiénicas en las viviendas ponía en riesgo la vida de los niños.

El testimonio de los médicos acerca de las condiciones higiénicas de las escuelas es demoledor y aparece en la mayoría de las topografías médicas. En el medio rural los niños abandonaban la escuela a los diez años para ayudar en las faenas del campo y cuidar de los animales domésticos. Las niñas ejercían como niñeras y asistentas en el servicio doméstico de la burguesía urbana hasta que se casaban a los quince o dieciséis años. Las tasas de alfabetización eran muy bajas, alrededor del 50 por cien, y el analfabetismo era significativamente más alto entre las mujeres. 
La preocupación por los problemas de higiene en la infancia se refleja en el Primer Congreso de Higiene Escolar que se iba a celebrar en Barcelona en 1912. Dicho Congreso se proponía estudiar los problemas de higiene en la educación y mejorar las condiciones materiales de la escuela, dar impulso a la educación física en nuestro país y aplicar los preceptos de la ciencia a los programas y métodos de enseñanza.

Los objetivos de los médicos que publicaban tratados de higiene escolar eran dictar reglas para el perfeccionamiento físico, intelectual y moral del niño. Se proponían popularizar conocimientos de higiene infantil, criticar malas costumbres, destruir los errores borrar prácticas anticientíficas, deshacer preocupaciones del vulgo y combatir ideas extraviadas sobre la higiene de las personas desde su nacimiento.

Gracias a la Inspección Médico-Escolar, se pusieron de manifiesto todas las deficiencias higiénicas que se observaban, tanto en los escolares como en las escuelas, y se indica el medio de corregirlas para que de esta forma España se situara a la misma altura que las demás Naciones.

La Inspección Médico.Escolar denunciaba que las escuelas no eran edificios aislados, no tenían ventilación ni una iluminación adecuada. Muchos establecimientos carecían de urinarios y lavabos, y los retretes eran insuficientes, no tenían algunas aguas y sifón. Asimismo los peldaños de las escaleras de los edificios solían ser muy elevados, constituyendo un peligro para los niños que tenían que subir a gatas.

Hacían falta escuelas para que dejara de existir esa sobrecarga que hacía de los centros escolares un lugar malsano y antipedagógico, y para dar entrada a muchos niños que esperaban sitio vagando por las calles.

Las entradas a la escuela constituían muchas veces un peligro para los niños por tener que utilizar la misma puerta que el servicio de incendios, la Casa de Socorro, la Tenencia de alcaldía, etc. por ser sitios destinados a establecimientos insalubres y peligrosos.

Muchas escuelas estaban situadas en casas de vecindad, en barrios poco saludables, donde los vecinos depositaban los detritus, restos de la limpieza de las casas y excrementos, hasta que los carros de la limpieza pasaban a recogerlos una o dos veces al día.

Uno de los aspectos en que más incide la prensa de Castellón a finales del siglo XIX, es la falta de condiciones higiénicas de los locales de las escuelas y la repercusión de esta circunstancia en la salud de los niños. Además hace hincapié en la necesidad de 
atender a la difusión de la primera enseñanza en la capital y la urgencia de crear escuelas de ambos sexos en los barrios periféricos.

Como consecuencia del rápido crecimiento de la población en las últimas décadas del siglo XIX, el Ayuntamiento tiene que proveerse rápidamente de nuevos espacios para alojar la demanda escolar y también de profesores, para dar respuesta a esta situación. La falta de escuelas y sus condiciones higienicas lo denuncia con insistencia la prensa y los propios profesores.

Por los expedientes de instrucción pública de centros escolares consultados, hemos podido conocer el relevante papel que la Comisión permanente de Instrucción Pública tuvo en la consecución de mejoras y aumento de centros escolares. Los informes de la Comisión fueron siempre escuchados y atendidos por la Corporación municipal.

En la última década del siglo XIX surgen dos nuevas escuelas municipales, la Escuela Centro de niñas, que era aneja a la Normal de Maestras y la Escuela del caserío del Grao. También se remodelan o cambian de emplazamiento las antiguas escuelas construidas en el siglo pasado, para responder mejor a las modernas prescripciones pedagógicas y condiciones higiénicas.

Con el inicio del siglo XX se producen importantes mejoras en las escuelas públicas, tanto a nivel pedagógico como higiénico. El Real Decreto de 26 de octubre de 1901, por el que el Estado asume los gastos de personal y mantenimiento, supone un alivio a los municipios, pudiendo de esta forma invertir mas en edificios escolares. También el Real Decreto de abril de 1905, de Carlos María Cortezo, amplia y agiliza las subvenciones. El mismo decreto publica las nuevas Instrucciones Técnico-higiénicas para la construcción de colegios.

En pocos años, el celo del ayuntamiento de Castellón empieza a dar los primeros frutos, ampliando y mejorando las escuelas existentes y construyendo otras nuevas, diseñadas según las nuevas normas.

A finales de la primera década del siglo Xx, sabemos por las Guías Oficiales de Castellón y Provincia del creciente aumento de centros escolares, como la Escuela de la calle Pi i Margall o la Escuela de la calle Ros de Ursinos. Muchas de las escuelas municipales estaban situadas en edificios alquilados y adaptados a la función docente.

La construcción de dos grupos escolares nuevos, para niños y niñas, de promoción municipal y subvención estatal, ajustados a la nueva Instrucción Técnico- 
sanitaria, no se hace esperar. En la temprana fecha de 1908, se están ejecutando en los nuevos ensanches de la ciudad, el Grupo Escolar de la calle Herrero y el de la Ronda Magdalena. Lo que denota el interés del Ayuntamiento por hacer más y mejores colegios.

En la segunda y tercera década del siglo XX el mapa escolar cambia sensiblemente de aspecto, desapareciendo paulatinamente las «escuelas-habitación», situadas en el centro de la ciudad, generalmente en locales alquilados, por nuevos grupos escolares ubicados en el extrarradio. ${ }^{1334}$

Todo ello se tradujo en una mejora pedagógica e higiénica, reduciéndose progresivamente el hacinamiento en las aulas. Hechos que políticos y maestros manifestaron en charlas y artículos en prensa.

Se han confeccionado dos mapas con las escuelas públicas, uno del último tercio del siglo XIX y el otro del primer tercio del siglo XX, en donde podemos apreciar el desarrollo y evolución de los centros escolares y la dispersión de su localización, pasando del centro urbano a la periferia de la ciudad. También se constata, a partir de la implantación de las primeras escuelas del siglo XVIII, el emplazamiento de algunas de ellas buscando su proximidad a la población escolar de los barrios periféricos.

A raíz de una serie de artículos publicados en el periódico El Clamor, siempre preocupado por la cultura y la educación, hemos podido aproximarnos al estado de la enseñanza pública a mediados de la segunda década del siglo XX en la ciudad de Castellón. Los artículos, escritos entre abril y julio de 1914, bajo el título Estadística de las escuelas públicas de Castellón y que en parte hemos transcrito, vierten datos que valoramos de gran interés para hacer un diagnostico de la situación.

Con los datos extraídos de los artículos publicados en el periódico El Clamor y las Guías Oficiales de Castellón y Provincia de las mismas fechas, hemos confeccionado unas tablas que nos ha permitido hacer un análisis comparativo entre las distintas escuelas y estas con la normativa vigente.

Un primer aspecto que observamos, es que en más de un 60 por ciento de los centros escolares se estaba impartiendo la enseñanza graduada, frente al resto de escuelas que continuaba con la enseñanza unitaria. Lo que suponía pasar del anterior

\footnotetext{
${ }^{1334}$ Ver tabla 2: Evolución de las escuelas de Castellón en el transito del siglo XIX al siglo XX, en el capitulo I.
} 
sistema «escuela-aula» a la «escuela-colegio». La innovación pedagógica llevaba consigo más aulas y más maestros, además de un nuevo sistema de organización y formación del profesorado.Todo esto suponía por parte de la corporación municipal transformar y ampliar centros, y por parte de los profesores adaptarse al nuevo sistema educativo. Aunque con el Real Decreto de 26 de octubre de 1901, el Estado asume los gastos de personal y mantenimiento, los ayuntamientos, a cambio, tienden que duplicar y adecuar los centros escolares a su costa, ya que el Real Decreto de 1905, de Carlos María Cortezo, redujo drásticamente los alumnos por aula a 25-40 para la enseñanza graduada. Tanto el Ayuntamiento como los profesionales de la docencia realizaron un gran esfuerzo para convertir en enseñanza graduada todas estas escuelas en fechas tan tempranas. Lo que denota por parte de la corporación municipal y maestros su predisposición a las innovaciones pedagógicas. Debemos recordar, que pocos años antes, el Real Decreto de 23 de septiembre de 1898, de Germán de Gamazo, dicta las primeras normas que obligaban a convertir las escuelas en graduadas. El Decreto de 25 de febrero de 1911, establecía su funcionamiento, y el de 1918, es el Primer Reglamento de Escuelas Graduadas.

También se desprende de los datos obtenidos, que en la segunda década del siglo XX, en la ciudad de Castellón, casi la mitad de los centros escolares eran escuelahabitación, instalados en locales o viviendas alquiladas, generalmente situadas en planta piso. Lo que suponía la sistemática renovación de contratos cada cuatro o cinco años o el cambio de emplazamiento, también para buscar mejores y más amplios locales. Tan solo hay en estas fechas dos grupos escolares municipales, de reciente creación, que cumplen con la Instrucción Técnico-sanitarias de 1905.

Por las descripciones de los artículos de El Clamor, y consultados planos y fotos de la época, se desprende que la mayoría de las escuelas ocupaban edificios amplios y aparentemente sólidos, con estancias grandes para albergar las aulas y otras dependencias escolares.

A excepción de las aulas de los citados grupos escolares, las clases del resto de escuelas públicas no reúnen todas las exigencias higiénicas que las nuevas normas imponían en materia de ventilación, iluminación y orientación para la entrada de luz. Requisitos difíciles de cumplir si no se trata de construcciones escolares de nueva edificación. La mayoría de las escuelas ocupan edificios propios de difícil adaptación o locales alquilados adecuados al uso docente. 
Se han visitado los edificios existentes, también se han consulado fotografías antiguas de algunas fachadas y se ha buscado su emplazamiento y orientación en planos de la época, para valorar las condiciones de habitabilidad. En la mayoría de los casos se trata de edificios de gran fachada, que solían hacer esquina a dos o tres calles, con abundantes ventanas de generosas dimensiones, a las que recaían las aulas.

Más de la mitad de las escuelas no tenía patio o jardín, el emplazamiento de muchas de ellas en el centro de la ciudad impedía disponer de espacios abiertos de juego y las que lo tenían no cumplían con las dimensiones reglamentarias.

Las escuelas eran pqueñas, solían tener tres aulas, con un profesor por aula. En casi todos los casos la superficie y altura de las clases era la recomendada, siendo la dimensión media no inferior a los 60 metros cuadrados y la altura sobre 4,5 metros.

Como se puede apreciar en la tabla, la alta escolarización que figura en todas las escuelas sobrepasa en la mayoría de los casos el número de alumnos permitidos por aula. Mientras que en las escuelas unitarias es poco significativo, en las de enseñaza graduada es muy acusado, doblándose en ocasiones el número de alumnos permitidos. Debemos recordar que para las escuelas unitarias, desde el R.D. de 5 de octubre de 1883 la capacidad del aula se fijó en un máximo de 60 alumnos y en 1,25 metros cuadrados de aula por alumno, y para las escuelas graduadas, a partir del R.D, de 28 de abril de 1905, entre 25-40 alumnos. Todo este hacinamiento se traduce en que la relación de superficie de aula por alumno no llegaba al mínimo establecido de 1,25 m²/alumno, y en consecuencia, el volumen por alumno tampoco se alcanza. Incluso considerando los que realmente asistían, y en el caso concreto de las escuelas graduadas, tampoco se cumplía como podemos ver en apartado correspondiente de la citada tabla.

Otro tema preocupante que se detecta es el alto grado de absentismo escolar, que gira en torno al 20 por ciento, siendo más elevado en las niñas que en los niños; llegando en los párvulos al 50 por ciento.

Por las descripciones que hemos recogido de los artículos antes citados del periódico El Clamor, los nuevos centros escolares de la calle Herrero y de la Ronda Magdalena se componían de tres aulas para niños y tres para niñas y disponían de patio ajardinado para recreo, despacho para el profesor, aseos y otras estancias complementarias. Las dimensiones de las aulas y de los patios se ajustan a la normativa del Ministerio de Instrucción Pública. Pero mientras la escuela de la Ronda Mijares cumple con el número de alumnos y alumnas fijados para la enseñanza graduada, la 
escuela de la calle Herrero alojaba más de los que fijaba la ley. En los dos casos se aprecia un alto índice de absentismo que recogemos en las tablas. Los grupos escolares estaban alejados del centro de la ciudad y los alumnos que acudían a ellos procedían en gran parte de los nuevos ensanches, donde estaba asentado el proletariado urbano. Estos nuevos centros de promoción municipal, inaugurados en 1910, se ajustaban ya a las últimas Instrucciones Técnico-higiénico de 1905. Hecho que se aprecia en algunas fotos de época, lo que denota el interés del Ayuntamiento y de los técnicos municipales por construir los nuevos edificios escolares ajustándose a las últimas tendencias.

Un papel importante en promocionar la salud de los niños y niñas lo tuvieron los médicos y profesores del Instituto, así como el Inspector de Primera enseñanza de Castellón, que mediante publicaciones en prensa y conferencias en los centros de sociabilidad pusieron de manifiesto la situación de las escuelas de Castellón, instando a los poderes públicos a construir nuevos edificios no solo para mejorar la enseñanza primaria sino también para mejorar la salud de los niños que a ellas concurrían.

La preocupación por la salud de los niños desfavorecidos llevó al Inspector de Sanidad, José Clará, y al Inspector de Primera Enseñanza, José Senet a organizar las primeras colonias escolares de vacaciones, en el verano de 1915.

Los resultados de la estancia de los niños en Lucena fueron muy positivos en todos los aspectos, educativos porque fomentaron la educación ambiental, social y cultural de los colonos y físicos, ya que los datos antropométricos tomados antes y después de la colonia revelaron, por término medio, el aumento de 1 kilo de peso, por niño; 1,25 centímetros en estatura y 0,76 centímetros en amplitud torácica.

Dentro del concurso social que prestaron las clases populares y la prensa local, destaca singularmente el apoyo personal y decisivo que mereció la colonia por las autoridades de Castellón.

Visto los resultados obtenidos en la primera colonia escolar, la Junta Provincial de Primera Enseñanza, en marzo de 1916, nombró una comisión formada por el Inspector provincial de Sanidad José Clará, Inspectores de primera enseñanza Emilio Monserrat y José Senent, presididos por el Gobernador Teodoro Izquierdo, para que gestionara del Estado, el dinero suficiente para organizar, no solo una colonia con niños de la capital, sino también otra marítima compuesta de niños del interior de la provincia, necesitados de los baños y la vida en la costa. 
Las colonias eran igual de beneficiosas para la educación intelectual y moral. Las continuas excursiones que realizaban los colonos se prestaban para la explicación de lecciones de botánica, zoología, mineralogía, agricultura, etc., los ejercicios de redacción al llevar su diario, las descripciones y cartas a las familias, desarrollaban el lenguaje y la escritura. Se les enseñaba a vivir en sociedad, a cumplir con sus deberes y a respetar y ser respetados en sus derechos y así ir formando su carácter y desarrollando su voluntad.

La tercera colonia escolar también fue organizada por José Senent y José Clará. Para dicha colonia el Estado concedió 3.000 pesetas. Se gestionó algún donativo más de entidades y corporaciones con el objeto de disponer de la cantidad necesaria para atender al mantenimiento de los cuarenta colonos de que se había de componer aquella.

En 1915, el Inspector José Senent, presentó a la aprobación del Ayuntamiento de Castellón un Ensayo de un plan orgánico para el funcionamiento de los «Baños Escolares» en la playa de Castellón de la Plana durante el verano de 1915.

El objetivo de los baños escolares era también, la protección y cuidado de los niños, la educación física, el desarrollo y mejora fisiológica de los mismos.

Los baños escolares debían beneficiar a los niños de las escuelas públicas, que por su condición social, negligencia de los padres y estado de salud, necesitaban durante el verano restaurar sus fuerzas físicas mediante ejercicios convenientes a plena luz y a pleno aire y con la acción tonificadora de los baños de playa. A los beneficios conseguidos por los niños en orden a la salud había que añadir los resultados pedagógicos de disciplina moral y de enseñanza bajo el influjo de la acción educadora de los maestros directores.

El sostenimiento y organización de los «Baños Escolares», se encomendaba principalmente a los Municipios y a la ayuda de los particulares e instituciones benéficas.

Teniendo en cuenta el carácter de ensayo que debían tener los «Baños Escolares» en el primer año de funcionamiento, debía limitarse a 100 niños el número de los que disfrutaran sus beneficios en el verano de 1916. Los cien escolares se repartirían en 50 niños y 50 niñas.

No se llegaron a organizar los baños escolares en 1916, como se esperaba, sin embargo, en Castellón, en la segunda quincena de julio, organizado por el director de la 
Beneficencia, Juan Aragonés, se realizaban los baños de los asilados en la casa de Beneficencia.

En Castellón, a partir de 1917, se establecieron colonias que tenían una finalidad más educativa que higiénico-sanitaria. Podemos citar la escuela-bosque y la colonia escolar católica, inauguradas a partir de 1917.

Como conclusión final el balance del periodo que estudiamos es muy positivo, creemos que la ciudad de Castellón avanzó hacia la modernidad como corresponde a su condición de capital de provincia, tanto en urbanismo, higiene, en la incidencia de enfermedades, enseñanza e higiene escolar. No obstante, creemos que las diferencias sociales eran significativas y los poderes públicos no disponían de suficientes medios para socorrer a los más necesitados. Lo que queremos destacar también es el altruismo y la empatía que los políticos republicanos, los profesionales de la medicina y educativa desplegaron para ayudar, en épocas de crisis, a las personas más necesitadas de Castellón. 


\section{FUENTES Y BIBLIOGRAFÍA}




\section{ARCHIVOS Y FUENTES}

ARCHIVO CENTRAL DEL MINISTERIO DE EDUCACIÓN Y CULTURA DE MADRID:

Primer Congreso Español de Higiene Escolar. Declarado oficial por Real Decreto de $1^{\circ}$ marzo de 1912.

DELOBEL, Jules (1876): Higiene escolar. Traducción de Avilés Rodríguez, Ángel, médico de la Beneficencia municipal de Cartagena. Saturnino Calleja, Madrid.

RODRIGUEZ LÓPEZ, Isaac (1915): Apuntes de Higiene General comprendiendo la Higiene-Escolar. Tipo-Litografía Auber y Pla, Barcelona.

ROSADO FERNÁNDEZ, Juan (1913): Tratado Enciclopédico de Higiene y terapéutica Escolar, Doméstica y Social. Tipografía de G. Casañal, Zaragoza.

MARISCAL Y GARCÍA, Nicasio (1888): Higiene de la vista en las Escuelas. Editorial El Cosmos. Madrid.

MASIP BUDESCA, Eduardo (1910): Higiene Escolar. Tip. y Tap. M. Payá y compañía, Zaragoza.

-(1912): Memoria presentada a los Excmos. Sres. Ministro de Instrucción Pública y Bellas Artes y Director General de Primera Enseñanza. Imprenta y Litografía de Policarpo Sáez, Madrid.

-(1913): Memoria presentada a los Excmos. Sres. Ministro de Instrucción Pública y Bellas Artes. Director General de Primera Enseñanza y Alcalde presidente del Excmo. Ayuntamiento de esta Corte. Imprenta litográfica de Policarpo Sáez, Madrid.

MIRÓ LAPORTA, Vicente (1899): Higiene y Educación del niño, Librería de Victoriano Suarez, Madrid.

ARCHIVO CENTRAL DEL MINISTERIO DE EDUCACIÓN DE ALCALÁ DE HENARES

Expedientes personales de Catalino Alegre, Francisco Domenech y Antimo Boscá.

\section{ARCHIVO DE LA DIPUTACIÓN PROVINCIAL DE CASTELLÓ:}

Boletín Oficial de la Provincia Castellón. Años 1885, 1890, 1918.

«Proyecto del Hospital Provincial de Castellón de la Plana», Manuel Montesinos. Doc. I, 9 de marzo de 1882.

Colecciones fotográficas, y Archivo Más.

ARCHIVO MUNICIPAL DE CASTELLÓN: 
Actas del Ayuntamiento de Castellón. Años: 1880, 1883, 1884, 1885, 1909, 1918

Expedientes de Instrucción Pública correspondientes a los centros escolares de Castellón desde 1880 a 1930.

Expedientes de solicitud de permisos de obras, desde 1880 a 1930.

Guía oficial de Castellón y Provincia, de 1890 a 1920,

Ordenanzas de urbanismo e higiene de la Capital.

La Escuela, 1913, 1915, 1916, 1918.

El Clamor, 1880, 1881, 1882, 1883,1884, 1885, 1886, 1887, 1888, 1889, 1890, 1896, 1909, 1910, 1912, 1913, 1914, 1915, 1916, 1917, 1918

La Provincia, 1880, 1882, 1883,1884, 1885, 1886, 1888, 1889, 1890

El Heraldo de Castellón, 1895, 1896, 1918

Revista de Castellón, 1882, 18841887.

Revista Médico-Farmacéutica. Años: 1881, 1884, 1885.

La Cruz de Castellón, 1909.

El Cruzado, 1909.

Diario de la Plana, 1898.

La Verdad. 1889.

ARCHIVO HISTÒRICO DE LA BIBLIOTECA MUNICIPAL DE CASTELLÓN:

Boletín de Estadística Municipal de Castellón 1918-1921.

RIBERA GÓMEZ, Emilio (1897): Elementos de Historia Natural. (5 $5^{\mathrm{a}}$ ed.). Imprenta de Manuel Alufre, Valencia.

ARCHIVO HISTORICO DEL INSTITUTO DE ENSEÑANZA MEDIA DE CASTELLÓN

Memorias del Instituto de Enseñanza Media años: 1863-1903

Expedientes personales de Domingo Herrero, Catalino Alegre, Francisco Domenech, Antimo Boscá, Antonio Maylin...

Fuentes legislativas:

Decreto de 3 de junio de 1873. Colección Legislativa de 1873. Colección Legislativa de España de 1873.t. CX.

Real Decreto de 26 de febrero de 1875. Colección Legislativa de Instrucción Pública de 1875. 
Compilación Legislativa de Instrucción Pública. Tomo II. (1878): Primera Enseñanza. Imprenta de T. Fortanet, Madrid.

Real Decreto de 12 de abril de 1901. Colección Legislativa de España de 1901, vol. $2^{\circ}$.arts. 3-5.

Planos originales y Memorias técnicas del Instituto de Enseñanza Media.

Consulta del libro de texto de Ciencias Naturales: PEREDA Y MARTÍNEZ, Sandalio (1870): Programa razonado de un curso de Historia Natural con nociones de Fisiología e Higiene. $5^{\text {a }}$ Edición. Imprenta de A. Gómez Fuentenebro, Madrid.

\section{ARCHIVO HISTORICO DEL COLEGIO DE MÉDICOS DE CASTELLÓN}

Registro General de Colegiados. Tomo I números 1-500.

ARCHIVO HISTÓRICO DEL AYUNTAMIENTO DE LUCENA DEL CID.

Planos y croquis del emplazamiento de la «Casa hospedaje» de las colonias escolares castellonenses.

CENTRO DE DOCUMENTACIÓN DE RECUPERACIÓN DE LA MEMORIA HISTÓRICA DE LA UNIVERSIDAD JAUME I

Legajo 318 b, expediente 33 .

Centro Documental de la Memoria Histórica de Salamanca. Justicia. Expedientes de Causas. Sumario 1374-44 contra Vicente Gea Mariño por delitos de Masonería.

INSTITUTO NACIONAL DE ESTADÍSTICA DE CASTELLÓN:

Anuario Estadístico: 1869, 1870, (1882-1901), (1886-1892), 1900, (1901-1915), 1902, 1903, 1904, 1905, 1910, 1919.

ARCHIVO HISTÓRICO DEL COLEGIO TERRITORIAL DE ARQUITECTOS DE CASTELLÓN

Tipos de viviendas en distinto barrios de la ciudad de Castellón.

Visita a las viviendas de labradores del barrio de San Félix, y casas burguesas del siglo XIX-XX en la calle Mayor y calle de Enmedio.

\section{LIBROS Y REVISTAS}

ABAD GARCÍA, Vicente (1984): Historia de la naranja, 1781-1939: Comité de la Gestión de la Exportación de Frutos Cítricos, Valencia. 
ABAD, Vicente (1992): «El crecimiento capitalista», en CHUST, Manuel (direc.): Historia de Castellón, Levante de Castellón, p.562

AGUILAR RÓDENAS, Consol (1986): La educación en Castellón a ravés de la Prensa (1868-1900). Diputación Provincial de Castellón.

ALVAREZ RICART, María del Carmen (1988): La mujer como profesional de la medicina en la España del siglo XIX. Anthropos, Barcelona.

ALBARRACIN TEULÓN, Agustín. (1983): La teoría celular, Alianza Editorial. Madrid.

ALBARRACÍN TEULÓN, Agustín (1988): «Las ciencias biomédicas en España de 1800 a 1936». En SÁNCHEZ RON, José Manuel, (ed.). Ciencia y sociedad en España CSIC, Madrid.

ALBARRACÍN TEULÓN, Agustín (1993):«Las Ciencias Médicas». MENÉNDEZ PIDAL, Ramón: Historia de España tomo XXXIX. La edad de plata de la cultura española (1898-1936) Identidad. Pensamiento y Vida. Hispanidad. Espasa Calpe, Madrid.

ALVAREZ RICART, María del Carmen (1988): La mujer como profesional de la medicina en la España del siglo XIX. Anthropos, Barcelona.

ARCHILES CARDONA, Ferrán (2002): Parlar en nom del poble. Cultura política, discurs i mobilització social al republicanisme castellonense (1891-1909). Excmo. Ajuntament de Castelló de la Plana.

ALTAVA RUBIO, Vicenta (1993): Aportaciones al estudio de la Enseñanza Media en Castellón (1846-1900). Tesis inédita. Universidad de Valencia. Facultad de Filosofía y Ciencias de la Educación. Departamento de Educación comparada e Historia de la Educación. Valencia.

AGUILAR RODENAS, Consol (1986): La educación en Castellón a través de la Prensa (1868-1900), Diputación de Castellón.

ARNICHES, Carlos (1933): «Sección preparatoria del Instituto Escuela de Segunda Enseñanza-Madrid», en A.C.9. Revista Trimestral. Publicación del G.A.T.E.P.A.C. (1933), año III. Barcelona. Madrid. San Sebastián.

BÁGUENA CERVELLER, María José, «La enfermedad y su prevención», en Historia de la Medicina Valenciana. Tomo III.

BARONA VILAR, Josep Lluis. (2002): Salud, enfermedad y muerte. La sociedad valenciana entre 1833 y 1939. Institució Alfons el Magnanim, València. 
-(2007): José Chabás Bordehore (1877-1963). Tuberculosis y Medicina Social en la Valencia del primer tercio del siglo XX. Consell Valencià de Cultura, Valencia.

-(2007): « ¿Por qué mueren los niños? El debate ideológico sobre la salud infantil en la sociedad española (1904-1939)», en Campos, Ricardo y otros (eds.): Medicina, Ideología e historia en España (siglos XVI-XXI), Consejo Superior de Investigaciones Científicas, Madrid.

BARONA VILAR, Carmen (2006): Las políticas de la salud. La sanidad valenciana entre 1855-1936.Universitat de València.

BARONA VILAR, Josep Lluis y BERNABEU MESTRE, Josep (2008): La salud y el Estado. El movimiento sanitario internacional y la administración española (1851-1945). Universitat de Valéncia.

BALBÁS, José Antonio (1882) «La higiene pública en Castellón durante los tiempos pasados y saneamiento del cuadro», en Revista de Castellón, 1882.

BALAGUER I PERIGUELL, Emili (1996): Balmis o L'esperit de la Il. Ilustració en la medicina española, Generalitat Valenciana, Valencia.

BELTRAN I FOS, Enric (1984): L'arròs. Institució Alfons el Magnanim, Valencia.

BELLÉS MATEU, Joan F: El Paisatge del Desert de las Palmes: la seua imatge cultural (1900-1936). Boletín de la Sociedad Castellonense de Cultura. Tomo LXXXI. Enero- Junio 2005. Cuad. I-II.

BELLÉS, Salvador (2012): «Seres humanos de Castellón. Operador de leyenda en años de epidemias en elperiodicomediterraneo.com/.../seres-humanos-de-castellonpor-salvador-belles-operador-de-ley... Última entrada 30/10/2012.

BELLIDO BLASCO, Juan Bautista (2012) «Remembranza: Juan bautista Bellido Tirado Castellón 20/8/1878 - 18/11/1952: médico y decano del Hospital Provincial de Castellón». En www.memoriacastello.cat/11050603.html. Última entrada $30 / 10 / 2012$.

BERNAL. Miguel Antonio y PAREJO BARRANCO, Antonio (2001): La España liberal (1868-1913). Síntesis, Madrid.

BURRIEL DE ORUETA, Eugenio (1971): «Desarrollo urbano de Castellón de la Plana, en Estudios geográficos, nº XXXII, Madrid, Revista Saitabi. 
CABANILLES, Antonio Josef (1975): Observaciones sobre la historia natural, geografía, agricultura, población y frutos del Reino de Valencia Tomo I, Biblioteca Valentina. [Edición facsímil del original. Madrid: Imprenta Real, 1795,1797].

CATALÁ SALA, José. (1987). Ideología y ciencia biológica en España entre 1860 y 1881. La difusión de un paradigma. CSIC, Madrid.

CAMPOS, Ricardo; MONTIEL, Luis; HUERTAS, Rafael (coordinadores): (2007): Medicina, Ideología e Historia en España (SIGLOS XVI-XXI). Consejo Superior de Investigaciones Científicas. Madrid.

CAPITAN DÍAZ, Alfonso (1994): Historia de la educación en España. Tomo II. Pedagogía contemporánea. Dykinson, Madrid.

CARRERAS, Albert y TAFUNELL, Xavier (Coords.) (2005): Estadísticas históricas de España. Vol. I. siglos XIX-XX. Fundación BBVA, BILBAO.

COLEGIO OFICIAL DE MÉDICOS DE CASTELLÓN (2000), Libro del I Centenario.

COSSIO, Manuel Bartolomé: «Idilio pedagógico», en La Escuela Moderna, 1899, T.I.

CHILLIDA MELIÁ, Joaquín (1882): Higiene de las escuelas. Centro editorial de la Asociación Tipográfica, Castellón.

CRUZ, J. Ignacio (1991): Las colonias escolares valencianas (1906-1936), Institut València de la Juventut, València.

CLEVELAND, P. HICKMAN (1967): Principios de Zoología. Ediciones Ariel, Barcelona.

DELGADO CRIADO, Buenaventura (1994): Historia de la educación en España y América. La educación en la España contemporánea (1789-1975). Volumen 3. Morata, Madrid.

DELOBEL, Jules (1876): Higiene escolar. Traducción de Avilés Rodríguez, Ángel, médico de la Beneficencia municipal de Cartagena. Saturnino Calleja, Madrid.

ESTEBAN, León (1997): «Introito a la Historia de la Escuela», en Historia de la Educación. Revista interuniversitaria. Ediciones Universidad, Salamanca.

FERNÁNDEZ SORIA, Juan Manuel (2011): De las negras bombas a las doradas naranjas. Colonias Escolares 1936-1939, en ESCRIVÁ MOSCARDÓ, Cristina y MAESTRE MARÍN, Rafael. Eixmam Edicions, Valencia. 
FERNÁNDEZ SANTARÉN, Juan Antonio. (2014): Santiago Ramón y Cajal. Epistolario. La Esfera de los Libros, Madrid.

GARCÍA BARRENO, Pedro (1998): «La medicina española hacia su modernización» SANCHEZ RON, José Manuel ed.: Un siglo de ciencia en España. Consellería de Cultura y Ciencia. Valencia.

GARCÍA-FARIA DEL CORRAL, Francisco Javier (1995): La epidemia de gripe de 1918 en la provincia de Zamora. Estudio estadístico y social. Instituto de Estudios Zamoranos «Florian Ocampo» Diputación de Zamora. Salamanca.

GARRIDO, Samuel (1986): Los trabajadores de la derecha. Diputación de Castellón, Castellón.

- (2004): Canem gentil. L’evolució de les estructures agràries a la Plana de Castelló (1750-1930), Excm. Ajuntament de Castelló.

GIEDION, S (1980): Espacio tiempo y arquitectura, editorial, Dossat, S.A. Madrid.

GIMENO MICHAVILA, Vicente. (1984). Del Castellón Viejo. Publicaciones de Seminario de Estudios Económicos y Sociales de la Caja de Ahorros y Monte de Piedad de Castellón.

GIORDAN, A; RAICHVARG, D; DROUIN, J. M.; GAGLIARDI, R; CANAY, A. M. (1988); Conceptos de Biología. 1. La respiración. Los microbios. El ecosistema. La neurona. Labor, Madrid.

GIORDAN, André; HOST, Víctor; TESI, Delfo; CAGLIARDI, Raúl. (1988): Conceptos de Biología 2. La teoría celular. La fecundación los cromosomas y los genes. La evolución. MEC Y Labor, Madrid, Barcelona.

GIRALT I RAVENTÓS, Emili (1968): «Problemas históricos de la industrialización en Valencia», en Estudios Geográficos. Instituto Juan Sebastián Elcano. Madrid, agosto-noviembre.

GOMIS BLANCO, Alberto (1989): Las Ciencias Naturales en el siglo XIX (1833-1874): Morfología, Fisiología y Sistemática. Universidad Complutense de Madrid, Madrid.

GUINOT RODRIGUEZ, Enrique y SELMA CASTELL, Segi (2002): Las acequias de la Plana de Castelló. Camins D’Aigua. El Patrimonio Hidráulico Valenciano. Generalitat Valenciana. 
HERNÁNDEZ NIEVES, Purificación (2009): La Evolución de las Ciencias Naturales en la Segunda Enseñanza Española (1836-1970) Universidad de Extremadura, Cáceres.

KRAEPELIN-SCHÄFFER. (1942); Curso y prácticas de Biología. Para uso de las Escuelas superiores y para la Enseñanza autodidáctica, Labor, Barcelona.

ESTEBAN, León (1997): "Introito a la Historia de la Escuela", en Historia de la Educación. Revista interuniversitaria. Ediciones Universidad, Salamanca.

LÓPEZ PIÑERO, José María y NAVARRO BROTONS, Víctor (1995): Historia de la Ciencia al País Valencià. Alfons el Magnanim. Valencia

LÓPEZ PIÑERO, José María. (2002): La medicina en la historia. La esfera de los libros, Madrid.

-(2006): Santiago Ramón y Cajal. PUV, Valencia.

LÓPEZ PIÑERO, José María y TERRADA FERRANDIS, María Luz (2007): El libro médico y biológico valenciano (siglos XV-XIX). Generalitat Valenciana, Valencia.

-(2008): Charles Darwin. Universidad de Valencia, Valencia.

-(2008): El Darwinismo valenciano del siglo XIX y su fundamento histórico. (1909-2009). Homenaje a Darwin de los estudiantes de medicina valencianos. Primer centenario. Consell Valencià de Cultura, Valencia.

-(2009): Facsímil de Tribuna Médica dedicado a Charles Darwin. Consell Valencià de Cultura. Valencia.

LÓPEZ PIÑERO, José María y BUENO CAÑIGRAL, Francisco Jesús (2009): Segundo Centenario de la Real Expedición Filantrópica de la Vacuna de la Viruela 1803-2003, Consell Valencià de Cultura, Valencia.

LLASOLA GIL, Gerard (2006): Republicanisme, identitat popular i hegemonía municipal. Castelló de la Plana, (1913-1917). Publicaciones de la Universitat Jaume I

LLOP VIDAL, Enric (Coord.) (1996): Guía de arquitectura. Castelló. Diputació de Castelló, Castelló.

MADOZ, Pascual (1982): Diccionario Geográfico estadístico-histórico de Alicante, Castellón y Valencia, Institución Alfonso el Magnánimo, Valencia, T.1. [Edición facsímil del original, 1845].

MARISCAL Y GARCIÁ, Nicasio:(1888): Higiene de la vista en las Escuelas. Editorial El Cosmos. Madrid. 
MASIP BUDESCA, Eduardo (1910): Higiene Escolar, Tip. y Pap. M Payá y comp ${ }^{\mathrm{a}}$, Zaragoza.

-(1912): Memoria presentada a los Excmos. Sres. Ministro de Instrucción Pública y Bellas Artes y Director General de Primera Enseñanza. Imprenta y Litografía de Policarpo Sáez, Madrid.

-(1913). Memoria presentada a los Excmos. Sres. Ministro de Instrucción Pública y Bellas Artes. Director General de Primera Enseñanza y Alcalde presidente del Excmo. Ayuntamiento de esta Corte. Imprenta litográfica de Policarpo Sáez, Madrid.

MARTÍ Manuel (1992): «La Restauración», en ORTELLS CHABRERA, Vicente (Dir.), La Ciudad de Castellón, Ayuntamiento de Castellón.

MARTIN LÓPEZ, Ramón (1997): «La construcción y creación de escuelas en la España del primer tercio del siglo XX», en Historia de la Educación. Revista interuniversitaria. Ediciones Universidad, Salamanca.

MARTÍNEZ NAVARRO, Joan Ferrán (2009): «Lepra y salud pública en España» en COMES IGLESIA (Dir.): Cuidados y Consuelos. Cien años de Fontilles. Generalitat Valenciana, Valencia.

MÁS TORRECILLA, Vicente Javier (1997): El Hospital Provincial. Proyecto inconcluso. Aproximación histórica. Diputación de Castellón.

MATEU TORTOSA, Enric. (1987): Arroz y paludismo. Riqueza y conflictos en la sociedad valenciana del siglo XVIII. Edicions Alfons el Magnànim. València.

MAYORDOMO, Alejandro (2007): «Regeneracionismo y educación: La construcción pedagógica de la sociedad y la política», en SALAVERT, Vicente, SUÁREZ CORTINA, Manuel eds. (2007): El regeneracionismo en España. Universidad de Valencia.

MIRÓ LAPORTA, Vicente (1899): Higiene y Educación del niño, Librería de Victoriano Suarez, Madrid.

MONFERRER GUARDIOLA, Rafael: «El cólera de 1855 y 1885 en Castellfort. Recuerdo médico, aspectos sociales y estudio epidemiológico». Estudis Castellonencs n 4, Diputación de Castellón 1987-1988.

MONLLEÓ PERIS, Rosa (1996): La Gloriosa en Valencia (1864-1868). Edicions Alfons el Magnànim. Generalitat Valènciana, Valencia. 
-(1992): «Del Sexenio Democrático a la Guerra Civil», en Ortells Cabrera, Vicente (Coord.): La ciudad de Castellón de la Plana. Excmo. Ayuntamiento de Castellón de la Plana. Castellón.

-(1996): «1822. Castelló, capital de provincia» en Ortells Cabrera, Vicente (Coord.): La ciudad de Castellón de la Plana. Excmo. Ayuntamiento de Castellón de la Plana. Castellón.

MOSER, Werner M. (1933): «La escuela como construcción funcional» en A.C. 9. Revista Trimestral. Publicación del G.A.T.E.P.A.C. (1933), Año III. Barcelona. Madrid. San Sebastián.

MCLESTER, A. Lee. (1973): La historia de la vida, Omega, Barcelona.

NADAL OLLER, Jordi (1976): La población española, siglos XVI-XX. Ariel, Barna.

NUÑEZ, Clara Eugenia ((2005): «Educación», en CARRERAS, Albert y TAFUNELL, Xavier (Coords.): Estadísticas Históricas de España. Siglos XIX - XX. Volumen I. Fundación BBVA, Bilbao.

ORDOÑEZ, Javier; NAVARRO, Víctor; SÁNCHEZ RON, José María (2007): Historia de la Ciencia. Espasa Calpe, Madrid.

PADILLA BOLIVAR, Antonio (1974): «La gripe de 1918. Veintiún millones de muertos», Historia y vida, $\mathrm{n}^{\circ} 72$, Madrid.

PATUEL CHUST, Pascual y OBIOL MENERO, Emilio (1887): «La gripe de 1918 en Vila-Real. Reconstrucción temporal y análisis demográfico». Boletín de la Sociedad Castellonense de cultura. Tomo LXIII. Enero-Marzo.

PEÑIN IBAÑEZ, Alberto (1978): Valencia 1874-1959 Ciudad, arquitectura y arquitectos, ETSAV.

PENIIN, Alberto.; GRANDE, Francisco, VARELA, Santiago. (1988): «Arquitectura y Urbanismo», en AGUILERA CERNI, Vicente (coord.) Historia del Arte valenciano. El siglo XX hasta la guerra del 36, T.6, Consorcí D’Editors Valencians, S.A.

PERDIGUERO, Enrique y otros (2007):«La propaganda sanitaria en España en la II República: La Sección de Higiene Social y Propaganda de la Dirección General de Sanidad», en Campos, Ricardo y otros (Coord.): Medicina, Ideología e historia en España (siglos XVI-XXI), CSIC, Madrid. 
PEREYRA, Miguel (1982): «Educación, salud y filantropía: el origen de las colonias escolares de vacaciones en España», en Revista Interuniversitaria, $\mathrm{N}^{\circ} 1$.

PÉREZ MOREDA, Vicente (1980): «La crisis de mortalidad en la España interior. Siglos XVI. XIX, Siglo veintiuno de España, Madrid.

PERIS TORNER, Juan (1994): Tren a vapor entre Onda y el Grao de Castellón de la Plana, Ayuntamiento de Castellón.

PEVSNER, Nikolaus (1980): Historia de las tipológicas arquitectónicas, editorial Gustavo Gili. S.A., Barcelona Pero el sanatorio más paradigmático que recoge estos planteamientos, es el de Paimio (1929-33), en Finlandia, del Arq. Alvar Aalto, en S. Giedion, Espacio tiempo y arquitectura, editorial, dossat,s.a. Madrid 1980, pg. 608.

PIQUERAS ARENAS, José Antonio (2013): «El lento paso hacia la modernidad: economía y transformaciones desiguales en el siglo XIX», en AGUILAR CIVERA, Inmaculada (coord.) Castellón, un territorio en comunicación: de la diligencia al TRAM, Valencia, Consellería d'Infraestructures, Territori i Medi Ambient, Generalitat Valenciana.

PUBLICACIÓN DEL G.A.T.E.P.A.C. (1933). Revista trimestral, año tercero, primer trimestre, Barcelona.

QUÉNEL, Philippe y DAB, William (1994): «Las epidemias de gripe», Mundo Científico, $\mathrm{N}^{\mathrm{o}} 152$, Vol. 14.

RODRIGUEZ LÓPEZ, Isaac (1915): Apuntes de Higiene General comprendiendo la Higiene-Escolar, Tipo-Litografía Auber y Pla, Barcelona.

ROMEU ALFARO, Fernanda (1964): «La crisis de 1917 y sus consecuencias económicas y sociales en la Región Valenciana». Saitabi, nº XIV.

ROSADO FERNÁNDEZ, Juan. (1913): Tratado Enciclopédico de Higiene y Terapéutica Escolar, Doméstica y Social, Tipografía de G. Casañal, Zaragoza.

REINHARD-ARMENGAUD (1966): Historia de la población mundial. Ariel, Barna.

RUIZ RODRIGO, Cándido (1997): «Maestro, Escuela y Sociedad (de la Restauración a la II República», en Historia de la Educación, Revista interuniversitaria. vol. 16, Universidad de Salamanca.

SAIZ PASTOR, Candelaria y VIDAL OLIVARES, Javier (2001): El fin del Antiguo Régimen (1808-1868). Economía. Síntesis, Madrid. 
SALA CATALÁ, Javier (1987): Ideología y ciencia biológica en España entre 1860-1881. La difusión de un paradigma. Consejo Superior de Investigaciones Científicas. Madrid.

SALAVERT, Vicente, SUÁREZ CORTINA, Manuel (eds.) (2007): el regeneracionismo en España. Política, educación, ciencia y sociedad. Universitat de València.

SANCHEZ ADELL. José (1949): El Gobernador Bermúdez de Castro. Notas para el estudio de una época en Castellón: 1791-1807. B.S.C.C., t. XXV.

SÁNCHEZ GIMÉNEZ, José (1984): «La población, el campo y las ciudades» en Menéndez Pidal, Ramón: Historia de España. Los comienzos del siglo XX. La Población, La Economía, La Sociedad (1898-1931). Vol. XXXVII, Espasa Calpe, Madrid.

SÁNCHEZ GOZALBO, Ángel (1919): Contribución al estudio de la gripe de 1918 en la provincia de Castellón. Hijos de Armengot, Castellón.

SANCHEZ RON, José María. (1988): Ciencia y sociedad en España. Consejo Superior de Investigaciones Científicas. Madrid.

SÁNCHEZ SANTIRÓ, E. (1998). Cientifics i Professionals. La Facultad de Ciències de Valencia (1857-1939) Universidad de Valencia.

SARTHOU CARRERES, Carlos (1915): Geografía General del Reino de Valencia, Editorial Alberto Martín, Barcelona.

SEGARRA BLASCO, Agustí (1986): «Evolució demográfica de Castelló de la Plana (1857 - 1936). Boletín de la Sociedad Castellonense de Cultura. Tomo LXII. Castellón Abril.

SENENT IBÁÑEZ, Juan José: Memoria de la Primera Colonia Escolar Castellonense en Lucena del Cid. 20 de julio a 20 de agosto de 1915. Castellón, Imp. Joaquín Barbera.

SIMO, Trinidad ((1973): La arquitectura de la renovación urbana en Valencia, Albatros Ediciones, Valencia.

SORIANO MARTÍ, Javier y PONS CHUST, Raül (2014): «La Panderola, patrimonio de la Plana. 125 años configurando el paisaje (1888-2013)», 18 Cuadernos del Museo del Transporte de la Comunidad Valenciana, Valencia, Generalitat Valenciana. 
SOS PARADINAS, Alejandro (2013): Biografía del profesor Dr. D. Vicente Sos Baynat. Diputación de Castellón, Castellón.

TATON, René Direc. (1973): Historia General de la Ciencias. Vol. III «La Ciencia contemporánea I El siglo XIX» Destino, Barcelona.

TORRES BALBAS Leopoldo (1968):«La Edad Media», Resumen Histórico del urbanismo en España, Instituto de Estudios de la Administración Local, Madrid.

USÓ i ARNAL. Joan Carles, (1982): La masonería castellonense contemporánea (1874 - 1939). Tesina de Licenciatura inédita. Universidad de Valencia. Facultad de Geografía e Historia.

VALLS TORLÁ, Javier; LLANSOLA GIL, Gerard; MOLLEÓ PERIS, Rosa (2003): Rumbo al progreso el puerto de Castelló a través de la historia, VALLS TORLÁ Javier (coord.), editores Lunwerg.

VARIOS (1984): Diccionario terminológico de ciencias médicas. Salvat, Barcelona.

VEGA GIL, Leoncio (1997): «Pedagogía Institucionista y educación social en Castilla León». Historia de la Educación. Revista interuniversitaria. Universidad de Salamanca. Núm. 16.

VIÑAO FRAGO, Antonio (1982): Política y educación en los orígenes de la España contemporánea. Examen especial de sus relaciones en la enseñanza secundaria. Siglo XXI de España Editores, Madrid. 


\section{APÉNDICE DOCUMENTAL}




\section{LA CASA DEL LABRADOR EN EL VIEJO RAVAL}

Dentro del barrio del Raval de San Félix y partiendo de una parcelación bastante regular (la mayoría de las parcelas tienen de 3 a $4 \mathrm{~m}$. de anchura, con fachada a una sola calle, por 20 a $25 \mathrm{~m}$. de profundidad), existían y existen para un mismo tipo de viviendas de labrador, una amplia gama de variantes, que se originan como consecuencia de las distintas situaciones económicas y sociales de los propietarios.

Tomaremos como objeto de este pequeño estudio una vivienda de llaurador artesá (aquél que poseía pequeñas fincas que trabajaba él mismo, es decir la clase media del labrador entre el pobret y el ric) construida hacia 1870, debiendo destacar, en primer lugar, que en toda la concepción prima tanto su utilidad de cara a la actividad agrícola de sus moradores, como su función de hogar de los mismos.

La edificación se desarrolla en cada planta de forma extremadamente longitudinal entre los muros medianeros, como consecuencia de la forma alargada de las parcelas. Así en planta baja se suceden una serie de espacios articulados a través de una gran puerta de madera con anchura suficiente para permitir el paso del carro de labranza hacia el interior; en su parte inferior y delantera de ella se colocaban los guardarrodes, elementos de piedra, con rica diversidad de formas, que impedían que los extremos de los ejes del carro rozaran las jambas de la puerta. Tras la puerta se encuentra un amplio espacio denominado entrà de carro, tanto en él como en todo el paso que pisa la caballería el suelo se realiza con tierra apisonada, si bien junto a la pared del pasillo corre una faja pavimentada con baldosas rojas sobre la que se alineaban las sillas de pino, utilizadas en las tertulias de la calle. Excavado en el centro de este recinto y bajo una tapa de madera se hallaba la sicha o balsa, cuyo fin era conservar frescas las balas de cáñamo, el trigo y otros productos; en techo y anclado a un cabiró se colocaba una anilla a modo de polea para facilitar el manejo de los productos que se almacenan en la balsa. En otras partes del mismo techo se colgaban melones, tomates, calabazas, maíz y otros frutos para su mejor conservación. Tras la primera puerta interior de doble hoja, nos encontramos con la pastera, cuarto de reducidas dimensiones donde se amasaba el pan en una artesa o pastera de madera. Más adelante hallamos el comedor, con su característico llar graciosamente alicatado; en el lado opuesto de la estancia se ubicaba, 
dentro del muro medianero, una alacena realizada en madera y vidrio, para guardar l'obra o vajilla de diario.

Seguidamente nace la escalera, de tres tramos, con ojo central para permitir el izado de los productos agrícolas que se almacenaban en la última planta, realizada con bóveda de ladrillo y pavimentada con baldosas rojas y blancas esmaltadas con mamperlan de madera; barandilla de fábrica, rematada en yeso y curvada suavemente en cada cambio de sentido de los peldaños, formando un conjunto continuo habitualmente alabeado rematado por un pasamanos redondeado y pintado en distinto color. Bajo la escalera se ubica el rebost, especie de despensa donde se guardaban las tinajas de aceite y el frito. Enfrente justo del inicio de la escalera se abre un hueco en el muro donde aparecía siempre un botijo con agua fresca.

$\mathrm{Al}$ interior de la escalera existe un pequeño dormitorio y más allá un cuarto para cubas llenas de buen vino traído del trull, donde los hombres pisoteaban la uva hasta exprimirle todo su jugo.

Pasando una amplia puerta entramos en la cuina, abierta en su parte superior a un patio por el que penetra la luz, el aire limpio y el agua de lluvia. En un ángulo se encuentra la cocina de leña y su campana de humos, cercano a ésta se hallaba el fornal donde se calentaban grande recipientes de agua destinada a la colada o a la matanza; a su lado, el fregadero, y enfrente, el canterer, armario empotrado que contenía los cántaros de agua traída desde la fuente. De la cocina nacía una rustica escala de mano que conectaba directamente con la planta superior. Las paredes de la cocina, así como las del pasillo y las del comedor están artísticamente alicatadas hasta la altura de la vista, mientras que el pavimento, donde existe, es de losas.

La cocina conecta directamente a través del paso con la cuadra, encontrándose entre ambas el retrete. En la cuadra, junto al pesebre y la porquera, nace una escalera de mano para subir a la pallissa. Por último, tras una puerta encontramos un pequeño patio posterior, por el que, en este caso concreto, circulaba el agua de una acequia.

En planta primera a fachada se disponía el dormitorio principal que se abre a la calle a través de un balcón con barandilla de hierro forjado; entre éste y la escalera existe una alcoba generalmente utilizada como dormitorio de los niños.

Al otro lado de la casa se sitúa una tercera estancia con salida a una galería cubierta y abierta al patio que se abre a la cocina; esta galería en forma de L, se utiliza en algún caso para trabajos artesanos, como la carpintería, debido a su amplitud y buena 
situación. A través de ella se accede a la pallissa donde se guardaba la paja y el alimento de los animales, además de otros utensilios y aperos de labranza; en el suelo de la misma existía un agujero por donde se vertía directamente la paja sobre el pesebre.

Por la escalera principal se accede a la planta segunda, a modo de desván, utilizada para almacenar todo tipo de productos del campo, algarrobas, patatas, arroz, maíz, o los melones verdes y amarillos que se colgaban del techo y de las paredes. En la parte posterior se abre una amplia terraza en torno al patio interior.

Mediante una escalera de pronunciada pendiente se accede al sostre, espacio abuhardillado empleado como pequeño almacén agrícola.

El sistema constructivo se desarrolla entre los muros medianeros formados de mamposteria tradicional con aglomerante de mortero de cal; sobre ellos se apoyan los diferentes forjados y la cubierta. Las vigas son de madera de sección rectangular solventándose el entrevigado con revoltón cerámico sobre el cual se colocaba una capa de mortero de cal apisonada.

La cubierta es de dos aguas, resuelta con teja árabe sobre rayoles apoyadas en el entramado de madera; el encuentro de ésta con la fachada se solventa con un alero realizado con un escalonamiento de ladrillos enfoscados y pintados.

La composición de fachada es coherente con la sobriedad del resto de la casa; en el grueso muro se abre la puerta de entrada en planta baja, la puerta balconera en el primer piso y una pequeña ventana en la segunda planta; la carpintería es de maderas nobles, siendo las persianas también de lamas de madera con trabajado remate superior. El acabado de fachada se realiza a base de enfoscado de mortero pintado en colores y tonos suaves.

Es de destacar que a pesar de la ausencia de pretensiones teóricas o estéticas y desde el criterio de la mejor utilización del reducido espacio disponible, la casa que se ha descrito posee una riqueza espacial extraordinaria, conseguida mediante adecuada utilización de elementos que hoy son de plena actualidad en la composición arquitectónica moderna.

Sirva este sencillo artículo como incentivo a la recuperación si no de un modo de vida inevitablemente superado si de una sobria arquitectura tradicional ligada muy directamente a él y de la que la casa del labrador es un magnífico ejemplo. 


\section{ACTA DEL ANÁLISIS DE LOS LÍQUIDOS ATENUADOS DEL MICROBIO DEL CÓLERA}

A continuación La Provincia inserta el acta donde se puede juzgar la importancia del análisis microscópico verificado:

«Acta.- En la ciudad de Valencia, a 4 de junio de 1885 y hora de las diez y media de la mañana, constituidos en la sala de profesores de la facultad de medicina de esta ciudad todos los señores que compone la comisión científica nombrada por real orden de 28 del mes anterior (mayo) con el fin de estudiar la profilaxis del cólera del Dr. Ferrán, y con asistencia de este señor y de sus ayudantes el doctor D. Amalio Gimeno y el licenciado en ciencias químicas-físicas D. Inocente Pauli, los agregados a la comisión, Sres. D. Vicente Cabello, D. Anacleto Cabezas, D. Antonio Frean, el ayudante del Dr. Mendoza, D Manuel Romera, y por último, el doctor Eduardo de la Granja, representante del Gobierno de los Estados-Unidos de América; el Dr. D. Rafael Tunon, del Ayuntamiento de Sevilla, y D. Félix Michelena, con Tomas Acha, de la Diputación provincial de Guipúzcoa; el delegado del señor ministro de la Gobernación, don Francisco Castellote, y el administrador, D. Antonio Guillem.

El presidente de la comisión científica, don Francisco Alonso Rubio, invita al doctor Ferrán a que presente los líquidos atenuados para la inoculación, con el objeto de demostrar que contienen los vírgulas del cólera. Dicho señor expone dos pequeños frascos, uno que se lacrará y servirá para las inoculaciones que hayan de practicarse, y el otro para el análisis químico, y ambas para el examen microscópico. Hecha por el señor presidente la elección del frasco que ha de servir para el análisis químico, el Sr. Ferrán marcó el otro por sí mismo.

El referido doctor presentó además dos frasquitos de líquidos preparados y esterilizados para que los individuos de la comisión puedan sembrar cultivos puros de vírgula y observar la evolución musiforme asignada por el Dr. Ferrán a este microbio. Admitidas por la comisión, esta, con todos los individuos presentes, se trasladó a la sala de disección, y los Sres. García Sola y Mendoza procedieron, con la intervención del Sr. Ferrán y sus señores ayudantes, el examen microscópico del líquido presentado al efecto. 
En este momento se presentan en el local los señores D. Francisco López Allue y D. Modesto Sánchez Ortiz, redactores de los diarios madrileños El imparcial y el Correo; los doctores y licenciados en Medicina D. Francisco Iñiguez de Montoya, D. Francisco Romero García y D. Manuel Furió, representantes de la diputación provincial de Albacete; D. Anastasio Gamero, de la de Toledo, y D. José María Castillo, de la de Murcia; D. José Aparicio, D. Federico Rubio, D. Pascual Martin Martin, D. Vicente Serrano Martínez, D. Mateo María Ginés, D. Francisco Campa y D. Rafael Pastor, decano y ayudante respectivamente de la facultad de Medicina. Del matraz modelo Ferrán, que contenía el cultivo profiláctico destinado al análisis químico se hicieron por los referidos doctores Ferrán, Mendoza y García Solá, auxiliados de los señores doctores Navas, Maeso y González Castro; preparaciones microscópicas, que se sometieron a examen de los concurrentes y que montadas han quedado a disposición de las comisión oficial, después de lacrada y sellada la caja en que se han depositado.

Al mismo examen microscópico y de igual naturaleza se sometió el líquido del matraz destinado a las inoculaciones; las separaciones de este líquido quedan también selladas y lacradas. A continuación, en un tubo de gelatina esterilizada, se sembraron con un estilete de platino las vírgulas del cultivo del segundo matraz, el cual quedó lacrado y sellado como las preparaciones anteriores. Penetra en la sala el Sr. D. Elías Martínez Gil, individuo de la comisión oficial.

Seguidamente se procedió a encerrar el matraz destinado al análisis químico, que contiene unos cincuenta gramos de líquido vacuna de Ferrán, cantidad que el doctor San Martin considera suficiente, dada la imposibilidad de emprender el análisis en una cantidad de varios litros. Y se dio por terminado el acto, de que certifico»:

El presidente, Francisco Alonso; el secretario, F. Castellote; Aureliano Maestre de San Juan.- (Siguen las firmas).

La Correspondencia de Valencia.

FUENTE: la Provincia, 4/0671885. 
CARTA DE UN MÉDICO NOTABLE, EL DOCTOR PULIDO, DIRIGIDA AL SR. ROBLEDO, MINISTRO DE LA GOBERNACIÓN SOBRE EL BRILLANTE RESULTADO QUE DA EN ALCIRA LA VACUNA FERRÁN.

[...] No abrumaré a V.E. con muchas cifras, para no aburrirle, ni traeré a cuento las que Algemesí, Alberique, Benifayó... y otros lugares presentan de su modesta cosecha, para defender la misma causa con iguales argumentos; pero sí le diré lo que enseña Alcira, ese pueblo memorable ya para siempre en los fastos de la medicina, por haberse prestado a la comprobación de la virtud anticolérica de la vacuna Ferrán.

Consta por declaración de todos el cuerpo médico de Alcira, a quien se debe estimar como uno de los más dignos y heroicos de nuestro país, que allí existe vacunado el 55,45 por 100 del censo de habitantes; es decir, más de la mitad de la población, y que desde $1^{\circ}$ de mayo hasta el 17 de junio, periodo en que la epidemia ha hecho sus mayores estragos, se ha conducido el cólera del modo que expresan las siguientes cifras, cuya exactitud nadie osará poner en duda, porque nadie ha podido alterarlas siendo fruto de un trabajo escrupuloso y honrado de los médicos todos de la ciudad.

Habitantes, 16.000 .

Inoculados, 3.664.

Reinoculados, 5.210 .

Total, 8.874, o sea el 55,46 por 100 .

Invasiones.-No inoculados, 192; inoculados, 24; reinoculados, 17.

Defunciones totales.- No inoculados, 102; inoculados, cinco; reinoculados, uno.

Idem para los cálculos de profilaxis.- No inoculados, 102; inoculados, uno; reinoculados, uno

Altas.-No inoculados, 75; inoculados, 18; reinoculados, 15

Existencias.- No inoculados, 15; inoculados, uno; reinoculados, uno.

Para no hacer confusa a V.E. esta enseñanza, me contraeré a decirle que casi todas las inoculaciones se hicieron entre fines de abril y principios de mayo, por lo cual las sutilezas y reparos sobre materia de tiempo deben variar poco las deducciones; pero aunque así no fuese, los datos sobre mortalidad, por su naturaleza, han de ser invariables 
siempre en sentido desfavorable. Vayamos, pues, a confrontaciones, las cuales son estas en cuentas honradas y sencillas:

$1^{\circ}$.Que entre la población inoculada hubo por debajo de una cuarta parte menos de invasiones que en la no inoculada, o sea el 21,26 por 100 (41 para 192).

$2^{\circ}$. Que la mortalidad absoluta de la segunda línea, aun estimándola así arroja una diferencia en los mismos periodos de la epidemia, de perecer entre los no inoculados cuatro veces más gente que entre los inoculados, o sea 102 para 192 invadidos de aquellos (el 53,25 por 100), y seis para 41 de estos (14,26 por 100).

$3^{\circ}$. Que eliminando de esta cifra de seis muertos entre 41 atacados los cuatro que no deben figurar para las averiguaciones de la profilaxis-por haber sido atacados los enfermos dentro de los cinco primeros días de la inoculación, plazo que Ferrán señaló desde el principio como necesario para asegurarse de que no había ya enfermedad contraída en el individuo; la mortalidad de los inoculados disminuye todavía hasta reducirse a una tercera parte, apareciendo solo fallecidos dos sujetos (uno inoculado y otro reinoculado) entre 41 invadidos, o sea 4,36 por 100 frente al 53,24 por 100 que arrojan los no inoculados. ¡Dato hermoso, consolador, trascendentalismo, que parece anunciar que el descubrimiento de Ferrán es verdadero! Porque no creo que de otro modo pueda explicarse que a las mismas alturas de epidemia den los de un caso por 192 invadidos 102 muertos, y den los de otros por 41 atacados, ¡solo dos muertos! ¿Qué mayor benignidad que rebajar el terrible cólera a la mortalidad de los catarros leves?

El Dr. Pulido no quiere convencerse de una cosa.

$\mathrm{Y}$ es que el Sr. Romero Robledo conoce perfectamente la eficacia del sistema Ferrán; pero en cuanto se adopte y se propague deja él de ser el Salvatore de la patria, dejando al mismo tiempo de favorecer a unos cuantos amigos con enormes dietas.

Ese es el secreto de su odio a Ferrán.

FUENTE: La Provincia, 28/06/1885. 


\section{$\mathrm{N}^{\mathrm{o}} 4$}

\section{EL CÓLERA.-CONSIDERACIONES GENERALES.}

Conviene decir la verdad pura y neta sin ambages ni rodeos; vale avisar el peligro para conjurarlo, que vivir en dulce ignorancia y ser sorprendido por la epidemia, sería punible si el cólera nos encontrara desprevenidos por no alarmar a la gente y produjera estragos lamentables.

Redunda en beneficio del público dar a conocer lo que se sabe del cólera y los recursos que tiene la ciencia como más eficaces para combatirlo, pues aparte de las muchas ventajas que reporta, evita el empleo de drogas, específicas y amuletos que casi siempre son perjudiciales y hacen descuidar la verdadera higiene. Nada para esto mejor que la publicidad de cuanto la medicina tenga averiguado, y este camino sigue la prensa y los médicos.

Me limitare pues a ordenar y razonar tal como yo entienda las ideas sentadas por las personas más competentes en este ramo del saber...

La higiene es la única garantía contra la epidemia; ¿qué es el cólera? Después de tantos estudios y observaciones prolijas, en realidad, de verdad no lo sabemos porque no voy a sostener ninguna hipótesis de si es una criptógama urocistis oculta, ni células anulares, bacterias, baccillus en forma de coma, etc., para terminar en conclusión que ignoramos la causa colerígena. Sin embargo, la opinión que cada día gana terreno, es la que considera al principio morbífico como un ser vivo, dada su evolución y reproducción.

Conocemos los efectos de la enfermedad, y sin quitarle importancia pues al fin y al cabo es una enfermedad pública, se puede asegurar que no es tan mortífera como el miedo lo pinta; y la medicina tiene, respecto a esta dolencia, la certeza que en otras muchas enfermedades; sin ser esto obstáculo para que los estudios de tantos hombres eminentes haya dado lugar a un tratamiento racionalmente científico de tifo asiático.

El origen del cólera morbo es la India, y según se afirmó en las conferencias de Constantinopla y Viena, siempre viene de fuera cuando aparece en otros países.

Dejar sentado y ratificado este hecho es tanto como acreditar con no poca certidumbre, la ventaja de defenderse los países sanos, y cerrar el paso a esta plaga. 
No cabe duda tampoco que la causa colerígena necesita medios apropiados para existir y propagarse. Las inmundicias, aguas estancadas, sustancias orgánicas en putrefacción jamás engendran el veneno colérico, pero sirven de terreno abonado para que evolucione, predisponer a la economía a enfermar, y quitar resistencia a los órganos que con predilección ataca la epidemia poniéndoles en condiciones de receptividad.

Lógicamente, pues, se desprende, que a fin de atacar el principio colerígeno, nada hay mejor que la limpieza individual y pública, la ventilación, desinfección y saneamiento.

Es cosa resuelta, según afirmaron las conferencias y han confirmado los experimentos, que el hombre es el mejor medio de transmisibilidad, y las deyecciones el principal receptáculo del agente morbífico. Hiersech y Burdon Sanderson, han experimentado con papel de filtro impregnado de diarrea de coléricos secado y dado de comer mezclado con alimentos a cierto número de ratones, que el primer día no atacó a ninguno de estos el cólera; el segundo día enfermaron algunos, el tercero y cuarto fueron atacados casi todos, muriendo la mayor parte; al quinto día disminuyó el número de enfermos, y pocos días después se extinguía el poder contagioso de la sustancia de que impregnaron el papel.

Esto manifiesta que al pronto el veneno está como muerto, y necesita para desarrollar su actividad el movimiento de fermentación del flujo intestinal. Si pues al momento de aparecer el elemento colerígeno lo destruimos, o mejor dicho, le removemos todas las causas abonadas de evolución, evitaremos su propagación; así como si le abandonamos infectará a los individuos que se pongan en contacto produciendo sus naturales consecuencias.

Deben pues desinfectarse las deposiciones de los coléricos y las letrinas donde se viertan. Las ropas sucias por las deyecciones sería prudente mojarlas con una disolución de sulfato de cobre (50 gramos por litro de agua) taparlas luego en cajas herméticamente cerradas y transportarlas a lavaderos públicos destinados al efecto fuera de la población, con la dotación perenne de agua suficiente a fin de removerla con frecuencia.

Respecto a la transmisibilidad por la atmósfera opina el doctor Méndez Álvaro que para formar juicio definitivo necesitase un estudio más amplio y profundo que existe en la actualidad; a pesar de que la conferencia de Viena admitió que en ciertas condiciones particulares de confinamiento, puede conservar el veneno morbífico su 
actividad por tiempo indeterminado y transmitirse en ciertos lugares que está la atmosfera confinada. Abunda la idea entre la mayoría de higienistas de que el aire ambiente no es sino el vehículo del agente generador del cólera, y que cuando se transmite la enfermedad por la atmósfera, su acción queda limitada en la inmensa mayoría de casos a distancia muy corta del foco de la infección. Por manera que en el veneno colerígeno como en el tífico, el aire libre agota con la rapidez su acción y a corta distancia del foco.

Salta a la vista entonces, la conveniencia de ventilar las habitaciones de los enfermos, la necesidad de evitar el hacinamiento y la bondad de las medidas encaminadas a impedir las aglomeraciones de personas como en teatros, escuelas, ferias, etc.

Los efectos de uso de un lugar infectado, se tiene por cierta su propiedad de transmitir el cólera, con más razón si han servido a coléricos: encerradas las ropas, y a cubierto del aire, puede transmitir el germen a grandes distancias. Deben al efecto desinfectarse estas sustancias contumaces si hay sospecha de que pueden contener el veneno; si han servido a coléricos lo mejor será quemarlas o por lo menos exponerlas a la influencia del chorro de vapor a la temperatura de $120^{\circ}$. Las cajas cerradas deberán abrirse al aire libre fuera de la población y fumigar su contenido.

Aunque no es cosa probada la transmisión del cólera de los animales al hombre, se sospecha la posibilidad, porque si nuestra especie lo comunica a aquellos, se puede inferir la recíproca. Será prudente en verdad no permitir el cierre de ganados dentro del recinto de la población, así como conviene evitar la acumulación de animales en las casas, puesto que además de consumir oxígeno e impurificar la atmosfera con sus emanaciones y secreciones, es posible que transmitan el germen epidémico.

Por lo que respecta a la transmisión del cólera por los alimentos, la conferencia de Viena no se atrevió a resolverlo: pero es evidente que los alimentos indigestos y de mala calidad producen indigestiones y diarreas, las cuales en época colérica, predisponen a que sea la puerta de entrada del agente morbífico las autoridades tienen el deber de ejercer gran vigilancia, en los mercados, inspeccionando las sustancias alimenticias con objeto de permitir la venta de las que no reúnan buenas condiciones.

Todas las bebidas pueden transmitir el cólera, y en especial el agua. El doctor koch, de Berlín, en la última epidemia de Egipto, encontró en un depósito de agua de que se surtía una población atacada de cólera, el baccillus en forma de coma, y atribuyó 
a esto la explosión del cólera. Es necesario que el agua que consume un pueblo reúna todas las condiciones para ser potable, evitando se arroje inmundicias que puedan alterarlas y producir estragos. Ahoga se le presenta a nuestro municipio ocasión propicia para cubrir la parte de canal que atraviesa la ciudad, de cuyas aguas se surte la mayor parte del vecindario, con la seguridad de que ganará mucho la higiene, y sería un ejemplo de limpieza dado a sus administrados.

En otros artículos me ocuparé de la desinfección y desinfectantes, de la higiene individual y pública, así como de las visitas domiciliarias preventivas.

Félix Roig

FUENTE: La Provincia, 13/07/1884 


\section{EL CÓLERA II. DESINFECCIÓN Y DESINFECTANTES}

Enunciadas en al artículo anterior las cuestiones científicas sobre el cólera, que, formando un cuerpo de doctrina, constituyen la base de los sistemas preventivos, me ocuparé de uno de los medios de privar de las condiciones de vida al germen morbífico.

Por medio de la desinfección nos proponemos quitar al aire o cualquier otro cuerpo los gases mefíticos, miasmas o gérmenes microbio-orgánicos. Los agentes de que nos valemos son los desinfectantes.

¿Existe algún medio o procedimiento merced al cual pueda destruirse o perder su intensidad el principio generador o contagioso del cólera? La conferencia de Viena resolvió la cuestión negativamente, y he ahí la razón porque muchos médicos niegan la eficacia de los desinfectantes. Más la expresada conferencia, al aclarar la cuestión, manifestó que hay medíos de desinfección que pueden destruir con alguna probabilidad o hacer perder su intensidad a la causa colerígena. Si no dieron, pues, seguridad, afirmaron la probabilidad.

La hipótesis de que el veneno del cólera era un ser organizado, sostenida por la mayoría de médicos, la confirmaron las comisiones francesa y alemana que estudiaron el año último la enfermedad en Egipto; y recientemente el doctor Koch, de Berlín, en una conferencia dada en el hospital de Pharo (Francia), afirma, que el microbio es un organismo que vive, se reproduce por escisión, y muere más o menos pronto, según las condiciones en que se encuentra. Si separamos todas las causas que sirven de terreno abonado para su evolución y necesarias para su vida, como deyecciones, humedades, fermentos pútridos etc., indirectamente destruimos o abreviamos su existencia.

Se dirá que esto es hipotético, no lo niego, pero es racional. Después de todo, en medicina pocas veces encontramos la verdad, y con las hipótesis nos vemos precisados a formar juicios más o menos aventurados.

Por manera que no conocemos medios que sean propiamente desinfectantes, es decir, que destruyan el veneno químicamente o por acción molecular, pero sí que tenemos agentes que indirectamente, quitándole medios de evolución, agotan pronto su vida e impiden su propagación.

Tenemos un desinfectante por excelencia es el calor: «el fuego todo lo purifica», se dice desde antiguo, y los experimentos modernos prueban que el calor a ciertas temperaturas destruye los virus, miasmas y gérmenes animales, con una seguridad de 
acción que ningún agente le iguala, mas no podemos utilizarlo en todas ocasiones, como veremos.

No se destruyen todos los microbios a una misma temperatura, así como también varía la acción del calor, ya sea seco o húmedo; el aire seco a una temperatura de más $140^{\circ}$ y continuado por espacio de dos horas, es insuficiente para destruir ciertos esporos; el vapor de agua a $110^{\circ}$ aniquila todo rastro de vitalidad.

El grado de calor ha de tener un límite, y este es la temperatura máxima que los tejidos pueden soportar impunemente sin perder el color ni alterar la solidez. Una temperatura de más 105 a más $110^{\circ} \mathrm{C}$ continuada por espacio de dos horas, a la par que mata los gérmenes morbíficos, no compromete en nada los tejidos de lana, y menos la ropa de lienzo.

Averiguados los anteriores datos es fácil la aplicación del calor como desinfectante de las ropas, ya de lana ya de algodón o lienzo.

Para llevar a cabo esta operación se han inventado varios aparatos más o menos perfeccionados, que la índole de este escrito me impide detallar: basta saber, que una estufilla encendida en un lugar reducido y cerrado, es suficiente para uso de casas particulares, y una estufa seca con un termómetro regulador del aire, puede servir para los establecimientos públicos.

Si se quiere emplear el vapor acuoso, donde existe una caldera que pueda sufrir la presión de tres atmosferas y se construya una cámara cerrada en la que se colocarán los objetos que se trata de desinfectar es suficiente para montar un aparato destinado a esta operación.

El agua hirviendo es un buen medio que se usa para desinfectar la ropa de lienzo, pero no sirve para los vestidos de lana y algodón, porque los deterioran.

Como se comprenderá, debe preferirse la desinfección por el calor en todos aquellos utensilios y sustancias varias que pueda emplearse.

Las letrinas, focos principales de infección, conviene que sean desinfectadas por los agentes sólidos y líquidos. Los primeros obran en virtud de su propiedad absorbente; carbón, yeso, cenizas, tierra seca, etc.: y entre estos es preferible la última, en la localidades como ésta que no tienen letrinas donde vayan a parar las sustancias fecales.

La tierra seca y los demás absorbentes deben su acción a la retención de los gases mefíticos; parece también que absorbiendo el agua de las deyecciones y 
multiplicando el contacto de las sustancias orgánicas con el oxígeno, impide en parte el desenvolvimiento de la fermentación pútrida.

Ello es, que empleada empíricamente hace 20 años para desodorar las sustancias fecales, y utilizarla como abono fertilizante, en la actualidad se ha metodizado su uso de tal forma, que se han hecho estudios serios para averiguar la manera de conseguir buenos resultados.

La primera condición es que la tierra esté secada al sol o en un horno y guardarla en tiempo lluvioso bajo un cobertizo; debe pulverizarse groseramente y echarla sobre las deposiciones inmediatamente, antes que estas entren en putrefacción. La mejor tierra es la arcillosa y la de jardín o de cultivo. Para una evacuación completa (150 gramos de materias sólidas y 200 de orina) se necesita kilogramo y medio de tierra; mas como si se mezcla en cantidad insuficiente no desaparece completamente el olor es prudente pecar por exceso que por defecto.

Como se ve, el empleo de este medio, no ofrecería ninguna dificultad en una población eminentemente agrícola como la nuestra, puesto que con solo tener un depósito de tierra seca en casa, y tirar la cantidad indicada después de cada deposición, a fin de que se mezclase con las sustancias fecales, tendríamos conseguido el objeto. Además sería de gran utilidad para sanear la ciudad de uno de los principales focos de infección, y los agricultores tendrían un precioso abono.

La cal viva y los polvos de gas se usan para enterramientos de cadáveres, desinfección de los suelos, etc.

Aunque los desinfectantes sólidos son preferidos por algunos que afirman como el doctor Koch en la última conferencia de Marsella, que la sequedad es lo único eficaz contra el microbio del cólera, sin embargo se usan también los líquidos y gaseosos en determinadas ocasiones.

Me ocuparé brevemente de estos últimos, formulados ya en algunos periódicos eligiendo lo más económicos y de fácil aplicación.

El sulfato de hierro (caparrosa verde), se usa en disolución al 10 por 100; es bastante permanente, porque el sulfuro de hierro que forma primeramente al obrar sobre el ácido sulfhídrico, se transforma de nuevo en sulfato de hierro por la sustracción de oxígeno de las combinaciones orgánicas poco estables, vuelve después al estado de sulfuro ferroso, y el movimiento molecular es incesante. 
Las disoluciones de cloruro de zinc al 5 por 100, tenidas como excelentes por su virtud desodorante y antiséptica, son declaradas recientemente por el doctor Koch como malos desinfectantes, por haber encontrado en este sal de microbios.

El ácido fénico en disolución al 5 por 100, es muy bueno, como poderoso antiséptico que mata todos los infusorios, pero es caro, y tiene el inconveniente de ser poco permanente, en razón a su extraordinaria volatilidad.

Todas estas sustancias, así como el ácido clorhídrico y sulfúrico al 5 por 100, son las de uso más común cuando se cree conveniente utilizar los desinfectantes líquidos para alcantarillas, ropas sucias, letrinas, vómitos y baldeo de los suelos.

Al tratar de sanear habitaciones particulares, salas de hospital, establecimientos públicos y mercancías, se prefieren las fumigaciones: en especial las de ácido hiponítrico, cloruro de cal y ácido sulfuroso.

Los gases de ácido hiponítrico se consiguen mezclando ácido nítrico comercial (agua fuerte), con doble cantidad de agua, añadiendo virutas de cobre o una moneda del mismo metal.

Para desprender vapores de cloruro de cal (polvos de vas), se añade vinagre a un lechada de aquella sustancia.

El ácido sulfuroso se produce quemando en el espacio que se quiere fumigar, 30 gramos de azufre por metro cubico, humedeciendo el recinto.

Todos estos gases son irrespirables: se ha de tener presente para tomar precauciones y evitar consecuencias desagradables.

Últimamente, nunca debe olvidarse los desinfectantes naturales, la ventilación y la limpieza, pues son sin duda alguna importantes factores para preservarse del contagio colérico

Félix Roig

FUENTE: La Provincia, 17/07/1884 


\section{EL CÓLERA III: HIGIENE INDIVIDUAL}

Después de indicada la opinión dominante hoy día sobre la naturaleza de la causa colerígena, los medios por donde se transmite y los agentes ya directos o indirectos de que podemos valernos para atacar su evolución, propóngome exponer las medidas que la ciencia aconseja a fin de preservar del cólera al individuo.

Pero antes de empezar, me obliga un deber de cortesía a decir cuatro palabras y a manifestar mi gratitud al ilustrado del autor del artículo «El cólera», publicado el día 20 de este mes en el periódico de esta localidad El Clamor, por haberme honrado ocupándose de mis pobres escritos.

En primer lugar: le devuelvo con creces todas las frases tan bondadosas para mí como inmerecidas; y además declaro que reconozco en el articulista perfecto derecho para juzgar como quiera mis escritos, y sobrada competencia para tratar el asunto con más autoridad que yo.

Me permitiré por ahora aclarar los dos cargos fundamentales que me dirige:

$1^{\circ}$. El haberme olvidado mencionar el miedo como auxiliar de las epidemias; a lo cual debo contestar, que creyéndome autorizado para elegir el plan en mi concepto más conveniente, con tal de ser aceptable, reservé ocuparme del miedo al hablar de las pasiones.

$2^{\circ}$. Reprueba el articulista que yo he encomiado el celo del Gobierno porque se propone librarnos de la epidemia, pues teniendo obligación de cumplir con su deber, dice no merece sino justicia seca. Debo declarar que me permití el lujo de un aplauso, porque así lo creí justo; pero si esto es un inconveniente, no insisto toda vez que en último resultado no influye gran cosa en el estudio de la enfermedad.

Hechas estas aclaraciones principales, me ocuparé de las demás contradicciones que dice que he incurrido a medida que encuentre oportunidad.

Verdaderamente sería embarazosa mi situación, si me animara el propósito de decir novedades después de cuanto han publicado los periódicos; pero como mi objeto, según manifesté al principio de estos escritos, no es otro, sino inculcar en el ánimo las ventajas de los preceptos higiénicos, exponiéndolos de manera que estén al alcance de todos, sigo mi plan, porque en último resultado los buenos consejos no dañan por ser repetidos. 
La higiene dije es la única garantía para preservarse del cólera, y por lo mismo, ya que no tenemos un preservativo especial, es necesario conocer las precauciones que la experiencia ha considerado útiles para precaverse de aquella dolencia.

Todo individuo deber atender a su parte moral, a la material u orgánica y a los medios que le rodean y sobre él influyen.

El hombre tiene necesidad de sentir; pues las sensaciones y sentimientos están unidos al ser humano como la afinidad a la molécula mineral: y la parte moral tiene tal relación con la material, que casi nunca sufre el alma sin que el cuerpo se resienta.

Las sensaciones tristes o deprimentes en general que producen debilidad y decaimiento, debe evitarse en tiempo de epidemia. Las alegres y placenteras, contenidas en ciertos límites entonan y vivifican al cuerpo, pero cuando degeneran en pasión, producen estragos lamentables....

Nunca es más lamentable el influjo fatal de las pasiones que en tiempo de epidemia: el vicio y el libertinaje encuentran su castigo, como la virtud, la moderación y la templanza recompensa.

No detallaré la influencia de cada una de las pasiones, porque la índole de este escrito me lo impide; si diré, sin embargo, que los excesos que se comenten contra la castidad, tal vez sean los que más víctimas ocasionan.

Sigue el miedo (ya llegó, y a pesar de la prisa del articulista, creo que a tiempo), que pone en un estado penoso al alma con perturbación de los sentidos, producido por la rápida percepción de un peligro real o imaginario; es una pasión concéntrica y debilitante, perjudicial en tiempo de epidemia. Sin embargo; unos le dan poca o ninguna importancia (Nemeyer) y otros como el ilustrado médico de El Clamor le concede mucha, bien que éste la apoya en una noticia en forma de gacetilla de un periódico político que acaba en una cuarteta humorística, a la que yo no me atrevería a dar la autoridad científica que se pretende.

Por mi parte creo que el miedo es un factor digno de tenerse en cuenta, porque además de otros trastornos que produce en el cuerpo, los primeros efectos suelen ser la perturbación de las vías gástricas, que ponen al organismo en condiciones de receptividad.

Conviene pues, conservar la tranquilidad de espíritu, y hacerse cargo que la imaginación agranda los peligros. En algunas personas causa terror el solo nombre de cólera morbo asiático sin considerar que muchas enfermedades de nombre vulgar 
pueden causar tantos estragos como aquella. Repito, hasta que el distinguido articulista del periódico citado me demuestre lo contrario, que en muchas enfermedades tiene la medicina la misma seguridad que en el cólera, y empleamos, como en éste, tratamientos racionalmente científicos que curan...

Aparte de la limpieza del cuerpo, siempre necesaria, que no puede olvidarse sin perjuicio de la salud, cuyas reglas, están al alcance de todo el mundo, debemos atender a los alimentos, bebidas, vestidos y género de vida.

En pocas palabras diré lo que se refiere a la alimentación, si entrar en detalles. El buen régimen alimenticio es un preservativo del cólera; y por regla general el que lo observa regular no debe variarlo, así como el que lo lleva malo precisa que le corrija. Nada de preferir un alimento por otro con pretexto de que ciertas sustancias preservan más que otras o son de más fácil digestión; nadie mejor que el mismo individuo sabe lo que le sienta bien, y dicho se está, que el alimento más nutritivo, es el que en parecidas condiciones, mejor se digiere.

Siempre, por supuesto, los alimentos han de ser de buena calidad y en cantidad proporcionada. Es prudente abstenerse de comer toda sustancia que no esté bien cocida, singularmente, las legumbres, ensaladas y frutas.

Las bebidas usuales deben continuarse tal como se tenga costumbre, si son buenas y en proporcionada cantidad. Sabido es que se puede transmitir la causa colerígena por medio de las bebidas, y claro está que debemos cerciorarnos de su pureza.

No hay que decir que si en el agua destinada para beber una población se vertieran deyecciones coléricas, sería una causa de infección de las más perniciosa; pero las filtraciones de los depósitos son también muy perjudiciales; así es que en caso de dudas de la bondad de aquel líquido convendrá hervir por la noche la cantidad necesaria para el consumo del día siguiente, batiéndola después para que se airee antes de usarla.

Si los licores en corta cantidad son convenientes a los estómagos lánguidos que necesitan estímulo para hacer la digestión menos laboriosa, el empleo inmoderado es perjudicial. Sería altamente beneficioso hacer comprender a las gentes los peligros del abuso de los licores, inculcándoles que ninguna virtud preservativa tiene, y que al contrario predisponen a ser más fácilmente atacado el individuo.

El abrigo del cuerpo no debe ser excesivo ni deficiente; la estación y la costumbre deben servir de norma. No comprendo las ventajas de emplear la lana rociada 
en una disolución de ácido fénico para abrigo interior: se recomienda en tiempo de epidemia llevar el vientre y los pies bien abrigados, y no exponerse a corrientes de aire.

Si siempre es bueno observar una vida morigerada, metódica y arreglada, es mucho más necesario cuando un peligro nos amenaza de cerca, y puede hacer pagar caro el menor desorden. Además de cuanto hemos manifestado respecto a las pasiones, el trasnochar y la concurrencia a espectáculos donde haya aglomeración de gentes, debe evitarse; conviene acostarse pronto y levantarse entrado el día, procurándose un sueño tranquilo y reparador que restaure las fuerzas.

El ejercicio moderado y sin experimentar fatiga, es útil, así como el trabajo material y también el de bufete ordenados, son convenientes; sobre todo si alterna en justa proporción el del cuerpo con el del espíritu.

El hombre no debe atender solo a su cuidado sino también debe cuidar el medio que directamente obra sobre él. Si a la administración pública incumbe lo que a la colectividad se refiere, cada individuo en particular tiene que atender a su habitación o morada.

Si fuera posible, convendría que cada casa reuniera las condiciones de construcción y habitabilidad que la higiene aconseja; pero a falta de estos dos casos principales, debe procurarse en cada habitación: limpieza y ventilación.

Las casas debe procurarse estén limpias exterior e interiormente, blanqueando paredes y techos, barriendo los suelos y evitando la acumulación de basuras del barrido y de restos de comida; límpiense las cuadras sacando el estiércol frecuentemente y rociando el sitio que ocupaba con agua de cal u otra disolución desinfectante. Los sumideros, portales, buhardillas y corrales, deben estar limpios, y sobre todo merecen preferente atención las letrinas y orinales, que ya expusimos la manera de desinfectarlos.

Todos los días se ventilarán repetidas veces los cuartos interiores y exteriores, alcobas, escaleras, pasillos y desvanes, pues la pureza del aire fuertemente ozonizado parece que difunde y debilita el germen colérico.

Si desgraciadamente se tuviera un atacado en casa, además de la ventilación y limpieza, es precisa la desinfección como expresé en el artículo anterior, empleando para cada objeto el desinfectante que más convenga y pueda usarse con mayor facilidad.

Quiero repetir que siempre que sea factible debemos preferir el calor; y aprovecho esta ocasión para aclarar algo de confusión que he notado después de 
publicar el artículo «Desinfectantes» al hablar de aquel agente, debido a la precipitación en que fue redactado. Si la temperatura de más $140^{\circ} \mathrm{C}$ es alguna vez insuficiente para matar algunos esporos, en general bastan más $110^{\circ} \mathrm{C}$, que es la resistencia del color y solidez de los tejidos de lanas, para destruir los virus.

La misma temperatura de calor húmedo o vapor acuoso obra con más seguridad y prontitud que el calor seco: debe pues preferirse, siempre que sea posible, aquél a este. Las ropas de lienzo, toleran mayores temperaturas sin alterar la solidez del tejido.

Réstame advertir, que entre los desinfectantes gaseosos parece que hoy se da la preferencia a los vapores nitrosos; y quiero hacer constar, que se desprenden mejor de la mezcla sola de ácido nítrico (agua fuerte) y cobre, que añadiéndole doble cantidad de agua a aquel líquido.

Si este artículo sirve de algún beneficio a mis conciudadanos, como concede hasta ahora al primero el reputado médico que se ha encargado de la crítica y análisis de mis escritos, habré colmado mis deseos, siquiera le encuentre mil defectos. Si merezco la honra de una crítica razonada por persona tan perita, le deberé gratitud, porque además de ilustrarme me estimulará mi trabajo.

Félix Roig

FUENTE: La Provincia, 24/07/1884 


\section{EL CÓLERA IV. HIGIENE INDIVIDUAL (CONTINUACIÓN)}

Expuestos, aunque someramente, los principales cuidados que debe observar el individuo para preservarse de la epidemia colérica, réstame tan solo ocuparme, para terminar el asunto, de la diarrea premonitoria y de la emigración.

Observando el doctor Julio Guerin en la epidemia de 1832, en Francia, que los sujetos atacados de cólera presentaban de ordinario una diarrea más o menos prolongada antes de la explosión de la enfermedad, le sirvió este dato, para aconsejar el tratamiento inmediato de aquella, a fin de evitar desde el principio el cortejo de síntomas graves que caracterizan al tifo asiático.

Los ingleses, sacando partido de este hecho, después de comprobar la importancia práctica que encierra, no se contentaron en aconsejar el tratamiento de esta indisposición, sino que teniendo presente la apatía y descuido del enfermo, se adelantaron a indagar y buscar a los individuos que sufrían la diarrea, que denominaron premonitora, criando al efecto el sistema de visitas preventivas, que después ha seguido Francia.

Verdad es, que tal diarrea no siempre precede al cólera; éste, algunas veces se presenta fulminante, ejecutivo, haciendo que en poco tiempo llegue el enfermo a sufrir los síntomas más alarmantes. Sin embargo, es lo excepcional; y para confirmarlo basta un ejemplo: en Paris, desde los primeros días de noviembre de 1853 a 22 de enero de 1854, de 974 coléricos admitidos en los hospitales de la capital, 740 habían sido atacados de diarrea premonitoria y 166 solamente aparecieron exentos de ella; los 68 restantes, no pudieron suministrar dato alguno sobre este punto.

Ahora bien, es sabido que estas diarreas anunciadoras, como podemos llamarlas ceden fácilmente si se les prestan pronto los recursos de la ciencia; y por lo antes expuesto se desprende, que si se las atiende con cuidado, evitaremos la explosión del cólera, disminuyendo por consiguiente el número de víctimas.

Téngase presente, pues, que a la menor indisposición de vientre es necesario llamar al médico.

La emigración es el medio eficaz que las personas debían llevar a cabo. Ya de antiguo se dice que el mejor preservativo contra el cólera es el empleo de las tres LLL: huir luego, lejos y largo tiempo. 
Es preciso salir de la población lo más pronto posible: al primer caso que se presente, hay que estar de marcha, pues esperar a que se generalice la dolencia es exponerse a llevar el germen morbífico al punto donde se traslade el individuo.

Se dice huir lejos, en el sentido de buscar un punto donde no pueda influir el foco infeccionado; pero ciertamente lo que se ha de buscar es, que el sitio que se elija esté en una altura, pues a pesar de haberse observado las epidemias coléricas en todas elevaciones y latitudes, no cabe duda que atacan siempre más a los países bajos que a los altos. Aunque a decir verdad, mejor que la altura debía buscarse la constitución geológica del terreno y la hidrológica del país: por eso además de elegir un lugar alto y ventilado, convendría que estuviera situado sobre terreno rocoso y que en sus inmediaciones no hubiera nada que favoreciera la putrefacción de organismos, como pantanos, charcos, tierras húmedas, etc.

Dada las condiciones de transmisibilidad de la causa colérica, lógico es de decir, que el que tenga facilidad de incomunicarse absolutamente y cuente con todo lo necesario para los usos comunes de la vida mientras dure la epidemia, se librará seguramente del tifo asiático.

Aconsejase volver tarde, hasta que se dé por terminada completamente la epidemia porque si se regresa antes, siquiera sean pocos los atacados del cólera, los que vienen de un país sano suelen adquirir la dolencia al llegar al sitio infestado.

¿Es conveniente la emigración? Seguramente es útil para el individuo que se marcha, y para la colectividad que se queda; el primero se libra de la influencia morbosa, y los demás reciben beneficio, porque disminuyendo el número de habitantes, se evita el hacinamiento y la condensación del aire, purificándose este valioso agente que tanta influencia tiene sobre la salud del cuerpo.

Si fuera posible disminuir los barrios pobres y populosos, la epidemia terminaría más pronto porque se quitarían elementos de vida, y se aislaría el mal, ya que solo los acaudalados pueden participar de esta ventaja, no olviden que sus hermanos pobres quedan entre un foco mortífero, y amenazados de la miseria, compañera inseparable de las epidemias: socórranles en cuanto puedan, que, es de almas nobles y caritativas, sentir amor al prójimo, y aliviar el infortunio de sus semejantes. 


\section{EL CÓLERA V. HIGIENE PÚBLICA}

El individuo que vive en sociedad, está influido por sus semejantes, y no bastan los esfuerzos aislados para prevenirse contra las enfermedades, sino que deben todos obrar de común acuerdo para cumplir las prescripciones higiénicas....

$\mathrm{Al}$ rico le es fácil atender a los cuidados higiénicos, pero el pobre que muchas veces falto de subsistencias no cuenta con recursos suficientes para vivir, mira con indiferencia las reglas para conservar la salud. A estos deben, pues, atender sus tutores con mayor solicitud.

Si el primer deber de una autoridad es proporcionar bienestar a sus administrados, ninguno hay tan necesario como la salud, que es el don más precioso de la vida.

No indicaré todo cuanto tienda a corregir las causas de insalubridad, ni la manera de sanear la población, porque mis consejos deberían dirigirse a las autoridades, que tienen sus juntas de Sanidad compuestas de personas ilustradísimas, lo han llevado a cabo y con más inteligencia que yo pudiera verificarlo.

Mi objetivo es tratar de las visitas médicas preventivas, como anuncié en mi primer artículo, por creer que es un asunto de importancia práctica digno de tenerse en cuenta, y hasta ahora, que yo sepa, nada se ha determinado en concreto para el caso de que fuéramos visitados por el cólera.

Dije anteriormente que esta enfermedad, en general no se presenta de improviso con todos los síntomas graves que la caracterizan, sino que la precede una diarrea fácil de contener, que tratada desde luego, disminuye el número de víctimas en una población epidemiada. Dejé sentado, que hay enfermos de índole apática que en las dolencias que no producen dolor y les permiten dedicarse a sus ocupaciones habituales, les repugna llamar al médico, ni recurrir a la botica.

En esto se funda, cabalmente este sistema preventivo.

Hay naciones más adelantadas que la nuestra, donde la reglamentación de las visitas preventivas es admirable. No entro en detalles, porque al que le interesen, puede leerlos en el informe del doctor Meliér a la junta de higiene pública de Francia. De lo que únicamente trato, es de llamar la atención a quien convenga, para que se estudie, si dadas las condiciones de la población y medios de que se dispone, sería fácil llevar a cabo en esta localidad algo parecido que diera buen resultado. 
El primer inconveniente en que se tropieza, es, que aquí no puede haber un cuerpo médico que se dedique especialmente a este servicio como sucede en otras partes. Castellón (población de más de 30.000 almas) tan solo tiene ¡dos titulares! Y por cierto míseramente retribuidos. Los médicos que desempeñan estas plazas, como todos los demás, visitan en una ciudad donde la asistencia médica está mal recompensada, y por lo mismo necesitan muchos clientes para poder vivir modestamente. De manera que no pueden abandonar sus múltiples atenciones, $\mathbf{y}$ dedicarse a un solo servicio. Creemos, sin embargo, que simplificando el trabajo de este sistema, podría conseguirse mucho.

Deberían en primer lugar reducirse las visitas preventivas a las clases indigentes que ninguna o muy poca importancia dan a las enfermedades que no obligan a guardar cama, ignorando además toda noción de profilaxis.

Podría nombrarse para los pobres de cada distrito una comisión compuesta de un médico, un farmacéutico, un practicante o persona inteligente y un individuo de las juntas de socorro para pobres, que deben existir en cada barrio.

El servicio médico estaría a cargo de los facultativos que tiene el municipio, de los del hospital y la casa de Misericordia: si no bastaran, se invitaría a los demás profesores de la población a fin de completar dicho servicio con los que voluntariamente quisieran comprometerse. Cada uno se obligaría a visitar a los pobres del distrito que se le designara, cuando le dieran noticia de los afectados de diarrea o perturbaciones gástricas.

El farmacéutico, facilitaría gratis los remedios que el médico prescribiese, con receta que indicara era para pobre, reclamando su importe a la administración municipal encargada del pago.

El practicante, a falta de poder hacerlo personalmente el médico, indagaría y preguntaría a todos los indigentes del distrito, casa por casa, si sufrían alguna indisposición del aparato digestivo; inculcándoles, para poder llenar mejor su cometido, las ventajas de poner pronto remedio a la dolencia. Tomaría nota detallada de cada enfermo, y la remitiría al médico a fin de que este les pudiera asistir desde luego.

El individuo de la junta de socorros a domicilio, avisará al centro de donde dependiera, de los enfermos que necesitaran de la caridad pública o privada. Y aquí debo advertir, de que no teniendo noticia de que existan estas juntas, la autoridad debe procurar que se organicen de antemano, pues si la asistencia es siempre un deber de la 
sociedad, para con aquellos de sus miembros que carecen de lo necesario, en tiempos de epidemia es una ley imperiosa.

Este pensamiento, más o menos modificado, creo que sería fácil de llevar a cabo en esta población, siendo de esperar resultados ventajosos.

He terminado lo que me propuse decir al público en estos artículos, encaminados a destruir preocupaciones, dar a conocer los medios aconsejados para preservarse del cólera y las reglas de conducta más convenientes fundadas en los datos de la ciencia. Puedo recibir censuras ciertamente justas, si se atiende a la inteligencia como he expuesto el asunto; siempre inmerecidas, se tiene presente el móvil que me ha guiado.

Félix Roig

FUENTE: La Provincia, 3/08/1884 


\section{EXPOSICIÓN QUE DIRIGE AL GOBIERNO LA COMISIÓN PROVINCIAL EN DEMANDA DE SOCORROS PARA LA PROVINCIA DE CASTELLÓN}

Excmo. Sr.: La comisión provincial, haciéndose interprete de la aflictiva situación porque vienen atravesando los pueblos de esta provincia y en nombre de los ayuntamientos de la misma, ha acordado dirigirse atenta y respetuosamente a V.E. exponiendo a su alta consideración que el malestar y pauperismo que por todas partes ha sembrado la absoluta pérdida de las últimas cosechas, debido a los temporales que sin interrupción reinaron en el pasado año, ha venido a agregarse en las presentes y angustiosas circunstancias la aparición de la epidemia reinante que se presenta con caracteres verdaderamente alarmantes y amenaza invadir rápidamente la población provincial. Para hacer frente a tantas necesidades, el presupuesto provincial se encuentra impotente por completo, pues apenas resta por invertir del capítulo de calamidades la exigua suma de 3.500 pesetas, a consecuencia de haberse gastado el resto de la consignación en atender en parte a las desgracias antes mencionadas.

Faltaría, pues, a uno de sus principales deberes esta corporación, si dejando de inspirarse en los más puros sentimientos de humanidad y clemencia no elevase su modesta pero autorizada voz ante la consideración de V.E. en demanda de algunos recursos con que poder socorrer al sinnúmero de desagraciados que la presente epidemia ha de ocasionar con la paralización de los trabajos y transacciones que la actual enfermedad está ya causando, ante cuyos males han de sucumbir, a no dudarlo, en la miseria o la desesperación muchos de los hijos de esta provincia.

Esta Comisión, excelentísimo señor, al formular esta que estima justa pretensión, confía sincera y profundamente en la noble conducta de V.E., que al distribuir sus dones únicamente los concede al que inmerecidamente sufre la desgracia, y espera, por tanto, que uniendo el nombre de Castellón, a los de Murcia, Granada, Valencia y otras provincias hermanas en la desgracia, se hará acreedora a la apasionada gratitud de estos habitantes, que invocarán una vez más el nombre de la nación y del Gobierno de S.M. como el más seguro vínculo de la protección y mutua caridad. 
En su virtud:

La Comisión provincial suplica a V.E. se digne a conceder del fondo de calamidades públicas la parte que estime procedente para atender a los fines indicados en los pueblos que sufran la epidemia colérica y en proporción con las atenciones que exigen las demás provincias.

Es gracia que espera obtener de la benevolencia de V.E.

Castellón 12 de junio de 1885. (Siguen las firmas.)

FUENTE: La Provincia, 13/06/1885. 


$$
\mathrm{N}^{\mathrm{o}} 6
$$

\section{TABLA 23. INVASIONES Y DEFUNCIONES EN CASTELLÓN POR}

\section{CAUSA DEL CÓLERA. JUNIO DE 1885.}

\begin{tabular}{|c|c|c|}
\hline Día & Invasiones & Defunciones \\
\hline 1 & 0 & 0 \\
\hline 2 & 0 & 0 \\
\hline 3 & 0 & 0 \\
\hline 4 & 0 & 0 \\
\hline 6 & 0 & 0 \\
\hline 7 & 0 & 0 \\
\hline 8 & 0 & 0 \\
\hline 9 & 0 & 0 \\
\hline 10 & 0 & 0 \\
\hline 11 & 0 & 0 \\
\hline 12 & 0 & 0 \\
\hline 13 & 0 & 0 \\
\hline 14 & 0 & 0 \\
\hline 15 & 0 & 0 \\
\hline 16 & 0 & 0 \\
\hline 17 & 0 & 0 \\
\hline 18 & 0 & 0 \\
\hline 19 & 2 & 0 \\
\hline 20 & 5 & 5 \\
\hline 21 & 0 & 0 \\
\hline 22 & 0 & 0 \\
\hline 23 & 7 & 3 \\
\hline 24 & 3 & 6 \\
\hline 25 & 1 & 2 \\
\hline 26 & 6 & 0 \\
\hline 27 & 3 & 0 \\
\hline 28 & 4 & 2 \\
\hline
\end{tabular}




\begin{tabular}{|c|c|c|}
\hline 29 & 7 & 7 \\
\hline 30 & 4 & 2 \\
\hline Total & 42 & 27 \\
\hline
\end{tabular}

FUENTE: Boletín Oficial de la Provincia de Castellón, 1885. Elaboración propia.

TABLA 24. INVASIONES Y DEFUNCIONES EN CASTELLÓN POR CAUSA DEL CÓLERA. JULIO DE 1885.

\begin{tabular}{|c|c|c|}
\hline Día & Invasiones & Defunciones \\
\hline 1 & 5 & 2 \\
\hline 2 & 4 & 3 \\
\hline 3 & " & 1 \\
\hline 4 & 4 & 1 \\
\hline 5 & 5 & 3 \\
\hline 6 & 7 & 6 \\
\hline 7 & 6 & 2 \\
\hline 8 & 15 & 5 \\
\hline 9 & 6 & 6 \\
\hline 10 & 13 & 5 \\
\hline 11 & 8 & 8 \\
\hline 12 & 9 & 3 \\
\hline 13 & 13 & 8 \\
\hline 14 & 15 & 6 \\
\hline 15 & 15 & 9 \\
\hline 16 & 0 & 0 \\
\hline 17 & 0 & 0 \\
\hline 18 & 0 & 0 \\
\hline 19 & 0 & 0 \\
\hline 20 & 0 & 0 \\
\hline 21 & 0 & 0 \\
\hline 22 & 0 & 0 \\
\hline 23 & 0 & 0 \\
\hline 24 & 0 & 0 \\
\hline
\end{tabular}




\begin{tabular}{|c|c|c|}
\hline 25 & 0 & 0 \\
\hline 26 & 0 & 0 \\
\hline 27 & 0 & 0 \\
\hline 28 & 0 & 0 \\
\hline 29 & 16 & 10 \\
\hline 30 & 21 & 7 \\
\hline 31 & 171 & 98 \\
\hline Total & 9 & 13 \\
\hline
\end{tabular}

FUENTE: Boletín Oficial de la Provincia de Castellón, 1885. Elaboración propia.

TABLA 25. INVASIONES Y DEFUNCIONES POR CAUSA DEL

CÓlERA EN CASTELLÓN, AGOSTO DE 1885.

\begin{tabular}{|c|c|c|}
\hline Días & Invasiones & Defunciones \\
\hline 1 & 13 & 7 \\
\hline 2 & 7 & 6 \\
\hline 3 & 14 & 15 \\
\hline 4 & 14 & 12 \\
\hline 5 & 10 & 6 \\
\hline 6 & 10 & 7 \\
\hline 7 & 14 & 4 \\
\hline 8 & 10 & 7 \\
\hline 9 & 5 & 4 \\
\hline 10 & 9 & 3 \\
\hline 11 & 4 & 0 \\
\hline 12 & 4 & 2 \\
\hline 13 & 8 & 6 \\
\hline 14 & 3 & 1 \\
\hline 15 & 5 & 4 \\
\hline 16 & 2 & 0 \\
\hline 17 & 4 & 3 \\
\hline 18 & 0 & 2 \\
\hline 19 & 2 & 0 \\
\hline
\end{tabular}




\begin{tabular}{|c|c|c|}
\hline 20 & 4 & 3 \\
\hline 21 & 0 & 2 \\
\hline 22 & 0 & 0 \\
\hline 23 & 0 & 0 \\
\hline 24 & 0 & 0 \\
\hline 25 & 0 & 0 \\
\hline 26 & 0 & 0 \\
\hline 27 & 0 & 0 \\
\hline 28 & 0 & 0 \\
\hline 29 & 0 & 0 \\
\hline 30 & 0 & 0 \\
\hline 31 & 144 & 94 \\
\hline Total & & 0 \\
\hline
\end{tabular}

FUENTE Boletín Oficial de la Provincia de Castellón, 1885. Elaboración propia. 
$\mathrm{N}^{\mathrm{o}} 7$

TABLA 26. DEFUNCIONES POR CAUSA DEL CÓLERA EN 1885.

TABLA COMPARATIVA DE LA INCIDENCIA EN ALGUNOS PUEBLOS DE

LA PROVINCIA

\begin{tabular}{|c|c|c|c|c|c|}
\hline Pueblos & Junio & Julio & Agosto & Sept. & Total \\
\hline Alcalá & 0 & 40 & 20 & 0 & 60 \\
\hline Alcora & 35 & 152 & 18 & 0 & 205 \\
\hline Almazora & 9 & 74 & 60 & 0 & 143 \\
\hline Burriana & 144 & 68 & 18 & 0 & 230 \\
\hline Cabanes & 0 & 16 & 80 & 0 & 96 \\
\hline Cálig & 0 & 17 & 116 & 0 & 133 \\
\hline Castellón & 27 & 98 & 94 & 0 & 219 \\
\hline Jérica & 29 & 71 & 0 & 0 & 100 \\
\hline Nules & 150 & 76 & 9 & 0 & 235 \\
\hline Onda & 0 & 18 & 46 & 0 & 64 \\
\hline San Jorge & 0 & 0 & 78 & 16 & 94 \\
\hline Segorbe & 108 & 77 & 15 & 0 & 200 \\
\hline Vinaroz & 0 & 34 & 253 & 1 & 288 \\
\hline Villarreal & 297 & 83 & 75 & 0 & 455 \\
\hline
\end{tabular}

FUENTE: Boletín Oficial de la Provincia de Castellón, 1885. Elaboración propia. 
CARTA DEL ALCALDE JOSÉ FORCADA DIRIGIDA A TODOS LOS CASTELLONENSES

Higiene y alimentación: He aquí las dos más poderosas armas para combatir, y con ellas vencer al bacilo de Pfeiffer que hace estragos en nuestra ciudad, y como de higiene y alimentación se carece en la casa del pobre, donde no hay ni camas para dormir, ni ropas para abrigarse, ni pan para comer, y en donde además toda suciedad tiene su asiento con la obligada secuela de tristezas, dolores y amarguras que conturban el espíritu ha acordado la Corporación Municipal, que es la salvaguardia de los intereses comunales y el centinela vigilante de la salud del pueblo pedir a todos sus administrados la inmediata y urgente disposición a colocarse en condiciones de defensa contra la calamidad pública que nos azota.

A este efecto y teniendo en cuenta que es el dinero la primera condición para hacer higiene y para adquirir alimentos hace, por mi conducto, un llamamiento a la generosidad y nobles sentimientos de los castellonenses, esperando que las cerradas puertas del auxilio se abrirán poniendo en manos de las comisiones postulantes como mínimum, y en calidad de donativo, la cantidad equivalente al importe de un semestre del impuesto sobre inquilinato.

La gravedad del momento a nadie se le oculta, los enfermos pobres de la ciudad necesitan socorros y la salud del pueblo a todos importa. Acudamos, pues, como humanos primero y como castellonenses después, a remediar las tristezas y amarguras de los que luchan con la muerte en un ambiente de privaciones y miserias.

FUENTE: El Clamor, 19/10/1918. 


$$
\mathrm{N}^{\mathrm{o}} 9
$$

TABLA 1. MUERTE POR GRIPE EN CASTELLÓN EN1918

\begin{tabular}{|l|c|c|}
\hline Meses & CS-H & CS-M \\
\hline Enero & 0 & 0 \\
\hline Febrero & 0 & 0 \\
\hline Marzo & 0 & 0 \\
\hline Abril & 1 & 0 \\
\hline Mayo & 0 & 0 \\
\hline Junio & 3 & 1 \\
\hline Julio & 1 & 0 \\
\hline Agosto & 0 & 17 \\
\hline Septiembre & 18 & 141 \\
\hline Octubre & 131 & 0 \\
\hline Noviembre & 0 & 0 \\
\hline Diciembre & 0 & 159 \\
\hline Totales & 154 & 0 \\
\hline
\end{tabular}

FUENTE: Boletín de Estadística Municipal de Castellón de 1918-1921. Elaboración propia. 
TABLA 2. ESTADÍSTICA DE LAS CAUSAS DE MORTALIDAD EN SEPTIEMBRE DE 1918 EN LA CIUDAD DE CASTELLÓN

\begin{tabular}{|c|c|c|}
\hline ENFERMEDADES & Hombres & Mujeres \\
\hline 1.- Fiebre tifoidea (abdominal) & 0 & 2 \\
\hline 2.-Tifus exantemático & 0 & 0 \\
\hline 3.- Fiebre intermitente y caquexia palúdica & 1 & 0 \\
\hline 4.- Viruela & 0 & 0 \\
\hline 5.- Sarampión & 0 & 0 \\
\hline 6.- Escarlatina & 0 & 0 \\
\hline 7.- Coqueluche & 0 & 0 \\
\hline 8.- Difteria y Crup & 1 & 0 \\
\hline 9.- Gripe & 18 & 17 \\
\hline 10.-Cólera asiático & 0 & 0 \\
\hline 11.-Cólera nostras & 0 & 0 \\
\hline 12.-Otras enfermedades epidémicas & 1 & 0 \\
\hline 13.-Tuberculosis pulmonar & 6 & 4 \\
\hline 14.-Tuberculosis de las meninges & 0 & 0 \\
\hline 15.- Otras tuberculosis & 0 & 0 \\
\hline 16.- Cánceres y otros tumores malignos & 0 & 2 \\
\hline 17.- Meningitis simple & 1 & 2 \\
\hline 18.- Hemorragia y reblandecimientos cerebrales & 0 & 8 \\
\hline 19.-Enfermedades orgánicas del corazón & 1 & 1 \\
\hline 20.- Bronquitis aguda & 0 & 3 \\
\hline 21.- Bronquitis crónica & 2 & 3 \\
\hline 22.- Neumonía & 1 & 0 \\
\hline 23.- Otras enfermedades del aparato respiratorio & 9 & 3 \\
\hline 24.- Afecciones del estómago (excepto cáncer) & 2 & 0 \\
\hline 25.- Diarrea y enteritis (menores de 2 años) & 4 & 3 \\
\hline 26.- Apendicitis y Tiflitis & 0 & 0 \\
\hline
\end{tabular}




\begin{tabular}{|l|c|c|}
\hline 27.- Hernias y obstrucciones intestinales & 0 & 0 \\
\hline 28.- Cirrosis del hígado & 0 & 1 \\
\hline 29.- Nefritis y mal de Bright & 1 & 4 \\
\hline $\begin{array}{l}\text { 30.- Tumores no cancerosos y otras enfermedades de los } \\
\text { órganos genitales de la mujer }\end{array}$ & 0 & 0 \\
\hline 31.- Septicemia puerperal (fiebre, peritonitis, flebitis) & 0 & 0 \\
\hline 32.- Otros accidentes puerperales & 0 & 1 \\
\hline 33.- Debilidad congénita y vicios de conformación & 0 & 0 \\
\hline 34.- Senilidad & 0 & 5 \\
\hline 35.- Muertes violentas (excepto suicidios) & 2 & 0 \\
\hline 36.- Suicidios & 0 & 0 \\
\hline 37.-Otras enfermedades & 7 & 3 \\
\hline 38.-Enfermedades desconocidas o mal definidas & 0 & 1 \\
\hline
\end{tabular}

FUENTE: Boletín de Estadística Municipal de Castellón de 1918-1921. Elaboración propia. 
TABLA 3 ESTADÍSTICA DE LAS CAUSAS DE MORTALIDAD EN OCTUBRE DE 1918 EN LA CIUDAD DE CASTELLÓN

\begin{tabular}{|c|c|c|}
\hline ENFERMEDADES & Hombres & Mujeres \\
\hline 1.- Fiebre tifoidea (abdominal) & 3 & 1 \\
\hline 2.-Tifus exantemático & 0 & 0 \\
\hline 3.- Fiebre intermitente y caquexia palúdica & 2 & 1 \\
\hline 4.- Viruela & 0 & 0 \\
\hline 5.- Sarampión & 0 & 0 \\
\hline 6.- Escarlatina & 0 & 0 \\
\hline 7.- Coqueluche & 0 & 0 \\
\hline 8.- Difteria y Crup & 1 & 0 \\
\hline 9.- Gripe & 131 & 141 \\
\hline 10.-Cólera asiático & 0 & 0 \\
\hline 11.-Cólera nostras & 0 & 0 \\
\hline 12.-Otras enfermedades epidémicas & 1 & 0 \\
\hline 13.-Tuberculosis pulmonar & 11 & 7 \\
\hline 14.-Tuberculosis de las meninges & 0 & 1 \\
\hline 15.- Otras tuberculosis & 1 & 1 \\
\hline 16.- Cánceres y otros tumores malignos & 1 & 1 \\
\hline 17.- Meningitis simple & 2 & 1 \\
\hline 18.- Hemorragia y reblandecimientos cerebrales & 5 & 16 \\
\hline 19.-Enfermedades orgánicas del corazón & 7 & 15 \\
\hline 20.- Bronquitis aguda & 9 & 11 \\
\hline 21.- Bronquitis crónica & 5 & 10 \\
\hline 22.- Neumonía & 0 & 0 \\
\hline 23.- Otras enfermedades del aparato respiratorio & 11 & 11 \\
\hline 24.- Afecciones del estómago (excepto cáncer) & 0 & 0 \\
\hline 25.- Diarrea y enteritis (menores de 2 años) & 7 & 11 \\
\hline 26.- Apendicitis y Tiflitis & 0 & 0 \\
\hline
\end{tabular}




\begin{tabular}{|l|c|c|}
\hline 27.- Hernias y obstrucciones intestinales & 0 & 1 \\
\hline 28.- Cirrosis del hígado & 0 & 1 \\
\hline 29.- Nefritis y mal de Bright & 1 & 2 \\
\hline $\begin{array}{l}\text { 30.- Tumores no cancerosos y otras enfermedades de los } \\
\text { órganos genitales de la mujer }\end{array}$ & 0 & 0 \\
\hline 31.- Septicemia puerperal (fiebre, peritonitis, flebitis) & 0 & 0 \\
\hline 32.- Otros accidentes puerperales & 2 & 2 \\
\hline 33.- Debilidad congénita y vicios de conformación & 0 & 0 \\
\hline 34.- Senilidad & 0 & 0 \\
\hline 35.- Muertes violentas (excepto suicidios) & 19 & 14 \\
\hline 36.- Suicidios & 2 & 3 \\
\hline 37.-Otras enfermedades & 225 & 262 \\
\hline 38.-Enfermedades desconocidas o mal definidas & 0 & 2 \\
\hline
\end{tabular}

FUENTE: Boletín de Estadística Municipal de Castellón de 1918-1921. Elaboración propia. 
TABLA 4. MUERTE POR GRIPE EN SEPTIEMBRE DE 1918 SEGÚN EDAD EN LA CIUDAD CASTELLÓN

\begin{tabular}{|c|c|c|c|c|c|c|c|c|c|c|c|c|c|c|c|c|c|c|c|c|c|c|c|}
\hline \multicolumn{2}{|c|}{$\begin{array}{l}<1 \\
\text { año }\end{array}$} & \multicolumn{2}{|c|}{1 a 4} & \multicolumn{2}{|c|}{5 a 9} & \multicolumn{2}{|c|}{$\begin{array}{l}10 \text { a } \\
14\end{array}$} & \multicolumn{2}{|c|}{$\begin{array}{l}15 \text { a } \\
19\end{array}$} & \multicolumn{2}{|c|}{$\begin{array}{l}20 a \\
24\end{array}$} & \multicolumn{2}{|c|}{$\begin{array}{l}25 a \\
29\end{array}$} & \multicolumn{2}{|c|}{$\begin{array}{l}30 a \\
34\end{array}$} & \multicolumn{2}{|c|}{$\begin{array}{l}35 a \\
39\end{array}$} & \multicolumn{2}{|c|}{$\begin{array}{l}40 a \\
44\end{array}$} & \multicolumn{2}{|c|}{$\begin{array}{l}45 a \\
49\end{array}$} & \multicolumn{2}{|c|}{50 a 54} \\
\hline V & $\mathrm{H}$ & V & $\mathrm{H}$ & V & $\mathrm{H}$ & V & $\mathrm{H}$ & V & $\mathrm{H}$ & V & $\mathrm{H}$ & V & $\mathrm{H}$ & V & $\mathrm{H}$ & V & $\mathrm{H}$ & V & $\mathrm{H}$ & V & $\mathrm{H}$ & V & $\mathrm{H}$ \\
\hline 0 & 1 & 0 & 1 & 1 & 1 & 0 & 1 & 0 & 2 & 5 & 3 & 1 & 4 & 2 & 2 & 6 & 0 & 1 & 1 & 0 & 0 & 0 & 1 \\
\hline
\end{tabular}

\begin{tabular}{|l|l|l|l|l|l|l|l|l|l|l|l|l|l|l|l|l|l|l|l|l|l|l|l|l|l|l|l|l|}
\hline $\begin{array}{l}55 \text { a } \\
59\end{array}$ & $\begin{array}{l}60 \text { a } \\
64\end{array}$ & $\begin{array}{l}65 \\
69\end{array}$ & $\begin{array}{l}70 \text { a } \\
74\end{array}$ & $\begin{array}{l}75 \text { a } \\
79\end{array}$ & $\begin{array}{l}80 \text { a } \\
84\end{array}$ & $\begin{array}{l}85 \text { a } \\
89\end{array}$ & $\begin{array}{l}90 \text { a } \\
94\end{array}$ & $\begin{array}{l}95 \text { a } \\
99\end{array}$ & $\begin{array}{l}\text { Mayor } \\
100 \\
\text { años }\end{array}$ & $\begin{array}{l}\text { No } \\
\text { consta }\end{array}$ & \multicolumn{2}{l|}{$\begin{array}{l}\text { Total } \\
\end{array}$} \\
\hline V & H & V & H & V & H & V & H & V & H & V & H & V & H & V & H & V & H & V & H & V & H & V & H \\
\hline 0 & 0 & 1 & 0 & 1 & 0 & 0 & 0 & 0 & 0 & 0 & 0 & 0 & 0 & 0 & 0 & 0 & 0 & 0 & 0 & 0 & 0 & 18 & 17 \\
\hline
\end{tabular}

FUENTE: Boletín de Estadística Municipal de Castellón de 1918-1921. Elaboración propia. 
TABLA 5 MUERTE POR GRIPE EN OCTUBRE DE 1918 SEGÚN EDAD EN LA CIUDAD DE CASTELLÓN

\begin{tabular}{|c|c|c|c|c|c|c|c|c|c|c|c|c|c|c|c|c|c|c|c|c|c|c|c|}
\hline \multicolumn{2}{|c|}{$\begin{array}{l}<1 \\
\text { año }\end{array}$} & \multicolumn{2}{|c|}{1 a 4} & \multicolumn{2}{|c|}{5 a 9} & \multicolumn{2}{|c|}{$\begin{array}{l}10 a \\
14\end{array}$} & \multicolumn{2}{|c|}{$\begin{array}{l}15 \text { a } \\
19\end{array}$} & \multicolumn{2}{|c|}{20 a 24} & \multicolumn{2}{|c|}{25 a 29} & \multicolumn{2}{|c|}{30 a 34} & \multicolumn{2}{|c|}{$\begin{array}{l}35 \text { a } \\
39\end{array}$} & \multicolumn{2}{|c|}{$\begin{array}{l}40 a \\
44\end{array}$} & \multicolumn{2}{|c|}{$\begin{array}{l}45 a \\
49\end{array}$} & \multicolumn{2}{|c|}{$\begin{array}{l}50 \mathrm{a} \\
54\end{array}$} \\
\hline V & $\mathrm{H}$ & V & $\mathrm{H}$ & V & $\mathrm{H}$ & V & $\mathrm{H}$ & V & $\mathrm{H}$ & V & $\mathrm{H}$ & V & $\mathrm{H}$ & V & $\mathrm{H}$ & V & $\mathrm{H}$ & V & $\mathrm{H}$ & V & $\mathrm{H}$ & V & $\mathrm{H}$ \\
\hline 1 & 1 & 10 & 7 & 3 & 5 & 5 & 4 & 8 & 24 & 16 & 19 & 23 & 26 & 19 & 20 & 11 & 8 & 6 & 7 & 7 & 6 & 6 & 4 \\
\hline
\end{tabular}

\begin{tabular}{|c|c|c|c|c|c|c|c|c|c|c|c|c|c|c|c|c|c|c|c|c|c|c|c|}
\hline \multicolumn{2}{|c|}{$\begin{array}{l}55 a \\
59\end{array}$} & \multicolumn{2}{|c|}{$\begin{array}{l}60 a \\
64\end{array}$} & \multicolumn{2}{|c|}{$\begin{array}{l}65 a \\
69\end{array}$} & \multicolumn{2}{|c|}{$\begin{array}{l}70 a \\
74\end{array}$} & \multicolumn{2}{|c|}{$\begin{array}{l}75 a \\
79\end{array}$} & \multicolumn{2}{|c|}{$\begin{array}{l}80 a \\
84\end{array}$} & \multicolumn{2}{|c|}{$\begin{array}{l}85 a \\
89\end{array}$} & \multicolumn{2}{|c|}{$\begin{array}{l}90 \mathrm{a} \\
94\end{array}$} & \multicolumn{2}{|c|}{$\begin{array}{l}95 \mathrm{a} \\
99\end{array}$} & \multicolumn{2}{|c|}{$\begin{array}{l}\text { mayor } \\
100 \\
\text { años }\end{array}$} & \multicolumn{2}{|c|}{$\begin{array}{l}\text { No } \\
\text { consta }\end{array}$} & \multicolumn{2}{|c|}{ Total } \\
\hline V & $\mathrm{H}$ & V & $\mathrm{H}$ & V & $\mathrm{H}$ & V & $\mathrm{H}$ & V & $\mathrm{H}$ & V & $\mathrm{H}$ & V & $\mathrm{H}$ & V & $\mathrm{H}$ & V & $\mathrm{H}$ & V & $\mathrm{H}$ & V & $\mathrm{H}$ & V & $\mathrm{H}$ \\
\hline 8 & 2 & 2 & 4 & 0 & 1 & 1 & 3 & 2 & 0 & 1 & 0 & 0 & 0 & 0 & 0 & 0 & 0 & 0 & 0 & 2 & 0 & 131 & 141 \\
\hline
\end{tabular}

FUENTE: Boletín de Estadística Municipal de Castellón de 1918-1921. Elaboración propia. 
$\mathrm{N}^{\mathrm{o}} 14$

CARTA ABIERTA DE LOS ESTUDIANTES DEL MAgISTERIO, DANDO LAS GRACIAS A LA PRENSA DE CASTELLÓN POR LA BRILLANTE DEFENSA QUE HACEN EN PRO DE LA CREACIÓN DE LA ESCUELA NORMAL DE MAESTROS

Poco podemos decir que no sea gratitud por la brillante campaña sostenida por la prensa local en pro de la creación de la Escuela Normal; pero necesario es que la voz de los estudiante del Magisterio se oiga públicamente, que llamemos la atención de las fuerzas vivas de la capital, que supliquemos a todo Castellón, para que todos unidos, con los ayuntamientos al frente, solicitemos de la diputación provincial esta mejora, que tantos beneficios reportaría.

Considerad por un momento a una juventud ávida de saber, anhelante de esparcir por la patria la ilustración, deseosa a trueque de sacrificios de plantar la semilla de la virtud en los tiernos corazones de los que mañana serán los honrados ciudadanos esperanza de la patria, que en un momento las ilusiones, los ensueños se diseminan, se esparcen como el humo aún ante la luz del sol, púa en medio de una alegre juventud.

Considerad a una multitud de padres, que tras penosos trabajos y cuantiosos sacrificios, logran hacer estudiantes a su hijo amado y se ven obligados a suspender sus esfuerzos ante la imposibilidad de hacer frente a los gastos que se han multiplicado.

Nosotros rogamos a elementos oficiales y particulares, a obreros y patronos, para que directa o indirectamente presten su concurso, su influencia, el granito de arena necesario para que entre todos podamos conseguir nuestros deseos.

Acudamos el día 19 a la sesión que celebrará la diputación, para que se vea el interés de la capital; hagamos saber con nuestra presencia, que los deseos de toda la opinión se hallan basados en la Escuela Normal y habremos prestado un señalado beneficio a Castellón, a su provincia y a la patria. Firma José M ${ }^{a}$ Soler por la Comisión.

FUENTE: El Clamor, 12/09/1914 
CARTA DE LA DIRECTORA DE LA ESCUELA NORMAL DE MAESTRAS, LEONOR VELAO DIRIGIDA A LOS SEÑORES DIPUTADOS

A los señores diputados.

Loable y bienhechora me parece la actual campaña emprendida por la prensa en pro de la creación de la Escuela Normal de Maestros y causa la más justa de ser atendida por nuestras dignas autoridades, ya que en el pasado año demostraron el más vivo celo al elevar a Superior la Normal de Maestras y no creo que ese interés decaiga, ni omitan gasto ni sacrificio alguno.

Estos dignos castellonenses que tanto procuran mejorar su hermosa tierra, que tantos adelantos implantan atendiendo siempre al progreso material y moral de su país, no pueden abandonar la creación de un centro, base de la cultura social; un centro de donde han de salir los educadores del hombre, los modeladores del corazón humano, los que han de formar con su trabajo el pueblo del porvenir. Siendo verdaderamente cierto que la vulgarización de la cultura aminora los delitos, los gobernantes deben procurar que en esa cultura se propague y la tranquilidad del ciudadano estará más garantida.

Los establecimientos de enseñanza deben aumentar para la ilustración de que tanto carece nuestra querida España, regué de los grandes centros intelectuales, a los más apartados poblados.

Esa juventud que anhela instruirse, que desea adquirir conocimientos que ha de llevar al corazón de la encantadora niñez, merece ser atendida en sus justas pretensiones.

Ya nuestro digno gobernador, da pruebas del interés que la cuestión le inspira prometiendo protección a los jóvenes estudiantes que le han visitado y animado de su buen deseo convoca a la diputación para que la Normal de maestros se cree según las vigentes disposiciones.

Solo falta la buena voluntad de los señores diputados, quienes indudablemente aceptarán la propuesta sin reparar en el sacrificio que a la corporación le cuesta en bien de su amado pueblo, con lo que conseguirá despejar las tinieblas de la ignorancia en este escogido vergel, donde las brisas del mar templan los ardores del sol; donde las flores y las frutas se confunden llevando la abundancia y la alegría al resto de España. 
¡España! Pueblo infeliz sumido luengos años en la ignorancia; inundado su espíritu de amargura, el corazón del hombre, no podía gozar la paz, desconociendo lo más elemental de las ciencias que tenía en abandono.

Hombres humanitarios, han clamado por la vida del alma y a esta pueblo español, que ha sido suntuoso templo falte hoy enfermo en lecho de flores. ¿Quién ha de llevar esa luz a su inteligencia? ¿Quién ha de ser el médico que salve al paciente víctima del abandono intelectual? El educador de la niñez; el maestro de escuela.

Si en nombre de Dios han arrancado ya, de brazos de madres ignorantes y desgraciadas a quienes no se pensó educar, hijos que tenían abandonados, dándoles el alimento espiritual y corporal a que tienen derecho.

Señores, diputados, atended la justa petición de los alumnos del Magisterio defendida ya por el señor gobernador.

Únanse las fuerzas vivas para crear un centro que supone la regeneración social; levantad templos de sabiduría que ahuyenten para siempre la ociosidad, el deshonor, la intriga; derramad en vuestra patria el bienestar, la paz del alma.

Ya que con tanto interés elevasteis a superior la Normal de Maestras, que tengo el honor de dirigir, no retiréis vuestra pródiga mano y acordes, en la sesión del día 19, dad más luz a esta hermosa tierra levantina, teatro de gloriosos hechos, y si con su heroísmo don Jaime la arrancó del yugo musulmán, arrancadla también de la ignorancia ampliando sus medios de regeneración y por la educación, por la divulgación de la ciencia, sembrando así de flores el espinoso camino de la vida y rescatando delincuentes al presidio y al vicio.

Leonor Velao

FUENTE: El Clamor, 14/09/1914 
PRESUPUESTO DE LOS GASTOS QUE PODÍA REPORTAR LA ESCUELA NORMAL DE MAESTROS

Examinado el decreto del 30 de agosto tenemos:

\begin{tabular}{|l|l|}
\hline & Pesetas \\
\hline Dos profesores a 3.000 pesetas & 6.000 \\
\hline Cuatro ídem a 2500 pesetas & 10.000 \\
\hline Siete ídem especiales a 1.000 pesetas & 7.000 \\
\hline Dos auxiliares a 1.000 pesetas & 2.000 \\
\hline Un oficial de secretaria & 1.000 \\
\hline Un conserje & 750 \\
\hline Un portero & 650 \\
\hline Gratificación al director & 500 \\
\hline Gratificación al secretario & 250 \\
\hline Material & 2.000 \\
\hline Total & 30.150 \\
\hline
\end{tabular}

Esta cantidad sería más reducida si se aceptase el ofrecimiento del claustro de profesores del Instituto referente al material científico, mobiliario, etc.

Expuesto preguntamos: ¿Puede la corporación provincial soportar el pago de 30.000 pesetas anuales después de satisfacer las obligaciones contraídas?

Nosotros entendemos que sí y lo afirmamos rotundamente porque sabemos, como insinuábamos otro día, que hay sobrantes de algunos capítulos para los gastos del último trimestre de este año o primero de curso y con lo que adeudan al contingente provincial solo Vinaroz y Burriana sobra para mantener la Escuela más de cinco o seis años, contando que no pasará esta obligación al Estado tan pronto como se supone.

Es más si no estamos en un error, el Estado tiene el deber de reintegrar a la diputación el importe de las matrículas de los alumnos y siendo esta así habría que rebajar también de las 30.000 pesetas esa cantidad. 
En resumen que, a nuestro entender si la Escuela Normal de Maestros no se crea será porque no querrá hacerse un pequeño sacrificio, sacrificio, repitiendo lo que hemos dicho desde el principio de esta campaña, ha de reportar inmensos beneficios a la clase modesta que siente vocación por la enseñanza, a la cultura y a la provincia toda.

Medítelo bien la diputación, examine la trascendencia del asunto, tantee bien los medios de que dispone, y si lo hace así, libre de prejuicios, tendrá que venir con los que propongamos esta obra, en que la Escuela Normal de Maestros puede y debe crearse.

Esta es nuestra opinión que exponemos llanamente y sin fórmulas retóricas.

Cuando el nuevo, gobernador de Castellón, don Ángel Pérez tomó posesión de su cargo, los periodistas le recomendaron el asunto de la Normal de Maestros, prometiendo este, hacerse cargo para que su fundación fuera una realidad.

FUENTE: El Clamor, 15,09/1914 


\section{CARTA ABIERTA AL NUEVO GOBERNADOR DE CASTELLÓN DE LOS REDACTORES DE EL CLAMOR}

Para el señor gobernador:

A consecuencia de lo dispuesto en el R.D. del 30 de agosto último, el primero de octubre próximo desaparecerán de nuestro Instituto los estudios de Magisterio, quedando muchos desheredados de la fortuna sin poder continuar la modesta pero honrosa carrera de maestros por serles imposible trasladarse a otra capital.

Este y el desdoro que significa para Castellón y su provincia no poseer un centro de cultura de la índole del que se trata, impulsó a la prensa y a cuantas entidades se preocupan del problema de la enseñanza a acudir ante la diputación en demanda de la creación de la Escuela normal de Maestros.

$\mathrm{Su}$ digno antecesor, accediendo a los requerimientos de las 21 sociedades obreras, Círculo Mercantil, Ayuntamiento, Cámara de Comercio, Claustro del Instituto, Casinos de Artesanos, Dependientes de comercio, comisiones escolares, etc., ofreció todo su apoyo a la realización de tan laudable obra y comenzó por convocar a la corporación provincial para la tarde de 19 del actual a fin de que sin demora se acordase sobre el particular.

El haber sido aceptada por el gobierno la dimisión del señor del Río, ha impedido que aconsejara desde el sitial presidencial de la diputación, la creación de la referida escuela, contra tiempo que, de no haber recaído en usted el mando de la provincia seguramente hubiese hecho inútiles cuantos trabajos y esfuerzos se han realizado hasta hoy.

Como sabemos que es $\mathrm{V}$. hombre de vasta cultura y amante de la enseñanza como el que más, no reparamos en dirigirle el ruego de que interceda también en la demanda, para que con su valiosa cooperación se decida la diputación provincial a la instalación de la indicada Normal.

Si lo hace V. así y por su influencia o intervención la Escuela se crea, podrá vanagloriarse de que su labor al frente del gobierno civil de esta provincia tuvo el más honroso de los comienzos.

FUENTE: El Clamor, 15/09/1914 


\section{CARTA DEL INSPECTOR DE PRIMERA ENSEÑANZA JOSÉ SENENT EXPONIENDO SU OPINIÓN SOBRE LA SUPRESIÓN DE LA ESCUELA NORMAL DE MAESTROS}

El último decreto reorganizando las Escuelas Normales y estableciendo la unidad de título en la carrera del Magisterio, puso en compromiso de honor a las diputaciones provinciales que hasta ahora solo sostenían los estudios elementales del magisterio. El dilema fue decisivo, escoger entre la supresión de todo estudio del magisterio o ponerse a la misma altura de todas las escuelas Normales para conferir el título único de maestro superior.

Todas las diputaciones españolas que sostenían Escuela Normal elemental aceptaron el compromiso de continuar los estudios del Magisterio, en virtud del Real Decreto del 14...Faltaba que resolviera Castellón en este pleito de la enseñanza en el cual se han arriesgado diputaciones cuyo contingente provincial era bastante inferior al de la provincia castellonense.

La opinión más respetable moralmente, la opinión popular a través de toda la prensa diaria castellonense se declaró a favor de la Escuela Normal. Todas las sociedades obreras, la Asociación provincial de maestros públicos, los claustros de profesores de la Normal de Maestras y del Instituto sintieron la necesidad de ese centro de cultura. Catedráticos del Instituto ofrecieron su concurso aceptando desinteresadamente la enseñanza de muchas asignaturas, y otras entidades prometieron apoyar materialmente la realización de la obra de la Escuela Normal. Solamente faltaba que decidieran los diputados provinciales.

No dudamos que los señores diputados secundarán la opinión unánime y clamorosa por la Normal y que pronto tendrá Castellón, al igual que las otras provincias que le limitan, su centro de formación del Magisterio, plantel de maestros, los que han de educar al pueblo haciéndole sentir fuertemente el amor a la tierra como condición primera para el mejoramiento moral y material de esta bella región castellonense. La provincia que desee tener buenas escuelas debe preocuparse en formar primeramente buenos maestros. 
Hay que aspirar a tener una escuela Normal verdad, propia, que pueda competir en profesorado y medios de enseñanza con las otras Escuelas Normales y para ello ha de bastar que la Diputación se ajuste por entero a todas las nuevas reformas que preconiza el Real Decreto citado.

La Normal no solo ha de ser plantel de Maestros, fomentando la vocación de los hijos de la provincia, procurándoles medios y facilidades de estudio, sino que además, con su Escuela graduada práctica, ha de ofrecer un modelo vivo y pródigo en enseñanzas para todas las Escuelas de la capital y provincia, públicas como privadas.

Enfocado de esta manera el problema de la Normal, la Diputación, no solo ofrenda a la patria un centros de cultura sino que crea en la región la casa solariega del Magisterio castellonense, hogar fecundo donde se forme nuestro Maestro, el más interesado por la prosperidad y bienestar de este suelo.

La creación de la Normal ha de emplazarse mirando el futuro. La carrera del Magisterio va cara el día; aumentan el sueldo de los Maestros, el decoro de la clase, y crece la matrícula en todas las Normales de España. Castellón ha visto aumentar desde la fundación de su Escuela Normal elemental el número de estudiantes del Magisterio. Sin duda alguna estos estudiantes han de crecer enormemente el día que la Normal tenga sus locales propios y elevada a superior, tenga tanto prestigio como las Normales de otras provincias.

La creación de la Normal aportaría un número de intelectuales a la población, de cuyo valor y contribución a la cultura del país no podemos dudar.

No hemos de hablar de los muchos beneficios económicos que alcanzaría la capital de la provincia al aumentar su población con nuevas familias, de la protección que recibirían los estudiantes hijos de la región generalmente desheredados de la fortuna y de los recursos que merced a la Normal, podrían estos alcanzar con becas pensiones al extranjero, bolsas de viaje, etc.

La Escuela Normal de Maestros por la importancia que hoy día tienen estos funcionarios, es correlativa y tan necesaria como la Normal de Maestras y el Instituto de segunda enseñanza. De suprimirse la Normal de Maestros queda rota y deficiente la enseñanza en Castellón.

Muchas otras razones a favor de la Normal han de encontrar seguramente la Diputación provincial, cuya vida próspera no solo le permite levantar soberbios 
edificios de beneficencia y caridad, sino que ha de darle arrestos para acometer de lleno estas otras mejoras para la enseñanza.

El Estado ha brindado ocasión a la provincia castellonense para demostrar su interés por la cultura y esta debe aceptar gallardamente el compromiso de honor.

Los señores diputados tienen la palabra.

José Senent

El Clamor, 19/09/1914 


\section{CARTA DE RAMÓN Y CAJAL AL PADRE ANTONIO VICENT:}

Valencia, 1 de enero de 1885

Mi querido P. Vicent:

Recibí la suya con gran contento, si bien no dudaba nunca que me escribiría Vd. Y por ella veo lo satisfecho y complacido que V. está al lado de esos sabios.

Yo quisiera también imitarle a $\mathrm{V}$. pero las circunstancias me lo impiden, teniendo que resignarme a ver y seguir aunque de lejos el movimiento científico de la Alemania y de la Bélgica.

Casi todos estos tres últimos meses los he consagrado al estudio del núcleo y del protoplasma, y he tenido la dicha de comprobar casi todos los detalles estructurales que describen Fleming y Carnoy con algunos otros de mi propia cosecha que verán la luz cuando pueda publicarlos.

He aquí copia de algunos de mis dibujos algo esquemáticos

Aquí Cajal incluye un dibujo bajo el cual se lee el texto que sigue:

-núcleo

-filamento de cromatina del núcleo con textura muscular

-filamentos de plastina

-célula del estómago suceur de la larva de la mosca

Dígale a V. a Carnoy que he comprobado en el cloporter y en las larvas de múscidos su red de plastina del núcleo, aunque algunas veces en las larvas no me ha aparecido red, sino un glomérulo sumamente delgado y pálido que no se colorea por el verde de metilo ni por el violeta de dalia.

En las células intestinales del cloporte he descubierto una singular disposición, así como un cosido de célula a célula que me parece ser igual que el que se manifiesta entre las células epidérmicas de la piel humana, y cuyos detalles se podrán ver en la figura adjunta:

Aquí Cajal incluye un dibujo.

De suerte que aparte de las dos membranas que describe Carnoy hay que añadir un hilo estriado que cose las células impidiendo su retracción. 
El nucléolo para mí es estructurado, contra la opinión de Fleming y Strassburger. No participo de la creencia de Carnoy de que el nucléolo no tiene existencia real según la definición de Valentin porque siempre es o un boyau apretado o un enclave o un recodo del boyau etc., pues yo he visto claramente los nucléolos del estómago suceur de las larvas con un nucléolo formado de un boyau acromático que se colorea por la safranina pero no por el metilo y formado de una sustancia de gran índice de refracción que hinchan y estropean los ácidos. Véase este dibujo

Aquí Cajal incluye un dibujo bajo el cual se lee el texto que sigue:

-nucleolo formado de un filamento de una materia no coloreable por el metilo y solo bien observable en agua

-Boyau del núcleo que aparece solamente después de la adición de agua acetificada

-protoplasma con la red de plastina

La estructura reticulada la he comprobado en el hombre, en las células conectivas, las epiteliales de las fauces, las del cuerpo de Malpigio, etc. por estas y otras cosas comprenderá $\mathrm{V}$. que no me conviene interrumpir mi obra, antes al contrario es urgente en 1r.término que yo publique lo comprobado, siquiera para dar a entender que no son desconocidos en España estos conocimientos y para dar a la estampa lo poquísimo que como fruto de 7 años de trabajos he podido recoger. Además, aunque quisiera interrumpir la publicación de mi obra no podría, pues ya hace dos meses que comenzó y tengo formal compromiso con el editor para publicarla.

Habla V. de las nuevas cosas que Carnoy ha descubierto en el tejido muscular, etc. quisiera que V. me remitiera un apunte de esas nuevas doctrinas, para darles cabida en mi libro siquiera fuese de un modo sucinto, tanto más cuanto que tengo también sobre la célula muscular un concepto de textura muy distinto al que ordinariamente se tiene. Yo crepo que la fibra reticular es simplemente un reticulum protoplasmático ligeramente diferenciado, que la materia interfibrilar está formada de las trabéculas longitudinales y los discos transversales con modificaciones y diferenciaciones necesarias al mejor cumplimiento de la función. En la figura se ve cómo los discos oscuros de la fibra se resuelven en trabéculas de un reticulum protoplasmático que arranca del nucléolo, siendo la materia interfibrilar de los músculos ordinarios representada por trabéculas longitudinales, etc.

Aquí Cajal incluye dibujo bajo el cual se lee el texto siguiente: 
-célula muscular del estómago de una larva de lepidóptero tratada por el agua ácida.

No puedo extenderme en estas coas porque me saldría de los límites de una carta amistosa, baste lo dicho para darle a entender que aunque V. trabajaba al lado de sabios ilustres yo he hecho lo que he podido también, ¡Ah! ¡Quién tuviera esos magníficos objetivos a que Fleming, Strassburger y Carnoy deben sus descubrimientos! ¡Quién pudiera poseer un Seibert 1/6 o un Zeiss 1/18! Aquí desgraciadamente las facultades no tienen material y, aunque yo me empeñara en pedir uno de esos objetivos, no me lo permitiría el decano por falta de fondos. Mucho envidio más aún esa riqueza de medios técnicos de que Vs. gozan, con la que se hace cuanto se quiere. Yo tengo que resignarme con un objetivo 8 de inmersión Verik y éste gracias a que es de mi propiedad, que por la Facultad no tendría más que un 5 o un 6 Nachet.

Espero con ansiedad el marzo y abril para entregarme en cuerpo y alma al estudio de los karyokinesis. Para vello tengo ya a mi disposición la magnífica obra de Fleming: Zelltheilung y su memoria de los Archv für micros. Anatomie: Ueber den Theilungsvorgand der Zellkerne und das Verhältniss der kerntheilung zur zelltheilung, 1882 , etc.

Dígame cuándo publica Carnoy la segunda parte de su obra, pues tengo gran ansiedad por conocerla. Le dará Vd. en mi nombre una calurosa felicitación por sus trabajos, que revelan una paciencia y unas aptitudes más que germánicas, y que demuestran que no es solamente en Alemania y bajo la religión protestante donde florecen los estudios biológicos.

Igualmente si algo nuevo encuentra V. publicado en inglés, alemán o francés sobre estas materias (y sus frecuentes relaciones con Carnoy se lo harán a V. saber) estimaría me lo remitiera enseguida, lo mismo que la nueva parte de la obra de Carnoy, pues sabe V. cuánto me interesan estos estudios.

De Ferrán tengo noticias frecuentes. Ha descubierto la vacuna del cólera y se ha vacunado él mismo. Sus trabajos hacen mucho ruido. A mí me remitió alguinso microbios con los que he parcticado algunas experiencias.

Sin más, sabe cuánto me alegro de su salud y felicidad, y mande V. lo que guste a su verdadero amigo y servidor.

S. Ramón y Cajal

Calle de Pizarro, 8 pral. izquierda, Valencia 
FUENTE: FERNÁNDEZ SANTARÉN, Juan Antonio (2014): Santiago Ramón y Cajal. Epistolario. La Esfera de los Libros, Madrid. pp. 300-303.

Vicent Dolz escribió a Santiago Ramón y Cajal el 28 de enero de 1901 lo siguiente: 28 de enero de 1901

\section{Sr. D. Santiago Ramón y Cajal}

Mi ilustre y amado en Xto. Amigo:

Acabo de recibir desde el tomo I hasta el IV de su Revista Trimestral; y la Relación de los títulos y méritos y trabajos científicos. Le estoy por ello agradecido y estoy, como V. sabe, a la correspondencia. Sé por mis amigos de ésa que pronto tendremos en Madrid un Instituto Cajal como en Francia existe un Instituto Pasteur. Que sea pronto, que propios y extraños tengamos un centro científico y un maestro eminente que pueda ilustrar a profesores y a discípulos que a él acudan. Tengo que participarle que en Madrid saldrá pronto una revista redactada por los PP. de la Compañía de Jesús y en ella se me ha encargado de la redacción del Boletín Biológico. Para la debida información recibo ya las mejores revistas del extranjero. Me he hecho suscribir a la hermosa Revista Trimestral Micrográfica, y esperemos que con la ayuda de mi ilustre amigo D. Santiago cumpliremos con el cargo que la obediencia me ha impuesto. He pensado que lo más conveniente y propio será empezar citando al estado actual de la biología. Recuerdo que me habló V. de un libro de citología de un español americano. Desearía conocer el título de la obra y donde se vende porque me lo compraría. No se incomode en contestarme porque ya tendré ocasión de algún amigo que pase a preguntárselo. Mi respeto a su Sra. y familia y sabe que lo respeta y ama su mejor amigo de su maestro.

q.b.s.m.

Antonio Vicent

FUENTE: FERNÁNDEZ SANTARÉN, Juan Antonio (2014): Santiago Ramón y Cajal. Epistolario. La Esfera de los Libros, Madrid. pp. 303-304 


\section{CONFERENCIA DE ODÓN DE BUEN: «DARWIN Y SUS TEORÍAS EVOLUCIONISTAS»}

Ante numeroso público, que llenaba por completo el amplio local del Centro del Partido, dio anteanoche su anunciada conferencia sobre Darwin y su teorías evolucionistas" el sabio catedrático de Historia Natural de la Universidad de Barcelona, don Odón de Buen.

Pocas veces, como anoche, se vio dicho local tan concurrido de señoras y señoritas, que con su presencia, patentizaban de una manera evidente que la mujer castellonense ha comenzado a interesarse por las transcendentales teoría de las ciencias modernas.

Al penetrar en el salón el señor Buen fue saludada su presencia con una ensordecedora salva de aplausos que no terminó hasta que el joven presidente, señor Huguet Segarra (don Cayetano), pronunció breves palabras de presentación del ilustre conferenciante del que dijo, no necesitaba de tal requisito, pues de sobra era conocido 'por haber tenido la dicha de escucharle los castellonenses en dos ocasiones más y por su fama mundial como hombre de ciencia y como político sobresaliente de las filas democráticas españolas. Eso sí -añadió el señor Huguet- yo debo dar las gracias al señor Buen, en nombre de todos los correligionarios, por el sacrificio que supone abandonar sus múltiples ocupaciones del sabio profesor para venir a Castellón y satisfacer con sus luminosas enseñanzas, el deseo de saber de este pueblo culto y amante del progreso en todas sus varias y complejas manifestaciones.

Las últimas frases, sencillas pero elocuentes del señor Huguet, fueron premiadas con calurosos aplausos.

Hecho el silencio ocupó la tribuna el señor Buen, comenzando su notabilísima conferencia con palabra reposada, a la par que elocuente, propia del hombre de ciencia, acostumbrado a la tarea diaria de explicar en la cátedra a sus alumnos los complicados estudios de las ciencias Naturales.

Señoras y correligionarios-comenzó el señor de Bueno podéis imaginaros la honda satisfacción que siento en estos momentos al ocupar de nuevo estas tribuna para hablar a los amigos de este pueblo tan querido por mí y que siempre ha tenido conmigo 
tantas deferencias que cada vez que vengo contraigo una nueva deuda de gratitud con vosotros; resultando de aquí, que siempre soy deudor vuestro y de ello me congratulo, pues así tendré siempre un motivo más para veros y abrazaros efusivamente.

Y es que- continua- a pesar de los sinsabores y asperezas de las luchas políticas y sociales existe en el fondo del alma humana un sedimento de bondad y pureza de ideales que hace que, los hombres que batallamos a diario por el triunfo de las ideas modernas de verdad y razón, encontramos siempre, como ahora en estos momentos me ocurre a mí, un oasis donde se espacia el espíritu y se fortalece el ánimo para proseguir con más entusiasmo que antes si cabe, la lucha pertinaz e incesante en pro de la verdad científica que en plazo no lejano acabará, para siempre, con esa otra ciencia fantasma dualista que tanto mal ha hecho a la humanidad retardando su progreso y evolución hacia su perfeccionamiento social e intelectual (grandes y prolongados aplausos).

Dedica a continuación, el ilustre conferenciante, calurosos elogios a la Juventud Republicana de Castellón, por la labor sólida y eficaz que viene realizando con la serie de conferencias políticas sociales y científicas que se dan en su casa social.

Pasa seguidamente a ocuparse de lleno sobre el tema objeto de su conferencia, haciendo un ligero estudio psicológico del carácter de aquel gran genio llamado Carlos Darwin, autor de la más grande de las teorías modernas que había de revolucionar totalmente las creencias de todos los hombres de ciencia de su época y había al propio tiempo de destruir la falsa doctrina dualista, que aún por desgracia hoy hombres en España que la defienden sin poder demostrarlo científicamente, como lo demostramos nosotros en los laboratorios y de una manera incontrovertible y sin lugar a dudas.

Refirió como Darwin acumulaba estudios sobre estudios, como transcurrieron veinticinco años de su vida en incesantes investigaciones para afirmarse más y más en sus teorías evolucionistas, hasta llegar por fin al convencimiento propio de la verdad de sus conclusiones de que todo se transformas; de que toda planta, de que toda materia evoluciona incesantemente hasta llegar a su completo desarrollo, al perfecto estado de su característico modo de ser.

Relató, con bastante minuciosidad, la lucha que se entabló en toda Europa al lanzar a la publicidad Darwin, su libro "Origen de las especies" y como gracias a una valiosa y entusiasta pléyade de jóvenes discípulos, Haeckel, entre, ellos, que aún vive, logró imponerse a los verdaderos hombres de ciencia, hasta llegar ahora en que ya ni si quiera se discuten por temor, los que aún no los han aceptado públicamente, a caer en el 
ridículo más espantoso ante las revelaciones maravillosas del microscopio que pone ante los ojos del hombre, no ya solo al de estudios, sino hasta del profano la verdad inconfusa de la doctrina darwiniana de la transformación de las especies.

Citó también, como ya el célebre poeta alemán Goethe, antes de que Darwin lanzara al mundo sus célebres teorías, esbozó la idea de que no existía efecto sin causa "teoría que se llamó de la causalidad" y que sirvió luego para hacer más firmes las teorías transformistas.

Enumeró todas las teorías sobre la creación de las cosas y los seres que sostuvieron Lineo, Cuvier y Lamarck y otros muchos hombres de ciencia, haciendo resaltar el progreso que se había realizado desde Darwin a los tiempos actuales gracias al empeño y al entusiasmo de gran número de sabios químicos, naturalistas, geólogos, físicos e histólogos, sin olvidar a nuestro gran Ramón y Cajal, que comenzaron una ruda y empeñada labor de estudio y de investigación que nos han conducido hasta llegar hoy en día, si no totalmente al final del exacto conocimiento de la célula embrionaria en sus misteriosas y grandes manifestaciones de vida ultrauterina; se ha llegado hasta afirmar de una manera concreta y categórica, que en plazo no lejano será un hecho real y positivo la selección de la especie humana por medio de una operación, no sabemos cómo realizada, en la célula, para extirpar de ella los gérmenes morbosos que hacen, por ley de herencia, que nazca un ser en anómalas condiciones para entablar la llamada lucha por la existencia.

Habló finalmente de como se ha glorificado no hace mucho a Darwin con motivo de su centenario y como, aunque parezca mentira, España, la atrasada, la tradicional España de la rutina social y política envió, mandando los conservadores, su representación oficial a Edimburgo, patria del sabio naturalista, donde se celebraron las grandes fiestas en su honor y como también de aquellos días en que de real orden se prohibía la explicación en la Universidades españolas las teorías evolucionistas, hemos llegado hoy día a ver en casi todas las cátedras de Historia Natural de España el retrato de Darwin presidiendo las explicaciones de los profesores.

Benditos los pueblos-termina el señor Buen que inspirándose en la verdad científica y haciendo abstracción de prejuicios rancios y caducos, encaminan sus pasos hacia lo porvenir guiados por el faro luminoso de la ciencia que indica el fin de la suprema aspiración.

FUENTE: El Clamor, 7/01/1911 


\section{CONFERENCIA ACERCA DE LA HIGIENE EN CASTELLÓN DEL} PROFESOR DON PEDRO ALIAGA EN EL CASINO DE ARTESANOS

Aliaga explicó las diferentes causas que influyen para que Castellón no estuviera a la altura que debiera en cuestión de higiene, comparando las cifras de mortandad en los diversos países de Europa con las de España, y Castellón que arroja datos que dicen bien poco en pro de nuestra ciudad.

Entrando a examinar las principales causas, se fijó en las condiciones en que se suministra a Castellón el agua del río Mijares, criticando a los que con su apatía permiten que sea y un peligro constante para la salud pública

Llamó la atención sobre el estado de las calles en Castellón y de la limpieza que en las mismas se efectúa, enumerando los múltiples peligros a que están expuestos los ciudadanos.

Habló sobre los terrenos pantanosos situados en puntos no lejano de Castellón, ocupándose de las consecuencias que reportan bajo el doble punto de vista de la higiene y la riqueza, pues que ellos son causa de que los labradores permanezcan en la ciudad en vez de vivir en las tierras que cultivan.

Y por último se ocupó de los establecimientos públicos. Se felicitó que estén en construcción el hospital y la cárcel, para sustituir a los malos edificios que a estos objetos están destinados. Hizo observar las deficiencias de que adolecen las escuelas públicas, no solo para la enseñanza, sino también para la salud de los niños que a ellas concurren. Recordó con tal motivo los hechos realizados por Castellón en diversas ocasiones, alentando a sus oyentes para hacer un esfuerzo supremo para construir algún local adecuado para la primera enseñanza.

No fueron vanos los esfuerzos del señor Aliaga, «pues según las últimas noticias, importantes personajes de Castellón se agruparán para algunos de los objetos por aquel señor señalados.»

FUENTE: El Clamor, 8/12/1888 


\section{SEGUNDA CONFERENCIA DE PEDRO ALIAGA SOBRE LA HIGIENE EN CASTELLÓN}

El profesor del Instituto don Pedro Aliaga, el lunes 10 a las 9 de la noche dio una conferencia en el Casino de Artesanos sobre «La Higiene en Castellón», el público era numeroso, atraídos por lo practico e interesante del tema, que iba a ser tratado y la competencia que todos reconocen en el disertante.

Aliaga comenzó su conferencia en un tono familiar y al alcance de todas las inteligencias, demostrando la importancia de la conservación de la salud que es el mayor de los tesoros, porque una vez perdida se pierde también con ella el bienestar, la tranquilidad y todo lo que el hombre más estima, y luego paso a examinar si la ciudad de Castellón, es verdaderamente higiénica, o si por el contrario deja que desear en este importantísimo punto de la vida civil, y con la elocuencia de la estadística nos hizo ver, que a pesar de su buen clima es de las poblaciones de España en que la cifra de la mortalidad es más espantosa, llegando a la enorme proporción de treinta y cuatro, por mil, el número de las defunciones anuales, y siendo los niños de corta edad los que pagan mayor contingente a una muerte prematura.

Pasó luego a examinar las condiciones de los alimentos, las aguas y los aires como agentes morbosos, hizo atinadas observaciones sobre la alimentación de nuestros labradores, que hubiese convenido se hallasen presentes para aprovechar advertencias que tan de cerca les tocaban, y luego pasó al examen de las aguas, lamentándose de que sirvan de sumideros corrientes que proporcionan aguas potables y que con muy poco coste podrían ser preservadas de toda clase de inmundicias. Se ocupó también de los marjales, y de la necesidad imperiosa de su desecación que tanto contribuiría al aumento de la población, de la salubridad y de la riqueza.

Por último, pasó a estudiar las condiciones del aire atmosférico, encontrándolo sano en el secano, vicioso en la huerta y más todavía en la capital. Habló de las condiciones del hospital y la cárcel, y se fijó principalmente en las escuelas, de las que hizo un estudio detenido, lamentándose amargamente del abandono en que se encuentra la educación de la infancia, del escaso número de escuelas que hay en la población, y de las pésimas condiciones de luz y capacidad de las mismas, de donde resulta que son un peligro constante para la vida de la niñez. Con esta ocasión prorrumpió el orador en 
quejas conmovedoras que hicieron honda impresión en el público. La concurrencia salió sumamente complacida, tributándole calurosos aplausos.

FUENTE: La Provincia, 13/12/1888. 


\section{REUNIÓN DE LA JUNTA DEL CASINO DE ARTESANOS PARA FOMENTAR Y MEJORAR LA INSTRUCCIÓN PRIMARIA EN CASTELLÓN}

El jueves 3 de enero de 1889, se reunió la junta nombrada por el Casino de Artesanos, para fomentar y mejorar la instrucción primaria en esta capital.

Asistió la directiva del Casino, los señores conferenciantes y representantes de la prensa. Después de una discusión se acordó imprimir la exposición redactada por el señor Salinas (profesor de Retórica del Instituto), para elevarlo al ayuntamiento, pintando con vivos colores el lamentable estado de las escuelas, pidiendo respetuosa pero enérgicamente, que se remedie con urgencia las apremiantes necesidades de la instrucción primaria en Castellón. Mañana, después de la conferencia que se dará en los salones del citado casino de Artesanos, se expondrán los acuerdos tomados y se leerá la exposición

Creemos que la sesión estará muy concurrida, atendiendo la importancia del asunto que en él debe tratarse.

En el notable trabajo del señor Salinas se encarecen los beneficios de la enseñanza, manifestando que difunde entre las clases populares la educación, la cual reforma las costumbres, suaviza los modales y dilata los horizontes de la inteligencia, eleva los sentimientos del corazón, dispone y capacita para vivir la vida regular y ordenada de las sociedades modernas, avalora los productos del trabajo dándoles una dirección cada día más inteligente y progresiva, y arranca, por último, la niñez de los brazos de la ociosidad y de la vagancia, convirtiendo en miembros útiles de la sociedad del porvenir a los que tal vez sin el maestro que guía sus inseguros pasos, concluyeran sepultándose en el abismo de la perdición, porque el delito es el hijo natural de la ignorancia.

Según las desconsoladoras estadísticas registradas en el trabajo que extractamos tomadas de unos estudios realizados por el insigne hijo de esta provincia señor Gimeno Agius, la provincia de Castellón es una de las tres últimas que menos sumas destina a la enseñanza, resultando que mientras las provincias castellanas dedican tres y aun cuatro pesetas anuales por habitante, ésta solo destina 72 céntimos de peseta por individuo, lo cual da por resultado que escasamente llegue al 20 por 100 el número de los varones que saben leer y escribir, cuando pasa de 60 por 100 en aquellas provincias, siendo casi 
negativa la instrucción de la mujer, pues escasamente llega al 7 por 100. Añade que prescribiendo la ley de 9 de Setiembre de 1857 la existencia de un escuela de niños y otra de niñas por cada 2.000 habitantes con censo de 26.000 almas y 4.400 niños de 4 a 12 años de edad, hay solo abiertas en esta capital siete escuelas públicas que carecen por completo de condiciones de capacidad e higiene, a tal extremo que debiendo tener según las disposiciones vigentes cada niño un espacio de un metro veinticinco centésimas y cinco metros cúbicos de aire, apenas cuentan la quinta parte de espacio para moverse y el volumen de un metro cúbico de aire respirable.

De estas y otras consideraciones no menos dignas de tenerse en cuenta, concluye la exposición, demostrando la absoluta necesidad de la reforma de las escuelas de esta capital, para que Castellón se encuentre en este ramo a la altura que le corresponde.

FUENTE: La Provincia, 6/01/1889 


\section{SEGUNDA REUNIÓN EN EL CASINO DE ARTESANOS PARA PEDIR AL AYUNTAMIENTO NUEVOS CENTROS DE INSTRUCCIÓN PRIMARIA}

En el Casino de Artesanos, el lunes por la noche después de una conferencia del señor Gasset, subió a la tribuna el ilustrado profesor del Instituto señor Aliaga, para dar cuenta de las gestiones practicadas por la comisión que entiende en la creación de nuevas escuelas en esta capital; y el docto catedrático señor Salinas, dio después lectura a una brillante, razonada y entusiasta exposición dirigida al Ayuntamiento, a cuyo pie van ya innumerables firmas, en la que se demuestra palmariamente la imperiosa necesidad que existe de llevar a cabo cuanto antes nuevos centros de instrucción primaria que llenen las exigencias de la moderna pedagogía, y las condiciones higiénicas tan atendidas hoy en los edificios construidos paras la enseñanza. El numeroso público que llenaba el salón del Casino, aplaudió repetidas veces los conceptos tan magistralmente tratados en la exposición que fue leída con entonación y sentimiento.

Por nuestra parte nos asociamos también gustosos a tan nobles propósitos, y ofrecemos el humilde concurso de La Provincia, para la recomendable obra de propagar la instrucción pública, nervio del progreso, y bandera de la civilización y de la: cultura.

FUENTE La Provincia, 10/01/1889 
CONSIDERACIONES SOBRE LA ESCUELA MODERNA EN LA PRENSA DE CASTELLÓN

[...] Dase hoy más importancia que nunca a la instrucción primaria. Reconócese universalmente que la educación del niño debe interesar a la patria, considerando que el porvenir de la misma depende del desarrollo físico e intelectual de las nuevas generaciones. Por eso los gobiernos de todos los países atienden con preferencia al profesorado y mejoran con arreglo a los consejos de la higiene y de la pedagogía el régimen interior de las escuelas y todos sus servicios materiales.

No es ni debe ser la escuela de nuestros días aquella estancia de reducido espacio, lóbrega y sin ventilación, pobremente alhajada de bancos deslucidos y mesas toscas en que un profesor de rostro avinagrado hacíase espantable y odioso a los muchachos por la rigidez de su sistema inspirado en aquel rudo aforismo: la letra con sangre entra.

La escuela moderna ha perdido su triste aspecto de cárcel sombría y sus prácticas inquisitoriales. Y así debe ser. El niño ha de ir a la escuela, y ha de cumplir con los deberes que allí le impongan, no forzado por el terror, sino atraído por la confianza, la expansión y la simpatía. La base fundamental del sistema de educación de párvulos, establecido por Montesinos, consiste en hacer agradable a los niños la estancia en la escuela.

Froebel, comprendiendo lo importante que es inculcar a los niños el amor a las personas encargadas de comunicarles los primeros conocimientos, pensó acertadamente que las mujeres pudieran cumplir mejor que los hombres esta nobilísima misión. Su carácter más afable y dulce que el del hombre, es mucho más adecuado para el trato de los niños de corta edad.

Pero no solamente bajo este aspecto capitalísimo ha variado la escuela, no viéndose ya regentarla el tipo parsimonioso y cruel, caricaturizado por Quevedo en su famoso dómine Cabra, sino que también ha sufrido saludable y radical reforma, así en el orden pedagógico como en el higiénico.

No se tortura a los niños con violentos ejercicios de memoria, como antes sucedía, obligándoles a aprender por rutina mecánica lo que sin el auxilio de la reflexión y el juicio había de olvidar brevemente. Un método racional les enseña a discernir de las cosas por comparación, y a apropiarse los primeros conocimientos sin esfuerzo, mediante la sencilla y natural explicación de sus sentidos. 
No es menor el cambio que se ha efectuado en el material de la escuela. Un salón amplio, bien ventilado y esplendido de luz ha venido a reemplazar al estrecho y lóbrego recinto en que los escolares se apiñaban. En la escuela moderna tiene tanta importancia, cuando menos, que la educación intelectual, el desarrollo físico y la salud de los niños

En España se viene realizando, siquiera sea lentamente, este progreso. Así en Madrid como en muchas capitales de provincia y en otros pueblos de importancia hay ya escuelas regidas conforme a los adelantos de la moderna ciencia pedagógica. El sistema de enseñanza Froebel va prevaleciendo, y el Estado no permanece indiferente, como antes, a la mejora de la primera enseñanza en todos sus ramos.

Esto no basta para que lamentemos todavía que el perfeccionamiento no se lleve con la premura que exige asunto tan importante. Mucho queda por hacer, sobre todo en lo relativo al saneamiento de las escuelas de párvulos, que en las grandes poblaciones necesitan reunir singulares condiciones higiénicas.

Para suplir tales deficiencias, en otros países se han establecido las colonias escolares, y también entre nosotros se ha ensayado recientemente este sistema. Ya que en el interior de una gran población no sea fácil construir las escuelas rodeadas de vastos jardines en que los alumnos pudieran solazarse y robustecerse con ejercicios corporales al aire libre, se han organizado periódicas excursiones al campo y estancias prolongadas de los niños, bajo la dirección de sus profesores, en comarcas saludables y pintorescas.

Muchos años hace que en Dinamarca y Suiza se establecieron las colonias escolares durante las vacaciones veraniegas. Inglaterra, Francia y Alemania han adoptado también esta costumbre, que influye poderosamente en el desarrollo físico de los niños. En Leipzig, desde 1882, hay establecidas otras colonias con el título de urbanas, más fáciles de plantear, porque consisten en la construcción de edificios cerca de las ciudades en parajes convenientemente situados.

El ideal de la escuela moderna no llegará a su perfecta realización hasta que por todos los medios se consiga el desenvolvimiento en la infancia de los dos elementos esenciales del organismo humano: el psíquico y el fisiológico.

Plausibles son los esfuerzos realizados en los últimos años por el Museo Pedagógico de instrucción primaria de Madrid por aclimatar entre nosotros la práctica de las colonias escolares durante las vacaciones de verano; pero es necesario que en la 
iniciativa le ayuden como en otros países acontece, no solo el Municipio y el Estado, sino también los particulares.

El mejor medio para atender a las necesidades de la moderna escuela y para dotarla de las condiciones que hoy se exigen, sería la creación de Cajas escolares como en Francia existen. Estas cajas, que se constituyeron por ley de 1867 en todos los municipios, reciben ingresos de los donativos particulares y de las subvenciones del Ayuntamiento, del departamento y del Estado. Sus fondos se destinen a la asistencia de las escuelas, a recompensas pecuniarias a los alumnos asiduos y aplicados, y al socorro de los más pobres.

FUENTE: La Provincia, 17/01/1889 


\section{UNA OBRA BENÉFICA: HABLA EL DOCTOR GEA}

Crispín siente gran predilección por el doctor Gea. Su conversación le atrae, le domina. Su fluida palabra le encanta.

Sí -me decía- mucho se puede hacer, mucho; aunque la consignación es corta, aunque con 8.000 pesetas poco se puede lograr de una manera definitiva.

Hermosa institución sería La gota de leche, aunque su funcionamiento es caro y se presta a grandes corruptelas por parte de los beneficiados.

También sería una obra humanitaria, el sanatorio para tuberculosos, pero no en la forma que apuntas- me decía el doctor- sino para evitar tan terrible mal en la infancia.

¿Cómo?...Sencillísimo. Bastaría recoger a los niños de padres tuberculosos y buscar matrimonios de honradez intachable que, por una modesta retribución, se encargarían de cuidarlos, de educarlos y hacerlos hombres, lejos de Castellón, en la montaña, en aquellos pueblos que por sus condiciones higiénicas lograsen destruir los gérmenes de tan terrible enfermedad.

¿Ventajas?...Muchísimas. Todo los tuberculosos, desgraciadamente puede contagiar a los que le rodean, y su enfermedad aún no ha logrado dominarla la ciencia .irremisiblemente, el tuberculoso ha de desaparecer del mundo de los vivos. Y calculo lo triste que resulta en la actualidad ver a aquellos inocentes niños, quizá contagiados por el contacto, y que muerto su padre no les queda otro recurso que la Casa de Beneficencia.

Con este plan de que hablo ¡cuánto bien no haríamos a las criaturas, a las que libraríamos del contagio y a las que les daríamos, y esto es lo más importante, unos padres adoptivos que no los abandonarían, que completarían su educación, que los tendrían como a hijos!...

-Hermosa idea es también la pensión para esa nube de criaturas que vemos abandonadas por nuestras calles, y mucho mejor si pudiéramos combinarla con la gota de leche, y es un asunto digno de estudio, pues seguramente que con esta institución disminuiría muchísimo la mortandad de la infancia en nuestras clases humildes; pero para ello se necesita una mayor subvención y tengo para mí que no puede implantarse por vía de ensayo, sino cuando se cuente con el dinero para hacer una obra definitiva...

¿Mi opinión?... ¡Ah, querido Crispín!, la obra más completa, la más visible, la que yo creo que llenaría mejor el fin deseado, es una cantina escolar. 
Crear una escuela nueva, una escuela semi al aire libre, con cantina escolar. Eso sería una obra benéfico-social. Y lo sería porque además de darse el pan del cuerpo, se daría el pan de la inteligencia.

Yo crearía una escuela reducida, una escuela para tan solo 40 niños, que son los suficientes para un profesor, y estos 40 niños, recogidos entre los de la clases menesterosas encontrarían allí la comida y la educación.

El doctor Gea se entusiasma. Estamos cumplidos con el Estado, me dice; tenemos el número de escuelas oficiales que marca la ley; esta nueva escuela podría ser del municipio, del pueblo, y en ella se darían la educación e instrucción que la moderna pedagogía reclama, educación e instrucción todo lo racional y progresiva que los tiempos reclaman.

Una escuela al aire libre, dirigida siempre por el mismo maestro, para un número determinado de años y con cantina escolar. Ese es el ideal.

Con ella podríamos convencernos: $1^{\circ}$ de la asistencia a la escuela de los niños pobres, libres de todo sobre cargo de la enseñanza y con la gran ventaja de tener la comida segura; $2^{\circ}$ de las ventajas que reportaría la enseñanza planteada sobre el mismo grupo de niños, por un mismo profesor y durante un determinado número de años, que bien pudieran ser cuatro, desde los seis a los diez años y $3^{\circ}$ de las ventajas que reportaría la enseñanza al aire libre, estando los niños en contacto con la Naturaleza, gran maestra de los hombres.

-No, no resultaría caro, Crispín. Calcula 40 niños con un gasto de 0,50 pesetas diarias durante los 240 días de clase anual que se pueden contar, solo alcanzaría el gasto de manutención unas 4.800 pesetas anuales. Añadamos a esto un maestro con 2.500 pesetas anuales de sueldo; 500 pesetas para material y 200 para imprevistos, y tendríamos el presupuesto de las 8.000 pesetas, ya que, por subasta encontraríamos quien se encargase de suministrar los alimentos en las buenas condiciones que, seguramente exigiría el maestro que ve hijos en sus discípulos.

Solo puede pararnos a meditar el gasto de la construcción y menaje de la escuela, gasto que yo juzgo cubierto con el primer año de subvención.

- ¿Lugar del emplazamiento?... Nuestro hermoso paseo. Donde estaba el antiguo fielato de Morella, en la caseta del guarda, y mejor en el gimnasio que se va a construir, podría edificarse la nueva escuela, sencilla, dos salones, una para clases y otro para 
comedor; cuatro paredes en las debidas condiciones higiénicas, sin lujos, serían lo suficiente.

- No no sería una escuela solo para pobres: no separaríamos a los pobres de los ricos, porque en la misma escuela se podrán admitir niños pudientes pagando una modesta pensión, y seguramente serian muchos los ricos que aceptasen para sus hijos este internado.

-Luego, el plan completo, la reforma total de las escuelas.

El doctor Gea, en alas de su poética concepción, ve el magnífico resultado que podría dar una escuela semi al aire libre y con cantina escolar.

Y con su insinuante, con su atractiva palabra, hace pasar por mi vista un plan nuevo, grande, cambiando poco a poco la manera de ser de las actuales escuelas, montando en todas las cantinas escolares, aunando, al esfuerzo del ayuntamiento, la subvención del Estado y hasta la de los particulares, que entonces, cuando todos podríamos ver los grandes resultados que se obtendrían en aquella escuela, sería hora de ampliar la idea, de pedir auxilios a todos y estableceríamos una magnifica forma de enseñanza cíclica e integral enseñanza obligatoria, que, gustaría indudablemente a los maestros porque podrían desarrollar un completo plan de enseñanza, que gustaría a los padres porque sus hijos, saldrían de la escuela con buen bagaje de cultura y bien educados física y moralmente y encantaría a los niños porque desaparecería lo mucho de cárcel que actualmente tiene la escuela para los pequeños... 


\section{HABLA EL DOCTOR CLARÁ}

El doctor Clara es una figura de primera fila y un carácter.

El inspector provincial de Sanidad, con su talento nada común, con el cariño grande, intenso, que profesa a la Ciencia cautiva.

El doctor Clará es un espíritu altruista. Por eso es indiscutiblemente el suyo el espíritu de la Asociación de caridad.

Yo creo, comenta el doctor Clara, sinceramente que la Asociación castellonense de caridad es el único organismo laico que oficialmente debe acudir a remediar todas las necesidades, a practicar todas las obras de beneficencia.

La Asociación está dividida en comisiones. Hasta hoy solo funcionan dos, la del Comedor y la del Ropero, pero trabajamos con fe y entusiasmo para que poco a poco puedan hacerlo las demás, dependiendo siempre de la Junta central, de la asamblea magna.

La Asociación está constituida por personas abnegadas pertenecientes a todas las clases sociales y a todos los matices de la población. Son personas que trabajan por altruismo, por amor al prójimo y no por obligación. Y solo así puede gobernarse una obra benéfica, pues si se llegase a la municipalización del servicio, yo creo que sería un mal, ya que los concejales, al ser elegidos, lo son por sus condiciones políticas y administrativas, no por el entusiasmo que puedan sentir para realizar una obra benéfica.

La Asociación comprende la acción tutelar del individuo desde que nace hasta que muere. La Asociación tiende a coger al recién nacido y darle la primera cucharada de leche y guiarle y ayudarle toda su vida hasta que, terminada esta, le deje en el ataúd. Todo está comprendido en el Reglamento que estudiamos ahora, y todo confiamos alcanzarlo.

En primer lugar, la gota de leche, que me permito afirmar que en general no está comprendida. La gota de leche no es dar unas cucharadas de leche al niño que necesita biberón. La gota de leche es un consultorio para niños, un consultorio donde un médico, debidamente impuesto de la puericultura que no estudiamos todos en las condiciones debidas, de consejos para conservar la salud del niño, y que, con una acción constante, vigile su desarrollo, facilite su crecimiento haciendo disminuir la horrorosa mortalidad que sufrimos en Castellón.

De pronto, la voz del doctor adquiere tonalidades de ira. 
Un Promedio de 200 niños mueren al año en Castellón. En el último año han fallecido 220 evitables, seguro, seguro, segurísimo, repite el doctor Clará, pues todos ellos han muerto de catarros, bronquitis, diarreas infantiles y meningitis derivados de las diarreas. Y todo por falta de higiene en los niños, por falta de condiciones en las madres.

No, no lo crea V. la clase que podríamos llamar baja, es la que se hace cargo más pronto de las cosas. Es la medicina ciencia de fe, y las clases humildes, en esto he salido chasqueado, admiten como dogmático lo que aconseja el médico. Las clases elevadas no tienen fe, desean enterarse antes de obedecer lo que se les aconseja, y como para convencerse han de estudiar, han de trabajar y no estudian, dificultan el trabajo de la ciencia.

Y digo que he salido chasqueado porque cuando establecimos el servicio de desinfección, creía yo que pondrían dificultades, y ha resultado que son los mismos vecinos los que piden y hasta denuncian los casos de enfermedad infecciosa, cosa que no ha ocurrido aún con las clases elevadas.

Sí; la gota de leche es lo único que se podría hacer con la cantidad de que puede disponer el ayuntamiento. La gota de leche obedecería a una necesidad imperiosa, pero no, repito, suministrar leche a cucharadas, sino estableciendo un Consultorio.

Segunda faceta de la vida del niño a la que también acudirá la asociación. El cuidado de los niños destetados cuyos padres van a trabajar por el mundo y no pueden atenderles. Esto ya requiere una acción intensiva más importante. Son quizá tres o cuatro mil los pequeñuelos que van por esas calles tirados de cualquier modo, ya que no pueden con ellos las niñeras.

Con vuestro Forcada Peris, (alcalde de Castellón y médico), he sostenido largas conversaciones sobre esto. Quizá aquellos sueños de Forcada y míos lleguen a convertirse en realidad y podamos algún día recoger en amplios almacenes a todas esas paseadoras con las criaturas y ponerles bajo la dirección de esas pobres mujeres que hacen escuela en sus casas. Allí se les daría a todas almuerzos y meriendas y también HIGIENE. Allí, limpios y aseados los niños, evitaríamos la propagación de la diarrea infantil que es la que más estragos produce.

Pero esto, para después para después.

Tercera faceta, las escuelas de corrección, las de anormales y talleres de trabajo. 
-La cantina escolar quizá será lo que estableceremos más pronto, porque es más barata, aunque yo le doy muchísima más importancia a la gota de leche, porque se ha de evitar, se ha de borrar esa enorme desesperante cifra de 200 niños que mueren al año.

El doctor vuelve a entusiasmarse. Con vivos colores pinta el cuadro. Que mueran los viejos es triste, si, repite don José Clará, pero es la selección natural. Lo que no debemos consentir es que mueran los niños, que son el porvenir, que son la esperanza... esto, esto es una cuestión social.

Mi interpelado vuelve a su habitual calma y dice:

Con la cantina escolar resolveríamos el problema de la enseñanza obligatoria.

Según mis cálculos, son 300 los niños que necesitan de las cantinas. Esto puede resolverlo el Comedor con menos que doblar lo que hacemos actualmente. Esto para nosotros resultaría muy barato, pues no puede usted imaginar lo económico que resulta dar bien de comer y por poco dinero cuando se administra bien.

Las colonias escolares no tienen aplicación en esta capital. Aquí se hace durante todo el año vida de campo, y apenas llegan a media docena los niños raquíticos. Enhorabuena que se atiende en esta forma a los pequeños de las grandes ciudades, pero aquí no hay caso.

A todo quiere atender la Asociación y como cúpula de su obra, la asistencia a los pobres y el asilo para los ancianos.

Todo esto no podremos hacerlo sin el decidido apoyo de todos y sin la protección del ayuntamiento.

Esta corporación debe encargar a la Asociación todos los servicios de beneficencia.

La protección del ayuntamiento debe comenzar por darnos un edificio, en lugar céntrico, donde instalar el Comedor, con pequeño departamento para la gota de leche y un salón para las cantinas escolares. La Bolsa del trabajo en construcción sería un local magnifico, donde podrían establecerse todos los servicios.

Hay que trabajar para que Castellón entero vea aquella nube de mendigos que antes le molestaba continuamente, en el Comedor. Se les vería bien vestidos, correctos, sin hacer el menor ruido para comer y hasta... sin beber el caldo en el plato.

$\mathrm{Y}$ he de hacer constar que en un año de funcionamiento, solo han muerto siete pobres, siete pobres que han sido otros tantos graves disgustos para el buen Tarín. 
Castellón nos da 800 pesetas mensuales para el Comedor y ya llegan al mismo buen número de donativos.

Esta, amigo mío, no es la caridad oficial, siempre árida, siempre seca, es el esfuerzo particular, llámese caridad cristiana, altruismo, o como quieran llamarlo.

Ya funcionan el Ropero y el Comedor, repite el Inspector provincial de sanidad. Instituyamos ahora la gota de leche y pediremos luego la subvención al Estado para las cantinas escolares.

Evitemos esas 220 defunciones, exclama; procuremos que el ayuntamiento dedique también a este fin la cantidad que dedica a nodrizas, que no sabemos si lactan o no a los niños que son subvencionados por el municipio y con nuestra directa intervención sabrán los concejales todos que el dinero que vota va directamente al humanitario fin que lo destinan...

-Sí, repita usted que lo único, lo indispensable, lo primero que debe hacerse es la gota de leche.

Crispín

FUENTE: El Clamor, 1/08/1914 


\section{HABLA DON CAYETANO HUGUET BREVA}

¿Quién no conoce a don Cayetano Huguet? ¿Quién no ha estrechado una vez su mano? ¿Quién no se ha sentido atraído por su palabra insinuante, persuasiva? ¿Quién no conoce al señor Huguet Breva como entusiasta de la Educación, como adalid de la cultura?

Su pasión por esta tierra, su amor entusiasta por la patria chica, le obsesiona. Cuanto a la terreta se refiere, tiene para En Gaetá una importancia tal, que es capaz de todos los sacrificios, que son por él aceptados como deber ineludible.

Corazón de niño, bondadoso por excelencia, su pensamiento está usufructuado por Castellón y los humildes.

Reciente está su desprendimiento cediendo los terrenos para Gimnasio y fábrica de luz eléctrica en beneficio de Castellón, y en la memoria de todos debe perdurar su modestia renunciando al acuerdo del ayuntamiento que intentó poner su nombre a una calle de la capital. ¡Digno ejemplo de valor cívico que todos debemos recordar!

Vestir, alimentarse e instruir a los niños indigentes, y asistir a los ancianos desvalidos es un deber ineludible de toda sociedad de sentimientos cristianos y democráticos. La llamada gota de leche, las cantinas escolares, las colonias infantiles en los meses estivales, las escuelas al aire libre, las de anormales y el comedor para los pobres son otras tantas notas desprendidas de aquel deber social. Yo entiendo que Castellón debe y puede ir resueltamente y sin vacilaciones a la conquista de todas ellas.hemos comenzado por el Comedor de los pobres, cuyo funcionamiento hay que esperar vaya consolidándose y engrandeciendo cada día más; y seguidamente ¿a cuál de las otras mencionadas o análogas por mencionar tocaría el turno?- Yo, por lo que a mi pobre opinión se refiere, he de manifestar que estoy dispuesto a aceptar y apoyar con cariño cualquiera de ellas propuesta y aceptada por los demás; ya que a todas ellas las considero mejores.-Pero me objetará usted, mi amable Crispín: ¿Es que usted, como todos los demás no siente una pequeña predilección por alguna de estas obras?-Sí, la siento, y declaro ingenuamente que es en favor de las cantinas escolares. Si he hecho antes la afirmación de que defenderé con cariño todo acuerdo que acepten los demás, es porque creo que la prelación de una u otra de las obras mencionadas no debe constituir la manzana de discordia demorando la realización de una obra, pero sin negar la capital importancia de todas ellas forzoso es reconocer que la extinción del analfabetismo se impone; no tiene demora si pretendemos que Castellón sea una ciudad progresiva y con 
aspiración a figurar entre las primeras de España. Y una de las causas principales de la ignorancia es, sin duda, la miseria y la inteligencia. Procuraremos, pues, proporcionar al niño pobre vestido, alimento sano y abundante y libros y habremos removido uno de los principales obstáculos que le alejan de la escuela. Los ayuntamientos de Castellón vienen haciendo esfuerzos muy laudables en pro de la enseñanza del pueblo desde hace algunos años; pero no nos hagamos ilusiones: el número de analfabetos en Castellón es abrumador; y esto de ninguna manera se ve mejor que en la práctica, porque a veces las estadísticas suelen resultar desiguales. Recuerdo que hace muy pocos años estaba librando en una finca mía, del Maestrazgo, una cantidad de uva, y convenía al comprador estar ausente de la misma encargándome que tomara nota del peso para dársela cuando él volviera. Habían de cargar en sus carros respectivamente siete u ocho carreteros de Castellón, todos jóvenes, cuya edad oscilaba entre 18 y 24 años; los invité para que por lo menos uno de ellos tomara, juntamente conmigo, nota del peso para que esta justificación sirviera de mayor satisfacción, no solo al comprador, sino que también a mí mismo. No lo pude conseguir; ninguno de ellos podía tomar aquellos sencillos apuntes; unos, no habían ido a escuela; otros, habían olvidado lo poco que habían aprendido en el tiempo insuficiente que la había frecuentado. Tuve que persuadirme de una verdad triste: del gran número de analfabetos que hay entre las clases `populares de Castellón.

Yo apunto la idea, exclama don Cayetano, de crear una asociación popular para atender a la alimentación higiénica e instrucción de los desheredados de la fortuna, con el título de «Asociación popular de obras benéficas» cuyo objeto sería realizar de una manera prudente y paulatina, pero segura y progresiva, todas las mencionadas obras; con atribuciones para albergar recursos por cuantos medios creyera conducentes, incluso el de suscripción popular que yo me atrevería a iniciar por ahora con 250 pesetas anuales, todo sobre la base de la cantidad que ofrece el ayuntamiento.

Creo que en el estado depresivo por que pasa la Sociedad Española en los actuales momentos, donde no hay más ideal que la plaza de toros, debiéramos esforzarnos en dar un ejemplo sano llegando a la realización de estos pensamientos propios de pueblos cultos y altruistas... 


\section{HABLA D. MANUEL BELLIDO ALBA (ABOGADO DE CASTELLÓN)}

[...] En mi insignificancia social y desde mi absoluto retiramiento de la vida pública-exclama mi interpelado,-voto por las CANTINAS ESCOLARES.

Sin ellas, la enseñanza obligatoria es ilusoria por irrealizable, porque sin pan y condumio para el cuerpo no puede haber alimento y cultura para el espíritu.

Obligación sagrada, de derecho natural, es en los padres gobernar y alimentar a sus hijos. y cuando estos se multiplican, donde no han logrado las perversidades maltusianas cegar las fuente de la vida, y el salario es incongruo para mantener la prole, se ayudan con el realillo que el trabajo de sus pequeños rinde para comprar pan y abrigo.

¿Con qué derecho obligaremos a esos padres a matricular a sus hijos en la escuela? Exclama el señor Bellido, obvio es que nos dirá antes que varios famélicos, desmedrados y éticos, los prefiero analfabetos e ignorantes.

La cantina escolar, amigo Crispín solventas esta objeción incontestable, dando en alimentos el menguado jornal que ganaría el pequeño a recoger basura o colillas, a menar en el Huerto de Sogueros, a vocear periódicos.

Niñeras, menaors, colmeros, caracoleras, raterillos y toda laya de vagabundos maleantes que pululan por nuestra ciudad y nuestra vega, destruyéndose unos a otros con ejemplos perniciosos y conversaciones inedificantes, poblarían nuestras escuelas instruyéndose en toda disciplina y aprendiendo provechosos menesteres.

Y es tal el entusiasmo que siento por las cantinas escolares, que cuando algún tiempo vino a mi casa una respetable señora a consultarme sobre qué obra benéfica podría instituirse con las rentas de su patrimonio el día que ella falleciera, no titubeé ni un instante en mi consejo y por mi intervención, cuando fallezca la persona que hoy usufructúa sus rentas, se creará en Castellón una escuela parroquial con cantina escolar.

-Créame usted, repetía el señor Bellido, el analfabetismo que nos deprime, cedería con las cantinas escolares su puesto a la cultura que dignifica y a la ilustración que ennoblece.

No puede haber enseñanza obligatoria para la clase obrera y menestral, si no hay antes pan y condumio asegurado para la masa escolar...

El señor Bellido, con su cálida palabra, pinta el hermoso cuadro que a este respecto presentan Navarra y las provincias vascongadas. La descripción que de 
aquellas costumbres hace, adquieren tal colorido que Crispín se siente dominado por la persuasiva palabra del elocuente orador.

Allá, en aquellas provincias del Norte de España, la enseñanza obligatoria es un hecho. En aquellas provincias han desaparecido los analfabetos, en aquellos el amor a la escuela es grande, la cultura, superior a las restantes provincias españolas....

La Asociación Castellonense de Caridad, obra altruista de iniciativa privada, digna de toda ponderación, ha limpiado en parte nuestras calles de pordioseros y vagabundos, y digo en parte porque la extinción completa de la mendicidad es irrealizable,...

Las cantinas escolares, son el digno complemento y remate de tan plausible obra, porque barrerán de la vía públicas tanto golfillo de uno y otro sexo, desarropado de cuerpo y de alma que en ella hacen la vida de abandono y vagancia.

$\mathrm{Si}$ abrir una a escuela, es cerrar un presidio, abramos el estudio para los desheredados que son precisamente la masa ingente de que se forman los bollos del horno de nuestras cárceles y habremos conseguido restar a la criminalidad el más fuerte de sus contingentes.

Mucho y muy bueno puede hacer nuestro Municipio con esas $6.000 \mathrm{u} 8.000$ pesetas que aproximadamente rendirá el arbitrio sobre consumo de energía eléctrica en el alumbrado particular que reserva para una obra benéfica social; pero lo óptimo -entre todo lo realizable con tan exiguo presupuesto- es en mi humilde sentir, la creación de las Cantinas escolares.

De la administración de esta obra, estoy seguro que se encargaría la misma junta de la Asociación castellonense de Caridad, que está haciendo el milagro, con muy exiguo presupuesto, de dar comida abundante a los mendigos de la ciudad.

Y aunque de pronto, no se llegue al total desarrollo de tan meritísima obra por escasez de medios, plantéela su excelencia con generoso desprendimiento, dele una organización y régimen autónomo y desmunicipalizado, y tenga la seguridad de verla crecer y medrar con donativos particulares, subvenciones testamentarias y quizá con mandos importantes que le den pingues recursos para una vida próspera y lozana.

¡Dichoso quien ponga la primera piedra en obra tan regeneradora! Tendrá la gloria de verla medrada y próspera y de saborear sus óptimos frutos en los días de su vida. 
Cayó don Manuel Bellido y seguramente que, ante su vista como ante la mía, se agitaba una generación nueva completamente redimida por el estudio y el trabajo.

Una generación educada para el bien, para el amor, para la prosperidad del pueblo que la vio nacer.

¿Caridad?... ¿Altruismo?.. Como quieras estimado lector.

Muy condensada te sirvo la opinión de don Manuel Bellido ¿Será esta la mejor obra benéfico social que puede insistir nuestro ayuntamiento?...

Crispín.

FUENTE: El Clamor12/09/1914 


\section{HABLA D. FRANCISCO BADENES (MÉDICO DE LA BENEFICENCIA)}

El repórter desea que este plebiscito resulte lo más completo posible. El repórter procura ofrecer a los que en última instancia han de decidir, el mayor acopio de materiales para que la obra resulte firme, para que, cuanto menos la cimentación, sea sólida.

Y recordando que hace algunos años don Francisco Badenes, el distinguido médico de la Beneficencia Provincial y querido amigo nuestro publicó en El Clamor varios artículos ocultando su nombre con el pseudónimo Doctor Zeda, en busca ha ido el repórter, y, aunque con grandes excusas, ha logrado que le diera su opinión.

Modesto en grado suma se presentó el Doctor Zeda a Crispín.

Don Francisco Badenes negose a .hablar.

Creía su opinión tan poco importante, de tan poco peso, que ni remotamente pensaba pudiera recibir la visita de Crispín.

Modesto artesano de la Ciencia, seguramente pasó un mal rato al verse interpelado. Hubiese querido en aquellos instantes, borrar lo que hace años escribió, lo que dio pie a Crispín para ir hablarle...

Y los razonamientos del cronista para decidirle, quizá contribuían más y más a aumentar sus excusas.

¿Por qué hemos de ser así?... ¿Por qué los jóvenes, los que sentimos hondo, los que tenemos un ideal, no nos armamos en caballero y por él rompemos lanza?...

¿Fue ésta excitación a sus ideales lo que movió al Doctor Zeda a complacer a Crispín?...

Indudablemente, porque el señor Badenes ha dedicado muchas horas al estudio y las más y más preciadas para él, han tenido `por base cuanto se refiere a la mortalidad infantil, y su espíritu al ver esa macabra caravana de criaturas cuyas vidas son segadas en capullo por la muerte, se ha conmovido profundamente y ha procurado, por todos los medios, difundir aquellas ideas que podrían conservar la vida a aquellos inocentes seres que sucumben para siempre cuando apenas han llegado al alborear de su existencia...

-¿Qué he decirte, después de la conversación que publicaste del doctor Clará?...

¿Cómo quieres que hable yo después de tantos otros que de manera tan brillante han efectuado?...me repetía el doctor Zeda. 
-Pues ya que lo quieres, sea. Relee aquellos articulitos míos que tú mismo me has recordado, y en ellos verás que mi opinión no puede ser otra que la expuesta por el doctor Clara: LA GOTA DE LECHE.

Y es parta mí esta institución algo que me obsesiona, algo que me atrae de manera irresistible, hasta el extremo de que con mi padre político don Fernando Gasset y con mi tío don Rafael, la he estudiado mucho antes del acuerdo del ayuntamiento, por si ellos, con su influencia, podían dotar a Castellón de una obra benéfica social de tanta importancia.

-Si querido Crispín, quedé encantado del pensamiento del distinguido doctor Gea. Una escuela al aire libre con cantina escolar, sería una magnifica institución, pero que desgraciadamente, con el dinero de que puede disponer actualmente el municipio, los beneficios llegarían hasta muy pocos niños.

Y además de esta dificultad que el ayuntamiento debe orillar lo más pronto posible para que las cantinas escolares sean un hecho, yo creo que tenemos un deber muy grande que dejamos incumplido, el de evitar la muerte a una porción de niños, que anualmente desaparecen de nuestro lado.

Podríamos decir que en las cantinas escolares formaríamos al hombre de mañana, pero indudablemente que con la gota de leche formaríamos al niño que necesita la cantina escolar para que el hombre goce de aquellas condiciones físicas necesarias para ser útil a la sociedad.

-Si amigo mío; hay que formar una escala. Tomemos al niño desde el momento de la concepción de la madre, si nos es posible, y acompañémosle durante su vida hasta dejarlo en el sepulcro.

Comencemos por la gota de leche, venga luego la casa cuna, a la que seguirá la cantina escolar, y si cuando ya hombre necesita salud, construyamos sanatorios donde la encuentre y para final de su vida preparémosle el asilo.

Pero ante todo, evitemos que mueran esos niños, hagamos que la semilla germine en el claustro materno en debidas condiciones, demos reglas a las madres para que los frutos de la concepción no se pierdan, demos al niño la leche cual la necesita su estómago para digerirla, instruyamos a las madres para que los cuiden debidamente...

Esto, esto debe ser la gota de leche.

Horroriza pensar lo que actualmente ocurre. 
Llega una catástrofe, un Titanic que se va a pique, y el mundo se conmueve profundamente. Algún centenar de personas ha perecido. Hay que instruir expedientes, hay que averiguar y depurar responsabilidades...miles y miles de niños perecen anualmente en nuestra nación, algunos centenares en nuestro pueblo, y nadie se conmueve, nadie pretende depurar las responsabilidades que unos y otros puedan caberles en aquella cabalgata fúnebre que diariamente pasa ante nuestros ojos...

¡Y pensar que quizá en aquellos niños, en aquellos seres que sin ninguna emoción dejamos marchar para siempre, los hay de mirada tan penétrate, tan clara, que para decirle: yo soy una inteligencia futura, yo seré un hombre capaz de regenerar la patria...

Y aquel niño muere, quizá por ignorancia de la madre, quizá por no habérsele rodeado de las debidas condiciones higiénicas.

Esto evitaría seguramente la gota de leche. Ella sería una verdadera escuela de madres.

Actualmente, por reglas general, las madres cuidan a sus hijos sin aquellos conocimientos necesarios para asegurarles la vida.

Y no se crea que ocurre esta deficiencia solo en nuestras clases menesterosas, no, pues también lo podemos apreciar en nuestras clases elevadas en donde encontraremos, si, mujeres que saben cuidar perfectamente a un perrito de pura raza, un canario o una cotorra y que ignoran si el alimento que toman sus hijos es apropiado a su edad, a sus necesidades y en cantidad conveniente.

-Yo no veo gran inconveniente en que esa cantidad fuese administrada por la Asociación castellonense de Caridad, teniendo presente que en la misma figuran concejales que habrían de defender en todo caso los intereses del municipio.

Lo que hay que tener muy presente, es que esta institución debería inaugurarse de una manera modesta, sin gastos de personal, sin grandes vuelos.

Una estufa, unas cuantas botellas, algo, muy poco para el material indispensable, y nada más. Porque yo creo que no faltarían médicos que sin retribución alguna, se encargasen de la dirección. Si la plaza de médico fuese GRATIS y el ayuntamiento lo creyese oportuno, yo no titubearía, a falta de otro mejor, en ofrecer mis servicios.

-Hay que evitar que se mueran tantos niños, querido Crispín, repite el Doctor Zeda. Mueren muchos, muchos, que no deben morir.

Y el señor Badenes, recordando lo que hace años escribió en El Clamor repite: 
Debemos fijarnos todos en que cada niño que muere, es un sumando menos en el capital humano; es una merma en el banco vital de su pueblo, que pierde con el individuo un equivalente monetario, pues si las lágrimas afectan a la familia, las defunciones hacen perder al estado una cantidad que, durante un año, asciende a millones de pesetas.

El señor Badenes, en alas de su ideal, se remonta tanto, que cree firmemente salvar la vida de tantas criaturas con la gota de leche.

Para el señor Badenes resultaría sumamente fácil, como la alimentación mixta y hasta con una lactancia artificial bien estudiada en cada caso, defender con éxito la vida del niño.

-Hay que tener en cuenta, repite el Doctor Zeda, que la ignorancia de algunas madres llega hasta el extremo de dar al niño aún en los primeros días de su vida, leche de vaca pura. Naturalmente, los niños no pueden digerirla y enferman.

Todas, todas saben que el biberón se ha de limpiar, pero ¡cuán pocas tienen nociones sobre la cantidad de leche que han de suministrar, las horas en que han de efectuarlo y las restantes condiciones todas tan importantes como la limpieza!...

Instituyamos la gota de leche donde puedan acudir las madres cuyos recursos no les permita consultar a un médico y habremos evitado muchísimas defunciones.

-Sí; yo creo que con ello podría suprimir el municipio de sus presupuestos la cantidad que fija paras nodrizas.

No se hable tampoco de los abusos que podrían ocurrir, pues indudablemente que, con una poca vigilancia, se evitarían en absoluto.

Instituyendo premios que satisficiesen la vanidad de aquellas madres que criasen mejor a sus hijos, indudablemente que habría entre todas un pugilato digno de encomio que redundaría en beneficio no solo de los niños, sino también del municipio.

Y el Doctor Zeda, recordando de nuevo aquellos trabajos que publicó en el Clamor relata la leyenda bretona de Richepin pintando con vivos colores el amor maternal.

-Hagamos por los niños toda clase de sacrificios, seamos maltusianos al revés; olvidemos a Arias Gonzalo que ofrece en holocausto a Zamora la sangre de sus siete hijos. Es más humana la conducta del conde de Lara que engendra a Mudaira, caudillo y vengador de los siete infantes de Castilla muertos en Araviana... 
Todo por los niños, exclama el señor Badenes, que ellos son la alegría del hogar y la esperanza de la patria.

El cronista atardeció al señor Badenes su intervención en este plebiscito. ¿Comentarle?..¿Para qué?...

Luchemos con el Doctor Zeda para que, en una forma o en otra con el dinero de la luz eléctrica municipal o con otro, llegue un día en que contemplemos tan hermosa institución, en que podamos arrebatar a la muerte su preciosa presa, en que podamos evitar ese borrón de cientos de niños, muertos por ignorancia de las madres o por falta de alimento...

Crispín

FUENTE: El Clamor 19/09/1914 


\section{HABLA EL INSPECTOR DE PRIMERA ENSEÑNANA D. JOSÉ} SENENT

El Inspector de $1^{a}$ enseñanza don José Senent es un joven de cultura nada vulgar.

Dedicado a la enseñanza, por vocación, a ella dedica todos los momentos de su vida realizando una labor cultural intensa, digna de todo encomio.

Del fuste de los modernos pedagogos, su lucha por implantar los métodos y sistemas más apropiados para la educación de la niñez, le ha colocado al frente de los jóvenes entusiastas que dedican los mejores alientos a propagar y difundir aquellos procedimientos que han de darnos una juventud física, moral e intelectualmente preparada para las luchas de la vida.

Buena prueba de ello es su labor al frente de una de las colonias escolares organizadas en Valencia, con la que el señor Senent ha pasado el último verano dedicando al trabajo, a la educación de la niñez, el tiempo que otros destinan al descanso, a recuperar las fuerzas pérdidas durante el curso.

El señor Senet se presenta sumamente modesto. Huye de la exhibición, y seguramente que, al atender los ruegos muy reiterados de Crispín para que emitiera su opinión sobre una obra benéfica, lo ha hecho tan solo porque con ello ha tenido ocasión una vez más, no tan solo de hacer alarde de los estudios por él realizados, sino para poner a contribución de la obra cultural que lleva a cabo, los entusiasmos, el cariño que siente por la niñez de hoy, por los hombres de mañana que pueden dar esplendor y grandeza al pueblo que les vio nacer...

Don José Senent habla al cronista sobre Colonias escolares y Escuelas al aire libre.

Es una de sus pasiones, quizá la idea que le domina, seguramente la que le atrae con fuerza irresistible.

Cuando un distinguido amigo de Crispín nos presentó mutuamente hace algunos meses, el cronista, que aún siente pasión por el hábito del dómine, se sintió encantado, dominado, no tan sólo por los conocimientos que sobre la materia expuso el señor Senent, sino por el atractivo, por el vistoso ropaje con que vistió sus ideas.

Y hoy, al escuchar de nuevo su amena charla, al verle emocionado hablando sobre Colonias escolares y Escuelas al aire libre, Crispín ha dejado algunos momentos de tomar nota porque su atención se preocupa más que de informar a mis pacientes 
lectores sobre la opinión de señor Senent, en asimilar aquellos conceptos que, quizá sin ser nuevos para el cronista, iban envueltos en tan brillante ropaje que parecían desconocidos...

El señor Senent es uno de los jóvenes que llegan a la meta. Sus facultades y su fe en el estudio le hacen acreedor de los elevados sitios que indudablemente ocupará en el Magisterio.

He aquí muy condensado, verdaderamente exprimido, lo que el señor Senent dijo al cronista:

-Admirable me ha parecido llevar al plebiscito, a la encuesta pública este asunto de la obra benéfica. Pocas veces ocurre esto con las entidades políticas y administrativas y al efectuarla así el ayuntamiento de Castellón, ha añadido un nuevo timbre a su nombre por el respeto que ha tenido con el principio democrático que debe informar todas las obras para que tomando parte en ellas el mayor número de interesados, sean sus decisiones acatadas y defendidas por todo el pueblo.

El valor de la encuesta pública nace de la confrontación, del choque de ideas que se presentan para que el público pueda cotejar y para que los directores de la cosa pública puedan fallar con una mayor amplitud de miras y con un mayor acierto.

La gran cuestión de la obra benéfica es saber cuál tiene más probabilidades de éxito, cual puede ser mejor administrada con el dinero de que dispondrá el ayuntamiento, ya que por su finalidad, todas son buenas, todas son aceptables.

Y en estas condiciones ¿cuál es la obra que ofrece más garantías de acierto? ¿Cuál será la que, dadas las necesidades de nuestra vida social y en atención a las personas que han de intervenir en su administración podrá dar mejores rendimientos, mejores resultados?

Las obras benéficas podríamos dividirlas en dos grandes grupos; las que como la higiene, son para prevenir y las que, como la medicina son para curar.

Ahora bien, yo creo que vale más prevenir que curar, que es mejor evitar que haya pobres de cuerpo y espíritu que consentir los haya para acudir luego en remedio de sus necesidades. Por eso pienso que debía imponerse ese criterio, y cualquiera que sea la decisión del ayuntamiento, que sus mirar fueran dirigidas por ese camino procurando crear para Castellón hombres sanos de cuerpo y espíritu y no dejar que se empobrezcan fisiológica y moralmente para tener que acudir luego a remediarles con la caridad o la cárcel. 
La obra que debe emprender el municipio-continua el señor Senent- debía emplazarse dentro del conjunto de las ya comenzadas, bien de cultura, de higiene, etc., teniendo bien presente que debe el ayuntamiento procurar por aquellas que son nacidas de su seno, dejando a las iniciativas, al ingenio y actividades de los particulares aquellas otras que de la caridad particular viven, aquellas que por la caridad particular son ya como seres vivos con más o menos energía, pero que por los particulares pueden llegar a su completa formación.

Y con estas, creo se debe dejar a un lado a aquellas otras que son como sus hijuelas, y que seguramente logrará con los entusiasmos que animan a los castellonenses, la Asociación de Caridad. Esta entidad, por el esfuerzo particular y con la subvención de las entidades oficiales que seguramente no regateará nuestro ayuntamiento, es la encargada del comedor y también, por el tiempo, de la gota de leche y de las cantinas escolares.

Dejemos que se desenvuelva la Asociación Castellonense de Caridad, pero pensemos en una cosa nueva, en una de las tantas obras benéficas sociales que fallan aún en Castellón.

-¿Qué por cuál me decido yo?... Por mi modestia, ya que bien poco puede pesar mi opinión, no puedo menos que proclamar la necesidad de aquellas obras que son como el complemento de la obra de cultura llevada a cabo por este ayuntamiento.

Nos encontramos dentro de la ley, dentro del arreglo escolar, pero no se ha hecho aún nada para acabar la brillante acción del municipio en favor de la cultura de la niñez. Y el complemento necesario, imprescindible, es la escuela al aire libre y la colonia escolar.

Con esto no inventariamos nada. Bilbao, Barcelona y otras capitales tienen ya establecidas estas obras complementarias de cultura.

El señor Senent, en párrafos brillantes, pinta el funcionamiento de las escuelas de Bilbao.

Allí, por iniciativa y por formidable impulso de las izquierdas, no hay ni un niño que deje de ir a las escuelas; allí está verdaderamente implantada la enseñanza obligatoria.

Y durante todo el año se organizan las colonias escolares ¿Cómo?... Muy sencillo. La inspección médica de acuerdo con los maestros, va seleccionando a los niños que necesitan las colonias escolares, con los que se forman tres grupos: los que 
necesitan baños, los que necesitan colonias escolares y aquellos que, para recobrar la salud perdida, necesitan sanatorios.

He ahí el complemento de la obra de cultura que, de manera tan brillante, de manera tan hermosa, ha llevado a cabo el municipio castellonense.

Y como aún queda mucho que decir, lector amigo, perdona que, por primera vez, me permita suspender hasta el lunes la publicación de esta interesante charla. Así, al menos, no te robaré espacio para otros temas de mayor actualidad.

Crispín

FUENTE: El Clamor, 5/012/1914. 
HABLA EL INSPECTOR DE PRIMERA ENSEÑNANA D. JOSÉ SENENT (2)

Baños.-Colonias y Sanatorios escolares.- Este es el complemento de la obra de cultura que nuestro ayuntamiento debe imponerse en opinión de don José Senent y cuyo estudio, muy a la ligera por cierto, procurará Crispín trasladar a sus estimados lectores.

-Muchos son los niños, me decía el señor Senent, que necesitan baños de mar. Y si estos baños están convenientemente dirigidos, convenientemente administrados, ¡cuánto bien no se podría hacer a los niños!

Mil niños son los que Bilbao lleva a los baños todos los años. Castellón podría hacer otro tanto, con muy poco gasto.

Durante los dos meses del calor podrían organizarse dos expediciones de cien niños cada una que, dirigidas por dos o tres maestros, pasarían un mes en la vecina playa, haciendo vida en plena naturaleza, pasando el día en la hermosa pinada.

Y allí recibirían las lecciones prácticamente y fortalecerían su cuerpo y su espíritu.

La Colonias escolares podrían organizarse muy bien. A ellas irían aquellos niños que necesitan climas de altura y para conseguirlas con éxito extraordinario no se necesitan más de tres o cuatro mil pesetas.

El gobierno tiene consignación en sus presupuestos y seguramente que, cuando tantos ayuntamientos permanecen inactivos sin hacer nada por la cultura de la niñez, el nuestro conseguiría una buena subvención para que las colonias alcanzasen todo su esplendor.

Y para completar las obras, los sanatorios para aquellos niños cuya salud los requiriese a juicio del médico.

Una casa de campo en un pueblo de la montaña bastaría para convertirla en un sanatorio, donde encontrasen los niños la salud perdida.

¡Hablar de las ventajas de las Colonias escolares! Calculad ese número importantísimo de criaturas anémicas que se regeneran con el ejercicio espontáneo en plena naturaleza, con buena alimentación, con una higiene bien dirigida y, sobre todo, con el tónico de la alegría que sienten los niños al vivir a cielo abierto, en plena naturaleza! 
Aquellos niños, con la propiedad grandísima que tienen sus cuerpos en formación para asimilarse raudales de vida, se transforman en el transcurso de un mes, acumulan en sus organismos fuerza vital para todo el año.

Pero al lado de estas ventajas, con ser las más importantes, se puede lograr un desarrollo de sentimientos, de gustos e inclinaciones por la contemplación de la Naturaleza, por el goce de vivir libremente en medio de ella, por la constante novedad de escenas y objetos que les alejan de tantos placeres malsanos y de tantas causas de corrupción moral; se puede lograr que los niños adquieran sin esfuerzo alguno y de una manera intuitiva muchas nociones de Geografía, Historia Natural, Industria, Agricultura, Comercio, y finalmente se pueden lograr también aquellas ventajas que nacen de la intimidad de la familia, cuya vida hacen los niños en la Colonia, pudiendo el maestro dirigir, encauzar los gustos, las aficiones del niño...

El señor Senent siente verdadera pasión por las Colonias escolares. Horas y horas hablaría del asunto, pero se asusta de las dimensiones que puede tomar al ser desarrolladas en esta charla.

Y comienza a hablar a grandes rasgos, de la escuela al aire libre.

Dedica un cumplido elogio al doctor Gea, patrocinador de una escuela al aire libre con cantina escolar.

El tipo actual de perfección en el extranjero, ya no es como en España, la escuela graduada. Allá es la escuela al aire libre. En España se ha intentado algo, lo más saliente de lo realizado hasta ahora, son las instituciones Manjón y Altamira.

Tienen las escuelas al aire libre muchas de las ventajas de las colonias escolares, y sobre las actuales escuelas las de librar a los niños de esas cárceles a las que damos el nombre de escuelas. Allí el niño, como en las colonias, se educan en plena naturaleza, y el maestro saca de esta todas las grandes enseñanzas que le permiten el estar en contacto con los objetos reales. Allí el niño se educa con la mayor perfección intelectual y fisiológicamente... la escuela al aire libre, aunque no con tantas ventajas, puede considerarse como una colonia escolar permanente.

Ahora bien; ¿convendría una sola escuela, con un maestro, o sería más conveniente construir en distintos puntos varios pabellones donde fueran por turno los alumnos de las escuelas a conseguir esta enseñanza intuitiva?...

Luchemos-termina diciendo el señor Senent-luchemos para crear hombres fuertes moral y fisiológicamente y así seguramente lograremos exterminar en Castellón 
esa plaga de pobres de cuerpo y de espíritu para cuya obra, con un desprendiendo digno de los ilustres hombres que rigen los destinos de esta capital, dedica el ayuntamiento la cantidad que le ha de producir el impuesto municipal sobre la luz eléctrica...

Perdone el amigo Senent al repórter que no ha logrado condensar mejor su pensamiento, ni traducir con toda la brillantez que merecen las palabras llenas de fe en lo porvenir, llenas de entusiasmo por la regeneración de la niñez, que en un rato de agradabilísima exposición pronunció ante este deslavazado cronista...

Crispín

FUENTE: El Clamor, 7/12/1914 


\section{HABLA D. MIGUEL MARTÍ BLAT}

El actual director del Instituto de esta capital, interviene en este plebiscito.

Si el cargo que ocupa en nuestro primer centro docente no le obligara a ello, sus trabajos al frente de la Asociación Castellonense de Caridad, sus luchas por la extinción de la mendicidad, el cariño que siente por nuestro pueblo, hubiesen sido motivos más que suficientes para que Crispín le importunara hasta lograr su opinión.

Y aunque el carácter del señor Martí Blat no gusta de exhibiciones, aunque hubiese preferido pasar desapercibido, el repórter no ha cejado hasta conseguir que hablase, hasta conseguir condensar en las cuartillas el pensamiento grande, poético, el sueño a que acaricia el director de nuestro Instituto, en favor de los pobres, en favor de los necesitados.

Bellísima concepción la del señor Martí Blat. El repórter háyase bastante cohibido, pues es tal la amplitud del pensamiento del repetido señor, que teme no saberlo trasladar a las cuartillas.

No sé si el señor Martí Blat escribe versos, pero lo que puedo asegurarse, lector amigo, es que el distinguido catedrático de matemáticas es un poeta.

Un poeta que siente hondamente. Un poeta que, en alas de su fantasía, remontase a las sublimes regiones de lo ideal y con su palabra correcta y decir castizo, da forma a su concepción, lo viste con un ropaje encantador, y sobre todo, le infunde un soplo de vida.

El señor Martí Blat sueña con la extinción, no de la mendicidad callejera, sino con la extinción de los pobres. El señor Marti Blat sueña con una reforma tal de nuestro modo de ser, de nuestro modo de vivir, que resulte imposible la pobreza en nuestro pueblo, pero no tan solo la pobreza económica, si me permites la frase lector amigo, sino también la pobreza moral.

El señor Martí Blat no solo se preocupa de los que han hambre de pan, sino también de aquellos que necesitan alimento para su inteligencia, y en su poética concepción, desearía que todos los esfuerzos debidamente canonizados, no solo se dirigieran a mitigar los gritos del estómago del pobre, sino también se encauzaran de tal modo, que hicieran imposible la pobreza, donde a los jóvenes, a los niños que ahora llegan a la vida una educación tal que les fortaleciera corporal y moralmente para luchar contra todos los obstáculos que les ha de presentar la vida... 
¿Cómo? ¿Con qué medios se puede realizar esa magna obra?... ¿Qué sacrificios nos habíamos de imponer los castellonenses para que nuestra población alcanzase aquella perfección ideal, para convertir en sublime realidad la poética concepción del señor Martí Blat?...

Concedámosle la palabra, lector amigo, pues seguramente te cautivará el pensamiento que, demasiado condensado, voy a servirte como opinión del distinguido profesor de Matemáticas.

-Bien quisiera, comenzó el señor Martí Blat, acertar al dar forma a mi pensamiento, al dar una opinión sobre la obra benéfica que el ayuntamiento trata de instituir con los rendimientos que le proporcione el impuesto municipal que gravará la luz eléctrica de su fábrica.

Usted, amigo Crispín, ha querido secundar el noble propósito del ayuntamiento llevando a las columnas de El Clamor la opinión de aquellas personas que, por su vasta cultura, por sus generosos sentimientos o por el cargo que ocupan parecen indicadas para aconsejar el modo de realizar dicho propósito. Y no pudiendo por lo primero, me coge usted por lo último para arrancarme lo que yo quisiera tener bien guardado en lo íntimo de mi conciencia.

No es que yo conceda a mi opinión un valor que la haga inapreciable hasta el extremo de hacerme pensar su exteriorización, no; lo que ocurre es que la Naturaleza suele mostrarse caprichosa al forjar el carácter de los hombres y tuvo, al forjar el mío, el raro capricho de hacerlo transigente es lo de terca en lo que afecta al ejercicio de la Caridad. Sí; en esto soy radical, hasta la exageración y temo, no sin fundamento, que mi opinión, en el caso que sirve de motivo a su atenta consulta, amigo Crispín, sea tenida como utópica.

Pero sea como quiere, ahí va lo que pienso, pues no he de hacer objeto de regateo lo que tan poco vale, ni hay motivo nunca para dejar de ser franco y veraz aunque de antemano sepamos la suerte que ha de correr la opinión vertida...

-Vayan por delante tres afirmaciones concretas.

La caridad, ejercida a medias, no resuelve nada; dejarla confiada a los sentimientos individuales, es condenarla a perpetua desorganización; debe ser función municipal.

$1^{\text {a }}$. Digo que la caridad ejercida a medias no resuelve nada, empleando el eufemismo, para decir que constituye un daño. El que da cinco céntimos a un pobre, no 
le saca de su pobreza, pero le recuerda que muchas monedas como aquella le igualarían al rico.

¿Qué logramos con dar una limosna?...Remediamos quizá, la necesidad del momento pero ¿y después?...Indudablemente que con ello no sembramos en el alma del pobre ideas de orden y trabajo.

$2^{\text {a }}$. Necesidad de que la caridad esté organizada. La limosna callejera y los socorros domiciliarios llevados a cabo por diferentes asociaciones son como arroyuelos por los que se pierde el agua sin fertilizar. Pero si las mismas venas líquidas son recogidas en un cauce común convenientemente dispuesto mediante un sistema de esclusas y compuertas, puede aprovecharse totalmente la potencia fertilizante.

He aquí el problema magno: encaucemos la caridad y la caridad será fecunda.

Y 3 $3^{\mathrm{a}}$. Después de los dicho anteriormente, comprendiendo la necesidad de encauzarla debidamente, ¿se comprende fácilmente que la caridad no puede ser función particular?...

¿Será el Estado?..¿Será función de las diputaciones?...No, amigo Crispín, no. Si el Estado se encargase de la caridad, sería exponerla a una serie inacabable de irregularidades y desproporciones y si estuviese a cargo de las diputaciones adolecería de los mismos inconvenientes recrudecidos aún por su proverbial penuria.

Pero los municipios, en contacto directo con las necesidades del pueblo, pueden y deben tener a su cargo el remedio de aquellas necesidades en términos de totalidad.

-¿Qué daríamos pasto a la maledicencia?...

Miserias humanas, amigo mío, que debemos despreciar. También ahora dicen que influye la política, las amistades particulares, etc., en el Comedor de los pobres. Hay que cerrar los ojos y los oídos a la maledicencia, cuando se abra con un fin recto.

Para que el municipio se encargase de la caridad, bastaría una clasificación de los servicios en dos grupos: vecinos que por sus rentas o profesiones pueden gobernarse sin auxilio ajeno; vecinos que carecen de bienes de fortuna. Estos a su vez, pueden clasificarse en jornaleros y menesterosos.

A estos últimos debe atender la solicitud del municipio. Una vez conocido su número, (cosa no difícil) fácil sería calcular la cantidad necesaria para atender a sus necesidades todas durante el año, cantidad que repartida entre los vecinos pudientes a título de Arbitrio de la Caridad, recargada aún en un 50 por 100, para lo que luego diré, 
exigiría de cada castellonense. Esta cantidad sería mucho menor que la que empleamos hoy con igual fin cada uno sin obtener resultado práctico alguno.

El 50 por cien de recarga, constituiría un remanente con que atender a los jornaleros en tiempos calamitosos y el sobrante podría acumularse en años sucesivos hasta llegar, con el tiempo a constituir un capital cuyo interés aminorara el arbitrio y hasta llegara a extinguirla...

El señor Marti Blat, en alas de su fantasía remontase a las serenas regiones del ideal que le anima. Su privilegiado cerebro esculpe con gran precisión su pensamiento. Sigámosle, lector amigo...

-¿No habrá-exclama- no habrá en Castellón 10.000 pesetas a quienes no afectaría el desprendimiento de 10 pesetas al año? ¿No podrían reunirse anualmente 100.000 pesetas para remediar las necesidades todas de nuestros pobres?... Véase que hace la Asociación Castellonense de Caridad con unas 24.000 pesetas y calcúlese lo que podría hacer con 100.000 .

No es un sueño, dice el señor Martí Blat, pensar en un palacio de Caridad, con mesa, cama, ropero, escuelas y talleres. No es un sueño pensar en que Castellón pudiera aportar esa cantidad para ponerse a la cabeza de todas las capitales españolas. No es un sueño pensar en un Palacio de Caridad con vida propia y donde se mitigasen las necesidades todas de nuestros menesterosos.

Una obra grande, muy grande de donde se diera el pan del cuerpo y del espíritu, amigo mío, podría elevarse a muy poco coste, con un pequeño esfuerzo de parte de todos, con el auxilio de todo Castellón...

Y allí, amigo Crispín, sus escuelas y sus talleres. Allí, sus escuelas para que esos niños que hoy acuden al comedor y que no sabemos en qué pasan el día, pudieran instruirse, aprender a leer, y escribir y allí también sus talleres para que aprendieran un oficio útil para sí y sus semejantes, allí sus talleres para evitar, en una palabra, que los niños de hoy, sean los pordioseros de mañana.

Escuelas y talleres, repite el señor Martí Blat, en los que los niños de los pobres encuentren los medios de redimirse de la pobreza en que nacieron, descongestionado el Palacio con la fuerza de sus brazos para buscar aquí o fuera el trabajo portador del sustento. 
Un palacio con un jardín grande, donde los pobres vivieran con la satisfacción interior de quien ve, al final de su vida, cubiertas todas sus necesidades, amparados sus hijos, no por la caridad del Estado, sino por aquella otra de los particulares asociados a la obra del municipio.

Crispín

FUENTE: El Clamor 9/01/1915 
$\mathrm{N}^{\mathrm{o}} 26$

\title{
A LA COLONIA ESCOLAR DE CASTELLÓN
}

\section{HIMNO}

\author{
Hacia el monte partamos \\ pequeños escolares \\ a buscar en su flora \\ veneros de salud \\ y entre el musgo y la hiedra \\ que visten los cipreses \\ vistámonos nosotros \\ de oxígeno y virtud.
}

Allí nuestro organismo

recobrará las fuerzas perdidas

por la infecta vida de la ciudad

y nuevas concepciones

hará nuestro intelecto

de la Naturaleza, de Dios y su bondad.

Corriendo entre la selva

nos fortaleceremos.

Conquistando aptitudes para una profesión

que devuelva a la patria, con creces,

lo que ahora nos entrega, gustosa,

con santa abnegación. 
Bendita la colonia escolar que nos cobija.

Bendita una y mil veces tan bella concepción.

Bendita eternamente la caridad

que obra milagros como este.

¡¡Bendito Castellón!!

Emilio Zorita

FUENTE: La Escuela, 23/07/1915 


\title{
PRIMERA COLONIA ESCOLAR DESDE LUCENA
}

\author{
Diario de un niño
}

Día 21 de julio

Nos levantamos a la hora de costumbre; nos limpiamos; tomamos el desayuno y fuimos a coger flores y luego marchamos a la «Torreta del Oso» donde cantamos mucho. Allí contamos muchos cuentos, Carnicer contó «Tirafaldetes»; Vilar, el del «Alcalde Pot»; María contó uno del ladrón y Vicente el del «Escarabatet» y por la tarde fuimos a esperar a don José, a doña Manola, a don Benjamin Ballester y a su hijo Rogelio y luego cantamos «El burro de la vinagre», la «Salve bandera» y el «Himno de la colonia». Luego nos fuimos a casa cenamos y tocó el gramófono como de costumbre.

A la hora de las otras noches nos acostamos.

FUENTE: El Clamor, 24/07/1915.

\section{Diario de una niña}

Día 6 de agosto

Observaciones meteorológicas.

Presión barométrica a las 8 de la mañana, 735; a las 8 de la noche, 735; temperatura a la 8 de la mañana, 24; a las 8 de la noche, 25; máxima, 25; mínima, 21; estado del cielo a las 8 de la mañana, despejado; a la 8 de la noche, despejado; dirección del viento a las 8 de la mañana, calma; a las 8 de la noche, calma.

Por la mañana hicimos el diario y bajamos a jugar al juego de bolos. Luego nos fuimos a comer y después a la fuente de Tomás donde merendamos. De allí marchamos al río de Lucena donde también jugamos. Después fuimos a una roca grande en la que nos sentamos y contamos cuentos. Don José nos explicó que era la tierra y los minerales. Ya tarde marchamos a casa a cenar. Tocó el gramófono y nos acostamos.

FUENTE: Clamor, 9/08/1915. 


\section{SEGUNDA COLONIA ESCOLAR CASTELLONENSE EN LUCENA DEL CID}

\section{Diario de la niña Carmen Campos (10 años)}

Día 5 de agosto

En este día por la mañana salimos con el auto a la 9 durante el camino cantamos y el inspector don José nos enseñó varias cosas y en nuestra compañía venían don José Clará y la inspectora doña Asunción Pleyán, a la entrada de Alcora paramos, bebimos todos y nos dirigimos para Lucena pasamos la Foya y el señor Inspector nos enseñó un castillo árabe que se llama el castillo de Alcalatén y también nos enseñó la Rambla de la Viuda y el chalet del señor Clará y pasamos Figueroles y entonces empieza el río de Lucena y por el camino encontramos el coche que iban los niños y al entrar en el pueblo nos recibió el Ayuntamiento de Lucena el vuelo de campanas y los niños de las escuelas con la bandera, después fuimos a la casa colonia comimos tomamos la siesta y después nos fuimos de excursión a la fuente de San Vicente y allí merendamos y luego fuimos a una era que hay detrás de la ermita de San Vicente y allí jugamos y después nos fuimos a casa cenamos y luego a dormir.

FUENTE: El Clamor, 9/08/1916.

\section{Diario de la niña Carmen Campos (10 años)}

Día 20 de agosto

Observaciones meteorológicas

Temperatura 8 mañana $23^{\circ}, 8$ noche $22^{\circ}$, máxima $24^{\circ}$, mínima $21^{\circ}$; presión barométrica 8 mañana 714, noche 712, estado del cielo 8 mañana despejado, 8 noche nublado, dirección del viento, 8 mañana, N; 8 noche NE.

En este día por la mañana se nos explicó la vida de los insectos diciéndonos que hay tres cuartas partes más de insectos que los otros. Luego se nos dijo que los insectos se componen de cabeza, tórax y abdomen y los insectos como las mariposas, la abeja, el saltamontes, se componen de cuatro alas, seis patas o sea tres pares y que nacen del tórax y esos cuernos que tienen se llaman antenas. La mosca de cabeza tórax y abdomen $\mathrm{y}$ tienen dos alas y dos balancines en los cuales se mantienen, respiran por el abdomen 
que está formado por anillos y a cada lado tienen un agujerito por el cual respiran como la abeja, la mariposa, la mosca y el saltamontes y otros insectos.

Luego nos hablaron de los pulgones, los animalitos que chupan la savia de los rosales y otros animalitos llamados mariquitas que se comen los pulgones; y los rosales, se limpian con agua de tabaco y jabón.

Luego también nos explicaron algo sobre la Santa misa, más tarde nos fuimos a misa la oímos con devoción y nos marchamos a visitar al cura del pueblo don Fernando Vicente. Luego nos fuimos a casa y él mismo nos obsequió con una caja de galletas.

Por la tarde fuimos a merendar a la fuente del Bale, merendamos y luego fuimos a coger flores secas muy bonitas para adornar el comedor.

Más tarde fuimos a casa y recibimos un obsequio de Agustí y Fabregat que eran cuatro sandias luego a descansar.

FUENTE: El Clamor, 22/08/1916

\title{
TERCERA COLONIA ESCOLAR CASTELLONENSE EN LUCENA DEL
} CID

\author{
Diario del niño Enrique Mercé (11 años)
}

Día 1 de agosto

Salimos de Castellón a las seis de la mañana con el coche y nos despedimos de nuestros padres. Nos acompañaban dos maestros para explicarnos cosas muy bonitas. Primeramente vimos un rulo que estaban apisonando la carretera para que los carros pasaran bien, después almorzamos en la venta llamadas de Sicilia. Vimos un canal del pantano que regaba los campos. Después el castillo de Alcalatén. Vimos la rambla, sobre la que estaban haciendo dos grandiosos puentes. Entramos en Alcora y cambiaron de caballerías; movió el coche, vimos La Foya, Figueroles y directo a Lucena. Cerca de Lucena nos encontramos con el auto que iban las niñas y entramos juntos a Lucena y nos esperaba todo el pueblo, tocaron las campanas, la música y salió al encuentro el alcalde de la población. 
Nos acompañaron a la colonia que es una casa muy grande y muy bonita. Nos dieron la comida visitaron la colonia unos cuantos señores y el alcalde.

Por la tarde fuimos de paseo a la era. Aquí estamos muy bien todos a mí me gusta la sala porque pasa mucho aire bueno para la salud.

FUENTE: El Clamor, 3/08/1918.

\section{Diario del niño Enrique Mercé (11 años)}

\section{Día 2 de agosto}

Nos levantamos por la mañana, abrimos las ventanas y los balcones, los dos compañeros nos ayudamos a plegar la cama que se duerme y muy comodón.

Luego nos quitamos la camisa para lavarnos el cuello, cabeza y cara para estar todos muy limpios que es lo que quieren los profesores.

Después el desayuno y ejercicios corporales. Redactamos el diario y como era hora de comer, comimos muy bien; luego fuimos de paseo a la fuente de San Vicente cuya agua que bebemos aquí en la colonia es tan rica y cristalina que da gusto beberla.

Después a recoger espliego para adornar tan agradable sala. Merendamos muy bien, fuimos a una era y jugamos a la hélice, después fuimos cantando la canción del soldado a la Colonia Escolar y antes de comer nos contó el profesor don José María un cuento muy bonito.

Vino la hora de cenar y cenamos muy bien; tocó el fonógrafo y las niñas bailaron y acudió mucho gentío de Lucena. Llegó hora de acostarse y nos acostamos con mucho silencio y... hasta mañana.

FUENTE: El Clamor, 5/08/1918 


\section{LA SEGUNDA COLONIA ESCOLAR. IMPRESIÓN DE UNA VISITA}

Designado por la Asociación provincial del Magisterio, partí entusiasmado hacía Lucena para estudiar en la práctica la organización y funcionamiento de la obra de Bion.

Las montañas de Lucena ofrecían las mejores posibilidades de encontrar la plenitud de condiciones higiénicas que debían tener las colonias escolares.

Las ventajas climatológicas del poblado son conocidas de antiguo por las gentes de la capital que, al llegar el veraneo, se trasladan a dichas montañas en busca de la salud. Por otra parte Lucena está a más de 500 metros sobre el nivel del mar, altura preconizada para colonias escolares presentadas por el Dr. Calvet en el Congreso de Colonias escolares (Paris) 1910.

En sitio cercano al pueblo, en las afueras, junto al camino, está la Casa- colonia. A la ventaja de ser un edificio nuevo y espacioso, reúne la del aislamiento, sin temor de los inconvenientes de la vecindad del poblado.

En dicha Casa-colonia los niños disfrutan de mucho aire y luz, buena alimentación y suficiente descanso. Con estos factores, claro está, que se pueden lograr grandes beneficios a favor de la salud del colono. Allí todo son rostros alegres, caras risueñas, risas y cantos. Le pregunté a uno de los colonos: ¿Quieres venir a casa?- No, contestó rápidamente.- ¿Por qué?- Porque aquí juego, como y...no me pegan.

A las diez de la mañana, los colonos que tiene gusto en redactar el «Diario» se reúnen alrededor de una mesa. El director interviene suscitando previamente una conversación entre los mismos niños sobre los recuerdos y observaciones más interesantes, y cuando se han evocado las impresiones salientes del día anterior, quedan aquellos en libertad de escribir lo que más les agrade.

En los juegos los profesores dejan de serlo para convertirse en niños. De este modo alientan y estimulan el ánimo de los pequeñuelos y persiste la armonía que en todo preside los actos de la colonia.

Por la tarde emprenden el camino que conduce a una fuente o al «Castell»y después de merendar aprovechando las oportunidades, se les dan explicaciones de mineralogía, botánica, zoología, agricultura, historia, etc.

Con esto queda demostrado que las colonias escolares no solo se ocupan de la salud del cuerpo sino también del alma. «Mens sana in corpore sano»; este es el ideal de 
la educación. En las colonias escolares se atiende a estos dos fines y por eso Nymeyer dijo: «La colonia escolar es una escuela tal como debería ser».

¡Cuánta caridad supone esta institución! ¡Cuánto amor a los niños!

La colonia escolar castellonense instalada en Lucena del Cid, la forman, como ya dijimos, 40 niños (20 de cada sexo) bajo la dirección de abnegados profesores que tienden a despertar en el niño con sus explicaciones del más elevado tono moral, el amor a sus semejantes, la gratitud, el orden, la convivencia, base del respeto mutuo y a reconocer el principio de autoridad, piedra angular del edificio llamado Sociedad.

El aire de los montes, saturados de oxígeno y libre de los agentes patógenos que en la ciudad le vician y adulteran, llena los pulmones de estos niños que, pobres en su mayoría y anémicos en totalidad, vienen aquí a restablecer la perdida de salud y al pálido color de su tez, que en los primeros días de colonia daba a estos rostros infantiles el triste aspecto de enfermos, sustituye el rosado tinte que en sus mejillas se dibujaba, dando muestras inequívocas de restaurada salud.

En la primera semana aumentaron los colonos por término medio 400 gramos. La segunda semana el aumento no se ha elevado a tanto, debido a que las excursiones han sido más largas; pero no por eso ha disminuido la salud, todos están buenos, alegres, cada día que transcurre aumenta el apetito y las pocas ganas de volver a Castellón.

Estos niños guardan eterno agradecimiento a los que con sus trabajos han logrado apartarles del hospital.

D. José Clará puede estar orgulloso de su obra, así como también el culto y activo Inspector de primera enseñanza D. José Senent Ibáñez, que no ceja en su empeño de realizar su ideal, consistente en llevar a la práctica las más bellas teorías pedagógicas.

TOMÁS GALLEGO

Castellón y agosto de 1916

FUENTE: La Escuela, 15/09/1916, pp. 291-292 


\section{LA SEGUNDA COLONIA ESCOLAR CASTELLONENSE, ESTUDIADA DESDE SU ASPECTO FÍSICO}

Voy a daros, lectores amables, unas cuantas noticias que os mostrarán con aire sintético lo que se hace en la colonia durante la permanencia de los niños en ella, respecto a lo que concierne a la educación física, supuesto que el orden y funcionamiento de la misma ya os lo han dado a conocer compañeros que me han precedido con plumas más autorizadas que la mía.

Ante todo os diré que la colonia es un poema vivo en donde el niño juega libremente, como libremente vuelan los pájaros en el espacio: revolotea, corre y salta, como revolotea la mariposa, como corre y salta el corderillo nunca fatigado de correr y saltar.

La situación de la Casa Colonia, algo separada del pueblo y en una de las partes más altas y sanas de Lucena, en un edificio de sencilla pero higiénica construcción, con dormitorios y dependencias perfectamente ventilados, iluminados y alegres, separada de aquellos puntos donde se agitan vehículos en que el niño corre peligro de ser atropellado, rodeada de anchos y espaciosos lugares y muy cerca de agrestes y hermosas montañas, convida irresistiblemente al juego y nos trae a la memoria las escuelas que hoy reclama la pedagogía moderna, presentando al niño los problemas más difíciles y complicados, arriba en la montaña, en el alegre y risueño campo entre árboles, flores, pájaros y mariposas y en medio de una atmosfera de expansiva alegría.

El niño en la colonia, vive siempre en constante actividad. Se le ve subir y bajar, ir y venir, correr y brincar.

Trabajan unos, otros descansan. Vense a estos en el patio ejercitándose entusiasmados en admirables juegos froebelianos, en tanto que otros se entregan libremente a otra clase de ejercicios físicos como el bolo, pelota, carreras, etc. Veréis a aquellos escribiendo juiciosamente el diario y escuchando encantados las hermosas explicaciones del pedagogo Senent, en tanto que a otros se ven escribiendo silenciosamente a sus familias. Les vemos por aquí coleccionando minerales y plantas, por allá rodeando a los profesores y haciéndoles muchas preguntas que son satisfechas con gran afabilidad. En suma, se dedica cada cual a la ocupación que le es más de su agrado, pero siempre respetándose mutuamente, trabajando con cariño y respirando un ambiente de franca y familiar fraternidad. 
Niños pálidos, raquíticos, tristes, débiles y algunos de ellos sin gusto por nada, fueron los escogidos para formar parte de la colonia. Pertenecientes a familias humildes, habitando en la ciudad en casas antihigiénicas, situadas algunas en barrios malsanos, no conocían la vida en medio de las montañas ni habían admirado la puesta del sol ni los múltiples encantos que por doquier nos brinda la naturaleza, nada de esa vida de encantadora y amplia libertad.

En los primeros días, según oí decir a los compañeros que me precedieron, la naturaleza de estos niños se mostraba débil, empobrecida, raquítica, con organismos faltos de nutrición, pero más tarde, los resultados de esta vida se habían mostrado rápidamente. Sus naturalezas habían robustecido, desarrollado sus energías y renacido a nueva vida sus espíritus.

Se disponía de un instrumento de peso y talla, haciéndose constar todos los sábados el mejoramiento físico del niño, llegando algunos de ellos a aumentar hasta dos $\mathrm{y}$ tres kilos, y si unos pocos permanecieron en el mismo estado, es porque las excursiones de alpinismo menudeaban con mucha frecuencia y al excesivo ejercicio se disminuía de peso y dos rebajaron un centímetro de talla, pero en cambio se curtía y coloreaba la piel, al contacto del sol y del aire, se oxigenaba y purificaba la sangre haciéndose rica en glóbulos rojos, se acumulaban energías y se prevenían para hacer frente a ese terrible azote que les amenaza, llamado Tuberculosis.

Los cantos que ejercen verdadera influencia en la educación física del niño por desarrollarse de una manera considerable los órganos de la respiración, ocupaban especial predilección en la vida de colonia. La mayor parte regionales y algunos de ellos acompañados de ejercicios gimnásticos, contribuían a dar flexibilidad al pecho y desarrollo a todos los órganos del cuerpo.

Entre otros merecen mencionarse los dirigidos por Da Amelia del Cerro y D. Vicente Nicolau y titulados «Cantos al Señor» $\mathrm{y}$ «El pajarito».

Con los ejercicios gimnásticos que en ellos se practicaba, se desarrollaban los músculos, se adquiría soltura y gracia en los movimientos, y elegancia y agilidad en las evoluciones.

Los niños son visitados con mucha frecuencia por el médico, aunque no haya ningún enfermo y caso de haberlo es atendido debidamente por las profesoras que le prestan cuidados y cariños verdaderamente maternales. 
Los baños semanales, los paseos y excursiones, el buen régimen alimenticio, la limpieza extremada, los ejercicios físicos y la vida higiénica de la colonia, hacen que el niño encuentre lo que necesita para desarrollarse y lograr el vigor del cuerpo y del alma.

Para terminar diré que la colonia castellonense fue trasladada de Serra (Valencia) a esta provincia por los esfuerzos y trabajos de un espíritu hidalgo y generoso, como es el de nuestro ilustre Inspector de Primera Enseñanza D. José Senent, alma, vida y sostén de tan hermosa institución, que con su apoyo incondicional, su trabajo esforzado, sus sabias orientaciones y su amor sin límites a los niños, ha convertido a la colonia en hada misteriosa que transforma al niño enclenque, raquítico y sin resistencias físicas, en hombre sano, vigoroso, con ideas bellas y pensamientos elevados.

AMPARO BRANDEZ

FUENTE: La Escuela, 30/10/1916, pp.333-334 